\title{
Der Volksroman Romuz-e Hamze als Musterbeispiel persischer Erzählkunst
}

\author{
Untersuchungen unter sprachlichen, sozialen, \\ religiösen und kulturellen Gesichtspunkten
}

\author{
INAGURAL-DISSERTATION \\ zur Erlangung des Doktorgrades \\ der Philosophischen Fakultät der \\ Georg-August Universität Göttingen \\ Seminar für Iranistik
}

\author{
vorgelegt von \\ Robabh Sabri \\ aus Iran
}

Göttingen 03. 02. 2011

Betreuer/in: Uni Prof. Dr. Ulrich Marzolph

Erstgutachter/in: Prof. Dr. Philip Kreyenbroek

Zweitgutachter/in: Prof. Dr. Irene Schneider

Vorsitzende/r des Prüfungsausschuss: Prof. Dr. Jens Peter Laut 


\section{Der Volksroman Romuz-e Ḥamze als Musterbeispiel persischer Erzählkunst}

Untersuchungen unter sprachlichen, sozialen, religiösen und kulturellen Gesichtspunkten 


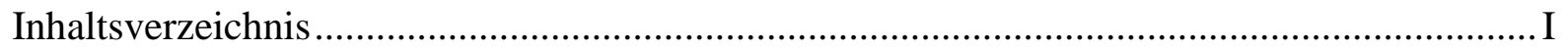

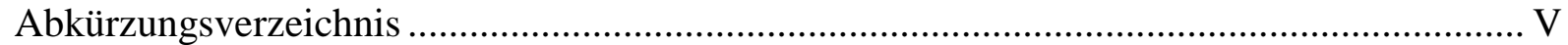

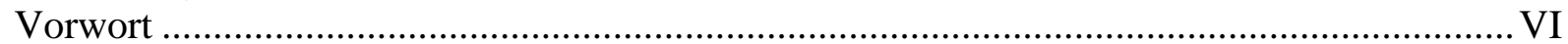

1. Einleitung.................................................................................................................................... 1

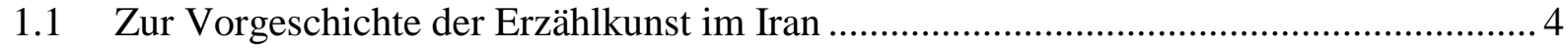

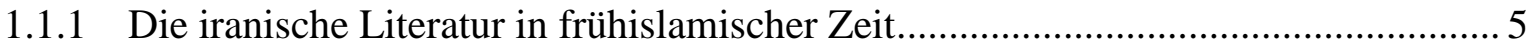

1.1.1.1 Entstehungsgeschichte des Šāh-nāme ............................................................ 7

1.1.1.2 Die iranische Literatur bis zum Ende der Seldschukenzeit (1040-1194) .............. 8

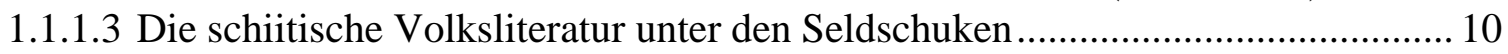

1.1.1.4 Manāqebiyān (Lobredner) und Fażā'eliyān (Vorzugsredner) ........................... 11

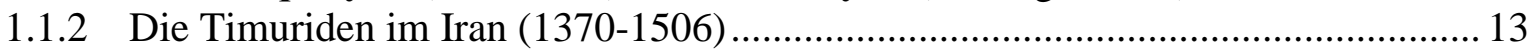

1.1.2.1 Volkstümliche Religiösität im 15. Jahrhundert ............................................... 14

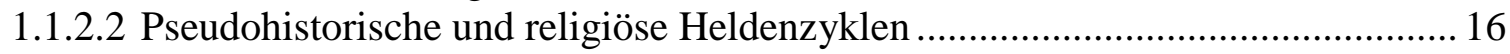

1.1.2.3 Die verschiedenen Erzählergruppen in der Timuridenzeit................................. 17

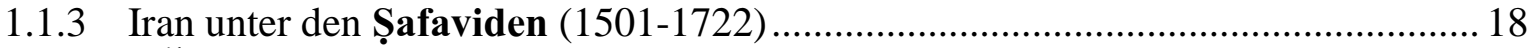

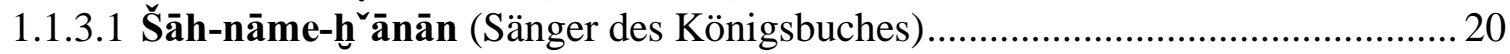

1.1.3.2 Qeșṣe-h̆ð̄ānān (religiöse Märchenerzähler) ......................................................... 20

1.1.3.3 Șurat-h̆ð̄̄nān (Geschichtenerzähler/Bänkelsänger) .......................................... 23

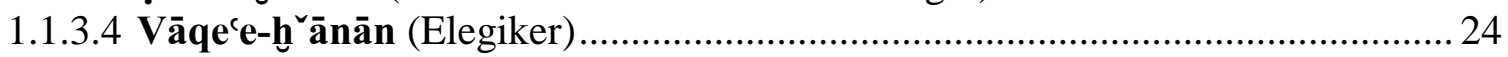

1.1.3.5 Ma'reke-girān (Straßendarsteller) ............................................................... 25

1.1.4 Die Situation der Erzählkunst im Iran während der Qāğāren- und der Pahlavizeit26

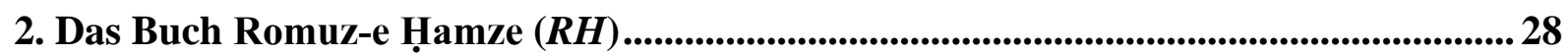

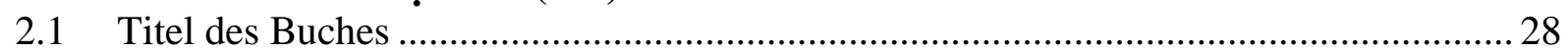

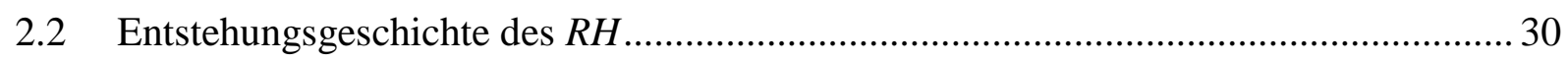

2.3 Zur Autorenschaft .............................................................................................. 31

$2.4 \quad$ Beschreibung des lithographischen Exemplares des $R H$............................................. 35

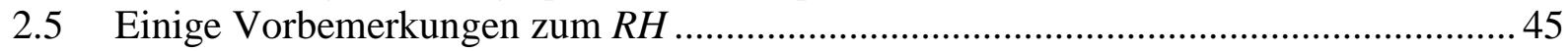

$2.6 \quad$ Inhalt und Zielsetzung des $R H$......................................................................... 47

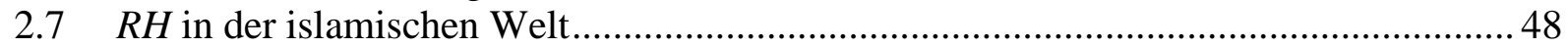

$3 \quad$ Inhalt des $R H$.................................................................................................................56

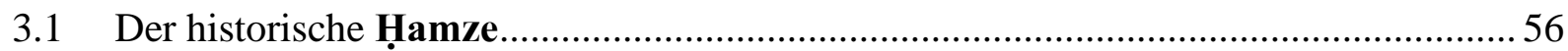

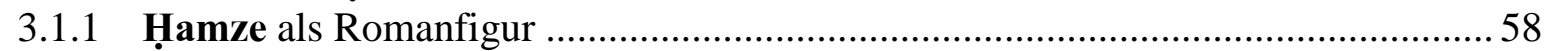

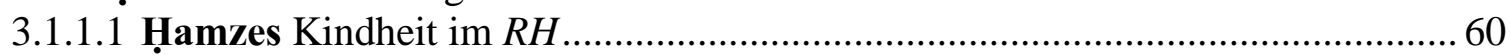

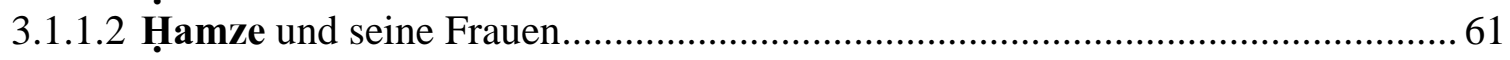

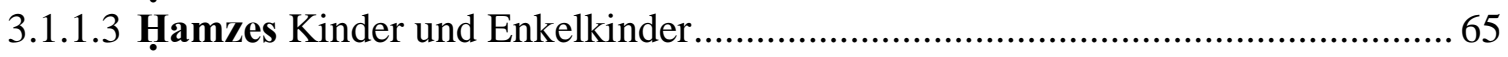

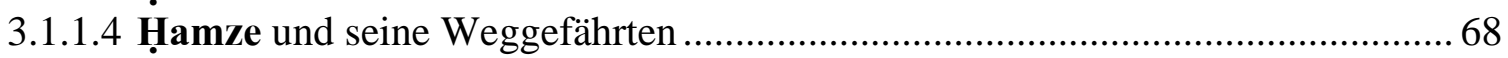

3.1.1.5 Ḥamze und seine Feinde........................................................................... 72

3.1.1.6 Ḥamze und seine Kriege .............................................................................. 75

3.1.1.6.1 Die Darstellung des ğehād im $R H$.......................................................... 77

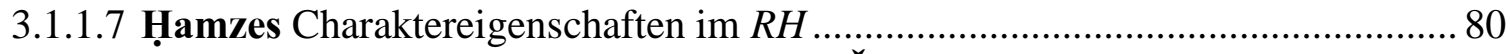

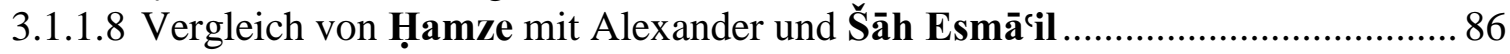

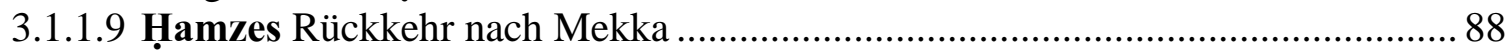

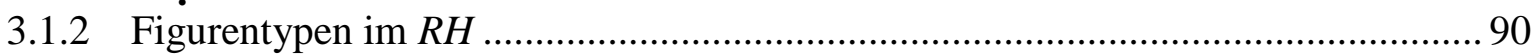

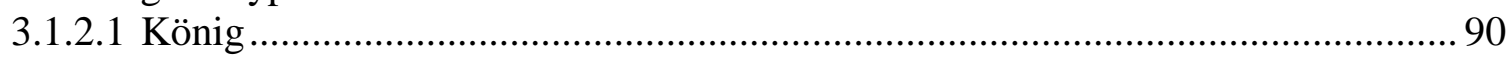

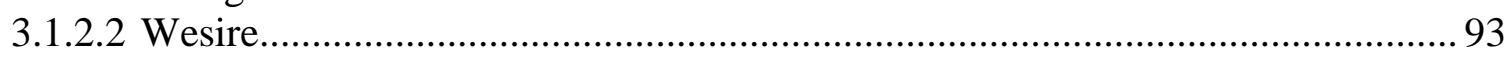

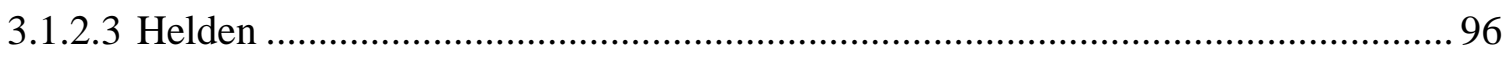

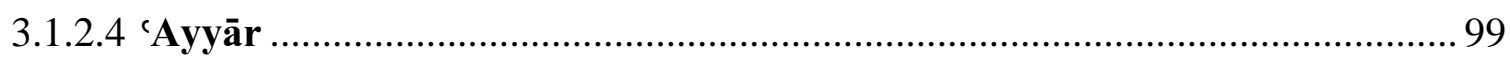




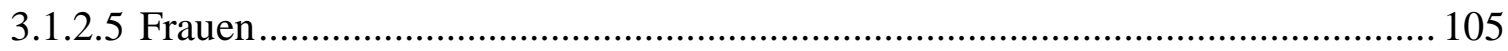

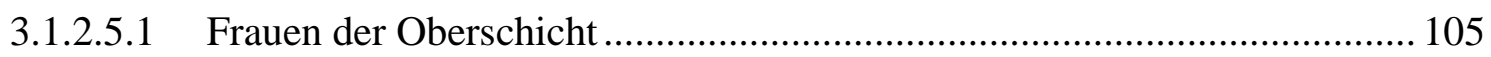

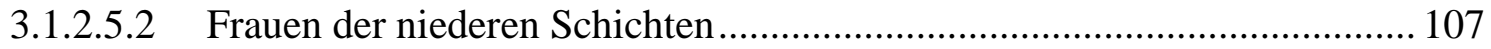

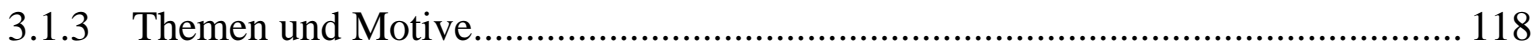

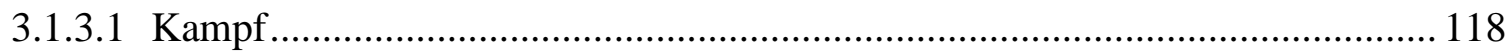

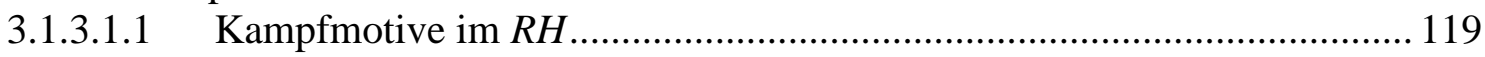

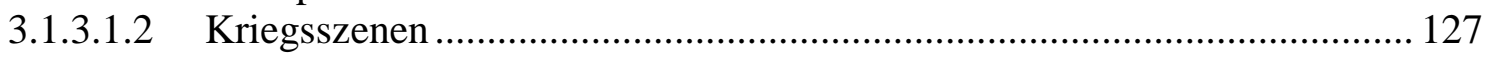

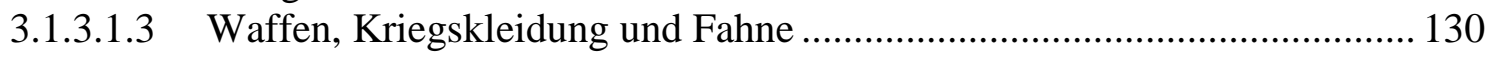

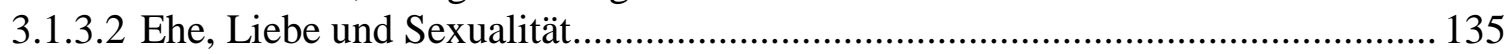

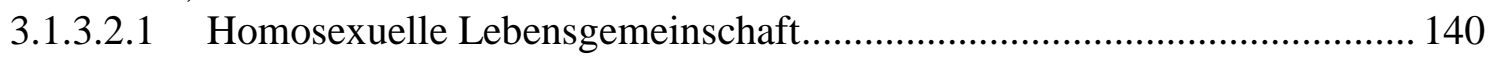

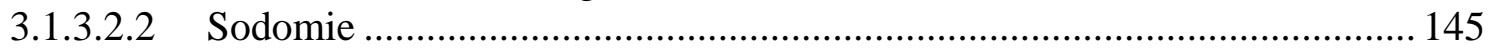

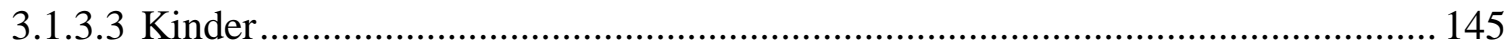

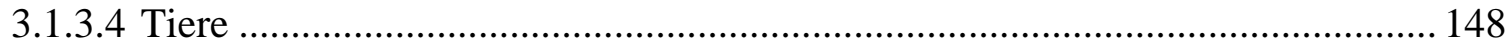

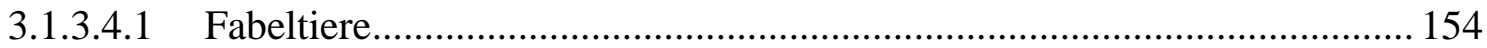

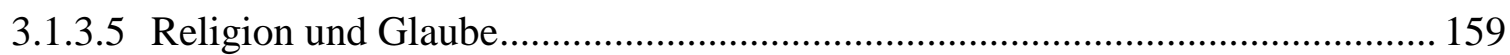

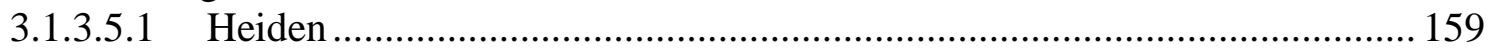

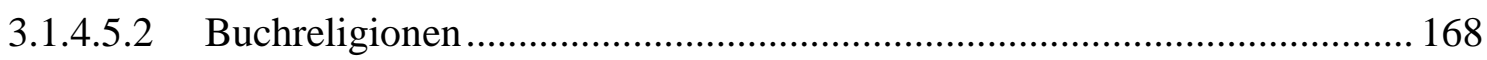

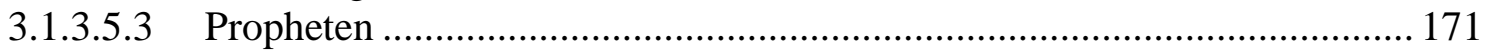

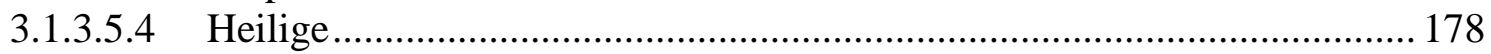

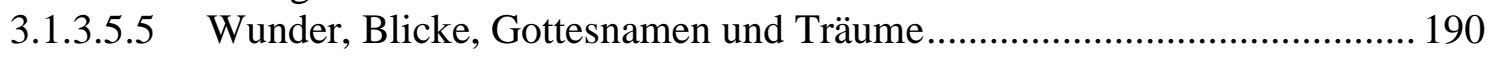

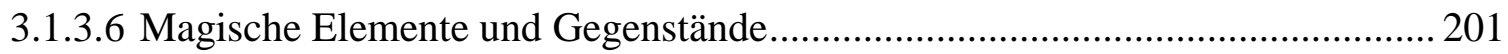

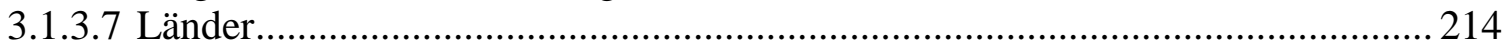

3.1.3.7.1 Real existierende Orte und Länder der Reiseroute ................................... 215

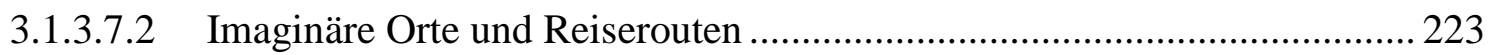

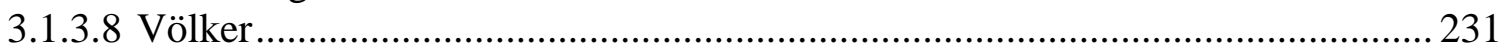

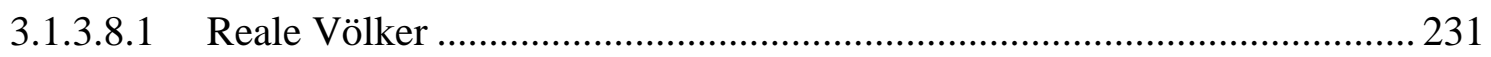

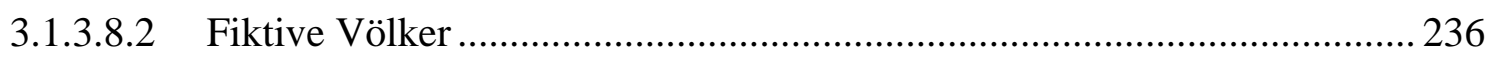

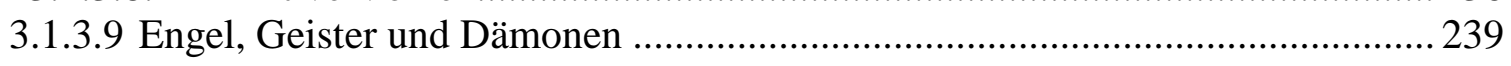

3.1.3.10 Vorislamische Persönlichkeiten ............................................................. 255

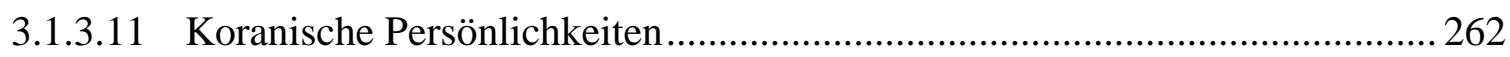

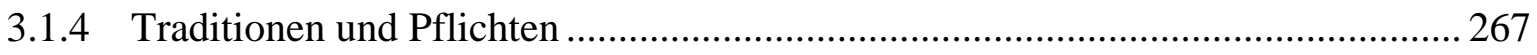

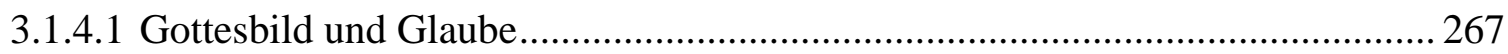

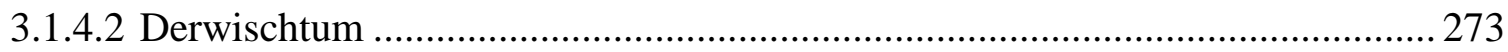

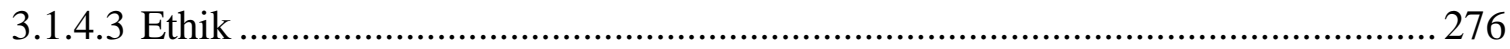

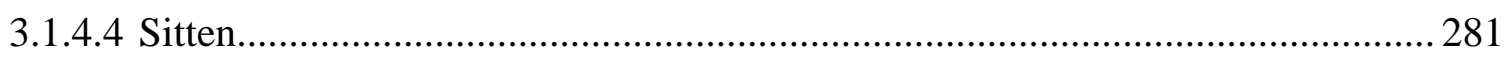

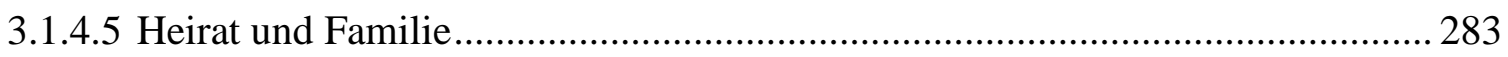

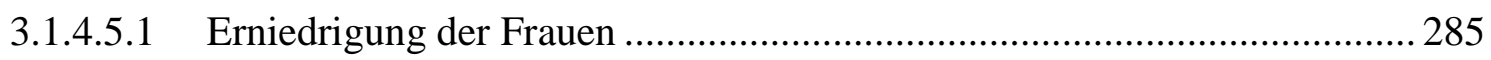

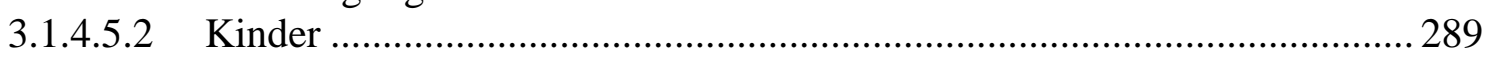

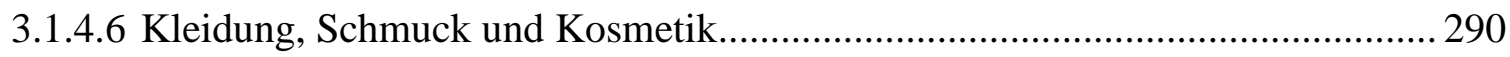

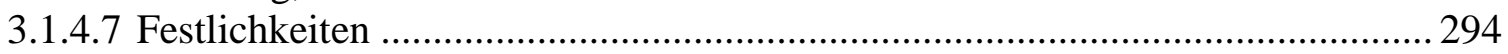

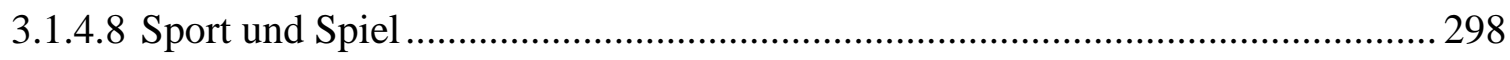

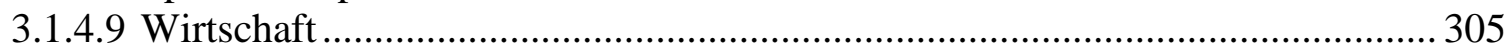

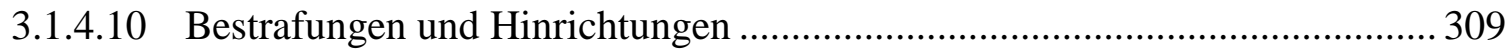

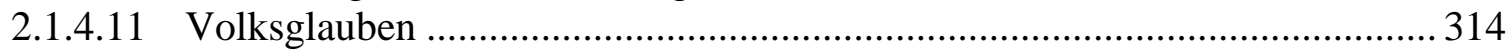

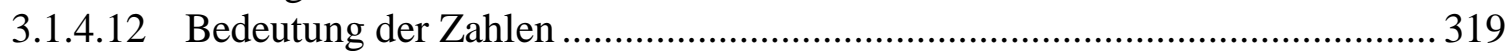

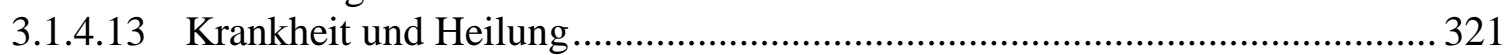

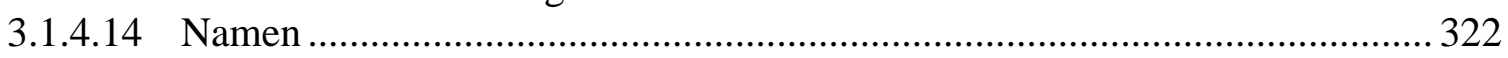

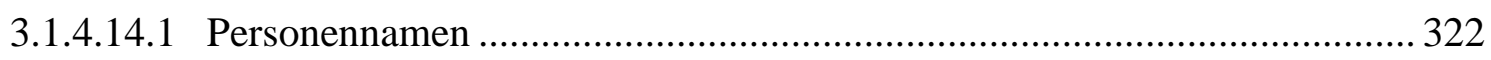

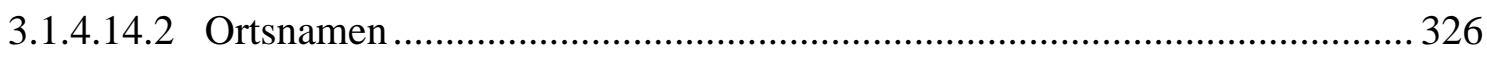

3.1.5 Zusammenfassende Betrachtung der Ausarbeitung ........................................... 329 
4. Überblick über die Grammatik

4.1 Einführung zur Qualität des sprachlichen Stils ......................................................... 332

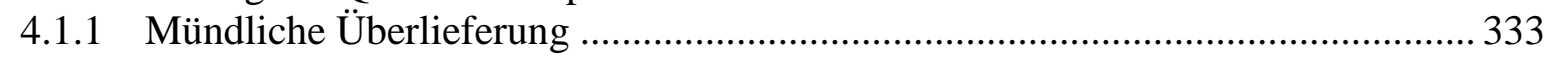

4.1.1.1 Formeln, ihre Funktion und Anwendung …………………………………........ 334

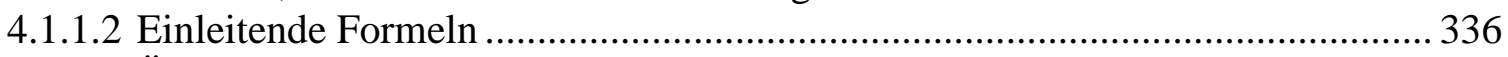

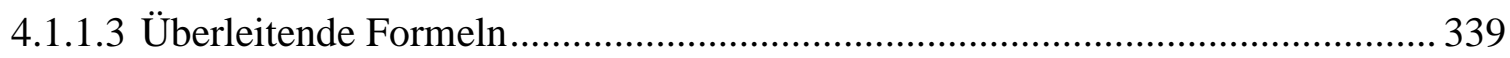

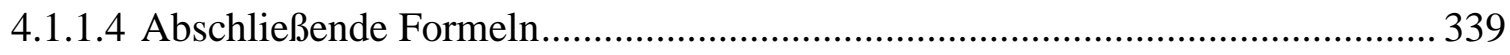

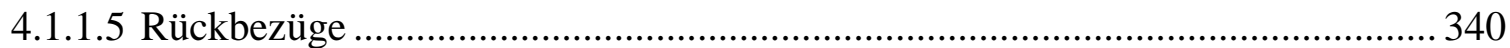

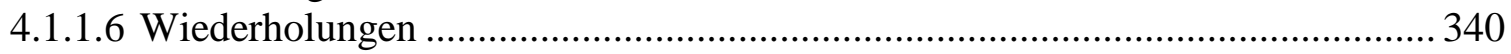

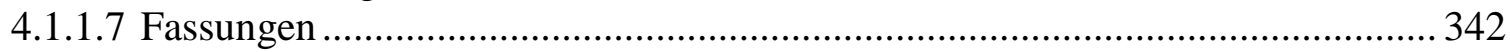

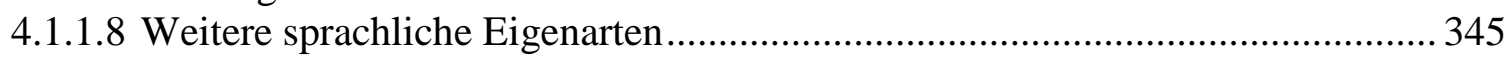

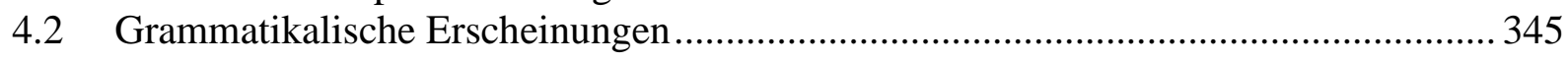

4.2.1 Sprachliche Kompetenzen eines Vortrages ……………........................................ 346

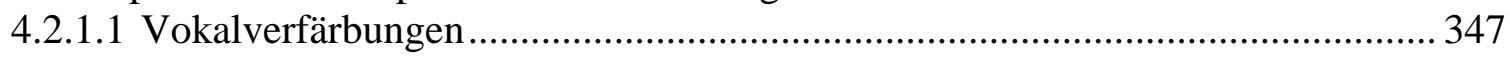

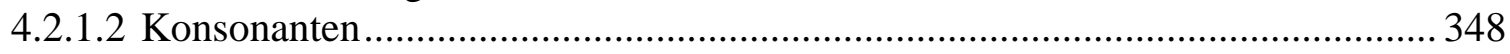

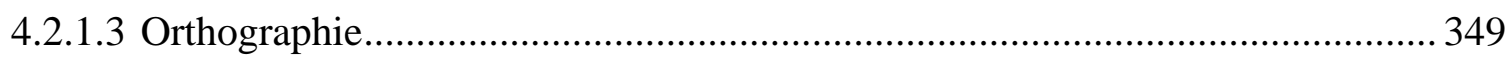

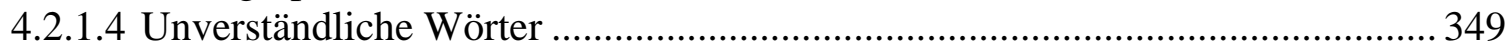

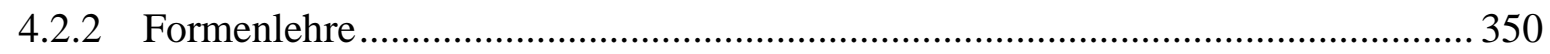

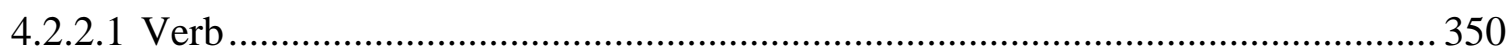

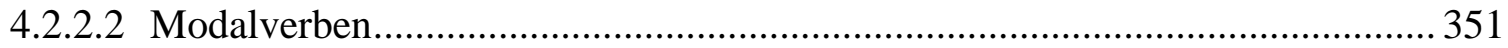

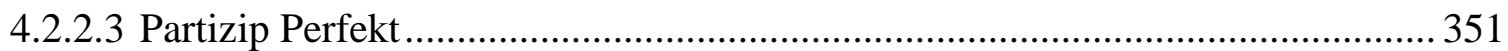

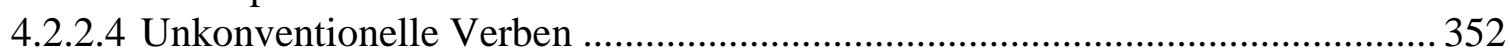

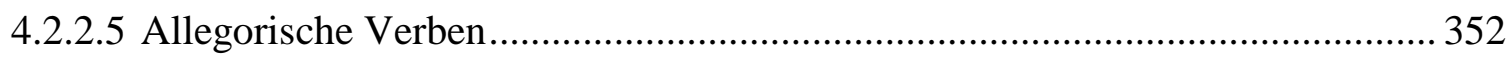

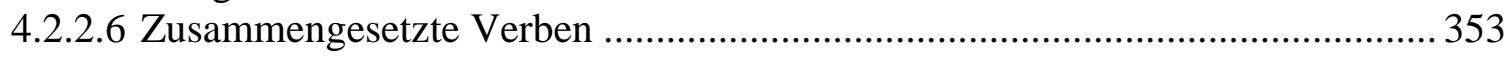

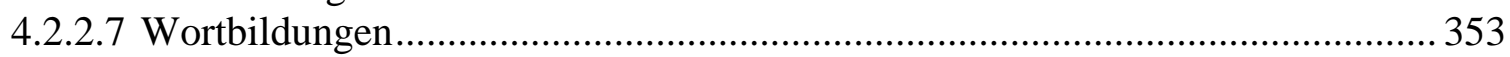

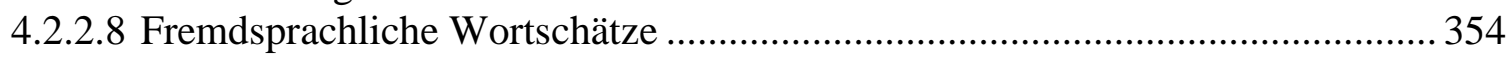

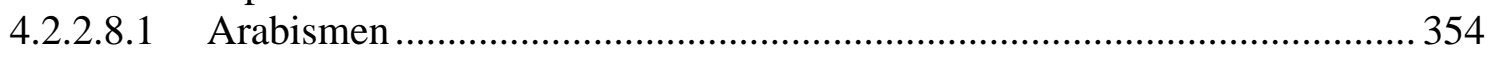

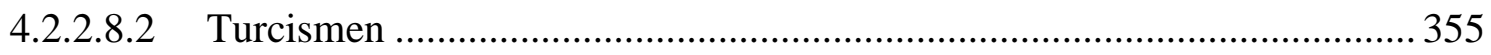

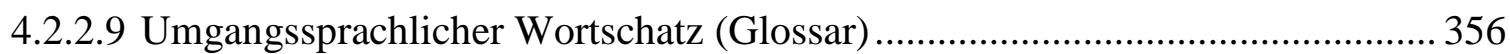

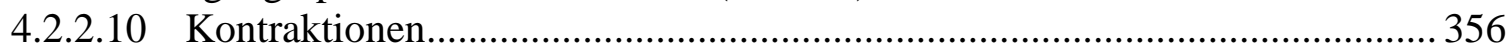

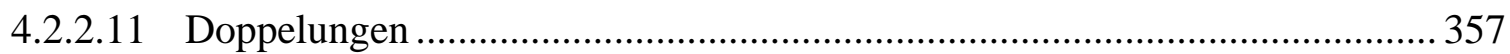

4.2.2.12 Zusammengesetzte ähnlich lautende Wörter(Kompositum)........................... 357

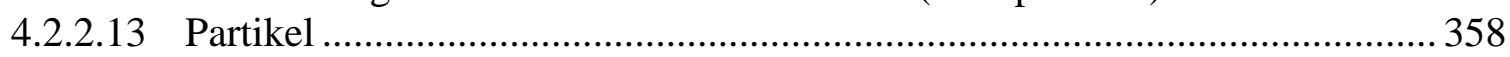

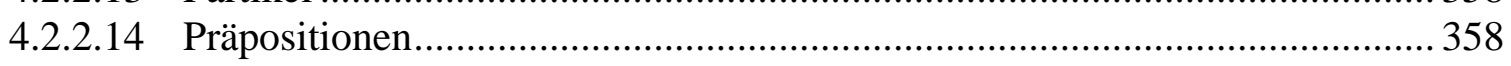

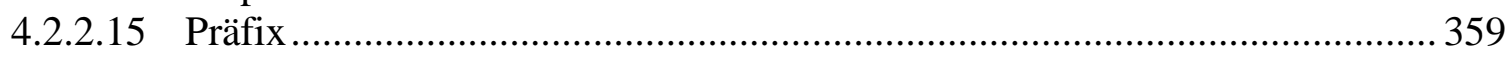

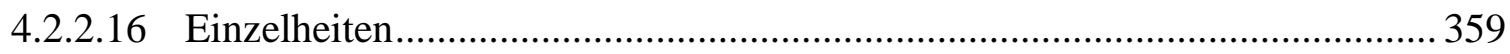

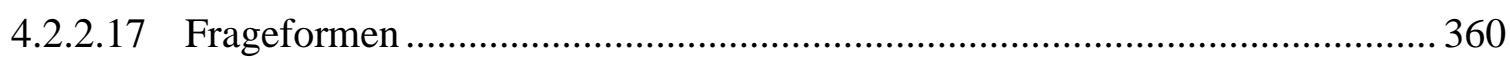

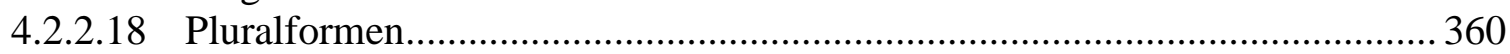

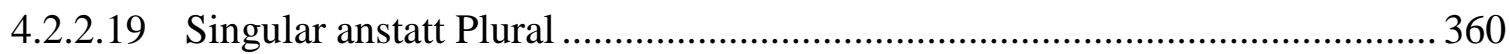

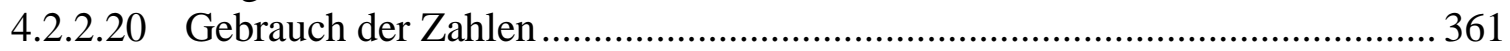

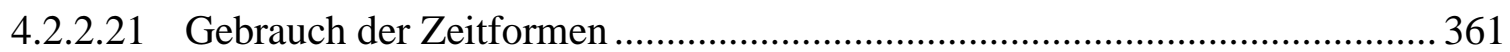

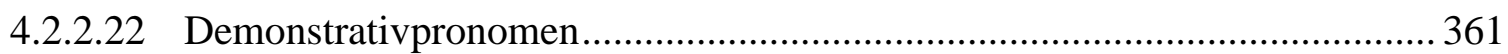

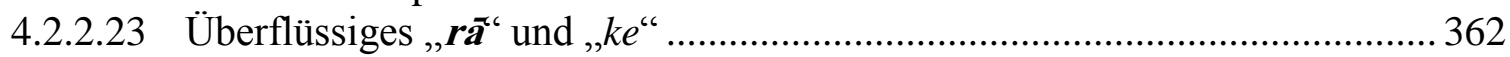

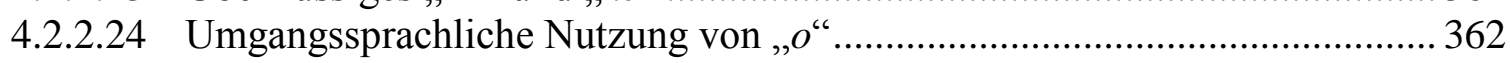

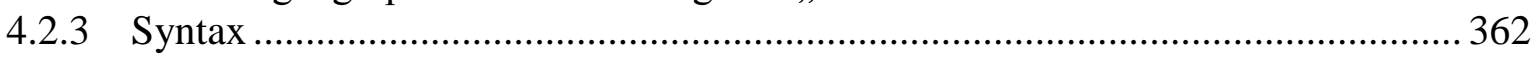

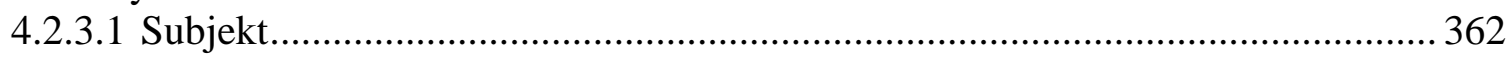

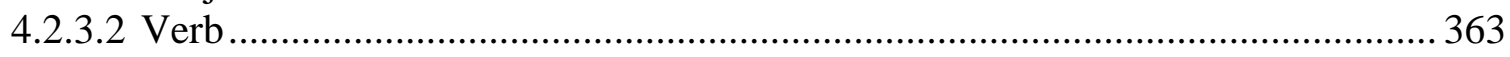

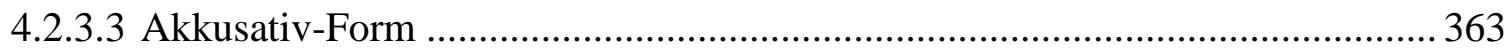

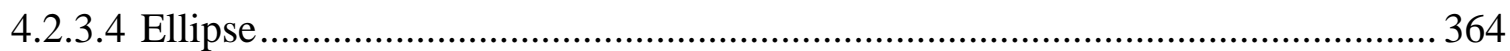

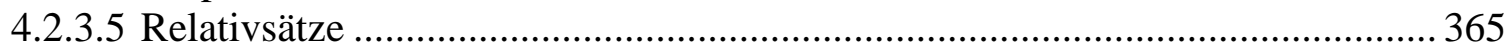

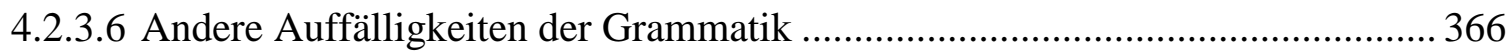




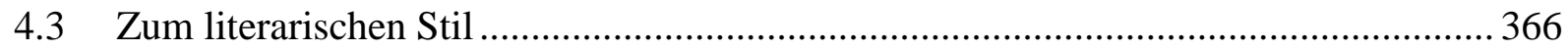

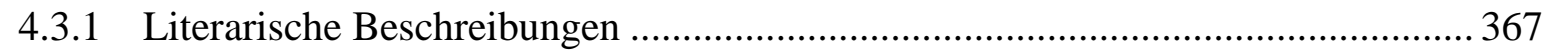

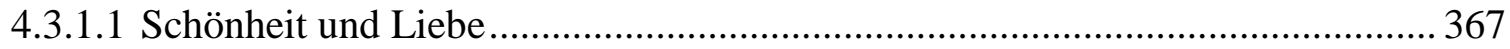

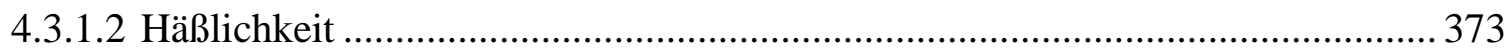

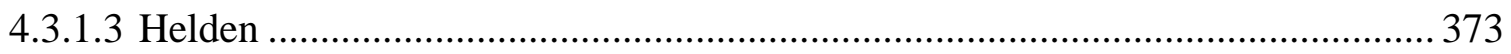

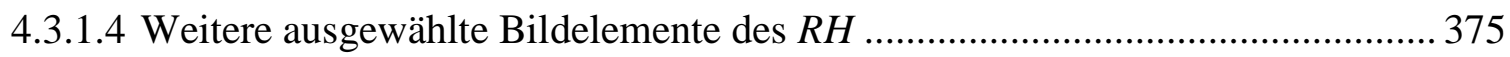

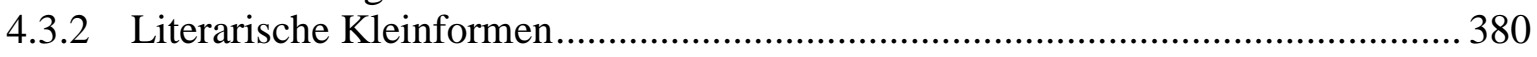

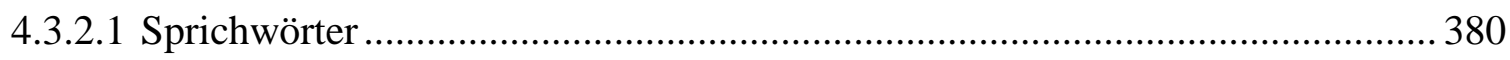

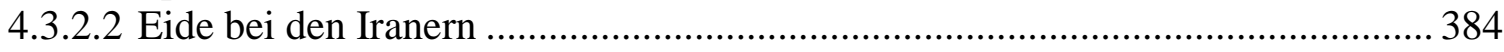

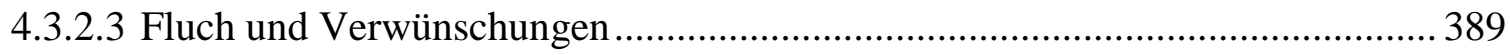

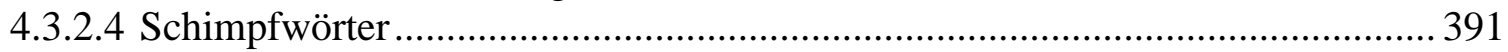

5. Zusammenfassung der wesentlichen Handlungsstränge.......................393

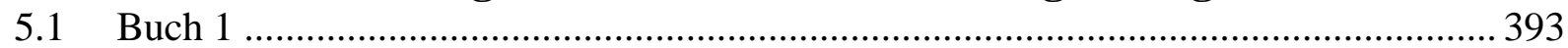

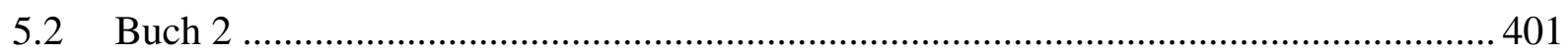

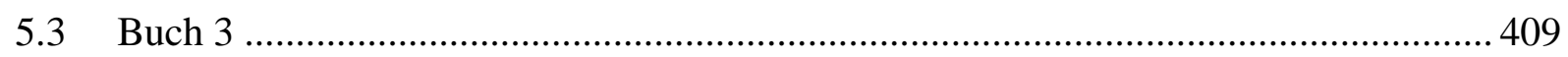

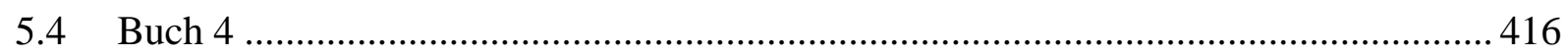

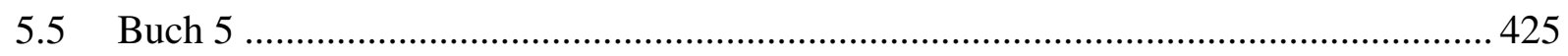

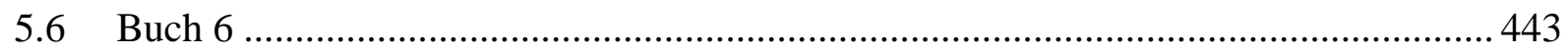

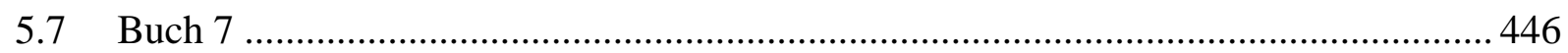

6. Schlussbetrachtungen .........................................................................449

Literaturverzeichnis................................................................................454 
Abkürzungsverzeichnis

AAS =Asian and African Studies

AFS =Asian Folklore Studies

JAFS = Journal of American Folklore Society

AN =Abu Moslem-nāme

AT =Aarne/Thompson

CHI =The Cambridge History of Iran

EI =Enzyklopädie des Islam

$E^{2} \quad=$ The Encyclopaedia of Islam New Edition

Elr $\quad=$ Encyclopedia Iranica

EM =Enzyklopädie des Märchens

EN=Eskandar-nāme

HdI =Handwörterbuch des Islam

HL = Haft Laškar

$H K G=$ Handbuch der Kulturgeschichte

$\mathrm{HO}=$ Handbuch der Orientalistik

$J A=$ Journal Asiatique

JAOS =Journal of the American Oriental Society

$J A F \quad=$ Journal of American Folklore

JRAS =Journal of the Royal Asiatic Society

MSOS =Mitteilungen des Seminars für Orientalische Sprachen Berlin

$Q H=$ Qeșse-ye Hamze

PTF = Philologiae Turcicae Fundamenta

RH = Romuze-e Hamze

TPV = Typologie des persischen Volksmärchens

ZDMG =Zeitschrift der Deutschen Morgenländischen Gesellschaft

Die im Text verwendete Umschrift orientiert sich am System der Deutschen Morgenländischen Gesellschaft. 
Vorwort

Die vorliegende Arbeit stellt meine Dissertation dar, die am 3. Feb. 2011 an der Georg August Universität in Göttingen zur Begutachtung eingereicht wurde.

Mein besonderer Dank gilt meinem Doktorvater Herrn Professor Ulrich Marzolph, der mich mit Anregungen, Rat und wissenschaftlichen Hinweisen unterstützt hat, mich lange Zeit betreut hat und seine private Bibliothek zur Verfügung gestellt hat. An dieser Stelle bedanke ich mich bei Herrn Professor Doktor Gabriel Viehhausen und Frau Anna Werner-Parker, die den Text Korrektur gelesen haben. Außderdem möchte ich mich bei allen Mitarbeitern der Universitätsbibliothek und Studierende der Georg August Universität für die freundliche Unterstützung bedanken. Nicht zuletzt gilt mein Dank meiner Familie für ihren Zuspruch und ihre stets tatkräftige Unterstützung. Ich hatte vor diese Arbeit meinem Vater zu widmen, doch ich bin mir meinem Vaterland mehr verpflichtet diese Arbeit den Menschen im Iran zu widmen. Möge Gott mein Volk und mein Land von Lüge, Ungerechtigkeit und Trokenheit befreien und bewahren. 


\section{Einleitung}

Die vorliegende Arbeit widmet sich einer detaillierten Untersuchung des Romuz-e Hamze (imfolgenden $R H$ ), einer in der Qāğārenzeit verfassten und gedruckt vorliegenden volkstümlichen Fassung der legendären Erlebnisse des Hamze, Onkel des Propheten Moḥammad. Die sechs Teile dieser Arbeit sind wie folgt gegliedert: (1) Geschichte der Erzählkunst im Iran; (2) Entstehungszeit des $R H$; (3) Inhalt des Werkes vor dem Hintergrund der gesellschaftlichen, kulturellen, religiösen, wirtschaftlichen und politischen Rahmenbedingungen; (4) Erzähltechnik und Sprache des Werkes; (5) ausführliche Zusammenfassung; (6) abschließendes Schlußwort.

Das $R H$ ist im Wesentlichen im 15./16. Jahrhundert entstanden, jedoch reichen die kulturellen, geographischen, religiösen und politischen Wurzeln seiner Entstehung sehr viel tiefer in die Vergangenheit zurück. Für ein angemessenes Verständnis des Werkes ist es daher notwendig, zahlreiche Zeugnisse aus unterschiedlichen Bereichen hinzuzuziehen.

Aus forschungsgeschichtlicher Sicht muss darauf hingewiesen werden, dass die Erforschung der persischen Volksliteratur nach wie vor darunter leidet, dass sich iranische Literaturwissenschaftler deutlich mehr für die Werke der klassischen Literatur interessieren. Sie haben die Volksliteratur bislang weitgehend thematisch und inhaltlich als ungeeignet oder gar minderwertig verstanden. Als erster Wissenschaftler hat sich Moḥammad Ğacfar Maḥğub Anfang des 20. Jahrhunderts ausführlich mit Themen der persischen Erzählkunst beschäftigt. In seinen grundlegenden Arbeiten hat er sowohl die literarisch-philologische als auch die folkloristische Seite des Themas erfasst. ${ }^{1}$ In der Mitte des 20. Jahrhunderts trug Abu 'I-Qāsem Enğavi-Širāzi eine umfassende Sammlung von Texten aus der mündlichen Überlieferung zusammen, darunter auch Material zu den populären Epen. Die Sammlung wird heute im Textarchiv des Folklore-Museums des Iranischen Rundfunks aufbewahrt. ${ }^{2}$ Der Literaturwissenschaftler Zֵabiḥallāh Șafā hat sich intensiv mit der Geschichte der Epik im

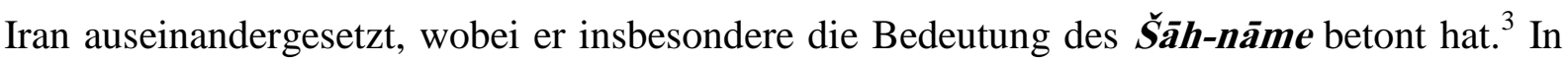
jüngerer Zeit haben Literaturwissenschaftler wie Mạ̣mud Omidsālār ${ }^{4}$ oder Mehrān Afs̃āri

\footnotetext{
${ }^{1}$ Maḥgub, Moḥammad-Ğa‘far: Adabiyāt-e ‘̄āmmiyāne-ye Irān, hrsg. von Ḥasan Znu al-Faqāri, in 2 Bänden, Teherān 1382/2003.

${ }^{2}$ Enğavi-Širāzi, Abu 'l-Qāsem: Mardom va Šāh-nāme, Teherān 1354/1975; id., Mardom va qahramānān-e Šāh-nāme, Teherān 1337/1958.

${ }^{3}$ Șafā, Zabihallāh: Hamāse-sarāèi dar Irān, Teherān 1333/1954; aṭ-Ṭarsusi, Abu Ṭāher Moḥammad b. Ḥasan b. 'Ali b. Musā: Dārāb-nāme, hrsg. von Žabiḥallāh Șafā, in 2 Bänden, Teherān 1374/1995; Big̉ami, Moḥammad b. Ạ̣mad: Firuzšāh-nāme, hrsg. von Znabiḥallāh Șafā, Teherān 1339/1960.

${ }^{4}$ Omidsālār, Maḥmud: Storytellers in Classical Persian Texts, in: Journal of American Folklore 97, 1984, S. 204-212; id., u. Teresa Omidsālār: Narrating Epics in Iran, in: Traditional Storytelling Today. An international sourcebook, ed. Margaret Read MacDonald, London 1999, S. 326-340.
} 
ihre Aufmerksamkeit dem Bereich der Erzählkunst im Iran gewidmet. ${ }^{5}$ Studien wie Ğacfar Šahris Buch Teherān-e qadim liefern Informationen über die traditionelle Erzählkunst im Iran. Seine Angaben sind für dieses Gebiet besonders aufschlussreich, da er aus eigenem Erleben berichtet. ${ }^{6}$

Unter den außer iranischen Wissenschaftlern hat Ulrich Marzolph sich in zahlreichen Arbeiten mit persischer Volksliteratur und persischer Erzählkunst beschäftigt. Sein Aufsatz zur mündlichen Überlieferung des Volksromans Hosein kord-e Šabestari ist ein Versuch, den iranischen Volksroman vor dem Hintergrund der Arbeiten Milman Parrys und Alberts Lords zu verstehen. ${ }^{7}$ Mary Ellen Page hat in ihrer Dissertation die Lage der professionellen naqqālān (Rezitatoren) im Irander 1970er Jahre untersucht. ${ }^{8}$ Auch von William Hanaway liegen zahlreiche Arbeiten zur persischen volkstümlichen Literatur vor. ${ }^{9}$

Allgemein fällt auf, dass die iranische Volksliteratur vor allem vom philologischen und historischen Gesichtspunkt aus bislang kaum untersucht worden ist. Relativ spärlich ist die Volkserzählkunst als soziale und kulturelle Erscheinung dokumentiert und erforscht worden.

Mit insgesamt 1.149 Seiten bietet das $R H$ im Bereich der Volksliteratur das größte einheitliche Textkorpus, das in persischer Sprache bislang erschienen ist. Die vorliegende Arbeit leistet insofern einen wichtigen Beitrag zum Verständnis der persischen Volksliteratur, als sie das $R H$ als zentrales Werk dieser Gattung detailliert untersucht, wobei inhaltliche und sprachliche Aspekte im Vordergrund stehen. Verfolgt werden dabei ein theoretischmethodisches und ein empirisches Ziel. Das theoretisch-methodische Ziel der Arbeit besteht darin, eine zusammenhängende Konzeption der historischen Erzählkunst als eine Lehre der komplexen und dynamischen Organisation zu entwickeln und die Aufgaben, Methoden und Beschreibungsmittel einer solchen Konzeption im Kontext darzustellen.

In empirischer Hinsicht gelten vor allem zwei Fragen als Leitlinien des Hauptteils der Arbeit: (1) Welche Organisationsprinzipien von historischen Erzählprozessen gibt es? (2) Wie werden diese bei der konkreten Text- oder Vortragsgestaltung umgesetzt?

Um zu einer sachlichen Kritik bei diesem Thema zu gelangen, werden aus der Fülle der dargebotenen Sachgebiete einige ausgewählt, die bisher noch wenig Aufmerksamkeit auf sich

\footnotetext{
${ }^{5}$ Afšāri, Mehrān u. Madāyeni, Mahdi: Haft laškar. Ṭumār-e ǧāme'-e naqqālān az Kiyōmars tā Bahman, Teherān 1377/1998.

${ }^{6}$ Šahri, Ğa‘far: Tehrān-e qadim, Bd. 2, Teherān 1371/1992, S. 139-158.

${ }^{7}$ Marzolph, Ulrich: Ganğine-i az gozārehā-ye qālebi dar dāstān-e cāmmiyāne-ye Ḥosein kord-e Šabestari, in: Qeș̣e -ye Ḥosein kord-e Šabestari, hrsg. von Irağ Af̃̄ār u. Mehrān Afšāri, Teherān 1385/2006, S. 439455.

${ }^{8}$ Page, Mary Ellen: Naggali and Ferdowsi: Creativity in the Iranian National Tradition, Ph.D. Dissertation, University of Pennsylvania 1977.

${ }^{9}$ Hanaway Jr., William L.: Persian Popular Romances before the Safavid Period, Ph.D. Dissertation, Columbia University 1970.
} 
gezogen haben. Viele Fragestellungen ergeben sich mithin vor dem Hintergrund der Qualität und Bedeutung der zur Verfügung stehenden Quellen. Manches Problem kann nur angeschnitten werden, vieles muss offen bleiben.

Schließlich sollte es in einem großen interdisziplinären Bemühen in dieser Arbeit gelingen, die Geschichte des menschlichen Geistes auf einige elementare gedankliche Einheiten herunterzubrechen und deren wechselnde Konstellationen und Muster der Zusammensetzung quer durch die Epochen und Kulturen zu verfolgen. So möchte diese Arbeit mit Hilfe der Geschichte und soziologischer Ansätze den langfristigen strukturellen Wandel der iranischen Gesellschaft erklären. Es geht darum, die Mentalitätsgeschichte der Iraner, ihre Veränderungen und Ausprägungen und eine Vorstellung von einer Entwicklung der Ideen festzuhalten. Darüber hinaus soll in dieser Arbeit ein Fokus auf die mentalen Strukturen der „einfachen Leute“ gelenkt werden. Die Untersuchung richtet sich daher auf die Wurzeln des Denkens der Iraner in der Übergangsphase vom Mittelalter zur Neuzeit. Es geht darum zu zeigen, dass sich im $R H$ die geschichtliche Entwicklung der Weltanschauung der Iraner, ihrer Identität, ihres Selbstbildes und dessen Veränderung durch die Jahrhunderte wiederfinden.

In diesem Zusammenhang kommen viele Fragen auf. Was ging in den Köpfen von Menschen vor sich? Was empfanden all die Menschen, die von der Geschichte der „großen Männer“ und den ideengeschichtlichen Gipfelwanderungen von großen Historikern nicht erfasst wurden, in Bezug auf Geburt und Tod. Was dachten sie über Sexualität und Liebe? Wie kam es, dass Frauen und Männer als Hexen bzw. Hexer denunziert wurden? Wie wird Gewalt erklärt? Tausend Fragen, auf die wir im $R H$ eine Antwort finden können.

Diese Arbeit betrachtet den Untersuchungsgegenstand aus der Perspektive unterschiedlicher akademischer Disziplinen, wie der Geschichts- und Religionswissenschaft sowie der Literaturwissenschaft. Viele historische Werke müssen benutzt werden, um die im $R H$ geschilderten Entwicklungen auf religiösem, kulturellem, gesellschaftlichem, wirtschaftlichem und politischem Gebiet erklären zu können.

Im ersten Teil dieser Arbeit wird ein kurzer Blick auf die Geschichte der Erzählkunst im Iran geworfen. Im zweiten Teil wird die Entstehungszeit des $R H$ behandelt. Der dritte Teil beschäftigt sich mit der Verstärkung des kollektiven Erlebens; hierzu gehören beispielsweise die Urbanisierung, die Bevölkerungszunahme, das allgemeine Wirtschaftswachstum im 15. und 16. Jahrhundert, die politischen Beziehungen mit Nachbarstaaten und europäischen Ländern, endlich die Entwicklung der Schia im Iran als Staatsreligion.

Schließlich hat diese Arbeit zum Ziel, den Zusammenhang der drei Themen „Erinnerung“, „Identität“ und „kulturelle Kontinuierung“ zu erläutern. 
Der vierte Teil der Ausarbeitung beschäftigt sich mit der Sprache und der Erzähltechnik des Werkes. Der fünfte Teil stellt alles bisher Ausgeführte in einen Zusammenhang. Daran schließt sich ein Schlusswort an.

\subsection{Zur Vorgeschichte der Erzählkunst im Iran}

Will man das Dunkel lichten, das um die Herkunft der Erzählkunst im Iran liegt, dann ist es nötig, bis in die Frühzeit zu gehen. Die epische Tradition der Iraner in der Frühzeit war ausschließlich mündlicher Natur. Ihr Anfang reicht wenigstens bis in die medische Zeit (715550 v. Chr.) zurück.

Bevor das Musizieren im Iran berufsmäßig ausgeübt wurde, traten bei Festen besonders begabte Stämmesangehörige als Vorsänger auf. Die medischen Priester (lat. Magus u. altper. Magu $)^{10}$ die innerhalb des Stammesverbandes hoch angesehen waren, konnten gleichzeitig Traumdeuter, ${ }^{11}$ Seher, Sänger und Ärzte sein. Herodot beschreibt im ersten Buch der Historien in den Abschnitten 131 bis 140 die Sitten der Perser. Bei der Beschreibung ihrer religiösen Bräuche in Abschnitt 132 erwähnt er, dass bei Opferhandlungen ein Magier das Lied von der Erschaffung der Götter sang.

Neben den Erzählungen mit mythischem gab es auch solche mit historischem Inhalt. Besonders beliebt waren Erzählungen über Kyros. Zu Beginn seiner Erzählung über Kyros schreibt Herodot:

$$
\begin{aligned}
& \text { „Ich will diese Geschichte so schreiben, wie sie einige Perser erzählen, sofern } \\
& \text { sie die Taten des Kyros nicht übertreiben wollen, sondern die Wirklichkeit } \\
& \text { schildern. Ich wäre jedoch in der Lage, über die Geschichte des Kyros noch } \\
& \text { drei andere Darstellungen nachzuweisen.“12 }
\end{aligned}
$$

Einen weiteren Hinweis liefert Xenophon (um 430-356 v. Chr.) in seiner Kyrupädie:

$$
\text { „Von Kyros aber erzählen und singen die Perser auch heute noch.“13 }
$$

Eine Untersuchung der persischen Literatur muss ihren Ausgangspunkt in der Sasanidenzeit (224-651 n. Chr.) nehmen. Leider ist der größte Teil der sasanidischen Literatur verloren gegangen, nur ein Bruchteil ist uns überliefert. Aus dieser Zeit stammt die schriftliche Fassung des Avesta. Als epische nicht-religiöse Literatur haben sich Kärnāmak-ĩ Artakhshīr-Pābakān und das Yãtkār-ĩ Zarīrān (Zarēer-Buch) erhalten. ${ }^{14}$

\footnotetext{
${ }^{10}$ Boyce, Mary: Zoroastrians: their religious beliefs and practices, London/New York 2001, S. xxi.

${ }^{11}$ Vgl. Mo'azzen-Ǧāme‘i, Moḥammad: Adab-e pahlavāni, Teherān 1379/2000, S. 81.

${ }^{12}$ Herodot: Historien, Buch I. 95, hrsg. von Josef Feix, München 1963.

${ }^{13}$ Zitiert nach: Tafażżoli, Aḥmad: Tārih̆-e adabiyāt-e Irān piš az Eslām, Teherān 1376/1997, S. 17.

${ }^{14}$ Vgl. Widengren, Geo: Die Religionen Irans. Die Religionen der Menschheit Bd. 14, Stuttgart 1965, S. 4ff.
} 
„Zur Zeit Chosraus I hat also schon eine einigermassen offizielle

Gesamtdarstellung der persischen Geschichte existiert.“15

In der sasanidischen Zeit gab es neben den mündlichen auch schriftlich festgehaltene Heldengeschichten. ${ }^{16}$ Das unter Hosrou Parviz (591-628 n. Chr.) zusammengestellte Hodãynāmak verarbeitet mythische, märchenhafte und historische Stoffe gleichermassen und liefert eine chronologisch geordnete Geschichte des Irans von der Erschaffung der Welt und der Regierung des Urkönigs Keiōmars bis Hosrou II. ${ }^{17}$ Angeblich trugen die Priester und der Landadel zur schriftlichen Fixierung dieser Werke bei. ${ }^{18}$

Was die Entstehung der Chronik betrifft, nimmt man an, dass zwischen der Komposition des Königsbuches und der Fertigstellung des vollständigen schriftlichen Textes eine beträchtliche Zeitspanne liegt.

\subsubsection{Die iranische Literatur in frühislamischer Zeit}

In seinen letzten Jahren war das Sasanidenreich durch Kriege gegen Römer und östliche Nomadenvölker sowie Thronstreitigkeiten geschwächt, sodass es in der Zeit von 634-651 eine leichte Beute der Araber wurde. Das wichtigste Ziel der Araber war, Steuern zu erheben, weniger die Verbreitung des Islams; allerdings traten viele Perser freiwillig zum Islam über. Die Araber waren vielfach nicht in der Lage, die eroberten Gebiete selbst zu verwalten und ließen deshalb die einheimische Verwaltung bestehen. Auch die soziale Ordnung änderte sich nicht. So überließen die Araber die Verwaltung des Landes den marzbānān (Grenzwächtern) und den dehqānān (Landadel) und kamen nur über diese mit der unterworfenen Bevölkerung in Kontakt. ${ }^{19}$ Auch wenn viele Perser arabisch lernten, wurde der Iran, anders als Syrien, Ägypten und andere Gebiete in Nordafrika, nicht arabisiert.

Der Landadel verfügte über die Bildung und die Muse, sich mit der Geschichte des Landes zu beschäftigen, epische Erzählungen und historische Schriften zu bewahren. Während der Epoche der Umaiyyaden verschärften sich die Auseinandersetzungen innerhalb des arabischen Lagers zwischen den politischen Parteien. Unruhe rief im Iran die Tatsache hervor, dass die Umaiyydenherrscher Muslime nicht-arabischer Herkunft benachteiligten. So war es kein Wunder, dass sich viele Perser den Aufständischen, die sich auf das Haus des Propheten beriefen, anschlossen. Der Anführer des letzten erfolgreichen Aufstandes, Abu Moslem, war

\footnotetext{
${ }^{15}$ Nöldeke, Theodor: Geschichte der Perser und Araber zur Zeit der Sasaniden. Aus der arabischen Chronik des Tabari, Leyden 1878, S. XVI f.

${ }^{16}$ Vgl. Ḩāleqi-Moṭlaq, Ǧalāl: Mošk-dāne. Derangi dar adabiyāt-e sāsāni, in: Irān-šenāsi, Vol. XVI, No. 2, (2004), S. 233-236.

${ }^{17}$ Vgl. Șafā, Zabiḥallāh: Hamāse-sarā’i dar Irān, Teherān 1333/1954, S. 60.

18 Ebd.

${ }^{19}$ Vgl. Wellhausen, Julius: Das arabische Reich, Berlin 1960, S. 308.
} 
selbst Perser. Es gelang ihm, die umaiyydischen Dynastie zu stürzen und neue Herrscher aus dem Haus des Propheten an die Macht zu bringen.

Die neuen Herrscher aus der 'Abbasidendynastie verlegten ihre Residenz nach Baġdād und stützten sich zu einem großen Teil auf persische Soldaten und Beamte. In der Zeit nach Hārūn ar-Rašid (gest. 809) entstanden selbstständige iranische Fürstentümer, die nur dem Namen nach dem Kalifen untertan waren. Alle diese Dynastien (Șafariden, ${ }^{20}$ Buyiden, ${ }^{21}$ Ziyariden und Samaniden ${ }^{22}$ ) behaupteten, Nachkommen der Sasaniden zu sein.

Nach dem Fall des Sasanidenreiches, dessen Staatsprache das Pahlavi (Mittelpersisch) war, entwickelte sich die neupersische Sprache in arabischer Schrift. ${ }^{23}$ Sie bildete das Fundament für eine eigene kulturelle Entwicklung des Irans, die im Laufe ihrer weiteren Geschichte große geographische Gebiete im Westen bis nach Kleinasien, im Osten bis Zentralasien und Indien prägte. Die ersten Zeugnisse neupersischer Literatur tauchten im Osten auf und beschränken sich bis zum zehnten Jahrhundert auf Sistān, Transoxanien und Horāsān. ${ }^{24}$ Das Neupersische wurde zuerst in der höfischen Dichtung verwendet. Viele Würdenträger und Fürsten verstanden wenig oder gar kein Arabisch, ${ }^{25}$ sodass die Dichter ihre Werke auf Neupersisch verfassten. ${ }^{26}$ Am Samanidenhof gab es eine große Schar von Dichtern und Gelehrten, die das alte iranische Heldentum wieder ans Tageslicht brachten.

Die offizielle Förderung und Verbreitung des religiösen islamischen Schrifttums auf Persisch scheint das kulturelle Leben zur Zeit der Samaniden zu charakterisieren. Dieser Prozess der bis in die Sprache hineinreichenden Iranisierung des Islams und die weitgehende Identifikation mit dem samanidischen Staatswesen trugen zur Ausbildung eines iranischen Selbstbewusstseins bei. Der Samanidenkönig musste religiöses islamisches Schrifttum in einer anderen als der arabischen Sprache von den Religionsgelehrten anerkennen lassen, um es verbreiten zu können.

„Der Sāmānidenherrscher Abu Șāleḥ Manșur b. Nuḥ (Regierungszeit 961967 n. Chr.) wollte, da er das Arabische nur schwer zu lesen vermochte, eine persische Übersetzung des Tafsir aț-Ṭabaris anfertigen lassen. Er rief die 'ulamā' von Transoxanien zusammen und verlangte ein fatvā

\footnotetext{
${ }^{20}$ Bāstāni-Pārizi, Moḥammad-Ebrāhīm: Ya'qub leịs, Teherān 1367/1988, S. 75.

21 Biruni, Abu ar-Reihāan: Al-ātār al-bāqiya 'an al-qurūn al-hāliya, aus dem Arabischen ins Persische übersetzt. von Akbar Dānā-Serešt, Teherān 1352/1973, S 61.

22 Biruni, S. 63.

${ }^{23}$ Vgl. Bahār, Moḥammad-Taqi: Sabk-šenāsi, Bd. 2, Teherān 1337/1958, S. G.

${ }^{24}$ Vgl. Lazard, Gilbert: The rise of the new Persian language, in: CHI, Vol. 4, hrsg. von Richard Nelson Frye, London 1975, S. 595-632, hier S. 594.

${ }^{25}$ Vgl. Bahār, S. 16.

${ }^{26}$ Vgl. Lazard, S. 594.
} 
(Rechtsgutachten) darüber, ob eine Übertragung dieses arabischen

Korankommentars ins Persische gestattet sei. “27

Diese Übersetzung war und ist eines der ältesten Zeugnisse der neupersischen Sprache.

\subsubsection{Entstehungsgeschichte des Šāh-nāme}

Ferdousi begann das Šāh-nāme zur Zeit des Samaniden Nuḥ b. Manșur (976-997) zu verfassen. Über die Quellen des Šāh-nāme gibt es zwei verschiedene Meinungen. Unter iranischen Wissenschaftlern herrscht die Ansicht vor, dass Ferdousi schriftliche Quellen verwendete. ${ }^{28}$ Die westlichen Wissenschaftler sind dagegen überwiegend der Auffassung, die neupersische Literatur (besonders mit Blick auf das Šāh-nāme) sei ein Reflex der mündlich überlieferten Bardendichtung, es handle sich weitgehend um „Oral tradition““. ${ }^{29}$

Um die Frage zu entscheiden, muss die Möglichkeit der Existenz schriftlicher Quellen untersucht werden. So wissen wir von arabischen Schriftstellern, dass in frühislamischer Zeit viele Bücher auf Pahlavi existierten. ${ }^{30}$

Aus dem Vorwort des Šāh-nāme-ye bozorg (Großes ک̌āh-nāme) geht hervor, dass im Jahre 957 Abu Manșur, Sohn des 'Abdal ar-Razzāq, des damaligen Herrn von Ṭus, dem Abu Manșur al-Ma'mari befahl, eine Königschronik in Prosa zusammenzustellen. Al-Ma'mari bearbeitete mit vier alten mobads und deqānān, denn nur diese waren imstande Pahlavi zu lesen, mündliche und schriftliche Überlieferungen. Aus der Vorrede, die Timurs Enkel Bāisonqor (1425/26) zum Šāh-nāme schreiben ließ, erfahren wir, dass sich unter dem schriftlichen Material eine Chronik der sasanidischen Könige befand, die Hosrou I. (533-579 n. Chr.) hatte zusammenstellen lassen. ${ }^{31}$

Ferdousi spricht also selbst von schriftlichen Quellen, die er verwendet hat. In der Einleitung

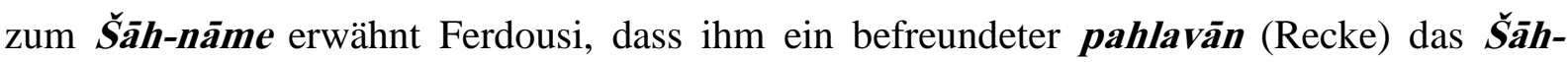
nāme des al-Ma'mari gegeben habe, um es poetisch zu bearbeiten. ${ }^{32}$ Als weitere schriftliche

\footnotetext{
${ }^{27}$ Bahār, S. 16.

28 Vgl. Omidsālār, Maḥmud: Dar defā' az Ferdousi, in: Nāme-ye Farhangestān, 3 Jahrsgang, Nr. 4, 1376/1997, S. 1-21, hier S. 6; Hुāleqi-Moṭlaq, Ğalāl: Dar pirāmun-e manābec-e Ferdousi, in: Irān-šenāsi, Vol. X, Nr. 3, autumn 1998, S. 512-539; ders.: Yeki mehtari bod garden-farāz. Ta'ammoli dar Šāh-nāme, in: Mağalle-ye dāneškade-ye adabiyāt va 'olum-e ensāni-ye dānešgāh-e Mašhad XIII (2536/1977), S. 198202.

${ }^{29}$ Davidson, Olga M.: Poet and Hero in the Persian Book of Kings, London 1994, S. 33-41; vgl. De Bruijn, J. T. P.: Die persische Volksliteratur im Mittelalter, in: Neues Handbuch der Literaturwissenschaft, Bd. 5, hrsg. von Klaus Von See, Wiesbaden 1990, S. 456-474, hier S. 470.

${ }^{30}$ Vgl. al-Mas'ūdī, Abū al-Hasan 'Ali b. al-Husain: at-Tanbīh wa -'l-išrrāf, hrsg. von 'Abdallāh Ismā'īl aṣȘāwī, Miṣr 1375 h/1938, S. 92; Ferdousi, Bd. 2, S. 1674; 1778; vgl. al-Mas'ūdī: Murūğ ad-dahab wama‘ādin al-ğawāhir, Bd. 1, hrsg. von Charles Barbier de Meynard, Bairut 1965, S. 318; Șafā, Hamāse-sarā’i dar Irān, S. 88-92.

${ }^{31}$ Vgl. Șafā, Hamāse-sarā̄i dar Irān, S. 102 f.

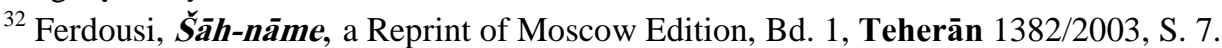


Quellen nennt er ein nāme-ye hosrovi (Buch über die Kaiserschaft), ein nāme-ye bāstān (Buch des Altertums) ${ }^{33}$ und ein nāme-ye pahlavi(Pahlavi-Buch). ${ }^{34}$

Weiter sagt Ferdousi in seiner Einleitung, dass aus diesem daftar (Heft) viele Geschichten gelesen und erzählt wurden. ${ }^{35}$ Der Dichter Daqiqi habe angefangen, die Geschichten und Erzählungen, die sich darin befanden, in Versform wiederzugeben. ${ }^{36}$ Nach seiner Ermordung übernahm Ferdousi tausend Verse von ihm über Guštāsp und dessen Kampf mit Arğāsp. ${ }^{37}$

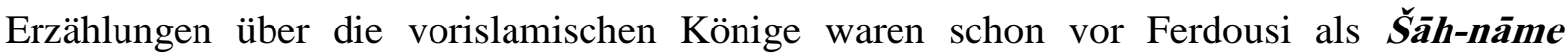

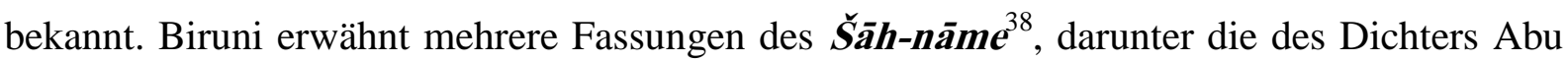
'Ali Moḥammad b. Aḥmad Balhii. ${ }^{39}$

Das heißt natürlich nicht, dass es daneben keine mündliche Überlieferung heroischer Stoffe gegeben hat, und dass manche Sagen, die Ferdousi ins Šăh-nāme aufgenommen hat, nicht auch mündlich überliefert wurden; doch existierte wahrscheinlich eine mündliche und eine schriftlicheepische Tradition nebeneinander. ${ }^{40}$

Marzolph fasst zusammen, dass „Ferdousis Werk [...] sich also weder ausschließlich noch überwiegend aus schriftlichen Quellen herleiten [lässt] wie auch seine weitere Tradierung, trotz der eindeutigen Abfassung eines autoritativen Textes, weder ausschließlich noch überwiegend schriftlich stattfand."

\subsubsection{Die iranische Literatur bis zum Ende der Seldschukenzeit (1040-1194)}

Während zu Lebzeiten Ferdousis in der epischen Dichtung das Nationale vorherrschendes Thema war, änderte sich dies nach seinem Tode und eine Vielzahl unterschiedlicher Themen (Liebe, Tod, Krieg u.a.) fand Eingang in die Dichtung. Kennzeichen dieser Entwicklung ist der zunehmende Umfang der Texte bei gleichzeitig instabiler Überlieferung, der Wechsel von der Versform zur Prosa und die wachsende anonyme oder pseudonyme Literatur. De Bruijn sieht dies als Anzeichen sekundärer Verschriftung mündlicher Erzählungen. ${ }^{42}$ Die Gründe für

\footnotetext{
${ }^{33}$ Ebd. Bd. 1, S. 11.

${ }^{34}$ Ebd. Bd. 1, S. 7; vgl. Hูāleqi-Moṭlaq, Dar pirāmun-e manābe'-e Ferdousi, S. 533-538.

${ }^{35}$ Ferdousi, Bd. 1, S. 6.

${ }^{36}$ Ebd.

${ }^{37}$ Ebd.

${ }^{38}$ Biruni, S. 61; vgl. Hูāleqi-Moṭlaq, Dar pirāmun-e manābec-e Ferdousi, S. 518; Ṣafā, Hamāse-sarā’i dar Irān, S. 103.

${ }^{39}$ Biruni, S. 142.

${ }^{40}$ Vgl. Omidsālār, Mạ̣mud u. Teresa: Narrating Epics in Iran, in: Traditional Storytelling Today, Ed. Margaret Read MacDonald, London 1984, S. 326-340, hier S. 329.

${ }^{41}$ Marzolph, Ulrich: Das persische Nationalepos im Spannungsfeld von Überlieferung und ideologischer Instrumentalisierung. Überlieferung und Deutung. Zur historischen Funktion der Volkserzählung und ihrer Instrumentalisierung in der Gegenwart. (Vorträge des 11. internationalen Symposions zur Volkserzählung. Innsbruck vom 5-8. Oktober 1997. ed. L. Petzoldt/G. B. Bronzini), in: Lares 65, 1-2 (1999), S. 81-99, hier S. 88.

${ }^{42}$ Vgl. De Bruijn, hier S. 470.
} 
diese Verlagerung waren soziale, politische und religiöse Veränderungen im iranischen Kulturbereich sowie die Veränderung des Bildungssystems ${ }^{43}$, und die Vernichtung der einheimischen Dynastien durch die Invasion der Türken, die schließlich die Entstehung türkischer Dynastien im Iran zur Folge hatte. ${ }^{44}$ Die Ghaznaviden und Seldschuken versuchten, ihre Herrschaft durch religiöse Vereinheitlichung abzusichern. Die weitere Bearbeitung der iranischen Heldenepen konnte dagegen als politische Opposition verstanden werden. Cejpek hebt das eskapistische Element des neuen Literaturgeschmacks hervor:

„Erst die Seldschukeninvasion verursachte eine Geschmacksveränderung in der
Kunstliteratur, indem die verheerende Wirklichkeit selbst in Abkehr von der
hilflosen Gegenwart $\mathrm{zu}$ verschiedenen, manchmal sehr romantischen
Erzählungen aufforderte. “45

In den neueren Versionen der iranischen Epen wurde das Tableau der Nebenfiguren um Personen mit arabischen oder türkischen Namen erweitert. Die handelnden Personen ließen sich von Liebe und Religion leiten. ${ }^{46}$ So wurden die Erzählungen über die Vergangenheit des Irans aus ihrer Verankerung in der Geschichte herausgelöst und in eine Märchenwelt übertragen. $^{47}$

Dennoch transportierten, so Hanaway, viele Romane dieser Zeit, etwa das Dārāb-nāme und das Samak-e 'Ayyār, in den Reden und Handlungen ihrer Charaktere und der dort beschriebenen Sozialstruktur viele Erinnerungen an die vorislamische Zeit. ${ }^{48}$

Der Einfluss des ک̌̆āh-nāme auf die historischen und pseudo-historischen Romane (Eskandar-nāme, Vis o Rāmin, Dārāb-nāme, Farāmarz-nāme, Šahriyār-nāme und Ğahāngir-nāme) sowie die religiösen Heldenzyklen Hamze-nāme und Abu Moslem-nāme machte sich in der Sprache, der Darstellung der Helden, der Beschreibung von Schlachtszenen und Naturschilderungen bemerkbar.

Die Seldschuken eroberten Baġdād im Jahr 1055 und beendeten damit die Buyidenherrschaft. Sie übernahmen die Rolle von Vorkämpfern der sunnitischen Orthodoxie. Die Kalifen konnten mit Hilfe der Seldschukenherrscher ihre Macht, die sie an die schiitischen Buyiden

\footnotetext{
${ }^{43}$ Vgl. Hanaway, Jr.,William L.: The Iranian Epics, in: Heroic Epic and Saga: an Introduction to the world's Great Folk Epics, hrsg. von Felix J. Oinas, Bloomington/London 1978, S. 76-98, hier S. 92.

${ }^{44}$ Vgl. Șafā, Hamāse-sarāi dar Irān, S. 156 ff.

${ }^{45}$ Vgl. Cejpek, Jiří: Iranische Volksliteratur, in: Iranische Literaturgeschichte, hrsg. von Jan Rypka, Leipzig 1959, S. 464-548, hier S. 481.

${ }^{46}$ Vgl. Șafā, Hamāse-sarā’i dar Irān, S. 154-159.

${ }^{47}$ Vgl. Hanaway, Jr.,William L.: Epic Poetry, in: Persian Literature, hrsg. von Ehsan Yahrshater, New York 1988, S. 96-112, hier S. 105.

${ }^{48}$ Ders.: Love and War, New York 1974, S. 4.
} 
verloren hatten, wiederherstellen. ${ }^{49}$ Für die iranische Kultur zeigten die Seldschuken wenig Interesse. Die Tatsache, dass die Türken im Iran Fremde waren, war den Seldschukensultanen nicht unbekannt. ${ }^{50}$ Höchstwahrscheinlich verstanden sie überhaupt kein Persisch und konnten deswegen die Feinheiten der persischen Sprache und ihre literarischen Gattungen nicht unterscheiden.

Die sunnitischen Rechtsgelehrten verboten das Lesen iranischer Geschichtsbücher. Im Buch Bạ̣r al-fawã'id lesen wir, dass das Lesen persischer Bücher, die nicht religiösen Inhalts sind, wie die Romane Vis o Rāmin, Ǧāmāsh, Lohrāsh und Vāmeq o 'Azrāan, zur fünften Schande gehören. Das Lesen dieser Bücher könnte zu Ausschweifung oder Ketzerei verführen und damit von der Suche nach Gott ablenken. ${ }^{51}$

Mit diesen Ereignissen trat das Epos in eine für unsere Arbeit entscheidende Phase: jene des Aufkommens religiöser Heldenepen. Solche Erzählungen existierten außer in persischen auch in türkischen und arabischen Versionen und verbreiteten sich oft noch weiter in der islamischen Welt. Ein gutes Beispiel dafür ist die Geschichte von Ḥamze.

\subsubsection{Die schiitische Volksliteratur unter den Seldschuken}

Die Liebe zum Propheten und seinen Verwandten spielte eine große Rolle in der Entwicklungsgeschichte des Islams in seinen unterschiedlichen Ausprägungen. Es existierten populär-religiöse Vorstellungen, die sich in Erzählungen und Gedichten niederschlugen.

Ausgangspunkt und Zentrum der politischen, religiösen und literarischen schiitischen Bewegung war Kūfa am Euphrat. In schiitischen Kreisen waren Erzählungen, in deren Mittelpunkt der Prophet Moḥammad und seine Familie stand, sehr gefragt. Im Folgenden wird das schiitische Erzählgut dargestellt und werden seine Wurzeln untersucht.

Die islamischen hadit-Kompilatoren und die Kenner der Genealogie suchten authentisches Überlieferungsmaterial hinsichtlich der Lebenszeit des Propheten und seiner Familie. Dadurch wollten die islamischen Gelehrten das Leben des Propheten und seiner Familie bestmöglich rekonstruieren. Dazu dienten ihnen ḥādit (Lehrüberlieferungen), maḡāzi (Kriegsberichte), siyar (Prophetenbiographien), manāqeb (hagiographische Literatur) und tabaqāt (Sammelwerke).

\footnotetext{
${ }^{49}$ Vgl. Bosworth, Clifford Edmund: The political and dynastic history of the Iranian World, in: CHI, Vol. 5, Cambridge 1961, S. 1-203, hier S. 45; vgl. Haas, 'Abdülkadir: Die Bektaši, Berlin 1987, S. 20.

${ }^{50}$ Vgl. Neẓām al-Molk, Siyāsat-nāme, hrsg. von Hubert Darke, Teherān 1340/1961, S. 204.

${ }^{51}$ Vgl. Anonymus: Baḥr al-fawā'id, hrsg. von Moḥammad-Taqi Dāneš-Pažuh, Teherān 1345/1966, S. 115.
} 


\subsubsection{Manāqebiyān (Lobredner) und Fażā'eliyān (Vorzugsredner)}

Um die weitere literarische Entwicklung des Irans zu verfolgen, müssen wir an dieser Stelle die Entwicklungsgeschichte der Schia im Iran darstellen. Es existieren zahlreiche Forschungensarbeiten über die politischen Folgen der Ausweitung des islamischen Herrschaftsbereiches, aber fast keine über den Vorgang der Schiitisierung der Gedankenwelt von bereiten Schichten der Bevölkerung. Wir wissen, dass die Mehrheit der Iraner vor dem 16. Jahrhundert Sunniten waren. Wie aber gelang es den Herrschern, die Schia in die Herzen der Bevölkerung zu pflanzen? Die Schiitisierung der Massen war zweifellos ein folgenschwerer historischer Prozess, dessen Ergebnisse in der späteren Volksliteratur sichtbar wurden.

Im 12. Jahrhundert entstanden neue literarische Gattungen. Hier finden wir ein buntes Durcheinander von altiranischen epischen Elementen und islamischen Motiven. $\mathrm{Zu}$ diesem Zeitpunkt begannen sich die volkstümlichen religiösen Erzählgattungen zu verfestigen. Man sieht in dieser Periode die vielfältige gegenseitige Beeinflussung von Hoch- und Volksliteratur in dem Sinne, dass dieselben Motive verwendet wurden, wenn auch zu verschiedenen Zwecken.

Unter den ersten drei Seldschukensultanen Ṭoġril, Alp Arslān und Malekšāh war die Situation der Schia sehr ungünstig. Malekšāhs Wesir Neẓām al-Molk, der selber ein eifriger schafiitischer Sunnit war, schrieb in seinem Buch Siyāsat-nāme (Buch der Politk) den Boykott der Schiiten vor. Die Schia wurde als „üble Lehre“ bezeichnet, ihre Anhänger versuchte man rigoros aus allen öffentlichen Ämtern zu entfernen. ${ }^{52}$ Daher erhalten wir über das literarische Wirken der Anhänger der Schia im Iran im Laufe des 11. und 12. Jahrhunderts nur wenig Auskunft. Wir wissen, was die Schiiten in Theologie und Politik anstrebten. Ihr Hauptinteresse galt natürlich der Verbreitung ihrer Lehre und der Bekämpfung der Sunnitischen. ${ }^{53}$ So entfaltete sich die schiitische Literatur, von der aber nur ein Teil erhalten ist. Die schiitische Literatur speiste sich aus den ,übertreibenden extremen Überzeugungen, die je nachdem aus polemischen, politischen oder enthusiastischen Gründen um das Imamat gesponnen und mit der Zeit zum Volksglauben geworden sind.“54

\footnotetext{
${ }^{52}$ Vgl. Neẓām al-Molk, S. 203 f.

${ }^{53}$ Vgl. Mez, Adam: Die Renaissance des Islam, Heidelberg 1922, S. 56 -68.

${ }^{54}$ Vgl. Falaturi, 'Abd al-Ğavād: Die Zwölfer-Schia aus der Sicht eines Schiiten, in: Festschrift Werner Caskel zum siebzigsten Geburtstag 5. März 1966, hrsg. von Erwin Gräf, Leiden 1968, S. 63-95, hier S. 75.
} 
Im Iran fiel diese Rivalität zwischen beiden Gruppen besonders im Bereich der Literatur auf. Im 12. Jahrhundert gab es im Iran zwei Typen von Erzählern. Die schiitischen manāqebiyān und ihre sunnitischen Gegner fä̇ä'eliyān traten als konkurrierende Geschichtenerzähler auf. ${ }^{55}$ Ein unbekannter sunnitischer Schriftsteller verfasste im Jahr 1160 ein Buch über die Schiiten unter dem Titel Ba'd fậāị ar-rawāfị̣ (Einige Schandtaten der Abgelehnten). Zwar ist es verloren gegangen, wird aber in dem historisch und theologisch wichtigen Werk an-Naqd (Ungültigkeitserklärung) benutzt. Dessen Verfasser, 'Abd al-Ğalil Qazwini Rāzi, der ein zu seiner Zeit hoch geschätzter schiitischer Gelehrter war, versuchte, alle Beschuldigungen gegen die Schiiten zu widerlegen und ihre Erzähler zu verteidigen. Der anonyme Verfasser des Ba'd fậāiọ ar-rawäfị̣, der sehr starke anti-schiitische Tendenzen aufweist, beschuldigte die schiitischen Lobredner u.a., erfundene Geschichten über 'Ali vorzutragen. So zum Beispiel, dass 'Ali ganz allein die Festung Heibar mit ihren 5000 Kämpfern erobert habe. Er soll das Tor von Heibar, das 100 Männer nicht bewegen konnten, mit einer Hand herausgerissen haben; ferner soll er in eine Höhle gestürmt sein, um mit Dschinns (Dämonen) zu kämpfen. ${ }^{56}$ Dies sei bezeichnend für die Gedankenwelt der Schiiten.

Im Laufe der Zeit entstanden immer mehr epische Erzählungen über 'Ali und die Mitglieder seiner Familie wie Hekāyat-e Moḥammad-e hanafìye, ${ }^{57}$ Ğang-nāme-ye Hosein, Dāstān-e Karbalā und Mo'̌ǧezāt va ḥekāyāt maulā Amir al-mo'menin. ${ }^{58}$

An der politischen Zersplitterung der iranischen Bevölkerung hatte die schiitische Propaganda großen Anteil. Die traurig-rührende Geschichte vom Leiden der heiligen Familie des Propheten in Karbalā stellte das wichtigste Motiv des schiitischen Epos dar. Auch die Betonung bestimmter Züge von 'Alis Biografie wie seine Kämpfe im Lande der Dämonen, die Rückkehr der Sonne, das Gespräch mit der großen Schlange, das Tor von Heibar usw. stand im Zusammenhang mit religiös-politischen Auseinandersetzungen innerhalb der islamischen Gesellschaft. ${ }^{59}$ Imām 'Ali wurde von den Schiiten wegen seines Mutes als Vorbild eines vollkommenen Menschen verehrt. Außerdem nahmen die schiitischen Imāme bei den Iranern eine Sonderstellung ein. Nach iranischer Vorstellung hatten sie gewissermaßen den königlichen Glanz (pers. xvarnah) der vorislamischen persischen Tradition übertragen bekommen. Durch die Heirat Ḥoseins, 'Alis jüngerem Sohn, mit Šahr Bānu, der Tochter des

\footnotetext{
55 Vgl. Maḥğub, Moḥammad-Ğa'far: Az manāqebiyān va fażā'eliyān tā rouże-h̆̌̄āi, in: Adabiyāt-e ‘̄mmiyāne-ye Irān, Bd. 2, Teherān 1381/2002, S. 1207-1242, hier S. 1207-1215.

${ }^{56}$ Vgl. Qazwini-Rāzi, Nașer ad-Din 'Abd ar-Rašid 'Abd al-Ǧalil: an-Naqḍ, hrsg. von Moḥammad-Ğa'far Mohaddes-Armu'i, Teherān 1358/1980, S. 66f.

57 Vgl. Storey, Charles Ambrose: Persian Literature, Bd. 1. 1, London 1927-1939, S. 229; Rieu, Charles: Catalogue of the Persian Manuscripts in the British Museum, London 1881, Vol. 2, S. 856.

${ }^{58}$ Vgl. Storey, Bd. 1. 1, S. 231.
} 
letzten sasanidischen Königs Yazdegird III., von der Legenden berichteten, wurden die schiitischen Imāme zu Nachkommen der Sasaniden-Dynastie ernannt. ${ }^{60}$

Im Islam war die Verehrung von Heiligen ursprünglich unbekannt. Allerdings genossen Personen, die sich durch besondere Frömmigkeit auszeichneten, indem sie der Welt entsagten, um allein für Gott zu leben, besondere Hochachtung unter den Muslimen. Bei den Muslimen waren Heilige Vorbilder. Bestimmte Șufis wurden als Wundertäter verehrt und um Beistand in allen Nöten des Lebens angerufen. Sie hatten die Aufgabe, zwischen den Gläubigen und ihrem unerreichbaren, allmächtigen Gott zu vermittlen.

Wir müssen beachten, dass mittelalterliche Darstellungen ein völlig anderes Interesse an ihren Helden hatten als moderne. Die offizielle theologische Lehrmeinung stand der volkstümlichen Glaubensvorstellung entgegen.

\subsubsection{Die Timuriden im Iran (1370-1506)}

Das 14. und 15. Jahrhundert bildete für den Iran in wirtschaftlicher, politischer und religiöser Hinsicht einen wichtigen Zeitabschnitt. In dieser Zeit erfuhren Handwerk und Handel, besonders mit landwirtschaftlichen Erzeugnissen, einen großen Aufschwung. Die einschneidendsten Veränderungen des sozialen und kulturellen Lebens brachte die Entwicklung des Städtewesens. Die Städte waren zugleich politische Zentren und militärische Stützpunkte. Seit dem 14. Jahrhundert verlief die Entwicklung der Städte parallel zur Konsolidierung der politischen Macht. Im Laufe des 14. Jahrhunderts wurden viele Städte und Märkte durch die mongolischen Herrscher, die Il-Khane (1220-1350) gegründet. Wichtigster Teil einer Stadt war der Markt. Die größte Bevölkerungsgruppe in den iranischen Städten waren die Handwerker. Bis zum 15. Jahrhundert stieg ihre Zahl stark an und sie schlossen sich zu Zünften zusammen. In der Regierungszeit der timuridischen Fürsten verbesserte sich die wirtschaftliche Lage. Sie hatten Interesse daran, die Städte, die durch Timur zerstört worden waren, wieder aufzubauen. Šāhroh und Ulug Beg widmeten sich dieser Aufgabe. Die Handelsstraßen dehnten sich hauptsächlich von Osten nach Norden aus (nach China und von Harāt über Kābul nach Indien). Zahlreiche Städte, besonders Eṣfahān, Harāt und Širāz, entwickelten sich zu blühenden Wirtschaftenszentren; außerdem wurden sie zu Mittelpunkten

\footnotetext{
${ }^{59}$ Strothmann, Rudolf: Die Zwölfer-Schī $a$ : zwei religionsgeschichtliche Charakterbilder aus der Mongolenzeit, Leipzig 1926, S. 63.

${ }^{60}$ Spuler, Bertold: Iran in früh-islamischer Zeit. Politik, Kultur, Verwaltung und öffentliches Leben zwischen der arabischen und der seldschukischen Eroberung, Wiesbaden 1985, S. 231.
} 
von Kunst und Wissenschaft. ${ }^{61}$ Der Aufstieg des Bürgertums machte sich auch im Literaturbetrieb bemerkbar.

Die Feindseligkeit zwischen Sunniten und Schiiten war zu diesem Zeitpunkt nicht mehr so stark wie früher. Die Verehrung 'Alis als Hauptglied der mystischen Kette der Șufi-Meister nahm bei Schiiten und Sunniten eine besondere Stellung ein. Letztere begannen allmählich große Symphatien für 'Ali zu zeigen.

Nach den Wirren der mongolischen Eroberung folgte nun eine Zeit der Entspannung. Ein Kennzeichen war die Neubelebung und Verinnerlichung des religiösen Lebens. Dies äußerte sich im Aufschwung religiöser Bruderschaften.

\subsubsection{Volkstümliche Religiösität im 15. Jahrhundert}

Das 15. Jahrhundert ist durch das Erstarken eines volkstümlichen Islam gekennzeichnet, einer theologiefernen Glaubenshaltung mit starker Zunahme des Wunderglaubens, abergläubischer Praktiken, des Ordenwesens und der Heiligenverehrung. Alles dies sind Erscheinungen, die sich erst nach der Entmachtung der 'abbasidischen Kalifen und dem Verfall der sunnitischorthodoxen Theologie unter den Mongolen verbreiten konnten.

Das einfache Volk beschäftigte sich nicht mit tiefgreifenden theologischen Diskussionen. Solche Themen wurden in islamischen Schulen von Studenten und Theologen diskutiert. Es suchte hingegen einfache religiöse Formen für das alltägliche Leben. Die Versammlungen in den Derwischkonventen, gemeinsame żekr (Gebetsformeln), sam̄̄`(ekstatische Tänze) und die religiösen Erzählungen, die dort vorgetragen wurden, waren für das einfache Volk die bestimmenden Formen des islamischen Glaubens. Um sich Legitimität zu verschaffen, bezeichneten sich die Ordensmeister als Nachkommen des Propheten Mohamamad. ${ }^{62}$ Sie verbreiteten weitere Erzählungen über die Mitglieder der Prophetenfamilie, die in den Augen des Volkes als eine Macht angesehen wurde, die in der Lage war Wunder zu vollbringen.

Die schiitische Propaganda war zu diesem Zeitpunkt sehr stark, so dass die Timuriden sich gezwungen sahen, die schiitischen Imāme zu verehren. Ein gutes Beispiel dafür ist das Verhältnis des Nachfolgers Timurs, Šāhroh, zur Schia. ${ }^{63}$ In dieser Zeit soll die 'AliVerehrung im Iran eine Blütezeit erlebt haben. Die Schiiten verbreiteten sich nicht nur in den traditionellen Zentren der Schia, wie Gilān, Mazandarān, Huzestān, Rey, Qom, Kāšān und

\footnotetext{
${ }^{61}$ Vgl. Roemer, Hans Robert: Persien auf dem Weg in die Neuzeit. Iranische Geschichte von 1350-1750, Beirut 1989, S. 134.

${ }^{62}$ Die șafavidische Könige, die eigentlich aus einer kurdischen Familie stammten, hatten sich erlaubt einen alidischen Stammbaum für sich zu beanspruchen und sich als Nachkommen des siebten Imām Musā alKāzim zu bezeichnen. Siehe: Halm, Heinz: Die Schia, Darmstadt 1988, S. 109.

${ }^{63}$ Vgl. Amoretti, Biancamaria Scarcia: Religion in the Timurid and Safavid Periods, in: CHI, Vol. 6, hrsg. von Peter Jackson, London/New York/New Rochelle/Melbourne/Sydney 1986, S. 610-658, hier S. 612.
} 
Sabzevār in Horāsān, sondern auch in den sunnitischen Regionen. Auf literarischem Gebiet benutzten die Schiiten für ihre Machtausübung neben dem ritterlich-höfischen Roman den pseudohistorischen und religiösen Heldenzyklus, eine Ausweitung bekannter Heldengeschichten zu umfangreichen Verserzählungen. Sie waren zunächst für die Oberschicht des Militärs gedacht, wendeten sich dann immer mehr an ein breiteres Publikum, dessen literarisches Bedürfnis sie befriedigen wollten.

„Zu dieser Zeit (15. Jahrhundert) entfaltete sich die schiitische Dichtkunst und man kann sagen, dass diese Epoche der eigentliche Ausgangspunkt der Verbreitung der schiitischen Dichtkunst ist. “64 Viele schiitische Werke entstanden, darunter das Buch Divān Hāvarānnāme, das im Jahr 1427 von Maulānā Moḥammad Ḥosām ad-Din aus Hosaf in Horāsān (gest. 1470) verfasst wurde. ${ }^{65}$ Das alte Ethos der Heldendichtung, welches das Š̆āh-nāme beherrschte, wurde auch im Divān übernommen; hinzu kamen noch Abenteuerlust und Fabulierfreude der damaligen Zeit. Es handelte sich um die Kämpfe 'Alis und seiner Genossen Mālek und Abu 'l-Meḥğan gegen heidnische Fürsten, vor allem Qobād, den König von Huāvarān. ${ }^{66}$

In solchen Werken, in denen vorislamische Elemente gewissermaßen in den schiitischen Charakter eingearbeitet wurden, ist 'Ali der Verteidiger der Schwachen und der Helden, die sich in Gefahr befinden. ${ }^{67}$ Er nimmt den Platz der guten Geister des Heidentums ein. Soroudi vermerkt, dass 'Ali neben seiner hohen religiösen Stellung den Rang eines nationalen iranischen Helden, dessen Verehrung in engem Zusammenhang mit patrotischen Gefühlen steht, bekleidet. ${ }^{68}$

Die Zeit der Mongolen und Timuriden brachte den Iranern einschneidende Veränderungen auf gesellschaftlichem und literarischem Gebiet, wobei sich gesellschaftlicher Wandel erst nach einer gewissen Zeit auf die Literatur auswirkte, deren Inhalte sich unter Beibehaltung von Form und Stil nach und nach veränderten. Während in der alten persischen Dichtung im Heldenepos hauptsächlich das Nationalgefühl seinen Ausdruck fand, wurde dieses später unter der Herrschaft der Mongolen und Timuriden von der islamischen Religion abgelöst.

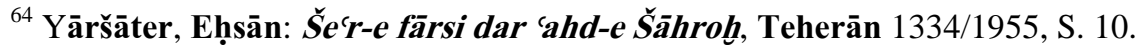

${ }^{65}$ Vgl. Ethé, Hermann: Neupersische Literatur, in: Grundriss der iranischen Philologie, zweiter Band, hrsg. von Wilhelm Geiger u. Ernst Kuhn, Strassburg 1896-1904, S. 212-368, hier S. 235; vgl. Șafā, Hamāse-sarā’i dar Irān, S. 378.

${ }^{66}$ Ethé, Neupersische Literatur, S. 235.

${ }^{67}$ Anonymus: $R H$, Bd. 2, S. 284-285.

${ }^{68} \mathrm{Vgl}$. Soroudi, Sarah Sorour: Islamization of the Iranian national hero Rostam as reflected in Persian folktales, in: Jerusalem Studies in Arabic and Islam II, Jerusalem 1980, S. 365-385, hier S. 376.
} 


\subsubsection{Pseudohistorische und religiöse Heldenzyklen}

Für die Beantwortung der Frage nach dem Verhältnis von einer national geprägten Dichtung zu den pseudohistorischen und -religiösen Heldenzyklen, bietet diese Arbeit zwei Grundpositionen an: Entweder werden die Veränderungen von Stil- und Ausdrucksformen als strikter Bruch empfunden, oder man legt sie als eine innere Entwicklung aus, die sich allmählich anbahnt.

Es ist zu berücksichtigen, dass die Diskussion über den pseudoreligiösen Heldenzyklus bisher noch zu keinem befriedigenden Abschluss gelangt ist. Der Einfluss von einer national geprägten Heldendichtung der Frühzeit auf spätere Werke wie $R H$ und $E N$ ist zu verdeutlichen. Die großen Kriegsschilderungen, wie sie uns im $R H$ begegnen, sind besonders charakteristisch für eine bestimmte Art der Darstellung und einen geistigen Hintergrund, auch dort, wo 'Ali oder Hamze als eine Kopie von Rostam erscheinen.

Der Unterschied zwischen den pseudohistorischen bzw. religiösen Heldenzyklen und dem nationalen Epos ist nicht so groß: in beiden Bereichen werden Grundzüge der iranischen Mentalität dargestellt.

Es wird zu klären sein, unter welchen Voraussetzungen sich die pseudohistorischen bzw. religiösen Heldenzyklen von den früheren national geprägten Epen als eigenständig abgrenzen, zumal die Verfasser pseudohistorischer bzw. religiöser Heldenzyklen vor einem anderen gesellschaftspolitischen Hintergrund in Erscheinung treten als die Erzähler der frühen Heldenepen.

Es ist die veränderte Struktur des Zeitalters, auf die man sich von der Quellenkunde her als Kriterium vielfach berufen hat. In der Tat lässt sich deutlich machen, dass der Übergang vom Nationalepos zu den pseudohistorischen und-religiösen Heldenzyklen am Ende des ersten Jahrzehnts des 12. Jahrhunderts einer bestimmten gesellschaftlichen Entwicklung zuzusprechen ist.

In dieser Zeit machen sich Anzeichen bemerkbar, die generell für das Aufkommen einer neuen Bewertung von Kunst zu sprechen scheinen.

Da die Erzähler bemüht waren, die Gunst des Publikums zu gewinnen, mussten sie darauf bedacht sein, ihm zu gefallen. Zu fragen wäre nach den Erwartungen des Publikums, die überwiegend von einem religiösen Gefühl (schiitisch/sunnitisch) geprägt waren, wobei die Schiiten mit der Zeit eindeutig an Macht gewannen und damit bewirkten, dass der pseudohistorische bzw. religiöse Heldenzyklus inhaltlich zu frühislamischen schiitischen Glaubenswerten zurückkehrte. 
Die spätmittelalterliche iranische Volksliteratur liefert eine Fülle an heroischen Zyklen, die unter dem Gattungsnamen ḩamāse-ye mazhabi (religiöses Epos) und ḥamāse-ye tārihi (historisches Epos) zusammengefasst werden. Wie bei einem Epos üblich sind die Helden dieser Erzählungen historische oder semihistorische Persönlichkeiten. Die Hauptfiguren im Eskandar-nāme (Alexanderroman), im Ğahāngir-nāme, eine epische Geschichte über Ğahāngir den Sohn des Rostam, und im $R H$ sind Vorkämpfer des Islams. Es gibt wichtige inhaltliche Unterschiede dieser Werke besonders dort, wo Dämonen und Zauberer auftreten. Von derartigem Inhalt ist der Roman Abu Moslem nahezu frei.

Ein Heldenepos, in dessen Mittelpunkt ein historischer Held steht, wird von den Erzählern nicht selten, um dem Geschmack der Zuhörer zu entsprechen, fantasievoll ausgeschmückt und zu einem Zyklus erweitert.

\title{
1.1.2.3 Die verschiedenen Erzählergruppen in der Timuridenzeit
}

Für den Stand der Erzählkunst unter der Herrschaft der Timuriden haben wir eine ausgezeichnete Quelle aus dem Persischen unter dem Titel Fotovvat-nāme-ye soltāni (Verfasser Kamāl ad-Din Họosein Vāeez Kāšefi, gest. 1504), die besonders reiche Informationen über die Erzähler enthält, die auf Straßen und Plätzen u.a. Lobreden und Sagen anboten. In dieser Quelle stoßen wir auf das arabische Wort ma'reke, das ursprünglich Schlachtfeld bedeutet, aber auch für Versammlungsort steht ${ }^{69}$, wo jeder seine künstlerlischen Fähigkeiten darbieten kann. Es treten u.a. maddāḥān (Lobredner), qeș̣ee-guyān (Erzähler, die religöse Geschichten vortragen) und afsāne-guyān (Erzähler, die Geschichten aus dem Bereich der Sagen anbieten) auf. ${ }^{70}$ Die Lobredner bieten Kāšefi zufolge vier verschiedene Arten des Vortrages an:

\begin{abstract}
„Wenn die Leute fragen, wie viele Arten des maddāḥ es gibt, sage: Die maddāḥān hatten vier verschiedene Darstellungsformen: Die erste Gruppe heißt maddāḥ-e sāde-h̆ª̄n [Lobredner, die einfach singen]. Sie singen Gedichte auf Arabisch oder Persisch. Die zweite Gruppe heißt gàrrā-ȟ̄ānān [Lobredner, die in Prosaform singen]. Sie singen die Geschichten und Wundertaten des Propheten in Prosaform. Die dritte Gruppe heißt morașșa ȟān [Lobredner, die ihre Gesänge ausschmücken]. Sie lesen in Prosa und Versen. Die vierte Gruppe bilden diejenigen, die verschiedene Versformen gelernt haben. Sie gehen von Tür zu Tür und verkaufen ein panegyrisches
\end{abstract}

\footnotetext{
${ }^{69}$ Vgl. Vā'ez Kāšefi Sabzevāri, Kamāl ad-Din Ḥosein: Fotovvat-nāme-ye solțāni, hrsg. von MoḥammadĞa'far Mạ̣ğub, Teherān 1350/1971, S. $275 f$.

${ }^{70}$ Ebd. S. 280.
} 
Gedicht/Elegie gegen ein Stück Brot. [...] Äußerlich ähneln sie den maddāḥān, aber in Wirklichkeit gehören sie nicht zu ihnen. “" 71

Über die Erzähler schreibt er weiter:

„Wenn die Leute fragen, wie viele Arten des Erzählens es gibt, sage: zwei. Erstens diejenige, welche in Prosaform erzählt. Zweitens diejenige, welche die Erzählungen in Versform fasst: qeșṣe-h̆̌ānān und afsāne-h̆̌ānān. “72

In der zweiten Hälfte des 15. Jahrhunderts hat Mir 'Ali-Šir Navā'i, Minister des Solțān Ḥosein Baiqarā, eine Liste aller Zünfte und der dazu gehörenden Berufe aufgestellt. Auf dieser Liste standen die ma'reke-girān (Straßendarsteller) an zehnter Stelle und die naqqāls (Erzähler) an achtzehnter. ${ }^{73}$

\subsubsection{Iran unter den Șafaviden (1501-1722)}

Šāh Esmā̄il, der Begründer der Șafaviden-Dynastie, war ursprünglich das Oberhaupt einer extrem-schiitischen Șufi-Bruderschaft. Über seine wichtigste Lehre schreibt Halm:
„Muḥammad, 'Ali, die Imame und Schah Ismā'il selbst sind nichts anderes als die Hüllen, in denen sich das göttliche Licht (nūr-e elāhi) von der Erschaffung der Welt an in immer neuen Verkleidungen präsentiert hat. “74

Nach der Einnahme von Tabriz verkündete Šāh Esmācil die Zwölferschia als Staatsreligion, um die verschiedenartige Bevölkerung seines Reiches durch eine gemeinsame Glaubensvorstellung zu verbinden. Er selbst war Oberhaupt dieser Staatsreligion und nahm den Titel moršed (Ordensmeister) an. Er genoss ein so hohes religiöses Ansehen, das es ihm erlaubte, als einziger Repräsentant und Stellvertreter des verborgenen Zwölften Imāms aufzutreten. In der Person des ṣafavidischen Königs vereinte sich so die höchste religiöse und weltliche Autorität zu einem universalen Herrschaftsanspruch, wie es ihn in dieser Form seit dem Sturz des 'abbasidischen Kalifats nicht mehr gegeben hatte. Šāh Esmā̄il wurde sofort zu einer Heldenfigur, die von seinen Anhängern fast wie ein Gott verehrt wurde. ${ }^{75}$ Aus der volkstümlichen Überlieferung wissen wir, dass der zweifache Herrschaftsanspruch des Šāh

\footnotetext{
${ }^{71}$ Ebd. S. 286.

${ }^{72}$ Ebd. S. 304.

${ }^{73}$ Vgl. Bouvat, Lucien: Essai sur la Civilization Timouride, in: Journal Asiatique, Avril-Juin (1926), S. 193-299, hier S. 200.

${ }^{74}$ Halm, Heinz: Die Schia, Darmstadt 1988, S. 105.

${ }^{75}$ Vgl. Barbaro, Josefa and Contarini, Ambrogio: Travels to Tana and Persia, ins Englische übersetzt. von William Thomas, London 1873, S. 202 ff.
} 
Esmā'il auf einer Begegnung mit 'Ali im Traum gründete und einem Zusammentreffen mit dem Mahdi in der Realität, die ihn als künftigen Herrscher begrüßten. ${ }^{76}$

Die Iraner erfuhren während der Dynastie der Șafaviden auf geistigem Gebiet eine Förderung ihrer volkstümlichen Literatur, die bereits unter Esmā'il einen Höhepunkt erreichte. Esmā̄ils Begabungen übten auf die Turkmenen eine besondere Anziehungskraft aus. ${ }^{77}$ Er verfasste unter dem Dichternamen Hatâ̄ì Gedichte auf Türkisch, die eine beachtliche Popularität gewannen. $^{78}$

Mit seiner literarischen Tätigkeit verfolgte Šāh Esmācils zwei Ziele: in seinen Gedichten ging es erstens um die Darstellung und die Verbreitung der Schia besonders in den von ihm als Kriegsführer eroberten Gebieten und zweitens um die Herausforderung einer Bereitschaft zum Kampf unter seinen Anhängern.

Auf Šāh Esmācil folgte sein Sohn Ṭahmāsb I. (reg. 1524-1579), der das geistige Erbe seines Vaters fortführte, indem er u.a. zahlreiche schiitische Gelehrte aus dem Südirak und dem Südlibanon in den Iran berief. ${ }^{79}$

Die Verbreitung der Schia im Iran geschah nicht reibungslos, denn die Mehrheit der Bevölkerung war sunnitisch, ${ }^{80}$ und musste erst dazu gebracht werden, sich zur Schia zu bekennen, wozu neben den Theologen auch die Erzähler hauptsächlich beitrugen. Für die Arbeitsweise der Erzähler in der Regierungszeit des Šāh Esmācil bietet Sādāt Eškevari interessante Zeugnisse an:

\footnotetext{
„Šāh Esmāicil hat siebzehn Gruppen beauftragt, dass sie die Religion propagieren. Jede Gruppe hatte ihre eigene Kleidung und Sprache und machte Propaganda auf ihre Art. Einige Gruppen hielten für das Heer Reden über die Heldentaten 'Alis und seine herausragenden Eingenschaften. “" 81
}

\footnotetext{
${ }^{76}$ Vgl. Anonymus: ‘̄̄̇lam-ārā-ye Šāh Esmāîl, hrsg. von Aṣgarar Montaẓam-Ṣāḥeb, Teherān 1349/1970, S. 38 ff; vgl. Glassen, Erika: Schah Ismāīil, ein Mahdī der anatolischen Turkmenen, in: ZDMG 121 (1971), S. 6169, hier S. 69.

${ }^{77}$ Vgl. Kehl-Bodrogel, Krisztina: Die Kizilbaş/Aleviten, Berlin 1988, S. 18-26.

78 Vgl. Caferoğlu, Ahmet: Die aserbeidschanische Literatur, in: Philologiae Turcicae Fundamenta, Bd. II, Wiesbaden 1965, S. 635-699, hier S. 646.

${ }^{79}$ Halm, Heinz: Der schiitische Islam. Von der Religion zur Revolution, München 1994, S. 121.

${ }^{80}$ Vgl. Spuler, Bertold: Die Kultur des islamischen Ostens, in: Handbuch der Kulturgeschichte. Die Kultur des Islam Abt. 2, hrsg. von Eugen Thurnher, Frankfurt am Main 1971, S. 209-327, hier S. 245.

81 Sādāt-Eškevari, Kāẓem: Naqqāli va Šāh-nāme-ȟ̄āni, in: Honar va Mardom, Nr. 153, Tir va Mordād Teherān 1354/1975, S. 142-151, hier S. 146; vgl. Caferoğlu, S. 641-644.
} 


\subsubsection{1 Šāh-nāme-h̆̌ānān (Sänger des Königsbuches)}

Jean Chardin, der in der șafavidischen Zeit in den Iran reiste, schreibt: „Um auf den königlichen Festen eine Atmosphäre der Fröhlichkeit zu schaffen, bezahlte der König Tänzer, Sängerinnen, Erzähler, Dichter, Schauspieler und Narren. ${ }^{682}$

Zu dieser Zeit wurden die Erzähler, die im Allgemeinen hoch gebildete Dichter und Literaten waren, danach eingeteilt, welchen Erzählstoff sie anzubieten hatten. In den Kaffeehäusern, ${ }^{83}$ auf den Schlachtfeldern vor Beginn eines Krieges ${ }^{84}$ und an den Höfen ${ }^{85}$ lasen die

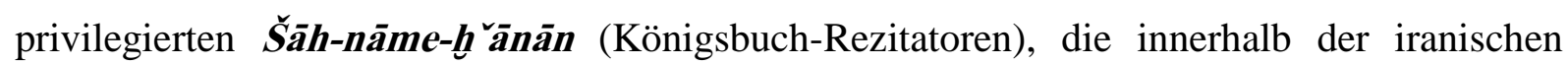
Gesellschaft aufgrund ihres Wissens hinsichtlich der Heldenepen eine herausragende Stellung einnahmen. Die șafavidischen Könige hielten in der Regel einen Königsbuch-Rezitator an ihrem Hof. In den Dichterbiographien erfahren wir etwas über deren Erzählungen aus dem Königsbuch.

\subsubsection{Qeș̣e-h̆̌ānān (religiöse Märchenerzähler)}

Die frühislamischen Quellen wie Geschichtsschreibung, Rechtsliteratur, kanonische Sammlungen der Aussprüche Moḥammads sowie die großen geisteswissenschaftlichen Werke geben uns Auskunft über Aufgaben und Bedeutung der Prediger, die als hatib (Freitagsprediger), wā' ę (Prediger), qāṣ̣ (freie Redner) und als ḥāki (Imitatoren) auftraten. Die Freitagsprediger erzählten in der Moschee religiöse Geschichten. ${ }^{86}$ Neben ihnen gab es auch die freien Redner in der Moschee. ${ }^{87}$ Die Prediger warnten die Gläubigen vor dem Strafgericht Gottes und riefen zur mou'eze (Umkehr) auf. Ihre Predigt begannen sie häufig mit Koranzitaten und Auslegungen, an die sich Ansprachen theologisch-politischen Inhalts anschlossen. Schließlich beantworteten sie Fragen aus dem Publikum und beendeten ihren Auftritt mit Koranrezitationen, Sprüchen des Propheten, Legenden oder anderen frommen Geschichten. Die quṣșāṣ (Sing. qāṣ̦s/freie Redner) wurden als Vermittler religiöser Stoffe

\footnotetext{
${ }^{82}$ Vgl. Chardin, Jean: Voyages du chevalier Chardin en Perse et autres lieux de Orient, Paris 1811, S. 126; Kaempfer, Engelbert: Am Hofe des persischen Grosskönigs (1684-85), hrsg. von Walther Hinz, Leipzig 1940, S. 205.

${ }^{83}$ Ġaribpur, Behruz: Te’ātr dar Irān, Teherān 1384/2005, S. 27; Nağm, Nāṣer: Dār al-halāfe Tehrān, Teherān 2536/1976, S. 189f.

${ }^{84}$ Vgl. Lesān, Hosein: Šāh-nāme-ȟ̃āni, in: Honar va Mardom, 14 Jahrgang, Nr. 159-160, Dey va Bahman, Teherān 1354/1975, S. 2-16, hier S. 12.

${ }^{85}$ Vgl. Naṣrābādi-Eṣfahāni, Mirzā Moḥammad-Ṭāhir: Tažkere-ye Naṣrābādi, hrsg. von Vaḥid Dastgerdi, Teherān 1317/1938, S. 307; Falsafi, Naṣrallāh: Zendegāni-ye Š̄a 'Ábbās-e avval, Bd. 2, Teherān 13391344/1960-1965, S. 67.

${ }^{86}$ Irwin, Robert: The Arabian Nights, aus dem Englischen ins Persische übersetzt. von Feridun Badrei, Teherān 1383/2004, S. 119.

${ }^{87}$ Vgl. al-Ğāḥīụ, Abū 'Uțān 'Amr b. Baḥr: Al-bayān wa-'t-tabȳin, Teil 1, tạ̣qīq Moḥammad 'Abd asSālām Hārūn, al-Qāhîra 1388 h/1968, S. 367; 368; Ġazzāli Ṭusi, Zain ad-Din Ảbu Ḥāmid Moḥammad:
} 
angesehen; ihr Wirken ist seit dem ersten Jahrhundert der hĕgrri (arab. al-hiğra bezeichnet die Auswanderung Moḥammads von Mekka nach Medina. Sie markiert den Beginn des Mondkalenders der islamischen Zeitrechnung) belegt. ${ }^{88}$

Bei der Entstehung und Weitergabe der populären Religionsgeschichten spielten die qușșās eine große Rolle, indem sie die Inhalte vielfach ausschmückten u.a. mit Hinweisen auf ewige Verdammnis. ${ }^{89}$ Quellen aus frühislamischer Zeit stellten diese freien Redner als Verfälscher religiöser Texte und Volksbelustiger dar, worin die Rechtsgelehrten eine Gefahr für das Gesetz sahen. ${ }^{90}$ Ibn al-Ğawzī führt z.B. an, dass sich die quș̣̦āṣ mit dem Inhalt der Offenbarung, wie er gepredigt wurde, nicht zufrieden gaben und diesen daher durch Begebenheiten ergänzten, welche vom Judaismus und anderen Religionen her bekannt waren $^{91}$, dass sie ferner historische Ereignisse verfälschten, da sie nur unzureichende und oberflächliche Kenntnisse des Koran und der sunna besaßen. ${ }^{92}$

Die quṣsāṣ nutzten die populär-religiösen Vorstellungen aus dem Bereich der Kosmologie, ${ }^{93}$ der Prophetologie,${ }^{94}$ der Eschatologie,${ }^{95}$ der Dämonologie und der Liebesgeschichten als Erzählstoffe. ${ }^{96}$ Es gelang ihnen, die Zuhörer zu faszinieren, sie zum Weinen zu bringen, ${ }^{97}$ und Angst einzujagen, indem sie die Schrecken des Jüngsten Gerichtes und der Hölle schilderten. ${ }^{98}$ Die Lehre des Islams, streng dargeboten von den Theologen und Predigern, wurde dem einfachen Volk durch die freien Redner anschaulich und daher leichter begreifbar gemacht; sie unterstützten ihren Vortrag durch Bewegung, Gestik und Mimik, in einer Art frommer Unterhaltung (pers. qeșse).

Die Märchenerzähler im iranischen Raum waren die qeș̣e-guyān. Ihre Texte waren meistens kurz und volkstümlich und erfreuten sich einer großen Zuhörerschaft. Vermutlich wurden sie von ihren arabischen Kollegen inspiriert. Bei der Verbreitung des Islams im Osten des Irans

Ketāb-e kimiyā-ye sa‘ādat, hrsg. von Aḥmad Ārām, Teherān 1333/1954, S. 406; Omidsālār, Maḥmud: Storytellers in Classical Persian Texts, in: JAFS, Vol. 97, Nr. 384, April-June (1984), S. 204-212.

88 Wolfensohn, Israel: Ka'b al-A ḩbār und seine Stellung im hadị und in der islamischen Legendenliteratur, Jerusalem 1933, S. 62.

${ }^{89}$ Vgl. Zarrinkub, 'Abd al-Ḥosein: Serr-e nei, Teherān 1372/1993, S. 125-131.

90 Vgl. insgesamt zu diesem Kontext: Ibn al-Ğawzi, Abū al-Farağ: Kîtāb al-quṣsạṣ wa al-muḍakkirīn. Including a Critical Edition, Annotated Translation and Introduction. by Merlin L. Swartz, Beyrout 1971, S. 57.

${ }^{91}$ Ibn al-Ğawzī, S. 10; 103; Goldziher, Ignaz: Muhammedanische Studien, Bd. II, Halle 1890, S. 164.

92 Ibn al-Ğawzī, S. 25; 102.

${ }^{93}$ Maqdisī, Abū-Zeid Aḥmad b. Sahl al-Balh̄i Muṭahhar b. Ṭāhir: Kitāb al-bad' wa-'t-Tārīhn, Teil 2, hrsg. von Clément Haurt, 6 Teile in 2 Bänden, Paris 1899-1907, S. 50.

${ }^{94}$ Ibn al-Ğawzī, S. 19; 103.

${ }^{95}$ Ibn al-Ğawzì, S. 114.

${ }^{96}$ Ibn al-Ğawzī, Abū al-Farağ: Talbis-e Eblis, ins Persische übersetzt. von 'Ali-Reżā Znakāvati-Qarāqözlu, Teherān 1368/1989. S. 102; Ibn al-Ğawzī, Kitāb al-quṣ̣āṣ wa al-mudhakkirīn, S. 115.

${ }^{97}$ Ibn al-Ğawzī, Kitāb al-quṣ̦āṣ wa al-muḍhakkirīn, S. 114.

98 Ebd. S. 19; Heath, Peter: Arabische Volksliteratur im Mittelalter, in: Neues Handbuch der Literaturwissenschaft, Bd. 5, Klaus von See (Hrsg.), Wiesbaden 1990, S. 423-439, hier S. 430. 
spielten sie eine bedeutende Rolle. Ibn Qutayba teilte mit, dass es in der Stadt Marv einen qāṣ̦ (Erzähler) gab, der seine Zuhörer mit einer Geschichte zum Weinen und danach mit einer anderen zum Lachen bringen konnte. ${ }^{99}$

Im politischen Machtstreben gewannen Reden mit religiösem Inhalt immer mehr an Bedeutung. Aț-Tabari berichtete, dass nachdem Abu Moslem mit seinem Heer von Sefidang nach Māhnān gezogen war, er den Naqib b. Muğāšíc zum Richter ernannte, der dort als Vorbeter nach dem Nachmittagsgebet Geschichten erzählte. ${ }^{100}$

Im Laufe der Zeit gerieten die religiösen Erzähler immer mehr in den Ruf von Scharlatanen und Lügnern; ${ }^{101}$ sie wurden daher von den Theologen und Rechtsgelehrten verachtet und der bid'a (Ketzerei) bezichtigt. ${ }^{102}$ Moḥammad b. Isḥāq Ḥamawi führte an:

„,Die betrügerischen qeșṣe-h̆̌ānān [Geschichtenerzähler] fügten der Biographie des Mohntār ibn Abi 'Ubaydah und des Ibrāhīm b. Mālek-e Aštar viele lügenhafte Erzählungen hinzu. Sie erfanden eine Sage über Moḥtār und nannten sie Moḩtār-nāme oder Haftād o du horuğ. Die einfachen Leute schrieben von diesem Buch viele Exemplare ab. Sie betrachteten das Buch als ein Heiligtum. Sie glaubten, dass das Buch von der Lüge frei sei.“103

Der Vorworf, den Ḥamawi als strenggläubiger Muslim gegen die Erzähler erhob, ist durchaus berechtigt. Es ist jedoch fraglich, ob seine Kritik Wirkung zeigte.

Wir wissen, dass vom 15. bis zum 17. Jahrhundert viele religöse Bewegungen entstanden. Dazu zählen die Anhänger häretischer Glaubensrichtungen z.B. die noqtaviyān bzw. ahl-e noqțe, die auf Maḥmud Gilāni zurückgehen, der um 1400 eine Lehre verkündet hatte, in der die Seelenwanderung eine wichtige Rolle spielte. Das Volk jedoch zeigte wenig Toleranz gegenüber den Erzählern, die ihrer Meinung nach ketzerische Themen anboten, und dadurch ihr Leben gefährdeten, wie es der Erzähler Moulānā Nassri aus Gilān tat. Dieser wurde, obwohl er ein sehr guter Geschichtenerzähler war, der Ketzerei beschuldigt und von dem Sohn des Mohntār Solțān Šaraf ad-Din getötet. ${ }^{104}$

\footnotetext{
${ }^{99}$ Zitiert nach: Bahār, Moḥammad-Taqi: Sabk-šenāsi, Bd. 2, Fußnote, S. 134.

100 aṭ-Ṭabari, Abū Ğa'far Moḥammad b. Ğarīr: Tārih al-'umam wa al-mulūk, ğuz. 6, hrsg. von Muṣtfā, Moḥammad, Kairo 1358 h/1939, S. 34.

101 al-Mas'ūdī, Abū al-Ḥasan 'Ali b. al-Ḥusain: Murūğ ad̆-ḍahab wa al-ma'ādin al-ğawāhir, hrsg. von 'Abd al-Ḥamid, Moḥammad Muḥī ad-Din, Teil 3, Miṣr 1377h/1958, S. 44; vgl. Mez, S. 315; vgl. Pauliny, Jan: Zur Rolle der qușșāṣ bei der Entstehung und Überlieferung der populären Prophetenlegenden, in: Asian und African Studies, Vol. 10, Bratislava 1974, S. 125-141.

102 Hamawi, Moḥammad ibn Isḥāq: Anis al-mo'menin, hrsg. von Mir Hāšem Moḥaddeș, Teherān 1363/1984, S. 141; vgl. Esmāicili, Hosein: Abu Moslem-nāme, Bd. 1, Teherān 1380/2001, S. 53-66; vgl. Babayan, Kathryn: Mystics, Monarchs and Messiahs, London 2002, S. 145; Ğáfariyān, Rasul: Din va siyāsat dar doure-ye Șafaviyān, Teherān 1370/1991, S. 234-237; Wolfensohn, S. 62.

103 Hamawi, S. 117.

104 Șadeqi-Ketābdār: Mağma'al-havāṣ. Aus dem Tschagataischen ins Persische übersetzt. von 'Abd ar-Rasul Hayyāmpur, Tabriz 1337/1958, S. 294.
} 
Um eine Literatur zu fördern, die abseits jeglicher Legendenbildung nur dem wahren Glauben dienen sollte, schrieb u.a. ein Gelehrter wie Moḥammad Bāqer Mağlesi (1627-1700), der einer der wichtigsten schiitischen Theologen des 17. Jahrhunderts war, über das Leben des Propheten und der schiitischen Imāme. Meskub zitiert in seinen Buch Hoviyat-e irāni va zabān-e färsi den Gelehrten Mağlesi:

„Die schlechtesten Überlieferungen sind die lügenhaften Überlieferungen [...] wie Šāh-nāme und andere Erzählungen, die von Ungläubigen und den Feueranbetern handeln. Manche Gelehrte fordern, diese zu verbieten. “105

Danach führte Mağlesi einige Aussagen von Propheten und des Imām Moḥammad-Taqi an, wonach die Erinnerungen des 'Ali b. Abi Ṭāleb wie ein Gebet und das Anhören von lügenhaften Märchen und Sagen der Feueranbeterein Zeichen für Heuchelei und Denunziantentum waren.

\subsubsection{3 Șurat-ḩॅānān (Geschichtenerzähler/Bänkelsänger)}

Die politischen Auseinandersetzungen des iranischen Volkes mit den Türken, die Unruhen verursachten, und die Bestimmung der Schia zur Staatsreligion zu Beginn des 16. Jahrhunderts bildeten vorzugsweise den Inhalt von Predigten und Erzählungen. Die șurath้ॅ̄ān (eine Art Bänkelsänger) trugen ihre Texte, die sich auf die oben erwähnten Ereignisse bezogen, mit Hilfe einer bildhaften Kulisse vor. Membré, Mitglied einer Handelsmission, erwähnte die șurat-h̆ȟān als erster in seinen Reiseberichten:

"The Sophians paint figures, such as the figure of 'Ali, riding on a horse, with a sword; and when they see the said figure of 'Ali, they take hold of their ear and bow their head, which is a kind of reverence. In their squares there are many Persian mountebanks sitting on carpets on the ground; and they have certain long cards with figures; and the said mountebanks hold a little stick and point to one figure after another, and preach and tell stories over each figure. So everybody gives them some money." 106

Diese șurat-h̆`ān, Anhänger der Șafaviden, setzten ihre Vortragsweise für politische und religiöse Propaganda ein. Sie verglichen die Kriege, die Imām 'Ali führte mit den Kriegen des Šāh Esmācil, um letzteren für seine Feldzüge zu legitimieren.

Das Leben der Imāme und Hinweise auf das Leben im Jenseits bildeten den Inhalt der Texte,

105 Zitiert nach: Meskub, Šāhroh: Hoviyat-e irāni va zabān-e fārsi, Teherān 1373/1994, S. 149.

${ }^{106}$ Membré, Michele: Mission to the Lord Sophy of Persia (1539-1542), translated with introduction and notes. by A. H. Morton, London 1993, S. 52. 
die die Bänkelsänger vortrugen. ${ }^{107}$ Volkstümliche Maler wählten als Motive Szenen mit religiösem Inhalt auf Leinwänden, vor denen Erzählungen dargeboten wurden. So entstand eine neue Art von religiöser Erzählkunst, genannt parde-dāri, die sich im Laufe der Zeit weiter entwickelte. $^{108}$

Seit dem 18. Jahrhundert nahmen die Gedenkfeiern für den Imām Ḥosein immer mehr die Gestalt eines öffentlichen ta'ziye (Passionsspiel) an. Naef vermerkt hierzu: „Weil die Passionsspiele so aufwendig waren, konnten sie nämlich nur in Städten veranstaltet werden. in den Dörfern kam ein neues bildliches Element den traditionellen Geschichtenerzählern zu Hilfe. ${ }^{109}$ Die Aufführung selbst wird parde-h̆̌̄āni genannt.“110 So fungiert die parde (Leinwand) als eine Art tragbare takye. ${ }^{111}$ Wenn die Erzähler von Stadt zu Stadt zogen, wurde sie für den Transport eingerollt.

Die entrollte Leinwand diente den Erzählern als bildhafte und unterstützende Darstellung ihres Textes an einigen wichtigen Stationen. Der ständige Wechsel zwischen Bild und Text, der als einfache Kommentierung von Bildmaterial verstanden werden kann, ähnelt durchaus dem Bänkelsänger in der europäischen Tradition.

\subsubsection{Vāqe`e-hู`ānān (Elegiker)}

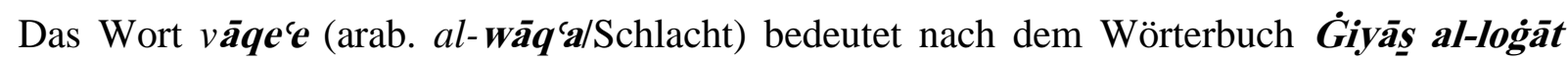
Traum, Vorfall, Schwierigkeit, Krieg, aber auch Tag des jüngsten Gerichts und Tod. ${ }^{112}$

Über die Entstehung und die Art des Vortrags wissen wir nur sehr wenig. Vermutlich bildete sie sich erst in vorislamischer Zeit heraus ${ }^{113}$ und entfaltete sich besonders im 15. Jahrhundert. Für die Entstehung der ta'ziye ist sie wichtig. Noch heute spielt die Elegie eine herausragende Rolle. Inhaltlich setzten sich die Elegien mit den Ereignissen von Karbalā und der Ermordung von Imām 'Ali in Kūfa auseinander. Franklin, der in den Jahren 1786-1787 den Iran bereiste, schreibt:

$$
\begin{aligned}
& \text { „Die ersten zehn Tage des Monats Moharram (des ersten des } \\
& \text { mohammedanischen Jahres) werden in ganz Persien als feierliches Trauern } \\
& \text { begangen. Die Eingeborenen nennen es Dèha, d.h. einen Zeitraum von zehn }
\end{aligned}
$$

\footnotetext{
107 Vgl. Moḥammad Pādešāh: Farhang-e ānanderāğ, Bd. 4, hrsg. von Moḥammad Dabir-Siyāqi, Teherān 1335/1956, hier S. 2774.

${ }^{108}$ Naef, Silvia: Bilder und Bildverbot im Islam. Vom Koran bis zum Karikaturenstreit. Aus dem Französischen ins Deutsche übersetzt. von Christiane Seiler, München 2007, S. 82.

${ }^{109}$ Ebd.

${ }^{110}$ Floor, Willem: The History of Theater in Iran, Washington D. C. 2005, S. 125.

111 Zelt oder Platz, auf dem schiitischen Passionsfeiern veranstaltet werden. Siehe: Junker, Heinrich F. J. und Bozorg Alavi: Wörterbuch Persisch-Deutsch, Leipzig/Berlin/München/Wien/Zürich/New York 1997, S. 183.

${ }^{112}$ Vgl. Rampuri, Ġiyās̄ ad-Din Moḥammad b. Ǧalāl ad-Din b. Šaraf ad-Din: Ġiyā̄s al-logāāt, hrsg. von Manșur Servat, Teherān 1375/1996, S. 937.

${ }^{113}$ Beyżā'i, Bahrām: Namāyeš dar Irān, Teherān 1380/2001, S. 84.
} 
Tagen. Während dieser Zeit beklagen die Perser und alle anderen Anhänger Alis den Tod des Imam Hossein, des zweiten Sohnes jenes Propheten, der im Krieg gegen Yazid, den Sohn des Moaweia, des Kalifen der Muselmanen, erschlagen wurde. Dies ereignete sich an einem Ort namens Kerbelaiè, was im Persischen soviel wie Kummer und Unglück bedeutet." ${ }^{114}$

An anderer Stelle berichtet er:

„Am 1 Moharram besteigen die Akhunds (niedriger Geistlicher) und Peish Namazz (mohammedanischer Priester/Vorbeter) die Kanzeln und beginnen das Leben und die Taten Alis und seiner Söhne Hassan und Hossein und die Umstände zu beschreiben, die das traurige Los des Imam Hossein begleiten: die Rezitation wird in einem flutenden, feierlichen Tonfall vorgetragen und ist wirklich rührend anzuhören, geschrieben mit all der pathetischen Eleganz, die die persische Sprache auszudrücken vermag. In Abständen schlagen sich die Leute gewaltsam auf ihre Brust, wobei sie bitterlich weinen und rufen: Weh um Hossein! Andere Teile der Wakàa bestehen aus Versen, die rhythmisch zu einer klagenden Melodie gesungen werden. Jeden Tag werden einige besondere Szenen der Geschichte von Leuten dargestellt, die dazu ausgewählt sind, die darin vorkommenden Personen $\mathrm{zu}$ verkörpern. Auch werden Bilder hervorgeholt und in Prozessionen durch die verschiedenen Stadtviertel getragen. “115

\subsubsection{Ma'reke-girān (Straßendarsteller)}

Zur Zeit der Șafaviden war der Naqib der höchste Aufsichtsbeamte über die Derwischorden und Straßendarsteller; für letztere bestimmte er ein kadhodā (Oberhaupt), dem sie zu Gehorsam verpflichtet waren und einen Teil ihrer Einkünfte abtreten mussten. ${ }^{116}$

In der Zeit der Qāḡāren war Moḥammad 'Ali der höchste Aufsichtsbeamte über die Derwischorden. ${ }^{117}$ Diese benötigten für ihr parse (Umherziehen), für den Vortrag ihrer Geschichten und für die Bitte um țalab (Almosen) einen moğallā (Erlaubnisschein), der von siebzehn moršed (Meistern) unterschrieben werden musste. ${ }^{118}$

Die 'A ğam-Derwische, eine Gruppe des Huāksār-Derwischordens, traten auf öffentlichen Plätzen mit Liedern, Gedichten, Taschen, Puppen- und Schattenspielen und türkischem

\footnotetext{
${ }^{114}$ Francklin, William: Observations made on a Tour from Bengal to Persia in the Years 1786-7, London 1790, S. 247.

115 Ebd.

116 Anonymus: Tezkera al-Moluk, hrsg. von Moḥammad Dabir-Siyāqi, Teherān 1332/1953, S. 50.

${ }^{117}$ Maḥ̆ub, Moḥammad-Ğa'far: Amir Arsalān-e rumi, in: Adabiyāt-e ‘āmmiyāne-ye Irān, Bd. 1, S. 473525, hier S. 493; vgl. Gramlich, Richard: Die schiitischen Derwischorden Persiens, zweiter Teil: Glaube und Lehre, Wiesbaden 1976, S. 164.

118 Afs̃āri, Mehrān: Fotovvat-nāmehā va rasāelele khāksāriyeh, Teherān 1382/2003, S. 272-287.
} 
Volkstheater auf. ${ }^{119}$ Besonders in den Winternächten und in den Monaten Moḥarram und Ṣafar waren ihre Aufführungen stark besucht. Heinrich Brugsch, der von 1860 bis 1861 im Iran war, schreibt:

„Der persische Derwisch besitzt ein ungewöhnliches Talent zum Erzählen, er ist dabei voller Leben und Feuer, und seine Fantasie weiß die einfachste Geschichte in das bunteste Gewand einer reich ausgeschmückten Darstellung zu kleiden." 120

Dann sagt er, dass die Derwischliteratur, so anziehend sie nach manchen Seiten hin ist, nur im Munde des Erzählers lebe und weder in Handschriften noch in Druckschriften aufzufinden sei. $^{121}$

Gegen Ende der Șafavidenzeit wurden die Șufiden von den Rechtsgelehrten heftig unterdrückt und verfolgt. Nun nahm das Wort Șufi immer mehr die Bedeutung von kāfer (Ketzer) an. Derwische, die sich weniger streng an Glaube und Gesetz hielten, versuchten weiterhin ein ungebundenes Wanderleben mit Musik, Tanz, Literatur und Drogengenuß zu führen. Beim einfachen Volk gewannen sie dadurch an Einfluss.

\subsubsection{Die Situation der Erzählkunst im Iran während der Qāğāanen- und der Pahlavizeit}

Während der Regierungszeit von Nāṣer ad-Din Šāh (1848-1896) fanden wichtige Reformen statt. Der König unternahm mehrere Reisen in europäische Länder und knüpfte dabei Kontakte. Auch die Anzahl der Europäer, die den Iran bereisten, nahm zu; darunter befanden sich viele Diplomaten und Geschäftsleute. Die iranische Gesellschaft sah sich immer mehr europäischen Einflüssen ausgesetzt u.a. auch auf dem Gebiet des Buchdrucks.

Zur Zeit der Qāğāren in den ersten Jahrzehnten des 19. Jahrhunderts nahm die Buchproduktion rasant zu. ${ }^{122}$ In der Regierungszeit von Nāṣer ad-Din Šāh wurden besonders Texte der klassischen persischen Literatur (Fabeln und romantische Epen), Texte mit

${ }^{119}$ Vgl. D'Allemane, H. R.: Du Kurdistan au pays des Bachtyaris, Bd. 1, ins Persische übersetzt. von ĠolāmReżā Samíi, Teherān 1378/1999, S. 254; Menzel, Theodor: Meddāḥ, Schattentheater und Orta Oyunu, Prag 1941, S. 29. Orta Оуипи bezeichnet das altes türkisches Volkstheater, das anstatt auf einer Theaterbühne mitten zwischen den Zuschauern gespielt wird. Der Platz, an dem das Theaterspiel stattfindet, heißt Palanka. Die Hauptcharaktere sind Kravuklu und Pișkār. Der weibliche Hauptcharakter ist Zenne und wird traditionell von einem Mann gespielt. Siehe: Boratav, Pertev Naili: Orta Oyunu, in: Encyclopédie de l'Islam, Vol. VIII, Leiden 1995, S. 181-182; Björkman, Walther: Kawuklu, in: Encyclopédie de l'Islam,Vol. IV, Paris/Leiden 1978, S. 838-839.

${ }^{120}$ Brugsch, Heinrich: Reise der K. Preussischen Gesandtschaft nach Persien (1860 und 1861), Bd. 2, Berlin 1864, S. 493.

${ }^{121}$ Ebd.

${ }^{122}$ Marzolph, Ulrich: Von der Handschrift zum Buch. Zur Periodisierung der frühen Druckgeschichte in Iran (1817-ca. 1990), in: Iranistik. Deutschsprachige Zeitschrift für iranischen Studien, 1 Jahrgang, Heft 2, Herbst und Winter 2002, S. 71-90. 
religiösem Inhalt und volkstümliche Erzählungen sowie Romane gedruckt. ${ }^{123}$ Unter den volkstümlichen Epen ragen die persische Version des Alexander-Romans und das Buch $R H$ heraus, das mit über 1.149 Seiten umfangreichste illustrierte Dokument der Qāğārenzeit. ${ }^{124}$ Gedruckte Bücher hatten nur eine geringe Auflage, weil sie aufgrund der hohen Kosten sehr kostspielig, also nur für Wohlhabende wie beispielsweise Kaufleute und Angehörige des Hofes erschwinglich waren. Die Iraner waren überwiegend Analphabeten und mussten sich daher die Texte vorlesen lassen.

Die Qāḡāren wurden von Reżā Šāh (1925-1941) entmachtet, der seine politischen Gegner und viele Gelehrte und Schriftsteller aus dem Land vertrieb oder gar tötete. ${ }^{125}$ Hart ging Reżā Šāh auch gegen den schiitischen Klerus vor, indem er u.a. öffentliche Trauerkundgebungen im Monat Moḥarram und das persische Passionsspiel verbot. ${ }^{126}$ Er wollte den iranischen Lebensstil nach europäischem Muster verändern z.B. auf dem Gebiet der Kleidung, der Modernisierung von Kaffeehäusern, Theater und Universitäten. Die Erzähler jedoch wehrten sich gegen dieses Vorhaben und versuchten, das Erbe der persischen Literatur zu bewahren, ${ }^{127}$ was oft nur im Verborgenen gelang.

Zweifellos zeigt die gebildete Schicht im heutigen Iran wenig Interesse an traditioneller Erzählkunst, da die erzählerische Tätigkeit für die Gesellschaft kaum von Bedeutung ist, obwohl seit der islamischen Revolution von 1979 auch Frauen den Beruf einer Erzählerin ausüben können. Die erste, die als naqqā̄l heute noch auftritt heißt Fāṭeme Ḥabibi (ursprünglich von Beruf Archäologin), bekannt unter dem Namen Gordāfarid. Sie hat eine große Zuhörerschaft im In- wie im Ausland. ${ }^{128}$

\footnotetext{
${ }^{123}$ Ders.: Persian Popular Literature in the Qajar Period, in: Asian Folklore Studies, Vol. LX1, (2001), S. 215221.

${ }^{124}$ Ders.: Honar-e taṣvirgari dar ketābhā-ye čāp-e sangi-ye zamān-e qāḡār (Die Kunst der Illustration in persischen lithographischen Büchern der Qajarenzeit), ins Persische übersetzt. von Bižan Ġeibi, in: Farhang-e Mardom, 2 Jahrgang, Sommer und Herbst, Nr. 6 und 7, Teherān 1382/2003, S. 33-39, hier S. 37.

125 Gelpke, Rudolf: Die iranische Prosaliteratur im 20. Jahrhundert, Teil 1, Wiesbaden 1962, S. 57.

${ }^{126}$ Hinz, Walther: Iran. Politik und Kultur von Kyros bis Reżā Schah, Leipzig 1938, S. 128-135; Halm, Heinz: Der schiitische Islam, München 1994, S. 89.

127 Vgl. Galunov, R. A.: Neskol'ko slov o perspektivakh sobirania materialov po fol'klory i teatr v Persii Dokladie, in: Akademii Nauk 17, Leningrad 1929, S. 307-312, hier S. 307.

${ }^{128}$ Siehe: The first woman storyteller, in: www. Jadidonline.com/story/20062007/fq/gordafarid.
} 


\section{Das Buch Romuz-e Hamze $(R H)$}

Volksepos und Volkssagen sind als Erzählgattungen anonym entstanden und stetig tradiert worden. Für die Romantiker hatte das Wort „Volk” einen besonders hohen Stellenwert. Im Reallexikon der Deutschen Literaturgeschichte, hrsg. von P. Merker u. W. Stammler, lesen wir: „Im Volksroman sah man nicht nur eine Dichtung für das Volk, über volksgemäße Themen, sondern direkte Schöpfungen des Volkes selbst. Grimm, Uhland u.a. haben hier tiefsinnige Gedanken angeknüpft: Ihnen war klar, dass derlei Dichtungen nicht erfunden werden können, sich vielmehr selbst dichten oder besser, dass das ganze Volk bewusst oder unbewusst an ihrer Schöpfung beteiligt ist.“129

Volksepen können mit ihrer Vielfalt an Themen durchaus als Stimme des Volkes angesehen werden, als geistige Dokumente einer bestimmten Zeit.

Das iranische Volksepos hat zum Inhalt Ereignisse aus der vor- und frühislamischen Zeit und bietet diese nicht nur zur bloßen Unterhaltung an, sondern auch als nationalpolitische Unterweisung, letztere besonders für die Gesellschaft des Irans im Mittelalter. Es soll versucht werden darzustellen, dass dem $R H$ auf dem Weg der Iraner zur Erreichung eines nationalen Selbstverständnisses ein hoher Rang in der iranischen Literaturgeschichte zukommt.

\subsection{Titel des Buches}

Die Geschichte von Hamze wurde unter elf verschiedenen Titeln erzählt. Der bekannteste Titel ist das Hamze-nāme (wörtlich: Buch [der Taten] Hamzes) ${ }^{130}$, weitere Titel sind: Dāstān-e/qeșse-ye Amir Hamze șāheb-qerān ${ }^{131}$, Qeș̣e-ye Amir-e 'Arab ${ }^{132}$, Șāḥeb-qerānnāme $^{133}$, Sirat Hamze ${ }^{134}$, Asmār-e Hamze (Abendplaudereien von Hạze) ${ }^{135}$, Ketāb-e Romuz-e Hamze (Buch der rätselhaften Vorkommnisse um Ḥamze) ${ }^{136}$, Zodat ur-romuz

\footnotetext{
${ }^{129}$ Reallexikon der Deutschen Literaturgeschichte, I. Aufl., hrsg. von Paul Merker u. Wolfgang Stammler, Berlin 1928/9, S. 486 f., s. V. „Volksepos”.

${ }^{130}$ Ethé, Hermann: Catalogue of the Persian, Turkish, Hindūstāñ and Pashtū Manscripts in the Bodleian Library, Part II, Oxford 1903, S. 1639.

${ }^{131}$ Rieu, Charles: Supplement to the Catalogue of Persian Manuscripts in the British Museum, London 1895, S. 241.

${ }^{132}$ Ethé, Catalogue of the Persian Manuscripts in the Library of the India Office, Bd. 2, Oxford 1937, S. 175.

${ }^{133}$ Șafā, Hamāse-sarā'i dar Irān, S. 379.

${ }^{134}$ Ethé, Neupersische Literatur, in: Grundriss der iranischen Philologie, zweiter Teil, S. 318.

${ }^{135}$ Blochet, Edgar: Catalogue Manuscrits Persans de la Bibliothèque Nationale de Paris, Tome 4, Paris 1934, S. 67; Rieu, Charles: Catalogue of the Persian Manuscripts in the Britisch Museum, Vol. II, London 1881, S. 761.

${ }^{136}$ Blochet, S. 69; Edwards, Edward: A Catalogue of the Persian printed books in the British Museum, London 1922, S. 246; Rieu, Vol. II, S. 760.
} 
Hamze $^{137}$, Ğang-nāme-ye Amir al-mo'menin Hamze b. 'Abd al-Mutțalīb b. Hāšìm b. 'Abd al-Manāf, ${ }^{138}$ Šāhzāde Hamze. ${ }^{139}$

Das Epos wird bei den Iranern dāstān genannt. Der elfte und letzte Titel des Buches lautet $R H$, mit dessen Ursprung und Entwicklung sich diese Arbeit beschäftigt. Wann und wo die erste Version als $R H$ in Erscheinung tritt, kann nicht genau bestimmt werden. Wahrscheinlich taucht sie unter dem Titel $R H$ im 17. Jahrhundert auf.

Der Gelehrte Faḩr az-Zamāni (1590) berichtet von ersten spärlichen Hinweisen auf das Buch $Q H$ zur Zeit der Ṣafaviden Anfang des 16. Jahrhunderts. ${ }^{140}$ Ṣafā, ein Literaturwissenschaftler des 20. Jahrhunderts, vertritt die Ansicht, dass der Roman von Ḥamze zur Șafavidenzeit im Jahr 1663 in Versform geschrieben wurde. Zudem sollen seiner Meinung nach zur Zeit der Zanden und Qāḡāren im Iran und sogar auf indischem Gebiet verschiedene Handschriften nachweisbar sein. ${ }^{141}$

Der indische Dichter Mirzā Asadallāh Hāān Ġāleb (1797-1869) ${ }^{142}$ vermutet als Verfasser von Ḥamzes Geschichte einen Menschen von Bildung in der Regierungszeit von Šāh 'Abbās II. (1642-1666); ferner teilt er mit, in Indien sei dieses Werk Qeșse-ye Hamze (The Tale of Amir Hamza) genannt worden und in Persien Romuz-e Hamze (The Secrets of Hamza). ${ }^{143}$

Aus ad-Darī́a ilā taṣānîf aš-Šî́a von Ag̀ā Bozorg Ṭehrāni (1876-1969) erfahren wir, dass Naqib al-Mamālek, der Erzähler am Hofe des Königs Nāṣer ad-Din Šāh, Geschichten gesammelt und ihnen den Obertitel Romuz-e Hamze gegeben hat. ${ }^{144}$ Mit seinem Namen ist ein weiterer Roman verbunden mit dem Titel Amir Arsalān. Die Tochter des Königs Nāṣer ad-Din Šāh, Fahrr ad-Doule, hat den Vortrag des Erzählers aufgeschrieben. ${ }^{145}$

${ }^{137}$ Ḥāğği qeșṣe-h̆ॅān Hamadāni, ein iranischer Erzähler in Diensten des Solțāns 'Abdallāh Qoṭb Šāh von Golconda (reg. 1611-1672), schrieb in seinem Reisebuch, dass er im Jahr 1612 nach Ḥeydar-ābād kam. Dort besuchte er den Solțān 'Abdallāh Qoṭb Šāh und übergab ihm als Geschenk eine Ausgabe der ḤamzeGeschichten in persischer Sprache. Er selbst verfasste eine Auswahl von Geschichten aus dem HamzeRoman in persischer Sprache mit dem Titel Zobdat ur-romuz Hamze. Siehe: Pritchett, Frances W.: The Romance Tradion in Urdu. Adventures from the Dastan of Amir Hamza, New Yourk 1991, S. 5.

138 Fleischer, Heinrich: Catalogus Codicum Manuscriptorum Orientalium Bibliothecae Regiae Dresdensis, Leipzig 1831, unter Nr. 346, S. 52; Rieu, Vol. II, S. 761.

139 Monzavi, Aḥmad: Fehrest-e noshehā-ye hatṭi, Bd. 3, nos. 1656, Eslāmābād 1359/1980, S. 1341; Ethé, Hermann: Catalogue of the Persian, Turkish, Hindūstān̄ and Pashtū Manscripts in the Badleian Library, Bd. 1, London 1903, S. 519-520.

${ }^{140}$ Faḩr az-Zamāni, ‘Abd an-Nabi: Terāz al-ahbār, MS, Parlamentsbibliothek Teherān, Nr. 14188, S. 18f.

${ }^{141}$ Sạāā, Tãrih̀-e adabiyāt dar Irān, Bd. 5, Teil 3, Teherān 1371/1992, S. 1512.

142 Russell, Ralph: Ghalib: A Self-Portrait, in: Ghalib: The Poet and his Age, hrsg. von Allen und Unwin, London 1972, S. 9-35.

${ }^{143}$ Vgl. Russell, Ralph and Khurshidul-Islam: Ghalib, Life and letters, 1797-1869; Vol. 1, hrsg. von Allen und Unwin, London 1969, S. 321.

144 Ṭehrāni, Āqā Bozorg: Ad siehe: Mo'ayyer al-Mamālek, Dust-‘Ali Hुān: Yãddāšthā’i az zendegāni-ye Nāṣer ad-Din Šāh, Teherān 1372/1993, S. 25.

145 Mạ̣ğub, Amir Arsalān-e rumi, in: Adabiyāt-e ‘āmmiyāne-ye Irān, Bd. 1, S. 473-525, hier S. 496; vgl. Mo'ayyer al-Mamālek, S. 25. 


\subsection{Entstehungsgeschichte des $R H$}

Im Buch Tãrih-e Sistān (Geschichte von Sistān) ist zu lesen, dass die ursprüngliche Erzählung aus dem Südosten Persiens stammt; dort erfuhr sie verschiedene Veränderungen. ${ }^{146}$ Die älteste Version dieser Erzählung, Mag̊āzi-ye Hamze, die schon früh verloren ging, wurde später als Qeșșe-ye Amir al-mo'menin Hamze, abgekürzt $Q H$, bekannt. Sie stammt vermutlich aus frühislamischer Zeit, kurz nach dem Übertritt der Iraner zum Islam, wofür es aber keine Belege gibt. Ferner existiert eine lithographische Fassung (Romuz-e Hamze), abgekürzt $R H$. Diese Untersuchung stützt sich auf beide Versionen.

Im Buch $Q H$ finden sich zahlreiche Spuren der altiranischen Kultur in Form von religiösen Mythen und Heldensagen. Hamze, die zentrale Figur im $Q H$, gewinnt mit der Zeit auch starke fantasievolle Züge. Die politischen Ereignisse im Osten des Irans während der Ghaznaviden- und Seldschukenzeit wie z.B. die Eroberung Indiens durch Mạ̣mud von Ghazna und die Auseinandersetzung zwischen Christentum und Islam, prägen den Erzählstoff mit Ḥamze im Mittelpunkt. Ein genaues Datum für die Entstehung des Buches $Q H$ ist nicht auszumachen. Der iranische Literaturwissenschaftler Š $\mathbf{e}^{\mathbf{a}} \mathbf{r}$ vermerkt:

„manchmal finden sich im Buch Ausdrücke, die uns an Prosawerke des 10. und

11. Jahrhunderts erinnern, und manchmal finden sich Ausdrücke, die uns an Prosawerke des 12. und 13. Jahrhunderts erinnern. “147

Die Kenntnis des Buches $Q H$ scheint bei den Iranern, gleich welcher Bildungstufe, weit verbreitet zu sein, wozu seine leicht verständliche Sprache und die Abenteuer seines Helden, der mit dem Onkel des Propheten Moḥammad identifiziert wird, wesentlich beigetragen haben. Der Gelehrte Faḩr az-Zamāni weist darauf hin, dass die Geschichte Ḥamzes schon in der Ghaznaviden-Zeit berühmt gewesen ist. ${ }^{148}$ In der Gedichtsammlung von Nāṣer Hosrou, einem Dichter im 11. Jahrhundert, finden wir Verse über Ḥamze, seinen Kundschafter, sein Pferd Ašqar und seinen Jubelschrei. Zwei Verse daraus lauten:

„Wo ist der Sprung des ‘Amr b. Umeiyaz-Žomrī;

Wo sind Ašqar und der Schrei des Onkels des Propheten?“149

Es gibt Hinweise darauf, dass das $R H$ von dem Buch Hā̃arān-nāme inspiriert wurde. Bestimmte Helden sind beiden Büchern gemeinsam, ebenso Kämpfe mit Dämonen und

\footnotetext{
${ }^{146}$ Anonymus: Tārih̆-e Sistān, hrsg. von Moḥammad-Taqi Bahār, Teherān 1314/1935, S. 170.

147 Anonymus: Qeșse-ye Amir al-mo'menin Hamze, Bd. 1, hrsg. von Ğa'far Še‘ār, Teherān 1347/1968, Vorrede. S. 4.

148 Faḩr az-Zamāni, Terāz al-ahbā̄, S. 18bf.

${ }^{149}$ Qobādiyāni, Nāṣer-Hosrou: Divān-e Nāṣer Hosrou, hrsg. von Seyyed Naṣrallāh Taqavi, Teherān 13041307/1926-1929, S. ‘ed.
} 
Ungläubigen. ${ }^{150}$ Ethé ist der Auffassung, das $R H$ weise auch manche Ähnlichkeit mit dem Buch Qeș̣se-ye šāh-e mardān 'Ali auf, vor allem liege eine ausgeprägt schiitische Tendenz beiden Büchern zugrunde. ${ }^{151}$

Im Vergleich mit dem $Q H$ stellen wir fest, dass das $R H$ als neue Version an Erzählstoff zugenommen hat und im 16. Jahrhundert vermutlich den größten Umfang erreichte. Ein Großteil des Erzählstoffes stammte aus vorislamischer Zeit. Die Erzähler vermischten auf fantasievolle Weise religiöse Inhalte mit kriegerischen Szenarien, was während der Șafavidenzeit im Iran besonders publikumswirksam war.

Stark beeinflusst haben das $R H$ auch Lehren aus dem Șufismus, der ab dem 14. Jahrhundert im Iran an Einfluss gewann. Traumschilderungen oder Berichte über Wundertaten von Heiligen zeugen davon.

Manche Geschichten spielen ganz oder teilweise im Osten des Irans, wo im 14./15. Jahrhundert grundlegende politische Umwälzungen stattgefunden haben. Zahlreiche Kriegszüge gegen die Türken, besonders gegen die Usbeken werden geschildert, mit deutlichen Hinweisen auf die Timuriden -und Șafavidenzeit. Das historische Ambiente, welches die beiden Erzähler Tekelu Hुān und Abu al-Ma‘āli Neišāburi anbieten, entspricht der șafavidischen Epoche. Im $R H$ wird der Krieg gegen die Usbeken, Osmanen, Inder und Ägypter erwähnt, der bereits in der Șafavidenzeit begann und wie häufig angedeutet in den Regionen von Eṣfahān oder Horāsān stattfand. Der Gebrauch von Schießpulver und Feuerwaffen wird erst bei der Schilderung der Niederlage des Šāh Esmā̄il in der Schlacht von Čāldirān erwähnt. Wenn im Text von tup (Kanonen), tufang (Feuerwaffen) und durbin (Fernglas) erwähnt werden, so weist dies auf spätere Schreiber hin.

Namen wie Badic az-Zamān, Alqāṣ und Ṭahmāsb usw.; die Prinzen gegeben werden, weisen auch auf diese Zeit hin. Ferner deutet auf die Șafavidenzeit hin die Erwähung, dass bang (Haschisch) und fuluniā (Opium) häufig von Hamze und seinen Helden eingenommen werden.

Der Sprachstil, in dem die historischen Ereignisse geschildert werden, lässt vermuten, dass das Buch $R H$ Anfang des 16. Jahrhunderts verfasst worden ist.

\subsection{Zur Autorenschaft}

Von elf verschiedenen Titeln ausgehend, ist anzunehmen, dass die Geschichten, die sich um die Person Ḥamze ranken, von mehreren Erzählern in dem Buch $R H$ gesammelt wurden. Ein einziger Autor ist demnach nicht zu benennen. Historische Quellen müssen gesucht werden,

${ }^{150}$ Ethé, Catalogue of the Persian Manuscripts in the Library of the India Office, Bd. 1,Oxford 1903, S. 519. 
um aus einer unbestimmten Anzahl von Autoren vielleicht doch den einen oder anderen ausfindig zu machen.

Aus dem Buch $Q H$ erfahren wir, dass Hamzes Bruder 'Abbās die Geschichte von Ḥamze verfasst haben soll. ${ }^{152}$ 'Abbās las diese Geschichte dem Propheten Moḥammad vor, wenn dieser traurig war.

'Abd an-Nabi Faḩr az-Zamāni dagegen meinte, dass ein gewisser Abu Bakr Bāqillānīis3 die Geschichte von Ḥamze geschrieben habe. Er schreibt:

„Ich habe Nağib ad-Din Ġiyāṣ ad-Din ‘Ali Naqib Hูān Mir 'Abd al-Lațif b.

Mir Yạ̣yā, den Verfasser des Buches Lobb at-Tawārih über die Erfindung der Geschichte Ḥamzes befragt. Er sagte, dass unter Solțān Mas'ud von Ġazna, Abu Bakr Bāqillānī der gelehrteste Wissenschaftler gewesen sei. Solțān Mas'ud litt unter Epilepsie, und die Ärzte konnten ihn nicht heilen. Abu Bakr Bāqillānī, der gelehrteste Wissenschaftler am Hof des Mas'ud von Ġazna, hat diese Geschichte abgefasst und sie dem Solțān Mas'ud vorgelesen.

Abu Bakr Bāqillānī hatte die Geschichte innerhalb von sechs Monaten vorgelesen. Der Solțān wurde innerhalb von vier Monaten geheilt.“،154

Im Buch $R H$, das in den Jahren 1857-1859gedruckt wurde, wird als Erzähler Abu al-Ma‘āli Neišāburi genannt (siehe: 2/239), über dessen Lebenslauf wenig bekannt ist. Einige Daten finden sich im Buch Tazkere-ye Naṣrābādi, einer zur Zeit von Šāh Soleimān (1667-1694) verfassten Sammlung von Biographien von fast 1.000 Dichtern und Schriftstellern aus der Ṣafavidenzeit. Abu al-Ma‘āli Neišāburi soll ein seyyed (Prophetenabkömmling) und das naqib (Oberhaupt) der Neišāburer seyyeds gewesen sein, zudem war er auch als kalāntar (Zunftältester) tätig, ein Amt, das er von seinen Vorfahren geerbt hatte, wodurch er und seine Familie auch im geistlichen Bereich eine herausragende Rolle im Leben der Bevölkerung von Neišāburs spielten.

Wie Naṣrābādi berichtet, genoss Abu al-Macāli Neišāburi am Hofe von Šāh 'Abbās I. ein hohes Ansehen. ${ }^{155}$ Fahr az-Zamāni zitierte von Abu al-Ma‘āli, dem Gelehrten und Dichter, in seinem Buch Ṭerāz al-ahbār einige Gedichte. ${ }^{156}$

\footnotetext{
${ }^{151}$ Ebd.

152 Anonymus: $Q H$, Bd. 1, Vorrede, S. vier; Pritchett, S. 12; Fleischer, S. 52.

${ }^{153}$ Abu Bakr Moḥammad at-Tayyib al-Bāqillānī war ein Ašcarit und mālikitischer Jurist. Geboren in Baṣra ca. 950 und starb im Jahr 1013. Siehe: Anșāri, Hạan: Bāqillānī, in: Dā'rat al-ma'āref-e bozorg-e eslāmi, Bd. 11, Teherān 1381/2002, S. 226-232.

${ }^{154}$ Normalerweise braucht man sechs Monate, um die Geschichte vollständig zu lesen. Siehe: Fahr az-Zamāni, S. $18 b f$.

155 Naṣrābādi-Eṣfahāni, Mirzā Moḥammad-Ṭāher: Tažkere-ye Naṣrābādi, hrsg. von Vaḥid Dastgerdi, Teherān 1317/1938,S. 100.

${ }^{156}$ Faḩr az-Zamāni, S. 104 f-106f.
} 
In einem persischen Manuskript aus der Bibliotheca Regiae Dresdensis wird Abu al-Ma'āli als Verfasser des Ğang-nāme-ye Amir al-mo'menin Hamza b. 'Abd al-Mutțalīb b. Hāšim b. 'Abd al-Manāf bezeichnet ${ }^{157}$, und in einer türkischen Handschrift als Verfasser der Geschichte von Ḥamze. ${ }^{158}$ Im Cod. Dresd. Or. S. 52; Nr. 346 ist als Verfasser deutlich der Name Abu al-Ma‘̄āli zu lesen, ebenso im Cod. Dresd. S. $155{ }^{159}$

Über Tekelu Hāan, einen weiteren Erzähler aus dem Buch $R H$, ist unsere Kenntnis auch nur spärlich. Von Moulavi Moḥammad Moẓaffar Ḥosein Ṣabā erfahren wir in seinem Buch Tazkere-ye ruz-e roušan über Tekelu-Hુān, dass er zuerst als Kämpfer am Hof des Solțāns Ḥosein Baiqarā diente ${ }^{160}$, der mit seinem Wesir Mir 'Ali-Šir Navā'i mancherlei künstlerische Aktivitäten förderte. ${ }^{161}$ Tekelu Hān lebte in einer politisch sehr unruhigen Zeit, die vom beginnenden Zerfall des Timuridenreiches gekennzeichnet war, was ihn schließlich zur Auswanderung bewog.

In der Biographie Tazkere des Sām Mirzā, dem Bruder von Šāh Ṭahmāsb, steht, dass Moulānā Zain al-‘̄̄bidīn Tekelu Hुān aus Širāz stammte und als Erzähler am Hof des Šāh Esmā'il tätig war. ${ }^{162}$ Er trug die Geschichte von Ḥamze vor, was auch Terāz al-ahbā̄r von 'Abd an-Nabi Faḩr az-Zamāni erwähnt worden ist. ${ }^{163}$ Šāh Esmā'ils Begeisterung für die vorgetragenen Abenteuer Ḥamzes war so groß, dass er sogar seine Söhne nach den zwei Helden im $R H$, Alqāṣ und Ṭahmāsb, benannte ${ }^{164}$ und den Erzähler mit einem Palast belohnte. $^{165}$

Für Faḩr az-Zamāni ist Tekelu Hyān der Verfasser des fünften Buches des $R H$, mit dem Titel Irağ-nāme ${ }^{166}$ das offenbar viel wertvolle historische Sachverhalte enthält. In ihm werden die kriegerischen Auseinandersetzungen des Nachfolgers von Solțān Ḥosein Baiqarā mit den Usbeken um die Stadt Harāt zur Zeit der Timuriden geschildert, dem höchstwahrscheinlich persönliche Erlebnisse zugrunde liegen.

Weitere Hinweise auf die Geschichte von Hamze finden sich in einem Roman mit dem Titel Abu Moslem-nāme. Aus einer türkischen Handschrift des Romans Abu Moslem-nāme

\footnotetext{
${ }^{157}$ Fleischer, S. 52.

158 Fügel, Gustav: Die arabischen, persischen, türkischen Handschriften der kaiserlichen und königlichen Hofbibliothek zu Wien, Bd. II, Hildesheim/NewYork 1977, S. 29.

${ }^{159}$ Fügel, S. 29; vgl. Van Ronkel, Philippus Samuel: Du Roman van Amir Hamza, Leiden 1895, S. 8.

${ }^{160}$ Șabā, Moulavi Moḥammad Moẓaffar Hosein: Tazkere-ye ruz-e roušan, hrsg. von Moḥammad Hosein Roknzāde, Teherān 1343/1964, S. 157; Dāvar, Šeih̆ Mofid: Tazkere-ye mer’āt al-foṣaḥā, Bd. 1, hrsg. von Maḥmud Dāvuudi, Širāz 1371/1991, S. 131.

${ }^{161}$ Roemer, S. 172.

162 Șafavi, Sām Mirzā: Toḥfe-ye sāmi, hrsg. von Vaḥid Dastgerdi, Teherān 1341/1962, S. 83.

${ }^{163}$ Fah̆r az-Zamāni, S. 18af.

164 Ebd. S. 19af.

165 Ebd.

${ }^{166}$ Ebd. S. $18 b f$.
} 
erfahren wir, dass dieser von einem gewissen Mollā Ğalāl Balhi verfasst wurde ${ }^{167}$, den Faḩr az-Zamāni als Verfasser der Geschichte von Qāsem und Badi` az-Zamān vermutete. ${ }^{168}$ In der Urdu-Version der Geschichte Ḥamzes wird ebenfalls Mollā Ğalāl Balhi als Verfasser genannt. $^{169}$

Im Bābur-nāme des Königs Zahir ad-Din Moḥammad Bābur steht geschrieben, dass ein Dichter namens Mir Sar-i Barahna auseinem Dorf in Andiğān, behauptete, ein seyyed zu sein. Unter Dichtern und Literaten von Horāsān war er bekannt, und er beschäftigte sich mit der Geschichte Hamzes. Ein temperamentvoller Vortrag und guter sprachlicher Ausdruck zeichneten ihn aus. ${ }^{170}$

In einem Manuskript des $Q H$, aufbewahrt in der Ganğbahš Bibliothek in Pakistan, lesen wir, dass ein gewisser Šāh Nāṣer ad-Din Moḥammad der Verfasser der Geschichte von Ḥamze sein soll. $^{171}$

Der lithographische Druck des Buches $R H$ aus den Jahren 1857-1859, der dieser Untersuchung zugrunde liegt, nennt insgesamt sieben Erzähler: Mollā 'Ali Hāan-e 'Allāme (5/849/22), Mollā Ḥāğği Moḥammad (5/832/19; 5/903/4), Mollā Ḥāğği Šekar-riz (5/855/15; 5/903/7), Mollā Ḥasan (5/903/6), Mollā Fatḥallāh (5/903/7) und Mollā cEnāyat Tekelu (5/903/7).

Die Geschichte von Ḥamze gewann immer mehr an Popularität, weil viele Erzähler sie an Höfen und auf öffentlichen Plätzen vortrugen. Daher wurde es notwendig, allgemeine Unterweisungen für seine Aufführungen zu verfassen. Mit dem Titel Dastur al-fuṣaḥā' verfasste der Schriftsteller 'Abd an-Nabi Fahr az-Zamāni ein Werk, das Regeln enthielt für die Art und Weise, wie die Geschichte von Ḥamze vorzutragen sei. Dieses Buch ist nicht erhalten, ein beträchtlicher Teil jedoch scheint in einem anderen Werk desselben Verfassers mit dem Titel Terāz al-ahbār enthalten zu sein, das Natur-, Liebes-, Fest- und Kriegsgedichte beinhaltet. Darin berichtet er auch über die Erzähler, ihre Stellung am Hofe und die Art ihrer Vorträge, ferner über den Ursprung der Geschichte von Ḥamze und deren berühmte Erzähler.

'Abd an-Nabi wurde höchstwahrscheinlich im Jahre 1590 in Qazwin geboren. Im Alter von etwa zwanzig Jahren machte er sich auf den Weg nach Indien. Aus seinem Buch Tazkere-ye

\footnotetext{
${ }^{167}$ Esmācili, Họsein: Abu Moslem-nāme, Bd. 1, Teherān 1380/2001, S, 32.

${ }^{168}$ Fah̆r az-Zamāni, S. 18b.

${ }^{169}$ Rieu, Vol. II, S. 761; Qoreishi, Salim ad-Din Qoreishi und Sims-Williams, Ursula: Catalogue of the Urdu Manuscripts in the India Office Library. Supplementary to James Fuller Blumhardt's Catalogue of 1926, London 1978, S. 55.

170 Bābur, Zahir ad-Din Moḥammad: Bābur-nāme, Bd. 1, Translated from the Original Turki Text. by Annette Susannah Beveridge, London: Luzac\&Company 1969 [1922], S. 280.

${ }^{171}$ Monzavi, Bd. 3, S. 1341; Rieu, Vol. II, S. 76o; vgl. Van Ronkel, S. 8.
} 
mei-h̆āne erfahren wir, dass er im Jahre 1610 nach Agrā, der Hauptstadt Indiens kam und dort eine Anstellung als Bibliothekar bei Mirzā Amānallāh Heān, dem Sohn von Mahābat Hān fand. ${ }^{172}$

\subsection{Beschreibung des lithographischen Exemplares des $R H$}

Von den Büchern $Q H$ und $R H$ gibt es wahrscheinlich mehrere Handschriften. ${ }^{173}$ Die folgende Untersuchung gilt einem lithographischen Druck des $R H$ in 7 Büchern, das zwischen 12741276 A. H./1857-1859 in Teherān hergestellt wurde. Dieser Druck wurde von Parviz Mirzā b. Fatḥ 'Ali Šāh, dem Onkel des Königs Nāser ad-Din Šāhs, in Auftrag gegeben und finanziert $(1 / 2)$.

Ein Werk von sieben Büchern in lithographischer Druckthechnik über einen Zeitraum von mehreren Jahren herzustellen, war im Iran kein ungewöhnlicher Vorgang. ${ }^{174}$ Diese Technik war viele Jahre vorherrschend, weil ihre Anwendung bekannt und das benötigte Material leicht zu beschaffen waren. ${ }^{175}$ Zur Bilddarstellung eignete sich diese Technik besonders gut (im $R H$ sind 137 Bilder). Das $R H$ wurde von mehreren Kalligraphen in einer sogenannten nasta liq-Schrift geschrieben und in verschiedenen Druckereien (kār-hāane) in zwei Auflagen gedruckt. Die zweite Auflage wurde im Jahr 1359/1940 veröffentlicht. ${ }^{176}$ Am Schluss eines jeden Buches finden sich die Signaturen der Kalligraphen.

Das $R H$ hat einen Umfang von 1149 Seiten. Während auf den ersten Seiten eines Buches die Seitenzahl angegeben ist, wird schon nach etwa 20 Seiten das Schlusswort einer Seite zu Beginn der folgenden als Kustode wiederholt; diese Verfahrensweise wird bis zum Ende des Buches in dieser Art beibehalten. Der Schriftspiegel mißt 28 x 16,7 cm. Jede Seite umfasst 38 Zeilen, jede Zeile enthält etwa 14 Wörter. Sämtliche sieben Bände weisen ungefähr 32.440 Zeilen auf. Die Anzahl der Wörter beträgt ungefähr 551.480, die der bildhaften Darstellungen 137. Der Text ist oft lückenhaft, ein Hinweis auch auf eine nicht erfolgte Endredaktion.

Die meiner Untersuchung zugrunde liegende Fassung des $R H$ weist eine umfangreiche Anzahl aus dem persischen Sprachgebiet stammenden Geschichten auf. Ein Vergleich der

\footnotetext{
${ }^{172}$ Faḩr az-Zamāni, 'Abd an-Nabi: Tazkere-ye mei-h̆āne, hrsg. von Aḥmad Golčin-Ma'āni, Teherān 1340/1961, Vorrede S. 11.

${ }^{173}$ Glück, Heinrich: Die indischen Miniaturen des Hamze-Romans im österreichischen Museum für Kunst und Industrie in Wien und in anderen Sammlungen, Zürich/Wien/Leipzig 1925, S. 21.

${ }^{174}$ Vgl. Marzolph, Ulrich: The last Qājār Shāh-nāme. The Shāh-nāme-e Bahādori, in: Shahnama Studies 1 (Pembroke Papers 5), hrsg. von C. Melville, Gambridge 2006, S. 259-276.

175 Ders.: Von der Handschrift zum Buch. Zur Periodisierung der frühen Druckgeschichte in Iran (1817-ca. 1900), S. 81.

176 Ders.: Narrative Illustration in Persian Lithographed Books, Leiden (Handbook of Oriental Studies, 1.60), 2001, S. 259.
} 
zahlreich vorhandenen Handschriften des $R H$ ergibt, dass sich viele Geschichten im Laufe der Zeit veränderten, beziehungsweise ergänzt wurden, oder einfach verloren gingen.

Die sieben Bände, aus denen das $R H$ besteht, symbolisieren in der persischen Kultur Vollendung; somit soll in diesen sieben Bänden alles gesagt werden, was es an Wichtigem zu berichten gibt.

Die Geschichte von Ḥamze wird chronologisch erzählt. Im ersten Buch erfahren wir von Geburt, Kindheit und Jugend des Helden; ferner von seinen Kämpfen mit geisterhaften Wesen. Das zweite Buch berichtet von Ḥamzes Auseinandersetzungen mit dem Perserkönig. Im dritten Buch wird geschildert, wie Ḥamze sich gegen Hexen und Türken behaupten muss. Im vierten Buch zieht Ḥamze gegen einen fiktiven König mit Namen Zomorrod, einen Ungläubigen, zu Felde. Im fünften Buch kämpft Vater Ḥamze gegen seine Söhne und diese wiederum gegeneinander. Nach erfolgter Aussöhnung mit den Söhnen und Vernichtung der Ungläubigen kehrt Ḥamze nach Mekka zurück. Das sechste und siebte Buch handelt von den Kämpfen der Nachkommen Ḥamzes mit den Ungläubigen, besonders den Usbeken.

Buch 1 umfasst die Seiten 1 bis 193. Es gliedert sich in 13 ğozv (Kapitel). Kapitel 1 bis 12 zählen je 16 Seiten, Kapitel 13 nur eine Seite. Der Kalligraph für das erste Buch war Seyyed 'Abdallāh Tafreši (1/193) und er signierte es im Jahr 1274/1857. Gedruckt wurde das Buch in der Druckerei von Āqā Mirzā 'Ali Akbar in Dār al-halāfe (Teherān). Das erste Buch beginnt:

ammā ḥokamā-ye cālam-e asrār va fażl-e in goftār va mohandesān-e dāstān-

e kohan va huše-činān-e hyarman-e sohan čonin naql kardeh-and ke .... (1/2).

Diesen Anfang kann man vielleicht so interpretieren: Ein Gelehrter [Erzähler], der das Geheimnis und die Bedeutung dieser Worte kennt, kannverstanden werden als ein gestaltendes Wesen. Er handelt wie ein Landwirt, der seine unterschiedlichen Getreidesorten im Herbst gebündelt in der Scheune unterbringt und bei Bedarf gezielt die Sorten nutzt, die er benötigt. Ebenso handelt der Erzähler und wählt die passenden Geschichten aus, die er dann auf verständliche, unterhaltsame Weise seinen Zuhörern mitteilt.

Der Text ist mit 137 Illustrationen geschmückt, die von Mirzā Ḥasan-e Eṣfahāni stammen, dem Sohn des Āqā Seyyed Mirzā Naqqāšse Eṣfahāni; beide waren sehr bekannte Illustratoren. ${ }^{177}$

Grundsätzlich erscheinen die Bilder auf der linken Seite, in eingen Fällen auch zwei auf einer Seite, machmal auch noch Text unter einem Bild.

${ }^{177}$ Ebd. S. 36. 
Die Bilder auf den Seiten 30 (Nr. 2), 137 (Nr. 14), 140 (Nr.15), 388 (Nr. 47), 578 (Nr. 69), 594 (Nr. 71), 635 (Nr. 76), 642 (Nr. 77), 652 (Nr. 78), 751 (Nr. 89), 771 (Nr. 92),1109 (Nr. 135), 1115 (Nr. 136) tragen die Signatur des Zeichners.

Das erste Buch enthält 21 Bilder. Auf der ersten Seite lesen wir den Titel, die Namen des Kalligraphen und der Druckerei, deren Standort und Erscheinungsjahr. Die Seiten 2 und 3 weisen jeweils zur Hälfte kreisförmig das Symbol der Qāğārendynastie, einen Löwen vor einer zweiäugigen, strahlenden Sonne, auf. Dieser Löwe ist umgeben von verschiedenen Pflanzenarten und Tierköpfen.

Bild 1, Seite 11, 9,21 x 6,5: Die Hochzeit von Anōširavān und Zarangiz, der Tochter des Kaisers von China.

Bild 2, Seite 30, 24,9 x 16,4. Szene 1: Ḥamze geht auf die Jagd und tötet einen gefährlichen Löwen, der im Wald Feyż lebt. Szene 2: Am nächsten Tag wird Ḥamze von Anōširvān in Audienz empfangen und er setzt sich auf den Stuhl des Rostam, der vorher Gostaham gehörte.

Bild 3, Seite 47, 22,5 x 16,5: Ḥamze schläft auf einem Bett in seinem Zelt. Direkt neben dem Bett stehen zwei bewaffnete Männer.

Bild 4, Seite 53, 23,3 x 16,4: Anōširvān setzt Ḥamze als Wächter des Frauengemachs ein.

Bild 5, Seite 63, 22,9 x 16,4: Ḥamze erhält von Anōširvān während eines Festmahls eine Krone.

Bild 6, Seite 70, 22,9 x 16,4: Hamze veranstaltet ein Gastmahl.

Bild 7, Seite 81, 21,8 x 16,6: Landehur b. Sacdān empfängt Ḥamze in Audienz.

Bild 8, Seite 87, 18,9 x 16,6: Ḥamze kämpft gegen Landehur, in der Szene darüber ist das Essen angerichtet.

Bild 9, Seite 100, 18,5 x 16,5: Ḥamze wird von Anōširvān zur Audienz empfangen.

Bild 10, Seite 109, 20,8 x 16,5: Ḥamze tötet Šakāve, der ein Feind des Feridun Šāh Yunāni (Königs von Griechenland) ist.

Bild 11, Seite 117, 18 x 16,5: Ḥamze tötet Qāren.

Bild 12. Seite. 128, 15,3 x 16,5: Hamze reitet auf die Jagd, dort trifft er einen Derwisch, der ein Bild eines Mädchens bei sich trägt, in das sich Ḥamze verliebt.

Bild 13, Seite 132, 19,9 x 16,5: Kampf zwischen Mobārak Šāh und Anōširvān in Ägypten. Bild 14, Seite 137, 22,2 x 16,5: Hamze kann die paris und divs sehen, nachdem er sorme-ye soleimāni (Zauberantimon) in die Augen gerieben hat.

Bild 15, Seite 140, 20,8 x 16,4: Ḥamze schläft im Palast Mahin-e Soleimān und wird von Feenkönig Šahbāl, dem König von Qāf, besucht.

Bild 16, Seite. 149, 17,6 x 16,4: Im Gebirge Qāf kämpft Ḥamze gegen Hezbar-e div. 
Bild 17, Seite 158, 11,8 x 16,4: Landehur kämpft gegen Natvāq, den Feldherrn Dārābs.

Bild 18, Seite 169, 21,6 x 16,4: Ḥamzes Verlobung mit Asmā'), der Königin des Geisterreiches.

Bild 19, Seite 176, 12 x 16,4: Landehurkämpft mit dem weißen Dämon.

Bild 20, Seite 191, 16,6 x 16,4: Mehrnegārs Vorbereitung zur Hochzeit mit Hamze.

Bild 21, Seite 192, 12,3 x 16,5: Ḥamzes Hochzeit mit Asmā’.

Buch 2

Buch 2 umfasst die Seiten 194 bis 335. Dieses Buch enthält 9 Kapitel. Die Kapitel 1 bis 8 umfassen 16 Seiten, Kapitel 9 lediglich 14. Die Kalligraphie wurde von Moḥammad-'Ali angefertigt (2/335). Der Druck ist auf das Jahr 1275/1858 datiert.

Das zweite Buch zeigt auf den ersten Seiten (194 und 195) König Nāṣer ad-Din Šah, in einem Sessel sitzend und von nackten Engeln umgeben, die an die europäische Darstellungsweise erinnern (im Format 14,2 x 16,4).

Bild 22, Seite 201, 16,5 x 16,1: 'Omar Yunāni, Ḥamzes Sohn, kämpft gegen Hām.

Bild 23, Seite 206, 15 x 16,4: 'Amr bringt Anōširvān, Bahtak, Malek Bahman, den Königvon Qohestān und seinen Kundschafter Kolu, in eine Decke oder einen Teppich eingehüllt, zu Ḥamze.

Bild 24, Seite 213, 12,4 x 16,4: Die nackten irakischen Kundschafter werden von den Leichenwäschern gesteinigt.

Bild 25, Seite 217, 16 x 16,4: König Anōširvān, seine Höflinge und Bahtaks Sohn, essen von Bahtaks Fleisch. Im Hintergrund steht 'Amr, der Bahtak getötet und sein Fleisch gekocht hat.

Bild 26, Seite 222, 14,5 x 16,4: Ḥamzes Begleiter raubt einem Derwisch die Kürbisschale. Ḥamze gegenüber ist eine Eselskarawane zu sehen, deren Besitzer den Derwisch zu Ḥamze schickte, um ihn davon zu überzeugen, dass sie keine wertvolle Ware mit sich führen.

Bild 27, Seite 227, 17,2 x 16,4: Ḥamze tötet den fränkischen Heerführer.

Bild 28, Seite 235, 16 x 16,5: Ḥamze sieht im Wald einen Löwen, der einen wilden Mann getötet hat. Hamze tötet seinerseits den Löwen.

Bild 29, Seite 247, 18,6 x 16,4: ‘Alam Šāh tötet Mandak-e ḥakim.

Bild 30, Seite 251, 15,1 x 16,5: ‘Alam Šāh besucht die Tochter Mālā-kards im Garten.

Bild 31, Seite 259, 18,5 x 16,5: Ein junger Mann (oben links) verkleidet sich als Priester, geht in eine Kirche, um die Priester zu betäuben und die Statuen zu stehlen. 
Bild 32, Seite 269, 18,2 x 16,4: Hamze und 'Amr treffen auf der Jagd den verschleierten Reiter und sein Heer.

Bild 33, Seite 278, 17,3 x 16,4: Karib tötet 'Ād b. Eskandar.

Bild 34, Seite 286, 18,6 x 16,5: Kalb, der Onkel von 'Alam Šāh, will Karib mit dem Schwert töten, aber ein Kundschafter hindert ihn daran.

Bild 35, Seite 296, 16,7 x 16,5: Die Kundschafter haben 'Alam Šāh festgenommen und ihn zu Eskandar-e Maġrebi gebracht.

Bild 36, Seite 303, 20,1 x 16,4: Karib tötet in Gegenwart Ḥamzes Eskandar Mağrebi.

Bild 37, Seite 312, 20,2 x 16,5: 'Amr steigt auf den 'Oqābin (ein Stangengerüst zum Festhalten von Gefangenen), um Ḥamze zu befreien.

Bild 38, Seite 320, 20,3 x 16,5: ‘Amr gießt für Sām-e ğādugar, Prinz Parviz und den Perserkönig Wein ein.

Bild 39, Seite 329, 18,6 x 165: 'Amr fliegt auf Tondak-e divs Schultern über Qārens Lager.

Bild 40, Seite 333. 18 x 16,5: Karib tötete 'Ād b. Eskandar.

Zwischen den Büchern 2 und 3 befinden sich auf den Seiten 336 und 337 zwei Bilder, die fast die ganze Seite ausfüllen.

\section{Buch 3}

Buch 3 umfasst die Seiten 338 bis 525. Dieses Buch enthält 12 Kapitel. Die Kapitel 1 bis 11 zählen je 16 Seiten, Kapitel 12 lediglich 12. Der Kalligraph war laut Signatur (3/525) Moḥammad 'Ali Teherāni. Es wurde im 1276/1859 in der Druckerei von Āqā Mirzā 'AliAkbar in Dār al-halāfe (Teherān) gedruckt.

Das dritte Buch beginnt auf den Seiten 338 und 339 mit einfachen Darstellungen von Blumen und Blättern im Format 14 x 16,5.

Bild 41, Seite 345, 20 x 16,7: 'Amr kommt an den Hof des Perserkönigs und sieht, dass dort ein Fest gefeiert wird.

Bild 42, Seite 351, 18 x 16,5. Szene 1: Die muslimischen Helden kämpfen mit den Feueranbetern. Szene 2: Qāren tötet Firuz-e Sāsāni und öffnet die Festungstür für 'Amr. Bild 43, Seite 358, 18,3 x 16,5: Karib tötet Qāren.

Bild 44, Seite 366, 20 x 16, 5. Szene 1: Ğamšid und Horšid, die Könige von Balḩ, verbeugen sich vor Ḥamze. Szene 2: Die Könige von Balh und ihre Leute gehen Ḥamze entgegen.

Bild 45, Seite 373, 18,4 x 16,5: Šamses Amme bringt 'Alam Šāh in den Garten von Šamse-ye Huāvari, der Prinzessin des Ostens. 
Bild 46, Seite 384, 18,3 x 16,5: Hosrou Hāan-e Huāvari, der König des Ostens, befiehlt seinem Feldherrn Ṭarmāsb, ‘Alam Šāh zu töten.

Bild 47, Seite 388, 18,3 x 16,5: 'Alam Šāh kämpft alleine mit dem Heer des Ostens.

Bild 48, Seite 395, 18,4 x 16,5: Anōširvān wird von Șalṣāl in einer Audienz empfangen. Plötzlich kommt Qarā H্ān, Șalṣāls Feldherr. Er bringt den Kopf Kahrāsbs, den er zuvor getötet hat.

Bild 49, Seite 403, 16,6 x 16,5: Samak rettet die Kundschafter vom Galgen.

Bild 50, Seite 409, 20 x 16,5: Badi az-Zamān ringt vor den Augen von Anōširvān und Șalṣāl mit Kahreš-e Hatā'i und überwindet ihn.

Bild 51, Seite 415, 19,1 x 16,8: Mālek-e Aštar tötet vor den Augen von Șalṣāl einen seiner Helden namens Babrkoš.

Bild 52, Seite 425, 18,3 x 16,9: Nesā und 'Amr im Brautgemach.

Bild 53, Seite 431, 20 x 16,7: ‘Amr tötet die Hexe Šamāme.

Bild 54, Seite 437, 20 x 16,7: Zardehang-e Hotani kämpft mit 'Amr.

Bild 55, Seite 445, 18,4 x 16,5: Șalṣāls Soldaten haben Samak festgenommen und ihn zu Ṣalṣāl gebracht. Șalṣāl verlangt von ihm, einen Götzen anzubeten.

Bild 56, Seite 450, 20 x 16,5: Ḥamze tötet Keivān-e ğādū, der sich zuvor in einen Löwen verwandelt hat.

Bild 57, Seite 460, 21,6 x 16,6: Ḥamze, Ğamšid, der König von Ğābalqāa, und seine Tochter Horšid suchen 'Amr, der sich in einem Gebirgstal befindet.

Bild 58, Seite 467, 20 x 16,5: Šamḩāl-e div bringt 'Amr zu Ḥamze und seiner Frau Asmā' ins Geisterland (Qāf).

Bild 59, Seite 479, 20,2 x 16,7: Malek Qāsem reißt 'Amr b. Ma`di Karib vom Pferd.

Bild 60, Seite 488, 20,2 x 16,7: 'Amr wird vom Scharfrichter mit dem Schwert bedroht, bekommt aber die Erlaubnis, vor Hormuz und Parviz zu singen.

Bild 61, Seite 495, 20,1 x 16,5: 'Amr singt in einer Audienz vor dem Perserkönig und dessen Sohn Parviz.

Bild 62, Seite 500, 19 x 16,5: ‘Amr und ein Dämon gehen ins Lager der Gottesanbeter, um zu betteln.

Bild 63, Seite 507, 20 x 16,5: 'Amr versteckt ein Mädchen im Berg und Ḥamze kämpft allein mit 700.000 Feueranbetern unter der Führung von Babrān, der auf einem Tiger reitet.

Bild 64, Seite 514, 21,8 x 16,5: Ḥamze kämpft mit seinem Sohn Badic az-Zamān, den er zunächst nicht erkennt.

Bild 65, Seite 523, 21,7 x 16,5: Auf Ḥamzes Wunsch trägt 'Amr Lobgedichte auf Karib vor. 
Zwischen den Büchern 3 und 4 befinden sich auf den Seiten 526 und 527 zwei Bilder, die fast die ganze Seite ausfüllen.

\section{Buch 4}

Buch 4 umfasst die Seiten 528 bis 725. Die ersten 12 Kapitel haben jeweils eine Länge von 16 Seiten, Kapitel 13 hat nur 6 Seiten. Geschrieben wurde es von Moḥammad-Ğacfar Golpāyegāni (4/725), gedruckt wurde es im Jahr 1275/1858 in der Druckerei von Āqā Mirzā 'Ali-Akbar in Dār al-halāfe (Teherān).

Am Anfang des vierten Buches begegnet uns auf Seite 528 in der Form eines ovales Medaillons das Portraiteiner Frau, das Gesicht unverhüllt, auf ungewöhnliche Art europäisch gekleidet (Format $14.5 \times 17.7)$.

Bild 66, Seite 535, 13 x 16,5: Ḥāreṣ b. Landehur tötet zwei Löwen mit bloßen Händen. Bild 67, Seite 551, 15,9 x 16,5: Ša‘ša‘ kämpft gegen Čālāk-e ‘ayyār.

Bild 68, Seite 565, 15,2 x 16,5: Malek Qāsem kämpft mit Ğām b. Ša‘šac und tötet ihn.

Bild 69, Seite 578, 23,6 x 16,5: ‘Amr bringt Ḥamzes Brief zu einem verschleierten Helden.

Bild 70, Seite 588, 18,3 x 16,5: Nur ad-Dahr kämpft gegen Ğamām und tötet ihn.

Bild 71, Seite 594, 22,5 x 16,5: Merih, Badi` az-Zamāns Feldherr, kämpft gegen Sergān, Ilāqs und Wilāqs Feldherrn, und tötet ihn.

Bild 72, Seite 603, 18,5 x 16,5: Zomorrods Engel haben Šāh Sacd aufgehängt und beschießen ihn mit Pfeilen.

Bild 73, Seite 611, 19,2 x 16,5: 'Amr kämpft mit Zomorrods Kundschafter Sāsān und nimmt ihn gefangen. 'Amrs Kundschafter spielen wegen dieses Erfolges die Trompeten.

Bild 74, Seite 620, 14,7 x 16,5: Karib und Nahid, der König von Nahid-ḥeṣār, reiten zusammen. Karib sieht im Wald einen Löwen und tötet ihn.

Bild 75, Seite 628, 21,8 x 16,5: Ḥamze kämpft gegen 'Anqavil und wird von dessen Schwert getroffen.

Bild 76, Seite 635, 16,6 x 16,5: Ḥamze kämpft mit Ṣenoubar Bānu, ‘Anqavils Schwester. Er wirft sie zu Boden.

Bild 77, Seite 642, 18,3 x 16,5: Ḥamze kämpft mit Zomorrod und reißt ihn vom Pferd.

Bild 78, Seite 652, 18,5 x 16,5: Ağrus-e div bringt 'Aẓame-e ğādūs Brief zu Ḥamze.

Bild 79, Seite 658, 19 x 16,5: Ḥamze kämpft mit Zarār-e ğādū und tötet ihn.

Bild 80, Seite 669, 21 x 16,5: Ein verschleierter Bote Nur ad-Dahrs kommt in Hamzes Zelt und verlangt, dass dieser seine Pferde seinem Herrn gebe. 
Bild 81, Seite 675, 19,4 x 16,5: Malek Qāsem geht in Nur ad-Dahrs Zelt und sieht, dass Nur ad-Dahr vermeintlich getötet worden ist (in Wahrheit wird dieser Effekt durch einen Hexenzauber hervorgerufen; Nur ad-Dahr ist also noch am Leben).

Bild 82, Seite 682, 22,3 x 16,5: Nur ad-Dahr und Asad reiten zu Malek Qāsems Lager.

Bild 83, Seite 690, 22 x 16,5: Ās verbeugt sich vor Ḥamze und sagt, dass 'Amr seine Nase abgeschnitten habe.

Bild 83, Seite 700, 21,9 x 16,5: Malek Irăg besucht Ḥamze und sie trinken miteinander Wein.

Bild 84, Seite 706, 19,2 x 16,5: Nur ad-Dahr kämpft mit Dārāb.

Bild 85, Seite 717, 20 x 16,5: ‘Uğān hat Landehur und seine Helden gefangen genommen und bringt sie in die Festung Faranqušiye.

Bild 86, Seite 721, 14,8 x 16,5: Ḥamid und Bahtak (in Frauenkleidern) halten Hochzeit.

Zwischen den Büchern 4 und 5 befinden sich auf den Seiten 726 und 727 zwei Bilder, die fast die ganze Seite ausfüllen.

Auf der vorletzten Seite, Seite 726 finden wir ein Bild, in dessen Zentrum, eingerahmt von Blumen und Blättern, das Erscheinungsjahr 1275/1858 steht. Auf der letzten Seite, Seite 727 folgt ein Bild, in dessen Mitte die Namen des Auftraggebers, Prinz Parviz Mirzā, und des Inhabers der Druckerei, Mirzā 'Ali-Akbar stehen, wiederum von Blumen und Blättern eingerahmt.

\section{Buch 5}

Buch 5 enthält die Seiten 728 bis 1053. Schon im Buch 4 auf Seite 723/20 wurde Buch 5 unter dem Titel Irağ-nāme erwähnt. Es gliedert sich in 21 Kapitel. Das erste Kapitel hat 15 Seiten, die Kapitel 2 bis 20 je 16 Seiten, das letzte Kapitel 21 hat nur 7 Seiten. Moḥammad'Ali (5/1053) schrieb das Buch, gedruckt wurde es im Jahr 1858 in der Druckerei von Āqā Mirzā 'Ali-Akbar-e bāsmeči in Dār al-ḩalāfe (Teherān).

Die obere Hälfte der Seiten 728 und 729 ist mit Ornamenten aus dem Pflanzenreich geschmückt, die auf jeder Seite die Gestalt Marias mit Jesus in ihren Armen umrahmen, beide von einem Heiligenschein umhüllt. Unterhalb dieser Darstelltung erkennen wir den Kopf eines schnurrbärtigen Dämons, von engelhaften Wesen umgeben. Über der Gestalt Mariens thronen zwei Löwen mit der persischen Krone auf ihren Häuptern. Im Hintergrund taucht eine Sonne mit menschlichen Gesichtszügen auf. (Format 13,3 x 16,4).

Bild 87, Seite 737, 21,8 x 16,5: Irağ kämpft mit Asad und verwundet ihn.

Bild 88, Seite 743, 20,9 x 16,5: Asad flieht aus Irağs Zelt. 
Bild 89, Seite 751, 18,5 x 16,5: Irağ reißt Ṭarmāsb vom Pferd und wirft ihn zu Boden.

Bild 90, Seite 757, 21,9 x 16,5: Irağ und Behzād trinken Wein, Malek Irağ schreibt einen Brief.

Bild 91, Seite 766, 21,8 x 16,5: Ṭarmāsb bringt Irağs Brief zu Asad. Asad bietet ihm vergifteten Wein an, trinkt selber davon und wird bewusstlos.

Bild 92, Seite 771, 19,8 x 16,5: Nur ad-Dahr trifft Zohre, Keivān Šāhs Tochter.

Bild 93, Seite 782, 21,4 x 16,5: Ḥamze schickt Badi' az-Zamān und 'Amr aus, um einen Brief zu Zebarğad Šāh zu bringen.

Bild 94, Seite 786, 21,6 x 16,5: Ġażanfar, Asads Sohn, kämpft mit Dārāb.

Bild 95, Seite 793, 20,2 x 16,5: Irağ kämpft gegen einen verschleierten Helden.

Bild 96, Seite 802, 19,2 x 16,5: Irağ kämpft gegen einen verschleierten Helden, der auf einem Kamel reitet.

Bild 97, Seite 811, 21,6 x 16,5: Die Hochzeit von Asad und Eqbāl Šāhs Tochter.

Bild 98, Seite 820, 20,9 x 16,5: Irağ auf der Jagd.

Bild 99, Seite 828, 17,5 x 16,5: Soleimān Šāh schlägt die Zelte außerhalb der Festung auf und schickt zwei Leute nach Ž 'l-Amān.

Bild 100, Seite 834, 20 x 16,5: Šāh Sa'd und seine Soldaten auf dem Schiff sichten einen Wal.

Bild 101, Seite 843, 20,4 x 16,5: Qoreiši Bānu, Ḥamzes Tochter, kämpft gegen Dämonen und tötet sie.

Bild 102, Seite 852, 22,8 x 16,5: Farhād Hुān, Landehurs Sohn, kämpft gegen Ğarmāsb.

Bild 103, Seite 860, 19,8 x 16,5: ‘Alam Šāh kämpft gegen Neyram.

Bild 104, Seite 866, 20,8 x 16,5: Asad sitzt in einer Kiste, die von Yāqūt Šāh ins Meer geworfen wird. Ein Wal verschluckt die Kiste.

Bild 105, Seite 875, 21 x 16,5: Malek Iră̆ kämpft gegen einen verschleierten Helden, um dessen Kopf Vögel fliegen.

Bild 106, Seite 878, 20 x 16,5: ب̣amze kämpft gegen Neyram.

Bild 107, Seite 883, 19 x 16,5: Horšid Bānu, Malek Qāsem und Giti-afruzs Tochter, wird von den Frauen getadelt, weil sie mit Irağ gekämpft hat.

Bild 108, Seite 889, 19 x 16,5: Mālek kämpft mit Zāl Hōan-e Usbek.

Bild 109, Seite 897, 19,6 x 16,5: Mālek kämpft mit dem Usbekenkönig Șalṣāl.

Bild 110, Seite 906, 20 x 16,5: Nur ad-Dahr kämpft mit Malek Irağ.

Bild 111, Seite 915, 20,2 x 16,5: Malek Irağ kämpft gegen Badi` az-Zamān. 
Bild 112, Seite 924, Die fränkischen Kundschafter haben Dārābs Kundschafter Fatāḥ festgenommen und ihn zu ihrem Oberhaupt Mahmur gebracht.

Bild 113, Seite 931, 22,8 x 16,5: Die Feen kämpfen gegen Asad, der viele von ihnen tötet.

Bild 114, Seite 939, 20 x 16,5: Šamās Šāh, Zomorrod und Zebarğad besuchen eine Kirche.

Bild Bild 115, Seite 950, 19,9 x 16,5: Hamze und 'Amr sehen im Garten eine Fee in Gestalt eines Vogels mit menschlichem Kopf und vier Ammengestalten.

Bild 116, Seite 960, 19,9 x 16,5: Keivān-e Takāvandi kämpft mit einem verschleierten Helden.

Bild 117, Seite 963, 18 x 16,5: Ḥamze reitet zur Jagd.

Bild 118, Seite 969, 22 x 16,5: Susan-e ğādū kämpft in Gestalt eines Drachen mit 'Amr b. Macdi.

Bild 119, Seite 976, 22,2 x 16,5: Dämonen kommen zu Šāh Soleimān und wollen seine Frauen mitnehmen.

Bild 120, Seite 985, 21,5 x 16,5: Asad hat seine Beute auf Kamele verladen.

Bild 121, Seite 994, 24,8 x 16,5: ‘Alam Šāh hebt Dudes Elefanten über seinen Kopf.

Bild 122, Seite 1002, 21,2 x 16,5: Ḥamze kämpft mit Irağ.

Bild 123, Seite 1004, 23,1 x 16,5: Ḥamze ringt mit Malek Irağ.

Bild 124, Seite 1013, 21,5 x 16,5: Nur ad-Dahr überwindet Dārāb und bringt ihn zu Ḥamze.

Bild 125, Seite 1019, 23 x 16,5: Irağ kämpft mit Qomhur.

Bild 126, Seite 1024, 21 x 16,5: 'Amr trifft Balāšur, der Badi' az-Zamān entführt hat.

Bild 127, Seite 1032, 22,5 x 16,5: Irağ tötet Panğāl.

Bild 128, Seite 1042. 19,2 x 16,5: ب̣amze kämpft mit Qomhur, seinen ihm unbekannten Sohn, und besiegt ihn.

Bild 129, Seite 1049, 21,8 x 16,5: Ḥamze richtet ein Fest aus.

Zwischen den Büchern 5 und 6 erscheinen auf den Seiten 1054 und 1055 wieder Pflanzen als Ornamente, die folgende Inschrift umrahmen: „Dieses Buch wurde in der Druckerei Ostād Karbalā'i Āqā Mirzā Feyżallāh Afšār im Jahr 1273 [1856] gedruckt.“

Buch 6

Buch 6 umfasst die Seiten 1056 bis 1121. Die ersten 4 Kapitel enthalten jeweils 16 Seiten, das Kapitel 5 lediglich 3 Seiten. Angaben zum Kalligraphen fehlen. Gedruckt wurde es im Jahre 1857 in der Druckerei von Ostād Karbalā’i Āqā Feyżallāh Afšār. 
Am Anfang des Buches befindet sich auf der Seite 1056 ein Bild, das in der Mitte oben einen Löwenkopf mit einer Krone und unten einen Dämonenkopf zeigt, beide sind von Blumenornamenten und Tierköpfen (Löwen, Pferde, Pfauen) umgeben. (Format 12.3 x 16.4).

Bild 130, Seite 1069, 22,3 x 16,5: Nur ad-Dahr kämpft gegen Malek Irăg.

Bild 131, Seite 1080, 20,2 x 16,5: Șalṣāl kämpft gegen Landehur.

Bild 132, Seite 1086, 17,3 x 16,5: Zelzele-e ğādu hat Rostam-e sāni, Malek Irağs Sohn, gefangen genommen.

Bild 133, Seite 1094, 22.5 x 16.5: Vor Šāh Sa`d ringen Malek Irağ und der verschleierte Held.

Bild 134, Seite 1102, 20,7 x 16,5: Mahnušlab und ihre Amme gehen ins Gefängnis, um Rostam-e sāni zu besuchen.

Bild135, Seite 1109, 23,8 x 16,5: Soleimān-e șāni kämpft mit einem verschleierten Helden.

Bild 136, Seite 1115, 21 x 16,5: Hạmze-e sāni kämpft gegen Lāhut und dessen Zauberdrachen.

\section{Buch 7}

Buch 7 umfasst die Seiten 1122 bis 1149. Buch 7 ist als einziges nicht in Kapitel unterteilt. Während die Namen des Kalligraphen und der Druckerei unbekannt sind, wird der Druck jedoch auf das Jahr 1276/1858 datiert.

Das Buch 7 beginnt auf Seite 1122 mit einem Bild, in dessen Mitte oben ein Löwenkopf mit einer Krone und unten ein Dämon zu sehen sind. Den Rahmen bilden wieder Blumenornamente und Tierköpfe (Format 12,3 x 16,4).

Bild 137, Seite 1143, 21,8 x 16,5: Ḥamze-ye șāni kämpft mit den Hexen.

\subsection{Einige Vorbemerkungen zum $R H$}

Das Buch $R H$ umfasst insgesamt 7 Bände mit 1.149 Seiten. Vollständig erhalten sind die Bände 1 bis 5; diese weisen eine Art roten Erzählfaden auf. Das Exemplar des $R H$, das meiner Untersuchung zugrunde liegt, ist stellenweise beschädigt. Einige Erzählungen haben keine Überschrift, manche Überschriften wiederum passen nicht zum Text. Im 5. Buch z.B. kündigt der Erzähler an, dass es sich um eine Geschichte von Dārāb handeln soll, in Wahrheit aber lesen wir etwas von einem gewissen Farhād, Sohn des Landehur, und von Ḥamzes Frauen $(5 / 836)$.

Manchmal haben Abschreiber Namen in verschiedenen Formen eingetragen (beispielsweise Salmān-e Fāresi, der anstatt Salmān oft Soleimān-e Fāresi geschrieben wird). 
Die einzelnen Episoden haben unterschiedliche Längen. Einige sind mehr als 5-6 Seiten lang, andere umfassen nur ein paar Zeilen. Vermutlich haben die Erzähler eine Geschichte ausführlicher vorgetragen, als es die wenigen Zeilen ahnen lassen, die oft nur als Stichworte dienen $(2 / 211 ; 5 / 838 ; 842 ; 843)$. Der Vortragende hat sich aber auch an die Regel zu halten, die Zuhörer nicht mit Einzelheiten einer Geschichte zu überhäufen, um sie nicht zu langweilen (2/365/24).

Der Text ist offenbar aus mehreren tumārs (Schriftrollen) zusammengestellt worden. Im Schlusswort (7/1149) schreibt der anonyme Sammler über seine Arbeit, er habe die Erzählung aus Bruchstücken gebildet und selbst nichts hinzugefügt. Die auf mehreren Rollen verteilten Bruchstücke unterscheiden sich in ihrem literarischen Wert durch den Gebrauch einer mehr oder weniger bilderreichen Sprache; je nachdem, ob der Erzähler am Hofe oder vor einfachem Volk seine Geschichte vortragen hat.

Die Bände 6 und 7 sind unvollständig, viele Handlungsstränge geraten durcheinander, viele Geschichten beginnen zwar, brechen dann aber ab. Beide Bände weisen insgesamt nur wenige Seiten auf und sie enthalten in der Urdu-Version weitere Erzählungen. Die Bücher La I-nāme und Turağ-nāme gibt es nur in der Urdu-Version, in der persischen fehlen sie völlig. ${ }^{178}$

Die Autoren des $R H$ versorgen uns jeweils am Anfang der Bände 1 bis 5 mit Vorinformationen über die Hauptpersonen ihrer Geschichten. Für den 6. Band fehlen diese Angaben (z.B. wissen wir nicht, wer Turağ-e bad-rag ist und warum er Krieg gegen die Muslime führt (6/1118-1121). Im 7. Buch erfahren wir, dass Turağ eingrünes Mal im Gesicht trägt, dass ihn als Ḥamzes Sohn ausweist. Von seiner Geburt und Kindheit wird jedoch nichts berichtet (7/1140). Seine Geschichte entstammt einem anderen Buch namens Turağ-nāme, das nicht in der persischen Version des $R H$ zu finden ist, sondern nur in einer Urdu-Version vorhanden ist. ${ }^{179}$

Schon in der Safavidenzeit sind viele Erzählungen des $R H$ verloren gegangen; deshalb versuchen manche Erzähler oder Schreiber die eine oder andere Lücke zu schließen, indem sie eigene Texte geschrieben haben. ${ }^{180}$ Im Buch Bustān-e hayāllesen wir, dass die Erzähler Geschichten verfasst haben, die zu den vorhandenen passen sollten, ${ }^{181}$ wie die Geschichte von Hendu-e hezār-dast (der tausendhändige Inder), die in der für diese Untersuchung benutzten

\footnotetext{
${ }^{178}$ Vgl. Pritchett, S. 270-271.

${ }^{179}$ Ebd.

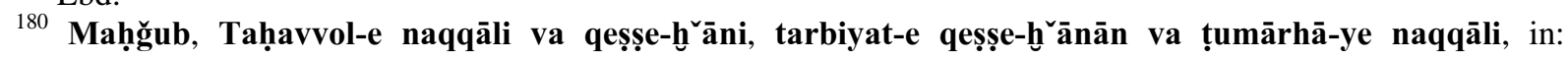
Adabiyāt-e 'àmmiyāne-ye Irān, Bd. 2, S. 1079-1113, hier S. 1100.

${ }^{181}$ Maḥğub, Bustān-e hyayāl, in: Adabiyāt-e 'āmmiyāne-ye Irān, Bd. 1, S. 617-676, hier S. 633.
} 
Ausgabe des $R H$ fehlt, in der Șafavidenzeit aber durchaus ein Bestandteil gewesen sein soll. $^{182}$

\subsection{Inhalt und Zielsetzung des $R H$}

Der Inhalt der Erzählungen spielt in vorislamischer Zeit. Ḥamze, die Hauptperson, handelt als weltlicher Held im Auftrag des Gottes Allāh, um den islamischen Glauben zu verbreiten. Der Erzähler mischt diesen Stoff aus vorislamischer Zeit mit Ereignissen, die zu seiner Zeit, also im 15./16. Jahrhundert in der islamischen Welt stattfanden. Offenbar handelt es sich um einen schiitischen Muslim, der seine Verehrung für 'Ali mehrmals zum Ausdruck bringt. Hinweise auf islamische und schiitische Glaubensgrundsätze kommen im $R H$ häufig vor, ebensoder persische Name für Gott (hodā). Sehr oft lesen wir als islamisches Glaubensbekenntnis, Iā ilāha illā Ilāh (Es gibt keinen Gott außer Allāh).

Diese Art Volksliteratur, ursprünglich aus einem einfachen Glauben an etwas Übernatürliches heraus entstanden, kann durchaus ideologisch-politischen Zwecken dienen. Die Erzähler benutzen ihr Material auch dazu, ihre Zuhörerschaft muslimischen Glaubens zu belehren, (5/951/2-3) daran zu erinnern, dass Ungläubige den Islam bedrohen. ${ }^{183}$

Die Erzähler, die die Schia verbreiteten, erzählten oft mangels tieferer religiöser Kenntnisse unrichtige und phantastische Geschichten über Persönlichkeiten des frühen Islam, die sie vielfältig abwandelten. Die schiitischen Rechtsgelehrten kritisierten diese Erzähler als Häretiker. Die Zuhörer waren oftmals nicht in der Lage, zwischen tiefer und oberflächlicher religiöser Erkenntnis, zwischen Wirklichkeit und Dichtung zu unterscheiden. Die offizielle schiitische Lehrmeinung stand in starkem Gegensatz zum $R H$. Dabei machten sich die Erzähler des $R H$ nicht über Autoritäten lustig und liessen sich auch nicht auf theologische Auseinandersetzungen ein. Diese Geschichtenerzähler waren durchaus in der Lage, eine Art Volksfrömmigkeit durch den Inhalt ihrer Erzählungen zu bilden. Es entwickelten sich neue religiöse Praktiken, die häufig mit der Lehrmeinung des theologischen Islam nichts zu tun hatten. Um den Geschmack der Zuhörer zu treffen, wurden Themen, die sich auf die Religion und die Geschichte des Islams beziehen, sogar verändert. Sehr oft begegnen uns in den Erzählungen über Propheten fantasievolle Ereignisse, die bestimmte Funktionen haben.

Das $R H$ ist mithin eine Anderswelt. Hier gibt es keine eindeutige raumzeitliche Ordnung und keine in klarer Kausalität miteinander verknüpften Geschehensfolgen. Unklar sind oft Anlass und Verlauf des Streits um Macht, Frauen und Reichtum: Wieso wird Hamze selbst in die

\footnotetext{
182 Sistāni, Malek Šāh Ḥosein b. Malek Ġiyāṣ ad-Din Moḥammad b. Šāh Maḥmud: Ihyãa al-Moluk, hrsg. von Manučehr Sotude, Teherān 1344/1965, S. 491.
} 
Auseinandersetzung verwickelt? Warum befreite beispielsweise Hamze den Perserkönig, nachdem ihn 'Amr festgenommen hatte? Ursache und Folge, Werden und Sein, Vorher und Nachher, Hier und Anderswo verschwimmen. Dies geschieht ohne eindeutige Strukturen, die der Handlung eine stringente Logik geben würden. Das Publikum war gern bereit, solche unlogischen Wendungen, Zeit- und Ortswechsel zu akzeptieren, solange es nur gut unterhalten wurde.

\section{7 $R H$ in der islamischen Welt}

In den islamischen Kulturen spielte der Hamze-Roman eine bedeutende Rolle. Wegen seines volkstümlichen Inhalts fand er weite Verbreitung. Übersetzt wurde er u.a. ins Türkische, ${ }^{184}$ Arabische ${ }^{185}$ Urdu, ${ }^{186}$ Georgische ${ }^{187}$ Malaiische ${ }^{188}$ und Javanische. ${ }^{189}$ Die Übersetzung in eine andere Sprache war mit bestimmten Eigenarten der fremden Kultur verbunden. In diesen unterschiedlichen Versionen spiegelt sich eine Vielfalt der islamischen Welt wieder.

Der Roman von Ḥamze heißt im Arabischen Sirat Hamza ${ }^{190}$ und weist dort, verglichen mit der persischen Urfassung, unterschiedliche Merkmale und Ausprägungen des Stoffes auf und existiert wie die meisten volkstümlichen Romane in verschiedenen Versionen.

Um den Einfluss des $R H$ auf die persische Literatur beurteilen zu können, müsste seine Bedeutung in Indien, in der Türkei und in den arabischen Ländern untersucht werden.

Iraner, Inder, Türken und der gesamte arabische Raum haben eine besondere Vorliebe zu erzählen und dem Erzählten (heldenhafte Kämpfe, humorvolle Dialoge, Liebesgeschichten, Märchen) zuzuhören. Die Geschichten über Ḥamze gewannen schnell an Popularität, weil sie sich gleichermaßen an gebildete wie ungebildete Zuhörer richteten. Sogar bei Trauerfeiern

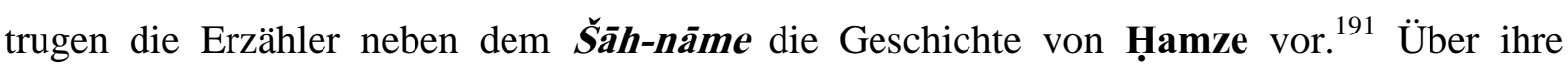
Beliebtheit schreibt Faḩr az-Zamāni:

183 Šahri, Ğa'far: Tehrān-e qadim, Bd. 2, S. 139-193; vgl. Modarres-Čahārdehi, Moḥammad: Hākssār va ahl-e haqq, Teherān 1368/1989, S. 71.

${ }^{184}$ Sezen, Lütfi: Halk Edebiyatinda Hamzanāmeler, Ankara 1991; vgl. Warren S. Walker: A Turkish Folktale: The Art of Behçet Mahir, New York 1996.

${ }^{185}$ Lyons, Malcom C.: The Arabian Epic, Bd. 2-3, Cambridge 1995, Bd. 2, S. 534-585; Bd. 3, S. 223-238.

${ }^{186}$ Pritchett, Frances W.: The Romance Tradition in Urdu. Adventures from the Dastan of Amir Hamzah, New York 1991; Monzavi, Aḥmad: A Camprehensive Catalogue of Persian Manuscripts in Pakistan, Bd. VI, Islamabad 1987, S. 933-939.

${ }^{187}$ Khoneli, Mose: Amiran Darejaniani. A cycle of medieval Georgian tales traditionally ascribed to Mose Khoneli, trans. by R. G. Stevenson, Oxford 1958.

${ }^{188}$ Hooykaas,Christiaan: Over Maleise Literatur, Leiden 1974, S. 151-157.

${ }^{189}$ Pigeaud, Theodore G. Th.: Javanses and Balinese Manuscripts, Wiesbaden 1975, S. 90; Ethé, Neupersische Literatur, in: Grundriss der iranischen Philologie, zweiter Teil, S. 318; Pritchett, S. 4.

${ }^{190}$ Marzolph, Ulrich: Ḥamze-nāme, in: EM, Bd. 6, Göttingen 1990, Sp. 430-435, hier S. 435.

${ }^{191}$ Malek Šāh Ḥosein Sistāni, S. 491. 
„Die Geschichte des Șāḥeb-qerāns ist sehr süß. Sie ist eine sehr bunte Sage. Obwohl sie eine lügenhafte Geschichte ist, ist das Lesen und Hören dieser Geschichte nützlich.“192

Als der Iran in der Șafavidenzeit in kriegerische Auseinandersetzungen mit dem osmanischen Reich und den Usbeken verwickelt war, erfreuten sich Erzählstoffe, die Krieg und Heldentum zum Inhalt hatten, bei Zuhörern größter Beliebtheit. Die Șafaviden waren hinsichtlich ihrer religiösen und politischen Absichten daran interessiert, bei den Soldaten (vorzugsweise bei denen, die sich in Qizilbāš-Kasernen aufhielten) Kampfbereitschaft zu wecken und somit unterstützten sie die Kunst der Erzählung.

Erwähnenswert sind folgende drei Erzähler, die sich auf den Vortrag des Ḥamze-Romans spezialisiert hatten: Mirzā Moḥammad Fāresi, der aus Bavanāt-e Fārs stammte. Nach dem Tod seines Lehrers trug er die Geschichte des Hamze in Kaffeehäusern vor. ${ }^{193}$

Ḥoseinā (gest. 1668), der ein sehr guter Musiker und Erzähler war. ${ }^{194}$

'Abd an-Nabi Faḩr az-Zamāni, der selber Schriftsteller und dazu Erzähler war, berichtet in seinem Werk Tazkere-ye mei-hã̄ne, dass er die Geschichte von Ḥamze zunächst gehört und dann auswendig gelernt habe. Im Alter von 19 Jahren wanderte er nach Indien aus. Dort diente er Mirzā Neẓām-e Qazwini, einem Verwandten, der eine Vorliebe für die ḤamzeGeschichte hatte und 'Abd an-Nabi Fahrr az-Zamāni bat, diese Geschichte zu erzählen. ${ }^{195}$

In der Qāğārenzeit war die Geschichte des Ḥamze ebenfalls sehr beliebt und wurde auf Straßen und Kaffeehäusern erzählt. In einem Katalog gedruckter Bücher, den Ḥāğği Mosā Tāğer Teherāni herausgab, findet sich die Ḥamze-Geschichte unter dem Obertitel qeș̣e va hekāyāt (Erzählung und Geschichte). ${ }^{196}$ Noch heute liest das iranischsprachige Volk der Belutschen in seinen nächtlichen Versammlungen u.a. die Märchen und Sagen von Amir Hamze, den vier Derwischen und Horam o Zibā. ${ }^{197}$

Nachdem Mạ̣mud von Ghazna (reg. 1030) im 11. Jahrhundert einen großen Teil Indiens erobert hatte, regierten dort verschiedene muslimische Herrscher. Die persische Sprache und Kultur nahm eine wichtige Position ein. Die Orientalistin Annemarie Schimmel schreibt: „Die

\footnotetext{
${ }^{192}$ Faḩr az-Zamāni, Terāz al-ahbār, S. 19bf.

${ }^{193}$ Nașrābādi, S. 401.

${ }^{194}$ Ebd. S. 357.

${ }^{195}$ Fah̆r az-Zamāni, Tazkere-ye mei-hāne, S. 760-762.

${ }^{196}$ Marzolph, Ulrich: Persian Popular Literature in the Qajar Period, in: Asian Folklore Studies, Vol. LX-2, Nagoya 2001, S. 215-236, hier S. 225.

197 Afšār, Irağ: Maqālāt-e Iran-šenāsi, Teherān 1369/1990, S. 432; bis Anfang des 20. Jahrhunderts war die Geschichte Hamzes im Iran, besonders in Aserbaidschan, sehr beliebt. Siehe: Basgöz, Ilhan: Türkish HikayeTelling Tradition in Azerbaijan, Iran, in: JAFS, Vol. 83, No. 330, Oct-Dec, Austin/Texas 1970, S. 391-405.
} 
Geschichte Ḥamzes muss in Indien in der Regierungszeit Mạ̣mūd von Ǵaznas populär gewesen sein.“198

Während der Herrschaft der Șafaviden wanderten viele Wissenschaftler, Erzähler und Künstler nach Indien aus ${ }^{199}$, um sich frei entfalten zu können. Die Könige von Indien und Dakan förderten an ihren Höfen die Erzähler. ${ }^{200}$ Sehr beliebt war das iranische Epos bei den mongolischen Kaisern von Indien. Erzähler lasen am Hofe des Kaisers Bābur aus dem Buch ک̌āh-nāme sowie die Qeșaṣ al-anbiyā' (Propheten-Geschichten) vor. ${ }^{201}$ Ġiyās ad-Din 'Ali, berühmt als Naqib Hgān, las dem Kaiser Akbar (reg. 1556-1605) iranische und indische Geschichten und Sagen vor. ${ }^{202}$ Dieser war von den Abenteuern Hamzes, die er von einem Erzähler an seinem Hofe mit Namen Darbār Hānn ${ }^{203}$ hörte, so begeistert, dass er sie persönlich in den Frauengemächern vortrug. ${ }^{204}$

Der in den Diensten des Mogulkaisers Akbar stehende Gelehrte 'Abd al-Qādir Badā'uni $(1540-1615)^{205}$ schreibt:

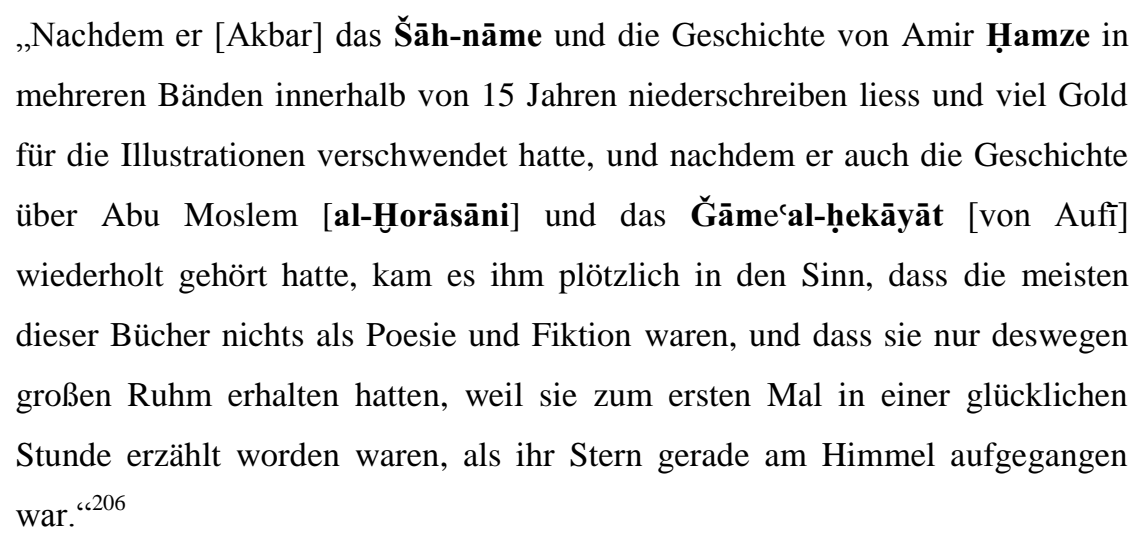

Akbar ließ ein Exemplar des Hamze-Romans mit prachtvollen Illustrationen anfertigen. Dies war ein ungewöhnliches, umfangreiches Unterfangen und das teuerste der gesamten Mogulenzeit. ${ }^{207}$ Eine der mächtigsten und reichsten Könige in der islamischen Welt erfüllte

\footnotetext{
${ }^{198}$ Vgl. Schimmel, Annemarie: Classical Urdu Literature from the Beginning to Iqbāl, Vol. 8, Fasc 3, hrsg. von Jan Gonda, Wiesbaden 1975, hier S. 204.

199 Șafā, Tãrih̆e adabiyāt dar Irān, Bd. 5, Teil 3, Teherān 1371/1992, S. 1505.

200 Ebd. S. 1502; mehr darüber siehe: Lekhawī, Āftāb Rāy: Tazkere-ye Reyāí al-cārefin, Bd. 2, hrsg. von Hosām ad-Din Rāšedi, Teherān 1982, S. 175.

201 'Ábd al-Ghani, Muhammad: A History of Persian Language and Literatur at the Mughal Gourt, Part I Bābur, Allahabad 1929, S. 10; 91; Mehr darüber siehe: Faḩr az-Zamāni, Tazkere-ye mei-h̄āne, S. 914.

${ }^{202}$ Vgl. Șafā, Tãrih̀-e adabiyāt dar Irān, Bd. 5 Teil. 3, S. 1503.

${ }^{203}$ Fah̆r az-Zamāni, Terāz al-ahbār, S. 20a.

${ }^{204}$ Vgl. Seller, John: The Adventures of Hamza, London 2002, S. 36; Franke, Heike: Akbar und Ğahāngīr, Untersuchungen zur politischen und religiösen Legitimation in Text und Bild, Bonn 2005, S. 41.

${ }^{205}$ Franke, Heike: Akbar und Ğahāngīi, S. 19.

${ }^{206}$ Vgl. Badā'uni, 'Abd al-Qādir: Montahab at-Tawārih̆, Bd. 1, hrsg. von Aḥmad-'Ali Sāḥeb, Teherān 1380/2001, S. 223.

${ }^{207}$ Vgl. Seller, John: The Adventures of Hamza, London 2002, S. 34; vgl. Egger, Gerhart: Der Hamza Roman. Ein Moghul-Handschrieft aus der Zeit Akbar des Großen. Schriften der Bibliothek des Österreichischen Museums für angewandte Kunst 1. Wien 1969.
} 
sich damit einen besonderen Wunsch. Von etwa 1557 bis 1572 arbeiteten die Künstler des kaiserlichen Ateliers unter der Anleitung der Iraner Mir Seyyed 'Ali und 'Abd aṣ-Ṣamad daran. ${ }^{208}$ Akbars Vater, Kaiser Homāyun, konnte während seines Aufenthalts im Iran beide Künstler anwerben. ${ }^{209}$

Auch Nāder Šāh gefiel die Geschichte sehr. Als er 1739 Delhi eroberte, nahm er im Verlauf der Plünderungen neben dem Pfauenthron auch die Prachtausgabe des Hamze-Romans als Beute mit. Als Moḥammad Šāh, der Kaiser von Indien, Nāder Šāh bat, auf das Buch zu verzichten, lehnte dieser ab. ${ }^{210}$ Somit verblieb es in der Folgezeit wahrscheinlich am kaiserlichen Hof in Iran.

1870 erhielt Nāṣer ad-Din Šāh eine Einladung, an der Weltausstellung in Wien 1873 teilzunehmen, wo Jakob Eduard Polak, der Leibarzt von Nāṣer ad-Din Šāhs, bei der Präsentation des Landes und der persischen Kultur eine wichtige Rolle spielte. ${ }^{211}$ Als ein vom Kaiser ernannter Kommissar bestimmte Polak, was in dem persischen Pavillon nach Wien gebracht und ausgestellt werden sollte. Darunter befanden sich auch die persischen Miniaturen der Mogulhandschrift des Hamze-nāme. ${ }^{212}$ Heute sind von einstmals etwa 1.400 Miniaturen nur noch 150 erhalten, die in verschiedenen Museen weltweit aufbewahrt werden. $^{213}$

Ein Vergleich zeigt, dass die Geschichte von Ḥamze in beiden Kulturen (der persischen und indischen Kultur) unterschiedlich aufgenommen, entwickelt und verbreitet wurde.

Pritchett erwähnt in ihrem Buch, dass die Urduversion der Geschichte von Ḥamze folgende Bände hat: Daftar-e Avval: 1. Naushirvān-nāmah 2. Hurmuz-nāmah. 3. Homān-nāmah; Daftar-e Duvvum: Kocak bākhtar; Daftar-e Sevvum: Bālā bākhtar; Daftar-e Chahārum: Iraj-nāmah; Daftar-e Panjum: Tilism-e hoshrubā; Daftar-e Shashum: Sandalī-nāmah; Daftar-e Haftum: Tūraj-nāmah; Daftar-e Hashtum: 1. La'l-nāmah; 2. Āftāb-e shujā'at; 3. Gulistān-e bākhtar; 4. Tilism-e fitnah-e nūr afshān; 5. Baqiyah-e tilism-e hoshrubā; 6. Tilism-e haft peikar; 7. Tilism-e khiyāl-e sikandarī; 8. Tilism-e naukhez-e jamshedī; 9. Tilism-e zacfrānzār-e Soleimānī. ${ }^{214}$

\footnotetext{
${ }^{208}$ Vgl. Seller, John: A Dated Ḥamza-nāma Illustration, in: Artibus Asiae 53/3-4 (1993), S. 503-505.

${ }^{209}$ Sobḥāi, Toufiq H.: Negāhi be tārih̀-e adab-e fārsi dar Hend, Teherān 1377/1998, S. 282.

${ }^{210}$ Kāẓim, Moḥammad: 'Ālam-ärāa-ye Nāder, Bd. 2, Faksimilie, hrsg. von Nikolai Miklucho-Maklai, Moskau 1965, S. 223a; Pritchett, S. 5; Faridany-Akhavan, Zahra: The Problems of the Mughal Manuscript of the Hamza-Nama 1562-77: A Reconstruction. Ph.D. Dissertation, Harvard University 1989, S. 2.

${ }^{211}$ Vgl. Slaby, Helmut: Bindenschild und Sonnenlöwe. Die Geschichte der österreichisch-iranischen Beziehung bis zur Gegenwart, Graz 1982, S. 112-113.

${ }^{212}$ Vgl. Harrer, Gudrun: Ein auf Persien spezialisierter Humboldtist, in: Der Standard. At /.../ Print Ausgabe, 24. 06. 2009; vgl. Cleveland Beach, Milo: The imperial image: paintings for the mughal court, Washington D.C. 1981, S. 58.

${ }^{213}$ Cleveland Beach, The imperial image, S. 58.

${ }^{214}$ Vgl. Pritchett, S. 270-271.
} 
Obwohl Perser und Türken in dauerhafte kriegerische Auseinandersetzungen verwickelt waren, war der Einfluss der islamisch-persischen Literatur auf die der Turkvölker stark. Im Bereich der Mythologie waren türkische und iranische Legendenstoffe ineinander verwoben. Die Türken versuchten, ihre eigene volkstümliche Kultur in einigen Bereichen der iranischen anzupassen. Nach Irène Mélekoff begann dies bereits in der karachanidischen Zeit. ${ }^{215}$

Seit der ersten türkischen Dynastie, die im 10. Jahrhundert im Iran herrschte, wuchs das Interesse an persischer Literatur deutlich, besonders zur Zeit der Timuridenherrschaft. Die fürstlichen Residenzen Samarqand, Širāz und Harāt waren zu dieser Zeit Anziehungspunkte für Künstler und Wissenschaftler. ${ }^{216}$ Ulug̀ Beg Mirzā, Baisonqur Mirzā, Ebrāhīm Mirzā und Moḥammad Ğuki Mirzā widmeten sich der Kunst und Wissenschaft. Unter ihrer Anleitung schmückten iranische Künstler Ferdousis dichterisches Werk Šāh-nāme mit prachtvollen Bildern aus. ${ }^{217}$ Nach Gerys Aussage bildete sich eine Kunstrichtung heraus, die bis in die Șafavidenzeit hinein wirken sollte. ${ }^{218}$

Bei der türkischen Zuhörerschaft erfreuten sich der Roman von Ḥamze und der Roman von Abu Moslem besonderer Beliebtheit. ${ }^{219}$ Ibn Taimīya (gest. 1328) lehnte die im 14. Jahrhundert unter der türkischen Bevölkerung Syriens beliebten Ḥamze-Erzählungen wegen ihres unhistorischen Charakters ab. ${ }^{220}$

Im Buch Badāye` al-vaqāye` aus dem 15. Jahrhundertlesen wir, dass in Gegenwart des Mir 'Ali-Šir Navā'i, dem Wesir des Solțān Ḥosein Baiqarā, ein Erzähler die Geschichten von Hamze, Eskandar (Alexander) und Abu Moslem auswendig vortrug. ${ }^{221}$ Das Auditorium ließ vor Begeisterung Silberstücke auf den Kopf des Erzählers regnen.

\footnotetext{
${ }^{215}$ Mélekoff, Irène: $\boldsymbol{A} \boldsymbol{b u ̄}$ Muslim. Le Porte-Hache du Khorassan, S. 43.

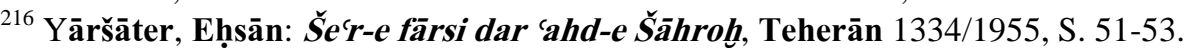

${ }^{217}$ Sims, Eleanor: The Illustrated Manuscripts of Ferdousi's Šāh-nāme Commissioned by Princes of the House of Timur, in: Ars orientalis, No. XXII, Vol. 22, 1992, S. 44-45; Marzolph, Ulrich: Das persische Nationalepos im Spannungsfeld von Überlieferung und ideologischer Instrumentalisierung, in: Lares 65, 1-2 (1999), S. 81-99, hier S. 91.

${ }^{218}$ Grey, Basil: The Pictorial Arts in the Timurid Period, in: CHI, Vol. 6, Cambrige 1986, S. 843-876, hier S. 845.

${ }^{219}$ Abu Moslem spielt auch eine wichtige Rolle in der Tradition der Bruderschaft (fotovvat). Abu Moslem war unter den Türken Kleinasiens besonders bei den türkischen Stämmen aus Anatolien und Qizilbaš im Iran sehr beliebt. Er und seine Achi-Gefährten sind Patrone der türkischen Futuvvet/Fotuvva geworden. Siehe: Taeschner, Franz: Zünfte und Bruderschaften im Islam, Zürich/München 1979, S. 235.

${ }^{220}$ Vgl. Marzolph, Ulrich: Hamze-nāme, in: EM, Bd. 6, Göttingen 1990, Sp. 430-436; vgl. Köprülü Zāde, Mẹ̣med Fưād: DieTürkisch-islamische Literatur das XIII J. U., in: EI, Bd. VI, Leiden/Leipzig 1934, S. 1011-1033, hier S. 1015; Taeschner, Die osmanische Literatur, in: HdO, 1. Abt., Bd. 5, Turkologie, Leiden/Köln 1963, S. 259-261; Boratav, Pertev Naili: Le conte et la légende, in: PTF II, S. 44-67, hier S. 6162.

${ }^{221}$ Vāṣefi, Ziyn ad-Din Maḥmud: Badāye` al-vaqāyeৎ, Bd. 1, hrsg. von A. N. Boldirev, Teherān 1349/1970. S. 476.
} 
Anfang des 15. Jahrhunderts wurde $Q H$ von Ḥamzavi (um 1400), dessen Bruder Aḥmedi (1412-13) mit seinem mesnavi unter dem Titel Eskandar-nāme berühmt geworden ist, ${ }^{222} \mathrm{im}$ Umfang von 24 Heftenunter dem Titel Ğāmi` ül-meknūnāt ins Türkische übersetzt und gewann dadurch an Beliebtheit. ${ }^{223}$ Die Erzählungen von Abu Moslem, Seyyed Bațțāl-e gāazi und der Hamze-Roman scheinen bei der anatolischen Bevölkerung und den Janitscharen sehr bekannt gewesen zu sein. ${ }^{224}$

Die türkische Version des Ḩamze-Romans war sehr umfangreich. Evliyā Ġelebi meint dazu, dass die Meddā!̣s (die türkischen Erzähler) ihn von ursprünglich 60 auf 360 Bände ausweiteten. ${ }^{225}$ Über Inhalt und Umfang des Romans schreibt der türkische Schriftsteller Sülaimān Fā’iḳ Efendi (1784-1837):

“[...] Möge Gott der Erhabene diejenigen retten, die den berühmt-berüchtigten Lügenfabeln (18) Ḥamza-nāme und 'Antar-nāme verfallen sind! Mit diesem Thema hat es etwas Merkwürdiges auf sich, und seine Aufklärung zählt zu den unbezwingbaren Schwierigkeiten, denn man läßt die Ḥamza-nāme genannten Bücher bei den Leihbuchhändlern holen und liest sie mancherorts. Man hat bis zu 15 Bände gesehen, aber es wird berichtet, daß es 30-40 Bände vom Ḥamzanāme gebe.

Unter dem einfachen Volk, das diese Bände liest, gibt es Leute, die ein überragendes Gedächtnis und Grips besitzen. Diese lernen die Geschichten auswendig und tragen sie in den Kaffeehäusern nach Art der Meddāḥs vor. Das Auditorium läßt die Silberstücke regnen und die meisten von den [...] (19) sind kraftlos und ohne Elan. Manche Leute verfallen dem ganz. Wenn sich einer von Verstand und Bildung (mürekkeb yalamiş 'uḳalādan) sagt: „Sehen wir mal, was es mit dem Ḥamza-nāme da auf sich hat!“ und es einmal gehört hat, versteht er bekanntlich, um was es sich handelt und kehrt sich davon ab, um nicht in der Abhängigkeit davon unglücklich zu werden. Nun, geht man dem Ḥamze-nāme einmal auf den Grund, so haben die rund 15 Bände keinen Anfang und kein Ende. Der Grund für seine Abfassung, sein Autor und der Zeitpunkt seiner Abfassung (20) sind unbekannt. Es handelt sich um eine Sammlung von Lügenlegende, deren Aufbau und Text verstehen lassen, daß der Autor ein Mann gewesen sein muß, der die Erfindung von allegorischen Bedeutungen beherrschte (21), und mit Thema und Sprache umzugehen wußte. Als Motiv für die Abfassung fallen einem zwei Gründe ein (22): zum einen, um

${ }^{222}$ Lewis, Geoffrey: Aḥmedī, in: $E l^{2}$, Bd. I, Leiden/London 1960, S. 299-300.

${ }^{223}$ Vgl. Babinger, Franz: Die Geschichtsschreiber der Osmanen und ihre Werke, Leipzig 1927, S. 13; Pritchett, S. 4.

${ }^{224}$ Vgl. Kellner-Heinkele, Barbara: Aus dem osmansichen Musik- und Theaterleben. Studien zur Geschichte und Kultur des Vorderen Orients, in: Festschrift für Bertold Spuler zum siebzigsten Geburtstag, hrsg. von Hans Robert Roemer u. Albrecht Noth, Leiden 1981, S. 181-196, hier S. 188.

${ }^{225}$ Ebd. S. 195. 
das Militär anzufeuern, zum zweiten könnte es erfunden worden sein, […] um es dem Firdawsī von Tūs im Lügen zuvorzutun “226

Fā'iḷ behauptet, der Hamze-Roman sei eine minderwertige Imitation des $\check{\boldsymbol{S}} \bar{a} \boldsymbol{h}$-nāme. ${ }^{227}$ Unter den gebildeten Türken erlangte er niemals den Status eines literarischen Werkes von Rang. Fā'iḳ schreibt weiter, jeder gebildete Mensch müsse ein solches Machwerk ablehnen, nachdem er einer Lesung beigewohnt habe. ${ }^{228}$

Bis etwa Anfang des 20. Jahrhunderts hat der Hamze-Roman die türkischen Märchenerzähler in den Kaffeehäusern mit Material versorgt. ${ }^{229}$ Menzel erwähnt in seinem Buch Meddāḥ, Schattentheater und Orta Oyunu: „Unter den Zuhöreren eines Meddāḥ in Brussa, der die Geschichte von Badi` und Qāsem vortrug, entstand eine Spaltung, weil die einen für den einen Helden, die anderen für den anderen Helden so lebhaft Partei nahmen.“230

Die muslimischen Gelehrten in den islamischen Ländern verachteten die Erzähler als Verfälscher ihrer religiösen Anschauungen und ihre Erzählungen als bid‘ a (Ketzerei). ${ }^{231}$ Sie waren der Ansicht, dass ohne religiösen Hintergrund lügenhafte Geschichten über Persönlichkeiten des frühen Islam erzählt würden. ${ }^{232}$ Wer den Erzählungen über Ḥamze zuhöre, begebe sich in Abhängigkeit vom Erzähler und damit vom Teufel. ${ }^{233}$ Islamische Gelehrte versuchten, die einfache Bevölkerung des Landes $\mathrm{zu}$ den wahren religiösen Glaubensgrundsätzen zurückzuführen. Im Iran schrieb Moḥammad-Bāqer Mağlesi (16271700), der die bedeutendste Figur unter den Mollās im 17. Jahrhundert war, über das wahrheitsgemäße Leben des Propheten und der schiitischen Imāme; auch die Ḥamze Geschichte wurde von Unwahrheiten gereinigt. ${ }^{234}$

Im osmanischen Reich tadelten die Religionsgelehrten ebenfalls den Erfolg des $R H$ beim Volk. 1826 wurde eine, von sunnitischer Glaubenshaltung geprägte türkische Übersetzung der Propheten-Vita gedruckt, um die Legendenbücher zu ersetzen, die die Staatsführung für die Aufsässigkeit unter den Janitscharen verantwortlich machte. ${ }^{235}$

Es ist die Frage, warum die Iraner die Geschichte von Ḥamze, einem arabischen Helden, so sehr schätzen und mit Begeisterung über Jahrhunderte tradieren, obwohl doch bis heute eine

\footnotetext{
${ }^{226}$ Ebd. S. 194.

${ }^{227}$ Ebd. S. 195.

${ }^{228}$ Ebd. S. 187.

${ }^{229}$ Vgl. Hammer-Purgstall, Joseph Freiherr: Geschichte des osmanischen Dichtkunst, Bd. I, Pest 1836, S. 71f.

${ }^{230}$ Vgl. Menzel, Theodor: Meddāḥ, Schattentheater und Orta Oyunu. Monographien des Archiv Orientàlní, Vol. X, Prag 1941, S. 6.

${ }^{231}$ Wolfensohn, S. 62; vgl. Ibn al-Ğawzī, Talbis-e Eblis, S. 101.

${ }^{232}$ Babayan, Kathryn: Mystics, Monarchs and Messiahs, S. 14; vgl. Esmā̄ili, Abu Moslem-nāme, Bd. 1, S. 5366; Hamawi: Anis al-mo'menin, S. 182; Șafā, Tārih̆-e adabìyāt dar Irān, Bd. 5, Teil 3, S. 1510.

${ }^{233}$ Șafā, Tãrih̆-e adabiyāt dar Irān, Bd. 5 Tẹil. 3, S. 1508.

${ }^{234}$ Mağlesi, Moḥammad-Bāqer: Hayãt al-qolub, Bd. 2, Teherān 1374/1995, S. 368-369.

${ }^{235}$ Kellner-Heinkele, S. 195.
} 
ständige Rivalität insbesondere zwischen den iranischen und arabischen Eliten herrscht. Ein Grund dafür ist, dass das $R H$ in der iranischen Version vieles enthält, mit dem sich der iranische Leser und Zuhörer identifizieren kann: religiöse Mythen und Motive, Königs- und Heldengeschichten und Historisches ganz allgemein. Auf diese Weise trat das Arabische als das Fremde in den Hintergrund. So wurde der Held der Geschichte nach den Vorstellungen, dem Geschmack des Volkes weitgehend „Iranisiert“.

In der Gestalt von Ḥamze verkörpert der Held die Rollen, Funktionen, Idealisierungsstrategien und Ausstattungsmuster der mittelalterlichen Werte. Seine Identitätswechsel vollziehen sich gehäuft im iranischen Milieu, in denen seine Gestalt neu moduliert und den zeitgenössischen Kontexten angepasst wird. Sie lassen die allgemeine Frage $\mathrm{zu}$, inwieweit sich die $\mathrm{zu}$ erwartende mittelalterliche Identifikationsfigur in einem Spannungsverhältnis zur aktuellen Figur manifestiert und welche Faktoren dafür ausschlaggebend sind. Man fragt sich, wie es die Erzähler schaffen, die Rollenwechsel zu verdeutlichen, die Ḥamze als legendäre Figur und als geschichtliche Person darstellen, ohne dass ein Bruch zu erkennen ist. Eine solche Darstellung von Heldentum muss sich nicht erst im Vergleich von Vitenüberlieferungen manifestieren. 
Inhalt des $R H$

Die Erzähler im $R H$ sind darum bemüht, die dem Zuhörer durchaus vertraute Gestalt Ḥamzes noch näher zu bringen, indem sie seinen Charakter und seine Taten immer wieder ausschmücken. So können sich um seine Person auch aus dem Volk heraus viele zusätzliche Legenden bilden, die schließlich in einen umfangreichen Romanzyklus münden. Dieser Prozess erreichte in der Timuridenzeit sein letztes Entwicklungsstadium.

Das Buch $R H$ wurde jahrhundertelang in mündlicher Form weitergegeben. In ihm zeigen sich die tiefen Überzeugungen und Verhaltensweisen der Menschen, ihre Wertesysteme, ihre Glaubensüberzeugungen und vielfältigen religiösen Vorstellungen, wie auch Tugenden wie Patriotismus oder Ehrgefühl. All dies wird zusätzlich geprägt durch die Person des „Erzählers“ und seiner persönlichen Sozialisation.

Um die gesellschaftliche Entwicklung im Iran des 15./16. Jahrhunderts zu verstehen, stellt das $R H$ als Sammlung volkstümlichen Erzählgutes, neben der klassischen Literatur, eine wichtige Quelle dar. Es bietet einen Einblick in das Gedankengut der Iraner durch die Jahrhunderte hindurch. Dies bietet zugleich ein Argument für die Bedeutung des Buches für die Forschung, denn es enthält gesellschaftlich relevante Fakten und Tatsachen, die in keiner offiziellen Geschichtschronik auftauchen.

Im Vergleich mit dem $Q H$ überwiegt im $R H$ das Fantasievolle in Form von Wunder- und Zaubergeschichten, was dem Geschmack des Zuhörers, der vor allem unterhalten werden will, mehr entgegenkommt. Kriegerische Auseinandersetzungen spielen in beiden Werken eine wichtige Rolle.

Sämtliche sieben Bücher beinhalten Geschichten, die hauptsächlich von irdischen Dingen wie Liebe, Kampf und Abenteuer, aber auch von übernatürlichem Geschehen wie Wunder und Magie handeln. Der Roman ist reich an bekannten Motiven, wie sich in ein Bild verlieben, zum Tode Verurteilung des Helden und dem Kampf zwischen Vater und Sohn. Hanaway spricht von „stock types“ in den persischen Liebes und Abenteuerromanen, die Stereotypen darstellen. $^{236}$

\subsection{Der historische Hamze}

In der Gestalt des Hamze begegnen uns im Grunde zwei Persönlichkeiten. Die eine ist Ḥamza b. 'Abd al-Muțțalib (gest. 625), ein Onkel des Propheten und einer der ersten Blutzeugen des Islams, der in der Schlacht von Uḥud sein Leben als Glaubenskämpfer geopfert hat. Die andere ist der Revolutionär Ḥamza b. 'Abdallāh (aš-Šārī) al-Atrak 
(Āzarak?) (gest. 825), ein persischer Hुāriǧiten-Führer, der Ende des achten und Anfang des neunten Jahrhunderts einen Aufstand gegen Hārūn ar-Rašīd und dessen Nachfolger anführte. $^{237}$

Nach den Schilderungen arabischer Historiker war Ḥamza b. 'Abd al-Muțtalib bei Beginn seiner Karriere schon ein reifer Mann. Er war ein tüchtiger Krieger, ein gewiefter Taktiker und er liebte die Jagd und die Reitkunst.

Moḥammad und Hamze waren Milchbrüder, d.h. sie hatten dieselbe Amme. ${ }^{238}$ Für Moḥammad war Ḥamze ein zuverlässiger Freund, was sich besonders in den Kämpfen zwischen den Mekkanern und Moḥammad zeigte. Während seines Kampfes mit den Mekkanern tötete er viele Heiden. Aufgrund seines Mutes wurde er als „Löwe Gottes und Löwe des Propheten“ bezeichnet. ${ }^{239}$ In der Schlacht von Uḥud tötete der Waḥši, schwarzer Sklave von Hind, Hamze mit einem Wurfspieß, riss seine Brust auf und reichte sein noch zuckendes Herz Hind, der Tochter des 'Utba, in das diese biss. ${ }^{240}$ Diese war nach dem Tod ihres Vaters durch die Muslime in der Schlacht von Badr von grenzenlosem Hass gegen Moḥammad und die Muslime erfüllt. Ḥamze hinterliess keine männlichen Nachkommen.

In der späteren Zeit erfahren wir über Ḥamza b. 'Abdallāh aš-Šārī al-Atrak (Āzarak) alHariğ̄i nur wenig. ${ }^{241}$ Zeitgenössische Quellen beschränkten sich auf Andeutungen. Der Verfasser des Buches Tãrih-e Sistān berichtete, dass Ḥamza b. 'Abdallāh Iraner war und seine Abstammung bis zu den alt-iranischen Königen zurück reichte. ${ }^{242}$

Da bei den Hुāriğiten die Frömmigkeit eines Imāms mehr galt als seine Abstammung, konnte Ḥamza b. 'Abdallāh diese in ihrem Widerstand gegen die 'Abbasiden anführen. Besonders die Stadt Sistān im südlichen Iran galt als Zentrum. Am Ende der Regierungszeit von Hārūn ar-Rašīd gelang es Ḥamze, im Osten Irans eine beherrschende Stellung einzunehmen, wozu die Einwohner der Stadt Sistan maßgeblich beitrugen. Im Jahr 795 unternahm er Kriegszüge bis nach Horāsān, imfolgenden Jahr sogar bis Būšang, Harāt und Neišābur. ${ }^{243}$ Zunächst

\footnotetext{
${ }^{236}$ Vgl. Hanaway, Jr., William L.: Love and War. Adventures from the Firuz Shāh-Nāma of Sheikh Bighami, New York 1974, S. 16.

${ }^{237}$ Vgl. Spuler, Iran in früh-islamischer Zeit, S. 53.

238 ad -Dahabī, Šams ad-Din Moḥammad b. Ạ̣mad b. 'Uțmān: Siyar a 'lām an-nubalā', ğuz' 1, Taḥqiq Ṣalāḥ ad-Din Munağğid, Kairo 1955, S. 127.

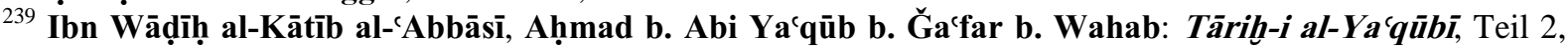
hrsg. von Martijn Theodoor Houtsma, Leiden 1969, S. 48.

${ }^{240}$ Vgl. Ibn Ishāq: Das Leben des Propheten. Aus dem Arabischen übertragen und bearbeitet. von Gernot Rotter, Stuttgart 1985, S. 147.

${ }^{241}$ Vgl. aš-Šahrestāni, Abū al-Fatḥ Moḥammad: Religionsparteien und Philosophen-Schulen, Teil 1, übersetzt aus dem Arabischen ins Deutsche mit erklärenden Anmerkungen. von Theodor Haarbrücker, Hildesheim 1969, S. 143.

${ }^{242}$ Vgl. Anonymus, Tārih̆e Sistān, S. 156.

${ }^{243}$ Vgl. Ibn al-Ațīr, 'Izz ad-Din Abū al-Ḥasan 'Ali as-Šaibānī: al-Kāmil fi at-Tarīhn. Aus dem Arabischen ins Persische übersetzt. von 'Abbās Hुalili, Bd. 10, Teherān 1355/1976, S. 94; vgl. Spuler, Iran in frühislamischer Zeit, S. 53.
} 
veranlassten die Unruhen im Osten des islamischen Reiches den Kalifen Hārūn ar-Rašīd im Jahr 808 persönlich dorthin zu reisen, um seinen Einfluss zu festigen. Sein früher Tod in Horāsān im darauffolgenden Jahr 809 verhinderte seine Bemühungen.

Der unbekannte Autor des Werkes Tãrih̆-e Sistān behauptet, dass nach Ḥamzes Tod ein Buch mit dem Titel Mağāzí-ye Hamze (Erzählungen von den Kriegszügen Ḥamzes) erschien, ${ }^{244}$ das wahrscheinlich die Grundlage für die spätere Version der Geschichte Ḥamzes $(Q H)$ darstellt.

Die Verschmelzung der beiden Ḥamzes zum Helden eines Abenteuerromans fand vermutlich schon im 11. Jahrhundert in Persien statt.

\subsubsection{Hamze als Romanfigur}

In Bezug auf Ḥamze beschäftigt sich diese Arbeit u.a. mit der Frage, wie die iranische Gesellschaft im Laufe der Zeit ihre kulturelle Identität bewahrt hat. Wie groß ist ihre Verbundenheit mit der Vergangenheit? Welche Mechanismen hat sie eingesetzt, um das Erbe ihrer Kultur zu bewahren?

Maurer gibt uns zu bedenken, dass Kultur dadurch entstehen könne, dass die betreffende Gruppe immer wiederholt, was das für sie Entscheidende, Gemeinschaftsstiftende sei. Dies könne zum Beispiel dadurch geschehen, dass sie die Funktion des Bewahrens durch Wiederholung auf einen eigenen, spezialisierten Berufsstand auslagert. ${ }^{245}$ Diesen Berufsstand stellen die iranischen Erzähler dar. Sie spielen eine große Rolle in der kollektiven Erinnerung des Volkes um die Vergangenheit lebendig zu halten. Besondere Handlungsgestalten werden entwickelt, um durch die Wiederholung bestimmter Themen und Motive in den Erzählungen an das Wesentliche zu erinnern.

Assmann erweitert mit dem Begriff Mythomotorik die Perspektive, indem er im erzählenden Vergangenheitsbezug zwei scheinbar entgegensetzte Funktionen erkennt:

„Die eine Funktion des Mythos wollen wir „fundierend“ nennen. Sie stellt Gegenwärtiges in das Licht einer Geschichte, die es sinnvoll, gottgewollt, notwendig und unabänderlich erscheinen lässt [...]. Die andere Funktion könnte man „kontrapräsentisch“ nennen [...]. Sie geht von Defizienz-Erfahrungen der Gegenwart aus und beschwört in der Erinnerung eine Vergangenheit, die meist die Züge eines Heroischen Zeitalters annimmt. Von diesen Erzählungen her fällt ein ganz anderes Licht auf die Gegenwart: Es hebt das Fehlende,

\footnotetext{
${ }^{244}$ Anonymus, Tãrih-e Sistān, S. 70; vgl. Bahār, Sabk-šenāsi, Bd. 1, S. 285.

${ }^{245}$ Maurer, Michael: Kulturgeschichte, Köln/Weimar/Wien 2008, S. 34.
} 
Verschwundene, Verlorene, an den Rand Gedrängte hervor und macht den Bruch bewußt zwischen einst und jetzt. ‘246

Infolgendessen wird die kulturelle Identität eines Volkes bzw. einer Gruppe stets durch den Blick auf die Vergangenheit definiert und relativiert.

Assmann zufolge wird jede Persönlichkeit und jedes historische Faktum schon bei seinem Eintritt in dieses Gedächtnis in eine Lehre, einen Begriff, ein Symbol transportiert; es erhält einen Sinn, es wird zu einem Element des Ideensystems der Gesellschaft. ${ }^{247}$ Aus diesem Zusammenspiel von Begriffen und Erfahrungen entstehen, was Assmann im Gegensatz zu Halbwachs „Erinnerungsfiguren“ nennen will. ${ }^{248}$

Die Erinnerung, bevor sie ins Gedächtnis gelangt, muss verinnerlicht werden, das kulturelle Gedächtnis operiert also mit Hilfe von Erinnerungsfiguren. ${ }^{249}$ Erst wenn Begriff und Bild unauflöslich miteinander verschmelzen, kann ein Ereignis im Gruppengedächtnis weiterleben. Solche Erinnerungsfiguren werden im Raum- und Zeitkontinuum innerhalb unterschiedlicher Gruppenkonstellationen gebildet. Die Erinnerungen werden im Raum erfahren und in einer bestimmten Zeit aktualisiert. Zeit und Raum sind Schauplätze von Symbolen der Identität und Anhaltspunkte für Erinnerung zugleich.

Die Geschichte von Hamze, in der sich Bilder und das gesammelte Wissen über die Vergangenheit kristallisiert, können wir als soziales Gedächtnis sehen. Hier konstituiert sich die kollektive Identität über ein „Erinnerungsmodell““. Für die Autoren des $R H$ ist diese Erzählung eine fundamentale Geschichte, die erzählt wird, um die Gegenwart als abhängig von der Vergangenheit dar zu stellen.

Hamze wird im $R H$ als „Auserwählter“ bezeichnet. Dies bedeutet für ihn Verpflichtung und in letzter Konsequenz höchste Verbindlichkeit dem Islam gegenüber. Daher entwickeln die Erzähler eine gesteigerte Form der Erinnerungskultur. In der Gestalt von Ḥamze werden die literarischen Motive in den Überlieferungen aus der Vergangenheit manifestiert. Er soll Vorbild sein und es wird von ihm erwartet, dass Großreich aus vorislamischer Zeit in der Form eines islamischen Imperiums wieder herzustellen. So wird im Gemeinschaftsgedächtnis der Zuhörer in der Gestalt des Ḥamze diese Vorstellung einer goldenen Zeit als Legitimation und anerkannte Autorität weiterleben.

\footnotetext{
246 Assmann, Jan: Das kulturelle Gedächtnis, Schrift, Erinnerung und politische Identität in frühren Hochkulturen, München 1999, S. 79.

${ }^{247}$ Halbwachs spricht in diesem Zusammenhang von „Erinnerungsbildern“. Siehe: Halbwachs, Maurice: Das Gedächtnis und seine sozialen Bedingungen. Aus dem Französischen ins Deutsche übersetzt. von Lutz Geldsetzer, Frankfurt 1985, S. 25.

248 Assmann, S. 37.

${ }^{249}$ Ebd.
} 
„Ruhm ist die sicherste Form der Unsterblichkeit, und lange leben heißt in der Erinnerung der Menschen zu überleben.“ ${ }^{250}$ Die Erzähler „sollten dazu verhelfen, den Ruhm dieses einzelnen Menschen unter den Zeitgenossen zu stärken und für die Nachwelt unsterblich zu machen. Er verherrlicht die großen, ruhmreichen und hervorragenden Taten der Helden und macht sie so unvergeßlich.“ Die Erzähler des $R H$ als Famaproduzenten ${ }^{251}$ stellten die Gestalt eines islamischen Helden, Hamze, ins Zentrum ihres Werkes. Auf diese Art und Weise hatten sie Hamze unsterblich gemacht.

Das $R H$ ist nicht „wahre“ Geschichte, sondern eine Pseudo-Geschichte, die dem Publikum präsentiert wird. Hamze wird mit denselben Gefühls- und Denkgewohnheiten dargestellt, wie ein muslimischer Herrscher im Mittelalter. Teile der komplexen Persönlichkeit eines Herrschers werden modellhaft an nur einigen ausgewählten Charaktereigenschaften untersucht, die es erlauben, ebensolche bestimmten Ausprägungen des kollektiven Verhaltens in der iranischen Bevölkerung zu isolieren und festzuhalten.

Dort werden die Gefühle, Emotionen und moralischen Werte, Sitten und Lebensgewohnheiten, wie auch die psychische Haltung der Menschen, die vielleicht nicht in allen Epochen die gleiche gewesen ist, sichtbar. ${ }^{252}$

Die persönliche Mentalität der Autoren selbst, aber auch die Mentalität der Menschen ihrer Zeit, fließt in die Erzählung ein. Wenn sie jedoch das Porträt von Ḥamze zeichnen, projizieren sie in ihn auch ihre eigene Gedanken- und Gefühlswelt.

\subsubsection{Hamzes Kindheit im $R H$}

Wunder und Zaubergeschichten begleiten die Gestalt Ḥamzes in der Literatur. Der Perserkönig Anōširvān hat einen schrecklichen Traum, den sein Wesir Bozorgmehr so deutet, das er von einem in der Stadt Heibar geborenen Araber besiegt werden wird. Drei Şăḥebqerān (Fürsten der glücklichen Konstellation), die noch im Mutterleib sind, werden die Feinde des Königs vernichten. Um die drei zu finden, entsendet Anōširvān Bozorgmehr nach Mekka. Als der Wesir dort ankommt, empfängt ihn 'Abd al-Moțțaleb mit offenen Armen. Während eines Festmahls wird 'Abd al-Moțtaleb ein Sohn geboren. Bozorgmehr gibt 'Abd al-Moțțaleb viel Geld, damit der soeben Geborene, es handelt sich um Hamze, gut versorgt

${ }^{250}$ Assmann, Aleida: Erinnerungsräume. Formen und Wandlungen des kulturellen Gedächtnisses, München 1999, S. 38.

${ }^{251}$ Das Wort „Fama“ bedeutet: „Sage, Gerücht, Gerede“. Der Fama entspricht in der griechischen Mythologie die Pheme. Personifikation des Ruhmes ist bei den Römern noch die Gloria. Der Fama wird in der lateinischen Sprache auch als „übler Ruf" oder „Nachrede“ aufgefasst. Siehe: Pape, Wilhelm: GriechischDeutsches Handwörterbuch, Bd. 2, Braunschweig 1914, S. $1267 \mathrm{f}$

252 Duby, Georges: Mentalitätengeschichte, in: Ideengeschichte, hrsg. von Barbara Stollberg-Rilinger, Stuttgart 2010, S. 137-163, hier S. 139. 
wird. Am selben Tag werden auch 'Amr b. Umeiye az-Znamrī und Moqbel, zwei zukünftige Freunde Ḥamzes, geboren. Drei Tage nach seiner Geburt verschwindet Ḥamze. Als 'Abd alMoțtaleb davon erfährt, ist er sehr besorgt. Bozorgmehr zerstreut seine Besorgnis, und lässt ihn wissen, dass Ḥamze sich in der Obhut des Feenkönigs befindet. Im Qāf-Gebirge wird Ḥamze von Tigern und Leoparden gesäugt. Schließlich kehrt er wieder nach Mekka zurück $(1 / 14)$.

Als Ḥamze sieben Jahre alt ist, schickt ihn sein Vater in die Schule, die er mit seinem Freund 'Amr besucht. Bozorgmehr gibt den Rat, dass Hamze die Kunst des Krieges, Moqbel die Kunst des Bogenschießens und 'Amr selber die Kunst des Kurierwesens erlernen sollen (1/15). 'Amr verabscheut die Schule aufs tiefste. Am Ende eines Spieles geht er soweit, seinen Lehrer zu töten. Daraufhin verstecken er und seine Kameraden sich in einer Höhle. Ḥamzes Vater jedoch bezahlt der Familie des Opfers ein Bußgeld und rettet dadurch seinen Kopf.

Die Freundschaft zwischen Hamze und 'Amr basiert auf einem Abkommen mit folgenden Punkten: Wann immer 'Amr Ḥamze verärgert hat, soll dieser sich möglichst schnell wieder mit ihm versöhnen, und ferner soll Ḥamze ihm immer die Kriegsbeute überlassen (1/19). Nachdem Ḥamze sich ein Jahr hindurch mit dem Kriegshandwerk beschäftigt hat, gilt er bereits als herausragender Krieger. Seine ersten Heldentaten beginnen in Mekka mit einem Kampf gegen den Ringer Sacd, dem er jedoch im ersten Wettkampf unterliegt. Hamze ist darüber sehr unglücklich und reitet in die Wüste. Dort trifft er auf einen Heiligen, dessen wundersamer Blick ihn kräftigt. Ḥamze kehrt nach Mekka zurück, kämpft erneut mit Sa`d und tötet ihn (1/20-21).

Als Ḥamze etwa 12 Jahre alt ist, greift Monzer Šāh, ein Verwandter Sa'ds, Mekka an und nimmt Ḥamzes Vater und seine Brüder gefangen. Daraufhin begibt sich Ḥamze in Begleitung seiner Freunde nach Yaman (Jemen), um Monzer Šāh herauszufordern und seinen Vater zu befreien (1/25).

Später besiegt Ḥamze auch Hešām b. 'Alqame. Dieser ist nach Madā'en gezogen, hat den Palast des Perserkönigs Anōširvān geplündert, 30.000 Gefangene genommen, den König zur Flucht nach Fārs getrieben und Mekka angegriffen (1/23-26).

\subsubsection{Hamze und seine Frauen}

Im Koran lesen wir, dass die Ehe mit einem ungläubigen Partner verboten ist. ${ }^{253}$ Will ein Muslim eine nicht-muslimische ungläubige Frau heiraten, so muss diese den Glauben ihres Mannes annehmen. Das islamische Eherecht erlaubte es einem Mann, mehrere Ehefrauen zu

$\overline{{ }^{253} \text { Koran, Sure. } 2,221 ; \text { Sure. } 60,10 \text {. }}$ 
haben und außerdem noch sexuelle Beziehungen zu anderen Frauen zu unterhalten. Hamze als islamischer Held ist nicht an ein singuläres Eheversprechen gebunden. Wie es der Koran erlaubt, heiratet er mehr als vier Frauen, die alle aus Königsfamilien stammen.

Dabei sind jene literarischen Konstellationen besonders beliebt, in denen die Liebenden aus verschiedenen Völkern, sozialen Schichten oder ideologischen Lagern stammen, wodurch sie in einen doppelten Konflikt gestürzt werden: Um ihr Glück zu verwirklichen, müssen sie die verinnerlichten Prinzipien überwinden und zudem die Interventionen von außen abwenden.

Im nachfolgenden Abschnitt werden seine bedeutendsten Frauen betrachtet, die ihm berühmte Söhne geschenkt haben.

Ḥamze ist Araber, seine erste Frau Mehrnegār Perserin. Er begegnet Mehrnegār zum ersten Mal, als er dem Perserkönig Anōširvān, der von einem Aufstand bedroht wird, erfolgreich zu Hilfe eilt und sie bei der anschließenden Feier erblickt. Beide verlieben sich leidenschaftlich ineinander, was dazu führt, dass sie gesellschaftliche Verhaltensformen, die die islamische Ethik vorschreibt, verletzen.

Ḥamzes Liebesgeschichte und Heirat mit Mehrnegār ist deshalb besonders bemerkenswert, weil beide verschiedenen Nationalitäten und Religionen angehören. Die Liebenden, die heimlich zusammenkommen und ihre Zweisamkeit ausschließlich im Verborgenen auskosten können, müssen sich vor Entdeckung und Bestrafung hüten. Um die Jungfräulichkeit ihrer Tochter zu bewahren, oder sie vor dem Bösen zu schützen, bewachen ihre Eltern sie oft. Wesir Bahtak, der gegen diese Liebesziehung ist, und viele Gründe für seine Gegnerschaft hat, von Ḥamze und Mehrnegār erfolgreich hinters Licht geführt, bewacht sie (1/30-40). Durch diese Liebesbeziehung wird der soziale Status Ḥamzes in Frage gestellt. Er steht dann häufig vor der bitteren Alternative: Entsagung oder Flucht an einen weit entfernten Ort. Im drastischsten Fall geht es um Leben oder Tod, weil nämlich die heimliche Liebesbeziehung zwangsläufig zur Todsünde führt, weil die Liebenden ein inneres Gebot der Sittlichkeit und Moral verletzten (1/60).

Bahtak, ein Wesir des Königs, versucht mit allen Mitteln diese Verbindung zu verhindern und Ḥamze zu töten ${ }^{254}(1 / 41-60)$. Als Ḥamze die Kriege, in die er geschickt wird, siegreich übersteht, kann er endlich Mehrnegār heiraten. Seine Liebe zu ihr findet jedoch ein tragisches Ende. Der kurz nach der Heirat geborene Sohn Qobād wird durch einen Kundschafter Anōširvāns getötet. Der Erzähler betont die Liebe einer Mutter zu ihrem Sohn. Mehrnegār trauert sehr lange und bringt sich schließlich um (2/306-307). Ḥamze lässt sie

${ }^{254}$ Bahtak schlägt vor, Ḥamze nach Indien zu schicken, um den Kopf Landehurs als Brautgeschenk zu bringen, in der Hoffnung, dass Ḥamze durch Landehur getötet wird. Siehe: Nowak, Ursula: Beiträge zur Typologie 
und den Sohn in Mekka beisetzen. Er wohnt in der Nähe ihres Grabes und aus Trauer vernachlässigt er seine Pflichten.

Kurz vor ihrem Tod bittet Mehrnegār Ḥamze, ihre Schwester Qahr, die zweite Tochter Anōširvāns, zu heiraten (2/307). Aus dieser Ehe geht ein Sohn, Ḥamze-ye șāni, hervor, der Hamzes Nachfolger wird.

Wie in iranischen Erzählungen aus vorislamischer Zeit, in denen ein Mensch ein übernatürliches Wesen heiraten kann, geht Ḥamze noch zu Lebzeiten von Mehrnegār auch eine Verbindung mit einer Feenprinzessin ein. ${ }^{255}$ Asmā' ist eine Tochter des Feenkönigs Šahbāl, der über die sagenhafte Gebirgskette Qāf herrscht, die angeblich die ganze Erde umschließt. Sie wird als anmutige, kühne, aber auch verschlagene Frau geschildert. Als Dämonen das Land Qāf angreifen, ruft Šahbāl Ḥamze zur Hilfe. Ḥamze wird dort 18 Jahre gefangen gehalten, um mit den Dämonen zu kämpfen. In dieser Zeit lernt er Asmā' kennen und verlobt sich mit ihr. Sie erfährt aber, dass Hamze im Land der Menschen bereits mit Mehrnegār verlobt ist. Vergeblich versucht, sie ihn bei sich zu behalten. Ḥamze jedoch beschließt seine Rückehr zu Mehrnegār, was ihm mit Hilfe des Vogels Simorğ (Phönix) und der Mutter des Propheten Heżr auch gelingt. Nach seiner Ankunft heiratet er zunächst Mehrnegār, geht dann aber ins Feenreich zurück und heiratet Asmā', die ihm eine Tocher Qoreiši (2/197) und einen Sohn Soleimān-e șāni schenkt (4/617).

Da die Verbindung Iran-Byzanz schon in vorislamischer Zeit von großer Bedeutung war, kommt diese in den iranischen Erzählungen oft vor. ${ }^{256}$ Hamze heiratet die byzantinische

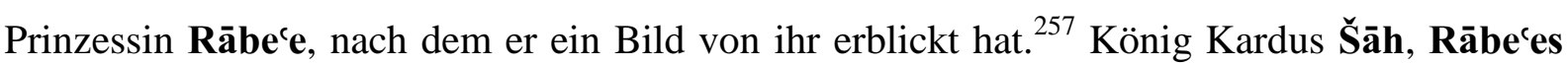

des arabischen Volksmärchens, Freiburg im Breisgau 1969, S. 126. (Motiv. Der Preis für die Braut. Typ. 112).

255 Beispielsweise die Geschichte von Šērō, dem Sohn von König Ardešir, und seiner Frau Mahzād pari im Ardešīr-Buch angeführt von Dorothea Blieske in ihrer Dissertation Šāhīn-e Šĩrāzīs Ardešīr-Buch, Tübingen 1966, S. 7; Widengren, Geo: Iranische Geisteswelt: von den Anfängen bis zum Islam, Baden-Baden 1961, S. 278; Rażi, Hāšem: Vandidād, Bd. 1, Teherān 1376/1997, S. 219; Afs̃ār, Irağ: Eskandar-nāme, Teherān 1344/1965, S. 378; 358.

${ }^{256}$ Nach einem Putsch kam Bahrām-e Čubin an die Macht und Perserkönig Hosrou Parvis II. (590-628) floh im Frühjahr 590 auf oströmisches Territorium. Er konnte schließlich seinen verlorenen Thron mit Unterstützung des oströmischen Kaisers Maurikios für sich zurückgewinnen, wofür Ostrom einige Territorien zugesprochen bekam. In der romantischen Literatur wurde erwähnt, dass die christliche Prinzessin Maria, Tochter des Kaisers Maurikios, mit Hosrou Parvis II. verheiratet war und in den Iran kam. In den literarischen Bearbeitungen des Širin-Mythos spielte diese angebliche Kaisertochter eine große Rolle. Sie war Rivalin Širins, die schließlich durch Širin vergiftet wurde. Siehe: Khaleghi-Motlagh, Djalal: Die Frauen im Schahname, Inaugural-Dissertation zur Erlangung des Doktorgrades der Philosophischen Fakultät der Universität zu Köln 1971, S. 89; Christensen, Arthur Emanuel: L'Iran sous les Sassanides, ins Persische übersetzt. von Rašid Yāsami, Teheāran 1375/1996, S. 580-582; 619.

${ }^{257}$ Vgl. Elfried, Moser-Rath: Frau, in: EM, Bd. 5, Göttingen 1987, Sp. 100-137, hier Sp. 111; vgl. AaTh, (Motiv. Das Bild der Frau versetzt den Mann in Liebe. 403, 516, 900). 
Vater, herrscht über Harušane (Malatya). ${ }^{258}$ Hamze befreit Rābece sogar aus der Gewalt eines Dämons. ${ }^{259}$ Danach bricht er zu neuen Abenteuern nach Madā‘en auf. Beim Abschied übergibt er Rābece ein Armband aus Rubin als Erkennungszeichen (2/231). ${ }^{260}$ Neun Monate danach bringt sie einen Knaben zur Welt, dem sie den Namen 'Alam Šāh gibt.

Im Auftag des Perserkönigs reitet Ḥamze nach Griechenland, um von König Feridun Šāh den fälligen Tribut zu fordern. Als er dort einen Drachen tötet, lassen sich Feridun und seine Söhne zum Islam bekehren. Feridun bittet daraufhin Hamze, sein Gast zu sein. Seine Tochter Maryam-Nahid sieht und verliebt sich in ihn. In der Nacht betritt sie heimlich Ḥamzes Schlafgemach, um in seiner Nähe zu sein. Bei Sonnenaufgang verlässt sie ihn, erblickt dabei das Tuch, das Mehrnegār Ḥamze zum Abschied geschenk hat, und nimmt es an sich. ${ }^{261}$ Schließlich erfährt Ḥamze, wer das Mädchen ist, das ihn nachts besucht. Nun entbrennt auch er in Liebe zu ihr. Der König gibt ihm seine Tochter zur Frau. Ḥamze wird Vater eines Sohnes, 'Omar b. Ḥamze Yunāni (1/110-111).

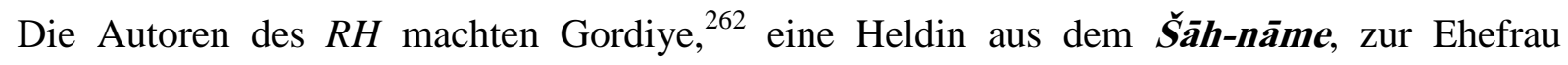
Hamzes:

Als Ḥamze mit seinem Freund 'Amr unterwegs nach Ardabil ist, erblickt er plötzlich einen verschleierten Jungen, der ihm eine Armbrust mit der Auforderung übergibt, diese zu spannen. Falls Ḥamze dies fertigbrächte, würde er ihm sämtliche Wünsche erfüllen. Ḥamze versagt. 'Amr jedoch bemerkt ein Stück Papier, das in der Armbrust steckt und auf dem er einen Zauberspruch vermutet. Er entfernt es, und Hamze kann daraufhin die Armbrust spannen. Dann entdeckt er, dass der verschleierte Junge in Wahrheit ein Mädchen ist, ${ }^{263}$ das angibt, die Tochter von Arqāṣ Šāh Ardabili zu sein und Gordiye zu heißen. Weil aber Āzarborzin, König von Tabriz, die Absicht hat, Gordiye zu heiraten, muss Ḥamze mit ihm um sie kämpfen. Er besiegt ihn, Gordiye wird seine Frau und schenkt ihm den Sohn Badi azZamān (2/271-72).

\footnotetext{
${ }^{258}$ Yāqūt, Šahāb ad-Din Abū 'Abdallāh Yāqūt b. 'Abdallāh al-Ḥamavi ar-Rūmi: Mu'̌̆am al-buldān, Bd. 2 , Bairut 1376 h/1957, S. 359.

${ }^{259}$ Elfried, Frau, in: EM, Bd. 5, hier Sp. 110.

${ }^{260}$ „Erkennungszeichen sind vorrangig Dinge, aber auch Handlungen und Vorgänge, die das Festellen der Identität einer Person oder Klärung eines Sachverhalts ermöglichen." Siehe: Wehse, Rainer: Erkennungszeichen, in: EM, Bd. 4, Göttingen 1984, Sp. 180-194, hier Sp. 180; vgl. Ferdousi, Bd. 1, S. 249.

261 (Motiv. Die Prinzessin ist Diebin. 516 A. (2). Siehe: Marzolph, Ulrich: Typologie des persischen Volksmärchens, aus dem Deutschen ins Persische übersetzt. von Kei-Kāvus Ğahāndāri, Teherān 1371/1992, S. 287.

${ }^{262}$ Sie war Schwester von Bahrām-e Čubin. Sie war eine Kriegerin und kluge Frau. Nach dem Tod ihres Bruders Bahrām, heiratete sie König Hosrou Parvis. Siehe: Khaleghi-Motlagh, Djalal: Die Frauen im Schahname, S. 80-84.

263 Aarne, Antti and Thompson, Stith: The Types of the Folktale, Helsinki, 1961 (Motiv. Frau in Männerkleidung. 514, 880, 884, 884 A).
} 
Ḥamze kommt zu Ohren, dass sich ein gewisser Zomorrod als Gottheit verehren lässt und dadurch gegen den islamischen Glauben verstößt. Daher macht er sich auf Weg nach Bāhttar, wo dieser Frevler herrscht. Dort trifft er 'Anqavil, einen Feldherrn von Zomorrod, kämpft mit ihm und besiegt ihn am Ende. Diese Niederlage bewirkt, dass 'Anqavil sich in die Einsamkeit zurückzieht und ein Derwisch wird. Als Șenoubar Bānu, 'Anqavils Schwester, den Grund für dessen Sinneswandel erfährt, fordert sie als verschleierter Ritter Ḥamze zum Kampf heraus. Ḥamze siegt nach zwei Tagen, erkennt Șenoubar Bānu als Kriegerin, entbrennt in Liebe zu ihr und heiratet sie. Sie bekennt sich zum Islam und schenkt ihm einen Sohn namens Dārāb-e Āb-parast (4/634-636).

Auch im Reich der Fabeltiere macht Ḥamze seine Erfahrungen. Auf seinem Weg von Qāf in das Menschenland begegnet er merkwürdigen Lebewesen, deren menschlicher Körper mit dem Kopf eines Tiers, das einem Kamel ähnelt, versehen ist. Ihr König Qeimāsb verlangt, dass Ḥamze seine Tochter 'Arvāne Hātun heiratet. Weil Ḥamze sich aber von ihrer Hässlichkeit abgestossen fühlt,wirft er sie eines Tages einfach ins Meer (1/179-181).

\subsubsection{Hamzes Kinder und Enkelkinder}

Ḥamzes Erstgeborener ist 'Omar b. Ḥamze Yunāni, dessen Mutter Maryam-Nāhid aus Griechenland stammt. Ausgezeichnet ist er dadurch, dass er im Kampf gegen die Feinde seines Vaters die ihm von Ḥamze geschenkte Rüstung Rostams, des Vorbildes aller Helden, tragen darf. Weil er aber viele Krieger verliert, verflucht ihn Hamze, und er findet ein rätselhaftes Ende. Nach der alten Version des Buches $Q H$ wird er von einer Frau in der Stadt Fahār getötet. ${ }^{264}$

Ḥamzes zweiter Sohn, 'Alam Šāh (seine Mutter ist Rābe'e, eine Byzantinerin), weiß lange Zeit nicht, dass Hamze sein Vater ist. In einem Zweikampf trifft er sogar auf ihn (2/222-226). Erst im Mannesalter, während eines Kriegszuges, klärt ihn seine Mutter in einem Schreiben darüber auf. Als Krieger und Feldherr macht er sich einen Namen. Wegen seines besonderen Mutes schenkt ihm Hamze den Stuhl Rostams (2/243). Er besiegt u.a. den fränkischen Feldherrn Mālā-kard. Mit seinem Vater begibt er sich auf einen Kriegszug in den Osten Irans; dort heiratet er Šamse Hāavari, die Tochter des Königs Hosrou Ḩāvari (3/371) und wird Vater eines Sohnes namens Qāsem (3/397/1).

Ḥamzes dritter Sohn Qobād, dessen Mutter Mehrnegār ist, rivalisiert mit 'Alam Šāh, der von seinem Vater bevorzugt wird. Bevor Qobād Selbstmord begehen kann, rettet ihm Imām

${ }^{264}$ Anonymus: $Q H$, Bd. 2, S. 330. 
'Ali das Leben und verleiht ihm magische Kräfte (2/255-260). Schließlich tötet ihn ein Kundschafter seines Großvaters, des Perserkönigs Anōširvān (2/304).

Die Mutter von Ḥamzes viertem Sohn Badi` az-Zamān ist Gordiye. Als die Feenprinzessin Asmā’ von der Heirat Ḥamzes mit Gordiye erfährt, befiehlt sie den Dämonen, Gordiye und ihren Sohn zu entführen und zu töten. Ihre Tochter Qoreiši verhindert dies und beauftragt nun ihrerseits die Dämonen, Badi` az-Zamān in ein bestimmtes Haus im Menschenland zu bringen. Sie setzen ihn aber an einem falschen Ort aus, an dem ein alter Ringkämpfer mit seiner Frau lebt. Da sie ihr eigenes Kind verloren haben, adoptieren sie Badic az-Zamān $(2 / 272-273)^{265}$ und bilden ihn zu einem Ringer aus, der schließlich sogar mit Hamze ringt. Dieser erkennt seinen Sohn an einem Armband (3/468) und wird von ihm auf seiner Reise in das Land Finsternis begleitet. Badi` az-Zamān kämpft, erobert und siegt in der Fabelwelt und im Menschenland (3/378-84).

Dārāb ist der Sohn von Ḥamze und Ṣenoubar Bānu. Als 'Amr mit Ḥamze in Streit gerät, geht er in die Stadt der Wasseranbeter Kešvariye, um einen Heerführer zu finden, der es mit Ḥamze aufnehmen könnte. Er erblickt dort einen Jungen mit einem grünen Muttermal auf der Wange, das ihn als einen Sohn Hamzes ausweist. Er unterrichtet ihn in der Kunst der Kriegesführung und stellt für ihn eine Armee auf, damit er gegen Ḥamze zu Felde ziehen kann (4/702-703). Im Verlauf des nun beginnenden Krieges erkennen Ḥamze als Vorkämpfer des Islams und Dārāb als ketzerischer Wasseranbeter, dass sich in Wahrheit Vater und Sohn gegenüber stehen $(5 / 1014)$.

Als Ḥamze gegen den Geisterkönig Malek Șādeq kämpft, erscheint plötzlich ein gewisser Qomhur und stellt sich beiden entgegen (5/961-962). Ḥamzes Kundschafter Šāpur entdeckt an Qomhur ein grünes Muttermal, was ihn als einen Sohn von Hamze ausweist, und verschont ihn im Zweikampf. Später schaffen es Ḥamzes andere Söhne nicht, Qomhur zu besiegen, so dass Ḥamze selbst gegen ihn antreten muss. Er besiegt ihn und erkennt nun, dass Qomhur sein Sohn ist. Ein Dämon berichtet, er habe Dorr-dāne, die Mutter Qomhurs, als Opfer eines Schiffbruchs auf dem Meer mit ihrem Kind gefunden. Vor ihrem Tod habe sie ihm noch einen Smaragd Ḥamzes übergeben können und das Kind habe er daraufhin in seine Obhut genommen und aufgezogen. Mit Freude hört Ḥamze davon, Qomhur darf in Zukunft zu seiner Linken Platz nehmen (5/1043).

Der zweifellos wichtigste Enkelsohn Ḥamzes ist Nur ad-Dahr. Als sein Vater Prinz Badi` azZamān, der Vertreter des rechten Flügels, Ḥamze, der den Vertreter des linken Flügels

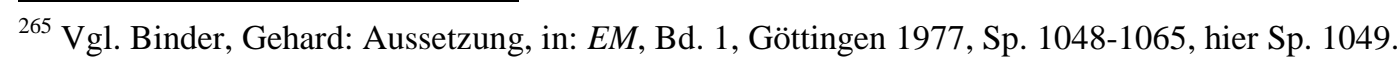


Qāsem bevorzugt, verlässt, übergibt er Nur ad-Dahr sein Eigentum. Dieser kämpft später unerkannt für Hamze gegen Zomorrod (4/604-605). Er ist auch in der Fabelwelt als Held tätig, wo er gegen dive, Hexen und Menschenfresser antritt (4/602).

Nur ad-Dahrs Liebesgeschichten sind besonders zahlreich und unterhaltsam. Von einem Derwisch erfährt er, Prinzessin Māhnušlab, Tochter des Königs Keivān Šāh, sei von einem Dämon entführt worden (4/713). Mit Hilfe von 'Amr gelingt ihre Befreiung (4/720). Er heiratet sie und wird Vater eines Sohnes Badi' al-Molk (4/724).

Unter den Enkelsöhnen Ḥamzes gilt Qāsem, der Sohn von 'Alam Šāh und Šamse als eine der Hauptfiguren. Er wird als ungerechter (3/516/4), habsüchtiger Türke (3/517/21) und Unheilsbringer (4/622/21) dargestellt. Bei der Geburt ist sein Gesicht rubinrot, in seiner linken Hand zeigen sich drei Blutstropfen (3/394), in seiner rechten fünf (Zeichen, die auch Dschingis Khan, der Anführer der Mongolen, aufwies). ${ }^{266}$ Astrologen weissagen daher seinem Vater, Qāsem werde viel Blut vergießen. Um seine Fähigkeiten als Krieger zu beweisen, kämpft er gegen Ḥamzes Gefolgsleute (3/477). Schließlich steht er Ḥamze selbst im Zweikampf gegenüber. Hamze wird jedoch rechtzeitig darüber in Kenntnis gesetzt, dass Qāsem sein Enkelsohn ist (3/482).

Eine weitere Hauptperson im $R H$ ist Irağ, Sohn von Malek Qāsem und seine Frau Giti-afruz, Tochter von Zomorrod. Seine Mutter, die auf der Flucht mit ihm niederkommt, setzt ihn aus. H“āăğe Farăg, ein Sonnenanbeter, findet ihn, zieht ihn mit seiner Frau auf und nennt ihn Irağ. Irağ wird später Oberhaupt der Sonnenanbeter. Nachdem Irağ jahrelang als Krieger gedient hat, kämpft er gegen Ḥamze, unterliegt diesem zunächst, verbündet sich aber später mit ihm im Kampf gegen Zomorrod.

Als Asad die Verlobte Eqbāl Šāhs entführt, eilt Irağ, der charakterlich als edelmütig galt, sofort zu Hilfe und versucht sie zu befreien; 5/799). Er wird als brutaler Herrscher geschildert. Er befiehl, die Stadt Āhtam zu zerstören und ihre Einwohner zu töten; 5/753). Er ist auf seinen zahlreichen Feldzügen in zwei Welten unterwegs, überwiegend aber im Reich der Fantasie. In beiden Welten tritt er als Held auf, der sich durch siegreiche Kämpfe gegen Löwen und Dämonen auszeichnet (4/711).

Unter Hamzes zahlreichen Söhnen und Enkelsöhnen gibt es durchaus rivalisierende Bestrebungen, um mehr an Macht und Einfluss zu gewinnen; sogar kriegerische Auseinandersetzungen finden statt. Am Endejedoch behält Hamze das letzte Wort und bestimmt den Sohn Ḥamze-ye sani zu seinem Nachfolger. 


\subsubsection{Hamze und seine Weggefährten}

Außer der Familie und der Dienerschaft gibt es noch eine dritte Gruppe von Menschen, zu denen Hamze eine enge Bindung hat und dies sind seine Gefährten. Diese bilden das dritte wesentliche Element an Hamzes Hof. Die Gefolgsleute bilden im $R H$ eine lockere Hierarchie unter den Adligen an Hamzes Hof und spielen eine Schüsselrolle in der internen Machtstruktur.

Die Gefolgsleute verkörpern die ritterliche Idealfigur. Der Lebensweg eines Ritters wird in allen Einzelheiten geschildert, die Abenteuer, die er zu bestehen hat, seinen vielen Irrwege bis er sich als wahrer Ritter bewiesen hat und der höchsten Weihe des Rittertums teilhaftig werden kann. Nach dem Bestehen an Hamzes Hof, kann der Ritter als treuer Freund aufgenommen werden. Drei ritterlichen Idealen sind sie verpflichtet: dem Dienst für den

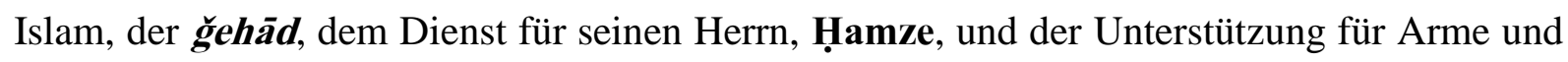
Schwache. Als ritterliche Tugenden gelten im $R H$ u.a.: Anstand und Wohlerzogenheit, Mäßigung der Leidenschaften, Glaube an Gott und Treue Ḥamze gegenüber, Aufrichtigkeit, Verlässlichkeit und Freigebigkeit.

An Ḥamzes Hof sind viele berühmte Ritter versammelt wie Landehur, Mālek-e Aštar, Salmān Fārisi, Bahrām-e Čubin, 'Amr b. Ma`di Karib, Karib, Moqbel und Tahmāsb b. 'Anqavil.

\section{Landehur}

Eine der Hauptfiguren im $R H$ ist Landehur, der sich als ein besonders treuer Weggefährte Ḥamzes erweist. Er ist der Sohn von Sa'dān und Enkelsohn des Propheten Šis (1/61). In jungen Jahren wird er Vollwaise. Sein Onkel Hošyār Šāh, als Stellvertreter des Königs von Sarandib, nimmt ihn an seinen Hof auf. Als er Hošyār Šāh einmal am Bart zupft, lässt ihn dieser unter den Fuß eines Elefanten legen, der jedoch das Kind verschont. Um seinen Anspruch auf den Thron zu verdeutlichen, rebelliert Landehur zu einem späteren Zeitpunkt mit Erfolg gegen Hošyār Šah. Dieser bittet Anōširvān um Unterstützung bei dem Versuch, seinen Thron zurückzugewinnen. Daraufhin wird Ḥamze von Anōširvān nach Indien geschickt, wo sich Landehur aufhält. Anōširvān hofft dadurch auch die Heirat seiner Tochter mit Ḥamze zu verhindern, wenn dieser im Kampf mit Landehur getötet wird (1/62). Ḥamze besiegt jedoch Landehur, bekehrt ihn zum Islam und gewinnt ihn als besten Freund (1/87). Als Ḥamze in das Land der Finsternis reiten will, ernennt er Landhur zu seinem Stellvertreter.

266 Rašid ad-Din Fażlallāh (gest. 1318): Ǧamic at-Tawārih̆, Bd. 1, hrsg. von Bahman Karimi, Teherān 1338/1959, S. 232. 


\section{Mālek-e Aštar b. Ḥarit an-Naḩacî}

Mālek-e Aštar b. Ḥariț an-Naḩẫ ist eine historische Figur. Er war ein bedeutender Feldherr ${ }^{\text {'Alis }}{ }^{267}$ und ebenso ein wichtiger Kämpfer für den Glauben. Sein Sohn Ebrāhīm b. al-Aštar war der berühmteste Feldherr Mohtārs. ${ }^{268}$

Die Gestalt Mālek-e Aštars hatte sich im Laufe der Zeit immer weiter entwickelt und die muslimischen Erzähler hatten in seiner Persönlichkeit ein unterhaltsames Motiv gefunden. Dort erhielt sein Leben einen wirkungsmächtigen Nachhall.

Im Buch Hā̃varān-nāme spielt Mālek-e Aštar ebenfalls eine zentrale Rolle. Als Feldherren von 'Ali kämpfen Mālek und Abu 'l-Meḥğan gegen heidnische Fürsten, vor allem gegen Qobād, den König von Hูāvarān. ${ }^{269}$

Im $R H$ ragt Mālek unter den Kriegern und Feldherren, die Ḥamze dienen, hervor. Dort wird er als amir al-omarāà’e dast-e čap bezeichnet (4/725/1). ${ }^{270}$ Māleks Heldentaten werden, verglichen mit den sonst üblichen Schilderungen, im $R H$ maßlos übertrieben dargestellt. Er verbündet sich mit den Kriegern, die auf dem linken Flügel von Ḥamzes Armee streiten (4/583).

\section{Salmān Fārisi}

Eine andere historische Persönlichkeit ist Salmān Fārisi (gest. 655-7). ${ }^{271}$ Salmān war Gefährte des Propheten und eine der populärsten Persönlichkeiten der islamischen Legende. „Er soll der Sohn eines Dihqāns in dem Dorfe Ḍjaiy in der Nähe von Eṣfahān gewesen sein.“272 Sein Name war Ruzbih, und Moḥammad und 'Ali weihten ihn in ihre geheimsten Lehren ein. Der Prophet Moḥammad hat über ihn gesagt, dass Salmān zu uns gehört [Angehörige des Propheten] ${ }^{273}$; er besitzt das Wissen der Ersten und der Letzten; das Paradies verlangt nach Salmān alltäglich und allnächtlich fünfmal. ${ }^{274}$ Salmān spielte eine bemerkenswerte Rolle in der Entwicklung des Ṣufismus und fotovvat. In der iranischen

\footnotetext{
${ }^{267}$ Vgl. Taeschner, Franz: Zünfte und Bruderschaften im Islam, Zürich/München 1979, S. 441.

${ }^{268}$ Vgl. Wüstenfeld, Heinrich Ferdinand: Der Tod des Husain ben Ali und die Rache. Ein historischer Roman aus dem arabischen Abhandlungen der königlichen Gesellschaft der Wissenschaften zu Göttingen, 30 Band, Göttingen 1883, S. 185-213.

${ }^{269}$ Vgl. Ethé, Neupersische Literatur, S. 235.

${ }^{270}$ Ando Shiro bemerkt: „Dieser Terminus technicus amir al-omarā bezeichnet der Wortbedeutung nach den obersten Emir, der demnach unter dem Herrscher die mächtigste militärische Stellung innegehabt haben müsste." Siehe: Shiro, Ando: Timuridische Emire nach dem Mu $q z z$ al-ansāab. Untersuchung zur Stammesaristokratie Zentralasiens im 14. und 15. Jahrhundert, Berlin 1992, S. 227.

${ }^{271}$ Levi Della Vida, Giorgio: Salmān al-Fārisī, in: EI, Bd. IV, Leiden/Leipzig, 1934, hier S. 124.

${ }^{272}$ Ebd. S. 125.

${ }^{273}$ Mağlesi, Bd. 2, S. 643; Massignon, Louis: Salmān Pāk et les prémices spirituelles de l'Islam Iranien. Publications de la Société des études Iransiennes et de l'art Persan, 7, Paris 1934, S. 16-19.

${ }^{274}$ Thorning, Hermann: Beiträge zur Kenntnis des islamischen Vereinswesens auf Grund von Bast MadadetTaufíq, Berlin 1913, S. 85-89; Mağlesi; Bd. 2, S. 649.
} 
fotovvat-Tradition war er 'Alis Nachfolger. ${ }^{275}$ Über seine Rolle im Ṣufismus schreibt Levi Della Vida:

„Die Gestalt Salmāns hat eine außerordentliche Entwicklung genommen. Nicht nur erscheint er als einer der Begründer des Șufismus in Gemeinschaft mit den Aṣhāb al-Ṣuffa sondern seine angebliche Grabstätte ist sehr bald ein Mittelpunkt religiöser Verehrung geworden. “276

Bei den Derwischen spielte Salmān eine ähnlich bedeutsame Rolle wie in den fotovvaBüchern. ${ }^{277}$ Er wurde als Schutzheiliger der Zünfte erwähnt. Er war ein Diener des Propheten und galt als dessen Barbier, weshalb er auch der pir (Patron) der Barbiere wurde. ${ }^{278}$ Bei den Derwischorden HGāksār trug er noch den Namen Solțān Maḥmud-e Pāṭili. Es wurde behauptet, dass er der Gründer der Hāàksār gewesen sei. ${ }^{279}$ Er hatte den persischen Beiname $\boldsymbol{p a ̄} \boldsymbol{k}$ (rein). ${ }^{280}$ Er soll insgesamt 330 oder 360 Jahre alt geworden sein. ${ }^{281}$

Als eine legendenhafte Vita des Salmān wird erzählt, er wäre von Geburt ein Königssohn gewesen, der während seines langen Martyriums unter Ungläubigen, Christen und Juden zu leiden hatte, bevor er schließlich von Moḥammad errettet worden war. Nie hatte Salmān an seinem Glauben gezweifelt. ${ }^{282}$

Im $R H$ ist Salmān sehr mutig und kämpferisch. Er beschützt Ḥamzes Frauen in der Festung Zú 'l-Amān (4/725). Landehur sagt über Salmān: „Er ist in Ḥamzes Diensten treu. Er glaubt an Gott und bewahrt Ḥamzes Frauen. Deswegen hilft ihm Gott.““(5/965).

'Amr b. Ma'di Karib und seine Familie

'Amr b. Ma`di Karib war ein historischer Held aus dem vorislamischen Arabien. Die aus dieser Zeit stammenden Erzählungen (aiyām al-‘arab) berichten über seine Heldentaten. ${ }^{283}$ Er war zudem ein bedeutender Dichter. ${ }^{284}$ Nach dem Tod des Propheten Moḥammad wandte er sich vom Islam ab. ${ }^{285}$

\footnotetext{
${ }^{275}$ Kāšāni, 'Abdal ar-Razāq: Tuḥfat 'I-ahavān dar bayān-e uṣul-e fotovvatva ādāb-e fatiyān, hrsg. von Moḥammad Mir-Dāmādi, Teherān 1351/1972, S. 12-13.

${ }^{276}$ Levi Della Vida, hier 124.

277 Ebd.

${ }^{278}$ Taeschner, Zünfte und Bruderschaften im Islam, S. 409.

${ }^{279}$ Vgl. Gramlich, Richard: Die schiitischen Derwischorden Persiens. Erster Teil: Die Affiliationen, Wiesbaden 1965, S. 82.

${ }^{280}$ Thorning, S. 88.

${ }^{281}$ Thorning, S. 89.

282 Thorning, S. 86-88.

${ }^{283}$ az-Ziriklī, Hair ad-Din: al-A Iām. Qāmūs tarāğim li-ašhar ar-riğāl wa an-nisā min al-'arab wa 'l-musta 'ribīn wa-'l-mustašrigīn, Bd. 5, Bairut 1984, S. 86.

${ }^{284}$ al-Mas'ūdī, Kìtāb murūğ ad-dahab wa-ma'ādin al-ğawāhir, Bd. 3, hrsg. von Charles Barbier de Meynard, Bairut 1970, S. 69-74.

${ }^{285}$ Ibn Hišām, Moḥammad 'Abd al-Malek: as-Sir ra an-Nabawiyya, Bd. 2, Ägypten 1375 h/1955, S. 585.
} 
Im $R H$ lesen wir, dass er der Kommandant einer Festung namens Tang-e Ravāḥl ist (1/22). Er bekleidet 17 Ämter an Ḥamzes Hof (1/25). Seine äußere Erscheinung und sein Benehmen lassen ihn nicht selten auch als Witzfigur auftreten, was natürlich dem Publikumsgeschmack entgegen kommt.

Als weiterer Gefährte gesellt sich zu Ḥamze Karib b. Ma`di, ein Sohn von 'Amr b. Ma`di und ‘Ādi Bānu, einer Tochter von Ma`ruf Šāh. ‘Ādi Bānu zieht ihn allein auf, und er nimmt zunächst an, dass er Ma'ruf Šāhs Sohn sei, der in Wirklichkeit sein Großvater ist (2/274). Als er dies erfährt, macht er sich daher auf die Suche nach seinem Vater. Karib trifft diesen endlich nach mancherlei Abenteuern im Heerlager Ḥamzes. Dieser nimmt ihn herzlich auf und lässt ihn im Audienzsaal an seiner rechten Seite sitzen (4/577). Karib wird später der Schwiegersohn Ḥamzes (5/876), und er führt viele Kriege mit den Usbeken (3/395).

Karibs und Zobaide-šir (eine Tochter Ḥamzes) Sohn ist Asad, der sich Ḥamze gegenüber stets loyal verhält, obwohl er „König der Verrückten“ genannt wird (5/758), was sich auf seine zwiespältigen charakterlichen Eigenschaften bezieht. Er begegnet den Dämonen und erhält übernatürliche Kräfte von 'Ali. Asad ist gegenüber Ḥamzes Familie sehr loyal. Er tötet die Sonnenanbeter und erbaut aus ihren Schädeln ein Minarett, möglicherweise eine Erinnerung an die Schädelpyramiden Timur Lenks (5/912). ${ }^{286}$

\section{Bahrām-e Čubin}

Bahrām-e Čubin, ein weiterer Weggefährte Ḥamzes, war in der vorislamischen Geschichte des Irans ein großer Held. Er war Oberhaupt der Familie Mehrān mit Sitz in Rey und Feldherr von Hormoz (578-590), ${ }^{287}$ gegen den er revoltierte und später auch gegen dessen Sohn Hosrou Parviz. ${ }^{288}$ Er konnte Hosrou besiegen, der Zuflucht beim römischen Kaiser suchte. Mit dessen Hilfe gelang es ihm, seine Herrschaft im Iran zurückzugewinnen. ${ }^{289}$

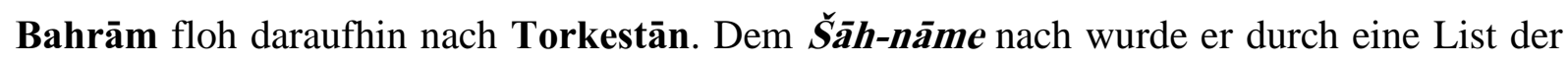
türkischen Königin getötet. ${ }^{290}$ Nach seinem Tod heiratete seine Schwester und Gattin Gordiye, König Hosrou Parvis. Über sein Leben exsitierte ein historischer Roman, dessen

\footnotetext{
${ }^{286} \mathrm{Vgl}$. Roemer, S. 72.

287 Justi, Ferdinand: Die Geschichte Irans. Von den ältesten Zeiten bis zum Ausgang der Sasaniden, in: Grundriss der iranischen Philologie, zweiter Teil, S. 541.

${ }^{288}$ Eslāmi-Nadušan, Moḥammad-‘Ali: Zendegi va marg-e pahlevānān dar Šāh-nāme, Teherān 1348/1969, S. 391-433.

289 Justi, Die Geschichte Irans, S. 542.

${ }^{290}$ Ferdousi, Bd. 2, 1768-1769; Anonymus: Moğmal at-Tawārih̆ wa-al-qeṣaṣ, S. 78; ‘Ādel, S. 169-170.
} 
Pahlavi-Original verloren ging, in Auszügen jedoch bei arabischen und persischen Chronisten auftaucht. $^{291}$

Im $R H$ erscheint Bahrām als Sohn des Kaisers von China. Als Gottesanbeter rebelliert er gegen seinen ungläubigen Vater. Dieser bittet den Perserkönig Anōširvān um Unterstützung, der seine Truppen unter der Führung von Gostaham nach China entsendet. Schließlich wird Bahrām jedoch von Gostaham gefangen genommen und nach Madā'en gebracht (1/33). Dort begegnet Bahrām Ḥamze, der ihn in einem Ringkampf besiegt. Danach wird er dessen Freund und einer seiner wichtigsten Heerführer (1/60).

Moqbel

Sowohl im $Q H$ wie auch im $R H$ erscheint ein gewisser Moqbel als treuer Gefährte Ḥamzes. Während er im $Q H$ als Prinz von Ḥalab (Aleppo) und Wegelagerer auftritt, ${ }^{292}$ ist er im $R H$ der Sohn des Sklaven 'Abd al-Moțtaleb. Wegen seiner Treue erhält er den Beinamen Vafādār (Treu; 1/13). ${ }^{293}$

\section{Ṭahmāsb b. ‘Anqavil}

Dieser ist der Sohn 'Anqavils. Er kämpft gegen Ḥamze und tötet viele Krieger, darunter Hamzes Sohn Širōye (4/666-667). Nur ad-Dahr wird ihn im Kampf besiegen, und er wird sich zum Islam bekehren (4/668). Sein Sohn Ṭarmāsb, der ein Sonnenanbeter ist und sich mit Irağ verbündet hat, zieht gegen seinen Vater Țahmāsb und Nur ad-Dahr zu Felde. Nur adDahr besiegt Ṭarmāsb und verlangt von ihm, sich zum Islam zu bekehren. Ṭarmāsb weigert sich, woraufhin Ṭahmāsb seinen Sohn Ṭarmāsb und seinen Enkelsohn Ğarmāsb tötet $(5 / 904)$.

\subsubsection{5 Ḥamze und seine Feinde}

Im $R H$ sehen wir zwei Typen von Ungläubigen. Zum einen sind sie würdige, angemessene Kontrahenten zum anderen sind sie weltverhaftete, verabscheuungswürdige Usurpatoren oder auch hinterlistige Feiglinge. ${ }^{294}$ Die Ungläubigen müssen einerseits, vom heroisch-ritterlichen Standpunkt aus, würdige Gegner der Helden sein, andererseits aber müssen sie zugleich, aus

\footnotetext{
${ }^{291}$ Nöldeke, Theodor: Geschichte der Perser und Araber zur Zeit der Sassaniden. Aus der arabischen Chronik des Tabari, Leiden 1879, S. 476.

292 Anonymus, QH, Bd. 1, S. 44.

${ }^{293}$ Bemerkenswert ist, dass in der Timuridenzeit dieser Titel tatsächlich Würdenträgernverliehen wurde. Der Historiker Yazdi berichtet in seinem Buch Zafar-nāme, dass Allāhdād, ein Feldherr Timurs, als Vafādār bekannt war. Siehe: Yazdi, Šaraf ad-Din 'Ali: Zafar-nāme, Bd. 2, hrsg. von Moḥammad 'Abbāsi, Teherān 1336/1957, S. 100.

294 Vgl. Schulz, Armin: Schwieriges Erkennen. Personenidentifizierung in der mittelhochdeutschen Epik, Tübingen 2008, S. 60.
} 
muslimischer Sicht, verabscheuungswürdige Wesen sein. Die Autoren des $R H$ tun sich ausgesprochen schwer mit solchen Uneindeutigkeiten. Ambivalenzen werden zumeist dadurch ausgedrückt, dass miteinander unvereinbare Eindeutigkeiten nebeneinander gestellt werden.

Die Autoren des $R H$ haben sie gewissermaßen übereinander kopiert, um allen Seiten gerecht $\mathrm{zu}$ werden, wie am Beispiel von Irağ ersichtlich wird: Obwohl er ein Sonnanbeter ist und natürlich für Muslime einen Feind verkörpert, wird er mit den gleichen Eigenschaften wie Nur ad-Dahr beschrieben (5/772). Nur ad-Dahrs Verhältnis gegenüber Irăg ist sehr ambivalent d.h. obwohl sie Gegner im Kampf sind, begegnen sie sich auf gesellschaftlicher Basis entspannt (4/711).

Der Auftritt der Helden in den Texten ist im wahrsten Sinne des Wortes glanzvoll, und sie werden mit den Attributen des Hell-Schönen beschrieben; dagegen sind die Ungläubigen, die häßlichen Gegner, die mit den Attributen des Dunkel-Häßlichen beschrieben werden. Das, was man sehen und unterscheiden kann, liefert die zuverlässige Wahrheit. Die Logik solcher Zuschreibungen unterscheidet sich jedoch formal nicht von dem Nebeneinander der explizit benannten muslimischen Vorstellungen von Ungläubigkeit.

Ḥamzes Feinde erhalten oft charakteristische Beinamen wie als māde-šàgäal (weibliche Schakale; 1/96/26), sag-e ḥarām-zāde (Bastardhund; 6/1065/11) ${ }^{295}$, bad-segāl (schlechtgeartet; 4/637/9), harām-zāde (uneheliches Kind/Bastard; 4/526/31), ${ }^{296}$ huk-piše (ein Verhalten wie ein Schwein; 5/855/10), ${ }^{297}$ ru-sìyāh (schwarzes Gesicht; 4/640/27) ${ }^{298}$ und nādān (Unwissend; 4/719/11).

295 Bis heute gilt der Hund im Iran als so schmutziges und unreines Tier, dass eine noch so geringfügige Berührung eine rituelle Waschung erforderlich macht.

${ }^{296}$ Im Islam ist zina'(Unzucht) ein großes Verbrechen und eine ungeheuerliche Abscheulichkeit, die direkt nach šerk (Vielgötterei/Polytheismus) und Mord kommt. Demjenigen, der/die Unzucht begeht, wurde eine gewaltige Strafe angedroht, sowohl im Diesseits als auch im Jenseits. Es ist einfach absolute Sünde, ohne verheiratet zu sein, Kinder zu zeugen. Die Verwendung als Schimpfwort geht darauf zurück, dass ḥarāmzäde aus Sicht der Muslime minderwertiger als echte Kinder waren. Die außerehelichen Kinder wurden allgemein als palid (schmutzig) bezeichnet, weil sie nur schlechte Eigenschaften von ihren Eltern erben. Hinzu kommt der Aspekt von Sündhaftigkeit außerehelicher Kinder, der durch die muslimischen Gelehrten geprägt wurde. Siehe: Koran, Sure. 17,32. Ansāri, Moḥammad-Reżā: zina', in: Dā'rat al-ma'ārif-e tašayyo', Bd. 8, Teherān 1379/2000, S. 506-514, hier S. 509f.

${ }^{297}$ Das Schwein ist aus religiösen Gründen das minderwertigste Tier im Islam. Wenn die Muslime ihren Hass gegen ihre Feinde äußern wollen, greifen sie als Beleidigung gern auf das Schwein zurück. Siehe: Ansāri, Moḥammad-Reżā: Huk, in: Dã'rat al-ma'ārif-e tašayyo', Bd. 7, Teherān 1378/1999, S. 338-341, hier S. 339.

298 Der Tag der Auferstehung ist ein Tag des Lohnes und der Strafe. Wer an Allāh glaubte und seine Gebote einhielt, den wird Allāh belohnen. Er ist glücklich und hat ein schönes, beleuchtetes Gesicht. Die Ungläubigen dagegen erwartet eine harte Strafe. Sie werden nach ihrem Tod mit einem schwarzen Gesicht auferstehen. Im Koran Sure 39,60 lesen wir: „Und am Tag der Auferstehung siehst du diejenigen, die gegen Allah gelogen haben; ihre Gesichter sind schwarz geworden. Ist nicht in der Hölle ein Aufenthaltsort für die Hochmütigen?" 
Diese Formen der Beleidigung mit sehr plastischen und oftmals platten Namen hat sich bereits ins kollektive Gedächtnis der Iraner eingeprägt.

Die Heiden und andere Ungläubige sind $\mathrm{zu}$ dumm, um $\mathrm{zu}$ erkennen, auf wen sie sich überhaupt eingelassen haben, und müssen dementsprechend mit ihrem Tod bezahlen.

'Anqavil

Ḥamze hat das Talent, aus seinen Feinden treue Freunde und Kampfgefährten zu machen. Ein Beispiel dafür ist 'Anqavil. Er gilt zwar auch als Widersacher Hamzes (Zomorrod wird von ihm im Kampf gegen Ḥamze unterstützt), wird aber als durchaus edelmutig und heldenhaft dargestellt. Als Ḥamzes Bruder 'Abbās ihn verwundet (4/632-634), er aber eine Bekehrung zum Islam ablehnt, begnadigt ihn Ḥamze dennoch, nach dem er versprochen hat, die Muslime nicht mehr zu bekriegen und sein weiteres Leben als Derwisch auf der Insel Kangān zu verbringen.

\section{Qāren}

In der vorislamischen Zeit kämpften die Iraner hauptsächlich gegen Rom und gegen einige Völker aus Zentralasien und Arabien. Aus dieser Zeit, besonders der parthischen Epoche, ist unter den sieben Familien, die reich und mächtig waren, besonders die Familie Kārēn (arab. Qāren) hervorzuheben. Bei der Krönung des parthischen Königs trug das Oberhaupt der Familie Kārēn die Krone des Königs. ${ }^{299}$ Im $R H$ versucht ein gewisser Qāren mit dem Beinamen div-band (Dämonenbezwinger) mehrmals, Ḥamze zu töten ${ }^{300}$ (1/107-108). Schließlich aber siegt Ḥamze und tötet Qāren (1/117-118).

\section{Șalṣāl}

Schon lange war diese Person als fiktive Figur in der volkstümlichen Literatur bekannt. Ein Dichter namens Seyyed 'Isā verfasste ein Buch mit dem Titel Șalṣāl-nāme, in dem er den Kampf Imām 'Alis gegeneinen Dämon Ṣalṣāl schildert. ${ }^{301}$ Im $R H$ ist dieser Ṣalṣāl König von Haṭā und Herrscher über die Usbeken. Er ist Götzenanbeter (3/416), und Ḥamze verlangt von ihm, dass er vom Götzendienst ablässt und sich zum Islam zu bekennt (3/416). Șalṣāl weigert sich und zieht gegen Ḥamze mit 1.800.000 Usbeken zu Felde (3/417-423); er unterliegt jedoch (3/426-457).

\footnotetext{
${ }^{299}$ Christensen, Arthur Emanuel: L'Iran sous les Sassanides, ins Persische übersetzt. von Rašid Yāsami, Teherān 1375/1996, S. 157-166.

${ }^{300}$ Marzolph, TPV (Motiv. Gift in der Speise. 314, 763, 837), S. 284.

${ }^{301}$ Taeschner, Franz: Die osmanische Literatur, in: Handbuch der Orientalistik, Abt. 1, Bd. 5, Leiden/Köln 1963, S. 259-261, hier S. 260.
} 
Zomorrod

Ein mächtiger Feind Ḥamzes ist Zomorrod, der nach dem Tod Anōširvāns dessen Rolle im $R H$ übernimmt. Er ist König von Bāhntar und beansprucht für sich, als Gottheit anerkannt zu werden. Im Kampf gegen Hamze erleidet er mehrere Niederlagen (3/503-5/848) und flieht schließlich, von Hamze verfolgt (5/884-885), in das Land der Finsternis. ${ }^{302}$ Auch Zomorrod verweigert ein Bekenntnis zum Islam und wird von Ḥamze getötet (5/1048).

Er wird im $R H$ mit vielen negativen Namen bedacht, die uns seine bizarre Persönlichkeit und seinen Irrglauben verdeutlichen. Man nennt ihn Zomorrod-e ru-siyāh (Zomorrod, dessen Gesicht schwarz ist; 5/850/20), Zomorrod-e bad-ā'in (Zomorrod, dessen Religion schlecht ist; 5/847/17), huk-e biše-ye żalālat va gomrāh, mag̉żub-e dargāh-e elāhi, bi-din (das Schwein des Hains der Abweichung, vom Weg abgekommener, in Ungnade gefallener am Hofe Gottes, Ungläubiger; 5/854/10).

Neyram-e Susan-puš-e Susan-parast

Ein besonders mächtiger Feind Ḥamzes ist Neyram, der über ein sagenhaftes Gebiet herrscht, das im Land der Finsternis liegt (5/848). Er besitzt magische Kräfte und ist Lilienanbeter. Ihm gelingt es, die Muslime zwei Mal zu besiegen und Hamze sogar zu verwunden (5/871-872), ein einmaliges Ereignis. Er fordert Ḥamze auf, Lilienanbeter zu werden, was dieser ablehnt. In einem Traum erfährt Ḥamze von dem Prophet Soleimān, wie er die Magie Neyrams zerstören kann. Bei einer erneuten kriegerischen Auseinandersetzung vermag daher Ḥamze Neyram zu besiegen (5/874-77). Als Neyram es ablehnt, sich zum Islam zu bekennen, und Hamze beschimpft, tötet ihn dieser (5/878).

\subsubsection{6 Ḥamze und seine Kriege}

Ḥamze führt seine Kriege von der Arabischen Halbinsel aus über den Iran, Byzanz, Indien, China, Zentralasien, Nordafrika bis nach Spanien und Franken. Im $R H$ ist er auch in der Welt der Fantasie in fiktiven Ländern und mit fantastischen Gestalten kämpfend als Held unterwegs. Rostam und Alexander der Große als literarische Figuren, sind Vorbilder für Hamze. Wie Alexander hat Hamze sieben Schlachten (gegen Griechenland, Antiochia, Țaranbusye, Hosrouviye, Byzanz und Ägypten), zu bestehen, die für den Verlauf der Erzählung wichtig sind.

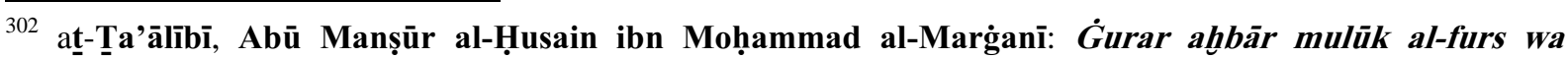
siyaruhum [Histoire des Rois des Perses], hrsg. von Hermann Zotenberg, Neudruck Teherān 1963, S. 432434. 
Auf dem Weg nach Griechenland gerät Ḥamze in eine kriegerische Auseinandersetzung mit Šankāve, einem Feind des Feridun, und tötet ihn. In Griechenland begegnet Ḥamze Feridun, dessen Söhne von einem Drachen gefangen gehalten werden; er befreit sie. Die Söhne preisen Hamze vor ihrem Vater so sehr, dass dieser sich schließlich zum Islam bekennt (1/110-111).

Ḥamze reitet weiter nach Antākiye (Antiochia). Qāren rät Ḥares Šāh, dem Herrscher des Landes, gegen Hamze Krieg zu führen (1/113). Da dieser sich aber nicht traut, Ḥamze in einer offenen Feldschlacht zu begegnen, versucht er Ḥamze auf hinterlistige Weise im Bad zu töten. Ḥamze erfährt durch seinen Freund 'Amr von diesem Plan; er tötet den König und zwingt die Einwohner von Antākiye, sich zum Islam zu bekennen (1/115-116).

Ḥamze kommt in das Land Taranbusiye (ein Fantasiegebilde). Der dort herrschende Anis Šāh ist ein hervorragender Polospieler. Er fordert Ḥamze zum Wettkampf heraus, in dessen Verlauf er Ḥamze zu besiegen oder gar zu töten hofft.

Der König befiehlt seinen Dienstleuten viele Gruben auf dem Spielfeld auszuheben, in der Hoffnung, dass Ḥamze in eine Grube falle und getötet wird. Ḥamze fällt in eine der Gruben, aber er kann gerettet werden. Er erobert die Stadt und tötet den König (1/118). Diese Art der Tötung errinnert an die Tötung Rostams durch seinen Bruder Šà̇ād. ${ }^{303}$

Nach der Eroberung des Landes Țaranbusiye reitet Ḥamze nach Hosraviye. Der König von Hosraviye, Hosrou Šāh, erfährt, dass Ḥamze angekommen ist. Ḥamze zeigt ihm den Brief des Perserkönigs und verlangt von ihm den Tribut. Der König sagt: „Ich habe eine Kuh, die ich auf meinen Schultern tragen kann. Ich gehe mit der Kuh die Treppe hoch und wieder herunter. Wenn du das gleiche tun kannst, werde ich Muslim werden und dir den Tribut bezahlen.“ Ḥamze trägt die Kuh, wie auch der König es getan hat. Als der König dieses sieht, wechselt er zum Islam und bezahlt den Tribut (1/119-120). Diese Geschichte hat Ähnlichkeit mit der Geschichte Bahrām Gōrs und seiner Sklavin Čehrāzād im Buch Haft peikar von Neẓāmi. ${ }^{304}$

Von Hosraviye reitet Ḥamze in Richtung Ägyten. Dort regiert 'Aziz-e Meșr, ${ }^{305}$ der Götzenanbeter ist. 'Aziz sperrt Ḥamze und seinen Soldaten ein und stellt Ḥamze vor die Wahl, die Götzen anzubeten oder zu sterben. Ḥamze weigert sich, die Götzen anzubeten. Mit

\footnotetext{
${ }^{303}$ Ferdousi, Bd. 1, S.1049.

${ }^{304}$ Neẓāmi-Ganǧavi, Elyās b. Yusof: Haft peikar, in: Kolleyāt-e Divān-e ḥakim Nezā̄mi-Ganğavi, hrsg. von Vaḥid Dastgerdi, Teherān 1335/1956, S. 668.

${ }^{305}$ Sein Name taucht auch in der Geschichte von Yusof und Zoleyhāā. Siehe: an-Neišāburi, Abu Bakr 'Atiq (berühmt als Sorābādi): Qeṣaṣ-e qor’ān-e mağid, hrsg. von Yạ̣yā Mahdavi, Teherān 1375/1996, S. 152.
} 
Hilfe der Prinzessin Zohre-Maryam, 'Azizs Tochter, befreien 'Amr und Moqbel Ḥamze aus dem Gefängnis. Hạamze erobert die Stadt und tötet 'Aziz (1/127).

Während Anōširvān mit Zubin Mekka belagert, meldet sich bei Ḥamze jemand, der sich als ein Ratgeber von Feenkönig Šahbāl ${ }^{306}$ zu erkennen gibt und ihn bittet, ihnen gegen die Dämonen auf dem Gebirge Qāf zu helfen. Die Hoffung aller Feen ruht jetzt auf Hamze, von dessen Tapferkeit im Kampf gegen die Dämonen der Feenkönig gehört hat. Ḥamze ist bereit, für achtzehn Tage dorthin zu gehen. Beim Aufbruch vergisst er jedoch, enšāàllāh (so Gott es will) zu sagen, so dass er statt 18 Tage 18 Jahre bei den Feen bleiben muss (1/138). Er erlebt in dieser Zeit unzählige gefährliche Situationen; er wird u.a. von Dämonen entführt und in Zauberburgen eingekerkert (1/165).

\subsection{Die Darstellung des ğehād im $R H$}

Im Islam ist die Lehre vom 亭hād von besonderer Bedeutung. Der Koran versteht unter ğehād die Bemühung um eine gute Sache, die Auseinandersetzung mit dem Bösen im Ringen um innere Läuterung, wobei am Ende durchaus kriegerische Mittel eingesetzt werden dürfen, was als eine Rechtfertigung für Kriege gilt. ${ }^{307}$ Der gläubige Muslim ist dem 亮hād verpflichtet. Wird er angegeriffen, so ist es seine Pflicht, sich für die gesamte Glaubensgemeinschaft einzusetzen. ${ }^{308}$ In frühislamischer Zeit war der ğehād in erster Linie ein Verteidigungskrieg. ${ }^{309}$

Ein historisches Faktum gerät bei der Untersuchung von Krieg und Frieden im Bereich des

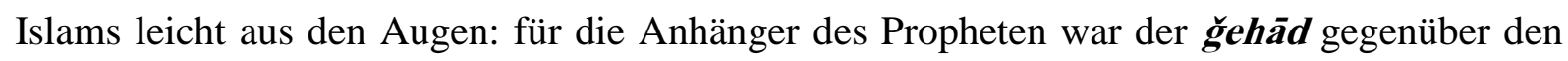
Stammeskriegen in vorislamischer Zeit auf der arabischen Halbinsel ein Fortschritt. Er beendete andauernde Blutrache-Fehden um Weideland, Wasserstellen, Vieh und nicht zuletzt Frauen und stellte eine gewisse Ordnung her.

Die klassischen šarī̌a Gelehrten teilen die Welt in zwei Gebiete ein: das dār al-ḥarb (Gebiet des Krieges) und das dār al-islām (Gebiet des Islams). ${ }^{310}$ Das Gebiet des Islams ist in dieser Sichtweise ein Gottesstaat, in dem das islamische Gesetz und die vom Islam festgelegte Gesellschaftsordnung vorherrschen. Das Gebiet der Nicht-Muslime wird grundsätzlich als Gebiet des Krieges bezeichnet. Die Muslime haben die Pflicht, ihr Gebiet gegen die Angriffe

\footnotetext{
306 Sein Name taucht auch in einem epischen Werk namens Qahramān-e qātel auf. Siehe: Anonymus: Qahramān-e qātel, Lithographischer Druck, Nationalbibliothek Teherān, Nr. 3619, S. 16.

307 Vgl. Lewis, Bernard: Die politische Sprache des Islam, 1. Aufl., Berlin 1991, S. 124; Watt, William Montgomery u. Welch, Alford T.: Mohammad und die Frühzeit. Islamisches Recht-Religiöses Leben, in: Der Islam I, Stuttgart/Berlin/Köln/Mainz 1980, S. 151.

${ }^{308}$ Lewis, S. 128.

${ }^{309}$ Watt, Montgomery u. Welch, S. 152.
} 
der Feinde zu verteidigen und im Gebiet der Nicht-Muslime dem Gesetz Gottes zum Sieg zu

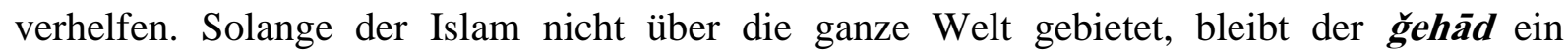
Dauerzustand. Diesen müssen die Muslime durch politische bzw. kriegerische Maßnahmen einleiten. Diese Vorstellung stammt aus der Zeit der islamischen Expansion in den ersten Jahrhunderten nach der hiğra.

Der historische Ḥamza b. ‘Abd al-Muṭtalib war Onkel des Propheten Moḥammad. Im RH ist er der große Streiter des Islams gegen die Ungläubigen. Er ist ein furchtloser, tapferer Held, siegreich in all seinen kriegerischen Unternehmungen und an allen Waffen ausgebildet. Die Entwicklung Ḥamzes zum idealen Helden und stärksten Vorkämpfer des Islams macht ihn zu einem Vorbild. Seine Entwicklung endet wie jene von Abu Moslem und Seyyed Batṭāl in der Erfüllung ihrer Aufgabe als Vorkämpfer des Islams.

Das $R H$ präsentiert in der Gestalt des Helden Ḥamze eine ältere Leitvorstellung politischer Legitimation und stellt sie zugleich in seiner Geschichte zur Diskussion. Im $R H$ wird erzählt, wie Ḥamze sich im Kampf gegen die Ungläubigen verhält.

Im Alter von 12 Jahren begegnet Ḥamze den Engel Ğebrā'īl, der ihm befiehlt, die Feinde des Islams zu bekämpfen. Unter seiner Führung breitet sich der Islam als religiöse und politische Macht über ein ausgedehntes, riesengroßes Gebiet aus, sowohl in der Realität (Europa, Indien, China, Afrika) als auch in der Fantasie (Qāf und das Land der Finsternis).

Um den Islam zum endgültigen Sieg zu führen, zieht Ḥamze gegen Geister, Hexen und jede Art von Unglauben zu Felde. Die Aufforderung, sich zum Islam als der wahren Religion und der Anbetung des Einen Gottes zu bekehren, erfolgt mittels schriftlicher Botschaften an Könige bzw. Statthalter. Werden diese missachtet, so greift Hamze selbst im Auftrag des Engels Ğebrā'īl als Heerführer in den Kampf ein (5/1045-1048).

In der Figur des Ḥamze sind die Optionen legitimer Herrschaft kombiniert; er ist zugleich Held und Herrscher (1/13). Seine Berufung als Wegbereiter des Islams ist also tatsächlich die größtmögliche Steigerung seiner Entwicklung zum idealen Helden. Besonders deutlich zeigt sich die Besonderheit seiner herausragenden Persönlichkeit nach seinem Zusammenbruch, seinen Selbstzweifeln an seiner Berufung, die ihn nach dem Tod seiner Frau heimsuchen.

Als Hamze nach dem Tod seines Sohns Qobād und seiner Frau Mehrnegār an der Notwendigkeit seiner Sendung zweifelt und seine Aufgaben nicht mehr erfüllen will, erheben sich seine mächtigen Feinde, und die Untergebenen werden aufständisch. Er verliert seine Unangreifbarkeit (Immunität) und wird durch Angriffe der Feinde und Plagen verletzt. Alle

\footnotetext{
${ }^{310}$ Vgl. Steinbach, Udo: Dāl al-himma. Kulturgeschichtliche Untersuchungen zu einem arabischen Volksroman,
} Wiesbaden 1972, S. 35. 
Rebellen, die Ḥamze einmal besiegt hat, erheben sich in dieser Phase noch einmal. Fariborz b. Qāren, der Enkelsohn von Qāren b. Fariborz, schickt seinen Kundschafter Kahanak nach Mekka, um Hamze zu berauben. Der Kundschafter kann Hamze gefangennehmen, seiner prophetischen Waffen berauben und zu Fariborz bringen (2/310). Ḥamze wird ins Gefängnis gebracht. Dort erscheint ihm Heżr im Traum. Dieser sagt ihm, dass Gott ihn bestrafe, weil er seine Pflicht als Vorkämpfer des Islams vernachlässigt habe (2/314). Letztlich soll dies verdeutlichen, dass dies nur die gerechte Strafe dafür ist, seinen göttlichen Auftrag vernachlässigt zu haben.

Im Koran steht, dass ein Krieger das Paradies gewinnt, wenn er im Kampf für den Glauben als Märtyrer getötet wird. $^{311}$ In frühislamischer Zeit zeigten die Muslime eine außerordentliche Opferbereitschaft, selbst das eigene Leben für ihre Religion einzusetzen. Der Märtyrertod ist als ideale Todesart beschrieben, selbst Krieger erleiden ihn. Auch Hamze, 'Ali und dessen Sohn Ḥosein sterben als Märtyrer. Der Wunsch, im Kampf als Opfer zu

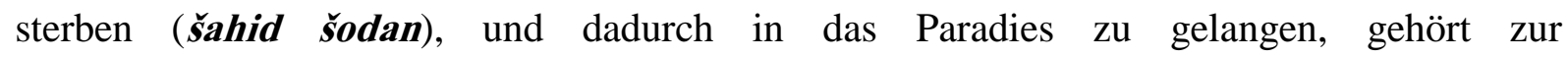
Glaubenseinstellung der Muslime bis in die heutige Zeit.

Als Märtyrer zu sterben, hat auch in der iranischen Geschichte eine besondere Bedeutung. Schon nach altiranischem Glauben erleidet der erste Mensch Keiōmars einen Opfertod. Seinem Körper sollen alle Nachgeborenen entstammen. Der Märtyrertod von Siyāvaš wird zum Symbol der Reinheit. Nach seinem Tod bilden sich bei den Iranern bestimmte Trauerzeremonien heraus.

Auch im $R H$ hat der Märtyrertod große Bedeutung. Ḥamze und seine Söhne sind bereit ihr Leben für den Islam hinzugeben und zu sterben. Dort findet sein Held Ḥamze, als farrāš-e rāh-e Moḥammad (Diener der Religion Moḥammads), seine Lebensaufgabe darin, den Islam gegen Ungläubige und falsche Religionen zu verteidigen.

Gläubige werden hodā-parastān (Gottesanbeter; 5/860/4) und pāk-din (fromm, gottesfürchtig; 4/561/15) genannt, Bezeichnungen, die in der iranischen Literatur des Mittelalters von besonderer Bedeutung sind. Ungläubige gelten als gabr (Feueranbeter; 5/861/12) oder bot-parast (Götzenanbeter; 5/862/5).

Im $R H$ ist kaum zu erfahren, dass die Muslime auf friedliche Weise die Verbreitung des islamischen Glaubens zu bewirken; vielmehr wird im Namen des Islams Gewalt ausgeübt. Das entspricht der Glaubenshaltung der Muslime im Mittelalter.

\footnotetext{
${ }^{311}$ Koran, Sure. 9,72.
} 


\subsubsection{Hamzes Charaktereigenschaften im $R H$}

Namen und Titel eines Menschen tragen eine besondere Kraft in sich. Der Name ist mit seinem Träger in sinnvoller Weise verbunden. Wenn ein Mensch besonders ausgezeichnet ist, ruht auf seinem Namen ein Segen, der sich auf andere Träger des gleichen Namens übertragen kann. Die Stärke eines Menschen drückt sich ebenfalls oft im Namen des Helden aus. Ḥamze $^{312}$ wird in der Erzählung vielfach als amir al-mo'menin (Fürst der Gläubigen) und Amir-e Șāhẹb-qerān (Fürst der glücklichen Konstellation) bezeichnet. ${ }^{313}$ Neben diesem Titel treten andere Bezeichnungen wie Amir und Soltānn als Abstrakta für „Macht“ und „Herrschaft“ auf (1/37/9). ${ }^{314}$ Diese Titel bezeichneten die weltlichen Herrscher im Iran. Weitere Titel sind: Šahriyār-e giti-setān (Weltherrscher; 1/52/11), ${ }^{315}$ Ğahān-panāh (Zufluchtsort; 1/22/27), ${ }^{316}$ Amir-e 'Arabestān (König von Arabien; 1/51/30), Amir kabir-e kešvar-gir (der König, der Eroberer ist; 1/54/23), Hāqān-e giti-setān (Kaiser, der der Weltherrscher ist; 1/60/20), Soleimān-e sāñi (Salomo der II; 1/142/7), ̌̌ekār konande-ye haft qolle-ye qāf (Jäger auf sieben Gipfeln des Qāf; 1/142/16), Amir-e ğahān-gir (König, der die Welt erobert hat; 2/255/8), Hosrou-ye hosrou-nešān (König, der königliche Eigenschaften hat; 4/710/16), Solțān al-barrein va hāqān-e al-baḥrein ${ }^{317}$ va bāğsetānande-ye mamālek-e Žo 'I-qarnein (König der Länder und der Meere, der Tributeinnehmer der Länder Alexanders; 4/724/13).

Die Figur des Ḥamze verkörpert eine vielschichtige Persönlichkeit. In der Hybridisierung seiner Persönlichkeit stellt er eine Integrationsfigur dar. Die von Hamze vollbrachten heroischen Taten haben eine exemplarische Wirkung auf das Kollektiv, dem er entstammt und zugehört. Die narrative Aufbereitung seiner Taten ist sicher im kollektiven Gedächtnis verankert.

Seine Kraft und Stärke, die für seine Heldentaten erforderlich sind, lassen ihn jedoch aus dem Kollektiv heraustreten. Dies lässt sein heroisches Potential sichtbar werden; zugleich führt diese Kraft aber auch zur Vereinzelung. So ist er als Individuum vom Kollektiv entfernt,

\footnotetext{
${ }^{312}$ Auf arabisch bedeutet Ḥamza der Löwe. Siehe: Dehḩodā, Logáat-nāme, ḥarf-e. Ḥ, Teherān 1330/1951, S. 798.

${ }^{313}$ Unter einer günstigen Konstellation Geborener. Dieser Titel ist historisch belegt. Er gehörte zu Timur. Siehe: Tārih̆-e Hāfez-e Abrū, Teil Zwei, bahšs-e ğoġrāfiyā-ye Horāsān, Edition und Einleitung. von Dorothea Krawulsky, Wiesbaden 1982, S. 52.

${ }^{314}$ Lewis, S. 65.

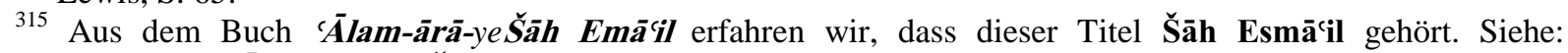
Anonymus: '`̄lam-ārā-ye Šāh Emācil, hrsg. von Aṣgar Montazer-Ṣāḥeb, Teherān 1349/1970, S. 65.

${ }^{316}$ Diesen Titel führten die șafavidischen Könige. Siehe: Kaempfer, Engelbert: Dar darbār-e Šahanšāh-e Irān, ins Persische übersetzt. von Kei-Kāvus Ğahāndāri, Teherān 1350/1972, S. 17.
} 
welchem er gleichwohl verpflichtet bleibt. Dabei kann er durchaus eine exemplarische Vorbildfunktion erlangen, allerdings nur durch die Erzählung seiner Taten.

Ḥamze möchte seine Feinde auch ehrenvoll besiegen. Er möchte sie im Zweikampf überwinden, und verzichtet auf unmoralische Methoden. So trifft Ḥamze im Land Qāf auf einen Efrit (mächtigen Dämon) und kann diesen besiegen. Der Efrit flieht und versteckt sich im goldenen Garten. Als Ḥamze dorthin kommt, findet er den Efrit schlafend vor. Ḥamze will ihn nicht im Schlaf töten, und so sticht er ihm mit seinem Schwert in die Füße. Der Dämon schreit auf, aber er erwacht nicht. Hamze sticht ihm noch einmal mit seinem Schwert in die Füße. Diesmal wacht der Dämon auf und flieht (1/163). ${ }^{318}$

In den persönlichen Eigenschaften Hamzes sieht man auch eine Inkarnation derjenigen Herrschertugenden, die generell den großen König ausmachen: königliche Haltung, Beharrlichkeit und Mut sowie Milde walten lassen, sind für ihn Eigenschaften des Herrschers.

Edelmut sowie mardānegi (Großmut) sind Charaktereigenschaften des Helden. Der Held ist Feinden gegenüber großzügig und rettet sie sogar, wenn sie in Gefahr sind. Dies zeigt sich bei einem Kampf zwischen Ḥamze und Ṭahmāsb Hुān. Als die feindlichen Heere auf der Brücke gegeneinander kämpfen, zerbricht die Brücke, und sie fallen alle ins Wasser. Hamze rettet erst Fariborz, seinen Feldherrn, und dann Ṭahmāsb, seinen Feind. Als Ṭahmāsb Ḥamzes Hilfsbereitschaft sieht, wendet er sich Ḥamze zu und wird zum Islam bekehrt (2/379).

Ein idealer Feldherr soll auch ein guter Soldatenvater sein. Ḥamze fühlt sich für seine Soldaten sehr verantwortlich. Im $R H$ wird berichtet, dass Neyram die Muslime zwei Mal besiegt und dabei wird im zweiten Kampf auch Hamze an sieben Stellen verletzt (5/871-872). Als Ḥamze sieht, das auch viele seiner Soldaten in ihrem Blut auf dem Kampfplatz liegen, weint er zum ersten Mal in seinem Leben (5/872).

Ḥamze ist ein gerechter Mensch. Er trifft in Qāf einen verschleierten Mann. Der Verschleierte wirft sich vor ihm zu Boden und sagt: „Ich bin Abu 'l-Mehğan. ${ }^{319}$ Mein Vater war der König der Andalusier (Andalos). Eines Tages jagte er einen Dämon. Dieser versprach ihm, wenn er ihn nicht töte, bekomme er vom Qāf ein Geschenk. Mein Vater akzeptierte sein

${ }^{317}$ Ein Titel, der historisch belegt ist und für die osmanischen Kaiser Verwendung fand. Siehe: Mohammad Hāšem, Āṣef (berühmt als Rostam al-ḥokamā): Rostam at-Tawārihu, hrsg. von Moḥammad Moširi, Teherān 1348/1969, S. 113.

${ }^{318}$ Vgl. Anonymus: Haft laškar, S. 173.

${ }^{319}$ Bei Abu 'l-Meḥğan at-Taqafĩ handelt es sich um eine historische Persönlichkeit. Er kämpfte für die Araber und gegen die Sasaniden. Er war zudem ein berühmter Dichter und starb im Jahr $650 \mathrm{n}$. Chr. in Aserbaidschan. Siehe: az-Ziriklī, al-A Iām, Bd. 5, S. 76. Sein Name taucht auch im Buch Hãararān-nāme auf, wo er eine wichtige Rolle spielt. Im Hãàvarān-nāme kämpften 'Ali und seine Genossen Mālek und Abu 
Versprechen. Der Dämon brachte daraufhin eine Feenprinzessin zu meinem Vater. Ich bin ihr gemeinsamer Sohn. Als der Dämon davon erfuhr, tötete er meinen Vater. Jetzt bin ich hierher gekommen, um Rache zu nehmen.“ Hamze tröstet ihn mit den Worten: „Sei ohne Sorge! So Gott will, werde ich dich wieder auf den Thron deines Vaters setzen“ (1/154).

Als pahlavān (Recke) sollte man eine harmonische Verbindung von Tugenden des Körpers und der Seele aufweisen. Die Höchstwerte des ritterlichen Ethos werden in der Person Ḥamzes perfekt dargestellt. Ein idealer Ritter wendet sich Andachtsübungen zu. Er ist bei Tag Held und Gottes Sklave bei Nacht. Er ist bereit, für seine Religion ins Feuer zu gehen und sich zu opfern (3/433-434). ${ }^{320}$ Immer, wenn Ḥamze ein Problem hat, betet er zu Gott. Hamze wird uns als schlechthin vorbildlich dargestellt. Er verrichtet das Gebet, bevor er auf das Schlachtfeld reitet (1/85/14). Aus dem $R H$ erfahren wir, dass Hamze die ganze Nacht mit Mehrnegār verbringt und frühmorgens das islamische Frühgebet verrichtet (1/53-54).

Mit der körperlichen Tüchtigkeit des Helden verbunden ist seine Wunderkraft. Ḥamze bekommt besondere Gaben von Gott. Als Schützling Gottes kann er die Angriffe mit zusätzlicher göttlicher Unterstützung zurückschlagen. Dies ist ein Beispiel für seinen Edelmut und seine Ideale, die von Gott unterstützt werden. Mit Hilfe von esm-e a'yam (dem großen Namens Gottes; 4/ 657) und bātel as-seḥr (der Zauberformel; 4/646) ${ }^{321}$ besiegt Hamze seine Feinde. Der Inhaber des esm-e a'zom siegt in allen Kämpfen, auch wenn sein Gegner unverwundbar ist und jeden Zauber vereiteln kann. So überwindet Hamze die stärksten Feinde und alle Gefahren (4/ 639).

Eine sehr wichtige Eigenschaft in epischen Werken ist die Schönheit des Helden. Adelige Schönheit transportiert höfische Werte, und Adel ist eine angeborene Qualität, die sich im äußeren Erscheinungsbild manifestiert: Als Ḥamze geboren wird, ist er schön wie die Sonne, und das Leuchten, das von ihm ausgeht, erhellt das Haus (1/13). Er hat ein grünes Muttermal

'l-Meḥğan gegen heidnische Fürsten, vor allem Qobād, den König von Hyāvarān. Siehe: Ethé, Neupersische Literatur, S. 212-368, hier S. 235.

${ }^{320}$ In der vorislamischen Zeit war die Feuerprobe bei Gerichtsanhörungen sehr wichtig. Die Feuerprobe galt als ein Mittel, um sich über die Wahrhaftigkeit eines Menschen Gewissheit zu verschaffen. In der vorislamischen Zeit wurde im Iran (wie vergleichbar im Mittelalter in Europa) die Feuer bzw. Schwefelprobe genutzt, um zu erfahren, ob ein Delinquent beim Verhör die Wahrheit gesagt hatte. Verbrannte er, hatte er gelogen. Verbrannte er nicht, war wahr, was er erzählt hatte. Das beste Beispiel dafür ist die Geschichte von Siyāvaš und dessen Feuerprobe. Siehe: Boyce, Mary: On Mithra. Lord of fire, aus dem Englischen ins Persische übersetzt. von 'Ali-Aṣgar Mirzā'i, in: Hasti 2, 4 Jahrgang, Nr. 14, Sommer Teherān 1382/2003, S. 89-97, hier S. 93; vgl. Ferdousi, Bd. 1, S. 304-305.

${ }^{321}$ Dehhodā, Bāṭel as-seḥr, in: Loğat-nāme, ḥarf-e. B-Bābak, Teherān 1336/1957, S. 443. 
in seinem Gesicht und eine hervorstehende Ader (1/62/20). ${ }^{322}$ Alle seine Nachkommen haben dasselbe Zeichen im Gesicht und sind dadurch immer zu erkennen.

Von besonderer Bedeutung ist auch die äußere Gestalt Ḥamzes. Er wird als außergewöhnlich kraftvoller Sportsmann beschrieben (5/1003), als sattelfester Ritter undausgezeichneter Jäger. Die äußere Schönheit eines Menschen ist vergänglich. Wenn der Glanz der äußeren Erscheinung verschwunden ist, und wenn dieser Körper in den falschen Kleidern steckt wie etwa bei Ḥamze, der nach 18 Jahren von Qāf in die Stadt Tanğe zurückkommt, in der Mehrnegār lebt, ist er nur schwer wiederzuerkennen. Ḥamze verkleidet seinen Körper, der das eigentliche Zentrum seiner adeligen Identität ist, ${ }^{323}$ und macht ihn unkenntlich. Überall dort, wo er sich auch zeigt, wird er zuerst nicht erkannt. Sogar seine Verlobte Mehrnegār ist nicht in der Lage ihren verkleideten Geliebten zu erkennen. Dieser Umstand, dass auch Mehrnegār ihn nicht sofort erkennt, verursacht eine Störung in der Beziehung des Paares, die aber überwunden werden kann. 'Amr ist zunächst der erste, der ihn wiedererkennt, und das nur, weil er die äußeren Erkennungszeichen der Geburtsmale ausmachen kann (1/183).

Die besonderen äußeren Merkmale, die einen Helden kennzeichnen, sind unauslöschlich ein Teil seiner Erscheinung. Dazu gehört auch die Stimme, an der Heroen indentifizierbar sind.

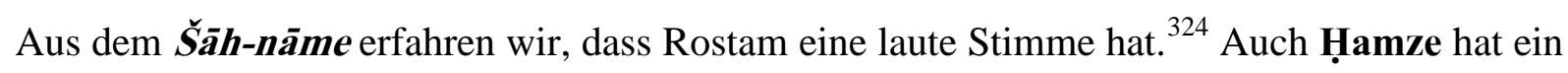
sehr lautes Organ. Am Ende seines Kampfes brüllt er: „Gott ist groß“ (1/88/2). Alle Gefährten Hamzes und seine Heere stecken Watte in ihre Ohren, um den Schrei nicht zu hören, und die Feinde fallen vor Schrecken zu Boden (5/1005). ${ }^{325}$

Ḥamze ist zugleich immer auch ein Verwandlungskünstler, der ausschließlich zweckrational und ohne Rücksicht auf heroische Werte neue soziale Identiäten annimmt. Es gelingt ihm dabei, seinen adeligen Stand zu verbergen, wobei er entweder mit Worten oder mit seinem ganzen Körper lügt. Eine Fülle von List- und Verkleidungsmotiven ist im $R H$ beschrieben. Ein Beispiel dafür ist Ḥamze, wie er bewusst die Evidenz des adeligen Körpers, bzw. „die metonymische Signifikanz der Schönheit ${ }^{\star 326}$ verbirgt und sich als wilder und tauber Mann präsentiert, um die Treue seiner Männer zu testen (2/240). Ḥamzes Helden spekulieren über die Identität dieses wilden Mannes. Es gibt einen großen Unterschied zwischen fürstlicher

\footnotetext{
${ }^{322}$ Geburtsmal ist oft gleichermaßen Zeichen edler Herkunft. Siehe: Wehse, Rainer: Erkennungszeichen, in: EM, Bd. 4, Göttingen 1984, Sp. 180-194, hier Sp. 192.

${ }^{323}$ Schulz, Schwieriges Erkennen. Personenidentifizierung in der mittelhochdeutschen Epik, Tübingen 2008 , S. 344.

${ }^{324}$ Ferdousi, Bd. 1, S. 204.

${ }^{325}$ Anonymus: $Q H$, Bd. 1, S. 141.

${ }^{326}$ Vgl. Hübner, Gert: Erzählform im höfischen Roman. Stuiden zur Fokalisierung im > Eneas〉, im Iwein> und im Tristan, Tübingen/Basel 2003 (Biblotheca Germanica 44), S. 385. Über Metonymie siehe: Birus, Hendrik:
} 
Erscheinung und niederem Stand. ${ }^{327}$ Hamzes Freund 'Amr ist der Kenner der adligen Zeichen und kann ihn aufgrund von seinem körperlichen Zeichen identifiziert.

Der König wird im Epos auch deshalb als passiv dargestellt, weil er durch seine bloße Existenz die Weltordnung, d.h. den Normalzustand, verkörpert. Dagegen ist der Held die Verkörperung des Ungewöhnlichen. König und Held versinnbildlichen die unterschiedlichen Erscheinungsformen menschlicher Existenz. So kann ein Held zwar König werden, erlebt aber dann keine Abenteuer mehr. Deswegen trägt Ḥamze niemals den offiziellen Königstitel, aber er lebt quasi wie ein König und sein Zeltpalast oder Wohnbereich spiegelt dessen Macht und Reichtum wider und veranschaulicht seine Funktion als Machthaber. Nach der mongolischen Eroberung verweist das Herrschafts- und Sozialgebilde „Hof“ allein auf neue Formen der Herrschaftsorganisation, und gleichermaßen auf die Ausbildung eines neuen Lebensstils, der im $R H$ beschrieben, gerechtfertigt und propagiert wird. Hamzes Hof ist nach mongolischen Traditionen und Prinzpien ausgerichtet. Er hat keine feste Burg oder Palast, sonderen ein tragbares Zelt das ihm als Palast dient. Ḥamze lässt sich einen prachtvollen Audienzsaal nach türkischem und mongolischem Vorbild errichten. Der Saal ist ein Zelt, das von 4000 Säulen getragen und mit unzähligen Stühlen ausgestattet ist. Jeder Held Ḥamzes hat in der Gefechtsformation bzw. in der Hofversammlung gegenüber Ḥamze prinzipiell eine bestimmte Position inne. Jedem von Ḥamzes Helden muss also grundsätzlich ein bestimmter Platz (Rang) zugeteilt werden. Im $R H$ sitzt Ḥamze in der Mitte und seine Helden werden nach dem Vorbild des Heeres angeordnet. Die Helden, die dem rechten Flügel angehören, sitzen im Saal auf der rechten Seite Hamzes und diejenigen, die dem linken Flügel angehören, sitzen auf seiner linken Seite.

Das $R H$ gibt uns Informationen von einer optimalen Versorgung und einem Unterhaltsystem des reisenden Herrschers und seines Hofes. Weiterhin gibt er einen Überblick über die Verwaltung und Organisation von einzelnen Ämten im Hamze Hof. Hamze macht seine Politik und Ansprüche durch Reisen in seinem Reich geltend. Er und sein Gefolge wurden während ihrer Reise verpflegt, versorgt und untergebracht. Von daher ist es nur natürlich, dass die verschiedenen Einsatzbereiche und Berufsbezeichnungen im $R H$ Erwähung finden. Dazu gehören: der amir-e šekār (der Jagdmeister; 3/426/11), der kešikči (der Leibwache; 4/576/27), der mir-āhor-bāši (der Pferdepflegemeister; 4/670/10), die parde-dārān (die Kammerdiener; 1/152/11), der șāḥeb ğam‘ān-e hazāne (der Schatzkämmerer des Hofes;

\footnotetext{
Metonymie, in: Reallexikon der deutschen Literaturwissenschaft, Bd. II, hrsg. von Harald Fricke, Berlin/New York 2000, S. 588-591.

${ }^{327}$ Hübner, S. 384.
} 
5/932/29), der šăter (der Bote; 4/694/21) und der yasāvul (persönlicher Adjutant am Hof; $1 / 124 / 22){ }^{328}$

Ḥamze besitzt auch negative Eigenschaften. Er hat den Drang, immer im Mittelpunkt einer großen Gesellschaft stehen zu wollen. Seine Brutalität im Krieg zeigt sich z.B. bei den gewaltsamen Bekehrungen oder dem Abschlachten ganzer Städte, in seiner Bereitschaft keine Gnade bei Verfehlungen walten zu lassen, in der Verstoßung seines Freundes auf Grund falscher Anschuldigungen oder in der Abweichung von den sexuellen Moralvorstellungen des Islams in seinem Verhalten (1/110-111). Er ist nicht an ein Eheversprechen gebunden Liebe und Treue nur zu einer einzigen Frau gilt für ihn nicht. Er geht sogar soweit seine eigene Ehefrau zu verstoßen. Gegenüber seinen Kindern ist er teilweise lieblos und grausam (2/200).

Weitere Punkte seiner ambivalenten Persönlichkeit sind Ḥamzes Verhältnis zum Alkohol und anderen Drogen, womit die ganze Bandbreite einer menschlichen Persönlichkeit widergespiegelt wird. Obwohl im Islam der Genuss von Wein streng verboten ist, scheint die Liebe zum Wein in den iranischen Erzählungen einen hohen Stellenwert zu haben. In der Entstehungszeit des $R H$ wurde dieses Verbot nur nachlässig von den Muslimen befolgt. Schuld daran war wohl der Umstand, dass zur damaligen Zeit insbesondere Mongolen und Türken viel Alkohol tranken. ${ }^{329}$ Żeiġam, ein jemenitischer Held, bietet Hamze vor Beginn des Wettbewerbs im Armdrücken Wein an, um seine Ausdauer zu testen, und dieser trinkt ihn bedenkenlos $(1 / 22)$.

Wenn nach militärischen Siegen oder erfolgreichen Jagdausflügen bazm (Feste) stattfinden, ist auch Alkohol mit dabei. Ein weiterer Aspekt einer solchen Festlichkeit ist die Anwesenheit von Tänzern, Tänzerinnen und Musikanten. Hierbei erweisen sich die Helden als die ausdauerndsten Trinker.

Der Genuß von Opium war zu jener Zeit zu Festlichkeiten, großen Feiern und anderen besonderen Gelegenheiten in der besseren Gesellschaft üblich. Als die freundliche Beziehung zwischen 'Amr und Ḥamze sich zu einer Feindschaft entwickelt, und dieser alle Helden Ḥamzes entführt, gerät Ḥamze in Panik vor 'Amr, und deswegen geht er mit Moqbel zu einer Insel namens Āhtam. Dort schickt Hamze Moqbel zum Markt, um nān (Brot), kabāb (gegrilltes Fleisch) und taryāk (Opium) zu kaufen (4/692).

Trotz seiner Perfektion als Kämpfer erscheint Ḥamze keinesfall ein Wissender zu sein. Er ist auf das Wissen und Talent seiner Kundschafter und Gefährten angewiesen.

\footnotetext{
${ }^{328}$ Qāżi Aḥmad Qomi: Holāṣat at-Tawārīh̆, Bd. 2, S. 1191-1197.

${ }^{329}$ Vgl. Spuler, Bertold: Geschichte der Mongolen, Zürich/Stuttgart 1968, S. 98.
} 


\subsubsection{Vergleich von Ḥamze mit Alexander und Šāh Esmāìl}

Alexander der Große war für höfische Ritter eine sehr wichtige Figur. Er lieferte die historische Vorlage für Hamzes Rolle als Welteroberer und Sendbote Gottes. ${ }^{330}$ Alexander übernahm die Herrschaft von seinem Vater, nachdem er für sein mazedonisches Vaterland gekämpft hatte. Er heiratete Roxana, die Tochter des Perserkönigs. ${ }^{331}$ Als historische Person und in seiner Funktion als Welteroberer wurde Alexander zum Idol und beeinflusste die islamische Literatur. In der islamischen Überlieferung wurde er vom König und Heerführer zum Propheten berufen.

Als Romanheld tritt er der Legende zufolge als großer Welteroberer auf, dessen Macht bis an die Grenzen der bekannten Welt reicht. Er gelangt an das Ende der Welt und kämpft dort mit Ungeheuern. Als er erfährt, dass sich irgendwo in der Nähe des Landes der Finsternis eine Quelle befindet, deren Wasser ewiges Leben verleihen soll, begibt er sich mit seinen Soldaten auf die gefahrvolle Reise ins Land der Finsternis.

In der Gestalt von Hamze und Alexander wird gleichermaßen, wenn auch Jahrhunderte auseinander, die Schöpfungsgeschichte eines großen Helden beschrieben. Die Sehnsucht nach einem starken Mann, der endlich Ordnung und Stabilität bringt, war nach den wirren Zeiten des mongolischen Angriffs sehr groß. So sahen die Erzähler sich gezwungen, solch einen großen Krieger zu erschaffen, damit jener alle islamischen Länder wieder vereint und später sogar die ganze Welt für den Islam gewinnt. Ḥamze löst in den Erzählungen nach und nach alle kollektiven und individuellen Probleme der Menschen. In dieser Funktion ist er der würdige Nachfolger Alexanders. Hamze wird vor allem als Kulturheld angesehen, in dem sich viele iranische Werte und Weltanschauungen wiederfinden.

In vielen Punkten ist Hamze mit Alexander dem Großen vergleichbar. Beide sind ursprünglich fremde Eroberer des Irans gewesen, und Ḥamze und Alexander haben große Sehnsucht nach Macht. ${ }^{332}$ Beide streben mithin den Status eines „Universalhelden“ an. Beide haben persische Prinzessinnen zur Frau genommen, und Ḥamze wird, ebenso wie Alexander, trotz seiner Fremdheit als islamischer, „transethnischer“ Held von der populären persischen Literatur als ihr zugehörig angesehen. ${ }^{333}$

\footnotetext{
${ }^{330}$ Bürgel, J. Christoph: Das Alexanderbuch. Iskandarname, übersetzt aus dem Persischen ins Deutsche, Nachw. und Anm. von J. Christoph Bürgel, Zürich 1991, S. 602-603.

331 Pfister, Friedrich: Der Alexanderroman. Eine Auswahl aus den verwandten Texten, Meisenheim am Glan 1978, S. 54.

${ }^{332}$ Vgl. Bürgel, J. Christoph: Krieg und Frieden im Alexanderepos Nizamis, in: The Problematics of Power. Eastern and Western Representations of Alexander the Great, Bern/Berlin/Frankfurt am Main/New York/Paris/Wien 1996, S. 91-108, hier S. 96.

${ }^{333}$ Heath, Peter: The Thirsty Sword. Sïrat 'Antar and Arabic Popular Epic, Salt Lake City 1996, S. 63; Yamanaka, Yuriko: From Evil Destroyer to Islamic Hero: The Transformation of Alexander the Great's Image in Iran, in: Annals of Japan Association for Middle Eastern Studies 8, 1993, S. 55-87.
} 
Es ist schwer vorstellbar, dass die Erzähler das Charakterporträt Ḥamzes historisch korrekt getroffen haben. Aber sie haben, wie noch gezeigt werden soll, typische Züge des ihnen wohlbekannten zeitgenössischen iranischen bzw. türkischen Rittermodells in dieses Bild übernommen. Ihnen zufolge erobert er verschiedene Länder nicht nur militärisch, sondern auch geistig, religiös und kulturell. Hamze zeigt dabei den eigenen Soldaten und seinen Feinden gegenüber große Sympathie.

Die folgende Übersicht vergleicht Ḥamze aus dem $R H$ mit der historischen Persönlichkeit aus dem Āram-ārā-ye Šāh Esmācil.

\begin{tabular}{|c|c|}
\hline Ḥamze & Šāh Esmācil \\
\hline Großer Freund der Jagd und vorzüglicher Reiter & Geschult in der Jagd \\
\hline $\begin{array}{l}\text { Den Schädel eines 'Efrit ließ er in Gold fassen } \\
\text { und benutzte ihn als Trinkgefäß }\end{array}$ & $\begin{array}{l}\text { Den Schädel des usbekischen Führers Šabāni } \\
\text { Hāan ließ er in Gold einfassen und benutzte ihn } \\
\text { als Trinkgefäß }\end{array}$ \\
\hline Vorkämpfer des Islams & Vorkämpfer der Schia \\
\hline Tüchtig in der Heeresführung & Großer Heerführer \\
\hline Seine Helden verbrannten die Gräber & $\begin{array}{l}\text { Unter Esmā'il wurden die Gräber der Feinde } \\
\text { berühmter Sunniten geschändet. Seine Feinde } \\
\text { wurden in Käfige gesperrt, zu Tode gequält, } \\
\text { gebraten und verspeist }\end{array}$ \\
\hline
\end{tabular}

Ḥamze ist das Vorbild der Krieger, besonders der Qizilbāš; er ist der große Kämpfer. Er besitzt durch die Gnadengabe Gottes Wunderkraft. Als Schützling Gottes kann er alle Angriffe zurückschlagen; er ist der Held der damaligen Zeit. Ḥamzes Figur wird durch die Erzähler weiterentwickelt, dem Geschmack der damaligen Zeit entsprechend. Deswegen waren seine Abenteuer bei den Türken im Iran, in Anatolien und im iranischen Aserbaidschan sehr beliebt.

Als die Schia unter den Šāh Esmā'il (1501-1524) zur offiziellen Staatsreligion wurde, bildete sich ein extremer schiitischer Glaube heraus, der sich im 16. und 17. Jahrhundert verbreitete und seinen politischen Einfluss ausdehnte. Seit der staatlich aufgezwungenen Konversion

\footnotetext{
${ }^{334}$ Im Roman sieht man einige Gemeinsamkeiten in der Darstellung Ḥamzes und Šāh Esmā̄il, z.B. die Verwendung des Schädels eines getöteten Gegners als Trinkschale. Nach Halm ist dieses eine alte Sitte der Steppenvölker gewesen. Siehe: Halm, Heinz: Die Schia, Darmstadt 1988, S. 104; Rumlu, Hasan-Beg: Aḥsan at-Tawārih̆, hrsg. von 'Abd al-Ḥosein Navā'i, Teherān 1357/1979, S. 161; vgl. Glassen, Erika: Krisenbewusstsein und Heilserwartung in der islamischen Welt zu Beginn der Neuzeit. Die islamische Welt zwischen Mittelalter und Neuzeit, in Festschrift für Hans Robert Roemer zum 65. Geburtstag, hrsg. von Ulrich Haarmann und Peter Bachmann, Beirut 1979, S. 167-179, hier S. 177.

335 Glassen, S. 175; Die Quellen erwähnen Hinrichtungen zahlreicher sunnitischer Persönlichkeiten (und Gräberschändungen) auf Befehl Šāh Esmā̄ils in Baġdād im Jahr 1507-8. Siehe: ad-Duri, Abd-al-'Aziz: Baghdād, in: $E I^{2}$, Vol. I, London/Leiden 1960, S. 894-908, hier S. 903.
} 
zum Schiismus unter den Șafaviden festigte sich der schiitische Glaube innerhalb der ethnisch (Türker, Araber, Kurden etc.) und religiösen (z.B. Sunniten, Christen, Zoroastrier) heterogenen iranischen Gesellschaft. Für die șafavidische Regierung, die als radikal schiitische Glaubenseifer bekannt war, waren die sunnitische Herrscher sowie das osmanische Reich und die Usbecken in Zentralasien ein Dorn im Auge. Die Bekämpfung des sunnitischen Machthabers, wurde für die Șafaviden als Voraussetzung für die Lösung aller Probleme in ihrer Gesellschaft, Staat und Politik angesehen. Für Šāh Esmā'il, der sich an der extremen Schia orientierte, war die antisunnitische Propaganda Kerngedanke seiner Idee. So mobilisierte er kollektiven Hass gegen Sunniten durch Erzähler und Romane wie RH. Das Werk ist daher einerseits symbolisch $\mathrm{zu}$ verstehen, aber andererseits bietet es den Herrschenden eine Art Nachschlagewerk für ihr eigenes Auftreten und ihren eigenen Regierungsstil.

Im Kontext der Kriege im 15. und 16. Jahrhundert und der damit einhergehenden Entstehung des ersten schiitischen Staates stellen solche Figuren wie Hamze eine besondere Herausforderung dar, diese im Sinne des muslimischen Glaubens nachvollziehbar zu machen. So entwickelten sich im Iran ausgeklügelte Legitmierungsstrategien, um die Rechtmäßigkeit von Gewalthandlungen zu rechtfertigen. Dies muss nicht immer direkt zu erkennen sein, sondern kann auch mehr indirekt fassbar werden.

\subsubsection{9 Ḥamzes Rückkehr nach Mekka}

Im früheren Erzählwerk über Hạzze, dem $Q H$, kehrt Ḥamze nach Mekka zurück, nachdem er alle Feinde besiegt und bekehrt und insbesondere das Zauberwerk des Zarathustra zerstört hat, und begegnet dort dem Propheten Moḥammad. ${ }^{336}$ Mit nur 71 Überlebenden kehrt Ḥamze nach Mekka zurück. Die Zahl 72 hat symbolische Bedeutung für die Schiiten und entspricht der Zahl von Hosein und seinen 71 Gefährten in Karbalā. ${ }^{337}$ Von hier an greift die Erzählung wieder auf historische Tatsachen zurück. Moḥammad floh aus Mekka nach Medina. Es kam zur Schlacht von Badr, in der das mehr als dreifach überlegene Heer der Mekkaner besiegt wurde, wobei sich Hamze und 'Ali die Hauptheldentaten teilten. Die Mekkaner rüsteten zu einem Vergeltungsschlag und trafen im Jahre 625 mit Moḥammad am Berg Uḥud bei Medina zusammen. In der für Moḥammad anfangs günstigen Schlacht, die aber dann fast in einer Niederlage endete, fand Ḥamze mit seinen Freunden Landehur, 'Amr

\footnotetext{
${ }^{336}$ Anonymus: $Q H$, Bd. 2, 525-538.

${ }^{337}$ Vaglieri, L. Veccia: Ḥusayn b. 'Alī b. Abī Ṭālib, in: Encyclopédie de l'Islam, Tome III, Leyden/Paris 1971, S. 607-615, hier S. 611. Im Islam kommt 72 als Zahl der muslimischen Sekten vor, von denen nur eine gerettet werden wird. Siehe: Schimmel, Annemarie: Die Zeichen Gottes. Die religiöse Welt des Islam, München 1995, S. 113.
} 
b. Macdi und Sacd den Heldentod. Hind, die Frau Tochter des bei Badr von Hamze erschlagenen 'Utba, rächte sich durch die Verstümmelung von Ḥamzes Leiche. Ḥamzes Frau, die Feenkönigin Asmā̄' und ihre Tochter Qoreiši, rächten sich dafür an Pur Hendi. Ḥamzes Leiche wird vom Propheten Moḥammad begraben. ${ }^{338}$

Im $R H$ dagegen lesen wir, dass Ḥamze nach 80 Jahren Kampf gegen die Götzenanbeter sein Reich aufteilt und sich auf den Weg nach Mekka begibt, um dem Propheten nahe zu sein (5/1052-1053). Die Verfasser des $R H$ schreckten offenbar davor zurück, ihn sterben zu lassen, da sie ihn so sehr verherrlichen.

${ }^{338}$ Anonymus: $Q H$, Bd. 2, S. 543-544. 


\subsubsection{Figurentypen im $R H$}

Die Entwicklung und der Wandel der Mentalität der Menschen sind mit ihrer politischen, religiösen und kulturellen Geschichte, die sich im Laufe der Jahrhunderte entwickelt hat, verbunden. Dies zeigt uns, dass sich die Menschen in epochentypischer Weise nach bewußten oder unbewußten Leitlinien Vorstellungen entwickeln, nach denen sie empfinden und nach denen sie handeln. „Insofern kann und soll die Beschäftigung mit dem Wandel der Mentalitäten der eigenen Geschichte, deren frühere Formen in uns oft das Gefühl des Fremden auslösen, uns sowohl das Denken, Empfinden und Handeln unserer Vorfahren verständlicher machen als auch das von Menschen unserer Umgebung, die aus anderen Kulturkreisen kommen. “339

Am Beispiel des $R H$ wird die Relevanz der Mentalitätsgeschichte der Iraner verdeutlich. Die Mentalität der Helden manifestiert sich in ihren Handlungen. Dieser Abschnitt konzentiert sich auf das Verhältnis von Konstanz und Wandel. In kurzer, prägnanter Form wird im $R H$ das historische und soziale Wissen des Volkes, bestimmte politische, religiöse, historische und kulturelle Ereignisse, die sich im kollektiven Gedächtnis gespeichert haben, dargestellt. Diese Darstellung soll untersucht werdn, um den Wandel der Vorstellungswelten, die jeweils historisches Sein auf intersubjektiver Ebene prägen, zu präsentieren.

Im $R H$ wird nicht nur die Geschichte der „großen Männer“ beschrieben sondern die Geschichte anderer sozialer Gruppen und Klassen, bis hin zur Geschichte des einfachen Volkes als oder Geschichte des „kleinen Mannes“.

Die fünf wichtigsten, am häufigsten vorkommenden Figurtypen im $R H$ sollen in den nachfolgenden Abschnitten analysierend betrachtet werden. Es handelt sich dabei um komplexe Idealtypen, die sich durch bestimmte Einzelmerkmale auszeichnen, die harmonisch miteinander verknüpft sind, d.h. jeder dieser Typen ist durch eine bestimmte Kombination von Merkmalen gekennzeichnet.

\subsubsection{König}

Es ist bemerkenswert, dass sich dem Betrachter trotz aller Veränderungen eine bemerkenswerte Kontinuität durch die rund zweieinhalbtausend Jahre selbstständiger iranischer Kulturgeschichte zeigt: Es erscheint also berechtigt, nach einigen Grundkoordinaten iranischer Königsideologie zu suchen. Dabei können die verschiedenen geschichtlichen Vorgänge und Akzentverschiebungen nicht detailliert betrachtet werden,

339 Dinzelbacher, Peter: (Hg.): Europäische Mentalitätsgeschichte. Hauptthemen in Einzeldarstellungen, Stuttgart 1993, S. IX. 
sondern es ist auf das zu achten, was die erwähnte Kontinuität ausmacht. Versucht man, sich in geraffter Form ein Bild der iranischen Königsideologie im allgemeinen und des weisen Šāh im Besonderen zu machen, erscheint es hilfreich und zweckmäßig, aus der Fülle der altiranischen Literatur einzelne Königsideologien herauszugreifen, da sie die wesentlichen Inhalte des Königsbildes in konzentrierter Form widerspiegeln. Die Quellen geben deutlich zu erkennen, dass der Perserkönig in vorislamischer Zeit als heiliges Wesen angesehen wurde. ${ }^{340}$ Er war das leibhaftige und lebende Abbild des Gottes, und aus diesem Grund übte er die alleinige Herrschaft aus. Er erscheint als allwissend und allmächtig, seine Entscheidungen hatten unbedingte und unbeschränkte Geltung. Die Macht dieses göttlichen Königs erstreckte sich über die Menschen wie auch über die Natur.

Die Stellung des Königs war sehr herausgehoben. In der mythischen Überlieferung wurden die Könige der Vorgeschichte bis zur Teilung der Erde unter den drei Söhnen Feriduns als "Könige der Welt" bezeichnet. Feridun anerkannte zu seinen Lebzeiten außer sich selbst

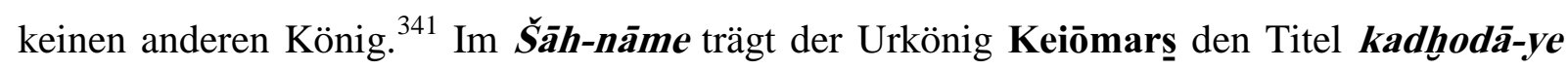
ğahān (Herrscher der Welt). ${ }^{342}$

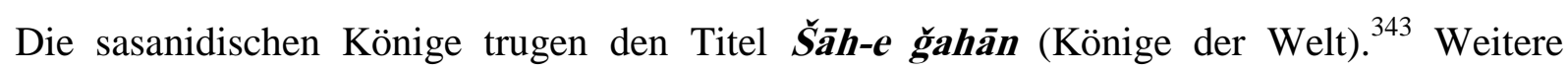
gebräuchliche Titel waren: piruzgar (den Sieg verleihend), horšid-făš (sonnenartig)) und horšid-čehr (von der Sonne abstammend). ${ }^{344}$ „Die alte Anschauung, dass der König der Vertreter von Sonne und Mond ist, findet sich auch während der Sassanidenzeit.“345

Der König Anōširvān war in der vorislamischen Geschichte des Irans eine prägende und herausragende Persönlichkeit in allen für einen Herrscher relevanten Bereichen. Er war einer der mächtigsten sasanidischen Könige. Er konnte durch besonnene, kluge und ausgleichende Herrschaftsausübung die inneren politischen Unruhen, die der Reformer Mazdak verursacht hatte, recht bald ersticken und eine Reform von der Spitze aus einleiten und umsetzen. ${ }^{346}$ Nach Erlangung der inneren Stabilität kämpfte er gegen die Türken und Römer. Er erwies sich dabei als großer Triumphator. ${ }^{347}$ Sein Hof war voller Gelehrter, Künstler und Wissenschaftler. Er liebte die Weisheit der Gelehrten und die wissenschaftlichen

\footnotetext{
${ }^{340}$ Vgl. Widengren, Geo: Die Religionen Irans, Stuttgart 1965, S. 153.

${ }^{341}$ Ferdousi, Bd. 1, S. 47.

${ }^{342}$ Ebd. Bd. 1, S. 11.

343 Ebd. Bd. 2, S. 1451.

344 Ebd. Bd. 2, S. 1491.

345 Widengren, Die Religionen Irans, S. 314.

346 Bal'ami, Abu 'Ali Moḥammad b. Moḥammad: Tārih̆-e Bal‘ami, hrsg. von Moḥammad-Ǧavād Maškur, Teherān 1337/1958, S. 151-156; vgl. Sāmi, 'Ali: Tamaddon-e sāsāni, Bd. 1, Širāz 1342/1963, S. 270-276.

${ }^{347}$ Bal'ami, S. 168.
} 


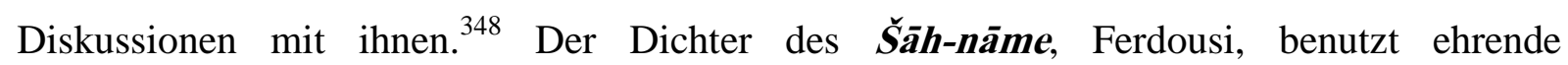
Bezeichnungen für Anōširvān wie z.B. ham šāh o ham pahlavān (sowohl König als auch

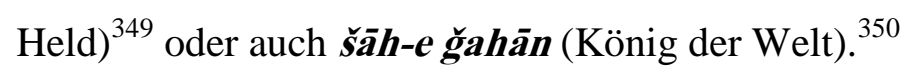

Im $R H$ treten drei bedeutsame sasanidische Könige auf nämlich Qobād, Hosrou Anōširvān und Hormoz.

Nach Anōširvāns Geburt gibt eine vertrocknete Quelle auf wunderbare Weise wieder Wasser. ${ }^{351}$ Nach dem Tod seines Vaters Qobād besteigt Anōširvān den Thron und ernennt Bozorgmehr und Bahtak zu Wesiren. Anōširvān wird im $R H$ meistens „König der sieben Länder“ genannt (1/22/24).

Trotz seines prunkvollen Bildes nach außen ist Anōširvān im $R H$ kein vollkommener Mensch, sondern er wird im Gegenteil als sehr schwach dargestellt: Die Araber vertreiben ihn schließlich aus seinem Land. Anōširvān und sein böser Wesir Baḩtak sind ausgesprochen große Feinde Gottes. Sie sind Feueranbeter, die dem siegreich vordringenden Islam starken Widerstand entgegensetzen.

Im $R H$ wird der Kampf des Helden Ḥamze gegen den persischen König Anōširvān mit großer Bedeutung aufgeladen. Auf Gottes Befehl hin geht Ḥamze zum Hof des Perserkönigs. Hier widmet er sich jahrelang der Aufgabe, den König für den Islam zu gewinnen, aber seine Versuche haben keinen Erfolg. Er stößt auf unzählige Hindernisse und hartnäckigen Widerstand. Bei den Ungläubigen fallen seine Worte auf keinen fruchtbaren Boden. Nach dem Tod der Prinzessin Mehrnegār und seines Sohnes Qobād kehrt Ḥamze nach Mekka zurück und will nicht mehr an der Macht bleiben. In dieser Situation versucht Anōširvān mit Hilfe anderer Könige, die Muslime wieder aus dem Iran zu vertreiben, bleibt jedoch ohne Erfolg.

$\mathrm{Zu}$ diesen Ereignissen existiert ein prominentes Vorbild: In der Geschichte von 'A ğib und Ǵarib aus den Erzählungen Tausendundeine Nacht lesen wir, dass Garib die Tochter des Perserkönigs Sabur aus der Gewalt eines Dämons befreit und sich in sie verliebt. Der König aber beschließt, mit Ġarib zu kämpfen. Er verliert letztendlich seine Herrschaft im Iran. ${ }^{352}$ Wenn wir diese Geschichte mit dem $R H$ vergleichen, dann sehen wir viele Parallelen.

\footnotetext{
${ }^{348}$ Ferdousi, Bd. 2, S. 1581-1588 u. 1479-1491; al-Mas'ūdī, Abū al-Ḥasan 'Ali b. al-Ḥusain: Kìtāb murū̌̆ addahab wa-ma'ādin al-ğawāhir, Bd. 1, hrsg. von Charles Barbier de Meynard, Bairut 1965 u. 1970, S. 310.

${ }^{349}$ Ferdousi, Bd. 2, S. 1451.

${ }^{350}$ Ebd.

${ }^{351}$ „In der Überlieferung unterschiedlicher Völker und Religionen wird die Entstehung von Quellen vielfach auf das Eingreifen von Göttern, Kulturheroen oder Heiligen zurückführt.“ Bei Buddhas und Jesus Geburt sprudelten Wasserquellen. Siehe: Wimmer, Erich: Quellwunder, in: EM, Bd. 11, Göttingen 2004, Sp. 108112, hier Sp. 108; 112.

${ }^{352}$ Littmann, Enno: Die Erzählungen aus den Tausendundein Nächte, Bd. IV, Wiesbaden 1953, S. 583-590.
} 


\subsubsection{Wesire}

Im vormodernen politischen System des Orients nehmen die Wesire (Minister) eine Schlüsselstellung ein. In den iranischen Erzählungen wie dem Dārāb-nāme und dem Firuzšăh-nāme begegnen wir immer einem guten und schlauen sowie einem bösen Minister. Anōširvān pflegt enge Verbindungen zu seinen Wesiren Bozorgmehr ${ }^{353}$ und Bahtak.

Bozorgmehr ist sowohl eine historische wie auch eine literarische Person, jedoch wissen wir vom historischen Bozorgmehr Buxtagan (Pahlavi Wuzurgmihr-Bōxtagān) ${ }^{354}$ mit dem Beinamen ḥakim (der Weise) nicht sehr viel: „Die Gestalt des Bozorgmehr ist rein legendär und es bestehen berechtigte Zweifel, ob überhaupt ein historischer Kern vorhanden ist. “ ${ }^{355}$ In verschiedenen historischen Werken lesen wir unterschiedliche Angaben zur Person Bozorgmehr. Aus dem Buch Tağārib al-umam fī al-ahbār mulūk al-'arab wa-'l-'ağam erfahren wir, dass König Hosrou Anōširvān eine Vorliebe für die Förderung von Wissenschaftlern hatte und sich gern mit diesen umgab, insbesondere mit seinem Wesir Bozorgmehr: So habe der König viele Gelehrte zu sich eingeladen, unter denen auch Bozorgmehr gewesen sei. Dieser solle dem König viele Weisheitssprüche übermittelt haben. Der König habe ihn verehrt und ihm die Erziehung seines Sohnes Hormozd überlassen. ${ }^{356}$ Nach Meinung des Historikers Mas'ūè̄ī war Bozorgmehr allerdings der Minister des Königs Hosrou Parviz. ${ }^{357}$ In den Überlieferungen wird Bozorgmehr als vollkommene und über alle Maßen weise und intelligente Persönlichkeit dargestellt. Der Historiker Abū Ḥanīfa adDīnawarī bezeichnete Bozorgmehr als den größten Gelehrten seiner Zeit. ${ }^{358}$ Bozorgmehr galt als der Verfasser eines Pand-namak (Weisheitssammlung) namens Āyātkar-e Vazurgmihr, eines praktischen Lehrtextes, der auf Veranlassung des Fürsten in der sasanidischen Zeit geschrieben wurde und als erzieherisches Werk für die höfischen Würdenträger konzipiert war. ${ }^{359}$ Al-Bāqillānī erwähnt, dass Bozorgmehr über die Weisheit geschrieben habe. ${ }^{360}$ Über sein Schicksal gibt es unterschiedliche Überlieferungen. Mas'‘ùdī schreibt:

${ }^{353}$ Der Name Bozorgmehr wird im Arabischen und Persischen in verschiedenen Formen überliefert z.B. Abuzarğmehr und Bozorğmehr. Siehe: Anonymus: Tağārib al-umam fī al-ahbār mulūk al-'arab wa-'l‘ağam, hrsg. von Reżā Anzābinežād u. Yaḥyā Kalāntari, Teherān 1373/1994, S. 301; Ferdousi verwendet die Schreibform Buzarğumehr. Siehe: Ferdousi, Bd. 2, S. 1475. Justi hingegen verwendet den Namen Bozorgmehr. Siehe: Justi, Ferdinand: Iranisches Namenbuch, Hildesheim 1963, S. 427.

${ }^{354}$ Hāleqi-Moṭlaq, Ğalāl: Bozorgmehr, in: EIr, Bd. IV, London/New York 1990, S. 427-429, hier S. 429.

355 Vgl. Christensen, Arthur Emanuel: La légende du sage Buzurgmihr, in: Acta Orientalia III/I (1930), S. 81128.

${ }^{356}$ Anonymus: Tağārib al-umam fĩ al-ahbār mulūk al-carab wa-'l-‘ağam, S. 301-315.

357 al-Mas'ū ${ }^{3} \overline{1}$, K⿳亠t冖āb murūğ ad-dahab wa-ma'ādin al-ğawāhir, Bd. 1, S. 318.

${ }^{358}$ Vgl. ad-Dīnawarī, Abū Ḥanīfa: Kitāb al-ahbār at-Ṭiwāl, hrsg. von Kračkovskij, Ignatijju, Leiden/Brill 1912, S. 73.

${ }^{359}$ Hāleqi-Moṭlaq, Bozorgmehr, S. 427.

360 al-Bāqillānī, Abū Bakr Moḥammad b. aṭ-Ṭaiyib: I'ğāz al-Qur’ān. Tahqīq Ạ̣mad Ṣaqr, Miṣr 1374h/1954, S. 32. 


\begin{abstract}
„Nach dreizehnjähriger Herrschaft aber beschuldigte ihn Parvis manichäischdualistischer Tendenzen, ließ ihn einsperren und schrieb ihm: Dein Wissen und dein Verstand haben dich nun so weit gebracht, dass du die Todesstrafe verdienst. Wenn ich ein glücklicheres Schicksal hätte, so schrieb ihm Bozorgmehr zurück, würde ich die Früchte meines Verstandes genießen. Da dies aber nicht der Fall ist, genieße ich jetzt die Früchte der Geduld. Und wenn ich auch viel Gutes verliere, so werde ich doch auch von vielem Schlechten befreit. Gereizt ließ Parvis ihn holen und befahl, ihm Nase und Mund zu zerschlagen.[...] wütend ließ Parvis Bozorgmehr [nach einer weiteren Diskussion] enthaupten. ‘6361
\end{abstract}

Dem iranischen Historiker Abu al-Fażl Beyhaqi (995-1077) zufolge wurde er noch in der Regierungszeit Hosrous hingerichtet. ${ }^{362}$ Andere verlegen seine Hinrichtung in die Regierungszeit von Hosrous Sohn Hormozd. ${ }^{363}$ Bei Ferdousi wird Bozorgmehr unter Hosrou eingekerkert, bis er schließlich seine Freiheit wiedererlangt. ${ }^{364}$

Laut Ferdousi stammt Bozorgmehr aus Merv. ${ }^{365}$ Er berichtet, dass der Perserkönig Anōširvān einen Traum hat, den die Traumdeuter nicht deuten können. Deshalb schickt Anōširvān Männer im ganzen Land aus, um jemanden zu finden, der den Traum deuten kann. In Merv sieht ein Kundschafter in einer Schule einen Priester, der die Kinder Zand und Avesta lehrt, unter ihnen Bozorgmehr. So wird Bozorgmehr an den Hof des Königs gebracht, um den Traum zu deuten. Hierdurch wird er zu einem der beliebtesten Höflinge Anōšsirvāns. ${ }^{366}$ Als Traumdeuter und Hellseher ist er äußerst erfolgreich und lernt die Kunst des Schachspiels, das von einem indischen Gesandten an den Hof des Königs Hosrou I. gebracht wird, an einem einzigen Tag bis zur Perfektion. Im Gegenzug lehrt er die Inder das nard (TricktrackSpiel). ${ }^{367}$

Dem $Q H$ zufolge sei Baḩt, Dāniyāls Sohn und Ǧāmāsbs Schwiegersohn, Bozorgmehrs Vater. ${ }^{368}$ Dagegen überliefert das $R H$, dass Bahts Vater der griechische Gelehrte Ğāmāsb sei. Im $R H$ lesen wir, dass Baht als einfacher Arbeiter am Bau eines Palastes und eines Gartens für Arqaš, den Wesir des Königs Qobād, in Madā'en tätig ist. Auf der Baustelle findet er einen Schatz und meldet dies dem Wesir. Dieser tötet Baht, um den ganzen Schatz für sich

\footnotetext{
${ }^{361}$ al-Mas'ūdī, Murūğ ạ

362 Beyhaqi, Abu al-Fażl Moḥammad b. Ḥosein: Tārih̆-e Beyhaqi, Bd. 1, hrsg. von Sacid Nafīsi, Teherān 1319/1940, S. 401-405.

${ }^{363}$ Ebd. S. 405.

${ }^{364}$ Ferdousi, Bd. 2, S. 1537-1538.

${ }^{365}$ Ebd. Bd. 2, S. 1476.

${ }^{366}$ Ebd. Bd. 2, S. 1475-1497.

${ }^{367}$ Ebd. Bd. 2, S. 1535-1542.

368 Anonymus: $Q H$, Bd. 1, S. 12; Grotzfeld, Sophia: Dāniyāl in der arabischen Legende, in: Festgabe H. Wehr, Wiesbaden 1969, S. 72-85.
} 
behalten zu können. Kurz darauf gebiert die Witwe des Ermordeten einen Sohn, den sie Bozorgmehr nennt. Im Alter von sieben Jahren schickt Bozorgmehrs Mutter ihn zur Schule. Er wird dort drei Jahre lang in allen wissenschaftlichen Fächern unterrichtet (1/6).

Eines Tages erbt der junge Bozorgmehr von seinem Großvater Ǧāmāsb ein magisches Buch, das durch einen Dschinn bewahrt wurde. Das Buch eröffnet den Zugang zu allen verborgenen Kenntnissen und Geheimnissen. ${ }^{369}$ Bozorgmehr liest und versteht das Buch. Er entschließt sich, in die Stadt Madā'en zu reisen. Dort arbeitet er als Gärtner im Garten des Wesirs. Dieser sieht ihn eines Tages, erkennt in ihm den Sohn des Ermordeten und weiß dadurch, dass dieser irgendwann Rache nehmen wird. Deshalb befiehlt er seinem Sklaven Bahtiyār, den Gärtner zu töten. Dieser tötet ihn jedoch nicht, sondern versteckt ihn.

Eines Nachts hat König Qobād einen Traum, den er jedoch am Morgen sofort vergisst. Bozorgmehr wird zum König gebracht und deutet den Traum. Die Deutung enthüllt Arqaš' Tat, der daraufhin zum Tode verurteilt wird. Der König ernennt nun Bozorgmehr zu seinem Ratgeber.

Bozorgmehr ist im $R H$ kein gewöhnlicher Mensch. Er hat eine besondere Beziehung zu Träumen, hat auch prospektive Träume und vielfach eine Begabung für Hellsehen. Man kann ihn als paranormal begabten Menschen bezeichnen, der mit dieser Begabung natürlich außerhalb der Norm steht. Er besitzt außerordentliches Wissen und eine ebenso außerordentliche Geisteskraft. ${ }^{370}$ Beim Anblick eines trächtigen Schafes berichtet er über das ungeborene Lamm (1/7). Überdies ist er Arzt (1/37). Zudem versteht er die Vogelsprache $(1 / 12)^{371}$ und beherrscht die Kunst der Wahrsagerei (1/144).

Im $R H$ ist Bozorgmehr Hamzes Ratgeber. Wegen seines Alters, seiner Weisheit und seiner Erfahrungen ist er in Gefahr ${ }^{372}$, gleichzeitig ist er aber auch wegen seiner sozialen und geistigen Stellung gefährdet ${ }^{373}$ und erleidet ein tragisches Schicksal. Nachdem Mazdak Ḥamze geblendet hat, fürchtet Bahtak, dass Bozorgmehr Ḥamze heilen werde. Deswegen überredet Bahtak den König, Bozorgmehr ebenfalls blenden zu lassen (2/218).

\footnotetext{
369 Ähnliches wird in der Geschichte von Bulūkiyā erwähnt. Dieser findet in den Schatzkammern seines Vaters in einem Kästchen ein Buch. Er liest das Buch und findet darin einen Bericht über Moḥammad. Siehe: Anonymus: Hezār o yek šab, Bd. 1, Nacht 482; Littmann, Enno: Die Erzählungen aus den Tausendundein Nächten, Bd. III, S. 772,

370 Die moderne Forschung gliedert die in den Texten überlieferten magischen und abergläubischen Vorstellungen und Praktiken nach drei Oberbegriffen auf: Divination (Wahrsagekunst), ars magica (kunstmässiges Zaubern oder zauberische Praktik) und Observation (Handlungen und Vorstellungen, die im Volk verwurzelt sind). Siehe: Daxelmüller, Christoph: Divination, in: EM, Bd. 3, Göttingen 1981, Sp. 718727.

${ }^{371}$ AaTh, (Motiv. Tiersprachenkundiger Mensch. 670, 670A, 671, 673).

${ }^{372}$ AaTh (Motiv. Altentötung. 981)

${ }^{373}$ Vgl. Horn, Katalin: Ratgeber, in: EM, Bd. 11, Göttingen 2004, Sp. 242-247.
} 
Im Unterschied zu Bozorgmehr ist Baḩtak der Bösewicht. Seine Rolle ist mit der Hāmāns, dem Minister des Pharaos, vergleichbar. ${ }^{374}$ Im Verlaufe der Erzählung wird er als arroganter, wenngleich begabter und fähiger Minister dargestellt, dem Machtmissbrauch nachgesagt wird. Er ist Feueranbeter, aber verehrt auch die altarabischen Gottheiten al-Lāt, al-Manāt sowie al-CUzzā (1/42). ${ }^{375}$ Überdies versteht er es, den König zu manipulieren.

Wegen all seiner bösen Taten erleidet Bahtak im $R H$ einen unschönen, plötzlichen Tod. 'Amr tötet Bahtak, bereitet aus dessen Fleisch ein Essen zu und bringt es zum Hof. Dort essen es Anōširvān und seine Höflinge. Bahtiyār, der Sohn Bahtaks, findet in seiner Schüssel einen Ring, der ursprünglich seinem Vater gehört hat. ${ }^{376}$ Dadurch wissen alle, dass das Essen aus dem Fleisch Bahgtaks zubereitet worden ist. Baḩtaks Sohn Bahtiyār tritt in den Dienst des Perserkönigs und wird später Zomorrods Berater. Er wird letztlich auch durch 'Amr ermordert.

Die Person Bahtaks wird gelegentlich das Opfer von 'Amrs komödiantisch-schräger Auffassung von Vergnügen. So schlägt 'Amr einmal den Höflingen ein Spiel vor, dessen Regeln besagen, dass niemand nach dem Essen aufstehen darf. Derjenige, der als erster aufsteht, muss 1.000 tumān bezahlen. 'Amr gibt Bahtak vor dem Essen eine Pille, die dieser einnimmt. Kurz danach bläht sich Bahgtaks Bauch auf, und er entleert sich in seine Hose. Danach schlägt 'Amr vor, dass die Anwesenden zu zweit tanzen sollen. Als alle getanzt haben und Bahtak an der Reihe ist, weigert er sich, zu tanzen. 'Amr nötigt ihn jedoch dazu. Als Bahtak tanzt, fällt der Kot aus seiner Hose, und wird von den Anwesenden verlacht (1/40-41; 4/711-712).

\subsubsection{Helden}

Bei grundlegenden sozialen und politischen Änderungen wächst die Nachfrage nach dem „großen Menschen“, der als historisches oder fiktives Idealbild die Gruppenidentität stärkt. ${ }^{377}$ Der Held verkörpert all das, was die Menschen zu sein wünschen, je nach dem Idealtypus der Zeit. Auf diesem Feld der Möglichkeiten bewegt sich der Held zwischen zwei Polen: „Er ist Gesetzgeber und Gesetzesbrecher.“378 Diese Definition umfasst also ganz unterschiedliche Heldentypen.

\footnotetext{
${ }^{374}$ Koran, Sure. 28,39; Abu Nașr Moḥammad b. Qațān: Serāğ al-qolub, hrsg. von Šerkat-e kānun-e nesbi-ye ketāb, Teherān o.J., S. 42.

375 Die drei in Mekka verehrten Hauptgottheiten. Siehe: Buhl, Frants: Al-Lāt, in: El, Bd. III, Leiden/Leipzig 1936, S. 20; ders.: Al-Manāt, in: El, Bd. III, Leiden/Leipzig 1936, S. 251; ders.: Al-'Uzzā, in: El, Bd. IV, Leiden/Leipzig 1934, S. 1157-1158.

376 Marzolph, TPV (Motiv. Erkennen: durch das Sehen des Ringes in der Speise. 403 (69), 408 (17), 425 B, 510A, 510B, 625A), S. 288.

${ }^{377}$ Vgl. Naumann, Michael: Strukturwandel des Heroismus, Königstein 1984, S. 67.

${ }^{378}$ Horn, Katalin: Held, Heldin, in: EM, Bd. 6, Göttingen 1990, Sp. 721-745, hier Sp. 722.
} 
Die Autoren des $R H$ haben bewusst ihre Helden gestaltet, indem sie gemeinsam aus mythologischen Figuren und Heldengestalten der früheren und aktuellen Geschichte ihre Heldenfiguren des Werkes erschaffen, die so national, kulturell und religiös Vorbildcharakter haben. Bei der Schilderung der Kämpfe stellt das $R H$ jeweils die individuellen Heldentaten in den Vordergrund, da diese in der iranischen Gesellschaft, besonders zur vorislamischen Zeit, idealisiert werden. Im $R H$ wird der Held im Wesentlichen durch seine Eigenschaften und seine „männlichen“ Qualitäten definiert. Die physische Stärke des Helden zeigt sich in seiner Kraft, ${ }^{379}$ Potenz und Bereitschaft zum Kampf, mit aller Brutalität und Grausamkeit, besonders im Zweikampf. „Der Held ist von der Natur mit einer ansehnlichen Gestalt und ausnehmender Leibesstärke begabt und durch tapfere Thaten hat er Ruhm erlangt und sich über den gemeinen Stand der Menschen erhoben.“380 Seine Tapferkeit, sein Mut (Mutprobe), die Bereitschaft zu Abenteuern und zu Reisen in fremde Länder, zu denen ihn bisweilen allein der Anblick des Bildes einer dort wohnenden Frau oder die Erzählung von ihrer Schönheit veranlassen, sind ein Teil seiner Motivation. ${ }^{381}$

Diese Helden kennen keine Angst und keine Furcht. Die Bereitschaft, den Glauben, das Vaterland und die Ehre zu verteidigen, ist als dominantes Element des iranischen Epos auch im $R H$ sehr präsent, besonders in den todbringenden Begegnungen der Helden mit ihren Feinden. Die Helden haben auf der Basis des bedenkenlosen Einsatzes von Gewalt ein großes Machtpotential erworben. Sie reagieren ihrerseits mit Zorn, so dass sie ihre Feinde erschlagen. Dieser Zorn verlangt nach Vergeltung. Gemäß der Logik des $R H$ ist das Streben nach Vergeltung jedoch mit dem Streben nach etwas Gutem gleichzusetzen, da die Vergeltung dort zur Gerechtigkeit gehört. Mithin ist der Gegenstand des Zornes das Gute. Wenn im $R H$ der Held in Zorn gerät, zeigt sich dies an der Veränderung seines Äußeren. Die Helden ,kochen vor Zorn“. Ihr Gesicht wird heiß, ihre Muskeln sind angespannt, die Welt verfärbt sich schwarz vor ihren Augen. Sie empfinden ihre Kraft und einen Impuls, zuzuschlagen, die Quelle des Zorns anzugreifen. Je stärker der Zorn ist, desto stärker und mit Energie aufgeladener fühlt sich der Mensch und desto größer ist das Bedürfnis nach körperlicher Aktion. Das Gefühl von körperlicher Stärke und Selbstbewusstsein lassen die Person großen Mut und Tapferkeit empfinden. Helden zeigen maximale Emotion und Einsatzbereitschaft, wenn es um eine gerechte Sache geht.

Die starken und tapferen Männer, deren Heldentaten im $R H$ als mustergültig dargestellt werden, tragen in der persischen Sprache jener Zeit die Bezeichnung Rostam-e dastān

\footnotetext{
${ }^{379}$ AaTh (Motiv. Kraftproben. 650 A).

${ }^{380}$ Naumann, S. 71.

${ }^{381}$ Vgl. Roth, Klaus: Mann, in: EM, Bd. 9, Göttingen 1999, Sp. 144-162.
} 
(Rostam, Sohn von Dastān; in dem Sinne, dass die so bezeichnete Person wie Rostam ist), pil-tan (Elefantenleib) und taham-tan (reckenhaft). ${ }^{382}$ Sie verkörpern in der iranischen Literatur einen bestimmten „Heldentypus”. Darunter versteht man einen Menschentyp, der es sich zur Gewohnheit gemacht hat, gegen wilde Tiere und verschiedene Naturerscheinungen zu kämpfen und der an seine körperliche Kraft glaubt. Die Helden sind alle tapfer, am Ruhm orientiert, stolz und sehr gesprächig, und sie besitzen übermenschliche Kraft. Oftmals wird erzählt, wie die Helden einen großen Löwen oder Drachen jagen. Ein wiederkehrendes Kennzeichen der Heroen zu Beginn ihrer Karriere ist es, ein menschliches Wesen aus der Gewalt eines Drachen oder Löwen zu befreien. Daher werden die Helden im $R H$ oft als eždehā șoulat (Drachengewalt; 5/837/15), šir-e žiyān (mit Löwenwut ausgestattet; 5/756/2), šir-e hašmludā (wie ein wütender Löwe; 5/921/21), šir-del (mit Löwenmutausgestattet; 5/950/25), šir-șoulat (Löwengewalt; 4/697/28), šir-gir (Löwenjäger; 5/791/20), dalirān-e šir-šekār (die Helden, die Löwenjäger sind“; 5/823/4) und als ğavānān-e eslām (Jugend des Islams; 5/863/16) bezeichnet. Diese Begriffe sind zugleich eine Bezeichnung für die Edlen und die Ritter-Elite. Beliebtes Anschauungsmittel um z.B. ihre Kraft und Stärke zum Ausdruck zu bringen, ist der Vergleich mit Tieren. Um ihre Tapferkeit und Schnelligkeit zu beschreiben, werden sie mit Leoparden, Tigern, Löwen und Panthern verglichen. ${ }^{383}$ Ihre Feinde werden mit dem Schakal (1/96/26) oder dem Hund (6/1065/11) verglichen. Für besonders negative Vergleiche wird das Schwein (5/855/10) benutzt.

Das $R H$ schildert die Einzelheiten der Kämpfe mit großer Vorliebe in allen Details der Kampfhandlungen. Kriegszüge, die die Erzählung anschaulicher machen, werden sehr lebendig geschildert. Die Berichte über Siege sind sehr ausführlich, aber die Niederlagen werden vollkommen verschwiegen. Die kühnen Helden des Islams (delirān-e eslām; 1/38/2) sollen nicht in unvorteilhaftem Licht erscheinen. Hier geht es nicht um Gut und Böse, sondern um Sieger und Besiegte.

Ein anderer Aspekt, den wir für wichtig erachten, ist das Erscheinungsbild der Helden. Der muslimische Held ist in jedem Augenblick des Geschehens ganz eins mit sich selbst und ganz eins für die anderen. Er präsentiert sich in dekorativem Gewand doch sein Glanz und seine Herrlichkeit unterscheiden sich von den glänzenden Rüstungen der Ungläubigen. Dementsprechend wird auch nicht nur sein Äußeres beschrieben, seine Rüstung und seine Waffen sondern auch die besondere Aura seines Auftrittes, mit der er den Ungläubigen

\footnotetext{
${ }^{382}$ Vgl. 'Adel, S. 217.

${ }^{383}$ Sindawī, Khalid: The role of the lion in miracles associated with shī'ite imāms, in: Der Islam, Bd. 84, Hefte 2, hrsg. von Conrad Lawrence, (2007), S. 356-390, hier S. 385.
} 
gegenübertritt. Die charismatische Ausstrahlung des Helden zeigt sich als Leuchtkraft seines schönen Körpers und der glänzenden Rüstung und dem Auftritt seines prächtigen Pferdes. Der Erzähler und sein Publikum interessierten sich sowohl für die heroische Taten der Helden als auch für Glanz und Glimmer der Kleidermode des Hofstaats, die den Rang der Helden wiederspiegeln. Unter den verschiedenen Arten der Kleidung im $R H$ ist das Kriegsgewand das wichtigste. Die Helden unterscheiden sich durch besondere Symbole auf der Rüstung von gewöhnlichen Soldaten. Die Untertanen erkennen die Helden anhand ihrer Kleidung, wobei z.B. die Kopfbedeckung mit der Feder des Simorg்s auf dem Helm wichtig ist.

Im $R H$ geht es nicht um die Darstellung persönlicher Erfahrung, sondern um idealtypische Figuren. Daraus erklärt sich die Vorliebe für Formeln und Klischees und tradierte Figuren. Die Helden und ihre Leistungen sollen damit für zukünftige Rezipienten nachvollziehbar sein. Diese sollen sie als herausragende Vertreter ihrer eigenen Gemeinschaft erkennen können.

Die dargestellten Heldenfiguren im $R H$ orientieren sich an der historischen Tatsache, dass im Laufe des 13. bis 16. Jahrhunderts die iranische Kultur geprägt und beeinflußt ist von der Kultur des türkisch-mogolischen Rittertums. Die Ritter waren ehemals Freie, die in den Dienst eines Königs bzw. Adligen traten und als Verwalter oder berittener Krieger ihrem Herrn dienten. Diese „Aufsteiger“ übernahmen oft die Lebensformen des iranischen Adels und mischten sie mit der nomadischen Lebensform bis sie sie schließlich zu einem oft starren Formenkult umwandelten. Äußerlich zeigte sich dies in Festen und Turnieren, in äußeren Symbolen den Wappen und ihrer Kleidung.

\subsubsection{4 'Ayyār}

Als ‘ayyārān (Vagabund) bezeichnet man eine Gruppe von meist jungen Männern, die sich untereinander als Brüder ausgeben und gemeinsame Interessen verfolgen.

Sozialgeschichtlich geht es um die Frage, ob es im alten Iran einen bestimmten Typus jüngerer Männer gab, die durch ihr Verhalten eine Art Elite bildeten. Im Mithraismus ist Mithra der Schirmherr der Freundschaftsbünde; es gab viele Anhänger dieser Religion, und deshalb ist zu vermuten, dass der Mithraismus einen großen Einfluss auf die Männerbünde hatte. Bahār ist der Meinung, dass die 'ayyārāan in der vorislamischen Zeit Verbindung zum Mithraismus hatten. ${ }^{384}$ Meistens fühlten sich Soldaten und Diebe mit dieser Religion verbunden. So hatte die kämpferische Ausprägung der Bünde eine Wurzel im altiranischen Kämpfertum. Im Buch Samak-e 'Ayyār lesen wir, dass die 'ayyārān auf Licht, Feuer, Meer

\footnotetext{
${ }^{384}$ Bahār, Mehrdād: Varzeš-e bāstāni-ye Irān va rišehā-ye tārihi-ye ān, in: Čistā, 1 Jahrgang, Nr. 2, Mehr Teherān 1360/1981, S. 148.
} 
und Gott geschworen haben. ${ }^{385}$ Dies ist auch ein Beleg dafür, dass die ‘ayyārāan mit dieser Religion verbunden waren.

In der Sasaniden-Ära gab es eine Klasse des persischen Adels, die sich von Kleinbauern und Kriegern unterschied, die āzādān. ${ }^{386}$ Ihr Ethos umfasste Begriffe wie Mut und die Bereitschaft, Wehrlosen zu helfen. Bis heute werden alle diese Werte als ğavānmardi verstanden.

Im islamischen Herrschaftsgebiet wurden die $\bar{a} z \bar{a} \boldsymbol{d} \bar{a} \boldsymbol{n}$, die militärischen Einheiten in der Sasanidenzeit, zu Kriegzeiten als Grenzposten, zu Friedenszeiten als Polizeitruppe in großen Städten wie Bașra und Kufa eingesetzt. ${ }^{387}$ Später wurden die āzādān ‘ayyār genannt, was vom altiranischen $\boldsymbol{y} \overline{\boldsymbol{a}} \boldsymbol{r}$ (Helfer, Gefolgsmann ${ }^{388}$ und Freund) ${ }^{389}$ abgeleitet wird. Das Ideal der ‘ayyārān war es ein mard (Mann) zu sein. In der iranischen Literatur wird das Wort mard häufig mit edlen Helden, tapferen Kriegern und mutigen Rittern in Zusammenhang gebracht. Dies war das Gegenstück zum unmännlichen bzw. unmenschlichen Menschen (nā-mard). Zum Moralkodex der Iraner gehörten u.a. Großzügigkeit, Freigebigkeit und Gastlichkeit. Die ‘ayyārānn lebten diese Ideale. Durch diese Haltung unterschieden sie sich von den übrigen Mitgliedern der Gesellschaft. Somit war im Iran der ‘ayyār ein bestimmter Sozialtypus, nicht einfach nur ein junger Mann, der sich, wie alle anderen auch, mehr oder weniger um die Erfüllung der sozialen Normen bemühte.

Die ‘yyārāan hatten einen gewissen Lebensstil und eine gewisse Haltung, die offenbar mit Jugendlichkeit, Gastlichkeit und Freigebigkeit in Verbindung gebracht wurde. ${ }^{390}$ In der islamischen Periode wird ğavānmardi (Edelmut) oft als Synonym für Begriffe wie ‘ayyāri und āzādegi verwendet, die alle im persischen Kontext stehen. ${ }^{391}$ So begegnen wir ğavānmardi als dem ritterlichen Ideal vieler persischer Kleinfürsten, die im 10. und 11.

385 al-Arrağāni, Farāmarz b. Hodādād: Samak-e 'Ayyār, hrsg. von Parviz Nātel-Hูānlari, Bd. 1, Teherān 1347/1968, S. 164.

${ }^{386}$ Diese Klasse von Adel wurde zum ersten Mal in Parther gebildet und wurde über in die Sassaniden Zustand, in dem sie eine Kraft, mit der gerechnet werden durchgeführt wurden. Sie begleiteten den König in den Kriegen und angezeigt großen Mut und Disziplin. Sie waren eindeutig die Vorläufer und Begründer der "Ritter" in der späteren iranischen Geschichte. Die āzādān/Ehrenbürger bewachten eifersüchtig ihren Status als Nachkommen der alten arischen Eroberer und Herrscher der Masse. Diese āzādān bildeten eine Vielzahl kleinerer Aristokratie der nachrangigen Administratoren, meist lebten auf ihre kleinen Stände und die Bereitstellung der Kavallerie Rückgrat der Sassaniden Armee. Renommiertesten unter ihnen waren die gepanzerten "Aswaran" die normalerweise entschied den Ausgang einer Schlacht. Siehe: Chaumont, M. L.: Āzād, in: Elr, Vol. III, London/New York 1989, S. 169-170, hier S. 169; Christensen, Arthur Emanuel: L'Iran sous les Sassanides, ins Persische übersetzt. von Rašid Yāsami, Teherān 1375/1996, S. 168.

387 Zākeri, Moḥsen: Sāsānid Soldiers in Early Muslim Society: The origins of 'ayyārān and futuwwa, Wiesbaden 1995, S. 112-128; Cahen, Claude: Tribes, Cities and Social Organization, in: CHI, Vol. 4, hrsg. von Richard Nelson Frye, Cambridge 1975, S. 305-328, hier S. 321.

388 Vgl. Widengren, Geo: Der Feudalismus im alten Iran. Männerbund, Gefolgswesen, Feudalismus in der iranischen Gesellschaft im Hinblick auf die indogermanischen Verhältnisse, Köln/Opladen 1969, S. 39.

${ }^{389}$ Vgl. Afšāri, Mehrān: Fotovvat nāmehā va rasāeel-e khāksāriyeh, Teherān 1382/2003, Vorrede S. 17.

${ }^{390}$ Bāstāni-Pārizi, Moḥammad-Ebrāhīm: Ya'qub-e leis , Teherān 1367/1988, S. 103-123. 
Jahrhundert auf iranischem Boden herrschten. Dieses Ideal wurde in den Schriften des Fürstenspiegels dieser Zeit mehrfach abgehandelt. Als Beispiel dafür sei hier das Qābusnāme des Ziyaridenfürsten Kei-Kāvus b. Eskandar genannt (verfasst 1082), in welchem im 44. und letzten Kapitel die ğavānmardibzw. fotovva abgehandelt werden.

„Das Prinzip der ğavānmardi beruht auf drei Dingen: erstens, daß du das, was du sagst, auch tust; zweitens, daß du in Wort und Tat die Wahrheit beachtest; drittens, daß du Geduld in deinen Handlungen übst. Denn alle Eigenschaften, die dem ğavānmardi zugerechnet werden, haben dies zur Grundlage [...]. Wisse, mein Sohn, daß der Edelste unter den 'ayyārān derjenige ist, der die verschiedenartigen Tugenden aufweist. Die erste ist die, daß er tapfer undmannhaft ist, daß er in jeder Angelegenheit ausdauernd ist; daß er zuverlässig und pünktlich im Einhalten seiner Versprechungen ist; daß er rein ist in sexueller Hinsicht; daß er ein reines Herz hat; daß er niemandes Schaden zu seinem eigenen Nutzen begehrt, sondern vielmehr seinen eigenen Nachteil im Interesse seiner Freunde in Kauf nimmt; daß er sich nicht an Hilflosen vergreift; daß er seine Hand nicht an Gefangene legt; daß er den Mittellosen Hilfe verschafft; daß er von den Unterdrückten das Böse abwehrt und sie verteidigt. ، 392

Die ‘yyāāān besaßen Großmut in jeder Lage und um jeden Preis, Freigebigkeit bis zum Exzess und Großmut im Gewähren von Schutz und im Kampfe, auch dem Feind gegenüber. Sie konnten als Einzelpersonen, aber auch als Vereinigungen auftreten. Solche Vereinigungen hatten meistens politische oder religiöse Ziele. In erster Linie sind diejenigen zu nennen, die sich dem ğghād widmeten. Besonders in den iranischen Grenzgebieten, in Sistān, Horasān und Transoxanien, wo der Boden für die Glaubenskämpfer vorbereitet war, waren die 'ayyārān sehr aktiv. ${ }^{393}$ In den wirren Zeiten vom 9. bis 12. Jahrhundert, als die Staatsgewalt der 'Abbasiden zerfiel, sorgten die 'ayyārān für Unruhe. Zeitweilig konnten sie lokal die Macht übernehmen. ${ }^{394}$ In Sistān sollen die 'ayyārān angeblich die einzige Macht der öffentlichen Ordnung gewesen sein. Im Laufe der Zeit haben im Iran viele Mitglieder der örtlichen Aristokratie mit den ‘ayyārān paktiert. So sind die ‘ayyārān an die Macht gekommen. Yáqub-e leis (gest. 879) sei als Prototyp des rechten ‘ayyār im Sinn der

\footnotetext{
${ }^{391}$ Hanaway, Jr., William L.: ‘Ayyār in Persian Sources, in: Elr, Vol. III, London/New York 1989, S. 161-163.

${ }^{392}$ 'Onșor al-Ma'āli Kei-Kāvus b. Eskandar b. Qābus b. Vošmgir: Das Qābūsnāme. Ein Denkmal persischer Lebensweisheit, übersetzt und erklärt. von Seifeddin Najmabadi in Verbindung mit Wolfgang Knauth, Wiesbaden 1988, S. $246 \mathrm{f}$.

${ }^{393}$ Vgl. Bāstāni-Pārizi, S. 61-67.

${ }^{394}$ Vgl. Taeschner, Franz: Futuwwa, eine gemeinschaftsbildende Idee im mittelalterlichen Orient und ihre verschiedenen Erscheinungsformen, in: Schweizerisches Archiv für Volkskunde Bd. 52, Heft 2/3 (1956), S. 122-158, hier S. 133.
} 
Tapferkeit und Freigebigkeit angesehen worden. ${ }^{395} \mathrm{Er}$ ist $\mathrm{zur}$ Legende und Leitfigur geworden. Später nahmen die ‘yyārāān oftmals am allgemeinen und umfassenden Widerstand der städtischen Gesellschaften gegen eine schlechte Staatsführung teil, und so waren sie ein wichtiges Druckmittel, um eine gerechte Staatsführung durchzusetzen. Manche klugen Machthaber nutzten ihr Potential, um eine Bedrohung von außerhalb abzuwenden.

Im arabischen Raum entstanden im 11. und 12. Jahrhundert die fotovva-Bünde (von arab. fatä/tapferer junger Mann) eine weitere, neue Form der politischen Gemeinschaft. Deren Kennzeichen waren Tapferkeit, Wahrhaftigkeit, Gastfreundschaft und Treue. ${ }^{396}$ Bei Baldick lesen wir: „Die Verwendung des Begriffs fotovva mit sozialen und organisatorischen Auswirkungen entstand außerhalb der arabischen Halbinsel, im Iraq und in Persien.“397 „Im 6./12. Jahrhundert versuchte Kalif Nāṣir, in der Lehre und in den bestehenden Organisationen der futuwwa die Grundlage für eine moralische und institutionelle Neuordnung des Kalifats zu finden.“' ${ }^{398}$ Diese Organisation stand den ‘ayyārāann sehr nahe und beeinflusste sie in jeder Hinsicht.

Ab dem 13. Jahrhundert, im Zuge der geänderten politischen Verhältnisse, veränderte sich der Begriff ‘ayyārān in seiner Bedeutung. Er wurde nicht mehr im positiven Sinne, sondern für negativ charakterisierte Personen gebraucht. Diese erschienen in der Poesie häufig als Trickdiebe. Später wurden sie nur noch als Lumpen und Strauchdiebe bezeichnet.

In der Șafavidenzeit erschienen die ‘ayyārāan als Menschen der untersten sozialen Schichten. Sie standen außerhalb der geregelten Berufe, waren Tagelöhner, Herumtreiber und Kriminelle, allerdings waren unter ihnen auch kleine Einzelhändler auf den Märkten zu finden. Sie lebten vor allem in den Vorstädten und waren aus der Sicht ihrer Gegner entlaufene Sträflinge, Diebe und Wegelagerer. In Zeiten einer starken Regierung sprach man kaum von ihnen, erhoben sich aber Missstände, so gerieten sie wieder ins Blickfeld der Menschen. Sie fielen in die reichen Stadtviertel ein, plünderten die Läden oder zwangen den reichen Leuten einen tariflich festgesetzten „Schutz“ auf, der diese vor Plünderungen bewahren sollte. Sie vergewaltigten auch Frauen und Kinder und störten das innere Leben der großen Ballungsräume in Eșfahān. ${ }^{399}$ Aus dem Buch Rostam al-ḥokamā erfahren wir, dass am Ende der Ṣafavidenzeit die Recken und die Kundschafter öffentlich mit Gewalt Frauen

\footnotetext{
395 Lambton, Ann Katharine Swynford: Islamic Society in Persia, in: Bulletin of the School of Oriental and African Studies, London 1954, S. 1-32, hier S. 18.

396 Taeschner, Futuwwa, eine gemeinschaftsbildende Idee im mittelalterlichen Orient und ihre verschiedenen Erscheinungsformen, hier S. 125.

${ }^{397}$ Baldick, Julian: The Iranian Origin of the futuwwa, in: IstitutoUniversitario Orientale di Napoli, 50 (1990), S. 345-361, hier S. 352-361.

398 Cahen, Claude: Zur Geschichte der städtischen Gesellschaft im islamischen Orient des Mittelalters, in: Saeculum 9 (1958), S. 59-76, hier S. 73.
} 
und junge Männer vergewaltigten; die Regierung war zu schwach, um etwas dagegen zu unternehmen. ${ }^{400}$

Der wichtigste Kundschafter im $R H$ ist 'Amr b. Umaiyya. Der historische Umaiyye az-Zamrī (arab. 'Amr b. Umaiyya aḍ-Ḍamrī), der im $R H$ auch 'Amr b. Umeiye Zahiri (1/36/28) und 'Amr b. Umeiye aż-Żamiri (1/155/16) genannt wird, war Zeitgenosse des Propheten Moḥammad. Er hat zusammen mit den mekkanischen Helden in den Schlachten von Badr und Uhud gegen den Propheten gekämpft. Danach wurde er zum Islam bekehrt. ${ }^{401}$ Der Prophet sandte ihn zu einem Nomadenstamm, um diese zu missionieren. ${ }^{402}$ Später sandte er ihn mit zwei Briefen zum Negus nach Abessinien, bei dem er seinen Auftrag auch erfolgreich ausführte. ${ }^{403}$ Er starb 677 unter dem Kalifen Mu'āwiya. ${ }^{404}$ Ibn al-Mi'mār schreibt, dass sein Grab in Homs sei. ${ }^{405}$

'Amr galt in der fotovvat-Tradition als Schutzheiliger der Bünde. In dieser Funktion wird er im Kitāb al-futuwwa von Ibn al-Mi'mār erwähnt. Ibn al-Mi'mār berichtet von der Gürtung der 17 ersten Bundesmitglieder durch 'Ali b. Abi Ṭāleb. ${ }^{406}$ Er schreibt, dass 'Ali zuerst die Lenden Salmān-e Fāresis, dann die 'Amr b. Umaiyya aḍ-Ḍamrīs gürtete. ${ }^{407} \mathrm{Er}$,gilt in den Futuwwabüchern als Kurier des Propheten; alle Kuriere (schuttāar) führen sich auf ihn zurück und haben ihn zum Schutzpatron. Nach Meinung der Verfasser der Abhandlung Resāle-ye šăterān war 'Amr b. Umaiyya aḍ-Ḍamrī der Vorstand der 'ayyārān. ${ }^{408}$ Es wurde berichtet, dass die sieben Propheten Adam, Šịs, Nuḥ, Heżr, Elyās, Ebrāhīm und Moḥammad ihn mit ihrem Blick erzogen hätten. ${ }^{409}$

Im $R H$ ist 'Amr ein großer Verteidiger des Islams gegen die Ungläubigen. Er ist ein furchtloser, tapferer Held, siegreich in all seinen Unternehmungen. Für Ḥamze ist 'Amr ein äußerst zuverlässiger, Vertrauen erweckender Freund. Als sich Ḥamze in Qāf befindet, beschützt 'Amr dessen Familie und bewahrt Mekka vor der Eroberung durch Anōširvān.

Er ist ein unermüdlicher Wanderer und Kenner von allerlei Kunstgriffen und Winkelzügen, der Festungen nicht durch Gewalt, sondern mit List erobert; zudem versteht er es beispiellos,

\footnotetext{
399 Afs̃āri, Mehrān: Fotovvat va aṣnāf, Teherān 1381/2002, S. 31.

${ }^{400}$ Eṣfahāni, Moḥammad-Hāšem: Rostam at-Tawārih̆, S. 109-110.

401 az-Ziriklī, al-Ä Iām, S. 73.

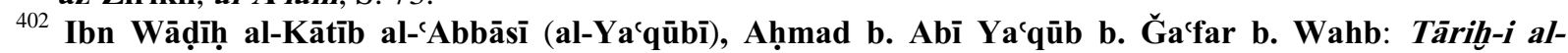
Ya'qübi, Teil 2, hrsg. von Martijn Theodoor Houtsma. Reprint of the ed. publ. in Leyden 1883: E. J. Brill 1969, S. 77.

${ }^{403}$ Ibn Hišām, Moḥammad 'Abd al-Malik: as-Sirra an-Nabawiyya, Bd. 1, Kairo 1375 h/1955, S. 224.

404 Thorning, S. 90.

405 Abī al-Makārim, 'Abdallāh Moḥammad (berühmt als Ibn al-Mi`mār al-bag̉dādī al-ḥanbalī): Kitāb alfutuwwa, hrsg. von Moṣțafā-Ǧawād, Baġdād 1958, S. 89; vgl. Thorning, S. 90.

${ }^{406}$ Ibn al-Mi'mār, S. 88; Taeschner, Zünfte und Bruderschaften im Islam, S. 439.

${ }^{407}$ Ibn al-Micmār, S. 88-89; Afšāri, Resāle-ye šāṭerān, in: Fotovvat va aṣnāf, S. 125.

${ }^{408}$ Afšāāri, Resāle-ye šāṭerān, S. 125.

${ }^{409}$ Ebd.
} 
Festgesellschaften zu unterhalten. Er besitzt einen unglaublichen Scharfsinn, unerhörte Schnelligkeit, überlegene Klugheit und ist ein unerhört begabter Dieb. ${ }^{410}$ Bereits in der Wiege stiehlt 'Amr Ringe, Armbänder und andere Juwelen (1/15). Er gerät in seltsame Zustände, z.B. einen todesähnlichen Schlaf. Er ist ein kluger Taktiker, Meister der Verstellungskunst, von großer Menschenkenntnis und Sprachbegabung. Auf der Wallfahrt zu der Grabstätte von Adam auf Ceylon erlernt er 72 Sprachen. ${ }^{411}$ 'Amr ist ein außergewöhnlicher Sänger, Musiker (4/713) und Krieger (4/628). 'Amr erscheint, wenn sein Name dreimal gerufen wird. ${ }^{412}$ Sein Bart beweist seine edle Abstammung. ${ }^{413}$ Dem entspricht es, dass 'Amr besiegte Feinde demütigt, indem er ihnen die Bärte abrasiert. Er kann eine Strecke, für die andere vierzig Tage benötigen, in wenigen Stunden zu Fuß zurücklegen (1/190). Er beherrscht den Ringkampf (4/693), hat jedoch Angst vor dem Meer und der Seefahrt (1/68) sowie vor Hexen (4/643). Obwohl er sehr reich ist und eine eigene Schatzkammer besitzt, ist er habgierig und sucht fortwährend nach Geld (4/604).

Die Kundschafter werden in der Regel als äußerlich hässliche Menschen beschrieben. ${ }^{414}$ 'Amrs Körper ist sehr ungleich proportioniert. Sein Oberkörper misst eine, sein Unterleib sechs Ellen. Sein Kopf ist so klein wie eine Nuss, sein Hals so dünn wie die Faser eines Palmblattes. Seine Augen sind so klein wie ein Korn Kümmel aus Kerman und seine Nase ähnelt einer Gurke (2/315).

Aus dem $R H$ ist zu ersehen, dass die ‘yyārān eine Organisation bilden. Da sich die Mitglieder von der Familie getrennt haben, leben sie gemeinsam mit anderen ‘ayyārān zusammen in einem Haus. ${ }^{415}$ Sie nennen ihren Versammlungsort yatim-hāne (Waisenhaus; 1/88/9). Das Oberhaupt der Kundschafter hat einen halife (Vertreter; 2/205/27). An der Spitze der 'ayyārān steht der sarhang(Vorsitzende).

Um die Feinde zu vernichten oder zu besiegen, haben die ‘ayyārān verschiedene Methoden. Meist verändern sie mit Hilfe einer Verkleidung ihr Aussehen und verwandeln sich in eine andere Persönlichkeit. So verkleidet sich 'Amr als Kahlköpfiger (1/48/30), als alter gelähmter Mann (1/94/15), als mollāa(1/94/20), als saqqāa (Wasserträger; 1/19) oder als Priester (3/399).

\footnotetext{
${ }^{410}$ AaTh (Motiv. Meisterdieb. 1525).

${ }^{411}$ Wie die schiitischen Imāme kennt er jede Sprache, und sei es die Sprache der Vögel oder sonstiger Lebewesen. Siehe: Gramlich, Richard: Die Wunder der Freunde Gottes, Wiesbaden 1978, S. 164.

${ }^{412}$ Diese Eigenschaft gehört zum Propheten Heżr. Siehe: Franke, Patrick: Begegnung mit Khidr, Beirut 2000, S. 37.

${ }^{413}$ Den iranischen Königen stand das Tragen längerer Bärte zu. Aber es entsprach generell der persischen Sitte, das Barthaar lang zu tragen. Siehe: Abka'i-Khavari, Manijeh: Das Bild des Königs in der Sassanidenzeit, Hildesheim/Zürich/New York 2000, S. 55.

${ }^{414}$ Bausani, Alessandro: An Islamic Echo of the „Trickster”: The 'ayyārs of Indo-Persian and Malay Romances, in: Gururājamanjarikā: Studi in Onore di Giuseppe Tucci, 2, Istituto Universitario Orientale, Naples 1974, S. 457-467, hier S. 457.

415 al-Arrağāni, Bd. 1, S. 43.
} 
Weiterhin benutzen die ‘yyārāan Betäubungsmittel. Diese werden entweder mit Wein vermischt oder Speisen beigefügt. Wenn ein Mensch daraufhin einen trockenen Hals bekommt oder absurd zu reden beginnt, bedeutet dies, dass das Betäubungsmittel wirkt. ${ }^{416}$ Es gibt auch eine Apparatur namens šabpare-ye ‘ayyāri (3/521/14). Mit seiner Hilfe kann man Menschen bewusstlos machen. Diese Apparatur ähnelt einem Ballon. Man befüllt sie mit dem Betäubungsmittel, verbindet sie mit einem Schlauch und schiebt diesen durch eine Spalte in ein Zelt. Weitere Variationen sind denkbar; so kann man auch mit Hilfe der Wärme einer Kerze langsam das Betäubungsmittel verbrennen und die Menschen durch die sich entwickelnden Gase bewusstlos machen (4/692). ${ }^{417}$ Um die Wirkung des Betäubungsmittels zu beseitigen, benutzt man ein rouganan (Öl) namens rouġan-e banaf̌̃e bādām. Dieses Öl besteht aus Mandel- und Veilchenöl. ${ }^{418}$

Im $R H$ spielen die 'ayyārān vor allem eine negative Rolle. Ihre Funktion ist die Mischung aus Kundschafter und Gaukler. ${ }^{419}$

\subsubsection{Frauen}

Im $R H$ werden zwei unterschiedliche Typen von Frauen dargestellt. Sie werden entweder mit positiven Attributen wie unbedingte Solidarität und Kampfbereitschaft für Mann und Familie dargestellt, oder sie verkörpern hinterlistige auf Verrat und Mord bedachte Frauen, die nur den eigenen Vorteil im Auge haben. Die Frauen entstammen unterschiedlichen gesellschaftlichen Schichten, sind Königinnen, Kriegerprinzessinnen, Kundschafterinnen, Prostituierte und Sklavinnen, jedoch werden keine Frauen aus dem einfachen Volk beschrieben.

\subsection{Frauen der Oberschicht}

Die Frauen aus der Oberschicht haben im $R H$ keineswegs nur eine passive Rolle, sondern sie sind sehr aktiv. Sie kämpfen nicht wegen des Vaterlandes, sondern wegen der Ehre, der Liebe und zum Schutz ihrer Familien. Die im $R H$ enthaltenen Berichte über kämpfende Frauen, die stets als Männer verkleidet auftreten, gehen auf die aus der Antike bekannten Amazonen zurück, die als wild und grausam galten. Unter den in der Art von Amazonen im $R H$ dargestellten Frauen sind die bekanntesten 'Ādi Bānu, Gordiye, Mahin Bānu und Horšid-e tāğ-bah̆š.

\footnotetext{
${ }^{416}$ Maḥ̆ub, Ravešhā-ye 'ayyāri va nofuz-e kār va kerdār-e cayyārān dar Šāh-nāme, in: Adabiyāt-e ‘ammiyāne-ye Irān, Bd. 2, S. 969-1014, hier S. 999.

${ }^{417}$ Ebd. S. 1001.

${ }^{418}$ Ebd. S. 1007.

${ }^{419}$ Gaillard, Marina: Le Livre de Samak-e Ayyār, Paris 1987, S. 27-42.
} 
Horšid-e tāğ-bahš ist von der Liebe zu ihrer Mutter Giti-afruz erfüllt (5/880). Als Irağ um Giti-afruz wirbt, fürchtet Hुoršid um deren guten Ruf. Dass Irağ der Sohn von Giti-afruz und somit der Bruder von Horšid ist, weiß keiner der Beteiligten. Horšid erklärt sich bereit, gegen Irağ zu kämpfen, um den Ruf ihrer Mutter zu verteidigen. Sie zieht eine Rüstung an und verschleiert ihr Gesicht. Beim Kampf kommt ihr Haar zum Vorschein, so dass Irağ erkennt, dass sein Gegner eine Frau ist (5/882-883). Diese Geschichte ähnelt der des Kampfes zwischen Gordāfarid, der Tochter Guždahams, und Rostams Sohn Sohrāb. ${ }^{420}$

Es fällt auf, dass im $R H$ Kriegerinnen stets unverheiratet sind und ihr Kriegerdasein mit der Heirat aufgeben. Hingegen wird in Erzählungen, die in vorislamischer Zeit spielen, wie etwa im Samak-e 'Ayyār, berichtet, dass Mardān-dohnt, die Frau des Farroḩ-ruz, auch nach ihrer Heirat Kriegerin blieb. ${ }^{421}$

Wir hören von Prinzessinnen, die ihre Heimat und Familie aus Liebe verlassen. Als wichtiges Beispiel sei hier Mehrnegār aufgeführt, die wegen Ḥamze auf beides verzichtet. Achtzehn Jahre lang zieht sie in verschiedenen Ländern umher und kämpft gegen die Feinde ihres Mannes.

$\mathrm{Zu}$ den Frauen der Oberschichtgehören auch üblicherweise Hofdamen und Ammen. Die Hofdamen repräsentieren oft ein unterhaltendes Element und treten als Vermittlerinnen der Interessen ihrer Herrinnen auf. Die jüngeren Hofdamen dienen den Prinzessinnen als Gefährtinnen. Ihnen können die Prinzessinnen Geheimnisse aller Art anvertrauen oder sie um Hilfe fragen. Sie können fremden Männern Zugang zu den Prinzessinnen verschaffen. Sie bleiben immer am Hof der Prinzessinnen und unterhalten sie. Das beste Beispiel dafür sind die Gefährtinnen von Mehrnegār, die mit ihr im Palast wohnen und sie mit Tanz, Musik und Spiel unterhalten (1/40-60).

Zum Hof gehörten die Ammen (pers. dãye), die in der besseren Gesellschaft eine sehr wichtige Stellung innerhalb der Familie hatten. Sie versorgten nicht nur die Säuglinge, sondern dienten auch als Erzieherinnen der älteren Kinder. Bis in die jüngste Vergangenheit hinein hatte die dāye in den Familien des Adels und des Großbürgertums einen angesehenen Platz und eine hohe Position.

Aus dem $\check{\boldsymbol{S}} \overline{\boldsymbol{a}} \boldsymbol{h}$-nāme erfahren wir, dass Rostam die Milch von zehn Ammen trank, um satt zu werden. ${ }^{422}$ In der iranischen Mythologie wird die Stelle der Nährmutter auch von Tieren

\footnotetext{
${ }^{420}$ Vgl. Ferdousi, Bd. 1, S. 252-253.

${ }^{421}$ al-Arrağāni, Bd. 5, S. 219.

${ }^{422}$ Vgl. Ferdousi, Bd. 1, S. 141.
} 
übernommen. Im Šāh-nāme wird Feridun drei Jahre lang von der Milch einer Kuh namens Barmāye ernährt, bis die Kuh von Żaḥḥāk getötet wird. ${ }^{423}$

Oft vermittelt die Amme zwischen dem Helden und den Frauen. Sie ist eine Meisterin aller Listen und der Künste der Liebe. Je nach Situation kann sie freundlich und hilfreich oder aber gefährlich sein. Aus dem Garšāsh-nāme erfahren wir, dass Gurang Šāhs Tochter eine Amme hat, die aus Kābul stammt. Sie soll afsun (Zauber) bzw. neyrang (Zauberei) betrieben haben. ${ }^{424}$ Aus dem Samak-e 'Ayyār kennen wir Mahparis Amme Šervāne, die eine gefährliche Hexe ist. ${ }^{425}$

Generell gelten die Ammen als gefährlich, weil man ihnen die Fähigkeit nachsagt, Böses tun zu können. Im $R H$ sind die Ammen eine beliebte Zielscheibe für Beleidigungen. Sie werden als alte, häßliche, zänkische und hinterhältige Frauen dargestellt. Sie werden von den Männern verhöhnt, offen beleidigt und zurückgestoßen. Besonders auffällig ist, dass die Ammen als alte Frauen noch gesteigertes Interesse am Intimverkehr haben. Ihre unangenehme physische Erscheinung wird dazu noch mit negativen moralischen Attributen beschrieben.

Im $R H$ vertraut Maryam-Nāhid als Mädchen ihrer Amme an, dass sie sich in Ḥamze verliebt habe. Zuerst warnt die Amme sie und sagt, ihr Vater und ihr Bruder würden sie töten, wenn sie davon erführen. Maryam-Nāhid bringt ihre Amme dazu, ihr zu helfen, indem sie ihr ein Parfümsäckchen schenkt. Daraufhin verrät die Amme der Prinzessin sogar, dass sie solche Dinge in der Vergangenheit häufiger unternommen habe (1/111).

\subsection{Frauen der niederen Schichten}

Eine tiefe vertikale Spaltung kennzeichnet die Welt des $R H$. Oberhalb der Trennungslinie finden wir die Adligen, in deren Händen der meiste Besitz und die gesamte Macht liegen, und darunter die niederen Schichten. Diese spielen eine eher untergeordnete Rolle im $R H$, wenn überhaupt werden nur Hexen, Prostituierte oder Sklavinnen, Sängerinnen und Tänzerinnen oder Kundschafterinnen erwähnt.

\section{Hexen}

Nach verbreiteter frühiranischer Auffassung galten Frauen als besonders gefährdet bzw. ansprechbar für die negativen Seiten von $\check{g} \bar{a} d \boldsymbol{u}$ (Magie). Diese generelle Ansicht ist auf ein dämonisches und magisches Verständnis weiblicher Sexualität zurückzuführen, das in enger Verbindung zum Unzuchts-Vorwurf steht, wie er beispielsweise von folgendem den Weisen

\footnotetext{
${ }^{423}$ Ebd. Bd. 1, S. 31.

${ }^{424}$ Asadi-Ṭusi: Garšāsb-nāme, hrsg. von ḤabibYag̀mā’i, Teherān 1354/1975, S. 22.

425 al-Arrağāni, Bd. 1, S. 23.
} 
zugeschriebenen Ausspruch zusammengefasst wird: „Prostitution und Hexerei vernichten alles." ${ }^{426}$

Im Koran wird ebenfalls berichtet, dass Zauberei unter den Menschen eine große Rolle spiele, wie z.B. unter den Israeliten in der Zeit von Moses. Nach islamischer Vorstellung tritt die Magie nur bei Ungläubigen, Ketzern und lasterhaften Menschen in Erscheinung. Der Prototyp des Zauberers ist König Namrud. Der Teufel erscheint diesem in Gestalt eines alten Mannes. Er gibt vor, dass Zauberei und Wahrsagekunst machtvoller seien als die Sternkunde, und lehrt ihn beides. Zuletzt redet er ihm ein, dass ein König seiner Größe unbedingt eines eigenen, neuen Götzen bedürfe. ${ }^{427}$

Die muslimischen Rechtsgelehrten sind der Meinung, dass die Herstellung von Amuletten mit

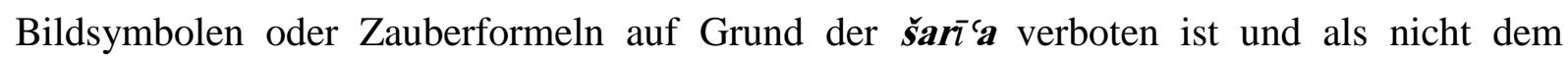
Glauben entsprechende Tat betrachtet werden müsse. „Nach der aš-šarī'a müssen die Zauberer getötet werden, wenn ihre Tätigkeit den Muslimen schadet.““428 Kontrastierend zu diesen Reglementierungen findet sich jedoch eine rege Praxis von sehr (Zauberei) in der islamischen Welt, insbesondere im Kontext eines Volksaberglaubens.

Die Figur der Hexen in den iranischen Sagen ist ein Mittel für die einfachen Menschen zur Erklärung der Welt. Was diese nämlich von ihrer Umwelt wahrnehmen und nicht rational verstehen, kann für sie durch das Wirken von Hexen verständlich und erklärbar werden. Die Hexen bedienen sich verschiedener Beschwörungsformeln und Talismane, um ihren Feinden allerhand Schaden zuzufügen. Die vier Elementarkräfte Erde, Wasser, Feuer und Luft sind die wichtigen Instrumente ihrer Zauberei. Durch magische Handlungenversucht die Hexe, die Natur zu beeinflussen, wie etwa Regen, Schnee und Wind herbeizurufen. Mit Hilfe des Regensteins sollte es möglich sein, das Wetter vorherzusagen und $\mathrm{zu}$ beeinflussen. Der Regenstein konnte verschieden gefärbt sein und wurde in Pferde- oder Rindermägen gefunden. $^{429}$

Auch bei anderen Völkern verbreitete sich der Glaube an den Regenstein. Nach Virolleaud hat diese Art von Magie ihre Wurzeln im Gilgameschepos. ${ }^{430}$

Mostoufi Qazwini berichtet: Qāżi Bahā' ad-Din Sacid aus Ardabil habe, dem Buch Tārih̆e Maǵreb zufolge, dem Verfasser von einem großen Stein außerhalb der Stadt erzählt, der in

\footnotetext{
${ }^{426}$ Vgl. Gignoux, Philippe: Le livre d'Ardâ Virâz, ins Persische übrtsetzt und bearbeitet. von Žāle Āmuzegār, Teherān 1372/1993, S. 87.

427 Vgl. Schützinger, Heinrich: Ursprung und Entwicklung der arabischen Abraham-Nimrod-Legende, Bonn 1961, S. 69-70.

${ }^{428}$ Butorābi, Hadiğe: Seḥr va ğādu, in: Dā’irat al-ma‘̄ărif-e tašayyo ‘ Bd. 9, Teherān 1381/2002, S. 116-118.

${ }^{429}$ Ebd. S. 41.

${ }^{430}$ Vgl. Virolleaud, Charles: Le Roman iranien de l'Emir Hamza, in: Académie des Inscriptions \& BellesLetters. Comptes rendus des séances (1948), S. 224-234, hier S. 228.
} 
Dürreperioden herbeigebracht worden sei, um den Regen herbeizurufen. ${ }^{431}$ Ebenso herrschte zu seiner Zeit im südpersischen Kermān der Aberglaube, dass durch Reiben des Steines, es am gewünschten Ort regnen werde. ${ }^{432}$ Die Iraner kannten diesen Stein unter der Bezeichnung sang-e yada. $^{433}$

Im Šāh-nāme wird diese magische Handlung vor allem zu Verteidigungszwecken verwendet. $^{434}$

Die Hexen im $R H$ als außerhalb der üblichen Normen stehende Menschen, können mit Hilfe der Techniken des manipulativen Umganges mit der Natur beeinflussen. Sie sind als privilegierte Menschen mit besonderer Begabung sowie auffälligen Erscheinung und Eigenschaften, die ihnen besondere Persönlichkeit verleiht. Im Gegensatz zu normalen Menschen ihrer Gesellschaft, gehen sie nicht den gewöhnlich alltäglichen Weg. Sie sind oft isoliert, sondern sich für Wochen und Monate ab. Das $R H$ berichtet von zahlreichen übernatürlichen Ereignissen, die oft von Hexen verursacht werden. Dort können die Hexen den Helden durch eine Zauberformel oder durch herbeibeschworenen Regen schaden. Eine andere Form des Regenzaubers wendet die Hexe A'rāa an. Auf dem Gipfel eines Berges füllt sie einen Waschzuber mit Wasser und streut Mehl hinein, und augenblicklich gibt es Schnee und Regen (5/768). Diese Form von Magie wird im persischen Sprachraum als yada kardan bezeichnet.

Die Hexen werden im $R H$ im Allgemeinen als patiyãre (böse Macht; 4/601/16), 'efrite (weiblicher Dämon; 4/601/18), ğādu und sāḥere (Hexe; 4/648/14) bezeichnet. Der Begriff patiyāre stammt aus vorislamischer Zeit und meint die bösen Geschöpfe Ahrimans. ${ }^{435}$

Für gewöhnlich haben diese Hexen eine menschliche Gestalt; sie sind jedoch fast immer alt und erschreckend hässlich. ${ }^{436}$ „Das häßliche Äußere der Hexen und ihre abgeschiedene Wohnung entsprechen ihrem bösen, dem Menschen feindlichen Charakter.““437 Dieser Auffassung entsprechend hausen Hexen in menschenferner Einsamkeit, wie etwa im Wald

\footnotetext{
${ }^{431}$ Mostoufi-Qazwini, Ḥamdallāh: Nozhat al-qolub, Leiden 1331h/1913, S. 385.

${ }^{432}$ Goldziher, Ignaz: Zauberelemente im islamischen Gebet, in: Orientalische Studien: Theodor Nöldeke zum siebzigsten Geburtstag, hrsg. von Carl Bezold, Bd. 1, Giessen 1906, S. 312; mehr über dieser Stein siehe: Hamadāni, Moḥammad b. Mạ̣mud: 'Ağăa’eb-nāme, hrsg. von Ǧa'far Moddares-Ṣādeqi, Teherān 1375/1996, S. $37 \dot{9}$.

${ }^{433}$ Dehḩodā, 'Ali-Akbar: Yada, in: Logaat-nāme, ḥarf-e. Y-Yaftan, hrsg. von Moḥammad Mocin u. Seyyed Ga'far Šahidi, Teherān 1325/1945, S. 166. Bajalijewa meint, dass diese Form von Magie unter Verwendung eines Regensteins bei den Türken seit alter Zeit verbreitet war. Die Kasachen kannten sie unter der Bezeichnung dshaj-tas, die Usbeken, Altaier und Mongolen unter dem Namen jada. Siehe: Bajalijewa,Toktobjubju Dshunuschakunowa: Vor-islamische Glauben der Kirgisen, ins Deutsche übersetzt. von Reinhold Schletzer, Berlin 2002, S. 41.

${ }^{434}$ Vgl. Ferdousi, Bd. 1, S. 500.

${ }^{435}$ Vgl. Jackson, A. V. Williams: Die iranische Religion, S. 651.

${ }^{436}$ Vgl. Gerlach, Hildegard: Hexe, in: EM, Bd. 6, Göttingen 1990, Sp. 960-992, hier Sp. 965.

${ }^{437}$ Ebd.
} 
oder auf einsamen Inseln, in Gebieten also, die dem gewöhnlichen Menschen nicht zugänglich sind.

Im Šāh-nāme ist Māzandarān (im nördlichen Iran) die Heimat der Dämonen und der Hexen. ${ }^{438}$ Im $R H$ bewohnen Hexen Berggipfel, unbewohnte Gebiete oder unterirdische Regionen. Šamāme wohnt in einer Höhle erbauten Palast. Das Eingangstor des Palastareals wird durch zwei Löwen, die sprechen können, bewacht. Hinter dem Tor liegt ein Meer, in dem sich ein Wal befindet. Um zu Šamāme und in den Palast gelangen zu können, muss man sich in den Rachen des Wales stürzen (3/426-429).

Um einen Schadenszauber rückgängig zu machen, muss die Hexe getötet werden und ihre Leber oder ihr Blut auf die Stelle gerieben werden, die geschädigt worden ist. Um die Zaubersprüche der Hexen wirkunglos $\mathrm{zu}$ machen, brauchen die Helden eine Gegenzauberformel, und dies ist der Name Gottes. Wenn Hexen den Namen Gottes hören, werden sie gezwungen, sich in ihrer gewöhnlichen hässlichen Gestalt zu zeigen, ${ }^{439}$ und das bedeutet, dass dies die wirkungsvollste Weise ist, einen Hexenzauber zu vernichten. Einmal schickt Zardošt (Zarathustra) einen Hexer ins Feld, um mit Ḥamze zu kämpfen. Ḥamze liest die Zauberformel bātel as-seḥr (Gegenzauberformel) und esm-e a'zam (den großen Namen Gottes) und vernichtet hierdurch dessen Magie (4/661).

Charakteristisch für die Hexen im $R H$ ist, dass sie Menschenfresser sind. ${ }^{440}$ Ihre zauberischen Manipulationen beruhen auf intellektuellen und technischen Fähigkeiten oder Täuschung (Illusion). Oft verwandeln die Hexen die Helden in Tiere, speziell in Vögel. ${ }^{441}$ Die Hexen haben oft die Fähigkeit, Raubtiere wie Löwen, Drachen und Leoparden als Reittiere zu benutzen (5/1113). Schlangen dienen ihnen als Peitschen (5/1113), und sie können sich nach Belieben in Adler oder Frösche verwandeln (5/827). ${ }^{442}$ Häufig sind sie die Geliebte eines Dämons (4/597) oder der Feinde Ḥamzes.

Wenn eine Hexe einen jungen Helden zum Beischlaf zwingen will, sperrt sie ihn in ein Gefängnis ein und droht ihm, ihn dort für immer festzuhalten, wenn er nicht mit ihr schlafe. Der Held erklärt sich meist dazu bereit und tötet dabei die Hexe, indem er ihre Seele vernichtet, die sich entweder in den Haaren, unter dem Hemd oder in einer Flasche befindet $(3 / 466)$.

\footnotetext{
${ }^{438}$ Vgl. Ferdousi, Bd. 1, S. 200.

${ }^{439}$ Ebd. Bd. 1, S. 200; 955.

${ }^{440}$ AaTh (Motiv. Die Hexe als Menschenfresserin. 327A).

${ }^{441}$ Gerlach, hier Sp. 968.

${ }^{442}$ Marzolph, TPV (Motiv des Sich-Verwandelns in Vogelgestalt. 720), S. 269.
} 
Innerhalb der Welt der Menschen streben die Hexen nach Macht. Im $R H$ lesen wir, dass auch Mitglieder der königlichen Häuser Hexen sein können. Asmar-e ğādu beispielsweise, die Mutter von Eskandar-e Savād-kuhi, ist eine Hexe (3/344).

Um an die Macht zu kommen oder an der Macht zu bleiben, benutzen die Hexen ihre körplichen Reize und ihre Sexualität als Hilfsmittel. Ein Beispiel dafür ist Zolfeyn, die Tochter Șalṣāls. Um ihre Verwandten, die von Ḥamze getötet wurden, zu rächen, verführt sie 'Alam Šāh zum Götzendienst. Als er sie heiraten will, verlangt sie Hamzes Kopf als Brautgeld (3/446).

Als Strafe für ihre abscheulichen Taten erleiden die Hexen des $R H$ stets den Tod. Dies hat auch einen historischen Hintergrund, da als Hexen verurteilte Frauen im Iran sowohl in der vorislamischen als auch in der islamischen Zeit mit dem Tode bestraft wurden. ${ }^{443}$ Außerdem hat die Darstellung der Brutalität im Zusammenhang mit der Tötung von Hexen eine erzählerische Funktion. ${ }^{444}$ Die Hinrichtungsform ist sehr grausam, z.B. das Zerreißen, Zerstïckeln der Hexe durch Schwerter oder Verbrennen. ${ }^{445}$ Die Helden haben große Angst vor Hexen, und aus Furcht vor ihrer möglichen Wiederkehr verbrennen sie ihre Leichen (5/813; 5/827). Mit der Tötung der Hexen sind stets Änderungen der Witterung verbunden: So erscheinen immer Blitze und ein heftiger Wind, und der Zaubergarten, wo sie wohnen, verschwindet (2/209).

\section{Prostituierte}

Die Stellung der Frau bei den Mongolen war weitaus freier als etwa bei den Arabern und Iranern. Die Frauen hatten große eigene Besitztümer, zeigten sich in der Öffentlichkeit, nahmen an offiziellen Veranstaltungen teil und empfingen Gesandte, hatten also auch repräsentative Funktionen gegenüber Fremden zu erfüllen. ${ }^{446}$ Mongolische Frauen konnten selbst an Kampfhandlungen teilnehmen. ${ }^{447}$ Der Einfluss der Freiheiten der mongolischen Frauen auf die iranische Bevölkerung war so groß, dass Fahr ad-Din (reg. 1295-1308) von Harāt sich um 1300 veranlasst sah, Gesetze zur strengeren Beachtung der weiblichen Verhüllungsvorschrift zu erlassen, was wohl den Umkehrschluss zulässt, dass mongolische Freizügigkeit auch auf die einheimischen muslimischen Frauen abgefärbt hatte. ${ }^{448}$

Im Laufe des 14. bis 15. Jahrhunderts kam es immer wieder vor, dass iranische Frauen und

\footnotetext{
${ }^{443}$ Vāḥhdi-Navā’i, Āvā: Neẓām-e ğazā i-ye Irān dar 'aṣr-e sāsāni, Teherān 1380/2001, S. 83.

${ }^{444}$ Vgl. Röhrich, Lutz: Grausamkeit, in: EM, Bd. 6, Göttingen 1990, Sp. 98-110, hier Sp. 106.

${ }^{445}$ Ebd. Sp. 106.

${ }^{446}$ Spuler, Bertold: Die Mongolen in Iran: Politik, Verwaltung und Kultur der Ilchanzeit 1220-1350, Berlin 1955, S. 395

${ }^{447}$ Ebd. S. 398.

${ }^{448}$ Ebd. S. 397.
} 
Mädchen unter der mongolischen und türkischen Herrschaft auf die eine oder andere Weise in der Prostitution gezwungen. Dies geschah vor allem dann, wenn ihre Familien die Steuern der fremden Herrscher nicht zahlen konnten. In diesem Fall wurden diese Frauen ganz offen im Basar und sogar vor der Moschee angeboten. ${ }^{449}$ Sklavinnen wurden auch gegen ihren erklärten Willen gewaltsam an die Freudenhäuser verkauft, weil deren Besitzer in der Regel besser zahlte als andere Käufer. So drohte ein Befehlshaber Šeih Șafi, seine Sklavinnen in ein bait-al fawāḥiš (Bordell) zu stecken. ${ }^{450}$

Aus dem 15. Jahrhundert wissen wir, dass Weinschenken, Opiumhäuser, Bordelle und Spielhäuser für Širāz eindeutig belegt sind, und man deshalb wohl annehmen kann, dass diese auch über ausreichenden Publikumsverkehr verfügten. ${ }^{451}$

In der Regierungszeit von Šāh 'Abbās der II. (reg. 1642-1666) gab es in Eṣfahān 12.000 Prostituierte, die Steuern bezahlten. Aus religiöser Überzeugung glaubten die Iraner, dass dieses unehrlich erworbene Geld eigentlich verbrannt werden müsse, daher nutzten sie es dazu, die Beleuchtung der Stadt zu bezahlen. ${ }^{452}$

Später erwachte in den Prostituierten der Wunsch nach repräsentativen Schlössern. Der Wunsch nach mehr Luxus führte nun zum Bau von Lustschlössern, zu denen häufig nur bestimmte Personenkreise Zugang hatten. Die schönsten und reichsten Prostituierten hatten ihre gewöhnlichen Häuser verlassen und wohnten in den von ihnen umgebauten wohnlichen Residenzen. In diesen Lustschlössern fühlten sich viele Politiker, Künstler wie Maler, Musikanten und Dichter zu Hause. Der Umgang mit Prostituierten war für Iraner unproblematisch. ${ }^{453}$ Aus Quellen ist belegt, dass selbst Šāh 'Abbās der II. viele Beziehungen mit verschiedenen Prostituierten gehabt hatte und deswegen sogar an einer Geschlechtskrankheit gestorben ist. ${ }^{454}$

Hier konnten die Männer mit schönen und jungen Frauen leben. Hier konnten die Männer sich dem Vergnügen widmen. Lustschlösser waren vor allem Orte der Feste, des Tanzes und der Musik, oft auch der Literatur und der Malerei. Die Lustschlösser in den großen Städten, zeichneten sich meist durch eine besonders reichhaltige und wertvolle Ausstattung aus. An vielen solchen Schlössern haben bedeutende Künstler gearbeitet. Berühmtes Beispiel ist das Lustschloss von einer Prostituierten aus Eșfahān namens 'Aziz Kāši, die als 12 tumāni

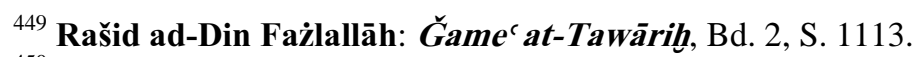

${ }^{450}$ Ibn Bazzāz, Tawakkoli b. Esmā'il Ardabili: Ṣafwat aṣ-Ṣafā, hrsg. von Ġolām-Reżā Ṭabāṭabā’i-Mağd, Teherān 1373/1994, S. 807.

${ }^{451}$ Limbert, John: Shiraz in the Age of Hafez, Seattle/London 2004, S. 72; 105.

${ }^{452}$ Vaḥid-Qazwini, Moḥammad-Ṭāher: 'A Sbbās-nāme, hrsg. von Ebrāhīm Dehqān, Teherān 1329/1950, S. 70-72.

${ }^{453}$ Olearius, Adam: Safar-nāme-ye Ādam Uli' āriyūs, ins Persische übersetzt. von Aḥmad Behpur, Teherān 1363/1985, S. 197; $221 f$.
} 
berühmt war. Dieses Schloss war sehr repräsentativ, weil es viele erotische Wandmalerei und teure Möbel besaß. Die Besitzerin, 'Aziz Kāši, war eine Prostituierte, welche ihr „Handwerk“ verstand; sie setzte also neben ihrem Körper ihren Verstand ein. Sie war eine sehr schöne Frau. Doch gerade durch ihren Verstand, Humor und Scharfsinn schaffte sie es die Aufmerksamkeit der einflussreichsten Männer auf sich zu ziehen und sich selbst in den Mittelpunkt zu rücken. Es kam wohl nicht selten vor, dass viele Männer ihren Monatslohn an die Prostituierten abgaben. ${ }^{455}$

Aus dem $R H$ erfahren wir, dass die sogenannten Freudenhäuser ein Zentrum für Männer der Umgebung und ein beliebter Treffpunkt und Ort der Kommunikation sind. Das Haus bietet sich auch an als Forum für Gespräche zwischen Männer und Frauen. Auch das Rauchen, Trinken von Alkohol, Fluchen und der gewaltsame Umgang mit den Frauen ist in solchen Häusern normales Alltagsgeschehen. Der Aufenthalt in diesen Lusthäusern ist durchaus nicht ungefährlich, und es gibt immer wieder Streitigkeiten. Es kommt besonders dann zu handfesten Auseinandersetzungen, wenn Gruppen von Männern zusammensitzen und sich um eine Frau streiten. Das Würfel- und das Kartenspiel sind in solchen Häuser wichtige Unterhaltungsangebote.

Im $R H$ geht 'Amr auf der Flucht vor den Sicherheitskräften der Stadt Irak in ein Bordell. Dort begegnet ihm eine Prostituierte, die Musik zu spielen versteht. Sie leitet das Haus, das außer Frauen auch Opium und Glücksspiel anbietet. Der Name der Frau ist Șa've-ye čangi. 'Amr ämusiert sich in ihrem Haus bei Wein und Kartenspiel und ihrem Spiel der Harfe. Schließlich verliebt er sich in die schöne Frau und heiratet sie (2/210).

\section{Sklavinnen}

Der Sklave wird im Persischen als bande (arab. 'abd oder golām) bezeichnet. ${ }^{456}$ Eine Sklavin wird als kaniz (arab. ̌̆āriya ${ }^{457}$ ) betietelt. Eine Sklavin, die als Nebenfrau ihres Herrn diente, wird im Arabischen surriyya genannt. ${ }^{458}$ Wird eine Sklavin ihrem Herren ein Kind schenken, dann wird sie umm walad (Kindesmutter) genannt und bekommt nach klassischen islamischen Recht spezielle Privilegien, so darf sie nicht mehr verkauft werden und wird nach dem Tod ihres Herrn frei. ${ }^{459}$ Trotzdem hatte sie aber nie den gleichen sozialen Status wie eine freie

\footnotetext{
${ }^{454}$ Bāstāni-Pārizi, Moḥammad-Ebrāhīm: Siyā sat va eqteșād-e ‘ậr-e Safavi, Teherān 1348/1969, S. 242.

455 Jeder, der dieses Haus besuchte, musste ihr 12 tumān bezahlen. Siehe: Bāstāni-Pārizi, Siyā sat va eqteșād-e 'așr-e Șafavi, S. 229f.

${ }^{456}$ Koran, Sure. 2,178; Brunschvig, R.: 'Abd, in: $E l^{2}$, Bd. 1, Leiden 1979, S. 24-40, hier S. 24.

${ }^{457}$ Brunschvig, S. 24.

${ }^{458}$ Ebd. S. 28.

${ }^{459}$ Ebd. S. 28.
} 
Frau. Ihr Kind aus dieser Verbindung ist frei. ${ }^{460}$ Der Übertritt zum Islam ändert ihren Sklavenstatus nicht.

Als Eigentum ihrer Besitzer konnten die Sklaven nach Belieben verschenkt, verliehen, verpfändet, vererbt oder verkauft werden. ${ }^{461}$ Andererseits haben sie Anspruch auf gute Behandlung, Versorgung und Verpflegung. In einer Überlieferung erklärt der Prophet Moḥammed:

„Eure Sklaven sind eure Brüder. Gott hat sie unter euren Befehl gestellt. Wer
nun die Oberhand über seinen Bruder hat, der soll von dem zu essen geben,
was er selbst isst, und ihm Kleidung geben, die er selbst trägt. Tragt ihnen
nicht auf, was ihre Kraft übersteigt. Und wenn ihr es doch tut, so helft
ihnen!" 462

Sklavinnen gab es in der islamischen Gesellschaft in großer Zahl. Sie waren Eigentum, mit dem man nach Gefallen umgehen konnte. Der Platz der Sklavinnen war im Haushalt. Waren sie noch jung, so war ihr Platz auch im Bett des Herrn. Die Haltung der Herren zu ihren Sklavinnen war manchmal ambivalent.

Hierbei schildert uns das $R H$, dass die Sklavinnen in einer schreklichen Sitaution lebten. In einer Stelle wird geschildert, dass 'Alam Šāh in der Jagd zwei Brüder namens Yalmāq und Qalmāq besiegt. Diese machen ihn bei einer Einladung durch mit einem Betäubungsmittel versetzte Speisen bewusstlos und legen ihn in eine Kiste, die sie ins Wasser des Flusses Amuye werfen. Die Kiste wird vom Gärtner der Königstochter gefunden und nach Hause gebracht (3/370-371). Der Gärtner nimmt 'Alam Šāh als Sohn an, und 'Alam Šāh arbeitet bei ihm im Garten. Dort trifft er zufällig die Königstochter Šamse an, die beiden verlieben sich ineinander und Šamse lädt 'Alam Šāh in ihr Schloss ein (3/373-374). Die Prinzessin hat eine Sklavin, die ungeschickt heißes Wasser auf die Hände der Prinzessin gießt. Die Prinzessin schlägt sie und diese geht zu der Mutter des Mädchens und teilt ihr mit, dass ihre Tochter mit einem fremden jungen Mann im Garten sei. Qamar Bānu, Šamses Mutter, informiert ihren Mann Hosrau Hูān. Als er aber später erfährt, dass der junge Mann der Sohn des Ḥamze ist, lässt er die vorher bewusstlos gemachten Liebenden töten: Dem Prinzen wird die Kehle durchgeschnitten, das Mädchen wird gesteinigt. Der Prinz und die Prinzessin werden später geheilt und heiraten (3/83-385).

Das $R H$ stellt das Spannungsverhältnis zwischen der natürlichen Liebe und erotischen Beziehungen in Verbindung mit der gesellschaftlichen Moral dar. So bilden Geschlechtsverhältnis, Sexualität, Ehe, Ehebruch und Familie Themen im $R H$, der als

\footnotetext{
${ }^{460}$ Ebd.

${ }^{461}$ Ebd.
} 
Vertreter dieser Literaturepoche gesehen werden kann. Dort finden wir auch Zeugnisse von Sexualität, die mit der sozialen Stellung von Mann und Frau bzw. Sklavinnen und ihrer sexuellen Beziehung verbunden sind. Die Sklavinnen sind in ihrem Sexualleben dem Besitzer untergeordnet.

Wir lesen, dass Sarhang-e Qașsāāb-e Meșri, 'Aziz-e Meșrs Kundschafter, eine Sklavin namens Nahāl besitzt. Eines Tages kommt er nach Hause und küsst sie. Zufällig sieht dies seine Frau und schlägt Nahāl. In ihrem Ärger geht diese zum ägyptischen König und verät ihm, dass Sarhang den Kundschaftern Ḥamzes geholfen habe, ihn zu befreien (1/126).

\section{Tänzerinnen, Sängerinnen}

Der Tanz vermittelt nur ansatzweise die Tatsache, dass die Kulturgeschichte des Tanzes meisten gleichzeitig auch die Sozialgeschichte der menschlichen Sexualität beinhaltet. Die unterschiedlichen Tänze beider Geschlechter repräsentieren auf inszenierte Weise disese wieder. Tanz war sittlich streng überwacht und reglementiert. Viele Wissenschaftler, die sich mit dem Thema Malerei im Iran beschäftigt haben, hatten in ihren Werken die Bildnisse von Tänzerinnen präsentiert. Dort sehen wir, dass die Künstler auf die Muskulatur, Physiognomie des Körpers, Bekleidungseigenschaften und Druckstärken der Hände und Hüfte, Kräfteverhältnisse aller Bewegungen, Gelenkigkeit beachtet hatten. Alle diese historisch tief verwurzelten Traditionen haben also mit der menschlichen Sexualität zu tun, wohingegen schon die geringste sinnliche Erregung in der Realität bekämpft werden musste.

Ganz besonders in den iranischen Tänzen sieth man typisches Verhalten der Tänzer bezüglich Flirten, Anmache, Abblitzen. Sinnlichkeit und Erotik lösten eher Ängste als Freude aus. Das gesamte Sittlichkeits- und Moralempfinden bezüglich sexueller Verhaltensweisen ist im iranischen Tanz repräsentativ enthalten.

Die Musiker und Tänzer bildeten innerhalb der iranischen Hofgemeinschaft einen festen Stand. Um das Volk zu unterhalten, ließ König Bahrām Gōr die Musikanten aus Indien kommen; er ließ sogar auf Jagdveranstaltungen von ihnen begleiten. ${ }^{463}$

In Islam ist es Aufgabe der Frau, nach dem ideologischen Bild der „guten muslimischen Frau“, viele Kinder zu bekommen, für ihren Mann zu leben und seine Wünsche zu erfüllen. Die Ehre der Familie war und ist im Islam wichtiger als die Interessen des Individuums. Und so ist eine Frau, die vor Männern tanzte, keine ehrenwerte Frau. Sie stellte ihre Familie in schlechtes Licht. Die Tänzerinnen wurden nicht als Künstlerin gesehen und erfuhren keine

\footnotetext{
${ }^{462}$ Ibn Ḥağar al- 'Asqalānī, Aḥmad Ibn Alī: Tag̉līq at-ta 'līq 'alā șaḥihh al-Buhārīi, Muğallad 3, ğuz' 4, Dirāsa wataḥqīq Sa 'ìd 'Abd-ar-Raḥmān Mūsā al-Qazqīi, Ammān 1985, S. 345.

${ }^{463}$ Abkaci-Khavari, S. 81.
} 
Respekt und Anerkennung. In der islamischen Gesellschaft im Mittelalter bis in die Neuzeit hatten in vielen Ländern die stadtlichen Frauen Recht auf Bildung. Zweck der weiblichen Erziehung war nicht unbedingt die Entwicklung ihrer Intelligenz. So konnten z.B. die Frauen den Tanz nicht in den öffentlichen Schulen lernen.

Die Zeiten aber hatten sich geändert. Der mongolische Angriff hatte in verschiedenen Bereiche der iranischen Gesellschaft seine Spuren hinterlassen. Es kam zu radikalen Veränderungen der iranischen Gesellschaft. Es war klar, dass harte Zeiten auf sie zukommen würden. Besonders hatte die politischen Veränderungen dieser Zeit die Bevölkerung beunruhigt. Die Lebensbedingungen waren bestürzend und die immense Steuerzahlungen verursachten die Frauenarbeit. Diese und die mongolische Kultur verursachten eine grundliegenden Wandel. Eine diese Veränderung war die Stellung der Frauen in der Gesellschaft. Die Frauen waren zu diesem Zeitpunkt wesentlich freier. Die Bewegungsfreiheit einer Frau hing davon ab, ob sie auf dem Land oder in der Stadt lebte und welcher sozialen Schicht sie angehörte. In der Stadt hatten die Frauen der unteren Klassen eine größere Bewegungsfreiheit. Ein gutes Beispiel ist der gemeinsame Tanz von Männern und Frauen bei samā $\subseteq$ Versammlungen. ${ }^{464}$

In den Häusern der Adligen arbeiteten viele junge, schöne und talentierte Mädchen aus den unteren Klassen als Tänzerinnen, Sängerinnen und Musikantinnen. Häufig wurden diese Künste auch von Prostituierten ausgeübt. ${ }^{465}$

Später berichten die Quellen, dass auch die männliche Tänzer sehr erotische Kleidung hatten und sich wie Frauen schminkten und deren Verführungskünste nachahmten. In den öffentliche Plätze, wie Kaffehäuser, trafen sich die Liebende und ihre Liebhaber. ${ }^{466}$

In Buchmalereien der Șafavidenzeit oder Qāğārenzeit sehen wir, dass die weiblichen Tänzerinnen sehr aufreizende Kleidung anhatten und ihre Tänze mit akrobatischen und verführerischen Bewegungen vollzogen. ${ }^{467}$

Nun wird versucht den oben genannten historischen Ereigniss in Verbindung mit $R H \mathrm{zu}$ bringen, um die Rolle der Tänzerinnen in dieser Arbeit zu erläutern.

\footnotetext{
${ }^{464}$ Ibn Bazzāz, S. 163.

${ }^{465}$ Olearius, S. $221 \mathrm{f}$

466 Šamisā, Sirus Šăhed-bāzi dar adabiyāt-e fārsi, Teherān 1381/2002, S. 228.

${ }^{467}$ Massoud-Ansari, Faramarz: Die Malerei zur Zeit der Qajaren-Dynstie (1796-1925) im Iran, Univ., Diss., Tübingen 1986, S. 250; Morand, Claude: Les peintres populaires de la legende Persan, Paris 1970, Bilder. $80 ; 81 ; 83 ; 84 ; 85$.
} 
Bei besonderen Anlässen waren die Musikanten immer präsent. Die Musikanten begleiteten Ḥamze auf seinen Veranstaltungen. Manche hohe Gäste wurden mit Musik und Spiel empfangen. Militärische Erfolge wurden durch Musik und Tanz gefeiert (2/210).

Im $R H$ kommen die Tänzerinnen im erotischen Zusammenhang vor. In einer Stelle lesen wir, dass Anōširvān auf Anraten des Baḩtak den Gostaham mit Ḥamze nach Sarandib sendet, um Landehur zu töten (1/83). Ḥamze besiegt Landehur (1/85). Vor Neid erfüllt lässt Gostaham, Ḥamze von zwei Sklavinnen vergiften. Zohre und Moštari gehen in der Nacht ins Ḥamzes Zelt und begeistern ihn mit ihrer Musik und Tanz am Ende fangen sie an mit ihm zärtlich zu kuscheln. Als Hamze unaufmerksam ist, geben sie ihn ein giftiges Weinglas (1/88).

Kundschafterinnen

Zumindest in der erzählenden Literatur kommen selbstbewusste und eigenständig handelnde Frauen als Kundschafterinnen vor. So hat Rābe'e ein Dienstmädchen, das Harfe spielt. Gegenüber Ḥamze und Rābe'e wettet sie, dass es ihr gelingen werde, 'Amr gefangen zu nehmen. Sie schafft es, 'Amrs Wachsamkeit auszuschalten, indem sie ein schönes Kleid anzieht, vorgibt, auf den Wettbewerb zu verzichten und 'Amr einlädt, mit ihr Wein zu trinken. Als 'Amr betrunken ist, versucht er, ihre Brüste zu küssen, die sie vorher mit einem Betäubungsmittel eingerieben hat. 'Amr wird bewusstlos und von ihr gefesselt zu Ḥamze als Nachweis ihrer Geschicklichkeit gebracht (2/230-231) 


\subsubsection{Themen und Motive}

In den folgenden Abschnitten werden einige ausgewählte Themen- und Motivkomplexe ausführlich analysiert und interpretiert. Diese Themen werden im geschichtlichen Kontext untersucht und ihr Auftreten in den literarischen Werken überprüft. Insbesondere soll ihr Erscheinen im $R H$ untersucht werden. Dadurch soll aufgezeigt werden, dass in diesem Bereich ein großes Potential für weitere Forschungen liegt. Es soll jedoch der Eindruck vermieden werden, dass sich die Gesamteinschätzung des Buches ausschließlich an den wenigen beispielhaft dargestellten Themen orientiert. Das vorliegende Kapitel soll also einer möglichen Verzerrung der Perspektive auf die Hauptquellen entgegenwirken und das Buch in seiner thematischen Vielfalt ins Blickfeld rücken. Zugleich sollen die folgenden Ausführungen die Überlegungen deutlich machen, die mich veranlasst haben, bestimmte Themen für die Analyse auszuwählen und andere davon auszuschließen.

\subsubsection{Kampf}

Im vorliegenden Abschnitt wird die motivgeschichtliche Basis der Kampfesdarstellung in iranischer Literatur beschrieben und ein Vergleich der Darstellung von Kämpfen in den klassischen iranischen Texten und im $R H$ vorgenommen.

Wenn man die Geschichte des Irans durchblättert, sieht man, dass das Land im Laufe der Zeit mehrere militärische Expansionen ausgeübt hat aber auch gleichzeitig die Griechen, Araber, Türken und Mongolen eine massive Offensive gegen den Iran hatten. Diese Kriege sind als ein Teil der iranischen Geschichte und ebenso als ein Teil im großen Puzzle der Kulturgeschichte des Irans. Die Erinnerungen an Kriege nehmen einen festen Platz in der iranischen Kultur und Gesellschaft ein. Die Erinnerung an den Krieg nähert einem nostalgisches Bild vom Iran in vergangenen Zeiten, aber auch heut zu Tage.

Die Art, wie das Volk an seinen Krieg erinnert, ist verbunden mit vielen Elementen, die im kollektiven und individuellen Gedächtnis fortleben. Die Kriegsgegenstände bzw. die Kriegskleidungen, Waffen und die Pferde verleihen den Helden eine besondere Dimension und sind unerlässlich. Andere Ursachen für Kriege, sind Kampfmotive und die Art diese zu führen. Diese zeigen das Bild von einer Gesellschaft, die sich idealisieren möchte. Aber in wie weit trifft jenes Bild in unserer Zeit zu? Hier wird der Versuch unternommen, die traditionelle Sicht vom kleinen heroischen im $R H \mathrm{zu}$ hinterfragen und den Horizont $\mathrm{zu}$ erweitern, um das Bild, das die iranischen Epos in der Welt vermittelten, in den Vordergrund stellen. 
Die Iraner konnten auf dieser Art und Weise ihre Selbständigkeit behaupten. Um den Kerngedanken der Iraner über Kriege plastisch vor die Augen des Lesers zu führen, soll hier ein Abriss in der altiranischent Geschichte gezeigt werden.

Im Rahmen der altiranischen Religion gab es zwei gegensätzliche Prinzipien, die als Zwillingsbrüder präsentiert wurden. Eines war das Symbol für das Gute und das Licht, das andere das Symbol für Verderbtheit und Dunkelheit. Ihr gewaltsames Aufeinandertreffen war der Beginn der Schöpfung. ${ }^{468}$ Die Dauer der Auseinandersetzungen zwischen Gut und Böse war im Grunde genommen deckungsgleich mit dem Alter der Welt, nämlich 9.000 Jahre. ${ }^{469}$

Die beiden konträren Prinzipien beeinflussten die Entwicklung der iranischen epischen Tradition in jeder Hinsicht. Der sich darin widerspiegelnde Dualismus präsentierte und etablierte sich in der epischen Tradition auf eine sehr spezifische Art. Das eher abstrakte Aufeinandertreffen von Gut und Böse, wird im Šāh-nāme in ein weltlich-konkretes Bildes umgesetzt, in den Konflikt zweier feindlicher Völker (Iraner und Türken) bzw. zweier Glaubensgemeinschaften, die gegeneinander kämpfen. So behandelt das gesamte Šāh-nāme den Krieg zwischen Iranern und Türken. Soweit das $R H$ die Türken thematisiert, erzählt es überwiegend von Lebensumständen und kriegerischen Handlungen der türkischen Stammesfürsten, die in wechselseitigen Beziehungen zueinander stehen und im Rahmen einer bestimmten Herrschaftsordnung von einem Hāann ${ }^{470}$ zusammengehalten werden.

Diese Feindschaft und der nach iranischer Auffassung ständige Krieg zwischen den Türken und den Iranern, sind im $R H$ ebenfalls deutlich präsent. Da nach der mythischen Weltentstehungsgeschichte ein steter Kampf zwischen Gut und Böse tobt, liegt es nahe, dass in den Volksepen das Motiv des ständigen Kampfes seine Fortsetzung findet. Der ständige Kampf ist so auch die selbstverständliche Lebens- und Daseinsform im $R H$.

\subsection{Kampfmotive im $R H$}

Nach alter Rittersitte ist der Zweikampf die höchste Kampfform. Von zwei einander gegenüberstehenden Heeren treten je zwei Einzelkämpfer vor. Der Ausgang des Duells zwischen ihnen wird als Kriegsentscheidung gewertet und so das Blutopfer der Massen vermieden. Dies ist generell ein Beleg dafür, dass die Kriegertugend auch in frühislamischer Zeit stets so hoch geschätzt wurde wie in den vorangegangenen Jahrhunderten.

\footnotetext{
${ }^{468}$ Jackson, A. V. Williams: Die iranische Religion, S. 651.

${ }^{469}$ Vgl. Benveniste, Émile: The Persian Religion According to the Chief Greek Texts, Paris 1929, S. 107.

470 Das Wort ist abgeleitet von „Khagan“ und ist ein Herrschertitel, der vor allem von den altaischen Reiternomaden Zentral- und Mittelasiens verwendet wurde und zahlreiche deutungen besitzt, zu deren Kern „Befehlshaber“, „Anführer“, „Herr“ und „Herrscher“" zählen. Siehe: Boyle, J. A.: Khāan, in: $E l^{2}$, Vol. IV, Leiden 1978, S. 1010.
} 
In der volkstümlichen Literatur des Irans ist der Zweikampf eine häufig wiederkehrende Situation. Zweikampfschilderungen folgen meistens demselben Muster, unterscheiden sich aber durch die Orte, an denen sie spielen (Festungen, Wald, Wüste, in der Finsternis, etc.), ihre Situation (Besitzstreit, Befreiung, Rache etc.) und die handelnden Personen (Ritter, Riese, Tier, etc). Dabei sind, je nach Perspektive des Verfassers, unterschiedliche Akzentuierungen möglich. So hat die volkstümliche Literatur bereits seit ihren Anfängen auch die tragischen Dimensionen des Zweikampfs betont, etwa in Duellen von Verwandten (Vater gegen Sohn, Sohn gegen Vater, Bruder gegen Bruder).

Der Kampf zwischen Vater und Sohn

Ein Kampf zwischen Vater und Sohn oder zwischen Enkelsohn und Großvater wird an mehreren Stellen im $R H$ beschrieben. Die Betonung der Konflikte zwischen Vater und Sohn ist im iranischen Heldenepos im Fokus der Erzählungen zu finden. Die Rostam-Sage zeigt verschiedene Details des Zweikampfes. Bei Ferdousi dauert der Kampf mehrere Tage. Im ersten Zusammentreffen besiegt Sohrāb Rostam. Dieser hat sich jedoch von Gott seine übernatürliche Stärke zurückerbeten. Unter dieser Stärke, die selbst Riesen übertrifft, bricht Sohrāb im zweiten Kampf wie ein Schilfrohr zusammen. Tödlich verwundet gibt er sich seinem Vater zu erkennen und bezeugt die Blutsverwandtschaft durch einen Onyx, den er einst von seiner Mutter bekommen hat. ${ }^{471}$

Auch im $R H$ schließt der Glaubenskrieg mit ein, dass Hamze gegebenenfalls selbst den eigenen Bruder, die eigenen Söhne usw. bekämpft. Im Mittelpunkt eines Epos steht immer der Zweikampf der Heroen, die entweder einen Konflikt beenden, einen in Unordnung geratenen Zustand bzw. eine Rangfolge wiederherstellen oder den Siegeszug des Islams voranbringen wollen. Der Sieger gilt nach altem Rechtsgrundsatz als Vertreter des Guten und Beschützer der Schwachen. Hamzes Taten geschehen im $R H$ aus tiefem Empfinden für den gerechten Glauben. So ist Hamze immer wieder in kriegerische Auseinandersetzungen mit seinen Kindern verwickelt. Auf der anderen Seite wird in episch-überhöhter Weise das Ideal eines Vaters beschrieben, der Oberhaupt, Autorität und Lehrmeister seiner Kinder ist, dabei aber mit Herz und Gefühl agiert.

Als Volksroman lässt das $R H$ seine Helden nicht sterben und vermeidet die Schilderung von besonders traurigen Situationen. So kommt es beispielsweise trotz der zahlreichen Zweikämpfe zwischen Hạmze und seinen Söhnen nie zu einem tödlichen Ausgang.

\footnotetext{
${ }^{471}$ Ferdousi, Bd. 1, S. 279.
} 
Der Perserkönig bittet Kardus Šāh um Hilfe. Dieser macht sich in Begleitung von 'Alam Šāh, Ḥamzes Sohn, auf den Weg nach Persien. 'Alam Šāh kann viele Helden Ḥamzes im Kampf besiegen. Als Rābe`e, 'Alam Šāhs Mutter, davon erfährt, schreibt sie sofort einen Brief an ihren Sohn, in dem sie ihm mitteilt, dass er Ḥamzes Sohn sei und nicht falsch handeln solle. Daraufhin verlässt 'Alam Šāh das Schlachtfeld. Auch Ḥamzes Freund 'Amr sieht, dass 'Alam Šāh ein grünes Muttermal hat und Ḥamze ähnlich sieht; dadurch erkennt er, dass 'Alam Šāh Ḥamzes Sohn ist. 'Alam Šāh bittet 'Amr, niemandem dieses Geheimnis zu verraten und 'Amr verspricht es. Danach bewaffnet sich 'Amr 'Alam Šāh mit Ḥamzes Rüstung und gibt ihm Ḥamzes Pferd Ašqar. Am nächsten Tag kommt 'Alam Šāh auf das Schlachtfeld. Hamze ist von seinem Erfolg überrascht und deswegen will er wissen, wer er ist. Ḥamze und 'Alam Šāh ziehen gegeneinander ins Feld. Ḥamze, der sich als Sa'd-e gong verkleidet hat, stürmt ihm entgegen. 'Alam Šāh kämpft gegen Ḥamze und weiß nicht, gegen wen er kämpft. Als das Pferd ihn sieht, bleibt es stehen. Als die beiden doch zu kämpfen beginnen, geht 'Amr dazwischen und sagt zu 'Alam Šāh: „Ein Pferd kennt seinen Besitzer und du erkennst deinen Vater nicht?““(2/240).

Im letzten Augenblick wird alles doch noch unblutig aufgelöst, weil man endlich miteinander spricht. Das harmonische Ende zeigt, wie überflüssig der vorausgehende Kampf gewesen ist: Alles hätte sich vermeiden lassen, hätte man zuvor miteinander kommuniziert. Das EinanderErkennen ist zwar typisch für die Heldenepik, aber eine Folge des Miteinander-Kämpfens, und oftmals wird erst dadurch die Verwandtschaft sichtbar. Katastrophen können nur vermieden werden, wenn man richtig auf die Zeichen achtet.

Das Verhältnis zwischen Personen und ihre Zugehörigkeit zu einer Sippe sind zentrale Punkte in Bezug auf die Religion und ihr Wertesystem. Das $R H$ beschreibt den Antityp zum gläubigen Vater, und so entsteht der Typus des ungläubigen Sohnes bzw. Enkelsohnes. Ṭarmāsb, der Enkelsohn des 'Anqavil b. Ṭahmāsb, will seinen Großvater, der gläubig ist, töten. Dagegen ist es bei einem gläubigen Sohn der ungläubige Vater, mit dem gekämpft wird.

Ein Beispiel dafür ist im $R H$ der Kampf Bahrāms, des Sohnes des Kaisers von China, mit seinem Vater. Bahrām ist Muslim, sein Vater aber ungläubig; so rebelliert Bahrām gegen seinen eigenen Vater. Dieser bittet den Perserkönig um Hilfe, und Anōširvān schickt seine Truppen unter dem Heerführer Gostaham nach China. Bahrām besiegt Gostaham zweimal, aber dann kann Gostaham Bahrām mit einer List gefangen nehmen und nach Madā'en bringen (1/33). 
Obgleich es im Islam eine unbedingte Gehorsamspflicht gegenüber den Eltern gibt ${ }^{472}$, kommt es auch im $R H$ vor, dass die Nachkommen vom Glauben abfallen oder sich aus machtpolitischen Gründen gegen die Eltern richten. Im $R H$ sind die Väter meist Vorbilder, die die Söhne früher oder später auf den rechten Weg zurückbringen. Als etwa Ġorub Šāh zum Islam bekehrt wird, informiert sein Wesir, der insgeheim Zomorrodsanbeter ist, den Sohn des Königs, Țolu‘ Šāh. Dieser zieht mit einem großen Heer gegen seinen Vater in den Krieg. Als Ġorub Šāh schließlich seinen Sohn besiegt und gefangennimmt, wird dieser zum Islam bekehrt (4/631).

\section{Kampf zwischen Brüdern}

Ebenso wie der Kampf zwischen Vorfahren und Nachkommen wird im $R H$ der Kampf zwischen Brüdern thematisiert. In der Welt des $R H$ ist Verwandtschaft eines der wichtigsten Ordungsprinzipien und das mächtigste dazu und von ihr sind Vermögen, Macht und viele Gefolgsleute und ihre Verbündeten abhängig. Innerhalb der Sippe sind die Verhaltensregeln und die Rangfolge von Ḥamzes Söhnen genau festgelegt. Wenn ein Prinz einen anderen durch größeren Reichtum und Macht, durch mehr Ansehen und höheren Status zu überbieten sucht, sind Verletzungen dieser Regeln häufig und verursachen dadurch eine fast ununterbrochene Spannung, die das Kennzeichen des heroischen Lebens im $R H$ ist. Ḥamzes Söhne sind keine Sympathieträger, denn sie verletzen oft die Moralprinzipien. Im $R H$ ist zu lesen, dass unterschiedliche gesellschaftliche Gruppen, die Gefolgschaft des Helden und seine Sippe sich in einem ständigen Konflikt befinden. Hamze hat seine Söhne und Gefolgsleute rechts und links von sich eingeordnet und ist ständig damit beschäftigt zwischen ihnen zu vermitteln. Das Verhältnis zwischen den einzelnen und der Sippe wird immer von neuem ausbalanciert; und dies drückt sich nicht zuletzt durch die Notwendigkeit des ständigen Sich beweisen Müssens aus.

Verwandtschaft ist im $R H$ weit mehr eine Kategorie des kollektiven Wissens, eine Ordnung der öffentlich zur Anschauung gebrachten Personenbeziehungen, als eine des Blutes und eines gemeinsamen Sippenkörpers, dessen Glieder identische oder ähnliche Eigenschaften haben. Dementsprechend ist diese Ordnung auch störungsanfälliger, und ihre Wiederherstellung muss Schritt für Schritt den Weg ins Kollektiv und in die Öffentlichkeit suchen. Identität definiert sich in diesem Rahmen ausschließlich als soziale Identität, im Sinne von Luhmanns

\footnotetext{
472 al-Kulainī ar-Rāzi, Abu Ğáf́ar Moḥammad b. Ya'qub b. Isḥāq: Uṣūl-i al-Kāfi, Bd. 6, hrsg. von Moḥammad Āhuundi, Teherān 1379/2000, S. 49-50.
} 
„Inklusionsindiviualität“; ${ }^{473}$ dementsprechend definiert sie nicht die Person selbst, sondern diese wird von außen definiert, als Summe ihrer Beziehungen zu anderen Personen. Der Verwandtenkampf soll nur den Status des Helden stabilisieren.

Die Söhne Ḥamzes konkurrieren untereinander um Machtpositionen. Dabei stehen Badic azZamān und seine Söhne gegen 'Alam Šāh und dessen Söhne. Jeder will der Erbe von Ḥamzes Macht werden. Jeder versucht, sich als der „beste“ Sohn hervorzutun. Hier scheint die Erzählung durch die politische Lage des Irans beeinflusst zu sein. Wir wissen, dass im 13. bis 15. Jahrhundert Mongolen und Türken im Iran regierten, und dass es bei jedem Herrscherwechsel Bürgerkriege zwischen den türkischen Stämmen gab. ${ }^{474}$

Die rivalisierenden Parteien im $R H$ werden durch ihre Zugehörigkeit zum rechten bzw. linken Flügel in Hamze Heer bestimmt. Die Kämpfe zwischen diesen Parteien werden besonders im fünften Buch beschrieben. Die Herrschergewalt Hamzes wird durch Insignien wie den Thron, das Zelt oder das Pferd symbolisiert (2/239).

Hamzes Söhne wollen an die Stelle ihres Vaters treten, was auf der metonymischen Ebene in der Übergabe der ritterlichen Ausstattung deutlich wird. Sie verlangen von Ḥamze, dass er ihnen sein Pferd, seine Rüstung, seine Kleidung und sein Wappen übergeben soll. Dies ist der Anlass für viele Kämpfe zwischen Hamzes Söhnen. Denn die Kleider, Waffen und Rüstungen, an denen der Held zu erkennen ist, sind äußere Zeichen; auch die eigene Identifikation geschieht mittels konventioneller Zeichen wie Fahne, Pferd und Wappen. Ihr Besitz bedeutet einen sicheren Platz innerhalb der Hofgesellschaft. Es sind zugleich Rechtszeichen, die zuverlässiger sind als statusindizierende Kleidung. Um ihrer habhaft zu werden, wenden Hamzes Söhne eine List an. Sie verlangen mit verschleiertem Gesicht von Hamze auf dem Schlachtfeld die äußeren Insignien. Ḥamze aber weiß, dass er seine Macht verliert, wenn er ihnen diese Sachen gibt.

Badic az-Zamān wird von seinem Vater verstoßen, und seine Neffen bringen ihn um das Erbe. Er muss sich mit eigener Kraft einen Machtbereich aufbauen, um so die Voraussetzungen dafür zu schaffen, seine Brüder zu besiegen. Auf diese Weise kann es ihm gelingen, nach langen Jahren seine wichtigsten Getreuen zu befreien, die ihm in Zeiten der Not beigestanden haben. Er reitet allein in unbekannte Länder und besiegt viele der Herrscher im Osten. Sein Sohn Nur ad-Dahr vertritt ihn am Hof von Ḥamze und Landehur, Karib und Asad unterstützen ihn (4/577). Später erscheint Badic az-Zamān unerkannt auf dem Schlachtfeld und verlangt von Ḥamze, ihm die Macht zu übergeben. Ḥamze hegt zwar große

473 Vgl. Luhmann, Niklas: Individuum, Individualität, Individualismus, in: Niklas Luhmann: Gesellschaftsstruktur und Semantik. Studien zur Wissenssoziologie der modernen Gesellschaft, Bd. 3, Frankfurt/M 1989, S. 149-258. 
Sympathien für ihn, aber er will noch nicht seine Herrschaft abgeben. Schließlich kommt es zu einer Aussprache, und Vater und Sohn versöhnen sich. Dieser Vorgang verdeutlicht die Tatsache, dass es sich hierbei auf der einen Seite um einen massiv gestörten Sippenverband (Hamze) handelt, dem aber andererseits die unbedingte Loyalität zwischen Herrscher (Badic az-Zamān) und Gefolgsleuten gegenübersteht. Der nicht auf Verwandtschaft, sondern auf bedingungsloses Vertrauen gestützte Personenverband wird so als ein zuverlässiges Bündnis dargestellt im Gegensatz zum archaischen Sippenverband, der sich als verlogen und intrigant präsentiert. Hier zeigt das $R H$ ein neues Konzept von Herrschaft, so wie es bei den Türken zu finden ist $(3 / 511)$.

Rache

Zum Ethos des Adligen gehört die als ğavānmardi (Edelmut) bezeichneteAchtung vor dem Gegner, der immer als Ebenbürtiger behandelt werden muss. Ein weiterer Wert, an dem sich das Handeln orientieren soll, ist die Menschenfreundlichkeit (mardomi), die sich vor allem im Verzicht auf Rache zeigt. Normalerweise strebt der Mensch danach, zugefügtes Unrecht durch Vergeltung am Beleidiger zu rächen. Diese primitive Anschauung ist auch in der Rittergesellschaft selbstverständlich. Rache, insbesondere Blutrache, ist Pflicht, sogar gottgewollt. Im گ̌āh-nāme ist ein sehr großer Teil des Gedichtes über Siyāvaš der Blutrache für Siyāvaš gewidmet. „Nach der Ermordung des Siyāvaš zieht Rostam, um Rache zu nehmen, nach Turān, erobert und verwüstet es völlig bis China hin, beherrscht es 7 Jahre lang und räumt es dann wieder ganz.“475

Im $R H$ herrscht die Tendenz vor, dass Rache, weitere Rache hervorruft. So kämpft Ṭarmāsb mit seinem Großvater 'Anqavil und tötet ihn (5/822). Als Ṭahmāsb b. 'Anqavil erfährt, dass sein Vater durch seinen eigenen Sohn getötet worden ist, kommt er zu Nur ad-Dahr und bittet diesen um die Erlaubnis, an seinem Sohn Rache nehmen zu dürfen. Nur ad-Dahr gestattet dies unter der Bedingung, dass sein Sohn nicht getötet werden dürfe, und Ṭahmāsb akzeptiert dies (5/830). Kurz darauf fordert Ṭahmāsb seinen Sohn auf, zu Gott zu beten und in Nur ad-Dahrs Dienste zu treten, so dass ihm seine Sünden vergeben werden. Ṭarmāsb lehnt ab, woraufhin Ṭahmāsb in Wut gerät und ihn tötet. Daraufhin will Ğarmāsb, Ṭarmāsbs Sohn, seinen Vater rächen. Er unterliegt jedoch und wird von seinem Großvater getötet (5/904).

\footnotetext{
${ }^{474}$ Roemer, S. 131-132.

475 Nöldeke, Theodor: Das iranische Nationalepos, in: Grundriss der iranischen Philologie, zweiter Band, S. 170.
} 
Die islamische Ethik kennt sehr wohl das Verbot rachsüchtiger Gesinnung. ${ }^{476}$ Zorn und Rachsucht sind verboten, denn durch beide kann man seine Seele zu Grunde richten. Dem Feind soll man auf seine Bitte hin Schutz und Sicherheit gewähren. Verzeihen können ist ein Zeichen vornehmer Gesinnung. Ein Beispiel des religiös motivierten Verzichts auf Rache kann man in der Episode sehen, in der Ḥamze 'Anqavil nicht tötet, als er ihm in die Hände fällt, obwohl `Anqavil im Dienst Zomorrods viele Krieger Ḥamzes getötet hat (4/634).

\section{Wettkampf}

Das Hauptmerkmal einer Kriegerkultur sind zwei Dinge: Tapferkeit und Ehre. Das eine ist das herausragende Kennzeichen eines Helden, das andere sein wichtigstes Ziel. Jede Wertung, jedes Urteil, jede Tat, alle Fähigkeiten und Fertigkeiten haben zum Zweck, größtmögliche Ehre zu erlangen auch unter Einsatz des eigenen Lebens. Es liegt in der Natur der Ehre, dass sie exklusiver Natur sein muss. Wenn jedermann das gleiche Mass an Ehre erlangt, dann gibt es für niemanden Ehre. Aus innerer Notwendigkeit heraus ist deshalb die Welt des $R H$ so außerordentlich kämpferisch, denn jeder Held sucht, den anderen zu übertreffen. Und weil die Helden Krieger sind, entbrennt der Wettkampf am heftigsten, wo es die höchste Ehre zu gewinnen gibt, und zwar im Einzelkampf auf dem Schlachtfeld. Dort erlangt der Held die größte Ehre, darin sieht er den Sinn seines Lebens. Drei Vorraussetzungen müssen dazu gegeben sein: die Person, mit der er kämpft, muss ebenbürtig sein; die Art und Weise, wie er kämpft muss ehrenhaft sein; und wie er sich vom Schlachtfeld entfernt, muss bescheiden und edelmütig sein.

Wettkampf in jeglicher Form hat im öffentlichen Leben der iranischen Helden immer eine große Rolle gespielt. Zur Ehre ihres Namens und auch zum Ruhme ihrer Familie und Gefährten beteiligen sich die Helden im $R H$ immer wieder an Wettkämpfen. Das $R H$ berichtet von einer großen Rivalität zwischen Ḥamzes Söhnen. Das Oberhaupt des rechten Fügels, Badi` az-Zamān, kämpft gegen seinen Neffe Qāsem, der das Oberhaupt des linken Flügels ist. Jeder von ihnen möchte sich bei Ḥamze als der Mächtigste beweisen. Schließlich ringen sie mehrere Tage erfolglos miteinander (3/511).

Selbstdarstellung der heroischen Identität im Kampf

Im $R H$ kommt der Gedanke an das völlig schuldlose Leiden und Sterben vieler Menschen im Krieg, den die Großen der Erde führen, nicht zum Ausdruck. Da gibt es keine Sehnsucht nach Frieden, wichtiger sind Ehre, Ruhm und Treue. Getötet zu werden ist leichter zu ertragen als

\footnotetext{
${ }^{476}$ al-Kulainī, Uṣūl-i al-Kãfi, Bd. 3, hrsg. von Ṣadr-Aḥmad Ḥāğğ Seyyed Ğavādi, Teherān o.J., S. 169-174.
} 
Schande. Das Heer denkt an den Ruhm ebenso wie der Feldherr, der sein Leben im Kampf aufs Spiel setzt. Die Helden sind sehr damit beschäftigt, für sich selbst Ruhm zu erlangen. Die Selbstdarstellung ihrer heroischen Identität ist ein wichtiger Anlass für kriegerische Aktivitäten. Sie spielt gerade in Zeiten des Zerfalls der politischen Ordnung eine große Rolle. Die Helden sind entschlossen, Hamze ohne Rücksicht auf die Gefahren für sich und andere in den Krieg zu begleiten. Eine bessere Art, sich zu beweisen, gibt es nicht. „Held werden bzw. bleiben“ ist die einzig positiv bewertete Handlungsperspektive. Im $R H$ lässt sich erkennen, dass nur der Aufstieg in der Rangskala überlegener Gewalt noch mehr heroische Identität und Ansehen verleiht. Karib hat zu beweisen, dass er ein Held ist und wie ein Held zu kämpfen weiß. Er will sich mit Ḥamzes Helden messen. Deshalb kann er erst vor Ḥamze erscheinen, nachdem er viele Heldentaten vollbracht hat (2/273-282).

Neid und Eifersucht

Eifersucht und Neid sind ebenfalls wichtige Triebfedern und Motive, die kämpferische Auseinandersetzungen entstehen lassen. Jeder Held ist für sich und seine Ehre verantwortlich. Zwar besitzt jeder von Geburt an seinen Rang, doch fordert gerade das System höfischer Anstandsregeln und Bräuche $\mathrm{zu}$ provozierenden Worten, Gesten oder Handlungen des Rangniederen gegenüber dem Ranghöheren heraus, was dann Konflikte zur Folge hat, die gewaltsam ausgetragen werden. Dafür mag der Konflikt zwischen 'Alam Šāh und Karib stehen: Nachdem Karib viele Heldentaten vollbracht hat, wird 'Alam Šāh auf ihn neidisch. 'Alam Šāh beleidigt Karib, indem er ihn schlägt. Karib schlägt zurück und verursacht in Ḥamzes Lager eine wilde Prügelei und verlässt danach das Lager. Ḥamzes schickt 'Alam Šāh zu Karib, um sich bei ihm entschuldigen und ihn ins Lager zurück zu bringen (2/287).

Beute

Ein wichtiger Antrieb für den Krieger ist das Streben nach Beute. Immer gehören die Angehörigen und das Eigentum des Besiegten dem Sieger. Hạmzes Söhne verlassen den väterlichen Haushalt und gründen ihr eigenes Anwesen. Ihr persönliches Eigentum ist ein bedeutender Machtfaktor für sie. Dazu gehören auch ihre gefüllten Vorratsräume, die für sie und die Gefolgsleute bereit stehen. Einen Krieg zu beginnen, bedeutet aus ihrer Sicht nicht nur, die Ungläubigen zu bekehren, sondern gibt ihnen auch die Gelegenheit für Beutezüge, um sich zu bereichern. Asad überfällt mehrere Malek Irağs Lager, plündert seine Schatzkammer und beschenkt mit dem Inhalt seine Soldaten und Freunde (5/807).

An anderer Stelle lesen wir, dass ب̣amze sich in 'Amrs Tochter verliebt. Dieser verlangt viel Geld und Geschenke. Hamze schickt 'Amr b. Karib nach Indien, um das nötige Geld von 
Landehur auszuleihen. Unterwegs begegnet 'Amr b. Karib den Gefolgsleuten von Fariborz b. Qāren. Er plündert sie aus und bringt die Güter und das Geld zu Ḥamze. Daraufhin kann Ḥamze 'Amrs Tochter heiraten. Als Fariborz b. Qāren darüber informiert wird, dass 'Amr b. Karib sein Geld und die Güter geplündert hat, zieht er in den Kamf und nimmt Ḥamze gefangen (2/308-310).

In manchen Fällen dient selbst der ğehād lediglich als Mittel, um rein weltliche Ziele zu verfolgen. Die großen Erfolge der Kriege unter Ḥamze bringen den Kämpfern reiche Beute ein. Mitunter scheut sich die Erzählung nicht, das Handeln ihrer Helden mit dem von Dieben zu vergleichen (1/133).

\section{Verrat}

Ein weiterer Anlass, um einen Krieg zu beginnen, ist Verrat. So geht Behzād, ein Gefolgsmann Nur ad-Dahrs, zu Irağ über, nachdem er von diesem besiegt und gefangengenommen wird. Er schlägt Irağ vor, Nur ad-Dahr zu töten. Irağ lehnt ab, doch als er betrunken ist, schreibt Behzād einen Brief, mit dem Auftrag, Nur ad-Dahr zu töten, und besiegelt dies mit Irağs Ring. ${ }^{477}$ Der Brief wird durch einen Kundschafter nach Faranqušiye geschickt. Der Kundschafter fällt unterwegs Asads Kundschaftern in die Hände, die den Brief entdecken, und Asad informiert Nur ad-Dahr über den Verrat (5/757-758).

\subsection{Kriegsszenen}

Da es sich bei Ḥamzes Auseinandersetzungen um einen gerechten Krieg handelt, kann Hamze immer ohne Probleme seine Helden und Freunde zu der Teilnahme an einen Heereszug überzeugen. Denn der Krieg wurde grundsätzlich als Anrufung Gottes gesehen, bei dem nur derjenige, der das Recht auf seiner Seite hatte, von Gott Hilfe erwarten konnte.

Im $R H$ kommt es zu einer massiven gegenseitigen Spionage zwischen dem muslimischen Herrscher und seinen Helden einerseits und den Feinde des Islam sowie den Vereinigten Staaten und ihren Verbündeten andererseits. Deswegen schickt Ḥamzes zuerst seinen Kundschafter in die Kriegsgebiete. Sie übernehmen die Tätigkeit von Spionen bzw. Agenten. $\mathrm{Zu}$ ihren Aufgaben gehört die Nachrichtengewinnung über menschliche und militärische Quellen und diese militärtechnischen Geheimnisse zu ihren muslimischen Feldherrn zu schicken.

Hamzes Freund und Kundschafter 'Amr, der als Meister der Spione bekannt ist und dessen Intelligenz als qal`e-gir-e bi ğang (Eroberer der Festungen ohne Krieg) im $R H$ betont wird, 
arbeitet in den Kriegsgebieten. Um in die feindlichen Städte eindringen zu können, benutzt er verschiedene Methoden. Diese sind Verkleidung, als Musiker, Geschäftsmann oder Priester, und die Ermordung von Wachmännern sowie die Aushebung von Tunneln. Zu seinen Abwehrmaßnahmen gegen entsprechende Maßnahmen fremder Kundschafter gehören die Entführung von Staatsmännern, der Kampf mit feindlichen Kundschaftern und die Zerstörung von Festungen, Wasserkanälen und Palastanlagen (4/535-538).

Später reiten die Nachschubstruppen, die im Laufe des Krieges die Soldaten versorgen müssen, zu den Schlachtfeldern. 'Amr b. Ma'di Karib, der am Hof der Veranwortliche für Logistik und Transport von Waren und Vieh ist (1/25), bereitet 12.000 Kamele, auf denen Hamzes Kostbarkeiten, wie sein tragbarer Zeltpalast, Belagerungswerkzeugen, Zusatzwaffen und Lebensmittel transportiert werden, vor. Hamzes Rüstung wie der Ringpanzer, der Topfhelm und der Schild befinden sich in den Kisten. Die Zelte mit den Lebensmitteln und Restwaffen, schützte man durch Kundschafter, die als Wachmänner zuständig waren.

Ganz am Ende reiten Hamze und seine Feldherren zum Schlachtfeld. Er und seine Ritter lassen die Zelte aufbauen, auf die auch die Heeresfahne aufgepflanzt werden.

Ḥamze hat keine Fußsoldaten und versucht nur mit Berittenen, die Welt zu erobern. Was ihm jedoch gelungen ist. Das Heer selbst besteht aus drei Abteilungen. Die wichtigste ist in der qalb (Mitte), in der sich die Vorhut aus Bogenschützen und Armbrustschützen befinden. Im dast-e rāst (rechten Flügel) und dast-e čap (linken Flügel) befinden sich die Ritter. Dem Heereszug folgten schließlich noch Kaufleute, die bei solchen Gelegenheiten reichlich Gewinn machten, Dienstleute und Muiskanten.

Im Allgemeinen reitet den Heeren ein starker 'alamdār (Fahnenträger) voran, der das besondere Ziel der gegnerischen Truppen ist. Denn das Entreißen der Fahne, die zur Sammlung der Kämpfenden dient und auf der häufig das Wappen des Fürsten abgebildet ist, kann schon zum Sieg führen (1/28). Die Fahnenlosen wurden dadurch nämlich völlig demoralisiert.

Die Größe der Heere ist gewaltig. Selbst gemessen an heutigen Maßstäben sind die im $R H$ dargestellten Heere riesig. Z.B. im Kampf zwischen Irağ und Nur ad-Dahr bieten Irăg, Dārāb und Mālek Aštar je 700.000 Mann auf, Lāhut 300.000 und Turağ 40.000. Insgesamt kämpfen so 2.440.000 Männer unter Irağ (5/760). Um die Schrecken des Krieges in besonders eindringlicher Weise $\mathrm{zu}$ verdeutlichen, brauchen die Helden außergewöhnliche Soldaten. Im Kampf gegen Irağ setzt Nur ad-Dahr die Menschenfresser ein (5/760).

${ }^{477}$ Schenda, Rudolf: Brief, in: EM, Bd. 2, Göttingen 1979, Sp. 784-789, hier Sp. 786; vgl. AaTh, (Motiv. 
Waren die Ḥamzesmänner bereit zu kämpfen, konnte mit den gegnerischen Truppen Ort und Zeit der stattzufindenen Schlacht vereinbart werden. Wie es im Heer kurz vor einer Schlacht aussehen konnte, beschreiben die Autoren des $R H$ :

Nachdem das Heer geordnet und vollzählig ist, setzten Ḥamzes Soldaten zur Vorbereitung.

Am Tag der Schlacht wurden die Helden mit Schlachtgesang und Kriegsgeschrei, begleitet von Pauken, Trommeln, Hörnern und Posaunen ins Schlachtfeld geführt. Die Helden werden in ihren Kämpfen stets von ihren Knappen und Kundschafter begleitet, die aber nur ins Kampfgeschehen direkt eingreifen durften, wenn ihr Herr stürzte oder in Lebensgefahr schwebte. Die Kämpfer tragen ihre beste und prachtvolleste Rüstung (1/82/16-23), (1/84/2328), (1/135/4-10), (1/136/1-9), (1/157/28-31).

Kriegsszenen sind im $R H$ fantastisch übertrieben beschrieben. Im Kampf können durch das Strahlen der Waffen und Rüstungen ebenso wie durch das Zerstören dieses Glanzes Dominanz- und Machtverhältnisse ausgedrückt werden. Der Glanz der Rüstung ist ein aggressiver Glanz, der die gleiche Funktion hat wie Lärm und lähmende Angst verursacht.

Bei der starken Anspannung aller Kräfte im Kampfe rinnt den Helden der Schweiß in Strömen auch über Rüstung und Ross. Unter der Wucht der Hiebe geben die stärksten Helme nach, gehen die Schilde in Stücke, die Panzer und Kettenhemden werden durchschlagen, die Schwerter schlagen gewaltige Wunden oder zerspringen gar im hitzigen Kampf.

Im Kampf werden die Pfeile wie Regen vom Himmel fallen und aus den Leichen entsteht ein Gebirge. Viele Menschen in solchen Schlachten sterben. Die verwundeten Sieger dagegen erhalten intensive Pflege, aber meistens werden sie durch Wunder geheilt. Nach der Schlacht werden die eigenen Toten bestattet. Besonders eindruckvoll ist die Bestattung der Früsten, die mit großen Ehren und Traufeiern beigesetzt werden (4/666-667).

Die siegereiche Soldaten nehmen von den gefallenen, ehemaligen Feinde, die Rüstung, Ringe, Schwerter und Kettenhemde ab (1/177). Den Siegern einer Schlacht, die ohne Verletzungen davongekommen sind, winken Siegesfeiern, fürstliche Mahlzeiten (1/80).

Die Autoren des Werkes waren nicht immer unparteiisch. Sie lieben es, die Zahl der Toten ihrer Favoriten so gering wie möglich erscheinen zu lassen, während die Gegner manchmal das Mehrfache ihrer Heeresstärke verloren haben. Hamze spaltet seine Feinde mit einem Hieb, und bei den gewaltigen Kämpfen fließt das Blut in Strömen. Auf einen Schlag fallen 300.000 Männer (2/300). Ḥamze kämpft, bis kein Gegner mehr am Leben ist, oder einige wenige kopflos flüchten. Nach dem Sieg äußert sich die Freude des Siegers in ätzender Ironie über das Schicksal der Besiegten. 
Geriet das Heer in eine gefährliche Situation und muss sich zurückziehen, flieht es in eine Festung oder ins Gebirge um sich dort zu verteidigen (1/88). Nach einer verlorenen Schlacht jedoch verfinstert sich die Sonne, und auf dem leichenübersäten Schlachtfeld hat Ḥamze Mühe, seine toten Helden zu erkennen (5/871-872).

\subsection{Waffen, Kriegskleidung und Fahne}

In den Geschichten, die den Kampf zum Inhalt haben, ist die Rüstung ein sehr wichtiger Faktor. Im Altertum bestand die Ausrüstung der Ritter aus Pferdepanzer, Panzerhemd, Brustpanzer, Beinschienen, Schwert, Lanze, Schild, Keule, Streitaxt oder Kolben, Köcher (darin zwei Bogen, mehrere Sehnen und dreißig Pfeile), sowie aus zwei gedrehten Sehnen, welche der Reiter hinten an seinen Helm knüpfte. ${ }^{478}$ „Die Hauptwaffen im Kampf zu Pferd waren Lanze und Bogen. Wurde zu Fuß weitergekämpft, kamen im Kriegsgetümmel Schwert und Keule zum Einsatz, und am Ende eines Zweikampfes wurde der Gegner mit einem Dolch getötet. “479 Als Nationalwaffen symbolisieren tir, hadank, nāvak (Pfeil) und kaman (Bogen) das iranische Kriegertum. ${ }^{480}$ Dem Garšāshb-nāme zufolge hat eine Frau den Bogen erfunden. Ğamšid übernimmt die Erfindung, aber erst Manučehr bringt an den Pfeilen Federn an. ${ }^{481}$ Eine weitere Frau, Gord-āfarid, die Tochter Guždahams, die als Heldenweib bekannt ist, wird als kamand-afgand (Lassowerferin) gerühmt. ${ }^{482}$

Das Spannen eines einzigartigen Bogens ist eine gängige Kraftprobe und ein beliebtes Märchenmotiv. ${ }^{483}$ Die Beherrschung der Schusstechnik ist Voraussetzung für den Erfolg. Ein guter Schuss weist den Helden als Anführer aus. Bräute können häufig nur durch den Nachweis besonderer Geschicklichkeit im Bogenschießen gewonnen werden. ${ }^{484}$

„Bei Kraftproben mit Pfeil und Bogen handelt es sich oft eher um Geschicklichkeitsproben, da nicht nur die Muskelkraft des Schützen, sondern auch ebenso die meisterhafte Beherrschung der Schußtechnik Voraussetzung für den Erfolg sind. “ ${ }^{485}$

Die Kunst des Bogenschießens wird immer hoch geachtet. Zur pahlavān-Prüfung gehört daher die Handhabung von Pfeil und Bogen. Der Bogen eines Helden kann im Epos von niemandem außer ihm selbst gespannt werden. Dagegen wird im $R H$ ein Beispiel beschrieben,

\footnotetext{
${ }^{478}$ Vgl. Abkaci-Khavari, S. 95.

${ }^{479}$ Ebd. S. 96.

${ }^{480}$ Ebd.

${ }^{481}$ Asadi-Ṭusi, S. 23.

${ }^{482}$ Ferdousi, Bd. 1, S. 253; 'Adel, Moḥammad-Reżā: Farhang-e nāmhā-ye Šāh-nāme, Teherān 1372/1993, S. 385.

${ }^{483}$ Vgl. Abkaci-Khavari, S. 97.

${ }^{484}$ Stein, Hans Joachim: Pfeil, in: EM, Bd. 10, Göttingen 2002, Sp. 898-906, hier Sp. 903.

${ }^{485}$ Ebd.
} 
dass dieser Regel wiederspricht. Bahrām entdeckt im Basar der Stadt Borhāniye eine Armbrust und ein Säckchen Geld. Ihm wird gesagt, die Armbrust gehöre Kahrum, dem Recken des Königs. Jedem, der diese Armbrust spannen könne, solle das Geld gehören. ${ }^{486}$ Bahrām kann die Armbrust spannen, gewinnt das Geld und verteilt es unter das Volk (1/171172).

Das Schwert ( ̌̌amšir oder tiğ) ist eine weitere Hauptwaffe der Helden, die es ständig bei sich trugen. Es gehörte zum Schmuck der Helden, Könige und Prinzen. In öffentlichen Zeremonien trugen die Könige und Prinzen kostbare Schwerter. ${ }^{487}$ Ein Held musste schwertkundig (šamšir-zan) sein. In allen europäischen und asiatischen Kulturen war das Schwert in Volkerzählungen dominant, präsent und prägend. Beispielhaft sei hier nur die Artus-Sage erwähnt. ${ }^{488}$ „Das auf der Insel Avalon geschmiedete Schwert Excalibur, das Artus aus einem Stein zieht, verleiht ihm Königtum und Herrscherwürde.“489

Zweikampfwaffen charakterisieren den muslimischen Helden und verleihen ihm eine besondere Ausstrahlung, am symbolträchtigsten ist hierbei das Schwert. Das Schwert steht als pars pro toto für den Krieg. Der islamische Krieger vergleicht sich gern mit dem Schwertkämpfer 'Ali und sieht im Krieg eine Fortsetzung alter Traditionen, in welchen er sich nun bewähren muss.

Das Heldentum ist in den unterschiedlichen epischen Werken stets mit einer bestimmten Waffenart verbunden. Dies gilt auch für Hamze. Für ihn wird das Schwert das Symbol für seine rücksichtslose Eroberungspolitik und als tapferer und gläubiger Held wird er von Gott immer mit dem Sieg beschenkt. Sein Schwert, Șamșām, gehört in der historischen Wirklichkeit 'Amr b. Ma`di Karib. „'Amr selbst behauptet in einem oft zitierten Vers, [...] es habe Ibn Dhī ḳaifān vom Volk der 'Āéd gehört." “490 Schwarzlose ist der Ansicht, dass es vorher im Besitz des himjaritischen Königs Șaḥbān gewesen war. ${ }^{491} \operatorname{Im} R H$ benutzt Ḥamze dieses Schwert nur, wenn ein schwerer Kampf bevorsteht, so auch im Kampf gegen Irağ (5/1000).

Um ein Schwert zu gewinnen, das eines Helden würdig ist, muss man eine besondere Gabe haben. So sieht Irăg in Ḥamzes Audienzsaal ein Schwert, das Qobād kurz vor seinem Tod dort aufgehängt hat. Derjenige, der es aus seiner Scheide herauszuziehen vermag, soll es

\footnotetext{
${ }^{486}$ AaTh (Motiv. Der gelungene Schuß. 1890/1890 F). Siehe: Gerald, Thomas: Schuß, in: EM, Bd. 12, Göttingen 2007, Sp. 247-249, hier Sp. 247.

${ }^{487}$ Abka'i-Khavari, S. 98.

${ }^{488}$ Sir Thomas Malory: Die Geschichten von König Arthus und den Rittern seiner Tafelrunde, Erster Band, Leipzig 1973, S.18.

489 Tuczay, Christa: Schwert, in: EM, Bd. 12, Göttingen 2007, Sp. 418-421, hier Sp. 419.

${ }^{490}$ Levi Della Vida, Giorgio: Șamṣāma, in: EI, Bd. 4, Leiden/Leipzig: Brill 1934, S. 150-151.

${ }^{491}$ Vgl. Schwarzlose, Friedrich Wilhelm: Die Waffen der alten Araber, Hildesheim 1982, S. 128.
} 
behalten dürfen. Ḥamze und seine Helden haben es erfolglos versucht. Erst Irăg zieht das Schwert heraus und nimmt somit Qobāds Eigentum in seinen Besitz (4/701).

In einer von Kriegen geprägten Gesellschaft ist es geradezu natürlich, dass auch Waffen und Rüstungsgegenständen magische Fähigkeiten zugeschrieben werden. In den epischen Werken besitzen die Helden magische Waffen, die sie bei besonderen Gelegenheiten bekommen, normalerweise in einer sehr schwierigen Situation, in welcher der Held keinen anderen Ausweg mehr sieht. Die magischen Waffen sind ein Geschenk Gottes und entstammen somit einer himmlischen Quelle. ${ }^{492}$ Manchmal begegnet der Held einem sehr mächtigen Feind, den er mit keiner normalen Waffe besiegen kann. Hierzu braucht er dann eine magische Waffe. Manchmal wissen die Feinde des Helden alles über die magische Wirkung seiner Waffe, deshalb wird zuweilen versucht, solche Waffen zu stehlen.

In der islamischen Zeit glaubten die Menschen eher daran, dass Waffen und Rüstungen mit besonderen Eigenschaften von den Propheten stammten. David war Prophet und König; er erhielt von Gott Wissen, wurde mit besonderer Gnade ausgezeichnet und war sehr fromm. ${ }^{493}$ Gott lehrte ihn, Panzerkleidung anzufertigen. Der Koran sagt: „Gott machte für ihn das Eisen biegsam und forderte ihn auf, Kettenpanzer anzufertigen und die einzelnen Teile gut aneinanderzufügen. “494 Wenn David mit seiner Hand das Eisen berührte, wurde es weich wie Wachs. ${ }^{495}$

Im $R H$ ist die Kriegskleidung ein wichtiges äußeres Merkmal der Helden. Sie ist oft symbolbehaftet, insbesondere dann, wenn es sich um Kleidungsstücke handelt, die in der Vergangenheit von Helden, Propheten oder Heiligen getragen wurden. Die Helden streben danach, solche Kleider zu besitzen, da ihnen oftmals magische Eigenschaften zugeschrieben werden. Mit ihnen sind sie auch besonders geschützt (bis hin zur Unverletzbarkeit).

In der epischen Tradition zeigt sich in der Beschreibung der Kampfszenen und der Kämpfer eine deutliche Differenzierung. Im $R H$ sind die muslimschen Helden glanzvolle Erscheinungen, während die Feinde als häßliche Gestalten beschriebenwerden. Der Glanz gehört den muslimischen Helden nicht selbst, sondern er gehört dem Himmel, und er ist nicht schon von vornherein gegeben, sondern entsteht vor allem im Zusammenhang mit kämpferischen Aktionen gegen die Ungläubigen.

\footnotetext{
${ }^{492}$ Vgl. Huāleqi-Moṭlaq, Ğalāl: Babr-e bayān, in: Gol-e ranğhā-ye kohan, Teherān 1372/1993, S. 275-342, hier S. 288

${ }^{493}$ Koran, Sure. 27,15; Sure. 6,84.

${ }^{494}$ Koran, Sure. 21,80.

495 an-Neišāburi, Abu Isḥāq Ebrāhīm b. Manṣur b. Half: Qị̣aṣ al-anbiyāà, hrsg. von Ḥabib Yag̉māì, Teherān 1340/1961, S. 271.
} 
Die Personen in der Schlacht werden auf konventionelle Weise erkannt: an ihren Wappen und ihren Kampfrufen. Ḥamze ist mit seinem strahlend schönen Körper, seiner edlen Kleidung bzw. Rüstung, seiner Haltung und seinen Gebärden einzigartig. Der Glanz der gepanzerten Körperoberfläche verschafft ihm einen charismatischen Auftritt. Zuverlässige Orientierung auf dem Schlachtfeld bieten die Kleidung, Wappen und die Fahnen (3/385/7).

Als Herrscher der Welt hatte Ḥamze die höchste Macht erreicht. Er trug die prophetische Kleidung und Rüstungen, die ihn gegenüber den Feinden fast unbesiegbar gemacht hatte.

Ḥamze bekommt seine Rüstung von einem göttlichen Boten. Er begegnet einem unbekannten Ritter, der ihm das Hemd Yusofs, das Schwert Qamqāms ${ }^{496}$ und Soleimāns Schwert Ṣamṣām übergibt. Zudem erhält er sā'ed-band o zānu-band (Arm und Kniebinde) von Yuša ${ }^{497}$ und die muze (Schuhe) von Șāleḥ. Des Weiteren bekommt er den zereh (Panzer) von David und Esḥāqs Pferd (1/21).

Badic az-Zamān findet Davids magisches Gewand (4/560). Im Kampf gegen die Hexe trägt er Soleimāns Kleid und wird deshalb nicht verletzt (4/655). Die Hexen versuchen daraufhin vergeblich, das Kleid zu stehlen (4/656).

Besonders provokativ sind in aller Öffentlichkeit die Heldengewände aus Raubtierefellen. In der vorislamischen Zeit gab es im Iran den Mythos der Rüstung aus Drachenhaut, der man Unverwundbarkeit zuschrieb. ${ }^{498}$

Manche Helden haben ein spezielles Kriegskleid aus Leopardenfell. Karib kommt in den Audienzsaal des Eskandar b. Heikalān und sieht dort einen Helden, der einen Waffenrock aus Tigerfell anhat und ein šir-qollāb (Schnalle; 2/281/21) um seine Taille trägt. Karib denkt, dass er Eskandars Feldherr ist.

Jede Truppe des iranischen Heeres besaß ihre eigene Fahne. Die Fahnen der Truppen und der Helden bestanden aus einem Stoff bzw. einem Stück Leder in Form eines Tieres oder mit dessen Abbildung darauf. Bei den Persern waren solche Fahnen schon aus vorislamischer Zeit als kultisch-militärisches Symbol eines Männerbundes bekannt. Widengren vermerkt: „Die Männerbünde in vorislamischer Zeit hatten eine Fahne, die von schwarzer Farbe war und einen Drachen als Emblem trug, oder die Fahne selbst war in der Form eines Drachen gestaltet."499

\footnotetext{
${ }^{496}$ Pādešāh, Moḥammad: Qamqām, in: Farhang-e ānanderāğğ, Bd. 4, S. 3287.

${ }^{497}$ Im Alten Testament ist Josua/Joshua Nachfolger Moses als Führer der Israeliten; vgl. Geiger, Abraham: Was hat Mohammad aus dem Judentum aufgenommen, Leipzig 1902, S. 179.

${ }^{498}$ Huāleqi-Moṭlaq ist der Meinung, dass das berühmte Panzerkleid des Rostam, Babr-e bayān, in Wirklichkeit aus Drachenhaut sei. Siehe: Hāleqi-Moṭlaq, Babr-e bayān, S. 305.

${ }^{499}$ Widengren, Die Religionen Irans, S. 25.
} 
Im Garšāshb-nāme tötet Garšāsb den Drachen, dessen Haut unverletzlich ist, indem er seine Augen und sein Maul verwundet. In Erinnerung an diesen Sieg wählt er eine Fahne mit dem Abbild eines schwarzen Drachen unten und eines goldenen Löwen darüber aus. ${ }^{500}$ Ursprünglich gehört eine Fahne mit diesem Symbol zur Familie Rostam. Rostam und sein Sohn Farāmarz führen diese Fahne stets bei sich. ${ }^{501}$

Wann immer man über das iranische Selbstverständnis spricht, kommt die Rede ebenso auf den Rostams Heldentaten und seine Kriegsgegenstände vor. Im $R H$ imitieren die Helden dieses Vorbild. Auch Ḥamze besitzt eine Fahne eždehā-peikar (mit dem Abbild eines Drachen; 1/28).

Wappen sind metonymische Zeichen, und die Helden werden an ihren Wappen identifiziert. Die Erzähler des $R H$ haben bewusst ihren Helden positiv besetzte Wappentiere zugeordnet im Unterschied zu negativ besetzten Wappentieren, wie dem Schwein, die sie ihren Feinden andichteten.

Ḥamzes Armee ist nach den Prinzipien türkischer Heere organisiert (vgl. 4/685). Das seldschukische Heer war in drei Abteilungen, dem Zentrum sowie dem rechten und dem linken Flügel aufgeteilt. Die Flügel standen unter dem Befehl von Emiren, wobei der Emir des rechten Flügels im Rang höher stand als der des linken Flügels. ${ }^{502} \mathrm{Im}$ Orientierungssystem der Nomaden Zentralasiens befanden sich der Norden rechts und der Süden links. ${ }^{503}$ Diese Ordnung wurde bis zur Timuridenzeit beibehalten.

Da das $R H$ aber hauptsächlich vom militärischen Kampf handelt, sind dies bezügliche Berufe und Dienstgrade hier sehr deutlich in der Überzahl: z.B. der amir al-omarā’’(Feldmarschall; 5/932/30), ${ }^{504}$ der qū

\footnotetext{
${ }^{500}$ Asadi-Ṭusi, S. 63.

${ }^{501}$ Hāleqi-Moṭlaq, Babr-e bayān, S. 322.

${ }^{502}$ Bei den Mongolen hatte die rechte Seite auch eine große Bedeutung. „Der Ausdruck, ,ich will deine rechte Hand sein" enthält das Versprechen der Heeresfolge und der kräftigen Mitwirkung an den kriegerischen Unternehmungen des Groß-Chans. Siehe: Sagang, Sečen: Geschichte der Mongolen und ihres Fürstenhauses, Zürich 1985, S. 462; vgl. Pritsak, Omeljan: Orientierung und Farbsymbolik: Zu den Farbenbezeichnungen in den altaischen Völkernamen, in: Saeculum V (1954), S. 377-383, hier S. 379.

${ }^{503}$ Vgl. Pritsak, S. 377; vgl. Gabain, Annemarie: Steppe und Stadt im Leben der ältesten Türken, in: Der Islam 29 (1949), S. 30-62, hier S. 34.

504 Amir al-omarä' war in der Timuridenzeit der Inhaber der höchsten militärischen Befehlsgewalt. Siehe: Röhrborn, Klaus-Michael: Regierung und Verwaltung Irans unter den Safawiden, in: Handbuch der Orientalistik, 1. Abt.: Der Nahe und der Mittlere Osten, Bd. 6: Geschichte der islamischen Länder. 5. Abschn., Teil 1: Regierung und Verwaltung des Vorderen Orients in islamischer Zeit. hrsg. von Bertold Spuler, Leiden/Köln1979, S. 17-57, hier S. 20. Auch in der frühen Ṣafavidenzeit gehörte dieses Amt zu einem Würdenträger, dem Hosein Beg lala. Siehe: Savory, Roger M.: The Safavid Administrative System, in: CHI, Bd. 6, hrsg. von Peter Jackson and Laurence Lockhart, Cambridge 1986, S. 351-373, hier 358.

505 qūrč̌ wurde nur für die Reitergarde des Hofes gebraucht. Siehe: Röhrborn, S. 35.

${ }^{506} \boldsymbol{q} \bar{o} \boldsymbol{r}$ č̌̀ $\mathbf{b a ̄ s ̌ ̆ ~ w a r ~ d e r ~ F u ̈ h r e r ~ d e r ~ R e i t e r g a r d e . ~ S i e h e : ~ R o ̈ h r b o r n , ~ S . ~} 36$.
} 
Selbstverständlich ist, dass man im Krieg treue Krieger in großer Zahl zu Seite haben muss, die dem Helden zu jeder Zeit beistehen können. Ḥamzes Armee wird mit jeder Eroberung größer, da sich ihm stets die Armeen der unterlegenen Feinde anschließen. Der Kern von Ḥamzes Armee besteht zunächst aus arabischen Truppen (1/24). Das Heer, das für die gerechte Sache des legitimen Königs kämpft, siegt auch, wenn Ḥamze nicht dabei ist.

Im $R H$ lesen wir über zahlreiche kriegerische Ereignisse und die damit verbundenen häufigen Feldzüge. Hamzes Heere tragen das ihrige zur Verelendung der Bevölkerung und zur Verwüstung der Länder bei. Hamzes Truppen pflegen nach der Eroberung die Städte zu plündern und auszurauben (5/879). Die Soldaten nehmen die Menschen gefangen und verschleppen sie, stehlen ihnen Geld und Lebensmittel und rauben ihr Vieh. Dies verursacht bei den Menschen in den eroberten Ländern immer heftigere Angst und lässt sie vor den Truppen fliehen.

\subsubsection{Ehe, Liebe und Sexualität}

Eros und Liebe spielen eine große Rolle im Leben der Menschen. Liebe verleiht dem Leben der Menschen Freude und Bedeutung. Westliche Wissenschaftler wie Röhrich betrachten Sexualität als ein Kommunikationsmedium.

„Sexualverhalten ist Kommunikation, ist ein Sozialverhalten, das von
kulturellen Normen bestimmt wird und dementsprechend historischem und
gesellschaftlichem Wandel unterworfen ist. Dabei hat die Einstellung
gegenüber dem Erotischen oft gewechselt. Jede Epoche hat ihr eigenes
Verhältnis zur Erotik, und die Entwicklung verläuft nicht geradlinig,
sonderneher in Wellenbewegungen im Wechsel zwischen sinnesfreudigen und
sexualfeindlichen Strömungen. “507

Seit frühester Zeit war im Iran erotische Literatur sehr beliebt. Die Kühnheit der romantischen Epik beruht auf der leidenschaftlichen Seite des menschlichen Herzens. In der iranischen Literatur findet man überall die schönsten Beispiele des romantischen Epos. Hosrou Parviz soll 12.000 Frauen in seinem Harem gehabt haben. ${ }^{508}$ Bahrām Gōr hat für seine sieben Geliebten sieben Paläste gebaut. ${ }^{509}$ Farrohn-ruz, Horšid Šāhs Sohn, heiratete in einer einzigen Nacht vier Frauen. ${ }^{510}$

In der frühislamischen Zeit wurden aufgrund der islamischen Gesetze und der islamischen Bildung die Entsexualisierung der Erzählungen und die Verdrängung der erotischen Szenen

\footnotetext{
${ }^{507}$ Röhrich, Lutz: Erotik und Sexualität im Volksmärchen, in: Liebe und Eros im Märchen. Veröffentlichungen der europäischen Märchengesellschaft, Bd. 11, Kassel: Röth 1988. S. 21.

${ }^{508}$ Abka'i-Khavari, S. 84.

${ }^{509}$ Neẓāmi, Haft-peikar, S. 690.
} 
ganz bewusst als Ziel verfolgt. Manche Theologen und Gelehrten waren sogar geneigt, das Lesen und Hören der persischen Erzählungen und Romane wie Vis o Rāmin zu verbieten. ${ }^{511}$ Sie betrachteten solche Erzählungen als Instrumente der Zerstörung der Volksseele, die die öffentliche Moral untergraben. ${ }^{512}$ Deshalb sind die Liebesszenen mit größter Zurückhaltung geschildert. Der Held hat vor der Hochzeit keine Beziehung zu seiner Geliebten. Im Laufe der Zeit, besonders im 10. und 11. Jahrhundert, wurde wegen der politischen und sozialen Änderungen im Iran das Interesse an der Liebe und den Formen des menschlichen Sexualverhaltens stärker. ${ }^{513}$ In der ghaznavidischen Zeit existierte ein großes Interesse an Themen wie Liebe und Schönheit und eine große Vorliebe für erotische Literatur. ${ }^{514}$ Am Hof der ghaznavidischen Könige begannen die Dichter, sich mit Liebesromanen zu beschäftigen. Mehrere romantische Epen entstanden am Hof Solțān Mạ̣muds. ${ }^{515}$ Im Laufe der Zeit nahmen erotische Motive in der Literatur und Malerei zu, insbesondere vor und während der șafavidischen Zeit. ${ }^{516}$

Wie die Lyrik und die Epik des 10. Jahrhunderts hatte Ferdousi eine durch das islamische Recht geformte Gesellschaft vor Augen. Außerdem konnte man im ک̌āh-nāme starke asketische Tendenzen in den Liebesgeschichten entdeckten. Die Liebe zwischen Zāl und Rudābe wurde als sittliches und ästhetisches Ideal dargestellt, jedoch wurde auch auf die Endlichkeit und Unvollkommenheit des menschlichen Lebens hingewiesen. ${ }^{517}$ Im Gegensatz zu Ferdousi nahm bei den späteren Erzählern der Anteil an erotischen Szenen zu. Lust und Fantasie wurden aus der Perspektive der Männer dargestellt. Dies war nachvollziehbar, denn die Rolle der Frau in den islamischen Gesellschaften war in Liebesdingen sehr eingeschränkt. Sie konnte ihre Reize nicht offen zeigen, Kontaktanbahnungen zum anderen Geschlecht waren kaum möglich und voreheliche Beziehungen nicht erlaubt. Dadurch war es umgekehrt natürlich auch für die Männer meist nicht möglich, ihre Lust auf das andere Geschlecht erfüllt zu erleben. Um dieser Neugier und diesen unerfüllten Sehnsüchten der Männer gerecht zu werden, gab es in den Erzählungen sehr offene erotische Darstellungen, aber eben nur aus der Perspektive der Männer. Trotz der Strenge des Islams war damals die erotische Literatur in den Volkserzählungen wesentlich offener als vergleichbare Erzählungen in der Literatur

\footnotetext{
${ }^{510}$ al-Arrağāni, Bd. 5, S. 1-10.

${ }^{511}$ Anonymus, Bahr al-fawāyed, S. 140.

512 Ebd. S. 143.

${ }^{513}$ Saafā, Hamāse-sarā’i dar Irān, S. 156-158; Cejpek, Iranische Volksliteratur, S. 481.

514 Vgl. Ethé, Neupersische Literatur, S. 240; Cejpek, Iranische Volksliteratur, S. 481; Hanaway Jr., William L.: Epic Poetry, in: Persian Literature, hrsg. von Ehsan Yahrshater, Columbia Lectures on Iranian Studies. 3, (1988), S. 105.

515 Ethé, Neupersische Literatur, S. 240; Afšār, Eskandar-nāme, S. 431; Anonymus, Moğmal at-Tawārih wa'I-qeșas, S. 92.

${ }^{516}$ Vgl. Wiebke, Walther: Die Frau im Islam, Stuttgart 1980, S.127.
} 
Europas. ${ }^{518}$ So wird im Eskandar-nāme erzählt, dass Eskandar jede Nacht bei mehreren Jungfrauen verbringt. 519

Im Folgenden werden die allgemeine Einstellung zur Sexualität (ihre Unterdrückung oder Betonung) sowie, die Formen ihrer Verwirklichung (übliche und tabuisierte Praktiken) im $R H$ untersucht. Im zweiten Teil soll die Darstellung von Sex als rein physisches Vergnügen im Unterschied zur lebensbestimmenden Liebe, die sich unschuldiger Gesten und lyrischer Ausdrücke bedient, untersucht werden.

Schon in der Wortwahl kommt die Erotik im $R H$ klar zum Ausdruck. Nähe und Distanz zwischen Mann und Frau drücken sich im Blickkontakt aus. So ist z.B. der erotische Blick eine ausgesprochen männliche Angelegenheit. Der Anblick einer Frau ruft den Wunsch hervor, sie sexuell zu besitzen. Die Schönheit der Frauen bzw. Mädchen versetzt den Helden regelmäßig in einen Zustand entflammter Liebe. ${ }^{520}$ Die Helden können sich auf den ersten Blick in ein Mädchen oder in ihr Bild verlieben (2/222-226). Sehr oft erblickt der Held ein schönes Mädchen und ist sofort in Liebe zu ihr entbrannt. Danach wird der Held ohnmächtig, oder ihm schwinden die Sinne. Auf diese Art und Weise nehmen sie den ersten Kontakt auf. Um die Prinzessin heiraten zu können, muss der Held sich erst beweisen. Oftmals muss er mit einem Drachen oder einem Dämon kämpfen, um eine Prinzessin aus seiner Gewalt zu retten.

Im $R H$ ist nachzulesen, wie Ḥamze und Mehrnegār mit wechselseitigen Blicken ihre emotionale Anziehung ausdrücken, was sie wiederum als Paar zum magnetischen Anziehungspunkt der allgemeinen Blicke macht. Die knisternde Erotik ist bei den Erzählungen sehr gut zu spüren. Das Bild des idealen Helden ist nicht vollständig, wenn nicht über seine außerordentliche Potenz und Manneskraft berichtet worden ist. Im $R H$ sind hochgradig erotische Szenen nachzulesen. Eine Szene beginnt damit, dass Ḥamze in Madā'en vom Perserkönig mit großer Freundlichkeit aufgenommen wird. Während eines Bades sieht Mehrnegār Ḥamze, und sie verliebt sich in ihn. Mehrnegār wirft eine Perle nach unten, um sich für Ḥamze bemerkbar zu machen. Plötzlich sieht Ḥamze die entblößte Königstochter Mehrnegār, die von außerordentlicher Schönheit ist, und er verliebt sich augenblicklich in sie. Die Möglichkeiten, Mehrnegār zu treffen, sind beschränkt, da sie nicht den Garten verlassen darf und der Garten auch von außen nicht zu betreten ist, da er von Wächtern kontrolliert wird. Deshalb klettert Ḥamze mit Hilfe eines Seils durch das Fenster zu seiner Geliebten, und es kommt zur ersten erotischen Begegnung: Er küsst, beißt und

\footnotetext{
${ }^{517}$ Ferdousi, Bd. 1, S. 233.

${ }^{518}$ Vgl. Röhrich, Lutz: Erotik, Sexualität, in: EM, Bd. 4, Göttingen 1984, Sp. 234-252, hier Sp. 251.

${ }^{519}$ Afš̄ār, Eskandar-nāme, S. 28.

${ }^{520}$ Elfriede, Moser-Roth: Frau, in: EM, Bd. 5, Göttingen 1987, Sp. 100-137, hier Sp. 111.
} 
streichelt sie, befühlt sie und treibt allerlei Weiteres mit ihr. Aber erst als Ḥamze bald darauf mit ihr die Ehe eingeht, kommt es zur tatsächlichen Vereinigung.

Eine weiteres Beispiel von 'Alam Šāh: Er hält sich in einem Garten auf, der auch von Šamseye Huāvari genutzt wird. Šamse kommt mit ihren Dienstleuten dorthin, um sich zu vergnügen. Eines Tages möchte sie im Wasserbecken schwimmen und entkleidet sich, wobei 'Alam Šāh sie heimlich beobachtet. Als er ihren schönen Körper sieht, ist der Prinz kurz davor, seinen Verstand zu verlieren (3/371). Diese Begegnung ist der Beginn der späteren erfolgreichen Eheschließung.

Höhepunkte der Schilderungen von Liebe und besonders Erotik sind die Hochzeitsnächte, die im $R H$ ausführlich und detailliert geschildert werden. In zahlreichen märchenhaften Geschichten und Erzählungen aus der frühislamischen Zeit wurde der geschlechtliche Verkehr zwischen Mann und Frau poetisch umschrieben dargestellt. Im Buch Samak-e 'Ayyā̄ beispielsweise wurden anfänglich die Hochzeitsnächte mit kriegerischen Begriffen wie dem eines Schlachtfeldes beschrieben; aber nicht offen hinsichtlich der sexuellen Details. ${ }^{521}$ In den späteren Werken beinhalteten die Schilderungen über die Hochzeitsnächte sehr viel Sexuelles; so ist im $R H$ ein deutlicher Wandel in der Betrachtung (und Beschreibung) der Erotik zu konstatieren. So lesen wir im $R H$ eine ausführliche Schilderung der Hochzeitsnacht des Ḥamze mit Mehrnegār:

ze bus o kenāraš šod kāmyāb;

čočašm-e botān karde āhang-e ḩॅ̄āb.

be dorr softan almās rā kard sāz;

sar-e dorğ o lacl-e gouhar kard bāz.

ḥariraš šod az zaḩm-e suzan donim;

gozar kard az āb-e gol čun nasim.

ze yāqut šod sang-e vei kāmyāb (1/192/11-12), (4/724/24-26), (5/773-8-14).

Auf Deutsch in freier Übersetzung etwa:

Vom Küssen und Nebeneinandersein wurde er glücklich.

Wie die Augen der Götzen haben ihre Augen die Absicht zu schlafen.

Sein Diamant [Penis] hat angefangen, ein Loch in ihre Perle [Jungfräulichkeit] zustechen.

Er hat den Kopf [Deckel] des Kästchens der Rubine und Edelsteine geöffnet.

Ihre Seide [Scheide] wurde von der Wunde des Nagels [Penis] in zwei Teile gespalten.

So ging das Blumenwasser [Sperma] wie eine leichte Brise hindurch.

Vom Rubin [Scheide] wurde der Stein [Penis] glücklich.

\footnotetext{
${ }^{521}$ al-Arrağāni, Bd. 5, S. 1-10.
} 
Im $R H$ wird Erotik als etwas Kostbares und Luxuriöses begriffen. Es gibt jedoch auch sehr offene, drastische sexuelle Schilderungen. Liebe ist dort nichts anderes als elementare Sexualität. So vergnügt sich 'Amr mit den Sklavinnen von Qoreiši Bānu, indem er sie küsst und ihre Brüste drückt. Als Ḥamze dazukommt, fordert 'Amr ihn auf, die Füße und Hände der Mädchen zu fesseln (5/885-886).

Eine andere erotische Szene sei hier kurz geschildert: Maryam-Nāhid sieht Ḥamze und verliebt sich in ihn. Sie, die zuvor noch Jungfrau ist, geht mehrmals in der Nacht in das Schlafzimmer des Ḥamze. Sie umarmt und küsst den schlafenden Ḥamze. Der nutzt gern die unerwartete Gelegenheit, nimmt aber wegen der Dunkelheit nicht wahr, wer ihn da liebkost. Als er einmal besonders schwer betrunken ist, nutzt sie die Gelegenheit und schläft mit Ḥamze, wobei sie schwanger wird (1/110-111). Ḥamze, der ja schließlich der Vorkämpfer des Islams ist, begeht hier eine für Muslime große Sünde, indem er (das einzige Mal im $R H$ ) mit einer Frau mehrmals schläft, ohne sie zuvor geehelicht zu haben.

Frauenraub

Das Motiv des Raubes genoss im Iran zur Zeit der Abfassung des $R H$ ungewöhnliche Popularität. Dies nutzten auch die Autoren im $R H$, die das Motiv dazu herangezogen, die Taten ihrer Helden aus zu gestalten. Insbesondere der Frauenraub ist im $R H$ eine beliebte Form der Heldentat, was durchaus den Gegebenheiten im damaligen Iran entspricht, denn der Krieg um eine Frau ist ein sehr oft vorkommendes Motiv in den iranischen Erzählungen. An dieser Stelle soll kurz untersucht werden, wie der Frauenraub im $R H$ beurteilt wird.

Wir lesen, dass Ṣalșāl eine Adoptivtochter namens Nesā hat. Sie kommt zu Șalṣāl und begegnet dort Hormoz, Anōširvāns Sohn. Sie verliebt sich in ihn, und beide verloben sich. Inzwischen sieht auch 'Amr Nesā und er verliebt sich in sie. 'Amr geht zu Ḥamze und erzählt ihm, dass er sich in Nesā verliebt habe, und daraufhin verspricht Hạze, ihm bei der Angelegeheit behilflich zu sein. Inzwischen heiraten Nesā und Hormoz offiziell und warten auf die Hochzeitnacht. Baḩtak versucht Șalṣāl von der Notwendigkeit einer sofortigen Heirat der beiden zu überzeugen, da ansonsten`Amr und Ḥamze die Heirat verhindern könnten. Letztendlich gelingt es 'Amr, Nesā zu entführen und sie zu zwingen, ihnzu heiraten (3/417423).

Ein anderes Motiv, dass in Rahmen der Liebesmotiv im $R H$ vorkommt, ist eine Form des Ödipus Syndroms. Fast überall auf der Welt ist es ein Tabu, dass Kinder ihre eigenen Eltern heiraten. „Das mythische Beispiel für den Inzest eines Sohnes mit seiner Mutter ist die 
Verbindung des Gayomart (Prototyp des Menschen) mit der Mutter Erde, Spandaramat, wodurch das erste Menschenpaar Mašyē und Mašyanē, gezeugt wurden. “522

Im $R H$ ist es Irăg, der sich in Giti-afruz verliebt, die jedoch seine unbekannte Mutter ist. Er sieht sie in einem Traum, verliebt sich in sie und umwirbt sie öffentlich. Er führt viele Kriege, um ihre Liebe zu erlangen. Giti-afruz ist traurig darüber, von einem Ungläubigen in dieser Form umworben zu werden, und die anderen Frauen von Ḥamze verspotten sie noch dazu. Irağ kommt bis vor die Festung, in der sie lebt, und rezitiert laut Liebesgedichte vor ihrem Fenster. Giti-afruz' Mann Qāsem hört von dieser Liebe und will Irağ töten. In einem ersten Kampf verletzt Irağ Qāsem schwer. Danach kämpft Ḥamze gegen Irăg, und dieser verliert den Kampf. Schließlich versteht Irağ, dass Giti-afruz seine Mutter ist und daher tabu für ihn. In einem anderen Beispiel lesen wir im $R H$ von Anōširvān, der in seine Tochter Qahr-e Gouhar-tāğ verliebt ist und sie heiraten will. ${ }^{523} \mathrm{Um}$ eine rechtliche Genehmigung zu erhalten, ruft er die Sachverständigen zur Beratung zu sich, um von ihnen die Erlaubnis zur Heirat zu bekommen (2/245-246). Diese Geschichte ist quasi identisch mit der Geschichte vom Bahman und seiner Tochter Homāy im Eskandar-nāme. ${ }^{524}$

\subsection{Homosexuelle Lebensgemeinschaft}

Eine Lebensform, deren ethische Einordnung unter verschiedenen Gesichtspunkten kontrovers diskutiert wird, ist die homosexuelle Lebensgemeinschaft. In Iran ist sie sowohl religiös geächtet als auch nach alter iranischer Tradition streng verboten und wurde mit dem Tode bestraft. $^{525}$ In der islamischen Zeit war sie ebenfalls streng verboten, wie man beispielsweise im Koran, sowie den hadit und fiqh-Werken sehen kann. Homosexuallität

\footnotetext{
${ }^{522}$ Khaleghi-Motlagh, Die Frauen im Schahname, S. 167f.

${ }^{523}$ In der vorislamischen Geschichte des Irans war die Blutsverwandten-Ehe (mittelpersisch. xwëdödah) sehr beliebt. „Als besonders verdienstvoll gilt die Blutverwandtenehe dann, wenn sie zwischen Vater und Tochter, Sohn und Mutter sowie Bruder und Schwester geschlossen wird." Im Avesta und in Pahlavischriften wurden solche Heiraten als die besten gepriesen. Wer nicht mit einem nahen Verwandten verheiratet sein mochte, beging eine große Sünde. So steht auch ganz außer Zweifel, dass es bei den alten Persern keinerlei Verbote in Bezug auf blutsverwandte Ehen gab. Bei den Muslimen sind solche Beziehungen eine große Sünde. Siehe: Stausberg, Michael: Die Religion Zarathushtras. Geschichte-Gegenwart-Rituale, Bd. 1, Stuttgart/Berlin/Köln 2002, S. 52; vgl. Herodot: Historien, Bd. 3, hrsg. von Josef Feix, München 1963, S. 389, 3, 31; vgl. Yarshater, Ehsan: Iranian National History, in: CHI, Bd. 3, Cambridge 1983, S. 410; vgl. Gignoux, Philippe: Le livre d'Ardâ Virâz, Kap. 7,4, ins Persische übersetzt und bearbeitet. von Žāle Āmuzegār, Teherān 1372/1993, S. 52; vgl. Marzolph, TPV (Motiv. Vater möchte seine Tochter heiraten. 706, 652A, 510B, 450), S. 269.

${ }^{524}$ Aus dem Buch Tãrih̆ ar-rusul wa-'I-mulūk erfahren wir von dem Inzest zwischen Bahrām-e Čūbin und seiner Schwester Gordiye. Siehe: aț-Tabarī, Tärīh ar-rusul wa-'l-mulük, Bd. 2, hrsg. von Abū 'l-Faḍl Ibrāhīm Moḥammad, Miṣr 1961, S. 178. Ein Beispiel für den Inzest einer Tochter mit dem Vater ist die Verbindung des Bahman mit seiner Tochter Homāy. Siehe: Ferdousi, Bd. 1, S. 1063; vgl. at-Ṭarsusi, Bd. 1, S. 10-11; vgl. Anonymus: Eskandar-nāme, Lithographischer Druck, Bd. 1, Jahr 1283 h/1866, S. 2.

${ }^{525}$ Vāḥedi-Navā’i, S.118.
} 
wird im allgemeinenals eine „schändliche Tat“ (fāhišsa) betrachtet. Über das Thema der sexuellen Beziehung zwischen zwei Männern sagt uns der Koran:

„Und die zwei von euch, die es begehen: straft beide. und wenn sie bereuen und sich bessern, dann laßt von ihnen ab. Siehe, Allah ist vergebend und barmherzig. “526

Die islamischen Gelehrten und Theologen widmeten sich ganz besonders dem Kampf gegen die Unzucht mit Knaben. ${ }^{527}$ Im Allgemeinen war und ist im Islam Unzucht zwischen Männern streng verboten; Knabenschändung sollte man mit dem Tod bestrafen. ${ }^{528}$ Rein männliche Sexualbeziehungen wurden und werden im Islam mit den heftigsten Worten verurteilt. ${ }^{529}$ Viele Rechtsgelehrte äußerten, dass liwāt noch viel schlimmer sei als zina'(Verkehr zwischen unverheirateten Mann und Frau). ${ }^{530}$ „Der Begriff liwāt ist im religiösen Sinne, definiert als ityānu ar-rağuli d.h. der Verkehr eines Mannes mit einem anderen Mann. “531 Jeder, der daran teilnahm war ein $\mathbf{l} \bar{u} \pi{ }^{532}$ Dies galt für denjenigen, der die Rolle des Penetrierenden übernahm, und jenen, der die Rolle des Penetrierten übernahm, gleichermaßen; dafür wurden die Begriffe $m a$ bun ${ }^{533}$ oder amrad benutzt. ${ }^{534}$

Aus sehr unterschiedlichen Motiven heraus werden die islamischen Rechtsgelehrten aufgefordert, sich zur ethischen Beurteilung von Homosexualität und homosexuellen Lebensformen zu äußern. Sie entsprechen der Erwartung einer Formulierung von Maßstäben zur Orientierung für eine ethische Bewertung. Meist ist das Resümee eindeutig: Du sollst nicht bei einem Knaben liegen, es ist ein Gräuel. ${ }^{535}$ Obwohl im Koran deutlich über die Bestrafung und nicht vom Tod die Rede ist, werden der Penetrierende und der Penetrierte mit dem Tode bestraft. ${ }^{536}$

\footnotetext{
${ }^{526}$ Koran, Sure 4,16.

${ }^{527}$ Dastġeib Širāzi, Seyyed ‘Abd al-Ḥosein: Gonāhān-e kabire, Bd. 1, Teherān 1361/1982, S. 194-199.

${ }^{528}$ Ebd. S. 198.

${ }^{529}$ Koran, Sure 7,78-79.

${ }^{530}$ Dastġeib Širāzi, Bd. 1, S. 196.

531 Zitiert nach: Bauer, Thomas: Liebe und Liebesdichtung in der arabischen Welt des 9. und 10. Jahrhundert, Wiesbaden 1998, S. 165.

${ }^{532}$ Bosworth, Clifford Edmund: Liwāț, in: $E I^{2}$, Vol. V, Leiden 1986, S. 776-779, hier S. 776.

${ }^{533}$ Ebd. S. 776.

${ }^{534}$ Bartloser Jüngling,der die Rolle des Penetrierten einnimmt. Siehe: Ibn al-Ğawzi, Abū al-Farağ 'AbdarRaḥmān: Damm al-hawā, hrsg. von Aiman al-Buhairī, Beirut, o.J., S. 85; Dehḩodā, Amrad, in: Logátnāme, ḥarf-e. an-Naği-Eiyou, hrsg. von Moḥammad Mocin, Teherān 1344/1965, S. 180. Anonymus: Hezār o yek šab, Bd. 1, lithographischer Druck 1275/1858, Nacht 131; Astarābādi, Bibi Hुānom: Ma ‘̄yeb ar-reğāl, Bd. 1, hrsg. von Afsāne Nağmābādi, Chicago 1371/1992, S. 62.

${ }^{535}$ Dastgeib Širāzi, Bd. 1, S. 194-199.

${ }^{536}$ In sieben islamischen Ländern kann homosexueller Geschlechtsverkehr mit dem Tode bestraft werden: im Jemen, Iran, Sudan (nördliche Landesgebiete), in Saudi-Arabien, Nigeria (nördliche Landesgebiete), Mauretanien und in den Vereinigten Arabischen Emiraten. Siehe: World Day against Death Penalty -Seven countries still put people to death for same-sex acts; Bosworth, Liwāt, S. 776.
} 
Auch Unzucht zwischen Frauen siḥ̄a (Tribadie) ist im Islam verboten ${ }^{537}$ Im Koran lesen wir:

„Und wer von euren Frauen etwas widerwärtiges [arab. făhiša] begeht: nehmt vier von euch als Zeugen gegen sie. Und wenn sie es bezeugen, schließt sie in den Häusern ein, bis der Tod sie nimmt oder Allah ihnen einen Ausweg zeigt. “538

Dieses Zitat bezieht sich hauptsächlich nach der allgemeinen Auffassung der Ausleger auf zina? Dabei vertritt Aț-Ṭabari ausschließlich die Deutung im Sinne von zina' (illegitimem Geschlechtsverkehr) zwischen einem Mann und einer Frau. ${ }^{539}$ Einige Koranausleger aber dagegen sind der Meinung, dass dieser Vers sich auf gleichgeschlechtlichen sexuellen Verkehr zwischen Frauen bezieht: Das selbe Verständnis über diesen Vers hat der spätere Kommentator az-Zamahš̌arī (gest. 1144). Er fügt aber hinzu, dass einige Ausleger die Verse 4,15 auf weibliche homosexuelle Akte bzw. homosexuellen Analverkehr beziehen. ${ }^{540}$

Nach Auffassung der schiitischen Rechtsgelehrten ist homosexueller Geschlechtsverkehr zwischen Frauenein zu bestrafendes Vergehen, wenn gewisse Voraussetzungen erfüllt sind. $\mathrm{Zu}$ den möglichen Strafen gehört die Auspeitschung (als Züchtigung). „Wenn eine Frau die Unzucht viermal begeht, müssen vier Männer als Augenzeuge gegen sie aussagen. Wenn es zu einer Verurteilung kommt, werdenbeide Frauen 100 mal ausgepeitscht. Wenn aber die Frauen umkehren und sich bessern, werden sie begenadigt und nicht bestraft." ${ }^{\text {"541 }}$

Homosexualität war zwischen muslimischen Kriegern sehr verbreitet. Al-Ğāḥiz berichtet darüber, dass in der Region Horāsān häufig diese sexuelle Variante der Liebe zwischen Männern ausgeübt wurde. ${ }^{542}$

Es handelte sich dennoch um eine im Wandel der Zeit mal mehr mal weniger tolerierte gesellschaftliche Lebensweise, die sich in der „schönen Literatur“ wiederfand. In den iranisch literarischen Werken kam es häufig vor, dass man mit seinen Sklaven schlafen durfte. ${ }^{543}$ Die allgemein vorherrschende Überzeugung war, dass junge Männer mindestens ebenso verführerisch und begehrenswert waren wie junge Frauen.

${ }^{537}$ Der Begriff sị̄ạq wird im Zusammenhang mit einer gleichgeschlechtlichen Praktik unter Frauen verwendet. Dies Praktik ist eine nicht penetrative sexuelle Akt, dabei eine Frau zum Zweck der klitoralen Stimulation ihre äußeren Genitalien an ihrer Partnerin reibt. vgl. Dastġeib Širāzi, Bd. 2, 306.

${ }^{538}$ Koran, Sure. 4,15.

${ }^{539}$ aṭ-Ṭabarī, Abū Ğa'far Moḥammad b. Ğarīr: Tafsīr at-Tabari, al-musammā Ǧāmi al-bayān 'an ta'wìl al-Qur'ān, ğuz' 8: Tafsīr sūratan-Nisā' min 8-87 wa-'l-ātār min 8658-10048, 2. Aufl., hrsg. von Maḥmūd Moḥammad Šākir, al-Qāhira: Dār al-Ma'ārif, [ca. 1971], zu Sure 4,15-16, S. 75.

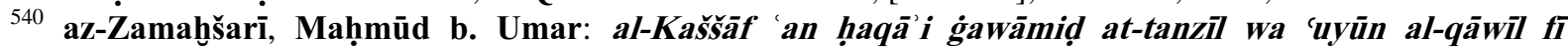
wuğūhihī at-ta'wī, ğuz 1, Beirut: Dār al-Kitāb al- 'Arabī, [ca. 20. Jh.], zu Sure 4,16, S. 487f.

${ }^{541}$ Dastġeib Širāzi, Bd. 2, $306 f$.

542 al-Ğāḥiz, al-Hayawān, Bd. 1, S. 148.

543 'Onșor al-Ma`āli Kei-Kāvus b. Eskandar b. Qābus b. Vošmgir, Qābus-nāme, hrsg. von Ġolām-Ḥosein Yūsofi, Teherān 1354/1967, S. 45; vgl. Šafici-Kadkani, Moḥammad-Reżā: Ṣovar-e hayāl dar še‘r-e fārsi, Teherān 1366/1987, S. 304-316. 
Auch die spätere mystische Literatur bewegte sich in Bildern des homosexuellen Erlebens. ${ }^{544}$ Der Mystiker fand beim Anblick der körperlichen Schönheit des vor ihm stehenden Jünglings den Weg, der ihn unmittelbar zum Erleben der Gottheit führte. Die Schönheit wurde schließlich zur göttlichen Manifestation. ${ }^{545}$ In der persischen Lyrik hat dann später die erotisch-mystische Beziehung des Mannes zum schönen Jüngling ihren stärksten künstlerischen Ausdruck gefunden.

Unter der mongolischen Fremdherrschaft sah man einen drastischen Sittenverfall. Homosexualität und Unzucht nahmen stark zu. Aus dem Buch Șafwat ạ̣-Safã erfahren wir von der Schilderung schrecklicher Höllenstrafen bei Ehebruch, Wollust und Unzucht mit Frauen und jungen Männern. Dies zeigte exemplarisch die verbreitete Homosexualität und Unzucht. Dort lesen wir weiter, dass einem Mann, der einen anderen geküsst hat, später beim Jüngsten Gericht die Lippen mit einer brennenden Schere abgeschnitten werden würden. ${ }^{546}$

Während der Herrschaftszeit der Mongolen im Iran mussten sich viele Knaben prostituieren, um ihr Leben zu retten. 'Obeid Zākāni (1300-1382) erzählt uns, dass ein Junge aus Eṣfahān einen Mongolen begegnete, der ihn töten wollte. Der Junge sagte ihm „töte mich nicht, stattdessen werde ich dir meinen Körper anbieten.“ Der Mongole bekam Mitleid mit ihm und tötete ihn nicht, stattdessen verging er sich an dem Jungen. ${ }^{547}$

Aus der Timuridenzeit stehen uns zu diesem Thema interessante Informationen aus den Büchern Bābur-nāme und Badāye` al-vaqāye` zur Verfügung. Bāburs autobiographische Darstellung bietet den besten Überblick über die unterschiedliche Behandlung von Homoerotik und Päderastie. Er scheute sich keineswegs, relativ ausführlich über ein eigenes Erlebnis zu berichten: Wie er sich leidenschaftlich in den Sohn eines Händlers verliebte und sich seinetwegen zum Narren machte. ${ }^{548}$ Für Bābur kam es aber offenbar zu keiner intimeren Beziehung. ${ }^{549}$ Anders dagegen die Äußerungen über Päderastie hoher Persönlichkeiten, die Bābur kurz beschrieb; dort tauchten Hinweise zu deren mehr oder weniger stark ausgeprägten Vorliebe für Knaben auf. ${ }^{550}$ Ganz unmißverständlich äußerte sich Bābur in einer allgemeiner gehaltenen Passage, wo er von einem „schändlichen Laster“ sprach und

\footnotetext{
${ }^{544}$ Vgl. Sacdi, Kolleyāt-e Sa'di. Lithographischer Druck, Teherān 1268h/1851, S. 473-474; vgl. Zarrinkub, 'Abd al-Ḥosein: Donbāle-ye ğostoğu dar tasvvof-e Irān, Teherān 1362/1983, S. 359-379.

${ }^{545}$ Vgl. Šamisā, Sirus: Šāhed-bāzi dar adabiyāt-e fārsi, Teherān 1381/2002, S. 113.

546 Ibn Bazzāz, S. 569.

${ }^{547}$ Zākāni, Neẓām ad-Din cObeid: Ah̆lāq al-ašrāe. Taṣḥịh va toużih ‘Ali Aṣgàar Ḥalabi, Teherān 1374/1995, S. 90.

${ }_{548}$ Bābur Pādšāh Ġāzī, Ẓahīr ad-Dīn Moḥammad: Bābur-nāme, Bd. 1, S. $120 \mathrm{f}$.

549 Ebd.

${ }^{550}$ Ebd. S. 26, 42, 45, 278, 307.
} 
darüber klagte, dass dieses unter Solțān Mạ̣mud Mirzāa ${ }^{551}$ so verbreitet war, dass es von jedem praktiziert wurde und nicht mehr als Schande, sondern geradezu als „Tugend“ galt.

Außderdem lesen wir im Buch Badāye` al-vaqāye` einen Bericht über den Günstling des Amirs Moḥammad Vali Beg. Er nannte Hֵ̆āğegi Moḥammad Čenār einen gewissenlosen Päderasten, der seine Polizeigewalt in der Stadt Harāt mißbrauchte. Da dieser Mann aber bei dem Amir hohes Ansehen genoß und dieser wiederum beim Mirzā, war es nicht möglich, diese Mißstände vor dem Mirzā offen zur Sprache zu bringen. 'Ali-Šir, der wußte, dass Mirzā einen heimlichen Berichterstatter in seiner Umgebung plaziert hatte, empfahl einem Mann in Gegenwart dieses Berichterstatters, als gute Einnahmequelle solle er in der Stadt junge Männer anhalten und so tun, als habe er Befehl, sie zu H్ ihm dann alles geben, was sie hätten, um heil davonzukommen. Durch den Bericht, den der Berichtstatter über diesen „Rat“ an den Mirzā weitergab, erfuhr dieser von den Verhältnissen des Ȟ్̛āğegi und befahl dem Amir, ihn aus der Stadt zu entfernen, wenn er nicht beide töten lassen wollte. ${ }^{552}$

Als Idealalter für Geliebte männlichen Geschlechts galten fünfzehn Jahre. ${ }^{553}$ Mit dem Sprießen des Bartes begannen die Probleme für beide Seiten, vor allem für die (meist jüngeren) Geliebten, von denen erwartet wurde, dass sie nun ihre gesellschaftliche Rolle als erwachsene Männer einnehmen und heiraten sollten. „Die Geschichte von Mạ̣mūd von Ghazna (gest. 1030) und Ayāz ist ein typisches Beispiel dieser Art der Liebe. “554

In diesem Zusammenhang können wir zwei Beispiele aus dem $R H$ anführen, die zu diesen historischen Tatsachen passen:

Borq-e Farangi nimmt 'Amr fest. 'Amrs Kundschafter machen sich auf dem Weg, um ihn zu befreien. Plötzlich kommt ein Junge und behauptet, dass er alleine 'Amr befreien könne. Als die Kundschafter ihn sehen, sagen sie zueinander: „Wir werden mit ihm Unzucht treiben.“ Der Junge verhindert dies, indem er ihnen Wein einschenkt und sie so bewusstlos macht (2/256).

An anderer Stelle lesen wir, dass ein Nachtwächter im Maghreb Mädchen und Jungen vergewaltigt, und die Leute deswegen sehr zornig sind. Sie sind sehr dankbar, als 'Alam Šãh ihn tötet $(2 / 297)$.

\footnotetext{
${ }^{551}$ Der jüngere Sohn von Abu Sacid Mirzā, Solțān Ḥosein Mirzās Vorgänger in der Herrschaft von Harāt. Er herrschte in der 2. Hälfte des 15. Jahrhunderts in den Gebieten von Termez, Čà̃āniyān, Badahšān. Siehe: Bābur, Bābur-nāme, S. 46f.

${ }^{552}$ Vașefī, Badāye` al-vaqãyec, S. 413-416.

${ }^{553}$ Sa'di, Moṣleḥ ad-Din: Kolleyāt-e Sa'di, Lithographischer Druck 1274b, Teherān 1274h/1857, S. 473-474.

${ }^{554}$ Schimmel, Annemarie: Mystische Dimensionen des Islam, 1. Aufl., Köln: Diederichs 1985. S. 414.
} 
Der allgemeine Terminus für Unzucht unter Männern ist im RH sar-giri kardan (den Kopf in die Hand nehmen; 2/256). Dies bedeutet, ein paar Männer nahmen den Kopf eines Jungen in ihre Hände und jemand treibt von hinten mit ihm Unzucht. ${ }^{555}$

Neben der Homosexualität unter Männern, gibt es im $R H$ auch die gleichgeschlechtliche Liebe unter Frauen. Es gibt im $R H$ Erzählungen über homoerotische weibliche Sexualität. Zur Veranschaulichung folgender Beleg: Im neunten Gebirge des Qāfs sieht Karib ein schönes Mädchen, das mit einer Kette gefesselt ist. Diese erzählt Karib, dass sie Gol-čehre heiße und Gouhar-e ğādu sie entführt und dort eingesperrt habe. Kairb fragt sie: „Wo ist sie?“ Das Mädchen sagt: „Ich weiß es nicht. Sie kommt jede Woche hierher, nimmt mich zu ihrem Palast und ist zärtlich zu mir“" (4/622/11).

\subsection{Sodomie}

Die Spuren der Sodomie in den kulturhistorischen Werken sind nicht ganz einfach zu verfolgen, und zwar auch deshalb, weil Sodomie vielfach nur kurz gestreift wird. Geschichtsschreiber, Kritiker und Dichter ergehen sich meist nur in Anspielungen. Der persische Dichter Sa`di stellte die Sodomie zwischen einem Mann und einem Esel dar. ${ }^{556}$ Der Esel verkörpert bei den Iranern offenbar die brutalste Geilheit. Aus dem Buch Tausendundeine Nacht ist zu ersehen, dass Frauen mit Affen und Bären Unzucht getrieben haben sollen. ${ }^{557}$ Aus religiösen Texten erfährt man, dass Tiere wie Esel und Pferd, wenn mit ihnen Unzucht getrieben worden war, in eine andere Stadt verkauft werden mussten; Tiere wie Schaf und Kuh mussten verbrannt werden. ${ }^{558}$

Im $R H$ lesen wir, dass Bahtak die Aufsicht über die Gefangenen des Neyram übernimmt. 'Amr will die Helden, welche im Gefängnis des Neyram sind, befreien. Er macht Bahtak bewusstlos und sperrt ihn in eine Kiste ein. Danach nimmt er Bahtaks Gestalt an und befreit die Helden. 'Amr verwandelt Bahtak in die Gestalt eines Priesters, bringt eine Eselin und legt den Penis des Bahtak in deren Geschlechtsorgan. Als Bahtak zu sich kommt, treibt er Unzucht mit der Eselin (5/863/30).

\subsubsection{Kinder}

Die zentralen und immer wiederkehrenden Motive im $R H$ sind Kindheitsgeschichten, unabhängig davon, ob sie als Bestandteil eines geschlossenen Epenzyklus oder als selbständige Erzählungen erscheinen. Hier wird von der gesellschaftlich ungefestigten

\footnotetext{
${ }^{555}$ Pādešāh, Moḥammad: Sar-giri kardan, in: Farhang-e ānanderāğ, Bd. 3, S. 2413.

${ }^{556}$ Sa'di, Kolleyāt-e Sa'di. Lithographischer Druck 1274b, Teherān 1274h/1857, S. 476.

557 Anonymus: Hezār-o yek šab, Nacht. 352; 354.
} 
Situation des jungen Helden berichtet, der aufgrund eines am Vater begangenen Unrechts oder durch dessen Tod, ohne familäre Bindungen, unter nicht standesgemäßen Bedingungen aufwächst. Weiter wird erzählt, wie die jungen Protagonisten in die Fremde ziehen, wo sie durch ihre Fähigkeiten im Umgang mit Waffen die Anerkennung eines fremden Herrschers und, damit verbunden, auch die Liebe der Königstochter erringen.

Bozorgmehr erfährt aus einem magischen Buch, dass sein Vater getötet worden ist und wächst daher als Waisenkind auf. Er zieht nach Madā'en und nimmt Rache an dem Mörder seines Vaters. Da er dem König in einer sehr persönlichen Angelegenheit einen wertvollen Dienst erweisen kann, wird er von diesem zu seinem Ratgeber ernannt (1/2-10). Im weiteren Verlauf der Erzählung werden alle Merkmale angesprochen, die den Helden kennzeichnen und verdeutlichen, inwieweit er die soziale Position des Vaters noch übersteigen wird.

Jedes Kind hat im $R H$ ein eigenes Profil und damit verbunden die Möglichkeit einer eigenen, im weiteren Verlauf der Erzählung zu entfaltenden Lebensgeschichte, durch die es seine Identität erhält. Das $R H$ profiliert einen spezifischen Zusammenhang von Lebensgeschichte und Identität: Der Rückgriff auf Lebenserzählungen dient hier dazu, die Biographie des Helden bereits an seinem Lebensanfang festzuschreiben; am Beginn des Lebens ist sein zu erreichendes Ziel, seine Bestimmung und Aufgabe bereits impliziert.

Viele Kinder im $R H$ werden durch einen Ersatzvater groß gezogen. Der Ersatzvater erkennt und respektiert den angeborenen Adel des Kindes. In dem Augenblick, indem er das Kind findet, wird er zunächst durch die Schönheit und durch das Lächeln des Kindes davon abgehalten, ihm einen Namen zu geben. Er allein ist im Gegensatz zu den nächsten Verwandten fähig, das wahre Wesen des Kindes zu erkennen, und das versetzt ihn in die Lage, ihm seinen endgültigen Namen zu geben.

Bei der Thematik „Kinder“ wird ein entscheidender Moment der Entstehungsgeschichte des $R H$ deutlich. Genau wie in der historischen Realität ist die Welt im $R H$ von ständigen Kämpfen und Auseinandersetzungen geprägt. Dabei werden Familien getrennt, und Kinder werden zu Waisen. Die Not der Mütter sieht man auch im $R H$ daran, dass oft Kinder ausgesetzt werden. Auf abenteuerlichen Wegen finden sie dann nach Jahren, in erwachsenem Alter, zu ihrem Vater oder ihrer Mutter zurück. ${ }^{559}$

Irağ wird gleich nach seiner Geburt ausgesetzt, vom Kaufmann H్̄̌ăğe Farağ in ein fernes Land mitgenommen und von ihm an Sohnes statt aufgezogen (4/539). Später trifft 'Amr auf ihn und bildet ihn zum Krieger aus. Eines Nachts sieht er im Traum eine schöne Frau im schwarzen Kleid, die sich ihm als Giti-afruz, Qāsems Sklavin und Zomorrod Šāhs Tochter 
vorstellt, und in die er sich verliebt. Zu diesem Zeitpunkt weiß er nicht, dass sie seine Mutter ist, und auch Giti-afruz ist sich dessen nicht bewußt. Eine Ahnung kommt ihr als sie Irăg das erste Mal aus der Distanz sieht, denn als Reaktion darauf fließt Milch aus ihren Brüsten (5/838). Als Iră̆ nach mehreren Kriegszügen gegen Ḥamze gefangengenommen worden ist und hingerichtet werden soll, schenkt er 'Amr ein Rubinarmband. Dieser erkennt sofort, dass es jene Rubine sind, die Hamze üblicherweise seinen Frauen gegeben hat. 'Amr befiehlt daraufhin, die Hinrichtung aufzuschieben, und erkundigt sich bei Ḥamze, wem er die Rubine gegeben habe. Hamze teilt ihm mit, er habe sie all seinen Frauen gegeben, und einen davon Rābe'e. Auf Nachfrage bei Rābe'e erfährt 'Amr, dass sie diese ihrem Sohn 'Alam Šāh gegeben habe. Der wiederum gibt an, sie seiner Frau Šamse gegeben zu haben. Šamse wiederum hat den Rubin ihrem Sohn Qāsem gegeben, und dieser seiner Frau Giti-afruz. Gitiafruz wieder, die während Hamzes Krieg gegen ihren Vater Zomorrod in schwangerem Zustand das Lager verlassen musste, hat das Armband ihrem Kind zusammen mit anderen Juwelen in die Decke gelegt, als sie es ausgesetzt hat. Auf der Flucht hat sie ihr Kind in ein Stück ihres abgerissenen fränkischen Kleides gewickelt und in einem beigelegten Brief mitgeteilt, dass das Kind aus einer vornehmen Familie stamme und gut behandelt werden solle. Das Kleid ist noch immer in ihrem Besitz, aber über den Verbleib des Kindes weiss sie nichts (5/1009-1010). 'Amr bringt nun Irağs Ziehvater Ȟูāğe Farağ zu Ḥamze und zwingt ihn, die Geschichte zu bestätigen. Ȟ్̛āğe Farağ bringt Irağs Windeln, die den Riss in Gitiafruz’ Kleid ausfüllen (5/1010-1011). Qāsem und Irağ, Vater und Sohn, die sich bisher als Todfeinde gegenüberstanden, versöhnen sich. ${ }^{560}$

Ein Kind von Adel zeichnet sich durch ein jederzeit sichtbares, am Körper manifestiertes Merkmal aus. Die Frage nach der Identität der Kinder ist sehr wichtig. Nur mit Hilfe der sichtbaren körperlichen Zeichen und der beigefügten Beigaben werden die Kinder ihre Identität beweisen können.

Das $R H$ stellt also auch hier unterschiedliche Modi des Erkennens einander gegenüber: Muttermal als visuelle Repräsentation eines adeligen Status, Kleidung (5/1009-1010), Testament (5/1014), Armband (5/1009) und Augenzeugen (3/482).

Die spontane, sofortige Identifikation mit Hilfe der sichtbaren oder versteckten körperlichen Merkmale ist sicherer als die eher archaische Variante der „Personenkenntnis“, die sich auf Kleider, kalkulierte Gesten oder andere äußere Statuszeichen beschränkt. Wenn äußere körperliche Zeichen nicht die Herkunft der Neuankömmlinge sofort erkennen lassen, sollte man auf die Stimme seines Herzens hören. Ein kleines Beispiel soll zeigen, dass das Herz ein

\footnotetext{
${ }^{559}$ Vgl. Binder, Gerhard: Aussetzung, in: EM, Bd.1, Göttingen 1977, Sp. 148-165, hier Sp. 150.
} 
zielsicheres Erkennen und Identifizieren von Menschen ermöglicht, wo die äußeren Sinne versagen: Obwohl Irağ Sonnenanbeter ist und schon lange gegen Muslime kämpft und viele Muslime getötet hat, zeigt Ḥamze große Sympathie für ihn. Im Zweikampf besiegt Ḥamze Irăg, aber er will und kann ihn nicht töten, sondern schickt ihn ins Gefängnis und hofft dabei, dass seine Ahnung ihn nicht trügt und er Irağs Abstammung ergründen kann (5/1050).

Ein ganz anderes Beispiel stellt die Phrophezeiung dar, dass ein bis jetzt ungeborenes Kind das Leben des Herrschers bedroht. Dieser potentiellen Gefahr versucht der betroffene Herrscher zu begegnen: Geschäftsleute kommen zu Lāhut dem Herrscher und berichten ihm, dass das Kind Badi` al-Molk sein Reich vernichten werde. Als Lāhut dies hört, beschließt er, Badi` al-Molk töten zu lassen, was ihm jedoch mißlingt (6/1067-1068).

Auch geistig und körperlich benachteiligte Kinder kommen im $R H$ vor. Ḥamze bekommt von Qahr einen Sohn, namens Ḥamze-ye șāni, der große körperliche Einschränkungen hat. Als er geboren wird, ist er an Armen und Beinen gelähmt. Schließlich wird er durch den Propheten Moḥammad geheilt (6/1095).

Im $R H$ finden sich auch Berichte über isoliert in der Wildnis aufgewachsene Kinder, die sich in ihrem erlernten Verhalten von normal aufgewachsenen Kindern unterscheiden. Dazu gehört auch Ḥamzes Sohn Qomhur, der von einem Dämon aufgezogen wird (5/1043). Er besitzt Riesenkräfte und wird als ein stark behaarter, nackter bzw. leicht bekleideter Urmensch dargestellt. Sein Aufenthaltsort ist der unbewohnte Wald. Seine Lebenweise gilt einerseits als halbtierisch und primitiv, andererseits aber auch als naturverbunden. Durch Zufall wird er von dem Geisterkönig Malek Ṣādeq entdeckt und tritt in dessen Dienst. Als Feldherr des Königs trifft er zu einem späteren Zeitpunkt auf dem Schlachtfeld mit seinem Vater Ḥamze zusammen und wird von diesem besiegt.

\subsubsection{Tiere}

Der Held hat neben seinem Kontakt mit Tieren wie Löwe, Pferd und Reh immer wieder auch Begegnungen mit mythischen Wesen wie Feen, wilden Kreatur und Drachen. Die einen helfen ihm, die anderen muss er bekämpfen. Er bewegt sich in zwei Welten, eine fiktive und eine reale Welt, in denen er positiven und negativen Wesen begegnet. Es geht hierbei um die Faszination des Mythischen, von der auch der Held beeindruckt ist. Dies betrifft auch seine besondere Fähigkeit, mit Tieren umzugehen. Im $R H$ spielen immer wieder mythische Motive eine Rolle, die den Helden eine Mittlerfunktion zwischen Natur und Kultur zuweisen. Im

\footnotetext{
${ }^{560}$ Vgl. Wehse, Rainer: Erkennungszeichen, in: EM, Bd. 4, Göttingen 1984, Sp. 180-194, hier Sp. 180.
} 
Folgenden werden einige der Tiere beschrieben, mit denen er gut kommunizieren kann und die ihm helfen, wenn er sie braucht.

Pferd

„Indem Leben des Helden ist die Auswahl des Rosses eine wichtige Episode. “561 Zu einem herausragenden Krieger gehört ein ungewöhnliches Pferd, das ihm als Kampfgefährte zur Seite steht und sich aktiv am Kampf seines Herrn beteiligt. Beim Abenteuer Rostams mit dem Drachen weckt sein Pferd Rahš̌ (der Leuchtende) den schlafenden Helden; und als dieser im Kampf zu unterliegen droht, spitzt Raḩ̌̌ die Ohren, trabt heran, schlägt seine Zähne in die Schulter des Drachen und zerreißt dem Ungetüm das Fell. ${ }^{562}$ Auch mit einem Löwen, der sich drohend den beiden nähert, kämpft Rahšs. ${ }^{563}$

Die Bindung zwischen Mensch und Tier ist sehr eng und intensiv. Kurz bevor Siyāvaš von Afrāsiyāb ermordet wird, nimmt er Abschied von seinem Pferd Šabrang-e Behzād (der Wohlgeborene). ${ }^{564}$

Ḥamzes berühmtestes Pferd heißt Ašqar. Er erhält es als Belohnung von der Feenprinzessin. Einmal kämpft Ḥamze mit Azmāyeš-e div und besiegt ihn. Als er ihn töten will, sieht er, dass der Div weint. Hamze fragt ihn: „Warum weinst du?“ Der Dämon antwortet: „Weil ich in jemanden verliebt bin.“ Aufgrund seiner Liebe zu Mehrnegār versteht ihn Ḥamze und tötet den Dämon nicht. Die Geliebte des Dämons ist eine Feenprinzessin, die Tochter des No`mān Šāh. Ḥamze erzählt dem König, dass der Dämon in seine Tochter verliebt sei. Letztendlich kann Ḥamze Nocmān Šāh überreden, dem Dämon seine Tochter zur Frau zu geben. Später schenkt die Fee ihm ein Kind, das in Wirklichkeit ein Pferd mit drei Augen ist (1/186), und dieses Pferd ist Ašqar (1/173). Das Pferd Ašqar ist sehr pflichtbewusst. Es liebt seinen Besitzer und rettet ihm viele Male das Leben (2/197). Ašqar ist bekannt für seine Schnelligkeit und seine Fähigkeit zu gewaltigen Sprüngen (5/970).

\section{Löwe}

Seit Anbeginn der Antike ist der Löwe im Iran das Sinnbild eines legitimen, unmittelbaren Herrschers und Trägers von Stärke, Gerechtigkeit, Vernuft, Edelmut und Tapferkeit. Wenn man sich mit diesem Thema der Kontinuitäten dieser Symbolwelt und des Spezifischen der iranisch-islamischen Löwensymbolik beschäftigt, ergeben sich sehr interessante Ergebnisse. Eine systematische Untersuchung der Wurzeln der Löwensymbolik und der unterschiedlichen

\footnotetext{
${ }^{561}$ Horn, Paul: Roß und Reiter im Šāh-nāme, in: ZDMG 61 (1907) S. 837-849, hier S. 840.

${ }^{562}$ Ferdousi, Bd. 1, S. 198.

${ }^{563}$ Ebd. Bd. 1, S. 196.
} 
Rezeptionsprozesse, die seit der vorislamischen Zeit, über das Mittelalter bis in die Neuzeit zu einem deutlichen Anstieg der Löwenvergleiche und Löwenidentifikationen von Herrschern führte, ist nicht Ziel dieser Arbeit.

Alleine in der persischen Literatur und Kunst gibt es zahlreiche Quellen, die auf die Herkunft der Löwenmetaphorik im herrschaftlichen Kontext und ihrer Deutung in Antike und Mittelalter hinweisen. $\mathrm{Zu}$ historiografischen und theologischen Quellen zählen auch die Werke aus dem Gebiet Epos, Herrscherspiegel, politische Apokalyptik und Tierdichtung sowie volkssprachliche Literatur. Außerdem sind in der iranischen Malerei, die Ikonographie und die Mosaiken viele Zeugnisse, die wichtige Erkenntnisse über Löwensymboliken bringen. Im Iran hat die Löwenmetaphorik ihre Bedeutung für die Herrschaftspropaganda durch den geradezu inflationären Gebrauch eingebüßt. Die Löwensymbolik und der Löwenvergleich finden sich hier vielfach wie in der kompletten islamischen Welt. Hier wurden die mündlich, schriftlich oder gegenständlich übermittelten Vorstellungen, Texte und Artefakte rezipiert und ihrem neuen oder alten Zweck zugeordnet.

Antike wie mittelalterliche Zeitgenossen wiesen den Herrschern als Löwen ganz unterschiedliche Bedeutungen zu, die auf ihre Tapferkeit oder moralische Integrität, auf ihre Funktion als Heidenkämpfer und Ketzerverfolger abzielten. Die Löwensymbolik in Schrift und Bild hatte ein wichtiges Ziel: Sie legitimierte die königsgleiche Stellung und verlieh den Königen sowie Helden repräsentativen Ausdruck. ${ }^{565}$

Um die Wichtigkeit der Löwesymbolik im iranischen Kulturboden zu verdeutlichen, erläutern wir einige historische Belege aus vor- und nachislamischer Zeit.

Wir wissen, dass die altiranische Kunst in erster Linie eine dynastische Kunst ist, welche bewusst im Dienst des Königes stand. Diese Kunst entstand im Umfeld der Königsresidenzen, in deren Ateliers Künstler und Handwerker tätig waren. Diese Kunst wurde im Auftrag des Königshofes für den König und die Eliten geschaffen.

Diese Art von Kunst wird als eine höfische, imperiale Propagandakunst definiert, die ihre Fortsetzung in der imperialen Kunst der Herrscher späterer Jahrhunderte (Moghulherrscher, Timuriden und Șafaviden) finden sollte. ${ }^{566}$ So nahm die Darstellung des Löwen in der

\footnotetext{
${ }^{564}$ Ebd. Bd. 1, S. 366; ‘Ādel, Moḥammad-Reżā: Farhang-e nāmhā-ye Šāh-nāme, S. 111.

565 Jäckel, Dirk: Der Herrscher als Löwe. Ursprung und Gebrauch eines politischen Symbols im Früh- und Hochmittelalter, Beihefte zum Archiv für Kulturgeschichte 60), Böhlau IX, Köln 2006, S. 134; 187f.

566 Vgl. Balzer, Wolfgang: Achaimenidische Kunst aus Babylonien. Die Siegel der Keilschriftarchive. Ikonographie. Stile. Chronologie, Inaugural-Dissertation zur Erlangung des Doktorgrades der Philosophie an der Ludwig Maximilians-Universität München 2007, S. 1.
} 
achämenidischen Kunst einen wichtigen Platz ein. Wir sehen die Löwensklupturen in ihren Palastanlagen besonders in Persepolis, Tempeln und Grabstätten. ${ }^{567}$ Jäckel, Dirk

Außderm spielte der Löwe auch in den iranischen Religionen wie Mithraismus eine sehr wichtige Rolle. In der mithrischen Kunst wird häufig eine Göttergestalt präsentiert, die eine nackte, aufrecht stehende Menschenfigur mit Löwenkopf darstellt, um dessen Leib sich spiralförmig eine Schlange windet. ${ }^{568}$ Die Rolle des Löwes ist auch in den Initiationsstufen des Mithraismus sehr sichtbar. Diese Religion hatte sieben Weihegrade und der Löwe (LeoTutela des Jupiter) war Repräsentant des vierten Grades. ${ }^{569}$

Eine andere Domäne, in der der Löwe sich bemerkbar machte, war das Reich der Erzählungen. In diesem Zusammenhang gibt es aus der vorislamischen Zeit eine Erzählung, in der Aṭ-Ṭabarī anführt, dass der persische Großkönig Bahrām Gōr (reg. 420/21-438/439) nach dem mysteriösen Tod seines Vaters Yazdegerd I. dessen Nachfolge an trat. Bahrām sah sich nun mit mehreren Problemen konfrontiert, vor allem mit einem starken Hochadel. Der überwiegende Teil des Adels wollte die Söhne des verhassten Yazdegerd von der Thronfolge ausschließen. Sie favorisierten zunächst mehrheitlich Hosrou, einen Prinzen aus einer sasanidischen Nebenlinie, als neuen König. Um sein Recht auf die Krone zu bekommen, musste Bahrām um seine Herrschaft und die Krone, die zwischen hungrige Löwen gestellt wurde, kämpfen. Mit Mut und Kraft konnte Bahrām sich letztendlich durchsetzen. ${ }^{570}$

In der islamischen Literatur ist der Löwe beliebtester Beiname, der als Bezeichnung und Vergleich des konkreten Helden benutzt wurden. 'Ali b. Abi Ṭāleb wurde Asad Allāh (Löwe Gottes) genannt. ${ }^{571}$ Die Bezeichnung 'Ali als Löwe im positiven Sinn ist ein Phänomen, das durch die iranischen bzw. schiitischen Dichter und Gelehrten wie Ibn Šahrāšūō und 'Aț̣ār in ihren Werken eingeführt wurde, um ihn zu ehren und für seinen Mut und seine Stärke zu loben. $^{572}$

Die Propagierung der Löwenhaftigkeit 'Alis diente seiner Legitimation als gerechter Herrscher des islamischen Reiches, die zu einen propagandistischen Kampf um die Herrschaft

\footnotetext{
${ }^{567}$ Du Gobineau, Joseph Arthur: Die Welt der Perser, aus dem Französischen ins Deutsche übersetzt. von Renate Navé, Gütersloh: Bertelsmann [u.a.], München/Berlin 1971, S. 63; 66; 83; 93; 95; Seipel, Wilfried (Hg.) Weihrauch und Seide. Alte Kulturen an der Seidenstraße, eine Ausstellung des Kunsthistorischen Museums, in Zusammenarbeit mit der Staatlichen Eremitage in St. Petersburg ; Kunsthistorisches Museum Wien, 21. Jänner bis 14. April 1996, S. 89 (Bild 63); 221( Bild 66); 233 (Bild 80); 239 (Bild 89) und 242 (Bild 92).

${ }^{568}$ Merkelbach, Reinhold: Mithras. Ein persisch-römischer Mysterienkult, Wiesbaden 1998, S. 296.

${ }^{569}$ Ebd. S. 77; 280.

570 aṭ-Ṭabarī, Abū Ğa‘far Moḥammad b. Ğarīr: Tārih ar-rusul wa-'I-mulūk, Bd. 2, in Persische übersetzt. von Abu 'l-Qāsem Pāyande, Teherān 1362/1983, S. 620; Seif, Hādi: Naqāši ru-ye kāši, Teherān 1376/1997, S. 176, Bild. 109.

${ }^{571}$ Ibn Manẓūr al-Ifrīqī al-Mișrī, Abū' l-Faḍl Ğamāl ad-Dīn Moḥammad b. Mukarram: Asad, in: Lisān al'Arab, Bd. 3, Bairut 1374h/1955, S. 72.
} 
über diese Symbol führte. Aus diesem Grund diente die Verwendung des Löwen durch die Dichter und Künstler als reines Machtsymbol, um seinen kämpferischen Charakter zu betonen. $^{573}$

Als Vorkämpfer des Islam möchte Ḥamze die Einbindung der Heiden aber auch Christen und Usbeken, die eigentlich zu der sunnitischen Gemeinde des Islam gehören, in die alte prophetische Form des Glaubes d.h. din Ebrāhīm (die monotheistische Religion Abrahams) herstellen und sie in die neue monotheistische Religion integrieren. Wer sich gegen den Islam entscheidet, den bekämpft Ḥamze wie ein Löwe.

Die Autoren des $R H$ vergleichen Ḥamze mit einem brüllenden Löwen. Ḥamzes Aggresivität, die Raubtierhaftigkeit, steht häufig in Verbindung mit Herrschaftsansprüchen. Sein Verhalten gegenüber seinen Feinden wird mit Löwen gleichgesetzt, das seiner Feinde mit dem Schakal. Die Gleichsetzung Ḥamzes mit dem Löwen stellt eine Verbindung zwischen seinen Kämpfen und altiranischen sowie schiitischen Parallele bzw. zu dem Nationalheld Rostam und 'Ali b. Abi Ṭāleb her.

Im $R H$ symbolisiert der Löwe Mut und Königlichkeit, da er als König der Tiere gilt. Eine richtige Heldenkarriere beginnt erst dann, wenn der künftige Held ein Löwentöter wird. Im $R H$ wiederholt sich dieses Muster oftmals. Ḥamze besitzt übermaß an Taperkeit. Wenn er hört, dass ein überdimensional große Löwe, der die Menschen einer ländlichen Region in Angst und Schrecken versetzt, geht er ins Wald und tötet den Löwen und zieht sein Löwenfell (1/31). Auf diese Art und Weise veranschaulicht er seinen Löwenmut und seine Löwenstärke.

Im $R H$ treten die Löwen auch als Beschützer auf. ${ }^{574}$ Wir lesen, dass Naduk und Mazdak, die Onkel von Bahtak, zu Ḥamze kommen. Als sie hören, dass Bahtak getötet wurde, rächen sie sich an Ḥamze, indem sie den Gutgläubigen mit einer Augensalbe blind machen (2/218) Ḥamze erfährt im Traum durch den Propheten Salomon, dass nur die Blätter des EiyubBaumes seine Blindheit heilen können. 'Amr findet den im Süden des Mağreb gelegenen Baum, der von zwei Löwen bewacht wird. Die Löwen bewachen den Baum und lassen Niemand in seine Nähe kommen. Nach allen Versuchen beruft 'Amr sich auf 'Ali b. Abi Ṭāleb, so lassen die Löwen ihn zum Baum gehen. Wenngleich es 'Amr zuerst nicht gelingt,

\footnotetext{
${ }^{572}$ Ibn Šahrāšūb, Moḥammad b. 'Ali: Manāqib 'Ali b. Abī Ṭāleb, Bd. 1, Qom 1379/1998, S. 297; 'Aț̣ār, Farid adDin: Moṣibat-nāme, hrsg. von Nurāni Veșāl,Teherān 1338/1959, S. 34.

${ }^{573}$ Vgl. Puin, Elisabeth: Islamische Plakate. Kalligraphie und Malerei im Dienste des Glaubens, Teil 3, Bremen 2008, S. 872f.

${ }^{574}$ Der Löwe ist auch in der schiitischen Literatur als Beschützer bekannt. Nach einer schiitischen Überlieferung wurde Hoseins Leichnam im Karbalā durch ihn geschützt. Siehe: Sindawī, Khalid: The role of the lion in miracles associated with shīcite imāms, in: Der Islam, Bd. 84 Hefte 2, hrsg. von Conrad Lawrence, S. 356390, hier S. 385ff; Seif, Hādi: Naqāši ru-ye kāši, Teherān 1376/1997, S. 110, Bild. 29.
} 
Blätter vom Baum zu pflücken, weht der Wind ihm nach einem Gebet zwei Blätter zu. Indem Ḥamze und Bozorgmehr den Saft der Blätter in ihre Augen reiben, werden sie geheilt (2/220). Auch auf andere Weise wird wilden Tieren besondere Bedeutung zugesprochen, denn es herrscht der Glaube, dass Kinder, die mit der Milch von Löwen gesäugt werden, besonders mutig seien. Auch Ḥamze und sein Sohn Badi` az-Zamān werden mit der Milch von Löwen und Leoparden gesäugt $(1 / 10 ; 2 / 272)$.

\section{Reh}

Das Reh hat im $R H$ meist eine wegweisende Rolle. Der Held wird durch ein Reh, dem er folgt um es zu jagen, an einen Ort geführt, wo er dann beispielsweise seine zukünftige Geliebte findet:Auf dem Weg nach Ardabil sehen Hamze und 'Amr ein Reh vor sich. Sie folgen dem Reh, bis plötzlich ein verschleierter Junge vor ihnen auftaucht. Diesen verfolgen sie bis zu einem Garten. Dort stellt sich heraus, dass der vermeintliche Junge in Wirklichkeit die Tochter des Arqāṣ Šāh-e Ardabili ist und Gordiye heißt (2/270).

Auch kommt es vor, dass Helden durch Zauberei in Rehe verwandelt werden. ${ }^{575}$ Auf dem Weg nach Zebarğadiye gelangen Ḥamze, Karib und 'Amr zu einem Palast, in dem eine Hexe lebt. 'Amr wird von ihr in ein Reh verwandelt. Erst mit Hilfe eines Zauberspruchs, den ein Mädchen vorliest, nimmt 'Amr wieder seine menschliche Gestalt an (5/784).

\section{Hund}

In der vorislamischen Literatur werden die Hunde manchmal im Zusammenhang mit Attentaten auf hochgestellte Persönlichkeiten erwähnt, und erleiden an deren Stelle den Tod. Wir lesen in dem Buch Kār-nāmak Ardešir Pābakān, dass beim Versuch, den König zu vergiften „das heilige Feuer plötzlich in Gestalt eines Adlers erscheint, der seine Flügel auf den Becher schlägt, der dadurch aus den Händen des Königs auf die Erde fällt. Die Hunde und Katzen lecken den Inhalt auf und sterben. ${ }^{\text {“576 }}$

Im Islam gelten Hunde als unreine Tiere. Im $R H$ beschimpft man auch die Ungläubigen als Hunde.

Auf dem Weg nach Griechenland versucht Qāren, Ḥamze zu vergiften, während er das Heer durch ein wasserloses Land führt. Als 'Amr sieht, dass Qāren versucht, Ḥamze vergiftetes Wasser zu geben, verhindert er dies, indem er zu Ḥamze sagt: „Gib das Wasser Qāren zu

\footnotetext{
575 AaTh (Motiv. Verwandlung in ein Reh. 450); vgl. Schmidt, Sigrid: Reh, in: EM, Bd. 11, Göttingen 2004, Sp. 471-474, hier Sp. 471.

${ }^{576}$ Tavadia, Jehangir C.: Die Mittelpersische Sprache und Literatur der Zarathustrier, Leipzig 1956, S. 138.
} 
trinken.“ Als Ḥamze das Wasser Qāren gibt, zittert Qāren, und das Glas fällt aus seiner Hand. Ein Hund, der das Wasser trinkt, stirbt (1/108).

Tauben

Tauben tauchen in den iranischen Erzählungen immer als Feen auf. 'Amr bringt den verwundeten Ḥamze nach Mekka. Als der Arzt seine Wunde sieht, sagt er: „Nur Gott kann ihn heilen.“ Er überlässt Ḥamze seinem Schicksal. Eines Tages kommen sieben Tauben in sein Zimmer. ${ }^{577}$ Sie legen ihr Federkleid ab und werden sieben schöne Feenfrauen, die erfolgreich Ḥamzes Wunde behandeln (1/136).

\subsection{Fabeltiere}

In den iranischen Erzählungen spielen Tiere eine sehr wichtige Rolle. Sie erscheinen als Boten, als Heilbringer, als Transporttiere, als Hüter von Schätzen, als Beschützer ihrer Besitzer, als Jagdhelfer, aber auch als Gegner. Fabeltiere sind ebenso sprachbegabt wie die Menschen. Auch handelt es sich bei den Tieren nicht selten um verwandelte Menschen oder Hexen, die sich in der Gestalt beispielweise eines Adlers zeigen.

Drache

Der Drache ist seit Urzeiten das Symbol des Chaos. Indem ihn der Held besiegt, überwindet er die Macht des Chaos und stellt die Ordnung wieder her. Die Drachen sind ein Symbol für üble Kräfte, die den Menschen schaden. Der Sieg und die Macht über die Drachen beweisen die Stärke der Helden und erhöhen ihren Status. So gehört der Sieg über einen Drachen zu den wichtigsten heroischen Aufgaben des Helden.

Aus vorislamisch-persischen Quellen wissen wir, dass der Drache selbst in den Mythen und Riten der Männerbünde eine Hauptrolle spielt, vor allem in dem mythisch-rituellen Geschehen am Jahresfest. ${ }^{578}$ In ihrem Kult verehren diese kriegerischen Männerbünde die Helden und Drachentöter Sām, Garšāsp und Rostam. Garšāsp tötet nicht nur den gehörnten Drachen, sondern auch den „Gandarv“ mit gelben Fersen. ${ }^{579}$ Sām besiegt den Drachen vom Fluss Kašaf, den er mit einem Keulenhieb erschlägt. ${ }^{580}$ Feridun entführt mit Hilfe der Götter

\footnotetext{
${ }^{577}$ Marzolph, TPV (Motiv. Die Feen kommen zur Hilfe. 465A (3, 4, 6, 7-8, 513 C. 5), S. 270.

${ }^{578}$ Widengren, Die Religionen Irans, S. 23.

${ }^{579}$ Sarkārāti, Bahman: Bāz-šenāsi-ye baqāyā-ye afsāne-ye Garšāsb dar manẓumehā-ye ḥamāsi-ye Irān, in: Sāyehā-ye šekār šode, Teherān 1385/2006, S. 251-286; Widengren, Die Religionen Irans, S. 50.

${ }^{580}$ Ferdousi, Bd. 1; S. 122.
} 
die beiden Geliebten des Drachen. Da sie zuvor vom Drachen entführt worden waren, ist dies eine Art Befreiung, die sie jedoch mit ihrer Heirat des Drachentöters bezahlen müssen. ${ }^{581}$

Im Šāh-nāme finden nicht nur Rostams Prüfungen und die Esfandiyārs eine Parallele, sondern auch historisch belegte Herrscher wie Alexander der Große und Bahrām Gōr müssen hier ihren Mut im Kampf gegen Drachen beweisen. ${ }^{582}$ In der historischen Epoche diente die Drachentötung als Bestätigung der Legitimität des Königs. ${ }^{583}$

Das $R H$ schildert die Auseinandersetzung der Helden mit dem Drachen, der als Symbol des Bösen gilt. Der Held ist der Typ eines ritterlich-adligen Drachentöters, der den Drachen im Zweikampf besiegt. Ein Beispiel dafür ist Ḥamzes Kampf gegen einen Drachen, der den Kämpfen Garšāsps mit Drachen sehr ähnlich ist. Ḥamze zieht nach Yunān (Griechenland) und trifft dort Feridun Šāh, den Statthalter von Yunan. Dieser berichtet Ḥamze von einem Drachen in der Nähe der Stadt, der zwei seiner Söhne geraubt hat. Wenn er diese zurückbringen kann und den Drachen tötet, wird er sich zum Islam bekehren. Ḥamze stimmt zu und macht sich auf den Weg. Als der Drache den Geruch des Menschen wahrnimmt, kommt er aus seiner Höhle um Ḥamze mit seinem Drachenfeuer zu töten. Dieser aber schießt ihm in die Augen und bringt sich in Sicherheit. Der Drache kann den Pfeil jedoch aus seinen Augen entfernen und weiterkämpfen. Schließlich tötet Hamze den Drachen mit seinem Schwert (1/110).

Im $R H$ kommt diese Szene oft vor. Bestimmte Motive, Strukturen und Situationen im Ablauf des Kampfes sind typisch und werden nur wenig variiert. Nach einer Entführung wird die Rettung des Opfers, vorzugsweise einer Jungfrau und Königstochter oder eines Sohns, dem Sieger ein Königreich bescheren.

Der Drache wird häufig mit dem Wasser in Verbindung gebracht. Ein Drache wird an einem Gewässer endeckt, wo er dessen Quelle blockiert und das ganze Wasser des Flusses schluckt, um es danach als giftiges Wachs zu erbrechen (3/494). Nach der Tötung des Drachen durch den Helden wird alles wieder wie vorher.

In Höhlen hausende Drachen bewachen in der Regel große Schätze und manchmal dienen Drachen und Schlangen als Wächter von Verborgenem und Geheimnisvollem (1/51) ${ }^{584}$ Nach erfolgreichem Kampf gegen die Drachen kann der Held diese Schätze erbeuten bzw. die Geheimnisse aufdecken.

\footnotetext{
${ }^{581}$ Sarkārāti, Bahman: Sohanrānihā-ye dovvomin doure-ye ğalasāt-e sohanrāni va baḥs darbare-ye Šāhnāme-ye Ferdousi, Teherān 1349/1970, S. 96-98.

${ }^{582}$ Ferdousi, Bd. 1, S. 1149; Bd. 2, S. 1392.

${ }^{583}$ Hāleqi-Moṭlaq, Babr-e bayān, hier S. 327.

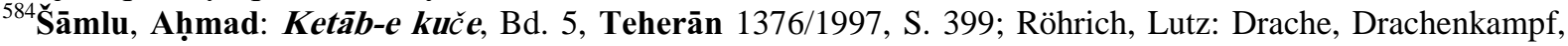
Drachentöter, in: EM, Bd. 3, Göttingen 1981, Sp. 787-820, hier Sp. 794.
} 


\section{Simorg}

Ein Vogel, der in der iranischen Literatur eine große Rolle spielt, ist Simorg. Es handelt sich um ein altiranisches Motiv, das wohl aus der vorzoroastrischen Zeit des Irans stammt. Im Avesta wurde er als der große „saēna“ Raubvogel bezeichnet (Pahlavi. Sémmurv und Neupersisch. Simorg ${ }^{585}$ Die Vorstellung von ihm ist die eines riesigen Falkens oder Adlers ${ }^{586}$, der sein Nest auf dem Baum aller „Samen“ oder „Baum aller Heilung“ hat. Dieser Baum wächst im Meer Vourukaša. ${ }^{587}$ Durch sein Gewicht und das Schlagen seiner Flügel zerbricht der Simorg seine Zweige und verstreut seine Samen, die dann von Wind und Wasser über die Erde getragen werden.

Der Simorg் ist ein sagenhafter Vogel und erscheint in den Märchen als guter Geist und Beschützer. Im Š ̌̄h -nāme ist er auch ein weiser Vogel. Er versteht die Sprache der Menschen. Sām setzt seinen neugeborenen Sohn Zāl auf dem Alburz aus, um der üblen Nachrede wegen dessen ungewöhnlichen weissen Haaren zu entgehen. Dort wird Zāl von dem Vogel Simorg் aufgezogen. Nach einer Vision in einem Traum, macht sich Sām auf den Weg zum Platz des Simorğs. Als Zāl von seinem Vater abgeholt wird, gibt Simorg் ihm eine Feder von sich mit, die ins Feuer gelegt wurde und den Vogel in Zeiten der Not herbeiruft. ${ }^{588}$ Zāls Frau Rudābe leidet unter ihrer Schwangerschaft. Bei der Niederkunft wird sie ohnmächtig und ihre Mutter Sindohnt holt Zāl an ihr Bett. Als er sie so leiden sieht, weiß er nicht, wie er ihr helfen kann. Plötzlich fällt ihm ein, Simorg zu Hilfe zu rufen. Er verbrennt eine der Federn. Simorg erscheint sofort. Er versichert Zāl, dass er sich nicht zu sorgen brauche. Simorg sagt: „Das Kind kommt nicht auf dem gewöhnlichen Wege zur Welt, sondern durch einen Kaiserschnitt.“ Er gibt genaue Anweisungen zur Durchführung der Operation, die später von einem geschickten Mobad vorgenommen wird. ${ }^{589}$

Auch im $R H$ treten die Vögel wie Simorg als Helfer der Menschen und Helden auf. Hamze will vom Berg Qāf ins Land der Menschen zurückkehren. Er sieht auf dem Weg einen riesigen Baum, auf dem sich das Nest von Simorg und seiner Brut befindet. Als Simorg்s Brut von einem Drachen bedroht wird, gelingt es Ḥamze diesen zu töten. Der dankbare Simorg் transportiert ihn daraufhin auf seinem Rücken zurück ins Menschenland. ${ }^{590}$ Zum

\footnotetext{
585 Justi, Iranisches Namenbuch, S. 302.

${ }^{586}$ Xenophon berichtete in Kyropädie, dass die Iraner den Adler für glücksbringend halten. Siehe: Xenophon: Kyrupädie. Die Erzählung des Kyros, ins Griechisch-Deutsch, hrsg. von Nickel Rainer, Zürich 1992, S. 468469.

${ }^{587}$ Vgl. Maḥ̆ub, Morḡān-e afsāne-i, in: Adabiyāt-e ‘ammiyāne-ye Irān, Bd. 1, Teherān 1382/2003, S. 239264, hier S. 243.

${ }^{588}$ Ferdousi, Bd. 1, S. 88 .

${ }^{589}$ Ebd. Bd. 1, S. 138.

${ }^{590}$ Vgl. Lindahl, Carl: Dankbare (hilfreiche Tiere), in: EM, Bd. 3, Göttingen 1981, Sp. 287-294.
} 
Abschied gibt Simorg Ḥamze ein paar seiner Federn und sagt: „Wenn du ein Problem hast, leg eine Feder ins Feuer, ich werde dir zu Hilfe kommen“ (1/174-175). ${ }^{591}$

Im $R H$ wird, durch das Tragen der Federn dieser besonderen Vögel, der Edelmut und die furchtlose Kraft des Helden vervorgehoben. ${ }^{592}$ Als Asmā’ Hamze erzählt, dass Asad Qahqahe-ye div besiegt hat, ist dieser darüber so erfreut, das er ihm als Belohnung eine von Simorg்s Federn gibt (5/886/16).

\section{Homā-Vogel}

Die iranische Tradition ist reich an fantastischen Erzählungen und Geschichten aus der Welt der Vögel. Es werden Geschichten erzählt, die im westlichen Kontext unbekannt sind, wie die Geschichte von dem geheimnisvollen, wunderbaren und sagenhaften Homā-Vogel. Solche Erzählungen sind dem iranischen Publikum bekannt. Diese erscheinen auch in der Welt des $R H$ aber anders, oft mit neuen, spannenden Details, wie z.B. die Geschichte von 'Amr b. Ma'di Karib und seiner Begegnung mit dem Vogel Homā.

An dieser Stelle scheint es notwendig darzulegen, welche historischen Hintergründe diese Erzählungen haben und wie sie sich im Laufe der Zeit entwickelt haben. Um die erste Spuren des Homā-Vogel zu finden, sollte man die Quellen aus der vorislamischen Zeit, die im iranischen Kulturraum zu finden sind, untersuchen. Daher werden wir uns zuerst mit dem Begriff xvarnah und seine Verbindung zum Homā-Vogel beschäftigen.

Xvarnah (Neupersisch. farr) ist ein iranischer Begriff und kann mit dem Ausdruck „Glanz des Glücks“ übersetzt werden. In den älteren Texten ist xvarnah in einem äußeren Symbol verkörpert, und zwar in der Gestalt des Varagan-Vogels. ${ }^{593}$ Er sucht seine Zuflucht in einem See, wo schließlich Apam Napat von ihm Besitz ergreift. ${ }^{594}$ Xvarnah nimmt verschiedene Gestalten an, um sich Menschen zu offenbaren. Als Vogel Vargen (Vragena) kommt er

${ }^{591}$ Vergleichbare Geschichten lesen wir in türkischen Erzählungen: Der mythische Vogel Chan(g) Chereti/Chan Gärdi, dessen Jungvögel der Held vor einer Schlange rettete, die sein Nest im Weltbaum heimsuchte, trägt ihn aus der unteren Welt heraus oder schenkt ihm für den Notfall eine Feder. Siehe: Taube, Erika: Zaubermärchen und Zauber im Märchen der Tuwiner, in: Zauber Märchen. Forschungsberichte aus der Welt der Märchen, München: Diederichs 1998, S. 294; vgl. Kuder, Ulrich: Haar, in: EM, Bd. 6, Göttingen 1990, Sp. 337-343, hier Sp. 338.

${ }^{592}$ Aus der altiranischen Kultur wissen wir, dass die Adlerfeder eine der wichtigsten Erscheinungsformen Gottes ist. Außerdem dienen Adlerfedern als Amulett. Siehe: Lommel, Die Yäšts des Avesta, Göttingen 1927, S. 134. Das Buch Yašt im Abschnitt Bahrām Yašt wird berichtet: „Wer einen Knochen dieses kräftereichen Vogels trägt oder wer eine Feder dieses kräftereichen Vogels trägt, den erschlägt auch ein weidlicher Mann nicht, noch treibt er ihn in die Flucht; viel Achtung trägt sie ihm ein, viel Glück, sie gewährt ihm Beistand, die Feder des Vogels der Vögel." Siehe: Lommel, Die Yäšts des Avesta, S. 139.

${ }^{593}$ Widengren, Geo: Iranische Geistswelt, S. 275; Lommel, Die Yäšts des Avesta, S. 179.

${ }^{594} \mathrm{Vgl}$. Christensen, Arthur Emanuel: Les typus du premier homme et du premier roi dans l histoire légendaire des Iransiens, Bd. 2, ins Persische übersetzt. von Žāle Āmuzegār u. Aḥmad Tafażżoli, Teherān 1377/1998, S. 335 . 
dreimal zu dem ersten mythischen König Ğamšid und verlässt ihn wieder. ${ }^{595}$ Der Falke ist gleichfalls ein im Königsbuch Ferdousi erwähnter Vogel, der als glückliches Omen gilt. KeiQobād träumt, dass zwei weise Falken vom Iran aus zu ihm kommen, und ihm die iranische Krone auf das Haupt setzen. So weiß er schon vor der Begegnung mit Rostam, dass er als künftiger König ausgesucht werden wird. ${ }^{596}$ Mithin gilt der Falke als Vogel der Könige und aus dem Verhalten der Falken lassen sich zudem Rückschlüsse auf das Wohl des Reiches schließen.

Bei späteren Dichtern ist er ganz allgemein ein Symbol für Glück und Macht. Der Schatten oder das Sich-Niedersetzen des Homā-Vogels (ein Falken-Ordal) auf den Kopf einer Person oder der Schulter schenkt dieser Königstümer. Dementsprechend sind ihre Federn der Schmuck der Turbane der Könige. Ein herausragendes Beispiel in der persischen traditionellen Literatur ist das Meisterwerk von Aț̣ārs Manteq at-Teyr. Er erzählt uns, dass in der Konferenz der Vögel sich Homā weigert die Reise zum König der Vögel Simorg̀ zu unternehmen, weil ein solches Unterfangen seine bisherigen Privilegien zunichte machen würde. ${ }^{597}$

Auch im $R H$ hat der Homā-Vogel seine besondere Bedeutung. In Hamzes Abwesenheit haben seineFreunde im Kampf gegen die Feinde des Islams große Schwierigkeiten zu überwinden und leiden zudem unter Nahrungsmittelknappheit. 'Amr b. Ma`di Karib macht sich auf den Weg, um Nahrungsmittel zu suchen. Auf dem Weg begegnen ihm die Bewohner einer anderen Stadt, die nach dem Tod ihres Königs nach einem Nachfolger Ausschau halten. Der Homā lässt sich auf dem Kopf von 'Amr b. Ma'di Karib nieder und den Bewohnern der Stadt wird dadurch mitgeteilt, dass dieser ihr neuer König sein wird (1/181-182). ${ }^{598}$

\section{Harpyien}

Harpyien wiederum haben die Gestalt von Frauen mit Flügeln und Armen. In der islamischen Kunst und Literatur finden wir den Morg்-e ädami. Er ist ein pfauenähnlicher Vogel, der ebenfalls mit der Gabe der menschliche Rede geboren ist und dessen Gesicht dem der Menschen gleicht. ${ }^{599}$ „In manchen Fassungen der Alexandersage begegnent Alexander dem Großen zwei Vögel mit Menschenköpfen. “600 Im Buch Tārih-e Negārestān wird berichtet,

\footnotetext{
${ }^{595}$ Lommel, S. 179.

${ }^{596}$ Ferdousi, Bd. 1, 175.

597 'Ațtāar, Farid ad-Din: Manteq aț-Ṭeyr, hrsg. von Șādeq Gauharin, Teherān 1348/1969, S. 51 f.

${ }^{598}$ Marzolph, TPV (Motiv. Glückbringender Vogel. 567), S. 269

${ }^{599}$ Cherry, John: Fabeltiere. Von Drachen, Einhörnern und anderen mythischen Wesen, ins Deutsche übersetzt. von Ingrid Rein, Christian Rochow und Thomas Schlachter, Stuttgart 1997, S. 239.

${ }^{600}$ Ebd. S. 239.
} 
dass der Vogel 'Anqā (Phönix ) ein menschliches Gesicht habe, Menschenfleisch fresse und sehr gefährlich sei. ${ }^{601}$ Auch im $R H$ wird von Harpien berichtet.

Im goldenen Garten des Salomon sehen Hamze und 'Amr eine Platane auf dem ein Feenprinz sitzt, mit dem Gesicht eines Menschen und dem Körper eines Vogels (5/949). Ḥamze fragt ihn: „Wer bist du?“ Er sagt: „Ich bin der Prinz des fünften Gipfels des Qāf. Wenn du die Zaubertafel in deinen Besitz nimmst, vergiss mich nicht“ (5/949-950).

\subsubsection{Religion und Glaube}

Mit Blick auf die Religionen zeigt uns das $R H$ in der Frühen Neuzeit eine Wechselbeziehung zwischen Anziehung und Abstoßung zwischen Furcht vor dem Unbekannten und gleichzeitiger Faszination. Neben den Konflikten die sich um die verschiedenen inner iranischen Glaubensrichtungen drehten, gab es seit dem 13. Jahrhundert verstärkt Auseinandersetzungen mit fremden Religionen nämlich den schamanitischen und buddhistischen Glaubensrichtungen, die während der Besatzungszeit der Mongolen im Iranaufgetaucht waren. Dem Kampf gegen die fremden Religionen in dieser Zeit schenkten die zeitgenössischen Historiker wenig Aufmerksamkeit aber auch Historiker in unserer Zeit kümmerten sich nicht darum. Hingegen wurde der Sorge um die Religion in der Volksliteratur des $R H$ große Beachtung gewidmet. Die Erweiterung unseres Blickes in geographischer wie chronologischer Hinsicht soll auch uns zu einem vertieften Bewusstsein der eigenen kulturellen Identität unter ihrer historischen Bedingungen führen. Bei der Darstellung dieser fremden Gedankenwelt spielen die Auseinandersetzungen mit den Ungläubigen, den falschen Göttern und Götzen, eine zentrale Rolle. Das $R H$ bringt die kraftvollsten Erzählungen, von Texten und Überlieferungstraditionen aus paganen Glaubensvorstellungen. Die Darstellung der Götter und Kulthandlungen vor dem Hintergrund der religiösen und historischen Interessen der Autoren des $R H$ beleuchten die Funktionen der Texte in Bezug auf fremde Religionen.

\subsection{Heiden}

Das arabische Wort šerk steht für Idolatrie, Heidentum, Polytheismus. „In den fiqh-Werken ist mušrik (Ungläubige) der eigenliche juristische Terminus für den Ungläubigen, doch wird auch oft kāfer gesagt.“602 „Nach wahhabitischer Lehre gibt es vier Arten von širk: Širk 'l'ilm, anderen als Gott Wissen zuschreiben; širk at-tașarruf, anderen als Gott Macht

\footnotetext{
${ }^{601}$ Ġafāri-Kāšāni, Aḥmad b. Moḥammad: Tãrih̆-e Negārestān, hrsg. von Mortażā Modarrsi-Gilāni, Teherān 1340/1961, S. 193.

${ }^{602}$ Björkman, Walther: Shirk, in EI, Bd. 4, Leiden/Leipzig 1934, S. 408-410, hier S. 408
} 
zuschreiben; širk 'l-cibāda, geschaffene Gegenstände verehren; širk 'l-‘āda, Zeremonien durchführen, in denen anderen als Gott Vertrauen entgegengebracht wird. “603 Das Wort kofr ist allgemeinste Bezeichnung für die Blasphemie. Zugleich bedeutet es Häresie und Unglaube. Einer, der die Wahrheit verbirgt oder leugnet, heißt kāfer. ${ }^{604}$ Das Wort umfasst sowohl die mušrekun (Ungläubige) wie die Schriftbesitzer. ${ }^{605}$

Es gibt nach der $\check{\boldsymbol{s}} \boldsymbol{a} \overline{\mathbf{n}} \mathbf{a}$ vier Kategorien von Menschen: Heiden, Schriftbesitzer, Muslime und Vertreter neuerer Religionen und Ideologien. Die Heiden und die Vertreter neuerer Religionen so wie Materialisten haben im klassischen Konzept der ̌̌arī $\mathbf{a}$ keine Existenzberechtigung.

Als Buchreligionen gelten im Islam unter anderem das Judentum, das Christentum, die Sabäer und der Zoroastrismus. Die Anhänger einer Buchreligion werden ahl al-ketāb (die Leute des Buches) bezeichnet. Nach islamischer Auffassung beruhen wahrhaftige Buchreligionen alle auf einer ursprünglichen göttlichen Offenbarung, die aber im Laufe der Zeit verfälscht worden ist. $^{606}$ In diesem Zusammenhang lesen wir im Koran, dass für diejenigen, die die Macht Gottes dadurch beschränken, dass sie sie auf mehrere Wesen aufteilen (wie z.B. die Christen mit Gott, Jesus und dem heiligen Geist), das Paradies verboten und ihr Platz stattdessen die Hölle ist. ${ }^{607}$ Sie haben jedoch die Alternative, sich zum Islam zu bekehren. ${ }^{608}$

In Verbindung mit Blasphemie sind immer auch die Begriffe ertedād (Apostasie) und ̌̌erk (Polytheismus) zu nennen. Die Muslime, die sich gegen den Islam entscheiden, werden mortadd (Apostat) genannt. Ein Apostat wird zu einem kāfer, einem Ungläubigen. Im Koran erwartet den Apostaten der Zorn Gottes und es werden ihm schwere Strafen im Jenseits angedroht. $^{609}$

Die Helden im $R H$ kämpfen gegen šerk und kofr. Die Durchsetzung der monotheistischen Lehre wird als eine Geschichte von Gewalt und Massakern beschrieben. Das $R H$ enthält ein hohes inhärentes Gewaltpotential und der dort propagierte Islam ist ausgesprochen intolerant. Die Ausprägung der religiösen Welt im $R H$ ist daher nicht frei von Hass, Gewalt und Feindschaft in den verschiedensten Formen.

\footnotetext{
${ }^{603}$ Hughes, Thomas Patrick: Schirk, in: Lexikon des Islam, München 2000, S. 645.

${ }^{604}$ Ebd. unter Kāfir, S. 385.

${ }^{605}$ Björkman, S. 408.

${ }^{606}$ Gemäß dem islamischen Recht erfahren wir, dass die Anhänger der Buchreligionen einen besonderen Schutz haben. Sie brauchen keinen persönlichen Einsatz bei der Verteidigung des Staates leisten, sondern können sich mit einer Ausgleichszahlung, der so genannten ğaziya (Schutzsteuer) davon befreien. Ansonsten genießen sie die gleichen Bürgerrechte, wie jeder andere Bürger. Siehe: Șadr-Ạ̣mad Ḥāğğ Seyyed Ğavādi: Ahl-e ketāb, in: Dā'rat al-ma'ārif-e tašayyo ’ Bd. 2, Teherān 1369/1990, S. 616-619.

${ }^{607}$ Koran, Sure. 5,76.

${ }^{608}$ Ḥāğğ Seyyed Ğavādi, Ahl-e ketāb, hier S. 618.

${ }^{609}$ Koran, Sure. 26,108f.
} 
Mit der Figur Ḥamzes ist der religiöse Eifer eng verbunden. Er wird als Person präsentiert, die zwischen wahr und falsch in der Religion unterscheidet. Hamzes Feinde erhalten oft charakteristische Beinamen wie żālemān (Unterdrücker), kāfer (Ketzer; 6/1056/28) und ätaš-parast (Feueranbeter; 4/561/14).

In vorislamischer Zeit galten auf der arabischen Halbinsel al-Lāt, Manāt und al- Uzzā als die Töchter Allāhs. ${ }^{610}$ Ihre Kultstätten waren al-Lāt, die aus einem weißen Stein bestand, und sich an dem Ort Tā') befand, al- Uzzā, die ein Baum im Wādī nahla im Tal der Palmen war, und Manāt, die aus Holz gebaut war und in Qudayd lag. All diese Kultstätten wurden von 'Ali zerstört. ${ }^{611}$

Diese Göttinnen werden im $R H$ an vielen Stellen erwähnt. Dies zeigt ein Beispiel von Anōširvān, der, obwohl er als Verteidiger der zarathustrischen Gemeinde bekannt gewesen ist, seinen Brief an Eskandar b. Heikalān im Namen der Lāt und Manāt unterschreibt (2/300).

Die Götzenanbeter im $R H$ haben die Wahl zwischen zwei Dingen: Entweder den Islam anzunehmen oder bekämpft zu werden. Wer sich weigert, für den gibt es nur den Kampf; und den Muslimen ist es vorgeschrieben, diese Götzendiener zu verfolgen und zu töten, wo immer sie auf sie stoßen.

Zur Entstehungszeit des $R H$ waren die Iraner Muslime und verehrten die oben genannten arabischen Gottheiten nicht mehr. Wir wissen, dass die Mongolen in ihren eroberten Gebieten wie Iran die Glaubensfreiheit verkündet hatten. Sie hatten aber ihre buddhistischen bzw. Schamanenrituale und Opfergaben weiter ausgeübt. Später ist der mongolische Herrscher Ġāzan (reg. 1295-1304) und die Oberschicht der Mongolen zum sunnitischen Islam übergetreten. Er kämpfte mit den Juden, Christen und Buddhisten. ${ }^{612}$ Der nächste Glaubenskämpfer des Islam im mittelalterlichen Iran war Amir Mobāriz ad-Din Moḥammad (1314-1358), der Gründer der Dynastie der Moẓaffariden, der mit mongolischen Götzenanbetern kämpfte. Die Quellen berichten, dass in der Stadt Kermān einige mongoliche Stämme lebten, die ihre Götzen verehrten und Amir Mobāriz ad-Din hatte mit Unterstützung der Gelehrten gegen sie gekämpft. ${ }^{613}$ So sehen wir, dass zu diesem Zeitpunkt in vielen Gebiete des Irans Götzenanbeterei üblich war. Aus diesen Gründen sahen

\footnotetext{
${ }^{610}$ Wellhausen, Julius: Reste arabischen Heidentums, Berlin/Leipzig 1927, S. 24-44.

${ }^{611}$ Nagel, Tilman: Staat und Gemeinschaft im Islam. Geschichte der politischen Ordnungsvorstellungen der Muslime, Zürich/München 1981, S. 41.

${ }^{612}$ Maškur, Moḥammad-Ğavād: Tārihb-e Tabriz tā pāyān-e qarn-e nohom-e heğri, Teherān 1352/1974, S. 462.

${ }^{613}$ Vgl. Bāstāni, Moḥammad Ebrāhīm: Vadi-ye haftvad, Bd. 1, Teherān 2535/1977, S. 323.
} 
sich die Autoren des $R H$ gezwungen als Sittenwächter der Religion gegen Götzenanbeterei zu kämpfen. So erzählen sie viel über Götzen und ihre Anhänger.

\section{Kalbanbeter}

Zu den Götzenanbetern gehörten auch die Kalbanbeter. Die Geschichte mit dem Kalb beruht auf einer Geschichte des Korans, die zuvor schon im Alten Testament auftaucht (Moses und das Goldene Kalb). Dazu berichtet an-Neišāburi, dass Sāmarī, als er Ǧebrā̄īl beim Untergang des Pharao im Roten Meer erkennt, ihn aber nicht erreichen kann, den Staub von den Hufen seines Rosses an sich nimmt und eine Handvoll dieses Staubes auf die Statue des Kalbes wirft, wodurch diese Statue lebendig wird. Nach einiger Zeit spricht Eblis (Teufel) aus dem Kalb und Sāmarī macht das Volk glauben, Allāh spräche zu ihnen aus dem Kalb, wie Musā aus dem Dornbusch gesprochen habe. ${ }^{614}$

Diese alttestamentarische Geschichte hat Einfluss auf die Erzählung im $R H$. Auch hier gelten die Tiere an einigen Stellen als Gottheiten. Dies zeigt das Beispiel von den Geschehnissen in der Stadt 'Anțali-ābād, der Residenz des Zardošt (Zarathustra), Zomorrods Vater. Dort leben in einem Teich zwei Frösche und ein Kalb, die in menschlicher Sprache sprechen können. Zardošt bringt sie in sein Land, wo sie verehrt werden. Als Ḥamze mit Zardošt kämpft und ihn besiegt, tötet er die sprechenden Frösche und das Kalb. Der Teufel, der in der Gestalt der Frösche und des Kalbes verborgen ist, kommt hervor und flieht (4/663).

\section{Zomorrodanbeter}

In den koranischen Überlieferungen lesen wir, dass Namrud ${ }^{615}$ und Fer'oun ${ }^{616}$ für sich die Göttlichkeit beanspruchten und der König Šaddād sich ein Paradies geschaffen hat. ${ }^{617}$ Die Schöpfer des $R H$ hatten, nach der hier vertretenen Ansicht, die Erzählungen des Korans vor Augen.

Zomorrod ist im $R H$ ein großer Feind des Islams, der für sich selbst göttliche Eigenschaften beansprucht. Er ist kennzeichnend für die Entstehungszeit des $R H$, da in dieser Zeit der Not und Wirren, bei gleichzeitiger Religionsfreiheit, der optimale Nährboden für viele neue religiöse Bewegungen jeglicher Art bereitet worden ist.

Im 14. Jahrhundert bildeten sich verschiedene Sekten im Iran heraus. Eine der mächtigsten waren die Hurufiye. Diese Sekte war eine heterodoxe muslimische Sekte mit gnostisch-

\footnotetext{
${ }^{614}$ an-Neišāburi, Abu Isḥāq Ebrāhīm b. Manșur b. Half: Qeșaṣ al-anbiyāà, hrsg. von Hạib Yag̉mā’i, Teherān 1340/1961, S. 213-214.

${ }^{615}$ an-Neišāburi, S. 46-58.

${ }^{616}$ an-Neišāburi, S. 172.
} 
kabbalistischen Zügen. Ihr Gründer, der von Mirān Šāh b. Timur getötete Fażlallāh Astarābādi (1340-1349), lehrte, dass Moḥammad zwar das „Siegel der Propheten“ sei, doch habe er nur den Zyklus der Propheten vollendet. Nach ihm habe aber ein neuer Zyklus der Heiligkeit, ein Zyklus der Erscheinung des Göttlichenim Menschen begonnen. „Faḍlallāh, der letzte der Heiligen, ist zugleich der erste in der göttlichen Reihe. Er ist der fleischgewordene Gott.“618 Die Ḥurufiya bestand nur wenige Jahre als selbstständige Organisation. ${ }^{619}$

Es ist bemerkenswert, dass es im 15. Jahrhundert in der Provinz Huzestān einen ṣufischen Orden oder besser gesagt eine ultraschiitische Sekte mit dem Namen Muša čša gab. Ein gewisser Seyyed Fayyāż leitete diese Sekte. Sie begann sich jedoch etwa seit Mitte des 15 . Jahrhunderts zunehmend auch weltlichen Angelegenheiten zuzuwenden, und strebte über ihren religiösen Anspruch hinaus politische Macht an. Die Sekte behauptete, dass 'Ali, der vierte Kalif, Gott sei, und in der Nachfolge auch ihr Oberhaupt, eben jener Seyyed 'Ali, der sich nach dem Verfasser des Mağālis al-mo'menin als Inkarnation 'Alis und der Gottheit selbst ausgab, ${ }^{620}$ das heißt „eine Inkarnation Gottes“ im Menschen darstellen wollte. ${ }^{621}$ Später in der Regierungszeit des Šāh 'Abbās I. (reg. von 1588 bis 1629) versammelte sich eine Gruppe in Qazwin um einen Noqțaviyaführer namens Derwisch Hosrou. Šāh 'Abbās I. ließ ihn unter der Anschuldigung, er verstoße gegen das Religionsgesetz und sei beim Weintrinken beobachtet worden, umbringen. ${ }^{622}$

$\mathrm{Zu}$ dieser Zeit hören wir auch in ganz Indien von einer starken religiösen Propaganda. Akbar, der Kaiser von Indien, erklärte seine neue Religion (din-e elāhi) und versuchte, diese zu einem Werkzeug der Staatsräson zu entwickeln. Darüber schreibt Franke:

„Da viele muslimische Gelehrte selbst bestätigten, dass Muhammads Botschaft
nun ihre Gültigkeit verlor, konnte man daraus folgern, dass es keinen Grund
mehr gab, am Islam als Staatsreligion festzuhalten. Nur allzu gern
schenkteAkbar diesen Stimmen sein Ohr und nutzte die Gelegenheit, die
vermeintliche religiöse Lücke durch eine eigene, der multikonfessionellen
Situation des Mogulreiches und seinen persönlichen Vorstellungen angemessen
Glaubenslehre zu füllen. Im Jahr 1582 proklamierte er den tauhīd-i ilāhī
(Bekenntnis der Einheit Gottes) oder dīn-i ilāhī (Göttliche Religion), der

\footnotetext{
${ }^{617}$ Neẓāmi, Eqbāl-nāme, S. 1271-1272.

${ }^{618}$ Huart, Clément: Ḥurūfī, in: EI, Bd. II, Leiden/Leipzig 1927, S. 359.

${ }^{619}$ Ritter, Hellmut: Anfänge der Ḥurüfisekte (Studien zur Geschichte der islamischen Frömmigkeit II), in: Orients, VII/I, 1954, S. 1-54.

${ }^{620}$ Šuštari, Qāżi Nurallāh: Mağāāles al-mo'menin, Bd. 2, Teherān 1368/1989, S. 400.

${ }^{621}$ Vgl. Caskel, Werner: Ein Mahdī des 15. Jahrhunderts, in: Islamica 4 (1929/31), S. 48-93; Minorsky, Vladimir: Musha'sha, in: EI, Ergänzungsband, Leiden 1938, S. 175.

${ }^{622}$ Falsafi, Bd. 4, S. 46-48.
} 
letztlich darauf abzielte, sämtliche Konfessionen des Reiches in ein für alle einheitliches System unter seiner religiösen Führung zu integrieren. “623

Die historische Realität beeinflusst die Autoren des $R H$ in besonderer Weise. Sie zeigen ihre Sorgen um die Religion und den Kampf mit dem Feind in der Darstellung der Gestalt Zommords. Er ist im $R H$ der König von Baktrien (Bāhntar) und erklärt sich selbst wie die Namrud und Fer'awn zu einer Gottheit. ${ }^{624}$ Natürlich weiß er, dass er kein Gott ist, auch wenn er dies immer wieder erklärt und ausrufen lässt: „Ich bin euer höchster Herr.“ Zomorrods doppelter Autoritätsanspruch als Gott und König findet sich im $R H$ wieder. Seine Macht steht im Dienst der Gottlosigkeit und des Kampfes gegen die Verbreitung des rechten Glaubens. Er will nicht Allāh dienen und befiehlt deshalb seinem Berater Bahtak, die Muslime umzubringen. Er und seine Anhänger verfolgen die Muslime erbarmungslos und Zomorrod kämpft mit seiner ganzen List gegen Hamze.

Zomorrod hat in seiner Rolle als Gott auch einen Erzengel namens Yāqut Šāh (3/485); während Bahtak Zomorrod als Teufel dient (5/780). Er hat 400 Propheten und mit Hilfe der Zauberei schafft Zomorrod sieben Himmel, einen Gottes-Thron, einen Garten und die Hölle (4/636). Das Paradies, das er seinen Anhängern verspricht, ähnelt demjenigen im Islam. ${ }^{625}$ In seiner menschlichen Rolle hat Zomorrod auch eine Familie und wohnt mit ihr in der prachtvollen Residenz Ṣabāyil (5/847). ${ }^{626}$ Sein Vater ist Zarathustra, sein Bruder heißt Zebarğad Šāh, der König von Zebarğadiye ist (5/780) und sein Sohn Lāhut ist ein guul (6/1056).

$\mathrm{Zu}$ seinen göttlichen Qualitäten gehören die Heilkraft und die Großzügigkeit allen Menschen gegenüber. Durch Handauflegen werden die Kranken von ihren Leiden befreit. Diese Wunderkraft bezeugt die Heiligkeit des Königs und soll zweifelsohne die Legitimität seiner politischen Machtansprüche belegen. Er behauptet, dass er mit seinem Speichel tödliche Wunden heilen könne. Er hat ein Wunderbecken, das die Toten wieder erwecken kann. Er spuckt seinen Speichel ins Gesicht seiner Anhänger, damit sie im Krieg Erfolg haben sollen (4/607). ${ }^{627}$ Diese Geste ist an vielen Stellen in der șufischen Literatur bezeugt. Ein Mann, den einen Șufi berührt, wird glücklich werden.

\footnotetext{
${ }^{623}$ Franke, Heike: Akbar und Ğahāngīr, S. 187.

${ }^{624}$ Koran, Sure. 79,24; Sure. 2,258.

${ }^{625}$ Vgl. Horten, Max: Die religiöse Gedankenwelt des Volkes des heutigen Islam, Halle 1917, S. 374.

${ }^{626}$ Pādešāh berichtet, dass Zomorrods Residenz von Nāder Šāh zerstört wurde. Pādešāh, qeițul, in: Farhang-e ānanderāğ, ḥarf-e q, Bd. 4, S. 3308.

627 Das Waschwasser des Propheten (Mohammad) wurde wegen der ihm innewohnenden Segenskraft als Medizin verwendet, und im Einklang mit alten Sitten vermochte er auch seinen Speichel verwenden, um jemanden zu heilen. Siehe: Mağlesi, Moḥammad-Bāqer: Hayāt al-qolub, Bd. 2, Teherān 1373-74/19941995, S. 180; Schimmel, Annemarie: Und Muhammad ist sein Prophet. Die Verehrung des Propheten in der islamischen Frömmigkeit, Düsseldorf; Köln: Diederichs 1981, S. 38.
} 
Ḥamze widmet sich viele Jahre lang der Aufgabe, Zomorrod für den Islam zu gewinnen. Er stößt auf unzählige Hindernisse und hartnäckigen Widerstand. Ḥamze stellt ihn schließlich vor die Wahl, sich entweder zur wahren Religion zu bekennen oder zu sterben. Er belagert einige Jahre lang Saabāyil, die Hauptstadt des Zomorrod, bis er sie nach langen Kämpfen erobern kann (4/619). Zomorrod kann von der Stadt Șabāyil fliehen und die Verfolgung von Zomorrod von Ort zu Ort bildet in der Folge den roten Faden der Erzählung. Schließlich flieht Zomorrod in Gestalt eines Derwisches nach Z Zu 'l-Amān. Er sieht dort seine Tochter Gitiafruz. Sie verlangt von ihm, sich zum Islam bekehren zu lassen, aber Zomorrod lehnt ab und er wird von den Muslimen festgenommen. Schließlich finden Zomorrod und Bahtak mit dem Tod ihre gerechte Strafe (5/1048).

\section{Sonnenanbeter}

Im Rahmen der altiranischen Religion hatte die Verehrung der Sonne eine besondere Bedeutung. ${ }^{628}$ Diese altehrwürdige Tradition hat auch im Koran als "Sonnenverehrung" eine herausragende Stellung gefunden. ${ }^{629}$

Auch in Indien war die Verehrung der Sonne sehr wichtig. Šahrestāni berichtet, dass zwei Sekten der Inder die Sonne bzw. den Mond verehren. Die Sonnenanbeter hießen „Dīnakîtïija“ (die Verehrer der Sonne). ${ }^{630}$ Er führte an:

„Sie glauben, dass die Sonne einer der Engel sei, mit Seele und Vernunft begabt, dass von ihr das Licht der Sterne und die Erleuchtung der Welt und die Hervorbringung der niederen Existenzen herrühre, und dass sie der Engel des Himmelkreises sei, welchem Verehrung, Anbetung, Räucherung und Anrufung gehören. “631

Nach Auskunft des Dabestān al-Mazāheb, einer Übersicht über die Religionen in Indien, die um 1650 von einem Parsen namens ZZu 'l-Fiqar Ardistāni verfasst wurde, soll die Verehrung der Sonne in Indien eine besondere Stellung eingenommen haben. ${ }^{632}$

Der indische Kaiser Akbar (1556-1605) verrichtete Dankgebete zur Sonne. Der jesuitische Missionar Monserrate berichtete gegen Ende seines Aufenthaltes (April 1582) am Hofe von Akbar über derartige religiöse Aktivitäten:

„Er [Akbar] hatte den Bau eines hölzernen Gebäudes von erlesener Machart befohlen und auf dem höchsten Punkt des Palastdaches einen Raum einrichten

\footnotetext{
${ }^{628}$ Widengren, Geo: Die Religionen Irans, S. 120.

${ }^{629}$ Koran, Sure. 91.

${ }^{630}$ aš-Šahrestāni, S. 366.

${ }^{631}$ aš-Šahrestāni, S. 366.

${ }^{632}$ Mobad Kei-Hosrou Esfandiyār: Dabestān al-Mazāheb, Bd. 1, hrsg. von Raḥim Reżāzāde-Malak, Teherān 1362/1983, S. 194.
} 
lassen; von dort beobachtete er den Tagesanbruch und betete zur aufgehenden Sonne." 633

'Abd al-Qādir Badā'uni (1540-1615) teilte uns in seinem Buch Montahab at-Tawārih weitere Angaben über den Ablauf von Akbars Gebeten mit:

„Es erging der Befehl, dass die Sonne täglich viermal verehrt werden sollte, nämlich in der Morgendämmerung, am Abend, am Mittag und um Mitternacht. (Seine Majestät) hatte es sich zur Gewohnheit gemacht, jeden Mittag 1001 Sanskrit-Namen (nām-i hindī) für die Sonne zu lesen, wobei er sich fromm zur Sonne wandte. Er pflegte dann, sich an seinen beiden Ohren zu fassen, drehte sich einmal um sich selbst und schlug dann mit seinen Fäusten gegen seine Ohrläppchen, und es gab noch viele andere Praktiken von derselben Art. Er trug das Hindu-Zeichen (qašqa) auf seiner Stirn und befahl, dass das königliche Orchester zu Mitternacht und bei Sonnenaufgang spielen solle.“634

Die Sonnenverehrung war auch bei den Mongolen sehr üblich. Beispielsweise musste der Tag der Inthronisierung eines Khans unbedingt ein sonniger Tag sein, denn wenn ein neuer Khan ausgewählt worden war, knieten alle Beteiligten der Zeremonie dreimal in Richtung Sonne nieder. ${ }^{635}$

Nach seiner Thronbesteigung im Jahr 1295 befahl der muslimische Ġāzān Hoān alle jüdischen, christlichen, buddhistischen und die Feuertempel zu zerstören und stattdessen Moscheen aufzubauen; weiterhin befahl er, alle Feueranbeter und Sonnanbeter, die sich weigerten sich zum Islam zubekehren, zu töten. ${ }^{636}$

Im Jahr 1608 gab es im Iran, in der Nähe von Kohkiluye, eine Derwischbewegung. Ein Derwisch, dessen Rufname Šāh Qalandar war, konnte in den Städten wie Fārs, Šuštar und Dezful sechs bis sieben Jahre lang regieren. Ihm gelang es, viele Menschen aus den Stämmen anzuziehen und so den Sonnenkult zu verbreiten. ${ }^{637}$

Auch im $R H$ sind die Sonnenanbeter eine sehr wichtige Gruppe der Götzenanbeter. In ihm wird berichtet, dass zu dem Kult auch die Verehrung der Sonne durch das Gebet gehört. Die Sonnenanbeter begeben sich in das Kloster, um dort die Sonne zu verehren. Im Kloster befindet sich eine gewaltige Volksmenge: Frauen, Greise und Jünglinge sowie Priester und

\footnotetext{
${ }^{633}$ Franke, Heike: Akbar und Ğahāngīr, S. 201.

${ }^{634}$ Badā'uni, 'Abd al-Qādir: Montahab at-Tawārih̆, Bd. 1, hrsg. von Ạ̣mad-'Ali Ṣāḥeb, Teherān 1380/2001, S. 224.

${ }^{635}$ Šabānkārei, Moḥammad b. 'Ali b. Moḥammad: Mağma' al-ansāb, Teherān 1363/1984, S. 294; HāleqiMoṭlaq, Bār va ā'in-e ān dar Irān, S. 217; Spuler, Bertold: Die Mongolen in Iran, Berlin 1955, S. 169; De Plano Carpini, Johann: Geschichte der Mongolen und Reisebericht 1245-1247, hrsg und übers. von Friedrich Risch, Leipzig 1930, (Veröffentlichungen des Forschungsinstituts für vergleichende Religionsgeschichte an der Universität Leipzig. 2. Reihe, Heft 11), S. 70.

${ }^{636}$ Maškur, S. 462.
} 
Mönche. Die Sonnenanbeter werden von Irağ geführt, der als ein großer Feind der Muslime unter Ḥamze im $R H$ erscheint. Ḥamze kämpft lange mit ihnen, bis sie endlich die Nichtigkeit ihres Glaubens erkennen.

Eine andere Form der Begegnung wird im $R H$ folgendermaßen erzählt:

'Amr ist von Ḥamze enttäuscht und er sinnt auf Rache. Er verlässt ihn, und gelangt in die Stadt Faranqušiye, wo man die Sonne anbetet, verkleidet als ein großer und reicher Geschäftsmann. Am nächsten Tag sieht er die Bewohner der Stadt zum Tempel gehen und 'Amr erfährt auf Nachfrage, dass die Menschen hier Sonnenanbeter sind. Zu Neujahr gehen alle Einwohner der Stadt, zwischen sieben bis siebzig Jahren, zum Tempel, um den hohen Priester der Sonne zu besuchen. 'Amr geht mit ihnen (4/695) und er tötet unbemerkt den Priester. Dann verkleidet er sich als solcher und sammelt alle Sonnenanbeter unter der Führung Irağs um sich, worauf sie zu Ḥamzes Lager reiten und lange Zeit gegen ihn kämpfen. Schließlich besiegt Ḥamze Irağ; er und seine Anhänger bekehren sich zum Islam.

\section{Lilienanbeter}

Zomorrod sucht auf seiner Flucht vor Ḥamze Zuflucht bei Neyram-e Susan-parast. Dieser ist Lilienanbeter und sein Hof ist in Lilienform erbaut (5/848). Bei den ersten Kämpfen erleiden Ḥamze und seine Männer eine schwere Niederlage nach der anderen (5/861). Daraufhin schickt Neyram einen Boten zu Ḥamze und verlangt von ihm, ebenfalls die Lilie anzubeten. Ḥamze weigert sich und entgegnet: „Wenn du vernünftig wärest, würdest du nicht eine Blume anbeten. Du musst wissen, dass ich, solange ich dich und die Feueranbeter nicht getötet habe, den Krieg nicht lassen werde“ (5/871).

\section{Wasseranbeter}

Das Wasser ist das wichtigste Element des Lebens und es wurde im Iran, in vorislamischer Zeit, und auch in Indien verehrt. ${ }^{638}$ Auch im Mandäismus der ältesten noch existierenden gnostischen Religion, spielt das Wasser eine wichtige Rolle. Sie geht auf die Lehren Johannes des Täufers zurück, des wichtigsten Propheten dieser Religion. ${ }^{639}$ Die Taufe wird dort nicht nur ein einziges Mal im Leben vollzogen, wie es zum Beispiel im Christentum der Fall ist. Die Mandäer haben die Vorstellung, dass sie während einer Taufe, masbūtāā genannt, ${ }^{640} \mathrm{der}$ Lichtwelt am nächsten sind und nehmen sie deshalb jede Woche, zumeist sonntags, vor.

${ }^{637}$ Ḥoseini-Monši, Moḥammad b. Mirak b. Mascud: Reyā̇̇ al-ferdous, hrsg. von Irağ Afšār u. Ferešte Șarrāfān, Teherān 1385/2006, S. 414-421.

${ }^{638}$ ašs-Šahrestāni, S. 370.

${ }^{639}$ Kurt, Rudolph: Gnosis und spätantike Religionsgeschichte, Leiden/New York/Köln 1996, S. 688.

${ }^{640}$ Ebd. S. 574. 
Durch das rituelle „Untertauchen“ glauben sie, die Vergebung aller Sünden, die Heilung von Krankheiten und die Vertreibung von Dämonen, sowie eine Reinigung des Körpers nach Menstruation und Geschlechtsverkehr erreichen zu können. Die mandäische Taufe findet traditionell in einem fließenden Gewässer (,Jordan“ genannt) statt. ${ }^{641}$ Im weißen Gewand wird der Gläubige von einem Priester in das Gewässer geführt und untergetaucht. Der Vorstellung nach hält das Leben für einen kurzen Moment an, um nach der Taufe als frisch und klar von neuem zu beginnen. Die masbütāa ist gerade deshalb so wichtig, weil sie zusammen mit der Seelenmesse die Voraussetzung für die Erlösung der Seele bildet. Früher hatte die Taufe eine derart zentrale Bedeutung, dass ungetaufte Kinder nicht zur mandäischen Religiongemeinschaft zählten.

Im $R H$ kommen auch Wasseranbeter vor. 'Amr betritt eine fremde Stadt und sieht dort in einem Textilgeschäft einen Jungen mit dem Muttermal in seinem Gesicht. Er vermutet, dass dieser ein Sohn oder Enkelkind von Hamze ist. Er spricht mit ihm und erfährt, dass die Menschen hier Wasseranbeter sind. Der Junge, Dārāb, fordert 'Amr auf, auch das Wasser anzubeten. Er weigert sich und geht in der Nacht in die Festung, tötet den Priester und verkleidet sich selbst als Priester (4/703). Diese Erzählung ist ähnlich der Erzählung von Irağs Sonnenanbeter, der gegen Ḥamze kämpfen.

\subsection{Buchreligionen}

Das $R H$ mit seiner vorwiegend islamischen Identität hat kein Verständnis für die Buchreligionen und steht im Konflikt mit anderen Kulturen, Religionen und Weltanschauungen. Oberstes Ziel dieser Untersuchung ist es, durch die Förderung einer offenen und neutralen Diskussion, kulturelle und religiös geprägte Konflikte, auf konstruktiv Weise im $R H$ aufzuzeigen.

Ausgehend von der Tatsache, dass jede Kultur, jedes Wertesystem und jede Religion Werte und Grundsätze bereithält, die zum Weltfrieden beitragen, sieht diese Arbeit ihr Aufgabe darin, die Machtkämpfe, die Ignoranz und vielerorts aufbrechende Gewaltbereitschaft zwischen rivalisierenden Gruppierungen zu zeigen.

\section{Zoroastrismus}

In der Kultur des Irans in der vorislamischen Zeit war das Feuer heilig. Mithin wurde auch das Feuer angebetet und der Kult hatte entsprechend Priester. Die Sasaniden stammten aus

${ }^{641}$ Ebd. S. 593. 
einer Priesterfamilie in Estaḩr. Sāsān war Feuerpriester des Nāhid-Feuertempels. ${ }^{642}$ Ardešir gewann die Mobads für sich und übernahm selbst die oberste Leitung ihrer Priesterschaft. ${ }^{643}$ Hosrou Anōširvān war bekannt als eifriger Feueranbeter und Verfechter der zoroastrischen Gemeinde.

Nach den islamischen Eroberungen wurden die Feueranbeter als Buchbesitzer anerkannt und einige berühmte Feuertempel blieben erhalten. ${ }^{644}$ Nach ihrer Unterwerfung wurde ihnen freie

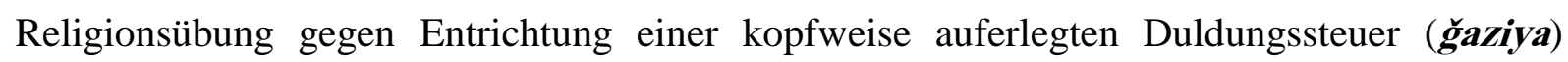
bewilligt. Büchner vermerkt dazu: „Die Unterwerfung Irans wäre unmöglich geworden, wenn die Araber die Zoroastrier als blosse Heiden betrachtet hätten, denen man nur die Wahl zwischen dem Islam oder dem Schwert hätte lassen können.“ ${ }^{\text {645 }}$ Mehr dazu führt Paret an:

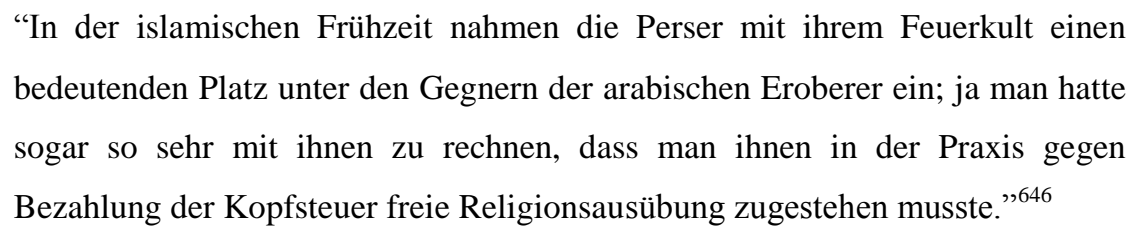

Die Feueranbeter werden im $R H$ als gabr bezeichnet und von Ḥamze, dem Vorkämpfer des Islams, gewaltsam unterworfen. In der Zeit der Eroberung kommen keine Übertritte vom Zoroasterglauben zum Islam vor. Am Hof des Perserkönigs sind seine Höflinge große Rivalen von Ḥamze, die des Öfteren versuchen ihn zu töten (1/10-50). Nach der Hochzeit mit Mehrnegār wird die Bevölkerung zum Übertritt zum Islam aufgefordert (1/192).

\section{Christentum}

Persien wurde im 17. Jahrhundert von vielen römisch-katholischen Mönchen besucht, die sich in dem Land oft lange Zeit niederließen. In der Regierungszeit des Šāh 'Abbās I. nahmen die diplomatischen Kontakte besonders mit den Großmächten zu und es kamen zahlreiche Botschafter in den Iran. „In diesen Zusammenhang gehört auch die Anwesenheit abendländischer Kaufleute, Künstler und Mönche.“6477 Die Mönche erhielten die Erlaubnis zum Bau einer Kirche und zur Gründung eines Klosters in Eṣfahān. Gabriel schreibt: “Als sich später in Europa das Gerücht verbreitete, dass Šāh 'Abbas I. keinerlei Widerwillen gegen Christen hege, sandte Papst Clemens VIII. eine größere Zahl Prediger nach Persien.“648 Die Toleranz des Šāh 'Abbās I. gab allen Anlass, einem erfolgreichen Ausgang der Mission mit

\footnotetext{
${ }^{642}$ Sāmi, 'Ali: Tamaddon-e sāsāni, Bd. 1, S. 325.

${ }^{643} \mathrm{Vgl}$. Widengren, Die Religionen Irans, S. 244-245.

${ }^{644}$ Ḥāğğ Seyyed Ğavādi, Ahl-e ketāb, S. 616-619.

${ }^{645}$ Büchner, V. F.: Madjūs, in: EI, Bd. III, Leiden/Leipzig 1936, S. 104-108, hier S. 105.

${ }^{646}$ Paret, Rudi: Die Geschichte des Islam im Spiegel der arabischen Volksliteratur, S. 9-10.

${ }^{647}$ Roemer, S. 320.
} 
Optimismus entgegenzusehen. Šāh 'Abbās war tatsächlich an religiösen Fragen interessiert. Er hatte den Wunsch nach Informationen hinsichtlich des christlichen Glaubens. So kamen die Karmeliter, Augustiner, Kapuziner und Jesuiten nach Persien, die sich meistens in Eṣfahān und an anderen Plätzen des Landes aufhielten. ${ }^{649}$ Die Priester hatten sehr intensive Gespräche mit dem König und zwar sowohl im größeren Rahmen mit anderen Theologen und Gelehrten, als auch im engeren Kreis.

Aus geschäftlichen Gründen hatte Šāh 'Abbās dreitausend armenische Familien aus der aserbaidschanischen Stadt Ğulfā nach Eṣfahān gebracht. Die Armenier hatten sich in einem neuen Stadtteil angesiedelt, der denselben Namen wie ihre Heimatstadt erhielt. Dort hatten sie ihre christliche Gemeinde gegründet. ${ }^{650}$ Doch anti-christliche Tendenzen der muslimischen Gelehrten verursachten sehr oft Auseinandersetzungen mit christlichen Gemeinden im Iran. Deshalb hatten die christlichen Missionare kaum die Gelegenheit, ihre Missionierungsarbeit voranzutreiben oder den Leuten über ihren Glauben Auskunft zu geben. Die Lage der Christen im Iran war sehr angespannt, und sie lebten unter ständiger Kontrolle und Beobachtung.

Von christlichen Kirchen wird im $R H$ an einigen Stellen berichtet. Zardošt (Zarathustra), Zomorrods Vater, hat sieben Kirchen in einem Garten namens Reżvān aufgebaut. Was unsere Aufmerksamkeit im $R H$ besondersfesselt sind die Beschreibungen der Kirchen, die als reichhaltig ausgestattete, prunkvolle Gebetshäuser beschrieben werden (2/259; 4/645).

Die Priester hingegen werden als schlechte Menschen dargestellt. 'Amr besucht eines Tagesein Kloster namens Deyr-e Minā, in dem ein Priester lebt, der Hexer ist und mit seinen zwei Töchtern eine sexuelle Beziehung hat (2/265-267). 'Amr tötet den Priester und vernichtet seine Magie.

Es wurde auch beschrieben, dass mehrere antichristliche Hass-Attacken auf Kirchen stattfanden. $\mathrm{Zu}$ den Schändungen gehörten die Ermordung der Priester und das Stehlen der Statuen (2/259).

Im Iran lassen sich unterschiedliche Ausprägungen der antichristlichen Bewegungen nachweisen, die bei einer Analyse des $R H$ und den dort auftauchenden Erscheinungsformen antichristlicher Denk- und Verhaltensmuster, analytisch und systematisch differenziert betrachtet werden müssen.

Grundlegend lassen sich propagandistische und rationale islamische Literatur unterscheiden. Die als propagandistisch bezeichnete, appellativ und emotional aufgeladene anti-christliche

\footnotetext{
${ }^{648}$ Gabriel, Alfons: Die Erforschung Persiens. Die Entwicklung der abendländischen Kenntnis der Geographie Persiens, Wien 1952, S. 94.

${ }^{649}$ Vgl. Gabriel, S. 93-98.
} 
Haltung wird funktionalisiert, um das religiöse Konzept zu legitimieren. Schließlich ist bei der Analyse von Erscheinungsformen der Christen im $R H$ zu berücksichtigen, an welche Zielgruppen der Text gerichtet ist, und welchen praktischen Zwecken er jeweils dient, wie etwa der Auseinandersetzung mit innenpolitischen Konkurrenten.

\subsection{Propheten}

Das $R H$ liefert die wichtigsten Glaubensgrundlagen des religiösen Lebens, der Rituale und Heiligenverehrung der Schiiten im Mittelalter. Diese haben durch die Jahrhunderte hindurch einen hohen Stellenwert für die Muslime. Diese sollen auf spannende Weise erzählt werden, um die Zuhörer in den Kaffeehäusern zu unterhalten.

Im vorangehenden Abschnitt behandelten wir im Wesentlichen „Propheten-Begegnungen“ als literarisches Motiv. Ein methodischer Ansatz, der das Imaginäre in einer Kultur erforschen will, darf hier jedoch nicht stehen bleiben, sondern muss die diesem Motiv zugrunde liegenden kollektiven Vorstellungen sichtbar machen. Damit ist gemeint, dass die Propheten religiös-dogmatisch sehr gut fassbar sind, sich jedoch der Volksglaube ein davon abweichendes Bild gemacht hat, welches für die Entwicklung und das Verständnis entsprechender Erzählungen noch wichtiger ist.

Im $R H$ lesen wir oft von Propheten und Prophetenerscheinungen wie beispielsweise von Ādam, Ebrāhīm, Heżr und Moḥammad, die sehr ausführlich beschrieben werden. Die Begegnung mit den Propheten geschieht meist im Traum. Wenn die Helden ihn sehen, begrüßen sie den Propheten, sprechen mit ihm und erhalten Heilung oder Handlungsanweisungen. Wenn er sich wieder entfernt, hinterlässt er Wohlgerüche wie Moschus, 'Ambra und Amber (1/60). ${ }^{651}$

\section{Ibrāhīm}

Der wichtigste Prophet in allen drei monotheistischen Religionen ist Abraham (arab. Ibrāhīm und pers. Ebrāhīm). Er begegnet uns in 25 der insgesamt 114 Suren des Korans. Der Name selbst kommt im Koran neunundsechzigmal vor. Ebrāhīm und seinem Sohn Ismā̄īl (pers. Esmāầl) werden die Etablierung des monotheistischen Kultes in Mekka zugeschrieben. Nach koranischer Auffassung ist Ebrāhīm der erste, der Gott erkennt und sich seinem Willen unterwirft. Er wird als der erste Muslim bezeichnet, der zusammen mit seinem Sohn Esmā̄il das Heiligtum der Ka'aba in Mekka gegründet hat. ${ }^{652}$ Ebrāhīms hateinen wichtigen Platz in

\footnotetext{
${ }^{650}$ Falsafi, Bd. 4, S. 201-216.

${ }^{651}$ Über den Wohlgeruch der Heiligen siehe: Daxelmüller, Christoph: Geruch, in: EM, Bd. 5, Göttingen 1987, Sp. 1097-1102, hier Sp. 1099.

${ }^{652}$ Koran, Sure. 2,118; 3,60.
} 
der fotovvat-Tradition. Er ist Abu 'l-fityān (Vater der fityān). ${ }^{653} \mathrm{Im}$ Buch Kitāb al-futuwwa des Ibn al-Mi'mār (gest. 1244) wird die silsila (Ahnenreihe) von 'Ali und den Propheten bis hin zu Ebrāhīm beschrieben. ${ }^{654}$

Ḥamze will die Menschen für den Islam gewinnen, aber nicht für den von Moḥammad verkündeten, sondern den von Ebrāhīm. Dies liegt daran, dass Ḥamze im $R H$ in der Zeit vor Moḥammad lebt und seine Abenteuer besteht; von den Verfassern ist eher beabsichtigt, dass Hamze sein Wegbereiter ist.

Das Motiv der Bekehrung durch Ebrāhīm begegnet uns im $R H$ in etwas spiritualisierter Form. Hier bekehrt Ebrāhīm mehrere Menschen, die Ḥamze zu Anfang feindlich gegenüberstehen, ihm dann aber in der Not helfen. Aslam-e, der Ratgeber des Mālā-kard (fränkischer Feldherr; 2/252), Șalṣāls Brüder Tomḡāğ Hoān ${ }^{655}$ und Maleke, Zarathustras Tochter (4/641) sehen den Propheten Ebrāhīm in ihren Träumen und sie werden dadurch zum Islam bekehrt (4/641).

Alle Begegnungen mit Ebrāhīm finden auf der Ebene von Träumen statt. Am Ende des Traumes verschwindet dann Ebrāhīm ganz plötzlich. Dieses plötzliche Verschwinden wird im $R H$ mit dem Begriff ġāyeb šodan (unsichtbar; 1/60) ausgedrückt.

Weiter wird berichtet, dass die Propheten dem Helden, der sich gerade in Gefahr befindet, helfen. Die Heiligen erscheinen am Bett eines Kranken, um ihn zu heilen oder ihm zumindest zeitweise Erleichterung zu verschaffen. Bei der Heilung spielen sie, eine große Rolle, so auch Ebrāhīm. Er befreit den Helden von seinem Leiden, von Schmerz, Unglück und Krankheiten. Er bewahrt die Menschen in letzter Sekunde vor dem drohenden Tod:

Ḥamze wird durch Gostaham vergiftet und er sieht in seinem Traum den Propheten Ebrāhīm. Ebrāhīm sitzt auf einem Thron aus Licht und kommt aus dem Himmel zur Erde. Er fragt ihn: „Warum weinst du?“ Ḥamze erzählt ihm von seiner Vergiftung. Ebrāhīm berührt ihn mit seinen Händen und heilt ihn (1/98).

Ein weiteres Beispiel berichtet von der Heilung Ḥamzes. Eines Nachts begibt sich Ḥamze in Begleitung eines befreundeten Knaben zu Mehrnegār. Als er sich in der Morgendämmerung von Mehrnegār verabschiedet und zurückgehen will, wird er von Qāren gesehen. Dieser will ihn festnehmen und schneidet dazu die Strickleiter mit Ḥamze ab. Ḥamze kommt zu Fall und

653 Pollok, Carmen: Fatā-Fityān-Futūwa: Studien zur Vorgeschichte der Männerbünde in vor- und frühislamischer Zeit, Dissertationvorgelegt von Carmen Pollok, Rheinischen Friedrich-Wilhelm Universität zu Bonn 1996, S. 95.

${ }^{654}$ Ibn al-Mi'mār, S. 140-142; vgl. Taeschner, Zünfte und Bruderschaften im Islam, S. 400. In der fotovvatTradition spielen die Propheten wie Ādam, Šīs Ebrāhīm und Moḥammad eine bedeutsame Rolle. Sie gehören zu den vier Patriarchen (̌̌ahär pir) der fotovvat. Siehe: Taeschner, S. 409.

${ }^{655}$ Truhart, Peter: Regents of Nations. Systematic Chronology of States and their political representatives in past and present, Part II, Asia/Australia-Oceania, München/New York/London/Paris 1985, S. 1079. 
verletzt sich am Kopf. Daraufhin flieht er mit seiner Armee nach Mekka, wo er in einem Traum den Propheten Ebrāhīm sieht und von ihm geheilt wird (1/60).

Ebrāhīm rettet die Menschen vor dem Verdursten oder Verhungern. Ebrāhīm schützt die Muslime vor den Ungläubigen. So lesen wir im $R H$, wie Ḥamze einst gegen Feueranbeter Krieg führte: In den heftigen Kämpfen leiden Hamze und seine Soldaten Hunger und Durst. Hamze betet, und kurz danach sieht er einen Jungen. Der Junge sagt, dass er in seinem Traum den Propheten Ebrāhīm gesehen habe. Durch Ebrāhīm sei er zum Islam bekehrt worden. Der Prophet habe zu ihm gesagt: „Geh zu meinem Kind und bring ihm das Wasser“ (4/619).

\section{Ilyās}

Im Koran ist Ilyās (pers. Elyās) Sems Sohn, der Enkel Noahs. ${ }^{656}$ Auch über den Propheten Elyās gibt es in der islamischen Tradition eine Legende, die sein Weiterleben erklärt. Eine viel zitierte Überlieferung, die at-Tálabī, die auf den persisch stämmigen Rechtsgelehrten 'Amr b. Dīnār (gest. 743) zurückführt, besagt: Elyās und Hुeżr bleiben solange am Leben, wie der Koran existiert. ${ }^{657}$ Nach Mağlesi bleiben Elyās und Heżr am Leben bis die Zeit des Imām-e Zamān (Herr der Zeit) kommt. ${ }^{658}$ Elyās und Heżr erscheinen im Șufitum als „Paar der Gegensätze“. Dem Volksglauben nach kann Elyās auch über den Regen verfügen. ${ }^{659}$

Elyās reist auf dem Festland und in den Steppen umher. ${ }^{660}$ Friedlaender schreibt, dass Elyās der Schutzengel der Wüsten sei und als al-Barrī „,der Festländische” bezeichnet werde. ${ }^{661}$

Elyās gilt auch als Wanderer der Meere. Aus dem Buch Bostān 'I-čarefīn wa tuḥfatalmuridin erfahren wir, dass Elyās auf den Meeren reist und sich um die Reisenden kümmert, die dort ihren Weg verloren haben. ${ }^{662}$

In den Volksromanen sind Elyās und Heżr ein Brüderpaar. Belege dafür, dass die beiden Brüder sind, finden sich im $R H$ (1/69). außerdem finden wir dort weitere Berichte über Elyās -Begegnungen. Die Wichtigsten davon sind die folgenden:

Ḥamze macht sich in Begleitung seines Kundschafters 'Amr mit dem Schiff auf den Weg nach Sarandib. Sie erreichen den Wasserwirbel von Eskandar, wo Ḥamze einen Obelisk mit einer Tafel findet. Dort steht geschrieben, dass nur derjenige, der unter einer günstigen

\footnotetext{
${ }^{656}$ Koran, Sure. 6,85; 37,123-132.

${ }^{657}$ Zitiert nach: Franke, Patrick: Begegnung mit Khidr, Beirut 2000, S. 136.

${ }^{658}$ Vgl. Meğlesi, Moḥammad Bāqer b. Moḥammad Taqi: Hayāt al-qolub, Bd. 1, Teherān 1374/1995, S. 312 .

${ }^{659}$ Wensinck, Arent Jan: Ilyās, in: EI, Bd. II, Leiden/Leipzig 1927, S. 501-502.

${ }^{660}$ Vgl. Mağlesi, Bd. 1, S. 311; vgl. Hamedāni, Moḥammad b. Mạ̣mud: ‘Ağãàb-nāme, hrsg. von Ğa'far Modarres-Șādeqi, Teherān 1375/1996, S. 106.

${ }^{661}$ Friedlaender, Israel: Die Chadirlegende und der Alexanderroman. Eine sagengeschichtliche und literahistorische Untersuchung, Leipzig/Berlin 1913. S. 121; 119.

${ }^{662}$ Rağāì, Aḥmad-‘Ali: Bostān 'I-'ārefīn wa tuḥatal-muridin, Teherān 1354/1975, S. 138-139.
} 
Sternenkonstellation geboren ist, das Schiff retten kann. Ḥamze steigt auf den Obelisk und findet dort eine Trommel und schlägt sie. Daraufhin kommen viele Fische herbei, die das Schiff aus dem Wasserwirbel herausziehen. Amir Ḥamze aber bleibt allein zurück und betet. Früh am Morgen sieht er im Meer einen König, der einen grünen Stock in seiner Hand hat, einen grünen Mantel trägt und von seinen Schultern bis zum Himmel von Licht umgeben ist. Elyās sagt zu Ḥamze: „Nimm deine Trommel, mach deine Augen zu und sprich siebenmal das șalawāt, danach öffne deine Augen.“ Hạmze tut dies. Als er seine Augen wieder öffnet, befindet er sich in der Nähe seines Heeres. ${ }^{663}$ Dann fragt Ḥamze ihn: „Wer sind Sie?“ Elyās antwortet: „Ich bin Heżrs Bruder“ (1/69).

In dieser Episode scheint es so, als ob Elyās eine starke Verbindung zum Wasser hat. Andere Quellen informieren uns darüber, dass Elyās als Herr über das Meer eingesetzt worden ist. ${ }^{664}$ In diesem Begegnungsbericht erscheint Elyās mit den gleichen Merkmalen wie Hueżr ausgestattet. Er hat einengrünen Stock in seiner Hand und trägt einen grünen Mantel. Elyās erscheintinder oben genannten Textstelle also in königlichen Gewändern. Er hat die Fähigkeit, in kurzer Zeit große Distanzen zurückzulegen. Diese Blitzreisen sind ein typisches Element in der islamischen Erzähltradition. In märchenhaften Erzählungen bilden sie oft den Abschluss einer Kette von Abenteuern und bringen den Helden wohlbehalten zum Ausgangspunkt zurück. Elyās übergibt Ḥamze eine heilbringende Gebetsformel und gibt sich bei dieser Begegnung selbst zu erkennen.

\section{Heżr}

Heżr ist eine mythische Persönlichkeit, von der man glaubt, dass er über göttliche Eingebungen verfügt und bis ans Ende der Welt leben wird, weil er das Wasser des Lebens getrunken hat. ${ }^{665}$ Die Menschen rufen ihn an als allgegenwärtigen Helfer und Ratgeber in der Not.

Im Koran Sure 18. Vers 59-81 sehen wir die früheste Spur der Heżrlegende vor uns. Er wurde im Vers 64 als "Knecht” bezeichnet, dem Allāh seine Barmherzigkeit gewährt und „sein Wissen offenbart hat." Moses unternimmt die beschwerliche und ereignisreiche Reise nur um durch ihn belehrt zu werden. ${ }^{666}$

\footnotetext{
${ }^{663}$ Mehr über die mit außergewöhnlicher Geschwindigkeit durchgeführte Reise (wie ein Blitz) siehe: Gramlich, Richard: Zur Ausdehnung der Zeit und Verwandten. Die islamische Welt zwischen Mittelalter und Neuzeit, in: Festschrift für Hans Robert Roemer zum 65. Geburtstag. hrsg. von Ulrich Haarmann und Peter Bachmann, Beirut 1979, S. 180-192, hier S. 190.

${ }^{664}$ an-Neišāburi, S. 338; Rağāi, S. 138-139.

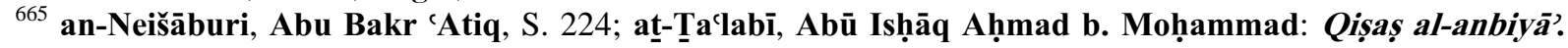
al-musammā 'Arā'is al-Mağālis, Miṣr 1371 h/1951, S. 305; Friedlaender, S. 182.

${ }^{666}$ Mağlesi, Hayāt al-qolub, Bd. 1, S. 275-287; Franke, Patrik: Begegnung mit Khidr, S. 60-72.
} 
Nach den Überlieferungen gibt es unterschiedliche Meinungen darüber, wo Heżr überhaupt „wohnt“; einige sehen seinen Aufenthaltsort im Meer, andere sehen ihn in der Wüste. ${ }^{667}$

$\mathrm{Zu}$ den Überlieferungen, die Heżr in der Wüste lokalisieren, gehören folgende Berichte:

Aus dem Buch Bostān 'I-cārefīn wa tuḥfatal-muridin erfahren wir, dass Heżr ständig durch die Wüste reist und sich um die Reisenden bemüht, die ihren Weg verloren haben. ${ }^{668}$ Der Hुeżrglaube ist besonders unter den Șufis verbreitet. Sistāni, ein Schüler von 'Alā' adDoula as-Semnāni, sagte:

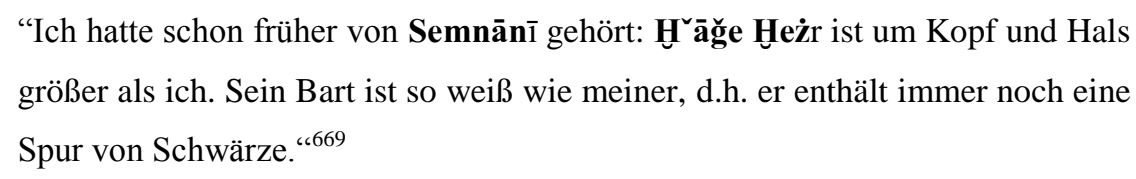

Heżr wird im $R H$ als țayy al-arż (Weltweiser) und barādar-e 'Ali b. Abi Täaleb ('Ali b. Abi Ṭālebs Bruder; 1/107/27) bezeichnet.

Die Begegnungen mit Heżr finden auf der Ebene von Träumen und von realen Handlungen statt. Heżr erscheint in folgender Geschichte als Überbringer einer frohen Botschaft:

Ḥamze macht sich auf den Weg, um seine Geliebte aus den Händen eines Dämons zu befreien. Ḥamze kämpft mit dem Dämon, besiegt ihn, tötet ihn und befreit seine Geliebte. Eines Nachts sieht er Heżr. Dersagt zu ihm: „Du musst Rābece heiraten.” Ḥamze antwortet, dass er Mehrnegār versprochen habe, sie zuerst zu heiraten. Aber Heżr besteht darauf: „Du musst sie heiraten, weil sie für dich einen Sohn gebären wird, der große Dinge tun wird;“ also heiratet Ḥamze Rābe`e (1/129-131).

Gott gibt den Menschen, was sie zum Leben brauchen. Nahrung, Kleidung und andere Dinge zum Leben. Das Gebet um Nahrung kann auf wundersame Weise erhört werden. Wenn dem Wanderer in Wüstengegenden das Wasser ausgegangen ist, ist sein Leben in Gefahr. In Notlagen kann die Rettung nur durch ein Wunder kommen. Gott tritt in solchen Situationen jedoch nicht selbst in Erscheinung, sondern lässt seine Propheten und Heiligen stellvertretend zum Wohle der Gläubigen wirken.

Die Vorstellung, dass Heżr Menschen in der Not hilft, zeigt sich auch in folgender Geschichte:

Während eines Gefängnisaufenthaltes sieht Ḥamze im Traum Heżr, der ihn wissen lässt, dass Gott ihn bestraft hat, weil er seine Pflicht als Vorkämpfer des Islams vernachlässigt habe. Heżr gibt ihm drei Sandkörner und sagt: „Du wirst in Zukunft niemals durstig und hungrig

\footnotetext{
${ }^{667}$ Mahdavi, Yaḥyā: Qị̣aṣ-e qor’ān-e mağid. Bar gerefte az Tafsir-e Surābādi, Teherān 1347/1968, S. 360; at-Ta labī, Qiṣaș al-anbiyã', S. 215; Friedlaender, S. $120 f$.

${ }^{668}$ Ră̌ằì, S. 138-139.

${ }^{669}$ Hartwig, Gordet: Die Sitzungen des 'Alā ad-dawla as-Semnānī, Zürich 1977, S. 80.
} 
bleiben. Wenn du Durst hast, nimm den Sand in deine linke Mundseite und wenn du Hunger hast, nimm den Sand in deine rechte Mundseite“"(2/314).

Die Begegnung mit Heżr findet auch auf der Ebene der Realität statt, wo sie mit „Glück“ und „Segen“ verbunden ist und er Ḥamze sowohl Ratschläge als auch gegenständliche Dingen mit auf den Weg gibt. So lesen wir im $R H$ :

Hูeżr lehrt Ḥamze bei einer Begegnung ein Gebet, dass ihn sein Aussehen verändern helfen kann (2/235-236). ${ }^{670}$ Dann gibt er ihm zudem den Sattel des Salomon und vier Hufeisen und sagt: „Wenn alle diese Hufeisen verloren gehen, wird dein Reich untergehen. Diese vier Hufeisen sind das Symbol für die vier Ecken der Welt"“ (1/179).

Heżr kümmert sich um alle Menschen, die unter Durst und Hunger leiden und leistet schnelle Hilfe. Er hat eine enge Beziehung zum Berufsstand der saqqå (Wasserträger), ${ }^{671}$ die er für seine Zwecke benutzt. Ein weiteres Beispiel: Ḥamze trifft den Propheten Heżr in der Wüste, wo dieser ihm vier Brote und ausreichend Wasser reicht und so vor dem Tode rettet (1/174).

Im $R H$ bekämpft Heżr auch Geister und böse Zauberer. In einem Beispiel eilt Heżr 'Amr zu Hilfe und befreitihn so von einem Hexer (4/624).

Im $Q H$ und $R H$ haben Elyās und Heżr eine gemeinsame Mutter, sind also Geschwister. ${ }^{672}$ Heżrs Mutter Āṣefe, die über Zauberkräfte verfügt, wohnt mit ihren Söhnen im Reich der Geister und Dämonen (1/180). Die beiden Brüder Elyās und Heżr, ebenso wie ihre Mutter, die jenseits des Feuerberges wohnt, haben die Kraft, Zaubersprüche auszusprechen, die den Zauber der Hexen bekämpfen.

Auf dem Weg ins Menschenland kommt Ḥamze an einen Bach. Dort trifft er die Mutter von Elyās und Heżz, die ihm ein Zauberseil gibt, das niemals nass wird und niemals brennt. Heżrs Mutter Āṣefe ist damit einverstanden, ihn auf seinem Weg bis zum Menschenland zu begleiten; um dort hinzugehen muss man sieben Meere und sieben Wüsten durchqueren. Sie verrichten ein gemeinsames Gebet. Nach dem Gebet sagt Āṣefe zu ihm, dass er seine Augen schließen solle. Als er seine Augen wieder öffnet, bemerkt er, dass er die sieben Meere und Wüsten hinter sich gelassen hat. So kommt Ḥamze ins Menschenland (1/180).

\footnotetext{
${ }^{670}$ Marzolph, TPV. (Motiv. Mit dem Gebet kann das Gesicht verändern 860 C; 2031 C), S. 281.

${ }^{671}$ Franke, Patrik: Begegnung mit Khidr, S. 100.

${ }^{672}$ Anonymus: QH, Bd. 1, S. 241; vgl. Mélekoff, Irène: La Geste de Melek Dānišmend, Bd. 1, Paris 1960, S. 164.
} 


\section{Soleimān}

Salomo (pers. Soleimān) war wie sein Vater Prophet und ein bedeutender König. Er empfing von Gott Wissen und wurde mit besonderen Gaben ausgezeichnet. ${ }^{673}$ Er war ein gerechter Mann und sehr fromm. ${ }^{674}$ Seine Macht benutzte er dazu, den Glauben an den wahren Gott zu verbreiten. In der islamischen Kultur sind Salomos Berühmtheit, Reichtum und Weisheit legendär. Auch aus dem Koran erfahren wir viel über die Weisheit und den Reichtum des Salomon. ${ }^{675}$ Der größte König und Prophet, Soleimān, gebot mit seinem hāātam (Ring) über Dschinn, Tiere, Vögel und Wind. ${ }^{676}$ Die ğinns haben mit ihren übernatürlichen Kräften dem König Soleimān gedient, z.B. bauten sie Gebäude und Wasserbecken. ${ }^{677}$ Ein wesentlicher Teil der Ausgestaltung der Erzählungen, insbesondere die Schilderung von Salomos Weisheit, Macht und Reichtum, dürfte bereits in der mündlichen Überlieferung anzutreffen sein.

Im $R H$ ist Soleimān der Gründer eines magischen Ortes, des Talismans. Er ist außerdem der Gründer vieler Städte und Gärten:

Ḥamze betritt eine Stadt und will dort Einkäufe tätigen, aber die Bewohner sprechen nicht mit ihm. Schließlich erreicht er ein Schloss, aus dem er Musik erklingen hört. Dort sieht er schöne Frauen, die ihm erklären, dass diese Stadt die Stadt des Schweigens heiße und die Bewohner der Stadt nur einmal pro Monat sprächen. Weiterhin erzählen sie, dass diese Stadt von Soleimān erbaut worden sei, und dass er hier seinen Schatz gelagert habe. Zum Schutz des Schatzes habe er einen Zauber über die Stadt ausgesprochen und einen Dämon als Wächter eingesetzt (1/173).

Man begegnet dem Propheten Soleimān auch imTraum:

Ḥamze, der durch Mazdak geblendet ist, sieht in seinem Traum den Propheten Soleimān. Der sagt ihm, dass nur die Blätter des Ayub Baumes seine Blindheit heilen können. 'Amr macht sich auf den Weg, um die Blätter zu finden. Nach ein paar Tagen findet er den magischen Baum und bringt zwei Blätter davon für Ḥamzes Heilung mit (2/219).

\section{Moḥammad}

Da die Erzählung in der vorislamischen Zeit angesiedelt ist, dürfte Moḥammad eigentlich nicht auftauchen, was aber dennoch im Zusammenhang mit Wundergeschichten geschieht.

\footnotetext{
${ }^{673}$ Koran, Sure. 27,15; Abū al-Ḥasan 'Ali al-Hasanī an-Nadwī: Prophetengeschichten aus dem Koran, ins Deutsche übersetzt. von Fatima Umm Abdallah, Deutschland 2006, S. 145.

${ }^{674}$ Koran, Sure. 6,84.

${ }^{675}$ Koran, Sure. 27,36; an-Neišāburi, S. 281-286; Mağlesi, Bd. 1, S. 351-372.

${ }^{676}$ an-Neišāburi, S. 277-278; an-Nuwairī, Šihāb ad-Din Aḥmad b. 'Abd al-Wahhāb: Nihāyat al-arab fi funūn al-adab, Bd. 14, Qāhira 1362 h/1943, S. 93; Šamisā, Farhang-e talmị̆āt, Teherān 1366-1987, S. 334.
} 
Die Szene, in welcher Moḥammad unerwartet auftaucht und eine Wunde mit der Hand berührt, stellt den mythischen Aspekt des Vorfalls heraus. Als Landehur nach Indien reist, nimmt ihn Ğazāyil, Landehurs Enkelsohn, fest und blendet ihn (5/1050-1051). Landehur sieht den Propheten Moḥammad in einem Traum. Der Prophet Moḥammad streicht mit seiner Hand über Landehurs Augen und dieser wird geheilt (6/1062-1063).

\subsection{Heilige}

Der Heilige als Typus des religiösen Ausnahmemenschen, als ein mit außerordentlichen Kräften, Charisma und Tugenden ausgestatteter Mensch, gehört zum Kern der religiösen Vorstellungswelt und erfährt aufgrund der Vorbildhaftigkeit seines Lebens und seiner Taten eine besondere Verehrung. ${ }^{678}$ In der islamischen Tradition nehmen daher die Heiligen nach dem Propheten die wichtigste Stellung ein. „Das Wort wali, dass wir gewöhnlich als Heiligen übersetzen, meint jemanden, der unter speziellem Schutz steht.“679 Die Heiligen besitzen baraka (eine Segenskraft). ${ }^{60}$ Durch die vielfältig wirksame Kraft der baraka kann nach islamischer Auffassung dem Bösen in der Welt begegnet werden. Man besucht die Heiligen bzw. ihre Gräber, um sie z.B. zu bitten, etwaige Feinde oder Übeltäter zu bestrafen. „Die Wunder, die die Heiligen wirken, sind mannigfacher Natur.“681 Man kann sie wie folgt ordnen: Auferweckung von den Toten, Sprechen mit anderen toten Heiligen, Trockenlegung des Meeres und Wandeln auf dem Wasser, Wandlungswunder, rasche Überwindung von Entfernungen, Sprechen mit Tieren und Bäumen, Krankenheilungen, Überwindung der Zeit, Stehen bleiben der Zeit, Erhörung der Gebete, Vorhersage von Unglücksfällen, Beeinflussung des Verlaufes der Dinge, göttlicher Schutz für die Heiligen, Blick in die Zukunft, schreckliches Erscheinen der Heiligen, göttliche Strafen für den, der die Heiligen nicht ehrt und Gestaltwandel. ${ }^{682}$

Die Heiligenverehrung war und ist im Iran immer populär. Der Glaube an die Segenskraft der Gottesfreunde und an die Wunderkraft der Heiligen galt als Zeichen der Frömmigkeit. ${ }^{683}$

\footnotetext{
677 an-Neišāburi, S. 283.

${ }^{678}$ Vgl. Speyer, Wolfgang: Die Verehrung des Heron, des göttlichen Mensch und des christlichen Heiligen. Analogie und Kontinuitäten, in: Peter Dinzelbacher, Dieter R. Bauer (Hg.): Heiligenverehrung in Geschichte und Gegenwart, Ostfildern 1990, S. 48-66, hier S. 49; vgl. Angenendt, Arnold: Heilige und Reliquien. Die Geschichte ihres Kultes vom frühen Christentum bis zur Gegenwart, München 1994, hier S. 9-14.

${ }^{679}$ Schimmel, Mystische Dimensionen des Islam, S. 284.

${ }^{680}$ Cotton, J. S.: Baraka, in: EI, Bd. I, Leiden: Brill 1913, S. 681.

${ }^{681}$ Kriss, Rudolf u. Heinrich Hubert Kriss: Volksglaube im Bereich des Islam, Bd. 1, Wiesbaden 1960, S. 9.

682 Seyyed-‘Arab, Hạan: Karāmat, in: Dā'irat al-ma‘ārif-e tašayyo‘, Bd. 13, Teherān 1391/2012, S. 605609, hier S. 607; 608. Mehr über Heiligeverehrung siehe: Goldziher, Ignaz: Le culte des saints chez les Musulmans, in: RHR, Bd. 2, 1880, S. 257-351; vgl. al-Qazwini, Die Wunder des Himmels und der Erde, aus dem Arabischen übertragen und bearbeitet. von Giese, Alma, Stuttgart/Wien 1986, S. 154; Schimmel, Und Muhammad ist sein Prophet, S. 79-83; Gramlich, Die Wunder der Freunde des Gottes, S. 165.

${ }^{683}$ Vgl. Gronke, Monika: Derwische im Vorhof der Macht, Stuttgart 1993, S. 81-85.
} 
Nach dem mongolischen Angriff und besonders in der Timuridenzeit nahm diese Art von Wundergläubigkeit stark zu. ${ }^{684}$ Die Heiligenverehrung findet sich auch in der muslimischen Werteordnung und in den Volkserzählungen wieder. Im $R H$ wird diese Heiligenverehrung in besonderer Weise aufgegriffen. Der Held, der ebenfalls durch seine besonderen Qualitäten und Fähigkeiten ein außergewöhnlicher Mensch ist, sucht die geistlichen Lebensformen, die auch in den mittelalterlichen Vorstellungen von Heiligen zu finden sind. Heilige heißen im RH mardān-e ḥaqq (Gottesmänner; 2/326).

In der schiitischen Tradition ist 'Ali b. Abi Ṭāleb der wichtigste Heilige. Nach schiitischer Auffassung steht er Gott besonders nah bzw. wird er in religiöser und ethischer Hinsicht als vorbildlich angesehen. Ihm wurde eine Funktion als Fürsprecher der Gläubigen gegenüber der göttlichen Autorität zugeschrieben. Eine Verehrung ist für ihn bereits in seinem Lebzeiten gegeben, aber erst nach seinem Tod ist allmählich eine große Verehrung erfolgt. Sein Grab und seine Reliquien entwickeln sich zu einem kultischen Zentrum besonderen Ranges.

In diesem Abschnitt wird der Versuch übernommen, 'Ali b. Abi Ṭālebs Rolle als Heiliger im $R H$ zu definieren.

\section{'Ali b. Abi Ṭāleb}

Wenn man schiitische Vorstellungen in Bezug auf den Propheten Moḥammad und seiner Familie berücksichtigt, kommt außer dem theologischen Bereich eine weitere Dimension hinzu, die volkstümliche Literatur. Dieser Abschnitt widmet sich der Untersuchung der schiitischen Legenden über 'Ali b. Abi Ṭāleb. Um seiner Bedeutung und Entwicklung im $R H$ gerecht zu werden, es notwendig, auf die unterschiedlichen Herausforderungen, vor allem auf die sozialgeschichtlichen, zu reagieren, und die Arbeit thematisch auf den volkstümlichen Bereich zu fokussieren. Zuerst muss betont werden, dass die Art und Weise, wie in der Wissenschaft mit den volkstümlichen Texten umgegangen wird, sehr unterschiedlich ist. Um einerseits die Rekonstruktionsumstände der verschiedenen Erzählungen im $R H$ und ihrer Beziehungen untereinander, und anderseits die historische Realität, die hinter den Texten steht, zu analysieren, muss man zweifellos unterschiedliche Untersuchungsfelder, die immer weiter ausgedehnt werden, mit heranziehen.

Bevor wir uns mit der Erörterung der Rolle 'Ali b. Abi Ṭāleb im $R H$ beschäftigen, müssen zunächst in aller Kürze einige der Hauptideen der Zwölferschia, das Ideengebäude und die

\footnotetext{
${ }^{684}$ Vgl. Amoretti, Biancamaria Scarcia: Religion in the Timurid and Safavid Periods, in: CHI, Vol. 6, hrsg. von Peter Jackson, London/New York/New Rochelle/Melbourne/Sydney 1986, S. 610-658, hier S. 613.
} 
komplexe historische Entwicklung nachgezeichnet werden. Auch heute noch wird diese Form des Glaubens von den Schiiten praktiziert. ${ }^{685}$

Die Schia ist ursprünglich im arabischen Umfeld aufgetaucht aber nach und nach wurden Elemente anderer Kulturen vorallem iranische aufgenommen und den Bedürfnissen der Zeit angepasst, was maßgeblich dazu beitrug, dass die iranische Identität nicht durch die arabischislamische Kultur assimiliert wurde. Dieser Prozess erreichte seinen Höhepunkt im 16. Jahrhundert, vor der Einführung der Zwölferschia als Staatsreligion unter den Ṣafaviden. Aufgrund ihrer eigenen ausgeprägten Kultur kam es zu Änderungen im islamischen Verständnis. Besonders die Spuren einer möglichen Synthese iranischer und islamischer Vorstellungen sind im Kernbereich der Imāmatslehre zu finden.

Es geht also um die Frage, in welchem Umfang und in welchen Formen die iranische Gesellschaft die arabische Form der Schia aufgenommen hat? Mit Hilfe welcher Institutionen und Sozialmechanismen sie den Wandel in der schiitischen Glauben verursacht hat? Wie sie zugleich ein Geschichtsbewußtsein ausgebildet hat? Um diese Fragen zu beantworten, untersucht dieser Teil verschiedene Ebene der schiitsichen Glaubenslehre im Bezug auf den RH.

Die erste Ebene der schiitischen Glaubenslehre befasst sich mit der Führung der Menschheit. Gott als Schöpfer der Welt hat eine absolute Herrschaft über seine Geschöpfe. Dies wird mit dem Wort walāyat-e motlaq-ye elāhiye (absolute, göttliche Herrschaft) bezeichnet. Gott ist den Menschen gegenüber barmherzig und will, dass die Menschen lernen und sich entwickeln. Da er selbst keinen direkten Kontakt zu den Menschen haben will, schickt er ausgewählte Menschen, die Propheten, auf die Erde, damit sie seinen Willen durchführen. Als seine Stellvertreter haben die Propheten Verfügungsmacht über ihre Gemeinden (walāyat annubuwwaya/Zyklus der Prophetie) und die Menschen müssen den Anordnungen der Propheten unbedingt Folge leisten. ${ }^{686}$

Die Sunniten und Schiiten glauben, dass der Zyklus des Prophetentums mit Moḥammad und der Offenbarung des Korans beendet ist und Moḥammad gilt für beide als der letzte Prophet (hātam al-anbiyā̃a , Siegel der Propheten). Im Gegensatz zu den Sunniten glauben die Schiiten, dass die religiöse Geschichte der Menschheit mit dem Tod des Propheten nicht beendet ist. „Der Prozess der Offenbarung Gottes an die Menschheit gilt zwar als abgeschlossen, doch auf den Zyklus der Prophetie [...], der durch die Verkündigung des göttlichen Gesetztes gekennzeichnet ist, folgt ein weiterer Abschnitt, der von der Existenz und

${ }^{685}$ Halm, Heinz: Die Schia, Darmstadt 1988. 
der Wirkung der Imāme geprägt ist, und den man mit dem Zyklus der spirituellen Initiation oder Gottesfreundschaft wiedergeben kann." 687

Nach schiitischen Überlieferungen ist die Existenz eines Imāms für den Fortbestand der Welt unerlässlich. Ohne seine Existenz hätte sie keinen Augenblick bestand. ${ }^{688}$ Wir lesen weiter: „Gott ließ die Erde seit dem Tode Adams (des ersten Propheten) noch nie ohne einen Imām, durch den man sich zu Gott führen lassen soll. Dieser ist Gottes Argument gegenüber seinen Knechten. Wer den Imām aufgibt, geht unter; wer an ihm festhält, wird wahrhaft zu Gott errettet. “689

Die schiitischen Imāme gelten als wāsețe-ye feïz (Vermittler von Gnade und Segen) zwischen Gott und den fehlbaren und unwissenden Menschen. Die Imāme verfügen als Auserwählte Gottes über Fähigkeiten, die gewöhnliche Menschen nicht haben (die Natur und sogar den Kosmos zu beeinflussen). ${ }^{690}$ Gott erweist ihnen die Gnade z.B. fähig zu sein, Menschen heilen zu können. Nach schiitischer Glaubensvorstellung wirkt die Botschaft der Imāme nach deren Tod weiter in verschiedenen Überlieferungen.

Die zweite Ebene der schiitischen Glaubenslehre beschäftigt sich mit der Quelle prophetischer Erkenntnis. Die Propheten haben Zugang zu göttlichem Wissen. Gott verleiht dem Propheten Moḥammad und seinen Nachfolgern, 'Ali und jedem der ihm folgenden Imāme, geheimes Wissen und die Unfehlbarkeit des Urteils. ${ }^{691}$ Gott verleiht dem Propheten Moḥammad und den Imāmen die Imunität gegen die Sünde ( 'eșmat, Unfehlbarkeit), die im Koran und in den schiitischen Traditionssammlungen belegt ist. ${ }^{692}$ Außerdem besitzen sie eine besondere Form von 'elm-e geib (ungesehenes Wissen) das von Gott stammt, und ihn gegen hatā (schuldhaftes Vergehen) schützt wie vor bloßem Irrtum. ${ }^{693}$

Vor diesem Hintergrund erhebt sich die Frage nach dem Ursprung der politischen Führung der islamischen Gemeinde. Wer ist berechtigt die islamische Gemeinschaft als rechtmäßiger

${ }^{686}$ Das Wort walāyat wird ins Persische in diesem Kontext mit dem ebenfalls vieldeutigen Abstraktum dusti (Freundschaft) übersetzt. Siehe: Ḥāğğ Seyyed Ğavādi, Șadr-Aḥmad, Emāmat, in: Dā’irat al-ma'ārif-e tašayyo ‘ Bd. 2, Teherān 1368/1989, S. 378-384, hier, S. 379.

${ }^{687}$ Macuch, Maria: Der 'iranisierte' Islam: Zur Entstehung einer eigenwilligen Synthese. in: Iran und iranisch geprägte Kulturen: Studien zum 65. Geburtstag von Bert G. Fragner. hrsg. von B. Hoffmann/R. Kauz/M. Ritter. Wiesbaden 2008 (Beiträge zur Iranistik 27), S. 315-335, hier S. 321.

${ }^{688}$ Ḥāğğğ Seyyed Ğavādi, Șadr-Aḥmad, Emām, in: Dã'irat al-ma‘ārif-e tašayyớ, Bd. 2, Teherān 1368/1989, S. 331-334, hier, S. 331.

${ }^{689}$ Nagel, Tilman: Geschichte der islamischen Theologie von Mohammad bis zur Gegenwart, München1994, S. 60; al-Kulainī ar-Rāzi, Abu Ğacfar Moḥammad b. Ya'qub b. Isḥāq: Uṣūl-i Kãfi, Bd. 1, hrsg. von Ḥāğğğ Seyyed Ğavādi Moṣțafavi, Teherān o.J., S. 251-254.

${ }^{690}$ Ḥāğğ Seyyed Ğavādi, Emām, hier S. 333.

${ }^{691}$ Corbin, Henry: The Meaning of Imam for Shici Spirituality, in: Expectation of the Millennium, New York 1989, S. 167-187, hier 184f; Halm, Der schiitische Islam, S. 45; Lambton, Ann Katharine Swynford: Political Theorye and Practice, in: Expectation of the Millennium, S. 93-107, hier S. 93; Nagel, S. 59

${ }^{692}$ Lambton, S. 99ff; Göbel, Karl-Heirich: Imamate, in: Expectation of the Millennium, S. 3-6, hier S. 5.

${ }^{693}$ Lambton, S. 100. 
Stellvertreter Gottes zu leiten? Es entstanden unterschiedliche religiöse Konzepte zwischen Schiiten und Sunniten. ${ }^{694}$ Nach schiitischer Auffassung sollte der Vertreter des Propheten zum einen für die Durchsetzung des religiösen islamischen Rechts und der Gesetze Verantwortung tragen, und zum anderen der spirituelle Führer sein, der befähigt ist, den versteckten oder esoterischen Sinn der Offenbarung zu deuten. ${ }^{695}$ Die Schiiten erkennen als oberste, göttlich inspirierte Autorität der muslimischen Gemeinde nur einen leiblichen Nachkommen des Propheten an, der von dessen Vetter und Schwiegersohn 'Ali und seiner Ehefrau, Fātima, abstammt. Nach Ansicht der Schiiten hatte der Prophet selbst seinen Vetter und Schwiegersohn 'Ali, als seinen wași (Nachfolger) designiert. ${ }^{696}$ 'Ali steht dank seiner verwandtschaftlichen Nähe zum Propheten genau wie dieser in der göttlichen Rechtsleitung; jeder, der die Führerschaft 'Alis ablehnt, ist im religiösen Irrtum befangen.

Die Aufgaben des Imāms teilen sich in zwei verschiedene Bereiche auf. Er ist zuständig für die Einhaltung der ک̌arī́a (Gesetze), sowie zugleich der Interpret der Offenbarung im Sinne des bātin (inneren, esoterischen Sinne), und ist somit der spirituelle Führer der Menschheit, der die islamische Gemeinschaft mit der verborgenen Welt verbindet. ${ }^{697}$ In zahlreichen schiitischen Überlieferungen wird die Erlöserfunktion der Imāme verdeutlicht. Nagel vermerkt: „Sich in Dingen des Glaubens an den Imām zu wenden, wird für die Schiiten der einzig sichere Weg zur Errettung am Jüngsten Tag. “698

Die dritte Ebene der schiitischen Glaubenslehre beinhaltet das Verhältnis zwischen Menschen und Imāme, das aus Freundschaft und Liebe besteht. Zum einen ist damit die Zuneigung und Liebe gemeint, die von den Gläubigen für die Imāme empfunden werden, zum anderen ist sie eine Qualität der Imāme selbst, durch die sie als Freund Gottes die Menschheit zur Erkenntnis führen. Im Zusammenhang mit der Zyklenlehre kennzeichnet walāyat oder dusti vor allem die Befähigung der Imāme, in ihrer Eigenschaft als Träger des göttlichen Charismas die esoterische Dimension der Offenbarung zu deuten. ${ }^{699}$

Nachdem diese Arbeit sich mit der Rolle der Imāme auf dem theologischen Gebiet beschäftigt hat, soll im weiteren Verlauf die Entwicklung der Ideengeschichte der Schiiten in Bezug auf ihren Glauben an die schiitischen Imāme, insbesondere an 'Ali b. Abi Ṭāleb, erläutern.

\footnotetext{
${ }^{694}$ Ḥāğğ Seyyed Ǧavādi, Emāmat, hier S. 381.

${ }^{695}$ Ebd. S. 380f.

${ }^{696}$ Shahabi, Mahmud: The Roots of Shicism, in: Expectation of the Millennium, S. 15-19, hier S. 16; Lambton, S. 99.

${ }^{697}$ Ḥāğğg Seyyed Ǧavādi, Emām, S. 331-334

${ }^{698}$ Nagel, S. 59

${ }^{699}$ Ḥāğğ Seyyed Ǧavādi, Emāmat, hier, S. 380.
} 
Zuvor soll aber erklärt werden, was unter Ideengeschichte $\mathrm{zu}$ verstehen ist. Barbara Stollberg-Rilinger erläutert: „Danach sind Ideen (unit ideas) unveränderliche, gleichsam kleinste gedankliche Einheiten, die sich im Lauf der Geschichte in unterschiedlichen Konstellationen und Ausprägungen finden lassen.“700 Sie schreibt weiter: „Gegenstände des Denkens, Wissens, Meinens - was Ideen sind, hängt davon ab, was im Kontext eines bestimmten ideengeschichtlichen Forschungsansatzes als Gegenstand definiert wird. Die einen verstehen darunter philosophische Theorien einzelner prominenter Denker, die anderen viel allgemeiner auch Glaubensvorstellungen, Weltbilder, Wertüberzeugungen, kollektives Alltagswissen - je nachdem, welche Fragen man stellt, welcher Methoden man sich bedient und auf welche Quellen man sich stützt.“701

Zur Untersuchung müssen die Mentalität der Vergangenheit und die Geschichte des schiitischen Gedankengutes zusammen betrachtet werden. Hierzu sind folgende Fragen wichtig: Mit welchen Methoden wurden diese Erzählungen in der schiitischen Gemeinde eingeführt? Welches religiöse und politische Gedankengut verbindet sie mit der Gesellschaft? Wie gestaltete sich ihre Einbettung in der iranischen Gesellschaft? Wie verlaufen die Kommunikationsvorgänge zwischen dem einfachen Volk und den religiösen Führern?

Unter diesem Gesichtspunkt scheint eine der bedeutendsten Fragen diejenige nach dem Glaubensverhalten der schiitischen Gemeinde zu sein, das häufigen Wandlungen unterlegen ist.

Dieser Wandel steht zweifellos in Beziehung zu den Veränderungen im Verhalten, der Vorstellungswelt und den Ausdrucksformen der Menschen in jeder Zeitepoche. In diesem Zusammenhang vermerkt Duby, dass ,eine noch offenere Untersuchung [...] sich auch für andere Elemente interessieren [muss], die es zusammengenommen erlauben, das Universum, das ganze psychologische, intellektuelle, moralische Universum` wieder zu erschaffen und die Vorstellungen, die sich eine bestimmte historische Gemeinschaft von der Welt, vom Leben, von der Religion, von der Politik zurechtschmiedete', zu rekonstruieren. Es geht darum, Mythen, Überzeugungen, Symbole auf ihrem langsamen Weg von einer Epoche zur anderen, von einem kulturellen Milieu zum anderen, mit den Veränderungen, die sie in den verschiedenen Bewusstseinstadien durchgemacht haben, zu inventarisieren. Im Laufe dieses langen Weges müssen die Vorformungen, Erweiterungen, fortschreitenden Verknöcherungen genau betrachtet und zu den Impulsen und Wiederständen in Bezug

\footnotetext{
${ }^{700}$ Stollberg-Rilinger, Barbara: Was heisst Ideengeschichte, in: Ideengeschichte, Stuttgart 2010, S. 7-42, hier S. 7.

${ }^{701}$ Ebd. S. 8.
} 
gesetzt werden, die sich aus dem kulturellen, sozialen und politischen Rahmen ergeben, ohne dabei die Einflüsse der materiellen Existenzbedingungen $\mathrm{zu}$ vernachlässigen, etwa die Technik, alle die Werkzeuge, über die Menschen in einer Gesellschaft verfügen. Die kollektiven Vorstellungen [...] sind nur zugänglich über die Bilder, die Ausdrücke, die sie fixieren. Sie sind es, die man aufspüren und aus den Spuren der Vergangenheit herausarbeiten muss." ${ }^{\text {7702 }}$

Duby fügt $\mathrm{zu}$ den allgemeinen Bedingungen kultureller Veränderungen aus: „Diese Bewegungen passen sich dem Gang der gesamten Kultur an und reagieren auf gleichzeitige Veränderungen der wirtschaftlichen, sozialen und politischen Rahmenbedingungen. Sie beschleunigen oder verlangsamen sich entsprechend in den jeweiligen Epochen, aber im Allgemeinen sind sie anpassungsfähig, ohne spürbare Brüche und nicht wie die unruhige Wellenbewegung an der Oberfläche durch plötzliche Stürme aufgewühlt.“،703

Die schiitischen Glaubensvorstellungen haben einen langsamen Wandel vollzogen und haben sich im Laufe der Zeit mit der zunehmenden Verbreitung neuer religiöser Vorstellungen erweitert. Wie konnten schiitische Mythen, Überzeugungen, Symbole auf ihrem Weg von arabischen zum iranischen Milieu ausbreiten? Welchen Charakter haben diese kulturellen Veränderungen? Die Mentalitätgeschichte der Schiiten im Iran und ihre Veränderungen im Laufe der Jahrhunderte kann nicht ohne Voruntersuchungen in Verbindung mit der historischen altiranischen und volkstümlichen Literatur betrachtet werden. Um dies $\mathrm{zu}$ erreichen, sind entsprechende Quellen heranzuziehen, eigene Fragestellungen $\mathrm{zu}$ entwickeln und eigene Verfahrensweisen anzuwenden. Die von mir gewählten Quellen sind religöse Überlieferungen, die Geschichte des Schiitentums und volkstümliche Erzählungen.

Die Einbeziehung der vorislamischen Einstellungen und Vorstellungen von iranischen Gelehrten, Dichtern und schließlich von Erzählern, zeigt einen großen Wandel in der kulturellen Entwicklung der Schia. Nach der Eroberung des Irans durch die Araber rückt das kulturelle Erbe der Iraner verstärkt in ihr Bewusstsein, gleichzeitig wird das Interesse der arabischen Gelehrten geweckt. Die iranischen Mythen werden, neu interpretiert, wieder in das Leben der Menschen zurückgebracht. Die iranische Literatur bzw. Erzählungen mit diesen neuen Gedanken bzw. Inhalten werden in der islamischen Gesellschaft verbreitet.

\footnotetext{
${ }^{702}$ Febvre, Lucien: Vue d'ensemble (wie Anm. 4), S. 218; ders., Vivre l'historie (wie Anm. 4), S. 190 [dt. Raulff, Lucien Febvre (wie Anm. 4), S. 89], Zitiert nach Duby, S. 159.

${ }^{703}$ Duby, Georges: Mentalitätengeschichte, in: Ideengeschichte, hrsg. von Barbara Stollberg-Rilinger, Stuttgart 2010, S. 137-163, hier S. 150.
} 
Um an die Wurzeln des Gedankenguts der Schia zu gelangen, muss man sich daher mit der schiitischen Literatur, die zum Teil fiktive Legendenliteratur und zum Teil geschichtliche Überlieferung ist, befassen. Es sind meiner Ansicht nach die volkstümlichen Erzählungen, in denen sich die Antwort auf die Herausforderungen des Wandels im schiitischen Gedankengut finden lassen. Die Verbreitung dieser Erzählungen unter den Iranern verursachen im Laufe der Zeit drastische Veränderungen, die Einfluss auf das Verhalten und die Einstellungen der Schiiten haben und mehr oder weniger schnell zum Gedankengut der Schiiten werden. Diese Entwicklung dringt in das Bewusstsein der Menschen ein, bieten Erklärungen für das Verhalten von Menschen und befähigen dazu, die Welt und sich selbst, mit anderen Augen zu sehen.

Wir beschäftigen uns nun mit dem Erzähler als Katalysator einer potentiellen Einstellungsänderung. Es findet eine Wechselwirkung zwischen dem Erzähler einerseits, der in Abhängigkeit von seiner Ausbildung, steht, dem Milieu dem er entstammt, seinen Traditionen und der Gesellschaft, in der er arbeitet, und seinem Publikum andererseits, das ihm seinen Lebensunterhalt verschafft und dessen Geschmack seine Werke bis zu einem gewissen Grad beeinflussen können. Im 16. Jahrhundert erreicht der Einfluss der Erzähler in der iranischen Gesellschaft seinen Höhepunkt. Die Erzähler versuchen bestimmte altiranische Auffassungen von Königtum, von moralischen Regeln, von religösen Praktiken und literarischen Erinnerungen in Bezug auf das altiranische Kulturerbe und die islamische Tradition bzw. der Schia, in ihre Erzählungen einfließen zu lassen. In ein neues Gewand geschmückt üben sie ihren Einfluss aus und werden ihrer neu gewonnenen Bedeutung in der Gesellschaft in jeder Weise gerecht. Um diese Annahme zu verdeutlichen, bringen wir an dieser Stelle ein Beispiel aus vorislamischer Zeit, dass im Schiitentum weiterlebt, nämlich den Lichtlehre-Glauben der Iraner aus vorislamischer Zeit und dessen Verbindung zu den schiitischen Imāmen. Es heißt, dass die Imāme, die mit dem Propheten blutsverwandt sind, zugleich Trägereines göttlichen Lichts ( Licht (nur-e mohammadi) bezeichnet wird. ${ }^{704}$ Dieses göttliche Licht existiert gemäß schiitischer Lehre seit Anbeginn der Schöpfung im Wesen eines jeden Propheten und wird seit Adam in jedem Zeitalter jeweils an einen designierten Nachfolger weitergeleitet. ${ }^{705}$

Die Verbindung, die zwischen der auf Blutsverwandtschaft beruhenden Herrscherlegitimation und dem von Gott verliehenen Charisma hergestellt wird, ist überdies eine der ältesten Ideen, denen wir im vorislamischen iranischen Schrifttum begegnen.

\footnotetext{
${ }^{704}$ Halm, Die Schia, S. 105; Lambton, S. 93; Rubin, Uri: Pre-existence and Light: Aspects of the Concept of Nur Muhammad, in: Israel Oriental Studies 5 (1975), S. 62-119.

${ }^{705}$ Mağlesi, Bd. 2, S. 3.
} 
Die Vorstellung, dass Heilige von Licht umhüllt sind, wurde aus der mesopotamischen Tradition abgeleitet. ${ }^{706}$ In der zoroastrischen Gemeinde erschien Ahura Mazda, die höchste Gottheit des Zoroastrismus, in der Form einer Lichtgestalt, die als xvarenah bezeichnet wurde. Das rvarenah galt daher als seine Manifestation. ${ }^{707}$ Das xvarenah (Neupersisch. farr und farr-e izadi sowie farr-e yazdān genannt) war eine unverzichtbare Bedingung für die Ausübung des Königtums. Es sicherte seinen Erfolg und versprach ihm ein glückliches Schicksal. $^{708}$

Die Vorstellung einer göttlichen Energie oder magischen Kraft des Geistes, die sich als Licht manifestiert, findet sich dann auch im Schriftum der mitteliranischen Periode und im $\check{\boldsymbol{S}} \bar{a} \boldsymbol{h}$ nāme wieder: in dem Begriff farr-e keyāni findet das alte xvarenah mit den entsprechenden Konnotationen bei Ferdousi seine Fortsetzung. ${ }^{709}$

Die Vorstellung vom xvarenah wurde auch in die islamische Tradition übernommen. Nach Nẹ̣ām al-Molk (1018-1092), der ein berühmter Wesir der Seldschukensultane Alb-Arsalān und seines Sohnes Malekšāh war, heisst es: „Wenn der König das göttliche Licht (farr-e izadi oder farr-e elāhi) und die Souveränität besitzt sowie über reiches Wissen verfügt, dann wird er das Glück beider Welten erlangen.“710

Ebenso findet man in dem Fürstenspiegel Naṣighat al-Moluk (Beratung für Könige) von Abu Ḥāmid Moḥammad al-Ǵazzāli (1058-1111) den Rückbezug zur vorislamischen Tradition des Irans. Er schreibt, dass man die Vorstellung so verstehen müsse, dass Gott ihm (dem König) und dem Königtum das göttliche Licht gegeben habe. ${ }^{711}$ Das königliche Licht und Charisma verleiht den iranischen Königen die Fähigkeit, außergewöhnliche Taten zu vollbringen, mit Weisheit zu herrschen, Gerechtigkeit walten zu lassen und über ihre Feinde zu siegen.

Die Lichtlehre findet sich auch in den islamischen Überlieferungen. Als Gott Moḥammad erschaffen wollte, hatte er vor Beginn der Zeit sein Licht erscheinen lassen und als dieses Licht sich in Verehrung vor ihm verneigte, formte er daraus eine durchsichtige Säule ( $a m u d$ an-nur), die nichts anderes war als der präexistente Prophet Moḥammad. Nach at-Tustari war Moḥammad in seiner Lichtnatur die Urschöpfung, der kosmische Ursprung des gesamten

\footnotetext{
${ }^{706}$ Vgl. Hubert Cancik, Helmut Schneider u. Jahannes Renger (Hg.): Nimbus, 3. I. (Alter Orient und Bibel), in: Der neue Pauly. Enzyklopädie der Antike, Bd. 8, Stuttgart/Weimar 2000, Sp. 947.

${ }^{707}$ Böcher, Otto: Licht und Feuer I, in: Theologische Realenzyklopädie, Bd. 21, Berlin/NewYork, S. 85.

${ }^{708}$ Vgl. Yarshater, Ehsan: Iranian commen Beliefs and world-view, in: CHI, Vol. 3 (1), Cambridge 1983, S. 343358, hier S. 345.

${ }^{709}$ Ferdousi, Bd. 1, S. 19.

${ }^{710}$ Neẓām al-Molk, Abu 'Ali Ḥasan Ṭusi: Siyāsat-nāme, Teherān 2535/1976, S. 81.

711 al-Ġazzāli, Abu Ḥāmid Moḥammad: Naṣị̣at al-Moluk, hrsg. von Ğalāl ad-Din Homāi, Teherān 1361/1983 S. 81.
} 
Universums. $^{712}$

Die Idee der Präexistenz des Propheten Moḥammad ist in den schiitischen ḥadịten enthalten. Dieser Überlieferung zufolge war das Licht des Propheten Moḥammad das erste Geschöpf Gottes. ${ }^{713}$ „Dem Propheten selbst wird der Ausspruch zugeschrieben: „Das erste, was Gott schuf, war mein Licht.“714 Das Licht des Propheten wurde zu einem der wichtigsten Bestandteile der islamischen Prophetenverehrung. „Seit der Schöpfung Adams geht eine göttliche Lichtsubstanz von einem auserwählten Nachkommen Adams in den anderen über, bis dass sie in die Lenden des gemeinsamen Großvaters des Moḥammad und des 'Ali gelangte; hier spaltete sich dieses göttliche Licht und gelangte teils zu 'Abdallāh, dem Vater des Propheten, teils zu dessen Bruder Abu Ṭāleb, dem Vater des ‘Ali.“‘715

Die Imāme sind vor allem Menschen, die sich dadurch auszeichnen, dass ihre Seele als erste von Gottes Geschöpfen aus Licht besteht, das ihnen besondere Fähigkeiten verleiht. ${ }^{716}$ Die Spekulationen rund um die Lichtsubstanz werden in jeder Literatur aufgegriffen, die sich mit der Heiligenerscheinung befasst und einen wichtigen Teil des schiitischen Erzählgutes bildet. Die Propheten und Gottesmänner von Adam bis hin zu Moḥammad gelten als Träger und Übermittler des göttlichen Lichtes und werden in der Malerei mit dem Flammennimbus geschmückt.

Berücksichtigt man die historischen Rahmenbedingungen dieser Entwicklung, ist der Verweis auf die vorislamische Tradition im Iran offensichtlich. Es scheint außer Frage zu stehen, dass hier mesopotamische und iranische Vorstellungen den Boden für die Aufnahme dieser Idee in die schiitische Lehre vorbereitet haben. Es handelt sich hierbei um eine kulturelle Transformation, die sich mit der Veränderung der gesellschaftlichen Wertsysteme und politischen Ordnung manifestiert hat.

Die Familie des Propheten steht bis heute im Zentrum des Islamischen Interesses. Die Liebe zur Prophetenfamilie verursacht einen radikalen kulurellen Wandel in der schiitischen Ausprägung des Islams im Iran. Die schiitische Verehrung 'Alis und seiner Nachfolger hat im Laufe der Jahrhunderte eine sich ständig verändernde Entwicklung erlebt.

\footnotetext{
${ }^{712}$ Böwering, Gerhard: The Mystical Vision of Existence in Classical Islam. The Qur'ānic hermeneutics of the Șūfĩ Sahl at-Tustarī (gest. 283/896), Berlin/New York 1980, S. 150; Schimmel, Und Muhammad ist seine Prophet, S. $113 \mathrm{ff}$.

${ }^{713}$ Mağlesi, Bd. 2, S. 3.

${ }^{714}$ Wensinck, Arent Jan u. Kramers, Johannes Hendrik: Nūr Muhamamadī, in: Handwörterbuch des Islam, Leiden 1941, S. 592.

${ }^{715}$ Goldziher, Ignas: Vorlesungen über den Islam, Heidelberg 1925, S. 206; Mağlesi, Bd. 2, S. 4.

${ }^{716}$ Imām Moḥammad al-Bāqir sagte: "Gott ist Einer und ein Einziger in seiner Einheit. Er hat ein Wort ausgesprochen, das ein Licht ward, und aus diesem Licht schuf er Moḥammad, mich selbst und meine Nachkommen. Dann sprach er ein weiteres Wort aus, das Geist ward, den er in dieses Licht eingehen ließ, und das Licht wiederum ließ er in unsere Körper eingehen. So sind wir (Imāme) Gottes Geist und Wort."
} 
Auch im Șufismus und Derwischtum spielt 'Ali eine bedeutsame Rolle. „Er gilt als der erste Mystiker und pir (Meister) und wird als der islamische Heilige par excellence verehrt.“717 In den Șufi und fotovvat-Schriften werden die Handlungen 'Alis als ğ is̄ār (Opferbereitschaft) bezeichnet. Er ist eine Mischung aus Tapferkeit und Kämpfertum. ${ }^{718}$

Des Weiteren wird 'Alis Bereitschaft zitiert, sein Leben für den Propheten zu lassen. In der fotovvat-Tradition wurde das Bild von 'Ali b. Abi Țāleb weiterentwickelt. So schreibt Taeschner:

„Er wurde als Prototyp des fatā der eigentliche Patron der futuwwa; seine Tapferkeit war allgemein bekannt, und es wird von ihm berichtet, dass er mehr als einmal sein Leben für den Propheten aufs Spiel gesetzt habe. Aus diesem Grunde lässt die Überlieferung eine unsichtbare Stimme, einen hātif, ihn als den wahren fatā, sein doppelspitziges Schwert Du-'l-Faqār als wahres Schwert bezeichnen. “719

Hoch- und Spätmittelalter entwickelten sich zu einer Epoche, die von Erzählungen über 'Alis dominiert war. 'Alis Bild wurde von seinen Anhängern idealisiert und mit vielen Legenden verbunden und so zum Prototyp eines jugendlichen Helden. Im Laufe der Zeit interessierten sich die schiitischen Erzähler für ihn. Sie sammelten ein Publikum um sich und erzählten die Geschichten von 'Alis Taten. Um die Herrlichkeit des Propheten und seiner Familie darzustellen erzählten sie großartige Wundergeschichten, die in deren historischen Lebensläufen gar nicht existierten. Die Legenden Moḥammads, 'Alis und ihrer Genossen enthielten außerdem fantastische und mythologische Elemente.

Man muss diese Form der Erzählungen als eine Art freischaffende Kunstform betrachten, die keinen historisch belegten Hintergrund hat. Solche Erzählungen haben jedoch Berührungspunkte mit den Prophetenlegenden einerseits und der legendären futüh-Literatur, der Darstellung der Eroberungen der Muslime nach Moḥammad, andererseits. In den schiitischen Erzählungen hilft 'Ali den Schwachen und Unterdrückten. Er nimmt den Platz der guten Geister des Heidentums ein, um den Helden, die von Gefahr bedroht werden, mit seiner bewaffneten Hand ( $\underline{Z} \boldsymbol{u}$ al-Faqār, sein berühmtes Schwert) beizustehen. ${ }^{720}$ Diese Geste und dieses Bild sind an vielen Stellen in der schiitischen Literatur bezeugt.

Siehe: Ayub, Mahmoud Mustafa: Redemptive Suffering in Islam: A Study of the Devotional Aspects of Ashura in Twelver Shicism, Den Haag 1978, S. 216.

${ }^{717}$ Frembgen, Jürgen: Derwische Gelebter Sufismus Wandernde Mystiker und Asketen im islamischen Orient, Köln 1993, S. 21.

718 Taeschner, Futuwwa, eine gemeinschaftsbildende Idee im mittelalterlichen Orient und ihre verschiedenen Erscheinungsformen, in: Schweizerisches Archiv für Volkskunde, Bd. 52 (1956), S. 122-158, hier S. 131.

${ }^{719}$ Taeschner, Zünfte und Bruderschaften im Islam, S. 16.

${ }^{720}$ Vgl. Mélekoff, Irène: Abū Muslim. «Le Porte-hache» du Khorassan dans la tradition épiqe turco-Iranienne, Paris 1962, S.38. 
Die schiitischen Autoren des $R H$ verherrlichen 'Ali mit vielen Beinamen. Er wird als $\check{\boldsymbol{S}} \bar{a} h-e$ velāyat (König der Erhabenheit; 2/322/19), Šir-e hodā (Löwe Gottes; 3/416/27), Maẓhar-e ‘ăgāyeb (Verkörperung des Wunderbaren und Fremdartigen; 2/219/22) und Morteżā (der Wohlgefällige; 2/313/11) bezeichnet und die Helden sollen von 'Ali selbst Wunderkraft erhalten haben. Die Wundertaten 'Alis spielen in den iranischen Erzählungen wiederholt eine bedeutende Rolle. So wird über die Heilung von körperlichen Leiden wie Blindheit und Verletzungen jeglicher Art durch Segenskräfte berichtet.

Auch wird von Begegnungen mit 'Ali berichtet, die dazu dienen Herrschaft zu legitimieren. Diese Berichte spielen eine wichtige Rolle für den schiitischen Glauben. 'Ali wird als Vorbild im Glauben und im Leben dargestellt. Er hat nicht nur in der Gedankenwelt der Schia sondern auch in der Welt der Ritter eine herausragende Funktion.

Die Begegnungen mit 'Ali finden meistens im Traum statt. ${ }^{721}$ Wo immer 'Ali auftaucht, ist sein Erscheinen mit Licht verbunden (2/260). Seine Auftritte in den Geschichten erfolgen ebenso plötzlich und überraschend wie sein Verschwinden am Ende der Begegnung.

Als Karib zu Boden fällt, sieht er 'Ali in seinem Traum. Dieser streicht dreimal mit der Hand über seine Wunde und sagt: „Habe keine Angst vor dieser Wunde, du wirst nicht daran sterben.“ Dann verschwindet er und hinterlässt den Duft von Amber (2/285).

Solche Erzählungen mögen vielleicht von orthodoxen Muslimen nicht akzeptiert worden sein; aber es gibt keinen Zweifel daran, dass der tiefe Glaube an 'Ali und seine Familie eine zentrale Stellung im schiitischen Weltbild einnimmt und der Schlüssel für das Verständnis der Handlungen der Protagonisten in der populären islamischen Dichtung ist.

Er ist der Verteidiger der Schwachen und Unterdrückten, der ein wenig auch den Platz der guten Geister des Heidentums einnimmt, um den Helden, die sich in Gefahr befinden, zu helfen. 'Ali nimmt „,neben seiner hohen religiösen Stellung, den Rang eines iranischen Nationalhelden ein, dessen Verehrung in engem Zusammenhang mit patriotischen Gefühlen steht." 722

Die Heiligen übermitteln den Gläubigen auf wunderbare Weise höhere geistige und religiöse Gaben. Eine in Șufikreisen weit verbreitete Lehre ist die Gürtelung (kamar bastan) durch Heilige. Die Funktion des Gürtels als Schutz der Zeugungsorgane dürfte in Verbindung mit dem Glauben an die magische Wirksamkeit und Bedeutung der „Manneskraft“ gerade bei

\footnotetext{
${ }^{721}$ Besonders in der für den Iran sehr bedrohlichen Șafavidenzeit waren heilsbringende Träume von 'Ali sehr häufig; so behaupteten die șafavidschen Könige, dass sie 'Ali in ihren Träumen gesehen haben und ihn in ihren Schwierigkeiten um Hilfe gebeten haben. Șafā, Tãrihu-e adabiyāt dar Irān, Bd. 5, Teil 1, S. 153.

${ }^{722}$ Soroudi, S. 376.
} 
einem Helden stehen: „Der Gürtel beinhaltet die Kraft des Helden.“723 Die Gürtung (bzw. Gürtelung) verleiht außergewöhnliche Stärke.

Im $R H$ finden sich verschiedene Szenen, in denen 'Ali einem Helden hilft, indem er ihn nur anblickt. Wenn er seinen Blick auf einen Helden richtet, wird ihm das ehrenvolle Geschenk des 'Ali zuteil, und er wird gesegnet und unbesiegbar gemacht (2/260).

In einigen Geschichten tritt 'Ali als ein König auf (4/576) und durch den Duft den er verbreitet und seine auffällige Schönheit, beeindruckt er die Menschen sehr. 'Alis Erscheinen ist immer mit Duft verbunden, denn das besondere Merkmal des Propheten ist eben sein Wohlgeruch: „Die Hände des Propheten werden als kühl und wohlduftend gepriesen, [...], und in allen Berichten wird der Duft, der von ihm ausströmte, hervorgehoben.“724

Karib hört, dass Eskandar-e Karbnus seine Rüstungen und viele andere kostbare Dinge in einem Talisman eingelassen hat. Um diesen Talisman vernichten zu können, verrichtet er das Gebet und sieht in seinem Traum Imām 'Ali, der zu ihm sagt: „Du wirst einen weißen Vogel sehen, erschieß ihn mit einem Pfeil. Die Tafel des Talismans ist bei ihm. Nimm die Tafel und tu alles, was auf der Tafel geschrieben steht." Als Karib aufwacht, riecht er den Duft von Amber (2/275).

Auf diese Art und Weise lassen sich in den vorgetragenen Erzählungen der Rezitatoren, die den Erwartungen ihres Publikums zu entsprechen suchen, die Veränderungen des Geschmacks verfolgen. Eine historisch zuverlässige Verknüpfung der Figuren und ihrer Handlungen ist dem $R H$ nicht unmittelbar zu entnehmen, weil sie dort durch die Erzählweise ins Märchenhafte entrückt werden.

\subsection{Wunder, Blicke, Gottesnamen und Träume}

Da nicht alles was im $R H$ unter Magie verstanden wird, erklärt werden kann, wird im Rahmen der vorliegenden Arbeit versucht, eine beschränkte Zahl von Darstellungen magischer Vorstellungen sowie Wunder, Gottesnamen und Beschwörungsformeln der Muslime anzuführenund $\mathrm{zu}$ kommentieren. In einem knappen Überblick sollen die historischen Entwicklungen und Hintergründe, die sich im Volksaberglauben wiederspiegeln, dargestellt werden. Offensichtlich haben die Iraner aus der vorislamischen Zeit viele Elemente adaptiert. Wunder sind seltene Erscheinungen, die Staunen erregen. Ein klar definierter islamischer Begriff für Wunder ist dem Koran fremd. Im Koran bedeutet al-bayyina, welches ein Substantiv darstellt, „der klare Beweis”725, das Menschenunmögliche heißt hāariq al-‘āda (es

\footnotetext{
${ }^{723}$ Marzolph, Ulrich: Gürtel, in: EM, Bd. 6, Göttingen 1990, Sp. 311-315.

${ }^{724}$ Schimmel, Und Muhammad ist sein Prophet, S. 32.

${ }^{725}$ Koran, Sure. 98,1; Antes, Peter: In der Ǎšrìya bis al-ǴGazzāĭ, Freiburg 1969, S. 22.
} 
bedeutet wörtlich: das Durchbrechen der Gewohnheit); Prophetenwunder werden im Koran als bayyināt bezeichnet. ${ }^{726}$ Gramlich hat die Wunder in vier Kategorien eingeteilt:

a) Der Anspruch auf die Göttlichkeit

b) Der Anspruch auf das Prophetentum

c) Der Anspruch auf die Gottesfreundschaft

d) Der Anspruch auf die Magie und den Gehorsam des Teufels ${ }^{727}$

Die islamische Dogmatik verwendet zur Bezeichnung der Wunder zwei Termini mu karāma (pers. mo'̌̆eze und karāmat). Der erste Terminus mu (̌̆iza. ist das Partizip der IV. Form des Verbs ‘ağaza, das stets als Erklärung für etwas Ungewöhnliches angeführt wird und auch im Koran belegt ist. ${ }^{728}$ Über $\boldsymbol{m u}$ (̌̌iza schreibt al-Baqdadī:

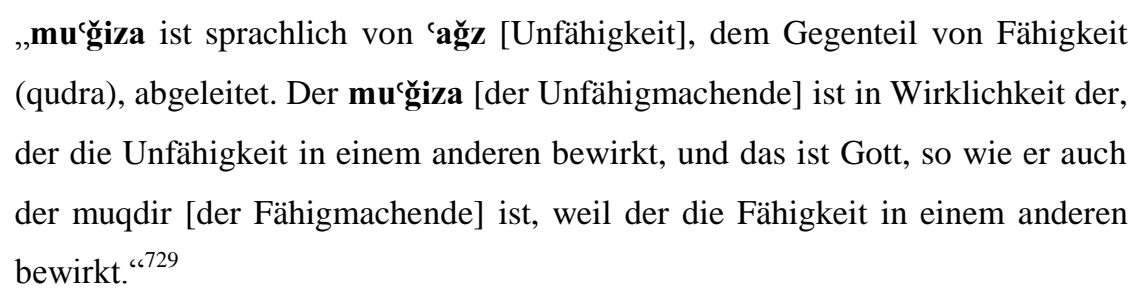

Im strengen Sinn ist das Machtwunder mu č̆izāa mit dem Anspruch auf das Prophetentum verbunden und daher nur beim Auftreten eines echten Propheten möglich. Denn das Wunder ist der Beweis für die Wahrhaftigkeit und für die göttliche Bestätigung des Anspruchs. ${ }^{730}$ So können die Propheten ihre Wahrhaftigkeit beweisen. Bei den Schiiten werden auch die Wundertaten der Imāme wie die der Propheten als Machtwunder bezeichnet.

Neben mu (̌̆iza kennt die islamische Theologie den Begriff karāma (Huldwunder), der die Wunder bezeichnet, die von Heiligen vollbracht werden. ${ }^{731}$ Karāma kann man wohl als „Gunstbeweise” Gottes für seine Gläubigen verstehen. Gemeint sind mit karāma jednfalls jene wunderbaren Gaben und Gnadenbeweise, mit denen Allāh seine Heiligen umgibt, sie beschützt und ihnen hilft. Karāma wird den Asketen und Frommen zuteil. ${ }^{732}$ Ihre außergewöhnlichen Werke sind nicht mit einem Anspruch auf Wahrhaftigkeit verbunden. Karāma und mư̌ğiza sind sich darin ähnlich, dass nur Gott die übernatürliche Kraft im

\footnotetext{
${ }^{726}$ Koran, Sure. 40,34.

${ }^{727}$ Gramlich, Die Wunder der Freunde Gottes, S. 19.

${ }^{728}$ Koran, Sure. 22,51.

${ }^{729}$ Zitiert nach: Gramlich, Die Wunder der Freunde Gottes, S. 27; Mehr darüber siehe: Wensinck, Arent Jan u. Kramer, Johannes Hendrik: Mưğiza, in: Handwörterbuch des Islam, S. $517 f$.

${ }^{730}$ al-Bāqillānī, I'ǧāz al-Qur’ān, S. 288.

${ }^{731}$ Vgl. Schimmel, Mystische Dimensionen des Islam, S. 292.

${ }^{732}$ Zirke, Heidi: Ein hagiographisches Zeugnis zur persischen Geschichte aus der Mitte des 14. Jahrhunderts. Das achte Kapitel des Șafwat, aș-Safã in kritischer Bearbeitung, Berlin 1987, S. 65.
} 
Propheten und im Heiligen entfalten kann, da beide aus sich selbst heraus keine Macht über die Natur besitzen.

Über viele Propheten und schiitischen Imāme weiß man allerlei Wunder zu erzählen; besonders über den Imām 'Ali, den Nachfolger des Prophten Moḥammad. Ihm wurden und werden in schiitischen Kreisen zahllose Wunder zugeschrieben. ${ }^{733}$

\section{Blick}

Den Menschen, die zu den Gläubigen gehören, wird durch den Blick irgendeines Heiligen geholfen. Die geistige Kraft des Blickes, die vom Auge des Heiligen ausgeht, hat eine außergewöhnliche Wirkung.

Der Muslim nennt diesen außergewöhnlichen Segen baraka. In den arabischen Wörterbüchern wird das Substantiv baraka allgemein mit „Segen“ oder „Segnung“ wiedergegeben. Im Persischen findet man unter baraka außerdem Begriffsinhalte wie “Überfluss, gutes Leben. Auch im Türkischen ist bereket nicht nur der „Segen“, sondern auch „,reichliches Vorhandensein, Überfluss ,,ja sogar“ Fruchtbarkeit.“734 „Die baraka hört mit dem Tode des Heiligen nicht auf, wirksam zu sein. Im Gegenteil: Gerade den verstorbenen Heiligen schreibt man besondere Kraftwirkungen zu.“735 Über die Auswirkungen die der Blick der Heiligen haben kann hat Gramlich ausführlich und gründlich berichtet. Um insoweit Wiederholungen zu vermeiden, wird an dieser Stelle auf seine Arbeit verwiesen. ${ }^{736}$

In Șufikreisen erscheint oft der Begriff nazar kardan (wörtlich: den Blick werfen). Es ist die Infinitivform des Nomen nazar. „Nach der sufischen/schiitischen Vorstellung der Imāme und Meister der Derwischorden können sie Novizen bzw. Anhänger mit ihrem Blick

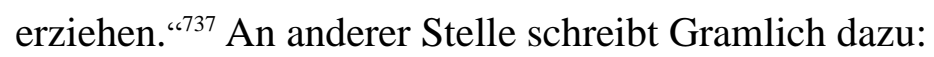

\footnotetext{
„Das im Orient so sehr gefürchtete „,böse Auge“ hat im Volksglauben und in der Sufik ein positives Gegenstück. Wie man vor dem Fluch des bösen Auges flieht, so sucht man andererseits den Segen des Blicks ,nazar“ des Heiligen zu erlangen." ${ }^{738}$
}

\footnotetext{
${ }^{733}$ an-Neišāburi, Abu Bakr 'Atiq, S. 125; Gramlich, Die Wunder der Freunde Gottes, S. 475.

734 Theorien zur Etymologie der Wortwurzel $b r k$ sind nachzulesen bei Chelhod, Josef: La baraka chez les Arabes ou l'influence bienfaisante du sacré, in: Revue de i'Histoire des Religion, No. 148, Paris 1955/1, S. 68-88, hier S. 77ff; Denffer, Dietrich: Baraka as basic concept of muslim popular belief, in: Islamic Studies, Vol. XV, Islamabad 1967, S. 167-186, hier S. 174; $183 f$.

735 Paret, Rudi: Symbolik des Islam, Stuttgart 1958, S. 60; mehr darüber siehe: Rentz, G.: Baraka, in: $E I^{2}$, Bd. I, Leiden/Leipzig 1960, S. 1032-1033.

${ }^{736}$ Gramlich, Die Wunder der Freunde Gottes, Wiesbaden 1987.

${ }^{737}$ Gramlich, Die schiitischen Derwischorden Persiens, zweiter Teil: Glaube und Lehre, Wiesbaden 1976, S. 205-207; Gramlich, Die Wunder der Freunde Gottes, S. 173-179.

${ }^{738}$ Ebd. S. 179.
} 
Die baraka des Blickes und des Atems des Imāms scheint für die Schiiten sehr wichtig zu sein. Mit baraka wird ein Begriff angesprochen, der für den islamischen Volksglauben von zentraler Bedeutung ist. Von Glück erfüllt erzählt daher der Erzähler „der Blick des Imāms sei auf die Helden gefallen.“ Der Blick des Imāms hilft dem Helden über alle Gefahren hinweg und kann ihn zum stärksten Menschen machen. Diese übermenschliche Wirkung des Blickes wird einer ihm innewohnenden geheimnisvollen überirdischen Kraft zugeschrieben.

Im $R H$ geht es oft darum, menschliches Verlangen nach Glück, Sieg und Erfüllung durch Überwindung leidvollsten Erlebens $\mathrm{zu}$ ungeahnter Erfüllung $\mathrm{zu}$ bringen. Dabei ist den Erzählern aber bewußt, dass diese Erfüllung nicht im realen irdischen Raum mit seinen begrenzten Möglichkeiten zu erwarten ist. Darum verlegt die Erzählung den Schauplatz der Begebenheiten, der Lösungen und der Erlösung, und vor allem seine integrierende Kraftquelle, das Wunder, aus der Ebene der wirklichen Welt in eine irreale, metaphysischgerechtere Welt. Hier lebt das Wunder in seinen vielfältigen Erscheinungsformen und Repräsentionen und seiner Kraft inmitten der menschlichen Gemeinschaft.

Die Autoren des $R H$ sprechen oft und gern von Wundern. An der Möglichkeit, dass durch Propheten und Heilige ungewöhnliche Dinge geschehen, zweifelt kaum einer. Mit ihren Taten beweisen die ihre Heiligkeit, Wahrhaftigkeit und Rechtgläubigkeit. Die Helden treffen auch auf hilfreiche Figuren, Gottes Gesandte, die ihnen aus Notsituationen helfen und ihnen eine bessere Position in der Gesellschaft ermöglichen. Die Helden bekommen Hilfe von einem Heiligen, wenn sie durch besondere Umstände machtlos sind oder wenn ihr Leben in Gefahr ist. Dazu muss der Held zuerst das Gebet verrichten bevor er einem Heiligen begegnen kann und dieser den Helden das erlösende Wort lehren kann.

Obwohl im $R H$ überwiegend von Kampf und Heldentaten berichtet wird, ist es nicht nur durch den epischen Inhalt, sondern auch durch die zahlreichen mystisch geprägten Begebenheiten gekennzeichnet. Es tauchen geheimnisvolle, magische Elemente auf, denen wir uns hier besonders zuwenden möchten. Hier treten die Heiligen, denen göttliches Wissen verliehen ist, besonders hervor. Sie bewirken bei den Rezipienten große Bewunderung und Begeisterung. Nachfolgend soll versucht werden, die Reflexionen mystischer Erfahrungen im RH nachzuweisen.

Die meisten Wunder betreffen auf irgendeine Art und Weise das Wohlergehen des Menschen. Das Wunder, das ihn von einer Krankheit befreit, ihn vor Not und Gefahr errettet oder ganz allgemein sein Wohl fördert. Einige Arten von Wundern seien hier erwähnt:

Anōširvān lässt dem Bozorgmehr die Augen ausstechen, gibt die Regierung auf und zieht sich nach Madā'en zurück. Bozorgmehr geht zu Ḥamze, der sendet ihn nach Mekka, wo 
seine Augen durch die Berührung mit Moḥammads heiligem Fuß wieder hergestellt werden (1/88).

Über eine besonders wirkungsvolle Handauflegung erfahren wir im $R H$, als Asad Selbstmord begehen will. Er wird davor durch einen königlichen Ritter gerettet. Der unbekannte Ritter berührt mit seiner gesegneten Hand den ganzen Körper Asads und sagt ihm: „Sei nicht traurig.“ Asad wirft sich dem Ritter zu Füßen und bittet: „Gib mir die Kraft, damit ich Irăg besiegen kann.“ Der Ritter sagt daraufhin: „Ich gebe dir Kraft, damit du endlich Irağ besiegen kannst.“ Asad gelingt es dann, mit Hilfe der vom Ritter erlangten magischen Kräfte, ihn schließlich zu besiegen (5/876).

Auch im $R H$ finden sich Stellen, die die Gürtung eines Helden durch einen Heiligen beschreiben. Über einen besonders wirkungsvollen Gürtel wird im Zusammenhang mit Qobād berichtet. Als dieser Selbstmord begehen will, wird er durch Imām 'Ali gerettet. 'Ali öffnet und schließt Qobāds Gürtel, hebt ihn danach dreimal hoch und setzt ihn wieder nieder. Mit seiner gesegneten Hand bindet er ihm den Gürtel neu. Dann gibt 'Ali ihm sieben Strähnen seiner Haare. ${ }^{739}$ Durch die Haare und die Gürtelung bekommt Qobād, Imām 'Alis magische Kräfte (2/255-261).

Alles, was den Heiligen umgibt, kann Aufnahme in einem Reliquienschrein finden, als deren Mittelpunkt der Heilige selbst betrachtet werden kann. In der volkstümlichen Meinung spielt das Haar des Propheten oder der Heiligen eine überaus wichtige Rolle. Solche Haare gelten als tabarrok (Segen). Mit den Haaren des Propheten verknüpft sich ein ganz besonderer Kult. „In der Nacht lailat al-qadr werden die Barthaare des Propheten besonders verehrt, die Behältnisse, worin man sie aufhebt, werden von den Gläubigen andächtig geküsst.““740

Ḥamze geht in Begleitung seines Kundschafter 'Amr auf Pilgerfahrt zu Adams Grab auf dem Berge Sarandib. Hamze sieht Adam in einem Traum. Adam gibt ihm sieben magische Haare, damit Ḥamzes Arme stark werden (1/74-75).

Im Mausoleum des Propheten Adam sieht 'Amr Adam, Mose, David, Edris und Heżr. Die Propheten geben ihm einen magischen Gegenstand. Adam gibt ihm einen magischen Spiegel und Becher und sagt zu ihm: „Wenn du ein bisschen Wasser oder Erde in den Becher tust und die Namen, die auf der Wand des Bechers stehen liest, dann 72 mal salawāt sprichst, kannst du dich in jede Gestalt, die du wünschst, verwandeln“(1/74). Edris gibt ihm einen Teppich, mit dem er sieben lebendige Elefanten tragen kann. David gibt ihm die Gabe, dass er klangvoll singen kann (1/74-75).

\footnotetext{
${ }^{739}$ Mehr über die Reliquienverehrung den Cultus der Walī's siehe: Goldziher, Ignaz: Muhammedanische Studien, Bd. II, Halle 1890, S. 357f.

${ }^{740}$ Kriss, Rudolf u. Kriss, Heinrich Hubert: Volksglaube im Bereich Islam, Bd. 1, S. 330.
} 


\section{Große Namen Gottes}

In der islamischen Tradition gilt der größte Name Gottes asmā’ al-ḥusnā (die schönen Namen des Gottes) oder esm-e allāh al-a'ỵam (die größten Namen des Gottes) als ein besonderes Geheimnis. Muslimische Zaubersprüche beinhalten heilige Namen. Nach allgemeiner Ansicht besitzt der größte Gottesnamen eine besondere Zauberkraft. „Nach allgemeiner muslimischer Auffassung sind alle Gottesnamen im Koran enthalten. “741 Nach der islamischen Vorstellung verleiht das Wissen um den größten Namen Gottes eine unbegrenzte Wundermacht. Mit dem höchsten Namen Allāhs sind besondere Eigenschaften und Bedeutungen verbunden. Dieser Name befreit von Schicksalsschlägen und Leiden, hilft bei einer schnellen Gesundung und hat vielerlei andere starke Wirkungen. Die Namen der Heiligen haben also ursprünglich den Zweck, den Gläubigen für ihre Anrufungen die wirksamsten Namen zu bieten. Darüber schreibt Gramlich:

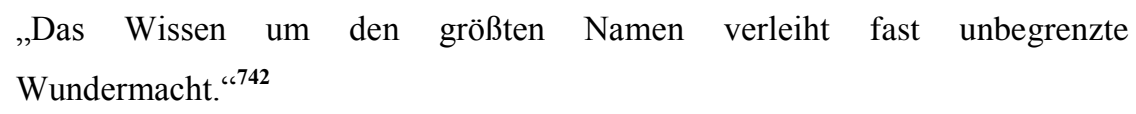

Gramlich verwertet hier Informationen, die wesentlich aus einer Monographie über Gottes gewaltigste Namen von 'Abd al-fatạ̣ b. Moḥammad aṭ-Ṭuhhī al-Falakī bezogen sind. Dieser bietet in seiner Monographie eine Fülle von Rezepten an, wie man mit Hilfe der größten Namen Gottes die verschiedensten Ziele erreichen kann, darunter:

„Gebetserhörung, Übers-Wasser-Schreiten, den Propheten im Traum sehen, Verkürzen der Distanz, Streitbeilegung, Gefeitsein gegen Eisen im Leib, Magie, böses Auge, Armut, Erwerbung der Gottesfreundschaft, Schädigung des Feindes, Schutz gegen böse Geister, Heilungen, Wunscherfüllungen jeder Art, Beruhigung des Meeres, Schutz gegen Waffen des Gegners, Sieg über Gegner, Besänftigung des Herrscherzornes, Geliebt-Werden, Gedächtnisstärkung und Zukunftskenntnis. “743

In der islamischen Welt gibt es verschiedene Auffassungen über die Anzahl der größten Namen Gottes. Goldziher schreibt:

„Die kanonische Festsetzung der Zahl sowie die Festsetzung der einzelnen Namen selbst ist späteren Ursprunges und weder bei Mālek b. Anas, noch bei

Buhāāī und Muslim anerkannt. In den Sammlungendes Timidīi und Ibn Māğa begegnen uns zu allererst im Anhang an die allgemeine Sentenz die 99

\footnotetext{
${ }^{741}$ Venzlaff, Helga: Der islamische Rosenkranz, Stuttgart 1985, S. 38.

${ }^{742} \mathrm{Vgl}$. Gramlich, Die Wunder der Freunde des Gottes, S. 165.

${ }^{743}$ Ebd.
} 
Gottesnamen, eine namentliche Aufzählung derselben; bei ersterem sogar mit der Bemerkung, dass sie aller Authentie ermangelt.“ ${ }^{744}$

Bei Buhāri und bei Muslim kann man folgenden bedeutsamen Satz lesen: „Allāh hat neunundneunzig Namen, hundert weniger einen; wer sie im Gedächtnis bewahrt, wird in das Paradies eintreten. “745 Al-Kulainī war der Meinung, dass der größte Name Gottes aus 73 Buchstaben besteht. Er schreibt: „Von den 73 Buchstaben hat Gott Adam 25, Noah 15, Abraham 8, Mose 4, Jesus 2, und dem Propheten Moḥammad 72 verliehen."746

Den höchsten Namen kannte auch Salomo. Auf seinem Siegelring war der Name eingraviert, und er verlieh seinem Träger Macht. ${ }^{747}$ Es wird erzählt, dass in der Mitte des sechseckigen Ringes des Propheten Salomon esm-e a'zam stand, und er seine Herrschaft über die Dämonen, Teufel, Riesen usw. diesem Ring zu verdanken hatte. ${ }^{748}$

In der muslimischen Welt war und ist der Gebrauch der größten Namen Gottes Mittel zum Zweck, um sich vor schlechten Einflüssen zu schützen. Man sucht Hilfe in allen Lebenslagen, wie Erleichterung von Sorgen, Erfüllung von Anliegen und Schutz von Geistern. ${ }^{749}$ Lane schreibt: „Dass die 99 Namen Gottes eine magische Wirkung haben sollen, wenn man sie oft wiederholt, auf Papier schreibt und bei sich trägt.“750

Der Glaube an die anti-dämonische Wirkung vom Namen des Gottes ist im Iran sehr alt. Purān-dohnt, die Tochter von Perserkönig, Dārā, kennt einen Geheimnamen Gottes. Mit dessen Hilfe kann sie die Dämonen und Hexen fesseln und so austreiben. ${ }^{751}$ Eskandar ist auch im Besitzt des Geheimnisses und beschützt damit sein Heer vor der Gefahr. ${ }^{752}$ Im Eskandarnāme lesen wir, dass Solțān Mạ̣mud von Ghazna die großen Namen des Gottes kennt und deswegen seine Siege erringt. ${ }^{753}$

\footnotetext{
${ }^{744}$ Goldziher, Ignaz: Zauberelemente im islamischen Gebet, in: Orientalische Studien. Erster Band, Theodor Nöldeke zum siebzigsten Geburtstag, hrsg. von Carl Bezold, Gießen 1906, S. 317; Schimmel, Und Muhammad ist sein Prophet, S. 101.

745 al-Buhāri, Abū 'Abdallāh Moḥammad b. Ismāî̀l: Kitāb al-ğāmi' aṣ-Ṣahịh, Publié par M. Ludolf Krehl, Leyden 1862-1908, S. 97/12; Muslim b. al-Ḥağḡāğ Abū al-Ḥusain: aṣ-Ṣhịh, Miṣr 1334h/1915, 48/6; Gardet, Louis: al-asmā' al-ḥusnā, in: $E I^{2}$, Vol. I, Leiden/Leipzig 1960, S. 714-717, hier S. 714.

${ }^{746}$ al-Kulainī, Usūl-i Käfi, Bd. 1, S. 334; Gramlich, Die Wunder der Freunde des Gottes, S. 166.

${ }^{747}$ Winkler, Hans Alexander: Siegel und Charaktere in der mu hammedischen Zauberei, Berlin/Leipzig 1930, S. 130.

748 an-Neišāburi, Abu Bakr 'Atiq, S. 368; 345; Kriss, Rudolf u. Kriss Heinrich Hubert, S. 15.

749 Vgl. Dorpmüller, Sabine: Religiöse Magie im Buch der Probaten Mittel. Analyse, kritische Edition und Übersetzung des Kitāb al-Muğarrabāt von Muḥammad ibn Yūsuf as-Sanūsī (gest. um 895/1490), Wiesbaden 2005, S. 200-222.

${ }^{750}$ Lane, Edward William: Sitten und Gebräuche der heutige Egypter, Bd. II, S. 64; Annemarie Schimmel, Traditionelle Frömmigkeit, in: Der Islam III. Islamische Kultur-Zeitgenössische StrömungenVolksfrömmigkeit, Stuttgart, Berlin/Köln 1990, S. 263.

${ }^{751}$ aț-Ṭarsusi, Dārāb-nāme, Bd. 2, S. 244.

752 Afs̃ār, Eskandar-nāme, S. 324.

${ }^{753}$ Ebd. S. 218.
} 
Auch im $R H$ ist der Gebrauch der größten Namen Gottes ein wirksames Element. Wir lesen, dass Ḥamze den geheimnisvollen Namen Gottes gegen die Zauberer ausspricht (4/658-659) Welchen Namen Ḥamze angerufen hat, wird im Text zwar nicht explizit ausgeführt, doch kann man davon ausgesehen, dass es ein von den Mystikern benutzter Anruf ist.

Die Wundererzählungen nehmen nicht umsonst im $R H$ einen großen Raum ein. Sie haben eine deutlich erkennbare Funktion. Sie sollen den Rang der Propheten ins Unermessliche steigern und damit die Macht des Glaubens beweisen. Mit solchen Erzählungen können die religiösen Ziele auf ungewöhnlichem Weg erreicht werden. Die Erzähler des Werkes nehmen an der geistlich-religiösen Bildung des Volks sehr aktiv teil. Sie interpretieren die Lehre des Propheten mit einer großen Toleranz. Solche Erzählungen sind bestimmt für das einfache Volk und um vieles attraktiver als die nüchternen theologischen Lehren.

Die Erzähler schmücken ihre Erzählungen mit Wundergeschichten aus, um ihre Zuhörer zu faszinieren. Es ist offensichtlich, dass solche Episoden für das Publikum interessanter sind als der nur nüchtern gehaltene Text des Korans. Die Erzähler nutzen die populär-religiösen Vorstellungen aus dem Bereich der Wunder und Prophetologie als Erzählstoffe.

Sie schildern die Wundergeschichten um den Menschen Hoffung zu geben. Es gelingt ihnen auch, die Leute zu faszinieren und positiv anzuregen. Die Vielfalt dieser Literatur spiegelt die wachsende Begeisterung des Publikums für Wunder im Mittelalter wider.

Schon von frühislamischer Zeit an spielten Wunder eine bedeutende Rolle in den volkssprachlich abgefassten Erzählungen. Nicht nur beim Klerus, sondern auch bei Fürsten und bürgerlichen Zuhörern und Lesern war diese Gattung beliebt. Um das Staunen hervorzurufen, brachten die Erzähler neue Inhalte auf und erdachten neue Gestalten.

Die Erzähler des $R H$ machen in der geschilderten Weise aus den ernsthaften und nüchternen religiösen Stoffen eine echte Gefühlserfahrung. So sieht man im $R H$ eine Affinität zur religiösen Ehrfurcht verbunden mit der Lust am Vergnügen. Diese Mischung führt dazu, dass die Texte und Erzählungen vom Publikum sehr viel besser verstanden und wirksamer angenommen werden.

Die Heiligen und Propheten waren offensichtlich eine Instanz, von der man sich in Notsituationen Hilfe erhoffte. Die wundersame Hilfe stärkte im Umkehrschluss den Glauben der Menschen. Man darf auch nicht vergessen, dass die Invasion der Mongolen im 13. Jahrhundert eine Katastrophe für den Iran bedeutete. Zahlreiche Kriegszüge, systematische Zerstörung, Ausplünderung und Verwüstung der Städte mit gnadenlosen Massakern und der Versklavung der Menschen fügten dem Iran schwere Schäden zu. $^{754}$ Diese äußeren

${ }^{754}$ Spuler, Bertold: Geschichte der Mongolen, Zürich 1968, S. 36-49. 
Verhältnisse unter der Mongolenherrschaft führten zu finanziellen Belastungen, die Armut hervorriefen, Hungersnöte und Krankheiten und gleichzeitig einer inneren Verlorenheit. „Alle diese Nöte mussten ihre Auswirkungen auf das Lebensgefühl der Bevölkerung haben und ein großes Bedürfnis nach Schutz und Hilfe wachrufen.“755

Träume

Der Traum, der Erkenntnisse über die Zukunft vermitteln kann, ist in allen Kulturen ein sehr wichtiges Motiv. Aber was ist ein Traum? Jacob schreibt dazu:

„Der Traum ist ein Zwischenzustand zwischen Schlaf und Wachen; er gehört zum Schlaf, indem er die Erinnerung an die meisten Beziehungen des Ichs auslöscht; er gehört zum Wachen, indem er einzelne wenige besonders starke Eindrücke, meist der jüngsten Vergangenheit, noch widerspiegelt.، ${ }^{756}$ Im Koran ist der Traum ein potenzielles Medium für die Selbstmitteilung Gottes an den Menschen. Der Josef (Yusuf) im Koran hatte einen Traum. Er sah im Traum, dass sich elf Sterne, Sonne und Mond vor ihm verbeugten. ${ }^{757}$ Dieser Traum war der Beweis für sein Prophetentum. Die Mitteilung Gottes an die Menschen, aber auch an die Tiere und an die Natur oder an die Schöpfung insgesamt geschieht durch Eingebung, durch natürlichen Instinkt, ${ }^{758}$ durch Anrede oder die Stimme Gottes, ${ }^{759}$ durch sonstige Zeichen $^{760}$ oder durch Inspiration und Träume. ${ }^{761}$ Der Traum ruyä' steht im Koran im Kontext von Prophetie. ${ }^{762}$ Er kann ein Geschenk mit Chancen und Risiken sein.

Es gibt unterschiedliche Arten von Träumen. Träume mit frohen Nachrichten, die von Gott stammen, sind gute Träume. ,Wenn man schläft, so breitet sich sein Geist aus wie das Licht einer Lampe oder das Licht der Sonne. Durch dieses Licht und die strahlende Helligkeit Gottes sieht er (der Schläfer) das, was der Engel der Träume ihm zeigt. Wenn die Sinne wieder zu ihrer Tätigkeit erwachen, so erinnert sich der Geist an das, was ihm der Engel der Träume gezeigt und gesagt hat.““763 Weitere Träume sind die bösen Träume, die vom Teufel

\footnotetext{
755 Gronke, Monika: Lebensangst und Wunderglaube. Zur Volksmentalität im Iran der Mongolenzeit, in: Deutscher Orientallistentag vom 26 September bis 30. September 1988. Ausgewählte Vorträge, hrsg. von Diem, Werner und Abdoldjavad Falaturi, Stuttgart 1990, S. 391-399, hier S. 397.

${ }^{756}$ Jacob, Georg: Märchen und Traum, mit besonderer Berücksichtigung des Orients, Hannover 1923, S. 63.

${ }^{757}$ Koran, Sure.12,4.

${ }^{758}$ Koran, Sure. $16,68$.

${ }^{759}$ Koran, Sure. 27,8.

${ }^{760}$ Koran, Sure. 19,10

${ }^{761}$ Koran, Sure. 12,4; 37,102.

762 Anșāri, Moḥammad-Reżā: Ruyā', in: Dā’rat al-ma‘ārif-e tašayyo ‘, Bd. 8, Teherān 1379/2000, S. 396-403, hier S. 398.

${ }^{763}$ Zitiert nach: Grunebaum, Gustave E.: Die Kulturfunktion des Traumes im klassischen Islam, in: Bustan, Heft 3-4, 9 Jahrgang (1968), S. 50-58, hier S. 53.
} 
gesandt sind. ${ }^{764}$ Nach Šahmardān b. Abi al-Hुeir (11. Jahrhundert) ${ }^{765}$ sind diese Träume falsch und bieten keine Auslegung. ${ }^{766}$ Eine dritte Gruppe von Träumen stammt aus unserem eigenen Ich. ${ }^{767}$

Der Traum hatte in der vorislamischen Zeit, aber auch in der mittelalterlichen Kultur des Irans, einen festen und anerkannten Platz. Man glaubte, dass man durch Träume Kenntnisse für die Zukunft gewinnen könne oder dass man beim Träumen, etwa durch die Erscheinung Heiliger, Weisungen erhalte. Die Iraner halten die Erlebnisse des Traumes für wahr. Die Wahrträume sind deshalb für sie große Wunder. Um die Träume zu deuten, braucht man einen Traumdeuter, dieser soll sich auf die Auslegung von Träumen und Visionen verstehen. Die Träume geben dem Kundigen Auskunft über den religiösen Zustand des Visionärs, über Neigungen seiner Triebseele und über seinen Fortschritt auf dem mystischen Weg, weil man im Traum die unterschiedlichsten Dinge sehen kann, wie die Propheten, Heilige, Engel oder Jungfrauen aus dem Paradies.

Im damaligen Sprachgebrauch der Iraner ist der Sammelbegriff für alle visionären Erlebnisse das Wort vāqe'e (eine Vision). Im Arabischen lautet die Entsprechung sena. ${ }^{768} \operatorname{Im} R H$ werden die Träume meistens als vãqe'e (1/36/29) oder sena (4/559/26) bezeichnet.

Bei den Iranern werden die Vorstellungen von Schlaf und Traum schon in recht frühen Zeiten zum Sagenstoff. Zur Verdeutlichung ihrer Vorstellungen sollen hier wieder einige Beispiele aus dem $R H$ geschildert werden, die gekürzt wiedergegeben werden.

Die Traumgeschichten von Propheten und Heiligen sind immer wahr, denn der Satan kann niemals die Gestalt eines Propheten annehmen. Sie bringen dem Gläubigen Trost, Heilung von Krankheiten oder Schwermut, oder helfen ihm, ein Problem zu lösen, wie die Befreiung aus Gefangenschaft.

Karib wird durch eine List von einem König festgenommen und im Gefängnis eingesperrt. Er träumt von einer Wiese, wo sich ein herrliches Schloss aus Rubinen befindet. Im Schloss gibt es einen kostbaren Thron, auf dem ein König sitzt, der in Licht gehüllt ist. Karib begrüßt den König ehrerbietig, indem er seine Hand auf das eigene Herz legt. Der König fragt ihn: „Warum bist du traurig?“ Karib erzählt seine Erlebnisse. Dann wird er im Traum bewusstlos. Als er zu sich kommt, riecht er schöne Düfte und ist von den Ketten frei. Anschließend

\footnotetext{
${ }^{764}$ Der im Arabischen übliche Begriff ahlām für Träume wird in der Regel in negativen Kontexten verwendet. Siehe: Dehhodā, Logat-nāme, ḥarf-e. Eșbāt-Eždehā, Teherān 1326/1947, S. 1096.

${ }^{765}$ Hāleqi-Moṭlaq, Ğalāl: Der Reste altiranischer Anschauung über das Pferd im Šāh-nāma, in: Deutscher Orientalistentag vom 28. September bis 4. Oktober 1975, Wiesbaden 1977, S. 1049-1060, hier S. 1051.

${ }^{766}$ Šahmardān b. Abi al-Hुeir: Nozhat-nāme-ye 'Alā'i, hrsg. von Farhang Ğahānpur, Teherān 1362/1983, S. 464.

${ }^{767}$ Vgl. Grunebaum, S. 52.

${ }^{768}$ Sayyāḥ, Aḥmad: Farhang-e bozorg-e ğāme`e novin-e Sayyāḥ, Bd. 1, Teherān 1377/1998, S. 900.
} 
kommen zwei hübsche Mädchen zu ihm ins Gefängnis und erzählen, dass sie die Königstöchter seien. Sie berichten, 'Ali im Traum gesehen zu haben, wodurch sie zum Islam bekehrt worden seien. Dann befreien sie Karib aus dem Gefängnis (4/576).

Im $R H$ gibt es endlose Wiederholungen der gleichen Motive hinsichtlich der Träume, besonders gilt dies für die Verleihung und Vermittlung von Kenntnissen und Fähigkeiten in Träumen.

Viele Träume sind z.B. ein Anlass zur Bekehrung von Ketzerei zum Glauben. Berühmt ist die Geschichte von der Bekehrung des fränkischen Fürsten (2/268).

Träume können zudem Kenntnisse vermitteln:

'Amr sagt zu Ḥamze, dass er ihn auf der Reise nach Āhtam nicht begleiten möchte. Als Hamze nach dem Grund fragt, sagt 'Amr, dass er in einem Traum gesehen habe, dass er und Ḥamze in Gestalt von Adlern miteinander kämpfen und sich gegenseitig Stück für Stück zerreißen. 'Amr fügt hinzu, dass er Angst habe, dass sie miteinander in Streit geraten könnten (4/686).

Andere Träume in Form von Alpträumen versetzen den Menschen in endloses und furchtbares Entsetzen:

Landehur sieht in seinem Traum, dass über Sarandib Rauch in den Himmel steigt. Dieser Rauch verdunkelt die Welt. Die Traumdeuter sagen ihm daraufhin, dass ein Chaos kommen werde, welches den Muslimen sehr schaden werde (7/1126). Kurz darauf verkündet Landehurs Enkelsohn Ğazāyel die Einführung der Götzenanbeterei und schadet so den Muslimen.

Ein sehr verbreitetes Märchenmotiv ist das Vergessen in Verbindung mit Träumen:

König Qobād hat einen schrecklichen Traum, den er morgens aber teilweise wieder vergessen hat. Keiner seiner Traumdeuter kann ihm den Traum deuten. Der König ruft seinen Wesir Arqaš und gibt ihm 3 Tage Zeit, um den Traum zu erzählen und zu deuten. Der Wesir kann den Traum jedoch nicht auslegen und wünscht sich, dass er Bozorgmehr nicht hätte töten lassen sollen. Er fragt seinen Sklaven Bahtiyar, ob dieser wirklich Bozorgmehr getötet habe. Nach längerem Nachfragen gesteht der die Wahrheit, dass dies nicht der Fall sei. Er bringt den Sklaven zu Arqaš. Am 3. Tag geht der Wesir zum König und sagt ihm, dass er einen kleinen Sklaven habe, der ihm den Traum deuten könne. Der König lässt daraufhin 
Bozorgmehr zu sich bringen. Dieser deutet ihm den vergessenen Traum und bringt den Verrat des Arqaš ans Licht. Arqaš wird daraufhin mit dem Tode bestraft (1/9). ${ }^{769}$

\subsubsection{Magische Elemente und Gegenstände}

Die meisten, aber nicht alle der im $R H$ vorkommenden magischen Elemente und Gegenstände haben ihre Wurzeln in der klassischen islamischen und iranischen Kultur. Zur Kontextualisierung der einzelnen Elemente im $R H$ wird daher der Hintergrund in unterschiedlichen klassischen Literatur als Entwicklungsprozess dargestellt.

Im $R H$ stammen die wunderbaren Gegenstände meist aus dem Besitz übernatürlicher Wesen. Die Helden erhalten sie entweder als Geschenk oder sie besiegen Dämonen in gefährlichem Kampf und bemächtigen sich so ihrer magischen Werkzeuge.

\section{Alexandrinischer Spiegel}

Eines der in allen Kulturen bekanntesten magischen Elemente ist sicherlich der Spiegel. Der Gedanke an einen Spiegel, in dem man die ganze Welt sehen kann oder alles, was irgendwo passiert, beobachten kann, ist sehr alt. Auch bei Salomon gehörte zu den sieben Kleinodien ein magischer Spiegel, worin er bereits Alexanders Eroberungszüge erblickt hatte. Um diese Kleinodien in ihren Besitz zu bringen, unternahmen die persischen Könige Eroberungszüge zum Gebirge Qāf, wo sie mit Dämonen kämpften. ${ }^{770}$

Mas'ūdī berichtet, dass Țāriq, der Eroberer Spaniens, in Spanien die Tischdecke des Salomon und einen magischen Spiegel fand, in dem er alles sehen konnte. ${ }^{771}$

Antike Autoren beschrieben den Turm von Alexandria als technisches Meisterwerk. Der alexandrinische Spiegel spielte eine große Rolle in der arabischen aber auch in der persischen Literatur. Alexander der Große soll den Turm von Alexandria mit dem berühmten Spiegel ausgestattet haben. Dort wurde das Feuer auf dem Leuchtturm durch einen Spiegel ersetzt, der es den Alexandrinern ermöglicht haben soll, weit entfernte Schiffe zu erkennen und angreifende Flotten durch das gebündelte Licht des Spiegels zu vernichten. Zu jener Zeit schickte der Kaiser von Rom seine Flotte zum Angriff gegen Alexandria. Die Muslime

\footnotetext{
${ }^{769}$ Eine ähnliche Geschichte erzählt uns Ferdousi: König Anōširvān hat einen schrecklichen Traum, den er morgens aber vergessen hat. Keiner der Traumdeuter kann ihm den Traum deuten. Der König ruft seinen Priester und schickt ihn durch sein Land, um jemanden zu finden, der den Traum erzählen und deuten solle. Der Priester macht sich auf den Weg. Endlich findet er in einer Schule Bozorgmehr. Der Priester bringt Bozorgmehr zum König. Bozorgmehr deutet ihm den vergessenen Traum und bringt den Verrat seiner Frau ans Licht. Die Frau des Königs und ihr Liebhaber werden daraufhin mit dem Tode bestraft. Vgl. Ferdousi, Bd. 2, S. 1476-1478.

${ }^{770}$ Hammer-Purgstall, Joseph Freiherr: Rosenöl, Bd. 1, Hildesheim/Zürich/New York 2004, S. 16-17.

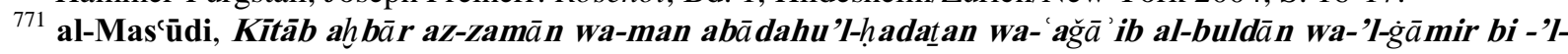
mā' wa-'I- 'umrān. Taṣḥ̄ị wa-murāğa 'a 'Abdallāh Ismā'īl aṣ-Ṣāwī, Miṣr 1357h/1938, S. 74.
} 
vernichteten seine Flotte mit Hilfe des magischen Spiegels. Daraufhin schickte der Kaiser einen Priester, damit er durch eine List den Spiegel vernichten sollte, was diesem auch gelang. ${ }^{772}$

In einer anderen Erzählung lesen wir, dass Alexander den Spiegel erfinden lässt. Alexander der Große kommt auf seinem Zuge nach Indien ins Diamantental. Niemand kann an die Edelsteine dort gelangen, denn es gibt große Schlangen, die einen Menschen mit ihrem Blick töten können. Alexander lässt einen Spiegel anfertigen, und als die Schlangen sich selbst darin erblicken, sterben sie. ${ }^{773}$

Im $R H$ dient der alexandrinische Spiegel vor allem der Nachrichtenübermittlung über weite Entfernungen. Dort wird berichtet, dass Irağ einen Talisman vernichtet und den Spiegel des Alexander in seinen Besitz nimmt. Ein Dämon gibt ihm den Rat: „Wenn du etwas zu sehen wünschst, siehst du es im Spiegel, aber zuvor musst du ein Gebet für Alexander sprechen.“ Als Irağ in den Spiegel blickt, sieht er, dass Asad gerade sein Heer vernichtet (5/814).

\section{Ğamšids Zauberbecher}

Ğamšids Zauberbecher, in dem man alle Geheimnisse der Welt sehen konnte, hatte einen würdigen Platz in der klassischen Literatur und der Volksliteratur. Bis ins 12. Jahrhundert war dieser Zauberbecher in der persischen Literatur als Kei-Hosrous Zauberbecher berühmt, in dem sich der ganze Kosmos spiegelt. Kei-Hosrous benutzt ihn einmal, um Bižan, der spurlos verschwunden ist, in seinem Gefängnis in dem Land Turān aufzuspüren. Diesen magischen Becher kann nur der König selbst benutzen und zwar nur am Nouruzfest nach einem Gebet. ${ }^{774}$ Neẓāmi erzählt uns, dass Eskandar in der Höhle Kei-Hosrous den Zauberbecher des KeiHosrou findet. Er ruft den weisen Apollonius zu sich und bittet ihn, mit ihm gemeinsam den Weltenschauenden Becher zu prüfen, und das in ihm verborgene Geheimnis zu enträtseln. Der kundige Mann schaut in seinen Kelch und liest die eingravierten Zeichen und Zahlen. An der Nahtstelle zwischen Gefäß und Sockel sind mehrere miteinander verbundene Linien gezogen. Diese betrachten die beiden sehr genau und erkennen, dass eine geheime Formel in ihnen verborgen ist. Der König und der Weise bewahren die Zahlen und Linien im Gedächtnis. Als der König schließlich nach Griechenland zurückkehrt, baut der Weise sein rundes Astrolabium nach dem Vorbild des Bechers. ${ }^{775}$

\footnotetext{
${ }^{772}$ Anonymus: Moğmal at-Tawārih wa al-qeșaṣ, S. 494; Peez, Erik: Die Macht der Spiegel. Das Spiegelmotiv in Literatur und Ästhetik des Zeitalters von Klassik und Romantik, Frankfurt am Main/Bern/New York/Paris 1990, S. 59

${ }^{773}$ Ullmann, Manfred: Das Motiv des Spiegels in der arabischen Literatur des Mittelalters, Göttingen 1992, S. 60 .

${ }^{774}$ Ferdousi, Bd. 1, S. 624.

${ }^{775}$ Neẓāmi, Šaraf-nāme, S. 1035.
} 


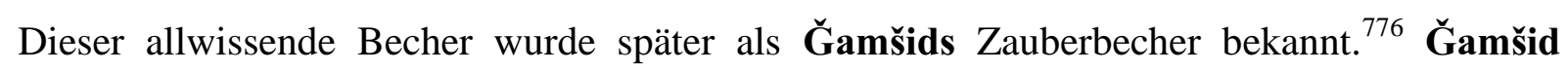
nutzte diesen, ganze Welten überblickenden Spiegel offenbar sehr oft. Der Becher hatte zudem noch andere Bedeutungen, die aus weiter zurückliegenden Zeiten stammten. Dort galt er als Symbol der Vortrefflichkeit, des Glanzes und der segensreichen Fruchtbarkeit. ${ }^{777}$

Im $R H$ taucht der Zauberbecher in zwei Erzählungen auf. An einer Stelle kämpft Badic azZamān mit Qahhār-ye div um seine Schätze. Er tötet ihn, vernichtet den Talisman der sieben Könige und nimmt Gold, Waffen, den magischen Stuhl des Kei-Hosrou und den Zauberbecher des Ğamšid in seinen Besitz (3/493-96).

An anderer Stelle lesen wir, dass ein Dämon für Asad den Zauberbecher Ğamšids einsetzt, um mit seiner Hilfe, die militärische Macht Irağs wirkunglos zu machen (5/818).

Wundermittel

Das Motiv des Wundermittels, das beim König aufbewahrt und von ihm verwaltet wird, kommt auch in der Geschichte von Rostam und Sohrāb vor. Als Rostam seinen eigenen Sohn im Kampf schwer verwundet, was er später bereut, verweigert ihm der Perserkönig das erforderliche Wunderheilmittel (nuš-dāru). Diese Geschichte gleicht ähnlich der folgenden Episode aus dem Königsbuch, nur bekommt hier der Held natürlich zum Schluss das begehrte Heilmittel.

Im $R H$ wird Hamze durch Gostaham vergiftet. Eqlimu ${ }^{778}$ kann ihn zwar heilen aber durch die Vergiftung verändert sich der Körper Hamzes. Diese Veränderungen sind sehr drastisch. Selbst Mehrnegār kann ihn nicht wieder erkennen. Eqlimu teilte 'Amr mit: „Wenn Ḥamze das nuš-dāru einnehmen kann, wird er endgültig geheilt.“ 'Amr fragt ihn: „Wo befindet sich das Wunderheilmittel?“ Eqlimu antwortet: „Beim Perserkönig.“ ‘Amr sucht den königlichen Palast in Gestalt eines alten Mannes auf, und erhält von Bozorgmehr das Wunderheilmittel (1/97).

\footnotetext{
${ }^{776}$ Šamisā, Sirus: Ğām-e Ğahān-namā, in: Dāneš, 1 Jahrgang, Šahrivar, Nr. 6, Teherān 1328/1949, S. 300ff.

${ }^{777}$ Hammer-Purgstall, Rosenöl, Bd. 1, S. 17.

${ }^{778}$ Dieser Name ist Eqlimiyā ähnlich. Eqlimiyā war Adams Tochter. Siehe: Lāri, Ṣoḥbat: Divān-e Sọnbat-e Lãri, hrsg. von Ma'refat, Ḥosein, Širāz 1354/1975, S. 287; im Buch Tağārib al-umam fī al-ahbār mulūk al-'arab wa-'-'ağam lesen wir, dass Eqlimun Alexanders Wesir war. Siehe: Anonymus: Tağăareb al-umam fi ahbār-i moluk 'I-'arab wa 'I-'ağam, S. 161; Eqlimun wurde auch als ägyptischer Priester bezeichnet. Siehe: al-Mas'ūdī, Kïtāb ah bār az-zamān wa-man abādahu 'I-ḥadatan wa-'ağà ì al-buldān wa-'I$\dot{g} \bar{a}$ mir bi'l-māa' wa-'I-'umrān, S. 116.
} 
Salomos Ring

Ein weiteres magisches Element war der Ring des Propheten Salomos. Dieser Ring, durch dessen Kraft er die Herrschaft über Menschen und Geister erhielt, hatte einen Stein, auf dem die größten Namen Gottes geschrieben standen 779

Im Buch Nihāyat al-arab lesen wir, dass Ğebrā'īl Salomon den Ring bringt, der hell wie die Sterne ist. Auf dem Ring steht geschrieben ašhadu an lã illāh ila allāh Moḥammad rasul u Allāh (ich bekenne, dass es nur einen Gott gibt und Moḥammad sein Gesandter ist). ${ }^{780}$

Im $R H$ sieht Ḥamze in seinem Traum den Propheten Soleimān. Dieser gibt ihm seinen Ring $^{781}$ und sagt: „Wenn du aufwachst, findest du das Giti-namā Minarett und dort kannst du sehen, was du wünschst, wenn du den Ring trägst.“ Auf diese Art und Weise findet Ḥamze seinen Gefährten Karib, der verwundet worden war (5/951).

Magische Bücher

Bücher, die Zugang zu verborgenem Wissen enthalten, sind immer ein reizvolles Element magischer Geschichten. Auch für den Propheten Dāniyāl wird solch ein Buch des Wissens geschrieben, dass er so sehr schätzt, dass er sich keinen Augenblick davon trennt. Gott befiehlt dem Engel Gabriel, Dāniyāl dieses Buch zu entreißen und es in den Fluss Ğaiḥūn zu werfen. Dieser nimmt Dāniyāls Buch und wirft es in den Fluss. Dāniyāl kann gerade noch fünf Blätter davon für sich retten. ${ }^{782}$ Bald darauf stirbt Dāniyāl. Vor seinem Tod übergibt er seiner schwangeren Frau die fünf Blätter als Erbteil für seinen Sohn. Dieser Sohn, der nach Dāniyāls Tod geboren wird, erhält den Namen Ğāmāsb. ${ }^{783}$ Er wird durch die Lektüre dieser Blätter zum größten Weisen seiner Zeit.

Im Buch Tausendundeine Nacht ist Dāniyāl ein griechischer Gelehrter, der während eines Schiffbruchs seine Bücher verliert. Nur fünf Blätter von allen Büchern bleiben erhalten. Nach seinem Tod erbt sein Sohn Ḥāsib Karim ad-Din diese fünf Blätter. Durch diese Blätter erfährt er überhaupt erst vom Propheten Moḥammad. ${ }^{784}$

Im $R H$ soll Ğāmāsb ${ }^{785}$ ein Buch, das Zugang zu verborgenem Wissen und auch zu

\footnotetext{
779 Šamisā, Farhang-e talmiḥāt, S. 334.

${ }^{780}$ an-Nuwairī, S. 93.

${ }^{781}$ Marzolph, TPV (Motiv. Soleimāns Ring. 314C (12), S. 268; vgl. AaTh, (Motiv. Zauberring. 560).

782 Grotzfeld, hier S. 72-73; Auch der türkischer Dichter Ismā'il Čelebi Faday berichtete vom Verlust eines Buches bis auf wenige Blätter im Ğaiḥun. Siehe: Hammer-Purgstall, Joseph Freiherr: Geschichte der osmanischen Dichtkunst, Bd. III, S. 128.

${ }^{783}$ Grotzfeld, S. 73.

${ }^{784}$ Anonymus: Hezār-o yek šab, Bd.1, Nacht 480.

${ }^{785}$ Eine wichtige Gestalt in der iranischen Literatur ist Ğamāsb. Im Gāthās ist Ğāmāsp Großwesir des Königs Vištāsp/Guštāsp (av. Vishtāspa). Er und sein Bruder Frashaostra sind Ratgeber des Königs. „Zoroasters Lieblingstochter Pourutshista wird an Dshāmāspa verheiratet.“ Siehe: Jackson, Die iranische Religion, S.
} 
verborgenen Geheimnissenenthält, verfasst haben. Das Buch zeigt tausend Jahre in die Vergangenheit und sagt für tausend Jahre die Zukunft vorher. Es ist in griechischer Sprache verfasst und wird durch eine Schlange geschützt. Das Buch offenbart die Antworten auf alle Fragen. Ğāmāsb hinterlässt dieses Buch seinem Erben und Nachkommen Bozorgmehr. Eines Tages fragt der Lehrer ihn, ob sein Großvater ihm ein magisches Buch vererbt habe. $\mathrm{Zu}$ Hause erfährt Bozorgmehr auf seine Nachfrage von seiner Mutter, dass sein Großvater tatsächlich für ihn ein Buch hinterlassen habe und verrät ihm den Aufbewahrungsort. Als Bozorgmehr den Ort aufsucht, sieht er eine Schlange, die in Wirklichkeit ein Dschinn ist, und das Buch für ihn bewacht hat (1/6). Mit Hilfe dieses Buches kann Bozorgmehr alles Wissen erlangen.

\section{Edelsteine}

Auch Edelsteine können magische Gegenstände sein. „Die Leuchtkraft der Edelsteine übt eine starke Faszination auf den betrachtenden, ihre Schönheit und ihr Wert eine schöpferische Reaktion auf den künstlerisch begabten Menschen aus.“786

Früher glaubten die Iraner, dass es Meereskühe gäbe die in der Nacht aus dem Meer stiegen, um Gras zu fressen. Um sich aber in der Dunkelheit zu orientieren, hätten diese Tiere leuchtende Edelsteine dabei, die sie zum Fressen ablegten. ${ }^{787}$ Neẓāmi berichtet in seinem Buch ک̌arf-nāme, dass Alexander und sein Heer an einen See mit honigsüßem Wasser gelangen. Im Bauch eines Fisches von gewaltigen Dimensionen wird ein Stein von ungeheurer Leuchtkraft gefunden, den Alexander einfassen lässt und nachts als Leuchte benutzt. $^{788}$ Im Samak-e 'Ayyār lesen wir, dass sich leuchtende Edelsteine in den Schatzkammern der Feen befinden. ${ }^{789}$

Im $R H$ wird von einem leuchtenden Edelstein im Bauch eines Wales berichtet. Als Asad in das Menschenland zurückkehrt, sieht er unterwegs viele Leute, die sich außerhalb einer Stadt versammelt haben. Asad tritt zu ihnen und als der König der Stadt ihn sieht, spricht er ihn an und sagt: „Ich heiße Yāqut Šāh und der Ort hier heißt Kohan-ḥeșār. Hier im Meer erscheint einmal pro Tag ein Wal. Stets sitzen viele Vögel auf seinem Kopf. Niemand weiß warum. „Wenn du dieses Geheimnis löst, werde ich Gott anbeten.“ Asad überlegt und denkt sich: „Die Lösung des Rätsels muss im Bauch des Wales verborgen sein.“ Er ruft die Tischler

624. Im $R H$ ist Ǧāmāsp ein Gelehrter aus Griechenland und der Großvater von Bozorgmehr. Er hintlässt seinem Enkelsohn ein magisches Buch (1/2-3).

${ }^{786}$ Engle, David: Edelstein, in: EM, Bd. 3, Göttingen 1981, Sp. 1003-1009, hier Sp. 1003.

${ }^{787}$ Asadi-Ṭusi, S. 149; Hedāyat, Șādeq: Neirangestān, Teherān 2536/1978, S. 123; Thompson, Motif-Index of Folk-Literature, (Motiv. Leuchtende Edelsteine. B. 722.3 ).

${ }^{788}$ Neẓāmi, Šarf-nāme, S. 1149. 
zusammen und lässt sie eine Kiste anfertigen. Danach versteckt er sich in der Kiste. Kurz darauf kommt der Wal und verschlingt die Kiste. Im Bauch des Wales steigt Asad aus der Kiste und findet dort einen Edelstein. Er nimmt diesen Stein, reisst den Bauch des Wales auf und kommt so wieder an Land zurück. Als Yāqut Šāh dies sieht, bekehrt er sich zum Islam (5/865-866).

Magische Bäume

Der Glaube an die Magie der Bäume ist weltweit verbreitet. In der Fantasiewelt können Bäume sprechen und sind Orte zahlreicher Wunder und Mysterien. Über den Glauben an Bäume schreibt Kan`ān:

„Der Glaube, dass Bäume Lebewesen sind, oder dass in ihnen übernatürliche

Kräfte wohnen und walten, war in allen semitischen Völkern und auch sonst in der antiken Welt verbreitet. ““790

Der Glaube an die Heiligkeit von Bäumen ist im Iran sehr alt. Auch nach der Annahme des Islams durch die Iraner ist der Glaube an die heilige Kraft der Bäume erhalten geblieben. ${ }^{791}$

Zum Gedenken an die Übernahme der zarathustrischen Religion durch Guštāsp pflanzte Zarathustra zwei Zypressen in Horāsān, in den Dörfern Kišmar und Faryumad. Die erste wurde im Jahr 846-47 auf Befehl des Kalifen Mutawakkil gefällt. Dazu wurde erzählt, dass im Schatten des Baumes über 10.000 Schafe Platz fanden und eine riesige Menge Vögel in seinen Zweigen nistete. Bei seinem Fall äußerten Tiere und Vögel ihren Kummer mit Klagelauten, so dass die Menschen in Erstaunen gerieten. Der Kalif befahl, den Baum nach Bagdad zu schaffen; aber es war ihm nicht bestimmt, den Baum zu sehen. Am Tage vor seiner Ankunft wurde der Kalif von seinen Leibwächtern erschlagen. Von den übrigen Leuten, die an der Zerstörung des Baumes teilgenommen hatten, lebte danach keiner länger als ein Jahr. Der zweite Baum, die Zypresse von Faryumad, blieb länger stehen und wurde im Jahre 114243 auf Befehl des Hāārazm Šāh Yanal-Tegin durch Feuer zerstört. ${ }^{792}$

Einen ähnlichen Baum findet man im $R H$. Zomorrod flieht in das Land der Finsternis, wo die Einwohner der Stadt einen Baum anbeten, in dessen Schatten tausendundein Menschen ausruhen können. Wenn nur ein Mensch mehr oder weniger unter dem Baum ist, spendet der Baum jedoch keinen Schatten mehr. Als Ḥamze zur Insel kommt, verlangt der König der

\footnotetext{
${ }^{789}$ al-Arrağāni, Bd. 5, 396.

790 Kan'ān, Tawfiq: Aberglaube und Volksmedizin im Lande der Bibel. (Abhandelungen des Hamburgischen Kolonialinstituts, Bd.e. xx), Hamburg 1914, S. 17-18.

${ }^{791}$ Barthold, Wilhelm: Zur Geschichte des persischen Epos, in: ZDMG, Bd. 98, ins Deutsche übersetzt. von Hans Heinrich Schaeder, Leipzig (1944) S. 142.

${ }^{792}$ Purhāāleqi-Čatrudi, Mehr-dohnt: Deraht dar Šāh-nāme, Teherān 1381/2002, S. 86.
} 
Insel, dass er dieses Rätsel löse. Ḥamze sieht in seinem Traum den Propheten Soleimān, der ihm sagt, dass sein Ring unter dem Baum versteckt sei und Hamze ihn finden müsse. So kann Hamze schließlich das Rätsel lösen und die Einwohner der Insel werden zum Islam bekehrt (5/740-741).

In vielen Fällen gibt es eine merkwürdige Verbindung zwischen Dämonen und Bäumen. So gibt es sprechende und heilende Bäume. ${ }^{793}$ Auch in iranischen Epen werden Bäumen vielfach Heilkräfte zugeschrieben.

Im Garšāshb-nāme wird von einem Baum berichtet, der sieben verschiedene Obstsorten trägt, und es heißt, dass jeder kranke Mensch, der von diesem Baum Früchte isst, gesund wird. ${ }^{794}$ Garšāsb sieht auf seiner Reise in einer Stadt einen Baum, dessen Blätter gegen Augenkrankheiten gut sind. ${ }^{795}$

Auch im $R H$ wird den Bäumen Heilwirkung zugeschrieben. Die Blätter des Ayub-Baumes heilen Hamzes Blindheit (2/219). ${ }^{796}$

Zaubersprüche

Zaubersprüche sind ein weithin bekanntes magisches Element. „Zahlreiche Märchen kennen die geheimnisvolle Kraft einer Zauberformel.“797 Im $R H$ wird das Aussprechen einer

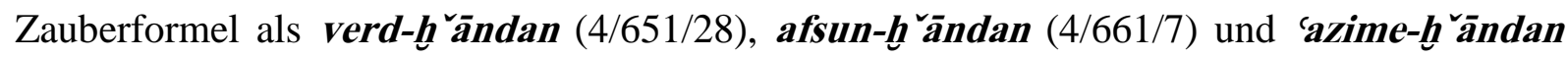
(Beschwören; 4/657/10) bezeichnet. Wichtig für die Wirkung der magischen Formel ist stets, dass der Wortlaut genauestens eingehalten wird. Sollte er vergessen werden, so bekommt der Held Probleme.

Im $R H$ dient der Einsatz von Zauberformeln als mächtige Waffe. Einmal lässt Șalșāls Tochter Zolfeyn damit Landehurs Arm erstarren, so dass seine Muskeln erschlaffen, und das Schwert seiner Hand entfällt. Daraufhin können ihn die Leute ergreifen und fesseln (3/446).

\section{Magische Haare}

Das Haar der Hexen oder die Federn der Feen haben im Volksglauben auch eine besondere Bedeutung und können die unterschiedlichsten Dinge bewirken. „Wer ein Haar verbrennt, löst damit ein Notsignal aus. “798 Der Held ruft eine Zauberin oder die Dämonen durch Verbrennen

\footnotetext{
${ }^{793}$ Pfister, S. 63.

${ }^{794}$ Asadi-Ṭusi, S. 192.

795 Ebd. S. 195.

${ }^{796}$ AaTh (Motiv. Heilende Pflanzenblätter. 612).

${ }^{797}$ Röhrich, Lutz: Das Märschen und die Wirklichkeit des magischen Weltbildes Zauber, in: Märchen und Wirklichkeit, Wiesbaden 1979, S. 75.

${ }^{798}$ Kuder, Ulrich: Haar, in: EM, Bd. 6, Göttingen 1990, Sp. 337-343, Sp. 338.
} 
ihrer Haare zu Hilfe. Die Feen geben dem Helden Federn aus ihren Flügeln, mit denen er sie in der Not rufen kann.

In einer Notsituation verbrennt 'Amr die Haare der Männer aus Qāf. Daraufhin erscheinen diese sofort, nehmen Ḥamze und seine Männer mit, und lassen sie in der Nähe von Ḥalab auf die Erde herunter (2/245).

Auch die Dämonen haben magische Haare. Als das Schiff des క̌āh Sacd durch Wassermenschen versenkt wird. verbrennt er die Haare des Tondak-e div. Dieser erscheint sofort, nimmt Sacd auf seine Schultern und bringt ihn in Sicherheit (4/645).

\section{Magische Steine}

Es folgen nun weitere Substanzen, die seit sehr langer Zeit mit Heilkraft in Verbindung gebracht werden. Ein Beispiel ist šăh-mohre (wörtlich: König der Steine). In vorislamischer Zeit wurde die mohre (Kugel) zu medizinischen Zwecken benutzt. ${ }^{799}$ Dieser Stein befindet sich laut Dehhyodā auf dem Kopf der Schlange. „Die Schlange hat einen Stein oder eine Krone auf ihrem Kopf.“ ${ }^{800}$ Früher glaubten die Iraner, dass šāh-mohre sich im Mund der Schlangen oder im Kopf des Drachen befinde. ${ }^{801}$

Im $R H$ heilt Ḥamzes Arzt ihn einmal mit Hilfe des šăh-mohre, indem er mit Hilfe des Steins alle Giftstoffe aus seinem Körper herauszieht (1/90). An anderer Stelle lesen wir, dass 'Amr sich auf den Weg macht und in das Tal der Schlangen gelangt. Dort sieht er, dass zwei Gruppen von Schlangen miteinander kämpfen. Die eine Gruppe besteht aus gläubigen Schlangen, die anderen aus ungläubigen. Als 'Amr sieht, dass die Ungläubigen die Gläubigen zu überwinden drohen, hilft er den gläubigen Schlangen und tötet den König der ungläubigen Schlangen. Für diese Hilfe gibt der König der gläubigen Schlangen ‘Amr aus Dankbarkeit den šāh-mohre (2/327). ${ }^{802}$

\section{Wunderkraft des Wassers}

Der Glaube an die Wunderkraft und Verwandlungskraft des Wassers ist sehr alt. „Wasser wird in den Anschauungen verschiedener Völker als ein den Dämonen widriges, sie abwehrendes, gegen sie Schutz bietendes Element betrachtet. ““803

\footnotetext{
799 'Afifi, Raḥim: Asātir va farhang-e Irān, Teherān 1374/1995, S. 326-327.

${ }^{800}$ Vgl. Schmidt, Sigrid: Stein, in: EM, Bd. 12, Göttingen 2007, Sp. 56-63, hier Sp. 56.

${ }^{801}$ Dehhodā, Šāh-mohre, in: Loġt-nāme, ḥarf-e. Š , Teherān 1341/1962, S. 180.

${ }^{802}$ Vgl. aṭ-Ṭarsusi, Bd. 1, S. 191.

${ }^{803}$ Goldziher, Ignaz: Wasser als Dämonen abwehrendes Mittel, in: Gesamte Schriften, Bd. V, hrsg. von Joseph Desomogy, Hildesheim 1973, S. 170-196, hier S. 177.
} 
In orientalischen Märchen wird erzählt, dass Menschen sich in Tiere verwandeln, wenn man sie mit Wasser besprengt. In der Geschichte von den Streichen der listigen Dalīla lesen wir, dass der Jude 'Ali verzaubert: „Da nahm der Zauberer eine Schale mit Wasser, sprach Beschwörungen darüber und sprach zu 'Ali: „Tritt hervor aus der menschlichen Gestalt und nimm die Gestalt eines Esels an! Und zugleich besprengte er ihn mit dem Zauberwasser.“804 Im $R H$ lesen wir, dass Bahgtak Angst hat, dass die muslimischen Kundschafter 'Alam Šãh entführen. Er fragt Zolfeyn, ob sie es mit Hilfe der Magie verhinderen kann. Daraufhin nimmt Zolfeyn etwas Erde vom Boden, an welchem 'Alam Šāhs Zelt aufgeschlagen war, und mischt diese mit Wasser, liest eine Zauberformel und gießt das Wasser auf 'Alam Šāhs Zelt. So können die Kundschafter sein Zelt nicht finden (3/442).

\section{Zauberkraft des Kollyriums}

Dem Kollyrium auch Kohle (pers. sorme) genannt, wurde eine günstige Wirkung auf die Sehkraft zugeschrieben. Im Buch Elāhi-nāme lesen wir, dass Namrud eines Tages eine Zaubersalbe findet. Er streicht die Zaubersalbe auf ein Auge wodurch ihm die Fähigkeit verliehen wird alle Himmelsspären bis hin zum Himmelsthron, sowie die sieben Stufen der Erde zu sehen. Als er auch noch Zaubersalbe auf das andere Auge reibt, öffnet sich ihm der Blick für alle unterirdischen Schätze. ${ }^{805}$

Manche glauben, dass die Dämonen zum ersten Mal Kollyrium zu Salomon gebracht hätten. Deswegen ist es auch bekannt als sorme-ye soleimāni (salomonische Kohle). ${ }^{806}$

Im $R H$ sind die Feen unsichtbar und die Helden müssen Kohle benutzen, um diese sehen zu können. Šahbāl reibt das Kollyrium in Ḥamzes Augen, damit er die Feen und Dämonen sehen kann (1/14).

\section{Zauberblume}

Auch Blumen repräsentieren die Zauberwelt und sind daher Bedeutungsträger, Zeichen und Symbol. „Die Zauberblume, welche meist durch Pracht, Farbe, Duft und Größe als auffallende oder fremdartige Blume geschildert wird, besitzt magische Kräfte. “807

Im $R H$ wird Neyrams Zauberkleid beschrieben, dass aus Lilienblättern angefertigt ist, und eine Hexe für ihn gemacht hat. Erst das Licht eines magischen Schwertes, das auf das Lilienkleid Neyrams fällt, löst die Blüten des Kleides von seinem Körper. Danach verliert Neyram seine Kraft und Hamze kann ihn töten (5/878).

\footnotetext{
${ }^{804}$ Littmann, Enno: Erzählungen aus den tausendundein Nächten, Bd. IV, S. 761.

${ }^{805}$ Atțār, Farid ad-Din: Elāhi-nāme, hrsg. von Hellmut Ritter, Istanbul 1940, S. 219.
} 


\section{Magische Begrenzung}

„In den meisten Kulturen findet sich die Vorstellung, dass Grenzen, seien es Länder-, Hausoder Feldgrenzen, heilig sind und unter göttlichem Schutz stehen.“ ${ }^{808}$

Die Markierung der Wohnung von psychisch Kranken, die automatisch als von einem bösen Geist besessen gelten, durch mit Messern auf dem Boden oder den Wänden gezogenen Linien, ist für die vorislamische Zeit im Iran bezeugt. ${ }^{809}$ Bis heute ist es im Iran beispielsweise üblich, dass man sofort nach der Niederkunft einer Schwangeren symbolisch mit der Hand eine Linie um Mutter und Kind macht, um sie (nach dem Volksglauben) vor bösen Einflüssen zu schützen.

Die Hexen saßen 40 Tage an einem ruhigen Ort, zogen dann um sich herum eine Linie und lasen dann die Zauberformeln. ${ }^{810}$ Diese Trennunglinie heißt hatt-e mandal. ${ }^{811}$ Man benutzte die magische Begrenzung, wenn man sich von einer feindlichen Macht bedroht und in großer Gefahr sah. Sogar der Prophet Moḥammad beschützte seinen Genossen Zubair b. 'Awwām durch diese magische Begrenzung vor Geistern. ${ }^{812}$

Im Buch Eskandar-nāme lesen wir, dass Eskandar sein Heer durch eine um es gezogene Linie (hatt-e manzal) vor den Feen beschützt hat. ${ }^{813}$

Im $R H$ entführt Sarḩāb-e ğādu Ḥamzes Helden und verwandelt sie in Rehe. Um seine übrigen Soldaten zu schützen, zieht Ḥamze eine Linie um sein Lager, liest die größten Namen Gottes und spricht Gegenzaubersprüche (4/645).

\section{Magisches Ö1}

Im $R H$ wird von Ḥafą b. Dāvuud, einem Gegner des Islams berichtet, der als Zauberer auftritt, welcher sich ins Feuer begeben kann, ohne dass es ihn verbrennt. Er ist Feueranbeter und sagt zu Ḥamze: „Mein Gott ist das Feuer, wenn du es schaffst, unversehrt durch das Feuer zu gehen, dann werde ich den Islam annehmen, anderenfalls musst du meine Religion annehmen.“ Ḥamze entgegnet ihm, dass dies für ihn keine Schwierigkeit sei, denn sein Großvater Ebrāhīm sei auch durchs Feuer gegangen. Er lässt nun viel Brennholz auf dem Kriegsfeld zusammentragen und lässt es anzünden, bis es ganz in Flammen aufgeht. Ḥamzes Kundschafter entdeckt im Zelt von Ḥafą zwei große Ölgefäße. Er sagt zu sich: Vielleicht ist

\footnotetext{
806 Šamisā, Sirus: Farhang-e ešārāt-e adabiyāt-e fārsi, Bd. 2, Teherān 1377-1379/1998-2000, S. 630.

${ }^{807}$ Meinel, Gertraud: Blume, in: EM, Bd. 2, Göttingen 1979, Sp. 483-495, hier Sp. 484.

${ }^{808}$ Köhler, Ines: Grenz, in: EM, Bd. 6, Göttingen 1990, Sp. 134-142, hier Sp. 135.

${ }^{809}$ Rażi, Bd. 3, S. 1298.

810 Šamisā, Fargang-e ešārāt-eadabiyāt-e fārsi, Bd. 1, S. 429.

${ }^{811}$ Nafīsi, Nāzem al-Aṭbbā', 'Ali-Akbar: Farhang-e Nafisi, Bd. 5, Teherān 1343/1965, S. 3539.

${ }^{812}$ Goldziher, Zauberkreise, in: Gesamte Schriften, Bd. V, S. 401-403, hier S. 403.

${ }^{813}$ Afšār, Eskandar-nāme, S. 382.
} 
es rouganan-e samandān (samandān Öl), ein besonderes Öl, dass den Zauberer vor den Flammen schützt. Er tauscht dieses Öl aus und Ḥamze reibt sich damit ein. Dann setzt er sich mit seinen Kleidern mitten ins Feuer und bleibt unversehrt. Der Zauberer macht es ihm nach, benutzt aber das falsche Öl und verbrennt (3/433-434).

Fliegender Teppich

Der Prophet Salomon besaß einen basāt (Teppich). Auf dem basāt saß Soleimān mit seinem Gefolge und seinem Heer. ${ }^{814}$

Ähnliche Teppiche findet man auch im $R H$. Bahrāms Tante, die eine Hexe ist, erfährt, dass Bahrām nicht rechtzeitig zu Ḥamze reiten kann. Sie befiehlt, 4.000 Tiere zu schlachten und danach ihre Häute miteinander zu vernähen um daraus einen großen Teppich anzufertigen. Bahrām begibt sich mit seinen 300.000 Männern auf den Teppich. Seine Tante liest eine Zauberformel, und der Teppich fliegt in kurzer Zeit mit Bahrāms Heer in Ḥamzes Lager $(2 / 328)$.

Amulette

$\mathrm{Zu}$ den meistgenutzten magischen Gegenständen gehören bis heute Amulette und Talismane. Amulette und Talismane sind in vielen Kulturen magische Gegenstände mit schützender Funktion, die durch zusätzliche Zauberformeln oder Segenssprüche verstärkt werden. ${ }^{815}$ Amulette schützen die Menschen meist gegen Krankheiten; sie kommen aber auch gegen Verzauberungen und Verhexungen zum Einsatz. Glücksbringer und schützende Gegenstände werden unter dem Begriff Talisman subsumiert. Wer diese trägt, wird gestärkt und unterstützt. Ihr Träger kann jeden Feind bewältigen. Zudem nützen Talismane als Gegenzauber, zum Lösen des Gebundenen, auch noch für den, der schon lange gefangen ist. Auch helfen sie bei Epilepsie, und dabei, Dämonen aus dem Körper auszutreiben. Amulette können Liebe hervorrufen oder abwehren. Sie machen dem Volksglauben zufolge den Krieger im Kampf unverwundbar. Im Laufe der Geschichte haben viele Menschen, vor allem die Priester in der semitischen Welt, sich mit dieser Magie beschäftigt; bei ihnen sind Magie und Zauberei tief verwurzelt.

Auf dem Weg nach Ardabil sehen Hamze und 'Amr einen verschleierten Jungen und verfolgen ihn bis zu einem Garten. Dort gibt der Junge Hamze eine Armbrust und sagt: „Wenn du diese Armbrust spannen kannst, erfülle ich alle deine Wünsche.“ Hamze schafft es

\footnotetext{
${ }^{814}$ an-Neišāburi, Abu Bakr 'Atiq: Qeșaṣ-e qor’ān-e maǧid, S. 283-284; Walker, J.: Soleimān, in: EI, Bd. IV, S. 561-563, hier S. 562.

${ }^{815}$ De Rachewiltz, Siegfried: Kette, in: EM, Bd. 7, Göttingen 1993, Sp. 1191-1194, hier Sp. 1192.
} 
nicht. 'Amr sieht, dass in der Ecke der Armbrust ein Papier steckt und er weiß, dass das Papier ein Zaubermittel ist. Er entfernt es und Ḥamze kann die Armbrust spannen und die Wette gewinnen $(2 / 270)$.

An anderer Stelle lesen wir im $R H$, dass Soleimān Ḥamze eine Gebetsformel gibt, die Ḥamze an seine Pfeile binden muss, damit er mit diesen gesegneten Pfeilen einen Dämon, der sich in die Gestalt eines Drachen verwandelt hat, schaden kann. Hamze trifft ihn mit einem dieser Pfeile und der Drache flieht (5/940).

\section{Talisman}

Das Wort Talisman (pers. telesm) wird im ganzen Text, im Gegensatz zur europäischen Bedeutung, nur im Sinne eines magischen Ortes gebraucht, wobei die Helden diesen Ort erobern und den ihm innewohnenden Zauber vernichten wollen. Wer ihn überwindet, gewinnt den Schatz, den der Zauber geschützt hat, oder löst eine böse Verzauberung.

Um in die unterirdischen Regionen zu gelangen, die von Schlangen und mehrköpfigen, Feuer speienden Drachen bevölkert sind, steigen die Helden in Brunnen hinab, auf deren Boden sie Gänge finden, die in die unterirdische Welt führen. Auf ihrem Weg treffen sie bei jedem Schritt Inschriften und Erinnerungen an diejenigen, die vor ihnen diesen gefährlichen Weg gegangen sind: Salomon, Alexander und die anderen Helden der iranischen Legenden. Das Ziel dieser über- und unterirdischen Reisen ist es immer, junge Menschen (insbesondere junge Frauen) zu befreien, die zuvor von schlechten oder menschenfressenden Geistern entführt worden sind.

Im $R H$ sind viele Talismane durch vorislamische iranische Könige wie Ğamšid, Alexander, Rostam oder Salomo erbaut bzw. gegründet wurden.

Talismane dienen auch als Zufluchtsort von Geistern. Man darf den Talisman nicht einfach verlassen, sondern man muss den Talisman vernichten (1/177). Ein Talisman kann auch ein Mittel zur Vernichtung der Feinde sein (2/207-209).

Immer gibt es irgendjemanden der beschreibt, was zu tun ist, um den Zauber aufzuheben. Der Held sieht in seinem Traum einen Propheten oder Heiligen, der ihm sagt, wie er den Zauber vernichten kann. (3/472). Eine Zaubertafel soll dem Helden darüber die nötigen Informationen geben. Die Zaubertafel ist immer versteckt und sie kann z.B. zwischen den Hörnern eines Dämons liegen (4/601), in der Brust eines Pfaus bzw. im Bauch eines Rehs stecken. Der Held muss ihn bzw. es töten, damit er die Tafel bekommen kann (4/596). Mit dieser ihn schützenden Zaubertafel muss er durch den Talisman gehen, wo er verschiedenen Versuchungen ausgesetzt sein wird. 
Talismane haben immer einen Wächter am Eingang. Dies kann eine alte hässliche Frau sein ein alter Mann (3/471), ein Dämon (4/596) oder ein wildes Tier (3/472). Sie verwehren den Eintritt in den Talisman deswegen müssen sie durch einen Schuss getötet werden (3/471).

Es gibt auch Dinge, die ein Held während seines Aufenthaltes im Talisman nicht tun darf. Er darf unter keinen Umständen mit dem Dämon sprechen (5/795). Den Wein, der ihm angeboten wird, darf er nicht trinken. (3/472). Er darf nichts essen, was ihm angeboten wird (5/795).

Das Ziel des Vernichtens des Talismans ist stets die Befreiung einer Prinzessin bzw. eines Prinzen, die durch einen Zauberer oder einen Dämon entführt worden sind, und der Raub der Schätze.

Im Talisman Gol-riz-e Soleimān sieht Badi` az-Zamān ein schönes Mädchen, das schläft. Der Prinz versucht sie zu wecken, aber das Mädchen schläft weiter. In ihrer Nähe befindet sich ein Glas, das in einer kleinen Badewanne steht. Als der Prinz das Glas in seine Hand nimmt, steht das Mädchen auf und sagt, dass sie Zarrin-fāl paris sei, die Hexe sie entführt und in diesem Schloss eingesperrt habe. Der Prinz tötet die Hexe und befreit die Prinzessin (4/596).

An einer anderen Stelle erfahren wir, dass Nur ad-Dahr nach der Vernichtung des Talismans die Schätze der 12 Könige in einem Talisman findet und diese an sich nimmt (4/602).

Mit dem Vernichten eines Talismans und dem Tod der Hexe oder des Dämons kommt heftiger Wind auf, und man hört merkwürdige Stimmen und die Natur reagiert auf heftige und stürmische Weise auf ihre Vernichtung (3/472).

Im Folgenden wird eine Geschichte über die Eroberung eines wichtigen Talismans beschrieben, zu dem Ḥamze ins Menschenland reiten muss. Asmā' befiehlt nur widerstrebend ihren Dämonen, dass sie Ḥamze bis zum Menschenland begleiten sollen. Danach befiehlt sie ihnen in ihrer Feensprache, dass sie Ḥamze in der ersten Wüste des Qāf allein lassen sollen. Die Dämonen bringen Hamze in die Wüste und verlassen ihn. Ḥamze sieht ein Pferd und besteigt es. Das Pferd wählt selbst den Weg und bringt Hamze in eine Stadt. Dort will er etwas kaufen, aber die Bewohner sprechen nicht mit ihm. Hamze ist überrascht undgeht zum Palast. Er sieht den König und begrüßt ihn, aber niemand antwortet ihm. Plötzlich hört er eine Stimme und folgt ihr. Er trifft auf eine Gruppe Feen, die ihm mitteilen, dass dies der Talisman der schweigenden Stadt sei und die Leute hier nur einmal pro Monat sprechen würden. Diese Stadt sei von Soleimān erbaut, und er habe seinen Schatz in dieser Stadt gelagert. Zum Schutz des Schatzes habe er einen Zauber über die Stadt ausgesprochen und einen Dämon als Wächter eingesetzt. Hamze geht in den Palast und findet dort eine Tafel, auf der geschrieben 
steht, dass der Palast zu Salomon gehört und er alles Ḥamze hinterlassen hat. Um das Erbe anzutreten muss Ḥamze den Baum im Talisman fällen, um den Dämon zu sehen und diesen mit Salomons Schwert zu töten (1/173).

Weitere magische Gegenstände sind:

Zauberbecher, mit dessen Hilfe 'Amr verschiedene Gestalten und Gesichter annehmen kann (1/74-75). Die Zauberschlafmütze und der Zaubersack von Salomon gehören ebenfalls dazu. Mit ersterer kann man sich unsichtbar machen, der Zaubersack kann viele Speisen auf goldenem Geschirr hervorbringen (1/188). Die magische Fangschnur wird niemals nass und zerreißt niemals (1/174-175) Schließlich ist noch die Zaubertafel zu nennen, die jeden der diese Zaubertafel ansieht, dem König zum Gehorsam verpflichtet (5/783-784).

\subsubsection{Länder}

Das $R H$ hat auch eine ethnologische Komponente: so beschreiben die unbekannten Verfasser des Werkes eine Reihe von Völker und Länder, die teilweise in der realen Welt der Fantasiewelt liegen.

Hamzes Reise führt ihn fast in die gesamte bis dahin bekannte Welt. Zunächst sucht er reale Orte auf wie beispielsweise Mekka, Jemen, Madā'en, Indien, Ceylon, Griechenland, Ägypten, Harušane (Malatiye) auf, reist zwischendurch zu einem fiktiven Ort, namens Qāf, um dann wieder reale Orte aufzusuchen, wie die westafrikanische Stadt Ṭanğa, und den Iran. Seine Reiseschilderung verläuft in höchstem Maße unsystematisch. Der Arabist Malcolm C. Lyons hat bei seiner Untersuchung der arabischen Fassung des Hamze-Romans zu den dort enthaltenen Ortsangaben festgestellt, dass die Schilderung der Eroberungsfahrten Ḥamzes von erheblicher Unkenntnis in Bezug auf die geographischen Gegebenheiten geprägt ist. ${ }^{816}$ Die fiktiven Länder und Orte, verbinden sich oftmals mit aus früheren literatrischen Werken bekannten Namen für fiktive Orte. Gerade aber die Vermischung von realen Ländern bzw. Orten mit fiktiven Ländern bzw. Orten bewirkt, dass die Geschichte fesselt.

Hamze benutzt fast alle verfügbaren Fortbewegungsmittel, um seine Ziele zu erreichen. Er benutzt Schiffe, wird auf den Schultern von Dämonen befördert, Vögel tragen ihn zum Bestimmungsort oder Pferde transportieren ihn. Die Fortbewegungsmittel sind wie die Ziele real oder fiktiv.

Ein großer Teil des $R H$ spielt in der Wüste und auf den Kriegsfeldern. Die Helden reisen z.B. innerhalb kürzester Zeit auf dem Nacken eines Dämons sitzend von China bis zum Schwarzen

\footnotetext{
${ }^{816}$ Lyons, Malcom C.: The Arabian Epic: heroic and Oral Story-Telling, Bd. 1, Cambridge 1995,S. 17.
} 
Meer. So können sie in einer Sekunde eine Distanz von mehreren tausend Kilometern überwinden.

\subsection{Real existierende Orte und Länder der Reiseroute}

Die Beschreibung von Reisen sind in der Welt des $R H$ ein stets wiederkehrendes Thema. Es werden die unterschiedlichsten Reiseabenteuer oder dokumentarische Beschreibungen niedergeschrieben. Die Gründe für eine Reise sind ebenfalls so unterschiedlich wie die Darstellungen in der Literatur. Der literarhistorische Rückblick zeigt, dass die bestimmenden Impulse im Altertum und im Mittelalter überwiegend von außen auf den Protagonisten wirkten.

Mit dem Aufbruch in fremde und unbekannte Länder, in Kriege, in Liebesaffären, in Traumund untererdische Welten, und gefährlichen Auseinandersetzungen mit Geistern und Dämonen ist mit der Reise fast immer eine besondere Prüfung und Entwicklung des Helden verbunden. Durch die Reise kommt es zu einem wunderbaren Reifeprozess des Helden, im Verlaufe dessen er zu kritischen Einsichten über sich selbst und seine Umwelt gelangt. Nach Beendigung der Reise kehrt er, oft verändert an Leib und Seele, in die alte Heimat zurück.

Die Autoren des $R H$ greifen immer wieder auf das Thema Reise zurück, um erzieherische, spannende, unterhaltsame, tragische und humorvolle Geschichten zu erzählen. Auch im $R H$ sind die Anlässe eine Reise anzutreten enorm vielfältig. Ein Wort Gottes, ein Ruf des Königs, die Aussicht auf Liebe, Ruhm und Ehre, Pilger und Abenteueroder sogar Ausflug und Spaziergang veranlassen den Helden zum Aufbruch in unbekannte Länder. So finden sich dort unzählige, sehr verschiedene Erzählmotive und Begründungen für die Reisen der Helden. Einmal werden Feinde verfolgt, ein andermal tritt der Held als Rebell und gerechter Räuber in Erscheinung oder er besucht die Unterwelt oder geht auf eine Zeitreise. Dort ist die Reise fast immer mit einem wunderbaren Reifeprozess der Helden verbunden. In ihrer Vielgestaltigkeit und Beliebtheit ist sie wohl nur vergleichbar mit den Themen rund um die Liebe, die Feindschaft und die Freiheit. Besonders wichtig scheint die Verbindung mit dem Motiv des Heimkehrers zu sein. ${ }^{817}$ Auf den Heimkehrer können gute wie böse Überraschungen warten; meist jedoch findet der Held problematische Situationen vor, wie den Verlust der Herrscherwürde, politische Umwälzungen oder gar die Verleugnung seiner Existenz (1/9293). Die Konfrontation mit diesen Situationen stellt den Heimkehrer zunächst auf die Probe, bevor er anschließend mit der alten Heimat Frieden schließt oder erneut aufbricht und seine Heimat für immer hinter sich lässt.

${ }^{817}$ Gerndt, Helge: Reise, in: EM, Bd. 11, Göttingen 2004, Sp. 504-514, hier Sp. 511. 
Die Erkenntnisse, die der meist jugendliche Held auf seinen Reisen gewinnt, die neuen Eindrücke lassen ihn die Welt mit anderen Augen sehen. Manchmal sind es auch Negative, in denen der Held zerschlagen und zerstört, ohne festen Boden unter den Füßen aus einer fremden, oft grausamen Welt heimkehrt.

Ḥamzes Wunsch nach Abenteuer und Ungebundenheit, aber auch nach moralischer Entwicklung, geistiger Vervollkommnung oder sentimentaler Beschaulichkeit treiben ihn in die weite Welt hinaus. Vor allem die Autoren des $R H$ sind vor diesem Hintergrund besonders produktiv. Sie versuchen, ihren Zuhörer die Notwendigkeit politischer und sozialer Umwälzungen im Iran schmackhaft zu machen.

In dem vorliegenden Abschnitt begleiten wir Ḥamze und seine Gefährten auf der Suche nach Abenteuern. Unser Weg führt uns durch von Rittern, schönen Fräuleins, mutigen Soldaten und lustigen Knappen bevölkerte Landschaften. Gelegentlich entdecken wir die realen Orte, die in der Fiktion Schauplätze so großer Romane sind.

Iran

Im Jahr 637/638 eroberten die Araber Ktesiphon (arab. Madā'en) die Hauptstadt des persischen Reiches. ${ }^{818}$ Solche Ereignisse hinterlassen in der Sagenbildung eines Volkes deutliche Spuren und bleiben immer Teil der kollektiven Erinnerung eines Volkes. Bei den arabischen Siegern entstanden in Bezug auf die Eroberung des Irans ebenfalls fantasievolle Erzählungen. Deshalb hatte der König von Persien eine Vorbildfunktion für den gesamten islamischen Raum in Bezug auf die facettenreiche persische Kultur. ${ }^{819}$ Je mächtiger die Araber in ihren Sagen den Perserkönig machten, desto strahlender war natürlich ihr eigener Sieg über ihn. So wurde z.B. in der Geschichte von 'A ğib und Ġarib, der König von Persien, der König der Welt genannt. ${ }^{820}$ Hingegen formten die Verlierer, auf iranischer Seite, die geschichtlichen Tatsachen nach ihren Vorstellungen und versuchten so der Situation die Bitterkeit der Niederlage relativieren. So sagt Paret:

"Eine besiegte Nation sucht ihre Ehre dadurch zu retten, dass sie im Sieger ihren Landsmann erkennt." $\$ 21$

Hinzu kam, dass die Eroberer oft Königstöchter der Besiegten ehelichten, so dass es auch einen gewissen realen Grund gab, sich mit den Siegern „familiär“‘ verbunden zu fühlen.

\footnotetext{
${ }^{818}$ Spuler, Iran in früh-islamischer Zeit, S. 10.

${ }^{819}$ Ebd. S. 289.

${ }^{820}$ Littmann, Enno: Erzählungen aus den tausendundein Nächten, Bd. IV, Leipzig 1921-1939, hier S. 455.

${ }^{821}$ Paret, Rudi: Die Geschichte des Islam im Spiegel der arabischen Volksliteratur. Philosophie und Geschichte, Bd. 13, Tübingen 1927, S. 18.
} 
Die Perser waren mit ihrem Status in der islamischen Gesellschaft nicht zufrieden. Die Dynastie der Umaiyyaden (667-750 n. Chr.) übte Druck auf die Perser aus. Der im 8. Jahrhundert neu erwachende iranische Nationalismus war dem Vorherrschaftsanspruch der Araber besonders verhasst. So bildete sich im Iran ein Kreis von Schriftstellern und Gelehrten, die die Ansprüche des Persertums gegenüber dem Arabertum in verschiedenster Art und Weise vertraten. Dieser Gelehrtenkreis nannte sich šu bildete den Beginn der persischen Nationalbewegung. Sie verachteten die nomadische Herkunft der Araber aus der Wüste. ${ }^{822}$ Der Stolz des Volkes, welches den Ruhm eines Siegers über Ninive für sich allein in Anspruch nahm, konnte sich mit dem Gedanken an die Unterwerfung unter ein fremdes Volk, besonders ein „niedrigeres“ Volk wie das der Araber, nicht anfreunden. Deshalb „erfanden“ die Iraner die sagenhafte Geschichte von der Verwandtschaft des Prophetenhauses mit der letzten einheimischen Dynastie, den Sasaniden. ${ }^{823}$ Die schiitischen Imāme waren somit Träger des charismatischen Anspruchs auf die Leitung der Gemeinde, da sie sowohl aus dem Hause des Propheten als auch aus dem Hause des persischen Königs abstammten. So schlug die Schia Wurzeln im Iran. گ̌úübiya, die als Verteidiger der Schia sehr bekannt waren, verankerten ihre politische Position im Iran, indem sie die Frage nach ihrer Legitimation sehr rationalistisch beantworteten.

Selbstverständlich spielt der Iran im $R H$ eine herausragende Rolle als Schauplatz der Ereignisse. Für die Araber im $R H$ sind die Perser Ungläubige. Dies hat auch historische Hintergründe. Daher sind Hamze und seine Gefolgsleute nicht eindeutig der einen oder anderen Kultur zuzuordnen. Im $R H$ ist Ḥamze zunächst Feind des persischen Königs, den er permanent versucht zum Islam zu bekehren. Zugleich ist Hamze aber auch sein Schwiegersohn. Nach der Eroberung des Irans kämpft Ḥamze nun gegen die Feinde des Irans. Die Stadt Madā'en ist eine große Kulturstadt und Hauptstadt des Irans in der sasanidischen Zeit. Sie ist somit der Schauplatz vieler bedeutender Ereignisse. Die Stadt wird mehrmals belagert, zerstört und geplündert (5/919).

Die Erzähler des $R H$ geben eine vielschichtige Darstellung historisch-politischer Vorgänge, die eine nationale Einheit in Abgrenzung zu den Usbeken und Osmanen (besonders im Hinblick auf eine schiitische Glaubensrichtung) herbeizuführen versuchen. In ihren Texten stellen sich die Erzähler als Sprachrohr der Herrschenden dar, indem sie für deren Absichten werben. Sie sprechen besonders die Gefühlswelt ihrer Zuhörer an, damit sich diese ihrer politischen Anschauung (und so den Interessen der Herrschenden) anschliessen.

\footnotetext{
${ }^{822}$ Șafā, Hamāse-sarā̄i dar Irān, S. 143-149.

${ }^{823}$ Spuler, Iran in früh-islamischer Zeit, S. 231.
} 


\section{Ḩațā}

Haṭā ist in der persischen Literatur Torkestān. ${ }^{824}$ Torkestān war im Altertum ursprünglich von iranischen Völkern besiedelt und bei diesen als Turān bekannt. Im Gebiet des heutigen Torkestān lebten im Laufe der Geschichte viele Völker, da das Gebiet seit jeher ein wichtiges Durchzugsgebiet der nomadischen Steppenvölker war. In der Zeit zwischen dem 7. und 8. Jahrhundert wurde ein großer Teil des torkestanischen Gebietes von Diversen Steppennomaden darunter auch frühe Turkvölker beherrscht, die dem feudalen Herrschaftsgebiet der Göktürken (blaue Türken) angehörten. ${ }^{825}$ Zwischen den Jahren 661 und 750 wurden weite Teile des späteren Torkestāns von den Arabern erobert und zum Islam bekehrt. Seit 1220 gehörte ganz Torkestān zum mongolischen Herrschaftsgebiet. ${ }^{826}$ Die mongolischen Ausfälle und damit verbundenen Verwerfungen von Europa bis China eröffneten Kontakte zwischen Völkern und Kulturen (unter der Herrschaft bzw. Vermittlung der Mongolen), die sich zuvor nicht gekannt hatten. Gerade später zur Timuridenzeit dehnten sich die Handelsstraßen nach Osten und Norden bis nach China und von Harāt durch Kābul nach Indien aus. ${ }^{827}$ Nach Hațā wurden in dieser Zeit viele Delegationen entsandt. ${ }^{828}$

Nach den Wirren der mongolischen Eroberung folgte nun also eine Zeit der Entspannung. Als ein Kennzeichen dieser Zeit fand eine Neubelebung und Verinnerlichung des religiösen Lebens statt. Dies äußerte sich auch im Aufschwung religiöser Bruderschaften.

Im $R H$ wird Hatāa als eine große Stadt beschrieben, die 12.000 Stadtviertel hat (3/421). Die Stadt ist Ṣalṣāls Residenz und die Einwohner der Stadt sind Usbeken, also Götzenanbeter (3/413). Ḥamze und seine Helden kämpfen gegen Șalṣāl in Hațā. Während des viertägigen Krieges werden viele Usbeken getötet, aber schließlich werden die Einwohner der Stadt Haṭā zum Islam bekehrt (3/456).

\section{Hotan}

Hotan ist eine große Oase des südlichen Tarim-Beckens in der autonomen Xinjiang Region Chinas, historisch gesehen ein wichtiges Königreich mit einer Iranisch sprechenden Bevölkerung. Die Stadt Khotan oder Kotan (heute Ho-t’ein) liegt südwestlich von Kašğar (heut Su-fu) in Sinkiang (Volksrepublik China).

\footnotetext{
${ }^{824}$ Hatā, Hitā auch Hitāi, ist identisch mit Nordchina: Jahn, Karl: Die Chinageschichte des Rašĩd ud-Din, Wien 1971, S. 19; Bosworth, Clifford Edmund: Karā Khițāy, in: $E I^{2}$, Bd. IV, Leiden 1978, S. 580-583.

${ }^{825}$ Golden, B. Peter: An introduchtion to history of the Turkic pepoles: enthnogenesis and state formation in medieval and early modern Eurasia and the Middle East, Wiesbaden 1992, S. 117.

${ }^{826}$ Vgl. Bosworth, Kạāā Khițāy, S.581.

${ }^{827}$ Roemer, Persien auf dem Weg in die Neuzeit, S.128.

${ }^{828}$ Ḥāfiże Abru: Zobde at-Tawārih̆, Bd. 2, hrsg. von Seyyed Kamāl Ḥāğğğ Seyyed Ğavādi, Teherān 1372/1993, S. 679 u. 822.
} 
Laut Yãqut lag Hotan in einem Gebiet zwischen Kāšğar und einer Landschaft namens Yūzkand im Ferḡāne-Becken. ${ }^{829}$

Im Laufe der Geschichte war die Stadt Hotan unter deutlichem politischen und kulturellen Einfluss des Irans, Indiens und Chinas. „In den ältesten chinesischen Berichten wird die Stadt Yutien genannt. “830 Man findet Spuren von allen drei Kulturen in Hotan. Schon früh war der Buddhismus die führende Religion in der Stadt, was auf den chinesischen Einfluss schließen lässt. ${ }^{831}$ Später erschienen in der Stadt Spuren persischer Grammatik und indischen Wortschatzes. ${ }^{832}$ Der Islam erreichte Hotan jedoch erst viel später.

„Im XIII. Jahrhundert stand Khotan nach Marco Polo [...] unter der Herrschaft des Kaisers von China. ${ }^{\text {“833 }}$ Später kam die Stadt Hotan unter die chinesische Herrschaft. ${ }^{834}$

Im $R H$ wird Ḥamze von Zardehang-e Hotani entführt und nach Hotan gebracht. Der König von Hotan Ya'qub Hān-e Hotani steckt Hạmze in einen Käfig. Als 'Amr nach Hotan kommt, um Hamze zu befreien, gelingt es ihm durch eine List die Stadt zu erobern. Ya'qub und die Einwohner von Hotan konvertieren zum Islam. Am Ende heiratet Ḥamze Ya'qubs Tochter Dorr-dāne. Danach reitet Ḥamze nach China und durch ihn werden die Einwohner Chinas zum Islam bekehrt (3/441-442).

Indien

Indien wurde in der gesamten vorislamischen Zeit als Hort der Stabilität, Sicherheit und des Reichtums betrachtet, und es nahm in den iranischen Erzählungen einen besonderen Stellenwert ein. Es war die Heimat vieler Sagen, Geschichten und Erzählungen. Indien war ebenso ein großes Schlachtfeld für die Muslime, besonders unter dem Solțān Mạ̣mud von Ghazna.

Die Stabilisierung des Irans unter den Șafaviden machte sich auch wirtschaftlich bemerkbar. Die wirtschaftliche Entwicklung des Irans im 17. Jahrhundert verlief durchaus positiv. Weiter strebten die șafavidische Könige, vor allem 'Abbās I., ganz ausdrücklich nach Verbesserung der Handelsbeziehungen. Zu diesem Zweck ließ er auch indische Kaufleute nach Eșfahān und in andere Städte kommen. In der Șafavidenzeit war der Iran aber nicht nur für den Handel, sondern auch für Kulturkontakte offen. Politisch pflegte der Hof in Eșfahān Kontakte zu vielen Höfen, darunter besonders $\mathrm{zu}$ dem Hof in Indien. Dem Ausbau der

\footnotetext{
${ }^{829}$ Yāqūt, Šihāb ad-Din Abū 'Abdallāh Yāqūt b. 'Abdallāh: Kitāb mưğam al-buldān, Bd. 2, Bairut 1375 h/1956, S. 347.

${ }^{830}$ Barthold, Wilhelm: Khotan, in: EI, Bd. II, Leiden/Leipzig 1927, S. 1041-1042, hier S. 1041.

${ }^{831}$ Ebd. S. 1041.

${ }^{832}$ Ebd.

${ }^{833}$ Ebd. S. 1042

${ }^{834} \mathrm{Ebd}$.
} 
Handelsbeziehungen und dem Glanz der neuen Hauptstadt diente auch die Umsiedlung einer großen Gemeinde Inder nach Eșfahān. ${ }^{835}$

Auch im $R H$ wird Indien als ein reicher Staat dargestellt. Als Ḥamze erfährt, dass 'Amr alle Gegenstände aus seiner Schatzkammer mitgenommen hat, ist er nicht traurig, sondern sagt nur: „Das ist nicht so schlimm, weil Indien in der Nähe ist““ (1/75/16). An anderer Stelle lesen wir, dass Mehrnegār seinen Sklaven H్̛̃āğe Almās nach Indien schickt, um dort Geschäfte zu machen $(1 / 103 / 22)$.

Sarandib

Sarandib spielte in der islamischen bzw. iranischen Literatur eine große Rolle. Sarandib existierte in Wirklichkeit als die Insel, die heute als Sri Lanka bekannt ist. Bei den arabischen Geographen des Mittelalters lautete die übliche Bezeichnung für die Insel Ceylon. ${ }^{836}$ Sarandib war der Ort, wo Adam nach der islamischen Tradition auf die Erde hinab gestiegen ist. Darüber schreibt Mas'ī $\mathbf{u}$ ī:

“Adam kam herab[ aus dem Paradies] nach Indien, zur Insel Ceylon auf den Berg ar-Ruhūn. Er trug ein Kleid aus paradiesischen Blättern, die er zusammengenäht hatte und die nun, als sie vertrockneten, von den Winden über Indien zerstreut wurden. Man sagt Gott allein weiß, ob es wahr ist!, dass die Ursache für das Vorhandensein der verschiedenen Parfums in Indien in diesen Blättern liegt.“،837

Nasafi berichtete, dass der Ort wo Adam gelandet war, Qadam-gāh (Fußabdruck) genannt wurde. ${ }^{838}$ Ibn Batțuta (gest. 1377) berichtete, dass er selbst die Insel besuchte und den heiligen Berg bestieg, um den auf ihm befindlichen Fußabdruck Adams zu sehen. Er führte dazu aus:

„Der Weg des Bābā ist schwer und beschwerlich zu ersteigen. Am Fuße des Berges, wo sich sein Zugang befindet, liegt eine Grotte, die auch nach Iskender benannt ist, Stufen sind in den Fels geschlagen, auf denen man emporsteigt, Eisenpfähle in den Fels gerammt und an ihnen Ketten befestigt, damit sich der Kletterer an ihnen festhalten kann. Es sind 10 Ketten. “839

\footnotetext{
${ }^{835}$ Bāstāni-Pārizi, Moḥammad-Ebrāhīm: Siyā sat va eqteșād-e ‘aṣr-e Șafavi, Teherān 1348/1969, S. 105; 113.

${ }^{836}$ Nafisi, 'Ali-Akbar: Sarandib, in: Farhang-e Nafisi, Bd. 3, Teherān 1343/1964, S. 1871.

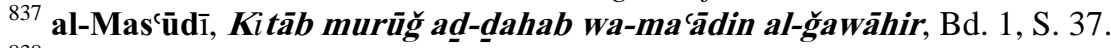

${ }^{838}$ Nasafi, 'Aziz ad-Din: Ketāb al-ensān al-kāmel, S. 391; an-Neišāburi, S. 20.

${ }^{839}$ Ibn Bațtuṭa, Abū 'Abdallāh Moḥammad b. 'Abdallāh b. Moḥammad b. Ibrāhīm: Safar-nāme-ye Ibn Baț̣tu, Bd. 2, ins Persische übersetzt. von Moḥammad 'Ali Movaḥḥd, Teherān 1348/1970, S. 697.
} 
In diesem Zusammenhang lesen wir im $R H$, dass Hamze sich in Begleitung seines Kundschafters 'Amr mit dem Schiff auf den Weg macht, um mit Landehur, dem König von Indien, zu kämpfen und seinen Kopf nach Madā‘en zu bringen (1/68). Als sie nach einiger Zeit Indien erreichen, schickt Ḥamze 'Amr in Landehurs Lager, um von dort die notwendigen Informationen in Bezug auf seine Truppen in Erfahrung zu bringen. Auf dem Weg nach Indien legt 'Amr einen Pause in Ceylon ein, wo sich das Adamsmausoleum befindet. ${ }^{840}$ Dort begegnet er einem alten Wächter, der ihm mitteilt, dass Ādam ihm eine Erbschaft hinterlassen habe, die er nur ausgraben müsse. ${ }^{841}$ Er folgt dem Rat und findet einen großen Rubin. Im Mausoleum sieht 'Amr viele andere wertvolle Gegenstände, die er an sich nimmt. Als er jedoch versucht, diese nach draußen zu tragen, schließen sich die Türen (Heilige bewachen ihre Schätze in der Grabstätte) ${ }^{842}$ Legt er aber die kostbaren Schätze an ihre Stelle zurück, öffnen sich die Türen wieder, und er kann das Mausoleum verlassen (1/74).

'Amr kommt mit den gesammelten Informationen zu Ḥamzes Lager zurück, woraufhin dieser in den Kampf zieht und Landehur besiegen kann. Ḥamze reitet mit Landehur nach Persien und übergibt seinen Gefangenen dem Perserkönig. Als er wie versprochen dessen Tochter zur Frau nehmen will, verweigert ihm dies der Perserkönig, sodass es zum Kampf mit Ḥamze kommt. Hạmze sieht sich genötigt, Landehur frei zu lassen, damit dieser ihn im Kampf unterstützt. Dieser schlägt Gostaham und treibt ihn in die Flucht. Landehur nimmt daraufhin den islamischen Glauben an und kämpft von nun an auf Ḥamzes Seite (1/75-85).

\section{Das Oströmische Reich}

In Kleinasien hatten die Araber schon lange Auseinandersetzungen mit dem Oströmischen Reich. Im Jahr 1071 n. Chr. hatten die türkischen Stämme unter Führung des Ālb-Arsalān den oströmischen Kaiser im Gebiet Manzikert/Malāzgirt (Armenien) in einer großen Schlacht besiegt. ${ }^{843}$ Dies galt als entscheidendes Ereignis bei der Türkisierung und Islamisierung Anatoliens. Von diesem Moment an eroberten die türkischen Stämme von

\footnotetext{
${ }^{840}$ Als Alexander mit dem Philosoph Balinās an den Adams Grabstätte kommt, habe er jene Ketten angebracht, um ihn zu besteigen. Pfister schreibt darüber: "Merkwürdigerweise kommen nun solche Ketten auch in der antiken Nysa-Episode vor, sodass ein Zusammenhang kaum abzuweisen ist. Die Kette der griechischen Nysa-Episode stammt also vermutlich aus dem Orient: das umgekehrte ist weniger wahrscheinlich. Chadhir und Alexander." Siehe: Pfister, Friedrich: Kleine Schriften zum Alexanderroman, Meisenheim am Glan: Hain 1976, S. 149.

${ }^{841}$ Ibn Batțuṭa berichtet, dass nämlich in den Felsen, wo sich der Fußabdruck befindet, 9 Löcher gemeißelt sind, in die die heidnischen Pilger Gold, Edelsteine und Perlen legten. Siehe: Ibn Batțuṭa, Bd. 2, S. 698.

${ }^{842}$ Wimmer, Erich: Grab, Grabwunder, in: EM, Bd. 6, Göttingen 1990, Sp. 51-63, hier Sp. 58; Das Motiv der magischen Türen findet sich auch in der älteren Literatur: Eskandar sah in Indien einen magischen Baum. Eskandar ging in den Baum und fand dort alles, was das Herz begehrt. Er nahm ein wenig Zucker und wollte rausgehen. Plötzlich wurde die Tür unsichtbar. Als er den Zucker an seinen Platz zurücklegte, wurde die Tür wieder sichtbar. Siehe: aț-Ṭarsusi, Dārāb-nāme, Bd. 2, S. 278.

${ }^{843}$ Vgl. Kreiser, Klaus: Der osmanische Staat 1300-1922, München 2001, S. 4.
} 
Anatolien aus immer weiter westwärts gelegene Gebiete. ${ }^{844}$ Im 12. Jahrhundert konnte Byzanz einige Gebiete wieder zurückgewinnen. Das oströmische Reich endete erst 1453 mit dem Fall von Konstantinopel an die Osmanen.

Im $R H$ reitet Ḥamze zur Stadt Hyarušane (Malatya), ${ }^{845}$ begegnet dort der Prinzessin Rābe‘e, verliebt sich in sie, heiratet sie schließlich und kann so in diesem Gebiet Fuß fassen. Er und seine Söhne haben viele Auseinandersetzungen mit Franken, die auch dieses Gebiet für sich gewinnen möchten. Das muslimische Heer bedient sich dabei einer besonderen Taktik, die den Franken so große Schwierigkeiten bereitet, bis sie schließlich von Harušane vertrieben sind.

\section{Das Frankenland}

Im Jahr 711 wandten sich die muslimschen Truppen unter Tāriq b. Ziyād bei Gibralter (Berg des Tariq) gegen das christliche Europa und landeten in Spanien. Der arabische Vorstoß in das Frankenland wurde durch Karl Martell 732 in der Schlacht von Torus und Poiliers gestoppt. Bis zum 9. Jahrhundert gelang den Arabern die Eroberung der Balearen und Sizilien. In der Folgezeit entstand, nach dem Ende des Umaiyyadenzeit, in al-Andalus ein selbständiges umaiyyadisches Reich.

Nach der Gründung des Șafavidenreiches (16. Jahrhundert) entwickelte sich ein Machtkampf im Gebiet Klein- und Zentralasiens zwischen den Turkvölkern und dem Iran. Der Gedanke an ein abendländisch-orientalisches Abkommen gegen die Osmanen hatte sowohl auf der europäischen als auch auf der iranischen Seite zahlreiche, zeitweise wechselnde Fürsprecher. Die Großmächte standen dem iranischen König als Partner zur Seite und so wurde der șafavidische König ein gefragter Gesprächspartner. In der Regierungszeit des Šāh 'Abbās I. nahmen die diplomatischen Kontakte zu. Viele europäische Großmächte nahmen Kontakt mit Šāh 'Abbās auf. ${ }^{846}$ Trotz dieser Bündnisse auf höchsten Ebenen änderte sich nichts daran, dass das iranische Volk (wie andere Muslime auch), weiterhin die Christen als Ketzer betrachtete und ablehnte. ${ }^{847}$

\footnotetext{
${ }^{844}$ Ebd. S. 4.

${ }^{845}$ Eine alte Stadt unweit vom oberen Euphrat. In hethitischer Zeit war diese Stadt berühmt. Später herrschten die Assyrer dort. Danach kam die Stadt unter persische und römische Herrschaft. Nach der Schlacht von Manzikert 1071 gelangte die Stadt in den Machtbereich des byzantinischen Generals Philaretos Brachamios; nach dessen Tod um 1090 wurde die Stadt von einem armenischen Herrscher namens Gabriel regiert. Im Jahr 1103 wurde Malatya von den Dānišmenden erobert und Gabriel getötet. Im Jahr 1243 fielen die Mongolen in die Stadt ein. 1273 litt die Stadt sehr unter arabischen Angriffen, zahlreiche Einwohner wurden als Sklaven verkauft. 1516 kam Malatya unter osmanische Herrschaft. Siehe: Honigmann, Ernst: Malatya, in: EI, Bd. III, Leiden/Leipzig 1936, S. 213-218.

${ }^{846}$ Lockhart, Laurence: European Contacts with Persia 1350-1736, in: CHI, Vol. VI, hras. von Peter Jackson and Laurence Lockhart, Cambridge 1986, S. 373-411, hier S. 373-409; Falsafi, Bd. 4, 157-159.

${ }^{847}$ Falsafi, Bd. 3, S. 67-97.
} 
Das $R H$ folgt der Tradition der islamischen Geschichtschreibung, wenn er die Kreuzfahrer mit

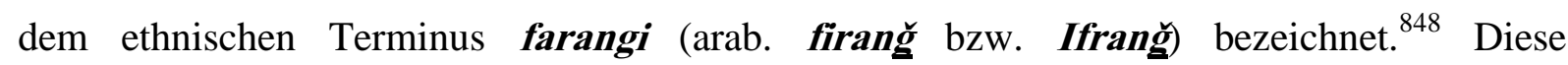
Bezeichnung ist in der Vergangenheit für die Bewohner des Fränkischen Reichs Karls des Großen benutzt worden. ${ }^{849}$ In späterer Zeit werden diese Begriffe für europäische Christen im Allgemeinen verwendet, ohne dass dabei eine weitere ethnische bzw. geographische Differenzierung vorgenommen wird. Dennoch impliziert dieser Begriff in erster Linie die Zugehörigkeit zum Christentum. Gestützt wird dies dadurch, dass die Autoren des $R H$ den Begriff kāfer (Ungläubiger) betonen. Auffällig ist, dass $R H$ weitergehend Begriffe wie Hund und Schwein benutzt. Festzuhalten bleibt, dass $R H$ durch die Verwendung des Begriffs „Franken“ die Kreuzfahrer vordergründig als „Fremde“ in kultureller sowie ethnischer Hinsicht aber auch als Glaubensgegner bzw. Christen darstellt. Die Franken stehen im $R H$ stellvertretend für die christlichen Westeuropäer. Bemerkenswert ist, dass die fränkischen Herrscher und die Muslime auf vielen Gebieten der Lebensgestaltung Ähnlichkeiten aufweisen (beispielsweise der Einsatz von Kundschaftern, um das Feindeslager zu erkunden oder die Unantastbarkeit ihrer Töchter). Aber dennoch sind nach Auffassung der Verfasser des $R H$, die Franken Ketzer, die einen Irrglauben verbreiten (5/919-920).

Das $R H$ wird im Hinblick auf die religiöse Identität und Abgrenzung zur Zeit der Kreuzzüge relativ stark beeinflusst. Im 15. und 16. Jahrhundert ist die religiöse Zugehörigkeit allein die wichtigste Determinante bei den Muslimen, um gegen Andersgläubige zu kämpfen.

Die Stadt Harušane ist ein großer Schauplatz kriegerischer Auseinandersetzungen. Diese Stadt wird mehrere Male durch die Franken angegriffen. 'Alam Šāh und sein Freund Lohrāsb machen sich auf den Weg, um Sa'd, der durch Franken festgenommen worden ist, zu befreien (2/249). Mālā-kard, der fränkische Feldherr, stellt sich ihnen entgegen. Ein wütender Zweikampf entbrennt zwischen 'Alam Šāh und Mālā-kard. 'Alam Šāh besiegt Mālā-kard und heiratet seine Tochter Lotbat-e Farangi (2/253-254). Durch diese Heirat werden zwei Häuser zu einem. Später zieht Ḥamze selbst gegen die Franken, besiegt den Fürsten und schließt einen Friedensvertrag mit Mazduq.

\subsection{Imaginäre Orte und Reiserouten}

Neben der realen Geographie gibt es im $R H$ die imaginäre Geographie. Die Helden sind im $R H$ zwischen der realen und imaginären Welt unterwegs, dessen Wunderwelt sie hypnotisierend anzieht. Sie zeigen uns die fantastischen Unmöglichkeiten dieser Welt. Diese stellt keine psychische, sondern eine intellektuelle, extravagante und übersteigerte

\footnotetext{
${ }^{848}$ Vgl. Lewis Bernard: Ifrandj, in: $E l^{2}$, Bd. III, Leiden/London 1971, S. 1070-1072, hier S. 1070.
} 
Beschreibung der Lebenswelt dar. Die Autoren des $R H$ sind nicht unlogisch, sondern gehorchen einer anderen Logik als der von den Helden allgemein vertretenen. Diese intellektuelle Extravaganz stellt das Konzept von Normalität in Frage und die gewalttätigen Reaktionen der Fabelwesen auf die Helden entsprechen den Erwartungen der Zuhörer. Der Glaube an das Vorhandensein von Übernatürlichem und seine erfolgreiche Bezwingung durch die Helden sind für das Sicherheitsbedürfnis der Menschen von großer Bedeutung.

Ḥamze begegnet skurrilen Geschöpfen, die nach ihrer eigenen Logik leben, wo aber die Ordnungssysteme aus der Menschenwelt große Bedeutung haben. Größenverhältnisse, der Zeitbegriff und die Zeit selbst, schließlich sogar die ganze Realität werden manipulierbar, durch neue Denk- und Sprachmuster, die sich durch ihre eigene Regelhaftigkeit definieren. Diese unterschiedlichen Welten ergänzen sich im Roman und Ḥamze kann sich in beiden Welten mühelos bewegen.

\section{Das Land Finsternis}

Bereits in der Antike war das Land Finsternis Gegenstand anhaltender Diskussionen auf dem religösen Gebiet. Im manichäische Theologumena wurde erklärt, dass die Finsternis in der Regel als Schlachtfeld des Lichtes und der Finsterniszu verstehen ist. ${ }^{850}$ Die Zeugnisse führen an, dass die Welt der Finsternis mit der irdischen Welt identisch ist und ihre eignen Herrscher hat (Riese, Drache, Unhold). ${ }^{851}$

In der islamischen Literatur nimmt das Land Zolomät (die Finsternis) einen bedeutenden Raum ein. Spuren der Finsternis findet man im Roman von Alexander. Wie z.B. die Suche nach der Lebensquelle, die sich den muslimischen Überlieferungen zufolge am Nordpol befinden sollte aț-Táăāīìi schreibt: „Von Indien zieht Alexander nach Șīn und nachdem er Șīn und Tubbat unterworfen hat, zieht er auf der Suche nach der Lebensquelle mit 400 Mann nach Zolomāt (die Finsternis), in die Gegend am Nordpol.“ ${ }^{852}$

Ferdousi lässt Alexander vom Amazonenland nach Westen ziehen. Er gelangt erst zu einer riesigen Stadt, wo die Menschen von großem Wuchs, rothaarig, hellhäutig und kriegerisch sind. Hier fragt Alexander nach den Sehenswürdigkeiten. Er bekommt zu hören, dass jenseits der Stadt die Sonne in einem Teich versinkt, jenseits davon sei die Finsternis. In dieser Finsternis soll sich die Lebensquelle befinden. ${ }^{853}$

\footnotetext{
${ }^{849}$ Ebd. S. 1070.

${ }^{850}$ Kurt, Rudolph: Gnosis und spätantike Religionsgeschichte, S. 236.

${ }^{851}$ Ebd. S. 318.

${ }^{852}$ at- $\underline{\text { Tacālībī, Abū Manșūr al-Ḥusain b. 'Abd al-Malik b. Moḥammad al-Marğanī: } \dot{G} u r a r}$ ahbār mulūk al-Furs wa siyaruhum [Histoire des Rois des Persses], hrsg. von Hermann Zotenberg, Neudruck Teherān 1963, S. 432-434.

${ }^{853}$ Ferdousi, Bd. 1, S. 1153-1155.
} 
Neẓāmi scheint seine Darstellung von aṭ-Ṭabari entnommen zu haben. Er schreibt:

„Ein Schleier ist unter dem Nordpol, unter ihm befindet sich eine lautere Quelle mit klarem Wasser. Ein Schleier, den man Finsternis nennt, aus ihrer Ruhe fließt das Lebenswasser hervor." ${ }^{\text {(854 }}$

Nach der Erzählung in Šaraf-nāme hören wir, dass Alexander zum ersten Mal von der Existenz einer Lebensquelle durch einen erfahrenen und alten Mann hört, der darüber bei einem Festmahl erzählt, wo jeder Gast die ihm bekannten Weltwunder anpreist. Ein Greis, der zugegen ist, erzählt also vom Lande der Finsternis, das sich unter dem Polarstern des Nordens befinde und in seiner Mitte die Lebensquelle, einen reinen Born klaren Wassers, berge. Auf eine wiederholte Anfrage Alexanders erklärt der Greis ein zweites Mal, dass sich das Land der Finsternis zur Rechten (unter dem Polarstern) befinde und dass der Weg kurz sei. Alexander begibt sich daraufhin mit seinen Truppen auf den Weg dorthin. An einer Höhle in der Nähe der Finsternis lässt er den Großteil der Truppe samt Gepäck zurück. Er geht nur mit wenigen ausgewählten jungen Männern, die kühn und stark, ausdauernd, standhaft und loyal sind. Alte und kranke Männer dürfen nicht mit weiterziehen. Er nimmt von den Leuten des Landes einen ortskundigen und erfahrenen Mann mit, den er als Führer an der Spitze der Armee marschieren lässt. Nachdem er seinen Befehlshaber hinsichtlich der zurückgebliebenen Truppen eingewiesen hat, schickt er auf Pferden und anderen Tieren die gezuckerten und gesalzenen Lebensmittel voraus. Als sie einen Monat nordwärts gewandert sind, ändert sich der Stand der Sonnenbahn. Vom Pol des Himmelskreises erscheint (Sonnen) Licht; es geht in einem Augenblick schnell auf und unter. Der Äquator legt seine Spitze an den Horizont; die Mittellinie bleibt am Nordpol stehen. Sie wandern immer weiter nordwärts, wo es immer dunkler wird, bis sich schließlich vollständige Finsternis einstellt. Hier bleiben sie ratlos stehen. Doch ein Jüngling, der seinen greisen Vater heimlich mitgenommen hat, erhält von diesem einen Rat, den er Alexander übermittelt. Man solle eine Stute wählen, die zum ersten Male trächtig sei. Das neugeborene Fohlen solle man vor den Augen der Mutter enthaupten und daselbst liegen lassen. Auf dem Rückweg würde dann die Stute, vom Mutterinstinkt getrieben, die Stelle, an der ihr Junges getötet wurde, rasch wieder finden. Der König tut dies also. Sie gelangen in ein Steinfeld und eine unsichtbare Stimme ruft: „Wer Steine trägt von hier, den wird die Reue erfassen, doch stärker noch bereits, wer gänzlich sie gelassen. ${ }^{\text {“855 }}$ Nachdem sie aus der Dunkelheit heraus gelang sind, sehen sie, dass die mitgenommenen Steine, Edelsteine sind. Diejenigen, die Steine genommen haben, reuen sich,

\footnotetext{
${ }^{854}$ Neẓāmi, Šaraf-nāme, S. 1145.

${ }^{855}$ Ebd. S. 1143-1154.
} 
dass sie nicht mehr genommen haben und diejenigen, die die Steine nicht genommen haben, reuen sich, warum sie nichts genommen haben.

Im $R H$ gibt es zwei Versionen von Hamzes Abenteuer im Land der Finsternis. Die erste Version von Hamzes Reise ins Land der Finsternis ist ähnlich wie die Geschichte von Alexanders Abenteuer im Buch ک̌araf-nāme.

Im $R H$ verfolgt Hamze Zomorrod in die Finsternis. Nachdem Hamze fünf Stationen der Finsternis durchlaufen hat, sieht er zwei Wege. Der Führer erklärt ihm, das der erste Weg in einer Wüste endet undder zweite nach Ḥaṭab 'l-Ğebāl führt, der größten Stadt im Land der Finsternis. Der König dort soll Qonud heißen. Hamze sendet einen Brief an Qonud und verlangt von ihm, sich zum Islam bekehren zu lassen. Zudem solle er ihm Zomorrod und Zebarğad geben. Qonud versammelt die Vornehmen seiner Stadt, um sich mit ihnen zu beraten und entscheidet sich schließlich für den Islam. Er lädt Ḥamze und seine Männer in seine Stadt ein. Hamze fragt ihn: „Wie konnte Eskandar das Land der Finsternis betreten? Qonud sagt: „Mit Hilfe der Stuten, welche Fohlen haben.“ Ḥamze befiehlt seinen Männern eine Stute zu finden, welche ein Fohlen hat. So gerüstet können sie die Finsternis betreten. ${ }^{856}$ In der Finsternis sind Hamze und seine Soldaten elend und verwirrt. Hamze betet. In seinem Traum sieht er den Propheten Salomon. Er gibt Ḥamze einen Juwel, der im Dunkeln Licht von sich gibt. So können Ḥamze und seine Soldaten in der Finsternis etwas sehen. Mit Hilfe dieses Juwels dringen sie in die Finsternis ein (5/884-910). Nach einer Weile hören sie eine Stimme in der Dunkelheit die sagt: „Wer von diesen Steinen nimmt, empfindet Reue, und wer sie liegen lässt, empfindet ebenfalls Reue.“ Manche der Helden nehmen Steine mit,manche lassen es sein. ${ }^{857}$ Als sie wieder ins Licht kommen, wo die anderen Soldaten sind, erkennen sie die Steine als Edelsteine. ${ }^{858}$ Da empfinden sowohl diejenigen Reue, die Steine genommen haben, als auch jene, die keine genommen haben.

Beim Vergleich dieser beiden Darstellungen fällt auf, dass die Verfasser des $R H$ ihre Version von Neẓāmi übernommen haben.

In einer zweiten Version der Geschichte im $R H$ lesen wir, dass Zomorrod zu seinem Bruder Zebarğad in das Land Finsternis zieht (5/740). Ḥamze verfolgt ihn auch dorthin, erlebt in einer vollkommen anderen Landschaft ein völlig anderes Abenteuer (5/780).

Die Autoren des $R H$ haben die Reisewege ihres Helden von der Wirklichkeit zum wunderbaren Reich des Abenteuers beschrieben, ohne der Glaubensbereitschaft ihrer Zuhörer allzu viel zuzumuten. Sie bemühen sich, den Übergang von der Alltagswelt der Wirklichkeit,

\footnotetext{
${ }^{856}$ Van Thiel, Helmut: Alexander der Große, in: EM, Bd. 1, Göttingen 1977, Sp. 272-281, hier Sp. 277.

${ }^{857}$ Nezāmi, Šaraf-nāme, S. 1151-1152; Ferdousi, Bd. 1, S. 1156-1157.
} 
zur unbekannten Wunderwelt glaubhaft darzustellen. Manche dieser Länder werden auch von überlieferten geographischen Kenntnissen der Antike bestätigt, die jedoch eine scharfe Trennungslinie zwischen Ost und West zu verwischen weiß. Literarisch gesehen heißt das, dass der Erzähler hier eine Übergangszone beschreibt, die gerade weil sie seinen Zuhörern halb vertraut und halb unbekannt ist, die Reise von der abendländischen Wirklichkeit zur östlichen Wunderwelt stufenweise, in kleinen Etappen und damit nachvollziehbar und glaubwürdiger, nahebringt. Die Zuhörer werden mit der Möglichkeit konfrontiert, dass die Welt der zeitgenössischen Wirklichkeit sich bei jeder Wendung auf unvorhergesehene Weise in den wunderbaren Bereich des Abenteuers und des Idealrittertums verwandeln könnte.

\section{Ğābalqā-ye Mašreq (das Weltenende im Osten)}

Nach der muslimischen Mythologie symbolisierte Ğābalqāà-ye Mašreq eine Stadt an der östlichen Grenze des Menschenlandes. Gegenüber Ǧābalqā lag Ğābalsā, eine Stadt an der westlichen Grenze des Menschenlandes. Diese beiden Städte lagen am Rand des aufgehängten Meeres (Daryā-ye moḥiț), das die Erde umfasste. ${ }^{859}$ Aṭ-Ṭabari schreibt: „Gott erschuf zwei Städte. Eine im Osten und die andere im Westen. Die Einwohner der ersten Stadt, welche im Osten Ǧābalq lag, sind die Reste des Gläubigen Volkes der 'ĀAd und die Einwohner der zweiten Stadt, welche im Westen Ğābalsā/Ğābarsa lag, sind die Reste der Gläubigen des Volkes Ṭamud, die an den Propheten Șālẹ̣ glaubten.“ ${ }^{860}$

Es gab verschiedene Auffassungen hinsichtlich der Ausdehnung und der Grenzen der Welt. Herodot meinte, dass Indien die östliche und Griechenland die westliche Grenze der Welt sei. Der griechische Geograph Strabon meinte, dass Indien die östliche Grenze der Welt markiere und Spanien die Welt nach Westen hinbegrenze. ${ }^{861}$ Zudem reichten ihre Kolonien in Italien und Nordafrika bis zum Ğabal Ṭāriq („Säulen des Herakles“). ${ }^{862}$

Alexander eroberte der Legende nach die ganze Welt. Als er Indien erreichte ließ Alexander seine Soldaten wissen, dass er nun das östliche Ende der Welt erreicht habe. Er beschrieb es so, dass sie jetzt in der Nähe des Ozeans seien, wo die Sonne aufgehe. ${ }^{863}$ Damit meinte er, dass dieser Ozean das Ende der Welt sei. Die gleiche „Denkweise hatten auch die

\footnotetext{
${ }^{858}$ Van Thiel, Sp. 277. (Motiv. Die Steine aus dem Land der Finsternis erweisen sich als Gold und Perlen. F. 166. 0. 1).

${ }^{859}$ Die muslimischen Geographen meinten, dass ein Ozean die Erde wie ein Gürtel umfasst halte. Der indische Ozean und Daryā-ye Maġreb (das westliche Meer) seien zwei Seiten (Weste und Ost) dieses Daryā-ye Moḥiṭ [aufgehängten Meeres]. Siehe: Șafavi, Seyyed Ḥasan: Eskandar va adabiyät-e Irān va šahsiyyat-e mazhabi-ye Eskandar, Teherān 1364/1985, S. 326.

${ }^{860}$ at-Ṭabarī, Abū Ğaffar Moḥammad b. Ğarīr: Tãrīh ar-rusul wa-'I-mulūk, Bd. 1, hrsg. von Abū al-Faḍl Ibrāhīm Moḥammad, Miṣr 1960, S. 69. Yāqūt, Bd. 2, S. 90-91.

${ }^{861}$ Zitiert nach: Șafavi, S. 326.

${ }^{862}$ Ebd.
} 
muslimischen Geographen in der islamischen Zeit. Ḥamze b. Ḥasan Eṣfahāni meinte, dass Afranğe an der westlichen Grenze der Welt läge.“684

Ḥamze als Nachahmer Alexander des Großen richtet sich natürlich auch nach diesen geographischen Sichtweisen. Bei dem Land Ğābalqāa, das ein Fantasieland ist, kann man feststellen, dass Herrscherbezeichnung, Königsname, Regierungsform usw. sich an persischen Vorbildern orientieren. Wir lesen im $R H$ über Zomorrod, derauf seiner Flucht vor Hamze bei Ğamšid Šāh-e ğābalqāi Zuflucht sucht. Der König von Ǧābalqā geht Zomorrod entgegen und sein Kundschafter Balāšur richtet großen Schaden in Ḥamzes Heer an und tötet seine Kundschafter (5/1015). Sein Feldherr Qomhur (Ḥamzes eigener Sohn) kämpft gegen Ḥamzes Helden (5/1019). Schließlich besiegt Ḥamze den König und die Einwohner des Landes bekehren sich zum Islam.

\section{Qāf}

Qāf ist in der islamischen Literatur ein mythischer Berg bzw. ein Gebirge und lag am Ende der Welt. Yāqūt schreibt: „Dort geht die Sonne unter und von dort auch wieder auf.“،65

Nach Karimān gilt das Gebirge Qāf, nach einer weit verbreiteten Meinung, als der Stammberg aller Berge der Welt. ${ }^{866}$ Bei den Iranern war Alborz ursprünglich das mythische Gebirge am Ende der Welt. ${ }^{867}$

Nach den islamischen Kosmographen nennt man das Alborz Gebirge Qāf. Maqqdisi schreibt: „Gott befahl dem Ğamšid, dass er zum Berg Alborz geht und er war Qāf.“868

Nach altem Volksglauben umschloss der Berg Qāf den weltumspannenden Ozean, der wiederum die Erde, die zu der Zeit als flache Scheibe betrachtet wurde, einschloss. Über Qāf schreibt Streck:

„Dieses mythische Gebirge bildet die Grenzscheide zwischen der sichtbaren und unsichtbaren Welt. Was dahinter liegt, weiß niemand.“869

Im Buch Manteq at-Tẹr schilderte 'Ațtāar die höchst beschwerliche Wanderfahrt des Ṣufi durch die sieben Stationen in Form einer Allegorie, welche die Seele bis zum völligen

\footnotetext{
${ }^{863}$ Pirniā, Mošir ad-Doule Ḥasan: Tãrih̆-e Irān-e bāstān, Bd. 1, Teherān 1311-1313/1932-1934, S. 93.

${ }^{864}$ Zitiert nach: Șafavi, S. 327.

${ }^{865}$ Yāqūt, Bd. 4, S. 291.

${ }^{866}$ Karimān, Họein: Pažūheši dar Šāh-nāme, Teherān 1375/1997, S. 104.

${ }^{867}$ Ebd. S. 126.

868 al-Maqdisī; Abū Zeid Aḥmed b. Sahl al-Balhuĩ: Kitāb al-bad' wa-at-Tawārīḥ, Teil 3, hrsg. von Clément Huart 1903, S. 140.

${ }^{869}$ Streck, Maximilian: Kāâf, in: EI, Bd. II, Leiden/Leipzig 1927, S. 658-660.
} 
Aufgehen in Gott zu durchlaufen hatte. Es war die Reise der Vögel durch die sieben Täler hin zum Berge Qāf, dem Thronsitz ihres überaus weisen Königs Simorg. ${ }^{870}$

In den iranischen Märchen und Erzählungen ist Qāf ein Ort, indem sich die Dämonen und Feen aufhalten. ${ }^{871}$ Alexander wandert ebenfalls in der Dunkelheit, die aber für ihn voller Hindernisse und Gefahren ist, bis er endlich an den Weltberg Qāf gelangt, den ein Engel in seiner Hand hält.

Qāf ist ein großer Kampfplatz und die Dämonen erheben Ansprüche darauf. Sie wollen die Herrschaft über Qāf für sich sichern. Asmā’ führt mehrere Auseinandersetzungen gegen die Dämonen. Um diese zu besiegen, braucht sie menschliche Hilfe. Hamze bleibt 18 Jahre im Qāf, besiegt alle Dämonen und bringt Sicherheit ins Königsreich. Die Beschreibung von Qāf orientiert sich an den gesellschaftlichen Vorbildern der Menschen.

Iram

Die Stadt Iram (pers. Eram) taucht in vielen literarischen Werken des iranischen Mittelalters in unterschiedlichem Kontext und unterschiedlicher Bedeutung auf. Iram gelangte in der islamischen Literatur zu großer Berühmtheit. Die mit der Säule im Koran erwähnte Ruinenstadt $^{872}$ wurde von den Muslimen „Iram“ (pers. Eram) genannt. Dieser legendäre Garten wurde von dem südarabischen König Šaddād b. 'Ad als Nachahmung des Paradieses gebaut und später unter Sand begraben. ${ }^{873}$ Iram war einerseits Symbol der Vergänglichkeit irdischer Macht, andererseits, und so auch hier, Sinnbild eines Ortes außerhalb von Raum und Zeit.

Iram, das irdische Paradies, galt als Garten und Wohnstätte der Dämonen. ${ }^{874} \mathrm{Im}$ Tausendundeine Nacht in der „Geschichte von Saif al-Moluk und der Prinzessin Badic alĞamāl steht, dass Badi` al-Ğamāl, die Tochter des Šammāh b. Šaruh [...] in der Stadt Bābel wohnte und im Garten Erams weilte. ${ }^{875}$

Im $R H$ befindet sich diese Stadt im Herzen des Gebirge Qāf. Dort finden sich viele Königreiche. Golestān-e Eram im Gebirge Qāf ist z.B. die Wohnstätte von Asmā̄ und die Hauptstadt des Feenkönigs (1/140). Im $R H$ ist Eram von Feen bewohnt und sie ist ein Ort des Vergnügungs (3/368). Diese Stadt ist nach menschlichem Vorbild erbaut, mit vielen Palästen

\footnotetext{
${ }^{870}$ 'Ațțār, Manteq at-Tẹr, S. 40.

${ }^{871}$ Alborz gilt wohl im iranischen Volksglauben als Sitz von Geistern und Dämonen. „Le Demavend contient la caverne où résidait le Démaon blanc, tué par Rustam; certains croient que le tyran Zahāk siège plus haut encore entouré de magiciens et de sorciers.” Siehe: Massé, Henri: Croyances et coutumes persanes: suivies de contes et chansons populaires, Bd. 2, Paris 1938, S. 414.

${ }^{872}$ Koran, Sure. 86,6.

${ }^{873}$ Koran, Sure 89,6-8; vgl. Wensinck, Arent Jan: Iram, in: EI, Bd. II, Leipzig/Leiden 1927, S. 554-555.

${ }^{874}$ Watt, William Montgomery: Iram, in: $E I^{2}$, Bd. III, Leiden/London 1971, S. 1270.
} 
und Märkten. Die Dämonen sind Asmā's Feinde und versuchen diese Stadt für sich zu erobern. Asmā̄, die Königin der Stadt verteidigt sie aber mit allen Mitteln. Da sie die Dämonen nicht allein besiegen kann, benötigt sie die Hilfe der Menschen. Die Stadt versinnbildlicht das Wunschbild der Menschen von einer Stadt, in der sie sorgenfrei und in Sicherheit leben können.

Quelle der Sonne

Im Koran wird die Geschichte des Zweihörnigen (Alexander) dem Propheten geoffenbart. Alexander erscheint darin als frommer Diener Gottes, dem die Macht auf der Erde gegeben war. Er gelangt bis zum äußersten Westen der Welt, wo die Sonne "in einer verschlammten Quelle untergeht“, und erlangt die Herrschaft über das dort lebende Volk. Dann schlägt der Zweihörnige den Weg zum äußersten Osten ein und gelangt an den Ort, wo die Sonne aufgeht. ${ }^{876}$

Im Šăh-nāme wendet sich Alexander, nachdem er die Amazonen verlassen hat, mit seinem Heer nach Westen, wo er eine gewaltige Stadt findet, die von kriegerischen Menschen bewohnt ist. Als er sich bei den Einwohnern nach den Merkwürdigkeiten ihres Ortes erkundigt, teilt ihm ein Greis mit, dass es hinter der Stadt ein Wasserbecken gibt, in dem die Sonne verschwindet. Dahinter läge die Finsternis, über die er unzählige Berichte vernommen habe. Doch habe ihm ein weiser und gottesfürchtiger Mann der mit Vernunft und Macht gesegnet sei, mitgeteilt, dass sich in dieser Finsternis eine Quelle befinde, die er als „Lebenswasser” bezeichnet habe. Diese Quelle käme aus dem Paradies und wenn man den Köper darin bade, dann verschwänden die Sünden. ${ }^{877}$ Friedlaender führt an: „Hinter Andalus erreicht Șacb das Weltmeer und schifft sich mit seinem Heere ein. Nach einer langen Seefahrt gelangen sie an die Quelle der Sonne, in der die letztere, den Worten des Korans gemäß, tagtäglich untergeht. Dahinter finden sie Inseln und hinter diesen das so genannte Sandtal, welches gleich mächtigen Sandbergen dahinströmt, aber am Sabbath ruht."878

Im $R H$ wird die Quelle der Sonne Kure-ye äftāb (Feuerplatz der Sonne) genannt. Afrug்-e Div teilt Irağ mit, dass es in der Nähe vom Feenland in Richtung Osten eine Quelle gebe. Aus dieser Quelle komme die Sonne heraus. Bei Sonnenaufgang ertöne eine schreckliche Stimme aus dieser Quelle. Jeder, der diese Stimme hört, werde taub. Irăg, der sehr neugierig ist,

\footnotetext{
${ }^{875}$ Vgl. Littmann, Bd. V, S. 249.

${ }^{876}$ Safavi, S. 232.

${ }^{877}$ Ferdousi, Bd. 1, S. 1154.

${ }^{878}$ Friedlaender, Israel: Die Chadirlegende und der Alexanderroman. Eine sagengeschichtliche und literahistorische Untersuchung, Leipzig/Berlin 1913, S. 197f.
} 
wünscht dennoch, diese Quelle zu sehen. Afruġ bringt ihn zu Kure-ye āftāb. Als Irağ dort ankommt, hört er eine laute Stimme und wird bewusstlos (5/745-746).

\subsubsection{Völker}

Das $R H$ ist geprägt durch eine Vielzahl realer und erdachter Völker, die im Folgetext dargestellt werden sollen, wobei sich die Darstellung auf eine Auswahl von Völkern und ihren beschriebenen Eigenschaften beschränkt.

\subsection{Reale Völker}

Um die Geschichte des eigenen Volkes kennen zu lernen, die Erinnerungen daran wachzuhalten und zu pflegen, haben die Autoren des $R H$ unterschiedliche reale Staaten und Völker dargestellt. Die Autoren stellen auf diese Art und Weise die lebendige Vielfalt der historisch gewachsenen Gemeinschaft der Iraner dar. Sie sollen sich ihrer eigenen Identität bewusst werden.

Die Vaterlandsliebe, die in europäischen Sprachen als Patriotismus bezeichnet wird, bedeutet hier eine besondere Wertschätzung der Traditionen, der kulturellen und historischen Werte und Leistungen des eigenen Volkes. In diesem Sinn versuchen die Autoren des $R H$ patriotische Gefühle mit dem eigenen Volk und seinem Land zu wecken, und die Iraner über andere zu stellen und damit andere Völker implizit abzuwerten. Das Buch stärkt das Zusammengehörigkeitsgefühl der Iraner und der Verbundenheit mit der gemeinsamen Religion und der eigenen Kultur, anderen nicht muslimischen Ländern gegenüber. Dadurch entsteht ein übersteigertes Bewusstsein vom Wert und der Bedeutung der eigenen Nation. Diese Bindung kann man auch als Nationalgefühl oder Nationalstolz bezeichnen. Im positiven Sinne kann diese Form der Vaterlandsliebe als Bekenntnis $\mathrm{zu}$ den Grundlagen der Gesellschaft und zur Verteidigung der Grund- und Menschenrechte verstanden werden.

Im $R H$ sind aber auch negative Ausprägungen eines Patriotismus beschrieben, die zu nationaler Arroganz, Chauvinismus und einem übersteigerten Nationalismus führen können. In diesem Sinne führen derartige negative Einstellungen unweigerlich zu Konflikten. Es wird der Versuch unternommen, die Vorherrschaft militärischer Wertvorstellungen als politische und gesellschaftliche Ziele zu definieren, sie durch Betonung des Rechts des Stärkeren und der Vorstellung, Kriege seien notwendig oder unvermeidbar, die Menschen zu beeinflussen.

Der Zwang zur allgemeinen Anwendung von Gewalt ist im $R H$ von den Helden als Mittel zum Zweck verwendet worden. Krieg ist dort das einzige Mittel und soll von friedlichen Mitteln ablenken. Im folgenden Abschnitt wird zuerst das Volk der Türken beschrieben, die über Tausende von Jahren in einem engen politischen Verhältnis zu den Iranern standen. 
Türken

Ein anderes Volk, das in der Geschichte des Irans eine wichtige Rolle spielte, waren die Türken. Der Ursprung der heutigen Turkvölker ist bis heute unbekannt. Geschichtlich greifbar wurden sie ab dem 6. Jahrhundert v. Chr. So wurden u.a. die „Türk“ mit den Xiongnu in Verbindung gebracht, deren Vasallen und Waffenschmiede sie waren. ${ }^{879}$ Vielfach wurden die Xiongnu als die Vorfahren der heutigen Turkvölker und der Mongolen angesehen. Doch diese These gilt als umstritten und konnte nicht eindeutig belegt werden. ${ }^{880}$

Schon in vorislamischer Zeit waren die Türken eine große Gefahr für die Iraner. ${ }^{881}$ Ihr Name war verbunden mit Zerstörung und Gewalt. ${ }^{882}$ Der Iran wurde über 1000 Jahre lang durch verschiedene Turkdynastien regiert.

Im $R H$ wird Ṭus, ein türkischer Feldherr von Ḥamze, zum Stadthalter auserwählt. Doch dieser rebelliert gegen Ḥamze und zerstört die Moscheen (3/462). Dann ermutigt Ṭus die Könige von Samarqand und China, gegen Ḥamze zu rebellieren. Es gelingt ihm nach vielen Kämpfen, ganz Torkestān zu beherrschen. Malek Qāsem bekämpft Ṭus und besiegt ihn (3/473). Später kämpfen Dārāb und Mālek Aštar gegen die Türken (5/890-900).

\section{Usbeken}

Die Bezeichung „Usbek“ leitet sich von Usbek Hुān ab, einem Herrscher der Goldenen Horde. Die Usbeken wurden zwischen dem 15. und 16. Jahrhundert als politische Macht sichtbar, als die von mongolischen Khanengeführten Stämme aus den nördlichen Steppengebieten in das bereits turkisierte Transoxanien einfielen. Sie stellten eine beträchtliche Bedrohung für alle Nachbarvölker dar. Unter Moḥammad Šeibāni Hูān fielen die usbekischen Stämme um 1500 in Samarkand, Buchara, Taschkent und Urgentsch (dem heutigen Köneürgenç) ein. Moḥammad Šeibāni gründete die nach ihm benannte Scheibanidendynastie.

Nach dem Tod des Ḥosein Baiqarā (1470-1506), dessen Residenz Harāt ein glänzendes Zentrum der islamischen Kultur war, brachen zwischen seinen Söhnen gewaltsame familiäre Streitigkeiten um die Nachfolge im Reich der Timuriden aus. Moḥammad Šeibāni, der

\footnotetext{
${ }^{879}$ Zieme, Peter: Die Alttürkischen Reiche in der Mongolei, in: Dschingis Khan und seine Erben: das Weltreich der Mongolen; [erscheintanläßlich der Ausstellung Dschingis Khan und seine Erben. Das Weltreich der Mongolen. 16. Juni bis 25. September 2005, Kunst- und Ausstellungshalle der Bundesrepublik Deutschland, Bonn, 26. Oktober 2005 bis 29. Januar 2006, Staatliches Museum für Völkerkunde München] / [Hrsg. Kunstund Ausstellungshalle der Bundesrepublik Deutschland GmbH. Koordination JuttaFrings], S. 64.

${ }^{880}$ Kaiser, Kalus: Kleine Geschichte der Türkei, Stutgartt 2003, S. 20.

${ }^{881}$ Widengren, Iranische Geisteswelt, S. 214.

${ }^{882}$ Rāmpuri, turk-tāzi, in: Ǵìās al-loğät, S. 203.
} 
König der Usbeken, nutzte diese Situation um das Gebiet der Timuriden durch mehrere Invasionen zu zerstören und schließlich zu erobern. ${ }^{883}$

Das Konzept des $R H$ steht in einem engen Zusammenhang mit den politischen Umständen des Irans im 13. bis 16. Jahrhundert. Unter mongolischer Herrschaft wurde Religionsfreiheit nur insoweit zugelassen, wie diese den Machtanspruch nicht in Frage stellten. Dies nutzten die Schiiten, weil sie die damals noch sunnitische Mehrheit der iranischen Bevölkerung für sich gewinnen wollten. Šāh Esmācil gründete im Jahr 1502 den ersten schiitischen Staat. Um die Legitimität einer iranisch-schiitischen Dynastie zu sichern, kämpfte er mit den Usbeken und den Osmanen.

Mit dieser Reichsgründung durch Šāh Esmā̄il änderten sich die Machtverhältnisse in Asien entscheidend. Durch den Sieg über die Usbeken konnte das iranisch-schiitische Reich zu einer starken Militärmacht aufsteigen, dessen Kennzeichen vor allem ein gesteigertes Nationalbewusstsein war, das sich im Laufe der Zeit, besonders den Osmanen und Usbeken gegenüber, äußerte. Zur Zeit der Gründung des iransisch-schiitischen Staates, welche die Reichseinheit herbeiführen sollte, war die Angst vor den Übergriffen der Nachbarstaaten auf den Iran sehr groß. Ein befürchteter gemeinsamer Angriff von Osmanen und Usbeken auf den Iran wäre Anlass genug gewesen, die Geschichte umzuschreiben. Tatsächlich begannen die Usbeken im 15. Jahrhundert von Zentralasien aus den Nordosten des Irans zu überfallen. Sie verwüsteten, brannten nieder und entvölkerten ganze Gebiete. Die Iraner sahen in ihnen auch eine ideologische Gefahr. Die Usbeken führten mehrere Angriffe durch, von denen der erste im Jahr 1510 sehr wichtig war. In diesem Krieg kam der Führer der Usbeken, Moḥammad Šeibāni, ums Leben. ${ }^{884}$

Unter Šāh Ṭahmāsb führten die Usbeken fünf Angriffe durch. ${ }^{885}$ Die Ṣafaviden erlitten stets schwere Niederlagen. ${ }^{886}$ Viele Iraner träumten von einer Eroberung usbekischer Regionen und der Ausdehnung der Schia. Aber die Umstände zwangen die schiitische Regierung im Iran in die Defensive.

\footnotetext{
„Der Schah befand sich auf dem Weg vom Jagdplatz in die Residenzstadt Qazwīn und zum kaiserlichen Palast, als von Murtażā Qulī Hāan, dem Statthalter von Marw, folgende Nachricht an den Hof gelangte: Die Kasachen und Kalmücken hätten sich zusammen getan, seien nach Taškand, das in der Nähe Samarqands liegt, gezogen und belagerten es. Sie raubten, plünderten und
}

\footnotetext{
${ }^{883}$ Roemer, S. 150-154.

${ }^{884}$ Rumlu, Hasan: Aḥsan at-Tawārih, hrsg. von 'Abd al-Ḥosein Navā’i, Teherān 1357/1978, S. 161; Roemer, S. 266.

${ }^{885}$ Roemer, S. 277.

${ }^{886}$ Eskandar-Beg Torkamān: Tarīh
} 
machten viele Gefangene und reiche Beute. Doch nur wenige seien bis in das Gebiet von Buhārā gelangt.، “887

Der ideologisch-politische Konflikt mit den Usbeken verbreitete sich auch in der Unterhaltungsliteratur. Diese beeinflusste die Masse der einfachen Menschen nach wie vor. Das $R H$ stellt auch eine Art „Nationalerziehung“ dar, um die iranischen Bürger zu Loyalität und Patriotismus zu verpflichten. Auch hier wird der sunnitische Islam mit den Usbeken bzw.Türken identifiziert. Unter türkischer Fremdherrschaft bildet sich ein extremer Hass gegenüber den Türken heraus. Dies führt dazu, dass sich in den Befreiungskriegen gegen die Usbeken und Türken ein verstärktes Nationalgefühl bildet.

Das $R H$ nimmt hier Bezug auf die historische Situation seiner Entstehungszeit, dem Ende der Timuriden und der Anfangszeit der Șafaviden. Die Usbeken werden hier als Gegner Ḥamzes und der Muslime dargestellt. Hier können wir Parallelen einer Feindschaft zwischen den Usbeken und den Șafaviden vermuten. Die ergebnislose Belagerung der Städte, die der Roman erwähnt, kann man schon an sich leicht mit der einjährigen Belagerung des nordöstlichen Teils des Irans durch die Usbeken in der Regierungszeit Šāh Esmā’ils und Šāh Ṭahmāsbs vergleichen. ${ }^{888}$ Die häufig vorkommenden Kriege mit den Usbeken und Türken und der Sieg der Iraner nähren den Nationalstolz der Iraner und stärken damit auch die schiitische Glaubensrichtung.

Ḥamze selbst unternimmt mehrere Angriffe auf Usbeken und Türken (3/369-370). Seine Kinder setzen diese in größerem Maßstab fort. Die so erfolgreichen Expeditionen Ḥamzes erinnern an die ersten militärischen Unternehmungen der Ṣafaviden.

Anoširvān flieht zu Șalșāl, dem König der Usbeken, der den Perserkönig unterstützt. 'Alam Šāh kämpft gegen die Türken und Usbeken und erobert Samarqand (3/390). Später kann Ṣalṣāls Tochter Zolfeyn mit Hilfe der Zauberei 'Alam Šāh für sich gewinnen. 'Alam Šāh kämpft jetzt gegen seinen Vater. Der Kampf gegen seinen eigenen Sohn fällt Ḥamze sehr schwer. Moqbel kann Zolfeyn töten und so wird die Zauberei vernichtet und infolgedessen erleiden die Usbeken eine schwere Niederlage und Șalṣāl muss fliehen (3/446).

Im $R H$ sind die Usbeken keine Muslime und sie werden als nādān (Unwissende; 3/484) bezeichnet. Weitere Angaben zeigen uns, dass die Usbeken meist nicht im offenen Kampf, sondern durch Zauberei, List und der Entführung der Helden siegen (5/888-890). Die usbekischen Angriffe haben immer den altgewohnten Charakter von Raub und Plünderungszügen (6/1056-1059).

\footnotetext{
${ }^{887}$ Ȟ̃āğagi-Eṣfahāni, Moḥammad-Ma'ṣum: Hulāṣat as-Siyar. Der Iran unter Schah Șafī (1629-1642). Nach
} der Chronik des Moḥammad-Ma'ṣum b. Ȟāăğagi-Eṣfahāni, hrsg. von Gerhard Rettelbach, München 1978, 
Zangi

Eine andere Bevölkerungsgruppe, die im $R H$ vorkommt, sind die Afrikaner. Der Begriff „Schwarz" in der persischen Sprache entspricht etymologisch dem persischen Wort siyāh (Schwarzer), das in der persischen Literatur ohne jede Einschränkung jeden Farbigen (Schwarzafrikaner) bezeichnen kann. In früherer Zeit findet der Begriff zangi als der gebräuchlichste Ausdruck für „Schwarz“ Verwendung. Das Auftreten dieser Bezeichnung in so früher Zeit gerade auf dem Gebiet der persischen Literatur bekräftigt die Annahme, dass der Name seinen Ursprung in der vorislamischen Literatur hat. Das Wort zäng, das wiederum auf einen afrikanischen Ortsnamen zurückgeht, der schon bei Ptolemäus als „Zingis“ auftritt, legt dies auch nahe. ${ }^{89}$ Unter bilād az-Zanğ verstehen die arabischen Geographen im Allgemeinen die ostafrikanische Küste südlich von Kap Guardafui; die südliche Begrenzung schwankt zwischen der Insel Pemba und Solfāla. ${ }^{890}$

Im $R H$ sind die dunkelhäutigen Afrikaner wegen ihrer Räubereien und Plünderungen berüchtigt. Die Zangis wurden als Menschenfresser und Wegelagerer dargestellt (2/222).

Betrachten wir eine beliebige aus dem $R H$ herausgegriffene Passage: Mehrās-e Zangi ist das Oberhaupt der Zangis und residiert in einer Festung. Von dort informiert er sich über die Geschäftsleute und ihre Besitztümer. Er nimmt sie fest, bringt ihre Güter in seinen Besitz und frisst zum Schluss ihr Fleisch. Ḥamze kämpft mit ihm und tötet ihn (2/222). Später treten Zangis in den Dienst Hamzes und unterstützen ihn im Kampf gegen die Sonnenanbeter $(5 / 750)$.

\section{Menschenfresser}

Das Menschen Menschenfleisch essen wird in der persischen Sprache als ādam- $\boldsymbol{h}$ ̌ã $\boldsymbol{r}$ (Menschenfresser) bezeichnet. Dieser Vorgang hat eine reale Entsprechung in der iranischen Geschichte, der unfassbar ist. So konnte der jenige, der ein Gebot des Königs missachtet hatte, damit bestraft werden, dass er von einem Menschen verspeist wurde. Die grausamste Art dieser Bestrafung war der Verzehr von Familienangehörigen. Hinweise auf Kannibalismus gab es in der vorislamischen Geschichte des Irans. Herodot berichtet, dass der Maderkönig Astyages seinem in Ungnade gefallenen Ratgeber Harpagos dessen Sohn zu verspeisen vorsetzte ohne ihn das wissen zu lassen. Erst nach Beendigung des Mahls klärte er

S. 139.

\footnotetext{
${ }^{888}$ Eskandar-Beg Torkmān, Bd. 1, S. 40-61.

${ }^{889}$ Grenville, G. S. P. Freeman: Al-zandj, in: $E I^{2}$, Vol. XI, Leiden 2002, S. 444-445.; Moritz, Bernhard: Arabien, Studien zur physikalischen und historischen Geographie des Landes, Hannover 1923, S. 128.

${ }^{890}$ Storbeck, Friedrich: Die Berichte der arabischen Geographen des Mittelalters über Ostafrika, in: $\mathrm{MSOS} \mathrm{XVII}_{2}$, 1914, S. 102-113.
} 
ihn auf. ${ }^{891}$ In der Ṣafavidenzeit wurden die Feinde der șafavidischen Könige aus Rache verzehrt. $^{892}$

Kannibalismus wird auch im $R H$ geschildert. Bāḡḡāšb und Aġdāš-e kešide-ru, Könige von Menschenfressern, nehmen den Prinz Hormoz fest und wollen ihn und seine Soldaten verzehren. Prinz Nur ad-Dahr kämpft gegen sie, besiegt sie und befreit den Prinzen Hormoz. Die Menschenfresser lassen sich zum Islam bekehren. Sie werden treue Gefolgsleute von Nur ad-Dahr und helfen ihm bei seinen Kämpfen (5/754-755).

\section{Das Volk ‘̄̄dd}

Ein sehr berühmtes Volk in der islamischen Tradition ist das Volk 'Ād. ' $\mathbf{A} \mathbf{d}$ ist ein historisch nichtidentifizierter altarabischer Stamm, der im Koran und in der vorislamischen Dichtung erwähnt wird. Sie sind ein mythisches Volk auf der arabischen Halbinsel, das laut Koran in vorgeschichtlicher Zeit von Gott ausgelöscht worden ist. Die 'ĀAd werden im Koran mit der sagenhaften „Säulenstadt Iram“ in Zusammenhang gebracht. ${ }^{893}$ Im Laufe der Zeit werden um diese islamische Überlieferung rund um die Säulenstadt und die Monumentalität ihrer Ruinen immer mehr Sagen gewoben. So erklärt sich der Vergleich eines übermächtigen, riesenhaften Menschen mit dem Volk 'Ad.

Nach Moğmal at-Tawārih wa al-qeșaṣ waren alle 7 Söhne des Eram b. Sām von großer Gestalt und Kraft und somit Riesen. 'Ad, der Älteste, zog nach Jemen. Alle Riesen wie '⿳亠二冖̆g b. 'Anāq und Mālūt stammen aus dieser Linie. In späterer Zeit hat der Name 'Ad schlechthin die Bedeutung „Riese“ angenommen. ${ }^{894}$

Im $R H$ begegnen wir Männern, die aus diesem Volk stammen. Als Nur ad-Dahr einmal bei Ṣadrān Šāh ist, kommt unerwartet einer von Țamud b. Āds Boten. Er gibt Tamuds Brief Ṣadrān Šāh, woraufhin der König schreckliche Angst bekommt. Tamud verlangt vom König, 100.000 Menschen zu ihm zu schicken, damit er und seine Männer sie verzehren können. Nur ad-Dahr kämpft mit Tamud und besiegt ihn. Tamud wird zum Islam bekehrt und wird ein Gefolgsmann von Nur ad-Dahr (5/754-755).

\subsection{Fiktive Völker}

Nach der Auflistung der realen Völker im $R H$ werden jetzt die fiktiven Völker des $R H$ dargestellt. Hier finden sich unter vielen anderen wunderbaren Berichten auch ein Reihe von monströsen Menschen und Tieren, so etwa die Menschen mit Hundsköpfen, die Riesen oder

\footnotetext{
${ }^{891}$ Herodot: Historien, Erster Band, Buch I, S. 115.

${ }^{892}$ Falsafi, Bd. 2, S. 126.

${ }^{893}$ Koran, Sure. 89,6-8.

${ }^{894}$ Anonymus: Moğmal at-Tawārih wa-al-qeșaṣ, S. 147.
} 
solche ohne Kopf, die ihr Gesicht auf der Brust tragen, oder die merkwürdigsten Reisetiere. Die ältesten, in der Literatur bezeugten wunderbaren Wesen finden wir in den islamischen Werken der Kosmographie. Aufgrund dieser Überlieferungen im ältesten uns noch erhaltenen Schrifttum des mittelalterlichen Kulturkreises, im iranischen Epos, können Entsprechungen mit den Wesen aus dem $R H$ gefunden werden. Auch hier findet man eine Mischung aus anspruchsvollen Darlegungen der Zeit und trivialen Unterhaltungsstoffen.

\section{Davāl-pāyān}

Davāl bedeutet Haut, Leder, Peitsche, Faden. Davāl-pāa ist ein Fabelwesen, wobei der Oberkörper wie der eines Menschen ist. Seine Beine sind sehr lang und schmal sowie ohne Knochen. ${ }^{895}$ Über die davāl-pāyānn schreibt Qazwīnī (1203-1283):

„Ein Volk auf einer anderen Insel dieses Meeres. Ihre menschliche Gestalt ist
so schön, wie sie nur sein kann. Ihre Füße haben keine Knochen, und ihre
Beine sind gleichsam verdickte Flüssigkeit. Sie bewegen sich kriechend
vorwärts. Wenn sie einen Gehenden finden, rufen sie ihn herbei, dass er sich
bei ihnen niederlasse, und wenn er sich gesetzt hat, springt einer von ihnen auf
seinen Nacken und schlingt seine Beine um ihn."

Über davāl-pāyān wird in vielen literarischen Werken berichtet. Es handelt sich um eine Sage, wie wir ihr in der iranischen Volksliteratur häufig begegnen. ${ }^{897}$

In der Geschichte von Sindbād-e Bạ̣ri erreicht Sindbād während eines Schiffbruchs eine Insel. Dort trifft er auf einen alten Mann, der in der Nähe eines Flusses sitzt. Der alte Mann bittet Sindbād, ihn auf seinen Schultern auf die andere Seite des Flusses zu bringen. Sindbād tut dies aber als sie auf der anderen Seite des Flusses angekommen sind, will der alte Mann Sindbād nicht mehr loslassen. Mit einer List gelingt es Sindbād sich zu befreien, indem er den alten Mann betrunken macht. ${ }^{898}$

In der Geschichte von Salim-e Ğauharis geschieht Salim das gleiche. Auch hier kann er sich nur durch den Einsatz von Wein befreien. ${ }^{899}$ Eine ähnliche Episode kommt auch im $R H$ vor, als Hamze sich mit seiner Flotte auf dem Weg nach Indien befindet (1/70-71).

\footnotetext{
895 Bolukbāši, 'Ali: Davālak-bāzi va taḥqiqi dar vāže-ye davāl, in: Honarva Mardom, Nr. 89, Teherān 1348/1969, S. 28-46, hier S. 38.

896 al-Qazwīn̄̄, Zakarīyā b. Moḥammad: Die Wunder des Himmels und der Erde. Bearbeitung und Übertragung.von Alma Geise, hrsg. von Erdmann, Stuttgart/Wien 1986, S. 236.

${ }^{897}$ Im Eskandar-nāme lesen wir, dass die davāl-pās weißhäutig sind und scharfe Zähne wie Löwen haben. Siehe: Af̌̄ār, Eskandar-nāme, S. 95; Afšāri u. Madāyeni, Haft-laškar, Teherān 1377/1998, S. 171.

${ }^{898}$ Anonymus: Hezār-o yek šab, Bd. 2, Nacht 556.

${ }^{899}$ Littmann, Bd. IV, S. 162-168; Haag-Higuchi, Roxane: Untersuchungen zu einer Sammlung persischer Erzählungen, Berlin 1984, S. 51-52; Marzolph, Ulrich: Sindbad der Seefahrer, in: EM, Bd. 12, Göttingen 2007, Sp. 698-707.
} 


\title{
Hundsköpfige
}

Nach Qazwīn̄is Bericht wohnten die Hundsköpfigen auf einer Insel im südlichen Teil des

Indischen Ozeans. Später wurde als ihr Wohnort eine Insel im Meer von China erwähnt.

Darüber schreibt Qazwīnī:

\author{
"Ihre Köpfe sind wie die der Hunde und ihre Körper wie die der Menschen. Sie \\ ernähren sich vor allem von den Früchten dieser Insel, aber wenn sie ein \\ Lebewesen finden, essen sie es."
}

Das Volk Sag-sarān (Hundsköpfige) bzw. Gorg-sarān (Wolfsköpfige) kommt oft in den epischen Werken der Iraner sowie in den Büchern Garšāsh-nāme und Šāh-nāme vor. Die beiden Namen sind mit Māzandarān verbunden. Diese Völker sind in der Gegend um Māzandarān beheimatet. Im Garšāshb-nāme sind die Sag-sarān als sehr mutiges Volk bekannt. Ihre Gesichter sind gelb wie die der Hunde und ihre Körper wie die der Ziegen voller Haare, ihre Zähne wie die Zähne des Wildschweins und ihre Ohren wie die der Elefanten. ${ }^{901}$ Die wichtigsten Stellen im Šāh-nāme, wo die Namen Sag-sarān und Gorgsarān erwähnt werden, sind die in Sāms Feldzügen gegen die Wolfsköpfigen. ${ }^{902}$ Sām zieht auf Befehl des Königs Manūčehr nach Manzandarān und unterwirft sie. ${ }^{903}$

Im Moğmal at-Tawārih wa al-qeșaṣ bittet Mahrāğ den Feridun um Hilfe gegen die Sagsārān. Der König schickt Sām hin und dieser bringt die Angelegenheit in Ordnung. ${ }^{904}$

Moḥammad b. Maḥmūd al-Qazwīn̄̄ vermerkt, dass $\underline{Z} \mathbf{u}$ 'l-Qarnin in der Gegend von

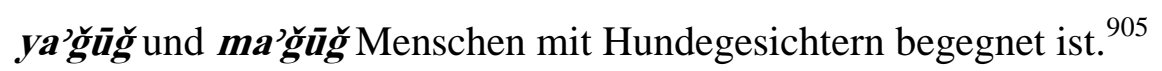

Im $R H$ sind die Hundsköpfigen nach menschlischem Vorbild, in einem eigenen Königreich organisiert. Landehur kämpft gegen Sāruk, der in Indien gegen Landehur rebelliert hat. Sāruk kann nicht gegen Landehur gewinnen, deswegen flieht er zu den Hundsköpfigen, um bei ihnen Schutz zu finden. Landehur zieht gegen die Sag-sarān und ihren König Helāl in den Kampf und besiegt ihn. (1/175-176).

\section{Kamelköpfige}

Über das Volk Šotor-sarān (Kamelköpfige) haben wir nur wenige literarische Hinweise. Auf dem Weg zum Menschenland sieht Ḥamze merkwürdige Lebewesen, die sehr kräftig sind. Ihr

\footnotetext{
${ }^{900}$ al-Qazwīn̄i, Die Wunder des Himmels und der Erde, S. 236.

${ }^{901}$ Asadi-Ṭusi, S. 174.

${ }^{902}$ Ferdousi, Bd. 1, S. 92.

${ }^{903}$ Ebd. Bd. 1, S. 92.

${ }^{904}$ Anonymus: Moğmal at-Tawārih wa al-qeșaș, S. 42.

905 al-Qazwīnī, Moḥammad b. Mạ̣mūd: Ātāir al-bilād wa ahbār al-‘abād, Bairut 1380 h/1960, S. 84; Van Thiel, Sp. 272-281.
} 
Körper ist wie der der Menschen und ihr Kopf wie der eines Kamels. Sie haben ihren eigenen König namens Qeimāsb, der Hạamze festnimmt. Nach vielerlei Verwicklungen akzeptiert Hamze die Tochter von Qeimāsb als Frau, um aus dem Gefängnis zu kommen. Danach aber ertränkt er die ihm Angetraute (1/179).

\subsubsection{Engel, Geister und Dämonen}

Geisterglaube ist tief in der Seele vieler Menschen verwurzelt und unterliegt keinem Zeitgeist. So lange die Welt besteht, gibt es ihn. Mit Geist wird ein unkörperliches, häufig mit übernatürlichen Fähigkeiten ausgestattetes Wesen bezeichnet. Gute Geister sind Beschützer der Menschen. Die sprituelle Welt, die Welt der Geister, ist im Islam im Zentrum des Glaubens. Die guten Geister wie malā'eke (arab. al-Malā'ika; Engel) erfüllen oft Aufgaben für Gott und beeinflussen das Leben der Menschen nachhaltig.

\section{Engel}

Im $R H$ existieren nach der traditionell-islamischen und iranischen Weltanschauung mehrere verschiedene übermenschlich-geistige Wesen. Dazu gehören insbesondere die ğginns (Geister), die paris (Feen), die divs (Dämonen), und die malā'eke (Engel). In welchem Verhältnis steht nun unser Text zu diesen Geistwesen? Im Leben der iranischen Bevölkerung des Mittelalters spielten die malä'eke, paris, dive und ğinns eine außerordentlich wichtige Rolle. Diesem Interesse der Zuhörer entsprechend gestalten die Autoren die Rollen und das Auftreten dieser übernatürlichen Wesen im $R H$ sehr lebendig und unterhaltsam. Zudem zeugt das Ausdenken und Einführen solcher Figuren in die Erzählung von großer Vorstellungskraft und Kreativität der Verfasser.

Der Geisterglaube ist in der islamischen Welt außerordentlich verbreitet. Die himmlischen Geister sind Engel. Die malä'eke sind die Bewohner der himmlischen Sphären. Zu diesen Engeln gehören die fünf singulären, großen Engelsgestalten ar-Rūḥ, Isrāfîl, Ǧibra’̄̄l, Mikā̄̄il und 'Izrā'̄îl. Nach der Prophetengemahlin ' $\overline{\mathbf{A}}$ 'iša sind die Engel aus Licht geschaffen. ${ }^{906}$ Über den Offenbarungsengel, Ğebrā'īl (arab. Ğibra'īll) ist innerhalb der islamischen Tradition eine große Anzahl unterschiedlicher Geschichten überliefert worden. Er wurde als șāḥib alwaḥy (der Herr der Offenbarung) charakterisiert. ${ }^{907}$ Qazwīnī führt an:

\footnotetext{
${ }^{906}$ Muslim, aṣ-Ṣahịh, 53,60, hrsg. von Moḥammad Fu'ād 'Abd al-Bāqī, Kairo 1374h/1955.

907 Koran, Sure. 2,97; Imām Faḩr ad-Din ar-Rāzi, Tafsīr al-kabīr, Bd.II, (zu Sure 2,30), Teherān 1970, S. 162, 20. Šamisā, Farhang-e talmiḥāt, S. 204; al-Qazwīnī: Die Wunder des Himmels und der Erde, S. 6768; Horam-Šāhi, Bahā ad-Din: Ğebrā'ìl, in: Dārat al-ma‘ārif-e tašayyơ Bd. 5, Teherān 1375/1996, S. 309-310.
} 
„Er ist der mit der Offenbarung betraute und der Bewahrer der Heiligkeit. Man nennt ihn auch den bevollmächtigten Geist, den heiligen Geist, den großen Vertrauten und den Pfau der Engel.“908

Er überbringt das Wort Gottes den Propheten. Er ist sehr mächtig und kann die Menschen bei Fehlverhalten bestrafen. Ferner bewirkt er Erdbeben, Finsternisse und die Vernichtung sündiger Völker: zum Beispiel das Volk Lots. ${ }^{909}$

Im Zusammenhang mit seiner Engelserscheinung wurde im hadi $\underline{t}$ und der tafsir-Literatur geschrieben, dass Ğebrā̄̄il in seiner Engelsgestalt 600 Flügel hat. Al-Kisā̄̄ führt an: „Er habe sechs mal hundert Flügel und zwei weitere, die nur beim Untergang der Städte ausgebreitet werden““. ${ }^{910}$ Er ist ganz bedeckt mit Haaren aus Safran, eine Sonne, die Erleuchtung der Offenbarung symbolisierend, steht zwischen seinen Augen und auf jedem Haar befinden sich ein Mond und Sterne. ${ }^{911}$

Im $R H$ entwirft der Erzähler ein besonderes Bild von Ǧebrā̄̄̄l. Er lebt dort als Teil der himmlischen Heerscharen, versunken zwischen Himmel und Erde. Ğebrāāīl kommt mit Soruš, einem vorislamischen Engel aus der altiranischen Religion, in Verbindung. Als Inspirationswesen begegnet uns so im $R H$ unter anderem mehrfach der aus dem Zoroastrismus in der islamischen Vorstellungswelt übernommene Botenengel Soruš. ${ }^{912}$

Als Ḥamze mit der Flotte an der Küste Indiens entlang fährt, kommen sie auf ihrer Fahrt zu einer Insel. Ḥamze macht sich auf den Weg, um zur Jagd zu reiten. Unterwegs verliert er sein Pferd und er ist deswegen sehr traurig. Plötzlich hört er Soruš Stimme. Sie sagt ihm: „Steh auf! Am Fuße des Berges gibt es einen Brunnen. Du musst die rituelle Waschung und das Gebet verrichten, damit du Ğebrā̄̄̄ll besuchen kannst. Ğebrā̄̄̄ll wird dir die Rüstung der sieben Propheten geben.“"(1/73).

Ḥamze betet und als er seinen Kopf erhebt, sieht er Ğebrā̄̄̄ll, der von seinen Schultern bis zum Himmel aus Licht ist. Ǧebrā̄̄ōl übergibt Hamze die Rüstung und gibt ihm einige Ratschläge (1/73).

Da die Engel in direktem Kontakt mit der Sphäre des Göttlichen stehen, sind sie mit dem Licht verbunden. Die Engel verbindet man mit strahlendem, aber sanftem Licht; gleiches gilt

\footnotetext{
908 al-Qazwīnī, Die Wunder des Himmels und der Erde, S. 67.

${ }^{909}$ ar-Rāzi, at- Tafsīr, Bd. III (zu Sure 2,97/98), S. 194, 22 u. 195, 10; an-Neišāburi, Abu Bakr 'Atiq: Qeṣaṣ-e qor'ān-e mă̌̆id, S. 83.

910 al-Kisā'̄, Moḥammad b. 'Adallāh: Qiṣaș al-anbiyā’', hrsg. von Isaac Eisenberg, Leiden 1922, S. 13.

${ }^{911}$ Horten, Max: Die Religiöse Gedankenwelt des Volkes im heutigen Islam, Halle 1917, S. 61; Horam-Šāhi, Ğebrā'-̄il, S. 309-310.

${ }^{912}$ In der vorislamischen Geschichte des Irans war Soruš der Wächter der Nacht und ein großer Feind der Geister und Hexen. Man bemerkt sein Erscheinen in der Nacht, wenn es hell und kalt wird. Zudem wird das Wasser angenehm, und die Pflanzen bewegen sich. Ein Hahnenschrei kündigt sein Kommen an. Sein Kommen bewegt die Tiere zur Fortpflanzung. Siehe: Biruni, S. 285-286.
} 
für die akustischen Erscheinungen, die im Zusammenhang mit göttlichen Phänomenen keine so herausragende Rolle wie der Glanz spielen, aber stets als angenehm und wohltönend erscheinen, und somit in besonderer Weise mit der göttlichen Transzendenz korrespondieren. Schließlich werden die Engel auch mit außergewöhnlichem Wohlgeruch in Verbindung gebracht. Auffällig ist, dass der Engel Ğebrā̄̄il trotz des vielen Lichts in der Gestalt eines weltlichen Herrschers erscheint. Ğebrā'̄ill fehlt somit außer dem Licht alles, was einen Engel erst zum Engel macht (z.B. die Flügel). Ğebrā̄̄il wirkt nicht wie ein religiöses Wesen. Interessant ist an dieser Episode, dass der Engel Ğebrā̄̄il Ḥamze sowohl vorislamische Königswaffen als auch Prophetenwaffen übergibt. Zudem gibt Ğebrā̄̄il dem Ḥamze sogar praktische Regierungsratschläge. So wird deutlich, dass Ḥamze von Beginn an als König betrachtet wird.

\section{Nakir und Monkar}

„Die Muslime glauben, dass gleich nach dem Begräbnis das besondere Gericht stattfindet. Man trifft am ersten Abend des Todes im Grabe den Monkar, den Abscheulichen, und Nakir, den Schrecklichen. Sie treten in abscheulicher schwarzer und blauer Gestalt auf. Ihre Augen sind wie eherne Töpfe oder wie der Blitz. Ihre Rede schallt wie Donner. Feuer fährt aus ihren Mündern hervor, wenn sie reden. Jeder hält einen eisernen Knüttel in der Hand, durch dessen Schlag er die Berge zu Staub schlägt. “913 Sie fragen den Sterbenden nach seinem Glauben und seinen Taten während seiner Lebenszeit. Daher rezitiert man, wenn ein Muslim dem Tod nahe ist, ihm das Glaubensbekenntnis, damit er es nicht vergisst. ${ }^{914}$

„Sie sind zwei raue, harte Engel, die jeden Einzelnen im Grab über seinen Herren und seinen Propheten befragen.“915

'Amr hat verstanden, dass Anōširvān und Baḩtak Mehrnegārs Tod vorgetäuscht haben. Er sagt daraufhin zu Ḥamze, dass Baḩtak eine alte Frau anstatt Mehrnegār begraben habe. Beide gehen zur Grabstätte Mehrnegārs und öffnen den Sarg. Als Hạze den Leichnam sieht, bemerkt er den ungewöhnlichen Zustand der Leiche und sagt: „Mehrnegār hat schöne Zähne wie Perlen und diese hat keine Zähne.“ 'Amr entgegnet daraufhin: „Sie hat die Fragen der Nakir und Monkar schlecht beantwortet, deswegen haben sie ihr die Zähne gezogen“ $(1 / 103 / 15-16)$.

\footnotetext{
${ }^{913}$ Horten, S. 287.

${ }^{914}$ Schimmel, Annemarie: Traditionelle Frömmigkeit, in: Der Islam III. Islamische Kultur-Zeitgenössische Strömungen-Volksfrömmigkeit, (Die Religionen der Menschheit Bd. 25, 3), Stuttgart/Berlin/Köln 1990, S. 242-267, hier S. 250; Paret, Rudi: Symbolik des Islam, Stuttgart 1958, S. 82; Olearius, Adam: Safar-nāme-ye Ādam Uli' āriyūs, ins Persische übersetzt. von Aḥmad Behpur, Teherān 1363/1984, S. 335.

915 al-Qazwīnī, Die Wunder des Himmels und der Erde, S. 74.
} 
Teufel

In der islamischen Erzähltradition ist der Šeitān (Teufel) ein früherer Gläubiger, der im Himmel zu Gott betete, dann aber von Gott verstoßen wurde. ${ }^{916}$ Er hat weiter das ewige Leben, aber keine Macht über die Gläubigen, jedoch kann er glaubensschwache Menschen beeinflussen und so Böses tun. ${ }^{917}$

Im $R H$ will der Teufel die Muslimen durch Furcht und Schrecken, die seine Anhänger verbreiten, vernichten. Die Fähigkeit des Teufels sich in unterschiedliche Gestalten zu verwandeln ist in der mittelalterlichen Literatur belegt, und findet sich auf ähnliche Weise auch im $R H$ wieder.

Eines Tages kommt der Teufel in Gestalt eines alten Mannes zu Lāhut, Zomorrods Sohn, und sagt ihm: „Ich bin die Seele deines Vaters und Ḥamze hat mich getötet. Jetzt gebe ich dir meine Gottheit.“ Daraufhin fühlt sich Lāhut als Gottheit und kämpft gegen die Muslime (5/1056-1057).

\section{Dschinn}

Das Leben des traditionellen Muslims ist von der Gegenwart guter und böser Geister umgeben. Die guten Geister sind die Diener Gottes, die seine Wünsche erfüllen und vor allem auch dazu da sind, um die Menschen zu beschützen. Zu den guten Geistern gehören in erster Linie die Engel. Die bösen Geister sind ihrer Natur nach vielfältig. Sie sind gefährlich und wohnen an unreinen Orten, wie öffentlichen Bädern und bestimmten Arten von Brunnen. ${ }^{918}$

Der Koran zeigt, dass in der vorislamischen Zeit die Araber die Dschinns (arab. ğinns) zu den Teilhabern Gottes machten. ${ }^{919}$ Der ǧinn-Glaube war ein Bestandteil ihres Lebens. „Der Glaube an die ğinn war in der Gedankenwelt der Araber, in der vorislamischen Zeit, tief verwurzelt. Sie glaubten, dass ihre Dichter und Priester von den ǧinn inspiriert werden.“ “920

Der Dämonenglaube hat in der islamischen Welt einen besonderen Stellenwert. Es ist kein Wunder, nimmt doch der Koran selber die ğinn als eine Realität an. Um über die Beschaffenheit der ğinn etwas zu erfahren, soll man zuerst auf den Koran und hadi t zurückgreifen. ${ }^{921}$ Die ihnen im Koran gewidmete Sure besteht aus 28 Versen. Da wird erzählt, wie sie an den Pforten des Himmels lauschen, um Geheimnisse zu erschleichen, und mit

\footnotetext{
916 an-Neišāburi, S. 6-7.

${ }^{917}$ Vgl. Butorābi, Hadiğe: Šeițān, in: Dā'rat al-ma‘̄àrif-e tašayyo ’ Bd. 10, Teherān 1383/2004, S. $220-223$.

${ }^{918}$ Vgl. Kriss, Rudolf u. Kriss, Hubert Heinrich, S. 15.

919 Koran, Sure. 37,158.

${ }^{920}$ Fatoum Aly Abd el-Gaphar: Der Ǧinn-Glaube als islamische Rechtsfrage nach Lehren der Orthodoxen Rechtsschulen, Diss. Uni. Mainz 1998, S. 7.
} 
Kometen vertrieben werden. ${ }^{922}$ Im Koran werden die ǧinn als Zwischenwesen zwischen Menschen und Engeln betrachtet. Dort dienten sie Salomo und errichteten große Bauten für ihn. Dem Koran zufolge, sollen die ǧinns noch über den Tod Salomos hinaus in dessen Dienst gestanden haben, bis ein Wurm seinen Stab zerfraß; und als er hinstürzte, erkannten die ğinns, dass wenn sie das Verborgene erkannt hätten, dann hätten sie nicht in dieser schändlichen Situation als Sklave Salomos bleiben müssen. ${ }^{923}$

Die ğinns gehören nicht nur einer Religion an sondern können Gläubige oder Ungläubige sein, den Naturreligionen, dem Judentum, dem Christentum und dem Islam angehören.

Unter den Genossen des Propheten Moḥammad waren auch ğinns. Sie hatten zum Propheten freundliche Beziehungen und manche begleiteten ihn auf seinen Kriegszügen. ${ }^{924}$ Sie besuchten den Propheten, um ihre religiösen Fragen zu stellen und Antworten zu bekommen. ${ }^{925}$ Es wurde erzählt, dass einige von ihnen der Predigt Moḥammads lauschten und sich bekehrten, andere dagegen Heiden blieben. ${ }^{926}$ Darüber schreibt Goldziher:

„Auch rechtgläubige Djinnen, welche die Legende im Verkehr mit dem

Propheten erwähnt, haben nach diesem Kanon ihre Stelle unter den Aṣ̣̣āb. “927

Es gibt auch negative Überlieferungen zu den ǧinn. Zur Zeit des Propheten Moḥammad kämpfte der Imām 'Ali auf Gottes Befehl mit den ğinns, die unter der Erde lebten. ${ }^{928}$

Über die Erschaffung der ğinns ranken sich die unterschiedlichsten Mythen. Im Gegensatz zu den Menschen, die nach islamischem Glauben aus dem Element Erde erschaffen worden sind, sollen sie aus Flammen bestehen, sind demzufolge aus dem Feuer erschaffen worden. Darüber berichtet Qazwīin:

„Gott habe die Engel aus seinem Licht des Feuers, die ğinnen aus seinen

Flammen und die Teufel aus seinem Rauch geschaffen. “929

Das äußere Erscheinungsbild der ğinns, wird in allen möglichen Formen dargestellt, z.B. in Gestalt einer schwarzen Katze, als Löwe, als Skorpion, als Adler, als Feuer, als Granatapfel ${ }^{930}$ als Affe ${ }^{931}$ oder als Schlange. ${ }^{932}$ Nach iranischer Vorstellung haben die ǧinns Ziegenfüße und Menschenkörper. ${ }^{933}$

\footnotetext{
921 Koran, Sure. 72.

${ }^{922}$ Koran, Sure. 15,16-18.

923 an-Neišāburi, S. 309-310.

${ }^{924}$ Goldziher, Aṣhāāb, in: El, Bd. I, Leiden/Leipzig 1913, S. 496-497.

925 al-Kulainī, Üsūl-i Kāfi, Bd.2, hrsg. von H. Rasuli, Teherān o.J., S. 242-243; Ḥā̄ri, Seyyed Mahdi: Ğinn, in: Dā'rat al-ma'ārif-e tašayyo', Bd. 10, Teherān 1383/2004, S. 449-452, hier S. 450.

${ }^{926}$ Koran, Sure. 46,72.

${ }^{927}$ Goldziher, Aṣ̣̣āb, S. 496-497.

${ }^{928}$ Mağlesi, Bd. 2, S. 245; Ḥā̄ri, S.452.

${ }_{929}$ al-Qazwīnī, Die Wunder des Himmels und der Erde, S. 171.

${ }^{930}$ Anonymus: Hezār o yek šab, Bd. 1, Nacht 16.
} 
Den ğinns werden viele negative Handlungen nachgesagt. Sie verursachen Krankheiten, töten die Menschen oder fügen ihnen andere Schäden zu; daher fürchtet man sich vor ihnen. Man versucht ihnen durch Flucht zu entkommen und versucht präventive Schutzmaßnahmen zu treffen, wie die Anwendung von Phylakterien und Beschwörungen und das Tragen von Amuletten. Das Eisen scheint offenbar den ğinns Schaden zuzufügen. Auch heute noch tragen viele Iraner eine Sicherheitsnadel, um so die ğinns fern zu halten.

Der wichtigste Schutz gegen die bösen Wesen ist ohne Zweifel der Name Gottes. Die ğinns haben sowohl Angst vor dem Koran als auch vor dem Namen Gottes. Auch heute noch glauben die Iraner, dass nach dem Verschütten von heißem Wasser, sofort bism Ilāhi rrạ̣mān-i ar-rạhim (im Namen des allbarmherzigen Gottes) gesagt werden muss, damit man die ğinns nicht verletzt falls sie sich gerade dort aufhalten. Weitere Schutzmittel gegen die ğinns sind das Zitieren der heiligen Formeln des Korans, vor dem sich alle ğinns, außer den muslimischen ğinns, fürchten müssen. ${ }^{934}$

Den Menschen ist es unter bestimmten Voraussetzungen möglich, mit den Dämonen durch kultische Handlungen Kontakt aufzunehmen. Die ğinns können auch mit Menschen sexuelle Beziehungen unterhalten und entführen dazu gern Jungen, Mädchen und Frauen. ${ }^{935}$ Ibn Bazzāz (gest. 1391-2) erzählt uns in seinem Buch Șawat aș-Safãa:

„Moḥammad Ḥāfeẓ [Urahne der Safaviden] wurde durch den ğinn entführt.
Nach einer Reihe von Jahren erschien er wieder in der Stadt. Hier erzählte er
den Leuten, dass der nach seiner Entführung so lange bei den ğinns bleiben
musste. “936

Manche Gelehrte halten die Heirat zwischen weiblichen ğinns und Menschen für möglich, jedoch auf jeden Fall für makrüh (verwerflich). ${ }^{937}$ Hingegen lehnen manche Gelehrte die Ehe zwischen Menschen und den ǧinn grundsätzlich ab. ${ }^{938}$ Im Buch Nihāyat al-arab lesen wir, dass die Mutter von Bilqīs (der Königin von Saba) ein ̌̌inn gewesen sei. ${ }^{939}$

\footnotetext{
${ }^{931}$ Ebd. Bd.1, Nacht 301; 302; vgl. Eisenstein, Herbert: Einführung in die arabische Zoographie, Berlin 1990, S. 224; Kan'ān, Taufik: Aberglaube und Volksmedizin im Lande der Bibel, Hamburg 1914, S. 15; Horten, Religiöse Gedankenwelt des Volkes im heutigen Islam, S. 125.

${ }_{932}$ Zbinden, Ernst: Die Ginn des Islams und der Alt-orientalische Geisterglaube, Bern/Stuttgart 1953, S. 76.

${ }^{933}$ Moḥammadi, Moḥammad-'Ali: $\boldsymbol{A} z$ mā behtarān, Teherān 1380/2001, S. 8.

${ }^{934}$ Moḥammadi, S. 16-22.

${ }^{935}$ Karbalāi-Tabrizi, ب̣afeẓ-Ḥosein (berühmt als Ibn Karbalāi): Rauḍat al-ğinān wa ğannat al-ğanān, Bd. 1, hrsg. von Ğa'far Solțān-Qarāì, Teherān 1344/1965, S. 111

${ }^{936}$ Ibn Bazzāz, S. 73.

${ }^{937}$ aš-Šiblī, al-Qāọī badr ad-Din Abū 'Abdalallāh: Ǵarā’ib wa '̌̆āìb al-ǧinn kamā yusauwiruha al-qur’ān wa as-Sunna, taḥqīq Ibrāhīm al-Ğamāl, al-Qāhira 1983, S. 105ff.

938 al-Ğāḥīẓ, Abū 'Uțmān 'Amr b. Baḥr: Kìtāb al-ḥayawān, Bd. 1, hrsg. von Moḥammad 'Abd as-Salām Hārūn Mișr 1965, S. 189.

939 an-Nuwairī, Bd. 14, S. 111; Anonymus: Tağārib al-umam fĩ al-ahbār mulūk al-‘arab wa-'l-‘ăgam, S. 113.
} 
Die Wohnorte der ǧinns befinden sich außerhalb der menschlichen Behausungen. Im Buch Nihāyat al-arab lesen wir, dass die ğinns sich in den Meeren, in der Luft, auf den Inseln und in der Ebene aufhalten. ${ }^{940}$ Sie treten an öffentlichen Plätzen wie den Moscheen oder den Bädern in Erscheinung. Auch in der Nähe von Feuer halten sie sich besonders gern auf. Nach iranischer Anschauung soll sich der Hauptsitz der ǧinns unter der Erde befinden. Wo immer die Natur sich in besonderer Weise präsentiert, findet man den ǧinn wie z.B. in Wasserquellen, Brunnen, Wasserfällen, Meeren, Flüssen, Einöden, Felsen, Klippen, Berggipfeln, Höhlen, Ruinen, Wüsten, und in alten Häusern. ${ }^{941}$ Im Buch Tausendundeine Nacht in der Geschichte von Seif al-Moluk und der Prinzessin Badic al-Ğamāl wohnt der König der Geister in der Burg von al-Kulzum. ${ }^{942}$

Auch im $R H$ leben die ǧinns ober- und unterirdisch. Im unterirdischen Reich gibt es vier Königreiche, die für die vier Elemente stehen; sie kämpfen daher auch gegeneinander, wobei sie sich auch von menschlichen Helden unterstützen lassen (6/1059-1070).

In der Stadt Takāb, im oberirdischen Reich, befindet sich der Wohnsitz des Ğinnkönigs Malek Șādeq, der für die Menschen unsichtbar ist. Um die Stadt sichtbar zu machen und sie zu zerstören, vernichtet Ḥamze einen Talisman namens Ṭelesm-e šabestān (5/947).

Im $R H$ treten die ğinns in unterschiedlichen tierischen Gestalten wie z.B. als Löwe oder als Schlange aber auch in menschlicher Gestalt, als alter Mann auf. Sie betätigen sich oftmals als Hüter und Bewahrer magischer Güter und Schätze (1/6). Ein ǧinn, der sich in die Gestalt einer Schlange verwandelt, gibt Bozorgmehr ein bedeutendes Buch, das er schon lange beschützt hat.

Im $R H$ wird ebenfalls von einer Heirat zwischen Mensch und ğinn berichtet. Malek Șādeq schickt seinem Bruder Malek Kei Kāvus die Bilder von Ḥamze und seinen Freunden. Kei Kāvus Tochter Mehr Bānu sieht das Bild von Nur ad-Dahr und verliebt sie sich in ihn (5/954). Eines Tages verschleiert sie ihr Gesicht und reitet auf die Jagd. Dort trifft sie Nur adDahr. Sie wendet sich Nur ad-Dahr zu und kämpft gegen Malek Ṣādeq und ihren Vater. Auf dem Kriegsplatz wird sie verwundet und Nur ad-Dahr erkennt, dass sie Mehr Bānu Königs Tochter ist (5/964). Der Zauberer Zamtār-e ğādu, verliebt sich in Mehr Bānu und entführt sie. Nur ad-Dahr befreit die Prinzessin aus seiner Gewalt, tötet ihn und heiratet sie (5/966967).

Die Erzähler des Werkes behandeln die ğinns wie menschliche oder halbmenschliche Wesen. Sie kämpfen auch gegen die Muslime, um ihre Ehre zu sichern. Zomorrod sucht Zuflucht

\footnotetext{
940 an-Nuwairī, Bd. 14, S. 90.

${ }^{941}$ Moḥammadi, Az mā behtarān, S. 16; 22.

${ }^{942}$ Littmann, Bd. V, S. 273.
} 
beim König der ğinns. Gemeinsam erklären sie Ḥamze den Krieg. Ḥamze stellt sich ihnen entgegen und soll eine ganze ğinn-Armee blutig geschlagen haben (5/809).

Um den Schaden, den ğinn anrichten können zu verhindern, liest man religiöse Schriften. So erfahren wir im $R H$, dass in dem Land Finsternis Ḥamze und seine Männer die Stimme von Geistern hören. Ḥamze befiehlt daraufhin den Gelehrten, den Koran zu lesen, um Schaden vom Heer abzuwenden (5/884-885).

\section{Efrīt}

Die Bezeichnung 'ifrìt (Pl. arab. 'afärīt, pers. 'efrit) ist der Name für eine böswillige und schreckliche ğinn-Art. ${ }^{943}$ Dieser Name taucht ein Mal im Koran auf. ${ }^{944}$

Im Buch al-Fīhrist wird cafärit als allgemeine Bezeichnung gebraucht, mit der sowohl die ǧinns als auch die šeitān bezeichnet werden. ${ }^{945}$ Im Kommentar zum Koran steht, dass ein 'efrīt unterschiedliche Fähigkeiten besitzt. ${ }^{946}$ Sie treten in männlicher und weiblicher Form auf. Weibliche 'efrite sind oft noch kräftiger und mächtiger als die männlichen.

Die 'efrit stehen im Dienste des Königs Soleimān und bieten ihm ihre Hilfe an, um u.a. den Thron der Königin von Saba zu ihm zu bringen. ${ }^{947}$ In einer anderen Erzählung stiehlt ein bösartiger 'efrit Salomos Ring und wirft ihn ins Meer. Salomo aber findet den Ring im Bauch eines Fisches wieder, den ihm ein Fischer bringt. ${ }^{948}$

Wo immer die Natur besonders merkwürdig ist, kann man den ğinn/'efrit finden. Sie bewohnen in der Regel Quellen, Brunnen und Höhlen. ${ }^{949}$ „Einige 'efrit d.h. solche, die Menschengestalt annehmen, wohnen in der Nähe der hohen Bäume, der Dornsträucher und

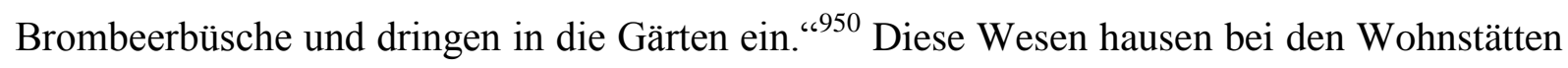
der Menschen und bevölkern die Gräber, d.h. sie lassen sich nahe den Gräbern der Menschen nieder. ${ }^{951}$

Die Autoren des $R H$ berichten von einem 'efrit, der ein mächtiger Dämon im Qāf ist. Ḥamze kämpft gegen ihn und kann ihn besiegen. Der Dämon kann fliehen und sich im goldenen Garten verstecken. Ḥamze spürt ihn dort auf und sieht, dass der Dämon schläft. Er will ihn nicht im Schlaf töten und sticht daher das Schwert in seine Füße. Der Dämon schreit auf, aber

\footnotetext{
943 ar-Rāzi, at-Tafsīr, ǧuz 24, S. 197; Anonymus: Hezār o yek šab, Bd. 1, Nacht 1.

${ }^{944}$ Koran, Sure. 27,39.

945 Ibn Nadīm, al-Fīhrist, Nachdruck Bairut 1966, S. 309; Purhāleqi-Čatrudi, Mehr-doht: Farhang-e qeș̣ehā-ye peyāmbarān, Teherān 1374/1995, S. 97.

${ }^{946}$ ar-Rāzi, at-Tafsīr, ğuz 24, S. 197.

${ }^{947}$ an-Neišāburi, S. 299.

948 an-Neišāburi, S. 305; Anonymus: Tağārib al-umam fĩ al-ahbāār mulūk al-‘arab wa-'l-‘ăgam, S. 115.

${ }_{949}$ Lane, Edward William: Sitten und Gebräuche der heutigen Egypter, Leipzig 1852, S. Kan‘ān, S. 16.

${ }^{950}$ Winkler, Hans Alexander: Siegel und Charaktere in der muhammedanischen Zauberei, Berlin/Leipzig 1930, S. 5.

${ }^{951}$ Vgl. Anonymus: Hezār-o yek šab, Bd.1, Nacht 21.
} 
erwacht nicht. Ḥamze sticht noch einmal sein Schwert in die Füße des Dämons. Dieses Mal wacht er auf und flieht (1/164).

\section{$\dot{\mathbf{G u l}}$}

„Im Allgemeinen wurden die $\dot{g} \boldsymbol{u} \boldsymbol{s}$ in altarabischen Gedichten als Symbol für Furcht und Schrecken erwähnt.““952 Sie werden in der Literatur oft als männliche Wesen bezeichnet. ${ }^{953}$ „Der $\dot{\boldsymbol{g} u l}$ ist ein Wüsten- $\check{\boldsymbol{g} i n n}$, der in verschiedenen Gestalten am Weg des Reisenden in der Nacht steht und ihn in der Wüste entführt.“954 Al-Ğāhiz schreibt, dass die Araber behaupten, dass der $\dot{\boldsymbol{g}} \boldsymbol{u l}$ in unterschiedlichen Gestalten erscheint, oft aber in Gestalt einer Frau mit Frauenkleidern und Schmuck und Eselshufen als Füße. ${ }^{955}$

Der männliche $\dot{g} \boldsymbol{u} \boldsymbol{l}$ ist gefährlich, da er ein menschenfressender Dämon ist, der in verschiedene Gestalten schlüpfen, aber seine Eselsbeine nicht ablegen kann. Seine Gestalt entspricht in etwa dem Teufel mit dem Pferdefuß. ${ }^{956}$ Die weibliche Verkörperung eines $\dot{g} \boldsymbol{u l s}$ ist ebenfalls eine menschenfressende, bösartige Dämonin, die die Wüste und die Wege unsicher macht und Reisende in der Wüste vom Wege weglockt und sie dann verschlingt. ${ }^{957}$

In der Geschichte von 'A ğib und Ġarib lesen wir jedoch, dass Sa'dān der ğuldes Berges und ein Menschenfresser ist. ${ }^{958}$

Im $R H$ sind die g̈uls ein Volk. Als Bahtak und Zomorrod in das Land Finsternis fliehen, erreichen sie eine Wüste, wo die g̈uls wohnen. Der König der ğgls, Nağm ist Menschenfresser und hat es auf sie abgesehen. Zomorrod kann ihn überzeugen ihm stattdessen seine Tochter zur Frau zu geben. Von ihr bekommt Zomorrod einen Sohn namens Lāhut (5/740).

Div

Bisher sind islamische Geister und übersinnliche Wesen behandelt worden. Im Folgetext soll auf altiranische übersinnliche Wesen eingegangen werden. Die Fantasie der Verfasser ist hier sehr groß. Die Menschen kämpfen gegen Geister und Dämonen. Die Dämonen wiederum kämpfen gegen die Menschen.

Der Glaube an das Vorkommen und Wirken dämonischer Mächte ist im Denken der iranischen Welt der Antike ganz selbstverständlich gewesen. Zum Namen div (Dämon) ist zu

\footnotetext{
${ }^{952}$ Aly Abd el-Gaphar Fatoum, S. 18.

${ }^{953}$ Ebd. S. 17.

954 al-Qazwīnī, S. 370.

955 al-Ğāḥ̄ịu, Kìtāb al-ḥayawān, Bd.VI, S. 220.

${ }^{956}$ Hamedāni, 'A '̆ğā'b-ñāme, S. 224.

${ }^{957}$ Hamedāni, S. 224.

${ }^{958}$ Littmann, Bd. IV, S. 449.
} 
bemerken, dass es ihn schon seit alter Zeit gibt. Die ursprüngliche Form des Namens ist „daēva“ ${ }^{959}$ Sie treten in allen religiösen Texten als böse Wesen und Untertanen des Ahrimans auf. „Was ihren Ursprung anbetrifft, so sind die Dämonen aus dem bösen Gedanken, aus der drug (Lüge), aus der Verkehrtheit des Geistes entstanden, und so haben sie schon von Natur aus den Samen der Finsternis in sich, wie es im Avesta heißt." ${ }^{960}$ Die dive werden als Widersacher der Gläubigen und als Helfer des Teufels dargestellt. ${ }^{961}$ In der dritten Gatha, Yasna 30, Vers 6. lesen wir, dass die Verwirrung über sie gekommen ist. ${ }^{962}$

„So kommt man zum Resultat, dass die divs einfach Personifizierungen von Sünden, Übeltaten, Nöten und Krankheiten sind. Es sind diejenigen Mächte des Übels, die umherwandeln und den Menschen angreifen, es sei denn, man bannt sie durch die höhere Kraft der Rechtschaffenheit oder beschwört sie durch religiöse Zeremonien, oder Tageslicht jagt sie in die Flucht. “963 In den uralten religiösen Texten sind die Dämonen zunächst gestaltlos gewesen, gewinnen jedoch in der späteren Literatur und den Kommentaren immer mehr an Gestalt. Im گ̌āh -nāme interpretiert Ferdousi die dive als schlechte Menschen, die gegenüber Gott undankbar gewesen sind. Er schreibt:

„Erkenne du den div als schlechten Menschen, als den, der Gott gegenüber undankbar ist. ${ }^{‘ 964}$

Die dive kommen in den epischen Dichtungen und Volksdichtungen sehr oft vor. An dieser Stelle soll der Entwicklungsprozess dieser Gestalt in den epischen Dichtungen und Volksdichtungen plastisch dargestellt werden. Im Gegensatz zu den Feen werden die dive gewöhnlich als männliche Wesen dargestellt. ${ }^{965}$

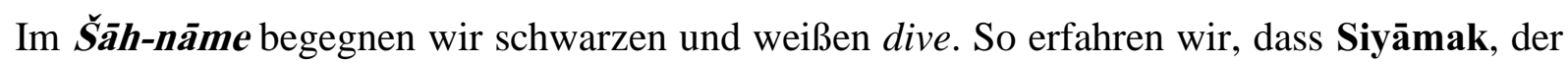
Sohn des Keiōmars, der erste König der Welt ist und von einem schwarzen div getötet wird. ${ }^{966}$

An anderer Stelle sagt Ferdousi, dass ein singender div zum Hof des Kei Kāvus kommt und singt für ihn ein Lied über die Schönheit seines Heimatlandes Māzandarān. Daraufhin entscheidet sich der König, nach Māzandarān zu reiten. Er wird dort durch die Dämonen

\footnotetext{
${ }^{959}$ Lommel, Hermann: Die Religion Zarathustras. Nach dem Avesta dargestellte, Hildesheim 1971, S. 90.

${ }^{960}$ Jackson, Die iranische Religion, S. 654f.

961 Ebd. S. 654.

962 Zitiert nach: Widengren, Geo: Iranische Geisteswelt, S. 151.

963 Jackson, Die iranische Religion, S. 654.

${ }^{964}$ Ferdousi, Bd. 1, S. 600.

965 Jackson, S. 653f.

${ }^{966}$ Ferdousi, Bd. 1, S. 206.
} 
festgenommen. Rostam erfährt davon und macht sich auf den Weg, um den König zu befreien. Er kämpft gegen den div-e sepid (weißen div), tötet ihn und befreit den König. ${ }^{967}$ Aus dem گ̌āh-nāme erfahren wir, dass der Wohnort der dive in Mazandarān ist. ${ }^{968}$ Mit Hilfe der Magie können sie sich in die Gestalt von Tieren verwandeln ${ }^{969}$ z.B. in die Tiergestalt eines Wildesels. ${ }^{970}$ Rostams Feind, der weiße div hatte eine jett-farbige (tiefschwarze) Haut und sein Gesicht und seine Haare waren wie die eines Löwen. ${ }^{971}$

Daneben verkörpern sie immer auch menschliche Fähigkeiten und Fertigkeiten, Eigenschaften und Verhaltensweisen und sind nach dem Vorbild und den Vorstellungen des Menschen gestaltet. Diese Anpassung an die Lebensweise der Menschen wirkt sich auch auf ihre Niederlassungen aus, denn die divs bauen Häuser aus Lehmziegeln. ${ }^{972}$ Der Legende nach lehren sie König Țahmurs die Schrift. ${ }^{973}$ Ferdousi sagt uns, dass dieser König mit dem Beinamen div-band (div-Besieger) ein Heer unter dem Siyāh-div (schwarzer div) besiegt. ${ }^{974}$

In der volkstümlichen Literatur wird der div als extrem hässlich beschrieben. Das Erscheinungsbild der Dämonen im $R H$ folgt weitgehend bekannten Stereotypen, was sich größtenteils mit der ikonographischen Tradition deckt. Die monströsen Züge der Dämonen werden besonders stark betont: Fratzenhaft verzerrte Gesichtszüge und große, breitstirnige Gestalten, die mit den Köpfen bis an die Wolken reichen. Sie werden als Tiere dargestellt und sehr poetisch beschrieben wie: Auf dem Kopf tragen sie zwei Hörner, ihre Hände sind so groß wie Baggerschaufeln, ihre Beine sind mächtig wie Masten, ihr Mund gleicht einer Höhle, ihre Ohren sind wie Schilder, ihre Zähne sehen wie Steinblöcke aus, ihre Nasenlöcher sehen wie Trompeten aus, ihre Augen sind wie brennende Fackeln und ihr Haar ist schwarz und furchtbar zerzaust, ihre Stimme klingt gewaltig und furcht-erregend, und dazu haben sie die Fähigkeit zu fliegen.

Wenn ein div erscheint, so sieht man ihn zuerst nur unbestimmt. Dann wird das Bild schärfer und verdichtet sich zu einer menschenähnlichen Figur von riesenhaften Ausmaßen. Sie sind Dämonen, deren Darstellung sich aus ihren bildhaften Namen erkennen lässt:

Im Buch $R H$ ist das Gebirge Qāf die Heimat der Dämonen, die im ständigen Kampf um die Vorherrschaft miteinander ringen. Sie werden in der Regel auch als dunkel und hässlich

\footnotetext{
${ }^{967}$ Ferdousi, Bd. 1, S. 207; Omidsālār, Mạ̣mud: Rostam's Seven Trials and the Logic of Epic Narrative in the Shāh-nāma, in: $A F S$, Vol. LX-1, S. 262.

${ }^{968}$ Ferdousi, Bd. 1, S. 186.

969 Omidsālār, Mạ̣mud: Div, in: EIr, Bd. VII, Casta Mesa California 1996, S. 428-431; Höttges, Valerie: Typenverzeichnis der deutschen Riesen- und riesischen Teufelssagen, in: FFC, Helsinki 1937, S. 140.

${ }^{970}$ Ferdousi, Bd. 1, S. 596.

${ }^{971}$ Ebd. Bd. 1, S. 206.

${ }^{972}$ Ebd. Bd. 1, S. 20.

${ }^{973}$ Ebd. Bd. 1, S. 18.

${ }^{974}$ Ebd. Bd. 1, S. 13.
} 
beschrieben. Sie treten in verschiedenfarbiger Gestalt auf; so gibt es rote (5/859/8), und schwarze divs (6/1098). Ihre Größe entspricht der einer Platane, und ihr Kopf ist groß wie ein Gewölbe und sie haben Hörner. Im $R H$ tritt ein div auch in Gestalt einer Wolke auf (5/750).

Weitere Dämonen zeichnen sich durch körperliche Absonderlichkeiten aus. Harās-e div ist ein Dämon, 400 zar $^{{ }^{9}}{ }^{975}$ groß und hat sieben Köpfe. Badi` az-Zamān kämpft mit ihm und besiegt ihn (4/570/16). Akvān-e čăhār-dast hat vier Hände (6/1084-1085). Sie können Menschenfresser sein und riechen Menschenfleisch (5/949). ${ }^{976}$ Qahqahe hat drei Augen und ist Menschenfresser (5/844/20).

Weitere Besonderheiten der Dämonen sind u.a. dass sie ein langes Leben haben können (1/165/27), dass sie keine Hitze vertragen (1/175) und, dass man sie nicht zweimal schlagen darf, da das die Wirkung der ersten Kampfhandlung wieder aufhebt (1/166). Einige der Dämonen sind unverwundbar (5/845/4), und ihre Leber gilt sogar als Heilmittel (1/177).

Sie werden mit dem Wort patiyāre (schrecklich bzw. abscheulich) bezeichnet, das aus vorislamischer Zeit stammt (1/148/20). Die Autoren des $R H$ unterscheiden zwischen guten und bösen Dämonen. Letztere können den Menschen beherrschen und ihm Schaden zufügen. Sie sind in der Regel die Widersacher der Helden.

Bei seiner Verfolgung von Zomorrod reitet Ḥamze nach der Stadt Čehel-arg. Dort begegnet er einem Dämon, den die Priester mit Hilfe der Zauberei in die Gestalt eines Drachen verwandelt haben. Er kann sich in menschlicher Sprache verständigen und die Einwohner der Stadt beten ihn an (5/937).

Zomorrod und Bahtak fliehen zu Qahqahe. Er schickt seinen Kundschafter Somum-e 'ayyār, um Ḥamze zu entführen. Qahqahe sperrt Hamze im Gebirge Bolur ein und will ihn töten, aber es gelingt Ḥamze zu fliehen (5/832).

Dämonen können sich auch in Prinzessinnen und Helden verlieben. An vielen Stellen im $R H$ kommt es vor, dass die Dämonen sich in eine Prinzessin verlieben, sie entführen und sie in ihren Palast bringen. Die Aufgabe des Helden ist es, mit dem Dämon zu kämpfen, ihn zu töten, und die Prinzessin zu befreien (1/173-175; 5/790). ${ }^{977}$

Die dive werden mit folgenden Charaktereigenschaften beschrieben: Sie tun stets das Gegenteil dessen, was die Menschen zu wollen vorgeben (1/173/27). ${ }^{978}$ Zudem haben sie auch

975 „Bezeichnung vorzugsweise für die persische Elle. Hieraus ermittelt sich I kanonische Elle, auf 49,875 cm. Entsprechend ist I zar'-e Isfahān $=\mathbf{8} / \mathbf{5}$ zar'-e šar' $\mathbf{i}=79,8 \mathrm{~cm}$. " Siehe: Hinz, Walther: Islamische Maße und Gewichte umgerechnet ins metrische System, in: Handbuch der Orientalistik, hrsg. von Bertold Spuler, Ergänzungsband. 1, Heft. 1, Göttingen 1955, S. 64.

${ }^{976}$ Vgl. Höttges, S. 149.

${ }^{977}$ Vgl. Höttges, S. 151.

978 Der Gedanke, dass die Dämonen alles stets umgekehrt machen, geht nach iranischer Ansicht bis auf die Schöpfung zurück. Biruni berichtet uns, dass der König Keiōmars Ahriman besiegt und danach auf der 
menschliche Moralvorstellungen, Ehrbegriffe und sogar Etikette. Sie schwören auf die Seele des Propheten Salomon (5/947/22), aber ihre Begrüßung geschieht im Namen der Dämonen Fis ${ }^{979}$ und Nāfis $(1 / 145 / 25)$.

Es wird angenommen, dass auch die dive die Blutrache kennen, ja es wird sogar gesagt, dass in der Schlacht der dive mit den Menschen viel Blut geflossen sei. Die Dämonen kennen die Blutrache und sie ist Teil ihres Lebens.

Arhang-e div will nur deshalb mit Ḥamze kämpfen, weil dieser seinen Bruder Arčang getötet hat (1/148).

Sie üben Berufe aus wie es sie auch bei den Menschen gibt, z.B. als Vorsteher der Hofhaltung und oberster Aufseher über die königliche Tafel (pers. sofreči/Truchsess; 1/148/26), ${ }^{980}$ Astrologen (5/940/25), Wächter eines magischen Werkes (5/795/18), Straßenzolleinnehmer (1/139/21) und Kundschafter (5/845).

Die dive können gelegentlich auch als Beschützer und Begleiter des Menschen auftreten (1/151/3). Es kommt auch vor, dass sie im Dienste von Helden stehen (4/652/8).

Nur ein weiblicher Dämon wird im $R H$ beschrieben. Es ist die Mutter von Qahqahe Vāheme, die ins Lager der Asmā' geht, mit Hilfe der Zauberei alle bewusstlos macht und Asad, Dārāb, Fariborz und Mālek gefangennimmt und sie zu Qahqahe bringt. Als bei näherer Betrachtung der Gefangenen Vāhemes Blick auf das schöne Gesicht des Asad fällt, verliebt sie sich in ihn und sucht nach einer Möglichkeit, ihn für sich zu gewinnen (5/977).

Pari

Gegenstände der Mentalitätengeschichte in der persischen Literatur sind das Denken und Fühlen, das Vorstellen oder Imaginieren, die vorrationale Vorstellung, außerdem das Unbewusste, das Unterbewusste und das Vorbewusste, der Habitus und das Ritualisierte, die Triebe, die Sinn- und Bedeutungsstrukturen und -konstruktionen. Das alles ist Bestandteil des menschlichen Handelns und sollte gegenüber den Ideen und Ideologien abgegrenzt und bewusst reflektiert werden.

Schulter des Teufels die ganze Welt bereist. Ahriman fragt ihn, wovor er Angst habe. Der König sagt, dass er vor der Hölle Angst habe. Sie erreichen dann die Hölle. Der Teufel wirft dort den König durch eine List auf den Boden und fragt, wo er beginnen solle, den König zu fressen beim Kopf oder bei den Füßen? Der Königwählt die Füße, da er noch ein wenig die Welt schauen will. Da der Teufel stets das Gegenteil tut,beginnt er den König vom Kopf an zu fressen Siehe: Biruni, S. 141-142.

${ }^{979}$ Ein Dämon, der die Gläubige verhindert das Gebet zu verrichten. Siehe: Pādešāh, Bd. 5, S. 3660.

${ }^{980}$ Sofreči-bāši war im Spätmittelalter ursprünglich die Amtsbezeichnung für den Vorsteher, des obersten Aufsehers über die königliche Tafel. Er bediente den König persönlich, er war also eine Vertrauensperson deren Bedeutung etwa einem Vorkoster der Antike gleichkam. Siehe: Dehḩodā, sofreči, in: Logat-nāme, ḥarf-e S, hrsg. von Moḥammad Mocin Teherān 1339/1960, S. 534. 
Um die Mentalitätsgeschichte der Iraner und seinen Wandel in Bezug auf die Geisterwelt zu vertiefen, wird in diesem Abschnitt die Darstellung der paris in den vorislamischen Quellen und nachislamischen Quellen wie im epischen Werk des $\check{\boldsymbol{S}} \overline{\mathbf{a}} \boldsymbol{h}$-nāme und anderen Quellen wie Tārih̆-e Bal'ami, Samak-e 'Ayyār und Eskandar-nāme untersucht. Schließlich wird dieser Befund mit der Darstellung im $R H$ verglichen.

In der vorislamischen Geschichte des Irans teilten die Iraner die Schar der Geister in „gute” und „böse” ein. Der ,gute Geist“ und der „,böse Geist“" wurden als Gottheiten des Lichtes und der Finsternis der Ober- und Unterwelt gesehen. Die Dämonen wurden als eine besondere Gruppe angesehen und die meist weiblichen paris, waren neben den divs die häufigste übernatürliche Gestalt in den iranischen Überlieferungen. Pairikās (av. pairika, phlv. parik $^{981}$ und in der neupersischen Sprache als pari bekannt) ${ }^{982}$ wurden in vorislamsicher Zeit immer als übelwollende Wesen dargestellt. ${ }^{983}$ So können wir weiter lesen, dass Ahriman die pairikās zusammen mit anderen übel wollenden Wesen schuf. ${ }^{984}$ Jackson schreibt:

„Außer den daēvas nennt das Avesta eine Liste übel wollender Mächte und
übler Persönlichkeiten, welche unter der allgemeinen Beschreibung von „yātū“،
(Hexe), pairikās, kavis und karapans, Banditen, Ketzern, Wölfen und
einfallenden sengenden Horden gruppiert werden.“"985

Etymologische Deutungen reichen von „Verführerin“ über „,fremde Frau“ bis zu „Dämon der sexuellen Lust.“986 Unter den bekanntesten pairikās finden wir Xnathaiti. Diese Dämonin wird von Ahriman als Landplage geschaffen. Sie versucht, Garšāsp zu verführen und mit ihm zu schlafen. ${ }^{987}$ Im Pahlavi Rivāyat zu Dātsatān i-Dēn̄̄k, Kap. VIII lesen wir, dass Yim nicht aus freien Stücken eine pairikā heiratet. Als er zusammen mit seiner Schwester Yimak aus der Versammlung Dahāks, der Menschen, der Dämonen und pairikās vor Ahriman zu fliehen versucht. Dieser sucht die beiden lange vergeblich und verkündet schließlich lauthals: „Ich denke, dass Yim sich im Meer versteckt.“ Ein Dämon und eine pairikāa, die anwesend sind, sagen: „Wir gehen fort und suchen Yim.“ Sie machen sich auf die Suche und finden ihn schließlich. Damit Yim und seine Schwester am Leben bleiben, treffen sie mit ihnen die Vereinbarung, dass Yim seine Schwester dem Dämon zur Frau geben solle und im Gegenzug er die pairikā zur Frau nimmt. Die Nachfahren der beiden Verbindungen sind von halb

\footnotetext{
${ }^{981}$ Omidsālār, Maḥmud: Peri (pari), in: EM, Bd. 10, Göttingen 2002, Sp. 743-746, hier Sp. 743.

982 Dehḩodā, Pari, in: Logat-nāme, ḥarf-e. P-Piyori, Teherān 1328/1949, S. 299.

${ }^{983} \mathrm{Vgl}$. Yarshater, Ehsan: Iranian common beliefs and world-view, in: CHI, Vol. 3 (1), Cambridge 1983, S. 343358, hier S. 349.

${ }^{984}$ Jackson, Die iranische Religion, S. $665 f$.

${ }^{985}$ Ebd. S. 665.

${ }^{986}$ Sarkārāti, Bahman: Pari, in: Sāyehā-ye šekār šode, Teherān 1385/2006, S. 1-25.

${ }^{987}$ Ebd. S. 2.
} 
menschlicher halb tierischer Natur. Yim und pairikā zeugen einen Bären, einen Affen, einen Gandarv und Menschen, die ihre Ohren auf der Brust haben. Aus der Verbindung von Yimika und jenem Dämon kommen die Schildkröte, die Katze, der Falke, der Frosch, der Kornwurm und viele andere schädliche Tiere. ${ }^{988}$ Sie erscheinen als schöne Frauen in menschlicher Gestalt, um gläubige Männer zu locken und zu verführen. ${ }^{989}$

Nach einer in der Antike weit verbreiteten Vorstellung brachten die paris Unglück. Die paris konnten in jemanden fahren und ihn erkranken lassen. Schon in vorislamischer Zeit kannten die Iraner viele antidämonische Handlungen zur Anwendung gegen sie. Ein gutes Schutzmittel gegen paris war der Gebrauch des Namen Gottes; außerdem fürchten sie Eisen in jeder Form. ${ }^{990}$

Bis heute gibt es im Iran den Glauben, dass jemand zuvor durch paris beeinflusst wurde, der verrückt geworden ist. ${ }^{991}$ Dafür benutzt man den Begriff pari-zade.

Im $\check{\boldsymbol{S}} \bar{a} h-n \bar{a} m \boldsymbol{e}$ finden wir eine große Anzahl von paris. Unter den mythischen Königen finden sich auch einige Könige, die die pairikās sowie daēvas beherrschen. Einer von ihnen ist Ğamšid, der eine große Zahl von paris und ğādugarān (Hexen) beherrscht. ${ }^{992}$

Abu 'Ali Moḥammad Bal'ami berichtet, dass ein pari den Siyāmak getötet hat und Hušang, der Sohn des Siyāmak, mit einem Heer von Menschen und Tieren und paris gegen Ahriman gekämpft hat, um sie zu rächen. ${ }^{993}$

Über die Eigenschaften der paris finden wir im Samak-e 'Ayyār Versuche einer detaillierteren Beschreibung. Sie werden dort u.a. als böse Geister dargestellt, die Tod und Unglück bringen. Sie halten sich besonders in der Nähe von Wasser bzw. in der Nähe von Wasserquellen, Brunnen, Wasserfällen und dort, wo die Natur besonders merkwürdig ist, auf. Den alten Vorstellungen zufolge, vergiften die paris auch die Brunnen der Menschen. ${ }^{994}$

Sie haben eine tierische Gestalt und sie können z.B. als Zebras, ${ }^{995}$ weiße Tauben aber auch als rote Wolken erscheinen. ${ }^{996}$ Um fliegen zu können nutzen sie ein Federkleid, das ihnen auch ihre Zauberkraft verleiht. ${ }^{997}$ Durch ihren schlechten und üblen Geruch den sie verströmen

\footnotetext{
${ }^{988}$ Widengren, Iranische Geisteswelt, S. 277-278.

${ }^{989}$ Vgl. Rażi, Hāšem: Vandidād, Bd. 1, Teherān 1376/1997, S. 219.

990 Afs̃ār, Eskandar-nāme, S. 378; 358.

991 Afšāri, Mehrān: Pari, in: Dāneš-nāme-ye ğahān-e Eslām, Bd. 2, hrsg. von Ġolām-cAli Ḥadād 'Ādel, Teherān 1375/1996, S. 634-636.

${ }^{992}$ Ferdousi, Bd. 1, S. 19.

${ }^{993}$ Bal'ami, Tãrih̀-e Bal'ami, S. 17.

${ }^{994}$ al-Arrağāni, Bd. 2, S. 551.

${ }^{995}$ Ebd. Bd. 5, S. 31.

${ }^{996}$ Ebd. Bd. 5, S. 143.

${ }^{997}$ Ebd. Bd. 5, S. 29.
} 
können sie sich nicht unbemerkt den Menschen nähern. ${ }^{998}$ Bei Gefahr suchen sie Zuflucht unter der Erde. ${ }^{999}$

Aus dem Eskandar-nāme erfahren wir, dass die paris an einem Ort wohnen, der dem Paradies ähnlich ist. ${ }^{1000}$ Die paris teilen sich in verschiedene Stämme auf, die sich durch ihr Aussehen unterscheiden. So gibt es eine Gruppe, die oberhalb der Gürtellinie menschlich und unterhalb tierisch (vierbeinig) ist. ${ }^{1001}$

Ihren Frauen wird große Schönheit nachgesagt. ${ }^{1002}$ Sie werden von Fürsten und Königen regiert. Königin Ārāqit ist ihr Oberhaupt und von ihr wird behauptet, dass sie sehr wollüstig sei, weil ihre Mutter eine menschliche Frau und ihr Vater ein pari gewesen sei. ${ }^{1003}$

Sie schlafen in der Regel tagsüber um in der Nacht stark zu sein und ihrer Tätigkeit nachzugehen. Sie können fliegen und sind nachts und im Dunkeln viel gefährlicher als tagsüber, ${ }^{1004}$ daher lässt sich auch ihre gute Nachtsicht erklären. ${ }^{1005}$

Im Laufe der Zeit wandelte sich die Meinung über die paris. Im Mittelalter werden sie keineswegs als Bastarde gesehen und haben ihre Bösartigkeit vollkommen verloren. In der klassischen Literatur dieser Zeit werden die paris sehr poetisch geschildert. In den späteren Werken sind die paris meist weiblich und haben in der Regel ein gutes Wesen.

Die faszinierende Vorstellung einer überirdisch schönen Frau, der man sorglos, außerhalb der Normvorstellungen und Zwänge der eigenen Gemeinschaft, beiwohnen kann, einer Frau, die nicht nur über Schönheit, sondern auch durch ihr überdurchschnittliches Wissen hervorsticht, ist zweifellos ein Reiz für die Tagträume und Fantasien der Iraner. Erotische Wunschvorstellungen spielen hier psychologisch gesehen eine wichtige Rolle.

Es stellt sich nun die Frage, wieso und warum sich das Gedankengut der antiken Dämonlogie in der volkstümlichen Literatur der Iraner so verändert hat? Aus bösen paris werden den Menschen wohlgesonnene Wesen, die ihnen zur Seite stehen. Die späten iranischen Märchen und Sagen wissen auch von einer Heirat zwischen einem König und einer pari zu berichten. Ğuneid, Abu Moslems Urgroßvater, heiratet die Tochter des Feenkönigs. ${ }^{1006}$

Im $R H$ sind die paris eine Gruppe schöner, verführerischer Frauen. Asmāà', die Feenkönigin, verliebt sich in Ḥamze. Schließlich kommt es allen Einsprachen zum Trotz doch noch zur Heirat (1/194).

\footnotetext{
${ }^{998}$ Ebd. Bd. 5, S. 49.

${ }^{999}$ Ebd. Bd. 5, S. 100.

${ }^{1000}$ Afšār, Eskandar-nāme, S. 354.

${ }^{1001}$ Ebd. S. 354.

1002 Ebd. S. 356.

1003 Ebd. S. 360.

${ }^{1004}$ Ebd. S. 372.

${ }^{1005}$ Ebd. S. 382.
} 
Die Rettung eines Mädchens vor oder aus den Klauen eines Dämons wiederholt sich sehr oft im $R H$. Stets erscheint Hamze als Erlöser und Retter und befreit die Frauen von den Dämonen. Als Ḥamze die Tochter des Feenkönigs, Ğān-afzā, aus der Gewalt eines Dämons befreit verliebt er sich in das Mädchen (5/865) und als Ğān-afzā den Mut Ḥamzes sieht, verliebt sie sich auch in ihn.

Als Dämonen das Land Qāf angreifen, ruft Šahbāl Ḥamze zur Hilfe (1/138). In dieser Zeit lernt er Asmā’ kennen und verlobt sich mit ihr. Als sie erfährt, dass Ḥamze im Land der Menschen bereits mit Mehrnegār verlobt ist, versucht sie vergeblich ihn bei sich zu behalten (1/170-180). Nach seiner Ankunft im Menschenland heiratet Ḥamze zunächst Mehrnegār, geht dann aber danach ins Feenreich zurück und heiratet Asmā̄', die ihm eine Tocher Qoreiši (2/197) und einen Sohn Soleimān-e șāni schenkt (4/617).

Im $R H$ begegnen uns die paris nicht nur vor dem Hintergrund erotischer Fantasien, sondern sie werden auch als Wesen von großer Brutalität gezeichnet. Asmā' und ihre Tochter Qoreiši Bānu sind Kriegerinnen. Asmā' ist eine starke Frau, die ihrem Vater die Herrschaftswürde abnimmt. Sie verteidigt jahrelang ihr Land gegen Dämonen und kennt keine Gnade. Als Asmā' erfährt, dass Ḥamze Gordiye geheiratet hat, beschließt sie diese zu töten.

Im $R H$ wird an vielen Stellen berichtet, dass die paris den Menschen zu Hilfe kommen. Als Ḥamze durch Zubin verwundet wird, bringt 'Amr ihn nach Mekka. Dort erscheinen sieben Tauben in Hamzes Zimmer. Diese ziehen ihr Federkleid aus und werden sieben schöne Feenfrauen, die erfolgreich Hamzes Wunde behandeln (1/136).

Wenn die paris der menschlichen Hilfe bedürfen, erscheinen sie den Menschen in Menschengestalt und bitten sie um Hilfe, indem sie eine gute Belohnung in Aussicht stellen (1/138).

Sie werden dann im Allgemeinen wie menschliche Wesen behandelt. Auch ihre Lebenswelt (Politik, Kultur und Krieg) entspricht menschlichen Verhältnissen. ${ }^{1007}$

\subsubsection{Vorislamische Persönlichkeiten}

Jede Kultur bildet etwas Herausragendes aus. „Dies wirkt verknüpfend und verbindend, und zwar in zwei Dimensionen: der Sozialdimension und der Zeitdimension. Sie bindet den Menschen an den Mitmenschen dadurch, dass sie als ,symbolische Sinnwelt ${ }^{6}$ einen gemeinsamen Erfahrungs-, Erwartungs- und Handlungsraum bildet, der durch seine bindende

\footnotetext{
${ }^{1006}$ Esmā'li, Bd. 1, S. 497.

${ }^{1007}$ Vgl. Omidsālār, Peri, in: EM, hier Sp. 744.
} 
und verbindliche Kraft Vertrauen und Orientierung stiftet.““1008 Assmann meint dazu weiter: „Dieser Aspekt der Kultur liegt den mythischen und historischen Erzählungen zugrunde. Beide Aspekte: der normative und der narrative, der Aspekt der Weisung und der Aspekt der Erzählung, fundieren Zugehörigkeit oder Identität, ermöglichen den Einzelnen, „wir“ sagen zu können.“" ${ }^{1009}$ Genau dieser Aspekt wird im $R H$ vertreten. Das $R H$ verbindet alle Aspekte der iranischen Geschichte. Es verbindet die Vergangenheit mit der Gegenwart, indem es die prägenden Erfahrungen und Erinnerungen formiert und in einer neuen und herausragenden Form wieder präsentiert. Bilder und Geschichten aus der Ursprungszeit werden im $R H$ unter anderen Raum- und Zeitbedingungen wieder lebendig. Dort kommen einige historische Persönlickeiten vor, die als Idealtypen für die Herrscher und Helden gelten. Das Werk $R H$ zeigt sich als große Bühne, wo alle wichtigen Figuren aus Politik und Religion aus der vorislamischen Zeit des Irans und der islamischen Welt auftreten.

\section{Alexander der Große}

Durch den Feldzug Alexander des Großen wurden die ägyptischen, iranischen und zentralasiatischen Völker mit der griechischen Kultur konfrontiert und umgekehrt kam Alexanders Heer mit den lokalen Kulturen in Kontakt. Die nachhaltigen Wechselwirkungen dieser Begegnung auf die Kunst und Kultur der oben genannten Staaten bilden einen Schwerpunkt der Literatur. Ein Höhepunkt in der Darstellung dieses gegenseitigen Einflusses unterschiedlicher Kulturstränge wird schließlich im Alexanderroman erreicht.

Alexander wurde in der vorislamischen Literatur des Irans als teuflisches Wesen betrachtet. In der sasanidischen Literatur gab es eine Legende, wonach er der persischen Religion, dem Zoroastrismus dadurch einen schweren Schlag versetzte, indem er religöse Schriften vernichten ließ. Daher war Alexander bei den Anhängern des Zoroastrismus verhasst. ${ }^{1010}$ Im Koran ist ausführlich von ihm die Rede. ${ }^{1011}$ Dort erscheint er unter der Bezeichung $\underline{D} \overline{\boldsymbol{u}}$ lQarnain (Zweihörnige). ${ }^{1012}$ Die islamische Wertschätzung für Alexander, die er im Koran erfährt, führt dazu, dass einige Autoren ihn zu den Propheten zählen. ${ }^{1013}$ Außerdem kommt Alexander auch in der arabischen Weisheitsliteratur vor, wo er als Gelehrter beschrieben

\footnotetext{
1008 Vgl. Assmann, Jan: Das kulturelle Gedächtnis. Schrift, Erinnerung und politische Identität in frühen Hochkulturen, Münschen 1999, S. 16.

${ }^{1009}$ Ebd. S. 16.

${ }^{1010}$ Safavi, S. 25.

1011 Koran, Sure. 18,83-98.

1012 Die im Orient verbreitete Bezeichung Alexanders als „Zweihörnig“ taucht schon in einer spätantiken Alexanderlegende in altsyrischen Sprache auf, wo Alexander ein christlicher Herrscher ist, dem Gott zwei Hörner auf dem Kopf wachsen ließ, womit er ihm die Macht verlieh, die Königreiche der Welt zu erobern. Siehe: Safavi, S. 300.

1013 Safavi, S. 100.
} 
wird. Sein Name wird in Spruchsammlungen erwähnt, wobei die Sprüche teilweise ihm zugeschrieben werden und teilweise von ihm handeln. ${ }^{1014}$

In der mittelalterlichen Literatur des Irans ist Alexander unter dem Namen Eskandar bekannt. Nach der Islamisierung des Irans wirkt sich diese Sage im gegenteiligen Sinne aus, denn nun macht man aus Alexander einen Vorkämpfer des Monotheismus gegen heidnische Götzendiener. ${ }^{1015}$

Im گ̌āhh-nāme ist Alexander ein römischer Kaiser und Christ, der unter dem Kreuzzeichen kämpft. Außerdem macht Ferdousi Alexander zu einem Halbbruder des Dareios und vereinnahmt ihn damit für das Persertum. Die Vernichtung des Perserreichs löst einen Bruderstreit innerhalb der iranischen Herrscherfamilie aus. ${ }^{1016}$

Neẓāmi erschafft im Eskandar-nāme eine völlig islamisierte Gestalt von Alexander. Er unterwirft Indien und China und gelangt im Westen bis nach Spanien. Wie schon bei Ferdousi sucht Alexander auch Mekka auf und reinigt dort die Ka'aba. ${ }^{1017}$ Außerdem ist er auch Philosoph und ein großer Förderer der Wissenschaft. ${ }^{1018}$

Nach dem berühmten persischsprachigen Dichter und Musikwissenschaftler aus Indien namens Amir Hosrou Dehlavi (1253-1325) ist Alexander ein monotheistischer Held, der den Zoroastrismus der Perser mit Feuer und Schwert ausrottet. ${ }^{1019}$

Alexander von Mazedonien, der große Welteroberer, dessen Macht bis zum Ende der bekannten Welt reichte, war ein Vorbild für die Verfasser des $R H$. So, wie Alexander, erobert Hamze die gesamte bewohnte Erde sowie die unbewohnten Erdteile. Er gelangt bis ans Ende der Welt.

Es ist eine Ehre für Hamze und seine Kinder Eskandars Eigentümer in ihren Besitz nehmen zu können. Die Helden bekommen auf vielerlei, merkwürdige Weisen die Waffen des Alexander. Im Wasserwirbel des Eskandar findet Ḥamze Alexanders Trommel, die sehr laut ist $(1 / 69 ; 5 / 776 / 27)$.

Alexander ist auch Gründer eines Talismans, in den er seinen Schatz verbirgt. Diesen nimmt Irağ in seinen Besitz (5/732).

\footnotetext{
1014 Stoneman, Richard: Alexander the Great in the Arabic Tradition, in: Stelios Panayotakis (Hrsg. von): the Ancient Novel and Beyond, Leiden 2003, S. 15-18.

1015 Safavi, S. 100f.

1016 Ferdousi, Bd.1, S. 1083.

${ }^{1017}$ Safavi, S. 146.

1018 Șafavi, S. 159.

1019 Keivāni, Mağd ad-Din: Eskandar-nāme, in: Dā'rat al-ma'ārif-e bozorg-e eslāmi, Bd. 8, hrsg. von Kāẓem Mosavi-Boğnordi, Teherān 1385/2006, S. 367-372, hier S. 370.
} 
Alexander wird im $R H$ auch als Bauherr eines Schlosses erwähnt. In der Finsternis erblickt Ḥamze ein Schloss, das mit Feen bevölkert ist. Die Feen erzählen ihm, dass dieses Schloss Alexander gehört habe, und dieser es einst in der Finsternis erbaut habe (5/885).

Ein Rückblick auf die Mentalitätsgeschichte des Irans im Früh- und Spätmittelalter zeigt eine eigentümliche Verschränkung zwischen den Ansätzen einer Bewusstseinsbildung und einer Grundhaltung. Diese hat seine Manifestation in der iranischen Volksliteratur gefunden. Der Alexanderroman wird daher zu einem grundlegenden Integrationsfaktor für die Entwicklung des literarischen Selbstverständnisses der islamisch-iranischen Gesellschaft. So sehen wir, dass die Gestalt des Alexander als Erinnerungsfigur eine sehr starke Veränderung im $R H$ erlebt hat und sich in neuer Form präsentiert.

\section{Anōširvān}

Der König Hosrau I. (531-579 n.Chr.) genannt Anōširvān (der mit der unsterblichen Seele) war in der vorislamischen Geschichte des Irans eine prägende und herausragende Persönlichkeit in allen für einen Herrscher relevanten Bereichen. Er führte das Sasanidenreich $\mathrm{zu}$ einem Höhepunkt, was auch seinen Widerhall in der Sagenwelt des Orients fand. Insbesondere hat er das durch die mazdakischen Einflüsse entstandene Chaos auf weise Art beseitigt. ${ }^{1020}$ Der König Hosrau Anōširvān war an griechischer Philosophie, Wissenschaft und Kunst interessiert. Unter ihm erlebte das Reich eine Zeit der kulturellen Blüte. Er zog viele Gelehrte an seinen Hof und stand im Ruf, eine gute philosophische Bildung zu besitzen. $^{1021}$

In der klassischen iranischen Literatur wird Anōširvān als ein weiser und gerechter König beschrieben. Wir finden in einer Erzählung wieder, dass er eine Glocke anfertigen ließ, die von außerhalb des Palastes betätigt werden konnte. Sobald ein Beschwerdeführer mit der Kette die Glocke ertönen ließ, wurde er von den Palasthütern vor Anōširvān geführt. ${ }^{1022}$

Dieses Element findet sich auch im $R H$. Als Moqbel bei seiner Audienz bei Anōširvān das Läuten der Gerechtigkeitsglocke hört, sieht er wie eine Schlange sich um den Hals eines Wasservogels windet, den Wasservogel beißt, und dieser sich der an der Gerechtigkeitsglocke reibt. Als Anōširvān dies sieht, sagt er zu Bozorgmehr: „Sieh! Die Vögel wissen auch, dass ich die Gerechtigkeitsglocke eingerichtet habe." Er will auch dem Vogel Gerechtigkeit widerfahren lassen und sagt weiter: „Ich möchte, dass jemand die Schlange erschießt, ohne

\footnotetext{
${ }^{1020}$ Sāmi, ‘Ali: Tamaddon-e sāsāni, Bd. 1, S. 270-276.

${ }^{1021}$ Ferdousi, Bd. 2, S. 1527.

1022 Šamisā, Farhang-e talmiḥāt, S. 138.
} 
den Vogel zu töten.“ Moqbel übernimmt diese Aufgebe und tötet die Schlange mit einem Pfeilschuss (1/26-27).

Die Konstellation von Herrscher und Ratgeber wird in der mittelalterlichen Literatur des Irans wiederholt thematisiert, und so gibt es eine Reihe standardisierter Eigenschaften und Verhaltensweisen, die den in ihr agierenden Figuren je nach Typ zugeordnet werden. Gemeinsam ist allen Berichten zufolge ihre Vorbildlichkeit in Bezug auf ihre weisen Ratschläge und ihre gegenseitige Treue. Im Allgemeinen scheinen sich bei der Interessen im fiktionalen Entwurf der Geschichte widerspruchsfrei miteinander zu decken; so intensiv, wie der Herrscher Rat sucht, so verlässlich erteilt der Berater guten Rat; und die Befolgung des einmal ausgesprochenen Ratschlags erscheint so selbstverständlich wie die tatkräftige Unterstützung des aktuellen Herrschers durch seinen weisen und tapferen Ratgeber. König und Ratgeber sind aber trotz aller ihnen angedichteten heldenmütigen Eigenschaften auch nur Menschen, die neben den positiven auch negative Charakterzüge in sich tragen.

Anōširvān ist nicht nur edel und tapfer, sondern auch verantwortungslos und feige, untreu und mörderisch, hinterhältig und aggressiv. Sein Ratgeber Bahtak ist nicht nur treu und loyal, sondern auch gemein und aufsässig. Bahtak hilft dem Perserkönig mit seiner List aber dadurch bringt er die soziale Hierarchie der adligen Welt durcheinander. Sie führen beide ein tragisches und von Leid geprägtes Leben mit vielen Niederlagen bis zu ihrem Tod.

Mazdak

Mazdak war der Gründer des Mazdakismus in der sasanidischen Zeit. ${ }^{1023}$ Der Perserkönig, Kavād (Qobād), wandte sich dem Mazdakismus zu. Unter Mazdakismus kann man mit heutigen Begrifflichkeiten eine sozialrevolutionäre Bewegung verstehen. Das niedere Volk glaubte offenbar aus innerer Überzeugung an diese Lehre. Dies führte letztlich zu sozialen Unruhen und König Kavād wurde durch die Aristokratie abgesetzt. Mit Hilfe eines Teils des Hochadels gelang es ihm, seinen Thron wieder zu besteigen. „In den Jahren 528/529 n. Chr. veranlasste Anōširvān, sein Sohn, eine grausame Massenvernichtung der Mazdakiten in seinem Palasthof. “1024

Im $R H$ wird Mazdak mit dem Beinamen hakim (Wissenschaftler) erwähnt. Er ist Bahtaks Onkel (1/147/7). Mazdak und Mandak, die Brüder von Arqaš, kommen in den Irak zu Ḥamze. Als Mazdak hört, dass Bahtak getötet worden ist, ist er sehr wütend und will Rache nehmen. Durch eine List macht er Ḥamze blind. Dieser wird aber mit Hilfe der magischen Blätter geheilt (2/218-219).

\footnotetext{
${ }^{1023}$ Ferdousi, Bd. 2, S. 1432-1438.

${ }^{1024}$ Widengren, Die Religionen Irans, S. 309-310.
} 
Rostam

Der Nationalheld der Iraner aus vorislamischer Zeit ist der Legende nach Rostam. Ohne seine heldenhafte Verteidigung der Landesgrenzen und der erfolgreichen Niederschlagung der Eroberungsversuche von Nachbarkönigreichen gäbe es der Legende nach kein Iran. Den späteren Überlieferungen zufolge ist Rostam trotz seiner vorislamischen Herkunft Kampfgefährte des Imām-e Zamān. ${ }^{1025}$

Ḥamze ist diesem Vorbild nachempfunden. Besonders deutlich wird dies in der folgenden Episode des $R H$ :

Rostam tritt in einer sehr kritischen Szene im Buch $R H$ auf. Dort wird erzählt, dass nach dem Tod von Ḥamzes Sohn und seiner Frau Mehrnegār, Ḥamze nicht mehr seine Mission und seine Kriege, die als ğehād bezeichnet werden, führen will, um den beiden nahe zu sein. Im Traum wird er daraufhin von Rostam getadelt, weil er schon zu lange den ğehād vernachlässigt hat, und wird aufgefordert, sich wieder seinen Pflichten zu widmen. Ḥamze hält sich drei Jahre in Mekka auf. In dieser Zeit erheben sich alle Rebellen, die Hamze jemals besiegt hat. Eines Nachts sieht Ḥamze in seinem Traum einen Jungen, der auf einem großen Pferd reitet und einen Bart mit zwei Spitzen hat. Der Junge greift Ḥamze mit dem Pfeil an und macht ihm große Vorwürfe und sagt: „Warum hast du deine Pflicht vernachlässigt?“ und verpasst ihm einen Schlag. (2/308). Das öffnet Ḥamze die Augen und er erwacht aus seiner Lethargie und wendet sich wieder dem Kampf für den Islam zu.

Im $R H$ verschmelzen vorislamische und iranische Elemente zu einem harmonischen Ganzen. So ist im $R H$ der heidnische Nationalheld Irans, Rostam, ein Vorkämpfer und Verteidiger des Islam, indem er Ḥamze zur Wiederaufnahme des Glaubenskrieges drängt.

\section{Zarathustra}

Zarathustra, einer der großen Religionslehrer des Ostens, war der Gründer der iranischen Nationalreligion. In ihm sahen die Iraner den Typus eines heiligen Menschen. Er war ein Vorkämpfer des Glaubens. „Das grosse Ereignis in dem letzten Lebensjahrzehnt des Propheten ist der heilige Krieg gegen den hyaonischen Anführer Aredshataspa [...] von Turan, welcher zweimal in Iran einfiel. [...] aber Zoroaster scheint im Kriege umgekommen zu sein.“ ${ }^{1026}$ „Er war bei seinem Tod, 563 v. Chr., siebenundsiebzig Jahre alt.“1027

\footnotetext{
${ }^{1025}$ Enǧvi-Širāzi, Abu 'I-Qāsem: Mardom va Šāh-nāme, Bd. 2, Teherān 1354/1975, S. 109.

${ }^{1026}$ Jackson, A. V. Williams: Die iranische Religion, S. 624.

${ }^{1027}$ Ebd.
} 
Um seine Person ranken sich viele Legenden. Der antike Philosophiehistoriker und Doxograph Diogenes Laertius (3. Jh. n. Chr.) brachte Zarathustra mit Magie in Verbindung. ${ }^{1028}$ Auch in islamischer Zeit wurde er als Hexer betrachtet. ${ }^{1029}$

Im $Q H$ wird er auch als Hexer dargestellt. Er besitzt ein Buch, das sich mit Magie befasst. Ḥamze findet das Buch in seinen magischen Gemäuern. Er zerstört die Gebäude und befiehlt 'Amr, das Buch zu verbrennen. 'Amr führt den Befehl nur zum Teil aus, denn er stiehlt fünf Blätter des Buches, da ihm die vollständige Vernichtung des Buches als Fehler erscheint. ${ }^{1030}$ Im $R H$ ist Zarathustra ein mächtiger König und ein Hexer. Er ist Zomorrods Vater und hat eine Tochter namens Maleke, die auch eine Hexe ist, sich aber später zum Islam bekehrt und 'Amr heiratet (4/650-651). Nach seiner Niederlage gegen Hamze begibt sich Zomorrod zum Hofe des Zarathustra und zusammen führen sie unzählige Kriege gegen Ḥamze. Nur mit Hilfe der Magie können sie gegen Hamze eine Zeit lang Widerstand leisten. Beide finden später unter schrecklichen Umständen den Tod (4/662-665).

Anschließend zieht diese Arbeit die Aufmerksamkeit des Betrachters auf einige fundamentale Fragen. Heutzutage gehört zu jedem Volk bzw. jeder Gruppe eine kulturelle Vergangenheit. Wie und woran erinnert man sich? Was darf man vergessen und was nicht? Wie bewahrt man seine Geschichte?

Um diese Fragen zu beantworten, lenkt diese Arbeit ihre Aufmerksamtkeit auf die Theorie des Heidelberger Ägyptologen Jan Assmann, der die erste wichtige Monographie zu dem Thema kulturelles Gedächtnis vorgelegt hat. Assmann zufolge ist die Vergangenheit nichts ,an sich“ Existierendes. Kein in sich geschlossenes Ganzes und auf alle Zeiten Unveränderliches, das es mit „objektiven“ Methoden frei $\mathrm{zu}$ legen gilt. Sie ist eine Konstruktion späterer Generationen, die sich ,ihre“ eigene Vergangenheit schaffen. ${ }^{1031}$

Das Bild der Vergangenheit, das durch die Autoren bzw. die Erzähler des $R H$ produziert wurde, unterscheidet sich zu der historischen Wirklichkeit. Dort erlangten die iranischen Persönlichkeiten eine völlig andere Stellung als in vorislamischen Zeit. Z.B. Zarathustra, der Gründer der iranischen Nationalreligion, wurde als Magier dargestellt. Der heidnischen Welteroberer Alexander den Großen, wurde als Muslim und Ḥamzes Vorbild präsentiert. Rostam, Nationalheld aus der vorislamischen Zeit, wurde als wahrer Muslim bezeichnet.

Nun stellt sich die Frage wie dies zustande kam. In der Betrachtung der Tätigkeit der iranischen Erzähler im Mittelalter und ihrer Auswirkungen in der iranischen Gesellschaft muss darauf aufmerksam gemacht werden, dass der Erzähler auch unter den Einflüssen der

\footnotetext{
${ }^{1028}$ Harmening, Dieter: Zauberei im Abendland, Würzburg: Königshausen und Neumann 1991, S. 15.

${ }^{1029}$ Vgl. al-Ḥoseini al-Madani al-Tatavi, 'Abdal ar-Rašid: Farhang-e Rašidi, Bd. 1, Teherān o.J., S. 779.

${ }^{1030}$ Anonymus: $Q H$, Bd. 2, S. 527-530.
} 
unterschiedlichen gesellschaftlichen Veränderung stand. Im Mittelalter gab es große Veränderung auf dem Gebiet der Religion. Des weiteren ist der politische Druck auf die Iraner gestiegen wodurch sich das individuelle Bewusstsein der Menschen verändert hat und es zu einem Wertewandel kam.

In diesem Zusammenhang können wir eine Theorie von Levi-Strauss anführen, derzufolge Gesellschaften, die Geschichte einfrieren wollen, die sogenannten „kalten Gesellschaften“ sind und solche, die eine Veränderung in der Geschichte zulassen, die sogenannten „heißen Gesellschaften“" sind. ${ }^{1032}$

In der iranischen Gesellschaft finden auf unterschiedlichen Ebenen sich stark voneinander unterscheidende Entwicklungen statt. Sie ist deshalb als eine heiße Gesellschaft anzusehen.

\subsubsection{Koranische Persönlichkeiten}

Nichts hätte einer traditionellen Religion ferner gelegen als die Angst, falsche Götter anzubeten. Ihre ganze Sorge galt vielmehr der Gefahr, eine wichtige Gottheit zu vernachlässigen. Die religiösen Erzählungenwollen mit Hilfe der kontrapräsentischen Wahrheit, sich im Gedächtnis der Gläubigen festigen um damit zugleich auch alte Traditionen vergessen zu machen, die nun als Heidentum abgestempelt werden. „Die Erinnerung der monotheistischen Wahrheit erfordert das Vergessen der polytheistischen Unwahrheit.“1033 Diese falschen Götter haben jedoch den Vorzug und die Verführungskraft der natürlichen Evidenz, die die Wahrheit der Offenbarung manchmal abgeht. Es handelt sich um die Götter dieser Welt, die von den monotheistischen Religionen, dem Judentum, dem Christentum und dem Islam radikal entzaubert wird.

\section{Namrud}

Namrud ist ein altorientalischer, im Tanach, in der Bibel und im Koran erwähnter Held und König. In der Regel geht man davon aus, dass es sich um eine Sagengestalt handelt, in der die unterschiedlichen Mythen und historischen Reminiszenzen zu einer archaischen Figur der Dichtung verschmolzen ist.

Mit ihm erfolgte die Aufnahme einer semitischen mythisch-legendären Gestalt schon in der vorislamischen Zeit. Angeblich war nämlich Namrud für die Iraner schon in der vorislamischen Zeit bekannt. ${ }^{1034}$ Nach Widengren gibt es eine Verbindung zwischen

${ }^{1031}$ Assmann, Jan: Das kulturelle Gedächtnis, S. 15-25.

${ }_{1032}$ Zitiert nach: Assmann, Das kulturelle Gedächtnis, S. 68.

${ }^{1033}$ Assmann, Jan: Religion und kulturelles Gedächtnis, München 2000, S. 74.

${ }^{1034}$ Widengren, Geo: Iranisch-semitische Kulturbegegnung in partischer Zeit, in: Arbeitsgemeinschaft für Forschung des Landes Nordrhein-Westfalen Geisteswissenschaften, Heft 70, Köln und Opladen 1960, S. 42. 
Zarathustra und Namrud. ${ }^{1035}$ In der Quelle wird erwähnt, dass Namrud als erster über Babylon herrschte und aus dieser von ihm erbauten Stadt zu den Persern übersiedelte und diese die Feueranbetung lehrte. ${ }^{1036}$ Im Buch al-Fïhrist wird gesagt, dass es ein Pahlavi-Buch gab, das von Namrud, dem König von Bābel, handelte. ${ }^{1037}$

Der Typ des aufsässigen Gewaltherrschers der sich gegen Gott und seine Gesandten wendet, findet sich oft in der Geschichte des Korans wieder. Im Koran wird Namrud b. Kan‘ān als mächtiger Götzenanbeter und Widersacher Abrahams dargestellt. ${ }^{1038}$

Der koranischen Erzählung nach kündigen Namruds Sterndeuter ihm an, dass ein Kind geboren werde, das seine Herrschaft stürzen und die Götzen zermalmen werde. Deshalb befiehlt Namrud alle Neugeborenen zu töten. So wird Ebrāhīm als einer der Sagenhelden, seit seiner Geburt verfolgt. ${ }^{1039}$ Später als Erwachsener, verkündet Ebrāhīm ihm seine Botschaft und lädt Namrud ein, den richtigen Weg (zum Islam) zu wählen. Namrud aber weigert sich, woraufhin Allāh eine Fliege durch die Nase in seinen Kopf (Stirnhöhle) fliegen lässt und Namrud wird 40 Tage gequält, bis er stirbt. ${ }^{1040}$

Er ist der Überlieferung nach der erste Machthaber auf Erden. Über ihn berichtete at-Ṭabari:

„Der erste König, welcher über den Osten und Westen der Erde herrschte, war

Namrūd b. Kanaan (Kana‘̄ān) b. Kusch (Kūš) b. Sām b. Nūḥ. “1041

Einer Nacherzählung zu folge hat sich Namrud selbst zum Gott erklärt und lässt sich als Gott verehren. Um Allāh zu stürzen, baut er einen Turm. Er lässt sich von Adlern in einer Sänfte in den Himmel tragen. Dort schießt er, um Gott zu töten, einen Pfeil ab, der blutig zu ihm zurückkommt, woraufhin er grau und alt auf die Erde zurückstürzt. ${ }^{1042}$

Einer anderen Legende zufolge: „... wurde Nimrod so anmaßend, dass er sich für einen Gott hielt. Iblis erschien dem König in Gestalt eines alten Mannes. Er stellte ihm dar, dass Zauberei und Wahrsagekunst besser als Sternenkunde seien, und lehrte ihn beides. Zuletzt redete er ihm ein, dass ein König von seiner Größe unbedingt eines eigenen, neuen Götzen bedürfe. “1043

\footnotetext{
${ }^{1035}$ Ebd. S. 46.

${ }^{1036}$ Ebd. S. 43.

${ }^{1037}$ Ibn an-Nadìm: al-Fïhrist, Nachdruck Bairut 1966, S. 306.

${ }^{1038}$ Koran, Sure. 21,73.

1039 an-Neišāburi, Abu Bakr 'Atiq: Qeṣaṣ-e qor’ān-e mağid, S. 71-73.

1040 an-Neišāburi, S. 57.

1041 at-Tabari, Bd. 1, S. 234.

1042 Samisā, Farhang-e talmị̄āt, S. 580.

1043 Schützinger, S. 69-70.
} 
Im $R H$ ist Namrud ein tyrannischer Herrscher, der sich als Gott verehren lässt. Er hat an seinem Hof 2000 Hexen. Balinās (Apollonios gest. um 120 n. Chr.), ${ }^{1044}$ eine dieser Hexen, erschafft mit Hilfe der Zauberei für ihn sieben Himmel (5/1034). Zomorrod gelangt auf seiner Flucht an den Hof des Namrud. Hamze verfolgt ihn bis dorthin und verlangt von Namrud, ihm Zomorrod zu übergeben. Dieser aber weigert sich. Später geraten diese zwei großen selbsternannten Gottheiten in Streit, den Namrud für sich entscheidet. Daraufhin erkennt Zomorrod seine Gottheit an. Schließlich gelingt es 'Amr den Palast im Himmel zu verbrennen und Hamze besiegt Namrud im Kampf (5/1039-1046).

\section{Pharao}

Dem Koran zu folge hat sich der Pharao (arab. Fir`awn) selbst zum Gott erklärt. ${ }^{1045}$ Im Traum wird ihm geweissagt, dass ein Kind geboren werde, das König sein werde, und das der Prophet Mose zusammen mit seinem Volk aus dem Land des Pharao führen werde. Daraufhin lässt der Pharao den Propheten Mose und seine gläubigen Anhänger unbarmherzig verfolgen. Dennoch gelingt ihnen die erfolgreiche Flucht aus Ägypten.

Im $R H$ ist Fir'awn (pers. Fer'oun) König von Fer'ouniye. Die Astrologen sagen Fer'oun vorher, dass sich in Ḥamzes Lager zwei junge Prinzen namens Rostam und Badi` al-Molk befinden, die Fer'oun und sein Reich vernichten werden. Fer'oun versucht nun die Kinder mit der Unterstützung seiner Hexen zu finden. Diese finden und entführen Badi` al-Molk und beabsichtigen ihn zu töten. Der Prinz wird aber rechtzeitig von seinen Getreuen befreit und kämpft nun seinerseits gegen die Hexen und tötet sie (7/1142-1144). Später kämpft der Prinz Badi` al-Molk erfolgreich gegen Fer`oun, besiegt und tötet ihn.

\footnotetext{
1044 Apollonios von Tyana (pers. Balinās; gest. um 120 n. Chr.), war ein antiker griechischer Philosoph. Er stammte aus der Stadt Tyana in Kappadokien und verbrachte sein Leben umherziehend und lehrend im Osten des Römischen Reichs. Seine außergewöhnliche Persönlichkeit und seine philosophische Lebensweise beeindruckten seine Zeitgenossen. Um sein Leben bildeten sich zahlreiche Legenden. Schon in der antiken Zeit betrachtet man ihn als Magier. Arabischen Autoren im Mittelalter kannten ihn. Sie nannten ihn Balīnüs (oder auch Balīnās oder Abulüniyūs). Sie betitelten ihn als „Herrn der Talismane“ und schrieben ihm die Errichtung von Standbildern zu, die die Städte magisch vor Unheil bewahrt hätten. Er wurde auch als Meister der Alchemie genannt und er besaß verborgenes Wissen. Die bekannteste und umfangreichste unter seinem Namen verbreitete Schrift war das „Buch über das Geheimnis der Schöpfung“, eine umfassende naturphilosophische Erklärung der Beschaffenheit des Universums. Der damit verknüpften Legende zufolge hatte Balinus dieses Buch in Tyana in einer Höhle entdeckt. Siehe: Weisser, Ursula: Das „Buch über das Geheimnis der Schöpfung “ von Pseudo-Apollonios von Tyana, Berlin 1980, S. 1-8; S. 2241. Aus dem Moğmal at-Tawārih wa al-qeșaș erfahren wir, dass er ein Waisenkind war und seine Mutter ihn zu einem Tempel brachte. Er blieb dort und lernte die Wissenschaft. Eines Tages konnte er durch eine List das Zauberbuch des Teufels in seinen Besitz bringen. Siehe: Anonymus, Moğmal at-Tawãrih wa alqeșaș, S. 129-133. Im Buch Eskandar-nāme von Neẓāmi ist er Alexanders Ratgeber. Siehe: Ṣafavi, S. 211-212. Im $R H$ wird er auch als Hexer vorgestellt.

${ }^{1045}$ Koran, Sure. 28, 38.
} 


\section{Šaddād}

Eine andere Figur aus dem Koran ist Šaddād, dessen Gottesfeindlichkeit und die von ihm erbaute paradiesische Siedlung ist in den islamischen Erzählungen sehr berühmt. Nach einer Überlieferung hatte 'Ādd zwei Söhne: Šaddād und Šadīd. Nach dem Tode Šadīds wird Šaddād zum König ernannt. Als er dann vom Paradies hört, lässt er in der Nähe Yemans eine Stadt erbauen, die ein Abbild des Paradieses sein soll. ${ }^{1046}$

Eine Geschichte mit anderem Inhalt wird im $R H$ beschrieben. Abu 'Amr Šaddād b. 'Ād ist ein König von Abessinien und ein treuer Vasall des Perserkönigs. Šaddād kommt nach Madā'en um den Perserkönig zu besuchen. Dort verliebt er sich in Mehrenegār, was diese sehr verärgert und sie verletzt ihn an empfindlicher Stelle. Auf einem Jagdausritt Šaddāds mit dem Perserkönig begegnet ihnen ein brüllender Löwe. Auf die Anfrage des Perserkönigs wer den Löwen töten könne erklärt sich Šaddād dazu bereit; woraufhin der Perserkönig ihn mit mit der Bemerkung brüskiert, dass das doch eher Männersache sei, und nicht die Sache eines Mannes, der keinen Penis habe. So verletzt der Perserkönig Šaddāds Ehre und dieser verlässt die Stadt und beschließt Rache zu nehmen. Nach einiger Zeit überfällt er Madā'en, nimmt den König Anōširvān gefangen und entführt ihn nach Abessinien. Ḥamze erfährt vom Vorgefallenen, zieht nach Ḥabaše (Abessinien) und rettet den König (2/230-243).

Im $R H$ ist seine Rolle nicht vergleichbar mit jener in der koranischen Geschichte. Im $R H$ ist keine Rede von seinen gottgleichen Eigenschaften und seinem von ihm selbst erschaffenen Paradies.

Der Koran steht im Mittelpunkt des Islams und sein Einfluss auf eine muslimisch geprägte Gesellschaft und das religiöse Wertempfinden der Muslime ist unbestritten. Die Frage nach Sinn und Sorge der muslimischen Gesellschaft innerhalb der Dimensionen von Vergangenheit, Gegenwart und Zukunft war eine der wichtigsten Aufgaben der Erzähler. Die Erzähler versuchten durch koranische Erzählungen das Interesse der Menschen zu erwecken, damit sie sich ihrem Weg mit dem Koran und der Vernunft anschließen.

Das Hören der prophetischen Botschaft, aus den bekannten koranische Passagen, war und ist in der islamischen Welt immer beliebt. In Bezug auf Prophetenerzählungen kommen im Koran die negativen Bilder vom tyrannischen Herrscher wie Namrud, Fer'oun und Šaddād, die als Gottesfeinde schon in frühislamsicher Zeit in die Umgangssprache eingeflossen sind, vor. Dort wurden sie als Erzfeinde Gottes dargestellt, die auf verschiedene Weise von Gott

$\overline{1046}$ Anonymus: Tağārib al-umam fĩ al-ahbār mulūk al-‘arab wa-'I-‘ağam, S. 61, Neẓāmi, Eqbāl-nāme, S. 1271-1272. 
bestraft wurden. Später fanden solche Erzählungen Eingang in das kollektive Gedächtnis der Muslime. Sie spielten bei den Muslimen eine wichtige Rolle als Antagonist und Hassobjekt. Im Jahr 1258 wurde Baġdād von den Mongolen unter Hülegü erobert. Die Mongolen töteten den letzten Kalifen al-Musta'sim bi-'llah (1212-1258). Infolgedessen vernichteten sie das Zentrum der religiösen Macht. Besonders hatte Hülegü die Gelehrte und Erzähler, die als Träger der islamischen Kultur in der Gesellschaft tätig waren, vernichtet. ${ }^{1047}$ In ihrem Terretorium wuchsen verschiedene Religionen wie Judentum, Christentum und Buddhismus weiter an und konnten ihr religiöses Leben sorglos weiterführen.

Geschichtlicher Rückblick über das Gedenken der Iraner zeigt uns, dass die Iraner unter dem Druck des verlorenen mongolischen Krieges, der Sorgen um das tägliche Überleben und unter politischer und religiöser Verwirrung leiden mussten. In dieser wirren Zeit im Iran hatten viele von ihnen ihr Glück in anderen Religionen gefunden. Dazu zählt nicht der Islam. Daher hat sich in der iranischen Gesellschaft allmählig eine soziale Kluft gebildet und nun kam es zu einem breiten Wechsel der Perspektiven in der Welt der Religion.

Später in der Șafavidenzeit war die Bedrängnis überstanden und eine gewisse Beruhigung eingetreten. Man begann sich wieder ethischen Verpflichtungen und kulturellen Belangen zu öffnen. So hatten sich in der damaligen Zeit die iranischen Erzähler, die immer das Andenken an die Werte und Normen bewarten, wieder an dem Kampf gegen falschen Glauben gewidmet. Sie erziehten ihr Zuhörer systematisch zu Hass auf alle, die nicht islamischen Glaubens waren und deklassierten die Ungläubigen zu Menschen zweiter Klasse. Die Ungläubigen, die andere Ideologien oder Religionen hatten, stellten sie als eine einzigartige Bedrohung für den Islam und muslimische Gesellschaft dar, die bekämpft und niedergerungen werden sollte. Gegenüber der nicht islamischen bzw. nicht schiitischen Einwohner waren sie genadenlos. Um ihre Ziele zu erreichen, benutzten sie die koranischen Erzählungen.

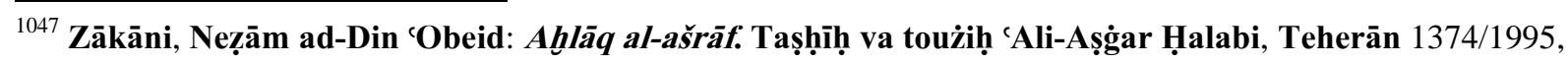
S. 139. 


\subsubsection{Traditionen und Pflichten}

Die vorliegende Untersuchung versucht zu zeigen, dass das $R H$ auch als nützliche Quelle für die Sozialgeschichte des Mittelalters im Iran dienen kann. Es kann als wertvoller Fundus dienen, um die Erforschung, von Vorurteilen, von Werturteilen, von Konzeptionen gesellschaftlicher Ordnung, von Denkschemata des Zeitalters und dergleichen mehr aufzuzeigen. Hierbei ist es wichtig zu beachten, dass deren Entwicklung unterschiedliche Gewichtung und Ausbreitung sowie Präsentation gegenüber etwa konstant bleibenden Elementen, herauszuarbeiten ist, und zwar unter Berücksichtigung der unterschiedlichen Zielsetzungen und Voraussetzungen der Verfasser.

Das Buch $R H$ berichtet nicht nur über Kampf, Liebe, Festlichkeit und List, sondern es vermittelt auch einen tiefen Einblick in die Kultur und das Alltagsleben im früheren Iran. In der volkstümlichen Literatur wie dem $R H$ findet man Informationen, die nicht Bestandteil der offiziellen Geschichtsschreibung sind. Es beschreibt Situationen, wie sie sich tatsächlich abgespielt haben könnten. Zwischenmenschliche Beziehungen in der damaligen Zeit werden dargestellt, ihr Glaube, ihre ethischen Grundsätze, ihre Essgewohnheiten, ihre Freizeitgestaltung, Tanz und Musik bis hin zum Sport werden in allen Einzelheiten beschrieben.

\subsubsection{Gottesbild und Glaube}

Im $R H$ stehen keine theologischen Abhandlungen im eigentlichen Sinne, sondern es wird dargestellt, was die Menschen wirklich glauben und wie sie den Glauben umsetzen. Um eine Kultur und Gesellschaft betrachten zu können, sind diese Aspekte des Glaubens im Alltag sehr wichtig.

Ein Aspekt in jeder Religion ist das Gottesbild, das die Menschen haben. Die Attribute Gottes werden im $R H$ sehr ausführlich dargestellt. Unter ihnen sind die wichtigsten: Gott ist der Barmherzige, der Gütige, der Hochheilige, der Friedensstifter, der Unterstützer, der Beschützer, der Mächtige, der Gewaltige, der Stolze, der Schöpfer, der Gestalter und der König. ${ }^{1048}$

Das überwältigende Gefühl von Gottes allumfassender Weisheit, Macht und Barmherzigkeit spiegelt sich ebenso im $R H$ wider. Dort wird Gott meistens als qāäi al-hāăğāt (der Richter der Wünsche; 1/166/6), ạ̣ad-e qadim (der Einzige, der sehr alt ist; 3/351/10), hodāvand-e zamin o zamān (der Gott der Erde und Zeit; 4/648/12) und als qāder-e qodrat-namāa (der Mächtige, der Machtzeigende; 1/120/25) bezeichnet. 
Alle Helden haben unbedingtes vollkommenes Gottvertrauen. ${ }^{1049}$ Dieses Vertrauen ist berechtigt, weil Gott sie in schwierigen Situationen niemals allein lässt. In der Not wenden sie sich an Gott und rufen seine Attribute an. Die Helden glauben, dass der Wille Gottes über Allem steht (1/59/11). Als Moqbel einmal von Wegelagerer überfallen wird und mit ihnen kämpfen muss, wird er von ihnen schwer verwundet. Moqbel kniet daraufhin nieder und betet zu Gott um Hilfe, die ihm dieser in Form einer Armee erfüllt (1/120).

Im Islam ist der Mensch Knecht Gottes und Diener Gottes zugleich. Der Islam fordert den absoluten Gehorsam gegenüber Gott. Sie haben gewisse religiöse Pflichten und sind aufgefordert, für den Dienst am Herrn immer verfügbar zu sein. Die religiösen Pflichten werden als arkān al-eslām (Stützen des Islams) bezeichnet. Alle Muslime sind verpflichtet, das Glaubenbekenntnis anzuerkennen (参hāda), dass es einen Gott gibt und Moḥammad der Gesandte Gottes ist. ${ }^{1050}$

Im $R H$ fordert Ḥamze die Ungläubigen auf, Allāh als einzigen Gott anzuerkennen und keine anderen Götter neben ihm zu haben. Es ist seine heilige Pflicht, dem Glauben zur Ausbreitung zu verhelfen bzw. ihn zu verteidigen. Die Missionierung erfolgt nicht durch Diskussionen über den Glauben, sondern dadurch, dass Ḥamze zuvor Ungläubige durch Kampf, Befreiung von Dämonen, Liebe und der Erfüllung spezieller, geforderter Aufgaben, wie z.B. einen Drachen zu töten, zum wahren Glauben bekehrt hat. Zur Annahme des wahren Glaubens müssen die zuvor Ungläubigen nur noch das Glaubensbekenntnis des Islams sprechen: dies ist dann der Akt der Bekehrung im $R H$.

Asad begegnet zwei Brüdern namens Soheyl-e huunāšām und Komail-e moštzan, die sich von einem Drachen bedroht fühlen. Sie sagen ihm: „In diesem Gebirge gibt es einen Drachen, der uns schadet. Wenn du ihn tötest, werden wir uns zum Islam bekehren.“ Asad tötet den Drachen und so bekehren sich die zwei Brüder zum Islam (5/833).

Gebet

Im Alltagsleben der Muslime beginnt jede Handlung ob im Alltagsleben oder Geschäftsleben ob in der Politik oder wirtschaftlichen Aktivitäten mit der bismi lāhi' 'r-raḥmān 'rr-raḥ̄m. Daneben gibt es das tägliche Gebet (arab. salāt, pers. namāz). Dies Gebet ist oberste Pflicht

\footnotetext{
${ }^{1048}$ Montgomery Watt u. Welch, Alford T.: Mohammad und die Frühzeit, islamisches Recht-Religiöses Leben, in: Der Islam I, Stuttgart [u.a.] 1980, S. 221.

${ }^{1049}$ Eines der wichtigsten Attribute muslimischer Frömmigkeit ist Tawakkol (vollkommenes Gottvertrauen und Hingabe an ihn). Gott, in seiner Absolutheit, ist der einzig Wahre und die Menschen können sich ganz auf ihn verlassen. Siehe: Dādbe, Aṣgarar u. Rafi'i, 'Ali: Tawakkol, in: Dã'rat al-ma‘ärif-e tašayyo' Bd. 5, Teherān 1375/1996, S. 153-155.

${ }^{1050}$ Vgl. Anșāiri, Moḥammad-Reżā: Šahādat, in: Dā'rat al-ma‘ārif-e tašayyo ’ Bd. 10, Teherān 1383/2004, S. 97-101, hier S. 97.
} 
für alle volljährigen Muslime und muss zu festgelegten Zeiten fünfmal am Tag in der Richtung der Ka`aba verrichtet werden.

Um die Gebete in der richtigen Weise zu vollziehen, sind spezielle Vorbereitungen nötig. Der Gläubige muss vor dem Gebet eine rituelle Teilwaschung (wuḍ $)$ ) vornehmen. ${ }^{1051}$ Danach beginnt er mit der Anrufung Gottes. Dann folgt das Glaubensbekenntnis und anschließend betet man die rak'as (Zyklen), die je nach Tageszeit unterschiedliche Länge haben.

Wenn die Helden im $R H$ ein spezielles Problem haben, verrichten sie ein besonderes Gebet. Danach bekommen sie durch einen Traum die Lösung für ihr jeweiliges Problem mitgeteilt.

Die Iraner kennen ein besonderes Gebet mit zwei Zyklen (namāz-e hăğăat). Ist man in einer Notlage, verrichtet man dieses Gebet und ihrer Vorstellung nach hat dieses Gebet einen großen Effekt. Als 'Amr die Blätter des Ayubs (Hiob) pflücken will, hat er Angst vor der schrecklichen Stimme des Baumes. Er verrichtet namāz-e hāăğat und kann unbehelligt die Blätter pflücken (2/219). Ḥamze als Vorkämpfer des Islams verrichtet regelmäßig die Ritualgebete (1/139).

\section{Bittgebet}

Man erhofft Hilfe und Schutz von Gott und er hilft all denen, die auf ihn hoffen. Der Mensch hat die Mittel, durch Worte und Handlungen die Gnade Gottes zu gewinnen. Solche Elemente sind zum Teil volkstümlich und zum Teil sind sie durch ḥadît und Gebetsbücher der Muslime belegt.

Einzelgebete nennt man $\boldsymbol{d} \boldsymbol{u} \boldsymbol{\varsigma} \overline{\boldsymbol{a}}$. Das $\boldsymbol{d} \boldsymbol{u} \boldsymbol{\varsigma} \overline{\mathbf{a}}$ ist die persönliche Form des Bitt- oder Dankgebets im Islam. „Das Leben des traditionellen Muslim ist von seiner Geburt bis zu seinem Tod von einer Vielfalt von Gebeten, Fleh- und Bittgebeten durchdrungen, die alle $\boldsymbol{d} \boldsymbol{u}^{\boldsymbol{c}} \overline{\boldsymbol{a}}$, „Gebet“", „Anrufung“ (Gottes), genannt werden.“" ${ }^{1052}$ Allgemein gilt, wer Gott in seiner Not anruft, wird erhört werden. Goldzieher schreibt:

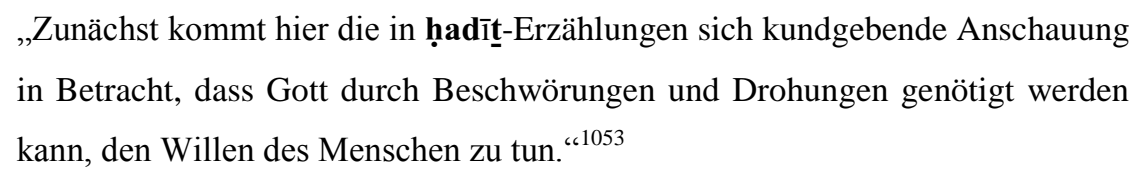

Es ist wichtig zu wissen, dass ein Bittgebet sowohl in freier Form vorgetragen werden kann, indem man Gott seine Wünsche äußert als auch durch das Rezitieren koranischer Verse.

\footnotetext{
${ }^{1051}$ Koran, Sure. 5,6.

${ }^{1052}$ Montgomery Watt, W u. Welch, Alford T: Mohammad und die Frühzeit, S. 287.

1053 Goldziher, Ignaz: Zauberelemente im islamischen Gebet, in: Orientalische Studien, Bd. 1, hrsg. von Carl Bezold, Giessen 1906, S. 304.
} 
Der Terminus für das Bittgebet im religiösen Sinne ist im $R H$ dar monāğăàt šodan, diese Wörter kommen häufig dort vor. Wenn das Gebet erhört worden ist, sagt man be hadaf-e ağābat resid (wortwörtlich: Der Pfeil des Gebetes hat sein Ziel getroffen; 5/785).

Das $\boldsymbol{d} \boldsymbol{u} \boldsymbol{\boldsymbol { c }} \overline{\boldsymbol{a}}$ ist mit bestimmten empfohlenen Bedingungen und Verhalten verbunden, um die größtmögliche Aussicht auf Annahme des Erbetenen sicher zustellen. Dazu gehört die rituelle Waschung und die richtige Gebetsrichtung. Man nimmt aus Respekt die Kopfbedeckung ab, formt mit den Händen eine Fläche und hebt sie zum Himmel empor (4/573).

Im $R H$ ist das $\boldsymbol{d} \boldsymbol{u}_{\boldsymbol{c}}^{\boldsymbol{c} \boldsymbol{\boldsymbol { a }}}$ ein starkes Bittgebet zur Rettung aus einer verzweifelten Lage, gegen Hoffnungslosigkeit und bietet gleichzeitig Zuversicht und Gottvertrauen. Auffällig sind im $R H$ Einzelgebete und Bittgebete mit dem Ziel, Verfolger, Unterdrücker und Feinde mit Hilfe des Gebetes zu verjagen und zu töten. Der fromme Krieger ist während des Krieges zu Zeiten großer Bedrängnis aufgefordert, Gott zu beschwören, dass er den Muslimen zum Sieg verhelfe. Strothmann gibt uns daher zu bedenken:

„Noch bedenklich ist die Wirksamkeit jener Gebete, die auf die Vernichtung der Feinde
gehen. “ 1054

Die Helden gehen in die Moschee und beten dann drei Tage lang. Danach begegnen sie im Traum einem Heiligen, der ihnen übernatürliche Kräfte verleiht. Wenn Hamze auf einem Kriegszug ist, verrichtet er immer vor dem Beginn des Kampfes das Ritualgebet. Mit Hilfe dieses Gebetes kann er den Dämon besiegen.

Man kann auch für Andere ein $\boldsymbol{d} \boldsymbol{u} \boldsymbol{\top} \overline{\boldsymbol{a}}$ formulieren. Dies Gebet für andere Menschen hat unter gewissen Umständen die besondere Fähigkeit, in wirkungsvoller Weise diese Menschen bei ihren Aktionen zu unterstützen und zu beflügeln. Durch das Gebet wünscht man ihnen Wohlstand, ein langes Leben, Zufriedenheit usw. So heißt es beispielsweise: pir šavi (Mögest du alt werden; 1/14), ellāhi barhordār šavi (Gott möge mit dir zufrieden sein; 5/948).

Besondere Bittgebete werden oft mit einem nazr (Gelöbnis) verbunden. Man verspricht Gott, wenn sein Gebet erhört werde, macht man etwas zum Wohl der Muslime.

Im $R H$ erfahren wir vom Perserkönig, dass er nachdem seine Tochter eine gefährliche Situation unbeschadet überlebt hat, viel Geld für den Feuertempel spendet, um seine Tochter künftig vor solchen Situationen zu bewahren (1/57).

Ein weiterer wichtiger Bestandteil der Glaubenswelt eines frommen Menschen ist der Segen für den Propheten, um eine besondere Gnade zu erhalten. „Der Segen über ihn kann den Gläubigen seinen Anblick schenken und auch dazu führen, dass man ihn im Traum

${ }^{1054}$ Strothmann, S. 118. 
erblickt.“1055 Das șalawāt drückt die Verehrung und Liebe gegenüber dem Propheten und dessen Familie aus. Nach islamischer Auffassung macht man damit auch Gott eine Freude. Der fromme Muslim spricht den Namen des Propheten niemals aus, ohne șalawāt zu sagen. Diese Formel lautet: „Oh Gott, segne Moḥammad und seine Familie“.

Als Ḥamze in Eskandars Wasserwirbel allein ist, kommt der Prophet Elyās, um ihm zu helfen. Er sagt zu Ḥamze: „Sprich sieben Mal das șalawāt und schließe deine Augen“ (1/69).

Der wichtigste religiöse Ausspruch eines Muslims im Alltag ist enšā’allāh (so Gott will). Der Wille Gottes spielt bei jedem Tun des Gläubigen die entscheidende Rolle.

Nach einer Überlieferung sitzt der Prophet Soleimān auf seinem Thron und sagt: „Ich werde heute Abend 70 Frauen beiwohnen, damit jede einen Sohn zur Welt bringe, die dann auf dem Gottesweg den heiligen Krieg führen sollen. “ Soleimān versäumt es enšāàallāh zu sagen. So wird außer einer einzigen keine seiner Frauen schwanger. Jene aber bringt ein behindertes Kind zur Welt. ${ }^{1056}$

Eine ähnliche Situation wird auch im $R H$, beschrieben. Hamze wird von den Feen in das Gebirge Qāf entführt. Ḥamzes Feinde, Zubin und Hormoz belagern noch immer Mekka. In Mekka wird Ḥamze schmerzlich vermisst und seine Kriegerschar verlässt die belagerte Stadt. 'Amr fragt Bozorgmehr um Rat und dieser weissagt ihm aus dem Buch des Ğāmāsb, dass Ḥamze erst in achtzehn Jahren nach Ṭanğe zurückkehren werde, weil er beim Antritt seiner Reise vergessen habe enšãăallāh zu sprechen. Er müsse deshalb statt der versprochenen Anzahl von Tagen die gleiche Zahl an Jahren dort bleiben (1/138).

Die traditionelle islamische Kultur und damit auch das tägliche Leben, die Sitten und die islamischen Gebräuche sind im $R H$ deutlich spürbar.

Ein Beispiel aus dem $R H$ sei hier kurz angeführt: Eine Stimme sagt zu Hamze: „Steh auf! Am Fuße des Berges gibt es einen Brunnen. Du musst die rituelle Waschung und zweimal das Gebet verrichten, damit du Ğebrā’̄ìl besuchen kannst“ (1/73). Der Held wäscht sich, um dem Engel rein gegenüber treten zu können.

Nach dem Beischlaf und vor dem Besuch einer heiligen Stätte ist z.B. eine gosl (Ganzwaschung) statt der Teilwaschung erforderlich.

\section{Schicksalsglaube}

Der Schicksalsglaube ist in der iranischen Geistesgeschichte sehr stark ausgeprägt. Er hat sich vor allem aus der zurvanitischen Religion entwickelt. In dieser Religion ist die oberste

\footnotetext{
1055 Schimmel, Und Muhammad ist sein Prophet, S. 84.

${ }^{1056}$ Mağlesi, Bd. 1, S. 361.
} 
Gottheit die Zeit. ${ }^{1057}$ Der Zurvanismus vertritt eine deterministische Anschauung und begründet diese mit mythischen Argumenten. Mit der Entwicklung eines mehr abstrakten Denkens wird aber die religiös-mythische Einkleidung abgelegt und nur der nackte Determinismus als konsequenter Schicksalsglaube bewahrt. Es ist auch wahrscheinlich, dass der dem alten Hoch-gottglauben innewohnende Schicksalsglaube sich vom Zervanismus unabhängig verhalten und als Ausgangspunkt gedient hat. Dass der Himmel als Schicksal eine so bedeutende Rolle spielt, spricht für diese Annahme. Darüber schreibt Widengren:

„Hinter dem griechischen Wort Chronos „Zeit“, verbirgt sich wohl der
avestische Name Zervan. Wie schon angedeutet, findet sich dieser ja an
gewissen Stellen im Avesta. Auch wenn diese wenig über sein Wesen
aussagen, so sind sie doch nicht nur darum wichtig, weil sie bekunden, dass
Zervan eine von den Magiern verehrte Gottheit war, sondern auch deshalb, weil
sie besagen, dass Zervan eine schicksalsentscheidende eschatologische Rolle
spielt.“1058

Zurvanitische Ideen blieben in der Tat nicht ohne Einfluss auf den Islam. So ist die ewige Zeit, die unaufhörliche Drehung des gestirnten Himmels, das čarh̆-o falak (Rad der Sphäre), wie die persischen Dichter später sagten. ${ }^{1059}$ Aber sie hatten damit vor allem das „Schicksal“ gemeint. Auch die sich wandelnde Zeit, zamāne oder rüzegãa, an die man als mit der Bewegung des Himmelsgewölbes in Zusammenhang stehend denkt, wird als schicksalbestimmend bezeichnet. ${ }^{1060}$

Im $R H$ begegnen wir sehr starkem Glauben an Vorherbestimmung. Dort wird das Schicksal als eines Art von Gaukelei (falak-e šobade-bāz, der Himmel ist der Gaukler; 1/58) dargestellt. Die Zeit bzw. das Schicksal werden als sehr launisch geschildert. Wir lesen an einer Stelle, dass Ḥamze im Bezug auf das Schicksal zu seinem Kundschafter 'Amr sagte: Bābā ğān: dourān bā mā bad h̆ॅ̄āste hamiše meitalh o širin o govārā rā dar kām-e mā zahr nemode. (Lieber Bābā: die Zeit ist gemein zu uns und verwandelt den süßen oder bitteren Wein in unserem Mund zu Gift; 4/657).

Im Islam ist der Glaube an Vorherbestimmuung al-qaḍā und al-qadar ${ }^{1061}$ einer der Säulen (arkān) des Glaubens. „Der Glaube eines Muslims ist nicht vollständig, bis er nicht weiß,

1057 Christensen, Arthur Emanuel: L'Iran sous les Sassanides, ins Persische übersetzt. von Rašid Yāsami, Teherān 1375/1996, S. 217-228.

1058 Widengren, Die Religionen Irans, S.150-151.

1059 Ringgren, Fatalism in Persian Epics, S. 49ff.; 9ff; Ehlers, Jürgen: Die Natur in der Bildsprache des S̆āhnāme, Wiesbaden 1995, S. 196.

${ }^{1060}$ Ebd. S. 196.

1061 „Das arabische Wort, das mit Vorherbestimmung übersetzt wird, lautet al-qadar Der Begriff Vorherbestimmung drückt aus, dass der Allmächtige allen Dingen und Lebewesen mit Seinem Wissen eine Existenz verleiht und allem eine bestimmte Form, Lebensspanne, funktion, Mission und bestimmte 
dass das was ihn trifft, ihn niemals hätte verfehlen können, und dass das was ihn verfehlt, ihn niemals hätte treffen können. Alles geschieht nach dem Willen Allāhs und gemäß seiner Bestimmung. “1062

Qāren b. Fariborz nimmt Ḥamze fest, lässt ihn in eine Kuhhaut einnähen und an den 'Oqābin binden. Hamze, dem der Tod in den Augen geschrieben steht, meint, dass alles Gottes Wille ist und geduldig wartet, für seine Befreiung auf göttlichen Zeichen. Sein Freund 'Amr kommt zur Hilfe und will ihn befreien, Hamze aber lehnt seine Hilfe ab und möchte nicht aus dem Gefängnis fliehen; weil er bis zum bitteren Ende dort bleiben wollte. Endlich sieht er in seinem Traum, dass der Prophet Heżr, der ihm gesagt hat, dass sobald seine Feldherren dort erscheinen, er befreit wird. (2/311).

In dieser Geschichte finden sich bereits einige zentrale Elemente des Gedankengutes des islamischen Helden, vor allem die Standhaftigkeit, die aus seinem Glauben erwächst und die Kraft vermittelt. So hatte der große Ḥamze, der unter anderem als gläubiger Held bekannt ist, volles Vertauen in Gott und seinen Willen, der wichtiger ist als menschliche Wünsche. Was also unterscheidet den islamischen Helden signifikant von einem säkularen Helden wie Zomorrod ist.

\subsubsection{Derwischtum}

Im Laufe des 13. und 14. Jahrhunderts wurden im Iran, im Osmanischen Reich und in Indien zahlreiche Derwisch-Orden gegründet. In der Folge dieses Phänomens gab es einen ausgeprägten Wunderglauben, einen Gräberkult sowie auch Pilgerfahrten zu den nichtkanonischen Wallfahrtsstätten.

Immer mehr von ihnen, mit ehemals esoterischem Charakter, entwickelten sich zu wahren Volksbewegungen. Im einfachen Volk galten sie und ihre Führer als eigentliche Vertreter des islamischen Glaubens. Die Konvente, die Gräber und Sanktuarien der Derwische, bildeten die wesentlichen Orte an denen die Gläubigen ihre Religion praktizierten. Sie lehrten einen unkomplizierten mythischen țariqa (Pfad), auf dem der Gläubige durch Liebe zu Gott vorangetrieben würde und an dessen Ende das Verschmelzen der Seele mit Gott im Zustand höchster Ekstase stünde. ${ }^{1063}$ Massenveranstaltungen, Versammlungen und gemeinsame

Eigenarten gibt. Der Begriff weist aber auch darauf hin, dass Gott alles bis hin zum winzigsten Teilchen kennt und dass Sein Wissen Raum und Zeit in ihrer Gesamtheit umschließt, während Er Selbst außerhalb von Raum und Zeit steht." Siehe: www. Islam-auf-deutsch.de

1062 Übersetzung wurde von islamischen Zentrum Münster e.V. übernommen.

1063 „Die Theorien von fanā (Entwerden) und baqā (ewiges Leben in Gott), zentrale Themen des Sufismus, werden hier aus dem koranischen Kontext entwickelt.“ Siehe: Schimmel, Annemarie: Mystische Dimensionen des Islam, Köln 1985, S. 74. 
Gebete waren Merkmale des Derwisch-Ordens. ${ }^{1064}$ Insbesondere in der islamischen Mystik lehrten die Mystiker Techniken, wie das monotone Wiederholen religiöser Formeln, żekr (Gebet) sowie Musikhören und samā`(ekstatischer Tanz). Diese sollten Verzückungen und einen Zustand der Selbstvergessenheit hervorrufen, in dem eine Gotteserfahrung dem Menschen möglich sein sollte. ${ }^{1065}$ Diese nach islamischen Normen nicht verankerten Praktiken verliehen dem volkstümlichen Islam der Derwische seine typischen Züge. Die Derwische besaßen Segenskräfte, von denen eine Fülle frommer Legenden berichtet. ${ }^{1066}$ Nicht selten wird daher zu wenig gesehen, dass die Derwische die Leute in Notlagen unterstützten. ${ }^{1067}$ Für das wundersuchende Volk der Perser, hatten die Derwische eine große Bedeutung.

In der șafavidischen Zeit waren die Derwische im Grunde stets eine politisch loyale Gruppe. Sie fühlten sich eng mit den politischen Machthabern verbunden. ${ }^{1068}$ Anfangs nutzten die Șafaviden die mit dem Derwischtum verbundene Dynamik zur Erlangung der Macht. Als Esmācil I. im Jahr 1499 aus Lāhiğān zur Eroberung Persiens aufbrach, waren offenbar alle seine Gefolgsleute Șufis. Später versuchten die Șufis und ihre Führer holafãa, in den Streitigkeiten der verschiedenen Qizilbāš Stämme zu vermitteln, um für sich politische Macht zu gewinnen. ${ }^{1069}$

Seit der Regierungszeit des Šāh Tahmāsb gewann der schiitische Klerus nach und nach großen Einfluss. Dagegen haben die Derwische ihre politische Macht und die damit verbundenen Privilegien verloren und wurden als Ketzer bezeichnet. Die Meisten von ihnen wanderten nach Indien aus oder wurden im Iran vom Hof vertrieben und endeten als Bettler oder Wanderderwische. Ende des 20. Jahrhunderts (dem Tief und Endpunkt ihrer Entwicklung) gingen Derwische bettelnd von Tür zu Tür oder sie baten auf den Straßen um Almosen. ${ }^{1070}$

Das Wort Derwisch kommt im $R H$ häufig als „Armer und Bettler“ vor (2/214), was sie in der Realität der Entwicklung der Bruderschaft zum Schluss auch waren.

\footnotetext{
${ }^{1064}$ Vgl. Șafavi, Raḥimzāde: Zendegāni-ye Šāh Esmāị Ṣafavi, Teherān 1341/1962, S. 34.

${ }^{1065}$ Schimmel, Mystische Dimensionen des Islam, S. 458-459; vgl. Ṣafavi, Raḥimzāde: Zendegāni-ye Šāh Esmāiol Safavi, Teherān 1341/1962, S. 34.

${ }^{1066}$ Ibn Bazzāz, S. 295-341.

1067 Ebd.

1068 Ebd.

${ }^{1069}$ Falsafi, Bd. 1, 181-182.

1070 Vgl. Afšāri, Mehrān: Vasile an-nağāt, in: Fotovvatnāmehā va rasā’yel-e haksāriye, S. 291; D’Allemagne, H.: Du Khorasanau Pays de Bakhtyaris, Bd. 1, S. 244.
} 
Im $R H$ kommen auch die Rangordnung der Derwische wie mohtār oder pir (der Pol; 3/437), moršed (2/250) qalandar ${ }^{1071}$ (4/712), abdāl ${ }^{1072}$ (4/535) und ahis ${ }^{1073}$ (5/828) vor.

Die Zentren der mystischen Aktivitäten der Derwische hießen hā̄neqāh, takye ${ }^{1074}$ und zāviye (Winkel). ${ }^{1075}$ Solche Einrichtungen förderten die kulturellen und theologischen Bestrebungen. Sie wurden durch die islamischen Regierungen unterstützt oder von einflussreichen Wohltätern gegründet und unterhalten. Dort lernte eine große Anzahl von Novizen unter strenger Aufsicht die umfangreichen Regeln und Gesetze ihres Ordens. ${ }^{1076}$ Eine besonders wichtige Position nahmen die šaihs at-talim ein, die für die theoretische Unterweisung verantwortlich waren. Daneben gab es die šaih at-tarbiya, die für die praktischen Aspekte der Ausbildung der Novizen zuständig waren und sie während der gesamten Ausbildungszeit bgleiteten. ${ }^{1077}$

Eine wichtige Periode für das Gebetsleben war die čelle (vierzigtägige) Klausur, der sich der morid (Novize) unterziehen musste. ${ }^{1078}$ Der Jünger, der sich einem tariqat (Pfad) anschließen wollte, musste als Anfangspflicht 40 Tage in der takye niedere Arbeiten leisten.

Aus dem $R H$ erfahren wir vieles über die Sitten der Derwische in den takye. Dort werden einige Verhaltensregeln der Derwische detailliert beschrieben. Wenn ein Derwisch sich entschließt, einen Meister zu finden, der ihn noch weiter belehren soll, muss er im Gegenzug seinem Meister zur Verfügung stehen.

Diese Form der gegenseitigen Abhängigkeit wird auch in der Geschichte vom Dämon deutlich, der sich in der Gestalt eines qalandars auf den Weg macht. Er begegnet 'Amr, der sich die Gestalt eines Heiligen zur Verkleidung angelegt hat. 'Amr fragt den Dämon: „Akzeptierst du den hedmat-e kabir (großen Dienst) oder den hedmat-e sagir (kleinen Dienst)?“ Der Dämon fragt: „Was ist der kleine Dienst und was der große?“ 'Amr antwortet: „Der große Dienst dauert 40 Jahre und der kleine 40 Tage.“ Der Dämon antwortet: „Ich möchte den kleinen Dienst tun“ (3/499).

\footnotetext{
1071 Seit dem 13. Jahrhundert war qalandar (Kalender) die übliche Bezeichnung für wandernde Derwische, mythisch bewegte Personen, die der Welt entsagt hatten und, teils nur mit Fetzen bekleidet, vagabundierend lebten. Nach Zarrinkub ist der qalandar der weniger rigorose Mystiker, der sein Leben ohne Einschränkung genießt. Zarrinkub, ‘Abd al-Ḥosein: Donbāle-ye ğostoğu dar tasvvof-e Irān, Teherān 1362/1983, S. 359379; Schimmel, Annemarie: Mystische Dimensionen des Islam, Köln 1985, S.133.

1072 Abdāl-Derwische sind gleischzusetzen mit qalandars; es handelt sich um eine andere Bezeichung, die ab dem frühen 14. Jahrhundert nachweisbar ist. Die Abdāls waren in der Ṣafavidenzeit Bettelmönche. Siehe: Kaempfer, S. 111.

1073 Die Ahis waren eine Derwischgruppe in Kleinasien, die mit militärpolitischer Macht ausgestattet waren. Siehe: Teaschner, Ahīi, in: $E l^{2}$, Vol. I, London/Leiden 1960, S. 321-323.

${ }^{1074}$ Nașrābādi, S. 284.

1075 Schimmel, Mystische Dimensionen des Islam, S. 328.

1076 Nurbaḩš, Ğavād: Dar harābāt, Teherān 1381/2002, S. 139-145.

${ }^{1077}$ Kurz, Susanne: Verachtet das Scherzen nicht. Die kulturhistorische Assagekraft von persischen Sammlungen humoristischer Kurzprosa, Teil 1, Dortmund 2009, S. 166.
} 
Eine weitere Funktion der Derwische war der gol-bāng (wörtlich: lauter Schrei; Lobgesang) also der Lobgesang auf die Imāme. Sie sangen auf öffentlichen Plätzen Lieder zur Verehrung Gottes, Moḥammads und der 12 Imāme. Imām 'Ali und Ḥosein hatten beim Lobgesang eine Sonderstellung. ${ }^{1079}$ Wenn die Derwische sich ihrem Versammlungsort näherten, sangen sie Ruhmgedichte für ihre Anführer; dabei verschränkten sie die Arme auf der Brust, wobei sie sich mit den Händen an die eigenen Ohren fassten. Dies galt als Zeichen hohen Respekts für die Anführer. Erst der Anführer konnte die Derwische davon entbinden, die Lobpreisungen fortzusetzen. Hatte ein Derwisch einen Fehler begangen, musste er dementsprechend lange (bis zum Signal durch den Anführer) diese Lobpreisungen fortsetzen. ${ }^{1080}$

Diese Tradition der Derwische taucht auch im $R H$ auf, wird aber dort als Kriegslist missbraucht. Auf dem Weg durch die Straßen der Stadt Șufiyā wird der gol-bāng von Ḥamzes Helden ausgeübt, die in Derwischgewändern verkleidet, Derwischgesänge vortragen (4/535). So können sie unerkannt die nötigen Informationen sammeln, um die Stadt später zu erobern.

Im Volk wurden die Derwische als „Gottesfreunde“, betrachtet, die auch über baraka (segenspendende) Kräfte verfügten und karāmat (Huldwunder) vollbringen konnten. Die Derwische verteilten während ihrer Ausgänge Bündel von Kräuterblättern als Gegenleistung für die Zuwendungen der Menschen.

Auch 'Amr verkleidet sich in Derwischgewändern und verschenkt das grüne Blatt barg-e $\boldsymbol{s a b z}$ (grünes Blatt) unbekannten Menschen, denen er begegnet (3/421), um seine Identität vor den Menschen und Sicherheitskräften der Stadt zu verbergen.

\subsubsection{Ethik}

Für die Ermittlung der einzelnen Wertbegriffe im ethischen System des $R H$ ist von entscheidender Bedeutung, in welcher Form sich der ethisch $\mathrm{zu}$ beurteilende Akt der Bekämpfung des Bösen und der Unterstützung des Guten vollzieht. Jeder Schritt des Menschen auf diesem Wege hat eine konkrete und eine abstrakte Seite. Ersteres zeigt sich in der Darstellung des alltäglichen Lebens der Menschen ebenso wie der Beschreibung der allgemeinen Weltanschauung, der Gründung und Verbreitung des Islams und der Ausdehnung des Reiches. Die Helden sind für die Erreichung dieses Zieles verantwortlich. Um das zu erreichen, müssen sie alle Ungläubigen, Dämonen, Hexen und schädlichen Tiere als Verkörperung des Bösen vernichten.

\footnotetext{
${ }^{1078}$ Schimmel, Sufismus und Volksfrömmigkeit, in: Der Islam III, S. 191.

${ }^{1079}$ Vgl. Birge, John Kingsley: The Bektashi order of Derwishes, New York 1937, S. 196-198.

${ }^{1080}$ Afs̃āri, Mehrān: Fotovvatnāmehā va rasāèl-e hāksāriyeh, Teherān 1382/2003, S. 161.
} 
Als insoweit abstrakte (geistliche) Seite aller Moral wird im $R H$ die Gottgläubigkeit

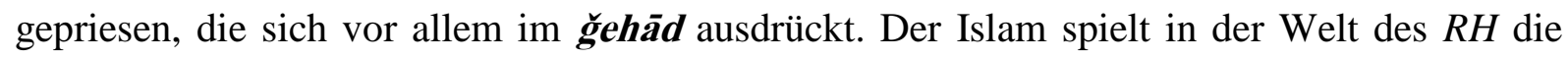
Schlüsselrolle. Das ganze Werk handelt so vom Widerstreit zwischen Gut und Böse. Die Helden sind die eigentlichen Herren der Welt. Sie sind Vorbilder für die gesamte Gesellschaft. Gleichzeitig beeinflusst natürlich das Menschenbild umgekehrt auch die literarische Gestalt der Helden. Die Welt des $R H$ ist voller Furcht, Plagen, Blut und Herausforderungen. Insofern handelt es sich natürlich beim $R H$ um ein phantastisches Werk, das mit den eigentlichen islamischen Moralvorstellungen nur dem Wesen nach übereinstimmt. Das Werk überzeichnet alles ins Grenzenlose.

Die sozial bedeutsamste Funktion der Erzählung besteht in der Vermittlung von Moralvorstellungen. Zahlreiche Erzählungen im Iran enden mit einer moralischen Schlussfolgerung.

So sagt das $R H$ : Ein idealer Feldherr darf nicht ohne Erlaubnis in Kämpfe eingreifen:

Qāsem kämpft gegen Lāhut. Plötzlich kommen Nur ad-Dahr und Asad mit ihren Männern; letztere sind verschleiert. Sie kämpfen mit Lāhut. Zomorrod schickt seinen Kundschafter ins Lager des Prinzen Nur ad-Dahr, um ihn zu entführen. Der Kundschafter verwundet den Prinzen. Als Qāsem erfährt, dass der verschleierte Ritter sein Cousin Nur ad-Dahr gewesen ist, ärgert er sich. Als Ḥamze erfährt, dass Nur ad-Dahr verletzt ist, kommt er ins Qāsems Lager. Qāsem sagt ihm: „Sie haben mir immer geraten, dass ich mit den Helden des rechten Flügels nicht rivalisieren solle. So habe ich sie niemals verfolgt und mit ihren Feinden gekämpft.“ Hamze küsst ihn und sagt: „Du hast Recht, und sie haben es falsch gemacht.“ Danach wirft Ḥamze Nur ad-Dahr das Fehlverhalten vor und sagt: „Warum hast du deinen Cousin verfolgt und in seinen Kampf mit dem Feind eingegriffen? Das ist nicht ritterlich“ (4/686).

Im Epos ist es Sitte, dass der Held nicht auf unehrliche oder hinterhältige Weise seine Feinde bezwingt.

Das $R H$ berichtet, dass Kalangān, 'Anqavils Kundschafter, Irağ entführt und ihn zu 'Anqavil bringt. Als 'Anqavil erfährt, dass er Irăg im Schlaf bewusstlos gemacht und entführt hat, ist er zornig. Er befreit Irağ und entschuldigt sich bei ihm. Am nächsten Tag kommt Irağ auf den Kampfplatz und kämpft mit 'Anqavil. Im Kampf bricht 'Anqavil sich die Beine. So kann er nur noch schwach kämpfen. Irağ fragt: „Was für ein Kampf ist das?“ ‘Anqavil sagt: „Um die Wahrheit zu sagen: Meine Beine sind gebrochen.“ Als Irağ dies hört, sagt er ihm: „Warum hast mir das nicht gleich gesagt!“‘ Danach verlässt er den Kampfplatz (5/787). 
Ein anderes Beispiel: Als Asad Irağ sieht, wirft er ihm vor, dass er ihn mit einem vergifteten Schwert verwundet habe. Irăg sagt, dass er nichts davon gewusst habe. Später erfährt er, dass sein Freund Behzād ihm ein vergiftetes Schwert gegeben hat und wirft ihm vor: „Du hast meinen guten Ruf zunichte gemacht“, und dann tötet er ihn (5/949).

Die hohe Ethik und Moral der Helden zeigt sich auch darin, dass sie ein gegebenes Wort unter allen Umständen zu halten haben. In diesem Zusammenhang finden wir im $R H$ das Zitat „sohan-e mard yeki ast“" (das Wort eines Mann ist fest; 5/916/26).

Ḥamze schickt einen Boten zu Irağ und fordert einen einjährigen Waffenstillstand. Irăg verspricht Ḥamzes Bote, dass er ein Jahr lang nicht kämpfen werde. Der Bote fordert: „Gib es mir schriftlich mit deinem Siegel.“ Irağ antwortet darauf: „sohan-e mard yeki ast.“

Zur Ethik gehört auch die Frage, wie eine Kultur mit ihren Verstorbenen umgeht. Die Mitglieder der zoroastrischen Religion begruben ihre Toten in dahme (das gewöhnliche Wort für Grabstätte). ${ }^{1081}$

Mehrnegār wird im $R H$ im dahma beigesetzt wird (1/103). Die Bestattung führen die ‘amale-ye mout (die Totengräber) durch (1/16).

Das $R H$ ist auch als Medium der Gefühlskultur an der Produktion, Regulierung und Codierung von Emotionen beteiligt. Die Emotion der Trauer, die hier im Mittelpunkt steht, ist in Handlungs- und Funtionszusammenhänge eingebunden. Ihre Darbietung muss als Teil von komplexen ästhetischen Verfahren der Sinnproduktion betrachtet werden. Man trauert öffentlich und sehr emotionell über den Verlust eines nahestehenden Menschen. Hamze erfährt vom Tod seines Sohnes Qobād. Auch Ḥamze trauert intensiv aber seine Trauer drückt sich durch in seinem Rückzug aus der Öffentlichkeit aus. Er verkündet, fortan keine Kriegszüge mehr führen zu wollen, schickt die Soldaten nach Hause und vernachlässigt seine Pflichten. Diese Zeit nutzen alle Rebellen, die Ḥamze jemals besiegt hat, sich wieder neu zu formatieren und es gelingt ihnen Ḥamze fest zu nehmen (2/305-314).

Deutlich anders ist die Funktion der Kleidung von Frauen in Trauerzeremonien. Zum Vergleich wird die Szene herangezogen, in der Mehrnegār vom Tod ihres Sohnes erfährt: Nach dem Tode Qobāds, Ḥamzes Sohn, betrauert ihn seine Mutter lautstark. In Anwesenheit ihrer Hofdamen zerkratzt sie sich ihr Gesicht, zerreißt ihr Kleid und verfällt in Lethargie. Sie hört auf zu essen und stirbt kurze Zeit darauf (2/305).

Zur symbolischen Trauer um den Tod eines Staatmannes gehört das Abschneiden des Schweifs und der Mähne des Reitpferdes seiner engsten Untertanen (3/348). ${ }^{1082}$ Nach Qobāds

${ }^{1081}$ „In der Sasanidenzeit war die königlichen dahme oft als begehbare Häuser bzw. Grabpaläste beschrieben."Abkaci-Khavari, S. 125. 
Tod, dem Perserkönig, schneiden die Staatsmänner die Schweife und Mähnen ihrer Pferde ab und es wird Asche vom Dach des Hauses auf die Straße oder auf die Köpfe der Trauernden geschüttet (1/102).

Die Verehrung der Seelen der Verstorbenen war auch in vorislamischer Zeit sehr wichtig. ${ }^{1083}$ Nach dem Tod eines Menschen kommen die Nachbarn und Geschäftsfreunde ins Haus des Verstorbenen, um die Hinterbliebenen zu besuchen (1/4). Die Besucher zitieren das Gebet, alfäteha, sprechen ihr Beileid aus und wünschen den Angehörigen Gesundheit (1/16). Die Trauerzeit dauert 40 Tage (1/6). Man ehrte den Verstorbenen, indem man ein Trauermahl gab. Man beköstigte die Trauergäste mit $\overline{\boldsymbol{a}} \boldsymbol{b} \boldsymbol{o} \overline{\mathbf{a}} \mathbf{s}$ (Wasser und Speise; 1/3).

Obgleich der Selbstmord religiös streng verboten ist, denkt ein unterlegener Held nach einer Niederlage als erstes an Selbstmord:

Qobād, der von seiner Schwäche im Kampf tief entäuscht ist, will Selbstmord begehen. Er wirft sich ins Wasser und verliert das Bewusstsein. 'Ali rettet ihn, bringt ihn an Land und sagt zu ihm: „Wer sich umbringt, ist ungläubig“ (2/260).

In der Entstehungszeit des $R H$ war die Moral so weit verfallen, dass Unehrlichkeit zum Alltag gehörte. Die das Land unterwerfenden Türken und Mongolen brachten ihre eigenen Sitten mit, die sich von den islamischen stark unterschieden, womit die Muslime sich nun allenthalben konfrontiert sahen. Im Laufe der langen Mongolenzeit verfielen die Sitten immer mehr und verrohten. Die Konflikte zwischen den Herrschenden und Unterdrückten verschärften sich.

Entsprechend werden zwar nicht die Hauptfiguren wie Ḥamze, aber doch viele der Personen der „mittleren Kategorie“ im $R H$ mit unmoralischen und lügnerischen Handlungen in Verbindung gebracht. Hamze nimmt die Rolle als Hüter der Sitten und Ethik ein und bestraft diejenigen, die gegen moralische Gesetze verstoßen. Ein Beispiel ist: 'Amr schlägt Ās die Nase ab. Dieser klagt ihn bei Hamze an und als dieser bei 'Amr nachfragt, ob dies wahr sei, antwortet dieser mit dem Brustton der Überzeugung ganz unverfroren: „Nein, das ist nicht wahr.“ Hamze durchschaut ihn und glaubt ihm nicht, und er vertreibt ihn von seinem Hof (4/687).

\footnotetext{
${ }^{1082}$ „Ein fester Platz bei Trauerfeierlichkeiten hatte die nuhe, das Rezitieren von Klageliedern, die eine besondere Stellung in der persischen Lyrik einnehmen. Unter den Persern finden wir als eingebürgerte Trauersitte das rituelle Weinen und Wehklagen und damit verbundenen blutigen Verstümmlungen, Ritzungen, Haarabscheidungen, Pferdeopfer, das Pferdeschwanzabschneiden und das Verbrennen von Haus und Besitz. Fiel jemand im Krieg, wurden Schwanz und Mähne seines Pferdes kurz geschnitten, der Sattel quer auf das Pferd gehängt, ebenso die Waffen des Helden wie Keule, Helm, Panzer etc." Siehe: Abkaci-Khavari, S. 128. ${ }^{1083}$ Wolff, Fritz: Avesta. Die heiligen Bücher der Parsen, Straßburg 1910, Yasna 59, 24-26, S. 82.
} 
Gleiches gilt auch für den Fall, dass einem Helden etwas zur Verwahrung gegeben wird. Er hat das verwahrte Gut unter Einsatz seines Lebens zu schützen „dar amānat ḩiyānat nakon.“

Ḥamze findet am Strand des Maghrebmeeres eine Kiste und will sie 'Amr schenken (1/181). Er kommt nach Ṭanğe und gibt die Kiste 'Amr b. Ma'di zur Aufbewahrung. 'Amr b. Ma'di, der neugierig ist, öffnet in der Nacht die Kiste. Plötzlich kommt ein Dämon heraus. ${ }^{1084}$ Der Dämon will seinen Befreier vernichten. In diesem Moment kommt Heżr und fragt den Dämon: „Wie heißt du?“ Der Dämon sagt: „Ich heiße Kağvāğ, und Soleimān hat mich in diese Kiste eingesperrt. Jetzt will ich diesen Menschen fressen.“ Heżr gelingt es, den Dämon wieder in die Kiste einzusperren. Er gibt 'Amr b. Ma'di den dringenden Rat, verwahrtes Gut unberührt zu lassen (1/186).

Eine schändliche und eines Helden unwürdige Handlung ist es, ,ḩun-e nā ḥaqq rihtan hubb nist"“ (Blut ungerechtfertigt zu vergießen).

Baht arbeitet schwer als Lastenträger auf dem Marktplatz. Die Leute geben ihm viele Aufträge. Andere Lastenträger sind neidisch und wollen Baht töten. Einer von ihnen sagt: „Es ist nicht gut, unrechtes Blut zu vergießen.“ So beschließen sie, Baht Geld zu geben, damit er nicht mehr auf den Markt kommt (1/4).

Im nachfolgenden Abschnitt soll auf das generelle islamische Handelsverständnis eingegangen werden. Die Muslime sind zu Ehrlichkeit und Wahrhaftigkeit verpflichtet. Dies gilt bei der uneigennützigen Behandlung des Vermögens von Waisen, beim korrekten Umgang mit der Waage und bei der strikten Unterlassung, Mitmenschen zu verleumden. Prinzipiell soll der Diener Allāhs zu dem stehen, wozu er sich verpflichtet hat. Das bevorstehende Endgericht wird jeglichen Betrug und jede Lüge aufdecken. Schließlich muss sich der Mensch stets seine eigene Nichtigkeit angesichts der göttlichen Allmacht vor Augen führen.

In diesem Zusammenhang lesen wir im $R H$, dass im Talisman šabstān Ḥamze sieht, dass vom Himmel die Feen Lebensmittel ins Meer werfen und die Fische sie essen. Ḥamze fragt Hֵāăe ‘Abdal ar-Raḥim: „Woher kommen diese Lebensmittel für die Fische?“ Er antwortet: „Wenn ein Knecht Gottes, beim Wiegen stiehlt, gibt Gott dieses Gestohlene den Fischen zum fressen“(5/947).

Das $R H$ ist ein Unterhaltungsroman und dort begegnen einem in der Regel nur heldenhafte Aktionen und fantastische Erzählungen. Nur an einer einzigen Stelle des $R H$ kommt es zu

${ }^{1084}$ AaTh, (Motiv. Geist im Glas. 331). 
einer direkten Wertung der „realen Welt“; ansonsten überwiegt weitgehend der Unterhaltungscharakter.

Hamze und 'Amr erreichen einen Palast und sehen im Audienzsaal das Gemälde eines Königs, der auf dem Thron sitzt. Unter dem Thron sitzt der Wesir und an der Saaldecke sind alle Vögel, die Gott geschaffen hat, abgebildet. Am Hals des Wesirs hängt eine Tafel und Ḥamze liest was auf ihr steht: „Man muss wissen, dass die Welt keine Treue kennt. Dies ist Soleimāns Audienzsaal. Soleimān war König. Am Tag widmete er sich armen Leuten und in der Nacht betete er. Er webte Einkaufskörben um seinen Lebensunterhalt zu bestreiten. Wegen seines Königtums wird er am Jüngsten Tag 40 Jahre später als alle anderen in das Paradies eintreten“ (5/951).

\subsubsection{Sitten}

Sitten und Gebräuche sind eng verwandt und oft äußerer Ausdruck der Ethik einer Gesellschaft. Besonders deutlich zeigt sich die Bedeutung von Sitten beim Aufeinandertreffen von Kulturen, wie sie sich im Iran während der Entstehungszeit des $R H$ durch die mongolischen und türkischen Eroberer auf die Bevölkerung auswirkte. Letztlich finden wir im $R H$ altiranische, islamische, mongolische und türkische Sitten.

$\mathrm{Zu}$ den üblichen Sitten jener Zeit gehören auch die genauen Audienzvorschriften bei Hofe. In der vorislamischen Zeit haben wir ausführliche Informationen aus den historischen Quellen. „Der Audienzsuchende wurde vom König aufgefordert, vorzutreten. Nachdem er sich wiederum zu Boden geworfen hatte, verharrte er in dieser Stellung, bis der König das Wort an ihn richtete. Je nach seinem Rang blieb er stehen oder durfte sich auf den Boden, auf einen Sessel oder gar auf den Thron neben den König setzen. Seiner Stellung gemäß erhielt er einen Platz vor dem König, zu seiner Rechten oder zu seiner Linken. “1085

Die Sitte sağde-kardan (Verneigung bis zur Erde) gegenüber dem König war sehr üblich. Hierbei handelte es sich um eine altiranische Sitte. Die Achämenidenherrscher hatten diese Sitte von den mesopotamischen Königen übernommen. Man warf sich vor dem Großkönig zu Boden und küsste oftmals auch den Boden. ${ }^{1086}$ Streng geregelt war die Zulassung der Untertanen zur Audienz. Die Sitte pā-bus kardan (Fußkuss) war sehr üblich, sogar die Steigbügel wurden geküsst.

Nach der Islamisierung des Irans wurden einige Änderungen daran vorgenommen. Die Audienz wurde immer mit allem Pomp abgehalten. Die Anordnungen und Vorschriften

\footnotetext{
1085 Abka'i-Khavari, S. 79.

${ }^{1086}$ Widengren, Die Religionen Irans, S. 152.
} 
gingen teilweise auf die vorislamische Zeit zurück und teilweise richtete man Empfänge nach dem Vorbild des mongolischen Hofes aus.

Bei den Mongolen war es üblich, dass der Herrscher gut bewacht wurde. Er saß in der Mitte der Wachen in seinem prächtigen Zelt auf einem Thron, links und rechts saßen seine Verwandten. Vor dem Thron saßen Gelehrte und Gäste. Niemand konnte sich jedoch dem Herrscher ohne Erlaubnis nähern, da er sonst getötet worden wäre. ${ }^{1087}$

„Bei den Festen wurde der Reichtum des Königs zur Schau gestellt, das goldene und silberne Tafelgeschirr kam zur Verwendung. Die Stadt und der Palast waren festlich geschmückt. Die Feste waren Anlass zu allgemeinen Audiezen, bei denen der König beschenkt wurde und Geschenke verteilt. “'1088

Entsprechend findet man im $R H$ die Städte, die festlich geschmückt sind und wo Musikanten bei fröhlichen Gelegenheiten aufspielen (1/28). Wenn ein vornehmer Gast erwartet wird, legt man einen Teppich aus (1/51).

Im $R H$ präsentieren sich die Gäste besonders würdevoll und in prunkvoller Kleidung. Während der Audienz verneigt Bozorgmehr sich gegenüber dem König bis zur Erde (1/22). Bei der Thronbesteigung wird der Fuß des Königs geküsst (2/220).

Die Gäste sprachen zuerst einen Segen und standen dann dem König Rede und Antwort. Am Ende küssten sie ja nach Rang die Hand, den Ring, den Thorn oder den Boden vor dem Thron. $^{1089}$

Als Ḥamze sich zum Palast des Perserkönigs begibt, reitet 'Amr b. Ma`di Karib vor ihm und trägt eine Streitaxt vor sich her. Ḥamze steigt vom Pferd und will die Steigbügel des Perserkönigs küssen als dieser ihn zum ersten Mal besuchen kommt. Die Audienz endete in einer Feier, wo gemeinsam gegessen und getrunken wurde $(1 / 28 ; 1 / 52)$.

Besucher können nicht ohne Voranmeldung zu Hamze gehen, sie brauchen die ezn (Erlaubnis) vom Türwächter. Will ihn also jemand besuchen, so muss er vorher die Erlaubnis bei ihm einholen (1/25). Ist der Besucher ein wichtiger Mensch, so geht man ihm entgegen. Die Söhne des Großwesirs Bozorgmehr besuchen Ḥamze. Als sie am Zelt ankommen, gehen Hamzes Helden ihnen entgegen (1/27).

Ein wichtiges Detail bei jeder Audienz ist die Seite an der sich der Gast niederlassen darf. In der islamischen Tradition ist die rechte Seite der Gläubigen die gute Seite. Die linke Seite wird bei den Gläubigen als die Unglücksseite betrachtet. Traditionell wird die linke Seite mit dem Bösen in Verbindung gebracht. Man soll z.B. mit der Rechten essen und trinken, denn

\footnotetext{
${ }^{1087}$ Hāleqi-Moṭlaq, Bar va ā’in ān dar Irān, in: Gol-e ranğhā-ye kohan, S. 218.

1088 Abkaci-Khavari, S. 80.

${ }^{1089}$ Ebd. S. 79.
} 
mit der Linken isst und trinkt der Teufel. ${ }^{1090}$ Nach schiitischer Auffassung bekommt man am Tag des Jüngsten Gerichts ein „Beurteilungspapier“. Wird dies bei der Übergabe in die linke Hand gelegt, bedeutet dies, dass man in die Hölle kommt.

In der Șafavidenzeit saßen die schiitischen Höflinge oder Gäste auf der rechten Seite und die sunnitischen Gäste auf der linken Seite des Königs. ${ }^{1091}$

Irağ gewährt Landehur einen besonderen Wunsch und als dieser darum bittet, auf dessen rechter Seite zu sitzen, da sich dort die Gläubigen befinden, gibt er diesem statt (5/753).

Die Invasion mongolischer Stämme aus Zentralasien erfasste und veränderte die islamische Welt. Eine jahrhundertealte gesellschaftliche und wirtschaftliche, religiöse und kulturelle Entwicklung wurde gefährdet und schließlich abgeschnitten und stattdessen entwickelten sich neue Formen kultureller Erscheinungen in der iranischen Gesellschaft. Als ein Beispiel dieser Änderung war das Annehmen des Weinglases bei einer Auftragsvergabe, was bei den Mongolen eine symbolische Bedeutung hatte, denn es war gleichbedeutend einem gesprochenen Treueeid dem Partner gegenüber. ${ }^{1092}$

Im $R H$ findet sich ein entsprechendes Beispiel. Ḥamze füllt seine Trinkschale mit Wein und sagt: „Ich brauche jemanden, der diese Schale von mir nimmt, den Wein trinkt und meinen Brief zu Eskandar b. Heikalān bringt“(2/283-285).

\subsubsection{Heirat und Familie}

„Die Ehe ist ein Hilfsmittel für das Seelenheil [...].“1093 Sie soll vor allem den Mann vor der Gefahr des zina'(Ehebruchs) und der Unzucht schützen. So wird die Heirat dem Gläubigen explizit als Schutz vor zina' empfohlen. ${ }^{1094}$ Der Koran empfiehlt die Ehe unbedingt. ${ }^{1095}$ „In der frühen had Glaubens bezeichnet.“1096 Die Ausübung der Sexualität ist nur im Rahmen der Ehe erlaubt. Der Koran sagt zu den Beziehungen zwischen Mann und Frau in der Ehe:

„Und zu seinen Zeichen gehört es, dass er euch aus euch selber Gattinnen geschaffen hat, damit ihr bei ihnen wohnet. Und er hat bewirkt, dass ihr

\footnotetext{
${ }^{1090}$ Reinfried, H.: Sifat an-Nabī Mālek, Muwatțạ Bräuche bei Zauber und Wunder bei Buchari, Dissertation, Freiburger 1915, S. 10ff.

${ }^{1091}$ Falsafi, Bd. 4, S. 5.

1092 Hāleqi-Moṭlaq, Bar va ā’in ān dar Irān, S. 218.

1093 Mernissi, Fatima: Der politische Harem. Mohammad und die Frauen, aus dem Französischen ins Deutsche übersetzt. von Marie Luise Knott und Brunhilde Wehinge, München 1991, S. 37.

${ }^{1094}$ Vgl. Mernissi, Fatima: Geschlecht Ideologie Islam, München 1991, S. 51.

1095 Koran, Sure. 24,32.

${ }^{1096}$ Wiebke, Walther: Die Frau im Islam, Stuttgart [u.a.] 1980, S. 393.
} 
einander in Liebe und Güte zugetan seid. Darin liegen Zeichen für Leute, die nachdenken. “'1097

Zeitweilig wich das tatsächliche Verhältnis der Muslime zur Sexualität stark von den koranischen Idealen ab. Im Islam war und ist die gleichzeitige Heirat mit bis zu vier Frauen erlaubt. Die Männer hatten zudem die Möglichkeit, „Umgang“ mit ihren Sklavinnen zu haben. ${ }^{1098}$ Der Zweck der Ehe war nicht nur das Sichern einer Nachkommenschaft und der Fortbestand der Familie, sondern erfolgte oft auch aus geschäftlichen und politischen Gründen.

Die Eheschließung war schon immer in Adelskreisen ein Mittel der Politik. So fanden Verbindungen zwischen Arabern, Türken und Persern statt. Die politisch oder militärisch unterlegenen Herrscher boten sehr häufig, dem Sieger ihre Töchter als Frau an. Solche politischen Ehen, besonders unter den königlichen Familien, hatten im Iran immer große Bedeutung für die Staatsmänner.

Bei einer geplanten Heirat in Adelskreisen ist eine der zentralen Fragen die nach dem geeigneten Partner. Wer zueinander gehört und für einander bestimmt ist. Im Brautbewerbungsschema und bei der Partnerwahl ist die Kampfkraft des Mannes ein großes Zeichen. Von großer Wichtigkeit ist die körperliche Präsenz des Helden, auf die eine stabile Herrschaft gegründet werden kann. Die Partner müssen einander in gewisser Weise ebenbürtig sein, aber der Held muss sich durch heroische Taten legitimieren während die Frau als repräsentatives Aushängeschild nur als Mittel zum Zweck für den Herrschaftserhalt nötig ist.

Traditionsgemäß sollte ein Mädchen immer verheiratet werden. Die Eltern hatten die Verpflichtung, die Tochter rechtzeitig zu vermählen. Es wurde als nicht gut angesehen, wenn die Töchter zu lange im Elternhaus blieben. Die Mädchen konnten bei der Heirat in der Regel keine eigene Wahl treffen und zur Heirat bedurften die Mädchen unbedingt der Erlaubnis ihrer Eltern. Nach dem Brauch der damaligen Zeit war es üblich, dass der Bräutigam bei dem Vater und den Verwandten der Braut um ihre Hand anhielt. Die Brauteltern verlangten vom Bräutigam das šir-bahā (das Geld, das der Bräutigam der Mutter der Braut dafür schenkt, dass sie diese großgezogen hat).

Der Hauptzweck der Ehe im $R H$ ist es, für Nachkommen zu sorgen und so den Fortbestand der Familie zu sichern. Die Ehe aus Liebe ist jedoch im $R H$ auffallend oft das Motiv zur Heirat. Dort kommt es sehr oft vor, dass Ḥamze sich Gemahlinnen aus königlichen Häusern nimmt. Auch hier sind die Eltern verpflichtet ihre Töchter zu verheiraten auch ohne deren 
Zustimmung (1/92). Sie muss nicht gefragt werden und sie muss der Entscheidung der Eltern zustimmen (1/93). Das Mädchen muss unberührt sein und der Begriff „,Jungfräulichkeit” wird im $R H$ mit mohr (Siegel) ausgedrückt (1/193).

Jede Verbindung beginnt mit der Verlobung und die Verlobungszermonie heißt širini-h̆orān (Süßigkeiten verspeisen). An diesem Tag essen die Gäste širini (Süßigkeiten), kale-qand (Zuckerhut) und šǐse-nabāt (Kandis;1/112).

Auch die Sitte der Mitgift durch den Bräutigam wird im $R H$ beschrieben, als nämlich Anōširvān von Ḥamze Landehurs Kopf als šir-bahā verlangt (1/100).

Bei der Eheschließung ruft man den mollā (Geistlichen; 1/112). Die Braut wird vorher geschminkt, schön gekleidet und mit viel Schmuck ausgestattet (1/193-194). Wenn die Braut zum ersten Mal vor dem Bräutigam ihr Gesicht entschleiert, muss er ihr ein Geschenk geben, welches man bis heute ru-namāa (das Geschenk des Bräutigams für seine Braut) nennt.

Die Feierlichkeiten dauerten eine Woche lang. Im Verlauf des Hochzeitsfestes werden die Gäste mit Musik und Liedern unterhalten. Auf die Köpfe der Gäste wird der Saft von Blumen gesprenkelt und die Gäste amüsieren sich mit Feuerwerk (1/188). Die Leute werden mit Speisen, šarāb (Wein), šarbat (Getränk; 5/810), noql o nabāt (Konfekt und Kandis; 5/810), maze und $\boldsymbol{k e y f}$ (Genuss; 1/189) und bang (indischer Hanf; 5/810) versorgt. ${ }^{1099}$

In der Hochzeitnacht tauschen bzw. teilen sich Braut und Bräutigam im Brautgemach gerdak-sarāy, 3/422), eine piyāle (Schale) Wein miteinander (3/420). Nach der Hochzeit leben auch Ḥamzes Frauen in einem Harem. Dort werden sie durch einen riš-safid (wörtlich: Weißbart, Vorsteher, Führer) ${ }^{1100}$ bewacht (5/789/11).

\subsection{Erniedrigung der Frauen}

Über die gesellschaftliche Rolle der iranischen Frauen im Mittelalter weiß man nicht all zu viel. Wenn wir das Leben der Frauen, wie es in verschiedenen Quellen und Berichten niedergeschrieben ist, betrachten, kommen wir zu der Schlussfolgerung, dass ihnen von der herrschenden Männerwelt stereotype Charakterzüge zugesprochen werden. Diese Akzeptanz der ihnen zugesprochenen Eigenschaften und Fähigkeiten ist nicht Ausdruck ihrer inneren Charakterstruktur, sondern ist durch äußere, vor allem pseudomoralische und soziologische

\footnotetext{
${ }^{1098}$ Koran, Sure 4,3; 4,24f; 23,6; 70,30.

${ }^{1099}$ Khaleghi-Motlagh, Die Frauen im Schahname, S. 151.

1100 Schon längst hatten alle Städte Irans einen ra'is (offiziellen Vorsitzenden; 1/118/16), einen angesehenen Älteren. Im $R H$ sind sie in den Dörfern als Führer der Dorfgemeinschaft tätig. Wenn ein staatlicher Beamter das Dorf besucht, muss der ra is ihm zu Diensten sein (2/323). Bei den riš-safid (wörtlich: Weißbart, Vorsteher, Führer) handelt es sich um erfahrene Männer höheren Alters, die in der Führung der Städte und Gemeinden empfehlend tätig sind. Siehe: Qāżi Aḥmad Qomi: Holāṣat at-Tawā rīḥ, hrsg. von Hans Müller, Wiesbaden 1964, S. 527.
} 
Faktoren bestimmt, wie z.B. Verbote und Gebote durch die staatlichen oder religiösen Gesetze.

In den iranischen Erzählungen werden die Frauen im Allgemeinen diskriminiert. Die persische Erzähler, die zum großen Teil aus dem Volk stammen und unter dem Einfluss der islamischen Erziehung und Ethik in der mittelalterlichen Kultur des Irans aufgewachsen sind, stellen die weiblichen Figuren der persischen Literatur als lustbegierig, unwissend, rechtlos und letztlich als Sklavinnen der Männer dar. Danach sieht das Urteil über die Frauen folgendermaßen aus: Die Frau besitze keinen Verstand, ${ }^{1101}$ daher könne man von ihr nicht lernen, und daher dürfe man sie auch nicht zu Rate ziehen, denn die Frauen seien keine guten Ratgeberinnen. Man dürfe den Frauen kein Geheimnis anvertrauen, denn sie redeten gerne und viel. Sie seien ein Unglück und benutzten List und Zauber. Die Frauen im Iran sind in der Vergangenheit das unerwünschte Geschlecht gewesen, und dies ist aus kulturellen, religiösen, wirtschaftlichen und politischen Gründen teilweise auch heute noch so. Diese Auffassung lässt sich in der Literatur gut belegen.

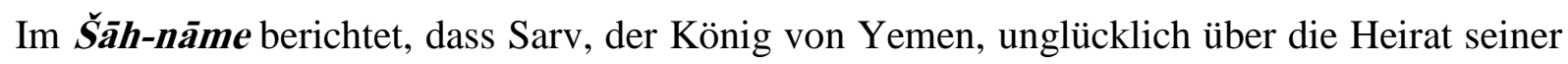
drei Töchter mit den Söhnen des Feridun ist.

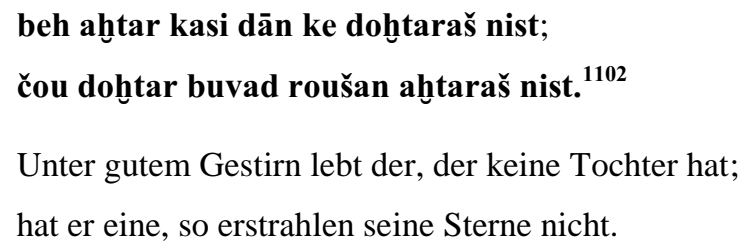

In den volksliterarischen Werken wird es oft so dargestellt, dass die Frauen „nicht vollständige Menschen“ seien. ${ }^{1103}$ Ihr Platz sei nicht in der Öffentlichkeit, sondern in einem dunklen Winkel des Hauses. ${ }^{1104}$ Frauen seien nur halb soviel wert wie Männer. ${ }^{1105}$

Durch die Verhältnisse im Iran zur Zeit der mongolischen Herrschaft, kam es dazu, dass sich die mongolischen und türkischen Vorstellungen hinsichtlich der Rolle der Frau immer mehr durchsetzten. Bei den Mongolen waren die Frauen frei und nahmen in jeder Hinsicht am öffentlichen Leben teil. ${ }^{1106}$ Sie tranken Alkohol, verführten Männer und verfolgten ihre eigenen Interessen. Hinzu kam, dass die Mongolen auch iranische Frauen als Tribut nahmen, wenn beispielsweise der Vater oder Ehemann die Steuern nicht bezahlen konnte. Auch offene

\footnotetext{
1101 Afs̃ār, Eskandar-nāme, S. 52; 363.

${ }^{1102}$ Ferdousi, Bd. 1, S. 53.

1103 Afs̃ār, S. 145; 185.

${ }^{1104}$ Afšāar, S. 120.

1105 Asadi-Ṭusi, S. 29.

1106 Spuler, Die Mongolen in Iran, S. 395-398.
} 
Prostitution wurde üblich. ${ }^{1107}$ Zusammengefasst kam es zu einem Verfall der Sitten; positiv formuliert aber auch $\mathrm{zu}$ einer gewissen Öffnung des Irans für freiheitliche Strömungen hinsichtlich der Rolle der Frau.

Die Frauen im $R H$ stehen also stellvertretend für die adlige iranische Frau in mongolischer und timurdischer Zeit, für die Frau des Mittelalters bei Hofe und nicht der Frau aus dem Volk. Entsprechend ist das Leben am Hofe im $R H$ sehr prachtvoll und sorgenfrei. Prinzessin Mehrenegār hat ein Leben voller Vergnügungen. Sie feiert mit ihren Hofdamen, trinkt Wein, tanzt, spielt Theater und beherrscht die Schießkunst (1/57). Daneben treibt sie erfolgreich Geschäfte mit fernen Ländern (z.B. Indien). Als Frau ist sie stets an der Seite ihres Mannes, mit dem sie auch den Palast verlässt und 18 Jahre lang gegen ب̣amzes Feinde kämpft. Wir finden in Mehrnegār die Frau, die dem idealen Vorbild der mittelalterlichen Ehefrau entspricht: Sie protestiert nicht auch wenn sie von Ḥamze schlecht behandelt wird, fügt sich in alle seine Anordnungen ohne offen eine eigene Meinung zu vertreten; sie lebt nur für ihren Mann und ihren Sohn.

Ḥamzes Hauptharem ist in der Festung Zú 'l-Amān. Er ist ein sicherer Ort für die Frauen seiner Getreuen und daher wohnen auch Ḥamzes Frauen in dieser Festung. Sie alle sollen in erster Linie ihren jeweiligen Männern bei Bedarf Gesellschaft leisten.

Die Frauen sind Schönheitsideale ihrer Zeit, die jedoch ihre Ehre zu verteidigen wissen. Als Ḥamzes Frauen erfahren, dass Irağ überall über seine Liebe zu Giti-afruz spricht, sind sie sehr wütend. Hamzes Frau Gordiye und 40 Frauen aus Ḥamzes Haus verschleiern ihr Gesicht, reiten auf den Kriegsplatz und kämpfen gegen Irağ und seine Männer (5/831).

Historisch belegt ist, dass die Frauen in der Safavidenzeit mit ihren Männern auf den Kriegszügen zusammen Seite an Seite kämpften. ${ }^{1108}$ Tāğli-hnānom, Šāh Esmāclis Frau, verschleierte ihr Gesicht und kämpfte mit osmanischen Soldaten. Sie wurde im Čāldirān durch die osmanischen Soldaten festgenommen und als Kriegsgefangene zum Hof des osmanischen Sultans gebracht. ${ }^{1109}$

Im Allgemeinen werden demnach die Frauen als minderwertig betrachtet, was ihre physische, psychische und ethische Konstitution betrifft; sie gelten als unfähig, vernünftig zu denken und werden als etwas schlechthin Wertloses beschrieben. Es wird gesagt: rāḥat az barā-ye zanān

\footnotetext{
${ }^{1107}$ Vgl. Nahğavāni, Moḥammad b. Hendušāh: Dastūr al-kātib fí ta'yīn al-marātib, Bd. II, hrsg. von 'Abd al-Karim 'Alizāde, Moskva 1976, S. 292.

${ }^{1108}$ Vgl. Šoğāc', 'Abd al-Ḥamid: Zan va siyāsat va ḥaram-sarā dar 'aṣr-e șafavi, Teherān 1384/2005, S. 114; Ġoravi, Moḥammad: Ma'āhnež-e ețtelā'āt-e Monteskiyo darbāre-ye ravābeț-e zanā-šu’i dar Irān, in: Našri-edānešgāh-e adabiyāt va 'olum-e ensāni-ye Tabriz, šomāre-ye Bahār 1352/1973, S. 21-50, hier S. 35.

1109 Anonymus: ‘̄̄lam-ārā-ye Šāh Esmāîl, S. 526-527.
} 
ast (Gemütlichkeit ist für die Frauen; 3/382). Man erniedrigt seinen Gegner im Kampf, indem ihn az zan kamtar (weniger als ein Weib; 4/688) nennt.

Die Familienehre zu verteidigen wird zu allen Zeiten als ein hohes Gut gesehen und bezieht sich oftmals auf ein Fehlverhalten der Frau, dass unter allen Umständen geahndet und verteidigt werden muss. Als. Hormoz erfährt, dass seine Schwester, Mehrnegār, mit Ḥamze in einem Bett geschlafen hat, wird er wütend, geht mit dem Schwert in den Palast seiner Schwester und will sie töten. Aber 'Amr kann mit Hilfe einer List rechtzeitig Hamze aus der Schatzkammer, wo er mit Mehrnegār zusammen geschlafen hat, herausbringen und Mehrnegār retten (1/50).

Ein anderes Beispiel dazu: 'Amr erreichtdas Land Ğābalqā. Dort begegnet er Horšid, der Tochter von Hosrou Hูān-e Hुāvari König von Ğābalqā. Er verliebt sich heftig in sie aber das Mädchen befiehlt, ihn zu schlagen und aus dem Palast zu werfen. Hamze, der schon lange keine Nachrichten mehr von 'Amr bekommen hat, reitet nach Ğābalqā. Ḥamze findet 'Amr in der Wüste und bringt ihn in die Stadt. Diese Nachricht erreicht das Frauengemach und Horšid lässt verlauten: „Wenn sie mich 'Amr zur Frau geben, werde ich mich umbringen.“ $\mathrm{Da}$ 'Amr sehr hässlich ist, will sie ihn auf keinen Fall heiraten. 'Amr verändert daraufhin sein Aussehen in die Gestalt des 'Ağil, Hạmzes Bruder, und heiratet sie durch diese Täuschung unter fremder Identität. Horšid erfährt den Betrug nach der Hochzeitsnacht und ist sehr betrübt. Als sie 'Amr darauf anspricht, sagt er, dass er sich sofort scheiden lassen könne wenn sie das wolle, aber wenn sie es sich danach wieder anders überlegen würde, käme eine erneute Heirat nicht wieder in Frage, auch wenn sie ihm Geld dafür geben würde (3//457-461).

Im Krieg galten Frauen, Kinder und alte Leute in erster Linie als Kriegsbeute. Sie wurden brutal geschlagen oder vergewaltigt. Bei einem verlorenen Krieg waren so die Frauen und Kinder die Hauptverlierer. Sie waren stets in Gefahr und gefangen genommen zu werden.

Haben die Helden einen Krieg verloren, so lassen sie ihre eigenen Frauen durch die Bewacher töten. Dārāb-e āb-parast belagert die Stadt 'A Ăam. Ṭāher, der Stadthalter der Stadt 'A ğam will daher Ḥamzes Schwiegertochter und Širōyes Frau, Yāqut-Malek töten, um zu verhindern, dass die Frauen in die Hände der Feinde fallen (5/789).

Ein anderes Beispiel ist die Vergewaltigung der Mädchen in Madā'en: Als Hamze nach Madā'en zurückkommt, erfährt er, dass Qiyāsān, Stadthalter des Perserkönigs, ihn nicht in die Stadt lassen will. Ḥamze betritt die Stadt mit Gewalt und seine Männer zerstören die Stadt. Zarangiz, Mehrnegārs Mutter, versteckt Mehrnegār vor ihnen. Haamze kann sie finden und da sie sich lieben, nimmt er Mehrnegār gegen den Willen der Eltern mit sich. 
Für die gewaltsame Gefangennahme Minderjähriger in seinem eigenen Tross steht nachfolgendes Beispiel: 'Amr b. Ma'di, einer von Ḥamzes Getreuen geht in Bahtaks Haus, nimmt dessen 12-jährige Tochter als Gefangene, bringt sie zu seinem Zelt und vergewaltigt sie. Als Mehrnegār dies erfährt, wird sie sehr traurig und sagt zu Ḥamze: „Ist es vernünftig, dass sich im Heer des Islams Leute so benehmen?“ Hamze gibt ihr Recht (1/133).

\subsection{Kinder}

Dem $R H$ nach entstehen die Kinder aus einem Tropfen Wasser (Samen), der aus dem Rücken des Mannes in den Uterus der Frau fließt. Über den weiteren Hergang wird nichts mehr gesagt. $\mathrm{Zu}$ bemerken ist, dass im $R H$ das Wort pošt (Rücken) auch als Terminus für Abstammung oder Geschlecht gebraucht wird und Schwanger werden heißt (notfe baste ร̌odan; 1/131).

Üblicherweise sind die Ehefrauen Hamzes bei der Geburt nicht bei ihm und bei seiner Familie. Zunächst wächst das Kind also bei der Familie der Mutter auf. Im Erwachsenen Alter machen sich nur die Söhne, die weit in der Überzahl sind, auf den Weg zu ihrem Vater.

Bei der Geburt selbst sind immer erfahrene Frauen anwesend. Im $R H$ kommt bei Bozorgmehrs Geburt eine erfahrene Frau, die qābele (Hebamme) heißt, zur Geburtshilfe (1/6). Nach der Geburt wird das Neugeborene in einen Stoff namens mamāt eingewickelt und die Gelehrten kommen, um dem Neugeborenen einen Namen zu geben (1/14).

Am dritten Tag nach der Geburt wird bis heute üblicherweise ein Schaf als raqiqa geschlachtet (1/6). Während der 'aqiqa wird ein wenig Haar des Neugeborenen abgeschnitten und gewogen und das Gewicht in Gold wird als Almosen an arme Leute verteilt. ${ }^{1110}$

Die Adelskinder werden durch eine Amme groß gezogen. Auch Ḥamzes wird durch eine Amme namens ‘'̄di Bānu (Stamm aus Bani Tamim) betreut und genährt (1/14).

Die Kinder wurden mit sieben Jahren zur Schule geschickt. Adelskinder wurden immer zu erst in der Kriegskunst unterrichtet. Die Kriegsbereitschaft der Iraner zwang sie dazu, körperlich in guter Verfassung zu sein. So hatte in der Erziehung der Jugend (aber auch im Alltagsleben) die ritterliche Erziehung einen festen Platz. Bei den türkischen Dynastien verwalteten die militärischen Feldhaber die Staatsgeschäfte für den minderjährigen Sohn des Solțāns. ${ }^{1111}$ Ähnlich wie bei den Seldschuken gab es auch bei den Șafaviden das Amt lalegi (Prinzenerzieher). Der lale, der Erzieher des Prinzen, war ein Vornehmer aus den Stämmen

\footnotetext{
${ }^{1110}$ Schimmel, Traditionelle Frömmigkeit, in: Der Islam III, S. 243.

${ }^{1111}$ Cahen, Claude: Atabak, in: $E I^{2}$, Bd. I, Leiden/London 1960, S. 731-732.
} 
Qizilbāšs, und mit seinem Amt war die Oberherrschaft über eine Provinz verbunden. ${ }^{112}$ Das Speerwerfen, Bogenschießen, das Ringen, das Kämpfen mit Keulen, Ballspielen und Beilwurf war immer ein wichtiger Teil der Erziehung. In den Zeiten der Wirren wurden diese Übungen weiter gepflegt.

Diesen Erziehungsstil sieht man auch im $R H$. Die Schule heißt maktab und der Lehrer ist ein āhund. Er lehrt den Kindern das Lesen und Schreiben (1/6). Hamze geht ebenfalls in die Schule aber seine Liebe gilt der Kriegskunst. Die Erzieher der Prinzen, die lale (4/667) lehren sie die Kunst des Reitens, des Schießens und des Bogenschießens (2/196).

Die Erziehung der Mädchen unterliegt anderen Gesetzmäßigkeiten als die der männlichen Nachkommen. Es ist im Mittelalter in den adligen Familienkreisen üblich, dass sich die Eltern schon bald nach der Geburt eines Mädchens überlegen, wie sie dieses nun am sinnvollsten in die eigenen politischen Pläne einbinden können. Die Mädchen brauchen wegen ihrer angenommenen schwachen psychischen Konstitution ständige Aufsicht, weil sie sonst von ihrer natürlichen moralischen Verworfenheit geleitet werden und ihre männlichen Angehörigen schwer schädigen.

Als junges Mädchen verstößt Mehrenegār gegen die Normen ihrer Zeit. Trotz strenger Aufsicht besucht sie ihren Liebhaber Ḥamze vor der Heirat, um mit ihm Zeit zu verbringen. Gegen den Willen ihrer Eltern, verlässt sie den Palast und zieht zu Ḥamze (1/41-58).

\subsubsection{Kleidung, Schmuck und Kosmetik}

Die gewählte kulturgeschichtliche Epoche bietet sich aus zwei Gründe als Paradigma an: Zum einen stellt sie den historisch und methodisch idealtypischen Moment der Entstehung einer neuen Gesellschaft dar, die sich in neuer epischer Literatur und einer neuen Kleidungsform (der höfischen Mode) symbolisch instituiert; zum anderen ist sie auch deswegen beispielhaft, weil das kulturgeschichtlich Neue, das die Hofgesellschaft des Mittelalters hervorbringt, in vielfachen Transformationen über Jahrhunderte Bestand hatte und noch bis heute nachwirkt.

Das $R H$ ist gute Quelle für die Trachten und Kleidungen der damaligen Zeit. Die Schilderungen, die sich dort wiederfinden, geben uns ausführliche Informationen über Bekleidung und Schmuck.

Die Oberschicht präsentiert ihre soziale Stellung, indem sie sich auf der Höhe der jeweils neuesten Mode zeigt. Die soziale Funktion der Mode, den Kreis der gesellschaftlich Privilegierten nach innen zu normieren und nach außen abzugrenzen, ist nicht nur auf die

$\overline{1112}$ Eskandar-Beg Torkamān: Tarih h-e 'Ālam-ärā-ye 'Abbāsi, Bd. 1, S. 125; 131; Falsafi, Bd.1, S. 42; Ṣafā, Tãrihh-e adabiyāt dar Irān, Bd. 5, Teil 1, S. 130. 
Kleidung beschränkt sondern auch auf Schmuck, Kosmetik, Möbel und Architektur der Paläste.

Die beschriebenen Trachten und Kleidungsstücke sind auch das Thema der vorliegenden Arbeit. Die höfische Gesellschaft des 15. und 16. Jahrhunderts versucht durch die besondere Form ihrer Kleidung ihren Status zu definieren und die Identität ihres Standes zum Ausdruck zu bringen.

Zur Kleidung der Königin und Prinzessinnen gehören ein Hemd aus leichter Wolle, Hose und ein Schleier. Im $R H$ besteht die Kopfbedeckung der Frauen aus einem langen Schleier. Sie bedecken ihr Gesicht mit einem Seidentuch namens borqa'(1/184). Die Frauen haben eine Schleppe, an den Füssen tragen sie Schuhe oder Stiefel. Zur Kleidung gehört weiter ein Gewand aus ausländischem Seidenbrokat (5/1009-1010).

Die erotische Dimension der höfischen Kleidung zeigt sich im $R H$ in besonderer Weise bei den Gewändern der Frauen. Ihre Gewänder sind transparent und lassen die körperliche Schönheit durchscheinen. Die Autoren schildern den außerordentlichen Kleiderluxus der Prinzessin Mehrnegār: Prangende Gewänder, aus verschiedenartigen Stoffen, fein gewebt, farbig, mit Gold und Silber durchwirkt und mit Edelsteinen besetzt.

Ein weiteres Beispiel ist die Beschreibung von Mehrnegārs Aussehen in der Hochzeitsnacht. Ausführlich und detailiert werden alle Einzelheiten ihrer Garderobe beschrieben, ihr Make-up und der Schmuck, den sie trägt (1/193).

Bestimmten Schmuckstücken wurden bei den Iranern besondere Bedeutungen zugeschrieben. Hierzu gehörte das Gold, dem besondere Kräfte und Schutzfunktionen zugeschrieben wurden. ${ }^{113}$ Schmuck hatte bei den Iranern u.a. auch symbolische Bedeutung. Das Tragen von Schmuck aus Gold und Edelsteinen kennzeichnete die adeligen Frauen. In der Sasanidenzeit behängten die Adligen sich mit Gold und bunten Edelsteinen und stellten damit ihre edle Abstammung, ihren Rang und die damit verbundene Macht und ihren Reichtum zur Schau. ${ }^{114}$ Auch im $R H$ besitzen die Frauen gušvāre (Ohrgehänge), angoštar (Ringe), Halsketten, Armreifen usw. Mehrnegār schmückt sich mit nim-tāğ (verziertes Stirnband; 1/43). ‘Arvāne hāatun trägt an ihren Fußgelenken halhāal(Ringe; 1/179).

Die Kleidung der Männer im $R H$ spiegelt den Platz der gekleideten Person innerhalb der mittelalterlichen Ständeordnung des Irans wieder. Kleidung des Königs, Kleidung des Kriegers und die Kleidung der unterschiedlichen Gruppen und Bevölkerungsschichten.

\footnotetext{
${ }^{1113}$ Anonymus: Nouruz-nāme (mansub be 'Omar b. Ebrāhīm Hayyām Neišāburi), hrsg. von A. Ḥoṣuri, S. 30.

${ }^{1114}$ Siehe: Abkaci-Khavari, S. 64.
} 
Mit der Art des Kleidens verbindet sich ein bestimmtes Verhaltensrepertoire, das auch die Art des Essen, Gehens und Sprechens umfasst und sich mit einem spezifischen Ethos des Liebens, Kämpfens und Herrschens verbindet. Für die höfische Gesellschaft ist die bewusste Präsentation einer spezifischen Lebensform eine Frage der Ehre, der Repräsentation und Legitimation der beanspruchten sozialen Stellung.

In Anōširvāns Kleidung und Schmuck ist ein wesentliches Formelement von Herrschaft zu erkennen. Die Könige tragen viele Edelsteine, um ihren Schnurbart zu schmücken. Ein königliches Kleid ist čahär-qab, das allerdings ursprünglich ein türkischer König bei seiner Thronbesteigung trug (2/220/26). ${ }^{1115}$

Bei den Audienzen tragen seine Höflinge auch besondere Kleidung, die qabā (Tunika) mit einem goldenen Gürtel darüber (1/23). In ihre Freizeit tragen sie ein langes Gewand, das mit Blumen geschmückt ist, die (qabā-ye golgun; 5/787/12).

Ist die Kleidung auch nur ein Symbol einer bestimmten sozialen Stellung, so ist sie dies aufgrund ihrer unmittelbaren Augenfälligkeit in besonderer Weise. Dies wird durch die Beschreibung einer höfischen Sitte deutlich, bei der die geladenen Fürsten hala't (Ehrenkleider) und andere Kostbarkeiten vom König bekommen (2/323).

'Amr verkleidet sich als Sänger und begibt sich zum Hof Landehurs. Dort sieht er Landehur in einem prachtvollen Kleid und einer Krone. Auf seinem Tisch ist ein wertvolles Tafelservice aus Gold und Edelsteinen. 'Amr, der noch nie so viel Gold und Edelsteine gesehen hat, macht sich daran all diese Kostbarkeiten zu stehlen (1/80). Als Ḥamze dies erfährt, reitet er in Begleitung 'Amrs zu Landehur und gibt ihm alles, was 'Amr gestohlen hat, zurück. Landehur lädt beide in den Palast ein und veranstaltet ein königliches Fest. 'Amr lobt in überschwänglichen Worten seine Krone und Landehur gibt sie ihm. Dies wiederholt 'Amr sieben Mal und erhält so sieben Kronen (1/80).

Bei besonderen Anlässen trägt das einfache Volk auch besondere Kleidung; ein Festkleid, ein Ehrenkleid, ein Opferkleid oder ein Kleid für Trauerfeierlichkeiten. Die Bekleidung der Männer besteht aus Oberkleid, Hosen und Turban; man fertigt die Kleidung meist aus Leder, Seide, Baumwolle, Hanf und Pelzen an. Ein kurzes Männerkleid heißt arhāaliq; 5/782). Die

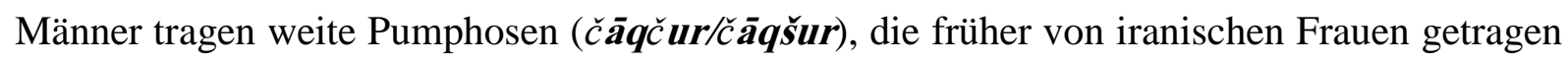
worden sind, wenn sie auf die Straße gegangen sind. Für die Mütze als Kopfbedeckung gibt es im $R H$ viele Begriffe wie šab-kolāh (eine Mütze, die man in der Nacht benutzt; 3/364). Eine Mütze, die bekanntlich von Usbeken getragen wird, nennt man tãqiye-ye usbaki, 3/382). Der Turban heißt mandit, 5/908).

${ }^{1115}$ Pādešāh, čahār-qab, in: Farhang-e ānanderāğğ, ḥarf-e č, Bd. 2, S. 1400. 
Auch die Derwische zeichneten sich durch eine ganz spezielle Kleiderordnung aus: So haben die Derwischorden im Laufe der Jahrhunderte ziemlich differenzierte Trachten entwickelt. Sie trugen Wollmäntel und neben dem Wollmantel bürgerte sich bald auch das Flickengewand ein herqe (ein aus Flicken verschiedener Farben zusammengesetzter Überhang). Zu den traditionellen Ausrüstungsgegenständen der Derwische gehörten auch Kriegsinstrumente wie tabar (Axt), mantašā (Keule), ta limi (Stock) und rašme (Leine). In frühislamischer Zeit hatten die erwähnten Gegenstände kriegerischen Charakter, aber in späterer Zeit besaßen die Waffen dekorativen Charakter. ${ }^{1116}$

Das wichtigste Stück der ganzen Derwischausstattung war die Derwischmütze tāğ (Krone). Die H్Gāksārderwische trugen ein weißes, langes Kleid und hatten ungeschorenes Kopfhaar. Die Mütze bestand aus Filz oder Stoff und sollte seine Krone darstellen. Die Zahl der tark (der Mützenzwickel) besaß bei den Derwischen eine spezifische Symbolik. Die Ḩāksārderwische hatten eine Mütze mit davāzdah tark (zwölf Falten) für die zwölf Imāme der Schia. ${ }^{1117}$

Einer der wichtigsten Ausrüstungsgegenstände für die fahrenden Derwische war die kaškul (Bettelschale). Die kaškul war meist von ovaler Form und aus Metall, Kürbis oder Holz und diente Derwischen zur Aufnahme von Almosen und Nahrung oder auch als Schlagwaffe. ${ }^{1118}$ Hamze, der seine Identität verbergen will, kommt nach achtzehn Jahren von Qāf in einem Derwischgewand nach Ṭanğe. Er hat in seiner Hand eine kaškul, um seine Taille eine Kette und in seiner Hand einen Spazierstock (1/183).

Obwohl der Islam gegen das Schminken der Frauen in der Öffentlichkeit ist, ist die Anwendung von Kosmetik im Iran bis heute weit verbreitet. Die Frauen dürfen dieses Mittel aber nicht für die Verführung anderer Männer benutzen. Die wichtigsten Schönheitsmittel im islamischen Iran sind: vasme (das Schwärzen der Augenbrauen), das Schwärzen der Augenlider mit sorme (Antimon), sorhāāb (das Rotschminken der Wangen), sefidāb (weißes Pulver), das Färben der Hände und Haare mit dem rotgelben Henna. Das entfernen der Gesichtshaare band-andāhtan (das Entfernen der Gesichtshaare mit einem Faden).

Auch Schönheitsmittel werden im $R H$ beschrieben. Mehrnegār färbt ihre Füße mit Henna (1/44/7). 'Arvāne hāātun schminkt sich mit gelber und roter Henna und rötet ihre Wangen mit sorhāāb und sefidāb(1/179).

\footnotetext{
${ }^{1116}$ Vgl. Frembgen, Jürgen: Derwische. Gelebter Sufismus Wandernde Mystiker und Asketen im islamischen Orient, Köln 1993, S.150.

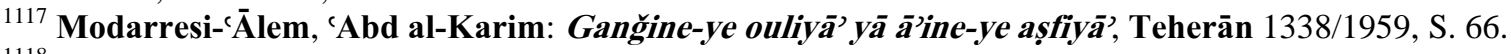

${ }^{1118}$ Ebd. S. 66-70.
} 
Das wichtigste Schönheitsmerkmal für die Männer im Iran ist der Bart. Bart und Haare werden mit roter Henna gefärbt. Das Entfernen der Gesichtshaare und Köperhaare (nurekešidan) ist ebenfalls ein wichtiger Bestandteil der kosmetischen Behandlung. Dies wird mit einem Spezialmittel, dem nure (Gemisch aus gelöschtem Kalk und Arsen; 1/17) erreicht.

\subsubsection{Festlichkeiten}

In vorislamischer Zeit hatte die Darstellung der Festlichkeiten eine zentrale Funktion bei der Festlegung neuer Standards der Selbstdarstellung. Sie führten zur Etablierung eines höfischen Symbolsystems, mit dem sie sich nach innen verständigen und zugleich nach außen abgrenzen konnten. ${ }^{1119}$ Dies zeigt uns auch die Sozialisation am Hof des Hamze, die sich in der Ausformung höfischer Verhaltensstandards und höfischer Lebensformen nach dem Vorbild der altiranischen Vorfahren und den türkisch-mongolischen Herrschern darstellt.

Das $R H$ liefert ein ganzes Panorama an Beispielen für höfische Phänomene wie modische Kleidung, Tanz, Körperhaltung, höfische Gebärde und Musik.

Nach einer Schlacht wird gemeinsam dessen Ende gefeiert. Freude darüber löst die Klagen ab, und das Schicksal der Verwundeten tritt für den Moment in den Hintergrund. Der Rausch der Zerstörung wird abgelöst durch ein Fest, bei dem man sich in friedlichen Ritualen wieder gegenseitiger Bindungen versichert. Die Sorgfalt, mit der man sich kleidet und sich Männer und Frauen schmücken, steht für die Dominanz der Augenlust.

Natürlich beginnt jede Festlichkeit mit dem Empfang der Gäste, um dann die zuvor geleisteten Erfolge zu feiern. Die Darstellungen des Hofzeremoniells und der höfischen Kultur sind sehr farbenprächtig und minutiös in ihrer Anordnung. Die Schilderungen sind sehr genau und können nicht nur der Fantasie der Autoren des $R H$ entsprungen sein. Prachtvoll ist die Beschreibung der Hallen des Palastes. Hamze ist überwältigt von dem Empfang, der ihm in Madā'en bereitet wird, als er den Thron, den er aus Feindeshand gerettet hat, zu König Anoširvān zurückführt. Als er schon fast am Ziel angelangt ist, kommen ihm der König und seine Höflinge zur Begrüßung entgegen geritten, und Ḥamze küsst die Hände des Königs. Dann begibt man sich hoch zu Ross in den Palast, wo Hamze ein Ehrenplatz neben dem König zugewiesen wird und er über seine Abenteuer berichten darf (1/28). Die Feste, wie sie der König veranstaltet, heißen bazm-e šăhāne (1/6). Die Mundschenke schenken beim königlichen Fest Wein aus, und die Sänger und Schauspieler unterhalten die Gesellschaft (1/31).

${ }^{1119}$ Abka'i-Khavari, S. 78-86. 
Im Zentrum des Vergnügens und jeder Festlichkeit stehen die Musik, Tanz und der Wein. Musik hat eine große Zauberkraft und sie gilt als besonderes Entspannungsmittel. Der Held, der Erholung vom Kampf sucht, kann sich mit Hilfe der Musik von der Anspannung befreien. Die Musikanten werden in der persischen Sprache als arbāb-e tarab (wörtlich: Meister der Fröhlichkeit; 5/763) bezeichnet.

Im $R H$ begegnen wir vielen Musikinstrumenten. Einige von ihnen gibt es auch heute noch, von anderen gibt es nur noch den Namen in literarischen Werken. Im nachfolgenden einige Namen: robāb (Zither), nāi (Flöte), qānun (Saiten-Instrument), daf (Tamburin), tombak (Trommel), arğanun (Orgel), barbat (Laute), čang (Harfe), dutār (Mandoline), čahārtār (Mandoline), šeštār (Mandoline), tanbure (Tamburin) und čaġāne (Glocken; 1/62).

'Amr kennt das iranische Modalsystem und er kann gut singen (3/495). ${ }^{1120}$ Er besitzt eine klangvolle Stimme und er singt sentimentale Klagelieder und spielt sie u.a. bei Befreiungsaktionen aus der Gefangenschaft von Hexen (4/580).

Die Sklavinnen sind oftmals Sängerinnen und Tänzerinnen. Zur Untermalung des Abends spielen Musiker und treten Tänzer und Tänzerinnen auf. Der Perserkönig ,Anōširvān, hat zwei Sklavinnen, die als Sängerinnen und Tänzerinnen bei ihm beschäftigt sind (1/38). Die Tänzerinnen werden als (mutreb und raqqāṣ) bezeichnet (1/36).

Der Tanz murče dārad ist ein erotischer Tanz von Frauen für Frauen, die sich dabei langsam ausziehen. Bei diesem Tanz sitzen die Tänzerinnen in einer Runde zusammen, und jemand spielt Tamburin und man tanzt anschließend zu zweit (1/41).

Ein weiterer wesentlicher Aspekt jeder Festlichkeit sind die Speisen. Gutes Essen und reichlich Getränke gehören zu jedem Fest. Bei Hofe heißt das Servieren der Speisen (šilānkešidan; 1/58).

Die Speisen und Getränke, die Herrschende im Vergleich zu dem einfachen Volk gegessen und getrunken hatten, waren im Iran schon in vor- und nachislamischer Zeit sehr unterschiedlich. Auch ihre Esskulturen waren sehr unterschiedlich. Im Laufe der Zeit änderten sich die kulinarischen Sitten erheblich, erst unter dem Einfluss der islamischen, dann später türkisch- und mongolischen Kultur, insbesondere während der Phase der mongolischen Herrschaft. Zudem beeinflusste zeitweise die starke Ausdehnung des Reiches und die

\footnotetext{
${ }^{1120}$ Das iranische Melodiesystem ( $m a q \bar{a} \boldsymbol{m}$ ) besteht aus zwei unterschiedlichen Bereichen. Das eine ist das Großmaqām (dastgāh) und das andere das Klein-maqām (āvāz). Die maqāme sind in eine Vielzahl von guše (Winkel, Abschnitt) genannten Unter-maqāmen (Submodi) unterteilt, die wiederum in größere und kleinere unterschieden werden. Der im Wort dastgāh erscheinende Begriff (gāh) leitet sich vom Altpersischen ab. Dabei handelt es sich um Gesänge, die zu bestimmten Anlässen und Zeiten gesungen werden. Noch heute bedeutet gāh nicht nur „Ort“ sondern darüber hinaus „Zeit“, „Raum“ und „Stimmung. Siehe: Oggar,
} 
Einverleibung von Techniken und Sitten aus Zentralasien bzw. Turkvölker, die iranische Esskultur. Es ist leider bis jetzt keine umfassende Studie über Essgewöhnheiten der Iraner im Mittelalter gemacht wurden.

Im späten 15. und im frühen 16. Jahrhundert zeigt sich in der Ausbreitung und Ausfächerung der volkssprachigen Literatur das besondere Bemühen darum, die traditionelle, adlige Kultur und ihre Lebensweise dem einfachen Volk nahezubringen. Das $\boldsymbol{R} \boldsymbol{H}$ umfasst eine Epoche vom 11. Jahrhundert bis zum 16. Jahrhundert n. Chr. und damit mehr als 500 Jahre. So ist das Werk eine wichtige Quelle für Forschung der Esskultur im Iran. Dort sehen wir überraschenderweise die Beschreibung üppiger, kostbarer, königlicher Mahlzeiten. Die am häufigsten geschilderten Speisen sind eher der Mittelschicht zugehörig. Bei einer Hochzeit isst man zarde-pelāV (Reisgericht; 1/95). Vor den Wettkämpfen nehmen die Sportler u.a. gušt (Fleisch), ein Glas šarbat (süße Getränke) und qand (Zuckerwürfel; 1/34) zu sich.

Weitere erwähnte Speisen sind:

Kašgak (2/216/11), ${ }^{1121}$ harise (2/236/20). ${ }^{1122}$ Die Suppen heißen šurbā (2/236/2) und die Beispielesind: āš-e māst (eine Suppe aus Kräutern und Joghurt; 2/236/21) und šurbāae horus-bačče (Hühnersuppe aus jungen Hühnern; 4/688/14). Das Grillfleisch nennt sich šišlik (3/412/30) und gegrillte Fisch ist kabāb-e māhi (4/645/23).

Auch Getränke dürfen bei den Festlichkeiten im $R H$ nicht fehlen. Die Liebe zum Wein teilen die Iraner mit vielen anderen Völkern. Obwohl der Verkauf und Genuss von Wein den Muslimen nach islamischem Gesetz verboten ist, behält der Wein seine hohe Wertschätzung. ${ }^{1123}$

Die Verbreitung der Weinlokale nahm in der Mongolenzeit zu. Europäischen Reisenden fiel die Trunksucht der Mongolen geradezu als eine ihrer kennzeichnenden Eigenschaften auf. Um die Mitte des 13. Jahrhunderts berichtete Johann de Plano Carpini von ihnen: „Trunkenheit gilt bei ihnen als ehrenvoll; wenn jemand allzu viel getrunken hat, erbricht er sich auf der Stelle, hört aber trotzdem nicht auf, wieder aufs neue zu trinken.“1124 Die große Anzahl der Betrunkenen, die in den Basaren der Städte die Menschen beeinträchtigten, war

Thomas: „Betrachtungen zu Musik Persische Gespräche“. Teil 1, in: Spektrum Iran. Zeitschrift für islamische-iranische Kultur, Nr. 4, (2001), S. 33.

${ }^{1121}$ Eine sehr wichtige Speise in der Safavidenzeit war kašgak. Sie wurde aus Roggen und Weizen zubereitet. Falsafi, Bd. 4, S. 16; Dehḩodā, kašgak, in: Loggat-nāme, ḥarf-e. K-Kāhn-e hašt-behešt, Teherān 1336/1957, S. 562.

1122 Diese bestand aus Hähnchenfleisch und Weizen. Dehḩodā, harise, in: Loğat-nāme, ḥarf-e. H-Hāni garmale, Teherān 1341/1962, S. 199.

1123 Koran, Sure. 5,90-91.

${ }^{1124}$ Plano Carpini, S. 95. 
eine ständige Belästigung. ${ }^{1125}$ Streitereien und Gezänk unter den Betrunkenen führten zu ungebührlichem Lärm. Zudem gab es bei Unruhen auf den öffentlichen Plätzen wie den Basaren infolge Trunkenheit Tote und Verletzte. ${ }^{1126}$ Trotz des religiösen Verbots des Weintrinkens unter Muslimen war es in allen sozialen Schichten im Mittelalter durchaus verbreitet. $^{1127}$

Im Buch Sawat as-Safã wurde beschrieben, dass auch die Vorleser des Korans betrunken ihrer Pflicht nachgingen. ${ }^{1128}$ Um diesen Missstand $\mathrm{zu}$ beenden, erließ der mongolische Herrscher Ġāzān strenge Strafen. Die Betrunkenen wurden in den Basaren aufgegriffen, entkleidet und mitten auf dem Markt als warnendes Beispiel an einen Baum gebunden. ${ }^{1129}$

Die mit dem Alkohol verbundenen Probleme zogen sich bis zur Șafavidenzeit hin. Erst König Šāh 'Abbās II. der Zweite bekam das Problem in den Griff, indem er sehr harte Strafen für Prostitution und Alkoholgenuss einführte. ${ }^{1130}$ Dies aber war oft provisorisch, da viele șafavidischen Könige selbst stark dem Alkohol zugeneigt waren. ${ }^{1131}$

Zuvor aber wirkte sich der allgemeine Sittenverfall auch auf die Darstellung der gesellschaftlichen Ereignisse im $R H$ aus. Hier ein Beispiel:

Als Qobād getötet wird, wünscht seine Mutter Mehrnegār sich von Ḥamze, dass er den Alkohol verbieten solle. Dies tut er auch, jedoch sind seine Männer darüber allesamt sehr betrübt. Die Männer bitten 'Amr inständig, dass er dies Problem lösen soll. 'Amr täuscht daraufhin eine Krankheit vor. ${ }^{1132}$ Hamze eilt besorgt herbei und 'Amr teilt ihm mit, dass der Arzt als einzig denkbares Medikament Wein genannt hat, den er aber wegen des Verbotes nicht trinken darf. Hamze lässt daraufhin Wein bringen. Da 'Amr sich wünscht, nicht allein zu trinken, schließen sich Ḥamze und immer mehr Männer dem Trinken an. Mehrnegār ist sehr traurig darüber, dass Ḥamze die Trauerzeit nicht geachtet hat (2/306).

„Für das Einschenken des Weines bildete man meistens schöne Frauen oder Knaben als sāqiyān (die Weineinschenkerinnen) aus. “ ${ }^{1133} \mathrm{Im} R H$ wird bei allen festlichen Gelegenheiten Wein getrunken. Dabei gibt es festgelegte Rituale für das Ausschenken des Weines. Als Bedienung werden sehr schöne Jungen im Alter von ca. 15-18 Jahren ausgewählt, die mit viel Eleganz und Hingabe ihre Aufgabe erfüllen (1/36).

\footnotetext{
${ }^{1125}$ Nahğavāni, Bd. II, S. 289-290.

${ }^{1126}$ Rašid ad-Din Fażlallāh: Ğamic at-Tawārih̆. Tārih̆-e mobārak-e Ġāzāni, S. 1087.

${ }^{1127}$ Ibn Bazzāz, S. 730

${ }^{1128}$ Ibn Bazzāz, S. 368

${ }^{1129}$ Rašid ad-Din Fażlallāh, S. 1087.

1130 Vgl. Vaḥid-Qazwini, Moḥammad-Ṭāher: 'Abbās-nāme, hrsg. von Ebrāhīm Dehqān, Teherān 1329/1950, 70-72.

${ }^{1131}$ Șafā, Tãrih̀-e adabiyāt dar Irān, Bd. 5, Teil 3, S. 110.

1132 AaTh, (Motiv. Die vorgetäuschte Krankheit 1313, 1313 A-C).

${ }^{1133}$ Khaleghi-Motlagh, Die Frauen im Schahname, S. 101.
} 
Der Weingenuss wird zelebriert und hat feste Gebräuche. Man trinkt den Wein in der ersten Runde ganz schweigend. In der zweiten Runde trinkt man ihn flüsternd. Man glaubt, dass die dritte Runde zur Venus gehört (dore sevvom be zohre-ye čangi ta‘alloq dārad), deshalb trinkt man den Wein dieser Runde beim Tanzen (1/31).

Der Wein wird aus der piyāle (Trinkschale) getrunken (1/36). Die Trinkschale Ḥamzes besteht aus der Schädeldecke eines Dämones (1/189). Zum Wein legt man erst eine pišandāZ (Serviette) hin und darauf werden Beilagen wie nuql o maze (Knabberzeug; 3/412) gereicht. Man trinkt den Wein mit typischen Trinksprüchen wie: auf tāq-e abru-ye Bahtak (auf den Bogen von Bahtaks Augenbraue) oder auf den Geliebten (1/43/30). Außerdem werden Wetten darüber abgeschlossen, wer am meisten trinken kann (2/195). Das Weingeschirr ist sehr kostbar und sehr schön. Es gibt auch nichtalkoholische Getränke bei den Festmahlen:

Dazu gehörensüße Getränke wie šarbat (1/28) und af̌̌ore (1/104), die bei einem Gastmahl gereicht werden. Aus Zucker und Saft wird ein besonderes Getränk namens bid-mešk (ägyptische Weide; 2/295) hergestellt.

\subsubsection{Sport und Spiel}

Die Helden im $R H$ besitzten eine übernatürliche Macht, die ihnen gegenüber ihren Gegnern körperlich und geistig erhebt und sie zu außergewöhnlichen Leistungen befähigt. Sie nutzen sie vorrangig, um ihr oberstes und natürlichstes Bedürfnis zu befriedigen, nämlich ihren Heldenmut zu zeigen und den Ruhm für sich zu gewinnen, der ihnen ihrer Ansicht nach zusteht. Ihr Leben haben sie ihren Taten und der daraus resultierenden Ehre gewidmet. Sie sind bereit sich in gefährlichen Situationen zu bringen, die nicht unbedingt im Bereich ihres persönlichen Interesses liegen, die sie aber dennoch reizen, weil sie ihnen die Möglichkeiten verschaffen, ihre Werte zu demonstrieren.

Im $R H$ trauert man der antiken Vorstellung und Bedeutung der Helden nach. Wie in der Antike bot die körperliche Gestalt und Leistung großen Anlass zur Bewunderung. Der gewaltige Körper, mit Größe, Kraft und Stärke ausgestattet, war noch wichtiger als alle sonstigen Taten dieser Kraftnaturen.

Sport ist einer der wichtigsten Bereiche, wo die Helden ihre Gabe zeigen konnten. Die Jagd schulte den männlichen Charakter und die Liebe zur Jagd zeugte von edler Herkunft. Der ideale Held war ein ausgezeichneter Jäger. In der Jagd wird der Held geboren, denn ursprünglich stehen kriegerische Eigenschaften wie Mut, Kraft und körperliche Fähigkeiten im Vordergrund. Andere Eigenschaften wie Klugheit, List, Einsicht, Besonnenheit und Großmut werden erst später in den Vordergrund gerückt. 
Jagd war ein vornehmlich männlicher Sport und galt im Iran als ein Vorrecht des Adels. Die Jagd war ein wichtiges Privileg der Adligen. Sie wurden von besonderen Lehrern in den Disziplinen der Jagd unterrichtet. Die Jagd war auch eine Vorbereitung auf den Krieg und war Bestandteil der vor-militärischen Erziehung.

Die Jagd gehört zu den wohl populärsten Motiven künstlerischer Darstellung des Menschen. Bereits in der Antike gibt es zahlreiche Darstellungen von Herrschern, die jagen. Nicht etwa nur Tiere, die besonders reichhaltiges Fleisch lieferten, sondern in besonderem Maße herrschaftliche Tiere, wie beispielsweise Löwen. Diese Tiere zu erlegen war weit weniger ertragreich als gefährlich und waren Beweis für den Mut, die Geschicklichkeit sowie die Kampfkraft des jeweiligen Herrschers und untermauerten seinen Herrschaftsanspruch.

So wurde im Iran von Anfang an das Recht zur Jagd mehr und mehr zu einem Recht des Adels. Schon in vorislamischer Zeit gehörte die Jagd zum adligen Alltag und wurde in besonderem Maße bei speziellen Gelegenheiten und Treffen zelebriert.

Die Jagd ist ein weiteres Attribut der Männlichkeit. Das Idealbild des königlichen Jägers in der persischen Literatur ist Bahrām Gōr. Er erlangt die Krone im Kampf gegen zwei Löwen. ${ }^{1134}$ Nach der Thronbesteigung gibt sich Bahrām wieder dem Vergnügen der Jagd hin. Bei diesen Jagden trifft der Held in der Regel auf schöne Frauen, die er immer in seinen Harem bringen lässt.

„Die Jagd oder der Auszug in die Welt ist für orientalische Liebesgeschichten typisch; denn hier findet der Held seine Geliebte. “" ${ }^{1135}$

Als jagdbare Tiere werden Wildesel, Strauße, Gazellen, Bergschafe, Rehe, Hirsche, Fasanen, Löwen und Wildschweine genannt.

Im $R H$ ist die Jagd eine aristokratische Sportart, die Niemand außer dem König oder Machthabern ausüben durfte. ${ }^{1136} \mathrm{Im} R H$ finden sich zahlreiche Jagdbeschreibungen in denen Ḥamze im Auftrag eine Königs steht. Er möchte seine Geschicklichkeit und Kraft beweisen und stellt sich als eine angsteinflößende Figur dar und geht auf die Löwenjagd oder in den Kampf mit Drachen (1/110).

Hier sehen wir eine Reihe von Erzählungen, die die Jagd dort als einen kulturellen, rituellen und rechtlichen Faktoren präsentiert. Sie hat strenge Regeln denen zufolge niemand einen Schuss auf ein Wild abgeben darf, bevor nicht der Held geschossen hat. Er hat das unbedingte Vorschussrecht vor den anderen für sich reserviert.

\footnotetext{
${ }^{1134}$ Ferdousi, Bd. 2, S. 1310.

1135 Spies, Otto: Zwei Volkstümliche Liebesgeschichten aus dem Orient, Helsinki 1939, S. 107.

${ }^{1136}$ Röhrich, Lutz: Jagd, Jagen, Jäger, in: EM, Bd. 7, Göttingen 1993, Sp. 394-411, hier Sp. 395.
} 
Als einmal 'Alam Šāh zur Jagd auszieht, erlegt er ein Reh. Plötzlich kommt ein unbekannter Reiter aus dem Adel und beschwert sich mit den Worten: „Warum hast du meine Jagdbeute erlegt?“( $3 / 370 ; 4 / 568)$.

Die Jagd wird im $R H$ durch Dienstleute sowie mir-šekāāān (Jägermeister) und quščiyān (Falknereien) organisiert (5/977/28).

Der beliebteste Sport (außerhalb der Jagd) war im Iran der Ringkampf. Die Kriegsbereitschaft der iranischen Dynastien benötigte die körperliche Leistungsfähigkeit ihrer Armee. Das Ringen wurde als Volkssport gepflegt und die Mitglieder einer sportlichen Vereinigung waren meist unverheiratete, junge Männer, die in der früheren Zeit als ğavānmard bekannt waren. Im Laufe der Jahrhunderte kristallisierten sich weiterhin viele Regeln, Techniken, Ränge und Verhaltenskodizes heraus, die auch heute noch aktuell sind und ihre jeweilige Verwendung finden.

In späterer Zeit rangen die pahlavān (Ringer) in Vereinen und speziellen Häusern den zorhā̄ne (Haus der Kraft). Hier fanden Ringkämpfe nach bestimmten halb-religiösen Ritualen statt. Die Rangfolge der Ringer ging vom nouče (Anfänger) und noȟāste (Fortgeschrittener) über den pahlavān (Ausgebildeter), zum meidāndār (Schiedsrichter und Lehrer) bis hin zum moršed (Leiter). Die Organisation des zor-hāne entwickelte sich wahrscheinlich bereits in der vorislamischen Zeit. ${ }^{137}$ Die Anführer der pahlavānān hatten im Iran, weil sie aufgrund ihrer Unerschrockenheit einen Machtfaktor darstellten, viel zu sagen. Manche von ihnen waren in einer Zeit schwieriger Lebensumstände für die Bevölkerung des Irans in die Reihe der Notabeln aufgenommen worden. ${ }^{1138}$

Im Šăh-nāme wird die ehrenvolle und heroische Form des Kampfes der košti (Ringkampf). Eindrucksvoll beschrieben. Der Ringkampf zwischen Rostam und seinem Sohn Sohrāb ist dafür ein gutes wenn auch blutiges Beispiel. Zunächst schleudert der junge Mann den Vater, ohne ihn zu erkennen, auf die Erde; dann aber bekommt der Alte den Sohn in den Griff, fasst ihn an Haupt und Nacken, wirft ihn zu Boden und stößt ihm das Schwert in die Brust, wie es das Recht des Siegers ist. ${ }^{1139}$

Die Sage vom Zweikampf zwischen Vater und Sohn ist auch im $R H$ zu finden. Der Ringkampf zwischen Ḥamze und Irağ ist besonders eindrucksvoll.

'Amr, der dem Ḥamze zu rächen geschwört hatte, denkt sich einen teuflischen Plan aus und stellt für Irağ ein Heer zusammen. Er will, dass Ḥamze und Irağ miteinander kämpfen und

\footnotetext{
${ }_{1137}^{137}$ Minorsky, Vladimir: Zur-khāna, in: EI. Bd. IV, Leiden/Leipzig 1934, S. 1344-1345, hier S. 1344 f.

${ }^{1138}$ Vgl. Partou-Beyżāi Kāšāni, Ḥosein: Tãrih̆-e varzeš̀e bāstāni-ye Irān, zor-hāne, Teherān 1382/2003, S. 145.

${ }^{1139}$ Ferdousi, Bd. 1, S. 279.
} 
sich gegenseitig aus dem Weg räumen und den Ruf Ḥamze als großen Held zu schaden. 'Amr achtet darauf, dass Irağ seinen Großvater nicht als solchen kennenlernt.

Irağ fällt mit seinem Heer in den muslimischen Ländern ein und erobert Hạamzes Territorium. Dabei nimmt er seinen Helden gefangen oder tötet sie. Die Nachricht, dass Irăg in den Iran eingefallen sei, erreicht ب̣amze aber er muss zuerst Zomorrod in die Finsternis verfolgen. Er gibt die Verantwortung der Kriegsführung gegen Irağ seinem Freund und Feldherrn Landhur. Später erobert Ḥamze das Land Finsternis und reitet nach Menschenland. Er stellt ein Heer zusammen und reitet zu Irağs Feldlager. Beim Eintreffen Ḥamzes wird zunächst ein Lager errichtet. Ḥamzes lässt den Gefangenen holen und verlangt nach Informationen über Irağ.

Ḥamze begibt sich am Abend heimlich zu Irağs Lager, um den ihm bekannten Heerführer Irağ wieder aus der Nähe zu betrachten. Ḥamze ist von Irağs Jugendlichkeit und seinem Reichtum überrascht. Aber er muss bevor er entdeckt wird ins muslimische Heerlager zurückkehren. Am folgenden Tag kommt es zum ersten Aufeinandertreffen der Heere, wobei sich zunächst die beiden Anführer Ḥamze und Irağ bekriegen. Ḥamze, der im Kampf bisher nie besiegt wurde, ist über die Kraft des Jünglings erstaunt. Ḥamze vermutet der Kämpfer könnte sein Sohn sein. Ḥamzes Herz brennt für Irağ, als er ihn nach seiner Abstammung fragt, aber erhält von Irağ keine Antwort, da Irağ eine Falle hinter der Frage vermutet. Da keiner der beiden Kämpfer an diesem Tag den Sieg davonträgt, verabreden sie sich für einen entscheidenden Zweikampf für den kommenden Tag.

Am folgenden Tag treffen sich die beiden Kämpfer auf dem Schlachtfeld, die beiden Heere halten sich im Hintergrund. Da auch Irăg von Ḥamzes Heldentaten und Mut sehr beeindruckt war, bietet er ihm an, auf den Kampf zu verzichten und sich friedlich zu verständigen. Doch Ḥamze will den Kampf austragen. In dem nun folgenden Ringen versucht Irağ Ḥamze zu Boden zu werfen und stößt ihm das Schwert in die Brust. Da kann Ḥamze ihn mit einer List aufhalten, in dem er Irăg davon überzeugt, dass seine Verletztungen nach dem ausgetragenen Zweikampf zu schwer sind, um weiter zu kämpfen. Er schlägt vor, dass sie das Schlachtfeld verlassen und nach ein paar Tagen wieder den Kampf aufnehmen. Des Weiteren fügt er hinzu: „Wenn man als Ehrenmann gelten wolle, müsse man dem zunächst unterlegenen eine zweite Chance einräumen.” Irăg lässt sich darauf ein und gibt Ḥamze frei. Ḥamze verlässt den Kampfplatz und geht zu seinem Zelt und betet zu Gott, sodass er mit Kraft gesegnet wird. Mit dieser neuen Kraft und Erfüllung stellt sich Ḥamze nun dem weiteren Zweikampf. Am folgenden Tag treffen sich die beiden Kämpfer auf dem Schlachtfeld. Mit dieser übermenschlichen Kraft zwingt Ḥamze nun Irăg, den ihm unbekannten Enkel, fasst ihn an Haupt und Nacken, wirft ihn zu Boden und stößt ihm das Schwert in die Brust, so wie es das 
Recht des Siegers will. Hamze ist somit der Sieger dieses Krieges (5/1003). Die Geschichte kommt aber nicht zu Tragodie, d.h. Ḥamze tötet Irağ nicht, sondern schickt ihn ins Gefängnis in der Hoffnung, dass er sich zum Islam bekehren lässt.

Im $R H$ beherrscht Ḥamze selbst die griechische, gilakische ${ }^{1140}$ und arabische Ringkampftechnik. Beim griechischen Ringkampf muss man drei Tage ringen. Wer den Anderen über den Kopf hebt, ist der Sieger. Beim gilakischen Ringkampf schlägt man mit der Faust. Jeder, der auf den Boden fällt, ist Verlierer (5/1003). Beim arabischen Ringkampf muss der Recke eine schwere Kette um seine Taille wickeln. Dann versuchen sie sich gegenseitig an ihren Ketten hochzuheben (4/673).

In den politischen Wirren der Zeit hatten die Ringer allgemein eine hohe Stellung. Aber dadurch, dass viele Ringer in einem Abhängigkeitsverhältnis zu ihrem Herren standen, hing ihr soziales, finanzielles und sportliches Wohlergehen nun auch vom Status des Förderers ab. Durch den Tod oder auch anderweitig resultierenden politischen Machtverlusts ihres Herren verloren sie auch ihre Privilegien und ihre gesamte soziale Existenz. So kam es dazu, dass viele Krieger dazu gezwungen waren, als Herrenlose durch das Land zu ziehen und sich eine neue Existenz aufzubauen. Einige stellten ihre Kampfkünste artistisch in der Öffentlichkeit zur Schau. Hier stellen wir bereits eine Entwicklung eines professionellen Ringertums fest. Aus diesen Gruppen sollten sich später die Berufsringer etablieren. Das $R H$ berichtet, dass einige aus der Landbevölkerung stammende Ringer wegen ihrer Fachkenntnisse hohe Stellungen bei Hofe erlangen konnten.

Ein anderes Beispiel beschreibt Badi` az-Zamān, der von seinem Adoptivvater, der ein alter und herrenloser Ringer war, den Ringkampfer lernt (2/272). Als Erwachsener ist er zu einem großen Ringkämpfer geworden, der von Stadt zu Stadt reitet, und erfolgreich mit anderen Ringkämpfern ringt (2/398). Wenn ein Ringer seinen Rivalen auf den Boden werfen kann, bekommt er ein manšur-nāme (Zeugnis; 3/467). Von den besiegten Kämpfern nimmt er deren Urkunden entgegen.

Im $R H$ ist der Ringkampf ein Mittel um die Bekehrung zum Islam zu bewirken. Denn im Fall einer Niederlage muss sich der Gegenspieler zum Islam bekehren. Ein Beispiel ist der Kampf von Keivān, einem Feldherrn des Badi` az-Zamān, mit Šāhpur, einem Feldherrn des Moslem Šāh. Dieser sagt zu Keivān: „Wir ringen miteinander. Wenn du mich besiegst, werde ich Muslim und wenn ich dich besiege, musst du Feueranbeter werden.“ Keivān

\footnotetext{
${ }^{1140}$ Gilān liegt im Norden des Irans. Es grenzt im Norden an das Kaspische Meer, im Westen an die Provinz Ardabil, im Osten an die Provinz Māzandarān sowie im Süden an die Provinzen Zandschan und Qazvin. Gilakische Ringkampftechnik soll aus dieser Provinz stammen.
} 
akzeptiert diese Bedingung und sie ringen miteinander. Schließlich besiegt Keivān seinen Gegner Šāhpur, sodass der zum Islam bekehrt wird (4/592).

Der Ringkämpf dient in den heroischen Erzählungen im Gefolge von Ḥamze als ein Instrument um die Rangfolge innerhalb der Gruppe immer wieder auszutarieren.

An einer Stelle lesen wir, dass Nur ad-Dahr mit seinem Cousin Malek Qāsem in den Ring steigt. 'Amr hat vorher den Ringplatz gesäubert und dort Erde verstreut. Er wickelt den fute (Lendenschurz) um seinen Körper und wartet, dass der kohne-savār (Lehrmeister) ${ }^{1141}$ auf den Ringplatz kommt. Sie können erst mit dem Kampf beginnen, wenn der Lehrmeister den Kampf eröffnet. Sie kämpfen tagelang, um festzustellen, wer der mächtigste Held ist (4/670). Wo immer ein Ringkampf stattfindet, geschieht dies vor Publikum. Vor dem Beginn der Ringkämpfe wird der Platz durch die Dienstleute des Königs gesäubert. Dann stellen die Dienstleute die Stühle für die Höflinge und den Thron des Königs am Rand des Kampfplatzes auf. Die Frauen des Königs nehmen hinter goldenen Wänden Platz. Die Menschen sehen von den Dächern der Häuser und den Straßen zu. (1/35).

Die Recken kommen auf den Kampfplatz, wo sie von den Zuschauern begrüßt werden. Nach Nennung des Namens des Propheten Moḥammad durch den moršed (Leiter), antworten die Zuschauer salawāt (1/35) und der Wettkampf beginnt.

Ein anderer wichtiger Sport im Iran ist das Pferderennen, das seine Wurzeln in der altiranischen Kultur hat. Wesentliche Bestandteile des Krieges im Mittelalter waren die Reitkunst, das Bogenschießen und das Ringen. In den Erzählungen führt der Held die Armee und greift selbst in das Geschehen ein. Hamze ist geschickt im Kampf und im Sport. Einmal holt 'Amr aus seiner Tasche Ringe und verstreut sie auf dem Sportplatz. Hamze, der auf seinem Pferd sitzt, sammelt alle Ringe mitseiner Lanze auf (4/670). Er ist auch geschickt im Ringkampf, dessen Griffe er alle kennt (4/671). Des Weiteren versteht sich Ḥamze in der Handhabung sämtlicher Waffen.

Im $R H$ schlägt Bahtak, der ein Gegner Ḥamzes ist, Qāren vor, an einem Pferderennen mit Ḥamze teilzunehmen. Qāren akzeptiert den Vorschlag und am nächsten Tag reiten Qāren und Ḥamze mit ihren Pferden gemeinsam in die Arena ein und präsentieren sich dem König. Vor dem Wettbewerb kommt Bahtak zum Steigbügelhalter des Königs und sagt ihm: „Du musst einen Wasserkrug und Schüsseln nehmen. Dann geh hinter diese Brücke. Wenn das Pferd des Ḥamze kommt, musst du Lärm machen.“ Der Steigbügelhalter akzeptiert den Vorschlag, diesen Betrug auszuführen. Hamzes Pferd rennt sehr schnell, weshalb er zuerst beim Steigbügelhalter ankommt. Doch dieser macht keinen Lärm, weil er Ḥamzes Pferd nicht 
erkennt. Erst als das zweite Pferd kommt, macht der Steigbügelhalter großen Lärm, der Qārens Pferd erschreckt. Qāren wird auf den Boden geworfen und so gewinnt Ḥamze letztlich trotz des vorgesehenen Betruges doch das Pferderennen (1/29).

Laufwettbewerbe

In der Șafavidenzeit war der Kurierdienst der Kundschafter sehr wichtig. Um die besten Kundschafter für den Hof zu ermitteln, fanden Wettkämpfe statt. Viele ausländische Reisende berichteten über diese Laufwettbewerbe. Die Läufer trugen eine Glocke am Oberarm und einen Rock als Beinkleid. Die Gewinner bekamen Preise und Auszeichnungen. ${ }^{1142}$

Auch 'Amr will beweisen, dass er der beste Läufer im Königreich ist. Er spricht mit den Kundschaftern des Anōširvān und behauptet: „Diejenigen, die vor dem König laufen, müssen gute Läufer sein. Ich bin besser als sie alle, und daher muss ich vor dem König laufen." Des Königs Kundschafter verweigern ihm die Teilnahme am Wettbewerb. Als Anōširvān dies erfährt, sagt er zu 'Amr: „Ich weiß nicht, ob du besser als meine Kundschafter bist.“ 'Amr antwortet: „Aber sie können es überprüfen.“ Der König befiehlt seinen Dienstleuten, eine Zieltafel aufzustellen, auf die er einen Pfeil schießt. Daraufhin laufen 'Amr und die Kundschafter des Anōširvān um die Wette bis zur Zieltafel. 'Amr kann den Wettbewerb gewinnen und dem König den Pfeil bringen (1/29).

Weitere Männerspiele sind: das panğe-andāhtan (Armdrücken; 1/22), das čougān-bāzi (Polo; 4/655) und die guy-bāzi (Ballspiele; 1/96). Hierbei werden kleine Bälle nach oben geworfen und wieder gefangen.

Gesellschaftsspiele sind: die ganğafe-bāzi (Kartenspiele; 3/399) und die șorāhi-bāzi (Jonglierkunst; 4/720). Hierbei wird zur Unterhaltung der Trinker mit vollen oder leeren Trinkgefäßen jongliert.

Eine Vielfalt weltlicher Vergnügungen mit theatralischer Komponente fand sich auch in Kinder bzw. Jugendspielen wieder. Auch die Jugendlichen im Spätmittelalter schätzten solche Spiele sehr. Aus $R H$ erfahren wir, dass theatralische Elemente sich im Jugendspiel halten konnten. Viele Themen, die mit alltäglichen Leben zu tun hatten, wurden zum Theaterstück gemacht. Dort finden sich auch die Elemente aus dem politischen System, die als Botschaft vermittelt wurden.

\footnotetext{
${ }^{1141}$ Partou-Beyżāi Kāšāni, S. 61; Rašid ad-Din Fażlallāh: Ğami` at-Tawārih̆. Tãrih̆e mobãrak-e Ġāzāni, S. 1087.

${ }^{1142}$ Mir Ğ́cfari, Ḥosein: Šāter va šāṭer-davāni dar 'aṣr-e Ṣafavi, in: Honar-e Mardom, 15 Jahrgang, Nr. 174, 2536/1977, S. 50-61.
} 
Zu den ältesten Spiel der Kinder zählt das Spiel šăh o dozd (der König und der Dieb). In diesem Spiel steht der König als Symbol der Gerechtigkeit und der Dieb als Symbol der Chaos und Verderben im Vordergrund.

Die Söhne des Adels verbrachten ihre Zeit im Garten und spielten das Spiel šāh o dozd. Dieses Spiel war eine Art Münzspiel. Auf einer Seite des Spielgerätes stand das Wort Wesir und auf der anderen Seite Dieb geschrieben. Jeder Spieler musste das Spielgerät werfen. Wenn die Seite, auf der Wesir geschrieben stand nach oben zeigte, konnte der Spieler alles, was er sich wünschte, befehlen. Wenn die Seite, auf der Dieb geschrieben stand oben lag, musste er alles, was der Wesir befahl, tun.

Welche Auswirkungen ein derartiges Spiel haben kann wird im $R H$ beschrieben. Eines Tages gehen Ḥamze und 'Amr in Begleitung von 40 Jungen in einen Garten. Dort spielen sie das Spiel šăh o dozd. Im Verlauf des Spiels wird Ḥamzes Lehrer Wesir und 'Amr Dieb. Der Lehrer gibt den Jungen den Befehl, 'Amr zu schlagen. Ein anderes Mal wird 'Amr Wesir und der Lehrer Dieb und 'Amr befiehlt einem Jungen, den Lehrer zu töten (1/18), was dieser auch tut.

Im Spätmittelalter spielten die Mädchen auch gerne Theaterstücke, die mit ihrer zukünftiger Rolle als Frau und Mutter in direkter Verbindung standen.

Die Töchter des Adels veranstalten dem $R H$ zufolge ebenfalls Spiele, die weniger gewalttätig waren. Mehrnegār und ihre Hofdamen spielen das Spiel carus-bāzi (Brautspiel) auf ihren Ausflügen, an denen nur Frauen teilnehmen können. Bis heute sind diese Spiele im Iran lebendig (1/50/21).

\subsubsection{Wirtschaft}

Die Verarmung der Menschen in der Mongolenzeit hinterließ nicht nur in den Erinnerungen der Erzähler ihre Spuren. Wir wissen, dass es unter der Herrschaft der Mongolen eine große wirtschaftliche Not gab. ${ }^{1143}$ Diese zwang viele Menschen, sich Banden von Dieben und Wegelagerern anzuschließen. ${ }^{1144}$ Mit der wachsenden Anzahl verödeter Städte und wüster Landstriche stieg auch die Zahl der Bettler und Vagabunden merklich an.

Diese Entwicklungen prägten auch den Handel und die gesamte Wirtschaft zu jener Zeit, da die Handelsrouten völlig unsicher waren. Die verschiedenen Armeen ernährten sich aus dem Land. Raub war auf den Straßen an der Tagesordnung. Einige Bandenführer erlangten

\footnotetext{
${ }^{1143}$ Vgl. Rašid ad-Din Fażlallāh: Čamic at-Tawārih̆. Tārih̆e mobārak-e Ġāzāni, S. 1030

${ }^{1144}$ Ebd. S. 1051.
} 
geradezu Berühmtheit und leiteten Gruppen von beträchtlicher Stärke. Im Buch Safwat aṣȘafā werden die Wegelagerer als ein großes Problem dieser wirren Zeit beschrieben. ${ }^{1145}$ Interessant ist in diesem Zusammenhang eine Episode aus dem $R H$. So erfahren wir ausführlich von den Missständen der Wirtschaft und der Steuerpraxis.

Im $R H$ sind die Handelskarawanen ein bevorzugtes Ziel der Wegelagerer. Zahlreiche Hinweise legen Zeugnis ab, wie groß die Unsicherheit auf den Straßen ist. Überfälle auf Reisende und Diebstähle sind keine Seltenheit. Die Beseitigung der Wegelagerer ist eine wichtige Aufgabe der Helden.

Ḥamze gibt Moqbel den Tribut der fünf Städte, um ihn an den Perserkönig weiter zu leiten. Unterwegs trifft Moqbel einen Dieb namens Ās̄ār-e Ḥarāmi, der eine Bande von 12.000 Männern befehligt hat. Er kämpft mit Moqbel, verwundet ihn und nimmt das Geld in seinen Besitz (1/11; 1/120; 2/260).

Ein weiteres Merkmal der schlechten Wirtschaftssituation in der Mongolenzeit war die maßlose Steuer, die erhoben wurde, die schwer auf der Bevölkerung des Irans lastete. In dieser Zeit gab es die verschiedensten Formen der Abgaben, dazu noch Sondersteuern, die zu allen möglichen Anlässen erhoben wurden. ${ }^{1146}$ Das Volk wurde mit dem als ungerecht empfundenen Steuersystem (was Straßenzölle einschloss) über alle Maßen belastet. Die Steuereintreiber drangsalierten die Bevölkerung durch immer neue Forderungen. ${ }^{1147}$ Schließlich sprach sich sogar die mongolische Herrschaft im Iran für eine Reform des Steuersystems aus. ${ }^{1148}$

An anderer Stelle wird beschrieben, dass Bahtak 5.000 tumān von den Zünften und Geschäftsleuten verlangt und seine Steuereinnehmer das Geld mit Gewalt von den Leuten nehmen $(1 / 119 / 2)$.

Das $R H$ gibt uns auch Informationen über „organisierte Schutzgelderpressung“ in damaliger Zeit. In der Stadt Faranqušiye gibt es einen Mann namens Kaleāhani, der mit Gewalt von den Geschäftsleuten Geld nimmt. Als eines Tages Kaleāhani zu Irağs Geschäft kommt und sein Geld verlangt,tötet ihn Irağ (4/694-695).

Als Währungen finden wir im $R H$ unter anderem den $\boldsymbol{d i n} \overline{\boldsymbol{a}} \boldsymbol{r}(2 / 297) .{ }^{1149}$ und den Begriff zar-e $\boldsymbol{r} \boldsymbol{r a ̈ ' e ̌ g ~ ( s i c h ~ i m ~ H a n d e l ~ b e f i n d e n d e s ~ G o l d ; ~ 3 / 3 6 3 / 7 ) . ~}{ }^{1150}$ Eine weitere Währung im $R H$ ist ašrafi

\footnotetext{
${ }^{1145}$ Vgl. Ibn Bazzāz, S. 324, 1008; 1159. Mehr darüber siehe: Nahğavāni, Bd. II, S. 168-171; 219.

1146 Petrushevsky, I. P.: The socio-economic condition of Iran under the Il-Khāns, in: CHI, Vol. 5, Cambridge 1968, S. 483-537, hier S. 490; 529; Spuler, Die Mongolen in Iran, S. 306-309.

1147 Ibn Bazzāz, S. 819; Vgl. Lambton, Ann K. S.: Landlord and peasant in Persia: a study of land tenure and land revenue administration, Oxford 1953, S. 102-103.

${ }^{1148}$ Rašid ad-Din Fażlallāh: Ǧami‘ at-Tawārih̆. Tãrih̆e mobārak-e Ġāzāni, S. 1061-1068.

${ }^{1149}$ Die traditionelle Bezeichnung dinār, galtursprünglich nur für die islamischen Goldmünzen. Schon unter dem Kalifat waren im Iran Goldmünzen als Handelswährung üblich. So bildete auch nach dem Mongolensturm
} 
(4/692/28). ${ }^{1151}$ Eine andere wichtige Währung, die bis heute als Währung Gültigkeit hat, ist tumān. ${ }^{1152}$ Schließlich finden wir im $R H$ auch pul-e siyāh (Kupfermünzen; 4/692/28). ${ }^{1153}$ Zusammenfassend sehen wir, dass es im $R H$ keine einheitliche Währung aus einer historischen Epoche gibt.

Asad übergibt Hamze viel Geld in Form von reinem Gold als Geschenk. 'Amr nimmt das Geld an sich, woraufhin Ḥamze ihn fragt: „Warum nimmst du das Geld an?" 'Amr antwortet: „Ich will überprüfen, ob es da falsches Geld gibt.“ Ḥamze entgegnet ihm: „Ich kann das selbst machen“, und er gibt das Geld nach der Überprüfung an sein Heer weiter (5/988).

Das $R H$ ist eine wesentliche Quelle für die Verwaltungsforschung. Hier werden die höchsten Staatsämter und das Kanzleiwesen dargestellt. Verschiedene Berufe, die im $R H$ vorkommen, sind aus der Șafavidenzeit. Da das $R H$ aber hauptsächlich vom militärischen Kampf handelt, sind diesbezügliche Berufe und Dienstgrade hier sehr deutlich in der Überzahl.

Auch im Polizeiwesen finden sich, je nach Einsatzgebiet unterschiedliche Dienstgrade. Beim dārūgo handelt es sich um einen Stadthauptmann, dem Amtmann einer Stadt. ${ }^{1154}$ Aus dem timuridischen Hauptstadt Harāt des frühen 16. Jahrhunderts wissen wir, dass der dārūğge über bestimmte Berufsvereinigungen Polizeigewalt ausübte. ${ }^{1155}$ Die nachfolgenden Bezeichnungen beschreiben die Marktwächter im RH: dazu gehören der dāruġe-yebāzār (Basarpolizei; 2/215/30) und der šạne-e bāzār (Marktwächter; 4/576/25).

der dināar, die Goldmünze, als Grundlage des Geldwesens, also ein auf Gold und Silber beruhendes Geldsystem Hinz, Walther: Ein orientalisches Handelsunternehmen im 15. Jahrhundert, in: Die Welt des Orients 4 (1949), S. 312-340, hier S. 326-327.

${ }^{1150}$ Es scheint, dass dieser Begriff aus der Mongolenzeit zu stammen. Wir wissen, dass Ilhāan Ġāzān (12951304) versucht hatte, die Missstände des iranischen Wirtschaftssystems zu verbessern. Eine seiner wichtigsten Maßnahmen war die Reform des Geldsystems. „Er brach mit dem traditionellen, auf Gold und Silber beruhenden binären islamischen Geldsystem und setzte eine reine Silberwährung anseine Stelle, indem er einen dinar aus Silber einführte." Als Bezeichnung für den Silberdinar kommen aber auch Ausdrücke wie dinār-e sapd-e rǟ̆g (sich im Handel befindender weißer dinār) vor. ${ }^{1150}$ Siehe: Gronke, Monika: Derwische im Vorhof der Macht. Sozial-und Wirtschaftsgeschichte Nordwest Irans im 13. und 14. Jahrhundert, Stuttgart 1993, S. 232-233.

${ }^{1151}$ Die Prägung ašrafi fällt wahrscheinlich in die Regierungszeit des Ašraf-e Afg̉ān. Die Schaffung der neuen Münzen war durch das Ziel der Stabilisierung des Irans politisch motiviert. Siehe: Dehhodā, ašrafi, in: Log̉at-nāme, ḥarf-e Eždehā-Esḥāq, Teherān 1330/1951, S. 656.

1152 In der Safavidenzeit wurde der Begriff tumān für eine Währungseinheit benutzt. Im $R H$ taucht am häufigsten tumān als Währung auf (1/107). Dies ist eigentlich ein mongolisches Wort und bedeutet zehntausend. Dieses Wort hatte ursprünglich eine rein militärische Bedeutung (10.000 Soldaten sind ein tumān). Siehe: Doerfer, Gerhard: Türkische und mongolische Elemente im Neupersischen. Unter besonderer Berücksichtung älterer neupersischer Geschichtsquellen, vor allem der Mongolen und Timuridenzeit, Bd. 2, (Akademie der Wissenschaften und der Literatur, Veröffentlichungen der Orientalischen Kommision, Bde. XVI, XIX, XX, XXI), Wiesbaden 1963-1975, hier S. 632.

1153 Diese wurden in der Qāḡārenzeit hauptsächlich für kleine geschäftliche Transaktionen benutzt. Ihr Name leitete sich von der Bezeichnung ,dunkel“ ab, da die Münzen nicht aus Edelmetall waren. Siehe: Galunov, R. A.: Ma'rekegiri, in: Iran III, (1929), S. 94-106, hier S. 99-101; Aubin, Eugène: La Persed'aujourd'hui, ins Persische übersetzt. von 'Ali-Asġar Sacidi, Teherān 1362/1983, S. 262.

1154 Roemer, Hans Robert: Staatsschreiben der Timuridenzeit, Das Šaraf-nāme des 'Abdallāh Marwārīd in kritischer Auswertung. Persischer Text: Faksemile (HS Istanbul Üniversitesi I 87), VOK III, Wiesbaden 1952, S. 91; 176. 
Andere Gruppen des Polizeiwesens kontrollieren die Städte in der Nacht. Dazu gehörender

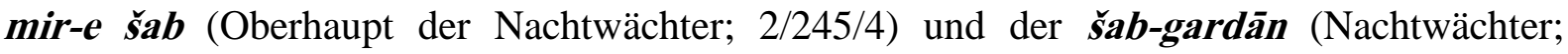
$4 / 656 / 27)$.

In der Stadt Maghreb übernimmt Ḥamze den Beruf des Nachtwächters und verpflichtet sich Eskandar b. Heikalān gegenüber zu folgendem: „Wenn ein dinār von jemandem gestohlen wird, werde ich 100 dinār Bußgeld bezahlen“ (2/297).

Diese Episode entsprach den historischen Tatsachen aus der Șafavidenzeit. Aus dieser Zeit war bekannt, dass die Nachtwächter große Verantwortung trugen. Auch sie mussten ein Vielfaches dessen als Buße bezahlen, was unter ihrer Aufsicht verschwand. ${ }^{1156}$

Der Bevölkerungszuwachs im 15. und 16. Jahrhundert und eine gesteigerte soziale Mobilität nach der mongolischen Eroberung, förderten die Entstehung und das Wachstum von Städten, Handwerksbetrieben und Märkten, was die Gesellschaft allmählich tiefgreifend veränderte. Die Urbanisierung, verbunden mit dem damit wachsenden Handel, muss als wesentlicher Impuls für den allgemeinen Aufschwung angesehen werden, da in den Städten eine verstärkte Arbeitsteilung sowie die Aufspaltung in sozial unterschiedliche Gruppen stattfand und dadurch die Konkurrenz zwischen den Ständen und damit den wirtschaftlichen Fortschritt förderten.

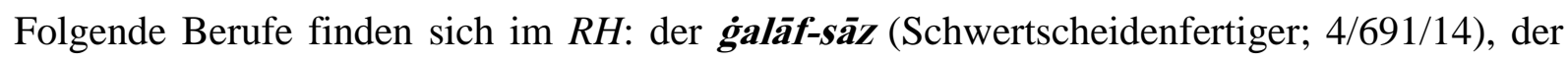
hamāà (Lastträger; 1/4), der moqaled (Unterhalter; 3/493/16), der pālān-duz (Sattler; 1/97/7), der pāre-duz (Flickschneider; 1/125/3), der tabāh (Koch; 2/215/28), der zargar-bāši (Goldschmiedemeister; 1/106/18) und der šāne-bin (Wahrsager, die sich einer Schafsschulter als Medium bedienen; 3/355/19).

Viele Bezeichnungen aus jener Zeit stammen aus dem städtischen Wirtschaftsleben, wie man es in jeder Stadt des Orients finden kann.

Um ein Geschäft aufzumachen, braucht man eine Erlaubnis. Die Erlaubnis heißt parvāne (5/911/19). Dort gibt es folgende Geschäfte: das dukān-e bazzāzi (Textilgeschäft; 4/705/5), die dukān-e hayāt-bah̆ši (Wassergaststätte; 4/713/13), das dukān-e kale-pazi (Eisbeingeschäft; 1/125/13), das dukān-e kabābi (Grillhaus; 2/320/10), das dukān-e keifforuši (Opiumgasthaus; 2/224/11), die dukān-e ḥalvāi (Konditorei; 2/224/12), der dukān-e dalāki (Massage- und Waschsalon; 2/277/2) und der dukān-e ramāli (Wahrsager; 5/798/16).

\footnotetext{
${ }^{1155}$ Ebd.

${ }^{1156}$ Falsafi, Bd. 2, S. 413.
} 


\subsubsection{Bestrafungen und Hinrichtungen}

Im $R H$ ist die richterliche Tätigkeit als eine untergeordnete Aufgabe des Helden. Dort gibt es keinen Hinweis auf das Amt des Qāżi, des islamischen Richter. Außerdem ist auch die Rechtspflege unter der Aufsicht des Königsratgebers aber auch der Kundschafter, zu deren juristischen Tätigkeiten im Iran es keine historischen Belege gibt.

Die Helden haben allerdings große Freiräume, um ihre Urteilsfindung und in der Verwaltung der Justiz zu beweisen. Dadurch erklärt sich auch die große Vielfalt der Entscheidungen, insbesondere in Angelegenheiten, die das Verhältnis der Menschen zueinander regelten, was heute als Privatrecht bezeichnet wird. Während in dem für den Herrscher sehr wichtigen Bereich des öffentlichen Rechts eine einheitliche Rechtsprechung zu beobachten war, fehlte es im privatrechtlichen Bereich an klaren Richtlinien und Entscheidungsmerkmalen. So fassen wir kurz, dass im $R H$ ein klares Rechtssystem nicht zu sehen ist und die Bestrafungs und Foltermethoden werden nach dem Wunsch des Helden durchgeführt.

Es muss deutlichen werden, dass sich Foltermethoden (pers. raveš-e šekanğe) und Bestrafungen (pers. moğāzāt) voneinander unterschieden. Foltermethoden wurden angewandt, um einem Verdächtigen ein Geständnis zu entlocken. Bestrafungen wurden eingeordent, um einen Überführten seine "gerechte" Strafe zuzufügen. Unter Strafen wird nochmals unterschieden in Ehrenstrafen, Leibesstrafen und Hinrichtungen. Ehrenstrafen zielen darauf ab, die Ehre des Verurteilten zu schädigen. Mit Leibesstrafen fügt man dem Verurteilten körperliche Schmerzen und Verstümmelungen zu. Und Hinrichtungen haben vorsätzlich den Tod des Verurteilten zur Folge. Die Durchführung der Folter und der Bestrafungen wurde vom ğallād (Scharfrichter) vollzogen.

Das Buch $R H$ berichtet uns von den Grausamkeiten, die in der damaligen Zeit öffentlich bekannt waren, aber auch über die Rechtsgrundlagen und die Prozessführung. Wir wissen über die Strafarten und die Exekution von Verbrechern Bescheid. Im Folgendem stellen wir verschiedene Foltermethoden vor.

Im Kloster Minā begegnet 'Amr einen mächtigen Priester, der ein Hexer ist. Dieser hat einen magischen siebenköpfigen Menschen erschaffen. 'Amr nimmt den Priester fest und foltert ihn und schlachtet seine Nase ab und bringt seine Augen heraus. 'Amr findet heraus, wie man den siebenköpfigen Menschen beseitigen und den zauberkräftigen den Priester besiegen kann. 'Amr zerbricht durch einen speziellen Stein den Zahn des Vaters, der dessen Lebenskraft enthält (2/265-67).

Ein anderes Beispiel ist die Folterung die Hexe Šamāme durch 'Amr. Die Hexe blindet Ḥamze und seine Freunde. Um Ḥamze zu heilen nimmt 'Amr die Hexe fest. Er foltert sie 
schneidet ihre Finger $a b$ und sticht Spieße in ihren Körper, zieht ihre Nägel ab, näht ihre Lippen, um ihre Zaubersprüche zu verhindern. Die Hexe aber gibt kein Geständnis. Endlich tötet er die Hexe, indem er mit einem besonderen Dolch ihren Zahn zerbricht. Indem er ihre Leber herausholt, um sie auf die Augen zu reiben damit sie gesund werden (3/430-432).

Die Formen der Bestrafung, sind das Abschneiden der Nase und der Ohren, Enthauptungen oder das Rausreißen der Zunge und das Geblendet werden. Schon seit dem Alterturm war im Iran die Blendung sehr beliebt. Besonders in den Königshäusern war es üblich, die politischen Gegner oder abgesetzten Fürsten zu blenden.

Den Körper des Feindes zu verletzen, kommt auch in dieser Geschichte vor: Anōširvān hat Angst, dass Bozorgmehr Ḥamze helfen könne. Daraufhin lässt der König Bozorgmehr blenden (2/218).

Manche der erzählten Episoden von Exekutionen zeugen von der sadistischen Lust am Quälen. Bahtak sticht 'Amr mit dem Messer, verbrennt ihn mit Feuer und foltert ihn auf vielfältige Weise $(2 / 215){ }^{1157}$

Den Körper zerschneiden und in die Wunden ähak (Kalk), zarnih (Arsen) und sude (zerriebene Nadeln) streuen, ist eine weitere Tötungsmethode (1/147).

Eine andere Bestrafungsmethode war die Benutzung des 'Oqābin. Hierbei handelte es sich um zwei Pfähle, zwischen denen der Delinquent angebunden wurde und dort bis zu seinem Tod verblieb. ${ }^{1158}$ Diese Strafe war zur Zeit der Ghaznaviden und der Seldschuken bekannt. ${ }^{1159}$ Qāren b. Fariborz nimmt Ḥamze fest, lässt ihn in eine Kuhhaut einnähen und an den 'Oqābin binden (2/311). Asad verlangt von Lāhut Šāh, Zomorrods Sohn, sich zum Islam zu bekehren. Aber Lāhut lehnt es ab und deswegen befiehlt Asad ihn an den 'Oqābin (Adlerkopf) zu binden (5/870/22).

Kriegsgefangene sind rechtlos, ebenso enttarnte Spione. Häufig werden Hände und Füße der Gefangenen gefesselt oder die Gefangenen werden an einen Baum oder eine Säule gebunden. Die Gegner werden, auch zu Erpressungszwecken, verprügelt. Das Aufhängen an Füßen oder Haaren kommt auch vor. Eine weitere Form des Aufhängens ist: Käkol-āviz kardan (an den Haaren aufhängen; 4/705). Als 'Amr festgenommen wird, befiehlt Qāren, ihn an seinen Haaren aufzuhängen (2/321).

Vielfach werden die prominenten Gegner in einem lächerlichen Gewand präsentiert. Auch diese Schilderungen haben einen historischen Bezug. Als Šāh Tahmāsb nach langer Zeit

\footnotetext{
1157 Spieker, Ira: Qualen, in: EM, Bd. 11, Göttingen 2004, Sp. 96-100.

1158 Dehhodā, ‘oqābin, in: Logáat-nāme, ḥarf-e. '-CEtak, Teherān 1341/1962, S. 348.

1159 Anvari, Ḥasan: Eștelāḥāt-e divāni-ye doure-ye Gaznavi va Salğuqi, Teherān 2535/1976, S. 225.
} 
seinen Feind Moẓaffar Solțān festgenommen hatte, präsentierte er ihn in einem lächerlichen Aufzug der iranischen Bevölkerung. ${ }^{1160}$

Im $R H$ wird in einer Episode um 'Alqame b. Hešām beschrieben, dass der Perserkönig, wenn auch unverschuldet, anstatt der Ehrenkleidung ihm die Leiche eines Tieres schickt. 'Alqame ärgert sich so sehr, dass er befiehlt, den Bart und Schnurbart des Bahtak zu rasieren, ihm Frauengewänder anzuziehen, ihn wie eine Frau schminken zu lassen und ihn so wieder zum Perserkönig zurück zu schicken (2/323).

Neben den bisher genannten Strafformen, gibt es auch das Konfiszieren von Eigentum. Hamze, der von Landehur entäuscht ist, überlässt die Besitztümer Landehurs den Helden der linken Seite (4/531). Um in den Besitz der Reichtümer zu gelangen, misshandelt und quält daraufhin Qāsem Landehurs Dienstleute, damit sie ihm diese zeigen (4/532).

In vorislamischer Zeit sowie in islamischer Zeit, musste man der Familie Blutgeld bezahlen, wenn man einen Familienangehörigen tötete.

'Amr hat Probleme mit seinem Lehrer und zusammen mit seinen Schulfreunden tötet er ihn. ‘Abd al-Muțtaleb, Hamzes Vater, muss den Angehörigen des Lehrers Gold geben, damit sie von weiteren Racheakten absehen. (1/19).

Viele Formen der Bestrafungen haben ihre Wurzel im vorislamischen Iran. Damals gab es drei Haupttatbestände, die auch in die islamische Zeit übernommen wurden: 1. Straftaten gegen Gott, indem man sich von Zarathustra abwandte. 2. Straftaten gegen den König, indem man seinen Interessen zuwider handelte. 3. Straftaten innerhalb der iranischen Gesellschaft. ${ }^{1161}$ Dabei sind die ersten beiden Gruppen Staatsverbrechen. Wer solch ein Vergehen beging, wurde exekutiert.

Die häufigste Exekutionsart im Iran war die Hinrichtung mit dem Schwert und die Hinrichtung mit Pfeilen. Eine andere Tötungsart die insbesondere Staatsgefangene betraf, wurde durch wütend gemachte Elefanten ausgeführt. ${ }^{1162}$ Eine weitere Form der Bestrafung betraf die Leichen der Verstorbenen. Sie wurden enthauptet, entweder, um sie auszustellen oder aber, um sie zum Zeichen des Sieges, anderen Gläubigen zu senden. Diese Form der Bestrafung finden wir auch in der sasanidischen Zeit. Dort wurde Mani, der Begründer des Manscheismus, enthauptet und sein Leichnam in der Öffentlichkeit präsentiert. ${ }^{1163}$

\footnotetext{
${ }^{1160}$ Rumlu, S. 356.

1161 Ibn Esfandiyār: Nāme-ye Tansar be Ğošansaf. Aus dem Arabischen ins Persische übersetzt. von Ibn Esfandiyār, hrsg. von Moğtabā Minavi, Teherān 1311/1932, S. 17; Rażi, Mağid: 'Aṣr-e avestā, Teherān 1343/1964, S. 168; Vāḥdi-Navāii, S. 112.

1162 Diese Strafe war in der vorislamischen Zeit bereits bekannt. Siehe: Vāḥdi-Navā’̀, S. 85.

1163 Anonymus: Tağārib al-umam fí al-ahbār mulūk al-'arab wa-'l-'ağam, S. 200.
} 
In islamischer Zeit bestrafen manche Herrscher ihre politischen Gegner mit Feuer, was in der vorislamsichen Zeit nicht üblich war, da das Feuer heilig war. Die Bestrafung durch Feuer erinnert an eine weitere wichtige historische Begebenheit: Als Šāh Esmāiil die Stadt Bagdad eroberte, verbrannte er die Gräber der sunnitischen Gelehrten (und somit auch ihre Gebeine). ${ }^{1164}$ Dies war nach islamischer Vorstellung eine unglaublich frevelhafte Tat. Auffällig ist, dass es in den islamischen Gesetzen keine Rechtfertigung für diese Bestrafungsmethode gibt. Erst am Tag des Jüngsten Gerichts kann Gott die Bestrafung durch Feuer vornehmen.

Auch im $R H$ wird diese Form der Bestrafung aufgeführt. Die Hinrichtungen werden oft auch mit Feuer durchgeführt. 'Amr wird mit Feuer und kochendem Wasser bestraft, überlebt aber wie durch ein Wunder (2/215).

Ein weiteres Beispiel stammt von Ḥamzes Sohn Badi` az-Zamān. Dieser besiegt Moslem Šāh und verlangt von ihm, dass er sich zum Islam bekehre. Doch der weigert sich und beharrt darauf, dass er keinen Gott außer dem Feuer anerkenne. Badi` az-Zamān befiehlt daraufhin, ihn dem Feuer zu übergeben (4/595).

Im $R H$ befiehlt König Qobād, dass sein Wesir Arqaš, weil dieser mit seiner Frau Verkehr gehabt hat, getötet wird. Seine Leiche wird zerstückelt und in der Stadt ausgestellt, damit die Leute ihn und sein Schicksal sehen können (1/9).

Malek Ġorub Šāh wird durch Ḥamze zum Islam bekehrt und als der Wesir des Königs erfährt, dass der König jetzt ein Gottesanbeter ist, schreibt er an den Sohn des Königs, Ṭolu' Šāh, einen Brief und bittet ihn um Hilfe. Dieser kommt mit seiner Armee zu seinem Vater und sagt: „Bist du wahnsinnig, dass du dich vom König der Welt (Zomorrod) abgewendet hast?“ Da entbrennt der Zorn des Königs gegen den Verrat des Wesirs und er tötet ihn und seine Verwandten. Der Wesir hat eine Tochter und als diese erfährt, dass ihr Vater getötet worden ist, schreibt sie einen Brief an Zomorrod. Diesem Boten begegnet 'Amr und er kann ihm den Brief abnehmen und erfährt dadurch was passiert ist. Als Malek Ġorub Šāh dies wiederum erfährt, tötet er auch die Tochter seines Wesirs (4/632-633).

Ein besonders verhasster politischer Gegner wie Bahtak, wird mit Pfeilen getötet, da viele an seinem Tod Anteil haben wollen (5/1047-1048).

Landehur wird von seinem Onkel den Elefanten vorgeworfen, um einen dynastischen Nachfolgestreit zu entscheiden. Er überlebt jedoch den Exekutionsversuch (1/62).

Landehur erobert die Stadt Ṭaranbusiye, tötet den König, enthauptet ihn, lässt seine Haut mit Stroh ausstopfen und hängt ihn an das Stadttor (1/118).

${ }^{1164}$ Vgl. ad-Duri, Baghdād, in: $E I^{2}$, Bd. I, London/Leiden 1960, S. 894-908, hier S. 903; Browne, Edward 
Will eine Stadt sich nicht kampflos ergeben, scheut man nicht davor zurück, diese aus Rache zu vernichten und keine Überlebenden zurückzulassen. Irağ befiehlt, die Einwohner der Stadt Āhtam nach verlorener Schlacht zu töten und die Festung dem Erdboden gleich zu machen (5/753).

Die Tötung mit Gift, galt als typisch weibliche Form des Mordens und war eine häufige Tötungsart. ${ }^{165}$ Eine sehr wirksame Giftsorte ist das indische Gift. Mit diesem Gift nimmt Širin, die geliebte Frau von Hosrou Parviz, sich das Leben, damit sie nicht zur Heirat mit dem neuen König Širōye, dem Sohn und Mörder ihres Mannes, gezwungen werden kann. ${ }^{1166}$ Die Vergiftung durch Frauen wird im $R H$ an vielen Stellen beschrieben. Als Zarangiz erfährt, dass Hamze ihre Tochter Qahr gesehen hat und sie heiraten will, ist sie wütend und aufgebracht.Sie vermischt Gift mit Wasser und Zucker, bereitet daraus ein süßes Getränk und überreicht es Ḥamze mit der Bemerkung: „Dies schickt dir meine Tochter.“ Ḥamze trinkt das Getränk, wird bewusstlos und wird von Zarangiz lebendig begraben. Als 'Amr von diesem Mordversuch erfährt, sucht er sie, nimmt sie gefangen und hängt Zarangiz an einem Baum auf (3/348). Auch Gostaham vergiftet Ḥamze mit zahr-e halāhel(1/88/15). Bahtak vergiftet ihn mit 2,5 mesqāil ${ }^{167}$ almās-e sude (Zerriebener Diamant; 1/107).

Im islamischen Glauben war die Bestrafung von Frauen und Kindern verpönt, da das Blut der Frau Unglück bringen sollte. ${ }^{1168}$ Daher war es nicht empfehlenswert, Frauen mit den meisten genannten Methoden zu bestrafen (insbesondere nicht mit dem Schwert). Hexen waren hierbei die Ausnahme, da sie dem Islam schaden könnten.

Über Bestrafungen von Kindern und Frauen wird im $R H$ wenig erzählt. Dort empfinden die Helden es schon als Schande, offen mit Frauen kämpfen zu müssen. Einige Ausnahmen gibt es allerdings. Es sind die favāheš (die Huren), die zur Strafe ein besonderer Weise auf dem Markt präsentiert werden (2/323). Um Fetne zu zwingen für ihn tätig zu werden, sagt Ğamšid Šāh-e Balhi zu ihr: „,Du musst 'Amr festnehmen und mir geben, ansonsten rasiere ich deine Haare, ziehe Därme über deinen Kopf, präsentiere dich so in der Stadt Balh und werfe dich schließlich vom Minarett"“ (3/368).

Im Gegensatz zu den altiranischen Ansichten über das Töten von Frauen, kommt diese Form der Bestrafung im $R H$ vor. Als 'Amr erfährt, dass Ḥamze durch Gostahams Sklavinnen

Granville: A literary History of Persia, Bd. IV, Cambridge 1951, S. 63.

${ }_{1165}$ Shojaei-Kawan, Christine: Mord, in: EM, Bd. 9, Göttingen 1999, Sp. 856-876, hier Sp. 861.

${ }^{1166}$ Ferdousi, Bd. 2, S. 1846.

${ }^{1167}$ Gewichtmasse, 1 mesqāl entspricht 5 g. Siehe: Junker Heinrich F. J. u. Bozorg Alavi: Wörterbuch PersischDeutsch, Leipzig [u.a.] 1997, S. 683.

1168 Afšār, Eskandar-nāme, S. 621; Tāğ-bahšs, Aḥmad: Irān dar zamān-e Safaviyān, Tabriz 1340/1961, S. 402. 
vergiftet worden ist, macht er sich auf den Weg, findet die Sklavinnen und tötet sie mit dem Dolch (1/89/3).

Bei Kindern gibt es im $R H$ keine Strafmaßnahmen, sondern es finden besondere Erziehungsmethoden Erwähnung. Als Bozorgmehr, Anōširvāns Lehrer ihm eines Tages eine Frage stellt, die dieser nicht beantworten kann, schlägt Bozorgmehr ihn mit der Peitsche. Als der Prinz weint, befiehlt Bozorgmehr ihn in eine siyāh -čāal(Gefängniszelle; 1/10) zu werfen. Schlagen mit dem Holz auf die Füße (1/26) und Fußtritte werden ebenfalls erwähnt (2/254). Ein anderes Mal gibt Bozorgmehr Anōširvān kein Essen oder hindert ihn daran zu schlafen $(1 / 10)$.

\subsubsection{Volksglauben}

Der Volksglaube, womit hier insbesondere jede Form von Aberglauben gemeint ist, geht auf die während der Entstehungszeit des $R H$ vorherrschenden Ansichten zurück. Teilweise finden wir diesen Aberglauben auch im altiranischen Volksglauben.

Eine dieser uralten iranischen Glaubensvorstellungen bezog sich auf die Wesenheit des jeweiligen Königs und der jungen, männlichen Mitglieder des Königshauses, denn diese galten seinerzeit als heilig. ${ }^{1169}$

Im $R H$ wird die Geschichte von Qobād beschrieben, der durch einen Kundschafter getötet wird. Daraufhin ändert sich das Wetter und ein heftiger Sturm bricht herein. Der Erzähler erläutert dieses Phänomen damit, dass schon in früheren Zeiten, wenn ein unschuldiger Junge als Märtyrer sterben musste, der Wind stärker wehte, da das Schicksal um ihn trauerte $(2 / 305 / 8)$.

Mancher Aberglaube bezog sich auf menschliche Körperteile und Nahrungsmittel:

Im Hexenaberglauben schlug sich vor allem eine partielle Anthropophagie nieder, die bestimmten Körperteilen, wie Herz, Augen, Geschlechtsteilen, Leber, Nieren, ja sogar Leichensekreten, besondere magische Heilkräfte zuschrieb.

Im $R H$ verursachen die Hexen, die das Prinzip des Bösen verkörpern, die Krankheiten. Um ihre Verhexung zu beseitigen, muss man sie töten und ihre Körperteile als Heilmittel benutzen. Unter ihren Körperteilen hat die Hexenleber eine eher untergeordnete Rolle. Ihr wurde die Heilkraft zugeschrieben und sie soll auch zum Beseitigung des Schadenzauber eingesetzt worden sein.

Die Leber der Hexen heißt davā-ye sohrābi. Sie gilt als Medikament und ist gut für die Heilung der Augen. Ḥamze und seine Soldaten werden durch eine Hexe blind. Als 'Amr die

${ }^{1169}$ al-Arraǧāni, Bd. 5, S. 177. 
Hexe tötet, bringt er ihre Leber zu Ḥamze. Dieser reibt sie in seine Augen und wird so geheilt (4/664; 4/661).

Damals glaubten die Menschen auch, dass man durch die Leber eines Menschen Weisheit bekommen könne. ${ }^{1170}$

Im $R H$ wird die Geschichte von Arqaš und Bozorgmehr erzählt. Als Arqaš eines Tages den jungen Bozorgmehr in seinem Garten sieht, weiß er aufgrund seiner astrologischen Kenntnisse, dass Bozorgmehr ihn in der Zukunft töten wird. Deshalb befiehlt er einem Sklaven, diesen zu töten, seine Leber zu grillen und sie ihm zum Essen zu bringen. Bozorgmehr erfährt davon, redet mit dem Sklaven und verspricht ihm, wenn er ihn nicht tötet, wird er ihm die Tochter des Arqaš zur Frau geben und ihm so seine gute Tat belohnen. Der Sklave tötet Bozorgmehr nicht und versteckt ihn. Stattdessen tötet er einen Hund, grillt seine Leber und bringt diese zu Arqaš. Als Arqaš diese Leber isst, vergißt er seine Weisheit (1/710). Hier findet man sogar noch einen zweiten Volksglauben, dass nämlich das Essen einer Hundeleber Vergessen bewirkt.

Das Trinken von Löwenmilch und Leopardenmilch (starke und edle Tiere) macht Helden mutig:

Als Ḥamze auf die Welt kommt, freuen sich die Feen und bringen ihn auf den Berg Qāf. Dort wird Ḥamze mit der Milch von Löwen und Leoparden ernährt, um Mut zu bekommen (1/10$15)$.

Ein bis heute lebendiges Vorurteil ist, dass man dann, wenn man am Abend viel isst, schlecht träumt:

Eines Tages kommt 'Amr zu Ḥamze und sagt, dass er ihn auf seinem Marsch nach Āhtam nicht dabei haben möchte, weil er ihn in einem schlechten Traum gesehen habe. Hamze entgegnet ihm, dass er wohl am Abend zu viel gegessen habe, deswegen habe er einen schlechten Traum gehabt (4/686).

Mancher Aberglaube hat einen religiösen Hintergrund:

Bei den Muslimen steht die offene Hand mit gerade ausgesteckten, geschlossenen Fingern in einer sehr engen Beziehung zu ihrer Religion. Die Hand entspricht der Einheit Gottes. ${ }^{1171}$ Sie ist durch ihre Form geradezu der Inbegriff ihres Glaubens geworden. Sie symbolisiert nicht nur die göttliche Vorsehung, sondern darüber hinaus die fünf „Grundpfeiler“ ihres Glaubens. Die zweite wichtigste Symbolik der Hand bezieht sich auf den Propheten Moḥammad und seine Familie und wird als die kabbalistische Hand bezeichnet, mit Moḥammad (Daumen),

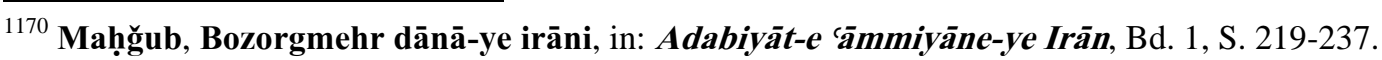


Fāṭima (Zeigefinger), 'Ali (Mittelfinger), Ḥasan (Ringfinger) und Ḥosein (kleiner Finger). ${ }^{1172}$ Die offene Hand mit gerade ausgesteckten, geschlossenen Fingern steht in einer sehr engen Beziehung zur Schia, und bezieht sich zudem auf hadit kasāa, ${ }^{1173}$

Die offene Hand ist heute in den islamischen Ländern als Schmuck und Schutzgegenstand zu einem Gegenstand der Alltagskultur geworden. ${ }^{1174}$ Bei den religiösen Mahlzeiten sucht man nach Zeichen der offenen Hand, die man regelmäßig findet und glaubt, dass auf diese Art das Essen gesegnet wird.

Im $R H$ finden wir ein entsprechendes Beispiel; ein Mann namens Kahanak-e ‘ayyār zieht ein Derwischgewand an, zeichnet eine Hand auf eine Pappe und klebt sie sich auf seine Brust. Danach läuft er, der Sonne ausgesetzt, nach Mekka. Als er in der Stadt Mekka ankommt, entfernt er die Pappe von seiner Brust auf der nun ein weißes Handzeichen zu sehen ist. Er geht zu Ḥamze und sagt ihm, dass er den Prophet Ebrāhīm in einem Traum gesehen habe. Dieser habe ihm eine Speiseplatte voller Datteln gegeben und gesagt, dass er nach Mekka gehen solle. Bald werde eine Krankheit namens vabā (Cholera) in Mekka auftreten. Dann solle er diese Datteln seinen Kindern und Leuten geben, damit sie die Krankheit nicht treffe. Kahanak entgegne Ebrāhīm, dass sie ihm vielleicht nicht glauben werden. Ebrāhīm legt seine Hand auf meine Brust und sagt, dass dies das Zeichen sei. Als Hamze und die Leute dies sehen, glauben sie Kahanak und geben ihm zum Dank viel Geld (2/310).

Der Einfluss angeblicher Heiliger auf das Volk, das diese als wahre Heilsbringer ansah sowohl im Diesseits als auch im Jenseits, erreichte unglaubliche Ausmaße. Die Menschen pflegten, die Heiligen aufzusuchen um dort Hilfe für alle ihre Nöte zu erbitten, und sie hofften, dass die Heiligen sie mit Amuletten oder wirkungsvollen Gebetsformeln versorgen würden.

Mancher Aberglaube stammte aus dem Bereich der Wissenschaft und dem Bereich der Astrologie:

Die astrologische Wissenschaft verfolgte zuerst einmal das Ziel, Horoskope zu erstellen, die zeigten, welchen Einfluss Sterne und Planeten auf eine Person am Tag ihrer Geburt oder auch sonst im späteren Leben haben würden. Dieses Wissen sollte helfen, in wichtigen Situationen des Privat- und Berufslebens, etwa bei der Wahl des Ehepartners, die richtigen

\footnotetext{
${ }^{1171}$ Seligmann, Siegfried: Der böse Blick und Verwandtes, Bd. 2, Berlin 1910, S. 168.

1172 Richter, E.: Oriental und kabbalistische Ursprungsbezirke der geistlichen Hand, in: Deutsche Gaue 43 (1951), S. 18-27; Budge, Ernest A. Wallis: Amulets and Superstitions, New York 1930, S. 469.

1173 Ḥāğğ Seyyed Ğavādi, Aḥmad-Șadr: Āl-e 'abā, in: Dā'rat al-ma‘ārif-e tašayyớ Bd. 1, Teherān 1366/1987, S. 197.

${ }^{1174}$ Vgl. Kriss, R. und Kriss Heinrich, H.: Volksglaube im Bereich des Islam, S. 2-7; Daxelmüller, Christoph: Hand, in: EM, Bd. 6, Göttingen 1990, Sp. 436-447.
} 
Entscheidungen $\mathrm{zu}$ treffen und ganz allgemein realistisch und erfolgreich zu planen; diese Horoskope sollten außerdem in der Lage sein, auch präzise gestellte Fragen zu beantworten.

Auch den politisch Mächtigen konnte die Astrologie nützlich sein. An den Herrscherhöfen scheint die Wahrsagekunst in den verschiedensten Formen populär gewesen zu sein, ganz besonders jedoch die Kunst des Sterndeutens. ${ }^{1175}$

Das $R H$ zeigt uns die Wirkung der Gestirne auf den Kampf von Landehurs Sohn, Farhād. Dieser will mit Irağ kämpfen, aber Šāh Soleimān rät ihm davon ab, denn die Astrologen haben ihm gesagt, dass morgen seine Sterne in schwacher Position seien und es deswegen sinnvoll wäre, wenn er nicht auf den Kriegsplatz ginge (5/841).

Auch bei der Entscheidung über das Datum einer Reise oder eines Kriegszuges waren Astrologen maßgeblich beteiligt. Man sprach von günstigen bzw. ungünstigen Zeiten. Im $R H$ wird vor jeder geplanten Reise von Ḥamze der günstige Zeitpunkt bestimmt (5/917).

Das Horoskop des Neugeborenen (insbesondere beim Adel) war immens wichtig, da die Familie früh wissen wollte, was dem Neugeborenen für ein Werdegang bevorstand. Das erste, was nach der Geburt eines Kindes geschah, war die Erkundung seines Schicksals durch die Astrologen. Die Befragung der Astrologen bei der Geburt eines Königssohnes finden wir auch in den historischen Texten. Es handelte sich dabei eindeutig um eine persische Tradition. Bei den Sasaniden war es üblich, anlässlich der Geburt eines Kronprinzen die Astrologen zu befragen. Es waren meist Magier (Priester), die diese Kunst ausübten. Im Tansar-Brief wurde ihr Rang in der festgefügten Ordnung der Stände im Sasanidenreich mit dem der Sekretäre gleichgesetzt. Neben den Astrologen ahtar-šomārān (Sternzähler) befragte man auch Wahrsager und Zauberer. ${ }^{1176}$

Im $R H$ wird diese Form der Vorhersagen an vielen Stellen beschrieben. Nach Qāsems Geburt sagen die Astrologen vorher, dass er ein großer Held werden und viel Blut vergießen werde.

Die Wahrsagerei hat bei den Iranern bis heute große Bedeutung. Eine Form der Zukunftsdeutung wird mit Sandlesen ausgeführt und gilt als besonders geheimnisvolle Wissenschaft. Nach dem arabischen Wort ramI(Sand) wird sie als ramāli bezeichnet. ${ }^{1177}$ Sie wird auf den Propheten Dāniyāl zurückgeführt. Diese Art von Wahrsagerei hat in der islamischen Gesellschaft eine lange Tradition. ${ }^{1178}$

\footnotetext{
1175 Bayat-Sarmadi, Dariusch: Erziehung und Bildung im Schahname von Firdousi, Inaugural-Dissertation zur Erlangung des Doktorgrades der Philosophischen Fakultät der Universität zu Köln 1970, S. 79; 168.

1176 Ibn Esfandiyār, Nāme-ye Tansar be Ğošansaf, S. 12.

1177 Siehe: Sağādi, Seyyed Ạ̣mad: 'Olum-e garibe, in: Dā’rat al-ma‘̄àrif-e tašayyo‘, Bd. 11, Teherān 1384/2005, S. 386-407.

1178 Varğāvand, Parviz: Raml, in: Dā’rat al-ma‘ārif-e tašayyo ‘, Bd. 8, Teherān 1379/2000, S. 327-329.
} 
Über den Einfluss der Wahrsagerei finden wir im $R H$ viele Beispiele: Irăg schreibt einen Brief an Giti-afruz, den Qāren-e qamar-bin ihr geben soll. Um dies machen zu können greift er zu einer List. Er kommt in die Stadt Zूu 'l-Amān und eröffnet dort ein Geschäft, in dem er Wahrsagerei betreibt. Nach kurzer Zeit hat er gewisse Berühmtheit erlangt. Ḥamzes Frauen hören davon, schicken jemanden zu ihm und laden ihn in das Frauengemach Ḥamzes ein, und so wird er in die Lage versetzt, Giti-afruz Irağs Brief zu geben (5/798).

Aberglauben in Verbindung mit Glück und Unglück:

Man glaubte, dass manche Menschen gesegnete Füße hätten; wenn diese Menschen irgendwo hingingen, sollte dies immer Glück bringen.

Als Ḥamze und Mehrnegār eines Tages zusammen spazieren gehen, findet Ḥamze unterwegs einen Schatz. Später bemerkt er zu 'Amr: „Ich gebe diesen Schatz zu Mehrnegār, da ich den Schatz wegen ihrer gesegneten Füße gefunden habe“ (1/51).

An anderer Stelle lesen wir, dass innerhalb eines Tages 15 Söhne und Neffen von Șalṣāl durch Fariborz getötet werden. Șalṣāl ist darüber sehr traurig und führt dies auf das schlechte Karma von Bahtak zurück und sagt zu ihm: „Bevor nicht eure schlechten Füße dies Land betreten haben, hatte ich nie solch ein Unglück“ (3/420).

Auch Blicken wird im Volksglauben Bedeutung zugeschrieben. Man benutzt gegen den bösen Blick eine häufig angewandte Segensformel, die in diesem Fall die Wirkung des bösen Blickes verhindern soll. ${ }^{1179}$

Der alte Glaube an die Zauberkraft des Auges, die schädigende Wirkung des bösen Blickes und die Angst davor wird auch im $R H$ deutlich. Eines Tages fällt ein Pferd ins Wasser, als es mit seiner Last gerade eine Brücke überquert. Die Leute versuchen, es aus dem Wasser herauszubringen, aber sie haben keinen Erfolg. Als Baht dies sieht, bringt er das Pferd mit seiner schweren Last aus dem Wasser heraus. Die Leute loben ihn lauthals, aber einige werfen ihm vor Neid böse Blicke zu, von denen Baht krank wird (1/3).

Aberglauben in Verbindung mit Tieren:

Nach iranischem Volksglauben bringen schwarze Hunde Unglück. ${ }^{1180}$ Wenn man einen Hund im Traum sieht, ist dies ein schlechtes Omen.

Als Ḥamze durch Gostahams Sklavinnen vergiftet wird, sieht 'Amr in seinem Traum zwei schwarze Hunde, die sich in Ḥamzes Audienzsaal befinden (1/88). Diese schwarzen Hunde sind in Wirklichkeit zwei Sklavinnen, die Hamze vergiften.

\footnotetext{
${ }_{1179}$ Vgl. Lane, Eduard: William: Manners and customs of the modern Egyptians, Bd. 2, London 1846, S. 52.

${ }^{1180}$ Vgl. Hedāyat, Șādeq: Neirangestān, Teherān 2536/1978, S. 98-100.
} 


\subsubsection{Bedeutung der Zahlen}

Die Bedeutung von Zahlen kann sowohl in den religiösen Bereich weisen, als auch mit astrologischen Vorstellungen verbunden sein. Bestimmte Zahlen gelten als günstig oder ungünstig.

Mit der Zahl zwei kann auch eine Art Unzuverlässigkeit ausgedrückt werden, die in der persischen Sprache „zweifarbig“ genannt wird, was „heuchlerisch“ bedeutet.

Das $R H$ kennt die negative Interpretation der Zahl zwei ebenfalls: sie weicht von der Einheit ab und gilt als die Zahl der Häretiker. Die Zahl zwei kann auch Knappheit, im Sinne von begrenzter Zeit zur Verfügung haben, ausdrücken (1/54).

„Die Zahl drei ist für das menschliche Denken, Empfinden und Handeln die bedeutsamste Zahl.“1181 Sie hat eine große mystische Bedeutung. Nach iranischem Volksglauben symbolisiert die Zahl drei das Streben nach Vollkommenheit. Um etwas zu vollenden sind nur drei Versuche erlaubt oder um das Ziel zu erreichen führt nur der Dritte zum Ziel. Hat ein König drei Söhne, so ist der Dritte der Klügste und Beliebteste.

Um Vollkommenheit zu erreichen, hat man nur drei Versuche. Fragen und Rätsel werden im $R H$ dreimal gestellt: „Bozorgmehr sagt zu Moqbel, Hamze wird in Indien vergiftet werden und 'Amr wird einen Arzt holen. Dieser wird nach šāh-mohre verlangen, um Ḥamze zu heilen. Danach wird 'Amr dich schlagen. Aber du darfst nicht die Wahrheit sagen, bis er dreimal mit der Peitsche zuschlägt. Dann darfst du ihm die Wahrheit sagen“ (1/67).

Manchmal taucht in orientalischen Märchen das Motiv der „drei Wege“ auf, zwischen denen eine handelnde Person sich entscheiden muss.

Sadd-e Bolur hat drei Wege zur Auswahl. Ein Weg führt durch die Wüste, der zweite gehört einem Dämon und der dritte geht durch sieben Meere (1/174).

Die Drei spielt ferner eine Rolle für die Wirkung im Gebet.

Ḥamze wünscht seine Gestalt zu verwandeln. Da kommt plötzlich Hèżr. Er lehrt Ḥamze ein Gebet und sagt: „Wenn du dich noch mal in deine eigene Gestalt zu verwandeln wünschst, dann lies diese Gebetsformel und gieße drei Schalen Wasser auf deinen Kopf.“ Durch dieses Gebet kann Ḥamze sein Aussehen verändern (2/235-236).

Im mystischen Bereich findet sich der Hinweis auf die vier Ecken der Welt. ${ }^{1182}$ Auch im $R H$ sieht man einen Hinweis auf die vier Weltecken. Eines Tages begegnet Hamze dem Propheten Heżr. Er gibt ihm den Sattel des Salomon und die vier Hufeisen und sagt: „Wenn

\footnotetext{
${ }^{1181}$ Lüthi, Max: Drei, Dreizahl in: EM, Bd. 3, Göttingen 1981, Sp. 851-868, hier 851.
}

${ }^{1182}$ Afšāri, Mehrān: Ā'in-e qalandari, Teherān 1374/1995, S. 147. 
diese Hufeisen fallen, wird dein Reich untergehen. Diese vier Hufeisen sind Symbol der vier Ecken der Welt"، $(1 / 179){ }^{1183}$

Die Zahl sieben hat im orientalischen Raum eine lange Tradition. In der iranischen Gesellschaft spielte die Sieben in der Kosmologie und Mythologie eine besondere Rolle. In der Pahlaviliteratur war der Herrscher des Irans der Herr der sieben Weltteile. ${ }^{1184}$ Aus den Urnebeln entstanden sieben Himmel und sieben Erden, ${ }^{1185}$ sieben Meere, sieben Sphären, sieben Wetterlagen. Sieben war eine vollkommene Zahl. ${ }^{1186}$

Auch im $R H$ ist der Perserkönig der Herr der sieben Teile der Welt (1/34). Amir führt sieben Kriege, um den Tribut einzusammeln (1/107).

Die Sieben spielt ferner eine Rolle bei der Erkennung und Heilung von Krankheiten, wobei häufig die rituelle Handlung siebenmal wiederholt wird.

Als Ḥamze vergiftet wird, sagen die Ärzte, dass er nur noch sieben Tage zu leben habe $(1 / 89)$.

Die Zahl neun hat ebenfalls eine besondere Bedeutung. Die Neun taucht sehr häufig im Zusammenhang mit der Geburt auf. Nach neun Monaten, neun Tagen und neun Stunden kommt das Kind auf die Welt (2/273).

Vierzig war eine vollkommene Zahl und hatte große mystische Bedeutung. ${ }^{1187}$ Der Glaube an die Magie der Vierzig war in der iranischen Gedankenwelt weit verbreitet. Vierzig war ganz allgemein die Zeit der Vorbereitung und des Wartens. „Die Wichtigkeit der Vierzig in der islamischen Tradition, die frühere Gedanken aufnimmt, kann aus dem Koran und der Tradition ersehen werden, wo die Vierzig oft als Frist für Trauer, Aktivität, Abwartung erscheint. “1188 In der islamischen Welt dauerte die Klausur (arab. arba ${ }^{11 n}$ und pers. čille), der Șufis vierzig Tage; es war und ist eine Zahl der Vorbereitung auf ein positives Ende. ${ }^{1189}$

\footnotetext{
${ }^{1183}$ Vgl. Schimmel, Die Zeichen Gottes, S. 113.

${ }^{1184}$ Die Einteilung der bewohnten Welt in 7 Regionen findet sich in der griechischen, aber auch in der alten iranischen Tradition. Nach iranischer Vorstellung sind die 7 Kešvar 7 kreisförmige Regionen. 6 dieser Kreise sind um einen mittleren Kreis angeordnet. Diese mittlere Region ȟaniras genannt, ist das Zentrum und Herzstück der Welt. Später wurden die fiktiven 7 Länder realen Ländern zugeorenet. 1. Indien, 2. Mag̉rib, 3. Syrien, 4. Irān-šahr, 5. Rum und Șaqāliba, 6. Hazarenland und Torkestān, 7. China und Tibat. In der Aufteilung der Welt nahm der Iran einen bevorzugten Platz ein. Siehe: Christensen, Arthur Emanuel: Les typesdu premier homme et du premier roi dans l'histoire légendaire des Iransiens, Bd. 1, ins Persische übersetzt. von Žāle Āmuzegār und Ạ̣mad Tafażżoli, S. 142.

${ }^{1185}$ Schimmel, Annemarie u. Endres, Franz Carl: Das Mysterium der Zahl. Zahlensymbolik im Kulturvergleich, Köln 1948, S. 165.

1186 Ebd. S. 147.

1187 Vgl. Roscher, Wilhelm Heinrich: Die Zahl 40 im Glauben, Brauch und Schrifttum der Semiten, in: Abhandlungen der Philologisch-Historischen Klasse der Königlichen Sächsischen Gesellschaft der Wissenschaften 27/4 (1909), S. 93-138.

${ }^{1188}$ Schimmel, Annemarie u. Endres, Franz Carl: Das Mysterium der Zahl, S. 262-263.

${ }^{1189}$ Schimmel, Traditionelle Frömmigkeit, in: Der Islam III, S. 262-263.
} 
Im $R H$ muss derjenige, der Derwisch werden will, zunächst 40 Tage als Laufbursche im Kloster dienen (3/499).

Die Zahl achtzehntausend hatte besonders für die Șufis eine mystische Bedeutung. Sie glaubten an 18.000 Welten. ${ }^{190} \mathrm{Im} R H$ lesen wir, dass Gott 18.000 Welten besitzt $(1 / 22)$.

\subsubsection{Krankheit und Heilung}

Ein weiteres Thema im $R H$ betrifft das Gesundheitswesen und die Behandlung von Krankheit. Dabei interessieren uns in erster Linie Hinweise, in denen Krankheiten und deren Behandlung sowie Ärzte und ihre Arbeitweise beschrieben werden.

Neben den Ausführungen zu Kampfhandlungen und dem Familienleben entnehmen wir dem $R H$ vielerlei Ausführungen zum Alltagsleben. Dies beginnt bei Krankheiten bzw. Verletzungen und ihrer Heilung und setzt sich über das Tragen von Gewändern und Schmuck fort. Auch tatsächliche Heilmethoden werden im $R H$ erwähnt: Knochenbrüche werden mit Brettern verkleidet bzw. geschient (tahte-band karden), danach werden sie mit einer bestimmten Salbe eingeölt (mumiyã’i čekāndan) und am Ende schließlich geheilt (4/671).

Wunden können genäht werden; der Terminus für das Nähen einer Wunde ist in der persischen Sprache bahiye zadan (nähen; 5/907). Ein anderer Terminus für das Behandeln von Wunden durch Chirurgen ist hošk-band kardan (geklammert; 1/16).

Im Märchen nimmt nicht der Arzt als solcher eine bedeutende Rolle ein, denn seine Arbeit und seine Fähigkeiten werden auf übernatürliche Helfer zurückgeführt. ${ }^{1191}$

Ein großer Arzt im $R H$ ist Eqlimu, dessen Wohnsitz auf der Insel Lāhur ist, wo er eine große Praxis mit Apotheke führt (1/89). 'Amr bringt ihn in die Festung Sarandieb, zum vergifteten Ḥamze. Sein Körper ist durch das Gift vollkommen schwarz außer einem kleinen weißen Fleck an einer Stelle am Unterarm, an der eine šāh-mohre (Kugel) steckt. Diese Kugel hatte er vor der Reise von seinem engen Freund und Ratgeber Bozorgmehr bekommen; diese Kugel sollte Ḥamze aus einer gefährlichen Situation in der Zukunft heraushelfen. Eqlimu holt die Kugel heraus und legt sie danach in Hamzes Mund. Die Kugel zieht das Gift aus seinem Körper und wird danach weiß. Anschließend gibt er die Kugel zur Giftabgabe in die Milch. Diesen Akt wiederholt er vierzig Mal, bis Amir Hamze giftfrei ist (1/91).

Ein weiteres wichtiges Medikament ist nach dem Volksglauben das Wasser. Das Trinken von Wasser aus goldenen Wasserbehältern ist gut für die Augen, und verbessert die Sehkraft deutlich (1/94/).

\footnotetext{
${ }^{1190}$ Sağğādi, Seyyed Ğa'far: Farhang-e eștelāḥāt va ta birāt-e 'erfāni, Teherān 1370/1991, S. 567.

${ }^{1191}$ Schwibbe, Gudrun: Krankheit, in: EM, Bd. 8, Göttingen 1996, Sp. 338-346, hier Sp. 342.
} 
Allgemein herrschte die Vorstellung, Krankheit werde durch Gegenstände verursacht, die von dämonischen Wesen oder Hexen hergestellt worden seien. Durch Abwehrmittel wie z.B. Amulette, durch göttliche oder weltliche Heiler, durch religiöse oder magische Heilhandlungen (Gebet, Gelübde, Wallfahrten, Wortzauber) könnten Krankheiten geheilt werden.

\subsubsection{Namen}

Die Namen sind wesentliche Strukturelemente eines literarischen Werkes. Die Erzähler des Werkes suchen nach dem ,passenden“ Namen für ihre Figuren oder auch für die Orte der Handlungen.

\subsection{Personennamen}

Wirft man einen Blick auf die Personennamen der Helden im $R H$ lassen sich folgende Regeln erkennen: Die Erzähler des Werkes sind in ihrer Namenswahl frei. Sie haben grundsätzlich zwei Möglichkeiten, um ihren Figuren Namen zu geben. Entweder erfinden sie Namen oder entnehmen sie der Geschichte und der Literatur. Es handelt sich also einerseits um fiktive und anderseits um authentisch-reale Namen, die aus dem vorhandenen, reichhaltigen Namensschatz der Vergangenheit und Gegenwart ausgewählt werden oder die bereits mit dem Stoff verbunden sind. Es ergeben sich daher vier Möglichkeiten der Namensgebung:

1. Name und Namensträger sind real

2. Der Name ist real, der Namensträger ist fiktiv

3. Namen und Namensträger sind fiktiv

4. Der Name ist fiktiv, der Namensträger ist real

Historische Personen aus der Geschichte werden mit ihren Namen in eine erdachte Geschichte versetzt; sie machen dabei eine Verwandlung durch: Sie werden also nicht erfunden, wohl aber zu fiktiven Figuren. Zu beachten ist also der Grad der Fiktionalisierung. Es sind Namen real-existierender Personen und Objekte aus der Geschichte oder Namen aus der iranischen Literatur, die vom Erzähler in das $R H$ integriert werden.

Im $R H$ gibt es eine große Anzahl von Namen, die sich auf Gestalten aus der Mythologie, auf konkrete historische Personen oder auf konkrete Dinge, Orte und Ereignisse beziehen. Diese Namen sind offenbar zu allen Zeiten wichtige literarische Bezugsgrößen gewesen. Mythische Gestalten wie Rostam, Sohrāb, Siyāvaš und Zardošt sind schon in der iranischen Literatur thematisch bestimmend eingesetzt worden. Rostam und Esfandiyār sind Gestalten nicht nur 
der mittelalterlichen Epik, von denen wir annehmen dürfen, dass ihr literarisches Bild auf reale Vorbilder zurückgeht. Alle diese sagenhaft umwobenen Namen haben ihre unverwechselbaren literarischen Konturen erhalten:

Ardešir (5/819/23), Oulād (1/92/23), Āzarborzin-e Tabrizi (2/271/3), Dārāb (1/46/15), Fariborz (3/419/18), Kāvus (5/1028/30), Qāren (5/798/12), Šāhpur (5/1023/27) und Sohrāb $(1 / 48 / 3)$.

Die im Mythos wurzelnden Vorstellungen von der unzertrennlichen Einheit vom Namen und dem Wesen des Namensträgers ist für die iranisch-literarische Welt von besonderer Bedeutung. Manche Namen sind aus dem Buch Šāh-nāme: Galbād (1/160), Kāmus-e Kušāni, der König von Zābol (2/207/10), Giv Gudarz (2/220/20), Lohrāsb (2/199/25) und Pašang (5/894/7).

Manche Namen kommen aus den Erzählungen aus Tausendundeiner Nacht, z.B. in der Geschichte von Ǵrib und 'A ğib. Dort steht, dass Zalzāl ibn al-Muzalzil ein Geisterkönig ist, ${ }^{1192}$ oder Ṣalṣāl b. Dāl, der ebenfalls ein Geisterkönig ist. ${ }^{1193}$

Die fremden nicht iranischen Namen sind teils arabisch und teils türkisch. So gibt es islamische und arabische Namen. Die Bedeutung der wichtigsten Heldennamen wie Asad oder sein Sohn Ġażanfar bedeutet z.B. Löwe, sie tragen gleichsam alle den Namen 'Alis. ${ }^{1194}$ Oftmals tauchen im $R H$ auch historische und religiöse Namen auf, die auch in der Geschichte des Islams vorkommen: 'Abd al-Muț̣aleb (1/19), ‘Abbās (4/632-720), 'Amr (1/24), 'Amr b. Karib Macdi (1/24) und Ebrāhīm b. Mālek-e Aštar (4/607/15).

Teilweise kommen im $R H$ Namen zur Anwendung, die aus dem Koran stammen: Abrahe (5/785/25), Ṭamud b. 'Ād (5/797/5) und 'Aziz-e Meșr(1/124/20).

Unter den fremden Namen sind viele türkische Namen: Āltun-Hูān (3/419/25), Āq-Fulād (3/419/6), Attān-bahādur (5/929/28), Budāg̀-bahādor (5/929/27), Ilderam (4/623/20), (3/451/13), Qarā-pulād (3/419/24) und Qarā-ḩān (3/393/5).

Selten sind europäische Namen im $R H$, wobei gesagt werden muss, dass die Verfasser die europäischen Namen fast alle erfunden haben, weshalb diese für Europäer auch kaum europäisch erscheinen werden: Azruq b. Marzuq (5/923/11) und Balinās (5/1028/29).

Manche Helden haben Tiernamen, die ein Symbol der Manneskraft sind. Es gibt eine Reihe von Personen, die nach Tieren benannt werden, wie Asad, Hamze und Żeigaam (alles bedeutet

\footnotetext{
${ }^{1192}$ Littmann, Bd. IV, S. 599.

${ }^{1193}$ Ebd. Bd. IV, S. 610.
} 
Löwe). Es gibt viele türkische Namen, wie Arsalān (Löwe), Sonqor (Falke), Šir Hān (Löwe), Palang Hān (Leopard) und Babar Ḩān (Tiger; 3/512/18).

Manche Namen haben die Bezeichnung von Edelsteinen wie: Almās (Diamant; 1/46/15), Zomorrod (Smaragd; 4/711/31), Zebarğad (Topas; 5/780).

Es gibt im $R H$ auch Namen, die sich von Waffenbezeichnungen herleiten: Šamšir-hnān und Hुanğar-hāan (Schwert bzw. Dolch; 3/412/2).

Die Bezeichnungen für Sonnenaufgang und Sonnenuntergang finden auch Eingang bei der Namensgebung im $R H$ : Ġorub Šāh, der König von Ġorubiye (Sonnenuntergang; 4/630/25), Ṭolu` Šāh der König von Ṭoluciye (Sonnenaufgang; 4/631/4).

Mitunter finden wir deminutive Namenszusätze mit denen die Feinde des Islams mit einem negativen Beinamen versehen werden: 'Antar Šāh (Affen König; 1/170/3), Manșur b. Alqāṣ-e ḩun-āšām (Bluttrinker; 4/607/14).

Die äußere Form des Namens und seine Bedeutung sind im Werk sorgsam auf den Namensträger abgestimmt, damit er die ihm zugedachte Funktion im Roman erfüllen kann. Namen und Figuren verschmelzen in der literarischen Darstellung zu einer Einheit.

Es ist bemerkenswert zu erwähnen, dass viele Namen im $R H$ eine ethnologische Bedeutung haben, und schon seit Jahrhunderten in Gebrauch sind. Daneben finden sich die künstlich gebildeten Namen, wie sie als fiktive literarische Namen in den Geschichten auftauchen aber heute auch uns in der Realität begegnen können. Dazu gehören:

Firuz-e aždehā-ḩ̌ār (Firuz, der ein Drachenesser ist; 4/557/27), Sohrāb-e pil-dandān (Sohrāb, dessen Zähne wie Elfantenzähne sind; 4/561/17), Fulād-e qavi-heikal (Fulād, der einen mächtigen Körper hat; 4/561/17), Esfandiyār-e mār-h̆̌ār (Esfandiyār, der ein Schlangenesser ist; 4/590/7), Abu 'l-hair-e dozd (Abu 'l-hair, der ein Dieb ist; 2/256/9), Farroḩzād-e ğāsus (Farrohgzād, der ein Spion ist; 2/283/20), Hordak (der Kleine; 5/837/5) ${ }^{1195}$ und Eblis-e 'ayyār (Kundschafter, der wie einTeufel ist; 4/585/25).

Der mit einzelnen Namen verbundene Inhalt kann auf die Entwicklung der Persönlichkeit des Namenträgers einwirken. Manche auftretenden Namen stellen besondere Eigenschaften oder Erlebnisse der nach ihnen benannten Gestalten dar. Die Namen drücken beispielsweise eine bestimmte Berufszugehörigkeit oder den Charakter der entsprechenden Person wie Stärke, Größe oder physische Besonderheiten aus.

${ }^{1194}$ Schimmel, Sufismus und Volksfrömmigkeit, in: Der Islam III, S. 222.

1195 Esmāîili, Bd. 1, S. 575. 
Die Dämonennamen sind in der Regel fiktiv, denn man kann ihre Namen nicht einmal auf eine lexikalische Bedeutung zurückführen. Zumeist klingen die Namen (in der jeweils vollständigen Version) sehr merkwürdig: Aflāk (4/574/8), Ağrus (4/652/8), Arčang (1/145/18) und sein Bruder Arhang (1/148/13), Aškbus (4/574/8), Fulād (1/150/11), Fulādzereh (1/155/4), Harās (4/561/17), Harbāl (1/150/2) und Harčāl (1/150/2).

Der Wohlklang eines Namens spielt bei der Namensgebung eine entscheidende Rolle und er übt offensichtlich eine eigentümliche Faszination aus.

Der Erzähler versucht, die Namen seiner Helden harmonisch klingen zu lassen. Durch Reim, Silbenidentität oder Umstellung erfindet der Erzähler die Namen seiner Helden, die mit denselben Buchstaben oder denselben Silben enden. Der Erzähler versucht, mehrsilbige Namen für bedeutende Personen zu benutzen, wozu er manchmal die Namen mit einem Adjektiv verbindet wie bei Naduk ḥakim (2/217/8) und Mandak ḥakim (2/217/8).

Der Erzähler spielt mit dem Namensklang wie auf einem Instrument. So hat er bei der Vokalharmonie einen größeren Spielraum. Ein gutes Beispiel dafür sind die Namen: Alqāb und Anșāb (4/665/10), Mālā-kard und seine Brüder Mālā-bord und Mālā-hyord (2/250/13), Hālut, Mālut, Ṭālut und Ğālut (5/935/5), Balinās und Čalinās (5/1028/29), Nārenğān und Qārenğān-e Gilāni (3/339/25).

Es kommt im $R H$ sehr oft vor, dass die Namen in zwei verschiedenen Schreibweisen zu finden sind, was auf die unterschiedliche Schreibweise der persischen Sprach zurück zu führen ist: Qarasi-e Tāğdār (2/260/31), Qebresi-e Tāğdār (2/261/3), Mazduq Šāh, der König des Frankenreiches(2/253/15), Maṣ'uq (2/314/25).

Alte iranische Frauennamen kommen im $R H$ sehr häufig vor: Horšid (Sonne) nach dem Firuz-nāme ist sie die Tochter des Hosrou I. [...] ihr Vater gab ihr aber aus Liebe den Beinamen Āzarmi (das schamhafte Mädchen). ${ }^{1196}$

Folgende Frauennamen kommen in der klassischen Literatur vor. Ein Beispiel dafür ist Gordiye, die im $R H$ Ḥamzes Frau ist. Sie war in der vorislamischen Geschichte des Iran schwester und Gattin von Bahrām-e Čūbine, dem Feldherrn von Hormozd IV. (579-590), der später gegen Hormozd und Hosrou II. revoltierte. ${ }^{197}$

Gouhar-Malek, die seldschukidische Prinzessin, war in der Geschichte des Irans Malekšāhs Tochter. ${ }^{1198}$ Neẓāmi nutzte in seinem Werk Hosrau und Širin diesen Namen. Gouhar-malek ist dort Širins Hofdame. ${ }^{1199} \operatorname{Im} R H$ ist sie Qāsems Frau.

\footnotetext{
1196 Anonymus: Mohmal at-Tawārih wa al-qeșaș, S. 37.

${ }^{1197}$ Ferdousi, Bd. 2, 1779-1784.

${ }^{1198}$ Dehhyodā, Gouhar-Malek, in: Loğat-nāme, ḥarf-e. G-Goberiyās, Teherān 1335/1957, S. 600.
} 
Auch bei den seltenen europäischen Frauennamen handelt es sich um „uneuropäisch“ wirkende Fantasienamen: Lo'bat-e Farangi, Tochter von Mazduq Šāh (2/253/20).

Ebenso wie in allen Volksmärchen aller Kulturen sind die Prinzessinnen und auch die Königinnen, im $R H$ wunderschön und liebreizend. Dies wird im $R H$ aber noch zusätzlich durch die Namensgebung unterstützt: Blumen und andere Wunder der Natur, die mit Schönheit in Verbindung gebracht werden, kommen in fast allen Namen dieser Personengruppe vor. Die Namen der Prinzessinnen bzw. Königinnen lauten: ‘Ālam-ārā pari (5/745/16), Del-afruz (5/788/16), Ġazāl-e gouhar-puš (5/749/22), Monavver-e gol-pirhan (1/162/24), Nesā-ye Lā adrei (3/339/28), Nastaran Bānu (4/541/4), Sayāre Bānu (4/563/22) Setāre Bānu (4/563/23) und Sarv-e ḩarāmān (5/800/14).

Gewöhnliche Frauen im $R H$ tragen zumeist bis heute im Iran existierende Namen, die typische Volksnamen sind:Fetne (1/41/20) bedeutet Versuchung, Betörung. Dieser Name ist der Name einer Frau aus dem Roman Bahrām Gōr ${ }^{1200}$, Gol-andām (ihre Gliedmaßen sind wie Blumen; 1/41/20) und Narges (Narzisse; 1/103/17).

\subsection{Ortsnamen}

„Im persischen Volksmärchen etwa werden historische Persönlichkeiten und Orte einerseits nur selten angeführt.“1201 In diesem Abschnitt beschäftigt sich die Arbeit damit herauszufinden, wo sich die Welt des $R H$ befinden könnte. Der Verfasser des Werkes benutzt eine große Anzahl konkreter Ortsangaben. Über 500 verschiedene Ortsnamen lassen sich aus dem knapp 1149 Seiten umfassenden Text herausfiltern. Dabei bewegen sich die Helden manchmal in einer Welt, die keine durchgreifende spezifische Ausgestaltung, gewissermaßen keine Dreidimensionalität, aufweist.

Manchmal verknüpft der Erzähler fantastische Erlebnisse mit Örtlichkeiten, die in der realen Welt existieren. Aber historische Orte werden insgesamt relativ selten genannt im Vergleich zu irrealen (erfundenen) Ortschaften.

Es ist gleichwohl bemerkenswert, dass die Verfasser des Werkes dennoch einigen wichtigen historischen Ortschaften große Relevanz einräumen. Die am häufigsten genannten Städte sind nämlich Madā'en und Mekka.

Weitere Orte sind: Ardabil (2/268/27), Azarbaiğān (2/268/24), Eṣfahān (3/486/18), Ğubāre $(2 / 216 / 18)$; ein Viertel in der Stadt Eșfahān, ${ }^{1202}$ Horāsān (hier wurde vom großen Horāsān

\footnotetext{
1199 Ebd. S. 600.

1200 Pantke, Mechthild: Der arabische Bahrām-Roman. Untersuchungen zur Quellen- und Stoffgeschichte, Berlin/New York 1974, S. 134.

${ }^{1201}$ Marzolph, Ulrich: Lokalisierung, in: EM, Bd. 8, Göttingen 1996, Sp.1172-1177, hier Sp. 1173.

1202 Honarfar, Luṭfallāh: Ganğine-ye āsā̄r-e tārihịi-ye Eṣfahān, Eṣfahān 1344/1965, S. 34.
} 
gesprochen; 3/355/11), Lāhiğān (3/340/16), Qohestān (2/204/19), Sarāb (2/271/4), Šahr-e Rey (3/339/3), Sāveğ-bulāg̀-e Qazwin (3/338/4), Semin-rud, in der Finsternis (5/850/22), Tabriz (2/271/3), Ṭāleqān-kuh (3/471/5), Ṭus (3/355/13), Zābol (2/202/3) und Zaranğ-ābād $(5 / 754 / 5)$.

Die Häufigkeit dieser Nennungen ist durch zwei Faktoren bestimmt. Einerseits beeinflusst durch die reale heimische Umgebung der Erzähler. Anderseits wissen wir, dass viele Erzähler als Wandererzähler tätig waren, so konnten sie die verschiedenen Ortschaften selbst besuchen. Außerhalb der Grenzen des Irans kennen die Erzähler des Werkes große Städte, die in Zentralasien liegen, wie Balḩ (3/354/23), Buhārāā (3/370/16), Samarqand (3/370/17), Fāryāb (3/370/19) und Biyābān-e Āqčir (3/396/13). Dazu in der Nähe von Hațā, Huāvar (3/381/16), Torkestān (3/387/7). Städte im heutigen Afg̉ānestān wie Harāt (3/355/14), Kābul (2/207/8) und Qandehār (4/580/5).

Der jeweilige Erzähler des $R H$ gibt die geographischen Realitäten manchmal nicht korrekt wieder. Als 'Amr nach Iraq reist, erreicht er den Fluss Zāyande-rud, der kurz vor dem Land Iraq sein soll, der jedoch durch die Stadt Eṣfahān fließt (2/210/14).

Ortsnamen, die im ک্̌̄̄h-nāme vorkommen, tauchen auch im $R H$ auf: Hāmāvarān (3/471/4) und Siyāvaš-gord (3/397/1).

Ortsnamen im arabischen Raum sind: Āb-e cadan (2/233/5), Āb-e baṣre (2/273/9), Bait alallāh (4/545/9), Masğed al-Ḥarām (4/545/9), Damešq (5/930/9) und 'Iraq (2/210/6).

Indische Ortsnamen sind: Qal'a-e Sarandib (1/89/9), die Insel Lāhur (1/89/18), Ağrukiye (1/162/1) und Zirbād-e hind (1/161/12).

Orte im Kaukasus sind: Biše-e Barda‘ (3/468/14), Šambुāliye (4/576/15) und Darband-e Qarādāg̀ (4/593/8).

Orte in China sind: Hōān-bāleq (3/381/15), Sanğān (5/789/13), Sanğāb (3/512/15) und Sanğām (3/521/5).

Afrikanische Orte im $R H$ sind: Afruğiye (5/923/21), Eskandariye (5/824/26) und Ḥabaše (Abessynien“; 2/244/14).

Europäische Orte sind: Farang (5/923/6), Farang-e bozorg Portegāl (2/267/28), Mazduqiye, eine Stadt im Frankenreich (2/250/4), Portegāl-e farang (2/262/21), Qebresiye (5/923/27), Qohistānāt-e qebresiye (2/260/31) und Șufiye (4/536/18).

Die Namen der europäischen Orte, Landschaften, Gebiete und Länder sind teilweise frei erfunden. Diese Namen stimulieren die Einbildungskraft des Erzählers. Diese Namen besitzen 
oft eine bestimmte Signalfunktion. So wird Ḥamze in Mekka geboren, später zieht er nach Yeman, danach reitet er nach Madā'en (Ktesiphon). Ḥamze erobert mithin die reale Welt. Nach den zahlreichen Siegen in weit entfernten Gegenden wie Ceylon, Nordafrika und den Ländern der Franken bekämpft er die phantastischen Bewohner der Fantasiewelten: riesenhafte Kannibalen, kamelfüßige Monster und Dämonen. Um seinen Zuhörer einen Bezugspunkt zu liefern, benutzt der Erzähler aussagekräfte ausgewählte Ortsbezeichnungen und zur Vermittlung seiner Intentionen setzt er gezielt und planvoll Bilder ein, die die normale Vorstellungskraft übersteigen: Alang-e Moštarisār (5/755/18), Darband-e Samāvāt (4/559/8), Ğābalqā-ye mašreq (3/457/24), Golestān-e Eram (4/645/20), Insel Fulful (5/73114) und Zolomāt (1/178/15).

Alle Planeten des Sonnensystems können auch als Namensherleitungen genommen werden: Ġorubiye ist die Hauptstadt des Malek Dude und er besitzt sieben Dar-band namens Qamarnamā (Mond), 'Oțāred-namā (Merkur), Zohre-namā (Venus), Āftāb-namā (Sonne), Merihb-namā (Mars), Moštari-namā (Jupiter) und Zoḥal-namā (Saturn; 5/917/11).

Die Ortsangaben im $R H$ machen deutlich, dass die Orte keineswegs den Zeitvorstellungen untergeordnet sind. Fantastische Bewegungen im Raum genießen immer ein großes Potential für den Erzähler, mittels phantastischer Bewegungen in der Zeit wie etwa der Zeitreise oder dem Phänomen der Bilokation. 


\subsubsection{Zusammenfassende Betrachtung der Ausarbeitung}

Man kann das $R H$ in seiner endgültigen Fassung einfach als großartiges Werk betrachten. Um ihm aber gerecht zu werden, ist es erforderlich, dass man es im Kontext der Dichtungen seiner Zeit sieht. Das Werk $R H$ muss immer aus der Perspektive der mittelalterlichen Erzählungen in mittelalterlicher Zeit gesehen werden. Es handelt sich dabei um einen Roman, der um bzw. kurz nach dem 15./16. Jahrhundert entstanden sein muss, also in der Blütezeit der ritterlichislamisch-türkischen Kultur. Diese Zeit hat ihre eigenen Ideale und ihr eigenes Menschenbild geprägt, dennoch besteht auch eine innere Verwandtschaft zwischen den verschiedenen Zeiten.

Der schaffende Geist einer Epoche erkennt sich in bestimmten Formen der Vergangenheit wieder und ergreift sie, um sich in ihnen auszudrücken. Das $R H$ ist so als Ausdruck der geistigen Strömungen dieser Zeit zu verstehen. Aber es wirft die Frage auf, inwiefern das $R H$ Ausdruck des ritterlich-islamischen Geistes ist. Es spiegelt nicht den islamischen Geist wider (so wie er heute verstanden wird), obgleich der Held im Namen des Islams siegt, so lebt er nicht nach islamischem Moralkodex. Muslime bemängeln, dass das Werk $R H$ keinerlei wirkliche islamische Frömmigkeit zeige, sondern vielerlei Sünden beschreibe (Alkohol, Unehelichkeit usw.).

Zusammenfassend lässt sich daher das $R H$ nur unter Berücksichtigung des kriegerischen und fremdbestimmten Charakters während der Entstehungszeit des Werkes verstehen. Es verkörpert wirklich voll und ganz das Bild einer schwierigen Zeit mit all seinen positiven und negativen Ausprägungen.

Aus nicht-islamischer Perspektive kann jedoch der Eindruck entstehen, dass das Werk $R H$ die Beschreibung eines religiösen Siegeszuges ist, der letztlich zur Ausbreitung des wahren Glaubens führt. So werden mit jeder Heirat und jedem Kriegserfolg mehr Menschen zum Islam bekehrt wobei zu berücksichtigen ist, dass eine Bekehrung nur aus Überzeugung als solche zu verstehen ist.

Viel stärker, als es bisher geschehen ist, muss man das $R H$ mit allen Buchdichtungen des hohen Mittelalters vergleichend analysieren, und nicht nur unter dem Gesichtspunkt von Heldengeschichten, sondern auch unter den in dieser Zeit entstandenen Ritterromanen, der religiösen Literatur und den volkstümlichen Dichtungen. Auch sollte diese Analyse mit Blick auf die literarischen Motive hin untersucht werden, im Hinblick auf die Sprache, auf die Kunst der Darstellung und auf das Ziel der Erzählung.

Das $R H$ ist sehr eng mit seiner Zeit verbunden und der Abstand zwischen ihm und den altiranischen Epen ist nicht groß und dennoch gibt es einige Unterschiede. Einer dieser 
Unterschiede besteht darin, dass das $R H$, trotz seiner Berührungspunkte mit dem altiranischen Epos, eigentlich außerhalb der vorislamischen Welt steht. Dennoch gibt es im $R H$ zwischen einzelnen dort agierenden Gestalten und den altiranischen Helden zahlreiche Übereinstimmungen, so dass die Verschiedenheit in der Darstellung der Charaktere und der Beschreibung des Geschehens im $R H$ und den altiranischen Epen nur geringfügig ist.

Im $R H$ treffen im Verlauf der Geschichten viele verschiedene Kulturen unvorbereitet und oftmals gewaltsam aufeinander. So kommt es stets $\mathrm{zu}$ Integrations- und Disintegrationsprozessen, zum kulturellen Austausch auf der einen Seite sowie der starken Betonung der eigenen Kultur und der strikten Ablehnung des Fremden auf der anderen Seite. Gerade dort, wo es zu intensiven kulturellen Austauschprozessen kommt, sind zugleich auch Umformungen, Verschmelzungens- und Abgrenzungsprozesse zu erwarten. Besonders im Bereich des Narrativen sind derartige Vorgänge zu beobachten.

Dass dem Erzählen eine entscheidende Funktion für die Konstituierung, Sicherung und Überlieferung sozialer (und auch kollektiver) Identitäten zukommt, ist in der kulturwissenschaftlichen Forschung unumstritten. ${ }^{1203}$ Es gibt einen bestimmten Handlungsverlauf, den der Erzähler nicht ändern kann, der fest vorgegeben ist, weil er eben nun einmal tief im Volksbewusstsein verwurzelt ist. Im $R H$ sieht man die engen Beziehungen zwischen den Heldentaten und dem Lebensgefühl des Volkes. Hier werden die Lebensformen in ein ganz neues Licht gerückt. Der mittelalterliche Staat und die gesamte Gesellschaft bauen hier auf ein Netz persönlicher Treueverhältnisse. Dies ist darauf zurück zu führen, dass persönliche Treueverhältnisse in der kriegerischen und wechselhaften Entstehungszeit des Werkes ungeheuere politische und oft existentielle Bedeutung haben.

Die Männertreue ist eine der obersten Tugenden in der iranischen Ethik. Hier berührt und verbindet sich das iranisch-islamische Ethos aufs tiefste mit dem Volksempfinden. Die Helden sehen ihre Aufgabe gerade darin die sittlichen Forderungen der Zeit in erhabener Gestalt zu verkörpern. Auf unverwechselbare, sehr lebendige Art sind die Helden des $R H$ groß in ihrer Leidenschaft: der Liebe, großem Schmerz, tiefem Hass und großer Verzweiflung.

Dieser Roman beschränkt sich nicht allein auf die Produktion von Unterhaltungsliteratur, sondern er hat in der Vergangenheit dazu beigetragen eine Änderung in der religiösen Gedankenwelt der iranischen Gesellschaft zu bewirken.

${ }^{1203}$ Vgl. Geertz, Clifford: The Interpretion of Cultures. Selected Essays, New York 1993; White, Hayden: The Value of Narrative in the Representation of Realiy, in: William J. Thomas Mitchell (Hrsg.): On Narrative, Chicago 1981, S. 1-23; ders.: The Content of the Form: narrative Discourse and Hisorical Repersentation, Baltimore 1987. 


\section{4. Überblick über die Grammatik}

Die von den naqqāls (Erzählern) geschaffene Sprache, die mit der Ausdrucksweise ihrer Zeit identisch war, ist ziemlich einfach. Die Ausdrücke sind charakteristisch für den Stil der epischen Erzählung, wie sie bei den älteren epischen Werken der Perser vorkommen. Die Erzähler verwendeten aber auch damals schon manche Wörter und Formen, die bis in die Gegenwart verständlich sind. Eine formelle Analyse zeigt, dass die iranischen Erzähler feste Wendungen besaßen. Sie benutzten einen speziellen Wortschatz, der in der iranischen Tradition der Erzählkunst über Jahrhunderte erhalten worden ist. Die iranischen Erzähler berichteten auf die gleiche Art wie ihre Vorfahren in der alten Zeit.

So kann man bei den epischen Werken wie $E N, H L$ und $A N$ feststellen, dass die Formeln, die der Erzähler des $R H$ in seinem Repertoire hat, wie etwa Wortschatz, Sprachrythmus und Redewendungen, Anfangsformeln oder bestimmte Ausdrücke am Schluss einer Erzählung, sowie gleiche grammatische Formen auch in anderen epischen Werken gefunden werden können. Die Schlussfolgerung ist, dass bestimmte Erzählformeln allgemein unter den iranischen Erzählern bekannt waren und von allen gemeinsam verwendet wurden.

Obwohl die verschiedenen Bände des $R H$ im zeitlichen Ablauf harmonisch aufeinander abgestimmt sind, ist der literarische Stil des Werkes sehr unterschiedlich. Diese Unterschiede lassen sich nur durch die Annahme der Pluralität der Autoren erklären. Der literarische Wert der Erzählung kann aufgrund der Unterschiedlichkeit der Erzählform nicht mit normalen Maßstäben gemessen werden, und sein Wert liegt eher in der beabsichtigten Wirkung auf die Zuhörer, sie zu einem bestimmten religiösen Denken hinzuführen. Im Text findet sich kein stabiler Schreibstil und keine Einheitlichkeit hinsichtlich Grammatik, Erzählstil, Wortwahl und Formen der Einleitung der Kapitel. Der Text ist insgesamt sehr farbenprächtig, wobei sich einige Passagen stilvoll und voller Methaphern präsentieren und andere Stellen sehr schlicht gehalten sind. Dadurch ist auch der Sprachrythmus sehr wiedersprüchlich. An einigen Stellen ist die Sprache des Erzählers sehr poetisch, und man sieht dort eine starke Tendenz zum Aufbau einer rhetorischen künstlerischen Spannung. An anderen Stellen ist jedoch keinerlei klassische Systematik zu erkennen, weil dort unter anderem keine Episode eingeleitet wird, kein Spannungsbogen festzustellen ist und keine Personen eingeführt werden. Die Unterschiede im Erzählstil im $R H$ sind zwar groß doch die stereotypen Wiederholungen sind ein Charakteristikum, das sich überall im $R H$ wiederfindet. 


\subsection{Einführung zur Qualität des sprachlichen Stils}

Die Erzähler benutzen die Alltagssprache. Sie achten kaum auf grammatische Regeln. Darüber sagt Lord:
„In unsere Muttersprache übernehmen wir kaum Worte und Sätze, die wir uns bewusst gemerkt hätten. Sie prägen sich uns nach dem üblichen Sprachgebrauch ein. Das gilt auch für den epischen Sänger, der seine spezielle Grammatik beachten muss.“1204

Grammatikalisch gesehen sind die Sätze sehr einfach und kurz. Die Verben werden im Text nicht in der richtigen Art und Weise angewendet. Damit ist gemeint, dass oft nicht einmal die Unterscheidung zwischen Singular und Plural im Verhältnis des Subjektes zum Verb Beachtung findet.

$\mathrm{Zu}$ berücksichtigen ist zudem, dass das Werk $R H$ offensichtlich nach mündlichen Erzählungen von Schreibern festgehalten wurde. Hinzu kommt, dass $\mathrm{zu}$ seiner Entstehungszeit der weit überwiegende Teil der Bevölkerung weder Lesen noch Schreiben konnte. Diese Menschen waren nur zu erreichen, indem man ihnen Erzählungen nicht in Schriftform vortrug, sondern so, als würde jemand frei erzählen. Unter dieser Zielsetzung des $R H$ ist nachzuvollziehen, dass der Stil der mittelalterlichen epischen Erzähler nicht als hochliterarisches Werk beabsichtigt ist, also keine Hochliteratur für die Elite darstellt, sondern natürlich und volksnah sein soll, ein Volksepos eben. Deshalb wird in der Untersuchung des Textes die Sprache so analysiert, als läge ein mündlicher Text vor, gewissermaßen ähnlich der Bewertung eines Vortrages. So soll die Sprache der „mündlichen Überlieferungen“ in ihrem ursprünglichen Zustand mit allen Unregelmäßigkeiten und Abweichungen präsentiert werden.

Das vorliegende Kapitel hat drei Teile: Im ersten Abschnitt behandelt es die mündliche Erzähltradition, welche im $R H$ verwendet wurde. Im zweiten Abschnitt werden die auffälligen sprachlichen Phänomene dargestellt. Absicht dieser Ausarbeitung ist es nicht, eine reine sprachliche Analyse des Buches vorzunehmen, weil die Grammatik der persischen Sprache den Wissenschaftlern hinreichend bekannt ist. Es wird daher lediglich die Sprache, wie sie in den persischen Überlieferungen vorkommt, mit der Sprache, die im Buch verwendet wird, verglichen und die bestehenden Unterschiede aufgezeigt. ${ }^{1204}$ Lord, Albert: Der Sänger erzählt (The singer of tales). Wie ein Epos entsteht, aus dem Englischen und
Serbokratischen übertragen ins Deutsche. von Martin Helmut, München 1965, S. 66. 
Im dritten Abschnitt wird der literarische Stil des $R H$ untersucht. Es geht dabei um die Prinzipien einer kommunikativ ausgerichteten historischen Erzählform im Überblick und im geschichtlichen Zusammenhang.

Danach folgen exemplarische Untersuchungen, der Erzählformen im persischen Epos des 16. Jahrhunderts in denen, die Prinzipien am Material vertieft und ihre Anwendungen demonstriert werden sollen. Die Arbeit ist deskriptiv ausgerichtet und bei den Darstellungen wird nicht nur versucht, die Ergebnisse und das zugrunde liegende Material zu präsentieren sondern, es soll dabei so gut es geht verdeutlicht werden, inwiefern diese Ergebnisse ein Beispiel für einen bestimmten theoretisch-methodischen Ansatz sind.

In der vorliegenden Untersuchung wird anhand der folgenden Beispiele eine Übersetzung der angeführten Termini und Passagen durchgeführt. Gelegentlich werden exemplarisch ausführliche Kommentierungen angeführt. In diesem Abschnitt wird auf besondere Erscheinungen in der persischen Erzählkunst eingegangen.

\subsubsection{Mündliche Überlieferung}

Die mündliche Überlieferung hat bei allen Menschen zu allen Zeiten eine lange Tradition. Die Dichtung in Versen und Strophen war dafür vorgesehen und wurde bei passender Gelegenheit vorgetragen. Man bezeichnet diese Dichtung als „Oral Poetry“. Oral Poetry in diesem Sinne trifft man auch im Mittelalter an. Es gibt dagegen auch Formen von Dichtungen, die sich einer eindeutigen Zuordnung zu mündlicher oder schriftlicher Dichtung entziehen. Mündlich überlieferte Erzählungen, die von Vortragenden aus dem Gedächtnis zitiert wurden, gehören nach modernem Verständnis durchaus zur wertvollen Literatur. Erst zu einem späteren Zeitpunkt beginnt man sie zum Teilschriftlich zu fixieren.

Die Erzähler konnten, auf Einzelblätter geschriebene, stichwortartige Texte bei sich tragen doch ihr Vortrag wurde weitgehend aus dem Gedächtnis rezitiert. Während des Vortrags war es möglich, dass der ursprüngliche Text stark verändert wurde, weil die Vortragenden mit ihren Quellen mehr oder weniger willkürlich umsprangen, den Wortlaut umstellten, Zusätze machten oder kürzten. Daher weichen die verschiedenen lithographischen Ausgaben unseres Buches $R H$ häufig voneinander ab. Das $R H$ ist das Resultat eines mündlichen Vortrages und ist mit großer Sicherheit auch für andere volkstümliche Erzählungen, die durch professionelle naqqāl(Erzähler) dargeboten wurden vorstellbar.

Lange glaubte man, dass über den Berufsstand der fahrenden Erzähler alles gesagt worden war; bis Milman Parry (amerikanischer Philologe und Homer-Forscher, 1902-1935) mit seinem Schüler, Albert B. Lord (1912-1991) in den Jahren zwischen 1932 und 1934 in 
Jugoslawien Tausende von Texten lebendiger mündlicher Epik sammelte. Die Analyse dieser Texte bestätigte seine Hypothese von einer mündlichen Überlieferung und zeigte deutlich die eigentliche Technik der mündlichen Komposition.

Die daraus entstandenen Aufsätze und das Buch seines Schülers Albert B. Lord bilden die Grundlage dieser Untersuchung der iranischen Erzählkunst. Auf dieser Grundlage wird herausgearbeitet, wie die naqqāls der Heldendichtung ihr Gedächtnis einsetzen, welcher Technik sie sich bei ihrem Vortrag bedienen und auf welche Arten der Kodierung des Wortlautes sie sich stützen, um schließlich ihren flüssigen Vortrag zu gestalten.

Heute glaubt niemand mehr an einen vollständig aus dem Gedächtnis gestalteten Vortrag strophischer Heldendichtung des Mittelalters. Unter den Erzählern hat es einige gegeben, die lesen konnten und andere, die nicht lesen konnten. Der Vortrag ist frei gesprochen worden und nicht vorgelesen. Aus Überlieferungen weiß man, dass die Lesekundigen am Tag vor ihrem Vortrag den Text auswendig lernten. Die Leseunkundigen mussten sich den Text vorlesen lassen, um ihn sich dabei einzuprägen. Beiden kam zugute, dass sich im $R H$ Textpassagen oftmals immer Wort für Wort wiederholten, so dass auf diese Weise Namen bzw. Orte häufig nur geändert werden mussten, um eine neue Episode erzählen zu können. Beim Vortrag eines auswendig gelernten Textes konnten Gedächtnislücken nicht immer ausbleiben; somit waren die Erzähler genötigt zu improvisieren.

\subsubsection{Formeln, ihre Funktion und Anwendung}

In der vorliegenden Arbeit „Das RH als Musterbeispiel der iranischen Erzählkunst“ soll eine tiefgreifende strukturelle Organisation der iranischen Erzählsprache aufgezeigt werden. Diese Erzählkunst lässt sich auf die durch mehrere Generationen hindurch gepflegte Erzählsprache einer mündlichen und epischen Tradition zurückführen. Diese Sprache besteht einerseits aus vielen mehrfach anwendbaren Formeln, andererseits aus einer Art Grammatik, die es dem Erzähler ermöglichte, diese Formeln zu sinnvollen Sätze zu kombinieren.

$\mathrm{Zu}$ den meist diskutierten Fragen der modernen Epenforschung zählt daher das Problem der Mündlichkeit und Schriftlichkeit. Demzufolge wird sich dieser Abschnitt mit typischen Wendungen, die im $R H$ regelmäßig vorkommen, beschäftigen.

Parry hatte herausgefunden, dass eine Gruppe von Wörtern bei gleichen metrischen Bedingungen regelmäßig verwendet wurde, um einen gegebenen Vorstellungskern auszudrücken. $^{1205}$ Die Erzähler benutzten solche vorgeformten Wendungen, die ihnen mühelos fertige Verse oder Sätze lieferten. Der zweite Punkt in der Theorie von Parry basierte 
auf der Verwendungshäufigkeit der Formeln. ${ }^{1206}$ Für ihn waren mündliche Dichtungen solche, die viele Formeln und Wendungen verwendeten. Die Formeln konnten mit kleinen Änderungen angewendet werden. Darüber schreibt Haymes:

„Die Dichtersprache besteht praktisch aus solchen metrisch vorgeformten
Wendungen, die mühelos dem Sänger fertige Verse liefern. Wir dürfen uns
diesen Vorgang aber nicht allzu steif und mechanisch vorstellen. Die Formeln
sind dem Sänger keine Heiligtümer, die er immer unverändert gebrauchen
muss; sie sind vielmehr metrisch-syntaktische Modelle, die bei einem guten
Sänger außerordentlich produktiv wirken können. “1207

Die Formeln sind im Sinne von Parry ganz allgemein jede Art von Wiederholung, manchmal von Sätzen, manchmal auch von einem einzigen Wort und oder einer Strophe. Die Frage ist, welche Formeln, die für die schriftlich abgefassten Dichtungen charakteristisch waren, verwendet wurden?

Nur die Formeln, die in vielen Zusammenhängen metrisch und inhaltsmäßig richtige Verse ergaben, konnten sich in der Erzähltradition einbürgern. Die natürliche Auslese der brauchbarsten Formeln führte nach Parry zu dem zweiten Kriterium, der Wirtschaftlichkeit. Er kennzeichnete das System mit den Stichworten „Wirtschaftlichkeit” und „Umfang”. Mit Wirtschaftlichkeit bezeichnete er die Vielfalt, die Ausdehnung der Epitheta. ${ }^{1208}$ In diesem System gab es für jede Handlung und Figur eine bestimmte Wortkombination. Diese Formeln waren fertige Teile, die der Erzähler/Sänger einfach in seinem Gedächtnis behalten konnte. Sie gaben dem Erzähler/Sänger die Möglichkeit, sich bei der Aufführung zu orientieren. Solche Formeln/Hilfsmittel halfen dem Erzähler auch bei der Gestaltung einer neuen Schöpfung. Parry sah in diesem System das Produkt einer natürlichen Auslese, die nur in einer mündlichen Tradition über Generationen hinweg weiter gegeben wurde. Im diesem Zusammenhang widmete sich die Ausarbeitung den Kriterien der Mündlichkeit in sogenannten typischen Kombinationen und typischen Szenen.

Man kann zu dem Schluss kommen, dass die Mehrzahl der betrachteten Szenen im $R H$ durch die Verwendung typischer Kombinationen und typischer Details gekennzeichnet sind. In der Tat benutzen die Erzähler fertige Formeln, typische Details und sich wiederholende Themen und Situationen. Der Gebrauch dieser Formeln in der persischen Literatur muss in der langen Tradition der mündlichen Überlieferung entstanden sein.

\footnotetext{
${ }^{1205}$ Parry, Milman: Untersuchung zur epischen Technik mündlichen Dichtens. Homer und homerischer Stil, in: Homer. Tradition und Neuerung, hrsg. von Joachim Latacz, Darmstadt 1979, S. 187.

${ }^{1206}$ Parry, Komplette Formelverse in griechischen und südslawischen Heldengesang, in: Homer, S. $277-279$.

${ }^{1207}$ Haymes, Edward: Mündliches Epos in mittelhochdeutscher Zeit, Göppingen 1975, S. 16.

${ }^{1208}$ Parry, Untersuchung zur epischen Technik mündlichen Dichtens, in: Homer, S. 193.
} 


\subsubsection{Einleitende Formeln}

Der epische Erzähler benutzt bestimmte Formeln und Themen mit einer besonderen Aufbautechnik. ${ }^{1209}$ Im $R H$ befinden sich verschiedene Arten von Formeln, die hier getrennt nach einleitenden Formeln, überleitenden Formeln und abschließenden Formeln angeführt werden.

Die einleitenden Formeln im $R H$ haben meistens literarischen Charakter. Der auffälligste Unterschied zwischen verschiedenen einleitenden Formeln ist der Umfang und die literarische Qualität des Satzes. Hier sehen wir auf der einen Seite einfache Formeln und auf der anderen Seite sehr literarische Formeln. Diese Veränderungen zeigen uns, dass die Autoren des Textes verschiedene literarische Vorlagen gehabt haben müssen, woran deutlich wird, dass das Buch aus verschiedenen Schriftrollen bestehen muss.

Die einleitenden Formeln sind nicht fest und haben verschiedene Längen. Manchmal werden in den einleitenden Formeln auch die Handlungsverläufe dargestellt.

Manchmal steht der Inhalt der einleitenden Formeln im Zusammenhang mit dem Inhalt der Erzählung. Ein Beispiel ist die Erzählung über Zomorrod, der für sich den Titel einer Gottheit in Anspruch nimmt und seine Niederlage durch die Muslime mit folgender Einleitung beginnt:

\footnotetext{
ma'reke-ārāyān-e soḩanvari va bazm-pirāyān-e dānešvari be emdād-e farrāšān-e ḩiyāl bāregāh-e soleimāni rā dar moqābel gombad-e 'arš-nemāye Zomorrod Šāh in čenin bar-sar-pā kardeand ke ...(5/865/1-2).

Die Straßendarsteller und die Organisatoren des Gastmahls der Gelehrsamkeit hatten mit Hilfe der Teppichausbreiter der Einbildung, den Audienzsaal Salomons gegenüber der dem Gottesthron ähnlichen Kuppel des Zomorrod Šãh so aufgeschlagen, dass $[\ldots]$.
}

Manchmal ist die Anfangsformel nur ein Vers:

Die erzähltechnischen Formeln, die der Erzähler verwendet, stehen meist für konkrete Situationen, die sie einleiten. Bei einer Aufführung ist es üblich, dass der Erzähler nicht sofort mit dem Epenvortrag einsetzt, sondern zunächst sich und sein Publikum einstimmt. Der Kompositionsprozess beginnt also mit einer bekannten oder vorgestellten Situation. Oft mit einer Rede oder mit kürzeren Liedern. Diese Reden sind teils literarisch und teils autobiographisch. So will der Erzähler die Zuhörer zunächst aufmerksam und nachdenklich

${ }^{1209}$ Marzolph, Ulrich u. Amirhosseini-Nithammer, Azar: Die Erzählungen der Mašdi Galin Hānom. Teil 2: Begleitband, Wiesbaden 1994, S. 24-29; ders.: Ganğine-i az gozārehā-ye qālebi dar dāstān-e cāmmiyāneye Hosein kord-e Šabestari, in: Qeș̣e -ye Hosein kord-e Šabestari, hrsg. von Irağ Afšār u. Mehrān Afšāri, Teherān 1385/2006, S. 439-455. 
machen. Dann beginnt der Erzähler seine Geschichte zu erzählen, wobei er selbstverständlich einleitende Formeln verwendet. Der Erzähler versucht dabei, manche dieser Formeln mit Blick auf die Hörgewohnheiten seiner Rezipienten zu wählen.

Die einleitenden Formeln können auch ein paar Gedichte in der Form von robā̄i (Vierzeiler) oder ein gazal (lyrisches Gedicht) oder să $\check{g}^{\mathbf{c}}$ (gereimte Prosa) sein. Diese Gedichte passen inhaltlich zu den nachfolgenden Geschichten. So erreichen die Erzähler die Aufmerksamkeit der Zuhörer und bereiten sie auf das Hören der Geschichte vor. ${ }^{1210}$

Dann erzählen sie die eigentliche Geschichte. Innerhalb der Geschichte kommen auch immer wieder Gesänge oder Gedichte aus der klassischen Literatur vor. Die Darstellung ist so teilweise in Prosaform und teilweise in Versform gehalten.

soḩan-pardāz-e guyā-ye ḩeradmand,

čonin bardāšt az dorğ-e gouhar band ke...

Der weise sprechende, gewandte Redner

Nimmt aus dem Kästchen des Edelsteins das Band, dass....

ammā čand kaleme az sar-e ḩanğar-gozārān cālam bešnavid:

kohne-dozdi ke robāyad ze šahān afsar-e šāhi, az šab rang-e siyāhi va folus az tan-e māhi va ze osfur par-e morg், kamand az kamar-e Borq [...] ḥağar az dahan-e māhi va šarar az nār, kabudi az falak girad va šuri az namak $[\ldots](5 / 795 / 29)$.

Hören sie ein paar Worte vom Meister der gewandt mit dem Dolch in der Welt kämpft, von einem alten Spitzbuben, der die Krone vom Kopf der Könige raubt, der die schwarze Farbe der Nacht raubt, vom Körper des Fisches die Schuppen, der dem Spatz seine Federn ausreißt und der von der Taille des Borqes das Fangseil raubt [...] von dem Mund der Schlange den Stein und vom Feuer den Feuerstrahl. Vom Himmel raubt er das Blau und vom Salz den salzigen Geschmack [...].

bābā-ye davandegān 'ālam;

ke u rāst davandegi mosallam;

hargez na-resad be gard-e u bād;

šāgerd-e daraš hezār Galbād;

gardun ze falāhnonaš mošabbak;

dar kaškak-e u hezār Baḩtak (1/36/24-28; 1/151/26-31).

Der Vater der Läufer der Welt;

zweifellos das Laufen ist für ihn;

niemals erreicht der Wind den Staub seiner Füße;

1210 Šahri, Ğa‘far: Teherān-e qadim, Bd. 2, S. 147. 
tausend Schüler wie Galbād [ein geschickter Kundschafter] sind vor seiner

Tür, der Himmel wurde von seiner Steinschleuder netzartig.

Tausend Personen wie Baḩtak [Anōširvāns Wesir] sind in seinem kaškask [eine Speise].

Sehr häufige Anfangsformeln sind:

ammā rāvi guyad/naql kardeh ke...

Aber der Erzähler hat gesagt, dass...

(1/13/24), (1/14/ 8), (1/26/16), (1/24/14), (1/25/18), (1/27/23), (1/37/17), (1/38/1), (1/43/10), (1/93/8),

(1/110/23), (1/115/11), (4/709/26), (4/719/10), (1/168/22), (1/173/29), (1/183/14).

ammāṣāḥebān-e soḩan čonin bayān kardehand ke čon...

aber die Besitzer der Rede haben erzählt, dass...

(4/564/31), (4/603/29), (4/608/4), (4/608/4).

ammā rāviyān-e ahbbār va nāqelān-e āșār čonin naql kardehand ke dar zamāni ke...

aber die Erzähler der Nachrichten und der klassischen Werke haben erzählt, dass in der Zeit...

$(1 / 153 / 22),(1 / 165 / 15-16),(1 / 186 / 22)$.

gozārande-ye dāstān čonin bayān karde ke čon...

aber der Erzähler dieser Geschichte hat gesagt, dass...

(4/542/1), (4/603/29), (4/608/4), (5/834/11).

Sehr selten fängt die Geschichte mit dieser Formel an:

ammā dar zamāni ke... (zu der Zeit; 1/173/26)

ammā vaqti ast ke... (aber es ist jetzt die Zeit, dass...; 1/183/14).

Es gibt im $R H$ Orts- und Zeitsprünge in der Handlung der Gesamterzählung und es beginnt oft eine völlig neue Episode, obgleich die begonnene noch gar nicht abgeschlossen ist. Diese kompletten Wechsel der Handlungsstränge, die manchmal schmuckhaft in Gedichtform gehalten sind, werden durch folgende Formeln eingeleitet:

dāstāni az šāhzāde Nur ad-Dahr be-šnavid.

negārande naqāšse Behzād-dast 'arus-e soḩan rā čonin naq̌̌ bast ke čon... $(5 / 855 / 2)$.

Hören sie nun zunächst eine Geschichte über Prinz Nur ad-Dahr. Die Maler [Erzähler], die Hände wie Behzād hatten, haben die Braut der Rede [Erzählung] so angemalt, dass.... [die Erzähler haben ihre Erzählung so ausgeschmückend gestaltet wie Behzad seine Gemälde].

dāstāni az Asad guš konid (5/788/24). 
Hören sie nun zunächst eine Geschichte von Asad.

dāstāni az Ṣalṣāl guš-konid (5/925/22).

Hören sie eine Geschichte über Șalṣāl.

\subsubsection{3 Überleitende Formeln}

Zu den überleitenden Formeln zählen zunächst häufig Wörter wie ammā, al-qeșse, az gàazāa und al-ḥāl. Die überleitenden Formeln betreffen einen Szenenwechsel innerhalb ein und derselben Geschichte (jeweils mit 20 Fundstellen):

al-qeșșe (also) kommt 450 Mal vor:

(1/5/31), (1/7/9), (1/10/9), (1/11/19), (1/16/7), (1/18/13), (1/19/28), (1/19/29), (1/43/13), (1/46/27), (1/50/8), (1/67/11), (1/71/20), (1/87/5), (1/90/2), (1/90/3), (1/104/9), (1/179/14), (1/181/27), (1/182/14).

az qażā (zufällig) kommt 523 Mal vor:

(1/5/18), (1/20/23), (1/21/31), (1/24/18), (1/27/23), (1/27/30), (1/29/1), (1/29/10), (1/29/20), (1/29/26), (1/31/6), (1/33/12), (1/37/18), (1/37/26), (1/39/28), (1/41/21), (1/49/7), (1/51/11), (1/58/20), (1/60/4).

al-ḥāl (jetzt) kommt 305 Mal vor:

(1/9/4), (1/10/23), (1/24/7), (1/24/15), (1/29/26), (1/32/1), (1/32/2), (1/32/17), (1/40/11), (1/41/15), (1/49/28), (1/50/18), (1/50/22), (1/51/7), (1/52/3), (1/52/21), (1/54/29), (1/56/17), (1/56/23), (1/56/28).

ammā (aber) kommt 511 Mal vor:

(1/9/2), (1/14/23), (1/19/24), (1/21/12), (1/28/10), (1/29/8), (1/31/8), (1/32/10), (1/33/10), (1/34/19), (1/35/10), (1/37/5), (1/52/25), (1/38/16), (1/42/24), (1/56/11), (1/56/9), (1/58/4), (1/59/6), (1/59/21).

\subsubsection{Abschließende Formeln}

Zwei Typen von Schlussformeln sind häufig belegt. Die Erzähler verwenden eine strukturierte kurze Formel. Die häufigsten abschließenden Formeln lauten (jeweils höchstens 20 Fundstellen, aber weitere Fundstellen sind vorhanden):

tā be-resim (bis wir erreichen; im Sinne von: bis wir noch einmal darauf zurückkommen).

(5/788/24), (5/790/25), (5/791/23), (5/792/26), (5/794/5), (5/795/29), (5/796/23), (5/800/29), (5/809/8), (5/810/7), (5/813/5), (5/823/29), (5/825/28), (5/826/11), (5/826/24), (5/826/28), (5/829/23), (5/830/6), $(5 / 836 / 23),(5 / 838 / 19),(5 / 838 / 26),(5 / 842 / 23)$.

tā be-resim bar in dāstān/tā be in dāstān be-resim.

Bis wir diese Geschichte erreichen.

(1/181/8), (4/695/2), (4/703/15), (4/704/15), (5/876/24), (5/808/26), (5/819/28), (5/821/6), (5/842/2), (5/942/29), (5/962/6), (5/962/9), (5/968/22), (5/987/9), (5/1027/9), (5/1035/3), (5/1036/30).

Manchmal endet die Abschlussformel mit einem Gastmahl oder einem Fest: 
išān niz bā dohytarān dar 'eiš šodand va naql-e Malek Irağ noql-e mağles-e išān bud (5/840/1).

sie haben sich auch mit den Mädchen vergnügt, und die Erzählung von Malek Irağ war die Süßigkeit ihrer Feier. [Tüpfelchen auf dem i].

[...] u rā deldāri dāde dar 'eiš šodand (5/954/6).

sie haben ihn getröstet und haben sich vergnügt.

be 'eiš o 'ešrat mašğul šodand (5/1047/26).

sie haben sich dem Vergnügen hingegeben.

\subsubsection{Rückbezüge}

Die Rückbezüge aktivieren die Erinnerung der Zuhörer und erscheinen so als ein selbstverständliches Mittel des textgestützten mündlichen Vortrags. Zwei Systeme der Rückbezüge sind zu unterscheiden: ein Verweis auf schon zu einem früheren Zeitpunkt vorgetragenes Geschehen und ein anderermal wird eine kurze Abfolge der Erzählung als Gedächtnisauffrischung angewendet.

qabl az in ‘arz šod ke/ke čon...

Vorhin wurde gesagt, dass...

(4/718/6), (5/800/29), (5/804/11), (5/805/29), (5/800/29), (5/805/27), (5/807/3), (5/807/10), (5/836/8), (5/845/20), (5/966/14), (5/968/9), (5/969/24), (5/973/4).

‘arż šod ke/kardim ke Iră̌ ...

Es wurde gesagt, dass Iră̌ ...

(4/699/5), (4/592/23), (5/800/30), (5/810/7).

\subsubsection{Wiederholungen}

Im Prinzip hat die epische Sprache eine gewisse Tendenz zur sprachlichen Formelhaftigkeit und zum Kompositionsprinzip der Wiederholung. Walter Arend sagte dazu:

„Der Sinn aller Wiederholungen ist der, dass etwas, was gleich ist, auch mit den gleichen Worten ausgedrückt werden muss.“"1211

Im $R H$ gibt es eine große Anzahl von wiederkommenden Ausdrücken. Soweit wie möglich werden Wortkombinationen und einzelne Worte bei den Wiederholungen unverändert beibehalten.

Wiederholungen bestimmter Verben:

be-dar- raft (fliehen) wird dieses Verb im ganzen Text 1020 Mal wiederholt, obgleich es im Persischen viele verschiedene Worte dafür gibt.

${ }^{1211}$ Arend, Walter: Die typischen Scenen bei Homer, Berlin 1933, S. 5. 
(1/16/3), (1/16/4), (1/17/26), (1/35/24), (1/41/13), (1/45/16), (1/51/23), (1/66/17), (1/68/23), (1/69/19), (1/71/19), (1/72/26), (1/78/9), (1/82/9), (1/82730), (1/86/16), (1/90/9), (1/93/7), (1/94/18), (1/97/25).

dāneste bāš (du musst wissen) wird im $R H 100$ Mal wiederholt.

(1/54/19), (1/54/18), (1/56/28), (1/56/31), (1/74/10), (1/89/1), (1/110/9), (1/114/3), (1/ 114/25), (1/125/8), (1/125/9), (1/131/15), (1/137/3), (1/143/1), (1/148/26), (1/150/21), (1/152/7), (1/155/28), (1/156/30), (1/166/6).

Wiederholung bestimmter Zeitadverbien:

ruz-e digar (Am nächsten Tag) kommt im RH 607 Mal vor.

(1/4/11), (1/4/16), (1/5/5), (1/5/7), (1/5/31), (1/6/7), (1/12/28), (1/15/19), (1/17/2), (1/18/17), (1/18/23), (1/18/28), (1/18/29), (1/19/25), (1/20/7), (1/20/10), (1/20/21), (1/21/12), (1/27/28), (1/36/12), (1/57/24).

dar in vaqt (in diesem Moment) wird 473 Mal verwendet.

(1/18/3), (1/20/24), (1/21/12), (1/25/8), (1/31/8), (1/33/25), (1/36/17), (1/37/23), (1/40/10), (1/44/11), (1/46/29), $(1 / 51 / 21),(1 / 59 / 5),(1 / 65 / 27),(1 / 73 / 22),(1 / 73 / 23),(1 / 76 / 27),(1 / 77 / 29),(1 / 89 / 8),(1 / 89 / 11)$.

Wortgruppen zur Beschreibung des Leids, der Gefühle und Schimpfworte:

Die Erzähler benötigten für den Aufbau ihrer Erzählung Satzgruppen, die eine jeweils bestimmte Sinninformation in sich tragen.

āh az nehād bar-āmadan (das Leid ihrer Seele offenbart sich) findet sich $213 \mathrm{Mal}$ im $R H$.

(1/15/18), (1/17/20), (1/24/15), (1/26/4), (1/29/11), (1/30/9), (1/37/1), (1/37/5), (1/37/11), (1/38/13), (1/40/20), (1/41/4), (1/41/9), (1/42/21), (1/45/17), (1/49/29), (1/52/20), (1/54/31), (1/52/20), (1/55/20), (1/55/21), (1/58/23).

ḥarām-zāde (Uneheliches Kind, Schuft) kommt 800 Mal vor.

(2/196/20), (2/197/8), (2/198/9), (2/197/16), (2/199/11), (2/201/9), (2/209/18), (2/209/31), (2/219/12), (2/220/4), (2/226/10), (2/281/20), (2/296/4), (2/297/9), (2/302/22), (2/302/30), (2/307/6), (2/307/7), (2/310/28), (2/324/26).

gabrān (Feueranbeter).Schimpfwort für dieZarathustra Anhänger. Dies finden wir im RH 875 Mal. (2/194/6), (2/194/7), (2/194/13), (2/195/2), (2/195/3), (2/195/5), (2/196/29), (2/197/1); (2/197/4), (2/197/15), (2/198/16), (2/198/17), (2/200/17), (2/200/23), (2/201/8), (2/203/24), (2/203/27), (2/204/6), (2/207/7), $(2 / 207 / 13)$.

nā-pāk (Unrein) kommt 210 Mal vor.

(2/194/10), (2/194/11), (2/196/26), (2/196/27), (2/197/5), (2/197/6), (2/197/29), (2/197/30), (2/198/13), (2/198/15), (2/202/11), (2/205/5), (2/207/15), (2/207/24), (2/207/26), (2/207/28), (2/207/30), (2/208/7).

Wortgruppen zur Beschreibung des Zeitablaufs:

dar ān sar zadan-e āftāb (Bei Sonnenaufgang) findet im $R H 400$ Mal Erwähnung. 
(1/60/26), (1/68/19), (1/69/21), (1/72/14), (1/80/1), (1/85/1), (1/89/26), (1/95/23), (1/102/17), (1/102/17), (1/104/22), (1/106/12), (1/111/23), (1/111/29), (1/120/14), (1/131/6), (1/137/22), (1/139/23).

ammā dar sar zadan-e āftāb (Aber bei Sonnenaufgang) kommt 370 Mal vor.

(1/136/14), (1/137/14), (1/144/11), (1/148/26), (1/148/27), (1/149/12), (1/150/3), (1/152/4), (1/153/3), (1/155/2), (1/157/9), (1/161/7), (1/162/7), (1/162/9), (1/162/15), (1/163/21), (1/164/26), (1/165/6), (1/167/21), (1/169/9).

Wiederholungen typischer Szenen im $R H$ :

Bestimmte Handlungen im $R H$ tauchen wiederholt auf. Sie werden mit denselben Details und denselben Worten erzählt wie z.B. ein Zweikampf, Liebesszenen, Abreise oder Ankunft, Tricks usw.

Ein Beispiel ist die Schilderung der Kriegsnacht: „Jene Nacht ist eine Nacht, wo der Kopf der Rachsüchtigen und Helden auf dem Kopfkissen keine Ruhe findet. Die Helden polieren den Rost von Schild, Panzer und Schwert und versorgen die Spitze der Pfeile mit Gift“ (1/82/1623), (1/84/23-28), (1/135/4-10), (1/136/1-9), (1/157/28-31).

\subsubsection{Fassungen}

Verschiedene Fassungen entstehen, weil die Erzählungen aus dem Gedächtnis wiederholt abgerufen und erzählt oder niedergeschrieben werden. Dabei wird der Wortlaut nicht in allen Fällen korrekt wiedergegeben und muss nachgebessert werden. Der Erzähler, der seinen Text teilweise im Kopf hat, wenn er die Erzählung wiederholt, lässt eigene Fantasien mit einfließen und erzählt sie anders oder neu. Der Erzähler übernimmt eine alte Version in Auszügen und fügt Zusatzsepisoden hinzu. Dabei wird seine Fassung zu einer eigenen Version der Geschichte. Natürlich geschieht das nicht beim ersten Erzählen einer Geschichte. Die Zusatzepisoden lagern sich nach und nach an.

Diese Vorstellung über das Entstehen verschiedener Fassungen ist jedoch nicht sicher, da die Umstände in der damaligen Zeit für uns unbekannt sind. Wir nehmen dies aber mit einer gewissen Wahrscheinlichkeit an. Mit Hilfe der unterschiedlichen Fassungen kann man die Vielgestaltigkeit der Epen in der mündlichen Tradition verfolgen. Diese Behauptung möchte ich anhand einiger Beispiele verdeutlichen.

Exemplar A aus dem Buch $Q H$ :

In der alten Version des $Q H$ lesen wir die Liebesgeschichte von Ḥamze und Rābe'e: Fatḥnuš hat eine Tochter, die Rābe'e-ye palās-puš (R., die mit Sacktuch bekleidete) heißt. Rābe'e hat sich im Traum in Ḥamze verliebt. Sie malt ihn und trägt immer ein Bild von ihm bei sich. Sie sagt: „Wenn ich jemanden finde, der ein solches Gesicht hat, werde ich ihn zu meinen Mann 
machen." Inzwischen hat sich der König von Frankenland als Bräutigam beworben. Aber das Mädchen akzeptiert ihn nicht. Deshalb lehnt ihr Vater die Brautschau ab. Aufgrund der Trennung von Ḥamze trägt das Mädchen grobe Wollkleidung. Immer wenn ein Unbekannter in die Stadt kommt, schickt Rābe'e ihre Sklavinnen zu ihm, um heraus zu finden, ob es Ḥamze ist oder nicht. Sie hat die Astrologen befragt: „Treffe ich Hamze oder nicht?“ Die Astrologen haben ihr gesagt: „Sei sicher, Ḥamze wird dir in dieser Stadt begegnen.“ Daher schickt Rābe'e ihre Sklavinnen zu jedem fremden Ankömmling, der die Stadt besucht. Sie ruft diese dann herbei und vergleicht sie mit dem Bild.

Eines Tages kommt Ḥamze in ihre Stadt. Rābere schickt ihre Sklavinnen zu ihm. Die Dienstmädchen erkennen ihn anhand des Bildes, das sie von ihm gemalt hat. Sie sagen Rābe`e Bescheid. Inzwischen haben der König vom Frankenland und sein Sohn die Stadt Harsane angegriffen. Ḥamze kämpft auf Wunsch der Stadtväter gegen das Heer des Königs und besiegt es. Schließlich heiratet Ḥamze Rābe`e (1/125-128).

Exemplar B aus dem Buch $R H$ :

Ḥamze geht zur Jagd und auf dem Weg sieht Ḥamze einen Derwisch, der in einem nahen Baum sitzt und etwas in seiner Hand hält. Der Derwisch schaut auf die Dinge, die er in seiner Hand hält. Von Zeit zu Zeit weint oder lacht er. Hamze ist darüber sehr verwundert. Also steigt Ḥamze von seinem Pferd herab und geht auf den Derwisch zu. Als der Derwisch Amir Ḥamze sieht, versteckt er, was er in seiner Hand hält in seiner Tasche. Ḥamze fragt: „Oh, König der Derwische, wie heißt du?““ Der Derwisch antwortet: „Derwisch No`mān.“ Ḥamze fragt: „Was hast du in deiner Hand?““ Der Derwisch sagt: „Frag nicht“. Aber Hamze besteht darauf zu erfahren, was es ist. Endlich holt der Derwisch ein Bild aus der Tasche und gibt es Ḥamze. Als Ḥamze das Bild sieht, verliebt er sich in die Frau auf dem Bild (1/129; 4/711). Derwisch No'mān teilt Ḥamze mit, dass dies das Bild von Rābe'e-ye šāl-puš-e aṭlas-bahšš, der Tochter des Kardūs Šāh sei.

Ein Dämon namens Qahhār hat sich auch in Rābe'e verliebt. Eines Tages, als sie mit ihrer Amme im Garten ist, entführt der div beide Frauen. Der König verspricht demjenigen, der die Prinzessin befreit, diese zur Frau zu geben. Sobald Ḥamze diese Nachricht vernimmt, macht er sich auf den Weg um seine Geliebte von dem Dämon zu befreien. Ḥamze kämpft mit dem Dämon, besiegt und tötet ihn und befreit seine Geliebte. Einer Nachts sieht Ḥamze Hुeżr im Traum. Heżr sagt zu ihm: „Du musst Rābe`e heiraten“. Ḥamze antwortet, dass er Mehrnegār versprochen habe, sie zuerst zu heiraten. Aber Heżr besteht darauf: „Du musst sie heiraten, weil sie für dich einen Sohn gebären wird, der große Dinge tun wird.“ Am 
nächsten Tag hat Ḥamze mit 'Amr gesprochen und ihm gesagt, dass er Rābe'e heiraten möchte, weil der Prophet Heżr es ihm befohlen habe. Daraufhin heiraten sie einander (1/129131).

Exemplar $\mathrm{C}$ aus dem Buch $R H$ :

Eines Tages wünscht Ḥamze zur Jagd zu gehen. Im Jagdbezirk sieht Ḥamze ein Reh. Er jagt das Reh und entdeckt plötzlich nahe am Flussufer einen Derwisch. Der Derwisch hat ein Blatt Papier in seiner Hand. Der Derwisch schaut auf das Papier, das er in seiner Hand hält. Von Zeit zu Zeit weint oder lacht er. Hamze ist darüber sehr erstaunt. Er ruft ihn zu sich. Der Derwisch versteckt das Papier in seiner Tasche und geht zu ihm. Hamze fragt ihn: „Oh König der Derwische, wie heißt du?“ Der Derwisch antwortet: „Derwisch No'mān.“ Hamze fragt: „Warum hast du geweint? Weshalb lachst du zwischendurch?“ Der Derwisch will es ihm nicht sagen, aber Hamze besteht darauf. Er holt das Papier aus der Tasche des Derwischs. Er sieht das gemalte Gesicht eines Mädchens auf dem Papier.

Ḥamze verliebt sich in das Mädchen auf dem Bild: „Wo ist dies hübsche Mädchen, das auf dem Bild zu sehen ist?“ Der Derwisch sagt: „Es gibt einen König, der Karus heißt. Er hat eine Tochter, die Rābe'e heißt. Seit zehn Jahren trägt sie grobe Kleidung und niemand weiß warum. Sie ist sehr klug und eine besonders geschickte Malerin. Jeden Tag malt sie ein Bild von ihrem eigenen Gesicht und verkauft es. Ich habe viele solcher Bilder gekauft und jetzt habe ich kein Geld mehr. Die Leute haben mir gesagt: „Wenn du dich von diesem Elend befreien willst, geh zu Ḥamze. Jetzt will ich zu Ḥamze gehen.“ Ḥamze gibt sich ihm zu erkennen und tauscht das Bild gegen seinen kostbaren Gürtel ein. Er sagt ihm: „Geh zu meinem Heerlager, gib meinen Gürtel 'Amr und vom ihm bekommst du Geld.“ Der Derwisch akzeptiert und geht weg. Hamze reitet nach Haršane. Karnus hat zwei Jungen und eine Tochter, die Rābe'e heißt. Vor zehn Jahren hat sie in ihrem Traum Heżr gesehen. Sie hat sich im Traum durch Heżr zum Islam bekehrt und er sagt ihr: „Du wirst die Ehefrau meines Sohnes sein.“ Von diesem Augenblick an ist Rābere in Ḥamze verliebt. Seit zehn Jahren wohnt sie in einem Garten außerhalb der Stadt und malt jeden Tag ein Gemälde von ihrem Gesicht. Heżr hat ihr nämlich gesagt, wenn er dein Gesicht sieht, wird er sich in dich verlieben. Sie hofft, dass die Leute ihre Bilder in verschiedene Länder mitnehmen werden und so viele ihr Bild sehen können, darunter auch Ḥamze.

Als dieser an den Hof des Königs kommt, macht er sich mit diesem bekannt. Eines Tages kommen die Botschafter des römischen Kaisers an den Hof. Dieser hat gehört, dass Karnus eine schöne Tochter hat. Die Botschafter sagen ihm: „Du musst so bald wie möglich deine 
Tochter zu mir schicken, sonst werde ich dich angreifen und deine Stadt zerstören." An diesem Tag kommen auch die Botschafter des fränkischen Königs. Der König der Franken hat auch gehört, dass Karnus eine schöne Tochter hat. Der fränkische König lässt sagen: „Wenn du mir deine Tochter nicht zur Frau gibst, werde ich dich angreifen und deine Stadt zerstören.“ Karnus sucht Rat bei Ḥamze. Dieser sagt: „Schicke du deinen Ring zum Basar und sage, dass jeder, der den Franken beseitigen kann, deine Tochter heiraten dürfe.“ Aber niemand meldet sich. Nach ein paar Tagen kommt Ḥamze an den Hof des Karnus und sagt, dass er mit dem Franken kämpfen möchte. Ḥamze zieht auf den Kriegsplatz und tötet den fränkischen Feldherrn. Danach kommt Ḥamze zurück an den Hof des Karnus und heiratet seine Tochter Rabe'e (2/222-226).

Der erste und der zweite Text sind kürzer als der dritte Text. Der dritte Text unterscheidet sich vom ersten und zweiten Text inhaltlich. Hierbei handelt es sich um eine Abweichung, die die natürliche Folge einer Neukomposition ist.

\subsubsection{Weitere sprachliche Eigenarten}

Die verschiedenen Abschnitte aus denen sich das $R H$ zusammensetzt, haben eine unterschiedliche literarische Gestalt. Hier spielt der Einfluss der geschriebenen literarischen Sprache eine wichtige Rolle. Die Erzähler fügen viele Elemente aus der klassischen Literatur hinzu. Es handelt sich hierbei um eine sehr starke Bildhaftigkeit des mündlichen Vortrags. Die Wörter bringen das Bild hervor. Das Bild selbst ist der Gedanke des Rollenschreibers oder Erzählers.

Die Erzähler fügen, aufgrund ihres Geschmacks und Erzählstils, jeweils ihren eigenen speziellen Wortschatz, Erzählstoff und die bevorzugten Gedichte hinzu. Deshalb findet man zwischen den gleichen Geschichten stilistische Unterschiede. Page hat in ihrem Buch Naqqãa $i$ and Ferdowsi eine Geschichte aus zwei verschiedenen tumār (Schriftrollen) untersucht. Sie hat uns gezeigt, dass die Rollen einer Geschichte oft nicht miteinander identisch sind. ${ }^{1212}$

\subsection{Grammatikalische Erscheinungen}

Da es sich im $R H$ schließlich um einen mündlich überlieferten Text handelt, wird sich diese Arbeit dem mündlich-sprachlichen Stils des Werkes widmen. Im folgenden Abschnitt soll gezeigt werden, inwiefern sich die gesprochene Sprache von der Geschriebenen unterscheidet. Zuerst wird kurz dargelegt, was gesprochene Sprache eigentlich ausmacht. Daran werden sich ein paar grundsätzliche Gedanken zur Vermittlung der Besonderheiten gesprochener Sprache 
anschließen und schließlich werden einige ausgewählte grammatische Phänomene, die im mündlichen Sprachgebrauch besonders häufig auftreten näher beschrieben. Des Weiteren soll auch die Beschreibung der grammatischen Phänomene in den Bereichen der phonetischen Erscheinungen, im Wortschatz, im Satzbau und in elliptischen Satzkonstruktionen beleuchtet werden. Es ist dabei nicht beabsichtigt, detaillierte Analysen anzustellen, sondern es soll eher exemplarisch aufgezeigt werden.

\subsubsection{Sprachliche Kompetenzen eines Vortrages}

Wie unterscheidet sich gesprochene Sprache von geschriebener Sprache, vor allem in grammatischer Hinsicht? Was sind die Voraussetzungen für einen fesselndenVortrag? Was kennzeichnet einen gelungenen Vortrag? Welche sprachlichen Kompetenzen setzt der Erzähler vorraus? Welche sprachlichen Fähigkeiten haben die persischen Erzähler gehabt? Mit welchen sprachlichen Mitteln haben sie mit ihren Zuhörern kommuniziert? Dies sind die Fragen, die in diesem Abschnitt erläutert werden.

Die iranische Volksliteratur zeichnet sich durch große sprachliche Kompetenz aus. Diese Kompetenz ist die Voraussetzung, um soziale Kontakte zu knüpfen. Die naqqāls können ihre Zuhörer durch ihreWorte beeinflussen. Um den Zuhörern sprachlich Nahe zu sein, benutzen die naqqāls in ihrem Vortrag, das jeweilige Sprachniveau der Adressaten. Für das einfache Volk sind ihre Sätze kurz und einfach. Die Erzähler haben in der gesprochen Form, nicht die Möglichkeit lange und komplizierte Sätze zu formen und dem Zuhörer wird dadurch das gleichzeitige Zuhören und Verstehen deutlich einfacher gemacht.

In gesprochenen Äußerungen sind zahlreiche Konstruktionen zu finden, die in schriftlicher Form als Verstoß gegen die Grammatik oder zumindest als äußerst mangelhafter Stil gewertet werden. Umgekehrt können aber auch mündliche Äußerungen Erstaunen bei den Zuhörern hervorrufen, wenn sie der Schriftsprache zu nahe kommen. Zwischen mündlicher und schriftlicher Sprache gibt es eine Reihe fundamentaler Unterschiede. ${ }^{1213}$ Unter anderem wird in mündlichen Gesprächen häufig auf Dinge oder Sachverhalte Bezug genommen, die für alle Gesprächspartner unmittelbar wahrnehmbar sind, etwa Gegenstände, die sie vor Augen sehen, so dass die Referenz darauf keiner Worte mehr bedarf oder zumindest mit wesentlich weniger Worten auskommt, als es in einem schriftlichen Text erforderlich wäre. ${ }^{1214}$

\footnotetext{
${ }^{1213}$ Haag,Winfried: An analytical approach to the teaching of spoken German, in: Oral skills in the modern languages degree, hrsg. von Gordon Doble und Brian Griffiths, London 1985, S. 51-72, hier S. 52.

${ }^{1214}$ Horowitz, Rosalind u. S. Jay Samuels: Comprehending Oral and Written Language, in: Comprehending Oral and Written Language: Critical Contrasts for Literacy and Schooling, hrsg. von Rosalind Horowitz, S. 1-52, hier S. 7.
} 
Ein zweiter großer Unterschied zwischen gesprochener und geschriebener Sprache liegt in den Produktionsbedingungen: Wer schreibt, kann sich in der Regel Zeit lassen und über seine Äußerungen nachdenken, bevor er sie niederschreibt. Später kann man wieder seinen Text überarbeiten. Mündliche Produktion muss demgegenüber in der Regel in sehr kurzer Zeit geschehen und was einmal geäußert ist, lässt sich nicht mehr revidieren. ${ }^{1215}$ So muss sie geläufig und einfach sein.

Auf der Grundlage mündlicher Erzählungen geschriebene Texte wie das $R H$ haben einige Besonderheiten in Bezug auf Vokalfärbung, Assimilationen oder Abschleifungen und der Orthographie. Im Folgenden wird eine Auswahl dieser Erscheinungsformen präsentiert.

\subsubsection{Vokalverfärbungen}

Es muss berücksichtigt werden, dass die Vokalverfärbung per se ein wichtiges Phänomen mündlicher Sprachverwendung ist und sie berührt nicht die geschriebenen Texte.

$\overline{\mathbf{a}}>\mathbf{a}$

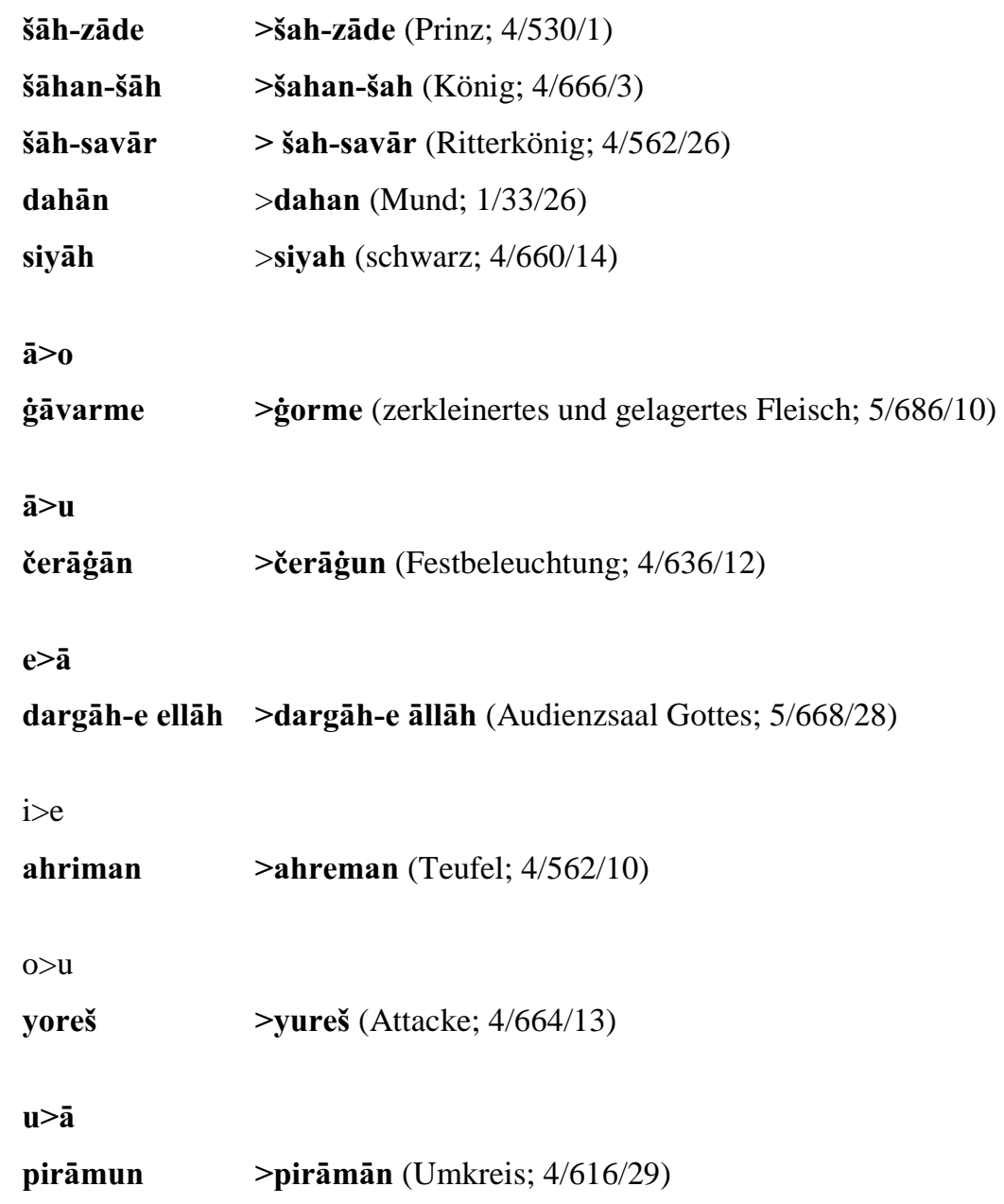

1215 Vgl. Parry, Über typische Szenen im Homer, in: Homer. Tradition und Neuerung, hrsg. von Joachim Latacz, Darmstadt (1979), S. 289-294, hier S. 291. 
$\mathrm{ou}>\mathrm{O}$

bad-gouhar >bad-gohar (schlecht geartet; 4/663/26)

$\mathrm{O}>\mathrm{u}$

otāq >utāg (Zimmer; 4/668/11)

ostād >ustād (Lehrer; 4/694/10)

\subsubsection{Konsonanten}

Gelegentlich belegt ist der Wegfall von „,“ insbesondere bei den Zahlen.

$\begin{array}{ll}\text { čahār-pāyān } & \text { >čār-pāyān (vierfüßiges Lebewesen; 4/690/3) } \\ \text { čahār-ğāneb } & >\text { čār-ğāneb (vier Richtungen; 4/613/6) } \\ \text { čahār-suq } & >\text { čār-suq (Markt; 4/533/9) } \\ \text { šab-e čahārdah } & >\text { šab-e čārdah (Vollmondnacht; 4/623/19) }\end{array}$

Weitere Phänomene von Assimilationen oder Abschleifungen liegen vor.

$\mathrm{b}>\mathrm{v}$

har-bār > > har-vār (Gewichtsmaß. Es entspricht 300 kg; 2/210/29)

pišbāz > >pišvāz (entgegengehen; 4/606/23)

bāz-šodan >vāz-šodan (offen werden; 5/886/19)

$b>m$

qāb $\quad>$ qām $($ Teller; $1 / 18 / 30)$

$\mathbf{b}>\check{\mathbf{z}}$

boz-mağe >boz-maže (kleiner Schmaus; 5/1051/12)

$\mathrm{f}>\mathrm{v}$

ğife-ye donyā >ğive-ye donyā (das irdische Gut; 6/1064/6)

$\check{\mathbf{g}}>\mathbf{f}$

ǧãliz $\quad>$ fāliz (Gemüsegarten; 1/108/12)

$\mathrm{p}>\mathrm{f}$

pol $\quad>$ fol $($ Geld; 4/532/19)

$\mathrm{q}>\mathbf{h}$

yaqe $\quad>$ yahe $($ Kragen; 5/1086/3)

$\mathrm{v}>\mathrm{b}$

bad-qavāre >bad-qabāre (häßlich; 5/949/10)

cayāl-vār > >ayālbār (Familie besitzend; 2/201/6) 
$v>f$

kutvāl , >kutfāl (Kommandant einer Festung; 4/563/8)

\subsubsection{Orthographie}

Im Text sind gelegentlich orthographische Fehler bedingt auch durch die zahlreichen gleichlautenden Konsonanten des Persischen anzutreffen. Die Schreiber bzw. die späteren Abschreiber waren offensichtlich nicht so hoch gebildet und arbeiteten teilweise nicht sorgfältig.

$\begin{array}{lll}\text { as̄ās } & \text { statt } & \text { asās (Einrichtung; 5/996/26) } \\ \text { caṭiye-bah̆š } & \text { statt } & \text { 'atiye-bahšs (Schenkende; 5/820/2) } \\ \text { siyāḥat } & \text { statt } & \text { iyāht (Reise; 5/661/25) } \\ \text { zāli } & \text { statt } & \text { zāāli (Greis; 5/899/28) }\end{array}$

\subsubsection{Unverständliche Wörter}

Im Text gibt es ein paar Fehler, bei denen es sich um Abschreibfehler handelt. Ein möglicher Grund dafür ist, dass die Abschreiber ihre Arbeit wenig aufmerksam verrichteten bzw. schnell schreiben mussten.

$\begin{array}{lll}\text { ān (jene) } & \text { statt } & \text { an }(1 / 64 / 19) \\ \text { āyā (Fragepartikel: etwa?) } & \text { statt } & \text { ayā }(1 / 64 / 11) \\ \text { barādar (Bruder) } & \text { statt } & \text { barābar }(5 / 810 / 2) \\ \text { pāsebān (Wache) } & \text { statt } & \text { pāsenā }(5 / 696 / 26)\end{array}$

Die Präposition „be“ ist überall mit den Nomen und Personalpronomen zusammen geschrieben worden.

čon bemanzel-e u dar-āmadand (4/618/11).

statt čon be manzel-e u dar-āmadand.

Auf diese Weise kommen sie in ihrem Haus an.

lebās rā beu pušānide (4/616/2). $\quad$ statt lebās rā be u pušānide.

sie haben ihn angekleidet.

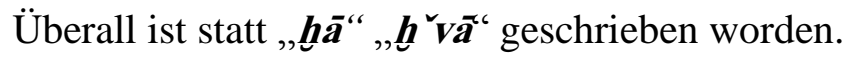

\begin{tabular}{|c|c|}
\hline ḩāmuš & >ḩ̌vāmuš (schweigsam, erloschen; 4/690/31) \\
\hline ḩāne & > h̆ avāne (Haus; 5/640/16) \\
\hline ḩāvar & > ȟavār (Osten; 5/825/4) \\
\hline ḩāle & > ȟ̌avāle (Tante; 3/429/12) \\
\hline
\end{tabular}




\subsubsection{Formenlehre}

Es ist klar, dass in den mündlichen Überlieferungen sowie in der schriftlich fixierten Dichtung zwar eine identische Sprache benutzt wird d.h. die selben grammatischen Strukturen, die selben syntaktischen Regeln und das selbe Grundvokabular aber das eine ist eher umgangssprachlich ausgerichtet, das andere könnte man als Schriftsprache bezeichnen. Deshalb wird hier nur versucht, die grammatischen Besonderheiten des Textes zu präsentieren. Das Verbalsystem, die Wortbildung, Fremdwörter, der Wortschatz, besondere Ausdrücke, umgangssprachlicher Wortschatz, Kontraktionen, Doppelungen desselben Wortes, Partikel, Adverbien, Adjektive und Personalpronomen werden hier dargestellt.

Dabei wird der Methodik besondere Aufmerksamkeit gewidmet und es wird versucht, diese Unterschiede verständlich werden zu lassen. Die Verschiedenheiten in der Sprach- und Sozialgeschichte und die Unterschiede im Wortschatz werden sich in dem thematischen Material und den Formeln widerspiegeln.

\subsubsection{Verb}

Manchmal finden sich im Text Sätze, in denen die Verben falsch konjugiert worden sind, d.h. dass das gebeugte Verb nicht zum Subjekt passt.

do barg be-činand va bi-yāvarand (2/219/8). statt do barg bečin va bi-yāvar.

Pflücken zwei Blätter und bringen sie. statt Pflück zwei Blätter und bring sie.

Mehrfach kommt es auch vor, dass Verben vom Sinn her gar nicht in den Satzzusammenhang passen.

Bābā did qabul na-konad (2/283/12).

Bābā hat es gesehen und akzeptiert es nicht.

mā rā Amir koğā h̆ॅ̄āhad dād? (1/143/4)

Wo wird der Amir uns geben?

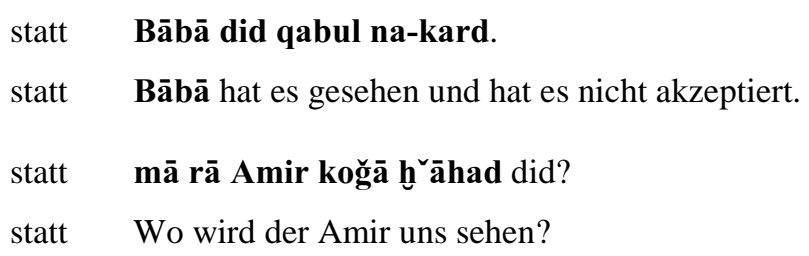

Es gibt Verben, die eine lexikalische Bedeutung haben, aber im Rahmen der Umgangsprache eine andere Bedeutung bekommen haben.

[....] did ke šahșịi ḥarf mi-zanad (1/114/21).

Er sah, dass jemand spricht.

čon Del-furuz did ke ğādu fahmide [...] (4/684/28). $[\ldots]$. statt

statt

statt

Als Del-furuz sah, dass die Hexe es verstanden hatte [...]. $\quad$ statt verstanden hatte $[\ldots]$.

\section{[...] šenid ke šahș̣i ḥarf mi-zanad.}

Er hörte, dass jemand spricht.

čon Del-furuz dānest ke ğādu fahmide

Als Del-furuz bemerkte, dass die Hexe es 


\subsubsection{Modalverben}

Die persischen Modalverben bilden Infinitivformen wie (budan), (̌̌odan), (dāštan) und (hāstan). Für die Sprache des $R H$ hat der Erzähler im Rahmen des Erzählstils bei den Schilderungen unterschiedlicher Zeitebenen der Geschehnisse einfache Verben als Modalverb verwendet, die manchmal zwei Bedeutungen haben. Hier gelten folgende Verben als Modalverb:

raft (wollen)

Dieses Verb raft (ging) drückt das Verb in erster Linie eine Forderung oder Absicht aus. raft ke qabul konad.

Er ging um es zu akzeptieren. Im Sinn von: Er wollte es akzeptieren (3/398/1).

dāštan (wollen)

Dieses Verb dāštan (haben) drückt wie oben eine Forderung oder Absicht aus.

dāšt ke hod rā be 'alamdār be-zanad.

Er wollte den Fahnenträger angreifen (1/166/6).

$\bar{a} \boldsymbol{m a d}$ (wollen)

Diese Verb āmad (kommen) drückt eine Forderung oder Absicht aus.

Manučeher-e ġolām āmad ke be bārgāh ravad.

Der Sklave Manučeher wollte in den Audienzsaal gehen (4/690/9).

\subsubsection{Partizip Perfekt}

Sowohl im $R H$ als auch in anderen iranischen Volksepen wie $H L$ und $E N$ wird das Partizip Perfekt verwendet. Man benutzt es um einen Umstand der Art und Weise auszudrücken. Mit Hilfe zweier exemplarischer Beispiele wird versucht, die Erscheinung des Partizip Perfekts zu verdeutlichen:

lebās rā be u pušānide (4/616/2).

Er hat ihm das Kleid angezogen.

čon Del-furuz did ke ğādu fahmide [...] (4/684/28).

Als Del-furuz bemerkte, dass die Hexe es verstanden hat [...] 


\subsubsection{Unkonventionelle Verben}

Unterschiede zwischen geschriebener und gesprochener Sprache bestehen nicht nur im Bereich der Grammatik. Differenzen gibt es insbesondere im verwendeten Wortschatz. Darauf soll hier jedoch nicht tiefer eingegangen werden.

Im Buch befinden sich in großer Zahl unkonventionelle Verben (heute nicht mehr gebräuchlich), die sich in verschiedene Kategorien unterteilen lassen. Die folgende Liste (geordnet nach dem persischen Alphabet) präsentiert die im Buch auftauchenden unkonventionellen Verben. In erster Linie sind es Objekte mit den Präpositionen „be“ und ,$a z^{\prime \prime}$.

āb-tāhntan (urinieren; 2/218/16)

āb dar čašm be gardeš dar-āmadan (weinen; 5/830/26)

āzār dāštan (krank sein; 1/16/6)

az ğā dar-āmaden (abfahren; 1/160/21)

az hod raften (das Bewusstsein verlieren; 2/305/2)

bad-rāh kardan (verführen; 1/18/9)

bar-țaraf kardan (töten; 4/611/23)

be-sar kešidan (trinken; 5/936/16)

pā az rekāb ḩāli kardan (vom Pferd heruntersteigen; 1/161/1)

pāy az raftār bāz-māndan (stehen bleiben; 4/561/16)

pāk koš kardan (töten; 2/216/3)

tig̀ dar-ham nahādan (mit dem Schwert einander schlagen; 5/892/25)

be tig̀ bāzi dar-āmadan (miteinander mit dem Schwert kämpfen; 5/922/24)

tig̀-e āb-dār (scharfes Schwert; 4/681/21)

\subsubsection{Allegorische Verben}

Hierbei handelt es sich um Begriffe, die man auf den ersten Blick nicht wörtlich verstehen sollte, um die wirkliche Bedeutung zu erfahren. Es handelt sich hierbei um Redewendungen, die eine tiefe Kenntnis der Umgangssprache verlangen, um die innere Bedeutung zu verstehen.

āb o āš dādan (Beerdigungszeremonie feiern; 1/146/24)

čub bar țabl āšenā kardan (trommeln; 4/669/26)

āstin bālā zadan (Maßnahmen ergreifen; 5/916/26)

az pā dar-āmadan (sterben, getötet werden; 4/568/29)

az ḥāli be ḥāli šodan (Gefühlsschwankungen; 1/148/16)

az sar bāz-kardan (sich von etwas frei machen; 1/164/3)

aẓhār-e ḥayāt kardan (seine Existenz zeigen; 4/660/8)

az meydān ru sorhb birun āmadan (vom Kriegsfeld siegreich zurückkommen; 5/996/9) 
angošt gereftan (den Treueid leisten; 1/153/16)

bā ğān o del qabul karden (sehr gerne akzeptieren; 1/180/31)

bāzi-dādan (betrügen; 5/894/4)

bār-e ḥaml gozāštan (gebären; 5/1046/20)

bar hod pičidan (zornig sein; 3/369/9)

bar-ham-hyordan (von etwas unruhig werden; 3/483/2)

be bād dādan (töten, vernichten; 5/996/4)

be bād-e čub gereftan (mit dem Holz schlagen; 5/648/10)

be ḥāl āmadan (kräftig werden; 1/124/6)

be hāne-ye zor dar-āmadan (sich anstrengen; 1/161/26)

\subsubsection{Zusammengesetzte Verben}

Im vorliegenden Werk treten gehäuft zusammengesetzte Verben auf, die in der heutigen Zeit nicht mehr in Gebrauch sind aber bis zur Qāğārenzeit geläufig waren.

az

az-nazar-oftādan (aus dem Blickfeld gehen, keine Aufmerksamkeit schenken; 3/436/6)

be

be dahan-andāhntan (etwas im Mund lassen; 4/690/10)

bar-ham

bar-ham-pičidan (sich verwickeln; 1/68/1)

be-dar

be talāš-dar-āmadan (sich bemühen; 4/560/13)dar

dar-asterāḥt-šodan (ausruhen; 3/422/22)

\subsubsection{Wortbildungen}

Durch Anhängen eines Suffixes entstehen viele neue Nomen. Diese verwendete Methode wird sowohl in der literarischen Sprache als auch der Umgangssprache benutzt.

Suffix,$i “$ zur Bildung einer Berufsbezeichnung aus einem Nomen.

dokān-e kabab-i (Brathaus; 4/619/23)

dokān-e bazāz-i (Textilwarenhandel; 4/606/22)

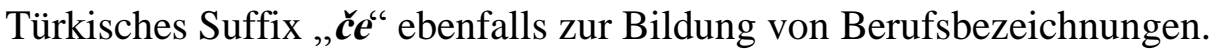

hiik-če (Weinschlauch bzw. Wasserschlauch; 4/610/22)

șanduq-če (Koffer bzw. Kasten; 4/661/14)

Suffix „sarä“ zur Bildung von Ortsangaben aus einem Nomen

kārevān-sarā (Herberge; 4/541/6)

halvat-sarā (entlegene Raum; 4/554/1) 
Suffix „h্̄āne“ zur Bildung von Ortsangaben aus einem Nomen.

ḥaram-ḩāne (Frauengemach; 4/656/18)

zanğir-hāāe (Gefängnis; 4593/26)

Suffix ,gāa“‘ zur Bildung von Ortsangaben aus einem Nomen.

āvard-gāh (Schlachtfeld; 4/664/2)

razm-gāh (Schlachtfeld; 4/660/18)

\subsubsection{Fremdsprachliche Wortschätze}

Der fremdsprachliche Wortschatz besteht hauptsächlich aus arabischen und türkischen Wörtern. Hier wird dieser knapp erläutert.

\subsection{Arabismen}

Im Jahre 642 erlitten die Perser bei Nahāvand eine schwere Niederlage gegen die Araber. ${ }^{1216}$ Die Iraner, die sich zum Islam bekehrten, mussten die neuen Gebetsformeln lernen. ${ }^{1217}$ Die persischen Adligen traten in den Dienst der Kalifen. ${ }^{1218}$ Die Verwaltungssprache des erweiterten arabischen Reiches war zu Beginn Persisch. Die Arabisierung der Verwaltungssprache nahm allmählich zu und mit ihr der Einfluss der arabischen Sprache auf allen gesellschaftlichen Ebenen. ${ }^{1219}$ Bald verfassten auch iranische Gelehrte, Wissenschaftler und Literaten ihre Werke auf Arabisch. „Der Gebrauch der ungewohnten arabischen Wörter wurde als Zeichen höherer Bildung und Kenntnis von Kunst und Dichtung betrachtet.“1220 Auch die Korrespondenz zwischen den Kalifen und den Ghaznawiden-Sultanen wurde zweisprachig, auf Arabisch und Persisch, geführt. ${ }^{1221}$

Im Text begegnen uns zahlreiche Fremdwörter. Der Anteil der arabischen Wörter im $R H$ ist sehr hoch. Dabei ist jedoch zu berücksichtigen, dass wie oben ausgeführt, es vor der Entstehung des $R H$ bereits einen regen Gebrauch arabischer Wörter im Iran gab. Hier einige Beispiele aus dem $R H$ mit arabischen Wörtern:

āhir al-amr (endlich, schließlich; 3/466/28)

ạ̣san (Bravo; 3/466/9)

allāh-akbar (Gott ist der größte; 3/391/25)

$\mathbf{1 2 1 6}$ Justi, Ferdinand: Geschichte Irans, S. 546f.

${ }^{1217}$ Lazard, Gilbert: The rise of the new Persian language, in: CHI, Vol. 4, Cambridge 1975, S. 594.

1218 Watt, W. Montgomery und Marmura, Michael: Politische Entwicklungen und theologiesche Konzepte, in: Der Islam, Bd. II, S. 187.

1219 Ibn al-Nadīm, Moḥammad b. Isḥāq: Al-Fīhrist, S. 442-43; Spuler, Bertold: Iran in früh-islamsicher Zeit, S. 244; vgl. Bahār, Moḥammad-Taqi: Sabk-šenāsi, Bd. 2, Teherān 1337/1958, S. 64.

1220 Nadjmabadi, Seifeddin: Gründe für übernahme der Fremdwörter in Neupersischen, in: Deutscher Orientallistentagvom 28. September bis 4. Oktober 1975, Wiesbaden 1977, S. 374-376, hier S. 375.

${ }^{1221}$ Beyhaqi, S. 348; 352; Spuler, Iran in früh-islamischer Zeit, S. 246. 
ilā al-ān (bis jetzt; 3/466/31)

al-amān (die Gnade, der Schutz; 4/533/16)

al-bāqi (der Rest; 3/426/31)

al-ḥāl (jetzt; 1/9/4)

fi al-ḥāl (jetzt; 3/459/23)

fi al-ḥaqīqa (in der Wirklichkeit; 3/461/9)

ḥaqq ta‘ālā (Gott der Erhabene; 3/413/23)

ḥasab 'l-amr (abhängig vom Fall; 3/456/11)

dastur 'I-'amal (Instruktion; 3/510/28)

dūū 'l-ğalāl (erhabene; 3/440/21)

fī al-faur (sofort; 3/454/15)

a'adā' (der Feind; 3/444/20)

ilā maǵrib (nach Westen; 4/528/3)

fa huwa al-murād (denn es ist erwünscht; 3/506/12)

fa huwa al-mațlūb (denn ist es gut; 3/461/4)

\subsection{Turcismen}

Man kann die türkischen und mongolischen Wörter, die oft im Text des $R H$ vorkommen, in 5 Gruppen einordnen:

1. Titel, die im Text sehr oft vorkommen, heute aber totes Sprachgut sind

2. Seltene Termini, die offensichtlich nur damals bekannt waren

3. Bezeichnungen für Dinge des täglichen Lebens, die heute nicht mehr verwendet werden

4. Bezeichnungen für Dinge des täglichen Lebens, die auch heute noch verwendet werden

5. Militärische Fachbegriffe

Hier einige Beispiele aus dem $R H$ mit türkischen Wörtern:

āqā (älterer Bruder, Onkel; 4/679/8)

āš (Speise für die Armen; 1/147/24)

ayāqčì (Mundschenk; 1/8/13)

bāğ̄i (Schwester; 1/103/13)

bāšī (Amtsträgerbezeichnung; 1/97/29)

bahādur (Kämpfer, Held, später Ehrentitel; 1/52/9)

bēgūm (Titel für Damen; 1/160/24)

böğče (Kleidungsbündel; 3/362/28)

bōg̀ma (so gemeint, dass ein fettes, hässliches Weib in übertragenem Sinne als eine ansteckende Krankheit (Angina) bezeichnet wird; 1/111/19)

čārqab (Königskleidung in Turkistan; 4/540/13)

čāvuš (Anführer der Armee; 5/824/6)

čìg (Zaun, Vorhang; 1/34/28) 


\subsubsection{Umgangssprachlicher Wortschatz (Glossar)}

Im $R H$ finden sich viele umgangssprachliche Ausdrücke und nicht alle können hier aufgeführt werden. Exemplarisch werden einige Beispiele erwähnt, um die Aufmerksamkeit der Iranisten $\mathrm{zu}$ gewinnen und zu zeigen, dass Volksromane, was ganz besonders für das Werk $R H$ gilt, eine Schatzgrube für die Sprachwissenschaften sind.

āb-e dahan (Speichel; 5/886/31)

ahl o ‘ayāl (Familie; 5/1011/11)

bād-e laġve (Gelähmt; 4/664/29)

bād-e šekam (Blähen; 1/43/3)

bālā-ye kasi (für, um, wegen jemanden; 3/386/16)

bad-čašm (böse Blick; 3/441/10)

bas kardan (fertig machen; 1/160/6)

biyār (mitbringen; 2/231/1)

bi-damāg (üble Laune, traurig; 4/505/16)

bi-damāğ-šodan (traurig sein; 1/185/24)

boġče-e raht (Reisbündel; 1/81/21)

borğ-e zahr-e mār (zornig; 3/406/5)

bozmače (Eidechse; 6/1051/12)

bu-bordan (mitbekommen; 3/341/5)

pohte (mit Erfahrungen; 4/509/15)

pas-andāḩtan (gebären; 5/881/21)

pirhan (Kleidung; 4/648/3)

pišvāz-raften/kardan (entgegen gehen; 2/269/25)

ğegar-guše (Kind; 3/405/1)

čārom (vier; 1/106/11)

čāq (Gesundheit; 3/499/12)

čāker (Diener; 3/490/26)

čerāġun (Festbeleuchtung; 4/636/12)

\subsubsection{Kontraktionen}

Typisch für die umgangssprachliche Wortbildung sind Kontraktionen, die oft lexikalischen Charakter haben:

$\begin{array}{ll}\text { har kasi ke } & \text { >har ke (jedermann; 4/536/31) } \\ \text { če kasi rā } & >\text { ke rā (welcher Mann; 4/545/10) } \\ \text { če kasi } & \text { >ke (welcher/welche; 4/546/22) }\end{array}$

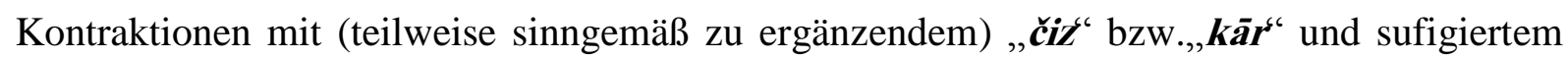
Personalsuffix. 
če kār karde budand

če čizi rohn nemude

če kār konam
$>$ če karde budand (Was haben sie getan; 4/622/22)

>če roh nemude (Was ist passiert; 4/560/4)

$>$ če konam (Was soll ich tun; 1/194/3)

Kontraktionen mit (teilweise sinngemäß zu ergänzendem) čegune (wie) und koğāa (wo) sufigiertem Personalsuffix.

čegune hasti $\quad>$ čoni (Wie fühlst du dich; 4/631/26)

čegune qasmat koni >čon qasmat koni (Wie willst du teilen; 2/234/8)

az koğāa dānesti $\quad>$ az če mi-dāni (Woher weißt du; 3/486/16)

\subsubsection{Doppelungen}

Der Wortschatz ist besonders reich an Doppelungen, die sich in verschiedene Kategorien unterteilen lassen. Durch Wiederholung eines Nomens oder eines Adjektivs werden viele Adverbien aufgebaut.

Adverbien für die Zeitangaben:

sā'at be sā'at dast-e Amir sangintar mi-šod (5/863/28).

Von Stunde zu Stunde wurde die Hand des Amirs schwerer.

ruz be ruz habar az bar-yeIrağ mi-āvardand (5/806/12).

Von Tag zu Tag brachten sie Irağ die Nachrichten.

Mengenadverbien:

Mengenbegriffe zeigen die Stärke der Handlungen. Hier wiederholt man das Wort ohne Präposition. Hierzu einige Beispiele:

qalam qalam bar ruye ham mi-andāhnt (5/654/2).

[Er hat die Toten] stückweise aufeinander gehäuft.

bā kuh kuh andoh (5/832/22).

Mit gebirgsartigem[große Enttäuschung] Kummer.

4.2.2.12 Zusammengesetzte ähnlich lautende Wörter(Kompositum)

In der persischen Umgangsprache werden häufig zusammengesetzte Wortkompositionen benutzt. Aus zwei oder mehreren Buchstaben oder Wörtern mit ähnlichem Klang bildet man diese Kompositionen.

ğāru pāru (fegen; 1/16/30)

tire o tār (dunkel und trübe; 1/49/26)

farš o foruš (Teppich; 1/166/5)

ğuš o horuš (Aufregung und Jammergeschrei; 1/158/3)

lāt o malāt (eine arabische Göttin in der vorislamischen Zeit; 2/244/25) 
mardāne o mofrdāne (tapfer; 1/183/22)

Fantasievolle Wortschöpfungen durch eingeschobenes „an“ im Inlaut.

māl o manāl (Reichtum, Eigentum; 2/313/13)

Fantasiebildungen durch eingeschobenes , $m^{“}$ im Inlaut.

šol o mol (matschig; 1/112/8)

\subsubsection{Partikel}

Die Partikeln werden in der persischen Sprache sehr oft benutzt. Im $R H$ sind alle Arten von Partikeln vertreten. Hier wird einen Auswahl von Intensitätspartikeln, Fokuspartikeln, Negationspartikeln, Modalpartikeln, Gesprächspartikeln präsentiert.

bālā-ye (für, wegen, um; 3/461/19)

bāz (noch einmal; 5/865/5)

tā-ye (wie; 4/553/10)

čašm $(j a ; 2 / 249 / 2)$

dar-dam (bald, sofort; 5/851/28)

dar-hāl (sofort; 1/49/16)

lā 'alāğ (hilflos; 3/466/10)

savā-ye (ohne; 5/812/9)

\subsubsection{Präpositionen}

Im Text befinden sich viele Präpositionen in verschiedenen Variationen, die manchmal nur in historischen und alten Texten allgemeingültig sind. Viele der Präpositionen haben sehr unterschiedliche Bedeutungen. Einige Beispiele seien hier erwähnt:

Sehr häufig kommt die Präposition $\boldsymbol{b} \overline{\boldsymbol{a}}$ (mit) mit dem Verb goftan (sagen) zusammen vor.

bā $>$ be

bā amir goft (4/616/4). statt be amir goft.

[Er] sagte dem Amir.

bā̀dar

bā del-e h.od goft (4/684/30). statt dar del-e h.od goft.

[Er] sprach mit sich selbst.

be $>\mathbf{b} \bar{a}$

išān rā be dāru-ye bi-huši dast baste (4/620/16). statt išān rā bā dāru-ye bihuši dast baste.

[Er] hat sie mit Hilfe des Betäubungsmittels bewusstlos gemacht. 
be $>$ dar

dast ḩod rā be ḥoż-e rạ̣mat forubord (4/628/16).

dast ḩod rā dar ḥoż-e rạ̣mat forubord.

[Er] hat seine Hand in die Zisterne der Barmherzigkeit getaucht.

bar>dar

bar aṭrāf-e u nešaste (4/666/2).

statt dar atrāf-e u nešaste.

[Er] saß in seiner Nähe.

bar $>$ be

bar dar-e dokān-e kabābi resid (4/619/22).

statt be dar-e dokān-e kabābi resid.

[Er] kam vor der Tür des Grillgeschäftes an.

rā $>$ be

„Im klassischen Persisch wurde die Endung rā auch manchmal zur Kennzeichnung eines Dativobjekts verwendet, vor allem bei den Verben goftan (sagen), dādan (geben), porsiden (fragen) und farmudan (sagen). “1222

kolu rā goft $(2 / 205 / 22)$.

statt be kolu goft.

[Er] hat Kolu gesagt [...].

rā>barāye

borğhā rā pāsebān ta'yin kardand (2/205/24). statt barāye borğhā pāsebān ta'yin kardand.

[Sie] haben die Wächter für die Türme aufgestellt.

\subsubsection{Präfix}

Im $R H$ kommen unzählige Präfixe vor, die in dieser Form und Menge heutezutage nicht mehr verwendet werden. Hier einige Beispiele:

bar

bar-āvardan (bringen; 1/41/20)

bar-ğastan (springen; 2/198/25)

dar

dar-āmadan (kommen; 1/39/11)

dar-residan (ankommen; 1/124/14)

foru

țabl foru-kuftan (trommeln; 4/568/16)

foru-ğastan (hinunter kommen; 4/569/28)

\subsubsection{Einzelheiten}

Hier werden einige sprachliche Besonderheiten des $R H$ erklärt, die häufig in der Umgangssprache benutzt werden. 
Die Worte čonān (solch, solch ein, ein solcher) und ānčonān (solch ein, so auf diese Weise) kommen häufig vor um die Stärke einer Handlung zu zeigen. ${ }^{1223}$

Amir band dast u rā čonān greft ke huun az angošthā-yeš ğastan kard (2/201/10).

Amir hat seine Hand so stark gedrückt, dass das Blut aus seinen Fingern herausgespritzt ist.

Amir čonān čub-dast bar farq-aš zad ke maġz-aš az damāḡg-aš birun āmad (2/225/10).

Amir schlug auf seinen Scheitel so stark, dass sein Gehirn herausgekommen ist.

\subsubsection{Frageformen}

Auffallend ist, dass sehr häufig im Text zwei Fragewörter in einem Satz vorkommen.

Dazu einige Beispiele:

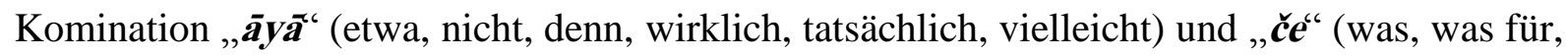
welch ein).

āyā rostam če kas bāšad (3/389/20)?

Vielleicht/Wer ist Rostam?

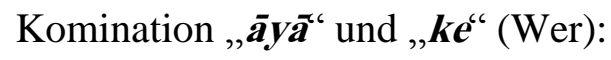

āyā kār-e ke bāšad? (3/369/12)

Vielleich/Wer hat es getan?

\subsubsection{Pluralformen}

Im Text kommt mehrmals die Doppelpluralform der Wörter vor. Das geschieht meistens bei arabischen Worten die in der Pluralform angewendet werden und die dazu noch eine persische Pluralendung erhalten. Wiederum einige Beispiele:

toğğārān (Geschäftsleute; 3/459/10)

$\begin{array}{ll}\text { statt } & \text { toğğār } \\ \text { statt } & \text { kofār } \\ \text { statt } & \text { omur } \\ \text { statt } & \text { ạ̣vāl }\end{array}$

kofārān (Ungläubie; 3/485/6)

omurāt (Handlungen; 3/518/23)

ạ̣vālāt (Zustand; 3/496/30)

\subsubsection{Singular anstatt Plural}

Man sieht sehr selten den Plural stattdessen den Singular:

hame-ye langari az ṭalā bud (3/412/29). statt hame-ye langarihā az ṭalā budand.

Alle Teller war aus Gold. $\quad$ statt $\quad$ Alle Teller waren aus Gold.

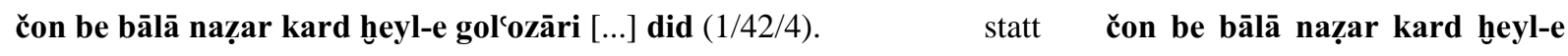
gol'ozārān [rān] [rā] did.

\footnotetext{
1222 Amin-Madani, Sadegh und Lutz, Dorothea: Persische Grammatik, Heidelberg 1972, S. 322.
}

${ }^{1223}$ Afšāri, Mehrān und Madāyeni, Mahdi: Haft laškar, Vorrede S. 37. 
Als er nach oben sah, hat er eine Gruppe von Rotwangig gesehen. statt

Als er nach oben sah, hat er eine

Gruppe von Rotwangigen gesehen.

\subsubsection{Gebrauch der Zahlen}

Die Grundzahlen sowie „do“ (zwei) und „se“ (drei) verbinden sich mit dem Suffix durch ein

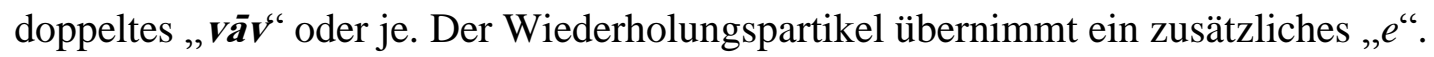

se bar-e noh-ṣad hezār kas (3/418/16)

Dreimal neunhunderttausend Leute statt 2.700.000 Männer

Manchmal äußert man nicht die genaue Zahl:

se čahār hezār kas košte šode budand (3/355/3).

Drei, vier Tausend Leute wurden getötet.

ānhā yek du piyāle šarāb nošidand (3/349/28).

Sie haben ein, zwei Schalen Wein getrunken.

\subsubsection{Gebrauch der Zeitformen}

Man benutzt die Zeitformen hauptsächlich in folgenden Fällen:

Für die Morgendämmerung:

dam-e șobḥ (kurz vor Morgen; 3/428/26)

Für den Mittag:

vaqt-e zohri (Mittag; 3/363/21)

Für den Nachmittag:

vaqt-e 'așri (Nachmittag; 3/504/17)

Auffällig ist bei den Zeitformen der Gebrauch des „i“, das man nirgendwo in der klassischen Literatur sieht. Dieses Phänomen sieht man nur in den Rollen, die in der Șafavidenzeit geschrieben worden sind. ${ }^{1224}$

Für den Abend und die Nacht:

dar vaqt-e šām (in der Abendzeit; 3/340/31).

\subsubsection{Demonstrativpronomen}

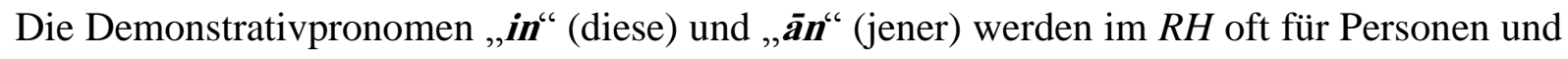
Sachen benutzt, was im iranischen Sprachgebrauch sonst unüblich ist.

goft: farzandān in [...] rā mi-šenāsid (1/64/25). statt goft: farzandān-e [in mard]rā mišenāsid.

${ }^{1224}$ Anonymus: ‘̄̄̄lam-ārā-ye Š̄̄h Esmācil, Vorrede S. 21. 
[Er] sagte seinen Kindern: „Kennen sie diese? Mann?

4.2.2.23 Überflüssiges „,rāa und ,ke“

Überflüssiges , ,räَ

Bābā šomā rā bāyad makke raft (1/36/4).

Bābā, sie müssen nach Mekka reisen.

Landehur rā be ḩāṭer resid (1/66/5).

Landehur hat sich daran erinnert.

Überflüssiges ,,$k e^{\text {“ }}$

ke bar bālā-ye sar-e amir āmad (1/111/28).

[Er] kam zum Kopfende des Amirs.

\subsubsection{Umgangssprachliche Nutzung von „o“}

Im $R H$ begegnen wir statt dem normalen „und“ oder dem Neuanfang eines Satzes massenhaft der umgangssprachlichen Kurzform „, $O^{“}$. Das lässt sich allerdings nicht im geschriebenen Wort, sondern nur beim mündlichen Vortrag feststellen.

[...] va dah man nān kešide dād bābā ḥamāl gereft o āmad goft be-ravid o 'amale-e mout rā habar dahid o hame čizihā rā kardand (1/16/16).

[Der Bäcker] hat zehn Kilo Brot gewogen und Bābā gegeben. Bābā hat Lastenträger angestellt und sagte: „Gehen Sie und benachrichtigen sie die Beerdigungsangestellten“, und [Sie] haben alles getan.

\subsubsection{Syntax}

Die nicht klassich ausgebildeten naqqāals behandeln die Sprachregeln sehr flexibel. In syntaktischer Hinsicht sind die Ausdrucksweise und die häufige Veränderung der Satzglieder im $R H$ auffällig, was beides gegen die literarische Norm verstößt. Nachfolgend werden die wichtigstenen Besonderheiten aufgeführt:

\subsubsection{Subjekt}

Das Subjekt steht normalerweise am Satzanfang, aber es kann auch in der Mitte oder am Ende des Satzes stehen. Manchmal gibt es im Text Sätze, die kein Subjekt haben.

Subjekt dem Verb nachgestellt:

Zunächst wird die Fassung des $R H$ vorgestellt, dann folgen die richtige Formulierung und danach die Übersetzung des Satzes: 
qażā rāčahār 'ayyār dārad Eskandar (2/266/1). statt qażā rā Eskandar čahār 'ayyār dārad.

Zufällig vier ‘ayyār hat Eskandar. staat Zufällig hat Eskandar vier 'ayyār.

moqaddamāt-e nazar yāftan rā naql kard Șāḥeb-qerān (1/21/11). statt Ṣāḥeb-qerān moqaddamāt-e nazar yāftan rā naql kard.

Vom Verfall des Blickes erzählte Șāḥeb-qerān. $\quad$ statt Ṣāḥeb-qerān erzählte vom

Verfall des Blickes.

Subjekt dem Objekt nachgestellt:

čon čašm Amir gošud (1/98/28).

Als sein Auge Amir geöffnet hat.

statt

statt

Amir rā Āzmāyeš bar taḩt nešānid (1/163/26)

statt

Amirhat den Āzmāyeš auf den Thron gesetz. gesetzt. čon Amir čašm gošud.

Als Amir sein Auge geöffnet hat.

Āzmāyeš Amir rā bar taḩt nešānid.

Āzmāyeš hat den Amir auf den Thron

\subsubsection{Verb}

In der Literatursprache steht das Verb am Ende des Satzes, aber in der Umgangssprache steht es manchmal an der zweiten Position. Während es in einem Gespräch legitim ist, das Verb wegzulassen, ist dies in einem mündlichen Vortrag normalerweise nicht üblich. Allerdings kommt es in diesem Buch häufiger vor.

Vorgezogenes Verb:

boland šod Amir ān dāne rā gereft (1/42/4).

Amir stand auf und hat das Korn genommen.

farmud be-zanand țabl-e ğang rā (4/536/5).

Er befahl die Kriegstrommel zu schlagen.

Verb in der Mitte des Satzes:

bā si hazār kas riḩtand dar miyān-e gabrān (1/26/16).

Mit 30.000 Soldaten griffen sie den Feueranbeter an.

dar in ğā hast 'ayyāri ke u rā Borq-e Farangi mi-guyand (2/251/16).

Es gibt hier einen Kundschafter, den man Borq-e Farangi nennt.

\subsubsection{Akkusativ-Form}

Normalweise steht das Akkusativobjekt zwischen dem Subjekt und dem Prädikat. Hier unterscheidet sich die Stellung dieses Akkusativobjektes ebenfalls von dem normalen Gebrauch. Manchmal steht es am Satzanfang oder es wird durch ein Pronomen ersetzt.

Akkusativ-Objekt am Satzanfang: 
Amir rā Āzmāyeš bar taḩt nešānide (1/163/26). statt

Amir hat den Āzmāyeš auf den Thron gesetzt.

čon čašm Amir gošud (1/98/28).

Als Amir sein Auge öffnete.
Āzmāyeš Amir rā bar taḩt nešānide.

statt Āzmāyeš hat den Amir auf den Thron gesetzt.

statt čon Amir čašm rā gošud.

Akkusativ-Objekt dem Verb nachgestellt:

yār ham ne-mi-šenāsad ma-rā (1/96/1).

Meine Geliebte erkennt mich nicht.

'Amr raft be țalab-e Bahtak (1/105/28).

'Amr ging auf die Suche nach Bahtak. statt

statt

statt

statt yār ham ma-rā ne-mi-šenāsad.

Meine Geliebte mich nicht erkennt.

'Amr be țalab-e Bahttak raft.

'Amr auf die Suche nach Bahtak ging.

\subsubsection{Ellipse}

Insgesamt ist die Auslassung eine Besonderheit der mündlichen Sprache. Es gibt in diesem Buch Sätze, in denen man die Auslassung eines Satzgliedes oder Teilsatzes nicht wahrnimmt.

Ellipse des Verbs:

Man kann nur schwer feststellen, was ausgelassen worden ist, und es hängt von den Einzelheiten des Satzes ab:

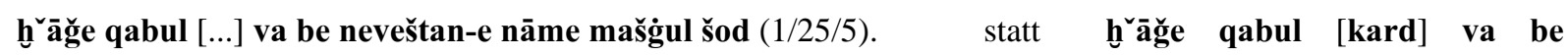
neveštan-e nāme mašğul šod.

Der ehrwürdige Herr hat es [...], und er begann, einen Brief zu schreiben. statt Der ehrwürdige Herr hat es [akzeptiert], und er begann, einen Brief zu schreiben.

Amir bā Bahrām va dalirān ravāne-ye bārgāh [...] (1/38/9).

statt Amir bā Bahrām va dalirān ravāne-ye bārgāh [šodand].

Amir [...] mit Bahrām und den Helden zum Audienzsaal. statt Amir [ging] mit Bahrām und den Helden zum Audienzsaal.

Beispiele für Ellipsen des Subjekts:

[...] be rāh oftād $(1 / 89 / 22)$.

[...] hat sich auf den Weg gemacht.

[...] tāziyāne bar u zad (1/116/18).

[...] schlägt ihn mit der Peitsche.

Ellipse des Akkusativ-Objektes:

Qāren [...] piš-e Šāh bar zamin gozārd (1/59/16). statt zamin gozārd. statt [`Amr] be rāh oftād.

statt [`Amr] hat sich auf den Weg gemacht.

statt [Amir] tāziyāne bar u zad.

statt [Amir] schlägt ihn mit der Peitsche. 
Qāren legte [...] vor den König auf den Boden. statt Qāren legte [das Fangseil und den Pfeil] vor den König auf den Boden.

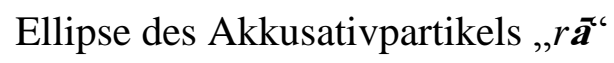

čon be bālā naẓar kard ḩeyl-e gol'ozāri [...] did (1/42/4).

statt $\quad$ čon be

bālā naẓar kard ḩeyl-e gol'ozārāri [rā] did.

Als er nach oben sah, hat er [...] Gruppe von Rotwangigen gesehen.

statt Als er nach

oben sah, hat er [eine] Gruppe von Rotwangigen gesehen.

farmud heyme-ye doulat [...] dar ān čaman bar-sar-e pā-kardand (3/365/20). statt farmud

ḩeyme-ye doulat [rā] dar ān čaman bar-sar-e pā-kardand.

Er befahl, [...] Zelt des Glückes auf dieser Wiese aufzuschlagen.

statt Er befahl, [das]

Zelt des Glückes auf dieser Wiese aufzuschlagen.

\subsubsection{Relativsätze}

Bei Relativsätzen gibt es kein bestimmtes Verbindungssystem zwischen den Sätzen. Manchmal gibt es keine Konjunktion und in diesem Fall wird die Verbindung durch eine Betonung geäußert. Sehr selten gibt es Sätze, in denen zwei Konjunktionen stehen. Manchmal stehen mehrere einfache Sätze hintereinander, in denen sehr häufig die Konjunktionen „,ke“ und ,va“ benutzt worden sind.

An dieser Stelle seien einige Beispiele erwähnt:

Relativsätze mit Konjunktion:

Die Partike ,ke“ stellt die Verbindung zwischen einem erklärenden Satz und dem näher zu bestimmenden personalen oder sachlichen Begriff her. Dazu einige Beispiele:

nahib dād ke be-gir az dast-e man (4/612/1).

Er hat geschrien: Nimm es von meiner Hand.

Relativsätze mit zwei Konjunktionen:

čon qahr in ḩabar šenideh bi-damāḡšod tā ke šab šod (2/348/14).

Nachdem Qahr diese Nachricht gehört hatte, war er traurig bis zum Abend.

Relativsätze ohne Konjunktion:

sar bar zānu nahāde zār zār mi-gerist (4/560/16).

statt sar bar zānu nahāde [va] zār zār mi-gerist.

Er hat seinen Kopf auf die Knie gelegt, laut geschluchzt. statt Er hat seinen Kopf auf die Knie gelegt und laut geschluchzt. 


\subsubsection{Andere Auffälligkeiten der Grammatik}

Unregelmäßigkeit der Kongruenzverhältnisse:

hamsāyegān yek qābele va yek šiše-ye ‘araq āvard (1/6/6).

statt hamsāyegān

yek qābele va yek šiše-ye ‘araq āvardand.

Die Nachbarn haben eine Geburtshelferin und eine Flasche Wein mitgebracht.

statt

Die

Nachbarn haben eine Geburtshelferin und eine Flasche Wein mitgebrachten.

tā yeki az kanizan āmadand (1/45/31).

Bis eine von den Sklavinnen kommen.

kommt.

\subsection{Zum literarischen Stil}

Literarisch gesehen sind die schriftlich überlieferten Texte des $R H$ von unterschiedlich literarischer Qualität. Der mündliche Vortrag der Erzähler enthält viele Elemente aus der schriftlich überlieferten sogenannten klassischen Literatur. In jedem Fall zeichnet er sich durch eine starke Bildhaftigkeit aus, die das Erzählte dem Zuhörer in sehr lebendiger Form vor seinem inneren Auge entstehen lässt.

Die Erzähler wählen aus der überlieferten Stoffmasse Geschichten aus, deren Inhalte einander gleichen, und können sie je nach ihrem eigenen Bildungsstand, auf unterschiedliche Weise darbieten. Dies zeigt sich am Umfang des Wortschatzes, syntaktischer Merkmale oder der Einfügung von Gedichten. Im $R H$ mischen sich Texte von literarisch hohem mit Texten von literarisch geringem Wert. Über den Einfluss der klassischen Literatur auf die populäre Literatur schreibt Hanaway:

„Die mündliche Überlieferung wird generell als ein Teil der populären Kultur gesehen, aber sie berührt auch an vielen Punkten die literarische Kultur.“1225

Die Erzähler versuchten, ihre Gedanken in ein poetisches Gewand zu kleiden. Ihre Zuhörer empfanden großes Vergnügen an solchen poetischen Stücken. Das Entzücken über ihre Verse ist bis heute bei dem iranischen Publikum ungeheuchelt und ehrlich.

Gewiss haben wir es hier mit allgemein poetischen Formen zu tun. Die naqqāls hatten eine große Vorliebe für rhetorische Formen. Wie nach einem festen Muster arbeitete die Einbildungskraft der naqqāIs. Im Text finden wir beliebte charakteristische Züge: wie die Bildsprache der Erotik, Beschreibungen von Schönheit, Hässlichkeit, Sonnenauf- und Sonnenuntergängen.

\footnotetext{
${ }^{1225}$ Hanaway, William: Dāstān-sarā'̄i, in: Elr, Vol. VII, Costa Mesa/California 1996, S. 102-103, hier S. 102.
} 
Die Verfasser der Texte verwendeten bei ihren Beschreibungen zahlreiche Metaphern. Nach der Auffassung der Zuhörer zeichnete sich ein guter Erzähler vor allem durch seine Fantasie und sein Wortspiel aus. Es. erweckte in ihnen tiefe Gefühle. Ihre rege Einbildungskraft fand fortwährend neue Eindrücke und sie genossen diesen Augenblick. In diesem Unterkapitel wird auf poetische Sonderbeschreibungen des $R H$ eingegangen.

\subsubsection{Literarische Beschreibungen}

Die Qualität der mündlichen epischen Aufführung hängt von der Geschicklichkeit des Erzählers ab. Der Erzähler versucht, die Helden ihre Pferde und Waffen, die prachtvollen Gärten und die Schönheit der Frauen literarisch zu beschreiben. An solchen Stellen kommt die Handlung der Erzählung zum Stillstand. Die Zuhörer genießen die farbenprächtigen Bilder, die vor ihnen entstehen. Bei den Szenen, in welchen der Held seine Waffen anlegt, handelt es sich um eine Ausschmückung. Sie sind rein künstlerisch (dramaturgisch) motiviert und beschreiben zugleich die Verehrung die dem Helden entgegengebracht wird. Möchte der Erzähler eine größere Szene beschreiben dann verwendet er besonders ausschmückende Worte. Die Beschreibungen und die Ausführlichkeit der Darstellung sind wichtige Merkmale für den Stil eines Erzählers. Die einzelnen Erzählungen im $R H$ sind von unterschiedlichem Umfang. Manche Beschreibungen von Landschaften und Gärten,der Tierwelt oder auch des Kriegsgeschehens sind in ausführlicher Form vorzufinden. Daneben gibt es aber auch sehr kurze Erzählungen. Bei einem überwiegend freien Vortrag verwenden die Erzähler in der Regel Stichworte als wichtige Gedankenstütze.

\subsubsection{Schönheit und Liebe}

An dieser Stelle soll sich der Frage zugewandt werden, was das Idealbild der iranischen Männer oder der iranischen Gesellschaft insgesamt war. Es wird mittels der ältesten Materialien, die zur Verfügung stehen, dieser Frage nachgegangen. Aus der Vielzahl der umfangreichen literarischen Stoffe, die zur Verfügung stehen, werden für die vorislamische und die islamische Zeit exemplarisch fünf Bilder aus dem Yašt, dem Tãrih-e Bal'ami, dem Šāh-nāme, dem Samak-e 'Ayyār und dem $R H$ ausgewählt. Ziel ist es zu untersuchen, ob das $R H$ seinen eigenen Stil verfolgt oder ob es die Muster der klassischen Literatur Persiens übernimmt. Als Motiv wird aus der Vielzahl der Möglichkeiten (Kampf, Krieg, Festlichkeiten, Ehe, Religion usw.) jenes der Schönheit ausgewählt, nicht zuletzt deshalb, um die schönsten Aspekte des $R H$ im Vergleich darstellen zu können.

In der Sprache der persischen Poeten finden wir Beschreibungen der einzigartigen Gestalt und der außergewöhnlichen Schönheit der Frauen. Die Dichter haben versucht, deren erotische 
Gesamtausstrahlung bis ins kleinste Detail zu beschreiben. Es ist bemerkenswert, dass das physische Porträt der Geliebten in der islamischen Zeit ganz dem vorislamischen Schönheitsideal entspricht. Es wird so beschrieben: Augen wie Narzissen ${ }^{1226}$, Augenbrauen wie Bögen, Wimpern wie Pfeile ${ }^{1227}$, Hals und Flanken wie eine Gazelle, eine zerbrechliche Taille wie eine Statue oder ein leuchtendes Gesicht wie der Mond. ${ }^{1228}$ Ihre ideale Statur (Kontrast von schmalem Oberkörper und breitem Unterleib) hob körperliche Details hervor z.B. Haare wie Fangschnüre, ${ }^{1229}$ die Zähne wie Perlen, die Brüste wie Granatäpfel).Im Folgetext sollen bezogen auf die einzelnen Körperteile Hintergründe solcher Schönheitsmerkmale und Ideale vorgestellt werden.

Das erste Bild ist die Beschreibung der Göttin Urdv̄i Sūrā Anāhitā: „Gestalt eines schönen Mädchens, eines sehr kräftigen, schön gewachsenen, das hoch gegürtet, hoch von Wuchs (?) ist, vornehmer Herkunft und edel, in einen kostbaren reichgestickten goldenen Mantel gekleidet. Wahrlich, wie sichs geziemt (?), Operzweige in der Hand haltend, prangend mit vierseitigem goldenem Ohrschmuck, ein Halsgeschmeide trug die hochedle Urdvī Sūrā Anahita an ihrem schönen Hals; sie umgürtete sich die Liebesmitte, damit ihre Brüste wohlgestaltet und verlockend (?) seien. Oben band sich Urdvī Sūrā Anahita einen goldenen Kopfputz mit 100 Sternen an, einen achtteiligen...(?) schönen, der mit Fähnchen und einer Verdickung versehen, gut gemacht ist.“ ${ }^{1230}$

Das zweite Bild ist aus dem Buch Tārih̆e Bal'ami von Abu 'Ali Moḥammad b. Moḥammad Bal'ami (gest. 974). Er führt an, dass eine schöne Frau in der sasanidischen Zeit so aussehen sollte:

„sie ist von geradem ebenmäßigen Wuchs, weder zu klein, noch zu groß. Ihr Gesicht und Wangen sind von heller Farbe, ihr Körper ist bis zu den Zehen weiß. Ihre Wangen sind rötlich gefärbt und schimmernd wie Mond und Sonne. Ihre Augenbrauen sind bogenförmig und weit auseinander. Die Augen sind groß und weiß, die Iris schwarz, die Wimpern schwarz, lang und gerade. Ihre Nase ist schmal und lang, das Gesicht weder lang noch ganz rund. Ihre Haare sind schwarz, lang und glatt. Ihr Kopf mittelmäßig, weder groß noch klein, der Hals weder lang noch kurz, so daß die Ohrgehänge ihre Schulter berühren. Ihre Brust ist breit und gewölbt, die Brüste klein, rund und hart. Die Schultern und Arme sind gleichmäßig, der Oberarm, wo die Armreifen hinkommen, fleischig, ihre Finger schmal, weder lang noch kurz. Ihr Bauch ist flach und in der

\footnotetext{
1226 Šafici-Kadkani, Moḥammad-Reżā: Șovar-e hayāl dar šerr-e fārsi, Teherān 1366/1987, S. 306-307. 1227 Ebd.

${ }^{1228}$ Bauer, Thomas: Liebe und Liebesdichtung in der arabischen Welt des 9. und 10. Jahrhunderts, Wiesbaden 1998, S. 218.

1229 Šafici-Kadkani, S.162-163

${ }^{1230}$ Lommel, Die Yäšts des Avesta, Yašt 5, 126-128, S. 43.
} 
gleichen Höhe wie die Brust. Ihre Pobacken sind hoch, ihre Taille schmal. Der Hals, wo die Halskette hinkommt ist schmal. Ihre Schenkel sind stark und fleischig, die Kniee rund, die Waden stark, die Knöchel klein und rund und die Zehen klein und rund. Wenn sie geht, ist sie schwerfällig. Sie ist gehorsam gegen ihren Herrn. Eine, die keine Not gesehen hat und in Wohlstand aufgewachsen ist. Sie ist schüchtern, vernünftig und sanftmütig. Ihr Vater ist aus vornehmen Geschlecht und ihre Mutter gütig. Ihre Herkunft ist besser als ihr Aussehen und ihr Aussehen übertrifft ihre Herkunft. Ihre Natur ist besser als ihr Temperament. Sie ist von Adel und Würde, fleißig und rechtschaffen.“1231

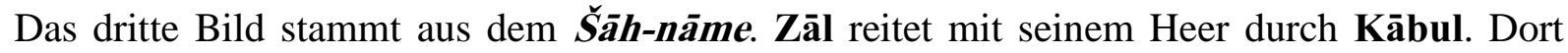
regiert Mehrāb, der von Żạ̣ḥāk abstammt. Mehrāb kommt Zāl mit vielen kostbaren Geschenken entgegen. Zāl empfängt ihn freundlich und findet Gefallen an ihm. Einer der Begleiter des Zāl erzählt ihm von der Schönheit Rudābes, der Tochter von Mehrāb, und bringt ihn so weit, dass er sich, ohne sie gesehen zu haben, in sie verliebt. Es heißt:

„Er, Mehrāb, hat eine Tochter,

deren Gesicht strahlender als die Sonne ist, von Kopf bis zu den Füssen ist sie wie Elfenbein.

Ihr Gesicht ist wie das Paradies, und ihr hochgewachsener Körper ist wie indische

Eiche $[\ldots]$.

Ihr Gesicht ist wie die Blüte des Granatbaums und ihre Lippen wie der Granatapfelkern.

Von ihrem silberweißen Körper wuchsen zwei schattige Bäume heran, ihre Augen sind wie zwei Narzissen im Garten, ihre [schwarzen] Wimpern stammen von den Federn eines Raben, ihre zwei Augenbrauen sind wie tarāz Bogen, dessen Behälter viel zärtlichen Moschus enthält.

[Sie] ist wie ein Paradies, von Kopf bis Fuß ist [sie] geschmückt voller Schmuck, Freud und Hab und Gut. “'1232

Das vierte Bild entstammt dem Samak-e 'Ayyār, einem Volksroman aus dem 11./12. Jahrhundert. Den meisten adligen Frauen im Samak-e 'Ayyār wird eine ideale Schönheit nachgesagt. Eine der wichtigsten Frauen ist Mahpari, die Tochter des chinesischen Kaisers. Sie hat wegen ihrer Schönheit viele Bewerber unter den Königen. Eines Tages gehen Horšid Šāh und Farroh-ruz, sein Bruder, mit einigen Reitern auf die Jagd. Nach einer großen Jagd und reichlichem Essen und Wein legen die Reiter sich zum Schlafen nieder. Horšid Šāh will sich noch ein wenig die Wiese anschauen. Dort sieht er einen Wildesel. Er versucht ihn zu

\footnotetext{
${ }^{1231}$ Zitiert nach: Abkaci-Khavari, Manijeh: Das Bild des Königs in der Sasanidenzeit, Hildesheim/Zürich/New York 2000, S. 191; Bal'ami, S. 226.

${ }^{1232}$ Ferdousi, Bd. 1, S. 94.
} 
fangen, doch der Wildesel kann fliehen. Der Prinz verfolgt ihn ein paar Tage ohne Erfolg. Endlich, als der Prinz eine Wüste erreicht, sieht er einen Pavillon. Er betritt ihn und sieht ein schlafendes Mädchen von großer Schönheit. An dieser Stelle soll es dem Verfasser überlassen werden wie der weitere Verlauf der Geschichte vorgetragen wird:

„Der Königssohn schaute die Person an; er sah ein Mädchen wie 100.000 Gemälde, mit rundem Kopf und breiter Stirn, mit Haaren wie Schnüre und Augenbrauen wie čāči-Bögen, zwei Augen wie Narzissen, die Wimpern wie Āraš-Pfeile, die Nase wie ein Klinge, der Mund wie ein Halbdinar, das Gesicht wie Silber, die Wangen wie Rosen, ein Kinn wie ein Bällchen mit Grübchen, ein kleines Hälschen, und ein hundertfaches Doppelkinn unter ihrem Kinn, einen Thorax wie ein Silberbrett, zwei Brüste wie Granatäpfel, kleine Unterarme und kleine Finger. Auf der Handoberfläche 1.000 Vertiefungen, die Finger hatte sie schwarz gemacht und an jedem Finger ein paar Ringe; ein Bäuchlein wie von der besten Mehlsorte, die man durch Seide siebt und mit Mandelöl mischt, einen Nabel wie ein Moschusbehälter, zwei Schenkel wie zwei Pferde [Schenkel] und zwei Unterschenkel wie zwei Elfenbeinsäulen. “1233

Wie wir oben gelesen haben, kommen diese Schönheitsideale in der klassischen Vorläuferliteratur vor. Gezeigt werden soll nun, dass auch die Verfasser des $R H$ das alte traditionelle Schönheitsideal verfolgen.

Um es vorweg zu nehmen: Im $R H$ wird kein eigenes Schönheitsideal entwickelt. Bei der Beschreibung der Schönheit der Frauen, spielen die paris und ḥuris (Himmelsfeen), die der klassischen Literatur entlehnt sind, eine wichtige Rolle. ${ }^{1234}$

äftāb-tal'at (Sonnengesicht; 5/808/30)

ğabin-e čon āftāb (sonnenähnliche Stirn; 1/32/3)

pari-čehre (Feengesicht; 5/640/5)

pari-peikar (Parikörper; 3/371/20)

ḥur-šamāyel (paradiesbewohnerähnliches Porträt; 5/861/2)

țāvus-e mast (betrunkener Pfau; 1/49/10)

șanam (Idol; 5/684/23)

gol-cozār (rosenwangig; 5/669/8)

lāle-roh (tulpenwangig; 5/826/4)

māh-e šabe-e čahārdah (Vollmond; 4/623/19)

nāzanin șanami ke kerešm-ye ğamāl-aš 'arusān-e behešt rā ğelvegari

āmuhti va az tāb-e cārez-aš āftāb cālam-tāb dar ātaš-e geyrat suhti čašm-e mast-aš bā tir-e gamze dar sine-ye ṣadaf rehnne sāhnti va lacl-e ğān-baḩ̌š-aš az tong-e šekarkām del rā ḥalāvat baḩšidi (5/640/5).

\footnotetext{
${ }^{1233}$ Zitiert nach: Khaleghi-Motlagh, Die Frauen im Schahname, S. 206, al-Arrağāni, Bd. 1, S. 13.
} ${ }^{1234}$ Vgl. Horten, S. 378. 
Ein feines, zartes [Mädchen], es glich einem Idol, das Liebäugeln ihrer Schönheit war so groß, dass sie den Bräuten des Paradieses die Koketterie beibrachte. Vom Licht ihres Gesichtes verbrannte die weltstrahlende Sonne im Feuer der Eifersucht. Ihre betrunkenen Augen durchbohrten mit dem Pfeil des koketten Blickes die Brust der Muschel. Ihre Lippen, die einem Rubin glichen, verleihen das Leben. Von ihren zuckerhaltigen Becher [Herz], verlieh sie die Süßigkeit dem Herzenswunsch [dem Liebhaber].

Beschreibung der Liebe im $R H$ :

Liebe ist im $R H$ ein Zauber, eine magische Kraft, die den Menschen in den Bann schlägt. Diese Liebesmagie geht von der strahlenden Schönheit der Frau aus, die mit ihrem Blick den Helden verzaubert. Sie verkörpert eine große Macht.

ḥeyrān-e ğamāl-e māh meșāl-e kasi šodan (5/79619).

sich verwirren in jemanden, welche(r) eine Schönheit wie der Mond hat.

Liebe im $R H$ verursacht einerseits Schmerz, Sorgen und Verzweiflung, anderseits schenkt sie Hoffnung, Freude und Glück. Nunmehr sollen Audrücke und Formulierungen aus dem $R H$ im Zusammenhang mit der Liebe vorgestellt werden:

asir kasi budan (Gefangene(r) der Liebe; 5/927/1)

dar piš-e kasi 'āšeq šodan (

gereftār šodan (in Schwierigkeiten geraten; 5/784/23)

'enān-e aḩiyār rā az dast dādan (die Kontrolle verlieren; 5/784/19)

Fast immer führt der Weg von der Schönheit der oder des Betrachteten, also über das Auge, zum Herz bzw. zu den Sinnen des Betrachters. Der Vorgang des Verliebens bzw. des Erblickens und Begehrens entspricht einem universellen, menschlichen Charakterzug. Die Autoren des $R H$ haben diese Bilder ausführlich und ganz konkret ausgemalt. Die Versinnbildlichung plötzlich hereinbrechender Liebe wollen sie eher als Metapher/Allegorie aufgefasst wissen und ihre dargestellten Liebesepisoden besitzen metaphorischen Charakter. Von einer Ausnahme (z.B. Fernliebe) abgesehen, funktioniert die Liebe im $R H$ nach einem relativ einfachen und einheitlichen Muster. Ausgehend vom Anblick äußerer Schönheit wird durch das Auge (das Betrachten) ein intensives Empfinden ausgelöst, das sich an das Herz und/oder an alle Sinne wendet.

del az dast dādan $(5 / 784 / 10)$

Das Herz verloren.

be hezār del māyele kasi šodan (4/570/2)

Mit tausend Herzen sich in jemanden verlieben. 
be yek del na ṣad del šeydā gardidan (5/861/2).

Nicht nur mit einem Herz, sondern mit hundert Herzen sich in jemanden verlieben.

ḩārhāāi dar del be-ham-residan (1/35/17).

Dornen im Bauch haben.

naqd-e del rā bāḩtan (4/711/9).

Das Bargeld des Herzens verlieren.

Die Liebe wird auch als etwas äußerst Bedrohliches angesehen und mit Wahnsinn und Geisteskrankheit gleichgesetzt, wenn oft nur ein Blick genügt, um eine Kette von destruktiven Reaktionen auszulösen. Gerade solche Beschreibungen sind geeignete Beispiele, um zu zeigen, dass die Erzähler vom altiranischen Epos geprägt sind. Am stärksten und vor allem als ursprünglicher Bestandteil des Allegorischen ist der Topos Auge und Herz. Nur dort wird die konkrete Metapher des Liebespfeils verwendet.

tā Mehr Amir rā did tir-i az kamān-b̧āne-ye abru-ye u ğastan kard tā par o sorhb-e sufār bar hadaf-e sineye Mehrenagār ğā kard (1/42/1).

Als Mehr Amir sieht, springt von seinen bogenartigen Augenbrauen ein Pfeil mit roter Endfeder ins Ziel, der in Mehrs Herz seinen Platz findet.

Das Thema Liebe zeigt uns die Untrennbarkeit von Lust und Liebe. Wenn man liebt dann ist alles Liebe und Lust.

lab bar lab gozāšstan (Lippen auf Lippen legen; 1/58/27)

bāzār-e buse garm šodan (der Markt des Kusses wurde warm; 1/44/29

dar āġuš gereftan (sich umarmen; 5/953/12)

dar baġal kešidan (sich umarmen; 6/1056/17)

Der Intimverkehr zwischen Paaren wird mit blumigen Umschreibungen und fantasievollen Metaphern umschrieben:

bā kasi be ṣoḥbat nešastan (sie saßen, um mit jemandem zu sprechen; 5/787/23)

dast dādan (die Hände jemandem geben; 5/ 930/19)

dast dar gardan dar āvardan (die Hände jemanden um den Hals legen; 4/677/31)

dast be mouze'-e maḅsuṣ resānidan (die Hand an der besonderen Stelle lassen; 4/719/2)

Zohre rābe dast-e Moštari dādan (Venus in Jupiters Hand geben; 5/769/7)

Die Schönheitsbeschreibungen der weiblichen Gestalten beschränken sich auf die Beschreibung der Kleidung und nicht des Körpers. Der Focus wird auf die visuelle Einheit zwischen dem diaphanen Körper und seiner prächtig-glanzvollen Kleidung gelegt, so etwa bei Hamze und Mehrnegārs Auftritt im Palast. 


\subsubsection{Häßlichkeit}

Die Häßlichkeit der dämonischen Gestalten will man in besonderer Weise zum Ausdruck bringen. Dies wird mit Hilfe der Hyperbel erreicht.

māde gùli derāz bālāi zešt-ru-i karih simā-i, du labaš čon lab-e derāz-e šotor bini-aš șān-i-ye ğahāz-e šotor, mu ze pestān-aš sar-zade čo giyāh, har yeki ham-čo hā̄rpošt-e siyāh (1/179/24-25).

Ein weiblicher Dämon ist sehr lang und hat ein häßliches Gesicht. Seine Lippen gleichen den Lippen eines Kamels. Seine Nase ist so groß wie der Sattel eines Kamels. Die Haare seiner Brüste kommen hervor wie ein Pflanzenstrauch. Jedes Haar gleicht einem schwarzen Igelstachel.

Im narrativen Arrangement folgt unmittelbar auf die Darstellung der äußeren Pracht des Helden immer die ausführliche Beschreibung seines Gegenübers als negativ besetzter ungläubiger Gegenpart: Gleich nach dem schönen Anōširvān tritt Șalsāl auf, König über ein dunkles, unzivilisiertes, vom Teufel bewohntes Land. So werden die Feinde des Helden immer als häßlich und schwarz bezeichnet:

čašm-e Anōširvān be țorfe ḥarām-zāde-i oftād ke haštād arağ pahnā-ye sine-ye u, va ruy čon ġeyțarān siyāh va riš-e sefid tā kamar-zanğir reside tāğ-e noh kongere bar sar bad-tarkib va karih-manẓar nahāde (3/394/23$25)$.

Anōširvān sieht zufällig einen merkwürdigen Bastard. Die Breite seiner Brust beträgt 80 Ellen. Sein Gesicht ist so schwarz wie Pech, und sein weißer Bart reicht bis zur Kette an seiner Taille. Auf seinem Kopf trägt er eine Krone mit neun Zacken. [Er ist] häßlich und von widerlichem Äußeren.

Auch die Hexen als Gegenspieler der Helden werden immer als häßlich und alt dargestellt:
čašm bābā bar patiyāre-i oftād ke pust-e ruy čin čin čon dam-e ḥadādān
bar ruy-ye ham oftāde va češm čon du mašcal-e suzande va mu-ye sar čon kāfur-e sefid (3/429/22).
Bābā wirft den Blick auf eine widerliche [Hexe], die Haut ihres Gesichtes ist faltig und zusammengefallen. Ihre Augen sind wie zwei brennende Fackeln und ihre Haare weiß wie weißer Kampfer.

\subsubsection{Helden}

In der epischen Tradition im Iran haben die epischen Dichter/Erzähler eine große Vorliebe für die Beschreibung der Einzelheiten der Kämpfe. „Die epische Erzählung wie das Epos selbst 
legt bei den Kämpfen viel mehr Gewicht auf die Leistungen der einzelnen Helden als auf die der Massen.“ 1235

Dazu zählt auch das Werk $R H$ mit seinen zahlreichen Kampfschilderungen. Den Autoren dieses Werkes stand ein umfangreicher epischer Stoff aus der alten Zeit zur Verfügung. Hier werden kriegerische Handlungen, welche die Erzählung anschaulicher machen, sehr lebendig dargestellt. Die Bilder der Helden, wie sie von anderen epischen Erzählungen dargeboten werden, zeigen die Tendenz zur Schilderung von Macht, Herrlichkeit und Kampfesmut in sehr emotionaler und erhabener Sprache. Die Helden sind alle tapfer, ruhmreich, stolz und sehr prächtig. Hier herrscht ein heroischer Ton vor und die Kraft der Helden ist schier übermenschlich. Ihre erste Heldentat ist stets das Töten eines Löwen oder eines Drachen.

Eine beliebte Metapher bei der Beschreibung der Großartigkeit der Helden ist der Vergleich mit Tieren. Als Ausdruck für Kraft und Stärke, Tapferkeit und Schnelligkeit gelten Leopard, Tiger, Löwe, Panther, Drache und Krokodil, während sein Feind manchmal mit Fuchs, Schakal oder Hund verglichen wird. Für negative Vergleiche, die Feigheit und Angst verkörpern, wird das Schwein genannt.

Die Helden suchen nach großen Ruhm und einem untadeligen Ruf. Sie werden als nām-dār (die Ruhm besitzen) bezeichnet, was gleichzeitig auch die Bezeichnung für die Edlen und die Ritter-Elite ist. Die Helden besitzen ein strenges Ehrgefühl und eine Verletzung ihres Ehrgefühls verursacht oft Konflikte mit ihren Feinden oder sogar mit der eigenen Verwandtschaft. Sie kennen keine Angst vor dem Feind und überwältigen ihn in einer ganz bestimmten Form. Dies wird meist so beschrieben, dass der Held den Feind aus dem Sattel hebt, über den eigenen Kopf hält und schließlich zu Boden wirft. Dann tötet er den ungläubigen Feind entweder mit der Hand, indem er ihm wie einem Hund das Genick bricht, oder er schneidet ihn mit dem Schwert wie eine Gurke oder ein Stück Käse entzwei (3/385/7), (4/545/3).

Die Autoren des $R H$ wollen den Helden nicht in einer unvorteilhaften Lage sehen. Das hat dazu geführt, dass Berichte über ihre Siege ausführlich geschildert werden und Niederlagen entweder verschwiegen oder mit dem Schicksal erklärt werden.

$\mathrm{Zu}$ einem hervorragenden Krieger gehört ein stattliches Pferd. Ein herrliches Exemplar adelt den Helden, und so darf es in der Beschreibung desselben nicht fehlen. Hier eine kurze Beschreibung des Pferdes Ašqar, auf dem Ḥamze zum Zweikampf reitet. „Sein Wiehern hallt wie der Donner, wenn er grollt, sein Pferd ist ähnlich dem Blitz in seinem Lauf, und wie der Südwind, der weht ist es geschwind im Laufen und Springen und erreicht den Vogel am

1235 Nöldeke, Theodor: Das iranische Nationalepos, in: zweite Auflage des im Grundriss der iranischen 
Horizont in seinem Lauf“" (2/199). Die Geschwindigkeit des Pferdes wird meist in Bildern von Pfeil, Wind und Blitz dargestellt. Den Autoren steht ein großes Repertoire an Vergleichsmaterial zur Verfügung, auf das sie bei jeder passenden Gelegenheit zurückgreifen können. Es geht ihnen nicht um Einmaligkeit, sondern um die stimmungshafte konstante Komponente.

\subsubsection{Weitere ausgewählte Bildelemente des $R H$}

Eine Beschreibung ist die kunstvolle sprachliche Darstellung. Sie ist die Kunst, mit Worten zu malen oder die Technik, mit Worten einen bildlichen Eindruck beim Zuhörer bzw. Leser hervorzurufen. In der Literatur ist die Sprache, ob mündlich oder schriftlich, prinzipiell das einzige Medium der Beschreibung. Die literarischen Beschreibungen im $R H$ unterscheiden sich durch die unterschiedlichen Literaten sehr voneinander.

Konkrete Dinge wie Menschen, Tiere und Natur, zeitliche Ereignisse, Feste und allgemeine Phänomene des menschlichen Lebens wie Freude und Kummer, Neid und Mitleid, Liebe und $\mathrm{Haß}$ sind beliebte Gegenstände in der iranischen Literatur.

Durch die Beobachtung der Natur, Erinnerungen an historische und kulturelle Ereignisse oder einfach die Kraft der Phantasie wurden die Autoren des $R H$ zu ihren Beschreibungen inspiriert. Sie strebten in ihren Erzählungen nicht nach Genauigkeit und Exaktheit, sondern versuchten, die Gegenstände möglichst interessant zu beschreiben, um das Interesse der Zuhörerschaft für sich zu gewinnen. So mussten die Beschreibungen von Personen und Ereignissen mit Übertreibungen ausgeschmückt werden, damit diese im Gedächtnis ihres Publikums blieben. Diese Funktion beruht gerade darauf, dass der durch die Beschreibung hervorgerufene bildliche Eindruck nicht identisch mit dem realen Bild des Gegenstands ist. Dies eröffnet den Phantasien der Zuhörer einen freien Raum, was man als den ästhetischen Effekt der literarischen Beschreibung bezeichnen kann. Manche Erzähler sahen es als eine literarische Herausforderung an, etwas darzustellen, was für die Zuhörer sinnlich schwer vorstellbar war. Allerdings besteht bei zu phantasievollen Ausschmückungen die Gefahr, dass die Erzähler nur klischeehafte Vorstellungen reproduzieren, was im $R H$ deutlich zu erkennen ist. Im Folgenden sollen einige Beschreibungen aus dem $R H$ vorgestellt werden.

Die Sonnenauf- und Sonnenuntergänge

In der epischen Tradition sind die Beschreibungen der Sonnenauf- und Sonnenuntergänge sehr charakteristisch. Vor der Schilderung eines Kampfes beschreiben die Autoren stets einen

Philologie erschienenen Beitrages, Berlin/Leipzig 1920, S. 53. 
Sonnenaufgang. Die Sonne erscheint mit ihrem Licht und ihrer Helligkeit. Sie kämpft gegen die Heere der Dunkelheit und vertreibt die Nacht. Hier sieht man eine thematische Harmonie. Auch das Heer der Ungläubigen (Dunkelheit) wird bald vom Heer des Lichts (Hamze) vertrieben.

Die Erzähler beschreiben den Sonnenaufgang mit stets wechselnden Bildern. Im $R H$ werden 80-mal Sonnenaufgänge und fast ebenso viele Sonnenuntergänge geschildert. Ohne Schilderung von Sonnenauf- und Sonnenuntergängen ist kein episches Werk der iranischen Literatur denkbar. Diese Naturschauspiele werden stets besonders ausführlich, bildgewaltig, farbenfroh und imposant geschildert. Letztlich schließen sich die Autoren des $R H$ auch bei diesem Motiv der Darstellung anderen epischen iranischen Werken an.

Lobsprüche

Die Verfasser des Textes haben viele Lobsprüche eingefügt. Der Name Ḥamze erscheint oft mit schmückenden Attributen und laqb (Beinamen), desgleichen die Namen von Angehörigen Hamzes, von hohen Würdenträgern und Helden. Durch eine Schilderung ihrer hervorstechenden Eigenschaften soll die Vollkommenheit der Helden betont werden.

Ḥamze auf seinem berühmten Streitroß wie er nach und nach die Welt erobert, hat eine übergeordnete Bedeutung im gesamten $R H$. Einige Beispiele werden hier zu Hamze und Malek Iră̌ erwähnt:

ṣaḥ̣eb-qerān-e zamān, yekketāz-e Irān o Turān, bar-ham-zanande-ye tāğ o taḩt-e bot-parastān, 'amm-e peyġambar-e āhnar az-zamān, Amir-e nāmdār, ṣolțān-e ašqar-savār (1/80).

Der glücklich Geborene der Zeit, einzigartiger Krieger im Iran und Turan, der die Götzenanbeter verwirrt und ihre Kronen und ihren Thron nimmt, der Onkel des letzten Propheten, der berühmte Amir, der König, der Ritter des braunen Pferdes.

Das folgende Beispiel handelt von Malek Irağ und seinen besonderen Eigenschaften.

šahanšāh-e mamālek-setān, barāzand-ye asās-e șāḥebqerān va ğelvedahande-ye 'alam-e eždehā-peikar, țelesm-gošā-ye nafir-e Ğam va țabl-e Eskandar (5/772/25).

Der erobernde König, nur er ist würdig, das Erbe des Glücklichgeborenen (ṣāheb-qerāns) zu empfangen und die Fahne mit dem Drachengesicht zu präsentieren und das Rätsel der Trompete des Ğams und der Trommel Eskandars zu lösen. 


\section{Reimprosa}

Reimprosa (arab. sa $\check{g}$ ) ist ein formelhafter Stil, bei dem eine Abfolge kurzer, oft parallel konstruierter Sätze oder Satzeile hintereinander steht, mit Reim, jedoch ohne die Bindung der Gedichtform, also ohne feste Silbenzahl und Metrum. Der Reim wird in der Regel nach zwei

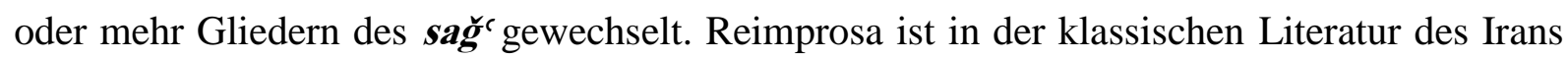
sehr verbreitet und hochangesehen. Im $R H$ kommt Reimprosa häufig vor.

Sowohl die Erzähler als auch ihre Zuhörer legen großen Wert auf rhythmische Harmonie. Die Erzähler berücksichtigen die innere Notwendigkeit des poetischen Textes in Abhängigkeit von den wechselnden äußeren Gegebenheiten. Die gebildeten Zuhörer genießen die Feinheit der Sprache und die künstlerischen Beschreibungen und aus diesem Grund bemühen sich die Erzähler darum, darauf einzugehen.

Viele iranische Erzähler verfügen über große literarische Qualitäten, einen hohen Kenntnisstand hinsichtlich klassischer Literatur und akademischen Wissens überhaupt, was für Erzähler von Volksepen recht ungewöhnlich ist. Bei der Rhythmusgestaltung einer Geschichte gibt es bestimmte Regeln und Vorschriften, die durch keine Übersetzung nachzuvollziehen ist. Dies wird durch das folgende Beispiel deutlich:

Hosrou-ye malek-e Sarandib o yal babr-nahāyat Šah-e orang-e șalābat be nasab vāreș-e Šis-e nabi-ye 'aẓam va akram be kamar čo żeyġam be honar Rostam-e Dastān be ǧegar Sām-e Narimān ḩalaf-e aršad-e Sa'dān va hodāvand-e 'amud-i ke čo razm nemudi šod kuh Uḥod sorme čon dast bordi bar do-dame az sar-e Merrih robudi kolāh (1/95/5-8).

Hosrou, König von Sarandib, der tigerartige Held, der König des festen Throns, der Nachfolger des großen und edelmütigen Propheten Šit, mit einer Taille wie ein Löwe. Seine künstlerischen Fähigkeiten sind wie die Rostams, des Sohnes des Zāl, dessen Beiname Dasten ist. Mit seinem Mut ist er wie Sām, der Sohn des Narimān. Er ist der älteste Sohn des Sa'dān, des Besitzers der Keule. Wenn er kämpft, wird der Berg Uḥud wie Antimon. Wenn er das zweischneidige Schwert in seiner Hand hält, entwendet er vom Kopf des Mars die Krone.

Versmaße

In den fast 1.800 Gedichten wird die Geschichte des $R H$ noch einmal in ein anderes Licht getaucht. Dadurch erhält das Buch eine zusätzliche Dimension. Der Fluß der Erzählung wird für kurze Zeit angehalten, wenn ein Gedicht sowohl die Zuhörer als auch die in der Geschichte handelnden Figuren zum Nachsinnen einlädt, zum Staunen bringt oder zu Tränen rühren möchte. Von Liebe und Haß, von Schönheit und Hässlichkeit, von Krieg oder Tod und 
vielen anderen Themen des menschlichen Lebens handeln diese glänzenden sprachlichen Juwele. Die Gedichte entstammen verschiedenen Dichtern wie Ferdousi (4/528/3), Ḥāfez (4/606/18) und Moḥtašam Kāšāni (4/552/14-15). Die Gedichtformen, die häufig vorkommen, sind meșrā̄ (Halbverse) sowie robāci(Vierzeiler) und gazal (Ghasel). Im Text finden sich viele Gedichte, die aus der Feder des Erzählers stammen; manche zeigen das schiitische Gedankengut des Erzählers. Ein sehr interessantes Gedicht lesen wir über 'Amr:

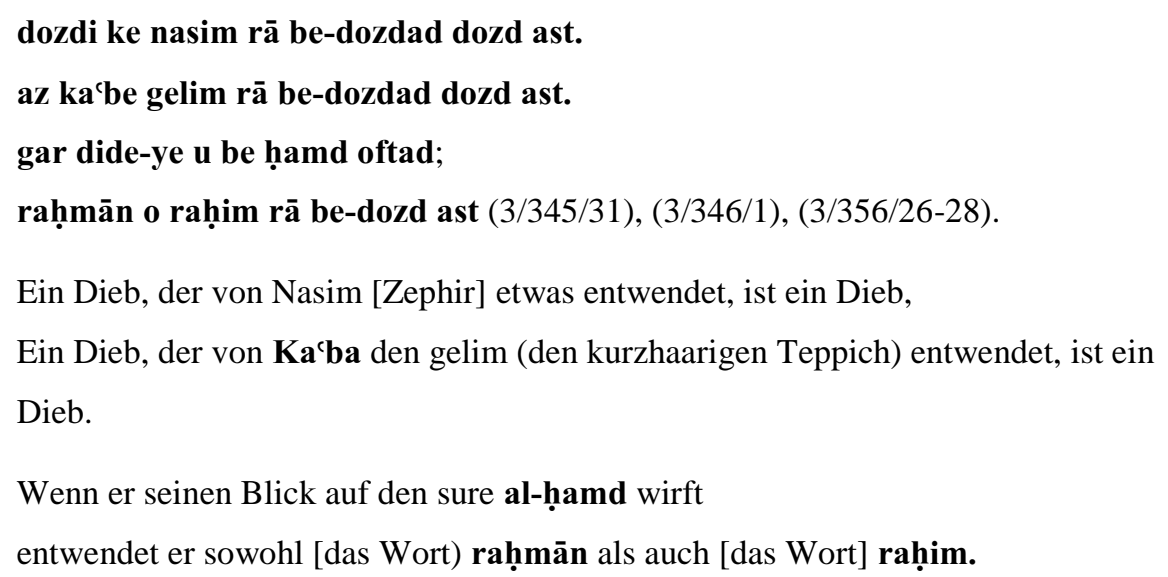

\section{Metaphern}

Die persische Sprache ist reich an Metaphern. Im Text befinden sich viele Beispiele, die in der klassischen Literatur sehr häufig vorkommen. Diese Tatsache zeigt uns, dass sich die Verfasser des Textes gerne der Metaphorik bedienen. Hier einige Beispiele:

čašm-e falak (das Auge des Himmels [im Sinne des Schicksals]; 4/462/5).

guš-e āsemān (die Uhr des Himmels [im Sinne des Schicksals]; 4/489/12).

hā̄ne-ye zor (das Haus der Gewalt [im Sinne eines gewalttätigen Angriffs]; 4/517/29).

\section{Übertreibungen}

Wir finden oft Übertreibungen im Text, etwa bei den Beschreibungen der Waffen, Festungen und Schlachten und letztendlich bei der Schilderung der Leidenschaft der Helden. Die Beschreibungen sind ähnlich wie im ک̌āh-nāme. ${ }^{1236}$ Hier werden einige Beispiele angeführt:

„Vom Staub, den ein Heer erzeugt. Er habe den Tag zur Nacht gemacht, oder wegen des Staubes habe man tagelang nicht gewußt, ob es Nacht sei oder nicht. Der Staub bildet Wolken, in dessen Dunkel die Lanzenspitzen als Sterne, die Schwerter als Sonne glänzen, während das Eisen (der Schutz- und Trutzwaffen) den Erdboden darstellt (1/82/16-23), 1/84/23-28). “

${ }^{1236}$ Ferdousi, Bd. 1, S. 533; 534. 
„Die Heere treten alle Hügel platt. Die Erde teilt sich unter den Hufen der Rosse, der Berg wird zum Meer (aus Blut) und die Ebene zum Berg (aus Leichen; 1/135/4-10), (1/136/1-9), (1/157/28-31). “

gardi barḩāst ke cālam rā tire kard (2/330/7).

Der Staub hebt sich und macht die Welt dunkel.

gardi bar-ḩāst ke piš-e čašm-e horšid rā tire kard (2/332/17).

Der Staub hebt sich und macht die Augen der Sonne dunkel.

Eine wichtige Eigenschaft eines Helden ist es, über einen „lauten Schrei“ zu verfügen.

čonān na're mi-kešid ke biyābān mi-larzid (4/571/19).

Er schreit so laut, dass die Wüste erzittert.

Farhād und Landeur kämpfen gegen die Ungläubigen. Um diesen heftigen Krieg zu beschreiben, benutzen die Autoren des $R H$ das Bild des Erdbebens:

Farhād va Landehur larze dar zamin afkandand (2/324/19).

Farhād und Landehur verursachten Erdbeben beim Kampf.

\section{Aufschneiderei}

Nach Meinung der Perser sollen die Erzähler durch ihre Übertreibung auf die Vorstellungskraft ihrer Zuhörer einwirken. Im Text finden wir eine Fülle von Aufschneiderei, die höchstwahrscheinlich die Bewunderung der Zuhörer hervorruft. Auf diese Weise können sie ihr Publikum fesseln und einnehmen.

'Ādi dar pāi-ye deraht pānșad man nān rā bā 'asal hord (2/203/11).

'Ādi isst am Fuße des Baumes 500 kg Brot mit Honig.

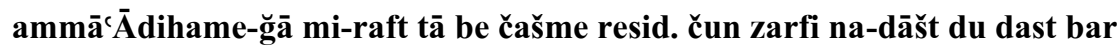

lab-ečāh gozāšt va āb-e čāh rā tamām hord (1/181/21).

'Ādi geht los. Schließich erreicht er eine Quelle. Weil er kein Geschirr hat, legt

er seine Hände auf den Rand der Quelle und trinkt das ganze Wasser.

Fantasie

Die lebhafte Fantasie des Erzählers lässt ihn beim Ankleiden eines Helden oder beim Aufzäumen eines Pferdes die natürliche Reihenfolge wählen, in der die Handlung, die beschrieben werden soll, abläuft. Er beginnt mit dem Ankleiden von Hemd und Hosen und endet mit der Beschreibung vom Aufsetzen der Kopfbedeckung und der Aufnahme der Waffen, wobei die genaue Reihenfolge eingehalten wird, in der sie der Held anlegt. Dies spricht für die Kraft und Kreativität der Autoren, sich völlig in die Rolle der Helden 
hineinversetzen zu können. So kann er sein Publikum mitreißen. In einem Beispiel kann man nachlesen, wie 'Amr auf den Schultern von Dämonen im Himmel „reitet“ und von dort die feindlichen Heere beschimpft (2/329).

\section{Humoresken}

Auf die humorvollen Schilderungen in verschiedenen Episoden im $R H$ ist schon mehrfach hingewiesen worden (1/153; 5/863). Sie kommen besonders deutlich vor in den Episoden, wo 'Amr b. Umeiye und Bahgtak als Hauptfiguren erscheinen. Neben der Vermittlung des Glaubens, der Schilderung von Kämpfen, der Liebe und der Erotik darf natürlich auch der Humor nicht fehlen, wenn ein Volksepos erfolgreich sein will. Letztlich wollen die Zuhörer ein Wechselbad der Gefühle erleben mit Spannungsbögen und komödiantischen Zügen. Beispielhaft sei hier die Szene geschildert, wo 'Amr dem Wesir des Königes Bahtak auf einer Feier beim König ein Abführmittel reicht und ihn anschließend zum Tanzen auffordert. Das Mittel wirkt und beim Tanzen sieht alle Welt (unter großem Gelächter), was Bahtak da beim Tanzen „verliert“ (1/15). Auch die beliebten Motive der Verkleidungen und Verwechselungen kommen in allen denkbaren Varianten vor. So wird beispielsweise Bahtak einmal als Braut verkleidet und in das Hochzeitsbett gelegt (4/721).

\subsubsection{Literarische Kleinformen}

Die iranische Literatur ist ein großes Feld, in dem sich feste Gattungskonventionen im Laufe der Zeit etablieren. In der volkssprachlichen, schriftlich fixierten Dichtung, die sich allmählich entwickelt hat, sieht man feste literarische Kleinformen wie Sprichwörter, Eide, Flüche und Schimpfwörter. Diese volkstümlichen Kleinformen sind für mehrere Jahrhunderte prägender und integraler Bestandteil der iranisch-islamischen Kultur. Sie zeigen den Prozess der Mentaltität der Iraner im Laufe der Zeit. Wie zu sehen sein wird, lassen sich Überreste der einst blühenden iranischen Kultur in der persischen Sprache wiederfinden. Daran können wir den Wandel in der Mentaltität der mittelalterlichen Gesellschaft des Irans nachvollziehen.

\subsubsection{Sprichwörter}

Im Rahmen der persischen Sprache gibt es verschiedene Formen von Sprichwörtern wie Anekdotenspruch, Schwankspruch, Zitatensprichwort usw. Viele Sprichwörter sind Gedichte, die durch häufigen Gebrauch volkstümlich geworden sind. Zur Quellenkunde der iranischen Sprichwörter gehören ebenso koranische Verse.

Der Koran als meistgelesenes Buch spielt eine große Rolle in der mündlichen Tradition. Basgöz ist der Meinung, dass das Zitieren von Koranversen, Hadithen, Sprichwörtern und 
volkstümlichen Gedichten auf gleicher Ebene ein Merkmal der iranischen Kultur ist, um eine Stellungnahme in einer hikaya-Erzählung zu unterstützen. Die Worte der Ahnen sind nicht der Koran, aber sie werden gleich hoch geschätzt. ${ }^{1237}$

Im Text des $R H$ kommt eine große Anzahl iranischer Sprichtwörter vor. Dies zeigt uns, dass die iranischen Erzähler sehr oft Sprichwörter zur Bekräftigung ihrer eigenen Aussage benutzen. Da ihre Zuhörer meistens Analphabeten sind, können sie die einprägsamen und oft rhythmischen Sprichwörter leicht behalten. Die Sprichwörter sind für die Erzähler ein gutes Mittel, um ohne Risiko auch ihre persönliche Meinung zu äußern, indem sie das Zitat vortragen. Sprichwörter sind auch im $R H$ oft zweiteilig und enthalten einen Endreim:

ādam-e gorosne az din bedar mi-ravad (5/786/8).

Der hungrige Mensch gibt seinen religiösen Glauben auf.

ān ğā ke ‘ayān ast če ḥāğat be bayān ast (5/967/2).

Das, was eindeutig ist, braucht nicht erwähnt zu werden.

ān če čašm binad del tamannā mi-konad (4/619/12).

Das, was das Auge sieht, begehrt das Herz.

aẓhar men aš-šams (2/315/8).

Heller als die Sonne.

az kise-ye halife mi-bahšad (1/51/19).

Almosen aus der Tasche des Kalifen [Dritten] geben.

az rasul-e hodā čonin naql ast ke ādam-e derāz bi-caql ast (5/783/22).

Der Prophet sagt: Ein großer Mensch ist ein dummer Mensch.

oštor-bāzi kardan (1/18/11).

Er spielt mit den Kameln [im Sinne von Unfug treiben].

al-va'de al-vafā $(5 / 835 / 5)$.

Halt dich an das, was du versprochen hast.

bali har kas az in āgāh bāšad ke delhā rā be delhā rāh bāšad (5/794/10).

Zwei Herzen werden sich immer finden.

pā rā birun az andaze birun gozāšštan (4/713/8).

Über die eigenen Grenzen hinausgehen.

paše čo por šod be-zanad pil rā (4/616/31).

Ärgert sich die Mücke, so ist sie sogar im Stande, den Elefanten zu besiegen.

čāhi az barā-ye bandegān-e ḩodā kande bud hyodaš dar ān čāh oftād (1/115/28).

${ }^{1237}$ Vgl. Basgöz, Ilhan: The Tale-Singer and his Audience, An experiment to determine the effecht of different audiences on a hikaya performance, in: Folklore, Performance and Communication, Ed. Dan Ben-Amos and Kenneth S. Goldstein, Mouton 1975, S. 143-203, hier S. 146-147.; 
Er ist in den Brunnen gefallen, welchen er für die anderen vorgesehen hatte.

čonin ast rasm-e sarā-e dorošt;

gahi pošt be zin o gahi zin be pošt (4/629/17).

So ist es gang und gäbe, manchmal reitet man auf dem Sattel, manchmal trägt man ihn.

čonin goft ruz-i hodāvand-e Raḩš;

be dašt āhu nā-gerefte ma-baḩš (4/708/11).

So sagt der Besitzer des Pferdes Rahš̌: Verschenke niemals ein Reh, welches du nicht selbst gefangen hast.

ān qadar čub bar pāyat be-zanam ke gorbe rā Abu 'l-Vafā nām nahi (3/480/15).

Ich werde so oft deinen Fuß peitschen, bis du die Katze für das treueste Geschöpf hältst.

čo dar tās lag̉zande oftād mur;

rahānande rā čāre bāyad na zur (5/725/10).

Fällt eine Ameise in eine Schale, so sollte der Retter sie mit dem Kopf und nicht mit der Kraft retten.

čo fardā šavad fekr-e fardā konim (4/714/3).

Erst morgen sollten wir uns um das morgen kümmern.

če hoš bovad ke bar-āyad be yek kerešme do kār (5/916/6).

Es ist gut, wenn man zwei Fliegen mit einer Klappe schlagen kann.

dar zir kāse nim kāse ast (1/9/1).

Im Geheimen etwas planen.

dozdi ke nasem rā be-dozdad, dozd ast (3/345/31).

Ein Dieb ist derjenige, der den größten Dieb bestehlen kann.

dar o divār guš dārand (2/267/3).

Die Wände haben Ohren.

donbe rā be dast-e gorg sepordan (1/54/9).

Das Schaf dem Wolfe überlassen.

dušine be maḥk-e amteḥān zadam kam ‘ayār bar-āmad (4/581/2).

Gestern Nacht habe ich etwas probiert, aber es gab aber kein gutes Ergebnis.

ze āb-e ḩord māhi-e hyord hyizad;

nahang ān beh ke daryā setizad (5/941/15).

In den kleinen Gewässern gibt es kleine Fische, während sich der Wal in großen Gewässern behauptet.

zoḥal rā dar 'ālam-e rendi az falak-e haftom be zir mi-āvared (3/494/29).

Der ist so schlau, dass er den Saturn vom Himmel herunter holt.

toḩm-e šotor va kine az šotor dāštan (1/179/30).

Diese Menschen gehören zur Rasse der Kamele, und sie hassen dennoch Kamele.

șābun-e u be ğāme-ye šomā na-ḩorde (4/650/2).

Seine Bosheit hat dich noch nicht getroffen. 
‘āqabat beyże-ye zāg zāà;

kešad ranğ-e bi-hude țāvus-e bāg (3/354/31).

Aus den Eiern der Krähe schlüpfen Krähen aus, der Pfau aber gibt sich umsonst Mühe (aus Kräheneiern einen Pfau auszubrüten.

'ešq o mošk rā natavān nahoft (5/757/26).

Die Liebe und den Duft kann man nicht verstecken.

garib kur ast (3/490/27).

Der Fremde ist blind.

țanāb-e mehr čonān pāre kon ke ruzi;

šavi ze karde pašimānbe ham tavāni bāft (5/811/17).

Trenne eine Freundschaft so, dass du im Stande bist, sie wieder herzustellen.

gar negahdār man ān ast ke mi-dānem;

šiše-e rā dar bag̉al-e sang negāh mi-dārad (4/661/22).

Ich glaube an jenen Gott, der Glas mit Steinen zu versöhnen weiss.

gorbe be šalvār-e kasi andāhnten (3/370/2).

Die Katze auf jemandes Hosen loslassen.

goli ke tarbiyat az dast-e bāğbān ne-gereft;

agar be čašme-ye horšid sar-zaned hyod-ru ast (5/983/24).

Jene Blume, die keine Erziehung der Gärtnerhand erfahren hat, wird auch beim Erreichen der Sonnenquelle ein Unkraut bleiben.

gelim-e baḩt-e kas-i rā ke siyāh bāfte-and;

bā āb-e zam zam o koșar sefid natvān kard (4/660/26).

Ist der Kelim schwarz geknüpft, so wird er auch nicht durch Wasser des Zam Zam [Fluss durch Mekka] und Kossar [Fluss im Paradies laut Koran] klar.

lacl-e Širin be kām-e Hosrou šod;

kuh bihude mi-kanad Farhād (5/975/7).

Die süßen Lippen von Širin wurden dem Mund Hosrous zuteil, umsonst klopft Farhād den Berg ab.

man az pei-ye Mošteri mi-gardam dočār-e Zoḥal mi-šavam (3/480/14).

Ich suche nach Jupiter, aber begegne dem Mars.

menet-e šekam do ğā ne-mi-tavān kešid (3/413/3).

Wenn man hungrig ist, muss man sich für eine Richtung entscheiden.

mihmān-e na-țalibide nā-ma'qolist (5/759/17).

Der uneingeladene Gast ist ein Unding.

muši yā palang $(4 / 521 / 29)$.

Bist du Maus oder Leopard.

nān-e bepaz ke betvāni hord (4/547/6).

Backe erst mal ein Brot, damit du später essen kannst. 
man naqd rā be nesiye ne-mi-forušam (4/672/15).

Ich tausche nicht Bargeld gegen Kredit.

har ke țāvus bāyad ğor Hindustān kešad;

har ke mạ̣bub bāyad konde o zendān kešad (1/95/28).

Jeder, der einen Pfau haben will, muss den Weg nach Indien beschreiten, jeder, der eine Geliebte haben will, hat Halsketten und Gefangenschaft zu ertragen.

yar dar ḩāne o mā gerde ğahān mi-gardim;

āb dar kuze o mā tešnelabān mi-gardim (5/966/30).

Die Geliebte weilt zu Hause, und wir suchen rund um die Welt nach ihr; Wasser ist im Krug, und wir irren durstig umher.

yek anār dāram va do bimār (2/225/31).

Habe einen Granatapfel und zwei Kranke.

\subsubsection{Eide bei den Iranern}

Im alten Iran wurde jede Art von menschlichen Bindungen von der Gottheit geschützt. Darum blickte der Sonnengott Mithra, der Schutzherr der Verträge, mit tausend Ohren und tausend Augen auf alle Gelöbnisse, Versprechen, Bundesabschlüsse und Freundschaften. In seinem Namen wurde geschworen. ${ }^{1238}$

Es gibt zahlreiche moralische Grundsätze, dass Versprechungen aller Art unter keinen Umständen gebrochen werden dürfen. Der Bundesbrüchige hat Unheil zu erwarten. Wie es Siyāvoš ausspricht:

„Da ich ein solches Bündnis gemacht;

Habe ich solche Schwüre vor Gott gebracht.

Wenn ich mich von der Gradlinigkeit wende;

Kommt Unheil von jedem Ende.“'1239

Wenn man eine Person im Verdacht hatte, stellte man dann durch den Eid fest, ob der Betreffende schuldig war oder nicht. Wenn der Betreffende unschuldig wäre, würde ihm das Feuer nicht schaden, hätte er sich dagegen vergangen, so würde das Feuer ihn töten. Dieser ganze vorislamische Ritus war vollkommen klar. Wenn der Betreffende schuldig war, so wirkte der Eid, im anderen Falle war er wirkungslos. Dieser Vorgang war ein Gottesurteil.

In der alten Sprache des Irans ist die gewöhnlichste Bezeichnung für den Eid sougand. Unter den verschiedenen Erklärungen dieses Wortes, welche die iranischen Philologen anbieten, müssen wir an derjenigen festhalten, die es als Bezeichnung für „Schwefel” angibt, welche

\footnotetext{
${ }^{1238}$ Lommel, Yt. 10,82, S. 79.

${ }^{1239}$ Ferdousi, Bd. 1, S. 325.
} 
wegen des beim Schwur gebräuchlichen Rituals die Bedeutung „Eid”, „Schwur” erhält. ${ }^{1240}$ Die abgeleitete Verbalform ist sougand hordan (schwören; vorislamisch: Schwefel trinken). “1241

Eine andere Bezeichnung für Eid ist qasam. Die abgeleitete Verbalform ist qasam hordan. Der Schwur ist ein Verbalsatz mit weggelassenem Verbum. Das am häufigsten gebrauchte Schwurpartikel ist das „be“. Manchmal benutzt man das Substantiv haqq, z.B. be haqq-e namak. Dieses haqq bedeutet: was jemand fordern kann und was er leisten soll, also seine Rechte und seine Pflichten. Diese Ausdrücke sind auch heutzutage noch üblich.

Im alten Iran war besonders der Schwur „beim König“ beliebt. Die Anschauung von der Majestät, die nur dem rechtmäßig, gottgeliebten Fürsten zusteht, ist uralt und weit verbreitet. Die iranischen Könige behaupteten, dass sie die Herrschaft von Gott bekommen hätten. Insbesondere Krone und Thron des Perserkönigs waren in der vorislamischen Zeit heilige Insignien und Symbole der Macht. Sie wurden direkt der Macht und Heiligkeit des Perserkönigs zugeordnet, so dass sie selbst als heilig galten.

Für die Kopfbedeckung der Könige sind die Bezeichnungen kolāh bzw. tāğ überliefert. Die Bezeichnungen für den Thron sind gāh bzw. taht. Goldener Thron und goldene Krone sind die Privilegien der Herrschaft. Sich auf einen goldenen Thron zu setzen bedeutet, die Herrschaft auszuüben. Das Buch Šāh-nāme beinhaltet viele Situationen, in denen auf den Thron und die Krone des Königs geschworen wurde. ${ }^{1242}$

be tāğ o tah̆t-e kiyān qasam (1/37/31).

Schwöre auf die Krone und den Sessel der Könige.

be tāğ o taḩt-e pādešāhān qasam (1/38/1).

Schwöre auf die Krone und den Sessel der Könige.

Aus der Fülle der altiranischen Literatur wissen wir, dass der Perserkönig als Träger des göttlichen Glanzes eine besondere Stellung innehat. Die Quellen geben deutlich zu erkennen, dass der Perserkönig als heiliges Wesen angesprochen wurde. Er war das leibhaftige und lebende Abbild Gottes und die Kraft dessen übte er die Herrschaft aus. Er erschien als allwissend und allmächtig, seine Beschlüsse hatten unbedingte und unbeschränkte Geltung. Die Macht dieses göttlichen Königs erstreckte sich sowohl über die Menschen als auch über die Natur. Der König war im Iran immer ein wesentliches Fundament des Staates. Über die Stellung des Königs in der Șafavidenzeit berichtet folgende Quelle:

\footnotetext{
${ }^{1240}$ Vāḥdi-Navā'i, S. 171-172.

1241 Ebd.

${ }^{1242}$ Ferdousi, Bd. 1, S. 409.
} 
„Jedem klugen und verständigen Menschen ist klar, dass dem Schah, der Schatten des Gottes auf Erden, gleich nach den Propheten und den Imamen die führende Stellung in der Weltherrschaft gebührt. So ist alles Glück, das diesem Reich vorherbestimmt ist, nicht so sehr auf der Anstrengung jedes einzelnen gegründet, sondern vielmehr eine Quelle des Glücks und der Wohltaten dieses standhaften Herrschers, dessen Pracht bis zum Himmel reicht. “1243

Auch ausländische Beobachter berichteten, dass in der Șafavidenzeit die Șufis immer auf den Kopf des Königs geschworen haben. ${ }^{1244}$

be sar-e Abu 'Ali qasam (1/15/3, 1/15/2, 1/39/23).

Schwöre auf den Kopf des Abu 'Ali.

be sar-e Šāh qasam (1/61/19).

Schwöre auf den Kopf des Königs.

Die schlechteste Charaktereigenschaft ist ein Treuebruch gegenüber Verpflichtungen. Dabei handelt es sich immer um eine konkrete Sache und was das Entscheidende ist, es handelt sich beim Eid entweder um ein Versprechen oder um die Feststellung einer Tatsache (für etwas nicht verantwortlich gewesen zu sein oder umgekehrt).

Bei den Iranern ist der Sachverhalt im Wesentlichen derselbe wie bei den anderen islamischen Völkern. Man schwört bei Gott und bei seinem großen Namen, bei seiner Heiligkeit und seiner Kraft. Der Schwörende spricht mit seinem ganzen Wesen. „Man schwört bei Gott, den man anbetet, oder beim Herrn der Ka`aba.“1245

be ān hodāi ke mi-parsti (1/150/2).

Ich schwöre auf deinen Gott, den du anbetest.

Eine andere Gruppe von Formeln bezieht sich auf die Beschreibung seiner Attribute oder seines Eigentums. Man schwört bei seiner Majestät, bei seinem Thron und seinen Geschöpfen.

be ğalāl-e qadr-e żu 'l-ğalāl (3/444/21).

Schwöre auf seine Herrlichkeit, die majestätisch und glorreich ist.

Man schwört beim dem Geiste des Propheten:

be arvāḥ-e ḥażrat-e Ebrāhīm qasam (1/90/2).

Schwöre auf den Geist des Propheten Ebrāhīm.

\footnotetext{
${ }^{1243}$ Eșfahāni, Moḥammad Ma'ṣum b. Ȟuuāğagī: Hulāṣat as-Siyar, S. 160.

${ }^{1244}$ Membré, Michele: Mission to the Lord Sophy of Persia (1539-1542), Translated with Introduction and Notes by. A. H. Morton, London 1993, S. 42.

1245 Pedersen, Johs: Der Eid bei den Semiten in seinem Verhältnis zu verwandten Erscheinungen sowie die Stellung des Eides im Islam, in: Studien zur Geschichte und Kultur des islamischen Orients, Zwanglose Beihefte zu der Zeitschrift “Der Islam”, hrsg. von C. H. Becker, Heft III, Strassburg: Trübner 1914., S. 161,
} 
In der Schia hat 'Ali b. Abi Tāàleb, der Vetter, Schwiegersohn und vierte Nachfolger des Propheten Moḥammad einen zentralen Platz. Die Schiiten verehren ihn und diese Verehrung für 'Ali, der ihnen wegen seiner Tapferkeit als Vorbild vorschwebt, bringt wohl vielfach eine Hinwendung zur Schia mit sich. So schwört man "beim 'Ali”.

be Šāh-e velāyat qasam (2/289/2).

Schwöre auf den König der Freundschaft.

be țāq-e abru-ye Šāh-e velāyat qasam (5/846/8).

Schwöre auf die Augenbrauen des Königs der Freundschaft.

Ein anderes wichtiges Mittel ist Salz. Die Funktion von Salz, Wasser, Brot und Licht in der iranischen Gesellschaft ist bis heute sehr wichtig. „Doch kann die Zusammengehörigkeit auch dadurch geschaffen werden, dass Zwei zusammen Salz und Brot essen.“1246

Tatsächlich schwört man bis heute im Iran auf Wasser, Licht, Salz und Brot. Salz spielt eine wichtige Rolle im Leben der Menschen. Es ist immer ein wichtiges Nahrungsmittel gewesen und hatte schon in vorislamischer Zeit sprituelle Bedeutung. Zarathustra empfängt die Offenbarung. Im Buch Yašt Kapitel I. Bahman Yašt lesen wir:

„Und die Menschen werden kleiner geboren werden, und ihre Tugend und Kraft ist geringer und trügerischer, sie sind schlechter veranlagt. Sie haben keine Dankbarkeit und keinen Respekt vor Brot und Salz, und auf die Waisen nehmen sie keine Rücksicht. “1247

In der vorislamischen Zeit war das „Salzbündnis“ zwischen dem König und seinen Dienstleuten sehr wichtig, mit dem sich die Dienstleute verpflichteten, dem König treu zu sein. ${ }^{1248}$ Im Š̆̄̄h-nāme lesen wir, dass Esfandiyār Rostams Einladung nicht annimmt, weil er nicht gegen ihn kämpfen will, da er so die Rechte des Salzes und Brotes brechen müsste. ${ }^{1249}$ In islamischer Zeit gewann Salz noch mehr an Bedeutung. „In allen möglichen schiitischen Büchern in ernsthafter und in populärer Darstellung erscheint die Mitgift (mahriye) Fāṭimas. Nach einer schiitischen Erzählung sprach der Engel zum Propheten [...]. Auch alles Salz ebenfalls Zwiebeln und Wasser der Erde sollen noch ihr Brautpreis sein.“" ${ }^{1250}$ Über Salz schreibt Eilers:

1246 Heller, Bernhard: Die Bedeutung des arabischen Antar-Romans für die vergleichende Literaturkunde, Leipzig 1931, S. 35.

1247 Wiedergren, Iranische Geisteswelt, S. 189.

${ }^{1248}$ Eaton, Richard M.: The Rise of Islam and the Bangal frontier 1204-1760, Berkeley 1993, S. 162.

${ }^{1249}$ Ferdousi, Bd. 1, S. 999.

1250 Eilers, Wilhelm: Schiitische Wasserheilige, in: Die islamische Welt zwischen Mittelalter und Neuzeit, Festschrift für Hans Robert Roemer zum 65. Geburtstag, hrsg. von Ulrich Haarmann und Peter Bachmann, Beirut 1979, S. 98. 
„Daher kommt es, dass man jetzt, sooft man ein wahres Wort sprechen will, damit der Gesprächspartner [...] es auch anerkennt, sagt: Bei diesem Salz, das der Brautpreis der Fāṭima-i-Zahrā’) ist, sage ich die Wahrheit.“'1251

Das Salz spielte auch eine herausgehobene Rolle in der fotuvva-Tradition. ${ }^{1252}$ Die Mitglieder dieser Organisationen wurden durch eine bestimmte Zeremonie aufgenommen. Man trank hierzu Salzwasser. Ibn Mi`mār sagt: „Das Wasser ist süß und das Salz ist salzig.“ Damit war gemeint, dass man in guten und in schlechten Zeiten die Ziele der Bruderschaft fördern muss. Insbesondere sollten die Starken den Schwachen helfen. In unglücklichen Situationen sollte man zu Gott beten und sich bei ihm bedanken. ${ }^{1253}$

Man spricht vom Recht des Salzes haqq-e namak-ȟ̌āregi, d.h. dem Verhältnis von Pflichten und Rechten, das dadurch entsteht, dass man die Speise eines fremden Mannes gegessen hat. ${ }^{1254}$ Salz erhält dann direkt die Bedeutung eines Bundes. Man kann sagen, zwischen zwei Leuten ist Salz, d.h. es besteht ein Bund. ${ }^{1255}$

be namak-e to qasam $(4 / 686 / 19)$.

Schwöre auf dein Salz.

Wenn man einen seiner Begleiter in Verdacht hat, ein Feind zu sein, lädt man ihn ein, damit er sich durch den Genuss der gemeinsamen Mahlzeit verpflichtet fühlt. Ein wahrer Feind wird es aber nicht riskieren wollen, durch die gemeinschaftliche Mahlzeit in ein Bundesverhältnis zu treten. Der Gast steht im Schutzverhältnis zum Wirt, so lange sein „Salz noch in seinem Bauch ist, oder auf seiner Zunge”, d.h. solange man den Geschmack spürt.

Im $R H$ lesen wir, dass Arg்aš, Qobāds Ratgeber, auf Befehl des Königs getötet wird, weil er eine sexuelle Beziehung mit der Königin gehabt hat. Er ist also ein Verräter, der nicht das Recht des Salzes achtet. Er wird als namak be harām (treulos; 1/9) bezeichnet.

An anderer Stelle lesen wir, dass Qobād 'Alam Šāh einlädt und sagt: „Meine Abstammung väterlicherseits ist von Soleimān und mütterlicherseits von Eskandar, und Ḥamze hat mein Eigentum in seinem Besitz. Es wäre gut, wenn ich mein Eigentum auf jene Weise nehme, dass in einem Auge Tränen und im anderen Lachen sei.“ Als 'Alam Šāh dies hört, ärgert er sich und sagt: „Wenn die Ehre des Salzes nicht dagegen spräche, hätte ich dich genommen und in den Himmel geworfen, damit du auf dem Grab deines Vater auf die Erde zurückfällst“ (2/262).

\footnotetext{
1251 Eilers, S. 99.

1252 Taeschner, Franz: Futuwwa eine gemeinschaftsbildende Idee im mittelalterlichen Orient und ihre verschiedenen Erscheinungsformen, S. 140.

1253 Ibn Micmār, S. 254.

${ }^{1254}$ Bāstāni-Pārizi, S. 110-113
} 
Man verpflichtet sich, seinen Herrn, dem man zu Dank verpflichtet ist, zu unterstützen. So lesen wir im $R H$ : Als die Iraker mit Ḥamze kämpfen wollen, sagt Landehur: „,namak Amir huub ast ke čašm-e mā rā begirad“" (es wäre schön, wenn wir das Salz des Ḥamze vor Augen hätten; 2/220/12). Dann kämpft er mit den Irakern und überwindet sie.

Im alten Iran war besonders der Schwur „bei unseren Ahnen“ beliebt. Womit wohl die fervašis (Ahnengeister) gemeint waren. An sie richteten sich Gebete und Schwüre aller Art. ${ }^{1256}$ Üblich sind auch bis heute Schwüre, die sich an der Familienehre orientieren:

be ğān-e mādar-at (2/404/11)

Schwöre auf das Leben deiner Mutter

be ğadd-am qasam $(3 / 546 / 28)$

Schwöre auf meine Vorfahren

\subsubsection{Fluch und Verwünschungen}

Die Verwünschung stellt das Gegenteil zur Fürbitte dar, das zu Gunsten anderer gemacht wird. Während man mit einer Fürbitte anderen das Gute ersehnt, verlangt man mit einer Verwünschung das außerordentlich Schlimmste für Jemanden. Der Fluch ist somit vorzüglich als Kampfmittel geeignet und er gilt als wörtlicher Angriff. So führt Pedersen an:

„Der Fluch bezeichnet alles, was böse und schädlich ist, alles, was mit normalen Verhältnissen nicht übereinstimmt, die Negation des Lebens. “1257

In vorislamischer Zeit war einer der schlimmsten Flüche jener, der die Kinderlosigkeit betraf und der sich auf einen schlechten Ruf bezog. ${ }^{1258}$ Es gehört vor allem zum Glück und zur Ehre der Iraner, ein freier Mann zu sein, einem alten edlen Geschlecht anzugehören, Vater vieler Söhne oder reich und mächtig zu sein.

Ein anderer Fluch bezieht sich auf alle Arten von Krankheiten und den Verlust von Körperteilen. Diese spezielle Anschauung geht zurück auf die alte iranische Religion. In den Fluchformeln werden dämonische Kräfte hergerufen. Ein Dämon wirft die Krankheiten in den Körper des Menschen. Das Böse hat Besitz von seinem Leib ergriffen.

Der Islam verbietet es allen Muslimen gegen sich selbst und oder gegenüber anderen solche Verwünschungen zu äußern. Der Prophet Moḥammad selbst bemühte sich stets vor der Aussprache einer Verwünschung zu hüten, trotz dessen was ihm an Unrecht widerfahren ist.

\footnotetext{
1255 Pedersen, S. 25.

${ }^{1256}$ Lommel, Herman: Die Religion Zarathustras nach dem Avesta dargestellte, Hildesheim 1971, S. 103.

1257 Pedersen, S. 64.

${ }^{1258}$ Lommel, S. 38, Vers 11; 3.
} 
Er sagte, dass er als ein Prophet der Barmherzigkeit gesandt wurde und nicht als Verfluchender. ${ }^{1259}$

Wir finden gegensätzlich hierzu im $R H$ eine anweichende Vorstellungen zu Flüchen. Dort befinden sich die Episoden, dass man sinnlos und ohne Gründe Fluchworte auszuspricht. Ḥamze ist der große Meister der Verfluchungen. Oft schickt Ḥamze seine Familienmitglieder durch einen Fluch in den Tod. Er verflucht seinen eigenen Sohn 'Omar-e yunāni und als infolgedessen wird dieser getötet.

Einige Flüche im $R H$ sind:

ātaš be ğān-at behorad (5/1000/5).

Möge das Feuer deinen Körper treffen.

ātaš be ğān-at oftad (5/999/3).

Möge das Feuer auf deinen Körper fallen.

ātaš be qabr-e pedar-at bezanand/oftad (2/354/19, 3/414/15).

Möge das Feuer deinen Vater im Grab anzünden/fallen.

balā be ğān-at behorad (3/478/23).

Dein Körper gerate in Schwierigkeiten.

elāhi bar sar-e gurat nešinam (3/449/10).

Oh Gott! Ich wünsche mir, dass ich an deinem Grab sitze.

elāhi pāre pāre šavi (2/339/ 1).

Möge dein Körper in Stücke geschnitten werden.

elāhi ān golhā bar-sar-e gurat bemānad (2/231/10).

Mögen jene Blumen auf deinem Grab sein.

elāhi az piš-e čašmmam kam šavi (2/288/10).

Mögest du vor meinen Augen verschwinden.

enšā'allāh az piš-e naẓaram kam šavi (2/203/4).

Hoffentlich wirst du vor meinen Augen verschwinden.

elāhi zabān-e bad-guyān boride bād (1/66/7).

Oh Gott! Möge die Zunge derjenigen, die schlecht über Menschen reden, abgeschnitten werden.

elāhi ğavān-marg šavi $(1 / 16 / 25)$.

Oh Gott! Mögest du in jungem Alter sterben.

elāhi be balā gereftār šavi (1/83/23).

Oh Gott! Mögest du in Schwierigkeiten geraten.

ostoḩān-e padarat be-suzad (2/288/27).

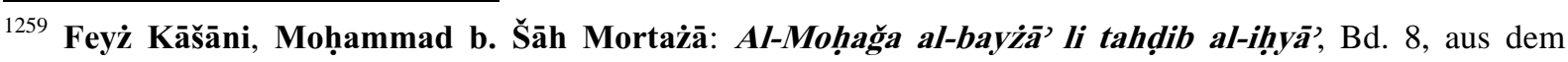


Mögen die Knochen deines Vaters verbrennen.

enšā'allāh az in bozorgtar na-šavi (1/16/30).

Hoffentlich wirst du nicht mehr wachsen.

zabān-at boride bād (1/91/15).

Deine Zunge soll abgeschnitten werden.

ğavān-marg šavi (1/15/5).

Mögest du früh sterben.

hodā surāhn surāhn-at konad (2/298/7).

Möge Gott dich durchlöchern.

hodāvandā dar kār-e u gereh andāz (2/326/10).

Oh Gott! Bereite du ihm Schwierigkeiten.

hodāgir šavi (1/167/31).

Der Zorn Gottes soll dich treffen.

hāne-at ḩarāb šavad (5/1027/1).

Möge dein Haus zerstört werden.

Beispiele für Selbstverfluchungen sind:

elāhi nāmmam az saḥf-ye ruzegār kam be-šavad (5/814/20).

Oh Gott! Möge mein Name von der Tafel des Schicksals verschwinden.

dastam/dastat boride bād agar... (4/725/123).

Meine Hand soll abgeschnitten werden, wenn...

\subsubsection{Schimpfwörter}

Neben Begriffen und Schilderungen von Schönheit sowie geistvollen und tiefsinnigen Redewendungen hat das $R H$ auch eine sehr vulgäre Seite, was sich insbesondere bei den Schimpfworten zeigt. Betrachtet man die iranischen Volksepen, die vor der Mongolenzeit entstanden sind, so gelten als die schlimmsten Schimpfwörter die Bezeichnung „Hund“ oder „uneheliches Kind“. Die Verrohung der Sitten und der Verfall der Moral durch die Mongolenzeit zeigen sich im iranischen Volksepos $R H$, indem dort Schimpfworte von bis dahin ungekannter Vulgarität und Schärfe vielfach und variantenreich Verwendung finden. Bedenkt man, dass im $R H$ der Kampf um den wahren Glauben (Islam) als Mission Amirs volksnah dargestellt werden soll, so ist diese Ausdrucksweise besonders unpassend. Um diese Entwicklung der iranischen Volksliteratur darzustellen, soll ein Vergleich mit der vorislamischen sowie der wahren islamischen Literatur bzw. den weiteren kulturellen und religiösen Hintergründen vorgenommen werden. 
Man beschimpft jemanden hinsichtlich seines Geschlechts oder seiner Familie. „Du Sohn eines Hundes“ ist ein Ausruf, den man heutzutage wie in der Vergangenheit hört. Hier ist die Grundlage, dass der Hund im Islam ein unreines Tier ist.

Man beschimpft oftmals jemanden wegen seines Glaubens. Der Glaube ist an das Leben und die Ehre des Menschen gebunden.

Diskriminierende Schimpfwörter nehmen in der persischen Sprach einen großen Raum ein. Beispielsweise benutzt man rassistische und homophobe Ausdrücke sowie Schimpfwörter, die Menschen wegen ihres Glaubens oder wegen einer Behinderung oder wegen einer schlechten wirtschaftlichen Situation diskriminieren. Auch beleidigt man jemanden durch den Beruf, die Nationalität oder die äußere Erscheinung und seine psychischen Eigenschaften.

Sehr groß ist im $R H$ die Reihe von Ausdrücken, durch die man den Betreffenden in seiner Ehre herabsetzt. Auch hier verflucht man jemanden in Bezug auf sein Geschlecht, seinen Beruf oder bezogen auf seine Familie, besonders der Fluch gegen die Mutter des Betreffenden ist populär: „Er sei der Sohn einer Frau, die Hure sein soll.““

Vor dem geschilderten Hintergrund seien nun Schimpfworte aus dem $R H$ genannt:

ātaš-parast-e zāālem (tyranischer Feueranbeter; 1/101/16).

āqā siyāh (schwarzer Herr; 1/118/21)

āqā gedā (Bettler; 1/95/24)

aldang (unfähig; 4/620/25)

ạ̣maq-e nā-pohte (unreifer Blödmann, Dummkopf; 4/499/27)

ahreman-zāde (Teufelskind; 5/820/22)

bad-qiyāfe! goh mahor (Du hässlicher Kerl! Iss keinen Kot; 4/555/12)

bad-nahād (von schlechter Natur; 5/753/3)

bad-qavāre (häßlich; 4/582/23)

bad-ā'in (schlechter Glaube; 5/843/17)

bi-āzarm (schamlos; 4/574/1)

bi-adab (unhöflich, dreist; 4/621/13)

bi-ḩāye (ohne Mumm; 1/94/25)

bi-šarm (schamlos; 4/574/1)

bi-morrovat (gnadenlos; 1/124/6)

patiyāre (Schlampe; 5/1032/16) 


\section{Zusammenfassung der wesentlichen Handlungsstränge}

An dieser Stelle soll nicht das ganze Buch zusammengefasst werden; da dieses zu umfangreich ist. Einzelne Geschichten sind sehr detailreich und umfassend. Hier sollen vielmehr die wesentlichen und interessantesten Geschichten und Motive vorgestellt und untersucht werden. Die Gliederung der Zusammenfassung orientiert sich an den Kapitelgliederungen des $R H$. Hoffnungsvolles Ziel ist es, weitere wissenschaftliche Untersuchungen des Inhalts des $R H$ anzuregen und zu ermöglichen. Hauptsächlich werden daher in der vorliegenden Ausarbeitung die Heldentaten der Hauptfigur Hamze und einiger weiterer wichtiger Figuren dargestellt. Dazu nun von Beginn an:

\subsection{Buch 1}

Als der Gelehrte Ğāmāsb in Griechenland verstirbt, muss sein Sohn Baḩt die Familie versorgen. Da er nichts gelernt hat, arbeitet er als Lastenträger. Als er seinen Beruf nach einem Unfall nicht weiter ausüben kann, begibt er sich nach Madā'en, der Hauptstadt des Perserkönigs Qobād, um Arbeit zu suchen. Im königlichen Garten findet Bahnt zufällig einen Schatz. Der Wesir Arqaš tötet Baht und nimmt den Schatz in seinen Besitz.

In Griechenland bekommt Bahts Frau einen Sohn, den sie Bozorgmehr nennt. Als der Knabe groß genug ist, um zur Schule zu gehen, lernt er aus einem Buch, dass sein Großvater ihm hinterlassen hat, dass Arqaš seinen Vater getötet hat. Er macht sich auf den Weg nach Madā'en, wo er Gärtner bei Arqaš wird. Arqaš weiss auf Grund seiner astrologischen Kenntnisse, dass der Knabe ihn töten werde. Deshalb befiehlt er seinem Sklaven Bahtiyār, den Knaben zu töten, seine Leber zu grillen und sie ihm zum Essen zu bringen. Bozorgmehr überzeugt den Sklaven, ihn nicht zu töten, und verspricht ihm die Tochter des Arqaš zur Frau. Der Sklave versteckt Bozorgmehr (1/1-10).

König Qobād hat einen schrecklichen Traum, den er morgens allerdings wieder vergessen hat. Da keiner seiner Traumdeuter helfen kann, gibt er Arqaš drei Tage Frist, den Traum zu erfahren und zu deuten. Arqaš weiss, dass seine Rettung einzig bei Bozorgmehr liegt, und erfährt auf Drängen von seinem Sklaven, dass dieser Bozorgmehr nicht getötet hat. Bozorgmehr deutet den vergessenen Traum dergestalt, dass Arqaš als Brautwerber des Qobād sich in dessen Braut verliebt habe und beide vereinbart hätten, nach der Hochzeitsnacht zusammen kommen zu wollen. Der König lässt Arqaš und die Prinzessin hinrichten und ernennt Bozorgmehr zu seinem Ratgeber. In Erfüllung seines Versprechens gibt Bozorgmehr dem Sklaven Bahtiyār die Tochter des Arqaš zur Frau. 
Dem Qobād wird ein Sohn geboren, den er Anōširvān nennt (1/8-9); der Sohn der Tochter des Arqaš erhält den Namen Bahtak. Während beide zusammen aufwachsen, überträgt Qobād die Erziehung des Anōširvān dem Bozorgmehr. Als Anōširvān nach dem Tod des Qobād den Thron besteigt, ernennt er Bozorgmehr und Bahtak zu seinen Wesiren.

Nach seiner Heirat mit der Tochter des Kaisers von China vernachlässigt Anōširvān seine Herrschaft, so dass Elend und Armut um sich greifen. Auf der Jagd bemerkt er zwei Eulen, die sich anscheinend miteinander unterhalten. Bozorgmehr übersetzt ihm die Unterhaltung: Die beiden Eulen wollen ihre Kinder miteinander verheiraten, und als Brautgeld für die Tochter verlangt die eine Eule ein verlassenes Dorf. Die andere erwiderte darauf, dass es genug zerstörte Dörfer gebe, solange dieser König an der Macht sei. Als Anōširvān dies hört, geht er in sich und entscheidet, künftig besser zu regieren (1/12).

Anōširvān hat einen Traum, den er am Morgen vergessen hat. Bozorgmehr deutet den vergessenen Traum, dass ein Feind, der noch nicht geboren sei, den Iran von Heibar aus angreifen und dem König die Herrschaft rauben werde. Allerdings werde ein Knabe aus Mekka dem König helfen und seinen Feind beseitigen. Also sendet der König Bozorgmehr nach Mekka, um den dortigen Herrscher 'Abd al-Moțtaleb zu treffen und den besagten Knaben zu finden. In der Nacht, in der Bozorgmehr Mekka erreicht, gebären 40 Frauen in Mekka 40 Knaben. Der Sohn des 'Abd al-Moțtaleb erhält den Namen Hamze, und Bozorgmehr sagt ihm große Macht voraus. Der Sohn des Kameltreibers Omeiye az-Zamrī erhält den Namen 'Amr, und der Sohn des Sklaven wird Moqbel genannt. Als Ḥamze am dritten Tag nach seiner Geburt plötzlich verschwindet, weiss Bozorgmehr, dass er in Qāf beim König der paris, Šahbāl b. Šāhruh, ist und dort mit der Milch von Löwen und Leoparden genährt wird. Bozorgmehr kehrt nach Madā'en zurück (1/10-15).

In der Zwischenzeit hat Bahtak, der dem Bozorgmehr feindlich gesinnt ist, den König überredet, Heibar anzugreifen. Bahtak nimmt Hešām, den Sohn des getöteten 'Alqama, zu sich und erzieht ihn. Hešām wird später ein großer Feind des Perserkönigs (1/14).

In Mekka wachsen Ḥamze und 'Amr zu außerordentlich kräftigen jungen Männer heran (1/16). Ḥamze erhält von einem geheimnisvollen Reiter das Hemd des Yusof, das Schwert Ṣamṣām, das Salomo gehört hatte, die Armbrust des Isaak, den Panzer des David und das Pferd des Isaak. Der Reiter schenkt 'Amr eine Kundschafterausrüstung und überträgt durch Auflegen der Hand dem Ḥamze außergewöhnliche Kraft (1/21).

Als die Brüder des Ḥamze den Tribut der Mekkaner zu Monder, dem Vasallen des Anōširvān, bringen, schliesst er sich ihnen an. Im Kampf besiegt er die Söhne des Monder, No'mān und 'Odvān. Diese versichern ihm, dass sie sich zum Islam bekehren würden, wenn 
er ihren Feind Żeiġam überwinde (1/22). Ḥamze besiegt Żeiġam, erobert den Jemen und zerstört einen Zauber namens Kuhestān. Monder, seine Brüder und Kinder bekehren sich zum Islam (1/25).

Als Hešām b. 'Alqama erfährt, dass sein Vater durch Anōširvān getötet wurde, plündert er den Palast in Madā'en und nimmt Krone und Thron des Anōširvān in Besitz, während der König nach Fārs flieht. Danach plündert er Mekka an und nimmt Ḥamzes Vater gefangen. Ḥamze befreite seinen Vater, tötete Hešām und nimmt Thron und Krone des Anōširvān an sich (1/23). Anōširvān kehrt nach Madā'en zurück und schickt einen Gesandten mit einem Ehrenkleid nach Mekka, um Ḥamze zu danken (1/25-26).

Auf dem Weg nach Madā'en erreicht Ḥamze die Festung Tang-e Ravāḥel, deren Herr 'Amr b. Ma`di Karib sich für den von Astrologen vorhergesagten Șāheb-qerān (Fürst der glücklichen Konstellation) hält. Als ihre Armeen aufeinandertreffen, kämpfen Ḥamze und 'Amr b. Ma'di Karib drei Tage im Zweikampf miteinander. Schließlich nimmt Hamze seinen Gegner gefangen und bekehrt ihn mit seinen 18 Brüdern zum Islam (1/23-24).

In Madā'en zieht Ḥamze den Zorn der Perser auf sich, als er sich im Palast auf den Stuhl des Rostam setzt (1/29). Auf der Jagd tötet Ḥamze einen Löwen (1/31).

Gostaham, Heerführer des Anōširvān, hilft dem Kaiser von China, einem Feueranbeter, im Konflekt gegen dessen Sohn Bahrām, einen Muslim. Er nimmt Bahrām mit einer List gefangen und bringt ihn nach Madā'en. Als er dort auf Ḥamze trifft, demütigt ihn dieser, indem er ihn vom Pferd zu heben droht, ohne dass er Widerstand leisten kann. Während Ḥamze sich mit Bahrām anfreundet, intrigiert Baḩtak, der Wesir des Königs, zusammen mit Gostaham gegen ihn. Diverse Mordanschläge (1/37) und Verleumdungen laufen ins Leere.

Ḥamze und Mehrnegār, die Tochter des Anōširvān, verlieben sich ineinander (1/40-47). Mehrnegār erklärt, dass sie sich ihm nur als erste Gemahlin hingeben werde. Während Bahtak wie auch Mehrnegārs Mutter Zarangiz versuchen, die Heirat zu verhindern, erhält Bozorgmehr als Ḥamzes Fürsprecher vom König die Genehmigung für die Heirat der Liebenden. Bahtak kann die Hochzeit vereiteln, indem er den König dazu überredet, dass Ḥamze zunächst seine Eignung als Schwiegersohn beweisen soll.

Landehur, Sohn des Sacdān, ist am Hof des Hošyār Šāh, König von Indien, aufgewachsen. Als er sich gegen Hošyār Šāh wendet, bittet dieser Anōširvān um Hilfe. Auf den Rat des Baḩtak verspricht Anōširvān die Hand seiner Tochter demjenigen, der Landehur überwinden könne. Ḥamze bietet sich an (1/62-66) und macht sich mit dem Schiff auf den Weg nach Sarandib. Nachdem sie Schiffbruch erlitten haben (1/68-69), erreicht Ḥamze zusammen mit seinen Freunden eine Insel. Die dort lebenden alten Männer lassen sich von ihnen auf den 
Schultern tragen, indem sie ihre Beine wie Riemen um den Hals legen und die Menschen als Reittiere benutzen. Mit einer List machen sie die Riemenbeinler betrunken und befreien sich $(1 / 70-71)$.

In Begleitung seines Kundschafters 'Amr geht Ḥamze auf Pilgerfahrt zu Adams Grab auf dem Berg Sarandib. Dort findet er den Schlüssel der sieben Städte (1/75). Im Mausoleum des Adam erscheint dieser Hamze im Traum. 'Amr erhält von Adam einen magischen Spiegel und einen Becher, mit dessen Hilfe er sich in verschiedene Gestalten verwandeln kann; Moses gibt ihm die Fähigkeit, 72 Sprachen zu sprechen; David verleiht ihm eine schöne Stimme; Edris gibt ihm einen Teppich, der das Gewicht von sieben Elefanten tragen kann; Heżr verleiht ihm die Fähigkeit, schnell zu laufen (1/74). Ḥamze erhält von Adam sieben magische Haare, die ihm Kraft verleihen.

In Sarandib begibt sich 'Amr als Kundschafter in die Stadt und kommt am Hofe Landehurs als Sänger in Gunst, stiehlt dann aber dessen goldene Weingläser und andere Kostbarkeiten und flieht. Ḥamze entschuldigt sich bei Landehur hierfür, und endlich begann der Kampf (1/7779). Zwischenzeitlich sendet Anōširvān auf Anraten des Bahtak den Gostaham mit seinen Söhnen nach Sarandib, um Landehur und die Araber zu töten. Im Zweikampf mit Landehur muss Gostaham aufgeben (1/83). Hamze besiegt Landehur und lässt ihn in ein eisernes Verlies sperren (1/85-88). Vor Neid erfüllt lässt Gostaham, Hamze von zwei Sklavinnen vergiften. Als 'Amr Hamze bewusstlos vorfindet (1/88), bringt er ihn und das Heer zur Festung Sarandib. Deren Herr Ğampur Šāh, Sohn des Hošyār Šāh, ist aufgrund eines Traumerlebnisses Muslim und hilft 'Amr. Während Gostaham und Hošyār Šāh die Festung belagern, holt 'Amr den Weisen Eqlimu von der Insel Lāhur, der Ḥamze in 40 Tagen heilt (1/89-90). Gostaham, der Ḥamze für tot hält, wird von Landehur in die Flucht geschlagen. Ḥamze lässt Landehur frei, der den Islam annimmt und fortan auf der Seite Ḥamzes kämpft. Zurück in Madā'en verkündet Gostaham, dass er Ḥamze und dessen Gefährten getötet habe und zeigt falsche Köpfe als Beweis vor. Baḩtak rät dem Anōširvān, Mehrnegār dem Fürsten Oulād-e Marzbān zur Frau zu geben, und Mehrnegār, die gezwungenermaßen ihre Zustimmung gibt, macht sich in dessen Begleitung auf den Weg (1/92-93). Auf dem Weg nach Madā'en trifft 'Amr auf das Heer und hört, dass Mehrnegār den Ḥamze noch immer liebt. 'Amr wird zunächst von Oulād gefangen genommen, doch kurz darauf wieder freigelassen. Landehur nimmt nun Oulād gefangen und sperrt ihn in ein Verlies. Er rettet die von Verbündeten des Oulād entführte Mehrnegār und bringt sie zu Ḥamze. Da Mehrnegār den durch die Vergiftung nach wie vor schwachen Ḥamze kaum erkennt, schickt dieser auf Rat des Eqlimu den 'Amr nach Madā'en, um dort von Anōširvān das Heilmittel nuš-dāru zu 
erlangen. In Madā'en verwandelte sich 'Amr in einen alten Mann und erlangt das Heilmittel, indem er an der Gerechtigkeitskette sein Verlangen nach Gerechtigkeit anzeigt (1/97). Ḥamze erhält durch Abraham im Traum seine volle Gesundheit zurück (1/98).

Als Ḥamze verlangt, Mehrnegār heiraten zu dürfen, behaupten der König und Bahtak, sie sei verstorben. 'Amr entdeckt, dass Mehrnegār noch am Leben ist (1/101-102). Nun behauptet Anōširvān, dass er kein Geld für die Hochzeit besäße, da die sieben tributpflichtigen Staaten ihren Tribut nicht entrichtet hätten. In der Hoffnung, dass er im Kampf getötet werde, wird Ḥamze geschickt, um den Tribut einzusammeln (1/106).

Auf dem Weg nach Griechenland leiden die Helden Hunger und Durst, weil der ihnen von Baḩtak als Führer mitgegebene Qāren sie einen falschen Weg führt. Qāren versucht, Ḥamze $\mathrm{zu}$ vergiften, was aber von 'Amr verhindert wird. In Griechenland wird Hamze von dem dortigen Statthalter Feridun Šāh freundlich aufgenommen (1/110). Auf Bitten des Feridun tötet Hamze einen Drachen, Feridun bekehrt sich zum Islam und gibt Hamze seine Tochter Maryam Nahid zur Frau. Maryam Nahid gebiert Ḥamze später den Sohn 'Omar (1/111-112). Auf dem Weg nach Antiochia erreicht Ḥamze die Festung Zarrin-ḥeṣār, deren Herrscher $\mathrm{Sa}^{\mathrm{c} d}$ er besiegt. Er erhält von ihm den Tribut der sieben Jahre, in denen nicht bezahlt worden war, und Sacd bekehrt sich zum Islam (1/113).

Bevor Ḥamze nach Antiochia kommt, hat Qāren den dortigen Herrscher Ḥaris Šāh gegen ihn aufgestachelt. Dieser verspricht, Hamze zu beseitigen, indem er das Bad über ihn zum Einstürzen bringen werde. 'Amr vereitelt den Plan und bringt stattdessen das Bad über dem Herrscher zum Einsturz (1/115-116).

Anis Šāh, der Herrscher von Ṭaranbusiye, will Ḥamze durch große Löcher auf dem Platz des Polospiels vernichten. Als Hamze in eines der Löcher fällt, kommt Landehur ihm zu Hilfe, und beide können sich befreien. Ḥamze tötet Qāren und nimmt dessen Armband an sich. In diesem Armband befinden sich sieben Rubine, die Ḥamze später seinen Frauen gibt; diese wiederum geben sie als Erkennungszeichen ihren von Hamze gezeugten Söhnen (1/115-118).

In Hosroviye verlangt der tributpflichtige Herrscher Hosrou Šāh von Ḥamze zunächst, wie er eine Kuh eine Treppe hinauf und wieder hinunter zu tragen. Ḥamze bewältigt die Tat erfolgreich, Hosrou wird Muslim und zahlt den Tribut (1/119-120).

Der Herrscher von Ägyten, 'Aziz-e Meșr, betäubt Ḥamze und seine Soldaten durch einen mit Betäubungsmittel vermischten Wein und sperrt alle ein. Bahtak rät Anōširvān, Ḥamze bei dieser Gelegenheit töten zu lassen. Auf der Suche nach Ḥamze erhalten Moqbel und der als Wasserträger verkleidete 'Amr Hilfe von einem Schneider, der sich zum Islam bekehrt hatte. 
Zohre Maryam, die Tochter des 'Aziz, wird durch den im Traum erscheinenden Propheten Abraham zum Islam bekehrt, und mit ihrer Hilfe befreit 'Amr den Hamze. 'Aziz wird von Ḥamze im Kampf getötet, die Einwohner von Ägypten Frauen, Männer und Kinder werden getötet und ihr Eigentum geplündert, bis sie sich schließlich zum Islam bekehren (1/121-128). Auf dem Weg nach Harušane verliebt sich Ḥamze durch ein Portrait in Rābece, die Tochter des Kards Šāh (1/129; 4/711). Rābece ist allerdings von dem in sie verliebten Dämon Qahhār entführt worden, und ihr Vater hat sie demjenigen versprochen, der sie befreit. Hamze tötet den Dämon und befreit die Geliebte. Auf Rat des ihm erscheinenden Heżr heiratet Ḥamze Rābe`e (1/129-131).

Danach zieht Ḥamze nun ausgestattet mit dem Tribut der sieben Staaten nach Madā'en, um Mehrnegār zu heiraten. Da der Stadthalter von Madā'en ihn am Betreten der Stadt hindern will, erobert Ḥamze die Stadt und lässt sie zerstören. In den Frauengemächern findet er Mehrnegār und nimmt sie mit sich (1/133). Als Anōširvān erfährt, dass Ḥamze die Stadt zerstört hat, bittet er den Mongolenfürsten Zubin b. Kāvus um Hilfe. Da es Zubin nicht gelingt, Ḥamze zu besiegen, täuscht er vor, sich zum Islam bekehrt zu haben (1/135), verwundet am folgenden Tag aber Ḥamze mit einem vergifteten Schwert. 'Amr bringt den bewusslosen Ḥamze nach Mekka (1/136), wo er von sieben paris geheilt wird (1/136). Während Anōširvān mit Zubin Mekka belagert, wird Ḥamze vom Ratgeber des Königs der paris gebeten, ihnen gegen die Dive auf dem Gebirge Qāf zu helfen (1/138). Ḥamze wird von den Feen nach Qāf gebracht (1/141). Auf dem ersten Gipfel des Qāf besiegt Ḥamze den div Afğān. Am Hofe des Šahbāl wird Ḥamze empfangen (1/139). Asmāà, die Tochter des Königs, ist in Ḥamze verliebt (1/140).

Mekka wird noch immer belagert. Bozorgmehr prophezeit aus dem Buch des Ğāmāsb, dass Ḥamze erst nach achtzehn Jahren zurückkehren werde, da er bei Antritt seiner Reise ins Land der paris vergessen habe, „So Gott will“ zu sagen; er müsse deshalb statt der versprochenen Anzahl von Tagen ebenso viele Jahre dort bleiben (1/142-143). In Mekka werden die Lebensmittel knapp. Durch eine List kann 'Amr mit den Muslimen und Mehrnegār zur Festung Tang-e Ravāḥel entkommen (1/144).

Im Land der paris tötet Ḥamze einen Boten des 'Efrit (1/146). Als Asmā' dies sieht, gibt sie ihm Salomos Schwert Lom'e-ye lāme (1/146). Inzwischen ist Asmā' entführt und in die Stadt Sang-rize-ye Soleimān gebracht worden. Der ebenfalls entführte Ḥamze wird von dem div Siyāmak befreit. Im Kampf mit Ḥamze wirft der 'Efrit ihn ins Meer (1/151-153).

'Amr erobert die Festung Gazestān, die daraufhin von den Feueranbetern belagert wird (1/151-152). 
Ḥamze erhält von dem Dschinn Mer’āt Brot und ein Boot. Auf einer Insel trifft er den Sohn des Königs von Andalus, dem er Beistand gegen den 'Efrit zusichert (1/154). Der div Kahungās, Herrscher der Festung Qāqm, wendet sich Ḥamze zu und bekehrt sich mit seinem Sohn Kās-Kahun zum Islam (1/154). Durch die Frau des Fulād-zehreh erfährt Ḥamze, dass Fulād-zehreh in Asmā' verliebt ist; er kann sie befreien.

'Amr erobert die Stadt Salsāliye durch eine List. Deren Herrscher und die Einwohner lassen sich zum Islam bekehren. (1/156-157).

Als Ḥamze ins Menschenland zurückkehren will, verlangt Šahbāl von ihm, zuerst Samandun und 'Efrit, die Oberhäupter der dive in Qāf, zu töten (1/165). Trotz seines Versprechens gegenüber Mehrnegār verliebt sich Ḥamze auch in Qamar-čehr pari. Als Asmā’ dies sieht, wird sie sehr wütend (1/164).

Ḥamze kämpft gegen 'Efrit und verwundet ihn. Obwohl dieser bittet, ihn noch ein zweites Mal zu schlagen, damit er sterbe, weiss Hamze, dass man einen div nicht zweimal schlagen darf (1/166). Ḥamze tötet Samandun (1/168). Danach heiratet er Asmā' und Qamar-čehr (1/169).

'Amr erobert die Festung Gonbad-e zard und bringt Mehrnegār dorthin (1/170). Bahrām und Landehur kämpfen mit Rebellen in Sarandib und besiegen den Herrscher Sāruk. Dessen Töchter machen Bahrām und Landehur mit einer List bewusstlos und werfen sie ins Meer (1/162-163). Bahrām kann sich retten und kommt in die Stadt Borhāniye. Da er die Armbrust des Kahrum spannen kann, erhält er das für diese Heldentat ausgesetzte Gold, das er an das Volk verteilt. Darauf tötet Bahrām einen Löwen, wird Feldherr des Königs und trifft Landehur wieder, der sich ebenfalls retten konnte (1/171-172). Sāruk sucht derweil Zuflucht bei Helāl, dem Herrscher der Hundsköpfigen. Der gegen ihn kämpfende Landehur wird ins Land Qāf gebracht, um gegen den weissen div zu kämpfen, der die pari Rāšede, die Tochter des Herrschers Rāšed, entführt hat. Landehur verliebt sich in Rāšede und kämpft gegen den weissen div, der aber fliehen kann. Als der weisse div von Landehurs Heirat mit Rāšede erfährt, entführt er Landehur und blendet ihn. Rāšedes Sohn Aršivan tötet später den weissen Div. Indem er Landehur die Asche von dessen Leber in die Augen reibt, wird dieser geheilt (1/175-177).

Der Div Ra'd-e šățer flieht vor Ḥamze zu der von Salomon erbauten Festung Zebarğad. Dort erfährt Ḥamze, dass die Dive keine Hitze vertragen konnten und tötet sie mit Hilfe des Feuers (1/175).

Ḥamzes Freunde, Mehrnegār und seine Soldaten ziehen viele Jahre von Festung zu Festung. Nachdem 'Amr die Stadt Ṭanğe erobert und Mehrnegār und die Muslime dorthin gebracht 
hat (178), wird er eines Tages von dem Div Tondak durch die Luft nach Qāf gebracht. Dort trifft er Ḥamze, der kurz darauf Hochzeit mit Asmā' feiert. Unter den Schätzen, die 'Amr von Asmā' erhält, ist eine unsichtbar machende Mütze. Inzwischen hat Asmā' von Ḥamzes Verlobter im Menschenland erfahren. Wenngleich sie versucht, ihn für immer in Qāf festzuhalten, lässt sie ihn schließlich ziehen.

Nach drei Tagen erreicht Ḥamze eine Stadt, deren Bewohner nur einmal im Monat sprechen. Die Stadt wurde von Salomon erbaut, der in ihr seinen Schatz gelagert hat. Zum Schutz des Schatzes hat Salomon einen Zauber auf die Stadt gelegt und einen Div als Wächter eingesetzt. Ḥamze kann den Zauber brechen (1/173). Er besiegt den div Āzmāyeš, den Wächter des Schatzes, tötet ihn aber nicht, da der div ihm gesteht, dass er in die Tochter des Feenkönigs No'mān verliebt ist. Durch Vermittlung Ḥamzes willigt No'mān Šāh in die Heirat seiner Tochter mit dem Div ein. Aus dieser Verbindung entspringt später Ḥamzes Pferd Ašqar, das drei Augen hat.

In der Wüste trifft Ḥamze den Heżr, der ihn mit Brot und Wasser versorgt. Am Fuß eines Felsens tötet er einen Drachen, der die Brut des Simorg bedrohte. Aus Dankbarkeit schenkt ihm der Simorg einige Federn, mit denen Ḥamze ihn jederzeit zu Hilfe rufen kann. Der Simorg fliegt Ḥamze auf dem Rücken bis zur Stadt Sadde-e Bolur (1/174-175). Dort trifft Hamze den Propheten Elias, der ihm den Dolch des Ṭahmures gibt (1/175).

Kurz darauf helfen die pari Lānisā und der div Āzmāyeš dem Ḥamze, das Menschenland zu erreichen. Aus Zorn darüber tötet Asmā' beide (1/179). In der Stadt der Kamelköpfigen heiratet Ḥamze 'Arvāne, die Tochter des Königs Qeimāsb. Weiter unterwegs befreite Ḥamze die Tochter des Königs von Qusțanțaniye aus den Händen eines divs (1/179-180). Āṣefe, die Mutter des Heżr, schenkt Ḥamze eine magische Fangschnur, die niemals nass wird und niemals zerreißt. Durch ein gemeinsames Gebet kann Hamze die vor ihm liegenden sieben Meere und sieben Wüsten in einem Augenblick hinter sich lassen (1/180) und kehrt ins Menschenland zurück.

'Amr ist zwischenzeitlich durch ein Vogelflugordal zum König einer Stadt gewählt worden und hat die Tochter des vorherigen Herrschers geheiratet. Als diese bereits am folgenden Tag verstirbt war, wollen die Einwohner der Stadt ihn gemäß ihrer Tradition zusammen mit ihr begraben. In diesem Moment erscheint Hamze und befreit ihn (1/182).

'Amr kehrt nach Ṭanğe zurück, um Mehrnegār auf Ḥamzes Ankunft vorzubereiten. Gemeinsam ziehen alle nach Madā'en, wo Ḥamze endlich die Zustimmung zur Heirat erhält. Ḥamze heiratet zuerst Mehrnegār, danach wird er auch offiziell mit der anwesenden Asmā’ 
verheiratet. Asmā̄' gebiert ihm später die Tochter Qoreiši, Mehrnegār den Sohn Qobād $(1 / 185 / 193)$.

\section{$5.2 \quad$ Buch 2}

Anōširvān und Bahtak sind nach wie vor mit der Eheschliessung nicht zufrieden und wollen sich mit dem Feldherrn Hām in Damešq verbünden. Als Ḥamze dies erfährt, macht er sich auf den Weg dorthin und besiegt Hām. Hām gibt vor, sich zum Islam zu bekehren. Aus dem Hinterhalt verwundet er Ḥamze mit einem vergifteten Schwert, worauf Ḥamze bewusstlos wird; sein Pferd Ašqar bringt ihn in Sicherheit (2/194-197). Nachdem Ḥamze genesen ist, werden die Feinde mit Hilfe von Asmā' und ihrer Tochter Qoreiši geschlagen (1/197). 'Amr schickt Mehrnegār nach Aleppo (2/197).

Inzwischen hat Maryam Nāhid in Griechenland Hạzzes Sohn 'Omar geboren, der sich allerdings für den Sohn des Feridun Šāh hält. Als 'Omar im Alter von 18 Jahren von seinem wahren Vater erfährt, macht er sich auf die Suche nach ihm. Beim Versuch, ein Meeresfohlen zu fangen, wird er ins Meer gezogen und rettet sich auf eine Insel (2/197-199). In der Stadt des Luhrāsb, Sohn des Goštāsp, tötet er einen Löwen (2/199). In Aleppo angelangt, tötet 'Omar Hām und Zubin und kommt endlich zu seinem Vater. Als Anōširvān und Bahtak in der Stadt Zābol Zuflucht suchen, verfolgt 'Omar sie, verliert bei der Verfolgung aber viele Soldaten (2/203).

Anōširvān und Baḩtak suchen Zuflucht bei Malek Bahman, dem Herrscher der Stadt Qohestān. Dieser fordert Ḥamze zum Kampf, wird aber von ihm besiegt. 'Amr erkundet die Stadt (2/205-206) und kann Anōširvān, Malek Bahman und Baḩtak durch eine List entführen und zu Ḥamze bringen, der sie aber freilässt (2/206). Der von Ḥamze besiegte Malek Bahman bekehrt sich zum Islam (2/207). Der Vater des Bahman, Malek Arḥab, wird im Kampf von Landehur getötet (2/208).

Anōširvān und Baḩtak suchen Zuflucht bei Kāmus-e Kušāni, dem Herrscher der Stadt Zābol. Dieser verspricht, Ḥamze in den Zauber des Rostam zu werfen und so endgültig zu besiegen. Als Ḥamze eintrifft, lädt er ihn ein und lässt auf der Jagd durch die Macht von Rostams Zauber einen Fluss zu einem großen Meer anschwellen. Danach flieht Kāmus nach Kābul. Als Ḥamzes Soldaten von seinem Schicksal erfahren, begeben sie sich gleichfalls in den Zauber. Indem 'Omar die Geliebte des Kāmus, eine Hexe, tötet, erlischt auch die Macht des Zaubers. Ḥamze findet die Waffen des Rostam, die er seinem Sohn 'Omar überlässt. Bahtak und Anōširvān ziehen weiter nach Iraq (2/210-212). 
Baḩtak und Anōširvān suchen Zuflucht bei Šahanšāh, dem Herrscher des Iraq. Ḥamze, der ihnen folgt, schickt 'Amr in die Stadt, um Informationen zu sammeln. Er wird zunächst gefangengenommen, durch seinen Neffen Abu 'l-Fath aber wieder befreit (2/212). Als er neuerlich festgenommen wird und getötet werden soll, stellt 'Amr sich tot. Als er später wieder zu sich kommt, erhält er nach einem Gebet im Traum von Heżr die Erlaubnis, Bahtak zu töten (2/215). In Verkleidung als Garkoch verkauft 'Amr auf dem Markt Essen. Nachdem es ihm gelungen ist, Bahgtak zu töten, bereitet er aus dessen Fleisch eine Mahlzeit zu, die Anōširvān und seine Höflinge verspeisen. Bahtiyār, Bahttaks Sohn, findet in seiner Schüssel einen Ring seines Vaters und merkt, dass das Essen mit dem Fleisch des Bahtak zubereitet ist (2/216-217). Anōširvān macht Baḩtiyār zu seinem Ratgeber und nennt ihn wie sein Vater Bahtak.

Naduk und Mazdak, die Brüder von Arqaš, kommen zu Ḥamze. Als sie hören, dass Bahtak getötet wurde, rächen sie sich an Ḥamze, indem sie den Gutgläubigen mit einer Augensalbe blind machen (2/218). Bahtak fürchtet, dass Bozorgmehr den Ḥamze durch das Zauberbuch des Ğāmāsb heilen werde, und Anōširvān lässt den Bozorgmehr gleichfalls blenden (2/218). Ḥamze erfährt im Traum durch den Propheten Salomon, dass nur die Blätter des EiyubBaumes seine Blindheit heilen können. 'Amr findet den im Süden des Maġreb gelegenen Baum, der von zwei Löwen bewacht wird. Indem er sich auf 'Ali b. Abi Ṭāleb beruft, lassen die Löwen ihn zum Baum gehen. Wenngleich es 'Amr zuerst nicht gelingt, Blätter vom Baum zu pflücken, weht der Wind ihm nach einem Gebet zwei Blätter zu. Indem Hamze und Bozorgmehr den Saft der Blätter in ihre Augen reiben, werden sie geheilt (2/220). Als Anōširvān von Ḥamzes Genesung erfährt, flieht er nach Madā'en. Ḥamzes Sohn Qobād besteigt den Thron (2/220) und Ḥamze reitet nach Mekka.

Ḥamze verliebt sich durch ein Portrait in $\mathbf{R a ̄ b e}^{\mathbf{e}}$, die Tochter des Königs Karnus. Er tötet den fränkischen Feldherrn, der um Rābe'es Hand anhielt, und erhält sie zur Frau (2/222-228). Danach lebt er 14 Jahre friedlich in Mekka.

Inzwischen haben die Astrologen Bahtak vorausgesagt, dass Hamze an der Küste von 'Adan ein Unglück erleiden werde, und Anōširvān ist an die Küste von 'Adan zu Fariborz b. Qāren, dem dortigen König, gezogen. Als Ḥamze dies erfährt, macht er sich ebenfalls auf den Weg. In der Nähe der Küste findet 'Amr einen Schatz, der den sieben Königen von 'Adan gehörte (2/233-234). Hạze fällt eines Tages am Strand ins Wasser und kann sich nur unter großen Mühen retten. Hueżr lehrt Ḥamze ein Gebet, mit dem er sein Erscheinungsbild verändern kann (2/235-236), und Hamze geht in Gestalt eines Verstorbenen in die Stadt. Er tötet einen entflohenen Löwen und wird dem Herrscher vorgestellt. Ḥamze gibt sich als Sacd- 
e gong aus und verspricht Fariborz, gegen Hamzes Soldaten zu kämpfen (2/236-237). Dadurch will er erfahren, wie viele seiner Soldaten ihm die Treue halten. Am nächsten Tag kämpft Ḥamze unerkannt gegen seine eigenen Soldaten und erkennt, dass sie ihm gegenüber treu sind.

'Alam Šāh, Ḥamzes Sohn von Rābe'e, hält sich für den Sohn des Karnus und zieht an der Seite des Anōširvān gegen Ḥamze in den Krieg. Als er durch einen Brief seiner Mutter den wahren Sachverhalt erfährt, lässt er von seinem Vorhaben ab, gegen $\mathrm{Sa}^{\mathrm{c} d}$, den Sohn des 'Omar, zu kämpfen (2/238-239). 'Amr hatte mittlerweile anhand des grünen Mals, welches das Kennzeichen aller Kinder Ḥamzes ist, erkannt, dass 'Alam Šāh Ḥamzes Sohn ist. Er bewaffnet 'Alam Šāh mit Ḥamzes Rüstung und gibt ihm Ḥamzes Pferd Ašqar. Als 'Alam Šāh, dem sich als Sa`d-e gong ausgebenden Ḥamze gegenüber steht, bleibt das Pferd stehen, und 'Amr erkennt, dass Sa`d-e gong Hamze sein muss. 'Alam Šāh misst seine Kräfte mit den Arabern unter dem Namen Rostam, bis Ḥamze ihn überwindet und seinen Sohn erkennt (2/241). Landehurs Sohn Farhād Hुān, der durch einen Mönch zum Götzenanbeter geworden ist, will auf der Seite des Anōširvān kämpfen. Auch er wird durch einen Brief seiner Mutter von der Identität seines Vaters unterrichtet und zieht daraufhin auf dessen Seite (2/240).

Ḥamze kämpft gegen seine eigenen Soldaten und nimmt sie nacheinander fest. Indem er die Gefangenen Fariborz übergibt, gibt er sich ihm als Ḥamze zu erkennen und verlangt, dass Fariborz sich zum Islam bekehrt. Fariborz will Ḥamze daraufhin töten, wird aber von diesem getötet. Ḥamze lässt Qāren, den Sohn des Fariborz, zur Erziehung bei Mahlāl-e 'Adani, einem Verwandten von Fariborz (2/242).

Omeiye, der Vater des 'Amr, bringt die Nachricht aus Mekka, dass Abu 'Amr Šaddād b. 'Ad dort die Mutter und die Schwester des Hamze festnehmen will. Indem Landehur zu ihrer Rettung aufbricht, flieht Šaddād nach Aleppo. Als Šaddād in Aleppo die Mehrnegār festnehmen will, verletzt diese seinen Penis mit einem Pfeil (2/242-243). Danach reitet Šaddād nach Madā'en, wo er von Anōširvān aufgenommen wird. Da Anōširvān den Šaddād auf der Jagd wegen seiner Verwundung am Penis verspottet, grollt ihm dieser, nimmt ihn gefangen führt ihn mit sich nach Abessynien. Zarangiz, die Frau des Anōširvān, veranlasst ihren Sohn Hormoz, Ḥamze um Hilfe zu bitten. Als Ḥamze in Abessynien eintrifft, erfährt er, dass Šaddād den Anōširvān verbrennen will, und sucht in Verkleidung als Geschäftsmann nach ihm. Zusammen mit dem als alter Mann verkleideten 'Amr begegnen sie Šaddāds Kundschafter Qirān. Dieser erkennt Ḥamze und seine Männer und erzählt Ḥamze, dass er vor 14 Jahren durch 'Ali zum Islam bekehrt worden sei. Um den langen Weg nach Aleppo zu überwinden, ruft Ḥamze die Männer von Qāf zu Hilfe, indem er deren Haare 
verbrennt. Ḥamze verlangte von Anōširvān, sich zum Islam bekehren zu lassen, aber Anōširvān verweigert dies (2/243-45).

Zurück in Madā'en verliebt sich Anōširvān in seine eigene Tochter Qahr. Qobād und 'Alam Šāh streiten sich um den Brief, den Anōširvān in dieser Angelegenheit an Ḥamze geschrieben hat, und Ḥamze muss den Streit schlichten (2/245-246). 'Alam Šāh erfährt, dass die Franken die Stadt Harušane, in der seine Mutter lebt, angegriffen haben, wobei sie Karnus, ‘Alam Šāhs Großvater, getötet haben.

Hamze sendet Sa'd gegen die Franken, der ihr Lager plündert und ihre Festung erobert. Durch eine List nimmt Zangāveh, einer der Mitstreiter des Mālā-kard, Sa'd gefangen, und 'Alam Šāh und sein Freund Lohrāsb machten sich auf den Weg, um Sacd zu befreien (2/249). Von einem ungläubigen alten Mann in die falsche Richtung gewiesen, reiten 'Alam Šāh und Lohrāsb in eine Wüste, wo sie vor Durst bewusstlos werden und durch einen Vogel, der ihnen Wasser bringt, gerettet werden. Als 'Alam Šāh in die Stadt geht, sieht er Sa'd bei Mālā-kard, der befiehlt, Sa`d in die Festung Qirāb zu bringen. 'Alam Šāh verfolgte sie, findet aber nicht den richtigen Weg und kommt in die Festung Dulāb, in der sich Mālā-kards Tochter aufhält. Die beiden gehen ein heimliches Verhältnis ein, das eines Tages durch die Amme entdeckt wird. Obwohl das Mädchen bereits Aslam, dem Sohns des Wesirs, versprochen ist, verzichtet dieser auf sie, da er schon vor langer Zeit Muslim geworden ist (2/50-252).

Danach zieht Hamze mit seinen Helden gegen die Franken, besiegt den Fürsten und vermittelt Frieden mit Marzduq (2/254). Marzduqs Kundschafter Borq verkleidet sich mit einer Hundemaske und kann 'Amr festnehmen. Ein junger Kundschafter wettet mit 'Amrs Kundschaftern, wer ihn schneller befreien könne. Er mischt Betäubungsmittel in das Essen der anderen und verspottet sie, indem er sie nackt so hinlegt, als ob sie Unzucht getrieben hätten. Im Frankenreich begibt er sich in die Dienste des Borq und befreit 'Amr. Außerdem plündert er die Schätze der Kirche (2/256-257).

Inzwischen hat sich Prinz Sa`d in Lu'bat, die Tochter des Frankenkönigs, verliebt. Die Amme des Mädchens kommt den Liebenden zu Hilfe, indem sie die Wächter des Sa`d mit einem Betäubungsmittel im Essen ausschaltet und den Prinzen befreit. Beide verlassen die Festung in Verkleidung und schließen sich dem Heer des Marzduq Šāh an (2/253-254).

Wegen des heftigen Streits zwischen Qobād und 'Alam Šāh spricht Ḥamze drei Monate lang nicht mit Qobād. Qobād ist deswegen so niedergeschlagen, dass er Selbstmord begehen will (2/255) und ins Wasser geht, wo er bewusstlos wird. Als er wieder zu sich kommt, ist ein in Grün gekleideter Mann bei ihm, der ihn wegen seines Selbstmordversuchs tadelt. Der Mann 
zeigt ihm seine übermenschliche Stärke, indem er ihn dreimal am Gürtel in die Luft hebt. Daraufhin überreicht er ihm sieben seiner Haare, gibt sich als 'Ali zu erkennen und verschwindet (2/255-260). Qobād, der durch das Zusammentreffen mit 'Ali magische Kraft erhalten hat, verteidigt eine Karawane gegen den Wegelagerer Firuz und bekehrt diesen zum Islam. Danach zieht er nach Qebresiye, wo Qaresi gegen Sacd-e Qohestāni kämpft. Um Sa`d zu überwinden, verspricht der König demjenigen, der ihn besiegt, seine Tochter als Frau. Qobād gelingt dies, er wird aber später durch Qaresi und Darasi gefangen genommen. Das erste Mal befreit ihn ein verschleierter Ritter, das zweite Mal Qaresis Tochter (2/255-261). Qobād verschleiert sich und verlangt von 'Alam Šāh die Herausgabe von Ḥamzes Eigentum. Mālā-kard erfährt, dass 'Alam Šāh seine Festung erobert und sich in seine Tochter verliebt hat, und stellt sich 'Alam Šāh entgegen (2/258). Im Kampf wird 'Alam Šāh schwer verwundet, so dass man ihn in die Festung bringt, um seine Wunden zu verbinden. Mālākard teilt Marzduq Šāh in einem Brief die Einzelheiten seines Sieges mit, worauf dieser mit einem grossen Heer anrückt, um die Festung zu erobern. Die Belagerten können sich allerdings erfolgreich gegen die Übermacht verteidigen. Als Sa`d von der Verwundung 'Alam Šāhs erfährt, rüstet er sich und macht sich zu seiner Hilfe auf. In der Schlacht tötet $\mathrm{Sa}^{`} \mathrm{~d}$ den Mālā-kard, wird allerdings mit einem Lasso von den Feueranbetern gefangen genommen und nach Afruqiya gebracht.

Marzduk erhält inzwischen Hilfe von Telqiyā, dem König von Portugal, der seinen Recken Farakās und seinen Bruder Farbekās mit ihren Truppen schickt. Im Zweikampf erhält 'Alam Šāh Hilfe von einem verschleierten Reiter, Mālā-kard wird von Farakās unterstützt (2/262). Schließlich kann 'Alam Šāh den Mālā-kard festnehmen. 'Amr erkennt in dem verschleierten Ritter Ḥamzes Sohn Qobād (2/264-66).

Ḥamzes Kundschafter sehen in der Stadt einen siebenköpfigen Menschen, der von einem der Zauberkünste mächtigen Priester erschaffen worden ist. 'Amr begibt sich zum Kloster Minā, in dem der Priester mit seinen zwei Töchtern lebt. Die jüngere Tochter teilt ihm mit, dass ihr Vater zu der älteren Schwester eine inzestuöse Beziehung habe und auch sie selbst begehre; sie seit aber seit drei Jahren Muslimin und Abraham habe ihr mitgeteilt, dass sie dem 'Amr gehöre. Auf Veranlassung von 'Amr findet das Mädchen heraus, wie man den siebenköpfigen Menschen beseitigen und den zauberkräftigen Vater besiegen kann. 'Amr zerbricht durch einen speziellen Stein den Zahn des Vaters, der dessen Lebenskraft enthält; indem er dessen geriebene Leber vor den Siebenköpfigen stellt, muss dieser so sehr lachen, dass er daran stirbt $(2 / 265-67)$. 
Als Hamze die Stadt Marzdukiye erobert, fliehen Marzduk und Telqiyā nach Portugal. Nachdem viele fränkische Feldherren sich zum Islam bekehren liessen, fährt Ḥamze mit 360 Schiffen und 360.000 Männern nach Portugal. Er erobert Portugal, und Marzduk und Telqiyā lassen sich zum Islam bekehren. Die Tochter des fränkischen Königs wird mit 'Alam Šāh verheiratet $(2 / 268)$.

Auf dem Weg nach Ardabil treffen Hamze und 'Amr auf eine verschleierte Person, die Ḥamze herausfordert, eine Armbrust zu spannen. Dies gelingt ihm allerdings erst, nachdem 'Amr einen auf einem Stück Papier in der Armbrust versteckten Zauber entfernt hat. Ḥamze erfährt, dass die verschleierte Person Gordiye, die Tochter des Herrschers von Ardabil, Arqāṣ, ist. Er besiegt Āzarborzin, den König von Tabriz, der um das Mädchen geworben hatte, und heiratete Gordiye (2/271-2). Die eifersüchtige Asmā’ will Gordiye zwar töten, wird aber von ihrer Tochter Qoreiši daran gehindert. Gordiyes Sohn wird von einem div zu Asmā' gebracht, wo Qoreiši ihn mit der Milch von Löwen und Leoparden ernährt. Als die dive das Kind später zurückbringen, setzen sie es fälschlicherweise bei einem alten Paar ab, deren Kind verstorben war. Die beiden nehmen den Knaben an Kindes statt an und nennen ihn Badi` az-Zamān. Indem Badi` heranwächst, wird er ein großer Ringkämpfer wie sein Ziehvater (2/272).

Ḥamze wird benachrichtigt, dass Anōširvān sein Heer in der Nähe von Baṣre versammelt hat, und begibt sich dorthin (2/272).

'Amr Ma`di Karib hat 'Ādi Bānu, die Tochter des Königs von Andalusien, Ma'ruf Šāh, geheiratet. ‘Ādiyes Sohn Karib hält Ma`ruf für seinen Vater, bis seine Mutter ihm mitteilt, wer sein tatsächlicher Vater sei. Als Karib zu seinem Vater ziehen will, warnt ihn 'Ādi, dass er eine Heldentat vollbringen müsse, um bei Hamze Aufnahme zu finden (2/272). Karib soll den unbekannten verschleierten Mann im Wald besiegen, unterliegt ihm aber. Als er sich niedergeschlagen umbringen will, wird er von 'Ali gerettet und mit Kraft begabt. Am folgenden Tag besiegt er den verschleierten Mann und erkennt, dass dies seine eigene Mutter ist. Mit ihrer Erlaubnis macht er sich auf den Weg zu Hamze. Unterwegs besiegt er Wegelagerer und gibt den geplünderten Kaufleuten ihre Waren zurück. Dann bricht er mit 'Alis Hilfe den Zauber des Karibnus 'Ad (2/275).

Inzwischen hat Anōširvān den Eskandar b. Heikalān, König von Maġrib, um Hilfe gebeten. Karib begegnet einem Teil des Heeres und tötet den Sohn des Eskandar (2/275-78). In Baṣre trifft Karib Ḥamze und seinen Vater 'Amr. Als Ḥamze ihm den Stuhl des Garšāsb gibt, erweckt dies den Neid des 'Alam Šāh. Ḥamze schickt Karib als Bote zu Eskandar, der zunächst erfolglos versucht, Karib zu töten. Nachdem Karib auf dem Rückweg bei einem 
Angriff von Eskandars Heer schwer verwundet worden ist, wird er durch einen im Traum erscheinenden Ritter geheilt (2/283-285).

Am Hof des Ḥamze stiftet der neidische 'Alam Šāh mit Hilfe seiner Onkel Kalb und Kalāb Zwietracht (2/285-286). Da 'Amr den Hamze daran hindert, 'Alam Šāh zu züchtigen, verflucht Ḥamze den 'Alam Šāh. 'Alam Šāh sucht den offenen Kampf mit Karib, Ḥamze bemüht sich, sie miteinander zu versöhnen (2/290-291).

Alčub Hुān, der Neffe des Eskandar b. Heikalān, unterstützt Anōširvān mit seinen Truppen. 'Amr macht Eskandar und Anōširvān mit einem Betäubungsmittel bewusstlos. Er bezwingt den Götzen des Alčub, welcher der Statue in Gestalt einer alten Frau entweicht, die sich in Rauch verwandelt und verschwindet (2/290-291). Nach zahlreichen Kämpfen wird Alčub von 'Amr besiegt (2/292) und bekehrt sich zum Islam. Eskandar b. Heikalāns flieht in den Maghreb.

Als 'Amr von einem weissen Falken nach Maghreb entführt wird, macht sich Ḥamze in Begleitung seiner Söhne auf, ihn zu retten. Als sie Äthiopien, das Reich des 'Amr b. Šaddād b. 'ĀAd, erreichen, wird die Stadt von einem Erdbeben erschüttert, und Samarāt, der Prophet des dortigen Götzen, sagt dem Eskandar voraus, dass er durch Muslime getötet werde. Als 'Alam Šāh in die Stadt kommt, tötet er einen Kundschafter des Eskandar, der Unzucht trieb, und wird festgenommen. Ḥamze begibt sich zu Eskandar, um 'Alam Šāh zu befreien. Er führt sich als H్Ȟāğe Bahrām ein und wird von Eskandar zur Nachtwache ernannt. Sarhang-e Meṣri tötet Eskandars Tante, eine Hexe; indem durch ihren Tod ihre Zaubermacht vergeht, wird 'Amr befreit. Inzwischen hat Anōširvān den Eskandar darüber informiert, dass Ḥamze im Mag̉reb ist. Anhand der mitgeschickten Bilder erkennt Eskandar den Ḥamze als Hูāăğe Bahrām und will ihn festnehmen, Ḥamze kann sich aber retten und flieht. Bei der Jagd kann Karib den Eskandar festnehmen. Mit Hilfe der Dive gelangen Ḥamze und seine Söhne in kurzer Zeit zu ihrem Lager zurück (2/299-301).

Ḥamze nimmt Eskandar gefangen. Als Bedingung, dass er sich zum Islam bekehre, verlangt Eskandar von Ḥamze drei Dinge: Erstens will er zusammen mit 'Alam Šāh sein; zweitens müsse Ḥamze ihm sein Schwert Șamṣām geben und drittens sein Pferd. Derweil sinnt der hinterhältige Eskandar weiter auf eine Gelegenheit, Ḥamze zu töten. Einen Mordversuch im Bad kann Moqbel vereiteln. Da 'Amr in grosser Sorge um das Wohl des Hamze ist, tötet Karib auf seine Veranlassung den Eskandar (2/290-304). Golnuš, ein Kundschafter des Eskandar, will diesen rächen und erhält von Anōširvān die Erlaubnis, Ḥamze zu töten. Golnuš verkleidet sich und tötet im Lager des Ḥamzes dessen schlafenden Sohn Qobād. Ḥamze tötet im Gegenzug den neugeborenen Sohn des Königs Anōširvān. 
Auf dem Weg nach Mekka begegnet Mehrnegār dem Marzbān b. Oulād, der sie zwingen will, mit ihm zu kommen. Um der Schande zu entgehen, nimmt Mehrnegār Gift. Wenngleich Hamze noch eintrifft, kann er Mehrnegār nicht mehr retten. Sie bittet ihn, ihre Schwester Qahr zu heiraten (2/307). Ḥamze begräbt Qobād und Mehrnegār in Mekka. In tiefer Trauer verkündet er, fortan keine Kriegszüge mehr führen zu wollen. Er schickt die Soldaten nach Hause und sendet 'Amr als König nach Ägypten. Als sich Ḥamze drei Jahre später in dessen Tochter verliebt, muss er sich zunächst viel Geld besorgen, bevor 'Amr seine Zustimmung zur Heirat gibt (2/308). Inzwischen haben sich alle Rebellen, die Hamze besiegt hatte, wieder erhoben. Hamze wird im Traum von einem Mann so heftiggeschlagen, dass er noch am Morgen die Schmerzen spürt. Ḥamzes Feldherr Mesqāa Šāh deutet die im Traum erschienene Person als Rostam, der Ḥamze für seine Pflichtvergssenheit tadeln wolle (2/308).

Qāren b. Fariborz hat einen Sohn namens Qāren hinterlassen, der seinerseits einen Sohn namens Fariborz bekam. Dieser Fariborz verliebt sich in Anōširvāns Tochter. Die von ihm nach Indien um Geld und Geschenke gesandten Dienstleute werden auf dem Rückweg von 'Amr b. Ma'di Karib ausgeraubt. Aus Rache sendet Fariborz seinen Kundschafter Kahanak nach Mekka, der Hamze festnimmt, seine Waffen raubt und alles zu Fariborz bringt. Wenngleich Fariborz den Ḥamze hinrichten lassen will, rät ihm sein Ratgeber, Ḥamze vorläufig nur gefangen zu halten. Qāren bindet Ḥamze daher in eine Kamelhaut und sperrt ihn in 'Oqābin ein. Bozorgmehr informiert 'Abd al-Moț̣aleb darüber, dass Ḥamze vier Monate und 15 Tage im Gefängnis bleiben müsse, da er seine Pflicht als Vorkämpfer des Islams vergessen habe. In diesem Zeitraum müsse 'Amr das Heer wieder sammeln; wenn nur ein Soldat fehle, werde Ḥamze nicht am Leben bleiben (2/310-313).

Durch einen Traum vorgewarnt, erfährt 'Amr, dass Ḥamze im Gefängnis ist, und macht sich auf den Weg zu ihm. Da er keine Gelegenheit findet, Hamze zu retten, wendet er sich in Briefen an die ehemaligen Freunde. Hamze wird in einem Traum von Heżr darüber aufgeklärt, dass Gott in strafe, weil er seine Pflicht als Vorkämpfer des Islams vernachlässigt habe (2/310-314). 'Amr gelingt es auf ausgedehnten Reisen in alle Länder innerhalb von 15 Tagen, alle Mitstreiter des Ḥamze wieder zu vereinen. Karib kommt aus Andalusien, kämpft gegen Qāren und nimmt ihn fest; Qāren wird allerdings von einer Hexe befreit und zu Anōširvān gebracht (2/319).

Anōširvān erhält Hilfe von dem Zauberer Sām. Dieser überlässt dem Baḩtak einen magischen Ring, der einen Drachen befehligt. 'Amr kann den Ring in seinen Besitz bringen und Sām und seine Zauberer durch den Diebstahl vom Sāms magischer Kiste töten (2/319320). 
Inzwischen hat Landehur den Qāren gefangengenommen, und 'Amr hat Fariborz b. Qāren besiegt (2/324). Fariborz erwirkt von 'Amr das Einverständnis, Ḥamze gegen seinen Vater auszutauschen. Beim Austausch der Gefangenen bringt Fariborz allerdings eine Stute mit, die Ḥamzes Pferd dazu bringt, ihr nach erfolgtem Austausch zu folgen. So bleibt Ḥamze in seiner Gefangenschaft, und 'Amr macht sich auf den Weg, um die Feldherrn des Ḥamze zu versammeln (2/325). In verschiedenen Verkleidungen dringt 'Amr mehrmals zu Ḥamze vor, um ihn zu besuchen und die nahe Hilfe anzukündigen (2/321).

In Balh stiehlt 'Amr einen goldenen Teller aus einem Geschäft, wird festgenommen und soll bestraft werden, wird aber durch einen geheimnisvollen alten Mann befreit. Der Alte ist Qiyāsān, der Ratgeber des Königs der Dschinns, Malek Șādeq. Er verlangt von 'Amr den, und 'Amr macht sich auf den Weg nach Darre-ye Mārān, wo sich der šāh-mohre befindet. Dort sieht er, wie weiße und schwarze Schlangen gegeneinander kämpften. Er tötet die schwarzen (ungläubigen) Schlangen, und der König der (gläubigen) weissen Schlangen gibt ihm aus Dankbarkeit den šāh-mohre. Dabei handelt es sich um Sand, der bei Hunger hilft, und ein Stück Holz, mit dessen Hilfe man sich auf dem Wasser bewegen kann, ohne zu sinken. 'Amr begibt sich nach China und holt von dort Bahrām (2/327-328).

Inzwischen trifft Hešām b. 'Alqame mit seinen Truppen ein. Er kämpft einen Tag gegen Qāren und einen weiteren Tag gegen die Muslime. Als weitere Truppen erscheinen, erfährt 'Amr, dass diese zu Șalșāls Söhnen gehören. Durch Geschenke an Șalṣāls Sohn Tumġāăğ Hāan verhindert 'Amr eine Allianz zwischen Hešām b. 'Alqame, Qāren und Șalṣāls Söhnen (2/330-331).

Ḥamze wird befreit und gesund gepflegt und erfüllt seine Dankespflicht gegenüber Gott. Als Qāren festgenommen wird, fordert Ḥamze ihn auf, sich zum Islam bekehren zu lassen. Qāren tut dies erst, nachdem Ḥamze ihm sein Schwert Șamṣām und die Feder des Simorg̀ überlässt (2/335).

\subsection{Buch 3}

Ḥamze verfolgt Anōširvān weiter nach Rei. In der Stadt Sāveğbulāg̀ verliebt er sich in Mehrnegārs Schwester Qahr. Als Zarangiz, Anōširvāns Frau, dies erfährt, lässt sie Ḥamze angeblich im Auftrag von Qahr ein mit Gift vermischtes Getränk schicken. Indem Ḥamze es zu sich nimmt, wird er bewusstlos, und Zarangiz begräbt ihn (3/340).

Anōširvān hat sein Heer wieder versammelt. Mit einer Nachricht bittet er Morād, den Herrscher von Lāhiğān, seine Tochter Nesā Anōširvāns Sohn Hormoz zur Frau zu geben; im Gegenzug werde Anōširvān seine Tochter Qahr dem Hormoz zur Frau geben. Auf dem Weg 
nach Rei lagern die Dienstleute der Nesā an dem Ort, an dem Zarangiz den Ḥamze begraben hat. Sie finden die vergrabene Kiste mit dem bewusstlosen Hạzze, und Nesā kehrt mit ihm nach Lāhiğān zurück. Die von Morād zu Ḥamzes Behandlung bestellen Ärzte (3/342) verlangen für seine endgültige Heilung das nur bei Anōširvān erhältliche nuš-dāru, und Nesā fordert das Heilmittel unter einer falschen Angabe bei Anōširvān an. Der misstrauische Anōširvān lässt das Heilmittel durch seinen Kundschafter Eskandar-e Savād-kuhi überbringen mit der Auflage, es keinesfalls Ḥamze zu überlassen. In Lāhiğān wirft Nesā den Kundschafter zu Boden, nimmt das Heilmittel an sich und schneidet ihm Ohren und Nase ab (3/343). Mit Hilfe des nuš-dāru wird Ḥamze geheilt.

Als Anōširvān dem zurückgekehrten Kundschafter Eskandar seine Tochter Qahr zur Frau zu geben droht, befreit 'Amr diese und tötet Zarangiz. Mit Unterstützung der unerwartet eintreffenden Hilfstruppen des Badi` az-Zamān können Ḥamzes Soldaten die Stadt Madā'en erobern. Anōširvān flieht nach Astar-ābād zu Behzād-e Nušin und von dort weiter nach Balh (3/354). Hamze kommt nach Madā'en und heiratet Āzar-čehr, von der er den Sohn Esfandiyār erhält. Danach reitet er nach Astar-ābād, wo sich Nušin zum Islam bekehren lässt und von Ḥamze als Regent eingesetzt wird. Ḥamze zieht weiter nach Horāsān, Ṭus, Harāt und Daryā-ye Marg̉āb. Auf der Suche nach Anōširvān kommt er nach Balḩ, wo Ğamšid Šāh und sein Bruder Horšid an der Macht sind.

Moqbel verhindert einen Mordversuch des Fariborz b. Qāren, Karib tötet den Fliehenden und bringt Hamze seinen Kopf (3/355-358).

In Balh nimmt der Kundschafter Sonqor den Fariborz fest, und König Ğamšid sperrt ihn in Afrāsiyābs Garten ein. Ǧamšids Tochter Anvar-ārā verliebt sich in Fariborz. 'Amr kann Fariborz und Anvar-ārā retten sowie Bahgtak und Anōširvān entführen (3/359-362). Ḥamze lässt den Perserkönig und Bahgtak allerdings wieder frei. Fetne, die Schwester des Sonqor, verkleidet sich mit Heiligengewändern, macht durch einen Granatapfel 'Amr bewusstlos, nimmt ihn fest und sperrt ihn in ihrem Haus ein. Als 'Amr wieder zu sich kommt, verwandelt er sich durch das Gebet, das ihn der Prophet Adam gelehrt hat, in einen alten Mann und wird von einer Sklavin befreit. Inzwischen hat Fetne den Ḥamze festgenommen und zu Ğamšid gebracht, der Ḥamze ins Gefängnis werfen lässt. Als Ǧamšid erfährt, dass 'Amr sich befreien konnte, fordert er von Fetne, ihn innerhalb von drei Tagen wieder festzunehmen. Inzwischen ist Fetne durch 'Amr zum Islam bekehrt, und sie arbeiten fortan zusammen, um Ḥamze zu befreien. Ḥamze ist allerdings bereits von dem Kundschafter Qerān befreit worden (3/368). Sonqor bekehrt sich ebenfalls zum Islam. 
Ḥamze erobert Balh. Ğamšid und sein Bruder Horšid sehen sich gezwungen, so zu tun, als ob sie sich zum Islam bekehren. Bei einer Einladung im Garten des Afrāsiyāb machen sie Ḥamze und seine Freunde durch Speisen, die mit Betäubungsmitteln vermischt sind, bewusstlos und nehmen sie gefangen. 'Amr kann zuerst sich und danach Ḥamze und seine Freunde retten. Nachdem Ḥamze befreit ist, sendet er Karib zu Fāryāb, um dort Moẓaffar und Ġażanfar zum Islam zu bekehren. Als Karib sie besiegt hat, behaupten sie, sich zum Islam bekehren zu wollen. Letztlich kann Ḥamze sie besiegen (3/364-365), und Ğamšid und Horšid lassen sich zum Islam bekehren (3/370). Anōširvān flieht nach Samarqand.

'Alam Šāh besiegt in der Nähe von Fāryāb die Brüder Yalmāq und Qalmāq, die ihm auf der Jagd ein Reh streitig machen. Die Brüder machen ihn bei einer Einladung durch mit einem Betäubungsmittel versetzte Speisen bewusstlos und legen ihn in eine Kiste, die sie ins Wasser des Flusses Amuye werfen. Die Kiste wird vom Gärtner der Königstochter gefunden und nach Hause gebracht (3/370-371). Der Gärtner nimmt 'Alam Šāh als Sohn an, und 'Alam Šāh arbeitet fortan bei ihm im Garten. Als die Königstochter Šamse den 'Alam Šāh dort zufällig antrifft, verlieben sich beide ineinander, und Šamse lädt 'Alam Šāh in ihr Schloss ein (3/373374). Da die Prinzessin eine tollpatschige Sklavin schilt, teilt diese der Mutter des Mädchens mit, dass ihre Tochter mit einem fremden jungen Mann im Garten sei. Qamar Bānu, Šamses Mutter, informiert ihren Mann. Šamse stellt ihrem Vater Hosrou den 'Alam Šāh vor, und jener überhäuft ihn mit Geschenken. Als er aber später erfährt, dass der junge Mann der Sohn des Ḥamze ist, lässt er die vorher bewusstlos gemachten Liebenden töten: Dem Prinzen wird die Kehle durchgeschnitten, das Mädchen wird gesteinigt. Der Gärtner bemerkt, dass die Halsschlagader des Prinzen nicht durchtrennt ist (3/83-385), und Sohail Hुān, Herrscher des Dorfes 'Isā-ābād, findet 'Alam Šāh und verhilft ihm zur Genesung. Auf der Jagd mit Sohail Hgān trifft 'Alam Šāh wieder auf die Brüder Yalmāq und Qalmāq, kämpft gegen sie und bekehrt sie zum Islam. 'Alam Šāh besiegt den Ṭus, der mit seinen Truppen nach Huāvar gekommen ist, um von Hosrou dessen Tochter als Frau zu fordern. Danach heiratet 'Alam Šāh die Šamse, die ihm später den Sohn Qāsem gebiert (3/386-389).

Inzwischen eroberte Ḥamze die Festung Fāryāb. Ġażanfar und Moẓaffar sehen keinen anderen Weg, als so zu tun, als ob sie sich zum Islam bekehren. Sie machen Ḥamze und seine Freunde bei einem Gelage bewusstlos und nehmen sie gefangen. Ġażanfar will Ḥamze nach Samarqand bringen, wird aber von Karib getötet. Moẓaffar flieht nach Nāzemiye (3/374377). Tol-e ābele-ru, der Statthalter von Samarqand, empfängt den Perserkönig. Sein Sohn Naṣr wird im Kampf von Karib besiegt und lässt sich zum Islam bekehren. Danach reitet er 
nach Samarqand, um seinen Vater ebenfalls vom Islam zu überzeugen. Als Ṭol, der weiterhin ungläubig bleibt, befiehlt, seinen eigenen Sohn zu töten, kann 'Amr diesen retten.

Als die Heere von Ḥamze und Ṭahmāsb Hูān auf einer Brücke kämpfte, zerbricht diese und alle fallen ins Wasser. Ḥamze versucht, Fariborz und Ṭahmāsb zu retten (3/378-379). Als Ṭahmāsb Ḥamzes Hilfsbereitschaft sieht, bekehrt er sich zum Islam. Inzwischen fügen Ḥamzes Soldaten den Söhnen des Ṣalṣāl eine schwere Niederlage zu, worauf diese nach Ḩānbāleq reiten (3/381). Die Türken können Ḥamze durch eine List festnehmen, er wird aber von Qimās Hāan wieder auf freien Fuss gesetzt (3/385). 'Alam Šāh kämpft gegen Qimās und verwundet ihn, worauf das Heer des Qimās flieht (3/389). Anōširvān flieht zuerst zu Oweis Ḩān in der Festung Tātār und danach zu Șalṣāl in Huațā (3/391). In der Festung Tātār lassen sich Oweis und sein Bruder, durch Karib zum Islam bekehren (3/391).

'Alam Šāh, der einen Sohn von Šamse bekommen hat, wird in H্āvar von Ṭus festgenommen und nach Hatā gebracht. Karib nimmt Ṣalṣāls Sohn Qarā H্ān fest, der aber nach Haṭā fliehen kann, worauf Karib ihm nachreitet und ihn in Șalșāls Audienzsaal tötet. 'Alam Šāh hat sich inzwischen befreit und verfolgt Ṭus. Da Ḥamze sich um Karib sorgt, schickt er 'Amr nach Hațā, wo dieser 'Alam Šāh und Badi` az-Zamān trifft (3/397).

Anōširvān flieht nach Ḩaṭā, wo in Șalṣāl empfängt. Auf dem Weg nach Hatạa verlieben sich Ḥamzes Kundschafter in Fatāne, Yazdaks Tochter. 'Amr fällt bei dem Versuch, sie zu entführen, in eine von ihrem Vater gegrabene Grube, kann sich aber mit Hilfe seiner Hundemaske befreien. Der Kundschafter Qerān entführt Fatāne, die kurz darauf von 'Amrān, 'Amrs Neffe, entführt wird (3/400-403). Qeimās greift Ḩāvar an. Ḥamze besiegte ihn und reitet nach Hațā.

Badi` az-Zamān, der von seinem Adoptivvater den Ringkampf gelernt hat, kommt nach Haṭā, wo er auf dem Markt einen entlaufenen Tiger des Königs tötet (3/398). In einem Schaukampf besiegt er in Anwesenheit von Ṣalṣāl und Anōširvān den lokalen Helden. Er wird zunächst von Șalṣāl gefangengenommen, dann von Kahreš befreit (3/402-411).

Ḥamze sendet den mit ihm verbündeten Mālek-e Aštar zu Șalṣāl, wo jener dessen Garten anzündet (3/411-414) und Ḥamzes Botschaft übergibt, dass Ṣalṣāl sich zum Islam bekehren soll (3/417). Nachdem Ḥamze in Hațā eingetroffen ist, bereiten sich beide Armeen auf die Schlacht vor. Am ersten Tag kämpft Ḥamzes Adoptivsohn Fariborz gegen Ṣalṣāls Sohn ĀqFulād und tötet ihn (3/418-419).

Nesā, die Adoptivtochter des Șalṣāl, und Anōširvāns Sohn Hormoz verlieben sich ineinander. Als 'Amr sich auch in Nesā verliebt, bitte er Ḥamze um Unterstützung, der sie ihm allerdings abschlägt, da er Mehrnegār versprochen hat, Hormoz zu helfen (3/421). 
Schließlich entschließt er sich aber doch, 'Amr zu unterstützen, und Nesā wird gezwungen, 'Amr zu heiraten (3/424-426). Șalṣāls Mutter Damāme-ye kuček ärgert sich sehr darüber und verspricht Ṣalṣāl, Ḥamze zu blenden. Als Ḥamze auf der Jagd ist, macht sie ihn und seine Gefährten mit einem Zauber blind. Im Kampf gegen die Usbeken erfährt Ḥamze die heldenhafte Unterstützung eines verschleierten Ritters (3/426-27).

Ṣalṣāls Töchter Ğahān-afruz und 'Ālam-afruz verwandeln sich in Adler und suchen Ḥamze. Als sie auf Samak und Qirān treffen, bekehren sie sich zum Islam und helfen ihnen, Ḥamze zu befreien (3/428). 'Amr wird durch Heżr im Traum geheilt. Er tötet Šamāme, indem er mit einem besonderen Dolch ihren Zahn zerbricht. Indem er ihre Leber auf die Augen von Ḥamze und seinen Freunden reibt, gesunden diese (3/430-432).

Ḥafą b. Dāvuud fordert Ḥamze zu einer Feuerprobe heraus (3/433). 'Amr vertauscht das magische Öl, mit dem Ḥafą sich vor dem Feuer schützen wollte, und gibt es Ḥamze. Dieser kann das Feuer unversehrt passieren, während Ḥafaz darin umkommt (3/432-434).

Ṣalṣāls Tochter Zolfeyn verzaubert 'Alam Šāh, so dass er sich in sie verliebt und die Götzen anbetet. Darauf verlangt Șalṣāl von ihm Ḥamzes Kopf als Brautgeld. Durch Zauberei kann Zolfeyn Hamzes Freunde gefangen nehmen (3/435-436). Inzwischen wird Hamze durch Zardehang, den Kundschafter des Ya'qub Hुān, König von Hotan, entführt (3/436-437). 'Amr, der Ḥamze befreien will, wird festgenommen. Mehr-ārā, die Tochter des Ya'qub Hgān, befreit 'Amr, und mit ihrer Hilfe kann 'Amr Ḥamze befreien. Ḥamze besiegt Ya'qub Huān. Dieser lässt sich zum Islam bekehren, und Ḥamze heiratete Mehr-ārā (3/440- 442).

In China besiegt Ḥamze den Samāk, den Sohn des chinesischen Königs, der sich zum Islam bekehrt. Samāk tötet seinen Vater, der sich der Konvertierung verweigert (3/442). Aus China zurückgekehrt, wird Ḥamze von Zolfeyn durch Zauberei gefangen (3/443). Die muslimischen Kundschafter entführen Șalṣāl und den Perserkönig (3/446). Als 'Alam Šāh gegen Landehur kämpft, schwächt Zolfeyn diesen durch einen Zauber, so dass sie ihn gefangennehmen kann. Der Zauberer Keivān, der Verlobte Zolfeyns, entführt 'Alam Šāh, der aber von Zolfeyn wieder befreit wird. Nachdem die muslimischen Kundschafter Hamze befreit haben, tötet er den Zauberer Keivān und viele Hexen (3/450). Zolfeyn will Ḥamze töten, wird aber ihrerseits von dem wachsamen Moqbel getöt, worauf ihr Zauber bricht. 'Alam Šāh kämpft gegen die Usbeken (3/449-451). Tumgāăğ Hāan, der Bruder des Șalṣāl, will sich nach einem Traum zum Islam bekehren (3/455). In der Schlacht unterliegen die Usbeken, Anōširvān und Ṣalșāl fliehen nach der Stadt Amkan (3/456), und Ḥamze überträgt die Regierung der Stadt Hatā an Ṭus. 
'Amr, der eine Botschaft des Ḥamze zu Hosrou Hāan in Ḩāvar bringen soll, verliebt sich auf dem Weg in der Stadt Ǧābalqā-ye Mašreq in die Prinzessin Horšid. Ḥamze hilft ihm dabei, die Prinzessin zu heiraten (3/458-461).

Im Gebirge Alburz stirbt Anōširvān, und Ḥamze nimmt an der Trauerfeier für ihn in Madā'en teil (3/463).

In der Stadt Hotan heiratet Hamze eine Frau. Als sie schwanger ist, wird sie als scheintot begraben und gebiert ihren Sohn 'Omar-e Gurzād im Grab. Țus, der wieder zur Götzenanbeterei zurückgekehrt ist, flieht nach Hotan, später über Samarqad, Balh, Fāryāb und Barbar zu Gāvlangi. Dort wird er von Qāsem, dem Sohn des 'Alam Šāh, getötet (3/464374).

In Ardabil wird Ḥamze von König Oqāt eingeladen. Er kämpft gegen Badi` az-Zamān, den er durch die Edelsteine als seinen Sohn erkennt (3/466-469). Ḥamze heiratete Mahine Bānu, die Tochter des Königs Kāhun (3/471).

Qāsem befreit seinen Vater 'Alam Šāh aus dem Zauber des Afrāsiyāb. Qāsem findet die Krone des Kei-Hुosrou sowie Fahne und Kleidung des Afrāsiyāb (3/470-472). Als Ḥamze gegen den verschleierten Qāsem kämpft, erkennt er diesen als seinen Enkel (3/476-482).

Badi` az-Zamān gerät in einem Garten in die Macht der Hexe Fetne. Er rettet sich durch Zerstörung ihrer Seelenflasche und befreit auch Hamzes Adoptivsohn Fariborz (3/483).

Der Kaufmann Ṣāleḥ erzählt Ḥamze von der Macht des Zomorrod, König des Westens. Hamze nimmt sich vor, Zomorrod zu besiegen (3/485).

Qāsem will gegen Badi` az-Zamān kämpfen. Dieser sammelt sein Heer (3/385).

In Hāmāvarān werden Baḩtak und Hormoz von dem dortigen König empfangen (3/471). Ḥamze besiegt den König, der sich zum Islam bekehren lässt. 'Amr tötete den hässlichen gul des Königs (3/500). Omeiye, 'Amrs Sohn von seiner Frau in Eṣfahān, macht sich auf die Suche nach seinem Vater (3/486). In Hāmāvarān arbeitet er als Kundschafter des ġul (3/491492).

Badi` az-Zamān befreit Gouhar-Malek, die Tochter des Kanğāb, die ihm erzählt, dass ihr Vater der Prophet des Zomorrod und sie selbst mit Zomorrods Sohn Yāqut Šāh verlobt ist. Badi` az-Zamān verliebte sich in sie (3/489-490) und tötet den Qahhār-e div. In der Nähe eines Gebirges tötet er einen Drachen; als er ihm den Kopf abschlägt, wird er von dem unangenehmen Geruch bewusstlos. Der Qahramān-e div bringt ihn in Sicherheit. In der Höhle des Drachen finden sie einen Schatz, darunter die Glaskugel des Ǧamšid und der magische Stuhl des Kei-Hosrou. Badic az-Zamān befreit den Sohn des Mağnun Šāh (3/493496). 
Auf dem Weg nach Hāmāvarān trifft Badi` az-Zamān den Šahanšāh, der ihn bittet, ihn gegen seinen eigenen Sohn Ġarārb zu unterstützen. Im Kampf gegen Ġarārb wird er von diesem festgenommen und später durch Omeiye befreit. Er verlangt von Ġarārb, sich zum Islam zu bekehren (3/501). Badi` az-Zamān sammelt ein Heer und befiehlt, dass niemand seinen Namen rufen dürfe (3/504).

Ḥamze kommt zu der Burg Qal'e-ye Falak-farsā, in der die muslimischen Brüder Ğamšid und Horšid herrschen. Danach reitet er nach Barbar. Hormoz und Bahtak treffen bei Gāvlangi, dem König von Barbar, ein, der seine Verwandten um Hilfe gegen die Muslime bittet (3/502-503).

Die Armee des Ḥamze wird mehrmals von den Truppen des Zomorrod angegriffen, ohne dass eine Entscheidung fällt. Zalzāl, Prophet Zomorrod, tötet Meșqāl Šāh, wird aber seinerseits von Landehur getötet (3/503). Zalzāls Vater Kanğāb Hูān, Herrscher von Sanğān, schickt die Leiche seines Sohnes nach Șabāyil zu Zomorrod mit der Bitte, ihn wieder lebendig zu machen (3/504). Zomorrod schickte seine Kundschafter zu Gāvlangi.

Ḥamze verliebt sich in Mehrangiz, die älteste Tochter des Gāvlangi, die durch einen Traum von Abraham zum Islam bekehren worden ist. Ein verschleierter Ritter unterstützt Ḥamze im Kampf gegen Babrān, den Verlobten der Mehrangiz, und tötet diesen. Ḥamze und seine Helden heiraten die Töchter des Gāvlangi (3/506-508). 'Amr lässt sich in Gestalt einer georgischen Sklavin an Gāvlangi verkaufen, macht diesen in der Nacht bewusstlos, rasiert ihm den Bart, schminkt ihn als Frau und flieht.

Badi` az-Zamān schlägt sein Zelt gegenüber Ḥamzes Lager auf und verlangt von ihm sein ganzes Eigentum sowie Qāsem (3/510).

Der Kundschafter Kardemard zeichnet in Ḥamzes Lager die Portraits von Ḥamzes Helden und bringt sie nach Ṣabāyil. Die Frauen und Töchter des Königs sehen die Bilder und verlieben sich in Ḥamzes Helden.

Die Feen retten Gouhar-Malek aus dem Zauber und bringen sie in ihre Heimatstadt. Aus Liebe zu Badi` az-Zamān wird sie krank, und ihr Vater schickt sie nach Barbar, wo Badi` azZamān gegen Ḥamze kämpft. Indem der Schleier des Badi` az-Zamān beim Kampf reißt, erkennt Ḥamze seinen Sohn. Gouhar-Malek hört die Freudentrommeln, erfährt den Sachverhalt und entführt Badi` az-Zamān zusammen mit ihrer Amme. Auf dem Weg begegneten sie einem schwarzen Mann (3/512-515), der sich in Gouhar-Malek verliebt. Als Badi` az-Zamān aus seiner Bewusst losigkeit erwacht, kämpft er mit dem schwarzen Mann und wird von diesem ins Meer geworfen. Badi` az-Zamān kommt in eine Stadt, wo er von dem Arzt Fārus an Sohnes Sohn angenommen wird. Als der Sohn der ebenfalls dort 
anwesenden Amme erkrankt, kommt sie zu Fārus und erkennt Badic az-Zamān (3/515-16). Sie informiert Gouhar-Malek, und Badi` az-Zamān heilt die Prinzessin.

Auf dem Weg nach Bāhntar rettet Qāsem den Jungen Fażl vor einem Löwen. Der Knabe nimmt ihn mit nach Sanğān, wo Qāsem am Hof des Ganğāb den Badi` az-Zamān im Arztgewand sieht. Badi az-Zamān bewältigt die Herausforderung, den Bogen des Qahramān-e 'Ağam zu spannen, und Ganğāb belohnt ihn. Als Ganğāb erfährt, dass Badi` az-Zamān der Sohn des Ḥamze ist, lässt er sich zum Islam bekehren. Badi` az-Zamān heiratet Gouhar-Malek (3/517-518).

Bahtak und Hormoz reiten nach Șabāyil zu Zomorrod, um ihm gegen Ḥamze beizustehen. Qāsem und Badi` az-Zamān kommen zu Ḥamzes Lager. Ḥamze greift Mahārān an und erobert Barbar. Danach reitet er nach Șabāyil (3/524-525).

In Qahāriye, dem Reich des Ṭeifur, befreit 'Amr den Siyāmak, Sohn des Landehur. Farangiz Bānu, die Frau des Ṭeifur, hat sich in Siyāmak verliebt und kommt mit ihnen (3/519-521).

\subsection{Buch 4}

Bei der Belagerung der Stadt Ṣabāyil gerät Ḥamze in Streit mit Landehur, enlässt ihn aus dem Heer und übergibt sein Vermögen dem Qāsem (4/531-532). Landehur begibt sich in ein Kloster, wo ihn 'Amr findet. In Derwischgewändern kommen sie zusammen mit Siyāmak und einem Teil der Helden Ḥamzes in die Stadt Șufiyā, wo sie durch den dortigen Herrscher festgenommen werden. Ḥamze reitet nach Șufiyā, erobert die Stadt, zerstört die Tempel und baute die Moschee auf. 'Amr überredet Landehur, sich wieder Ḥamze anzuschließen. Der Herrscher von Ṣufiyā und sein Sohn lassen sich zum Islam bekehren (4/535-538).

Omeiye, der Vater des 'Amr, überbringt Ḥamze einen Brief des 'Abd al-Moțaleb, in dem dieser ihn informiert, dass Šaddād, Sohn des Abu 'Omar Šaddād, Mekka belagert. Ḥamze schickt Bahrām-e gord, um gegen Šaddād zu kämpfen (4/537-538). Später zieht Ḥamze selbst nach Mekka und tötet Šaddād (4/545).

Zomorrod ruft den Zauberer Masrur zu Hilfe gegen die Muslime. Masrur verursacht eine große Kälte, und die Muslime erleiden eine Niederlage. Karib, Qahreš und 'Alam Šāh kämpften gegen die Ungläubigen und bringen Ḥamzes Frauen und Kinder in Sicherheit. Nachdem Giti-afruz, die Frau des Qāsem, und Nesā, die Frau des 'Amr, ihre zwei neugeborenen Söhne aussetzen müssen, werden diese von dem Händler Farăg, einem Sonnenanbeter, aufgenommen. Karib und Moqbel befreien Giti-afruz und bringen sie zu Ḥamzes Heer. Fatāḥ und Qimās Hēān retten 'Ālam-afruz, die Frau des Badi' az-Zamān $(4 / 555)$. 
'Amr wird durch eine Hexe entführt, von seinem Sohn aber wieder befreit. Die Rivalität zwischen Qāsem und Badi` az-Zamān erreicht ihren Höhepunkt.

In der Stadt Nastaraniye erfährt Qāsem von der Tochter des Nastaran Šāh, die mit Qahramān-e 'Ağam verlobt ist. Zomorrod erfährt, dass Qahramān zum Islam bekehrt ist und befiehlt Nastaran Šāh, seine Tochter jemand anderem zur Frau zu geben. Badic azZamān und Qahramān-e 'A ğam kommen zu Nastaran Bānu, um sie mit sich zu nehmen. Als Qāsem die Nastaran Bānu für seinen Freund Moẓaffar werben will, gerät er mit Badic az-Zamān in Streit. Qāsem besiegt Nastaran Šāh, der sich zum Islam bekehrt. Ḥamze entscheidet, dass Moẓaffar und Qahramān-e 'Ăğam miteinander ringen sollten; wer siege, solle das Mädchen erhalten. 'Amr verleiht Qāsem die Gestalt des Moẓaffars und Badi' azZamān diejenige des Qahramān-e 'A ğam, worauf die beiden Helden fünf Tage und Nächte gegeneinander kämpfen. Als Ḥamze beide erkennt, stellt er sich auf Qāsems Seite. Badi` azZamān verlässt das Lager und zieht nach Sanğān, danach nach Maġreb-zamin.

Auf dem Weg dorthin tötet Badic az-Zamān einen Löwen und tränkt auf Rat einer himmlischen Stimme seine Kleider mit dessen Blut (4/554). Von Ḥāres, dem Sohn des Ġażanfar Šāh und Prinzen von Samāwāt, erfährt Badi` az-Zamān, dass der Sklave Moslem die Macht usurpiert hat. Badi az-Zamān bricht mit Hilfe des mit Ḥāris befreundeten Marğān Šāh den Zauber des Malek Dād-bahšs. Er tötet einen Riesen und wird von einem div ins Meer geworfen. In einem Schloss rettet er ein schönes Mädchen und tötet die Hexe Sāmer. Er tötet einen weiteren Riesen und erhält das Pferd des Salomon sowie Gold und andere Wertgegenstände (4/554-560). In einem Meer aus Blut tötet er einen div, und kurze Zeit später findet er sich in einer Wüste wieder. Dort verwandelt er durch Vorzeigen eines Dolches einen Feuerdrachen in Asche. Danach kämpft er gegen Moslem, wobei er von Moslems Tochter Setāre unterstützt wird (4/562-563). Er erobert die Festung Rubin, und Setāre Bānu heiratet Ḥāris (4/570). Moslem flieht nach Šambvāliye zu Šamhnāl Šāh. Badic az-Zamān besiegt den siebenköpfigen Demon namens Harās-e div und bekehrt ihn zum Islam (4/570-571). Im Kampf gegen Kulāk wird er von dessen 70 Brüdern mit Fangschnüren gefangen genommen. Qamar-čehr verliebt sich in ihn und lässt ihn von ihren Kundschaftern befreien.

Eine Sklavin unterrichtet Moslem, dass Badi` az-Zamān von dem muslimischen Fleischer Ḥamid versteckt wird. Badi` az-Zamān tötet die Moslems Kundschafter, rettet die Kinder des Ḥamid und macht sich auf den Weg, während Šamḩāl Šāh ihn verfolgt. Beim Kampf gegen Šamḩāl Šāh wird Badi` az-Zamān vom Harās-e div unterstützt. Als Badi` az-Zamān den Kulāk tötet, will Šamhnāl Šāh sich zum Islam bekehren. Badi` az-Zamān tötet den div 
Aškbus, und Moslem flieht zu dem div Aflāk. Badi` az-Zamān erobert Šamhnāliye, zerstört die Feuertempel und lässt Moscheen errichten. Danach verfolgt er Moslem (4/572-575).

Ḥamze, der nach Sanğān gekommen ist (4/542-553), sieht Badic az-Zamāns blutige Kleidung. Im Glauben, dass Badic az-Zamān tot sei, veranstaltet er eine Trauerfeier für seinen Sohn und zieht danach in Begleitung von dessen Sohn Nur ad-Dahr zu seinem Heer (4/554-555). Die Helden des Ḥamze kämpfen gegen die Männer des Zomorrod (4/563-565).

Sayāre, der Kundschafter des Qāsem, befreit den von den Kundschaftern des Zomorrod entführten Held Abrahā (4/566).

Ḥamze und 'Amr kämpfen in der Wüste gegen den ġul Semerā und dessen Dämonen (4/573).

Karib wird mit einer List von Aṭlas Šāh gefangen genommen. Dessen Tochter Mehrnuš verliebt sich in ihn. Im Traum befreit 'Ali den Karib von seinen Ketten, und kurz darauf befreit Mehrnuš ihn endgültig aus dem Gefängnis. Auf der Flucht tötet Karib einen Marktwächter, wird dann aber im Kampf gegen die Männer des Aṭlas Šāh verwundet. Indem sein Heer eintrifft, tötet Karib den Aṭlas Šāh und heiratet Mehrnuš (4/576-577).

Bei den Truppen des Ḥamze tötet Badi` az-Zamān, der als verschleierter Ritter auftritt, Ṣalṣāl b. Ḥām, einen Held des Zomorrod. Am folgenden Tag kämpft er gegen den schrecklichen Orqul-e ḩešt-andāz. Von Zomorrods Kundschafter Eram-zād entführt, wird Badic az-Zamān von seinem Sohn Farrohn-zād befreit (4/577-586). Neuerlich von Zomorrods Kundschafter Karde-mard entführt, wird Badi` az-Zamān wiederum befreit (4/587-589). Kurz darauf kämpft er gegen Qāsem.

Badi` az-Zamān erhält die Nachricht, dass Moslem Samāwāt angreifen wolle, und zieht dorthin (4/591). Keivān, ein Held des Badi` az-Zamān, besiegt Šāhpur, einen von Moslems Helden, worauf dieser sich zum Islam bekehrt. Moslem flieht, wird aber von dem div Harās und Keivān festgenommen. Indem er die Haare seiner Tante Māhiye verbrennt, wird Moslem von ihr aus dem Gefängnis befreit und kommt nach Qara-bāğ zu Ilāq und Wilāq. Ein Wahrsager teilt Badi` az-Zamān mit, wo sich Moslem aufhält, und er verlangt von Ilāq und Wilāq, ihm Moslem auszuliefern. Badic az-Zamān besiegt Moslem im Kampf, Ilāq und Wilāq aber verlangen von ihm, den Zauber Golriz-e Soleimān zu brechen.

Im Traum erfährt Badi` az-Zamān vom Propheten Salomon, wie er den Zauber brechen kann. Er tötet einen div und kommt durch das Maul eines Drachen zu einem Schloss. Dort befreit er die von Sāmere entführte Fee Zarrin-fāl. Badi` az-Zamān tötet Sāmere, nimmt die Schätze des Zaubers in seinen Besitz und befreit die dort gefangenen Helden. Danach reitet er zu Ḥamzes Lager (4/595-597). 
Als Qāsem dies hört, will er auch einen Zauber brechen. Badi` az-Zamān zieht nach Șabāyil, wo er verschleiert gegen Zomorrods Helden kämpft. Zomorrod kann seine Anhänger nur dadurch beruhigen, dass er Engel über ihren Köpfen Gold ausschütten lässt. Zomorrod bittet Ṭahmāsb b. 'Anqavil, Azraq und Nașr b. Zalzāl um Hilfe (4/599). Naṣr zieht mit seinen Truppen nach Sanğān, um Gouhar-Malek festzunehmen. Der zur Hilfe herbeigeeilte Nur adDahr besiegt Nașr. Auf dem Weg wird Nur ad-Dahr in den Zauber der Hexe Gouhar geworfen. Er findet Māh, die Tochter des Malek Helāl, die bereits seit zehn Jahren hier gefangen ist. Mit ihrer Hilfe zerstört er die Lebenstafel der Hexe, muss danach gegen Raubtiere kämpfen und wirft sich in einem Meer aus Blut ins Maul eines Wals. Durch eine Wüste kommt er zu einer Stadt, in der ihm Papageien sagen, wie er den Zauber endgültig brechen kann. Im Bad steckt er seinen Kopf ins Wasser und kommt in einen Palast, wo er eine schlafende Hexe tötet. Wieder zurück an dem Ort, an dem er Māh gesehen hatte, nimmt Nur ad-Dahr das Eigentum der zwölf Könige, verschleiert sich und gibt die Rüstungen an seine Soldaten. Danach reitet er zu Hamzes Lager (4/601-603).

Zomorrods Kundschafter Waswās entführt Prinz Sa`d, der von einem verschleierten Reiter gerettet wird. Der Reiter verlangt von Ḥamze, dass Qāsem unterhalb von Badic az-Zamān sitzen solle. Badi` az-Zamān und Qāsem vereinbaren, dass der Stuhl Rostams demjenigen gehören soll, der Zomorrod festnimmt. Als Badi` az-Zamān und Qāsem die Stadt Sabāyil betreten wollen, fallen sie in eine von Zomorrod vorbereitete Grube (4/605-606), aus der sie durch einen Gang in den Garten des Kahrā-ye ahtar-šenās gelangen. Kahrā bringt sie zu Ḥamze (4/608).

Sāsān b. Zalzāl wird im Kampf von 'Amr festgenommen und mit dem Feuer bestraft (4/610612). Komkās wird durch den als verschleierter Reiter auftretenden Nur ad-Dahr getötet. Die Kundschafter Kardemard und Eram-zād entführen Ḥamzes Helden, die von Zomorrod ins Gefängnis geworfen werden. Nachdem Qāsem und Badi` az-Zamān beim Kampf gegen Zomorrod ins Wasser gefallen sind, werden sie von dem verschleierten Reiter gerettet. Plötzlich wird dieser von einer Hand aus einer Wolke entführt wird.

Ḥamze erfährt, dass Ṣalṣāl den Iran plündert, und schickt Elyās HUān, um gegen Ṣalṣāl zu kämpfen. Ḥamze lässt Asmā’ mitteilen, dass sie ihren neugeborenen Sohn Soleimān-e sāni nennen soll. Badi` az-Zamān reist mit Tondak nach Qāf (4/616-617). 'Amr will unter der Bedingung Șabāyil erobern, dass Zomorrods Eigentum ihm gehören werde (4/617). Nachdem sie verschiedene Unwegsamkeiten überstanden haben, besiegen Ḥamze und seine Söhne die Ungläubigen und nehmen Șabāyil ein (4/618-619). Qāsem, Badi` az-Zamān und Nur ad- 
Dahr zerstören die Stadtmauer. Ḥamze erfährt, dass Zomorrod und Šahr-āšub mit den Feueranbetern entkommen sind.

Karib sucht Nur ad-Dahr. Der Hexer Šāhroh hilft ihm, nach Qāf zu kommen (4/620). In einem Palast verliebt sich eine Hexe in ihn. Als er sie beschimpfte, wirft sie ihn ins Gefängnis. Die pari Gol-čehre erzählt ihm, dass sie von dem Zauberer Gouhar entführt wurde (4/622). Badi` az-Zamān wird von der Hexe Damāme entführt, die ihm mitteilt, dass der dreiäugige Qahqahe, der Ehemann von Gouhar, ihn töten will. Qahqahe befiehlt den Hexen, die Helden ins Meer zu werfen. Auf ein Gebet des Nur ad-Dahr werden die Helden durch ein Schiff gerettet (4/626-627).

Badi` az-Zamān sucht seinen Sohn Nur ad-Dahr. Durch den Zauberer Marğān, der durch Badi` az-Zamān zum Islam bekehren wurde, erfährt er, dass Zarand in Nur ad-Dahr verliebt ist. Feuerartige Adler nahmen Badi` az-Zamān, Karib und Šāh Sa'd mit (4/646). Qirān verkleidet sich in einem Schaffell und kommt durch Marğāns Hilfe zum Palast der Gouhar. Gouhar befiehlt aus Ärger über Nur ad-Dahr, Badi` az-Zamān zu töten.

Qirān macht die Hexe durch ein Betäubungsmittel bewusstlos und tötet Gouhar. Badic azZamān und Nur ad-Dahr töten alle Hexen. Marğān erzählt Badic az-Zamān, dass er in die Tochter des div Kangān verliebt ist. Marğān sieht, dass Ḥamzes Truppen wegen der Kälte verstreut sind. In Sanğān sieht er, dass Šarāre, der Urenkel des Zalzāl, die Stadt belagert. Die Helden schicken das Eigentum der Hexe, die in der Festung Qal'e-ye Bolur war, nach Golestān-e Eram (4/646-649). Asmā̄ gibt Badic az-Zamān ein Waffenkleid aus Salomons Schatzkammer, und die Helden fliegen nach Bāhntar. In der Stadt Sanğān besiegt Nur adDahr den Šarāre (4/650).

Zomorrod kommt nach Razāyil zu Girang Šāh, der seinen Sohn Neyrang gegen Qāsem kämpfen lässt. Von Qāsem besiegt, lässt sich Neyrang zum Islam bekehren und zieht nach Ṣabāyil zu Ḥamze. Dort übernimmt es Neyrang, eine Nachricht von Ḥamze zu Zomorrod zu bringen. Zornig will Gierang seinen Sohn töten lassen, Neyrang aber wehrt sich erfolgreich (4/622-623).

Baḩtak rät Zomorrod, sich um Hilfe an Ṭahmāsb b. 'Anqavil zu wenden. Dessen Armee kämpft gegen Ḥamzes Helden. Die von 'Anqavil gefangengenommenen Helden des Ḥamze werden zwar von 'Amr gerettet, dennoch sucht Ḥamzes Heer Zuflucht im Gebirge (4/628). 'Amr entführt 'Anqavil, der sich allerdings befreien kann. Am nächsten Tage verwundet er Ḥamze im Kampf. Țahmasb besiegt zahlreiche Helden und nimmt sie gefangen oder tötet sie. Auch Landehur ist ihm nicht gewachsen. 'Anqavil nimmt selbst Ḥamzes Sohn Farroh- 
savār gefangen. Als Farroh-savār sich weigert, ihn als Gott anzuerkennen, will er ihn töten lassen (4/622). ‘Anqavil verspricht Zomorrod, alle Muslime zu töten (4/624).

Sađd besiegt den div Čangāl, der für Qarār-bahš̌ um pari Ruḥ-baȟš, die Tochter des Morādbah̆š, kämpfte. Sacd heiratete sie (4/625-626).

Im Kampf mit ‘Anqavil wird Ḥamze verletzt. Sein Pferd Ašqar rettet ihn, bei einem Sprung fällt Ḥamze aber von seinem Rücken. Der in der Stadt Ġorubiye lebende Malek Ġorub Šāh findet Ḥamze, pflegt ihn gesund und bekehrt sich durch ihn zum Islam. Sein Sohn Ṭolu‘ Šāh tadelt ihn wegen seiner Abkehr von Zomorrod, und der König lässt seinen Wesir und dessen Verwandte töten. Die Tochter des Wesirs, die dies Zomorrod mitteilen lassen wollte, wird gleichfalls getötet (4/630-631).

'Amr findet Ḥamze, als dieser mit Ġorub Šāh und einem großen Heer aufbricht. Als sie bei Ḥamzes ankommen, schildert man ihm die Grausamkeit des Ṭahmāsb. Nur ad-Dahr besiegt Tahmāsb und fordert ihn auf, sich zum Islam zu bekehren. Tahmāsb will nicht Muslim werden, verspricht Ḥamze aber, niemals wieder gegen ihn Krieg zu führen (4/632-633).

Ḥamze kämpft auf der Jagd gegen die verschleierte Ṣenoubar, die Schwester des Ṭahmāsb. Sie heirateten (4/ 634-635).

Zomorrod flieht nach 'Anțaliye zu seinem Vater Zardošt, der ein Zauberer ist und ebenfalls behauptet, ein Gott zu sein. Zardošt empfielt, Ḥamze mit einer List zu töten. Die Zauberin Zarrine, Schwester des Zardošt, verliebt sich in Rostam. Wenngleich er sie tötet, kommt kurz darauf kam eine alte Hexe Zomorrod zur Hilfe. Mit magischer Kraft kann Zomorrod Ḥamzes Helden festnehmen. 'Amr rettet sich mit seinem Gesang vor der Hexe Sarhnāb (4/640-641). Maleke, die muslimische Tochter des Zardošt teilt 'Amr mit, dass Zomorrod unverwundbar sei, und gibt ihm eine Tafel, mit deren Hilfe Ḥamze ihn besiegen kann (4/641).

Ḥamze besiegt Āšub Ḩātun, die Verlobte des Moẓaffar (4/643-644). Sarhāāb verzaubert die von ihr entführten Helden in Rehe (4/645). Hamze beschützt sein Heer, indem er eine Linie um die Soldaten zieht und die größten Namen Gottes rezitiert (4/645).

'Amr wird in einem Garten Zeuge einer Zauberzeremonie von Bahtak, Zomorrod und Zardošt (4/646-647). Ḥamze beschützt sein Heer vor dem Zauber der Wetterhexe, indem er

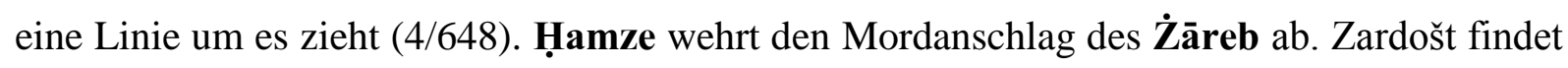
heraus, dass seine Tochter in Verbindung mit Hamze steht und wirft sie ins Gefängnis. Kankān nimmt 'Amr durch Zauberei fest und bringt ihn zu Zardošt.

Die Zauberin 'Azame hilft Ḥamze (4/652-653). Badi` kann mit ihrer Hilfe seine Brüder retten. Er tötet den Zauberer Aqsām im Kampf (4/655). Durch Zauberei nimmt Zarrine Ḥamzes Helden fest, und Zardošt sperrt Badic und Qāsem ins Gefängnis. Ḥamzes 
Kundschafter befreien 'Amr (4/656-658). Hamze töten den Zauberer Zarrāre. Durch magischen Regen macht die Wetterhexe Zarrine Hamze und seine Soldaten blind. Sie entführte die Helden und Söhne Hamzes, verliebt sich in 'Alam Šāh, wird aber von diesem getötet (4/ 659).

Mit Hilfe eines verschleierten Ritters befreit 'Amr Ḥamzes Söhne Badi' und Qāsem (4/659660). 'Amr nimmt die Gestalt des Kankān an, tötet die Hexen 'Unqā und Selsele, und heilt die Blindheit der Helden, indem er die Leber der Hexen auf ihre Augen reibt (4/660-661). Von Ḥamze festgenommen, lässt sich Zardošt zum Islam bekehren (4/662).

Ḥamze zerstört das Kloster des Zardošt mit dem sprechenden Kalb und dem sprechenden Sarg und errichtet eine Moschee (4/662-663).

Zomorrod flieht nach Āzār-kuh zu Alqāb und Anșāb. Zarrine befreit Zardošt wendet abermals einen Wetterzauber an. Zarrine und Zardošt werden von Nur ad-Dahr getötet (4/664665). Hamze wird von dem div Safāk entführt, der versteckt im Sarg von den Einwohnern der Stadt 'Anțali-ābād verehrt worden war. Soleimān-e sāāni tötete den div und befreit Ḥamze (4/668).

In Āzārkuh kämpft der unverwundbare Ṭahmāsb b. ‘Anqavil gegen Ḥamzes Sohn Širōye und tötet ihn. Sa`d nimmt Ṭahmāsb fest. Nachdem Nur ad-Dahr den Zardošt getötet hat, wird er von einer Hand aus einer Wolke entführt, die ihn in den Zauber des Aristoteles wirft. Nur ad-Dahr bricht den Zauber, sammelt ein Heer und zieht nach Āzār-kuh. Tahmāsb hat sich zwischenzeitlich befreit und kämpft gegen den verschleierten Ritter (Nur ad-Dahr). Dieser wirft Ṭahmāsb auf den Boden, tötet ihn aber nicht. Țahmāsb wird Nur ad-Dahrs Freund (4/666-668).

Nur ad-Dahr verlangt in einer Botschaft Hamzes Pferde. Als er nachts ein Pferd stehlen will, stellt sich ihm sein Vater Badic in den Weg, und beide ringen sieben Tage und Nächte miteinander. Der verschleierte Ritter verwundet Qāsem und Landehur im Kampf. Beim Kampf mit Ḥamze zerreißt der Schleier und Ḥamze erkennt Nur ad-Dahr (4/670-673). Kurze Zeit darauf wird Qāsem verdächtigt, Nur ad-Dahr getötet zu haben, und flieht. Qāsem wird getötet, und nacheinander erleiden Ḥamzes Helden den Tod (4/674-677).

Die Hexe La'le, Zarrines Schwester, verliebt sich in den von ihr entführten Nur ad-Dahr (4/677). Sie verspricht 'Amr, ihm Bahtak zu überantworten, wenn er Nur ad-Dahr ihr gewogen mache. 'Amr tötet La'le, indem er sie bewusstlos macht und ihren Magen dann mit geschmolzenem Blei füllt (4/680). Zomorrod flieht nach Āhtar zu seinem Bruder Lāhut. Nur ad-Dahr kämpft verschleiert gegen Lāhut und besiegt ihn. Ein Versuch des Zomorrod, Nur ad-Dahr entführen zu lassen, scheitert. 
Nur ad-Dahr nimmt Zomorrod im Kampf fest und bringt ihn in Hamzes Lager. Zomorrod kann sich befreien und flieht nach Ahtam. Als Ḥamze zu seiner Verfolgung aufbricht, hat 'Amr eine schreckliche Vorahnung (4/686). In Āhtam verwandelt sich 'Amr in die Gestalt von Bahtaks Kundschafter Zanbur und führt diesen in seiner eigenen Gestalt als 'Amr vor. Nachdem er den falschen 'Amr getötet hat, erkennt Bahtak den wahren 'Amr, der nachts von Ḥamzes Kundschaftern befreit wird. Indem 'Amr dem schlafenden As die Nase abschneidet, verstößt er gegen eine eindeutige Vereinbarung mit Ḥamze, und wird von diesem am kommenden Tag dem As überlassen (4/687-689). Zomorrod will 'Amr hängen lassen, ein Kundschafter befreit ihn (4/689). Da Hamze ihn nicht wieder bei sich aufnehmen will, behauptet 'Amr bei Zomorrod, dass er sich von Hamze getrennt habe. Mit Hilfe seines Verwandlungszaubers tötet 'Amr zahlreiche von Zomorrods Helden. 'Amrs Versuch, Ḥamze zu entführen, misslingt, und 'Amr begibt sich in die Stadt Farangušiye (4/690-693).

'Amr verkleidet sich als Geschäftsmann (4/692). In Farangušiye wird er Zeuge, wie Irăg, der Sohn des Händlers Farağ, einen im Schlamm versunkenen Kraftprotz rettet. 'Amr erkennt den Jungen durch sein grünes Mal als Nachkommen des Ḥamze (4/622-23). 'Amr lehrt Irağ die Kriegskunst, und jener tötet den Erpresser Kale-āhani. Am nächsten Tage sah er die Bewohner der Stadt zum Tempel gehen. 'Amr erfährt, dass die Einwohner von Farangušiye Sonnenanbeter sind (4/694-695).

In Āḩtam kämpfte As b. Anus gegen Ḥamze (4/699). 'Amr und Irağ erscheinen mit einer Armee und fordern Ḥamze auf, die Sonne zu verehren (4/699-700). Irăg gelingt es, bei einem Besuch bei Ḥamze das Schwert des Qobād aus der Scheide zu ziehen, und Ḥamze überlässt es ihm (4/701). Irağ freundet sich mit Nur ad-Dahr an, der ihm von der Verkleidung des 'Amr erzählt (4/703). 'Amr zieht nach Kešvariye, wo er den Jungen Dārāb durch sein grünes Mal als Nachkommen Ḥamzes identifiziert. 'Amr tötet den Priester der Wasseranbeter und verkleidet sich selbst als Priester (4/703-704). Zusammen machen sich 'Amr und Dārāb mit ihrer Armee auf den Weg.

Sa`d schickt Nur ad-Dahr zur Festung Z Zu 'l-Amān, wo er den Belagerer, Zalzāls Sohn Badr, besiegt. Badr täuscht vor, sich zum Islam zu bekehren. Badi` rettet Nur ad-Dahr und beide ziehen nach Āhtam (4/703-704). Da Ḥamze aus Sorge um seinen Vater nach Mekka zieht, ergreift Sāḥḥar Šāh, der Herrscher von Sāḥḥriye, die Gelegenheit, mit einer List Ḥamzes Helden festzunehmen. Dārāb besiegt Sāḥḥar Šāh und nimmt ihn fest. 'Amr lässt dem zurückgekehrten Ḥamze den Krieg erklären (4/704-705). Irağ und Nur ad-Dahr verwunden Dārāb im Kampf (4/705-706). Qāsem wird auf der Jagd von einem Drachen verschluckt (4/707). 
'Amr zieht zu den Mondanbetern nach Turağ (4/707). Er wird festgenommen und zu Laknāt, dem König der Schwarzen, gebracht, wo er sich durch Gesang retten kann. In Gestalt von Laknāt befiehlt er dessen Sohn Lakman, mit ihm und dem Heer zu Zomorrod zu reiten. Auf dem Schlachtfeld besiegt Lakman Fariborz b. Malek Helāl und nimmt ihn fest. Durch einen Traum versöhnt sich Ḥamze wieder mit 'Amr (4/708-709).

Zomorrod flieht nach Faranqušiye und verspricht Irağ seine Tochter Gouhar Malek als Frau (4/710). Im Kampf fallen Irăg und Nur ad-Dahr ins Wasser. Nur ad-Dahr besiegt den Wegelagerer Bahrām. In der Stadt Taḩt-e leqā rettet er Irağ-e tāğ-bahšs, den Sohn des Hosrou Šāh, aus einem Zauber, und Hosrou Šāh lässt sich zum Islam bekehren. Irağ rettet den Jungen Ğamšid-e la'l-qabā, den Sohn des Zomorrod-qabā, vor einem Löwen, und Zomorrod-qabās lässt sich als Sonnenanbeter bekehren. Zurück in Ḥamzes Lager, ist Irağ zunächst darüber betrübt, dass Nur ad-Dahr vermisst wird. Als jener wieder auftaucht, ärgert er sich aber darüber, dass Nur ad-Dahr mit Irağ-e tāğ-bahš zusammen ist und trennt sich von ihm (4/712-713). Nur ad-Dahr verliebt sich durch ein Portrait in die von dem div Qilās entführte Keivān Šāhs Tochter, Königs von Keivān-ābād (4/713). Nur ad-Dahr zieht nach Keivān-ābād. Irağ erfährt in der Stadt Ḥāmediye von König Ḥāmed Šāh, dass dessen Sohn Ḥamid in Keivān Šāhs Tochter verliebt ist, und zieht gleichfalls nach Keivān-ābād. Als der div Qilās versteht, dass Nur ad-Dahr und Irağ das Mädchen aus seiner Gewalt befreien wollen, entführt er Nur ad-Dahr und wirft ihn ins Meer. Ḥamze kommt nach Keivān-ābād (4/714-716). In Faranqušiye entführen die Kundschafter des Farağ den Landehur, der von Karib wieder befreit wird. Zusammen erobern und verwüsten sie die Stadt.

Nur ad-Dahr befreit auf einer Insel den König von Zevariye, Zevar Šāh, der sich zum Islam bekehren lässt (4/717-718). Der inzwischen auch nach Keivān-ābād gekommene Zomorrod lädt Irağ zu sich ein und zieht ihn auf seine Seite, so dass er gegen Ḥamze kämpft (4/718). Landehur trifft mit der Kriegsbeute aus Faranqušiye ein. Nur ad-Dahr kehrt nach Keivānābād zurück.

Inzwischen sang 'Amr immer noch für den Dämon. Der Dämon sperrte ihn in einen Sack. Eines 'Amr bringt den div dazu, Baḩtak zu holen. Er macht den Dämon bewusstlos, tötet ihn und befreit die Prinzessin. Danach verkleidet er Bahtak als Braut und schickt ihn in Ḥamids Frauengemach. Als Hamid mit der Braut schlafen will, bemerkt er, dass sie ein Mann ist. 'Amr bringt Māhnušlab zu Nur ad-Dahr, der sie heiratet. Asad tötet Ḥamid und verbrennt seine Leiche. Die Ungläubigen hören, dass Irağs Kopf abgeschlagen worden sei, und Zomorrod flieht in das Reich der Finsternis zu seinem Bruder Zebarğad Šāh (4/719-725). 


\section{$5.5 \quad$ Buch 5}

Die in Irağ verliebte Hexe 'Unqārus entführt ihn, wird aber von ihm getötet (5/728). In einem Garten verliebt er sich in Giti-afruz, die Tochter des Zomorrod. Irağ begibt sich mit vielen Juwelen zu Šāh Soleimān nach Ḥabāyil (Ṣabāyil), wo er in Ḥamzes Frauengemach Giti-afruz sieht (5/729-731). Auf der Insel Kāfuriye besiegt Irağ den Micād, der sich zum Sonnenanbeter bekehren lässt (5/731).

Der div Mahārus entführt Irağs Freund Eqbāl Šāh. Irağ folgt ihm, besiegt ihn im Kampf und befreit seinen Freund. Der div verspricht, Irağ die von ihm bewachten Schätze des Alexander zu überlassen. Asad plündert den Schatz und entführt Eqbāl. In Faranqušiye baut er aus den Schädeln der getöteten Sonnenanbeter hohe Türme (5/731). Irağ begibt sich nach Faranqušiye (5/734-735). Asad kämpft gegen die Armee des Irağ. In der Nähe von Irağs Armee gab es eine Festung. Der Dieb Zarqām stiehlt den Schatz, bekehrt sich durch Asad jedoch zum Islam (5/735). Irăg besiegt Landehur, der ihm Ḥamzes Zelt und andere Gegenstände überlassen muss (5/737-738). Asad plündert daraufhin Landehurs Schatzkammern. Irağ und Landehur ziehen nach Faranqušiye, wo ihnen der König von Torkestān, Tomġāğ Hāan, den Krieg erklärt (5/739). Asad tötet die ihm nachgeschickten Soldaten des Irăg (5/740).

Zomorrod flieht zur Insel der Baumanbeter. Ḥamze bringt ihren Herrscher Qahrāq Šāh dazu, sich zum Islam zu bekehren, indem er einen auf dem angebetenen Baum liegenden Zauber, der mit dem Salomos Ring erbunden ist, entfernt (5/740-741).

Zomorrod flieht ins Reich der Finsternis, wo er einen goldenen Damm errichtet. Ḥamze belagert die Stadt sieben Monate lang, bis Zarqum Šāh sich durch einen Traum zum Islam bekehrt und Ḥamze die Stadt überlässt (5/741).

Irağ belagert die Festung des Asad. Asad wird von einer in ihn verliebten Zauberin entführt, die er tötet (5/744). Irağ wird durch eine Hand aus einer Wolke entführt. Er trifft auf die pari ‘̄̄lam-ārā, deren Vater von dem div Afrug entführt wurde. Iră̌ besiegt Afrug im Kampf, und jener wird zum Sonnenanbeter. Afrug bringt Irağ an einen Brunnen im Osten, aus dem bei Sonnenaufgang eine Stimme ertönt, die so laut ist, dass er bewusstlos wird (5/745-746). Irağ besiegt Asad, der sich aber befreien kann. In Hānbāleq sieht Irağ, dass Sacd b. Qobād mit Ṣalṣāl kämpft. Irağ kämpft mit Șalṣāl, der aber von einer Hand aus einer Wolke zur Höhle des Afrāsiyāb entführt wird. Irağ befreit Qahreš und reitet nach Hațā. Sacd b. Qobād lädt Irağ und verärgert damit Asad (5/746-747). Irağ kommt nach Șabāyil, um die Stadt zu erobern und Giti-afruz an sich zu nehmen. Irağ erobert Șabāyil (5/748). 
Irağ besiegt den Mondanbeter Turağ (5/749). Turağ wird von seinem Pferd zu einem Müller gebracht, der ihn gesundpflegt. Im Garten trifft Tură̌ das Mädchen Ġazāl, deren Vater Ğamšid König der Stadt Zehre-zanğir ist. Turağ besiegt den in das Mädchen verliebten div Afruz, der verspricht, ihm zu dienen. Turağ heiratet Ġazāl und zieht mit den Truppen des Ğamšid nach Faranqušiye (5/749).

Als Asad mit Irağ kämpft, wird dieser von einer Hand aus einer Wolke entführt. Der div Afruz bringt Irağ zu Turağ, der ihn auffordert, den Mond anzubeten. Als er sich weigert, wird eingesperrt, kann sich aber befreien.

Ṭarmāsb b. Țahmāsb kämpft in 'Anqavil gegen die Muslime und die Sonnenanbeter. Er wird von Irağ besiegt. Asad sieht ein, dass er nicht gegen Iră̌ bestehen kann und zieht ins Reich der Finsternis. Ḥamze schickt Nur ad-Dahr nach Bāhntar, wo er gegen Irağ kämpfen und ihn aufhalten soll.

Irağ nimmt die Stadt Āḩtam ein und lässt viele Einwohner töten. Wenngleich Landehur ihn tadelt, wagt er es nicht, das von Ḥamze befohlene Bündnis mit Irağ zu brechen (5/753).

Irağ kommt zu der Stadt Morrașa'-negār, in der Landehurs Sohn Ḥāris herrscht. Die Sonnenanbeter können Ḥāris gefangennehmen, der aber durch Asad befreit wird. Ḥāris reitet ins Reich der Finsternis (5/753-754).

Ṭarmāsb fährt mit Hormoz b. Anōširvān auf einem Schiff ins Reich der Finsternis. Ein großer Alligator zerstört die Schiffe. Hormoz kommt auf die Insel der Menschenfresser (5/754), kann sich aber befreien. Nur ad-Dahr tötet den div Aḩrās, dem Manṣur, der Sohn des Königs Șadrān, geopfert werden sollte. Er besiegt die Menschenfresser des Ṭamud b. ‘Ād und bekehrt ihn zum Islam. Bei der Belagerung der Stadt Faranqušiye wird Nur ad-Dahr von den Sonnenanbetern gefangengenommen.

Irăg besiegt den verschleierten Ritter Behzād, der sich ihm anschließt (5/756). Lakman-e zangi ist empört darüber, dass Behzād einen ehrenvolleren Platz als er erhält und schließt sich Asad an (5/756).

Iră̌ will Nur ad-Dahr töten lassen. Asad erfährt von dem Plan, erobert Faranqušiye und befreit Nur ad-Dahr (5/756-758). Lakman wendet sich Asad zu, und zusammen plündern sie das salomonische Zelt des Irağ (5/759). Mālek-e Aštar und Dārāb erobern das Zelt von Lakman, Asad kann es aber zurückholen. Die Heere von Asad, Nur ad-Dahr, Irağ, Landehur,

Dārāb, Mālek, Lāhut, Zomorrods Sohn und Turağ bringen sich in Position (5/760-761). Irăg ist von einer edlen Tat des Nur ad-Dahr so beeindruckt, dass er ihn aufsucht. Als Asad dies sieht, beschimpft er die Sonnenanbeter (5/763). Irağ erobert Faranqušiye und zieht nach Moštari-ḥesār (5/766-767). Deren Herrscher Soheil Hुān ruft die Hexe 'Arāf zu Hilfe, die 
durch Wetterzauber zunächst einen Abbruch der Belagerung erreicht (5/768). Schließlich aber erobern die Soldaten des Irağ die Festung, und viele Einwohner werden getötet (5/769).

In Abwesenheit Ḥamzes erscheinen Badi` az-Zamān und sein Sohn Nur ad-Dahr als gleichwertige Gegner des Irağ. Beim Kampf wird Nur ad-Dahr von einer Hand aus einer Wolke entführt und in einen Audienzsaal gebracht. Er soll gegen einen verschleierten Kämpfer antreten, erkennt in diesem aber Zohre, die Tochter des Keivān-e anğom-sepāh. Nur ad-Dahr kämpft mit dem Feldherrn des Horšid Šāh, der um das Mädchen werben ließ, und tötet ihn. Keivān fesselt Nur ad-Dahr durch eine List. Als er ihn töten will, kommen die Menschenfresser (5/770-772). Schließlich lässt Keivān sich zum Islam bekehren, und Nur adDahr heiratet Zohre (5/773). Danach erobert er Faranqušiye (5/774).

In Saḥḥāriye kämpft Irăg gegen Manṣur-e Kāmrān und dessen Doppelgänger, den div Fulād. Asad kann das salomonische Zelt wieder in seinen Besitz bringen und tötet Fulād. Tahmāsb b. 'Anqavil hilft Asad gegen die Truppen des Irağ. Nur ad-Dahr erobert die Festung Ganğuriye, wo sich die Schätze des Irağ befinden (5/775). Danach besiegt er Sāren in der Festung Qamarbaḩš. Sāren lehnt es ab, sich zum Islam zu bekehren, und wird von Nur ad-Dahr getötet (5/776). Danach erobert Nur ad-Dahr die Festung Āftāb-namā (5/776). Ṭahmāsb verwundet seinen Sohn Țarmāsb im Kampf, wird aber seinerseits von Irăg verwundet (5/777).

Zomorrod ist zu Yaḥyā Šāh, dem König des Reichs der Finsternis, geflohen. Von Baḩtak gewarnt, schickt der König seinen Kundschafter Ğahāngir aus, um 'Amr festzunehmen. 'Amr nimmt ihn fest und schneidet ihm die Zunge ab. Dann verkleidete er sich als Ğahāngir und gibt Ğahāngir seine eigene Gestalt und ging so zum König. Als Bahtak das Blut des vermeintlichen 'Amr trinkt, teilt der richtige 'Amr den Sachverhalt in einem Lied mit (5/778779).

Im Reich der Finsternis wird Yaġmā von Badi` gefangen genommen und bekehrt sich zum Islam. Zomorrod flieht zu seinem älteren Bruder Zebarğad Šāh, der eine Zaubertafel besitzt, durch die ihm die Leute gehorchen müssen. Weil Zomorrod sich selbst zum Gott erklärt hatte, wollte Zebarğad ihn bestrafen, aber sein Wesir verhinderte dies. 'Amr, der das Lager des Zebarğad auskundschaften will, wird von einem Zauberhuhn entdeckt und gefangen genommen (5/780-781). Zebarğad schickt 'Amr zu Ḥamze gehe, und Ḥamze schickt Badi` mit einem Schreiben an Zebarğad, in dem er verlangt, den einen Gott anzubeten. Zebarğad verzaubert Badi` und macht ihn zum Götzenanbeter. Durch Zauberei kann Zebarğad Ḥamzes Freunde gefangen nehmen (5/783). 
Die Zauberin Damāme verwandelt 'Amr in ein Reh. Ein Mädchen gibt ihm seine menschliche Gestalt zurück und ermutigt ihn, Damāme zu töten (5/784). 'Amr entführt die Zaubertafel des Zebarğad, wodurch sie wirkungslos wird (5/784). So kann Ḥamze die Stadt erobern und Zomorrod und Zebarğad festnehmen (5/784).

Dārāb erobert Āhtam. Danach will er in 'Ağam den dortigen Statthalter Qahramān-e 'A ğam töten. Ġażanfar b. Asad tötet Abraha, Dārābs Gefolgsmann, und befreit Qahramān. Als 'Anqavil hört, dass Ṭahmāsb durch Irăg verwundet worden ist, kämpfte er gegen Irăg, wird aber von diesem verletzt (5/787-788).

Ğahān-ārā, die Geliebte Sārens, erfährt von seinem Tod und entführt Nur ad-Dahr, verliebt sich aber in ihn. Durch eine Zauberformel verliebt sich der Prinz in sie, erkennt sie aber an ihrem Mundgeruch als Hexe. Del-afruz, die Tochter des Nilgun Šāh, erfährt von der Liebe der Ğahān-ārā zu Nur ad-Dahr und verspricht, ihr zu helfen. Als Nur ad-Dahr sich in Ğahān-ārā verliebt, will die Hexe sie töten. Nachts tauscht Ğahān-ārā ihren Platz mit ihrer Amme, welche die Hexe dann tötet. Schließlich gelingt es Del-afruz, die Hexe zu töten. Nur ad-Dahr und Del-afruz heiraten, und sie und ihr Vater werden Muslime (5/788-789).

Dārāb erobert 'Ağam und tötet Qahramān. In Sanğān wird er durch eine List festgenommen (5/789). Badr b. Zalzāl von der Insel Fanduq trifft in Sanğān ein. Die Feldherren des Badic befreien Dārāb und Mālek, und Dārāb besiegt Badr. Dārāb zieht nach Șabāyil (5/792). Der Mondanbeter Turağ schließt sich Dārāb an, und zusammen ziehen sie zu dem Lager des Irağ. In Darband-e Ṭāvusiye kämpft Dārāb gegen die Feldherren des Badic (5/805).

Asad entführt die Braut des Eqbāl Šāh, des Sohns von Mālek Malakut, und verliebt sich in sie (5/790-791). Irağ tötet Āqdāšs kešide-ru. Asad entführt Eqbāl und tötet ihn später (5/799). Nur ad-Dahr richtet die Hochzeit für Asad und das Mädchen aus. Die Sonnenanbeter und die Gottesanbeter nehmen gemeinsam an der Hochzeit teil (5/790-810).

Auf dem Weg nach Āhttam wird Nur ad-Dahr von dem Wesir des Zarhāb Šāh gebeten, dessen von einem Drachen entführten Sohn zu retten (5/791-792). Er schießt einen Pfeil auf den Drachen, den dieser aber verschluckt. Nur ad-Dahr findet sich in einem Garten wieder. Als er etwas Obst pflücken will, ziehen die Bäume ihre Äste weg. Nachdem er geschlafen hat, findet er sich auf einem Schiff wieder, dessen Leute nicht mit reden. Sie teilen ihm mit, dass er im sich im Einbildungstalisman des Salomo befinde, wo nur derjenige zu essen erhalte, der nie spreche. Im Traum erfährt Nur ad-Dahr von Salomo, wie er den Zauber brechen kann. Er befreit den Sohn des Zarhāb, und der König und seine Untertanen werden zu Muslimen (5/794-795). Über Āḩtam zieht Nur ad-Dahr nach Morraṣa'-negār. Der Kundschafter Šabāhang macht ihn bewusstlos und bringt ihn zu seinem Herrn, dem Sonnenanbeter Qonud, 
der ihn ins Gefängnis wirft (5/796). Als der Kundschafter des Nur ad-Dahr, Zarqām, ihn befreien will, helfen ihm 40 in Schwarz gekleidete Männer. Zarqām erfährt, dass die schwarz Gekleideten Frauen sind, und verliebt sich in die Anführerin, Qonuds Tochter Sarv-e ḩarāmān. Die beiden heirateten (5/800), und Qonud lässt sich zum Islam bekehren. Auf dem Weg nach Āzār-kuh, besiegt Nur ad-Dahr Ṭarmāsb (5/804).

Irağ lässt seinen Wesir Qāren einen Brief an Giti-afruz überbringen. Er kam nach Znu 'lAmān, wo er Zugang zu Ḥamzes Frauen findet und Giti-afruz, der Frau des Qāsems, den Brief übergibt. Die Dienstleute der verärgerten Giti-afruz vertreiben Qāren aus der Festung (5/ 798-799).

Qāsems Söhne Falakzād und Malekzād kämpfen im Lager des Irağ gegen ihn. Irağ besiegt sie und nimmt auch Nur al-‘Ayān und Nur az-Zamān, die Söhne des Badi` az-Zamān, fest (5/801). Asad entführt Behzād und Arsalān Šāh, den Sohn des Mālek Malakut, um sie gegen die Gefangenen auszutauschen. Der Sohn des Qerān befreit die Prinzen aus der Gefangenschaft des Irăg (5/802-803).

Als Irağ den Qahreš hinrichten lässt, reitet Asad zu seinem Lager, wo ihn der Kundschafter Div-čehr bewusstlos macht und mitnehmen will. Asad wird von Zarqām befreit (5/803). In der Schlacht gelingt es Asad, das salomonische Zelt des Iră̌ in seinen Besitz zu bringen. Danach flieht er und bringt das Zelt zu Nur ad-Dahr. Dieser weist darauf hin, dass Hamze das Zelt dem Landehur gegeben habe (5/806).

Zebarğad kann sich befreien und flieht mit Zomorrod nach Sadd-e Čalipā. Als Ḥamze dort eintrifft, bekehrt sich der König kampflos zum Islam, und Ḥamze lässt ihm die Königswürde $(5 / 808)$.

Zomorrod flieht in die Stadt Damm Astfāfil. Bei der Verfolgung kommen Hamze und seine Feldherren zu einem Obelisken an einem Brunnen, dessen Spitze wie ein Menschenkopf ist. Um den Obelisken herum war eine Schrift, die niemand lesen konnte. Badi` az-Zamān tötet einen Löwen, der täglich mit einem div kämpft, worauf 100.000 Löwen erscheinen und sein Heer vernichteten. Badi` az-Zamān wird bewusstlos. Als er wieder zu sich kommt, fragt ihn der Löwe wer er sei. Als der Löwe erfährt, dass Badi` az-Zamān der Sohn des Ḥamzes ist, entschuldigt er sich bei ihm. Badi` az-Zamān sagte: „Jetzt sag du, wer du bist?“ Der Löwe erklärt ihm, dass sowohl er als auch der Div zur Zeit Salomosbeansprucht hatten, Herrscher der Dschinn zu sein. Wegen ihres Streits habe Salomo sie verflucht. Der Zauber könne nur durch ihn selbst gelöst werden. Im Traum erfährt Badi` az-Zamān von Salomo, dass er den Talisman Zauber erst nach Ḥamzes Tod brechen könne. Durch eine Hand wird Badic azZamān an einen Ort entführt, zu dem bereits alle Helden Ḥamzes sowie Ḥamze und 'Amr 
entführt worden sind. Durch einen Schutzzauber kann die dort lebende Hexe Hamze nicht verzaubern und bekehrt sich schließlich zum Islam. Sie befreite Hamze und seine Freunde (5/808-809).

Im Zelt des Nur ad-Dahr sieht Asad, dass diesem der Kopf abgeschnitten wurde. Allerdings ist dies nur ein Trugbild. Als Nur ad-Dahr seine Augen öffnet, befindet er sich in einem Garten. Die in ihn verliebte Hexe Badre hat ihn dorthin entführt. Als er sie töten will, kann er sich nicht mehr bewegen. Am Ende wird die Hexe durch einen unbekannten Helden getötet und der Prinz wird befreit. Der Befreier will sich nicht zu erkennen geben (5/812-813).

Die muslimischen Kundschafter entführen Irağ und bringen ihn zu Asad. Als Asad ihn töten will, wird Irağ durch einen div entführt (5/812-813). Asad erfährt Unterstützung von einem grün verschleierten Ritter, der sich als Eskandar-e Farroh-leqā, Ḥamzes Sohn von der Tochter des Marzbān-e Horāsāni, zu erkennen gibt.

Irağ ist von dem div Qirān entführt worden. Er ist in die Tochter des divs Šangāl verliebt, der von ihm verlangt hat, ihm den Spiegel des Alexander zu bringen. Der div Afrāq, der Wächter des Spiegels, hat ihn allerdings festgenommen und wollte ihn töten. Nach seiner Freilassung hat er erfahren, dass Irağ der Herrscher des Zaubers ist, und ihn deswegen entführt. Irağ besiegt den div Afrāq, und der Dämon übergibt ihm den Spiegel und wird durch ihn zum Sonnenanbeter. Mit Hilfe des Spiegels erfährt Irağ den Aufenthaltsort des Asad, aber Asad flieht, wobei er sich fragt, wie Irağ ihn finden konnte (5/814).

Sarhang, der Irağ entführt hat, trifft auf einen hässlichen Alten. Dies ist der Zauberer Nāqus, der in Malek Zardošt, die Tochter des Zardošt, verliebt ist. Da sie 'Amr geheiratet hat, ist er dessen Feind. Irăg will Sarhang töten, hält sich aber zurück, da nur Sarhang den Aufenthaltsort des von ihm entführten Behzād kennt. Als Irağ betrunken ist, gesteht er seine Liebe zu Giti-afruz. Der Zauberer fliegt als Adler nach Z Zu 'l-Amān, sein Versuch, Giti-afruz zu entführen, misslingt aber durch die Wachsamkeit der Gouhar-Malek (5/816-817).

Irăg erobert die Festung Armān mit den Schätzen des 'Amrs. Asad plündert die Schatzkammern des Irağ. Asad wird von einer Hand entführt. Er wirft den div 'Arāk, der ihn entführt hat, auf den Boden, tötet ihn aber nicht, als dieser verspricht, ihm den Ğamšids Zauberbecher, Ğām-e Ğahān-namā, und den div Qahqahe-ye zu beschaffen. Asad sagte: „Nimm mich mir dir, und ich werde mit ihm kämpfen.“ 'Arāk fliegt mit ihm zu dem Zauber, wo Asad ein Rad zerstört und sich in einen Brunnen wirft. Er tötet Qahqahe und den Zauberer Keihān. In einem Gewölbe findet er Ǧamšids Zauberbecher und nimmt ihn mit. 'Arāk teilt ihm mit, dass er durch eine Gebetsformel alles sehen könne, was er möchte (5/817-818). 
Von Zarqām erfährt Asad, dass Iră̆ den Spiegel des Alexander in seiner Tasche aufbewahrt. Als Irağs den Spiegel eines Tages benutzt, prahlt Asad mit dem Besitz des Ğām-e ğahānnamā. Asad stiehlt den Spiegel (5/818).

In Ǵorubiye erzählt der dortige König Irağ von einem dreiäugigen Fohlen, dass Ḥamzes Pferd Ašqar zusammen mit einem Pferd aus dem Meer gezeugt habe. Irağ zähmt das Pferd und reitet auf ihm fort. Šabrang, einer der Kundschafter von Asad, teilt ihm dies mit, und Asad stiehlt das Pferd (5/821-822).

Ṭarmāsb tötet Ardešir-e tond-hyu, den Neffen des 'Anqavil (5/819). ‘Anqavil verlangt von Irağ die Herausgabe des Țarmāsb. Im Kampf tötet Țarmāsb den 'Anqavil (5/822). Ṭahmāsb kämpft gegen seinen Sohn Ṭarmāsb und Irağ. Irağ besiegt einen verschleierten Reiter, der die Herausgabe des Landehur fordert, und erkennt in ihm Landehurs Sohn Ṭalha. Da dieser sich ihm nicht unterwerfen will, tötet er ihn (5/822-823). Asad und Țahmāsb kämpfen gegen Irağ. Beim Kampf mit Ṭahmāsb wird Iră̌ von einer Hand aus einer Wolke entführt (5/824-825), kommt aber bald wieder zu seinen Truppen zurück. Mit dem Schiff unterwegs nach Sabāyil, kommt Irağ zu Eskandar Šāh, den König von Alexandria. Durch einen Traum erlangt er das zweischneidige Schwert Alexanders (5/824-825).

Iră̌ nimmt Asad im Kampf gefangen. Asad will ihm gehorchen unter der Bedingung, dass Iră̌ in Asads Gegenwart den Namen von Giti-afruz, der Frau des Qāsem, nicht nennen darf. Als Asads Kundschafter Irağ entführen will, wird er von Irăg getötet (5/825). Asad macht Irağ betrunken, und Irağ vergisst die Bedingung und ruft den Namen der Giti-afruz in Asads Gegenwart aus. Asad wirft sich ins Meer und entkommt. Als er wieder an Land ist und sich niedergeschlagen erhängen will, zerreißt ein vorbeikommender Reiter das Seil. Asad fällt auf den Boden und wird bewusstlos. Als er wieder zu sich kommt, erhält Asad von einem ehrwürdigen Mann die Kraft übertragen, Iră̌ zu überwinden (5/825-826).

Ḥamze kommt in die Stadt Damm Astfāfil, wo die Brüder 'Aṭal al-Ǧibāl und Ḥağar alǦibāl herrschen. Zusammen mit 'Amr und Moqbel zerstört er einen Zauber, darunter einen von Magneten in der Luft gehaltenen Sarg. Adler heben Hamze in die Luft, er wird aber durch die von seiner Tochter Qoreiši befehligten Dive gerettet. 'Ațal al-Ǧibāl und Ḥağar alǦibāl bekehren sie sich zum Islam. Zomorrod flieht (5/827).

Irağ zieht wieder nach Șabāyil, wo er erfolglos versucht, Šāh Soleimān dazu zu bewegen, ihm Giti-afruz auszuhändigen (5/828-829).

Zomorrod flieht zu der dreiäugigen Qahqahe in die Hauptstadt von Ǧān b. Ğān. Auf Veranlassung von Zomorrod und Baḩtak lässt Qahqahe den Ḥamze durch Somnun, einen 
Kundschafter des divs Zarrin-bāl entführen. Wenngleich Zomorrod befiehlt, Hạze zu töten, wirft Qahqahe ihn zunächst nur ins Gefängnis der Stadt Pošte-ye tārik (5/830).

Nur ad-Dahr hat sich aus der Gefangenschaft der Badre befreit und erfährt in Moštari-ḥeṣār, dass Asad sich ins Meer geworfen hat. In 'Anțali-ābād nimmt er Leis b. 'Uğān fest und wirft ihn ins Gefängnis. Über die Festung Armān reitet er nach Alexandria (5/830).

Da Irağ die Stadt Șabāyil nicht erobern kann, reitet er zur Festung Zֵu 'l-Amān. Dort beschließen die Frauen, gegen Irăg zu kämpfen. Gordiye kämpft mit Behzād und zerschmettert ihn. Im Kampf gegen Irağ erfährt Gordiye die Hilfe der Șeboubar hāatun. Während Ḥamzes Frauen kurz vor der Niederlage stehen, kommen ihnen gewaltige Truppen zur Hilfe, darunter die des Ġażanfar b. Asad (5/831). Vereint können die Frauen die Truppen des Irağ schlagen. Horšid-e tāğ-bahš, die Tochter der Giti-afruz, verletzt Irağ mit einem Schwerthieb. Schließlich wird Irăg durch die verschleierten Männer festgenommen (5/831).

Asad macht sich auf den Weg, um mit Irağ zu kämpfen. Auf dem Weg trifft er auf eine Trauergemeinde, die Farrohy, den Sohn des Šahāb, des Herrschers von Mehrāqiye zu Grabe tragen, der beim Versuch, ein Meerpferd zu fangen, getötet wurden. Asad findet das Pferd, zähmt es mit einem Faustschlag und macht sich wieder auf den Weg, um mit Irağ zu kämpfen (5/831). Unterwegs besiegt er den Königs Ğamšid, der ihm das Pferd mit Gewalt wegnehmen will. Der König bekehrt sich zum Islam und wendet sich Asad zu. Er besiegt einen Drachen und bekehrt hierdurch die Brüdern Soheil-e huun-āšām und Komeil-e moštzan zum Islam (5/833).

Sacd will den von Qahqahe gefangengenommenen Ḥamze befreien (5/826). Als sie unterwegs einige Tage rasten, werden nacheinander zuerst Badi` az-Zamān und Karib und dann die anderen Helden entführt. 'Amr, der Erkundigungen einholen soll, wird von einer Hand entführt. Als 'Amr wieder zu sich kommt, befindet er sich in einem Garten. Die Zauberin Raḩšān gesteht ihm, dass sie in Abu 'l-houl, den Sohn des Qandoz, verliebt sei und die Helden entführt habe, damit 'Amr komme, um sie zu befreien. 'Amr verspricht ihr gegen fünf Kisten Juwelen zu helfen. Er spricht mit Abu 'l-houl und überredet ihn, Raḩšān zu heiraten. Danach bekehrt sich Rahš̌ān zum Islam. Wenngleich 'Amr sie auffordert, mit der Hexerei aufzuhören, will sie dies nicht tun, da sie den Muslimen helfen möchte (5/832). In einer Wüste trifft Rahš̌ān die Hexe Āq-Wāq, die erfolglos versucht hat, dem islamischen Heer zu schaden. Āq-Wāq übergibt Raḩšān vertrauensvoll vier Papiere, die ihre gesamte Zauberkraft enthalten, zur Aufbewahrung. Raḩšān gibt sie an Sa`d weiter, der durch Verbrennen der Papiere nacheinander die Zauber der Āq-Wāq vernichten kann (5/833-834). 
In Șabāyil stellt sich Ṭarmāsb dem Heer des Nur ad-Dahr entgegen. Als Ṭahmāsb seinen Sohn auf dem Kampfplatz sieht, fordert er ihn auf, sich Nur ad-Dahr anzuschließen. Als Ṭarmāsb sich mit unverschämten Worten dagegen verwahrt, kämpft Ṭahmāsb gegen ihn und tötet ihn (5/836).

Irağ gelingt es, die Stadt Șabāyil von der Wasserzufuhr abzuschneiden (5/837). Als er sie endlich erobert, zerstört er alles und plündert den Garten des Zomorrod, in dem die Bäume aus Gold und Edelsteinen waren (5/837-838).

In der Festung Zu 'l-Amān sieht Irağ die Frauen des Ḥamze. Als Šāh Soleimān dies erfährt, gibt er Befehl, die Frauen zu töten, aber Gordiye verwahrt sich dagegen (5/834). Šāh Soleimān hindert die Frauen an einem nächtlichen Überfall auf Irağ auszuführen. Als die Frauen ein Gelage abhalten, tadelt Gouhar Malek die Giti-afruz wegen ihres Verhaltens (5/836). Giti-afruz ist verzweifelt und will sich vergiften. Gordiye hindert sie daran, und Gouhar Malek und entschuldigt sich bei ihr (5/841). Farhād Hōan besiegt seinen Vater Landehur und nimmt ihn fest (5/840). Irağ wird entführt (5/841).

Bahrām-e hanğar-gozār, der seine Festung in der Nähe von ZZu 'l-Amān hat, lässt Irağ durch seinen Kundschafter Ḥāres entführen. Bahrām will Irağ töten, lässt ihn aber auf Rat seines Wesirs ins Gefängnis werfen. Als Ḥāres erfährt, dass Bahrām ihm nicht, wie versprochen, seine Tochter zur Frau geben will, befreit er Irağ. Irağ will Bahrām töten, lässt aber davon ab, als Bahrām verspricht, dass er Sonnenanbeter werde. Nun will Bahrām den Iră̌ vergiften lassen, dieser wird aber von der Tochter des Bahrām gewarnt. Von Bahrām aufgefordert den Becher mit Gift zu trinken, will Iră̆ ihm den Vortritt lassen. Bahrām wirft den Becher zu Boden und will fliehen, aber Irağ tötet ihn (5/842).

In Qāf kämpfen derweil die paris unter Führung von Asmā̄' und Qoreiši gegen Qahqahe und Zomorrod. Die paris fliehen in die Goldene Stadt, und Asmā' schickt den div Tondak um Hilfe zu Badi` az-Zamān und Nur ad-Dahr. Der div Zarrine, der Doppelgänger Zomorrods, kämpft mit Qoreiši. Qoreiši schlägt ihn, kann ihn aber wegen seiner Unverwundbarkeit nicht verletzen. Tondak bringt Asad zur Goldenen Stadt. Asad kämpft gegen Zarrine, überwindet ihn und nimmt ihn fest. Zomorrod lässt Asad entführen, und Qahqahe fesselt ihn mit einer schweren Kette, die Asad aber zerreißen kann. Wenngleich Zomorrod von Bahtak erfährt, dass Asad seine übermenschliche Kraft durch die Gnade eines Heiligen erhalten hat, will Qahqahe sich ihm am kommenden Tag stellen. Asmā' warnt Asad, aber dieser ist voller Zuversicht (5/843-846).

Nachdem Irağ den Bahrām getötet hat, trifft er auf einen verwundeten Feueranbeter. Dieser erzählt ihm, dass die Brüder Hušang und Ğušang ihm 72 Kaftane geraubt haben, die er von 
seinem Herrn, dem dreiäugigen Zolāl, zu Lāhut Šāh, dem Sohn des Zomorrods, bringen sollte. Als Irağ die Brüder zum Kampf fodert, ergeben sie sich kampflos und übergeben ihm ihr Beutegut (5/842).

$\operatorname{Sa}^{c} d$ und Raḩšān erreichen den Berg Bolur, wo Ḥamze in einer Grube gefangen ist (5/842). Der Prophet Salomo zeigt 'Amr im Traum den Weg, und 'Amr befreit Ḥamze (5/846).

Zomorrod erfährt durch Bahtak, dass Glück und Macht der Gottesanbeter durch Priester in der Stadt Landesāriye untergehen werden (5/847). Zomorrod und Bahtak fliehen nach Landesāriye, aber der dortige König verweist sie an Neyram-e Susan-parast in der Wüste Sargardān-e Qāf (5/848). Neyram ist Lilienanbeter. Seine in der Mitte des Flusses gelegene Festung hat die Gestalt einer Lilie (5/844). Sein Heer wird von sechs mächtigen Kommandanten geführt (5/848-849).

Nur ad-Dahr unterwirft Eskandar Šāh, den König von Alexandria. Der König erzählt ihm, wie Irağ den Zauber des Alexander gebrochen und den Schatz des Alexander in seinen Besitz genommen hat nahm. Nur ad-Dahr kommt zu dem neuen, von Irăg geschaffenen Zauber. Talisman. Im Traum erfährt er von Salomo, dass er im Schatten eines großen Baumes graben muss (5/850). Durch die Information auf einer Tafel am Hals des divs 'Aqiqāa wird er den Zauber brechen können. Nur ad-Dahr liest die Tafel und tut, was dort geschrieben ist (5/859).

Ğarmāsb b. Ṭarmāsb kommt zu Irağ, um Rache für seinen Vater zu nehmen. Irağ empfängt ihn freundlich und gibt ihm die Stellung seines Vaters (5/849). Im Kampf gegen Farhād verwundet dieser Ğarmāsb. Am nächsten Tag wird Farhād von Irağ besiegt. Dieser will ihm den Kopf abschlagen, sperrt ihn aber aber Bitten seines Vaters Landehur nur ins Gefängnis (5/854).

Zomorrod und Bahtak beschweren sich bei Neyram über Hamze und die Muslime, und Neyram verspricht, ihnen gegen die Muslime zu helfen (5/850-851). Das Heer des Ḥamze wird von den Truppen des Neyram schlagen, aber Hamze verlangt von Neyram, sich zum Islam zu bekehren (5/856-857).

Irağ belagert neuerlich die Festung Znu 'l-Amān. Eqbāl Šāh, der Enkelsohn des Mālek Malakut, wird im Kampf gegen die Muslime getötet (5/858).

Bāhntar ist im Machtbereich des Badi` az-Zamān. Der Wasseranbeter Dārāb und Mālek-e Aštar fahren mit einem Schiff nach Bāhntar-e kuček. Im Kampf gegen die Feldherren des Badi` az-Zamān erleiden sie eine Niederlage (5/854).

Dārāb verliebt sich in Ḥamzes Frau Șenoubar. In Abwesenheit Ḥamzes sind Asad und Nur ad-Dahr gleichwertige Gegner des Irağ (5/858-859). 
Die Truppen des Ḥamze stellen sich Neyram gegenüber auf. Ḥamzes Sohn 'Alam Šāh wird von Neyram mit seiner magischen Keule besiegt und festgenommen (5/861). Ebenso ergeht es vielen anderen Helden. 'Amr verwandelt sich in die Gestalt des Bahtaks, geht zu Neyram und bittet darum, dass die gefangenen Helden ihn beschützen sollen. 'Amr macht deren Wächter bewusstlos und befreit die Helden (5/859). Dann demütigt er Bahtak, indem er seinen Penis in die Scheide einer Eselin steckt (5/859-863).

Als Ḥamze mit Neyram kämpft, hebt ihn eine Hand aus einer Wolke zum Himmel (5/861). Der Feekönig Lo'lo' Šāh bittet ihn um Hilfe gegen den div Qarqeneqā̄, der in seine Tochter Ğān-afzā verliebt ist. Ḥamze stellt sich dem Heer des Qarqeneqā ${ }^{`}$ entgegen (5/864-865).

Asad kommt zur Festung Kohan. Deren Herrscher verspricht, Muslim zu werden, wenn Asad sein Problem löse. Er tötet einen Wal, indem er sich in einer mit Fleisch behängten Kiste von ihm verschlingen lässt, und nimmt einen dort vorhandenen Edelstein an sich. Der König bekehrt sich zum Islam (5/865-867).

Ḥamze wird durch eine List des Feldherr des Qarqeneq $\bar{a}^{c}$, Čangāl div, in einer Fallgrube gefangen, die sie sogleich mit Erde auffüllen. Die in Ḥamze verliebte Ǧān-afzā rettet ihn durch einen unterirdischen Gang. Ḥamze heiratet Ğān-afzā (5/867-868).

Irağ erhält Unterstützung von den Truppen des Lāhut Šāh. Šāh Soleimān wird von einem verschleierten Reiter unterstützt, der auf dem Kampfplatz viele Sonnenanbeter tötet (5/869870).

Ḥamze erfährt von von H్ర̌āğe 'Abdal aš-Šams, dem Wesir des Lo'lo' Šāh, dass der Asket Barqiyāsā in der Wüste Za'farānzār auf dem zweiten Gipfel des Qāf ihm helfen könne. Ḥamze kommt zu dem Asketen (5/872-873). Dieser teilt ihm mit, dass Neyram durch die Hexen Hezāre und Hezār-mu unterstützt wird. Hạze muss einen Zauber und sieben Schwerter aus Edelsteinen an sich nehmen, mit deren Hilfe er Neyram töten und die Magie der Hexen wirkungslos machen könne (5/873). Der Asket schildert ihm detailliert, wo und wie er an die Zaubertafel gelangen kann. im Traum erfährt Ḥamze von Salomo, dass das Licht der Feind Neyrams ist. Weiter teilt er ihm mit, dass die Zaubertafel im Bauch eines Löwen ist, den er mit der Faust töten muss (5/874). Ḥamze tötet den Löwen und liest die Zaubertafel. Er muss die Hexe Hezāre töten, in einem Gewölbe die diamantfarbene Kleidung und das diamantfarbige Schwert an sich nehmen und dann Hezār-mu töten (5/874). Ḥamze tut alles, wie auf der Zaubertafel beschrieben. Als er zurückkehrt, ist der heilige Mann gestorben, und Ḥamze begräbt ihn (5/874).

Als Neyram am nächsten Tag das diamantfarbige Schwert in der Hand des Ḥamze sieht, weiss er, dass er durch dieses Schwert getötet werden wird (5/876). Als ihm im Laufe des 
Kampfes fiel die Keule aus der Hand fällt, greift die sechs Helden von Hamze gemeinsam an. Das Licht ihrer Schwerter strahlt auf Neyram, und er verliert seine Kraft. Da Neyram sich weigert, sich zum Islam zu bekehren, tötet Ḥamze ihn. Die Truppen der Muslime fügen den vereinigten Feuer-, Zomorrod- und Lilienanbetern große Verluste zu (5/877-879).

Asad besiegt Irağ, und Irağ will sich umbringen (5/876). Behzād überreicht Irağ für den Kampf am kommenden Tag ein heimlich mit Gift präpariertes Schwert. Aber Asad wird von einer Hand aus einem Nebel entführt (5/880).

Nur ad-Dahr zieht nach Ġorubiye, danach nach Zarāyil. Der dortige Herrscher Girang Šāh ergibt sich kampflos, aber sein muslimischer Sohn Marzbān warnt Nur ad-Dahr, dass sein Vater Zomorrodanbeter sei und lüge. Nur ad-Dahr erlaubt Marzbān, seinen Vater zu töten, falls er sich heuchlerisch verhalte (5/880-881). Bei einem Gastmahl lässt Girang Nur ad-Dahr und seine Leute betäuben und ins Gefängnis stecken. Danach schreibt er einen Brief an Irăg (5/881). Die Kundschafter des Nur ad-Dahr finden das Antwortschreiben des Lāhut, indem dieser Girang auffordert, Nur ad-Dahr zu töten (5/881).

Irağ belagert wieder die Festung Z Zu 'l-Amān, und Horšid, die Tochter von Giti-afruz, zieht in den Kampf, um die Ehre ihrer Mutter zu verteidigen. Horšid verletzt Behzād, muss aber vor Irağ selbst ihre Rettung in der Flucht suchen (5/882-883).

Ḥamze verfolgt Zomorrod ins Reich der Finsternis. An einer Gabelung wählt er den Weg nach Ḥațab al-Ǧibāl, der Stadt des Qonud-e zarrin-kamar, der Zabarğad anbetet. Auf Verlangen des Hamze bekehrt sich Qonud zum Islam (5/880). Als sie durch die Finsternis reiten, hören sie Stimmen. Manche der Männer nehmen dort liegende Steine mit, die sich im Hellen später als Edelsteine erweisen. Hamze erhält im Traum von Salomo ein hell leuchtendes Juwel, mit dem sie sich orientieren können. Ḥamze lässt die heiligen Bücher lesen, damit die Geister dem Heer nicht schaden könnten (5/884-886).

Als sie einen beleuchteten Bereich erreicht haben, folgt Hamze auf der Jagd einem Reh und kommt zu einem von paris bewohnten Schloss (5/886). 'Amr bringt in Erfahrung, dass die paris die Sklavinnen von Qoreiši sind, die der div Aflāk entführt hat (5/886). 'Amr liebkost die Mädchen, als plötzlich Aflāk erscheint und er fliehen muss (5/887).

Als Irăg in der Nähe des rubinfarbigen Palastes Liebesgedichte für Giti-afruz vorträgt, ziehen Ḥamzes Frauen in den Kampf. Sie schlagen das Heer des Irăg und töten zahlreiche Sonnenanbeter (5/886-887).

Șalṣāl kann den Brunnen der Stille verlassen und erobert im Kampf gegen die Muslime Iran und Torkestān. Die Türken wollen Șabāyil und Bāhntar erobern. Als die Usbeken das Reich Badi` az-Zamān angreifen, befreien die Feldherren des Badi` az-Zamān, Dārāb und Mālek 
aus dem Gefängnis. Dārāb überwindet die Usbeken. Zāl Hูān gibt vor, sich zum Islam zu bekehren. Er lässt die Helden betäuben und gefangen nehmen (5/888). Dārāb und Mālek ziehen nach Bāhntar-e kuček. Die Söhne des Șalșāl ziehen über das Meer ebenfalls dorthin (5/889). Zunächst siegen die Türken, dann erleiden sie eine Niederlage.

Ḥamze besiegt Qahqahe und nimmt ihn und Zomorrod fest (5/890-891).

Die Armee der Sonnenanbeter unter der Führung des Irăg kämpft gegen die Truppen von Šāh Soleimāns (5/892).

Asad ist von 'Onșur entführt, die er an ihrem Mundgeruch als Hexe erkennt. Als Asad die Hexe töten will, setzt sie ihn gefangen (5/893).

Asads Sohn Ġażanfar wird von den Usbeken gefangen genommen (5/894).

'Onșur erfährt, dass Dārāb und Mālek, die von den Söhnen des Șalṣāl gefangen genommen worden waren, auf einem Schiff eingetroffen sind. 'Onșur verliebt sich in Dārāb und fesselt die Söhne des Ṣalṣāl (5/893). Dārāb kann Asad aus der Gewalt der Hexe befreien, und gemeinsam kämpfen sie gegen die Türken. Indem sie die fliehenden Türken verfolgen, kommen sie nach Haț̣ā. Der Kundschafter Zardehang entführt Dārāb, er wird aber wieder befreit. Mālek kämpft gegen Ṣalṣāl und besiegt ihn (895-897).

Um Irağ los zu werden, lässt Šāh Soleimān ihm eine falsche Braut zuführen (5/898).

Der Kundschafter Zardehang entführt Mālek und Asad, und Șalṣāl setzt sie gefangen (5/899).

Der Kundschafter Šabrang b. Qirān, der sie befreien will, erfährt er Hilfe von Fatāne, der Tochter des Yazdak, die sich als Muslimin zu erkennen gibt und sagt, dass Abraham sie ihm zur Frau bestimmt habe. Fatāne macht Ǧušang, den Wärter der Gefangenen, in sich verliebt und betäubt ihn (5/899). Šabrang und Fatāne befreien die Helden und töten Ğušang (5/900).

Nur ad-Dahr erobert die Festung Șabāyel und erlangt das Schwert des Alexander (5/901). Safil flieht zu Irağ. Nur ad-Dahr besiegt Lāhut (5/902). Irağ nimmt Behzād gefangen. Als Ṭahmāsb seinen Enkel Ğarmāsb im Kampf tötet, züchtigt ihn Nur ad-Dahr, und Ṭahmāsb verlässt das Lager (5/904-905). Turağ wird von Nur ad-Dahr verwundet (5/904-905). Am nächsten Tag wird Irağ im Kampf verwundet. Sein Pferd bringt ihn zu der Festung des Babrafkan, der sich zum Glauben der Sonnenanbeter bekennt (5/904-907). Babrafkan überlässt die Festung auf Rat des Irăg Ḥamzes Bruder 'A ğil-e mah-ru und gibt Irăg als seinen Sohn aus. In Șabāyil befreit Irağ, Mālek und Turağ. Farhād wird im Kampf getötet (5/909).

Ḥamze und sein Heer verlassen das Reich der Finsternis heraus. 'Amr erfährt, dass Irağ seine Schatzkammer geplündert hat (5/910). Badi` und Qāsem greifen Haft Darband in Ġorubiye an. Moškafruz, die Tochter des Dude, nimmt Ḥamzes Helden fest (5/913). 
'Amr entführt Irağ und erlangt seinen Schatz von ihm zurück (5/911-912). Qāsem kommt zur Festung Zú 'l-Amān und will Giti-afruz töten, da sie Schande über sich gebracht habe. Die Frauen können ihn aber überzeugen, dass Giti-afruz ihm treu geblieben ist (5/913).

Qāsem wird von Irağ verwundet, und Šāh Soleimān muss ihn retten (5/914). Irağ und Šāh Soleimān vereinbaren einen Waffenstillstand. Zomorrod kann sich befreien und zieht nach Ġorubiye. Ḥamze verfolgt ihn, und Badi` und Qāsem erobern das Land (5/917-918).

In Ṭāvusiye besiegt Irağ den Sternenanbeter Horšid, der sich fortan als Sonnenanbeter bekennt und mit Irăg nach Haft Darband zieht. Irağ erobert Haft Darband und überlässt das Land Horšid. Danach erobert er Sanğān, dass er Turağ überlässt (5/918-919). Auf dem Weg nach Iran wird er von Asad zum Kampf auf dem Meer herausgefordert (5/919).

Ṣalṣāl hat Torkestān erobert und marschiert nach Iran. Im Kampf zwischen Irağ und Asad auf dem Meer verursacht Damāme mit ihrer Hexerei einen heftigen Sturm (5/919). Die Schiffe der verfeindeten Parteien werden getrennt. Ġażanfar und sein Freund Keivān b. Giv kommen zu einem Ort, an dem sich die Tochter des Kulāk Šāh, des Königs von Kulākiye, in Keivān verliebt. Der Feldherr des Königs täuscht vor, sich zum Islam zu bekennen, lässt die jungen Männer aber betäuben und festnehmen (5/919).

Der in Irağ verliebte div Meriḩ rettet ihn vor der Menschenfresserin Šanğaraf (5/918).

Azruq Šāh, der König von Frankreich, will Dārāb und Mālek festnehmen. Sein Kundschafter Maḩmur wird von Dārāb festgenommen, bekennt sich zum Islam und verspricht, den Helden zu helfen, die Festung des Azruq zu erobern. Nachdem die Festung erobert ist, täuscht Azruq vor, sich zum Islam zu bekennen. Kurze Zeit später kann Azruq den Dārāb festnehmen (5/923). Mit Hilfe des Kapi Zaid werden die Helden befreit, sie erobern die Festung und plündern den Schatz (5/922).

Auf der Insel Nasnāsān hilft Asad dem Kāmel Ḩān, Qahreš und Fażl im Kampf gegen Nasnāsān.

Mošk-afruz kämpft verschleiert gegen die Helden des Ḥamze und besiegt viele von ihnen. Gegenüber 'Amr bekennt sie, dass sie sich in Qāsem verliebt habe. Sie werde die Helden erst freilassen, wenn sie mit Qāsem vereint sei. Als sie ihren Schleier lüftet, sieht 'Amr, dass sie hässlich ist. Er führt sie mit Qāsem zusammen, der sie tötet (5/927-935).

Nur ad-Dahr wird von einer in ihn verliebten Hexe entführt, die er tötet (5/924).

Asad, Dārāb und Mālek erreichten Bāhntar und kämpften mit dem Heer des Irăg. Auf der Jagd erfährt Irağ von einem zu brechenden Zauber (5/928-929). Asad wird von einer Hexe entführt. Er erfährt vom Propheten Salomo im Traum, wie er den Zauber brechen kann, und tut dies (5/929-930). Mālek und Dārāb verteidigen Madā'en gegen Ṣalṣāl, der beide 
entführen kann. Danach begibt sich Șalṣāl in den Zauber, um Asad dort zu finden und zu töten (5/930). Asad wird in dem Zauber von der in Irağ verliebten Tochter des Feekönigs Yāqut Šāh festgenommen (5/932). Irağ befreit Dārāb und Mālek. Asad wird von dem div Tondak zu Asmā' entführt. In ihrem Auftrag besiegt er den div Šaqilā, der sich zum Islam bekehrt (5/932-933).

Ḥamze besiegt Dude, der vorgibt, sich zum Islam zu bekehren. Zomorrod flieht nach Čehelarg. Ḥamze zieht nach Šamāsiye, wo der Drachenanbeter Šamās Šāh mit seinen 40 Brüdern herrscht (5/937). Šamās verspricht Ḥamze, sich zum Islam zu bekehren, wenn er den Drachen überwinde (5/938). Ḥamze kämpft mit einem verschleierten Reiter, in dem er Soleimān-e șāni, den Sohn des 'A ğil-e māh-parast, erkennt (5/937-938). Zomorrod und Baḩtak treffen bei Šamās ein, und zusammen besuchen sie eine prachtvolle Kirche (5/935). Ḥamze muss zusehen, wie der Drache Soleimān-e șāni und Nur ad-Dahr verschluckt (5/940). Im Traum erfährt Ḥamze von Salomon, dass der Drach der div Sarāqeme ist. Ḥamze schießt auf den Drachen, und der Drache flieht nach Takāb (5/940). Zomorrod und Bahtak fliehen gleichfalls nach Takāb. Šamās wird zum Islam bekehrt (5/941).

Dārāb verliebt sich in Șenoubar (5/941-942). Als die freundliche Beziehung zwischen Asad, Mālek und Dārāb zerbricht, schließen sich Dārāb und Mālek dem Irağ an. Da Irağ die beiden nicht zurückschicken will, kämpft Asad mit ihm, und Irağ verwundet ihn mit dem unwissentlich vergifteten Schwert. Sein Pferd bringt Asad vom Schlachtfeld (5/943). Während des Kampfes befreit Damāme ihren Sohn Ṣalṣāl aus dem Gefängnis des Irağ (5/943).

Ḥamze sieht durch ein Zauberminarett, dass Asad verwundet ist, und schickt ihm durch den Div Zoğāğak ein Zauberheilmittel. Als Asad später Irağ über das vergiftete Schwert aufklärt, tötet dieser Behzād im Zorn (5/954).

Auf dem Weg nach Takāb kommen Ḥamze und sein Heer in eine wasserlose Wüste. 'Amr trifft einen den Wahrsager Arganun, dem der Prophet Abraham im Traum aufgetragen hat, Wasserschläuche zu Hamze zu bringen (5/943-944). Zusammen mit Hamze bemüht Arġanun sich darum, einen Zauber zu brechen (5/944).

Zomorrod und der div Sarāqeme kommen nach Takāb, der von Dschinns, Feen und Dämonen bewohnten unsichtbaren Stadt des Herrschers Șādeq (5/945). ‘Amr besucht das von Salomo erbaute Gefängnis, das mit einer schweren Eisentür verschlossen ist. In Takāb tötet 'Amr den Hārun, den Astrologen des Herrschers, und begibt sich in dessen Gestalt an den Hof (5/946). Ḥamze erfährt von Arg்anun, dass er einen Zauber brechen muss, um die Stadt sichtbar zu machen. In dem Zauber trifft Ḥamze den 'Abdal ar-Raḥim, den Bruder von 
'Abdal ar-Raḥmān, der ihn berät. Ḥamze besiegt den div Zoğāğak, der ihm von nun an hilft. Zoğāğak rettet den von den Soldaten des Șādeq umringten 'Amr (5/947). Auf dem Weg zurück stiehlt 'Amr die goldenen Ohrringe und die goldene Kette des divs (5/948). Ḥamze überzeugt 'Amr durch das Versprechen eines reichen Lohns, ihm auf dem weiteren Weg zu helfen (5/948). Hamze und 'Amr kommen in eine Stadt, in der die Menschen, deren Lebenszeit abgelaufen ist, ins Feuer geworfen werden (5/949). Auf dem Weg zum goldenen Garten hat Ḥamze eine Auseinandersetzung mit 'Efrit, dem Onkel des Zoğāăak. Der div Qārus entführt Ḥamze und 'Amr aus der Gewalt von 'Efrit. Als er erfährt, dass einer der Männer Ḥamze ist, bekehrt er sich zum Islam (5/949). Ḥamze kommt zu einem Baum mit Käfigen, in denen Frauen mit Vogelkörper und Menschenkopf gefangen sind (5/950). Ḥamze kommt zum Salomos Audienzsaal und erfährt Einzelheiten über den zu brechenden Zauber (5/951). Als er den Zauber bricht, wird die Stadt Takāb sichtbar. Ḥamze bekehrt 'Efritān zum Islam (5/951).

Ḥamze verlangt von Ṣādeq, ihm Zomorrod auszuliefern. Da Șādeq sich weigert, ziehen sie gegeneinander in den Krieg (5/952). Șādeq bittet seinen Bruder Malek Kei-Kāvus um Hilfe. Dessen Tochter verliebt sich durch ein Portrait in Nur ad-Dahr (5/954). Kei-Kāvus trifft mit seinen Truppen ein (5/955). Seine unverwundbaren Helden töten Ḥamzes Helden bis ein wilder Mann auftaucht, der sie tötet.

Kalkāl wird durch Abraham im Traum zum Islam bekehrt. Als 'Amr und Ḥamze die gefangenen Helden befreien wollen, sind diese nicht dort (5/952). Šāhpur, der Sohn des Königs von Takāb, informiert sie, dass der Türwächter seines Vaters die Herrschaft an sich gerissen hat. Er selbst hat in einem prophetischen Traum von Ḥamzes bevorstehender Ankunft erfahren (5/957).

Dude und Badr b. Zalāzel treffen mit ihren Truppen ein (5/958). Dude verbündet sich mit Lāhut gegen Irağ. Irağ besiegt Badr b. Zalāzel und lässt dessen unzerstörbaren Mantel ins Meer werfen (5/959-960).

Nasem, Kundschafter des Șādeq, entführt Sa`d, der kurz darauf von einem wilden Mann entführt wird. Šāhpur, der Sa`d befreien will, erkennt den wilden Mann durch sein grünes Mal als Nachkommen des Ḥamze und lässt sich nicht auf einen Kampf mit ihm ein (5/962).

Mehr Bānu kämpft verschleiert gegen das Heer des Ṣādeq (5/964). Šāhpur tötet Zamtār, den Feldherrn der Hexe Susan (5/966-967). Susan trifft in Begleitung von Ṭoruğ b. 'U $\check{g} \mathbf{b}$. 'Anaq ein (5/967). Der Zauberhahn der Susan verrät den Aufenthaltsort des versteckten 'Amr, der daraufhin festgenommen wird (5/968). 'Amr singt ein Lied, und Susan lässt ihn zu ihrem Vergnügen in einen goldenen Käfig sperren (5/968). 
Als Mālek verletzt wird, bringt sein Pferd ihn in Sicherheit. Auf der Jagd findet ihn Akram Šāh, der Herrscher von Minu-negār, und nimmt ihn zu sich (5/970). Mālek soll für den König das Rätsel eines Zauberminaretts lösen (5/970). Mālek wird von Salomo beraten und mit einer Zaubertafel versehen (5/971). Er schlägt einen Div und weigert sich dann, ihn ein zweites Mal zu schlagen (5/971). Ein Mädchen, das sich als von einem div entführte Tochter des Königs von Ṭāvusiye ausgibt, bietet ihm ein Glas Milch an, das er aber wegen des Rats von Salomo ablehnt. Darauf verwandelt sie sich in einen Löwen, schließlich in einen Adler (5/971). Mālek tötet die Hexe Afğān und befreit den seit 15 Jahren von ihr gefangengehaltenen Fariborz b. Malek Helāl. Nachdem Fariborz noch die Hexe Mórbad getötet hat, ist der Zauber gebrochen, und Mālek und Fariborz verlassen den Zaubergarten. Als Akram dies sieht, bekehrte er sich zum Islam (5/972). Fariborz vermittelt zwischen Mālek und Asad, und gemeinsam ziehen sie gegen Irağ (5/972).

Als Asad, Mālek und Fariborz gegen Irağ, Dārāb und Turağ kämpfen, werden alle von einer Hand entführt (5/973). Asmā' bittet Asad um Hilfe gegen Qahqahe. Asad verlangt als Gegenleistung, dass sie Iră̌, Dārāb und Turağ töten müsse. Asmā') weigert sich mit Hinweis auf deren haschimitische Herkunft (5/973).

Šāhpur befreit die von Susan gefangenen Helden und verwundet sie. Šāhpur tötet Ṭoruğ b. 'Ŭ b. ‘Anaq und Susan (5/974-977).

Qahqahe lässt Asmā̄s Oberbefehlshaber Nefrit entführen, der Sympathie für ihn heuchelt (5/974-975). Nefrit entführt Irağ und bringt ihn zu Asmā'. Da Asmā' dem div Siyāmak einen niedrigen Platz als Nefrit zuweist, ist dieser unzufrieden, entführt Irăg und kommt zu Qahqahe (5/975).

Vāheme, die Mutter des Qahqahe, entführt die Helden zu Qahqahe. Sie verliebt sich in Asad und hält ihn auf der 'Anbar gefangen (5/977-978). Die Helden werden befreit, und ein schönes Mädchen bekennt seine Liebe zu Fariborz. Durch ihren Mundgeruch enttarnt Asad sie als Hexe und tötet sie (5/979).

Auf dem Weg zum Land der Menschen wird Irağ von einem Herrscher der divs und paris zum Wettkampf im Armdrücken herausgefordert. Er kann ihn nicht besiegen, und der König warnt ihn, dass seine Taten durch die Hilfe an Bedeutung verlieren (5/978).

Ḥamze nimmt Zomorrod und Ṣādeq gefangen. Danach zieht er zum Lager des Irăg (5/980). Nach der Festnahme des Zomorrod schließen sich Landehur und Mālek-e Aštar wieder Ḥamze an (5/985-987). Asad erhält von Hamze dessen Schwert und je vier Federn Stück des Simorg und des Roh. Das von Asad erhaltene Geld verteilt Hamze an seine Truppen (5/988). 
Ḥamze besucht seine Frauen in Șabāyil (5/991). Zomorrod kann fliehen und findet bei Dude Zuflucht (5/991).

'Alam Šāh bittet Ḥamze um Erlaubnis, gegen Dude kämpfen zu dürfen. 'Alam Šāh schleudert den Elefanten des Dude durch die Luft, wird dann aber von seinem Gewicht überwältigt und verletzt (5/993-995). Ḥamze verkündigt, dass derjenige, der Dude tötet, von ihm Kleid und Waffen des Rostam erhalte (5/995). Irağ tötet Dude und dessen 70 Söhne und schlägt dessen Heer vernichtend (5/996). Als Ḥamze dies sieht, überlässt er ihm auf Wunsch des ‘Alam Šāh dessen Rüstung.

Qāsem kämpft gegen Irağ (5/998). Ḥamzes besiegt Irăg im Kampf (5/1000-1003). Um sich zum Islam zu bekehren, verlangt Irağ, dass Qāsem sich von Giti-afruz scheiden lassen müsse (5/1006-1007). Mit Hilfe seinen Söhnen tötet Qāsem Irağ im Gefängnis. ‘Amr informiert den verärgerten Ḥamze, dass Qāsem nur einen Feueranbeter getötet habe, der er die Gestalt des Iră̆ gegeben hatte (5/1007-1008). Als Irăg sich neuerlich weigert, sich zum Islam zu bekehren zu lassen, überlässt Ḥamze ihn dem Qāsem, der Iră̆ hängen lassen will. Als Gitiafruz dies erfährt, weint sie (5/1008-1009).

Irağ bittet 'Amr, ihn in der Nähe von Giti-afruz zu begraben und überlässt ihm sein Armband mit Rubinen. Anhand der Rubine versteht 'Amr, dass Iră̌ ein Nachkomme des Ḥamze ist und bittet Qāsem um Aufschub der Hinrichtung. Indem er Hamze, dessen Frau Rābe`e, deren Sohn 'Alam Šāh und schließlich Giti-afruz, die Frau von dessen Sohn Qāsem, befragt, erfährt 'Amr, dass Iră̌ der Sohn von Qāsem und Giti-afruz ist. Farăg gesteht, dass er Irăg als Findelkind an Sohn statt angenommen hat. Qāsem versöhnt sich mit Irağ (5/1010-1011).

Nun verbündet sich Irağ mit Ḥamze und kämpft gegen Zomorrod. Er nimmt Turağ fest und bringt ihn zu Ḥamze. Der alte Held Tavakkol teilt ihnen mit, dass Turağ der Sohn des Badic az-Zamān von Ğahān-afruz, der Tochter des Zomorrod, ist. Turağ lässt sich zum Islam bekehren (5/1012). Nur ad-Dahr besiegt Dārāb und bringt ihn zu Ḥamze. Durch das Testament von Āzād-baḩt, der Sklavin der Șenoubar, bestätigt sich die Abkunft des Dārāb von Hamze (5/1014).

Zomorrod flieht nach Pol-e Donyā zu Ǧamšid Šāh, dem König von Ǧābalqā. Dessen Kundschafter Balāšur tötet Ḥamzes Kundschafter und verkauft ihr Fleisch an einem Grillstand (5/1017). Schließlich können Hamzes Kundschafter ihn festnehmen.

Qomhur, der Feldherr des Ğamšid, kämpft gegen Ḥamzes Helden (5/1019). Balāšur entführt Ḥamze (5/1021). Der div Gurang befreit Hamze. Zomorrod erhält Unterstützung von Namrud (5/1029). Namrud und Zomorrod streiten sich, weil jeder beansprucht, ein Gott zu sein (5/1033). Hamze fordert Namrud auf, sich zum Islam zu bekehren (5/1030-1031). 
Ein Mordanschlag des Namrud auf Ḥamze wird von Moqbel vereitelt (5/1037).

Nur ad-Dahr bricht auf Verlangen der Asmā̄ pari einen Zauber und tötet den siebenköpfigen Dämon. Mit Simorġs Hilfe fliegt er nach dem Goldenen Garten (5/1038).

Marzbān, der Vater des Zomorrods, kommt mit seinen 40 Söhnen zu Namrud. 'Amr tötet Balāğur, den Sohn des Balāšur, grillt sein Fleisch und serviert es Zomorrod und Balāšur, die davon essen (5/1040).

Ḥamze besiegt Qomhur und nimmt ihn fest. Er erfährt, dass Qomhur sein Sohn von Dorrdāne, der Tochter des Malek Yaḥyā ist (5/1041-1043).

Die Hexe Samandar veranstaltet einen Wetterzauber mit Kälte und giftigem Regen, gegen den selbst Ḥamze machtlos ist (5/1046-1046). 'Amr verwandelt sich als Namrud und verbrennt Namruds Himmel und Paradies (5/1045). Ḥamze, Asmāà und seine Söhne besiegen Zomorrod, Namrud und Bahtak und nehmen sie fest (5/1046). Als die Hexe getötet ist, erinnert sich Hamze des Gegenzaubers.

Zomorrod flieht als Hirt verkleidet nach Șabāyil und trifft auf seine Tochter Giti-afruz. er lehnt ihren Wunsch ab, sich zum Islam bekehren zu lassen. 'Amr nimmt ihn fest, und Zomorrod und Bahtak werden getötet (5/1047-1048).

Ḥamze veranstaltet eine große Feier und teilt seinen Söhnen mit, dass er nun 80 Jahre gegen die Götzenanbeter gekämpft habe und jetzt nach Mekka reiten wolle, um dem Propheten nahe zu sein. Daher verteilte er sein Reich. Er gibt den Mag̉reb an Karib, Hațā an Asad und Baḩtar an Badi` az-Zamān. Die Stadt Șabāyil gibt er zu gleichen Teilen an Nur ad-Dahr und Irağ. ‘Alam Šāh erhält Rum und Griechenland sein Sohn 'Omar (5/1051-1053).

In Indien hat Landehurs Tochter Širin-dohnt mit seinem Statthalter Šahbāl den Sohn Ğazāyil gezeugt. Dieser hat seinen Vater getötet und die Götzenanbeterei in Indien verbreitet. Als Landehur nach Indien kommt, nimmt Ğazāyil ihn fest und blendet ihn (5/1050-1051).

\subsection{Buch 6}

Indem Nur ad-Dahr und Irăg um die Nachfolge Ḥamzes streiten, werden sie plötzlich entführt. König Moṣaffā, der Herrscher von Arzaqiye, verlangt von ihnen, seinen Sohn Farroh wieder zu finden, der auf der Jagd in einen Brunnen gefallen ist (6/1059).

Lāhut erfährt von seiner Mutter Nağm-e ġul, dass er der Sohn des Zomorrod ist. Durch einen Trick kann er sich als Gott etablieren (5/1056-1057).

Sa'd b. Qobād, dem Ḥamze die Herrschaft über Torkestān gegeben hat, erfährt, dass Ṣalṣāl wieder einmal Iran bedroht. Im Kampf gegen Șalṣāl wird Sacd verwundet und flieht nach Harāt, wo er bei Moštari-Hูān Aufnahme findet. Als Șalșāl Harāt erobert und die Städte 
von Hुorāsān zum Gehorsam auffordert, flieht $\mathrm{Sa}^{\mathrm{c} d}$ nach Neišābur, wo er bei dem Herrscher Nuḥ Aufnahme findet. Der ungläubige Wesir des Nuḥ verrät $\mathrm{Sa}^{\top} d$ an die Usbeken, so dass er weiter nach Madā'en fliehen muss. Dort hörte er, dass Parviz b. Hormoz die Stadt erobert hat und die Götzenanbeterei verbreitet (6/1060-1061). Bei der Suche nach Juwelen für den Thron des Ṣalṣāl finden die Männer des Parviz Sa`d, und Ṣalṣāl tötet ihn. Ğazāyil schließt sich Șalṣāl an.

Nachdem Landehur im Traum vom Propheten Moḥammad geheilt worden ist, schließen sich die Einwohner Indiens ihm wieder an und zerstören die Götzentempel. Landehur zieht nach Iran (6/1062-1063). Šarar Bānu und Badr b. Zalāzel töten Ṭāher und erobern 'A ğam (6/1063). Kei-Kāvus kommt in die Stadt Takāb, wo er 'Ŭg b. 'Oruğ b. 'U.̆ b. 'Anaq trifft. Zusammen wollen sie für den getöteten Malek Șādeq Rache an Ḥamzes Söhnen nehmen. Lāhut erobert Aqšāmiye im Reich der Finsternis (6/1064).

Irağ und Nur ad-Dahr steigen in den Brunnen. Nur ad-Dahr erfährt, dass zwischen den Völkern der Feueranbeter des Malek Samāwāt und der Erdanbeter des Malek Ḥamid Streit besteht und verspricht, ihn zu lösen. Er schildert Irăg den Sachverhalt in einem Brief. Irăg denkt, dass Nur ad-Dahr Angst vor ihm hat und kämpft gegen ihn (6/1064-1067).

In Sanğān kämpft Badr gegen die Feldherren des Badi` und verwundet den Prinz Badi` (6/1066).

Gouhar Malek tötet Šarar Bānu im Kampf und erobert die Stadt 'A ğam zurück (6/1067).

Lāhut erobert das Reich der Finsternis. Auf der Insel Gerdāb erlangt er einen Zauberring, dessen Dämonen ihm zu Diensten sind (6/1067). Als Lāhut die Stadt Faranqušiye belagert, bittet Mālek Malakut den Irağ um Hilfe. Mit Hilfe der Dämonen erobert Lāhut Faranqušiye und zwingt die Muslime zum Gehorsam. Lāhut erfährt von der Existenz des Badi` al-Molk, des Sohnes von Nur ad-Dahr, von dem ihm prophezeit wurde, dass er ihn vernichten werde. Lāhut will Badi` al-Molk töten (6/1067-1068).

Malek Samāwāt lässt Nur ad-Dahr entführen und einsperren. Seine Tochter befreit ihn und zieht mit ihm zur Stadt der Erdanbeter. Irağ zieht gleichfalls dorthin (6/1069-1070).

Lāhut zieht nach Haft-manẓar, um Badic al-Molk zu töten, hat aber keinen Erfolg. In Zaranğābād wird Lāhut von Esfandiyār Hुān entführt. Dieser erpresst von ihm das Geheimnis des Zauberrings, nimmt den Ring in seinen Besitz und kann mit Hilfe der Ringgeister das Heer des Lāhut besiegen (6/1072-1074). 'A ğil-e māh-ru und sein Sohn Soleimān-e șāni kämpfen gegen die Ungläubigen. Der von einer Hexe befreite Lāhut fügt 'Ağil mit Hilfe von Zauberei eine Niederlage zu (6/1072-1073). In der Stadt Morraṣa'-negār 
kann Qāren-e Qamar-bin dem Lāhut den Ring abnehmen und überlässt ihn dem Knaben Badic al-Molk (6/1074).

Irağ entführt die Tochter des Malek Samāwāt und lässt sie in einen Zauber bringen. Als Nur ad-Dahr und Irağ sich in den Zauber begeben, tötet ein grün verschleierter Ritter die zwei roten Dämonen, bricht so den Zauber und erlangt den Stuhl des Ḥamze (6/1075-1076).

Im Lager des Sa`d erfahren Nur ad-Dahr und Irăg, dass die Ungläubigen alle muslimischen Länder erobert haben. Nur ad-Dahr kämpft gegen Șalṣāl, wird aber von diesem festgenommen (6/1076). Irağ wird im Kampf gegen Lāhut verwundet. Balāšur will Šāhpur entführen. Er wird von diesem festgenommen, kann sich aber wieder befreien (6/1078). Badr b. Zalāzel und Ğazāyil schließen sich Lāhut an. Landehur tötet Ğazāyil (6/1079). Danach tötet er auch Badr b. Zalāzel und besiegt dessen Vater (6/1082). Šāhpur tötet die mit Lāhut verbündeten Könige. Lāhut schickt die gefangenen muslimischen Helden zur Insel Qanduq, wo die Hexen auf sie aufpassen sollen. Landehur kämpft nochmals gegen Zalāzel, kann ihn aber wegen dessen Zauberpanzer nicht töten (6/1083). Balāšur entführt Sa`d, und Šāhpur entführt Lāhut. Šāhpur kann Sa`d befreien, der kurz darauf beim Kampf gegen den div Akvān verwundet wird. Šāhpur entführt Baḩtegān, den Sohn des Bahtak. Dieser sagt ihm, dass Lāhut die Helden auf der Insel Qanduq gefangen hält. Balāšur befreit Baḩtegān (6/1084-1085).

Irağ heiratet 'Ālam-ārāa, die Tochter des 'A ğil-e māh-ru, die ihm den Sohn Rostam-e șāni gebiert. Rostam wird von der Hexe Zelzele entführt, die auch den Sohn des Nur ad-Dahr in ihre Gewalt bringt. Die Hexe wird von einem mit einem Löwenfell bekleideten Ritter getötet (6/1085-1087).

Šāhpur kommt als Geschäftsmann verkleidet auf die Insel Qanduq, wo ihn Balāšur erkennt (6/1088). Er erhält Unterstützung von Ṭahmāsb b. ‘Anqavil, der Nur ad-Dahr, Iră̌ und die Helden befreit (6/1088-1089). Zusammen kommen sie zu Sa`d und kämpfen gegen Lāhut. Badic al-Molk besiegt den div Akvān und verfolgt den Fliehenden. Der Ritter mit dem Löwenfell tötet Zalāzel. Ein Ritter mit einer Edelsteinrüstung tötet Akvān. Der Ritter mit dem Löwenfell beweist seine Kraft, indem er als einziger einen schweren Bogen spannen kann (6/1092-1093). 'Amr überbringt einen Brief von Ḥamze an Sa'd, dass alle dem Ḥamzeye sāni, Hạamzes Sohn von Qahr, Gehorsam schulden (6/1094-1095). Der Ritter im Löwenpelz gibt sich als Ḥamze-ye șāni zu erkennen. Er schildert seine Heldentaten, und die Helden legen den Treueid ab. Der Ritter im Edelsteingewand gibt sich als Badi` al-Molk zu erkennen (6/1095). Lāhut flieht nach Ğābalqā. Ḥamze, der Lāhut verfolgt, wird von Tạ̣ayor, dem König von Taḥayoriye, in einen Zauber geworfen (6/1096). 
In Sarmadiye hilft Rostam-e sāani dem Sarmad Šāh gegen Šocle b. Šamāme. Šo le will sich zum Islam bekehren, wenn er einen Zauber breche. Rostam erfährt, wie er den Zauber brechen kann und führt alles aus. Sarmad und Šo le bekennen sich zum Islam. Anschließend bricht Rostam den Zauber, in dem sich Ḥamze ye șāni befindet und tötet Taḥayor Šāh (6/1098-1099). Lāhut will Nur ad-Dahr, Rostam-e sāāni und Irağ entführen lassen. Irağ wird durch Kerkere, den Vater des divs Akvān, verwundet. Sein Pferd bringt ihn zu Sām und dessen 40 Söhnen, die ihn heilen. Auf dem weiteren Weg kämpft er mit einem schwarz gekleideten Ritter, der ihn ins Wasser wirft (6/1100). Der Versuch des Almās, des Kundschafters des Kerkere, Badi` al-Molk zu entführen, wird von diesem vereitelt. Badi` azZamān, Nur ad-Dahr und Badi` al-Molk werden im Kampf verwundet (6/1101).

Balāšur nimmt Rostam-e sāni gefangen. Er wird von der Prinzessin Māhnušlab, der Tochter des Marāteb Šāh, befreit. Mit Hilfe des herbeigeeilten Ḥamze besiegen die Muslime die Ungläubigen. Rostam erfährt vom Schicksal seines Vaters Irağ und wird gleichfalls von dem schwarz gekleideten Ritter ins Wasser geworfen (6/1103-1104). Lāhut erhält Unterstützung von Manḥğan Šāh (6/1105). Dessen Kundschafter entführt die Helden, wird aber von Šāhpur getötet (6/1109). Ein grün verschleierter Ritter nimmt viele der muslimischen Helden gefangen (6/1109).

Ḥamze ye șāni erfährt durch Salomo im Traum, wie er die im Zauber gefangenen Helden befreien kann. Er bricht den Zauber, tötet die Hexen und befreit die Helden (6/1110-1111).

Ḥamze ye șāni kämpft gegen den grün verschleierten Ritter, der durch einen Gegenzauber vor ihm fliehen muss (6/1112). Vor Balāšur gibt sich der Ritter als Feldherr des Zauberers Ahżàr zu erkennen (6/1113). Die Muslime erhalten Hilfe vom Hexenheer des 'Efritān (6/1114). Nach einem Verwandlungswettkampf tötet 'Efritān den Ahżar (6/1117).

Kei-Kāvus Šāh hat zusammen mit Turağ und 'Oruğ b. 'Ŭg b. 'Anaq die Städte Takāb und Bāhttar erobert und Badi` az-Zamān festgenommen. Badi` al-Molk wird verletzt und von seinem Pferd in die Stadt Negārestān gebracht, deren Einwohner Löwenanbeter sind. Von Maẓālem Šāh gefangengenommen, wird er vom Kundschafter der in ihn verliebten Prinzessin befreit. Turağ wird von Šāhpur in einer Grube voll Schiesspulver getötet (6/11181121).

\section{$5.7 \quad$ Buch 7}

Badi` al-Molk besiegt Maẓālem Šāh. Auf Wunsch des Königs begibt er sich in einen Zauber, um diesen zu brechen. Auch der König selbst, seine Tochter und Šāhpur geben sich dorthin. Von Salomo darüber informiert, wie er den Zauber brechen kann, tut Badi` al-Molk dies, 
befreit Maẓālem Šāh, seinen Sohn Zāl, die Prinzessin und Šāhpur. Maẓālem Šāh lässt sich zum Islam bekehren (7/1124-1125).

Landehur ernennt seine Tochter Širin-dohyt zur Königin und Bešārat zum Kronprinzen. Als Bešārat die Širin-doht seinem Sohn zur Frau geben will, lehnt diese ab. Landehur erfährt im Traum, dass seinem Land Unheil drohe, und lässt Turağ mitteilen, dass Bešārat und sein Sohn getötet werden sollen. Turağ zeigt den Brief allerdings Bešārat und bringt ihn dazu, sich als Götzenanbeter zu bekennen (7/1126-1127).

Ḥamze ye șāni belagert die Stadt Ğābalqā. 'Amr-e sāani tötet im Bad Balāšur. Die Muslime besiegen die Ungläubigen. Lāhut flieht zu dem Zauber Nārenğ. Badi` al-Molk bricht in einem komplizierten Prozess einen Zauber. Unter anderem erlangt er den nachtleuchtenden Edelstein von einem Meertier.

Lāhut erhält Hilfe von Šábān Šāh. Dessen muslimischer Wesir rät Badic al-Molk, den vorherigen Herrscher Qerțās zu befreien (7/1128-1131). Badi` al-Molk befreit Qerțās, kämpft gegen Šacbān Šāh und befreit den von diesem gefangenen Ḥamze ye șāni. Lāhut flieht zur Festung Āhantāb (7/1131). Ḥamze nimmt Lāhut und Baḩtegān fest und tötet sie (7/1132). Badi` al-Molk wird zu Ḥamzes Nachfolger ernannt (7/1132). Ein Bote aus Sanğān informiert die Helden, dass Zomorrods Sohn Kanğāb die Stadt belagert (7/1133).

Ein Bote von Asmā' überbringt die Nachricht, dass Ġarāb b. Qahqahe Qāf belagert. Fer'un Šāh fordert von Hamze ye șāni zwei Kinder, die ihn und sein Reich vernichten können. Ein Ritter im Leopardenpelz nimmt Ḥamzes Helden fest und zerstört Zِu 'l-Amān, wo Ḥamzes Frauen sind. Ḥamze wird festgenommen und nach Faranqušiye gebracht. Nur ad-Dahr kämpft gegen Kanğāb und besiegt ihn (7/1134).

Badi` al-Molk und Rostam verfolgen auf der Jagd ein Reh. Rostam tötet in einem Garten eine schöne Frau, die eine Hexe ist. Badi` al-Molk besiegt einen Wegelagerer. Als Rostam und Badi` al-Molk hören, dass Fer'un Šāh Ḥamzes Heer vernichtet hat, reiten sie mit Sa`d nach Faranqušiye.

Ġarāb erobert die Stadt Zarrine und nimmt Siyāmak fest, der aber von der in ihn verliebten Mutter des Ġarāb befreit wird. Ġarāb will Siyāmak töten, der aber fliehen kann (7/1135). 'Alam Šāh und 'Omar b. Hạamze-ye yunāni kommen nach Qāf, um gegen Ġarāb zu kämpfen (7/1136).

Turağ-e bad-rag wird im Kampf von Landehur verwundet. Von seinem Pferd in die Stadt Kanābat gebracht, soll er getötet werden, wird aber von der Zauberin Badraqe entführt. Badraqe entführt Landehur und sperrte ihn in einem Zauber ein. Landehur wird von Māhi, der Tochter der Zauberin Ḥayāt, befreit. Badraqe und Turağ ziehen nach Sarandib. Turăg 
erobert die Stadt und tötet die Muslime (7/1137). Turağ kämpft gegen Šāh Soleimān und verlangt von ihm, dass er ihm Ḥamzes Verwandte und Qahre, Mošk-afruz, Giti-afruz und Horšid übergebe. Badi` al-Molk besiegt Turăg und nimmt ihn fest (7/1138-1139). Turăg wird befreit, und Nur ad-Dahr, Badi` az-Zamān und Asad kämpfen gegen ihn. Ahreman entführt Badi` al-Molk, der sich aber befreien kann und Turăg festnimmt. Badi` al-Molk erobert Sāmāniye und kämpft gegen Fer'un Šāh (7/1140). Turağ schließt sich Fer'un Šāh an, und Badic al-Molk kämpft gegen sie.

Bei dem Versuch, Ḥamze-ye șāni zu befreien, fallen sowohl Rostam als auch Turăg in einen Zauber (7/1141). Badi` al-Molk erobert Sanğāb. Danach fallen alle Helden und Ḥamze-ye șāni in einen Zauber. Badi` al-Molk erfährt von Salomo, wie er den Zauber brechen kann (7/1141). Er erhält Hilfe von Qamarzād b. Ḥamze, der ihn mit nach Qāf nimmt, wo er den div Mokalkal tötet. Danach rettet er Ḥamze-ye șāni aus dem Talisman.

Badi` al-Molk reitet zur Festung Golgun. Er wird von den Hexen in einen Zauber entführt, zusammen mit Rostam aber von Qahr-e zarrin-tāğ, dem muslimischen Wesir des Helāhel befreit. Badi` al-Molk kämpft gegen die Hexen und tötet sie (7/1142-1144). Danach besiegt und tötet er Fer'un Šāh. Im Kampf verwundet er einen verschleierten Ritter, der sich als Ḥamzes Sohn Dārāb erweist. Badi` al-Molk heiratet Ġazāl-e Gouhar-pušs. Ḥamze schickt seinen Sohn Dārāb gegen Turağ. Dieser wird verwundet und von seinem Pferd zu einer Festung gebracht. Dārāb fällt in einen Zauber und soll getötet werden, wird auf Fürsprache einer in ihn verliebten Frau aber am Leben gelassen (7/1145). Ḥamze-ye șāni macht sich auf den Weg, um Dārāb zu retten. Ġarāb flieht zu der Hexe Balāhād. Diese entführt Badi` alMolk, der von der pari Qamarzād wieder befreit wird.

Badi` al-Molk kämpft gegen Turağ und Eskandar und tötete beide. Badi` al-Molk tötet den siebenköpfigen Dämon und bricht einen Zauber. Dārāb heiratet die Frau des Turağ, die ihm vormals das Leben gerettet hatte. La'āan b. Turağ will seine Mutter und Dārāb töten, wird aber von Dārāb getötet. Badi` al-Molk begibt sich zu seiner Frau Ġazāl nach ZZu 'l-Amān (7/1147-1148). 


\section{Schlussbetrachtungen}

Das $R H$ beinhaltet die Denkweisen und Empfindungen, die das kollektive Gedächtnis der Iraner im Mittelalter veranschaulichen. Die mittelalterliche Literatur, wie sie sich im $R H$ darstellt, ist zu verstehen als die kunstvolle Zusammenführung und Verschmelzung dreier Bereiche: die iranische Kultur in vorislamischer Zeit, die islamische Kultur und die islamischiranische Kultur im Mittelalter selbst.

Das $R H$ verfolgt zwei wichtige Ziele, die allen Geschichten, Erzählungen und Liedern zugrunde liegen: Ausbreitung des Islams und die Legimitation zu Herrschen. Der Herrscher eines islamischen Reiches muss seine Berechtigung zu Herrschen erst begründen und muss seine Untertanen davon überzeugen, dass es zu der von ihm ausgeübten Herrschaftsform keine Alternative gibt. Es ist wichtig zu wissen, auf welche Rechtsgrundlage sich Herrscher berufen und welcher Methoden sie sich bedienen um die von ihnen erhobenen Machtansprüche zu rechtfertigen.

Die Legitimation einer Herrschaft kann im Islam immer nur als ein Auftrag Gottes verstanden werden. Bis heute ist es in vielen islamischen Ländern üblich, dass die Herrscher ihre Legitimation vor dem Hintergrund des Islams begründen. So versteht sich beispielsweise das saudische Königshaus als Hüter der beiden heiligsten islamischen Stätte (Mekka und Medina); das jordanische Königshaus leitet seinen Herrschaftsanspruch aus der familiären Abkunft von Moḥammad her („Haschemidendynastie“). Auch im Iran selbst hat sich später Schah Moḥammad Reżā Pahlavi dadurch legitimiert, dass er durch den zwölften Imām „gegürtet“" worden ist.

Ḥamze legitimiert seinen Herrschaftsanspruch religiös; er sieht sich als Streiter für den einzig wahren Glauben. Sein Titel, farrāš-e rāh-e Moḥammad (Wegbereiter für Moḥammad), macht dies eindeutig klar. Er wird durch die Anwendung von Gewalt zum Weltherrscher. Unzählige Episoden schildern seinen Weg. Aufgrund einer göttlichen Eingebung fühlt er sich berufen, ein neues Weltreich zu gründen. Hamzes Autorität, die er bei seinen Untertanen genießt, ist ebenfalls religiöser Natur. Das hohe religiöse Ansehen erlaubt es ihm, als einziger Repräsentant und Stellvertreter des Islams aufzutreten. Da auch der Prophet Moḥammad die arabischen Völker im Kampf eint, liegt es nahe, dass auch sein Wegbereiter Ḥamze ein Kriegsheld ist. In der Person von Ḥamze vereint sich so die höchste religiöse und weltliche Autorität zu einem universalen Herrschaftsanspruch, wie beim Propheten Moḥammad.

Ḥamzes Charakter wird als unversöhnlich und hart porträtiert. Seine Autorität und überwältigende Ausstrahlung verleiht seinen Gefolgsleuten den Mut und die Kraft, die Feinde zu besiegen. So gilt Ḥamze als vorbildliche Heldenfigur im Geiste des Islams, ausgezeichnet 
durch unnachsichtiges Handeln und rücksichtslosem Vernichtungswillen. Der Patriotismus der Zuhörer soll durch den Sieg des Helden im Kampf gegen fremde Völker geweckt und gestärkt werden.

Ḥamzes Soldaten werden im $R H$ als bedingungslose Kämpfer dargestellt, die selbst den eigenen Untergang in Kauf nehmen. Sie gelten mit ihrem Kriegerstolz und ihrer Waffengewalt als Vorbilder für die Kultur und den islamischen Glauben des mittelalterlichen Irans, schon in der Ṣafavidenzeit. Diese Verbindung aus Kriegerkraft und Glaubensstärke macht die Muslime gegenüber ihren Gegnern unbesiegbar.

Ein weiterer Aspekt, der hier berücksichtigt werden soll, ist die Rolle des $R H$ in Erinnerungen der Muslimen. Jan Assmann verweist in seinem Buch „Das kulturelle Gedächtnis, Schrift, Erinnerung und politische Identität in früheren Hochkulturen" darauf, dass das Kernwissen einer Kultur nicht von selbst, sondern erst im Zuge einer politischen Herrschaft entsteht. Denn Herrschaft und Erinnern stehen einem engen Verhältnis. „Die Herrscher usurpierten dafür nicht nur die Vergangenheit, sondern auch die Zukunft und sie wollen erinnert werden, setzen sich in ihren Taten Denkmäler, sorgen, dass diese Taten erzählt, besungen, in Monumenten verewigt oder zumindest archivarisch dokumentiert werden.“ (Assmann 1999, 71). Sie lassen sich, wie etwa auch im Ahnen- und Totenkult, sowohl retrospektiv als auch prospektiv legitimieren. Daher ist immer auch nach den Erinnerungsstrategien zu fragen, mit deren Hilfe sich politische Herrschaft entwickelt hat und welche Art von Erinnerung legitimierend ist. In diesem Zusammenhang gehört die Gestalt von Ḥamze eine Erinnerungsfigur für muslimische Herrschaft. Sie lassen ihre Taten und Kämpfe durch solche religiösen Persönlichkeiten wie Hamze legitimieren. Deswegen war diese Geschichte ein guter Nährboden für ihre Behauptungen. Mit solchen Begründungen wächst die Geschichte von Ḥamze immer weiter. Im kulturellen Gedächtnis der Muslime stellt das $R H$ eine Art Gründungsmythos dar, der im Verlauf der islamischen Geschichte immer zur Orientierung herangezogen worden ist. Das Buch berichtet von einer heroischen Vergangenheit, die in ihrer Vielfalt für die meisten Zuhörer unbekannt ist, da sie durch einen zeitlichen und kulturellen Abstand von ihr getrennt sind. Die im Buch dargestellte Vergangenheit liegt einige Jahrhunderte zurück, diese versuchen die Erzähler durch ihre Schilderung neu zu beleben.

Einerseits ist das Bild von der Vergangenheit, welches die Erzähler bieten, sehr bunt gemalt. Nicht zuletzt deshalb ist das Werk so unterhaltsam und damit auch erfolgreich. Die Erzähler versuchen, den Erwartungen ihres Volkes in ihren epischen Erzählungen gerecht zu werden. Schwierige Lebensbedingungen, wirtschaftliche Krisen, Ungerechtigkeiten sind bekanntlich ein guter Nährboden für die Volksliteratur. 
Andererseits versucht das Volk seine verzweifelte Lage in der Volksdichtung zu vergessen. Es wird daran erinnert, dass es schon bessere Zeiten gab und, dass es auch wieder Siege und bessere Zeiten geben wird. Die Erzähler „kämpfen“ daher mit ihrem Heldepos gegen alle Feinde des Irans. Entgegen der traurigen Realität ist ,ihr“ Amir Ḥamze stets siegreich. Daher schildern sie nie die Gegenwart, sondern nur die historische oder gar märchenhafte Vergangenheit. Daher wird der Epos mit der einen oder anderen Aktualisierung durch die Jahrhunderte tradiert.

Die Erzähler des $R H$ thematisieren u.a. Vorlieben und Abneigungen, Ängste und Gefahren, politische, soziale und moralische Entwicklungen. Auf diese Art und Weise verursachen die Erzähler drastische Veränderungen, die Einfluss auf das Verhalten und die mentalen Einstellungen der iranischen Gesellschaft haben. Durch ihre Erzählungen beeinflussen sie auf Dauer ihr Publikum und sind mitverantwortlich für kulturellen Wandel. In den Geschichten kann man die Veränderungen des Geschmacks verfolgen immer auch angepasst an die Erwartungen ihres Publikums.

Es ist bemerkenswert zu erwähnen, dass die Menschen unter verschiedene Einflusse leben und doch haben sie aber einen gemeinsamen Kern von Selbst-Bewusstsein den sie teilen. Dies bleibt im Laufe der Zeit im Bewusstsein der Gesellschaft verknüpft. Im Kern aber sehen wir eine Kontinuität unseres Selbst in der sozialen Horizontale von Gruppen und in der zeitliche Vertikale unserer Lebensgeschichte, die wir im Gedächtnis konstruieren können. Das Bewusstsein der eigenen Identität basiert auf Reihen von Erfahrungen und mentalen Verarbeitungen von verketteten Ereignissen, die zu Veränderungen durch Einsicht geführt haben. Diese Eigen-Identität ist durch die Aufnahme zugeschriebener Identitätsmerkmal immer eine multiple. Der Roman verdeutlicht die Kontinuitäten der Selbstwahrnehmung des iranischen Geistes und der Bewertung der Mitwelt aus der Sicht der Iraner.

Die Autoren des $R H$ haben das Bestreben die Eigenidentität zu präsentieren und zu verdeutlichen, indem sie Äußerungen Anderer sowie im großen Maße Interaktionen integrieren. Sie interpretieren, verarbeiten und integrieren jedoch auch äußere Einflusse. Die Autoren des Werkes reagieren gleichermaßen auf Begegnungen und Ereignisse, Hoffnungen und Wünsche der verschiedenen Gruppen und behalten Gewohnheiten und Einstellungen in dem Roman bei. Die Feinde enthalten zuerst schlechte und bedrohliche Eigenschaften die sich jedoch nach einer Kooperation und Versöhnung verlieren. In diesem Fall nennen wir den Islam, der zuerst mit der Gewalt den Iran erobert hat, aber später wurde er von den Iraner akzeptiert, dort hat er sich entfaltet und sogar daraus entwicklte sich eine Hochkultur. 
Obwohl der Islam die prägende geistige Kraft des Mittelalters ist, wirken die vorislamischen Ideale auch im Mittelalter weiter. Bestimmte altiranische Auffassungen von Königtum, Rittertum, von moralischen Regeln, von religösen Praktiken und literarischen Erinnerungen in Bezug auf den Islam bzw. der Schia, werden im $R H$ in neuem Gewand präsentiert und ihre Bedeutung für die Gesellschaft betont. Die iranischen Erzähler greifen die geschichtliche Figur des Hamze auf und formen sie und erfinden sie neu nach ihren Vorstellungen und vor ihrem kulturellen Hintergrund. Im $R H$ nimmt die Gestalt Hamzes viele vorislamische Charaktereigenschaften an. Die Erzähler entwerfen ein neues, anderes, fiktives ḤamzePorträt, das den Geschmack der iranischen Bevölkerung treffen soll, insbesondere den Geschmack der Soldaten, die eine der wichtigsten Zielgruppen des Werkes sind. Vorbilder aus alten Legenden und Geschichten werden für die Befähigung Ḥamzes, Kriege zu führen und $\mathrm{zu}$ herrschen, dazu herangezogen. Die Verfasser des $R H$ orientieren sich bei ihrer Schilderung von Hamzes Werdegang an den Taten Rostams und Alexanders.

Der Roman stellt, neben seinen besonderen Qualität als Herrscher und Kriegsführer, Ḥamze auch als schönen, starken und furchtlosen Menschen dar. Als jugendlicher Held werden ihm als herausragende Eigenschaften großer Stolz und unbedingte Treue seinen Gefolgsleuten gegenüber zugeschrieben. Das ändert sich jedoch im Alter, denn nun gewinnen Herrschsucht und Gewalttätigkeit die Oberhand.

Das Buch $R H$ kann das literarische Werk des Volkes genannt werden, weil es für eine breite Zuhörerschaft ohne hohen Bildungsanspruch verfasst worden ist. Dennoch lassen sich die Einflüsse der klassischen iranischen Literatur nachweisen. Das Šāh-nāme, Garšāsh-nāme und andere epische Werke der Frühzeit gelten als Vorläufer. Diese Mischung bleibt Jahrhunderte lang populär im Iran. Dabei kommt dieser Popularität sehr zustatten, dass das Werk in einer Schreibweise verfasst worden ist, die der gesprochenen Sprache entspricht.

Themen und Motive der Erzählung, die zum großen Teil fester Bestandteil der iranischen Kultur sind, entsprechen der vorislamischen und mittelalterlichen Weltordnung und sind traditionell festgelegt. Daher kann die Aufgabe der Verfasser nicht darin bestehen, etwas ganz Neues, Originelles zu schaffen, sondern die alten Motive in neuer Form wieder aufzugreifen. Der Wert des Verfassers zeigt sich vielmehr darin, wie er das vorgegebene Repertoire anwendet und variiert. Die Hauptthemen, die im $R H$ vorkommen sind auf wenige Bereiche begrenzt, daher wählen die Erzähler häufig auch Stoffe aus anderen Werken der Vergangenheit oder Gegenwart. Die Erzählungen bieten auch märchenhafte, phantastische und mythologische Motive, deren folkloristischer Hintergrund oft religiös bestimmt ist. 
Neben den Märchen entstammen viele Geschichten aus der vor- und nachislamischen Zeit und haben einen historischen Hintergrund. Die Erzähler benutzen schwer erkennbare historische Ereignisse als Handlungsteil ihrer Geschichten und geben uns so in ihren Schilderungen auch Einblick in die sozialen, wirtschaftlichen und politischen Verhältnisse ihrer Zeit. Das $R H$ zeichnet auf diese Art und Weise „ein Gemälde mittelalterlichen Lebens“, und so entsteht ein besonderes Sittengemälde der damaligen Zeit. Die Thematik reicht von der Geburt bis zum Tod, und sie wird mit unglaublichen Begebenheiten, übernatürlichen Erscheinungen, Weissagungen und Traumbildern ausgeschmückt. Breite Kreise der Bevölkerung nehmen nur eine Statistenrolle ein und insbesondere die Schichten des Bürgertums oder die der Landbevölkerung sind selten vertreten.

Das Buch $R H$ ist in verschiedener Hinsicht ein einmaliges Dokument. Untersuchungen dieses Werkes sollten insofern für die Islamwissenschaften nützlich sein und insbesondere von der Iranistik genutzt werden. 
Literaturverzeichnis

Aarne, Antti and Thompson, Stith: The Types of the Folktales. A Classification and Bibliography, Helsinki 1961.

'Abdalghani, Muhammad: A History of Persian language and literature at the Mughal court: with a brief survey of the growth of Urdu language. Babur to Akbar, Part I, Allahabad 1929.

Abi al-Makārim, 'Abdallāh Moḥammad (berühmt als Ibn al-Mi'mār al-Bag̀dādī alḤanbalī): Kitāb al-futuwwa, hrsg. von Moṣtafā Ğawād, Baġdād 1958.

Abka'i-Khavari, Manijeh: Das Bild des Königs in der Sasanidenzeit, Hildesheim/Zürich/New York 2000.

ad-Dīnawarī, Abū Ḥanīfa: Kitāb al-ahbāar atț̣iwāl, hrsg. von Ignatijju Kračkovskij, Leiden 1912.

ad-Duri, 'Abd al-'Aziz: „Baghdād“', in: $E I^{2}$, Vol. I, hrsg. von Hamilton Alexander Rosskeen Gibb [u.a.], London/Leiden 1960, S. 894-908.

ad-Dahabī, Šams ad-Din Moḥammad b. Aḥmad b. Uțān: Siyar a 'ām an-nubalā', ğuz' 1, Taḥqīq Ṣalāḥ ad-Din Munağğid, Kairo 1955.

‘Ādel, Moḥammad-Reżā: Farhang-e nāmhā-ye Šāh-nāme, Teherān 1372/1993.

'Afifi, Raḥim: Asātir va farhang-e Irān, Teherān 1374/1995.

Afs̃ār, Irağ: Eskandar-nāme, Teherān 1344/1965.

Ders.: Maqālāt-e Irān-̌̌enāsi, Teherān 1369/1990.

Afšāri, Mehrān: Ā'in-e qalandari, Teherān 1374/1995.

Ders.: Fotovvat-nāmehā va rasā'el-e khāksāriye, Teherān 1382/2003.

Ders.: Fotovvat va aṣnāf, Teherān 1381/2002.

Akashe-Böhme, Farideh: Sexualität und Körperpraxis im Islam, Frankurt am Main 2006.

al-Arrağāni, Farāmarz b. Hodādād: Samak-e 'Ayyār, hrsg. von Parviz Nātel-Huānlari, in 6 Bänden, Teherān 1347/1968.

al-Bāqillānī, Abū Bakr Moḥammad b. aṭ-Ṭaiyib: I'ğāz al-Qur’ān, Tahqīq Aḥmad Ṣaqr, Miṣr 1374h/1954.

al-Biruni, Abū ar-Reiḥān Moḥammad b. Aḥmad: al-Ātāir al-bāqiya can al-qurūn alhaliya. Chronologie orientalischer Völker, hrsg. von Akbar Dānā-Serešt, Teherān $1352 / 1973$.

al-Buhāri, Abū 'Abdallāh Moḥammad b. Ismāicil: Kitāb al-ğāmi` aṣ-Ṣaḥị̣, Publié par M. Ludolf Krehl, Leiden 1862-1908.

al-Ğāḥīy, Abū 'Uțmān 'Amr b. Baḥr: Kïtāb al-ḥayawān, Bd. 1, hrsg. von Moḥammad 'Abd as-Salām Hārūn, Miṣr 1965. 
Ders.: Al-bayān wa-'t-tabyīn. Taḥqīq va šarḥ Moḥammad 'Abd as-Salām Hārūn, alQāhira 1388 h/1968.

al-Ḥasanī an-Nadwī, Abū al-Ḥasan 'Ali: Prophetengeschichten aus dem Koran, ins Deutsche übersetzt. von Fatima Umm Abdallah, Deutschland 2006.

al-Ḥoseini al-Madani at-Tatawi, 'Abdal ar-Rašid: Farhang-e Rašidi, Bd. 1, Teherān o.J. al-Kisā'ī, Moḥammad b. 'Abdallāh: Qị̣aṣ al-anbìyā', hrsg. von Isaac Eisenberg, Leiden 1922.

al-Kulainī ar-Rāzi, Abū Ğa'far Moḥammad b. Ya'qūb b. Isḥāq: Uṣūl-i Kāfi, in 4 Bänden, übers. und hrsg. von Hāšem Rasuli u. Ḥāğğ Seyyed Ğavādi, Teherān o.J.

al-Maqdisī, Abū-Zeid Aḥmad b. Sahl al-Balḩī Muṭahhar b. Ṭāhir: Kïtāb al-bad' wa-'ttārīh, hrsg. von Clément Haurt, 6 Teile in 2 Bänden, Paris 1899-1907.

al-Mas'ūdī, Abū al-Ḥasan 'Ali b. al-Ḥosein: Ǩ̀tāb murūğğ al-dahab wa-ma‘ādin alğawāhir, hrsg. von 'Abd al-Ḥamid, Moḥammad Muḥi ad-Din, Teil 3, Ägypt 1377h/1958.

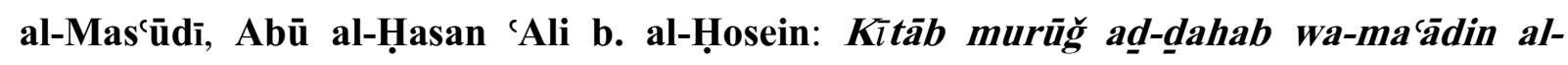
ğawāhir, in 3 Bänden, hrsg. von Charles Barbier de Meynard, Bairut 1965 u. 1970.

Ders.: Kitāb at-tanbīh wa-'I-išrā̃f, hrsg. von ‘Abdallāh Ismā̄īl aṣ-Ṣāwī, Miṣr 1375 h/1938.

Ders.: Kïtāb ahbār az-zamān wa-man abādahu 'I-ḥadatan wa- 'ağà'ib al-buldān wa-'Igāamir bi'l-māa' wa-'I- umrān, hrsg. von 'Abdallāh Ismāîil aṣ-Ṣāwī, Miṣr 1938.

al-Qazwīn̄i, Moḥammad b. Mạ̣mūd: Ātāâr al-bilā̃d wa ahbār al-cabād, Bairut 1380h/1960.

al-Qazwīnī, Zakarīyā b. Moḥammad: Die Wunder des Himmels und der Erde. Aus dem Arab. übertr. und bearb. von Alma Giese, Stuttgart/Wien 1986.

al-Ya‘qūbī, Aḥmad b. Abī Ya‘qūb b. Ğa‘far b. Wahab b. Wāọīh al-Kātīb al-‘Abbāsī: Tārihb-i al-Ya'qūbī, in 2 Bänden, hrsg. von Martijn Theodoor Houtsma, Leiden 1969.

Amin-Madani, Sadegh u. Lutz, Dorothea: Persische Grammatik, Heidelberg 1972.

Amoretti, Biancamaria Scarcia: „Religion in the Timurid and Safavid Periods”, in: CHI, Vol. 6, hrsg. von Peter Jackson, London/New York/New Rochelle/Melbourne/Sydney 1986, S. 610-658.

Āmuzegār, Žāle: „Āfarineš banā bar osturehā-ye Irāni“, in: Šenāhthte zan-e irāni, Teherān 1371/1992.

Angenendt, Arnold: Heilige und Reliquien. Die Geschichte ihres Kultes vom frühen Christentum bis zur Gegenwart, München 1994.

an-Neišāburi, Abū Isḥāq Ebrāhīm b. Manṣūr b. HUalf: Qị̣aṣ al-anbiyā̃o, hrsg. von Ḥabib Yag̀māì, Teherān 1340/1961. 
an-Neišāburi, Abu Bakr 'Atiq (berühmt als Surābādi): Qeṣaṣ-e qor’ān-e mağid, hrsg. von Yaḥyā Mahdavi, Teherān 1375/1996.

an-Nuwairī, Šihāb ad-Din Aḥmad b. 'Abd al-Wahhāb: Nihāyat al-arab fĩ funūn al-adab, Bd.14, Qāhira 1362 h/1943.

Anonymus: Abu Moslem-nāme, in 4 Bänden, hrsg. von Ḥosein Esmā̄ilili, Teherān $1380 / 2001$.

Anonymus: ‘̄̄̄lam-ārā-ye Šāh Esmãcil, hrsg. von Aṣgar Montazam-Ṣāḥeb, Teherān 1349/1970.

Anonymus: Baḥr al-fawāyed, hrsg. von Moḥammad-Taqi Dāniš-Pažuh, Teherān $1345 / 1966$.

Anonymus: Eskandar-nāme-ye haft ǧeldi, lithographischer Druck, Teherān 1315 h/ 1898.

Anonymus: Eskandar-nāme, hrsg. von 'Ali-Reżā Zूkāvati-Qarāgözlu, Teherān 1383/2004.

Anonymus: Haft Laškar. Tumār-e ğāme`e naqqāiān az Kiyomars tā Bahman, hrsg. von Mehrān Afs̃āri u. Mahdi Madāyeni, Teherān 1377/1998.

Anonymus: Hezār o yek šab, in 2 Bänden, lithographischer Druck Teherān 1275/1858.

Anonymus: Moğmal at-Tawārih wa al-qeșaṣ, hrsg. von Moḥammad-Taqi Malek ašŠo'arā' Bahār, Teherān 1318/1939.

Anonymus: Qahramān-e qātel, Lithographischer Druck, Nationalbiblothek Teherān, Nr. 3619.

Anonymus: Romuz-e Hamze, lithographischer Druck, Teherān 1274 h/1857.

Anonymus: Tabṣirat ul-'awāmm fi ma'rifat maqālātil-anām, hrsg. von 'Abbās Eqbāl, Teherān 1313/1934.

Anonymus: Tağārib al-umam fī al-ahbār mulūk al-'arab wa-'l-‘ağam, hrsg. von Reżā Anzābinežād u. Yaḥyā Kalāntari, Teherān 1373/1994.

Anonymus: Tārih̆-e Sistān, hrsg. von Moḥammad-Taqi Bahār, Teherān 1314/1935.

Anonymus: Tezkere al-Moluk, hrsg. von Moḥammad Dabir-Siyāqi, Teherān 1332/1953.

Ansāri, Moḥammad-Reżā: „Huk“, in: Dãa’rat al-ma‘ārif-e tašayyo ’ Bd. 7, hrsg. von ȘadrAḥmad Ḥāğğ Seyyed Ğavādi, Teherān 1378/1999, S. 338-341.

Ders.: „Šahādat“, in: Dā’rat al-ma‘ārif-e tašayyo, Bd. 10, hrsg. von Ṣadr-Aḥmad Ḥāğğg Seyyed Ğavādi, Teherān 1383/2004, S. 97-101.

Ders.: „Zina”, in: Dā'rat al-ma‘ārif-e tašayyo, Bd. 8, hrsg. von Ṣadr-Ạ̣mad Ḥāğğ Seyyed Ğavādi, Teherān 1379/2000, S. 506-514.

Anșāri, Ḥasan: „Bāqillānī“, in: Dā'rat al-ma‘āref-e bozorg-e eslāmi, Bd. 11, Teherān 1381/2002, S. 226-232. 
Antes, Peter: Prophtenwunder in der Ǎšañya bis al-Ġazzāh. Inaugural-Dissertation, AlbertLudwigs-Universität zu Freiburg 1969.

Ders.: Der Islam als politischer Faktor, Hannover 1997.

Ders.: Zur Theologie der Schica. Eine Untersuchung des Ğāmi` al-asrār wa-manba‘ alanwār von Saiyyid Ḥaidar Āmoli, Freiburg im Breisgau 1971.

Anvari, Ḥasan: Eștelāhātte divāni-ye doure-ye Gaznavi va Salğ uqi, Teherān 2535/1976.

Āqā Buzurg aṭ-Ṭeherānī, Muḥsen: ad-Darī'a ilā taṣānīf aš-Š̄ī́a, Bd. 8, Beirut 1983.

'Arab, Seyyed Ḥasan: „'Efrit”, in: Dā̄rat al-ma‘ārif-e tašayyo', Bd. 11, hrsg. von ȘadrAḥmad Ḥāğğ Seyyed Ğavādi, Teherān 1384/2005, S. 311-312.

Arberry, Arthur John: Catalogue of the Library of the India Office, Vol. 2, Part 6: Persianbooks, London 1937.

Arend, Walther: Die typischen Scenen bei Homer, Berlin 1933.

ar-Rāzi, Faḩr ad-Din Moḥammad b. 'Umar: at-Tafsīr al-kabīr, Bd. II, Teherān 1970.

Asadi-Ṭusi, ‘Ali b. Aḥmad: Garšāsb-nāme, hrsg. von Ḥabib Yaġmā’i, Teherān 1354/1975. aš-Šiblī, al-Qāọī badr ad-Din Abū 'Abdalallāh: Ǵarāìib wa '̌ğàib al-ǧinn kamā yusauwiruha al-qur'ān wa as-Sunna, tạ̣qīq Ibrāhīm al-Ǧamāl, al-Qāhira 1983.

aš-Šahrestāni, Abū al-Fatḥ Moḥammad: Religionsparteien und Philosophen-Schulen, Teil 1, übersetzt aus dem Arabischen ins Deutsche mit erklärenden Anmerkungen. von Theodor Haarbrücker, Hildesheim 1969.

Aṣef, Moḥammad-Hāšem: Rostam at-Tawarih̆, hrsg. von Moḥammad Moširi, Teherān 1348/1969.

Assmann, Jan: Das kulturelle Gedächtnis: Schrift, Erinnerung und politische Identität in frühen Hochkulturen, München 1999.

Ders.: Religion und kulturelles Gedächtnis, München 2000.

Assmann, Aleida: Erinnerungsräume. Formen und Wandlungen des kulturellen Gedächtnisses, München 1999.

Astarābādi, Bibi Hูānom: Ma‘̄ayeb ar-reğāă, Bd. 1, hrsg. von Afsāne Nağmābādi, Chicago 1371/1992.

'Aț̣ār, Farid ad-Din: Manteq aț-Teyr, hrsg. von Șādeq Gauharin, Teherān 1348/1969.

Ders.: Elāhi-nāme, hrsg. von Hellmut Ritter, Istanbul 1940.

Ders.: Moṣibat-nāme, hrsg. von Nurāni Veṣāl, Teherān 1338/1959.

aṭ-Ṭabarī, Abū Ğa'far Moḥammad b. Ğarīr: Tārih ar-rusul wa-'l-mulūk, Bd. 1, hrsg. von Abū al-Fạ̣l Ibrāhīm Moḥammad, Miṣr 1960. 
aṭ-Ṭabarī, Abū Ğa‘far Moḥammad b. Ğarīr: Tãrih ar-rusul wa-'l-mulūk, Bd. 2, aus dem Arabischen in Persische übersetzt. von Abu 'I-Qāsem Pāyande, Teherān 1362/1983.

Ders.: Tafsīr aț-Tabari, al-musammā Ǧāmi' al-bayān 'an ta'wīl al-Qur'ān, ğuz' 8: Tafsīr sūratan-Nisā' min 8-87 wa-'l-ātāa min 8658-10048, 2. Aufl., hrsg. von Maḥmūd Moḥammad Šākir, al-Qāhira: Dār al-Ma ārif, [ca. 1971].

at-Ta'ālībī, Abū Manṣūr al-Ḥosein b. Moḥammad al-Marg̉anī: ǴGurar ahbār mulūk alfurswa siyaruhum [Histoire des Rois des Persses], hrsg. von Hermann Zotenberg, Neudruck Teherān 1963.

at-Ṭa labī, Abū Isḥāq Aḥmad b. Moḥammad b. Ibrāhīm: Qị̣aṣ al-anbiyā̃à. Al-musammā 'Arā'is al-mağālis, Miṣr 1371 h/1951.

aṭ-Ṭarsusi, Abū Ṭāher Moḥammad: Dārāb-nāme-ye aț-Tarsusi, in 2 Bänden, hrsg. von Zabiḥallāh Șafā, Teherān 1345/1966.

Aubin, Eugène: La Perse d'aujourd'hui, aus dem Französischen übersetzt ins Persische. von 'Ali Asğar Sacidi, Teherān 1362/1983.

Ayoub, Mahmoud Mustafa: Redemptive Suffering in Islam: A Study of the Devotional Aspects of Ashura in Twelver Shi'ism (Religion and Society), Den Haag 1978.

az-Zamahš̌arī, Maḥmūd b. Umar: al-Kaššăf 'an ḥaqā'i gaawāmị̣ at-tanzīl wa 'uyūn alqāwīl fĩ wuğūhihī at-ta’wīl, ğuz 1, Beirut: Dār al-Kitāb al-'Arabī, [ca. 20. Jh.].

az-Ziriklī, Hair ad-Din: al-A Iām. qāmūs tarāğim li-ašhar ar-riğāl wa an-nisā’ min al‘arab wa 'I-musta'ribīn wa 'I-mustašrigīn, in 5 Bänden, Bairut 1984.

Babayan, Kathryn: Mystics, Monarchs and Messiahs, London/Harvard 2002.

Babinger, Franz: Die Geschichtsschreiber der Osmanen und ihre Werke, Leipzig 1927.

Bābur, Zahir ad-Din Moḥammad: Bābur-nāme, translated by Annette S. Beveridge, in 2 Bänden, New Delhi 1979.

Badā'uni, 'Abd al-Qādir: Montahab at-Tawārih̆, Bd. 1, hrsg. von Aḥmad 'Ali Sāḥeb, Teherān 1380/2001.

Bahār, Moḥammad-Taqi: Sabk-šenāsi, in 3 Bänden, Teherān 1337/1958.

Bajalijewa, Toktobjubju Dshunuschakunowa: Vorislamische Glauben der Kirgisen, übersetzt aus dem Russischen ins Deutsche von Reinhold Schletzer, Berlin 2002.

Bal'ami, Abu 'Ali Moḥammad b. Moḥammad: Tārih̆e Bal'ami, hrsg. von MoḥammadĞavād Maškur, Teherān 1337/1958.

Baldick, Julian: „The Iranian Origin oft he futuwwa”, in: istituto Universitario Orientale di Napoli, 50 (1990), S. 345-361. 
Balzer, Wolfgang: Achaimenidische Kunst aus Babylonien. Die Siegel der Keilschriftarchive. Ikonographie. Stile. Chronologie, Inaugural-Dissertation zur Erlangung des Doktorgrades der Philosophie an der Ludwig Maximilians-Universität München 2007.

Barbaro, Josefa/Contarini, Ambrogio: Travels to Tana and Persia: A narrative of Italian travels in Persia, Stanley, hrsg. von Henry Edward John 1827-1903, ins Englische übersetzt. von William Thomas, London 1873.

Barthold, Wilhelm: „,Khotan“, in: EI, Bd. II, hrsg. von Martijn Theodoor Houtsma [u.a.], Leiden/Leipzig 1927, S. 1041-1042.

Ders.: „Zur Geschichte des persischen Epos“, aus dem Russischen ins Deutsche übersetzt. von Hans Heinrich Schaeder, in: ZDMG 98, Leipzig 1944, S. 121-157.

Basgöz, Ilhan: „Türkish Hikaye-Telling Tradition in Azerbaijan, Iran”, in: JAFS, Vol. 83, No. 330, Oct-Dec, Austin/Texas (1970), S. 391-405.

Bāstāni-Pārizi, Moḥammad-Ebrāhīm: Yáqub-e leịs, Teherān 1367/1988.

Ders.: Siyāsat va eqteșād-e 'aṣr-e Safavi, Teherān 1348/1969.

Ders.: Vādi-ye haftvād, Bd. 1, Teherān 2535/1977.

Bauer, Thomas: Liebe und Liebesdichtung in der arabischen Welt des 9. und 10. Jahrhunderts, Wiebaden 1998.

Bausani, Alessandro: „An Islamic Echo of the Tricker? The 'Ayyārs of Indo-Persian and Malay Romances”, in: Gururājamanjarikā, Studi in Onore di Giuseppe Tucci 2, Istituto Universitario Orientale, Naples (1974), S. 457-467.

Bayat-Sarmadi, Dariusch: Erziehung und Bildung im Schahname von Firdousi, InauguralDissertation zur Erlangung des Doktorgrades der Philosophischen Fakultät der Universität zu Köln 1970.

Beinhauer-Köhler, Barbel: Fātima bint Muhammad: Metamorphosen einer frühislamischen Frauengestalt, Wiesbaden 2002.

Benjamin, Samuel Green Wheeler: Persia and the Persians, ins Persische übersetzt. von Ḥosein Kord-bačče, Teherān 1369/1990.

Benveniste, Emil: The Persian Religion According to the Chief Greek Texts, Paris 1929.

Beuck, Hans Heinrich: Die Boden Kulter in persien und ihre Ausfuhrerzeugnisse, Hamburg 1919.

Beyhaqi, Abu al-Fażl Moḥammad b. Ḥosein: Tārih̆-e Beyhaqi, Bd. 1, hrsg. von Sacid Nafisi, Teherān 1319/1940.

Beyhaqi, Abu al-Fażl Moḥammad b. Họosein: Tārih̆-e Beyhaqi, hrsg. von Ğacfar Modarres-Ṣādeqi, Teherān 1377/1998. 


\section{Beyżāì, Bahrām: Namāyeš dar Irān, Teherān 1380/2001.}

Birus, Hendrik: „Metonymie“, in: Reallexikon der deutschen Literaturwissenschaft, Bd. II, hrsg. von Harald Fricke, Berlin/New York 2000, S. 588-591.

Björkman, Walther: „Kạuklu“, in: Encyclopédie de l'Islam, Vol. IV, hrsg. von Clifford Edmund Bosworth [u.a.], Paris/Leiden 1978, S. 838-839.

Biğami, Moḥammad b. Aḥmad 'Ali: Dārāb-nāme, in 2 Bänden, hrsg. von Znabiḥallāh Ṣafā, Teherān 1374/1995.

Binder, Gerhard: „Aussetzung“, in: EM, Bd. 1, hrsg. von Kurt Ranke, Göttingen 1977, Sp. 1048-1065.

Binning, Robert B. M.: A Journal of two Years' Travel in Persia, Ceylon etc, Vol. 2, London 1857.

Binyon, Laurence; Wilkinson, J. V. S. u. Gray, Basil: Persian miniature painting: including a critical and descriptive catalogue of the miniatures exhibited at Burlington House, New York 1971.

Birge, John Kingsley: The Bektashi order of Derwishes, New York 1982.

Blieske, Dorrethea: Šāhīn-e Šīrāzīs Ardešīr-Buch, Diss. Phil. Fakultät der Eberhard-Karls Universität zu Tübingen 1966.

Blochet, Edgar: Catalogue Manuscrits Persans de la Biblothèque Nationale de Paris, Tome 4, Paris 1934.

Ders.: Catalogue Manuscrits turcs de la Biblothèque Nationale de Paris, Vol. 2, Paris 19321933.

Böcher, Otto: „Licht und Feuer I“, in: Theologische Realenzyklopädie, Bd. XXI, hrsg. von Gerhard Müller, Berlin/New York 1991, S. 83-90.

Böller, Friedrich-Karl: EthnologischeUntersuchungen zum Kitäb-i Dede Qorqut, Diss. der philosophischen Fakultät der Ludwig-Maximilians-Universität zu München1974.

Bolukbāši, 'Ali: „Davālak-bāzi va taḥqiqi dar vāže-ye davāl“, in: Honar va Mardom, Nr. 89, 10 Jahrgang, Esfand, Teherān 1348/1969, S. 28-46.

Boratav, Pertev Naili: „Le conte et la légende“, in: PTF II, Wiesbaden 1965, S. 44-67.

Ders.: „Orta Oyunu“, in: Encyclopédie de l'Islam, Vol. VIII, hrsg. von Clifford Edmund Bosworth [u.a.], Leiden 1995, S. 181-182.

Bosworth, Clifford Edmund: „Karāā Khițāy“, in: $E I^{2}$, Bd. IV, hrsg. von E. van Donzel [u.a.], Leiden 1978, S. 580-583

Ders.: „The political and dynastic history of the Iranian World”, in: CHI, Vol. 5, Cambridge 1961, S. 1-203. 
Ders.: „Liwāț“, in: $E I^{2}$, Vol. V, hrsg. von Clifford Edmund Bosworth [u.a.], Leiden 1986, S. 776-779.

Bouvat, Lusien: „Essai sur la Civilisation Timouride”, in: Journal Asiatique, Avril-Juin (1926), S. 193-299.

Böwering, Gerhard: The mysticalvision of existence in classical Islam: the Qur'ānic hermeneutics of the Șūfī Sahl at-Tustarī (d. 283/896), Berlin/New York 1980.

Boyce, Mary: „The Parthian Gōsān and Iranian Minstral Tradition”, in: JRAS (1957), S. 1045.

Dies.: Zoroastrians: their religious beliefs and practices, London/New York 2001.

Dies.: „On Mithra. Lord of fire“, aus dem Englischen ins Persische übersetzt. von 'Ali-Aṣgar Mirzāìi, in: Hasti 2, 4 Jahrgang, Nr. 14, Teherān 1382/2003, S. 89-97.

Boyle, J. A.: Khān, in: $E l^{2}$, Vol. IV, hrsg. von E. Van Donzel [u.a.] Leiden 1978, S. 1010.

Brednich, Rolf Wilhelm: „Gebet“, in: EM, Bd. 5, hrsg. von Rolf Wilhelm Brednich, Göttingen 1987, Sp. 792-800.

Ders.: „Gefangenschaft““, in: EM, Bd. 5, hrsg. von Rolf Wilhelm Brednich, Göttingen 1987, Sp. 833-846.

Browne, Edward Granville: A literary History of Persia, Bd. IV, Cambridge 1951.

Brugsch, Heinrich: Reise der K. preussischen Gesandtschaft nach Persien (1860 und 1861), Bd. 2, Berlin 1864.

Brunschvig, R.: 'Abd, in: $E l^{2}$, Bd. 1, hsrg. von Hamilton Alexander Rosskeen Gibb [u.a.], Leiden 1979, S. 24-40.

Buge, Ernest A. Wallis: Amulets and Superstitions, New York1930.

Buhl, Frants: „Muḥammed b. al-Ḥanafiya“, in: EI, Bd. III, hrsg. von Martijn Theodoor Houtsma [u.a.], Leipzig/Leiden 1936, S. 722-723.

Ders.: ,al-Lāt“", in: $E l$, Bd. III, hrsg. von Martijn Theodoor Houtsma [u.a.], Leiden/Leipzig 1936, S. 20.

Ders.: ,al-Manāt“, in: $E l$, Bd. III, Martijn Theodoor Houtsma [u.a.], Leiden/Leipzig 1936, S. 251.

Ders.: ,al-'Uzzā‘), in: $E l$, Bd. IV, hrsg. von Martijn Theodoor Houtsma [u.a.], Leiden/Leipzig 1934, S. 1157-1158.

Büchner, V. F.: „Madjūs“, in: EI, Bd. III, hrsg. von Martijn Theodoor Houtsma [u.a.], Leiden/Leipzig 1936, S. 104-108.

Bürgel, Johann Christoph: „Die persische Epik”, in: Handbuch der Kulturgeschichte. Die Kultur des Islams, Bd. 5, Kalus Von See, Wiesbaden 1990, S. 301-318. 
Ders.: „Krieg und Frieden im Alexanderepos Nizamis“, in: The Problematics of Power. Eastern and Western Representations of Alexander the great, Bern/Berlin/Frankfurt am Main/New York/Paris/Wien 1996, S. 91-108.

Butorābi, Hadiğe: „Seḥr va ğādu“, in: Dã’irat al-ma‘ārif-e tašayyo, Bd. 9, hrsg. von ȘadrẠ̣mad Ḥāğğ Seyyed Ğavādi, Teherān 1381/2002, S. 116-118.

Dies.: „Šeițān“, in: Dā'rat al-ma‘ārif-e tašayyo, Bd. 10, hrsg. von Ṣadr-Aḥamd Ḥāğğg Seyyed Ğavādi, Teherān 1383/2004, S. 220-223.

Caferoğlu, Ạ̣met: „Die aserbeidschanische Literatur“, in: PTF, Bd. II, hrsg. von Pertev Naili Boratav, Wiesbaden 1965, S. 635-699.

Cahen, Claude: „Zur Geschichte der städtischen Gesellschaft im islamischen Orient des Mittelaters“, in: Saeculum IX (1958), S. 59.76.

Ders.: „Futuwwa“, in: $E I^{2}$, Vol. II, hrsg. von Bernard Lewis [u.a.], Leiden/London 1965, S. 961-965.

Ders.: „Atabak“, in: $E I^{2}$, Vol. I, hrsg.von Hamilton Alexander Rosskeen Gibb [u.a.], Leiden/London 1960, S. 731-732.

Ders.: „Tribes, Cities and Social Organization”, in: CHI, Vol. 4, hrsg. von Richard Nelson Frye, Cambridge 1975, S. 305-328.

Calmard, Jean: „Popular Literature under the Safavids”, in: Society and Culture in the earlymodern Middle East: studies on Iran in the Safavid Period, hrsg. von Andrew J. Newman, Leiden/Boston 2003, S. 315-339.

Cancik, Hubert (Hg.): Der neue Pauly. Enzyklopädie der Antike, Bd. 8, Weimar 2000.

Caskel, Werner: „Ein Mahdī des 15. Jahrhunderts“, in: Islamica 4,(1929/31), S. 48-93.

Cejpek, Jiř́: „Die iranische Volksepik”, in: Iranische Literaturgeschichte. hrsg. von Jan Rypka, Leipzig 1959, S. 464-548.

Chardin, Jean: Voyages du chevalier Chardin en Perse et autreslieux d'Orient, Paris 1811.

Chardin, Jean: Voyages du Chavalier Chardin en Perse et autres lieux de l'Orient, Teil Eṣfahān, aus dem Französischen ins Persische übersetzt. von Ḥosein 'Ariżi, Teherān $1362 / 1983$.

Chaumont, M. L.: „Āzād”, in: Elr, Vol. III, hrsg. von Ehsan Yarshater, London/New York 1989, S. 169-170.

Chelhod, Josef: „La baraka chez les Arabes ou l'influence beinfaisante du sacré”, in: Revue de l'Histoire des Religions, Nr. 148, Paris 1955/1, S. 68-88. 
Cherry, John: Fabeltiere. Von Drachen, Einhörnern und anderen mytischen Wesen, aus dem Englischen ins Deutsche übersetzt von Ingrid Rein, Christian Rochow u. Thomas Schlachter, Stuttgart 1997.

Christensen, Arthur Emanuel: L'Iran sous les Sassanides, ins Persische übersetzt. von Rašid Yāsami, Teherān 1375/1996.

Ders.: Persische Märchen, Nachwort, hrsg. von Friedrich von der Leyen, Köln/Düsseldorf 1958.

Ders.: Les types du premier homme et du premier roi, dans l'histoire légendaire des Iransiens, ins Persische übersetzt. von Ạ̣mad Tafażżoli u. Žāle Āmuzegār, Teherān $1377 / 1998$.

Ders.: „La légende du sage Buzurgmīhr”, in: Acta Orientalia III/I (1930), S. 81-128.

Cleveland Beach, Milo: The imperial image. Paintings for the Mughal court, Washington D. C. 1981.

Colpe, Carsten: „Iranische Tradition“, in: Neues Handbuchder Literaturwissenschaft, Bd. 5, Kalus Von See, Wiesbaden 1990, S. 68-85.

Corbin, Henry: „The Meaning of Imam for Shici Spirituality“, in: Expectation of the Millennium. Shicism in History, hrsg. von Seyyed Hossein Nasr, Hamid Dabashi und Seyyed Vali Reza, New York 1989, S. 167-187.

Cotton, J. S.: „Baraka“, in: EI, Bd. I, hrsg. von Martijn Theodor Houtsma [u.a.], Leiden: Brill 1913, S. 681.

Dādbe, Aṣgàar u. Rafici, ‘Ali: „Tawakkol“, in: Dā̄rat al-ma‘ārif-e tašayyo` Bd. 5, hrsg. von Ṣadr-Aḥmad Ḥāğğ Seyyed Ğavādi, Teherān 1375/1996, S. 153-155.

Dastg̉eib Širāzi, Āyatallāh Seyyed 'Abd al-Ḥosein: Gonāhān-e kabire, Bd. 1, Teherān $1361 / 1982$.

Davidson, Olga M.: Poet and Heroin the Persian Book of Kings, Ithaca/London 1994.

Daxelmüller, Christoph: „Hand”, in: EM, Bd. 6, hrsg. von Rolf Wilhelm Brednich, Göttingen 1990, Sp. 436-447.

Ders.: „Furz“, in: EM, Bd. 5, hrsg. von Rolf Wilhelm Brednich, Göttingen 1987, Sp. 593-600.

Ders.: „Geruch“, in: EM, Bd. 5, hrsg. von Rolf Wilhelm Brednich, Göttingen 1987, Sp.10971102.

Ders.: „Divination“, in: EM, Bd. 3, hrsg. von Rolf Wilhelm Brednich, Göttingen1981, Sp. 718-727.

Dāvar, Šaih Mofid: Tažkere-e mer'āt al-foṣaḥā, Bd. 1, hrsg. von Maḥmūd Dāvuudi, Širāz $1371 / 1991$. 
D'Allemagne, H. R.: Du Kurdistan au pays des Bachtyaris, Bd. 1, ins Persische übersetzt. von Ġolām-Reżā Samici, Teherān 1378/1999.

De Bruijn, J. T. P.: „Die persische Volksliteratur im Mittelalter und ihr Verhältnis zur klassischen Literatur", in: Neues Handbuch der Literaturwissenschaft, Bd. 5, hrsg. von Klaus Von See, Wiesbaden 1990, S. 456-474.

Dehbozorgi, Ġolām-Ḥosein: „Simorg̀-e asāṭiri“, in: Ma‘āref, Vol. XVIII, Nr. 3, ĀzarEsfand, Teherān 1380/2001, S. 97-114.

\section{Dehhodā, 'Ali-Akbar: Log̉at-nāme, Teherān 1337/1958.}

Della Valle, Pietro: Famevx Voyages De Pietro Della Valle, Bd. 1, ins Persische übersetzt. von Mạ̣mud Behforuzi, Teherān 1380/2001.

Denffer, Dietrich: „Baraka as basic concept of muslim popular belief“, in: Islamic Studies, Vol. XV, Islamabad 1967, S. 167-186.

De Plano Carpini, Johann: Geschichte der Mongolen und Reisebericht 1245-1247, hrsg u. übersetzt von Friedrich Risch, (Veroffenlichungen des Forschungsinstituts für vergleichende Religionsgeschichte an der Universität Leipzig. 2. Reihe, Heft 11) Leipzig 1930.

De Rachewiltz, Siegfried: „Kette“, in: EM, Bd. 7, hrsg. von Rolf Wilhelm Brednich, Göttingen 1993, Sp. 1191-1194.

Dinzelbacher, Peter (Hg.): Europäische Mentalitätsgeschichte. Hauptthemen in Einzeldarstellungen, Stuttgart 1993.

Doerfer, Gerhard: Türkische und mongolische Elemente im Neupersischen. Unter besonderer Berücksichtung älterer neupersischer Geschichtsquellen, vor allem der Mongolen und Timuridenzeit. in 4 Bänden. (Akademie der Wissenschaften und der Literatur, Veröffentlichungen der Orrientalischen Kommision, Bde. XVI, XIX, XX, XXI), Wiesbaden 1963-1975.

Dorpmüller, Sabine: Religiöse Magie im Buch der Probaten Mittel. Analyse, kritische Edition und Übersetzung des Kitāb al-Muğarrabāt von Muḥammad ibn Yūsuf as-Sanūsī (gest. um 895/1490), Wiesbaden 2005.

Duby, Georges: „Mentalitätengeschichte“, in: Ideengeschichte, hrsg. von Barbara StollbergRilinger, Stuttgart 2010, S. 137-163.

Duda, Herbert W.: Ferhād und Schīrīn, Praha/Paris/Leipzig 1933.

Du Mans, Raphaël: Estat de la Perse en 1660, hrsg. von Charles Henri Auguste Schefer, Paris 1890.

Eaton, Richard M.: The Rise of Islam and the Bengal frontier 1204-1760, Berkeley 1993. 
Edwards, Edwards: A Catalogue of the Persian Printed Books in the British Museum, London 1922.

Egger, Gerhart: Der Hamza Roman. Ein Moghul-Handschrieft aus der Zeit Akbar des Großen. Schriften der Bibliothek des Österreichischen Museums für angewandte Kunst 1, Wien 1969.

Ehlers, Jürgen: Die Natur in der Bildsprache des Šāh-nāme, Wiesbaden 1995.

Eilers, Wilhelm: „Schiitische Wasserheilige“, in: Die islamische Welt zwischen Mittelalterund Neuzeit, Festschrift für Hans Robert Roemer zum 65. Geburtstag, hrsg. von Ulrich Haarmann u. Peter Bachmann, Beirut 1979.

Eisenstein, Herbert: Einführung in die arabische Zoographie, Berlin 1990.

Elfriede, Moser-Roth: „Frau”, in: EM, Bd. 5, hrsg. von Rolf Wilhelm Brednich, Göttingen 1987, Sp. 100-137.

Engle, David: „Edelstein“, in: EM, Bd. 3, hrsg. von Kurt Ranke, Göttingen 1981, Sp. 10031009.

Enğavi-Širāzi, Abu 'I-Qāsem: Mardom va Šāh-nāme, Teherān 1354/1975.

Ders.: Mardom va qahramānān-e Šāh-nāme, Teherān 1337/1958.

Eskandar-Beg Torkmān (monši): Tarih̆-e 'Ālam-ārā-ye 'Abbāsi, Bd. 1, Teherān $1314 / 1935$.

Eslāmi-Nadušan, Moḥammad-‘Ali: Zendegi o marg-e pahlavānān dar Šāh-nāme, Teherān 1348/1969.

Ethé, Hermann: Catalogue of the Persian, Turkish, Hindūstān̄ and Pashtū Manuscripts in the Badleian Library, Part II, London 1903.

Ders.: Catalogue of the Persian Manuscripts in the Library of the India Office, Bd. 1, Oxford 1903.

Ders.: „Neupersische Literatur”, in: Grundriss der iranischen Philologie, zweiter Teil, hrsg. von Wilhelm Geiger u. Ernst Kuhn, Strassburg. 1896-1904. S. 212-368.

Faḩr az-Zamāni, 'Abd an-Nabi: Terāz al-ahbār, MS, Parlomentsbiblothek Teherān, Nr. 14188.

Ders.: Tazkere-ye mei-hāne, hrsg. von Ạ̣mad Golčin-Macāni, Teherān 1340/1961.

Falāturi, ‘Abd al-Ğavād: „Die Zwölfer-Schia aus der Sicht eines Schiiten: Probleme ihrer Untersuchung", in: Festschrift Werner Cakel zum siebzigsten Geburtstag 5. März 1966, hrsg. von Erwin Gräf, Leiden 1968. S. 63-95.

Ders.: „Die Vorbereitung des Iranischen Volkes für die Annahme der Schia zu Beginn der Șafaviden-Zeit.” Die islamische Welt zwischen Mittelalter und Neuzeit, in: Festschrif für H. 
R. Roemer zum 65. Geburtstag. hrsg. von Ulrich Haarmann und Peter Bachmann, Bairut 1979, S. 132-145.

Falsafi, Naṣrallāh: Zendegāni-e Šāh 'Abbās-e avval, in 5 Bänden, Teherān 13391344/1960-1965.

Faridany-Akhavan, Zahra: The Problems of the Mughal Manuscript of the Hamza-name 1562-77: A Reconstruction, Ph.D. Dissertation, Harvard University 1989.

Farroḩi-Sistāni, Abū al-Ḥasan 'Ali: Divān ḥakim Farrohi-Sistāni, hrsg. von Moḥammad Dabir-Siyāqi, Teherān 1335/1956.

Faruqi, Shamsur Rahman: Sahiri, Shahi, Sahib Qirani. Dastan-e Amir Hamza Ka Mutalia, Allahabad 1999.

Fatoum, Aly Abdul-Gaphar: Der Ğinn-Glaube als islamische Rechtsfrage nach Lehren der Orthodoxen Rechtsschulen, Ph.D. Diss. Universität Mainz 1998, Frankfurt am Main 1999.

Ferdousi, Abū 'l-Qāsem: Šāh-nāme. a Reprint of Moscow Edition, Teherān 1382/2003.

Feyż Kāšāni, Moḥammad b. Šāh Mortażā: Al-Mohağa al-bayżā’ li tahḍib al-iḥyā’, Bd. 8, aus dem Arabischen ins Persische übersetzt. von Moḥammad-Ṣādeq ‘Āref, Qom 1376/1997. Fischer, Wolfdietrich: Grammtik des klassischen Arabisch, Wiesbaden 1972.

Fleischer, Heirich: Catalogue Codicum Manuscriptorum Orientalium Bilbliothecae Rejiae Dresdensis, Leipzig 1831.

Ders.: Codices Arabici Persici Turcici, Catalogus Librorum Manuscriptorum qui in Bibliotheca Senatoria Civitatis Lipsiensis asservantur (édité par E. W. R. Naumann), Leipzig 1838.

Floor, Willem: The History of Theater in Iran, Washington D. C. 2005.

Foruzānfar, Badi` az-Zamān: Šarḥ-e masnavi-ye šarif, Bd. 1, Teherān 1347-1348/19681969.

Fügel, Gustav.: Die arabischen, persischen, türkischen Handschriften der kaiserlichen und königlichen Hofbibliothek zu Wien, Bd. II, Hildesheim/NewYork 1977.

Franke, Heike: Akbar und Ğahāngīr. Untersuchungen zur politischen und religiösen Legitimation in Text und Bild, Bonn 2005.

Franke, Patrick: Begegnung mit Khidr. Quellenstudien zum Imaginären im traditionellen Islam, Beirut/Stuttgart 2000.

Franklin, William: Observation Made on a Tour From Bengal to Persia in the Year 1786-7, London 1790.

Frembgen, Jürgen: Derwische. Gelebter Sufismus Wandernde Mystiker und Asketen im islamischen Orient, Köln 1993. 
Friedlaender, Israel: Die Chadirlegende und der Alexanderroman. Eine sagengeschichtliche und literahistorische Untersuchung, Leipzig/Berlin 1913.

Gabain, Annemarie: „Steppe und Stadt im Leben der ältesten Türken“, in: Der Islam 29 (1949), S. 30-62.

Gabriel, Alfons: Die Erforschung Persiens. Die Entwicklung der abendländischen Kenntnis der Geographie Persiens, Wien 1952.

Gabrieli, Francesco: „Ibn al-Muqaffa““, in: $E I^{2}$, Vol. III, hrsg. von Bernard Lewis [u.a.], Leiden/London 1971, S. 883-885.

Ġafāri-Kāšāni, Aḥmad b. Moḥammad: Tārihb-e Negārestān, hrsg. von Mortażā Modarrsi-Gilāni, Teherān 1340/1961.

Ğa'fariyān, Rasul: Din va siyāsat dar doure-ye Ṣafaviyān, Teherān 1370/1991.

Gaillard, Marina: Le Livre de Samak-e Ayyār: structure et idéologie du roman persan médiéval, Paris 1987.

Galunov, R. A.: „Neskol'ko slov o perspektivakh sobirania materialov po fol'klory i teatr v Persii Dokladie”, in: Akademii Nauk 17, Leningrad 1929, S. 307-312.

Ders.: „Ma'reke giri”, in: Iran III, (1929), S. 94-106.

Ğamālzāde, Moḥammad-‘Ali: Farhang-e logāat-e ‘āmmìāne, hrsg. von MoḥammadĞacfar Maḥ̆gub, Teherān 1341/1962.

Gardet, Louis: „Al-asmā̄ al-ḥusnāa“, in: $E I^{2}$, Vol. I, hrsg. von Hamilton Alexander Rosskeen Gibb [u.a.], Leiden/Leipzig 1960, S. 714-717.

Ġaribpur, Behruz: Te'ātr dar Irān, Teherān 1384/2005.

Ġazzāli Ṭusi, Zain ad-Din Abu Ḥamid Moḥammad: Ketāb-e kimiyā̄oye sa'ādat, hrsg. von Aḥmad Ārām, Teherān 1333/1954.

Ders.: Naṣiḥat al-Moluk, hrsg. von Ğalāl ad-Din Homāì, Teherān 1361/1982.

Geertz, Clifford: The Interpretion of Cultures. Selected Essays, New York 1993.

Geiger, Abraham: Was hat Mohammad aus dem Judentum aufgenommen, Leipzig 1902.

Geldner, Karl Friedrich: „Avestaliteratur“, in: Grundriss der iranichen Philologie, zweiter Teil, hrsg. von Wilhelm Geiger u. Ernst Kuhn, Stassburg 1986-1904, S. 1-53.

Gelpek, Rudolf: Liebe und Abenteuer des Amir Arsalan, Zürich 1965.

Ders.: Die iranische Prosaliteratur im 20. Jahrhundert, Teil 1, Wiesbaden 1962.

Gerald, Thomas: „Schuß“, in: EM, Bd. 12, hrsg. von Rolf Wilhelm Brednich, Göttingen 2007, Sp. 247-249.

Gerlach, Hildegard: „Hexe“, in: EM, Bd. 6, hrsg. von Rolf Wilhelm Brednich, Göttingen 1990, Sp. 960-992. 
Gerndt, Helge: Reise, in: EM, Bd. 11, hrsg. von Rolf Wilhelm Brednich, Göttingen 2004, Sp. 504-514.

Gignoux, Philippe: Le livre d'Ardâ Virâz, ins Persische übersetzt und bearbeitet. von Žāle Āmuzegār, Teherān 1372/1993.

Glassen, Erika: Die frühen Safaviden nach Qã̄̇̃ Aḥmad Qumī (=IU5), Freiburg 1970.

Dies.: „Schah Ismā̄̄îl. Ein Mahdī der anatolischen Türkmenen?“, in: ZDMG 121, (1971), S. 61-69.

Dies.: „Krisenbewusstsein und Heilserwartung in der islamischen Welt zu Beginn der Neuzeit“. Die islamische Welt zwischen Mittelalter und Neuzeit, in: Festschrif für Hans Robert Roemer zum 65. Geburtstag, hrsg. von Ulrich Haarmann und Peter Bachmann, Beirut 1979, S. 167-179.

Glück, Heinrich: Die indischen Miniaturen des Hamze-Romanes, Wien/Zürich/Leipzig 1925.

Gobineau, Joseph Arthur: Die Welt der Perser, aus dem Französischen ins Deutsche übersetzt. von Renate Navé, Gütersloh: Bertelsmann [u.a.], München/Berlin 1971.

Golden, B. Peter: An introduchtion to history of the Turkic pepoles: enthnogenesis and state formation in medieval and early modern Eurasia and the Middle East, Wisbaden Harrassowitz 1992.

Goldziher, Ignaz: „Zauberelemente im islamischen Gebet”, in: Orientalische Studien, Theodor Nöldeke zum siebzigsten Geburtstag, Bd.1, hrsg. von Carl Bezold, Giessen 1906, S. 303-329.

Ders.: Muhammedanische Studien, Bd. II, Halle 1890.

Ders.: „Aṣ̣̣āb“, in: El, Bd. I, hrsg. von Martijn Theodoor Houtsma [u.a.], Leiden/Leipzig 1913, S. 496-497.

Ders.: Beitrag zur Literaturgeschichte der Schia und der sunnitischen Polemik, Wien 1874.

Ders.: „Le culte des saints chez les Musulmans”, in: Revue de l'Histoire des Religions, Bd. 2, (1880), S. 275-351.

Ders.: „Wasser als Dämonen abwehrendes Mittel“, in: Gesamte Schriften, Bd. V, hrsg. von Joseph Desomogy, Hildesheim 1973, S. 170-196.

Ders.: „Zauberkreise“, in: Gesamte Schriften, Bd. V, hrsg. von Joseph Desomogy, Hildesheim 1973, S. 401-403.

Ders.: Vorlesungen über den Islam, Heidelberg 1925.

Göbel, Karl-Heirich: „Imamate“, in: Expectation of the Millennium. Shicism in History, hrsg. von Seyyed Hossein Nasr, Hamid Dabashi und Seyyed Vali Reza, New York 1989, S. 3-6. 
Ġoravi, Moḥammad: „Farhang-e irāniyān az didgāh-e ğahāngardān va nevisandegān-e orupā’i dar sade-ye 17 milādi“", in: Našri-e dānešgāhe adabiyāt va 'olum-ye ensāni-e Tabriz, šomāre-ye Tābestān, Teherān 1354/1975, S. 249-284.

Ders.: „Ma’āḥež-e ețtelēēāt-e Monteskiyo darbāre-ye ravābeṭ-e zanāšu’i dar Irān“, in: Našri-e dānešgāhe adabiyāt wa Colum-e ensāni-ye Tabriz, šomāre-ye Bahār, Teherān 1352/1973, S. 21-50.

Gottschalk, Hans L.: „Die Kultur der Araber“, in: Handbuch der Kulturgeschichte. Die Kultur des Islam, hrsg. von Eugen Thurnher, Abt. 2, Frankfurt am Mein 1971, S. 10-204.

Gramlich, Richard: Die schiitischen Derwischorden Persiens. Erster Teil: Die Affiliationen, Wiesbaden 1965. Zweiter Teil: Glaube und Lehre, Wiesbaden 1976.

Ders.: Die Wunder der Freunde Gottes. Theologien und Erscheinungsformen des islamischen Heiligenwunders, Wiesbaden 1987.

Ders.: „Zur Ausdehnung der Zeit und Verwandtem”, in: Die islamische Welt zwischen Mittelalter und Neuzeit. Festschrift für Hans Robert Roemer zum 65. Geburtstag, hrsg. von Ulrich Haarmann und Peter Bachmann, Beirut 1979, S. 180-192.

Gray, Basil: „The Pictorial Arts in the Timurid Period”, in: CHI, Vol. 6, hrsg. von Peter Jackson, Cambrige 1986, S. 843-877.

Grenville, G. S. P. Freeman: „Al-zandj“, in: $E I^{2}$, Vol. XI, hrsg. von P. J. Bearman [u.a.], Leiden 2002, S. 444-445.

Gronke, Monika: Derwische im Vorhof der Macht. Sozial-und Wirtschaftsgeschichte Nordwest Irans im 13. und 14. Jahrhundert, Stuttgart 1993.

Dies.: „Lebensangst und Wunderglaube. Zur Volksmentalität im Iran der Mongolzeit, XXIV“, in: Deutscher Orientalistentag vom 26. bis 30. September 1988 in Köln, Ausgewählte Vorträge, hrsg. von Werner Diem u. 'Abdeljavad Falaturi, Stuttgart (1990), S. 391-399.

Grotzfeld, Sophia: „Dāniyāl in der arabischen Legende”, in: Festgabe Hans Wehr, Wiesbaden 1969, S. 72-85.

Grunebaum, Gustave Edmund: Der Islam im Mittelalter, Zürich 1963.

Ders.: „Die Kulturfunktion des Traumes im klassischen Islam“, in: Bustan. Österreichische Zeitschrift für Kultur, Politik und Wirtschaft der islamischen Länder, hrsg. von der HammerPurgestall-Gesellschaft Wien, Heft 3-4, 9 Jahrgang (1968), S. 50-58.

Gorgāni, Faḩr ad-Din Asad: Vis o Rāmin, hrsg. von Magali A. Todua, Teherān 1349/1970.

Haag-Higuchi, Roxane:Untersuchung zu einer Sammlung persischer Erzählungen. Čihil vašiš ḥikāyat yā ğāmi al-ḥikāyāt, Berlin 1984. 
Haag, Winfried: „An analytical approach to the teaching of spoken German”, in: Oral skills in the modern languages degree, hrsg. von Gordon Doble und Brian Griffiths, London 1985, S. 51-72.

Haas, Abdülkadir: Die Bektaši, Berlin 1987.

Ḥāfeẓ, Šams ad-Din Moḥammad: Divān-e Ḥāfez-e Širāzi, hrsg. von Moḥammad-Ğacfar Mạ̣ğub, Teherān 1346/1967.

Ḥāfize-e Abru: Zobde at-Tawārih̆, in 2 Bänden, hrsg. von Seyyed Kamāl Ḥāğğ Seyyed Ğavādi, Teherān 1372/1993.

Ḩ̌āğagi Eṣfahāni, Moḥammad Ma'ṣum: Hulāṣat as-Siyar. Der Iran unter Schah Ṣafi (1629-1642) nach der Chronik des Moḥammad Ma'ṣum b. Ȟ̃āğagi-Eṣfahāni, hrsg. von Gerhard Rettelbach, München 1978.

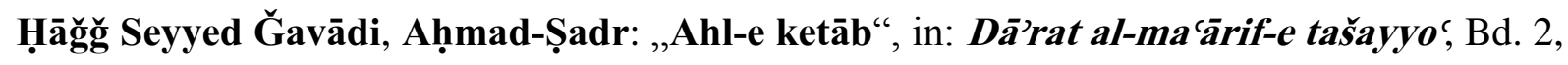
hrsg. von Ṣadr-Aḥmad Ḥāğğ Seyyed Ğavādi, Teherān 1368/1989, S. 616-619.

Ders.: „Āl-e 'abā”, in: Dā'rat al-ma'ārif-e tašayyo' Bd. 1, hrsg. von Ṣadr-Aḥmad Ḥāğğg Seyyed Ǧavādi, Teherān 1366/1987, S. 197.

Hāaleqi-Moṭlaq, Ğalāl: Die Frauen im Schahname, Inaugural-Dissertation zur Erlangung des Doktorgrades der Philosophischen Fakultät der Universität zu Köln 1971.

Ders.: „Bār va ā’in ān dar Irān”, in: Gol-e ranğhā-ye kohan, Teherān 1372/1993, S. 175274.

Ders.: „Babr-e bayān”, in: Gol-e ranğhā-ye kohan, S. 275-342.

Ders.: „Ḥamāse-sarā-ye bāstān“, in: Gol-e ranğhā-ye kohan, S. 19-51.

Ders.: „Mo'refi-e qate‘̄ât-e alḥāqi-e Šāh-nāme, in: Gol-e ranğhā-ye kohan, S. 127-170.

Ders.: „Dar pirāmun-e manābe`-e Ferdousi“, in: Irān-šenāsi, Vol. X, No. 3, Autumn (1998), S. 512-539.

Ders.: „Mošk-dāne“. Derangi dar adabiyāt-e sāsāni, in: Irān-̌̌enāsi, Vol. XVI, No. 2, Summer (2004), S. 233-236.

Ders.: „Bižan o Maniže va Vis o Rāmin“, in: Adab-e pahlavāni, hrsg. von Mahdi Mu’azzzen- Ğāmeci, Teherān 1379/2000, S. 293-319.

Ders.: „Bozorgmehr”, in: EIr, Vol. IV, hrsg. von Ehsan Yarshater, London/New York 1990, S. 427-429.

Ders.: „Yeki mehtari bud gardan-farāż’. Ta'ammoli dar šāh-nāme, in: Mağalle-e dāneškade-e adabiyāt va Colum-e ensāni-e dānešgāh-e Mašhad, 13 Jahrgang, No. 2, Summer (2536/1977), S. 198-202. 
Ders.: „Der Reste Altiranischer Anschauung über das Pferd“, in: Deutscher Orientalistentag vom 28. September bis 4. Oktober 1975 in Erlangen, hrsg. von Wolfgang Voigt, Wiesbaden 1977, S 1049-1060.

Halbwachs, Maurice: Das Gedächtnis und seine sozialen Bedingungen. (französisches Original: Les cadres sociaux de la mémoire, Paris 1925), Aus dem Französischen ins Deutsche übersetzt. von Lutz Geldsetzer, Frankfurt 1985.

Halm, Heinz: Die Schia, Darmstadt 1988.

Ders.: Der schiitische Islam, München 1994.

Ders.: Die islamische Gnosis, Zürich/München 1982.

Hamedāni, Moḥammad b. Maḥmūd: 'A ǧā’’b-nāme, hrsg. von Ğa'far Modarres-Ṣādeqi, Teherān 1375/1996.

Ḥamawi, Moḥammad b. Isḥāq b. Moḥammad: Anis al-mo'menin, Teherān 1363/1984.

Hammer-Purgstall, Joseph: Geschichte des osmanischen Dichtkunst, Bd. I u. Bd. III, Pest 1836.

Ders.: Juwelenschnüre Abul-Maani’s, Wien 1822.

Ders.: Rosenöl, Bd. 1, Hildesheim/Zürich/New York 2004.

Hanaway, Jr., William. L.: Love and war: adventures from the Firuz shāh nāme of Sheikh Bighami, New York 1974.

Ders.: Persian Popular Romances before the Safavid Period, Ph.D. Diss., Columbia University 1970.

Ders.: „Ferdowsi and the Art of Tragic Epic“, in: Persian Literatur, hrsg. von Ehsan Yahrshater, Columbia Lectures on Iranian Studies. 3 (1988), S. 109-119.

Ders.: „Epic Poetry”, in: Persian Literature, hrsg. von Ehsan Yahrshater, New York 1988, S. 96-112.

Ders.: „Dāstān-sarā’i in Iran”, in: EIr, Vol. VII, hrsg. von Ehsan Yarshater, Costa Mesa/California 1996, S. 102-103.

Ders.: „Amir Arsalān“, in: EIr, Vol. I, hrsg. von Ehsan Yarshater, London/Boston/Henly 1985, S. 958.

Ders.: „'Ayyār in Persian Sources”, in: Elr, Vol. III, hrsg. von Ehsan Yarshater, London/New York 1989, S. 161-163.

Ders.: „The Iranian Epics“, in: Heroic Epic and Sage: an Introduction to the World's Great Folk Epics, hrsg. von Felix J. Oinas. Indiana University Press/Bloomington/London 1978, S. 76-98. 
Ḥā̄ri, Seyyed Mahdi: „Ğinn“, in: Dā'rat al-ma`ārif-e tašayyo` Bd. 10, Șadr-Aḥmad ب̣āğğ Seyyed Ğavādi, Teherān 1383/2004, S. 449-452.

Ders.: „Reğāl“, in: Dā’rat al-ma‘ārif-e tašayyo`, Bd. 8, Ṣadr-Aḥmad Ḥāğğ Seyyed Ğavādi, Teherān 1379/2000, S. 162-164.

Ders.: „Reğāl al-ġeib”, in: Dā’rat al-ma‘ārif-e tašayyo, Bd. 8, Șadr-Aḥmad Ḥāğğ Seyyed Ğavādi, Teherān 1379/2000, S. 616-619.

Harrer, Gudrun: „Ein auf Persien spezialisierter Humboldtist”, in: Der Standard. at /.../ Print Ausgabe 2009.

Hartwig, Gordet: Die Sitzungen des 'Alā ad-dawla as-Semnān̄̄, Zürich 1977.

Ḥasani-Rāzi, Seyyed Mortażā b. Dāci: Tabṣirat al-a'wām fi ma'rifat al-maqālāt al-anām, hrsg. von 'Abbās Eqbāl, Teherān 1364/1985.

Hāšemi Sandilavi, Ạ̣mad: Tậkere-ye mahzan al-ğarā'ib, hrsg. von M. Bāqer, Lahore 1968.

Haymes, Edward R.: Das mündliche Epos. Eine Einführung in die „Oral Poetry“ Forschung, Stuttgart 1977.

Ders.: „Mündliches Epos in Mittelhochdeutscher Zeit“, in: Göppinger Arbeiten zur Germanistik, hrsg. von Ulrich Müller, Franz Hundsnurscher u. Cornelius Sommer, Nr 164, Göppingen 1975.

Heath, Peter: „Arabische Volksliteratur im Mittelalter”, in: Handbuch der Kulturgeschichte. Die Kultur des Islam, Bd. 5, hrsg. von Klaus Von See, Wiesbaden 1990, S. 423-439.

Ders.: The Thirsty Sword. Sīrat 'Antar and Arabic Popular Epic, Salt Lake City 1996.

Hedāyat, Reżā-Qoli: Tažkere-e Reyāż al-cārefin, Teherān 1316/1937.

Ders.: Mağma'al-fuṣaḥ̄ā, Teherān 1340/1961.

Hedāyat, Șādeq: Neyrangestān, Teherān 2536/1978.

Heller, Bernhard: Die Bedeutung des arabischen Antar-Romans für die vergleichende Literaturkunde, Leipzig 1931.

Hennig, Max: Der Koran, überarbeitet und herausgegeben von Murad Wilfried Hofmann, Kreuzlingen/München 2001.

Herde, Peter: „Taktiken muslimischer Heere vom ersten Kreuzzug bis 'Ayn-Diāālūt (1260) und ihre Einwirkung auf die Schlacht bei Tagliacozzo (1268)“, in: Das heilige Land im Mittelalter. Begegnungsraum zwischen Orient und Okzident, hrsg. von Wolfdietrich Fischer, u. Jürgen Schneider, Neustadt an der Aisch 1982.

Herodot: Historien, Band 1 u. 3, hrsg. von Josef Feix, München 1963.

Heusler, Andreas: Lied und Epos in germanischer Sagendichtung, Dortmund 1905. 
Hinz, Walther: Islamische Maße und Gewichte umgerechnet ins metrische System, in: Handbuch der Orientalistik, hrsg. von Bertold Spuler, Ergänzungsband 1, Heft 1, Göttingen 1955.

Ders.: Iran. Politik und Kultur von Kyros bis Reżā Schah, Leipzig 1938.

Ders.: „Ein orientalisches Handelsunternehmen im 15. Jahrhundert”, in: Die Welt des Orients 4 (1949), S. 312-340.

Honigmann, Ernst: „Malațya“, in: EI, Bd. III, hrsg. von Martijn Theodoor Houtsma, Leiden/Leipzig 1936, S. 213-218.

Hooykaas, Christiaan: Over Maleise Literatur, Leiden 1974, S. 151-157.

Horam Šāhi, Bahā ad-Din: „Ğebrā'ìl“, in: Dā’rat al-ma‘̄arif-e tašayyơ, Bd. 5, ȘadrẠ̣mad Ḥāğğğ Seyyed Ğavādi, Teherān 1375/1996, S. 309-310.

Horn, Katalin: „Held, Heldin“, in: EM, Bd. 6, hrsg. von Rolf Wilhelm Brednich, Göttingen 1990, Sp. 721-745.

Horn, Paul: „Geschichte Irans in islamischer Zeit”, in: Grundriss der iranischen Philologie, zweiter Teil, hrsg. von Wilhelm Geiger u. Ernst Kuhn, Strassburg 1896-1904, S. 551-605.

Ders.: „Roß und Reiter im Šāh-nāme“،, in: ZDMG 61 (1907), S. 837-849.

Horowitz, Rosalind u. S. Jay Samuels: „Comprehending Oral and Written Language”, in: Comprehending Oral and Written Language: Critical Contrasts for Literacy and Schooling, hrsg. von Rosalind Horowitz, San Diego/London 1987, S. 1-52.

Horten, Max: Religiöse Gedankenwelt des Volkes im heutigen Islam, Halle 1917.

Ḥoseini Monši, Moḥammad b. Mirak b. Mas'ūd: Reyā̇̇ al-ferdous, hrsg. von Irağ Afs̃ār u. Ferešte Șarrāfān, Teherān 1385/2006.

Höttges, Valerie: „Typenverzeichnis der deutschen Riesen-und riesischen Teufelssagen“, in: FFC, Helsinki 1937.

Huart, Clément: „Ḥurūfi“, in: EI, Bd. II, hrsg. von Martijn Theodoor Houtsma u. Arent Jan Wensinck, Leiden/Leipzig 1927, S.359-360.

Hübner, Gert: Erzählform im höfischen Roman. Stuiden zur Fokalisierung im `Eneas〉, im >Iwein> und im Tristan, Tübingen/Basel 2003 (Biblotheca Germanica 44).

Hughes, Thomas Patrick: Schirk, in: Lexikon des Islam, München 2000.

Ibn al-Ațīr, 'Izz ad-Din Abū al-Ḥasan 'Ali as-Šaibānī: al-Kāmil fi at-Tarīh , ins Persische übersetzt. von 'Abbās Halili, Bd. 10, Teherān 1355/1976.

Ibn Baț̣uṭa, Abū 'Abdallāh Moḥammad b. 'Abdallāh b. Moḥammad b. Ibrāhīm: al-

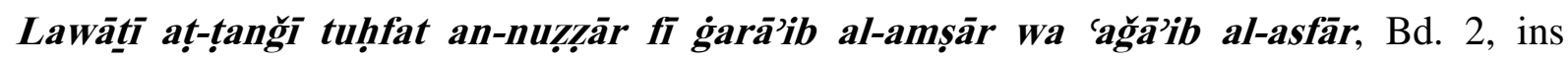
Persische übersetzt. von Moḥammad-‘Ali Mowaḥḥed, Teherān 1348/1969. 
Ibn Bazzāz, Tawakkoli b. Esmā̄il Ardabili: Ṣafwat ạ̣-Ṣafā. Kitāb al-mavāhib as-Sanīya fi manāqib aṣ-Ṣafaviya, hrsg. von Ġolām-Reżā Ṭabāṭabā'i-Mağd, Teherān 1373/1994.

Ibn Esfandiyār: Nāme-ye Tansar be Ǧošansaf, ins Arabische übersetzt. von Ibn Moqaffac, aus dem Arabischen ins Persische übersetzt. von Ibn Esfandiyār, hrsg. von Muğtabā Minavi, Teherān 1311/1932.

Ibn al-Ǧawzī, Abū al-Farağ: Kitāb al-Qușṣās wa-'l-muḍhakkin̄in. Including a Critical Edition, Annotated Translation and Introduction by Merlin L. Swartz, Beyrout 1971.

Ders.: Talbis Eblis, aus dem Arabischen ins Persische übersetzt. von 'Ali-Reżā ZakāvatiQarāgözlu, Teherān 1368/1989.

Ders.: Damm al-hawā, hrsg. von Aiman al-Buhairī, Beirut o.J.

Ibn Ḥağar al-'Asqalānī, Aḥmad Ibn Alī: Tağlīq at-ta 'līq 'alā ṣaḥịh al-Buhārē̄, Muğallad 3, ğuz' 4, Dirāsa wa-taḥqīq Sa '̄id 'Abd-ar-Raḥmān Mūsā al-Qazqī, Ammān 1985.

Ibn Hišām, Moḥammad 'Abd al-Malek: as-Sira an-Nabawiyya, hrsg. von Muṣtafā asSaqā, Bd. 1, Ägypt 1375 h/1955.

Ibn Ishāq: Das Leben des Propheten, aus dem Arabischen ins Deutsche übertragen und bearbeitet. von Gernot Rotter, Stuttgart 1985.

Ibn Manẓūr al-Ifrīqī al-Miṣrī, Abū'l-Fạ̣l Ğamāl ad-Dīn Moḥammad b. Mukarram: Lisān al-'Arab, Muğallad 13: [Nūn-Hā'], Bairut 1375h/1956.

Ibn an-Nadīm, Abū al-Farağ Moḥammad b. Isḥāq b. Abī Ya'qūb: Kìtāb al-Fìhrist, Nachdruck Bairut 1966.

Ibn an-Nadīm, Abū al-Farağ Moḥammad b. Isḥāq b. Abī Ya'qūb: Kùtāb al-Fìhrist, ins Persische übersetzt. von Moḥammad Reżā Tağaddod, Teherān 1346/1967.

Ibn Sa'd Kātib al-Wāqidī, Abū 'Abdallāh Moḥammad: Kìtāb at-Tabaqāt al-kabīr, hrsg. von Eduard Sachau, Leiden 1321 h/1904.

Ibn Šahrāšūb, Moḥammad b. 'Ali: Manāqib 'Ali b. Abī Ṭāleb, Bd. 1, Qom 1379/1998.

Irānšāh b. Abi al-Hुeir: Bahman-nāme, hrsg. von Raḥim 'Afifi, Teherān 1370/1991.

Irwin, Robert: The Arabian Nights, ins Persische übertsetzt. von Feridun Badrei, Teherān 1383/2004.

Jäckel, Dirk: Der Herrscher als Löwe. Ursprung und Gebrauch eines politischen Symbols im Früh- und Hochmittelalter, Beihefte zum Archiv für Kulturgeschichte 60, Böhlau IX, Köln 2006.

Jacob, Georg: Märchen und Traum. Mit besonderer Berücksichtigung des Orients, Hannover 1923. 
Jackson, A. V. Williams: „Die iranische Religion”, in: Grundriss der iranischen Philologie, zweiter Teil, hrsg. von Wilhelm Geiger u. Ernst Kuhn, Strassburg 1896-1904, S. 612-708.

Jahn, Karl: Die Chinageschichte des Rašĩd ad-Din, hrsg. von Robert Göbel, Wien 1971.

Junker, Heinrich F. J. u. Alavi, Bozorg: Wörterbuch Persisch-Deutsch, Leipzig/Berlin/München 1997.

Justi, Ferdinand: „Geschichte Irans”, in: Grundriss der iranischen Philologie, zweiter Teil, hrsg. von Wilhelm Geiger u. Ernst Kuhn, Strassburg 1896-1904, S. 395-549.

Ders.: Iranisches Namenbuch, Hildesheim 1963.

Kaempfer, Engelbert: Am Hofe des persischen Großkönigs (1684-85). Das erste Buch der Amoenitates exoticae. hrsg. von Walther Hinz, Leipzig 1940.

Kan ‘̄n, Tawfìq: Aberglaube und Volksmedizin im Lande der Bibel, Hamburg 1914.

Karbalāi Tabrizi, Ḥafeẓ Ḥosein (berühmt als Ibn Karbalāi): Roużat al-ğinān va ğannat al-ğanān, Bd. 1, hrsg. von Ğa'far Solțān-Qarā'i, Teherān 1344/1965.

Karimān, Ḥosein: Pažūheši dar Šāh-nāme. Dar bāb-e Raypahne-ye Teherān, Alborz, Māzandarān-e Ṭabarastān, Māzandarān-e Mag̉rib va Māzandarān-e Mašriq dar Šāhnāme, Teherān 1375/1996.

Kāšāni, 'Abdal ar-Razāq: Tuḥat 'l-ahawān dar bayān-i uṣul-i futuvvat va ādāb-i fatiyān, hrsg. von Moḥammad Mir-Dāmādi, Teherān 1351/1972.

Kāẓem, Moḥammad: 'Ālam-ārāâye Nāder, Bd. 2, Fasemile, hrsg. von Nikolai MikluchoMaklai, Moskva 1965.

Kehl Bordrogi, Krisztina: Die Kizilbaš/Aleviten, Berlin 1988.

Keivāni, Mağd ad-Din: Eskandar-nāme, in: Dā'rat al-ma'ārif-e bozorg-e eslāmi, Bd. 8, hrsg. von Kāẓem Mosavi-Boğnordi, Teherān 1385/2006.

Kellner-Heinkele, Barbara: „Aus dem osmansichen Musik und Theaterleben“. Studien zur Geschichte und Kultur des Vorderen Orients. Studien zur Geschichte und Kultur des Vorderen Orients, in: Festschrift für Bertold Spuler zum siebzigsten Geburtstag, hrsg. von Hans Roemer und Albrecht Noth, Leiden 1981. S. 181-196.

Khoneli, Mose: Amiran-Darejaniani: a cycle of medieval Georgian tales traditionally ascribed to Mose Khoneli, transl. by Robert Horne Stevenson, Oxford 1958.

Köhler, Ines: „Grenze“, in: EM, Bd. 6, hrsg. von Rolf Wilhelm Brednich, Göttingen 1990, Sp. 134-142.

Köprülü Zāde, Meḥmed Fưād: „Die türkisch-islamische Literatur das XIII Jahrhunderts“, in: EI, Bd. IV, hrsg. von Martijn Theodoor Houtsma, Leiden/Leipzig 1934, S. 1011-1033. Kreiser, Klaus: Der osmanische Staat 1300-1922, München 2001. 
Kriss, Rudolf und Heinrich Hubert: Volksglaube im Bereich des Islam, in 2 Bänden, Wiesbaden 1962.

Kuder, Ulrich: „Haar“, in: EM, Bd. 6, hrsg. von Rolf Wilhelm Brednich, Göttingen 1990, Sp. 337-343.

Kurt, Rudolph: Gnosis und spätantike Religionsgeschichte, Leiden/New York/Köln 1996.

Kurz, Susanne: Verachtet das Scherzen nicht. Die kulturhistorische Assagekraft von persischen Sammlungen humoristischer Kurzprosa, Teil 1, Dortmund 2009.

Lambton, Ann Katharine Swynford: Landlord and peasant in Persia: a study of land tenure and land revenue administration, Oxford 1953.

Dies.: „Islamic Society in Persia”, in: School of Oriental and African studies, university of London 1954, S. 1-32.

Dies.: „Political Theorye and Practice”. in: Expectation of the Millennium. Shicism in History, hrsg. von Seyyed Hossein Nasr, Hamid Dabashi und Seyyed Vali Reza, New York 1989), S. 93-107.

Lane, Edward William: Sitten und Gebräuche der heutigen Egypter, Leipzig 1852.

Ders.: Manners and customs of the modern Egyptians, Bd. 2, London 1846.

Lāri, Șọ̣bat: Divān-e Ṣoḥbat-e Lāri, hrsg. von Ḥosein Ma'refat, Širāz 1354/1975.

Latacz, Joachim: Homer. Tradition und Neuerung, Darmstadt 1979.

Lazard, Gilbert: „The rise of the new Persian language”, in: $C H I$, Vol. 4, hrsg. von Richard Nelson Frye, London 1975, S. 595-632.

Lekhawī, Āftāb Rāy: Tazkere-yeReyāż al-cārefīn, Bd. 2. hrsg. von Hosāan ad-Din Rāšedi, Islamabad 1977.

Lesān, Ḥosein: „Šāh-nāme-h̆̌āni“, in: Honar va Mardom, 14 Jahrgang, Nr. 159-160, šomāre-ye Dey va Bahman, Teherān 1354/1975, S. 2-16.

Le Strange, Guy: The lands of eastern caliphate. Mesopotamia, Persia and Central Asia from the Moslem conquest the time of Timur, ins Persische übersetzt. von Maḥmūd Erfān, Teherān 1337/1958.

Levi Della Vida, Giorgio: „Salmān al-Fārisī”, in: EI, Bd. IV, hrsg. von Martijn Theodoor Houtsma, Leiden/Leipzig 1934, S. 14-125.

Ders.: „Ṣamṣāma”, in: EI, Bd. IV, Martijn Theodoor Houtsma [u.a.], Leiden/Leipzig 1934, S. 150- 151 .

Lewis, Bernard: Die politische Sprache des Islam, 1 Aufl., hrsg. von Martin Bauer u. Otto Kallscheuer, Berlin 1991. 
Ders.: „Ifrandj”, in: $E l^{2}$, Bd. III, hrsg. von Bernard Lewis [u.a.], Leiden/London 1971, S. 1070-1072.

Lewis, Geoffrey: „Ạ̣medī“, in: $E l^{2}$, Bd. I, hrsg. von Hamilton Alexander Rosskeen Gibb [u.a.], Leiden/London 1960, S. 299-300.

Limbert, John: Shiraz in the Age of Hafez, Seattle/London2004.

Lindahl, Carl: „Dankbare (hilfreiche Tiere)“, in: EM, Bd. 3, hrsg. von Kurt Ranke, Göttingen 1981, Sp. 287-294.

Littmann, Enno: Erzählungen aus dem tausendund ein Nächten, in 6 Bänden, Leipzig 19211939.

Lockhart, Laurence: „European Contacts with Persia 1350-1736“, in: CHI, Vol. VI, hrsg. von Peter Jackson and Laurence Lockhart, Cambridge 1986, S. 373-411.

Lommel, Herman: Die Yäšts des Avesta, Göttingen 1927.

Ders.: Die Religion Zarathustras. Nach dem Avesta dargestellte, Hildesheim 1971.

Lord, Albert B.: Der Sänger erzählt (The singer of Tales), aus dem Englischen ins Deutsche übersetzt. von Martin Helmut, München/Hanser 1965.

Ludi, Šir-‘Ali‘ Hān: Tazkere-ye mer’āt al-hayāl, hrsg. von Ḥasan Ḥasani, Teherān $1377 / 1998$.

Luhmann, Niklas: „Individuum, Individualität, Individualismus”, in: Niklas Luhmann: Gesellschaftsstruktur und Semantik. Studien zur Wissenssoziologie der modernen Gesellschaft, Bd. 3, Frankfurt/M 1989, S. 149-258.

Lüthi, Max: „Drei, Dreizahl”, in: EM, Bd. 3, hrsg. von Kurt Ranke, Göttingen 1981, Sp. 851868.

Lyons, Malcom C.: The Arabian Epic: heroic and Oral Story-Telling, Bde. 2-3, Cambridge 1995.

Macuch, Maria: „Der ‘iranisierte’ Islam: Zur Entstehung einer eigenwilligen Synthese.”, in: Iran und iranisch geprägte Kulturen: Studien zum 65. Geburtstag von Bert G. Fragner. hrsg. von B. Hoffmann/R. Kauz/M. Ritter. Wiesbaden 2008 (Beiträge zur Iranistik 27), S. 315-335. Madelung, Wilferd Ferdinand: „The minor Dynasties of northern Iran”, in: CHI, Vol. 4, hrsg. von Richard Nelson Frye, Cambridge 1975, S. 198-249.

Mağlesi, Moḥammad Bāqer b. Moḥammad Taqi: Hayāt al-qolub, in 2 Bänden, Teherān $1374 / 1995$.

Maḥ̆ub, Moḥammad-Ğa'far: „̄̄'in 'ayyāri”, in: Adabiyāt-e 'āmmiyāne-ye Irān, Bd. 2, hrsg. von Ḥasan ZZu al-Faqāri, Teherān 1382/2003, S. 953-968.

Ders.: „Amir Arsalān-e rumi”, in: Adabiyāt-e ‘āmmiyāne-ye Irān, Bd. 1, S. 473-525. 
Ders.: „Az manāqebiyān va fażā'eliyān tā ruże-h̆`āni”, in: Adabiyāt-e ‘āmmiyān-ye Irān, Bd. 2, S. 1207-1215.

Ders.: „Bozorgmehr dānā-e irāni dar afsānehā-ye fārsi”, in: Adabiyāt-e cāmmiyāne-ye Irān, Bd. 1, S. 219-238.

Ders.: „Bustān-e ḩayāl”, in: Adabiyāt-e ‘āmmiyāne-ye Irān, Bd. 1, S. 617-676.

Ders.: „Tahavvol-e naqqāli va qeșṣe-h̆̌āni va tarbiyat-e qaṣṣe-h̆̌ānān va tumārhā-ye naqqāli”, in: Adabiyāt-e ‘āmmiyāne-ye Irān, Bd. 2, S. 1079-1114.

Ders.: „Sohanvari“, in: Adabiyāt-e 'āmmiyāne-ye Irān, Bd. 2, S.1053-1078.

Ders.: „Darbare-e padid āmadan-e ḥamāse-ye dini”, in: Adabiyāt-e ‘āmmiyāne-ye Irān, Bd. 2, S. 1243-1261.

Ders.: „Ravešhā-ye 'ayyāri va nofuže kār va kerdār-e 'ayyārān dar Šāh-nāme“, in: Adabiyāt-e 'ammiyāne-ye Irān, Bd. 2, S. 969-1014.

Ders.: „Morḡān-e afsānei”, in: Adabiyāt-e 'āmmiyāne-ye Irān, Bd. 1, S. 239-264.

Malory, Sir Thomas: Die Geschichten von König Arthus und den Rittern seiner Tafelrunde, Bde. 1-2, Leipzig 1973.

Marzolph, Ulrich u. Amirhosseini-Nithammer, Azar: Die Erzählungen der Mašdi Galin Hānom. Teil 2: Begleitband, Wiesbaden 1994.

Ders.: Narrative illustration in Persian Lithographed Books, Leiden (Handbook of Oriental Studies, 1.60) 2001.

Ders.: Typologie des persischen Volksmärchens, aus dem Deutschen ins Persische übersetzt. von Kei-Kāvus Ğahāndāri, Teherān 1371/1992.

Ders.: „Persian Popular Literature in the Qajar Period“, in: Asian Folklore Studies, Vol. LX-1, (2001), S. 215-236.

Ders.: „Social Values in the Persian Popular Romance Salīm-i Javāhirī’, in: Edebiyāt, New Series 5. (1994), S. 78-98.

Ders.: „A treasury of formulaic narrative: The Persian popular romance Hosein-e Kord”, in: Oral Tradition 14 (2) (1999), S. 279-303.

Ders.: „Das persische nationalepos im Spannungsfeld von Überlieferung und Ideologischer Instrumentalisierung“. Überlieferung und Deutung. Zur historischen Funktion der Volkserzählung und ihrer Instrumentalisierung in der Gegenwart. (Vorträge des 11. internationalen Symposions zur Volkserzählung. Innsbruck vom 5-8. Oktober 1997. ed. L. Petzoldt/G. B. Bronzini), in: Lares 65, 1-2 (1999), S. 81-99. 
Ders.: „Von der Handschrift zum Buch. Zur Periodisierung der frühen Druckgeschichte in Iran (1817-ca. 1990)“, in: Iranistik. Deutschaprachige Zeitschrift für iranischen Studien, 1 Jahrgang, Heft 2, Herbst und Winter 2002, S. 71-90.

Ders.: „Die Kunst der Illustration in persischen lithographischen Büchern der Qajarenzeit“, in: Farhang-e Mardom, ins Persische übersetzt. von Bižan Ġeybi, 2 Jahrgang, Sommer und Herbst, Nr. 6 u. 7, Teherān 1382/2003, S. 33-39.

Ders.: „Gürtel“, in: EM, Bd. 6, hrsg. von Rolf Wilhelm Brednich, Göttingen 1990, Sp. 311315.

Ders.: „Ḥamze-nāme“, in: EM, Bd. 6, hrsg. von Rolf Wilhelm Brednich, Göttingen (1990), Sp. 430-436.

Ders.: „Lokalisierung“, in: EM, Bd. 8, hrsg. von Rolf Wilhelm Brednich, Göttingen 1996, Sp. 1172-1177.

Ders.: „Sindbad der Seefahrer“, in: EM, Bd. 12, hrsg. von Rolf Wilhelm Brednich, Göttingen 2007, Sp. 698-707.

Ders.: „Ganğinei az gozārehā-ye qālebi dar dāstān-e cāmmiyāne-ye Ḥosein kord-e Šabestari, in: Qeș̣e-ye Hosein kord-e Šabestari, hrsg. von Irağ Afs̃ār u. Mehrān Afs̃āri, Teherān 1385/2006, S. 439-455.

Masse, Henri: Les épopées persanes: firdousi et l'épopée nationale, ins Persische übersetzt. von Mahdi Roušan-Żamir, Tabriz 1375/1996.

Ders.: „Abū Ṭahir Ṭarsūsi““, in: $E I^{2}$, Vol. 1, hrsg. von Hamilton Alexander Rosskeen Gibb [u.a.], Leiden/London 1960, S. 152.

Ders.: Croyances et coutumes persanes, Bd. 2, Paris 1938.

Maškur, Moḥammad-Ğavād: Tārihh-e Tabriz tā pāyān-e qarn-e nohom-e heğri, Teherān $1352 / 1974$.

Massignon, Louis: Salmān Pāk et les prémices spirituelles de l'Islam Iranien. Publications de la Société des études Iraniennes et de l'art Persan; 7, Paris 1934.

Massoud-Ansari, Faramarz: Die Malerei zur Zeit der Qajaren-Dynstie (1796-1925) im Iran, Univ., Diss., Tübingen 1986.

Maurer, Michael: Kulturgeschichte, Köln/Weimar/Wien 2008.

Meinel, Gertraud: „Garten“, in: EM, Bd. 5, hrsg. von Kurt Ranke, Göttingen 1987, Sp. 699711.

Membré, Michele: Mission to the Lord Sophy of Persia (1539-1542), Translated with Introduction and Notes. by A. H. Morton, London 1993. 
Mélekoff, Irène: Abū Muslim. «Le Porte-hache» du Khorassan dans la tradition épiqe turcoIranienne, Paris 1962.

Dies.: La Geste de Melek Dānišmend, Bd. 1, Paris 1960.

Menzel, Theodor: Meddāh, Schattentheater und Orta Oyunu. Monographien des Archiv Orientàlní, Vol. X, Prag 1941.

Ders.: „Beiträge zur Kenntnis des Derwisch tāğ“‘, in: Festschrift Georg Jacob, Leipzig 1932, S. 174-199.

Meredith-Owens, Glyn Munro: „Ḥamza b. Abd al-Muțtalib“, in: $E I^{2}$, Vol. III, hrsg. von Bernard Lewis [u.a.], Leiden/London 1971, S. 152-154.

Merkelbach, Reinhold: Mithras. Ein persisch-römischer Mysterienkult, Wiesbaden 1998.

Mernissi, Fatima: Die vergessene Macht. Frauen im Wandel der islamischen Welt, Frankurt am Main 1997.

Dies.: Der politische Harem. Mohammad und die Frauen, aus dem Französischen ins Deutsche übersetzt. von Marie Luise Knott und Brunhilde Wehinge, München 1991.

Dies.: Geschlecht Ideologie Islam, München 1991.

Meskub, Šāhrohn: Huviyat-e irāni va zabān-e fārsi, Teherān 1373/1994.

Mez, Adam: Die Renaissance des Islam, Heidelberg 1922.

Minorsky, Vladimir: „Musha'sha“”, in: EI, Ergänzungsband, hrsg. von Martijn Theodoor Houtsma u. Arent Jan Wensinck, Leiden 1938, S. 174ff.

Ders.: „Zūrkhāna“, in: EI, Bd. IV, hrsg. von Martijn Theodoor Houtsma u. Arent Jan Wensinck, Leinden/Leipzig 1934, S. 1344-1345.

Mir Ǧa‘fari, Ḥosein: „Šāṭer va šāṭerdavāni dar 'aṣr-e șafavi“, in: Honar-e Mardom, Nr. 174, 15 Jahrgang, Teherān 2536/1977, S. 50-61.

Mobad Kei-Hुosrou Esfandiyār: Dabistān al-Mazā̄heb, Bd. 1, hrsg. von Raḥim Reżāzāde Malak, Teherān 1362/1983.

Modarres-Čahārdehi, Moḥammad: Hāksār va ahle ḥaqq, Teherān 1368/1989.

Modarresi-'Ālem, 'Abd al-Karim: Ganğine-ye ouliyā' yā ā'ine-ye aṣfiyā', Teherān $1338 / 1959$.

Moḥammad Hāšem, Āṣef (berühmt als Rostam al-ḥokamā): Rostam at-Tawārih̆, hrsg. von Moḥammad Moširi, Teherān 1348/1969.

Moḥammad Kāzem: 'Alam-ārā-ye Nāderi, Bd. 2, Moskau 1965.

Moḥammd b. Munavar: Asrār al-tauhid, hrsg. von Żabiḥallāh Șafā, Teherān 1348/1969.

Moḥammadi, Moḥammad-‘Ali: Az mā behtarān, Teherān 1380/2001. 
Monchizadeh, Davoud: Topographische-historische Studien zum iranischen Nationalepos, Teil XVII. Die Länder Māzandarān und damit verbundene Probleme, Wiesbaden 1975.

Monzavi, Aḥmad: A Camprehensive Catalogue of Persian Manuscripts in Pakistan, Bd. VI, Islamabad 1987.

Ders.: Fehrest-e noshehā-ye htttti-e fārsi, Bd. 3, Teherān 1359/1980.

Mo’azzen-Ğāmeci, Moḥammad: Adab-e pahlavāni, Teherān 1379/2000.

Moritz, Bernhard: Arabien: Studien zur physikalischen und historischen Geographie des Landes, Hannover 1923.

Mošār, Huānbābā: Mo’allefin-e kotob-e čāpi-ye fārsi va 'arabi az āğāz tākonun, Teherān 1341/1962.

Mostoufi-Qazwini, Ḥamdallāh: Nozhat al-qolub, hrsg. von Guy Le Strange, Leiden $1331 \mathrm{~h} / 1913$.

Mo'ayyer al-Mamālk, Dust-'Ali Hुān: Yãd-dāšthāi az zendegāni-ye Nāṣer ad-Din Šāh, Teherān 1372/1993.

Mo'in, Moḥammad: Farhang-e fārsi, in 6 Bänden, Teherān 1343/1964.

Morand, Claude: Les peintres populaires de la legende Persan, Paris 1970.

Muslim b. al-Ḥağğāğ Abū al-Ḥosein: aṣ-Ṣaḥị̆, hrsg. von Moḥammad Fu’ād 'Abd alBāqī, Kairo 1374h/1955.

Nadjmabadi, Seifeddin: „Gründe für übernahme der Fremdwörter in Neupersischen“, in: Deutscher Orientallistentag vom 28. September bis 4. Oktober 1975, Wiesbaden 1977, S. 374-376.

Naef, Silvia: Bilder und Bildverbot im Islam. Vom Koran bis zum Karikaturenstreit, aus dem Französischen ins Deutsche übersetzt. von Christiane Seiler, München 2007.

Nafīsi Nāẓm al-Aṭbbā', 'Ali-Akbar: Farhang-e Nafiisi, Bd. 5, Teherān 1343/1964.

Nağafi, Abu al-Ḥasan: Farhang-e fārsi-e ‘āmmiyāne, Teherān 1378/1999.

Nagel, Tilman: Untersuchungen zur Entstehung des abbasidischen Kalifates, Bonn 1972.

Ders.: Timur der Eroberer und die islamische Welt des späten Mittelalters, München 1993.

Ders.: Staat und Gemeinschaft im Islam. Geschichte der politischen Ordnungsvorstellungen der Muslime, Zürich/München 1981.

Ders.: Mohammad. Leben und Legende, München 2008.

Nağm, Nāṣer: Dar al-hualāfe Tehrān, Teherān 2536/1976.

Nağmi, Nāṣer: Irān qadim va Tehrān qadim, Teherān 1362/1983.

Nahğgavāni, Moḥammad b. Hendušāh: Dastūr al-kātib fi tacyīn al-marātib, Bd. II, hrsg. von 'Abd al-Karim 'Alizāde, Moskva 1976. 
Nasafī, 'Azīz ad-Din b. Moḥammad: Ketābal-ensānal-kāmil: Mağmu'e-ye rasā'il va tașānif-e Aż̄iz ad-Dīn Nasafî. Be taṣḥiḥ va muqaddama-ye farānsavi-ye Marijan Molé, ins Persische übersetzt. von Seyyed Żiyā' ad-Din Dahširi, Teherān 1379/2000.

Naṣrābādi-Eṣfahāni, Mirzā Moḥammad Ṭāher: Tazkkere-ye Naṣrābādi, hrsg. von Vaḥid Dastgerdi, Teherān 1317/1938.

Naumann, Michael: Strukturwandel des Heroismus. Vom sakraln zum revolutionären Heldentum, Königstein 1984.

Navāb-Širāzi, 'Ali-Akbar: Tazkere-ye del-gošā, hrsg. von Manṣūr Rastgār-Fasāì, Širāz 1371/1992.

Needham, Rodney: „Halbwesen“, in: EM, Bd. 6, hrsg. von Rolf Wilhelm Brednich, Göttingen 1990, Sp. 401-405.

Neẓāmi-Ganğavi, Elyās b. Yusof: Haft peikar, in: Kolleyāt-e Divān-e ḥakim NezāāmiGanğavi, hrsg. von Vạ̣id Dastgerdi, Teherān 1335/1956.

Ders.: Das Alexanderbuch. Iskandarname, übertsetz aus dem Pers. Nachw. und Anm. von J. Christoph Bürgel, Zürich 1991.

Neẓām al-Molk: Siyāsat-nāme, hrsg. von Hubert Darke, Teherān 2535/1976.

Nöldeke, Theodor: „Das iranische Nationalepos“, in: Grundriss der iranischen Philologie, hrsg. von Wilhelm Geiger u. Ernst Kuhn, Strassburg 1896-1904.

Ders.: Das iranische Nationalepos, zweite Auflage des im Grundriss der iranischen Philologie erschienenen Beitrages, Berlin/Leipzig 1920.

Ders.: Geschichte der Perser und Araber zur Zeit der Sasaniden. Aus der arabischen Chronik des Tabari, Leyden 1878.

Nowak, Ursula: Beiträge zur Typologie des arabischen Volksmärchens, Dissertation Freiburg im Breisgau 1969.

Nurbaȟš, Ğawād: Dar harābāt, Teherān 1381/2002.

Oggar, Thomas: „Betrachtungen zu Musik Persische Gespräche“, Teil 1, in: Spektrum Iran. Zeitschrift für islamische-iranische Kultur, Nr. 4, (2001), S. 19-33.

Olearius, Adam: Safar-nāme-ye Ādam Uli'āriyūs, ins Persische übersetzt. von Ạ̣mad Behpur, Teherān 1363/1985.

Olearius, Adam: Safar-nāme-ye Ādam Uli'āriyūs, Bd. 2, ins Persische übersetzt. von Ḥosein Kord-bačče, Teherān 1369/1990.

Omidsalar, Maḥmūd u. Teresa Omidsalar: „Narrating Epics in Iran”, in: Traditional Storytelling Today: An international sourcebook, Ed. Margaret Read MacDonald, London: Fitzroy Dearborn 1984, S. 326-340. 
Ders.: „Div”, in: EIr, Bd. VII, hrsg. von Ehsan Yarshater, Costa Mesa/California (1996), S. 428b-431a.

Ders.: „Rostam's Seven Trials and the Logic of Epic Narrative in the Shāh-nāma”, in: $A F S$, Vol. LX-1, (2001), S. 259-293.

Ders.: „Dar defā' az Ferdousi“, in: Nāme-ye Farhangestān, 3 Jahrsgang, Nr. 4, Winter (1376/1998), S. 1-21.

Ders.: „Storytellers in Classical Persian Texts”, in: JAFS, Vol. 97, Nr. 384, April-June, (1984), S. 204-212.

Ders.: „Peri (Pari)“, in: EM, Bd. 10, hrsg. von Rolf Wilhelm Brednich, Göttingen 2002, Sp. 743-746.

'Onșor al-Ma‘āli Kei-Kāvūs b. Eskandar b. Qābūs b. Vošmgir:Qābūs-nāme, hrsg. von Ġolām-Ḥosein Yūsofi, Teherān 1354/1967.

'Onșor al-Macāli Kei-Kāvūs b. Eskandar b. Qābūs b. Vošmgir: Das Qābūsnāme. Ein Denkmal persischer Lebensweisheit, übersetzt und erklärt. von Seifeddin Najmabadi in Verbindung mit Wolfgang Knauth, Wiesbaden 1988.

Orang, Morād: Yasnā, Teil 2, Teherān 1340/1961.

Pādešāh, Moḥammad: Farhang-e Ānanderāăğ, hrsg. von Moḥammad Dabir-Siyāqi, in 7 Bänden, Teherān 1367/1988.

Page, Mary Ellen: Naqqali and Ferdowsi: Creativity in the Iranian National Tradition. Ph.D. Dissertation, Unversity of Pennsylvania 1977.

Pankte, Mechthild: Der arabische Bahrām-Roman. Untersuchungen zur Quellen und Stoffgeschichte, Berlin/New York 1974.

Pape, Wilhelm: Griechisch-Deutsches Handwörterbuch, Braunschweig 1914.

Paret, Rudi: Der Koran (Übersetzung), Stuttgart 1966.

Ders.: Die legendäre Maghāzi-Literatur, Tübingen 1930.

Ders.: Die Geschichte des Islam im Spiegel der arabischen Volksliteratur. Philosophie und Geschichte, Bd. 13, Tübingen 1927.

Ders.: Symbolik des Islam, Stuttgart 1958.

Parry, Millman: „Untersuchung zur epischen Technik Müdlichen Dichtung“, in: Homer. Tradition und Neuerung. hrsg. von Joachim Latacz, Darmstadt 1979, S. 179-266.

Ders.: „Komplette Formelverse in griechischem und südslawischem Heldensage“, in: Homer. Tradition und Neuerung. hrsg. von Joachim Latacz, Darmstadt 1979, S. 267-288.

Ders.: „Über typische Szenen im Homer“, in: Homer. Tradition und Neuerung, hrsg. von Joachim Latacz, Darmstadt 1979, S. 289-294. 
Partou-Beiżāi Kāšāni, Ḥosein: Tārih̆-e varzeš-e bāstāni-ye Irān, Zor-hāane, Teherān $1382 / 2003$.

Partouvi-Āmoli, Mahdi: Ams̄āl o ḥekam, Teherān 1374/1995.

Pauliny, Jan: „Zur Rolle der Qușṣāṣ bei der Entstehung und Überlieferung der populären Prophetenlegenden", in: Asian und African Studies, Depatment of oriental studies of then slovak Academy of sciences Bratislava, Nr. 10, (1974), S. 125-141.

Pedersen, Johs: Der Eid bei den Semiten in seinem Verhältnis zu verwandten Erscheinungen sowie die Stellung des Eides im Islam, in: Der Islam. hrsg. von Carl Heinrich Becker, drittes Heft, Strassburg: Trübner 1914.

Pelly, Lewis: Remarks on a recent Journey from Bushire to Shirauz, Transactions of the Bombay Geograpical Society 17 (1865).

Peez, Erik: Die Macht der Spiegel. Das Spiegelmotiv in Literatur und Ästhetik des Zeitalters von Klassik und Romantik, Frankfurt am Main/Bern/New York/Paris 1990.

Petrushevsky, I. P.: „The socio-economic condition of Iran under the Il-Khāns”, in: CHI, Vol. 5, hrsg. von John Andrew Boyle, Cambridge 1968, S. 483-537.

Pfister, Friedrich: Kleine Schriften zum Alexanderroman, Meisenheim am Glan: Hain 1976.

Pigeaud, Theodore G. Th.: Javanses and Balinese Manuscripts, Wiesbaden 1975.

Ders.: Der Alexanderroman. Mit einer Auswahl aus dem verwandten Texten, Meisenheim am Glan 1978.

Pirniyā, Mošir ad-Doule Ḥasan: Tārih̆-e Irān-e bāstān, Bd. 1, Teherān 1311-1313/19321934.

Pollok, Carmen: Fatā-Fityān-Futūwa: Studien zur Vorgeschichte der Männerbünde in vorund frühislamischer Zeit, Dissertation vorgelegt von Carmen Pollok, Rheinischen FriedrichWilhelm Universität zu Bonn 1996.

Pritchett, FrancesW.: The romance tradition in Urdu: adventures from the Dastan of Amir Hamzah/transl.,ed., and with an introd. by Frances W. Pritchett, New York 1991.

Pritsak, Omeljan: „Orientierung und Farbsymbolik: $\mathrm{Zu}$ den Farbenbezeichnungen in den altaischen Völkernamen“, in: Saeculum V (1954), S. 377-383.

Puin, Elisabeth: Islamische Plakate. Kalligraphie und Malerei im Dienste des Glaubens, Teil 3, Bremen 2008.

Purhāāeqi-Čatrudi, Mehr-dohyt: Deraht dar Šāh-nāme, Teherān 1381/2002.

Qaṭān, Abū Naṣr Moḥammad b. Qaṭān: Sarāğ al-qolub, Teherān o.J.

Qāżi Aḥmad Qomi: Holāṣat at-Tawā rīh ü, übers. und hrsg. von Hans Müller, Wiesbaden 1964. 
Qazwini-Rāzi, Naṣir ad-Din Abu al-Rašid 'Abd al-Ğalil: an-NaqZ, hrsg. von MoḥammadĞáfar Moḥaddeș-Armu’i, Teherān 1358/1979.

Qobādiyāni, Nāṣer-Hosrou: Divān-e Nāṣer-Hosrou, hrsg. von Seyyed Naṣrallāh Taqavi, Teherān 1307/1929.

Qoreishi, Salim ad-Din Qoreishi u. Sems-Williams, Ursula: Catalogue of the Urdu Manuscripts in the India Office Library. Supplementary to James Fuller Blumhardt's Catalogue of 1926, London 1978.

Rağāì, Aḥmad-'Ali: Bostān al-cārefīn va tuḥfat al-muridin, Teherān 1354/1975.

Rāmpuri, Ġiyās ad-Din Moḥammad b. Ğalāl ad-Din b. Šaraf ad-Din: Ġiyās al-logāāt, hrsg. von Manșūr Ś Servat, Teherān 1375/1996.

Rašid ad-Din Fażlallāh (gest. 1318): Ğami` at-Tawārih̆, in 2 Bänden, hrsg. von Bahman Karimi, Teherān 1338/1959.

Ders.: Ǧami` at-Tawārih̆. Tãrih̆-e mobārak-e Ġāzāni, hrsg. von Bahman Karimi, Teherān o.J.

Rastgār-Fasā'i, Manṣur: Eždahā dar asātir-e irāni, Teherān 1379/2000.

Rażi, Mağid: 'Aṣr-e Avestā, Teherān 1343/1964.

Rażi, Hāšem: Vandidād, in 4 Bänden, Teherān 1376/1997.

Merker, Paul. u. Stammler, Wolfgang: „Volksepos”, in: Reallexikon der Deutschen Literaturgeschichte, 1. Aufl., Berlin 1928/9, S. 486 f.

Reinfried, H.: Șifat an-Nab̄̄ Mālek, Muwatța؟ Bräuche bei Zauber und Wunder bei Buchari, Diss., philosophische Fakultät der großherzoglichen badischen Universität zu Freiburg 1915.

Rentz, G.: „Baraka“, in: $E I^{2}$, Vol. I, hrsg. von Hamilton Alexander Rosskeen Gibb [u.a.], Leiden/London 1960, S. 1032-1033.

Richter, E.: „Oriental und kabbalistische Ursprungsbezirke der geistlichen Hand”, in: Deutsche Gaue 43 (1951), S. 18-27.

Rieu, Charles: Catalogue of the Persian Manuscripts in the British Museum, Vol. II, London 1881.

Ders.: Supplement to the Catalogue of the Persian Manuscripts in the British Museum, Vol. 4. London 1895.

Ders.: Catalogue of the Turkish Manuscripts in the British Museum, Londres 1888.

Ringgren, Helmer: Fatalism in Persian Epics, Uppsala 1917.

Ritter, Hellmut: Das Meer der Seele. Mensch, Welt und Gott in den Geschichten des Farīd adDin 'Ațțār, Leiden 1955. 
Ders.: „Anfänge der Ḥurūfisekte“. Studien zur Geschichte der islamischen Frömmigkeit II, in: Orients, VII/I, 1954, S. 1-54.

Roemer, Hans Robert: Persien auf dem Weg in die Neuzeit. Iranische Geschichte von 13501750, Beirut 1989.

Ders.: Staatsschreiben der Timuridenzeit. Das Šaraf-nāme des 'Abdallāh Marwārīd in kritischer Auswertung. Persischer Text: Faksemile (HS Istanbul Üniversitesi I 87), VOK III, Wiesbaden 1952.

Röhrborn, Klaus-Michael: „Regierung und Verwaltung Irans unter den Safawiden“, in: Handbuch der Orientalistik, 1. Abt: Der Nahe und der Mittlere Osten. 6. Bd.: Geschichte der islamischen Länder, 5. Abschn., Teil 1, Regierung und Verwaltung des Vorderen Orients in islamischer Zeit, hrsg. von Bertold Spuler, Leiden/Köln 1979, S. 17-57.

Röhrich, Lutz: „Grausamkeit“, in: EM, Bd. 6, hrsg. von Rolf Wilhelm Berdnich, Göttingen 1990, Sp. 98-110.

Ders.: „Erotik und Sexualität im Volksmärchen“, in: Liebe und Eros im Märchen, Veröffentlichungen der Europäischen Märchengesellschaft, Bd. II (11), Kassel: Röth 1988, S. 20-48.

Ders.: „Drache“, Drachenkampf, Drachentöter“, in: EM, Bd. 3, hrsg. von Rolf Wilhelm Brednich, Göttingen 1981, Sp. 787-820.

Ders.: „Erotik, Sexualität“, in: EM, Bd. 4, hrsg. von Rolf Wilhelm Brednich, Göttingen 1984, Sp. 234-252.

Ders.: „Jagd, Jagen, Jäger“, in: EM, Bd. 7, hrsg. von Wilhelm Brednich, Göttingen 1993, Sp. 394-411.

Roscher, Wilhelm Heinrich: „Die Zahl 40 im Glauben, Brauch und Schrifttum der Semiten“, in: Abhandlungen der philologisch-historischen Klasse der königlichen sächsischen Gesellschaft der Wissenschaften 27/4 (1909), S. 93-138.

Roth, Klaus: „Mann“, in: EM, Bd. 9, hrsg. von Rolf Wilhelm Brednich, Göttingen 1999, Sp. 144-162.

Rotter, Gernot: Bis zu den Grenzen der Erde. Auszüge aus dem Buch der Goldwäschen (Murūğ adِ-dahab wa-macādinal-ğawāhir) Tübingen und Basel 1978.

Rubin, Uri: „Pre-existence and Light: Aspects of the Concept of Nur Muhammad”, in: Israel Oriental Studies 5 (1975), S. 62-119.

Rumlu, Ḥasan-Beg: Ạ̣san at-Tawārih̆, hrsg. von 'Abd al-Ḥosein Navā'i, Teherān $1357 / 1978$. 
Russell, Ralph: „Ghālib. A Self-Portrait”, in: Ghalib: the Poet and his Age, hrsg. von George Allen u. Unwin, London 1972, S. 9-35.

Russell, Ralph and Khurshidul Islam: Ghalib, Life and letters, 1779-1869; Vol. 1, hrsg. von George Allen und Unwin, London 1969.

Rypka, Jan: Iranische Literaturgeschichte, Leipzig 1959.

Ṣabā, Moulavi Moḥammad Moẓaffar Ḥosein: Tazkkere-ye ruz-e roušan, hrsg. von Moḥammad-Ḥosein Roknzāde, Teherān 1343/1964.

Šabānkārei, Moḥammad b. ‘Ali b. Moḥammad: Mağma‘al-ansāb, Teherān 1363/1984.

Sādāt-Eškevari, Kāẓim: „Naqqāli va šāh-nāme-ȟ̌āni”, in: Honar va Mardom, Tir va Mordād, Teherān 1354/1975, S.142-48.

Sadger, J. Isidor: Aus dem Liebesleben Nicolaus Lenaus, Leipzig/Wien 1925.

Sa'di, Moṣlẹ̣ ad-Din: Kolleyāt-e Sa'di, Lithographischer Druck, Teherān 1268h/1851.

Ders.: Kolleyāt-e Sa'di, Lithographischer Druck, Teherān 1274h/1857.

Ṣadeqi Ketābdār: Mağma' al-ḩavāṣ, aus dem Tschagataischen ins Persische übersetzt. von 'Abd ar-Rasul Hुayyāmpur, Tabriz 1337/1958.

Ṣafā, Żabiḥallāh: Hamāse-sarā'i dar Irān, Teherān 1333/1954.

Ders.: Mohtaṣari dar tārih̆-e tạ̣avvol-e nạ̣m va naṣr-e fārsi, Teherān 1366/1987.

Ders.: Tãrihh-e adabiyāt dar Irān va dar qalamrou-e zabān-e fārsi, in 5 Bänden, Teherān 1371/1992.

Ders.: Tārihb-e adabiyāt dar Irān, Bd. 5 Teil 3, Teherān 1371/1992.

Šafā, Šoğā‘ ad-Din: Toużị̣ al-Masā’l, Paris 1362/1983.

Ṣafavi, Raḥimzāde: Zendegāni-ye Šāh Esmācil Ṣafavi, Teherān 1341/1962.

Ṣafavi, Sām Mirzā: Toḥf-ye sāmi, hrsg. von Vaḥid Dastgerdi, Teherān 1341/1962.

Ṣafavi, Seyyed Ḥasan: Eskandar va adabiyāt-e Irān va šahṣiyyat-e mazhabi-ye Eskandar, Teherān 1364/1985.

Šafíi-Kadkani, Moḥammad-Reżā: Șovar-e hayāl dar še ree fārsi, Teherān 1366/1987.

Sağğādi, Seyyed Ğa‘far: Farhang-e loḡāt va eștelāhāt va tachirāt-e 'erfāni, Teherān 1362/1983.

Sagang, Sečen: Geschichte der Mongolen und ihres Fürstenhauses, Zürich 1985.

Sağādi, Seyyed Aḥmad: „Olum-e ġaribe“, in: Dā'rat al-ma‘ārif-e tašayyo, Bd. 11, ȘadrAḥmad, Ḥāğğ Seyyed Ğavādi, Teherān 1384/2005, S. 386-407.

Šahri, Ğa'far: Tehrān-e qadim, Bd. 2, Teherān 1371/1992.

Šahidi-Māzandarāni, Ḥosein: Farhang-e Šāh-nāme, Teherān 1377/1998. 
Šahmardān b. Abi al-Hูeir: Nozhat-nāme-ye 'Alāi, hrsg. von Farhang Ğahānpur, Teherān 1362/1983.

Šāmi, Neẓām ad-Din: Zafar-nāme, hrsg. von Felix Tauer, Praha 1937.

Sāmi, 'Ali: Tamaddon-e sāsāni, Bd. 1, Širāz 1342/1963.

Šāmlu, Aḥmad: Ketāb-e kuče, Bd. 5, Teherān 1376/1997.

Sarkārāti, Bahman: „Pari taḥqiqi dar ḥāšiye-ye osṭure-šenāsi-ye taṭbiqii“, in: Sāyehā-ye šekār šode, Tabriz 1385/2006, S. 1-25.

Ders.: „Gorz-e niyā-ye Rostam”, in: Sāyehā-ye šekār šode, S. 113-123.

Ders.: „Bāz-šenāsi-e baqāyā-e afsāne-e Garšāsb dar manẓumehā-e ḥamāsi-e Irān“, in: Sāyehā-ye šekār šode, S. 251-286.

Ders.: Sohanrānihā-ye dovvomin doure-ye ğalasāt-e sohanrāni va baḥs darbare-ye Šăhnāme-ye Ferdousi, Teherān 1349/1970, S. 96-98.

Šamisā, Sirus: Sabk-šenāsi-ye nașr, Teherān 1380/2001.

Ders.: Fargang-e ašārāt-e adabiyāt-e fārsi, in 2 Bänden, Teherān 1377-1379/1998-2000.

Ders.: Farhang-e talmihāt, Teherān 1366/1987.

Ders.: ک̌āhed-bāzi dar adabiyāt-e fārsi, Teherān 1381/2002.

Ders.: „,̌̄ām-e ğahān-namā““, in: Dāně̌, 1 Jahrgang, Nr. 6, Šahrivar, Teherān 1328/1949, S. 300-310.

Savory, Roger M.: „The Safavid Administrative System“, in: CHI, Bd. 6, hrsg. von Peter Jackson [u.a.], Cambridge 1986, S. 351-373.

Sayyāḥ, Aḥmad: Farhang-e bozorg-e ğāmeśe novin-e Sayyāḥ, in 2 Bänden, Teherān 1377/1998.

Schenda, Rudolf: „Heilen, Heiler, Heilmittel“, in: EM, Bd. 6, hrsg. von Rolf Wilhelm Brednich, Göttingen 1990, Sp. 655-665.

Ders.: „Brief“, in: EM, Bd. 2, hrsg. von Kurt Ranke, Göttingen 1979, Sp. 784-789.

Schimmel, Annemarie: Die Zeichen Gottes. Die religiöse Welt des Islam, München 1995.

Dies.: Und Muhammad ist sein Prophet. Die Verehrung des Propheten in der islamischen Frömmigkeit, Düsseldorf/Köln: Diederichs 1981.

Dies.: Classical Urdu Literature from the Beginning to Iqbāl, Wiesbaden Otto Harrassowitz, Vol. 8, History of Indian Literature, hrsg. von Jan Gonda, Wiesbaden 1975.

Dies.: Mystische Dimensionen des Islam, 1. Aufl., Köln: Diederichs 1985.

Dies.: „Sufismus und Volksfrömmigkeit“, in: Der Islam III, Stuttgart/Berlin/Köln 1990, S. 157-262. 
Dies.: „Traditionelle Frömmigkeit“, in: Der Islam III. Islamische Kultur-Zeitgenössische Strömungen Volksfrömmigkeit, Stuttgart/Berlin/Köln 1990, S. 242 -267.

Dies.: „Künstlerische Ausdrucksformen des Islam“, in: Der Islam III, Stuttgart/Berlin/Köln 1990, S. 267-296.

Schimmel, Annemarie u. Endres, Franz Carl: Das Mysterium der Zahl. Zahlensymbolek im Kulturvergleich, Köln 1984.

Schmidt, Sigrid: „Schlangenkrone-Stein“, in: EM, Bd. 12, hrsg. von Rolf Wilhelm Brednich, Göttingen 2007, Sp. 56-63.

Ders.: „Reh“, in: EM, Bd. 11, hrsg. von Rolf Wilhelm Brednich, Göttingen 2004, Sp. 471-474 Schuster-Walser, Sibylla: Das safawidische Persien im Spiegel europäischer Reiseberichte (1502-1722). Untersuchungen zur Wirtschafts-und Handelspolitik, Hamburg 1970.

Schulz, Armin: Schwieriges Erkennen. Personenidentifizierung in der mittelhochdeutschen Epik, Tübingen 2008.

Schützinger, Heinrich: Ursprung und Entwicklung der arabischen Abraham-NimrodLegende, Bonn 1961.

Schwarzlose, Friedrich Wilhelm: Die Waffen der alten Araber, Hildesheim 1982.

Seif, Hādi: Naqāši ru-ye kāši, Teherān 1376/1997.

Seligmann, Siegfried: Der böse Blick und Verwandtes: ein Beitrag zur Geschichte des Aberglaubens aller Zeiten und Völker, Bd. 2, Berlin 1910.

Seipel, Wilfried (Hg.) Weihrauch und Seide. Alte Kulturen an der Seidenstraße, eine Ausstellung des Kunsthistorischen Museums, in Zusammenarbeit mit der Staatlichen Eremitage in St. Petersburg ; Kunsthistorisches Museum Wien, 21. Jänner bis 14. April 1996. Seyller, John: The Adventures of Hamza. Painting and Storytelling in Mughal Indien: With contributions by Wheerler M. Thackston, Ebba Koch, Antoinette Owen and Rainald Franz, Freer Gallery of Art and Arthur M. Sackler Gallery. Smithsonain Institution, Washington D. C. 2000.

Ders.: The Adventures of Hamza, London 2002.

Ders.: „A Dated Hamza-nāma Illustration“, in: Artibus Asiae 53/3-4 (1993), S. 503-505, (Notice I).

Seyyed 'Arab, Ḥsan: „Krāmat“, in: Dā'irat al-ma'ārif-e tašayyo', Bd. 13, hrsg. von ṢadrAḥmad Ḥāğğ Seyyed Ğavādi, Teherān 1391/2012, S. 605-609.

Sezen, Lütfi: Halk Edebiyatinda Hamzanāmeler, Ankara 1991. 
Shahabi, Mahmud: „The Roots of Shicism“, in: Expectation of the Millennium. Shicism in History, hrsg. von Seyyed Hossein Nasr, Hamid Dehashi und Seyyed Vali Reza Nasr, State University of New York Press 1988.

Shiro, Ando: Timuridische Emire nach dem Mucizz al-ansāb. Untersuchung zur Stammesaristokratie Zentralasiens im 14. und 15. Jahrhundert, Berlin 1992.

Shojaei-Kawan, Christine: „Mord“, in: EM, Bd. 9, hrsg. von Rolf Wilhelm Brednich, Göttingen 1999, Sp. 856-876.

Sems, Eleanor: „The Illustarted Manuscripts of Ferdousi' Šāh-nāme Commissioned by Princes of the House of Timur", in: Ars Orientalis, No. XXII, Vol. 22 (1992), S. 43-68.

Sistāni, Malek Šāh Ḥosein b. Malek Ġiyāṭ ad-Din Moḥammad b. Šāh Maḥmud: Ihyāa alMoluk, hrsg. von Manūčehr Sotude, Teherān 1344/1965.

Šecār, Ğa'far: Qeș̣e-ye Amir al-mo'menin Ḥamze, in 2 Bänden, Teherān 1347/1968.

Sindawī, Khalid: „The role of the lion in miracles associated with shī'ite imāms”, in: Der Islam, Bd. 84, Hefte 2, hrsg. von Conrad Lawrence, (2007), S. 356-390.

Slaby, Helmut: Bindenschild und Sonnenlöwe, Die Geschichte der österreichisch-iranischen Beziehung bis zur Gegenwart, Graz 1982.

Soḅ̣āi, Tofiq H.: Negāhi be Tārih̀-e adab-e fārsi dar Hend, Teherān 1377/1998.

Soroudi, Sarah Sorour: „Islamization of the Iranian national hero Rostam as reflected in Persian folktales", in: Jerusalem Studies in Arabic and Islam II, Jerusalem 1980, S. 365-385.

Šoğāc, 'Abd al-Ḥamid: Zan va siyāsat va haram-sarā dar caṣr-e Ṣafavi, Teherān $1384 / 2005$.

Spies, Otto: Zwei Volkstümliche Liebesgeschichten aus dem Orient, Helsinki 1939.

Speyer, Wolfgang: „Die Verehrung des Heron, des göttlichen Mensch und des christlichen Heiligen. Analogie und Kontinuitäten”, in: Peter Dinzelbacher, Dieter R. Bauer (Hg.): Heiligenverehrung in Geschichte und Gegenwart, Ostfildern 1990, S. 48-66.

Spuler, Bertold: Die Mongolen in Iran. Politik, Verwaltung und Kultur der Ilchanzeit 12201350, Berlin 1955.

Ders.: Iran in früh-islamischer Zeit. Politik, Kultur, Verwaltung und öffentliches Leben zwischen der arabischen und der seldschukischen Eroberung, Wiesbaden 1985.

Ders.: Geschichte der Mongolen, Zürich 1968.

Ders.: „Die Kultur des islamischen Ostens”, in: Handbuch der Kulturgeschichte. Die Kultur des Islam, hrsg. von Eugen Thurnher, Abt. 2, Frankfurt am Mein 1971, S. 209-327.

Stausberg, Michael: Die Religion Zarathushtras, Geschichte-Gegenwart-Rituale, Bd. 1, Stuttgart/Berlin/Köln 2002. 
Stein, Hans Joachim: „Pfeil“, in: EM, Bd. 10, hrsg. von Rolf Wilhelm Brednich, Göttingen 2002, Sp. 898-906.

Steinbach, Udo: Dāl al-himma. Kulturgeschichtliche Untersuchungen zu einem arabischen Volksroman, Wiesbaden 1972.

Stollberg-Rilinger, Barbara: „Was heisst Ideengeschichte“, in: Ideengeschichte, Stuttgart 2010, S. 7-42.

Stoneman, Richard: „Alexander the Great in the Arabic Tradition”, in: Stelios Panayotakis (Hg): the Ancient Novel and Beyond, Leiden 2003.

Storbeck, Friedrich: „Die Berichte der arabischen Geographen des Mittelalters über Ostafrika“, in: MSOS XVII 2,1914, S. 102-113.

Storey, Charles Ambrose: Persian Literature: A Bio-Biliographical Survey, Vol. I, Part 1, London 1927-1939.

Streck, Maximilian: „Kāâ‘, in: EI, Bd. II, hrsg. von Martijn Theodoor Houtsma u. Arent Jan Wensinck, Leiden 1927, S. 658-660.

Strothmann, Rudolf: Die Zwölfer-Schica. Zwei religionsgeschichte Charakterbilder aus der Mongolenzeit, Leipzig 1926.

Šūštari, Qāżi Nūrallāh: Mağāles al-mo'menin, in 2 Bänden, Teherān 1368/1989.

Syrinx, Carola von Hees: Enzyklopädie als Spiegel des Weltsbildes. Qazwīn̄̄ Wunder der Schöpfung eine Naturkunde des 13. Jahrhunderts, Wiesbaden 2002.

Tabrizi, Moḥammad-Ḥosein b. Half (berühmt als Qātẹe): Borhān-e qãtes in 5 Bänden, hrsg. von Moḥammad Mocin, Teherān 1342/1963.

Taeschner, Franz: Zünfte und Bruderschaften im Islam. Text zur Geschichte der Futuwwa, Zürich/München 1979.

Ders.: „Der Anteil des Sufismus an der Formung des Futuwwaideals”, in: Der Islam 24 (1937), S. 43-74.

Ders.: „Futuwwa eine gemeinschaftsbildende Idee im mittelalterlichen Orient und ihre verschiedenen Erscheinungsformen“, in: Schweizerisches Archiv für Volkskunde Bde. 52, Heft 2/3 (1956), S. 122-158.

Ders.: „Die islamischen Futuwwabünde”. Das Problem ihrer Entstehung und die Grundlinien ihrer Geschichte, in: ZDMG, Bde. 87, Leipzig 1934, S. 6-49

Ders.: „Die osmanische Literatur”, in: $H d O, 1$. Abt, in 5 Bänden, Turkologie, Leiden/Köln 1963, S. 259-261.

Ders.: „Ayyār", in: $E I^{2}$, Vol. I, hrsg. von Hamilton Alexander Rosskeen Gibb [u.a.], Leiden/London 1960, S. 794. 
Ders.: „Akhī“, in: $E I^{2}$, Vol. I, hrsg. von Hamilton Alexander Rosskeen Gibb [u.a.], London/Leiden 1960, 321-323.

Tafażżoli, Aḥmad: Tārih̆-e adabiyāt-e Irān piš az Eslām, Teherān 1376/1997.

Taube, Erika: „Zaubermärchen und Zauber im Märchen der Tuwiner“, in: Zauber Märchen. Forschungsberichte aus der Welt der Märchen, München: Diederichs 1998.

Tāğ-bahš, Aḥmad: Irān dar zamān-e Ṣafaviyān, Tabriz 1340/1961.

Tavadia, Jehāngir C.: Die Mittelpersische Sprache und Literatur der Zarathustirer, Leipzig 1956.

Thiel, Helmut: „Alexander der Große“, in: EM, Bd. 1, hrsg. von Kurt Ranke, Göttingen 1977, Sp. 272-281.

Thompson, Stith: Motiv Index of Folk-literature, Helsinki 1923-1936.

Thorning, Hermann: Beiträge zur Kenntnis des islamischen Vereinswesens auf Grund von Bast Madadet-Taufíq, Berlin 1913.

Truhart, Peter: Regents of Nations. Systematic Chronology of States and their political representatives in past and present, Part II, Asia/Australia-Oceanin, München/New York/London/Paris 1985.

Tuczay, Christa: „Schwert“, in: EM, Bd. 12, hrsg. von Rolf Wilhelm Brednich, Göttingen 2007, Sp. 418-421.

Ullmann, Manfred: Das Motiv des Spiegels in der arabischen Literatur des Mittelalters, Göttingen 1992.

Uplegger, Helga: „Das Volksschauspiel“, in: Philologiae Turcicae Fundamenta II, hrsg. von Pertev Naili Boratav, Wiesbaden 1967, S. 147-162.

Vāḥdi-Navāi, Āvā: Neẓām-e ğazā'i-ye Irān dar 'aṣr-e sāsāni, Teherān 1380/2001.

Vaḥid-Qazwini, Moḥammad-Ṭāhir: 'Abbās-nāme, hrsg. von Ebrāhīm Dehqān, Teherān $1329 / 1950$.

Vā'ez Kāšefi Sabzevāri, Moulānā Ḥosein: Fotovvat-nāme-ye solțāni, hrsg. von Moḥammad-Ğa'far Maḥğub, Teherān 1350/1971.

Vaglieri, L. Veccia: „Ḥusayn b. 'Alī b. Abī Ṭālib“, in: Encyclopédie de L’Islam, Tome. III, hrsg. von Bernard Lewis [u.a.], Leyden/Paris 1971, S. 607-615.

Van Ronkel, Philippus Samuel: De Roman van Amir Hamza, Leiden 1895.

Vāṣefi, Zain ad-Din Maḥmud: Badāye' al-vaqāye’ hrsg. von A. N. Boldirev, in 2 Bänden, Teherān 1349/1970.

Venzlaff, Helga: Der islamische Rosenkranz, Stuttgart 1985. 
Virolleaud, Charles: „Le Roman iranien de l'Emir Hamza“, in: Académie des Inscriptions \& Belles-Letters. Comptes rendus des séances (1948), S. 224-234.

Ders.: „Le Roman de l'Émir Hamza, onkel de Mahomet“, in: L'Éthnographie N. S. 53 (1958/1959), S. 3-10.

Walker, J.: „Soleimān“, in: EI, Bd. IV, hrsg. von Martijn Theodoor Houtsma [u.a.], Leinden/Leipzig 1934, S. 561-563.

Walker, Warren S.: A Turkish Folktale: The art of Behçet Mahir, New York 1996.

Varğāvand, Parviz: „Raml”, in: Dā’rat al-ma‘ārif-e tašayyo, Bd. 8, hrsg. von Șadr-Aḥmad Ḥāğğ Seyyed Ǧavādi, Teherān 1379/2000, S. 327-329.

Watt, William Montgomery u. Marmura, Michael: „Politische Entwicklungen und theologische Konzepte“, in: Der Islam II, hrsg. von Hubert Cancik, Peter Eicher, Burkhard Gladigow u. Martin Greschat, ins Deutsche übersetzt. von Sylvia Höfer, Stuttgart/Berlin/Köln/am Mainz/ Kohlhammer 1985.

Watt, William Montgomery u. Welch, Alford T.: „Mohammad und die Frühzeit, islamisches Recht-Religiöses Leben“, in: Der Islam I, Stuttgart/Berlin/Köln/Mainz 1980.

Watt, William Montgomery: „Iram“, in: $E I^{2}$, Vol. III, hrsg. von Bernard Lewis [u.a.], Leiden/London 1971, S. 1270.

Wehse, Rainer: „Erkennungszeichen“, in: EM, Bd. 4, hrsg. von Rolf Wilhelm Brednich, Göttingen 1984, Sp. 180-194.

Wellhausen, Julus: Das arabische Reich, Berlin 1960.

Ders.: Reste arabischen Heidentums, Berlin/Leipzig 1927.

Weisser, Ursula: Das „Buch über das Geheimnis der Schöpfung“ von Pseudo-Apollonios von Tyana, Berlin 1980.

Wensinck, Arent Jan, Mensing Mensing u. Johan Peter Mari: Concordance et Indices de la Tradition Musulmane, Bd. V, Leiden 1965.

Ders.: „Iliyās“, in: EI, Bd. II, hrsg. von Martijn Theodoor Houtsma [u.a.], Leiden/Leipzig 1927, S. 501-502.

Ders.: „Iram“, in: EI, Bd. II, hrsg. von Martijn Theodoor Houtsma [u.a.], Leipzig/Leiden 1927, S. 554-555.

West, Edward William: „Pahlavi Literatur”, in: Grundriss der iranischen Philologie, zweiter Teil, hrsg. von Wilhelm Geiger u. Ernst Kuhn, Strassburg 1896-1904, S. 75-129.

White, Hayden: „The Value of Narrative in the Representation of Realiy”, in: Critical Inquiry, Vol. 7, No. 1. On Narrative, hrsg. von William J. Thomas Mitchell, Chicago 1981, S. 1-23. 
Ders.: The Content of the Form: narrative Discourse and Hisorical Repersentation, Baltimore 1987.

Widengren, Geo: Iranische Geisteswelt: von den Anfängen bis zum Islam, Baden-Baden 1961.

Ders.: Iranische-semitische Kulturbegegung in parthischer Zeit, hrsg. von Arbeitsgemeinschaft für Forschung des Landes Nordrhein-Westfalen Geistwissenschaften, Heft 70, Köln/Opladen 1960.

Ders.: Die Religionen Irans. Die Religionen der Menschheit, Bd. 14, Stuttgart 1965.

Ders.: Der Feudalismus im alten Iran. Männerbund, Gefolgswesen, Feudalismus in der iranischen Gesellschaft im Hinblick auf die indogermanischen Verhältnisse, Köln/Opladen 1969.

Wiebke, Walther: Die Frau im Islam, Stuttgart/Berlin/Köln 1980.

Ders.: „Die Frau im Islam“. Islamische Kultur-Zeitgenössische StrömungenVolksfrömmigkeit, in: Der Islam III, Stuttgart/Berlin/Köln 1990. S. 388-411.

Williams-Krapp, Werner: „Elternmord“, in: EM, Bd. 3, hrsg. von Rolf Wilhelm Brednich, Göttingen 1981, Sp. 1372-1379.

Wimmer, Erich: „Grab, Grabwunder“, in: EM, Bd. 6, hrsg. von Rolf Wilhelm Brednich, Göttingen 1990, Sp. 51-63.

Winkler, Hans Alexander: Siegel und Charaktere in der muhammedanischen Zauberei, Berlin/Leipzig 1930.

Wolfensohn, Israel: Ka'b al-Ạbar und seine Stellung im Hadț und in der islamischen Legendenliteratur, phil. Diss, Frankfurt/Main 1933.

Wolff, Fritz: Glossar zu Firdosis Schahname. Reprografischer Nachdruck d. Ausg. Berlin 1935, Hildesheim 1965.

Ders.: Avesta. Die heiligen Bücher der Parsen, Straßburg 1910.

Wüstenfeld, Heinrich Ferdinand: Der Tod des Ḥusain ben Ali und die Rache. Ein historischer Roman aus dem Arabischen, Abhandlungen der königlichen Gesellschaft der Wissenschaften zu Göttingen. 30. Band, Göttingen 1883.

Yamanaka, Yuriko: „From Evil Destroyer to Islamic Hero”. The Transformation of Alexander the Great's Image in Iran", in: Annals of Japan Association for Middle Eastern Studies 8 (1993), S. 55-87.

Yamamoto, Kumiko: From storytelling to poetry: the Oral background of the Persian epics, London 2000. 
Yāqūt, Šahāb ad-Din Abū 'Abdallāh Yāqūt b. 'Abdallāh al-Ḥamavi ar-Rūmi: Mu'̌̆am al-buldān, in 5 Bänden, Bairut 1374-1376h /1955-1957.

Yarshater, Ehsan: „The Development of Iranian Literatures”, in: Persian literature, Columbia Lectures on Iranian Studies: No. 3 (1988), S. 3-37.

Ders.: Šér-e fārsi dar ‘ahd-e Šāhrroh, Teherān 1334/1955.

Ders.: „Iranian national History“, in: CHI, Vol. 3 (1), Cambridge 1983, S. 359-477.

Ders.: „Iranian common beliefs and world-view”, in: CHI, Vol. 3 (1), Cambridge 1983, S. 343-358.

Yazdi, Šaraf ad-Din 'Ali: Zafar-nāme, in 2 Bänden, hrsg. von Moḥammad 'Abbāsi, Teherān 1336/1957.

Xenophon: Kyrupädie. Die Erzählung des Kyros, ins Griechisch und Deutsch, übers. und hrsg. von Nickel Rainer, Zürich 1992.

Zākāni, Neẓām ad-Din 'Obeid: Ahlāq al-ašrāf. Taṣḥị̣ va toużị̣ 'Ali-Aṣgar Ḥalabi, Teherān 1374/1995.

Zākeri, Moḥsen: Sāsānid Soldiers in Early Muslim Society: The origins of 'ayyārān and futuwwa, Wiesbaden 1995.

Zariri, Moršed 'Abbās: Dāstān-e Rostam va Sohrāb, hrsg. von Ğalil Dusth̆̌āh, Teherān $1369 / 1991$.

Zarrinkub, ‘Abd al-Ḥosein: Serr-e nei, Teherān 1372/1993.

Ders.: Gozašte-ye naşr-e fārsi dar naqš-e bar āb, Teherān 1370/1991.

Ders.: Donbāle-ye ğostoğu dar taṣvvof-e Irān, Teherān 1362/1983.

Zbinden, Ernst: Die Djinndes Islams und der altorientalische Geisterglaube, Bern/Stuttgart 1953.

Zieme, Peter: „Die Alttürkischen Reiche in der Mongolei“, in: Dschingis Khan und seine Erben: das Weltreich der Mongolen; [erscheintanläßlich der Ausstellung Dschingis Khan und seine Erben. Das Weltreich der Mongolen. 16. Juni bis 25. September 2005, Kunst- und Ausstellungshalle der Bundesrepublik Deutschland, Bonn, 26. Oktober 2005 bis 29. Januar 2006, Staatliches Museum für Völkerkunde München]/[Hrsg.Kunst- und Ausstellungshalle der Bundesrepublik Deutschland GmbH. Koordination Jutta Frings].

Zirke, Heidi: Ein hagiographisches Zeugnis zur persischen Geschichte aus der Mitte des 14. Jahrhunderts. Das achte Kapitel des Șafwat aṣ-Ṣafā in kritischer Bearbeitung, (islamkundliche Untersuchung. 120), Berlin 1987.

Zugmajer, Erich: Eine Reise durch Vorderasien, Berlin1905.

Zumthor, Paul: Einführung in die mündliche Dichtung, Berlin 1990. 
